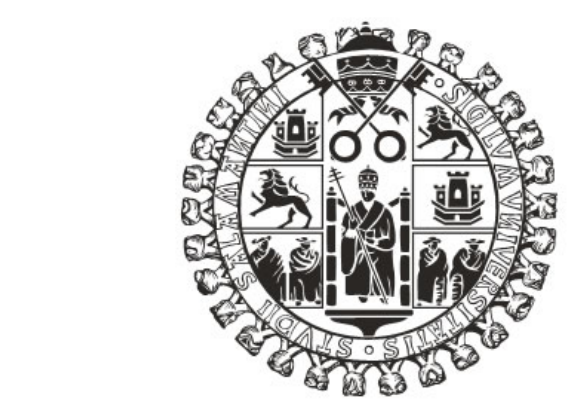

UNIVERSIDAD DE SALAMANCA

FACULTAD DE DERECHO

DEPARTAMENTO DE DERECHO ADMINISTRATIVO, FINANCIERO Y PROCESAL

PROGRAMA DE DOCTORADO

"ESTADO DE DERECHO Y BUEN GOBIERNO"

TESIS DOCTORAL

AGENTE ENCUBIERTO Y PROCESO PENAL GARANTISTA:

LÍMITES Y DESAFÍOS

FLÁVIO CARDOSO PEREIRA

SALAMANCA 2012 



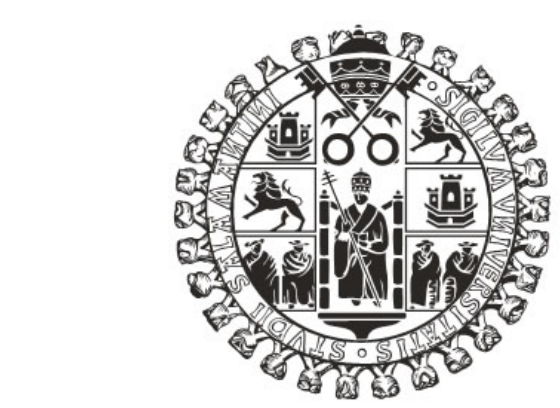

UNIVERSIDAD DE SALAMANCA

FACULTAD DE DERECHO

DEPARTAMENTO DE DERECHO ADMINISTRATIVO, FINANCIERO Y PROCESAL

PROGRAMA DE DOCTORADO

"ESTADO DE DERECHO Y BUEN GOBIERNO"

TESIS DOCTORAL

\section{AGENTE ENCUBIERTO Y PROCESO PENAL GARANTISTA: LÍMITES Y DESAFÍOS}

Tesis doctoral presentada por Flávio Cardoso Pereira para obtener el grado de Doctor en Derecho, dirigida por el Prof. Dr. D. Nicolás Rodríguez García, Catedrático (acreditado) de Derecho Procesal de la Universidad de Salamanca. 

En primer lugar, agradezco a Dios, mi guía.

También a mis padres Regis y Vânia, y a mi hermano Marcelo, con inmensa gratitud por todo. Del mismo modo a mi amada esposa Virginia y mis dos tesoros, Fabricio y Gabriel: gracias por la paciencia. 


\section{INDICE}

\section{CAPÍTULO PRIMERO: LOS DESAFÍOS DEL PROCESO PENAL CONTEMPORÁNEO}

I.1. La paradoja: eficacia del ius puniendi versus garantías y derechos fundamentales del imputado. La necesidad de un proceso penal equilibrado

I.1.1. Tensión dialéctica de fuerzas y proceso penal

I.1.1.1. Criminalidad de los nuevos tiempos y la crisis del Derecho Procesal penal

I.1.1.2. La tensión de fuerzas: garantías versus eficacia

I.1.2. Armonía procesal penal: un objetivo para conciliar la eficacia y las garantías.

I.1.2.1. La función primordial del proceso penal

I.1.2.2. ¿Es admisible una persecución sin límites en la búsqueda de la eficiencia penal o debe prevalecer un equilibrio procesal penal?

I.2. Eficiencia y garantías como vertientes del proceso penal equilibrado

I.2.1. La abusiva instrumentalización de las garantías. Un peligro inminente

a la seguridad pública

I.2.2. "Eficiencia penal": un concepto importante

I.2.3. La armonización de fuerzas y la búsqueda por un proceso penal equilibrado: una solución ideal en tiempos de crisis de tensión

I.3. El garantismo y la lucha contra el crimen organizado. La posible compatibilización de las garantías y la eficacia del derecho de punir estatal

I.3.1. Consideraciones generales respecto a la delincuencia organizada . .78

I.3.1.1. Evolución histórica y desarrollo como fenómeno criminal.

I.3.1.2. El concepto de delincuencia organizada. Una cuestión controvertible

I.3.1.3. Principales rasgos característicos

I.3.1.4. Breves apuntes sobre el tratamiento jurídico de la criminalidad organizada

I.3.1.4.1. Medidas de Política-criminal ................................................................96

I.3.1.4.2. Medidas sustantivas ...........................................................................100

I.3.1.4.3. Medidas procesales ............................................................................102

I.3.2. Crimen organizado y teoría del garantismo.................................................................115

I.3.2.1. Algunas notas esenciales sobre el garantismo penal y procesal.

La evolución hacia el garantismo "integral" en el proceso penal. 
I.3.2.1.1. El Garantismo y la contribución de FERRAJOLI

I.3.2.1.2. El Derecho Procesal penal y la teoría del garantismo

I.3.2.1.3. El punto ideal: el garantismo integral y proporcional

I.3.2.2. La lucha contra el crimen organizado: Los derechos y garantías fundamentales no son siempre absolutos

I.3.2.3. El proceso penal garantista y la búsqueda de un enfrentamiento eficiente al crimen organizado

\section{CAPÍTUlO SEGUNDO: LA "EMERGENCIA" PENAL Y EL DERECHO PROCESAL PENAL DEL ENEMIGO COMO POSIBLES SOLUCIONES CONTRA EL CRIMEN ORGANIZADO TRANSFRONTERIZO. UNA AFRONTA AL ESTADO CONSTITUCIONAL DE DERECHO.}

\section{II.1. El proceso penal de "emergencia" y su relación con el tratamiento} jurídico de la delincuencia organizada

II.1.1. Los derechos fundamentales y la "emergencia" como respuesta en la lucha contra la delincuencia organizada

II.1.1.1. La atención hacia la eficacia y la seguridad

II.1.1.2. La "emergencia" penal como posible solución para el control de la criminalidad organizada

II.1.1.3. El triste retorno a un pasado sombrío. El cambiar de las cosas después del 11 de septiembre de 2001

II.1.2. La concepción dogmática del Derecho Penal o Procesal penal del enemigo 156

II.1.2.1. La búsqueda del control de la delincuencia a través del imperativo de ley y orden..

II.1.2.2. Origen histórico de la concepción del "enemigo". 158

II.1.2.3. Qué significa el Derecho Penal y Procesal penal del enemigo.

La polémica contribución de JAKOBS

II.1.2.4. Visión crítica respecto a este pensamiento dogmático 164

II.2. El proceso penal y su lectura constitucional: una realidad innegable 171

II.2.1. El camino único para obtención de eficacia con garantías: Constitución y proceso penal ....

II.2.1.1. El proceso penal y su fórmula ideal: legitimación del ius puniendi con respecto a las garantías

II.2.1.2. La necesidad de una lectura constitucional del proceso penal..

II.2.1.3. Garantías procesales fundamentales en los pactos y convenios internacionales de derechos humanos.

\section{CAPÍTULO TERCERO: LA INVESTIGACIÓN CRIMINAL COMO PIEZA CLAVE EN LA PERSECUCIÓN PENAL}

III.1. La investigación criminal: algunas consideraciones generales 
III.1.2. Contenido de la investigación criminal. 188

III.1.3. Fundamentos y naturaleza del procedimiento de investigación...

III.1.4. La búsqueda de una investigación eficiente. Hay límites en la investigación preliminar

III.1.5. Investigación criminal y delincuencia organizada

III.2. Sociedad de riesgos y la insuficiencia de los actuales medios de investigación criminal 206

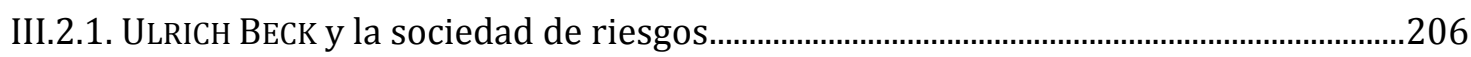

III.2.2. La insuficiencia de los actuales medios de investigación criminal..............................209

III.2.3. Una necesidad incuestionable: la implantación de nuevas técnicas de investigación penal.

\section{CAPÍTULO CUARTO: EL AGENTE ENCUBIERTO COMO MEDIO EXTRAORDINARIO DE INVESTIGACIÓN CRIMINAL}

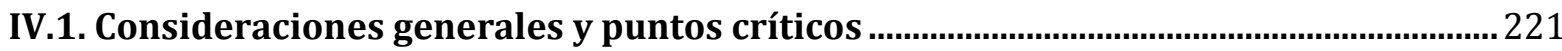

IV.1.1. Agente encubierto: orígenes históricos y marco conceptual ......................................221

IV.1.1.1. Un medio de investigación necesario para combatir el

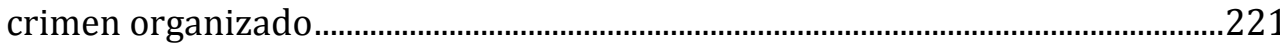

IV.1.1.2. El origen histórico de la figura del "agente encubierto" .................................230

IV.1.1.3. El marco conceptual del agente encubierto y de la técnica de

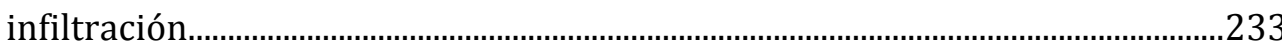

IV.1.2. El agente infiltrado en tratados y acuerdos internacionales........................................239

IV.1.3. Sujeto activo en las operaciones de infiltración .........................................................245

IV.1.4. Distinción junto a otras figuras de interés ......................................................................25

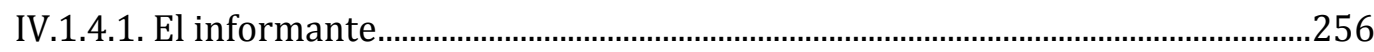

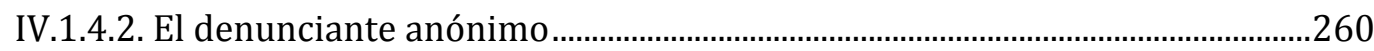

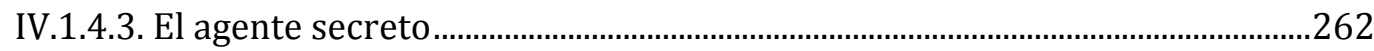

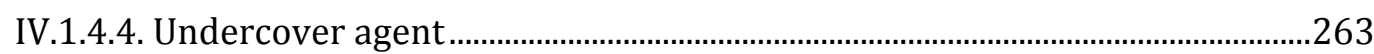

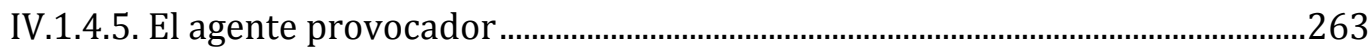

IV.1.5. Una referencia esencial: el "pentiti" en Italia...............................................................269

IV.1.6. Las principales características de la figura del agente encubierto ..............................275

IV.1.6.1. El carácter de medio extraordinario de investigación

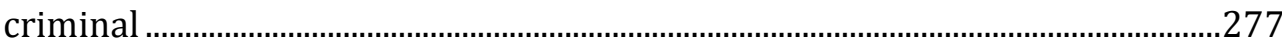

IV.1.6.2. Investigación restricta a la delincuencia organizada ....................................278

IV.1.6.3. Uso de identidad ficticia o supuesta y el engaño.............................................281

IV.1.6.4. La voluntariedad del infiltrado en la operación encubierta ...........................287

IV.1.6.5. La necesidad de justificación para una acción encubierta .............................288

IV.1.7. Principios básicos en una actuación de un agente infiltrado .......................................290

IV.1.7.1. Principio de legalidad ....................................................................................291

IV.1.7.2. Principio de especialidad ...............................................................................292

IV.1.7.3. Principio de subsidiariedad ..........................................................................294

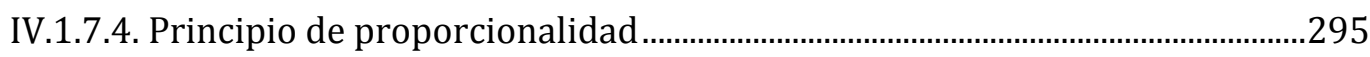

IV.1.7.5. Principio del control jurisdiccional...................................................................296 
IV.1.8. La responsabilidad penal, civil y disciplinaría del agente encubierto:

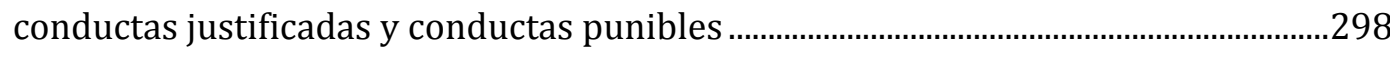

IV.1.8.1. La responsabilidad en el ámbito penal..............................................................298

IV.1.8.2. La responsabilidad civil ...................................................................................312

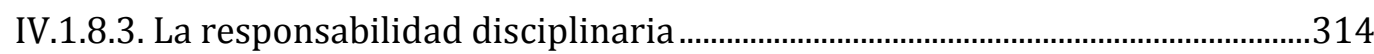

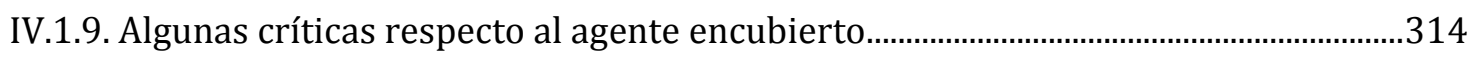

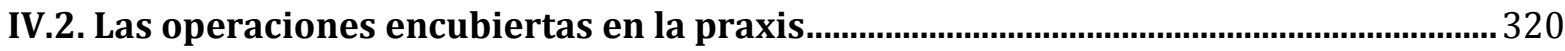

IV.2.1. Operaciones encubiertas: especies y finalidad ............................................................320

IV.2.2. Presunción de inocencia e infiltración policial..............................................................324

IV.2.2.1. Elementos básicos del principio de presunción de inocencia.........................324

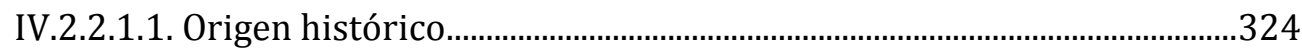

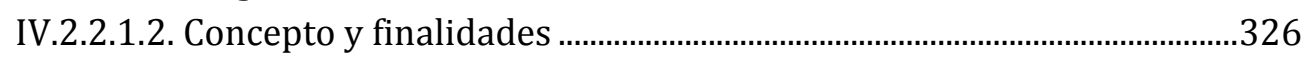

IV.2.2.2. Valoración de las actuaciones del agente infiltrado a la luz de

la garantía de la presunción de inocencia...................................................................330

IV.2.3. Algunas hipótesis de actuación de agentes encubiertos ..............................................334

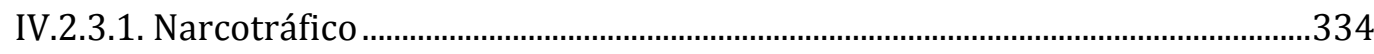

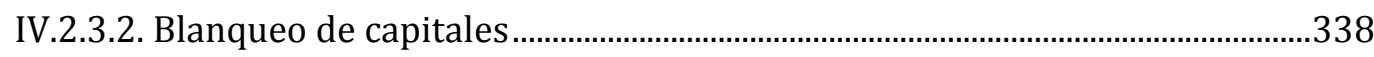

IV.2.3.3. Pedofilia o paidofilia........................................................................................... 340

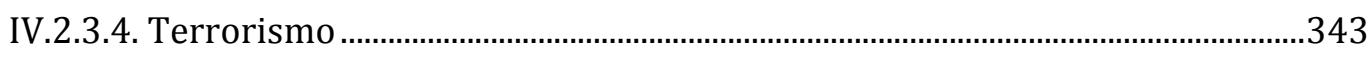

IV.2.4. Valoración crítica del control de la criminalidad organizada a través

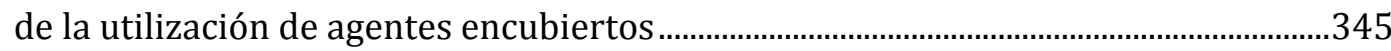

IV.2.5. Las operaciones encubiertas: lectura desde la realidad actual ....................................353

IV.3. La espera por soluciones eficaces en el control de la criminalidad ..............................359

IV.3.1. La necesidad impostergable de establecer un tratamiento procesal adecuado en relación a la criminalidad organizada..........................................................359

IV.3.2. La especialización de los órganos de persecución criminal, en

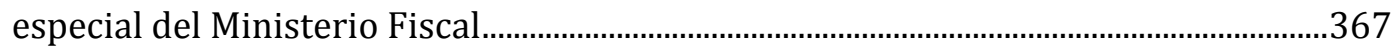

IV.3.2.1. Consideraciones generales sobre el Ministerio Fiscal ....................................367

IV.3.2.2. La creación de Fiscalías especiales ...................................................................371

\section{CAPÍTULO QUINTO: BÚSQUEDA DE UNA REGLAMENTACIÓN IDEAL Y ESPECÍFICA DE LA FIGURA DEL AGENTE ENCUBIERTO}

\section{V.1. Los requisitos básicos para ponerse en práctica una infiltración de un}

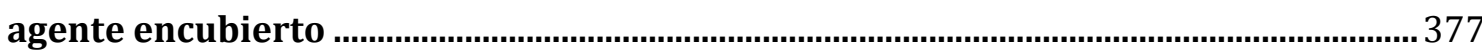

V.1.1. La estructuración de un plan eficaz de infiltración...........................................................377

V.1.2. Necesidad legal de una autorización fundamentada. Ponderación de intereses y principio de proporcionalidad..

V.1.2.1. La exigencia de una autorización motivada para empezar la infiltración

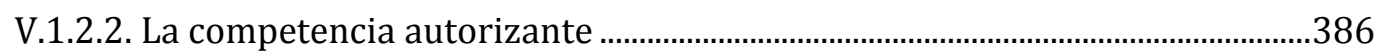

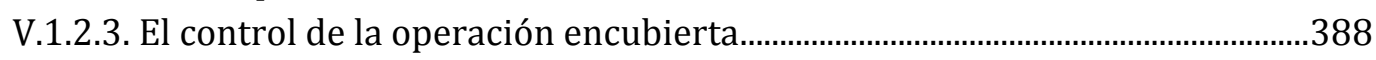

V.1.2.4. El contenido de la resolución autorizante .......................................................393 
V.1.2.5. El contenido original de la resolución y otras diligencias

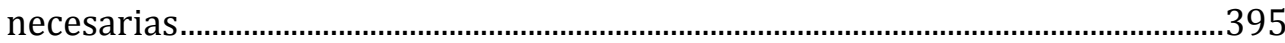

V.1.3. El plazo de duración de la operación encubierta ..............................................................396

V.1.3.1. La necesidad de fijar un plazo determinado para la duración de la infiltración

V.1.3.2. El límite temporal de la infiltración policial ........................................................397

V.1.3.3. Los riesgos en la operación y su repercusión en la duración de la medida

V.1.3.4. La posibilidad de prorrogar las operaciones encubiertas ...............................403

V.1.4. Preparación adecuada de los agentes que van a infiltrarse en una organización criminal

V.1.5. La búsqueda de un equilibrio procesal penal y la actuación de los agentes encubiertos. Especial referencia a los "puntos de equilibrio" que deberán ser alcanzados.

V.2.Límites a la actuación del agente encubierto: el criterio de la ultima ratio.

\section{CAPÍTULO SEXTO: VALORACIÓN DE LAS PRUEBAS OBTENIDAS A TRAVÉS DE LA ACTIVIDAD DEL AGENTE ENCUBIERTO}

VI.1. El derecho probatorio y el agente encubierto 415

VI.1.1. La búsqueda de la verdad en el proceso penal

VI.1.2. El concepto de prueba penal y su carácter de derecho fundamental

VI.1.3. El valor probatorio a ser dado a las pruebas obtenidas por el agente encubierto

VI.1.4. Relevancia del testimonio del agente encubierto

VI.2. Un eterno dilema: las prohibiciones de la prueba en el proceso penal........................ 438

VI.2.1. Breves consideraciones sobre las prohibiciones probatorias

VI.2.2. Las dificultades probatorias en materia de criminalidad organizada.

La prueba penal obtenida en operaciones encubiertas

VI.2.3. Los descubrimientos fortuitos o los hallazgos casuales del agente infiltrado

VI.2.4. El agente encubierto y la prueba ilícita

VI.2.4.1. Puntos de partida para la comprensión de la teoría de la prueba ilícita

VI.2.4.2. En busca de un concepto de prueba ilícita 454

VI.2.5. La prueba ilícita pro societate y el criterio de la proporcionalidad 461

\section{VI.3. El principio de proporcionalidad como limitante fundamental en el} uso de agentes infiltrados

VI.3.1. La valoración de la prueba obtenida en infiltraciones policiales a la luz del principio de proporcionalidad 
VI.3.2. La posible afección de derechos fundamentales en la actuación de un agente encubierto..

CONCLUSIONES.

499

BIBLIOGRAFÍA.

503 


\section{ABREVIATURAS}

Art

Artículo

ATC (AATS) ...................Auto (s) del Tribunal Constitucional

ATS ...............................Auto del Tribunal Supremo

BOE ................................Boletín Oficial del Estado

CE...................................Constitución Española

CADH.............................Convención Americana sobre Derechos Humanos

CEDH................................onvenio para la Protección de los Derechos Humanos y las Libertades Fundamentales

CP.................................ódigo Penal

CRFB............................Constituição da República Federativa do Brasil

EOMF ............................Estatuto Orgánico del Ministerio Fiscal

EUROPOL........................ ficina Europea de Policía

FBI...............................Federal Bureau of investigation

GAFI............................Grupo de Acción Financiera Internacional

INTERPOL.....................International Criminal Police Organization

LECrim.........................Ley de Enjuiciamiento Criminal

LOFCMF .......................ey Orgánica de Funcionamiento del Ministerio Fiscal

$\mathrm{n}^{0}$ …..............................número

ONU .............................. Organización de Naciones Unidas

PJ...............................Poder Judicial

ss..............................siguientes

STC (SSTC).................Sentencia (s) del Tribunal Constiutucional

STEDH (SSTEDH).....Sentencia (s) del Tribunal Europeo de Derechos Humanos

STF ............................Supremo Tribunal de Justiça

STJ ............................Superior Tribunal de Justiça

TC...........................Tribunal Constitucional 
TEDH.......

..Tribunal Europeo de Derechos Humanos

TFUE ..Tratado de Funcionamiento de la Unión Europea

TS

..Tribunal Supremo 


\section{INTRODUCCIÓN}

La constante y vertiginosa evolución de algunas formas de delincuencia, en especial cuando a la gravedad unen los componentes de la organización y la transnacionalidad, nos ha introducido en un mundo novedoso, diferente y mucho más complejo de lo imaginado hace pocos años. En este reciente y dinámico contexto se ha desarrollado, como pieza clave, un nuevo escenario dentro de una "sociedad de riesgos" marcado por una crisis de la Administración de Justicia, más acuciada en el ámbito penal, siendo uno de los factores de esta situación la ineficacia de los medios o técnicas tradicionales de investigación criminal. En este sentido, a día de hoy todavía no se ha logrado alcanzar la fórmula ideal, respetuosa con derechos y garantías procesales constitucionalizadas, que logre poner coto a los avances de la criminalidad posmoderna sin tener que utilizar métodos de búsqueda de pruebas e informaciones que lesionen a los derechos fundamentales de las personas investigadas.

Ante este panorama presentado surge nuestro interés en estudiar el tema de la actuación de la figura denominada "agente encubierto" o "agente infiltrado". Partiendo de la premisa de que el crimen organizado ha alcanzado niveles de sofisticación y de estructuración logística semejantes a una gran empresa, viniendo a provocar graves problemas al nivel de seguridad internacional, incluso poniendo en situación de alarma la estabilidad financiera de un sinnúmero de países, se impone la necesidad de que los órganos de persecución criminal utilicen el trabajo de los agentes encubiertos como forma de penetración en el ambiente cerrado, y demarcado por una implacable ley del silencio, de los grupos delictivos.

Y más que esto. La tarea se extiende a la labor de encuadrar este medio de investigación en el marco de un proceso penal garantista, el cual presenta como característica fundamental la búsqueda por una armonización o equilibrio de las dos fuerzas que se presentan en tensión: la búsqueda de eficiencia por parte del Estado y la preservación de las garantías de aquellas personas sometidas al proceso penal.

Desde esta perspectiva, y teniendo en cuenta las dificultades en conocer a fondo los principales detalles sobre el modus operandi, la estructura física y material, y el "poder de fuego" de algunas de las más conocidas organizaciones criminales, hemos decidido analizar específicamente la situación de esta especial técnica de investigación criminal, el agente encubierto, desde las vertientes fáctica y jurídica, pero sin olvidarnos valorar el objeto de estudio desde la perspectiva del ordenamiento jurídico español, trayendo aportes significativos del Derecho comparado.

Los estudios existentes actualmente acerca del tema del agente infiltrado o son muy escasos, o se limitan a analizar la cuestión desde el punto de vista crítico enfatizando el hecho de que esta técnica de investigación, tal y como se regula en la mayoría de los ordenamientos jurídicos, vulnera de derechos y garantías fundamentales de las personas. De una forma distinta, este tema ha sido abordado en nuestro trabajo desde una perspectiva peculiar y novedosa: el agente encubierto en el marco de un sistema procesal penal garantista, tratando además de presentar diversas sugerencias con el objetivo de encuadrar esta técnica de investigación en los parámetros de constitucionalidad que son característicos de los países democráticos. 
Nos interesa, así, demostrar que la práctica habida en los últimos veinticinco años en la persecución del terrorismo, el narcotráfico, la corrupción o el blanqueo de capitales permite concluir la necesidad de que la figura del agente encubierto sea incorporada a las legislaciones procesales penales como un medio extraordinario de investigación eficaz en la lucha contra las formas más graves de criminalidad, pero siempre que se haga de conformidad con los principios de proporcionalidad y del debido proceso legal. De hecho, así es reconocido por Naciones Unidas en sus esenciales convenciones contra el narcotráfico (Viena, 1988), delincuencia organizada transnacional (Palermo, 2001) y corrupción (Mérida, 2003).

El aparato informativo del que nos hemos valido para el desarrollo de la tesis doctoral ha sido muy abundante y fruto de nuestras pesquisas en varias instituciones de enseñanza e investigación en países como España (Universidades de Salamanca, Complutense de Madrid, Zaragoza y Toledo), Brasil (Universidades de São Paulo y Bahía), Argentina (Universidad de Buenos Aires), Colombia (Universidad Externado) y Portugal (Universidades de Coimbra y Lisboa), amén del notable acervo bibliográfico del Instituto Brasileiro de Ciências Criminais (IBCCRIM). De igual forma han sido muy importantes las pesquisas realizadas en sitios de internet como dialnet (http://dialnet.unirioja.es) o el portal iberoamericano de las ciencias penales (www.cienciaspenales.net).

Ya analizando el cuerpo y estructura del trabajo de investigación, se puede comenzar afirmando que el primero capítulo de la tesis se inicia con un apartado en el cual se aborda de forma directa la actual situación del Derecho Procesal penal contemporáneo. Nuestro estudio se ha basado desde un primer momento en analizar los posicionamientos dogmáticos relativos al estudio de la paradoja existente entre la eficacia del ius puniendi y las garantías y derechos fundamentales del imputado, así como sobre la necesidad del establecimiento de un proceso penal equilibrado. Como paso previo al examen concreto de esta cuestión hemos tenido la oportunidad de estudiar temas muy especiales tales como la tensión de fuerzas en el proceso penal, las funciones del proceso penal moderno, la eficiencia penal, etc.

En este mismo capítulo hemos también tratado el asunto relativo a la eficiencia y las garantías como vertientes del proceso penal equilibrado. El eje central de esta parte de la tesis ha partido del supuesto de eventuales observaciones de una abusiva instrumentalización de las garantías en los más diversos sistemas procesales penales, hecho éste que viene provocando una dificultad hercúlea en el control a la expansión de la criminalidad organizada marcada por la gravedad de sus conductas. En este sentido, ha sido habitual percibir en determinados sectores de la doctrina y de la jurisprudencia una valorización equivocada e irresponsable de los fundamentos del garantismo, y lo más grave, pues se defiende en ocasiones una idea de que las garantías deben ser dispensadas tan solo con relación al individuo, olvidándose de los derechos sociales como la seguridad ciudadana, la cual es inherente a la propia estabilidad de la sociedad.

Como consecuencia lógica de lo afirmado hasta aquí, ha sido analizado del mismo modo el tema del garantismo penal y procesal penal, y su posible compatibilización con el empleo de nuevas técnicas de investigación criminal, muy especialmente con relación al agente encubierto. Así, nosotros hemos defendido la idea de la aceptación de un garantismo positivo e integral, de forma que sean preservados tanto los derechos fundamentales individuales de aquellas personas sometidas a una persecutio criminis 
como los de la colectividad, que tiene derecho a un estatus de seguridad que venga a posibilitar el desarrollo de sus libertades. Han sido en este mismo capítulo analizados los puntos esenciales para la comprensión del fenómeno de la delincuencia organizada, consistiendo este análisis en un estudio que ha empezado con la problemática del concepto de crimen organizado, pasando por otros tantos temas conexos (orígenes, características principales, etc.), viniendo a terminar con una propuesta de medidas penales, procesales y político criminales aptas a proporcionar un control eficaz de la expansión de la delincuencia organizada.

El capítulo segundo del trabajo empieza con un estudio complejo del proceso penal de "emergencia" y su relación con el tratamiento jurídico de la delincuencia organizada. Además, se ha abordado el tema del crecimiento irrazonable del crimen organizado y como asunto "de moda" la tesis dogmática del Derecho Penal y del Derecho Procesal penal del enemigo como forma de lucha contra esta especie de criminalidad. Es importante esclarecer que luego de un análisis en profundidad de este modelo de respuesta penal, marcado por una fuerte carga de restricción al ejercicio de las garantías fundamentales de las personas investigadas o imputadas por delitos graves - como el terrorismo y el narcotráfico-, hemos tenido la oportunidad de demostrar que el Estado puede reaccionar contra estos fenómenos delictivos prevaliéndose de otros medios menos provocadores de vulneraciones innecesarias, los cuales se muestran más compatibles con los principios que habrán de nortear un proceso penal de índole garantista, en especial a partir de la obligatoria observación del principio de proporcionalidad.

El segundo capítulo encierra al tratar del destacado tema de la relación existente entre el Derecho Procesal penal y su lectura constitucional. En el mismo, partimos de la idea central de que un proceso penal marcado por el respeto a las directrices de matriz constitucional vendrá a fortalecer el encuentro del equilibrio entre la necesidad de tener que demostrar la eficiencia estatal y la también imprescindible necesidad de preservar los derechos y garantías fundamentales de los ciudadanos. Consideramos que ha quedado, por lo tanto, debidamente demostrado que el proceso penal moderno debe recibir una lectura constitucional.

El capítulo tercero de la tesis presenta como eje central el tema de la investigación criminal como pieza clave en la persecución penal, donde se ha analizado desde los rasgos característicos de esta fase de la persecutio criminis, pasando por su finalidad y objeto, y completándose con el análisis de la investigación criminal en lo relativo a las más destacadas actuaciones de las organizaciones criminales. No se ha olvidado dejar claro en varias ocasiones que esta actividad que normalmente se queda en manos de los cuerpos policiales deberá sujetarse a límites, de modo que no se permita una injerencia del Estado de forma abusiva sobre los derechos de las personas sospechosas de haber practicado algún delito. En resumen, hemos querido demostrar que la investigación criminal deberá obedecer a los dictados de un proceso penal garantista donde la armonización de los vectores eficiencia y garantía se presentan como un medio ideal para alcanzar un grado de respuesta estatal que venga a satisfacer los anhelos de la sociedad. Por fin, otro tema que ha sido objeto de tratamiento corresponde a la denominada "sociedad de riesgos" y su profunda relación con la visible insuficiencia de los actuales medios extraordinarios de investigación, los cuales no estarían correspondiendo a las expectativas en términos de eficacia, teniendo en vista el crecimiento alarmante de las modernas formas de criminalidad organizada. 
A continuación ha sido abordado, en el capítulo cuarto, el objeto central de nuestra tesis doctoral: el "agente encubierto" o simplemente "infiltrado". Se trata de un estudio que tiene por finalidad llevar a cabo un análisis de esta figura bajo el prisma del garantismo que debe permear el proceso penal contemporáneo. Y la razón para proceder así es muy clara sí consideramos que esta técnica extraordinaria de investigación posee una fuerte carga de restricción al libre ejercicio de los derechos fundamentales de aquellas personas sospechas de haber participado en actividades graves ejecutadas por las más destacadas organizaciones criminales.

En este mismo capítulo del trabajo han sido objetos de estudio tres temas imprescindibles a una primera aproximación directa a la técnica investigativa del agente encubierto: primero, las consideraciones generales y puntos críticos, con énfasis especial con relación a los orígenes históricos y marco conceptual, las normativas internacionales que se refieren al asunto, las más destacadas características de este medio extraordinario de investigación, así como los principios que deberán informar la actuación de estos agentes estatales en el control a la expansión de la delincuencia organizada. En segundo, las operaciones encubiertas en la praxis, habiendo sido preponderante el estudio de la problemática de la eventual compatibilidad entre el principio de presunción de inocencia y la infiltración policial. Del mismo modo hemos tratado, a modo de ejemplificación, de algunas de las más cotidianas actuaciones de los agentes infiltrados. Este capítulo lo hemos cerrado planteando algunas soluciones eficaces para el control del crimen organizado, pudiéndose citar como experiencia novedosa en algunos países, como por ejemplo España, las Fiscalías Especiales creadas para actuar en casos de delincuencia organizada.

Siguiendo con el tema del agente encubierto, en el quinto capítulo hemos estudiado la búsqueda de una reglamentación ideal o próxima de esta figura, con la intención de establecer ciertos requisitos obligatorios que a nuestro juicio deberán ser observados en los casos de autorización para una operación encubierta de infiltración. De este modo, han recibido especial atención los temas de la estructuración de un plan eficaz de infiltración, el cual deberá recibir un planeamiento detallado y dotado de los recursos necesarios para alcanzar el éxito de la operación y de la imprescindible ponderación en la expedición de la resolución de autorización para la labor del agente infiltrado en una determinada organización criminal. También, la no menos importante preparación de los miembros o agentes estatales que van a ingresar en el clan de delincuentes organizados, a la vez que deberán recibir entrenamiento físico, psicológico y técnico para el buen desarrollo de sus actividades. Se cierra este capítulo tras establecer los límites esenciales para la realización de una operación de infiltración policial, de modo que pueda ser encuadrada en el contexto de los parámetros de constitucionalidad inherentes a un Estado de Derecho. Estos límites tienen como objetivo establecer criterios para que la actuación del agente encubierto pueda ajustarse a los puntos de equilibrio que van a ayudar la conformación de un proceso penal garantista marcado por una armonía entre los vectores de eficiencia y garantía.

Por fin, en el último capítulo de la tesis nos hemos decidido a enfrentar uno de los temas más duros y controvertidos respeto al agente infiltrado, o sea, como deberán ser valoradas las pruebas obtenidas a través de realización de operaciones encubiertas. Los eternos dilemas de las prohibiciones en materia probatoria han sido el marco inicial de este estudio sobre la probática aplicada al tema de las infiltraciones policiales en el crimen 
organizado. Como consecuencia lógica, han sido destacados los principales problemas y dificultades en la búsqueda de material probatorio cuando se tratan de investigaciones relativas a clanes de delincuentes organizados que actúan a nivel transnacional. En este mismo contexto, la teoría de la prueba ilícita ha recibido especial atención, especialmente en relación al tema de la excepcional aceptación de la ilicitud probatoria pro societa desde que analizado el caso concreto a la luz del principio de ponderación de intereses, esto es, la proporcionalidad penal.

Además, se ha puesto de relieve la discusión respeto a la actuación encubierta y los derechos fundamentales a la intimidad, a la no autoincriminación y a la autodeterminación informativa.

Probablemente este trabajo no encontrará todas las soluciones para poner fin a la cuestión de la limitación de los derechos fundamentales afectados por medidas invasivas en la investigación criminal, como ocurre especialmente en la hipótesis de la labor de los agentes encubiertos en la lucha contra el crimen organizado. Sin embargo, el estudio por nosotros desarrollado nos conducirá, obligatoriamente, hasta una significativa conclusión general: la utilización del medio extraordinario de investigación criminal a través de la infiltración de agentes estatales se halla seriamente amenazado en razón de algunos ordenamientos jurídicos no incorporaren en sus respectivas legislaciones criterios específicos y detallados respeto a la puesta en práctica de esta técnica de control de la delincuencia organizada; incluso más, por no establecieren de forma clara y cristalina la incorporación de los principios de proporcionalidad y sus subprincipios de idoneidad, necesidad y ponderación. De este modo, hemos concluido que no se puede aceptar la actuación del infiltrado cuando su actividad va en contra los mandatos prescritos en la orden constitucional. 


\section{CAPÍTULO PRIMERO: LOS DESAFÍOS DEL PROCESO PENAL CONTEMPORÁNEO}

\section{I.1. La paradoja: eficacia del ius puniendi versus garantías y derechos fundamentales del imputado. La necesidad de un proceso penal equilibrado.}

\section{I.1.1. Tensión dialéctica de fuerzas y proceso penal.}

I.1.1.1. Criminalidad de los nuevos tiempos y la crisis del Derecho Procesal penal.

La realidad actual es indiscutible: el proceso penal vía de sus medios tradicionales de investigación y persecución del delito, no consigue dar una respuesta eficaz y concreta a la expansión de ciertas formas graves de criminalidad. Se quiere con esta afirmación, decir que las técnicas y medios normalmente empleados en el proceso penal como forma de obtenerse resultados eficaces en la búsqueda de la realización de la justicia penal, a ejemplo de las escuchas telefónicas, las pruebas periciales y las vigilancias o seguimientos personales, en los días actuales son insuficientes por sí solas para hacer frente en la persecución de las más destacables organizaciones criminales de carácter transnacional ${ }^{1}$.

Entonces, en general, se observa que las reglas procesales penales no han sido actualizadas de forma satisfactoria de modo a acompañar el desarrollo de las sociedades y de los problemas enfrentados en razón del crecimiento de la delincuencia.

Sin embargo, esta deseada modernización del proceso penal, al contrario de lo que piensan muchos, no es incompatible con el establecimiento de un Derecho procesal penal marcado por el respeto a las garantías y derechos fundamentales de los ciudadanos. Éste es un punto muy importante a tener en cuenta, en la medida en que presenciamos actualmente un proceso penal de índole garantista.

Es cierto, además, que el modelo y la construcción del proceso penal tienen que responder a los parámetros de constitucionalidad, respetando a los principios fundamentales, definiendo institutos y creando soluciones que puedan preservar los derechos fundamentales procesales y permitan realizar en el proceso la máxima concordancia práctica entre valores relativos a derechos fundamentales materiales².

Presenciamos entonces, la necesidad en los días actuales de establecimiento de un Derecho procesal penal garantista, el cual deberá tener como pilar de sustentación, las normas constitucionales de preservación de los derechos y garantías fundamentales de los ciudadanos e incluso de la propia colectividad.

\footnotetext{
1 En este sentido, relativamente al ordenamiento español, destaca GÓMEZ DE LIAÑO FONSECA-HERRERO que "resulta pacífico que nuestra Ley procesal penal era y es obsoleta, en cuanto a las diligencias aseguradoras del éxito de la fase de instrucción, máxima cuando nos referimos a una forma de criminalidad, que el legislador decimonónico no pudo prever". Vid. GÓMEZ DE LIAÑO FONSECA-HERRERO, M., Criminalidad organizada y medios extraordinarios de investigación, Madrid, 2004, pág. 40. Se destaca así la criminalidad organizada, representada especialmente por el trípode (narcotráfico, terrorismo y criminalidad económica), la cual ha asumido, ya desde hace tiempo y en continua progresión, nuevas características, ya sea por los mercados ilícitos que maneja, por los instrumentos que utiliza y, también, por la estructura que ha alcanzado y además por el alto nivel de sofisticación que caracteriza las bandas más destacadas de la delincuencia transfronteriza.

2 Vid. HENRIQUES GASPAR, A., "As exigências da investigação no processo penal durante a fase de instrução", VV.AA., Que futuro para o Direito processual penal?, Simpósio em homenagem a Jorge de Figueiredo Dias, por ocasião dos 20 anos do Código de Processo Penal português, Coimbra, 2009, pág. 87.
} 
Desde otra vertiente, han cambiado las notas características de la delincuencia que hasta entonces conocíamos, a la vez que vivimos ahora momentos de cierta inseguridad y miedo. En verdad, se observa un auténtico efecto alarma mundial en pro de la contención de la violencia.

Como señala BARONA VILAR, ha surgido lo que algún autor viene denominando como "terrorismo de la seguridad", producto de los tiempos que vivimos, en los que el derecho penal se ha convertido en la pócima aparentemente mágica de todos los males3.

En palabras de FERRAJOLI, incluso ha cambiado ante todo la cuestión criminal. En efecto, es de estos años el desarrollo de una criminalidad nueva, de la cual provienen las ofensas más graves a los derechos fundamentales y a la convivencia civil: la criminalidad del poder, en la doble forma de los poderes criminales, es decir, de la criminalidad organizada de la mafia y de la Camorra, pero también los crímenes del poder, desde los atentados hasta las intentonas de golpes de Estado, desde las tramas de los poderes invisibles hasta la gran corrupción organizada. Se trata de una criminalidad relativamente nueva, que es quizás el signo más perverso de la crisis profunda por la que ha atravesado en estos años nuestro sistema político4.

Ante esta realidad, las modernas estructuras de criminalidad, especialmente, el terrorismo, el blanqueo de capitales y el tráfico de estupefacientes, frecuentemente muy bien planeadas y organizadas, son dotadas de medios tecnológicos más avanzados y, por esto mismo, particularmente eficaces en el ejercicio de sus actividades criminosas, que atentan gravemente contra la seguridad e intereses fundamentales de los Estados, bien como la salud y bien estar de los ciudadanos ${ }^{5}$.

Se percibe entonces que el crimen organizado de carácter trasnacional ejerce la labor de práctica de actos graves de delincuencia, utilizándose de una estructura logística que puede ser comparada a una gran empresa, donde la jerarquía y la competitividad son las dos notas más características que se pueden observar.

Por lo tanto, la delincuencia organizada en los días de hoy presenta un grado de profesionalidad altísimo, equiparándose frecuentemente a grandes grupos empresariales, dotados de un fuerte poder financiero y tecnológico ${ }^{6}$.

\footnotetext{
3 BARONA VILAR, S., Seguridad, celeridad y justicia penal, Valencia, 2004, pág. 14. De todo modo, se puede afirmar que "el crimen transnacional ha ascendido por lo tanto a un nuevo estrellato en las guerras de la retórica de la seguridad internacional". En este sentido, Vid. SERRANO, M., "Crimen transnacional organizado y seguridad internacional. Cambio y continuidad", VV.AA., Crimen transnacional organizado y seguridad internacional. Cambio y continuidad, M. Serrano., M. Berdal coords., México, 2005, pág. 27. Interesante además sobre el tema de la inseguridad en los días actuales, la obra de CURBET, J., La glocalización de la (in) seguridad, Madrid, 2006. En este trabajo, el autor utiliza como titulo el término "glocalización" —y no globalización-, que ha sido utilizado recientemente por algunos sociólogos, en especial por Ulrich Beck, conocido por su popularización del paradigma de la sociedad del riesgo, y que corresponde a la realidad de un Estado-nación en fase de explosión/implosión en razón del crecimiento de la inseguridad y de la violencia.

4 FERRAJOLI, L., "Garantías y Derecho Penal", Democracia y garantismo, Madrid, 2008, pág. 200.

5 Vid,. GONÇALVES, F., JOÃO ALVES, M., GUEDES VALENTE, M. M., Lei e Crime. O agente infiltrado Versus o agente provocador. Os princípios do processo penal, Coimbra, 2001, pág. 253.

${ }^{6}$ Respecto del carácter empresarial de las grandes organizaciones criminales, FAZZONE señala que "las asociaciones criminales han elevado a ciencia este empeño". Vid. FAZZONE, E., "La valorización de la prueba en los procesos de criminalidad organizada", Poder Judicial, núm. 48, 1997, pág. 419. Además, como explica ZÚÑIGA RODRÍGUEZ, "las ganancias que obtiene la criminalidad organizada por sus negocios ilícitos son descomunales". Vid. ZÚÑIGA RODRÍGUEZ, L., Criminalidad organizada y sistema de derecho penal. Contribución a la determinación del injusto penal de organización criminal, Granada, 2009, pág. 3.
} 
En consecuencia, no se puede dudar que esas "nuevas" formas de delincuencia requieran la debida actualización del sistema penal, a efectos de que la respuesta sea de acuerdo con la gravedad y complejidad del fenómeno ${ }^{7}$.

Se observa como hemos ya mencionado, que los instrumentos penales y las técnicas de investigación tradicionales son insuficientes ${ }^{8}$ para hacer frente a un tipo de criminalidad que generalmente actúa en ámbitos transnacionales, posee una capacidad operativa muy superior a la de las clásicas organizaciones de delincuentes y dispone de ilimitados medios para la perpetración de los delitos, y que son necesarias nuevas respuestas en el orden penal, en el plano procesal y en el marco de la cooperación internacional ${ }^{9}$.

Respecto a este último aspecto, es básico que las autoridades judiciales de cada Estado tengan confianza en los sistemas judiciales de los restantes Estados ${ }^{10}$. La fe en las

7 AROCENA, G. A., "El agente encubierto. Consideraciones político-criminales", VV.AA., Temas de derecho procesal penal (Contemporáneos), J. I. Cafferata Nores y G. A. Arocena coords., Córdoba, 2001, pág. 110. Todavía, como advierte SOTOMAYOR ACOSTA, el gran problema es que "se busca la relativización de las reglas de imputación jurídica, de las garantías político-criminales y de los criterios procesales, con miras a que el sistema penal ofrezca más resultados y nuevas respuestas frente a la grave situación provocada por la delincuencia organizada". Vid. con detalles respecto a esta problemática, SOTOMAYOR ACOSTA, J. O., "Los estragos de la lucha contra la criminalidad organizada en el sistema penal: el caso colombiano", Revista de Derecho Penal, núm. 17, Montevideo, 2008, págs. 101-117.

8En este sentido, explica HURTADO POZO que "la condición y la complejidad que distinguen la nueva criminalidad ponen en evidencia la ineficacia de la reacción penal tradicional. Ésta tiene sus orígenes y ha sido organizada pensando en la necesidad de combatir la delincuencia individual común. De ahí, la urgencia de renovar, completar y perfeccionar el sistema de control penal en todos sus niveles: órganos de represión y de control, principios procesales y legislación penal material. De esta manera, se tiende a establecer un marco normativo eficaz, organizar los mecanismos nacionales e internacionales para perseguir a los responsables, establecer reglas de control policial y judicial transnacionales. Vid. HURTADO POZO, J., "Globalización y delincuencia organizada", Orientaciones de la Política Criminal legislativa, M. Moreno Hernández coord., México, 2005, pág. 21. Además, como ha señalado SCHNEIDER, "la comunidad internacional, desde hace algunos años, fue tomando consciencia de que pretender combatir el crimen organizado con las mismas vías legales que las arbitradas para la delincuencia común era absolutamente inoperante". Vid. SCHNEIDER, J.J., "Recientes investigaciones criminológicas sobre la criminalidad organizada", Revista de Derecho Penal y Criminología, núm. 3, 1993, pág. 724.

9 ZARAGOZA AGUADO, J. A., "Tratamiento penal y procesal de las organizaciones criminales en el Derecho español. Especial referencia al tráfico ilegal de drogas", VV.AA., "Delitos contra la salud pública y contrabando", Cuadernos de derecho judicial, núm. 5, 2000, pág. 112. Como consecuencia, respecto a la colaboración con la Administración de Justicia, afirman MAPELLI CAFFARENA; GONZÁLEZ CANO y AGUADO CORREA que "la colaboración entre los distintos responsables en la lucha contra la delincuencia organizada es uno de los factores básicos para alcanzar una represión eficaz de dicho tipo de delincuencia. Como se afirma en el Plan de Acción contra la delincuencia organizada de 1997, es necesarioque se intente alcanzar un efecto máximo de sinergia en la cooperación entre los servicios encargados del cumplimiento de la ley y el Poder Judicial". Vid. MAPELLI CAFFARENA, B; GONZÁLEZ CANO, Mà I I y AGUADO CORREA, T., Estudios sobre Delincuencia Organizada. Medios, instrumentos y estrategias de la investigación policial, Sevilla, 2001, pág. 35. Todavía, para un específico estudio sobre la cooperación penal internacional, Vid. ARANGÜENA FANEGO, C., "Avances en la cooperación judicial penal en la Unión Europea", VV.AA., Logros, iniciativas y retos institucionales y económicos : la Unión Europea del siglo XXI, I. Vega Mocoroa coord., 2005, págs. 101-133; BUJOSA VADELL, L., La cooperación procesal de los Estados con la Corte Penal Internacional, Barcelona, 2008; CARRIZO GONZÁLEZ-CASTELLS, A., "La colaboración entre Estados en el ámbito penal: técnicas de cooperación jurídica internacional", VV.AA., Hacia un Derecho penal sin fronteras, Ma․ R. Diego Días-Santos y V. Sánchez López coords., Madrid, 2000, págs. 149-160; DAMASO SIMÕES, E., "Cooperación judicial en materia penal dentro de la Unión Europea. Perfeccionamiento de los mecanismos de acción y coordinación", Revista del Ministerio Fiscal, núm. 9, Madrid, 2001, págs. 147-153; GONZÁLEZ VIADA, N., Derecho penal y globalización. Cooperación penal internacional, Madrid, 2009.

10 Significa en concreto que es mejor conocer otros ordenamientos jurídicos y confiar en el actuar de los operadores jurídicos de otros países, o dar efectos jurídicos a las resoluciones judiciales de otros países. 
garantías procesales que se observan en cada uno de ellos y la imparcialidad con la que se desarrollan los procesos que se sigan servirá para reforzar esa confianza mutua11.

Así, la unión de esfuerzos en materia de cooperación policial y judicial internacional, posibilitando el libre tránsito de las autoridades de diversos países por las áreas afectadas por la actuación de grupos de delincuentes organizados, a ejemplo de la creación de equipos conjuntos de investigación ${ }^{12}$, añadido a un reglamento penal y procesal penal ${ }^{13}$ moderno y adecuado a los nuevos tiempos, o sea, aptos a la concreción de la actividad persecutoria, podrán representar una esperanza en el control de la expansión de esta especie grave e insoportable de criminalidad ${ }^{14}$.

Dicho en otras palabras, concretamente por lo que respeta al ámbito penal del "espacio de libertad, seguridad y justicia", el notable aumento y agravamiento de las distintas formas de terrorismo y criminalidad organizada trasnacional demanda un incremento y facilitación de la cooperación interestatal, así como una actuación normativa común y armonizada que coadyuve al tan deseado objetivo de la prevención de la delincuencia y la eficaz lucha contra el crimen ${ }^{15}$.

Específicamente en relación a la delincuencia organizada, se observa que la misma se caracteriza por la combinación de determinados factores como son la sofisticación, el uso de las nuevas tecnologías a la hora de delinquir y la estructuración fragmentaria de que se compone. Estos factores hacen con que las técnicas tradicionales de investigación, como pueden ser la entrega y registro o intervención de comunicaciones, por sí solas, no puedan hacer frente a esta criminalidad 16.

11 BLANCO PEÑALVER, A., "El estado actual de las garantías procesales penales en el ámbito de la Unión Europea", VV.AA., Derecho y Justicia Penal en el siglo XXI, Liber Amicorum en homenaje al profesor Antonio González-Cuéllar García, Madrid, 2006, pág. 801. Por esto, algún autor, así HURTADO POZO, señala que "Los esfuerzos de uniformizar las leyes y los procedimientos, constituyen evidentemente pasos decisivos para combatir la nueva criminalidad. Habiendo ésta aprovechado y explotado las condiciones creadas por la globalización, su represión no puede alcanzar el nivel deseado sin que sea organizada a nivel supranacional". Vid. HURTADO POZO, J., "Globalización y delincuencia organizada", cit., pág. 25. También con detalles sobre el tema de la "Confianza mutua y armonización de ordenamientos", Vid. HOYOS SANCHO, M., "Armonización de los procesos penales, reconocimiento mutuo y garantías esenciales", VV.AA., El proceso penal en la Unión Europea: garantías esenciales, Valladolid, 2008, págs. 44-53.

12 Monográficamente, Vid. VALLINES GARCÍA, E., Los equipos conjuntos de investigación penal. En el marco de la cooperación policial y judicial entre los Estados de la Unión Europea, Madrid, 2006.

13 Lo que deberá quedar evidente es que cuando se habla de "reglamentos adecuados y modernos", se busca destacar que es notoria la necesidad de que los mismos presenten en sus textos preceptos penales y procesales específicos en la lucha contra las formas más graves de criminalidad, a ejemplo del uso de las técnicas extraordinarias de investigación, el comiso de bienes, etc.

14Respecto a este tema, sostiene con absoluta claridad CAFFERATA NORES que "contrariamente a lo que pregonan a algunos discursos (más o menos en boga según los vaivenes de la política), el hecho de que un sistema penal funcione en un Estado de derecho de base democrática, no significa para nada que deba ser blando, ni mucho menos que pueda favorecer la impunidad. Por el contrario, tiene que ser eficiente para lograr igualitariamente (o sea, tanto para enemigos como para amigos) el castigo del delito en todos los casos que así lo establezca la ley; pero especialmente en los relacionados con sus expresiones más violentas o aberrantes, con la criminalidad organizada, con el ilícito financiero y económico, y con la corrupción gubernamental y administrativa (anterior y contemporánea)". Vid. CAFFERATA NORES, J. I., "Crisis de eficacia de la investigación penal, causas, peligros, soluciones (Derecho de la víctima a una investigación eficiente)", Ejercicio concreto del poder penal. Límites, abusos, desafíos, J. I. Cafferata Nores coord., Córdoba, 2006, pág. 17.

15 Vid. HOYOS SANCHO, M., "Armonización de los procesos penales, reconocimiento mutuo y garantías esenciales", cit., pág. 43.

16 ESPINOSA DE LOS MONTEROS, R. Z., "El agente encubierto en el ordenamiento jurídico español", La prueba en el espacio europeo de libertad, seguridad y justicia penal, Navarra, 2006, pág. 227. 
En consecuencia, estos medios ya conocidos de búsqueda de datos, informaciones y pruebas que puedan servir al desarrollo de la persecutio criminis son absolutamente neutralizados por las técnicas de contrainteligencia de los clanes organizados, y de manera obvia, generando una sensación de desigualdad en la lucha contra la delincuencia.

Además, el modo como son perpetrados los delitos en el ámbito de las organizaciones criminales, incluyendo aquellas de molde empresarial, hace con que parte del instrumental procesal penal concebido para la criminalidad tradicional, o sea, las reglas contenidas en la ley, especialmente en el campo de las pruebas, se revele insuficiente ${ }^{17}$.

Pues bien, la verdad es que en los últimos tiempos y, en gran medida, potenciado por la pretendida lucha del Estado contra la denominada criminalidad organizada, se viene asumiendo una restricción de los principios que rigen el normal funcionamiento del sistema punitivo en su conjunto, a saber, tanto el Derecho penal como el Derecho procesal penal ${ }^{18}$.

De otra parte y concretamente, debemos afirmar una vez más que el proceso penal presenta dificultades con relación a la persecución de delitos practicados por la criminalidad organizada ${ }^{19}$.

Como forma de agresión a la paz, a la seguridad y a la estabilidad de las sociedades libres y democráticas, esta forma de delincuencia transnacional conduce los más distintos países a buscar respuestas institucionales comunes.

Esto nos pone en presencia de otra interesante cuestión: la lucha contra la criminalidad se organiza típicamente a través de la limitación de derechos fundamentales ${ }^{20}$. En realidad, en casi todo proceso penal, la intromisión del Estado en la

17 BALTAZAR JR, J. P., "Limites constitucionais à investigação. 0 conflito entre o direito fundamental a segurança e o direito de liberdade no âmbito da investigação criminal", Limites constitucionais da investigação, R. Sánchez Cunha., P. Taques y L. F. Gomes coords., São Paulo, 2009, pág. 211. En congruencia con lo expuesto nótese aún que no es posible olvidar que la prueba en el proceso penal es utilizada para la búsqueda de la verdad real delante de un caso concreto, objeto de aquella relación procesal. Y en dicha línea, los mecanismos probatorios han de se servir a la formación del convencimiento del juez, y al mismo tiempo, cumplen función no menos importante de justificar junto al cuerpo social la decisión adoptada; en otras palabras, además de ser un procedimiento cognitivo, la prueba es también un fenómeno psicosocial y desde ahí la extraordinaria importancia de su naturaleza y del modo como son obtenidas e incorporadas al proceso. En este sentido, Vid. GOMES FILHO, A. M., Direito à prova no Processo Penal, São Paulo, 1997, pág. 13. Para una mayor profusión respecto al tema, Vid. la clásica obra de CARNELUTTI, F., Das provas no Processo Penal, 1aㅡ edición, Campinas, 2005.

18 Vid. de forma integral este pensamiento dogmático en PORTILLA CONTRERAS, G., "Fundamentos teóricos del Derecho penal y procesal penal del enemigo", Jueces para la democracia, núm. 49, 2004, págs. 4350 .

19 Con el crecimiento de los grupos criminales organizados en los últimos tiempos y delante de los actos terroristas ocurridos en Nueva York, Washington, Madrid y Londres, "se discute si los poderes públicos son capaces de afrontar estos nuevos rectos o, realmente, las actuales Leyes y Reglamentos, dictadas, al menos formalmente, en base al respetode los principios y garantías fundamentales, son obsoletas e incapaces para responder a dichos desafíos. Va cobrando espacio la consigna fundamentada en una supuesta relación inversa entre garantías y seguridad. Por la misma se sostiene la necesidad de endurecer las leyes y medidas policiales para aumentar la seguridad, con un coste directo para los derechos humanos y las garantías penales y procesales". Vid. DAUNIS RODRÍGUEZ, A., "Seguridad, Derechos humanos y garantías penales: ¿Objetivos comunes o aspiraciones contrapuestas?", VV.AA., penal de la democracia vs. Seguridad pública, I Derecho. Berdugo Gómez de la Torre y N. Sanz Mula coords., Granada, 2005, pág. 213.

${ }^{20}$ HASSEMER, W., "Processo penal e direitos fundamentais", Jornadas de Direito Processual Penal e Direitos Fundamentais, M. F. Palma coord., Coimbra, 2004, pág. 17. Siguiendo idéntica línea de pensamiento, señala CHOCLÁN MONTALVO que "durante estos últimos años, y en el escenario político criminal comparado, se comprueban mejoras legislativas donde han sido objeto de especial regulación por una parte, la permisividad 
investigación puede generar una colisión entre los derechos fundamentales del afectado por el proceso con los derechos fundamentales de los demás ciudadanos que legitiman la persecución penal. Así, puede comprenderse que el proceso penal puede afectar de manera grave los derechos fundamentales de las personas y por ello es menester encontrar un punto de equilibrio entre la necesaria investigación de los hechos punibles, la salvaguardia de los derechos fundamentales y la dignidad humana ${ }^{21}$.

Teniendo claro que los derechos fundamentales deben ser preservados, habrá que encontrarse, por la ponderación, criterio que no atente contra el núcleo esencial de los derechos fundamentales, pero que preserve también el interés de toda la sociedad, en la persecución y punición de hechos delictuosos, sea quien sea que los haya cometido ${ }^{22}$.

Por lo demás, conviene destacarse un factor altamente preocupante, pues se habla incluso de una crisis ${ }^{23}$ que impregna actualmente el Derecho procesal penal, o peor, la propia administración de justicia penal.

Sobre el tema, se nota que la administración de justicia es burocrática, está sobrecargada de trabajo, enfrenta problemas respecto al tema de la investigación ${ }^{24}$, no respeta las garantías ciudadanas previstas en la Constitución, no atiende a las personas, es

de la utilización de técnicas modernas para afrontar la búsqueda de pruebas, y por otra, métodos novedosos y extraordinarios de investigación que permiten afirmar que la política criminal imperante en los últimos años supone importantes restricciones de derechos fundamentales". Vid. CHOCLÁN MONTALVO, J. A., "La criminalidad organizada. Concepto. La asociación ilícita. Problemas de autoría y participación", La criminalidad organizada. Aspectos sustantivos, procesales y orgánicos, Cuadernos de derecho judicial, 2001, pág. 218. Desde una vertiente distinta, advierte PORTILLA CONTRERAS que "el sistema procesal-penal contra la criminalidad organizada se ha caracterizado por una constante restricción de los principios básicos que rigen el tradicional funcionamiento tanto del Derecho penal como del Derecho procesal penal". Vid. PORTILLA CONTRERAS, G., "El Derecho penal y procesal penal del enemigo. Las viejas y nuevas políticas de seguridad frente a los peligros internos-externos", VV.AA., Dogmática y Ley Penal, libro homenaje a Enrique Bacigalupo, Tomo I, J. L. Barja de Quiroga; J. M. Zugaldía Espinar coords., Madrid/Barcelona, 2004, pág. 693.

21 CONTRERAS Alfaro, L. H., Corrupción y Principio de Oportunidad Penal. Alternativas en materia de prevención y castigo a la respuesta penal tradicional, Salamanca, 2005, pág. 25. Por esto, con razón GUZMÁN FLUJA al afirmar categóricamente que "el proceso penal es un instrumento de resolución de conflictos, de los llamados conflictos sociales o de trascendencia social, en los que se produce, con mayor o menor dimensión, una lesión del interés social, del interés público, del interés general, lesión que se alzaprima y que absorbe a la lesión individual o grupal sufrida, esto es, al interés particular, aunque no lo elimina". Vid. GUZMÁN FLUJA, V. C., Anticipación y preconstitución de la prueba en el Proceso Penal, Valencia, 2006, pág. 143. También en la misma línea de pensamiento, GIMENO SENDRA, V., Fundamentos del Derecho Procesal, Madrid, 1981, págs. 21 y ss.

22 Vid. BECHARA, F. R., "Crime organizado e o sigilo na investigação", Revista Síntese de Direito Penal e Processsual Penal, núm. 32, Porto Alegre, 2005, pág. 60. A este modo de pensar se denomina "garantismo integral y proporcional". A respecto y con detalles, VV.AA., Garantismo penal integral. Questões penais e processuais, criminalidade moderna e a aplicação do modelo garantista no Brasil, B. Calabrish; D. Fischer y E. Pelella coords., Salvador, 2010.

${ }^{23}$ Incluso, CAFFERATA NORES habla de una "crisis de eficacia de la investigación penal". Vid. CAFERRATA NORES, J. I., Ejercicio concreto del poder penal. Límites, abusos, desafíos, cit., págs. 17-19. En el mismo sentido se mantiene SÚAREZ-BÁRCENA, E. L., El modelo constitucional de investigación penal, Valencia, 2001, pág. 11. Ya en opinión de BARONA VILAR, con la cual no estamos totalmente de acuerdo, "la justicia ha entrado en un laberinto donde no se sabe si estamos ante una verdadera crisis, ante la exteriorización de insatisfacción de sujetos o sectores, quizás ante la ineficiencia o inoperancia del sistema mismo o simplemente quizás nos hallamos inmersos en una gran evolución jurídica que afecta, en consecuencia, a todos los ámbitos del derecho". Vid. BARONA VILAR, S., "Conformidad del acusado, paradigma de eficiencia de la Justicia Penal", VV.AA., Terrorismo y Proceso Penal Acusatorio, J. L. Gómez Colomer y J. L. González Cussac coords., Valencia, 2006, pág. 400.

24 Muchas veces el poder de investigación es cuestionable en algunos ordenamientos jurídicos, a la vez que la propia Constitución no lo permite de forma explícita o por otra parte, cuando una abusiva instrumentalización de las garantías dificulta la puesta en práctica de algunas técnicas investigativas más invasivas a los derechos fundamentales. 
lenta y formalista, está alejada de los ciudadanos y carece de prestigio social. Todos estos atributos, son elementos de la crisis ${ }^{25}$.

No obstante lo anterior, es bien sabido que el proceso penal en realidad atraviesa una caótica crisis en escala mundial. A respecto, las cuestiones que se pueden poner en la mesa de discusión son varias: lentitud para resolver los asuntos, insuficiencia de personal y de recursos económicos, ineficiencia para solventar las necesidades y expectativas de la víctima, excesiva burocratización del sistema de justicia, restricciones jurisdiccionales en materia de competencia territorial, entre otras ${ }^{26}$.

En cualquier caso, según la doctrina acentuadamente crítica, el servicio público de la Justicia no funciona o, si se prefiere, lo hace con tales deficiencias que no satisface mínimamente la demanda social27. Es por ello que se habla de crisis, de insatisfacción, de ineficiencia y de transformación; y más, podríamos seguir incluso calificando el momento con diversos términos, porque es constatable que un poco de todos ellos efectivamente configuran el estado actual de la justicia penal28.

Interesante todavía es la opinión de RODRÍGUEZ GARCÍA, cuando defiende que no tiene mucha justificación seguir recurriendo al denostado tema de que la administración de justicia está en crisis para intentar calmar los anhelos insatisfechos de todos aquellos que reclaman una justicia penal garantista pero que además sea rápida, barata y eficaz ${ }^{29}$. Esta nos parece ser una visión más realista y pragmática de esta discusión.

Asimismo, y por desgracia, no se puede negar que el proceso penal se encuentra en medio a una grave crisis relativa a una tensión de fuerzas que nos lleva incondicionalmente a una búsqueda del equilibrio entre la eficacia del ius puniendi estatal y la preservación de los derechos y garantías fundamentales de las personas sometidas al proceso penal ${ }^{30}$.

25 BINDER, A. M., Política criminal, de la formulación a la praxis, Buenos Aires, 1997, pág. 133. Abordando profundamente el tema de la crisis en el ámbito procesal penal, Vid. BERTOLINO, P. J., Proceso penal y servicio de la justicia, La Plata, 1992, págs. 82 y ss; LUCIANO GARCIA, J. A., "La crisis o el cuestionamiento al sistema penal. La diacronía genealógica entre el garantismo y la eficiencia", Revista de Ciencias Penales, núm. 2, Montevideo, 1996, págs. 59-82.

26 Vid. DAGDUD KALIFE, A., La prueba testimonial ante la delincuencia organizada, México, 2006, pág. XXVII. Con profundidad respecto a estas cuestiones, véase VV.AA, Crisis de la Justicia y reformas procesales. I Congreso de Derecho Procesal de Castilla y León, M. C. Calvo Sánchez y E. Pedraz Penalva coords., Madrid, 1988.

27 Así por ejemplo, Vid. MORENO CATENA, V., "La Justicia Penal y su reforma", Justicia, núm. 2, 1988, pág. 313. Además, la abundante literatura, los debates en torno a la ineficiente administración de justicia especialmente en el ámbito penal, y la proliferación legislativa que en materia procesal penal nos viene acostumbrando el legislador nacional e internacional en las últimas décadas justifican una situación que podemos hoy calificar de epidemia globalizada. En este sentido, Vid. BARONA VILAR, S., "Conformidad del acusado, paradigma de eficiencia de la Justicia Penal", cit., pág. 399. También la misma autora en Seguridad, celeridad y justicia penal, cit., pág. 13.

28BARONA VILAR, S., Seguridad, celeridad y justicia penal, cit., pág. 13.

${ }^{29}$ RODRÍGUEZ GARCÍA, N., "El derecho premial como remedio para lograr que la justicia penal española sea eficaz. Reflexiones a partir de la nueva regulación de la conformidad del acusado en el procedimiento abreviado", VV.AA., La influencia de la ciencia penal alemana en Iberoamérica, Estudios en homenaje a Claus Roxin, México, 2003, pág. 571.

30 Respecto a la dicotomía "garantías-eficacia", Vid. FRONDIZI, R. J., DAUDET, M. G., Garantías y eficiencia en la prueba penal, La Plata, 2000. Importante señalar la opinión de CONTRERAS ALFARO, que sostiene que "parece indiscutible que el Derecho penal sustantivo y procesal contemporáneo se encuentra sumido en una crisis que continuará existiendo, al menos en el ámbito procesal, mientras no encontremos el justo equilibrio entre derechos individuales y seguridad colectiva; un conflicto que se traduce en el ámbito adjetivo a la contraposición entre un sistema de enjuiciamiento criminal más eficiente, pero que limite los derechos fundamentales del imputado a favor de las atribuciones de los órganos de persecución y la celeridad del 
Por un lado, encontramos el interés público, por el otro, hallamos las garantías individuales, y ambos los elementos, por cierto, situados en el preciso marco del proceso penal y antes que nada, en función de su crisis actual ${ }^{31}$.

Pues bien, aunque se reconozca la existencia de una crisis procesal penal y delante de la tensión de fuerzas apuntada, según nuestro entendimiento, eficiencia y garantías como fuerzas aparentemente contrapuestas, deben ser llamadas a armonizarse en pro de un proceso penal justo y equilibrado. Sería la solución más plausible en los días actuales.

Por lo tanto, la realización de la justicia penal exige una importante dosis de garantías, pues caso contrario, se podrá caer en un auténtico terrorismo de Estado.

La total eficiencia, traducida en celeridad y economía de medios, tiene que ceder frente la consideración de que al querer punir todos los delincuentes, el Estado debe alejar el riesgo de castigar personas inocentes, así como tendrá que tener siempre presente que el peor de los delincuentes, por el simple hecho de serlo, no pierde jamás la dignidad inherente a la persona humana ${ }^{32}$.

De esta apreciación debe deducirse el entendimiento de que la idea de justicia impone que el derecho de la sociedad de defenderse contra el delito sea conjugado con el del individuo sometido al proceso, en forma que ninguno de ellos sea sacrificado en aras del otro. Claro está que en una expectativa así se apuntará a un proceso penal que, a la vez, proteja los derechos individuales de los ciudadanos a él sometido y satisfaga los intereses sociales para el logro de una recta administración de la justicia penal ${ }^{33}$.

Dicho en síntesis, habrá que buscarse un sistema que asegure eficiencia con garantismo ${ }^{34}$, valores fundamentales del proceso penal moderno, el cual encuentra su validez y fundamento en la Constitución ${ }^{35}$.

proceso, y un procedimiento penal garantista, que defienda a los individuos de los perjuicios estatales injustificados". Vid. CONTRERAS ALFARO, L. H., Corrupción y Principio de Oportunidad Penal. Alternativas en materia de prevención y castigo a la respuesta penal tradicional, cit., pág. 12.

31Vid. BERTOLINO, P. J., Proceso penal y servicio de la justicia, cit., pág. 74.

32 En la misma línea de pensamiento, PÉREZ MORENO incluso señala que "el catálogo de derechos de los ciudadanos en las constituciones, funciona como limite al poder del Estado y, a su vez, resguardo de sus derechos y libertades, último reaseguro de su condición humana". Vid. PÉREZ MORENO, E. P., Precisiones acerca de las garantías del imputado (A propósito de los Derechos ciudadanos)", Ejercicio concreto del poder pena. Limites, abusos, desafios, J. I. Cafferata Nores coord., Córdoba, 2006, pág. 276. Del mismo modo, interesante la opinión de GUZMÁN FLUJA al defender que "salvo que el Estado consiga demostrar a través del proceso penal que la hipótesis de la acusación es correcta, lo que sólo sucede al final, el derecho de penar es inaplicable o no ejercitable". Vid. GUZMÁN FLUJA, V. C., Anticipación y preconstitución de la prueba en el Proceso Penal, cit., págs. 146-147.

${ }^{33}$ En este sentido, BERTOLINO, P. J., Proceso penal y servicio de la justicia, cit., págs. 88-89. Expresando gran preocupación respecto al tema de la tensión de fuerzas que impregna el proceso penal moderno, sostiene GASCÓN INCHAUSTI que "la realidad no se cansa de darnos muestras de que el equilibrio entre eficacia y respeto a los derechos fundamentales es cada vez más frágil y delicado". Y complementa aduciendo que "la irrupción de nuevas formas de delincuencia, caracterizada cada vez más por su carácter organizado y transfronterizo, así como por la utilización de instrumentos sofisticados para ocultar las huellas de la infracción, parece estar obligando a los Estados a adoptar medidas de reacción más incisivas, siempre bajo el lema de la mayor efectividad: inevitablemente, ese incremento en la eficacia se hace siempre a costa de los derechos y garantías de los ciudadanos, y con frecuencia no sólo de aquéllos a los que pueda imputarse la comisión de un delito". Vid. GASCÓN INCHAUSTI, F., "Prólogo" a la obra "Tráfico de drogas. Prueba penal y medidas restrictivas de derechos fundamentales", Curitiba, 2009, pág. 9.

34 El uso del vocablo "garantismo", en el Derecho penal y en el Derecho procesal penal es presentado con varias acepciones por FERRAJOLI, L., Derecho y Razón, Teoría general del garantismo penal, Madrid, 1995.

35 Siguiendo raciocinio, "el proceso penal atinge la perfección deseable en el punto de encuentro del interés público de la represión penal rápida y segura, y del interés particular del argüido en una justicia que ofrezca suficientes garantías de defensa contra una condena injusta. (...) A los intereses sociales de la prevención 
Ciertamente, un verdadero Estado de Derecho debe satisfacer simultáneamente ambos reclamos y puede sintetizarse con la fórmula "eficiencia con garantías"36.

Correcto entonces, afirmar que el Derecho procesal penal no puede dejar de presentarse como un asunto constitucional ${ }^{37}$. Consecuencia lógica es que el marco de referencia de cualquier análisis del proceso penal tiene que estar en los principios constitucionales ${ }^{38}$ y por veces, en los tratados o convenciones internacionales firmados por los países.

Así es que se observa por un lado que la protección de los derechos y libertades públicas constituye el pilar básico de un Estado Constitucional, social y democrático de Derecho. Ya en la otra punta, se contempla un poder estatal que presionado por parte de la opinión pública y por los medios de comunicación, utiliza en la lucha contra la macro criminalidad la idea de que los fines justifican los medios.

Sin embargo, se observa como ya apuntado, que un efecto alarma ha sido verificado delante de la inseguridad ${ }^{39}$ generada en razón de la expansión del fenómeno de la delincuencia moderna, hecho este que de forma alguna viene a justificar el empleo de nuevas técnicas de investigación criminal o de cualquier medio restrictivo de derechos y garantías como respuesta irrazonable y a todo costo para ablandar el problema de la obsesión por la celeridad y eficacia punitiva del proceso penal.

Incluso se plantea una cuestión referida a la forma de incrementar la eficacia en la investigación penal sin menoscabar los derechos del imputado sobre quien recaen las sospechas de comisión del delito. Es decir, sin descuidar de la eficacia en la investigación penal, se debe buscar hacerla compatible con el respeto de una serie de garantías que determinen la existencia de un juicio justo. Garantías que se traducen en la aplicación en

general contra el crimen y en especial contra determinado delincuente, corresponde de la parte de este la necesidad de un proceso justo y garante de su defensa contra eventuales prepotencias del titular de la acción penal, el Estado". Vid. PINHEIRO, R., MAURÍCIO, A., A Constituição e o processo penal, Coimbra, 2007, pág. 46. Confirmando la necesidad de comprehender la Constitución como fundamento del proceso penal, destacase el hecho de que "una adecuada formación jurídica no puede desconocer la norma fundamental. En efecto, la Constitución de un país es la fuente inalterable que preserva la voluntad de los ciudadanos con vistas a asegurar la libertad, igualdad y su propia condición humana". En este sentido, Vid. PÉREZ MORENO, E. P., "Precisiones acerca de las garantías del imputado (A propósito de los Derechos ciudadanos)", Ejercicio concreto del poder pena. Limites, abusos, desafíos, cit., pág. 275.

36 SOLOMINE, M. A., "Praxis instructoria en un Estado de Derecho. Entre las garantías y la eficiencia", Cuadernos de doctrina y jurisprudencia penal, vol. 5, núm. 9B, Buenos Aires, 1999, pág. 131.

37 TORRÂO, F. P., A relevância político-criminal da suspensão provisória do processo, Coimbra, 2000, pág. 67.

38 De esta forma, "el catálogo de derechos de los ciudadanos en las constituciones, funciona como límite al poder del Estado y, a su vez, resguardo de sus derechos y libertades, último reaseguro de su condición humana". Vid. PÉREZ MORENO, E. P., "Precisiones acerca de las garantías del imputado (A propósito de los Derechos ciudadanos)", Ejercicio concreto del poder pena. Límites, abusos, desafíos, cit., pág. 276.

39 Vid. para mayor profusión, LÓPEZ SUÁREZ, N., "Inseguridad ciudadana: construcción o percepción subjetiva", Revista Iter Criminis, México, 1999, págs. 121-143; FAINBERG, M. H., La inseguridad ciudadana, Buenos Aires, 2003. En opinión de DAUNIS RODRÍGUEZ, "en la actualidad, emergen, nuevamente, los discursos que entienden necesario la implementación de medidas, no sólo policiales, sino también legales que proporcionen seguridad y tranquilidad a la sociedad y respondan con efectividad ante las disfunciones que generan dicha inseguridad". Sostiene además el mismo autor, que "lamentablemente, esta mayor rigidez y dureza en el control del terrorismo internacional ha supuesto, paralelamente, una peligrosa relajación del respeto de determinados derechos humanos y las garantías de los mismos". Vid. DAUNIS RODRÍGUEZ, A., "Seguridad, Derechos humanos y garantías penales: ¿Objetivos comunes o aspiraciones contrapuestas?", Derecho penal de la democracia vs. Seguridad pública, cit., pág. 215. 
todo caso de los principios de contradicción, igualdad de armas y publicidad de las actuaciones ${ }^{40}$.

La verdad es que el Derecho procesal penal busca disciplinar el ejercicio de la jurisdicción a través de principios y reglas que vengan a conferir al proceso, la más amplia efectividad, o sea, el mayor alcance práctico y el menor costo posible en la protección concreta de los derechos del ciudadano41. Además, según SCHÖNKE, el Derecho Procesal como institución tiene como finalidad asegurar el mantenimiento del derecho a través de las garantías de una protección de las leyes y la defensa del orden jurídico ${ }^{42}$.

Ahora bien, tiene razón HASSEMER al recordar que el Derecho procesal penal es el señor del proceso penal desde el momento en que aquél disciplina a éste en cuanto escenario que precisa el Derecho penal sustantivo para hacerse efectivo. Sin proceso penal no hay protección de bienes jurídicos ni realización de fin alguno que se quiera atribuir al Derecho penal. El Derecho procesal penal es el que hace con que el proceso penal sea un instrumento institucionalizado y que responda a principios y garantías concretas ${ }^{43}$.

En efecto, parece obvio que los problemas de seguridad ciudadana no pueden hallar una respuesta solvente sin más en un juicio penal ${ }^{44}$. Así, el proceso penal es el instrumento jurídico necesario para la aplicación del Derecho penal, de modo que si se ha de perseguir una conducta delictiva, el proceso es el instrumento imprescindible para ello ${ }^{45}$.

Pero, no sólo esto, pues deberá ser buscada la tutela procesal penal de los valores reconocidos en la Constitución.

Se objetiva, pues, establecer un marco estructural garantista al proceso penal.

Y esto no significa que los fines justifiquen los medios. Como relación jurídica compleja y dinámica, el proceso penal en si mismo debe formarse y desarrollarse con absoluto e imprescindible respeto a la dignidad humana de todos los ciudadanos ${ }^{46}$, especialmente de las partes, de tal modo que la justicia de su resultado signifique la seguridad de la adopción de las reglas más propicias a la amplia y equilibrada

40 RIAÑO BRUN, I., La instrucción criminal en el proceso penal, Navarra, 2008, pág. 14. Con profundidad sobre otras formas de garantías esenciales en el proceso penal, Vid. ARANGÜENA FANEGO, C., "Garantías procesales de los sospechosos e imputados", VV.AA., El proceso penal en la Unión Europea: garantías esenciales, Valladolid, 2008, págs. 138-168.

41Incluso PÉREZ MORENO habla de un "marco ético del proceso", al señalar que "el proceso penal no puede ser un escenario donde cobran vida sólo las pasiones, sino al contrario, se aplica la razón. En ese orden, debe tener un auténtico marco ético. Por contrapartida, cualquier proceso que la incertidumbre sobre su final está ausente, pierde esa cobertura ética que el vocablo le asigna y se transforma en un proceso aparente, carente de todo sentido y vacío". Vid. PÉREZ MORENO, E. P., Precisiones acerca de las garantías del imputado (A propósito de los Derechos ciudadanos)", cit., pág. 283.

42 SCHÖNKE, A., "Límites de la prueba en el derecho procesal", Revista de Derecho Procesal, núm. 3, 1955, pág. 374.

43 Vid. HASSEMER, W., Fundamentos de Derecho Penal, trad. F. Muñoz Conde y L. Arroyo Zapatero, Barcelona, 1984, págs. 149-150.

44 Vid. RAMOS MÉNDEZ, F., Enjuiciamiento Criminal, Octava lectura constitucional, Barcelona, 2006, pág. 32.

45 Cfr. MOREnO CATENA, V., "Los elementos probatorios obtenidos con la afectación de derechos fundamentales durante la investigación penal", VV.AA., Prueba y Proceso Penal. Análisis especial de la prueba prohibida en el sistema español y en el derecho comparado, J. L. Gómez Colomer coord., Valencia, 2008, pág. 75.

46 Según destaca AUGUSTO MEREIS, "no son los límites de los derechos humanos que tienen que adaptarse a las exigencias del proceso, pero es antes el proceso que tiene que se adaptar a las exigencias de los derechos humanos". Cfr. AUGUSTO MEREIS, M., "Homens de confiança", Será o caminho?, II Congresso de Processo Penal, Coimbra, 2006, pág. 101. 
participación de los interesados, a la neutra y adecuada cognición del Juez y la apuración de la verdad objetiva: un medio justo para un fin justo.

\section{I.1.1.2. La tensión de fuerzas: garantías versus eficacia.}

Hechas las debidas consideraciones preliminares respecto a la existencia de una posible crisis de la administración de la justicia penal ${ }^{47}$ y del crecimiento de la violencia delincuencial, importante señalar que este trabajo tiene, fundamentalmente, como objetivo, realizar una introductoria incursión a respecto de algunos desafíos enfrentados actualmente por la dogmática procesal penal desde la perspectiva constitucional ${ }^{48}$.

Como ya había sido afirmado anteriormente, muchos son los problemas que afectan el Derecho Procesal penal en los días de hoy. Se podría citar otra vez más como ejemplos más significativos la lentitud de los procesos judiciales, la ausencia de credibilidad de la justicia penal junto a la sociedad, la falta de un número suficiente de profesionales para la tarea de mantenimiento del funcionamiento dentro de un plazo razonable de la administración de la justicia penal, la exagerada burocracia en el desarrollo de los trámites procesales o el retraso del proceso penal frente a los avances de la criminalidad. Todos estos temas hacen parte de la complejidad del proceso penal contemporáneo.

Sin embargo, en nuestra opinión, el más destacado de los problemas enfrentados en el proceso penal dice respecto a la tensión ${ }^{49}$ de fuerzas que ponen en choque dos derechos

\footnotetext{
47 En palabras de BARONA VILAR, "muy probablemente la justicia penal refleja la gran metamorfosis a que está siendo sometido el Derecho, adornada de crisis, inoperancia, ineficiencia, insatisfacción y transformación de la misma. Cierto es, sin embargo, que es precisamente en el ámbito punitivo donde la necesidad de buscar soluciones o, si se quiere, evolucionar, se hace en todo caso más acuciante, por las consecuencias en los derechos fundamentales del mismo, y especialmente en el derecho a la libertad". Vid. BARONA VILAR, Seguridad, celeridad y justicia penal, cit., págs. 22-23.

48 Respecto a un interesante análisis constitucional del proceso penal, vid. como obra de referencia, RAMOS MÉNDEZ, F., Enjuiciamiento Criminal, Octava lectura constitucional, Barcelona, 2006. Vid. además para un estudio amplio del tema en el derecho comparado, ARAGONESES ALONSO, P., Proceso y Derecho Procesal, $2^{\mathrm{a}}$ edición, Madrid, 1997; LÓPEZ BARJA DE QUIROGA, J., Tratado de Derecho Procesal Penal, 2ª edición, Navarra, 2007; BINDER, A. M., Introducción al derecho procesal penal, 2a edición, Buenos Aires, 1999; CARRIÓ, A. D., Garantías constitucionales en el proceso penal, 5a edición, Buenos Aires, 2007; CORDÓN MORENO, F., Las garantías constitucionales del proceso penal, 2a edición, Navarra, 2002; DEL ROSAL, M. C., Tratado de Derecho Procesal Penal Español, Madrid, 2008; GIMENO SENDRA, V., Derecho Procesal Penal, 2a edición, Madrid, 2007; GÓMEZ COLOMER, J. L., Constitución y Proceso Penal, Madrid, 1996; GRANDINETTI C. DE CARVALHO, L. G., Processo Penal e Constituição, 4a edición, Rio de Janeiro, 2006; GRINOVER, A. P., "As garantias constitucionais do processo", Novas tendências do direito processual de acordo com a Constituição de 1988, São Paulo, 1990; LAURIA TUCCI, R., Direitos e Garantias individuais no Processo Penal Brasileiro, 2a edición, São Paulo, 2004; LEÃO, N. C., "Direitos fundamentais, garantias constitucionais e processo penal", Revista do Conselho Nacional de Política Criminal e Penitenciária, Brasília, Julio 98/diciembre 99, págs. 127-140; GARBERÍ LLOBREGAT, J., Constitución y Derecho Procesal. Los fundamentos constitucionales del Derecho Procesal, Navarra, 2009; LOPES JR, A., Direito processual e sua conformidade constitucional, Vol. I, Rio de Janeiro, 2007; MAGARIÑOS, M., "Garantías constitucionales del derecho procesal penal", Doctrina Penal, año 11, números 41-44, Buenos Aires, 1988, págs. 619-633; MONTERO AROCA, J., Proceso y Garantía Civil y Penal. El proceso como garantía de libertad y de responsabilidad, Valencia, 2006; MORELLO, A., Constitución y proceso. La nueva edad de las garantías jurisdiccionales, La Plata-Buenos Aires, 1998; PICÓ JUNOY, J. M., Las garantías constitucionales del proceso, Barcelona, 1997; SCARANCE FERNANDES, A., Processo Penal Constitucional, 4a edición, São Paulo, 2005; SCHMIDT, E., Los fundamentos teóricos y constitucionales del Derecho Procesal Penal, trad. J. Manuel Nuñez, Córdoba, 2006; SILVA JUNIOR, W. N., Curso de Direito Processual Penal: Teoria (Constitucional) do Processo Penal, 1aa edición, Rio de Janeiro, 2008; VARELA, C. A., Fundamentos constitucionales del derecho procesal, Buenos Aires, 1999; VV.AA., Processo Penal e garantias constitucionais, M. A. Marques da Silva coord., São Paulo, 2006.

49 Monográficamente, Vid. PASTOR, D. R., Tensiones: ¿derechos fundamentales o persecución penal sin límites?, Buenos Aires, 2004 y VV.AA., La tensión entre libertad y seguridad. Una aproximación socio jurídica, María J. Bernuz Beneitez y A. I. Pérez Cepeda coords., La Rioja, 2005. También destacados, los trabajos de
} 
estrictamente constitucionales, o sea, de un lado el derecho de punir del Estado ${ }^{50}$, representando la seguridad colectiva y de otro, el derecho a las garantías fundamentales a ser reconocido a las personas sometidas a la persecución criminal ${ }^{51}$.

Dicho en pocas palabras, existiría pues una relación de tensión entre la efectividad de la justicia y los postulados del Estado de Derecho, o entre el interés público en la eficiencia del proceso penal y la máxima protección posible del imputado. Todavía no se puede olvidar la constatación real y factible de que el conflicto de intereses, presente en la vida desde el comienzo de la existencia humana, es inevitable por el simple hecho de la convivencia social 52 .

Luego, importante señalar que el proceso penal probablemente representa el principal campo de tensión entre la seguridad pública y los derechos fundamentales de quien se ve sometido al mismo, comenzando por su derecho a la libertad, que aparece seriamente amenazado, tanto en razón de las medidas cautelares que puedan adoptarse durante la sustanciación del proceso, como por la definitiva imposición de una pena en una eventual sentencia condenatoria ${ }^{53}$.

Consecuencia lógica de esta proposición es que el proceso penal sirve para garantizar la seguridad pública, como un valor digno de especial protección, pues funciona precisamente como el elemento de cierre de la lucha contra la criminalidad y de las medidas de política criminal que deben adoptar los poderes públicos. Pero también debe salvaguardar los derechos de la persona que se ve sometida al proceso penal, pues cuando

BINDER, A. M., "Tensiones político-criminales en el proceso penal", Revista Jueces para la democracia, núm. 60, 2007, págs. 21-36; SANTANA, S. P., "A tensão dialética entre os ideais de garantia, eficiência e funcionalidade", Novos desafios do Direito Penal no terceiro milênio, Estudos em homenagem ao prof. Fernando Santana, Gamil Föppel coord., Rio de Janeiro, 2008, págs. 879 y ss; SCARANCE FERNANDES, A., "O equilíbrio entre a eficiência e o garantismo e o crime organizado", Revista Brasileira de Ciências Criminais, núm. 70, São Paulo, 2008, págs. 229-268.

50 Vid. MIR PUIG, S., Introducción a las bases del Derecho Penal, Barcelona, 1976, pág. 123, donde señala que "El Estado social y democrático ha de ser una síntesis que complemente y perfeccione el Estado clásico y liberal, no una alternativa a éste. El ius puniendi estatal tendrá que respetar siempre escrupulosamente los límites propios de una concepción garantista del Estado, la sociedad y el Derecho". Respecto a los límites imprescindibles del ius puniendi, Vid. además FERNÁNDEZ RODRÍGUEZ, M. D., Los límites del ius puniendi, Anuario de Derecho Penal y Ciencias Penales, Madrid, Vol. 47, 1994, págs. 87-113; GARCÍA-PABLOS DE MOLINA, A., Introducción al Derecho Penal, Madrid, 2005, págs. 553 y ss.

51 En opinión de VÉLEZ MARICONDE, "no es posible olvidar ninguno de esos intereses, cuya efectiva protección resulta, desde luego, en virtud del derecho procesal; el legislador debe buscar una solución armónica, un equilibrio que, desde un punto de vista político, signifique la correcta interpretación de las normas constitucionales". Vid. VÉLEZ MARICONDE, A., Derecho procesal penal, Tomo II, Buenos Aires, 1969, pág. 128.

52 Esta la opinión firmada por PACELLI DE OLIVEIRA, E., Curso de Processo Penal, Belo Horizonte, 2006, pág. 322. El mismo autor incluso aprovecha para señalar también que "el criterio hermenéutico más utilizado para resolver eventuales conflictos o tensiones entre principios constitucionales igualmente relevantes se funda en la denominada ponderación de bienes, presente hasta mismo en las opciones más habituales de la vida cotidiana".

53 MORENO CATENA, V., "El enjuiciamiento de delitos de terrorismo y el derecho de defensa", VV.AA., Terrorismo y proceso penal acusatorio, Valencia, 2006, pág. 378. En opinión de HOYOS SANCHO, "ese campo en continua tensión que es el Derecho procesal penal en un Estado democrático y de derecho, o en un espacio común que también pretende serlo, ofrece múltiples posibilidades de actuación en la tutela efectiva de los derechos y libertades; es complejo y dinámico a la vez, su configuración no es perfecta, pero tiene sus límites en el debido proceso o proceso justo ante órganos jurisdiccionales independientes e imparciales. No admite atajos; la historia reciente nos demuestra una y otra vez los elevadísimos costes que sobre el Estado de Derecho tiene prescindir de la que Ferrajoli denomina de necesaria asimetría en el tratamiento de la delincuencia, también de la más grave, o de una reacción de normalidad como respuesta adecuada, incluso frente a amenazas extremas como propone Kai Ambos". Vid. HOYOS SANCHO, M., "Armonización de los procesos penales, reconocimiento mutuo y garantías esenciales", cit., pág. 76. 
alguien es llamado como imputado aparece su libertad seriamente amenazada, y el valor político que representa la libertad, o el conjunto de derechos que conforman las libertades civiles, se ponen en riesgo, tanto por la definitiva imposición de sanciones en la sentencia condenatoria como en razón de las medidas cautelares y de las diligencias de investigación que puedan ordenarse durante la sustanciación del proceso ${ }^{54}$.

En todo caso, según MUÑOZ CONDE, es verdad que el Derecho procesal penal tiene su corazón dividido entre dos grandes amores: por un lado, la misión de investigar los delitos y castigar a los culpables; por otro, la de respetar en esa tarea determinados principios y garantías que se han convertido en el moderno Estado de Derecho en derechos y garantías fundamentales del acusado. Esto produce una contradicción difícil de solucionar: el respeto a las garantías y derechos fundamentales del acusado puede suponer y, de hecho, supone efectivamente, un límite a la búsqueda de la verdad que obviamente ya no puede ser una verdad a toda costa 55 .

Pero, aunque se vaya a tratar con más profundidad del tema en el desarrollo del trabajo, nos queda claro al principio, a par de la tensión mencionada, entender que en el proceso penal no hay dos intereses contrapuestos ${ }^{56}$, sino un único interés: el atinente a la exacta aplicación de la ley con respeto a las garantías del ciudadano. Esta es la idea que vamos defender en nuestra investigación: la búsqueda de eficiencia con garantías, tomando como clave los principios de proporcionalidad y del debido proceso legal.

Desde luego, defendemos la orientación de que la colisión de fuerzas no debe ser resuelta en abstracto, por medio de un orden aleatorio de preferencia de los valores constitucionales de la seguridad individual o de la seguridad colectiva, pero sí, analizándose el caso en concreto y llevándose en consideración el principio de proporcionalidad, y de modo específico, la intensidad de la amenaza concreta al derecho fundamental, la medida violadora del peligro de vulneración de la garantía, y por fin, el grado de afectación del interés general delante de la situación puesta en análisis.

Resta de todas las formas, establecida dogmáticamente la paradoja enfrentada por el proceso penal moderno: ¿eficiencia o garantías?57 0 en otros términos, ¿política de mano dura o garantismo?58

54 Cfr. MOREnO CATENA, V., "Los elementos probatorios obtenidos con la afectación de derechos fundamentales durante la investigación penal", cit., págs. 75-76.

55 MUÑOZ CONDE, F., La búsqueda de la verdad en el proceso penal, 2ª edición, Buenos Aires, 2003, pág. 14.

56 Respecto al tema en discusión, SOLOMINE defiende que "visualizar el proceso penal como una tensión de fuerzas antagónicas resulta sumamente útil para la comprensión de su correcta dinámica en un Estado de Derecho. Se trata de advertir que en cualquier persecución penal aparece una puja constante entre la necesidad de la sociedad de protegerse contra el delito, mediante un sistema de represión eficiente, y las garantías que amparan al imputado que actúan como límites que restringen y encauzan el poder estatal, neutralizando el riesgo de su uso arbitrario". Vid. SOLOMINE, M. A., "Praxis instructoria en un Estado de Derecho. Entre las garantías y la eficiencia",cit., pág. 130.

57 Interesante la posición de algún sector doctrinal en el sentido de que "debemos ser realistas y comprender que lo que en realidad colisiona no es garantismo con mano dura o eficiencia con garantías, sino concepciones del orden jurídico y social que son antagónicas, en función de comprensiones distintas del rol de hombre y de la sociedad". En este sentido, Vid. RUBÉN AUED, N., ALBERTO JULIANO, M., La probation y otros institutos del derecho penal, Buenos Aires, 2001, pág. 97.

58 En verdad, hay que tener presente como destaca GRINOVER, que "el garantismo no choca con la eficiencia de la justicia penal, siendo, además, éstos los dos valores fundamentales del proceso penal. Lo que se debe buscar, esto sí, son técnicas que hagan del proceso un instrumento adecuado a la realidad subyacente, efectivamente dirigido a los fines de la jurisdicción, que son fines jurídicos (la eficaz actuación del derecho material), pero también sociales (la pacificación) y políticos (participación y justicia)". Vid. GRINOVER, A. P., $O$ 
Como bienes jurídicos en confronto e intereses a ponderar entre sí, aparecen: de un lado, el interés de la persecución criminal encabezado por la comunidad jurídica ofendida y teniendo en la debida cuenta el significado de la materia criminal; y de otro lado, la idea de justicia y el imperativo de un proceso conforme a las exigencias de justicia.

De esta suerte, en estas situaciones se produce un conflicto entre el interés de la sociedad en la persecución del delito, su investigación, enjuiciamiento y castigo, y el interés individual y colectivo de la sociedad en ver protegidos los derechos y garantías constitucionalizados; una tensión entre el deber de los poderes públicos de realizar una eficaz represión de las conductas que llevan aparejado un reproche penal y la protección de los derechos fundamentales que debe dispensar el Estado ${ }^{59}$.

Sin embargo, algún autor, como PÉREZ ROYO defiende que en realidad, entre libertad y seguridad no hay ninguna tensión. Y no la hay, porque la seguridad es el elemento constitutivo de la libertad60, como ya observó MONTESQUIEU, en el famoso capítulo 6 del Libro XI Del Espíritu de las Leyes, en el que definió la libertad como "la tranquilidad de espíritu que proviene de la opinión que cada uno tiene de su propia seguridad"61.

Hechas estas consideraciones, habrá de registrarse que el proceso penal ha sido consagrado como un medio indispensable de administrar justicia para garantías de la sociedad y del individuo, de modo que cumple una doble función de tutela jurídica: protege el interés social por el imperio del derecho, o sea, por la represión del delincuente y el interés individual (y también social) por la libertad personal62.

A esta contemporánea y actual forma de comprensión de la ciencia procesal penal se puede calificar como claramente garantista e integral a su tiempo, debiendo las garantías individuales y colectivas quedar del mismo modo e intensidad, sometidas a la protección estatal.

De lo dicho resulta que el proceso penal es un campo de conflicto entre derechos individuales fundamentales ${ }^{63}$ e intereses sociales especialmente sensibles. En la síntesis

processo em evolução, Rio de Janeiro, 1996, pág. 206. También BERTOLINO, en el mismo sentido, señala que "desde el estricto campo dogmático no se plantearía conflicto alguno, esto porque en el actual estadio de la civilización jurídica, tanto el interés público cuanto las garantías individuales siempre vendrían a converger en la institución estatal". Vid. BERTOLINO, P. J., Proceso penal y servicio de la justicia, cit., pág. 78.

59 Cfr. RODRÍGUEZ GARCÍA, N., "Medios de prueba restrictivos de derechos fundamentales. Las intervenciones telefónicas", Conflicto social y sistema penal (Diez estudios sobre la actual reforma), M. R. D. Díaz Santos, E. F. Caparrós, L. Zúñiga Rodríguez coords., Madrid, 1996, pág. 45. En el mismo sentido, la STC 341/1993, de 18.11.93, al confirmar que "la eficacia en la persecución del delito, cuya legitimidad es incuestionable, no puede imponerse, sin embargo, a costa de los derechos y libertades fundamentales".

60 En este sentido, véase, PÉREZ ROYO, J., "La democracia frente al terrorismo global", VV.AA., Terrorismo, democracia y seguridad, en perspectiva constitucional, M. Carrasco Durán coord., Madrid- Barcelona- Buenos Aires, 2010, pág. 7.

61 Vid. MONTESQUIEU, C., De L'Esprit des Lois, Paris, 1965, pág. 586.

62 VÉLEZ MARICONDE, A., Derecho procesal penal, cit., pág. 127.

63 Es frecuente encontrar en la literatura penal y constitucional el empleo de conceptos sinónimos, tales como derechos fundamentales, derechos fundamentales procesales, derechos humanos, principios procesales, libertades públicas, garantías institucionales, etc. Pero en verdad se utiliza estos conceptos, para referirse por lo general a lo mismo: las garantías procesales penales constitucionalizadas. A respecto, Vid. CARO CORIA, D. C., "Las garantías constitucionales del proceso penal", Anuario de Derecho Constitucional Latinoamericano, Tomo II, 2006, pág. 1027. Con una opinión peculiar, defiende TOMÁS DE DOMINGO que "no se puede hablar propiamente de conflictos de derechos, pero sí de desajustes, pues las personas conciben su forma de estar en el mundo de diversas maneras". Vid. DOMINGO, T., ¿Conflictos entre derechos fundamentales?, Madrid, 2001, pág. 377. 
de HASSEMER, el "Estado de Derecho" vive de la contraposición entre formalidad de la justicia (garantías) y eficiencia (como esclarecimiento y condena de hechos) ${ }^{64}$. Este conflicto, a nuestro modo de ver, aparente, es típico y propio de un proceso penal democrático y marcado por la ausencia de arbitrariedad y autoritarismo.

Desde esta perspectiva, es notorio que en los tiempos que corren, parece haberse agudizado la tensión existente entre la legítima aspiración de la sociedad en su conjunto de prevenir y reprimir el delito y los derechos y garantías de que goza todo imputado sometido a proceso ${ }^{65}$. Y la explicación es lógica, delante de la expansión sin frenos de la criminalidad en los últimos tiempos.

Se observa pues el dilema existencial del proceso penal: efectividad de la coerción penal versus derechos fundamentales, siendo que para obtenerse una mayor efectividad de aquella, es necesaria la limitación de éstos.

Al contrario, ampliar los derechos y garantías importa algunas veces en dificultar la eficiencia de la coerción. Se busca, así, con total desespero, un punto de equilibrio, pues en un Estado democrático y de Derecho, los fines nunca justifican los medios, debiendo la eficacia de la coerción penal ser buscada con ética y respeto al contenido mínimo de los derechos y garantías fundamentales, sin radicalismo para una u otra corriente de pensamiento, para que así el proceso penal intente buscar la deseada perfección ${ }^{66}$.

En lenguaje figurado, es como siimaginásemos dos flechas, una representando el derecho de punir del Estado (principio instrumental punitivo) y la otra, las garantías del sujeto sometido al proceso penal (principio instrumental garantista), que vienen en sentidos opuestos, pero que en la verdad, no tienen que terminar chocándose, de modo a provocar la aniquilación de uno u otro de estos intereses ${ }^{67}$.

Como ya hemos adelantado, el interés es único, o sea, la eficiencia con garantías, lo que se va a conseguir cuando del establecimiento del equilibrio ${ }^{68}$ proporcional entre las dos fuerzas en tensión.

Y en este punto del análisis, ¿podríamos comprender los conceptos de celeridad (eficiencia) y garantías como antagónicos?

${ }^{64}$ HASSEMER, W., Critica al Derecho Penal de hoy, Buenos Aires, 1995, pág. 80.

65 Cfr. RUBÉN AUED, N., ALBERTO JULIANO, M., La probation y otros institutos del Derecho Penal, cit., pág. 95. Analizando la tensión de fuerzas en el proceso penal, interesante las palabras de BINDER al señalar que "la primera de esas fuerzas o tendencias es la que se preocupa por establecer un sistema de garantías o resguardos frente al uso de la fuerza estatal. Se procura en este caso evitar que el uso de esa fuerza se convierta en un hecho arbitrario. Su objetivo es, esencialmente, proteger la libertad y la dignidad de la persona. La segunda de esas tendencias se inclina a lograr una aplicación efectiva de la coerción penal. Su objetivo es lograr la mayor eficiencia posible en la aplicación de la fuerza estatal". Vid. BINDER, A. M., Introducción al derecho procesal penal, cit., pág. 56.

66 Sobre el tema, para una intensa profusión, Vid. BEDÊ JÚNIOR, A; SENNA, G., Princípios do Processo Penal. Entre o garantismo e a efetividade da sanção, São Paulo, 2009, págs. 24-25.

${ }^{67}$ Algún autor sostiene que en verdad, "a par de la baja efectividad de las garantías constitucionales, otro problema ha surgido delante de la colisión entre ellas, en el caso concreto, con la consecuente supresión o disminución de la esfera de protección de una de ellas. Así, estas garantías en colisión habrán de ubicar, muchas veces, en principios constitucionales que componen los denominados derechos fundamentales". Así, por ejemplo, GRANDINETTI CARVALHO, L. G., "Garantias Constitucionais-Processuais Penais (A efetividade e a ponderação de garantias no processo penal)", Revista da Escola da Magistratura do Estado do Rio de Janeiro, vol. 6, núm. 23, Rio de Janeiro, 2003, pág. 193.

68 Por esta razón, VÉLEZ MARICONDE advierte que "no es posible olvidar ninguno de esos intereses, cuya efectiva protección resulta, desde luego, en virtud del derecho procesal; el legislador debe buscar una solución armónica, un equilibrio que, desde un punto de vista político, signifique la correcta interpretación de la normas constitucionales". Vid. VÉLEZ MARICONDE, A., Derecho procesal penal, cit., pág. 128. 
Concretamente se puede contestar esta pregunta afirmando que no, vez que a la postre, en nuestro pensamiento, es posible obtenerse celeridad procesal en la búsqueda de eficiencia penal utilizándose del debido respeto a las garantías inherentes a la condición de investigado o imputado en un proceso penal. Es una tarea difícil pero no imposible.

De todo modo, la respuesta a esta asertiva según BARONA VILAR es que los dos conceptos fluctúan de forma pendular pretendiendo adquirir una mayor preponderancia el uno sobre el otro: la celeridad y las garantías, como un paseo entre el amor y la muerte, olvidando que son conceptos intrínsecamente creados para coexistir, buscando el equilibrio perfecto entre ellos. Del mismo modo que la vida necesita del amor y de la muerte para serlo en plenitud, el sistema punitivo necesita de la celeridad y de las garantías como coordinados del mismo ${ }^{69}$.

Precisamente, queda muy claro que el proceso penal está revestido de diversas garantías de reconocimiento constitucional que buscan no sólo otorgar al procesado un marco de seguridad jurídica, sino en última instancia mantener un equilibrio entre la búsqueda de la verdad material y los derechos fundamentales del imputado, los cuales constituyen un límite al poder punitivo estatal, cuya protección y respeto no pueden ser ajenos a una justicia penal contemporánea. Este conflicto de intereses se presenta, por ejemplo, cuando existe la necesidad de implementar procedimientos más eficaces de persecución penal ante la gravedad que revisten ciertas conductas delictivas, pero cuya legitimidad puede relativizarse ${ }^{70}$.

Así las cosas, el proceso penal como instrumento último de la política de seguridad pública, debe ser cuidadosamente diseñado, de modo que logre la mejor represión de las conductas delictivas, pero sin menoscabo al debido respeto de los derechos y libertades individuales; por eso representa uno de los momentos de equilibrio y tensión más delicados entre los intereses que ha de salvaguardar el Estado democrático de Derecho ${ }^{71}$.

Este sería el marco garantista del proceso penal, donde a través de la máxima defensa de los derechos fundamentales, y respectándose el criterio de proporcionalidad, se llega a la eficiencia en un proceso especialmente "justo".

La gran cuestión entonces consiste en el grado de composición admitido entre la garantía y la funcionalidad, de forma que un vector no excluya el otro. De este modo, como no se puede tolerar la adopción de un proceso penal ágil, listo a atender a las necesidades de deflación del sistema de justicia criminal, pero destituido de las garantías procesales, no se admite, de igual modo, un apego desmedido a su tradicional función de garantía, sacrificando, de este modo, a la exigencia de prestar una justicia rápida y eficaz ${ }^{72}$.

\footnotetext{
${ }^{69}$ Cfr. BARONA VILAR, S., Seguridad, celeridad y justicia penal, cit., pág. 24.

70 Vid. CARO CORIA, D. C., "Las garantías constitucionales del proceso penal", cit., pág. 1028.

71 MORENO CATENA, V., "El enjuiciamiento de delitos de terrorismo y el derecho de defensa", cit., pág. 378. Así lo ha reconocido el Tribunal Constitucional español, STC 130/2002, de 3.6.2002, al estipular que "la función del derecho fundamental a un proceso judicial con todas las garantías (art. 24.2 CE) en el ámbito de los procesos penales es, precisamente, asegurar ese interés público en que la condena penal, entroncada también con otro interés constitucional como es el de la persecución del delito (por todas STC 166/1999, de 27.9.1999), resulte de un juicio justo; interés constitucional en un juicio justo asentado en los principios del Estado de Derecho y en los valores constitucionales de libertad y justicia (art. 1.1 CE)".

72 Por esta razón, advierte SCARANCE FERNANDES que "no se debe pender para los extremos de un hipergarantismo o de una represión a todo costo". Vid. SCARANCE FERNANDES, A., "O equilíbrio na repressão do crime organizado", Crime Organizado. Aspectos processuais, São Paulo, 2009, pág. 10.
} 
Todo se resume, pues, en introducir en el ámbito del proceso penal, mecanismos tendientes a la obtención de su mayor eficacia, flexibilizando en situaciones extremas las garantías cuya previsión no sea necesaria. Se evita con esta actitud, la abusiva e innecesaria instrumentalización de algunas de las garantías, asunto este que tendremos la oportunidad de profundizar en el desarrollo de nuestro trabajo.

Presentando una opinión muy interesante respecto al asunto, aduce PACELLI que el problema central del proceso penal no parece más localizarse en una imaginaria disputa entre la libertad individual y la seguridad pública. Esta tensión entre los apuntados principios constitucionales es constitutiva de todo el derecho estatal que tenga por objeto relaciones de naturaleza jurídica entre el Estado y sus administrados. El derecho en todas sus manifestaciones, en el punto en que regula comportamientos, ya es una limitación a la libertad individual. La justificación de restricción a la libertad individual en el proceso penal sigue por lo tanto, el mismo camino de aquella que se refiere al derecho. Lo que deberá ser buscado es la construcción de criterios mínimamente objetivos para determinarse el campo de aplicabilidad de determinadas normas constitucionales, lo que no parece ser hecho solamente a partir de una ecuación cuanto a la eficacia de los principios de seguridad pública o de libertad individual. El grado de abstracción de tales principios no permite el establecimiento de cualquier criterio que los considere como puntos de partida ${ }^{73}$.

Hechas las debidas observaciones iniciales y como marco preliminar de nuestro estudio, nos parece correcto, afirmar a priori ser posible la defensa del ejercicio de la potestad estatal, como forma de resguardar la seguridad colectiva, con respeto a la preservación de las garantías fundamentales ${ }^{74}$, sea de modo parcial o total, a depender del caso concreto analizado a través de criterios de proporcionalidad y legalidad.

La tarea no es sencilla, pero consiste en un desafío posible y alcanzable a depender de la adopción de los citados criterios y del respeto a los parámetros de constitucionalidad.

Como asevera SCARANCE FERNANDES, ante la imposibilidad de definirse con claridad lo que configura este justo equilibrio y la gran dificultad en traducirle en los textos de ley o en la aplicación concreta del derecho, su búsqueda representa una meta, una directriz que debe seguir el proceso penal, haciendo con que ello, en el movimiento pendular de la historia, no se distancie del punto medio entre la protección a la libertad y la seguridad de la sociedad 75 .

73 Vid; PACELLI DE OLIVEIRA, E., Processo e hermenêutica na tutela penal dos direitos fundamentais, Belo Horizonte, 2004, pág. 6. En este mismo sentido, parece claro que el examen de las garantías procesales individuales debe ser hecho en concreto en cada y respectiva racionalidad jurídica, llevándose en cuenta, el caso fáctico y, como en la aplicación de cualquier norma constitucional, las implicaciones decurrentes de las referidas opciones, en lo que se refiere a la efectiva tutela de los intereses en disputa.

74 Con ello queremos decir que el ordenamiento jurídico no sólo debe preocuparse de establecer las consecuencias jurídicas para aquellas personas que vulneran bienes jurídicos, sino también establecer los límites al empleo de la potestad punitiva del Estado, en busca de que el justiciable no quede desprotegido ante probables abusos estatales (policiales, judiciales, penitenciarios). Por lo tanto, el Estado constitucional de Derecho blinda a sus habitantes las llamadas garantías constitucionales como instrumento de protección.

75 Cfr. SCARANCE FERNANDES, A., "O equilíbrio na repressão do crime organizado", cit., pág. 10. 
En consecuencia, deberá ser buscado el objetivo de alcanzar "eficiencia con garantías"76, lo que en nuestra opinión será la fórmula idónea para la realización en concreto del Derecho penal, lo que, como es lógico, exige un esfuerzo superador incompatible con la intolerancia, con la incompetencia y con la ausencia de compromiso.

Siguiendo este mismo raciocinio es importante y fundamental destacar una vez más que a nuestro modo de ver, este conflicto bélico entre el debido proceso penal y el eficaz control de la criminalidad no debe necesariamente existir77. En otras palabras, las garantías procesales no deben ser colocadas de forma antagónica a la eficiencia del proceso, visto como un instrumento de defensa social 78 .

Esta es la posición adoptada por la doctrina procesal penal contemporánea ${ }^{79}$.

AMODIO incluso afirma que los valores emergentes del Derecho penal europeo se congregan en una síntesis entre el garantismo y la defensa social. Refiere el citado autor a la existencia en Italia y en Alemania de una fase de expansión y estructuración de las garantías del imputado, seguida de otra direccionada a las exigencias de defensa social, habiendo actualmente la búsqueda de una síntesis entre las preocupaciones garantistas y de defensa social ${ }^{80}$.

76 Siguiendo esta misma línea de pensamiento, afirma BINDER que "para una correcta comprensión del Derecho procesal penal (y esto es también aplicable al Derecho penal) se debe tener en cuenta que la base de su formación básica tiene lugar un conflicto entre estas dos tendencias que normalmente han sido presentadas como antagónicas y cuya síntesis se ha mostrado como un ideal". Vid. BINDER, A. M., Introducción al derecho procesal penal, cit., pág. 56. Por eso es que un verdadero Estado de Derecho debe satisfacer simultáneamente ambos reclamos y puede sintetizarse con la fórmula "eficiencia con garantías".

77 Respecto a la ausencia en realidad, de la necesidad de establecimiento de una tensión en el proceso penal, RUBÉN AUED y JULIANO señalan que "en punto a la cuestión, debemos decir que estamos totalmente convencidos de que la dicotomía de marras es falsa y aparente, producto de los acalorados debates que se proponen a una sociedad que no acierta con los métodos para lograr estándares más aceptables de convivencia y que como consecuencia de ello se inclina por soluciones simplistas, las más de las veces contrarias a sus propios intereses". En este sentido, Vid. RUBÉN AUED, N., y JULIANO, M. A., La probation y otros institutos del Derecho Penal, cit; pág. 95. Desde otra perspectiva, GARCÍA RAMÍREZ afirma que "en la frontera entre dos siglos, un lindero que se relaciona más con nuestras expectativas que con nuestras realidades, la justicia penal atraviesa una etapa de grandes redefiniciones sobre algunos de sus temas fundamentales y tradicionales. A la cabeza figura el papel del sistema penal en el control social, es decir, la misión política de la justicia penal, con sus amplísimas consecuencias. En cada una de esas redefiniciones queda de manifiesto, con alcance más radical y profundo, la relación armoniosa o conflictiva entre las libertades y las garantías, por una parte, y las nuevas exigencias espontáneas o inducidas de la seguridad y la paz, por la otra. Se ha construido, de esta suerte, un dilema que muchos calificamos como falso, además de extremamente peligroso, cuya solución gobierna las mayores soluciones penales. Los datos de agitación autoritaria residen en cierto discurso de la seguridad ciudadana y en el proclamado conflicto entre due process y crime control". Vid. GARCÍA RAMÍREZ, S., "Algunas cuestiones del proceso penal", Memorias del Congreso Internacional de Culturas y Sistemas Jurídicos Comparados, http://www.bibliojuridica.org.

78 Vid. ABADE, D. N., Garantias do processo penal acusatório, Rio de Janeiro, 2005, pág. 119. Desde otro ángulo, ZAFFARONI presenta la distinta idea de que "se plantea una falsa disyuntiva cuando se dice que es posible cambiar seguridad por garantías. No existe tal compensación, pues se ceden garantías (controles al ejercicio del poder punitivo) a cambio de un poder punitivo de peor calidad y generador de mayores y peores conflictos, hasta que se ceden todas las garantías para acabar en el caos y, en definitiva, en un régimen totalitario, en que los conflictos seguirán existiendo, con mayor entidad, pero con cero comunicación y conocimiento público". Vid. ZAFFARONI, R. E., "En torno al concepto del crimen organizado", VV.AA., Nada personal. Ensayos sobre crimen organizado y sistema de justicia, Buenos Aires, 2001, pág. 14.

${ }^{79} \mathrm{En}$ este sentido, los enseñamientos de GRINOVER al señalar que "no debe existir incompatibilidad entre las tendencias al garantismo y a la eficacia, valores fundamentales del nuevo proceso penal latinoamericano". Vid. GRINOVER, A. P., "Lineamentos gerais do novo processo penal na América Latina", Revista de Processo, São Paulo, vol. 15, núm. 58, 1990, pág. 134.

80 Vid. con más profundidad, AMODIO, E., Processo penale. Diritto europeo e Common Law. Dal rito inquisitório al giusto processo, Milano, 2003. 
En efecto, surge la constatación de que es cierto que es necesario dotar el Estado de instrumentos necesarios a la defensa social. Esta es la regla. Pero, sin embargo, no se puede aceptar que éstos vengan a superar los valores defendidos en la Constitución.

Deberá ser buscado entonces, un camino constitucional, que sin duda, existe y apunta en dirección a la ponderación de los bienes constitucionales, como forma de obtención de la efectividad del proceso y de la sanción y, consecuentemente, para la célere solución del conflicto. Este según nuestra opinión, sea quizás el gran instrumento para buscarse el adecuado control de la expansión de la delincuencia.

De otra parte y siguiendo a SILVA SÁNCHEZ, se puede afirmar del mismo modo que la contraposición entre libertad individual y seguridad ciudadana no tiene por qué ser en sí misma un fenómeno negativo, por el contrario, debería entenderse como una invitación permanente al perfeccionamiento del sistema, un motor de evolución del Derecho penal que muestre rasgos significativamente dialécticos y se plasme en síntesis sucesivas de signo ascendentemente humanitario y garantístico ${ }^{81}$.

Detengámonos unos instantes para resumir y clarificar lo anterior y poder, así, seguir avanzando.

Si es verdadera la existencia de una tensión de fuerzas en el proceso penal ${ }^{82}$, por otro lado, debemos sostener que este conflicto entre eficacia penal y garantías no debe necesariamente conducir a un resultado que venga a producir perjuicios a los fines de la persecución criminal, o sea, la búsqueda de un proceso justo, eficiente, garantista, en tiempo razonable, con una decisión final que corresponda a los anhelos de la sociedad ${ }^{83}$.

Sólo si el resultado es obtenido a través de un instrumento diseñado y ejercido conforme a concretas garantías y principios, podemos hablar de un resultado aceptable ${ }^{84}$.

Dicho lo anterior el paso siguiente tiene que consistir en reconocer una vez más, que no es contradictoria la búsqueda de una eficiencia con garantías, pues se trata de una fórmula única e idónea para la realización de un proceso penal marcado por el respeto al Estado Constitucional de Derecho ${ }^{85}$. Corroborando nuestra opinión, aduce ANDRADE

\footnotetext{
81 Vid. SILVA SÁNCHEZ, J. Mạ., Aproximación al Derecho penal contemporáneo, Barcelona, 1992, págs. 13-14.

82 Según la opinión de MARTÍNEZ GARCÍA, incluso se podría afirmar sin miedo de equivoco que "en estos momentos, el análisis del desarrollo de los aspectos garantistas de nuestro corpus jurídico está sometido a una tensión entre la libertad de los ciudadanos y el control social que facilite la persecución de los delitos. Una tensión que está azuzada por una cuestión central que pone en jaque los fundamentos del derecho: el concepto de ciudadano y de Estado-nación se tambalean, y el papel que ambos jugaban en la construcción de derechos, libertades y garantías procesales se tambalea con ellos". Vid. MARTÍNEZ GARCÍA, E., Eficacia de la prueba ilícita en el proceso penal (a la luz la STC 81/98 de 2 de abril), Valencia, 2003, págs. 34-35.

83 Por esto, importante citar a RUIZ VADILLO que defiende la idea de que "el proceso penal es una institución muy compleja en la que confluyen sistemas y subsistemas varios: el derecho a un proceso sin dilaciones indebidas, a un proceso con todas las garantías donde se incluyen la proscripción de toda indefensión, el principio acusatorio, el derecho a la prueba (aunque el juez o tribunal pueda rechazar, motivándolo, la práctica de la que no sea pertinente o necesaria), el derecho a impugnar las resoluciones conforme a lo establecido en la ley, etc. Todos ellos son piezas de un sistema, coordinadas entre sí y que sólo dentro del conjunto alcanzan su verdadero sentido". Vid. RUIZ VADILLO, E., Estudios de Derecho procesal penal, cit., pág. 43.

84 Así la opinión de GUZMÁN FLUJA, V. C., Anticipación y preconstitución de la prueba en el Proceso Penal, cit., pág. 148.

85 Prefiero denominar el Estado de Derecho, en la actualidad, tras el fin de la segunda guerra mundial, de Estado Constitucional de Derecho o aunque, neoconstitucionalismo. Como expresión del pos positivismo en el Derecho Constitucional, la doctrina viene utilizando las expresiones "neoconstitucionalismo", "constitucionalismo avanzado" o "constitucionalismo de derechos", para designar un nuevo modelo jurídico que representa el Estado Constitucional de Derecho en el mundo contemporáneo, con reflejos directos en el
} 
FERNANDES que sería entonces posible conciliar al mismo tiempo las necesidades de garantía del ciudadano con las no menos necesarias funcionalidades y la eficiencia del sistema punitivo total ${ }^{86}$.

Por lo tanto, imprescindible señalar que la relación entre garantías y la eficiencia es un tema que, en rigor, atraviesa toda la justicia penal, vinculándose con el concepto del debido proceso ${ }^{87}$ entendido como un estándar axiológico que exige que nadie pueda ser privado de su libertad, sin que se cumplan ciertos procedimientos legales ${ }^{88}$. Estos están dirigidos a asegurar a las personas que las razones de su defensa sean escuchadas por un tribunal competente que deberá esforzarse por dictar en tiempo hábil una sentencia fundada que exprese el difícil equilibrio entre la libertad personal y la seguridad general ${ }^{89}$.

Ahora bien, los términos del debate entre éxito en la persecución del delito y respeto de los derechos del acusado podrían sintetizarse diciendo que en un sistema probatorio no sólo debe inspirarse en el respeto a las normas que garantizan los derechos del acusado, ni tampoco sólo en la prescripción de cuanto sea apto para descubrir "la verdad" y, en general, garantizar una eficaz persecución; un sistema probatorio debe mirar o debe servir, más esencialmente para establecer "disposiciones jerárquicas entre valores procesales y extraprocesales" regulando el modo de resolver en caso de eventuales colisiones entre garantía y eficacia ${ }^{90}$.

Ciertamente, a partir de estas premisas parece innegable que tanto el interés de la seguridad, a ser buscado mediante una protección penal eficiente ${ }^{91}$, cuanto los derechos fundamentales del investigado o acusado deben ser preservados, no habiendo razón para a priori afirmarse la primacía de uno o de otro, sin la debida ponderación. Así como en otras ramas del derecho, la relación de tensión debe ser resuelta a través del método de la ponderación, caso a caso, de acuerdo con las reglas ya construidas para las colisiones entre principios y la prohibición de exceso ${ }^{92}$ en la búsqueda de la concordancia práctica entre la

modo de interpretar la Constitución. Vid. con mayor profusión, CARBONELL, M., Neoconstitucionalismo(s), Madrid, 2005.También, MOREIRA, E. R., Neoconstitucionalismo. A Invasão da Constituição, São Paulo, 2008; DIMOULIS, D. D., OTO, E., Teoria do Direito Neoconstitucional, São Paulo, 2008. Además, como ha sostenido BALAGUER CALLEJÓN, "El Estado constitucional de derecho, la Constitución, en cuanto consenso fundamental del Estado y la sociedad, establece las condiciones de validez no sólo del resto de las fuentes del derecho sino también de los diversos ordenamientos que, en su caso, coexisten bajo su territorio". Vid. BALAGUER CALLEJÓN, F., "Fuentes de Derecho, espacios constitucionales y ordenamientos jurídicos", Revista española de Derecho Constitucional, núm. 69, 2003, pág. 187.

86 ANDRADE FERNANDES, F., O processo penal como instrumento de política criminal, Coimbra, 2001, pág. 829.

87 Vid. con amplitud, ESPARZA LEIBAR, I., El principio del proceso debido, Barcelona, 1995; BANDRÉS SÁNCHEZ-CRUZAT, J. M., Derecho fundamental al proceso debido y el Tribunal Constitucional, Pamplona, 1992; SUÁREZ SÁNCHEZ, A., El debido proceso penal, Bogotá, 2001; ALVARADO VELLOSO, A., El debido proceso de la garantía procesal, Buenos Aires, 2003; BACIGALUPO, E., El debido proceso penal, Buenos Aires, 2005.

88 Por esta razón se concluye que es innegable que el proceso penal es el único instrumento adecuado para la realización de la justicia penal, del llamado ius puniendi del Estado. Sosteniendo esta idea, Vid. VADILLO, E. R., Estudios de Derecho procesal penal, cit., pág. 37.

89 Vid. FRONDIZI, R. J., DAUDET, M. G., Garantías y eficiencia en la prueba penal, cit., pág. 3.

90 Vid. UBERTIS, G., "La ricerca della verità giudiziale", La conoscenza del fatto nel processo penale, Milano, 1992, págs. 36-37.

${ }^{1}$ De observarse que delante de esta constatación, se puede afirmar que "El Estado no cumple su tarea de seguridad tan sólocon la publicación de las leyes, pero sí, con su eficaz aplicación". Vid. ISENSEE, J., Das Grundrecht auf Sicherheit. Zu den Schutzpflichten des Freiheitlichen Verfassungsstaates, Berlin, 1983, pág. 21.

92 Monograficamente respecto al tema, Vid. TOLEDO MACHADO, M., Proibições de excesso e proteção insuficiente no direito penal, São Paulo, 2008. 
protección de la libertad y las necesidades de la persecución, sin generalización o recurso fácil y unilateral a uno u otro de los lados de la cuestión ${ }^{93}$.

Al fin de este apartado, cabe concluir que la tensión o la lucha en el proceso penal terminarán sin vencedor, a la vez que deberá, como ya afirmado, ser buscada la eficiencia con garantías, de modo a la obtención de una mejora en la prestación jurisdiccional y en la credibilidad de la administración de la justicia penal. Para la consecución de esta finalidad, la alternativa más plausible será la construcción de un arquetipo de "armonía procesal penal".

I.1.2. Armonía procesal penal: un objetivo para conciliar la eficacia y las garantías.

I.1.2.1. La función primordial del proceso penal.

La aproximación al estudio de cualquier tema relativo al Derecho Procesal penal, como de alguno de sus elementos estructurales, debe hacerse despejando con carácter previo una cuestión importante: ¿cuál es la finalidad del proceso penal?

Se podría, de forma precipitada, decir que se trata de un cuestionamiento académico desprovisto de cualquier sentido en el contexto de una investigación de esta naturaleza. En nuestra opinión, muy al contrario, pues a partir del análisis de esta indagación, y delante del estudio del desarrollo de las varias fases traspasadas por la ciencia procesal penal en los últimos años, llegaremos a la conclusión de que contemporáneamente no se puede prescindir del enfoque garantista y del carácter instrumental ${ }^{94}$ que impregna el Derecho procesal penal.

Pues bien, volviendo al planteamiento respecto a la función del proceso penal, es necesario para responder a esta pregunta partirse del hecho comprobado de que el proceso penal no puede considerarse como un fin en sí mismo, que tenga virtualidad propia, sino que en realidad es un mero instrumento de todo el sistema penal, es decir, de la respuesta que el ordenamiento jurídico produce a partir de la comisión de unos hechos con apariencia delictiva 95 .

A los fines de una comprensión integral del tema de la tensión de fuerzas, interesante plantear una vez más la pregunta: ¿cuál sería entonces la función efectiva del proceso penal? Dicho de otro modo, ¿buscar la eficiencia del ius puniendi estatal o mantener intactos los derechos y garantías de los investigados o imputados en un proceso penal?

93 En este sentido y citando amplia doctrina alemana, Vid. BALTAZAR JR., J. P., "Limites constitucionais à investigação. 0 conflito entre o direito fundamental à segurança e o direito de liberdade no âmbito da investigação criminal", cit., págs. 207-208.

94 Significa que la strumentalità del proceso penal reside en el hecho de que la norma penal presenta, cuando comparada con otras normas jurídicas, la característica de que el precepto tiene como contenido un determinado comportamiento prohibido o imperativo y la sanción tiene como destinatario aquello poder del Estado, que es llamado a aplicar la pena. Vid. LEONE, G., Elementi di Diritto e Procedura Pénale, 5a edición, Napoli, 1981, pág. 189. Además, es fundamental comprender que la instrumentalidad del proceso no tiene una visión exclusivamente jurídica y mucho menos jurídico-procesal. No es un instrumento que tiene como única finalidad la satisfacción de una pretensión (acusatoria). En síntesis, el proceso penal no puede ser considerado como un fin en sí mismo, pues su razón de existir está en el carácter de instrumento medio para la obtención de un fin. Con más detalles, Cfr. LOPES JR, A., "A instrumentalidade garantista do processo penal", http://www.juspodivm.com.br.

95 MORENO CATENA, V., "El papel del Juez y del Fiscal durante la investigación del delito", VV.AA., Hacia un nuevo proceso penal, Manuales de formación continuada, núm. 32, Madrid, 2006, pág. 57. 
La respuesta dependerá del punto de vista dogmático analizado. No es objeto de nuestro trabajo, agotar de modo integral toda la problemática relativa a las innúmeras ideas surgidas en el desarrollo de la historia del proceso penal, respecto a los fines de esta rama del Derecho. Nos cabe tan solo, analizar de modo conciso algunas ideas destacables sobre el tema.

A continuación, se expondrán algunas de las más importantes posturas existentes en la doctrina respecto a esta cuestión, desde una visión tradicional del proceso penal hasta el pensamiento contemporáneo que defiende esta rama jurídica como un instrumento al servicio de la preservación de las garantías fundamentales del ciudadano.

A partir de ahí, es algo normal y habitual, encontrar en la doctrina tradicional ${ }^{96}$, la afirmación que el proceso penal debe ser visto como el instrumento que la jurisdicción tiene para la exclusiva aplicación del ius puniendi del Estado ${ }^{97}$. 0 una vez más citándose a SCHÖNKE, deberíamos ver el proceso penal como institución que tiene como finalidad asegurar el mantenimiento del Derecho a través de las garantías de una protección de las leyes y la defensa del orden jurídico98.

Tendría entonces el proceso penal la finalidad no sólo de imposición de la pena, sino también la ejecución de la misma99.

En línea con esta doctrina tradicional, la finalidad del proceso seria únicamente propiciar la adecuada solución jurisdiccional del conflicto de interés entre el Estado ${ }^{100}$ y el infractor, a través de una secuencia de actos que han de comprender la formulación de la

96 En este sentido, señala de forma crítica RAMOS MÉNDEZ que "tradicionalmente se viene asignando al
uicio penal el ejercicio del ius puniendi del Estado. Tal concepción exclusivamente represora no concuerda con
el actual diseño constitucional. No se trata ya de imponer o no una pena a alguien cuyo punto de partida es
presuponer su condición de delincuente. Por el contrario, se trata de enjuiciar la conducta de un ciudadano
que, mientras no se demuestre lo contrario, es inocente del delito del que se le acusa. El juicio penal aparece
así como el mecanismo más drástico para la tutela de la convivencia en libertad en las diversas esferas de la
ida", Enjuiciamiento Criminal. Vid. RAMOS MÉNDEZ, F., Enjuiciamiento Criminal. Octava lectura constitucional,
cit., pág. 30. También interesante, la opinión de GIMENO SENDRA que destaca que "tradicionalmente y todavía
en el momento actual, en los manuales al uso (Fenech, Viada, Montero), viene concibiéndose el proceso penal
como el instrumento que la Jurisdicción tiene para la exclusiva aplicación del ius puniendi del Estado". Vid.
GIMENO SENDRA, V., Derecho procesal penal, cit., pág. 43. Ya en las palabras de FENECH, "el proceso penal es,
por tanto, aquella serie o sucesión de actos que se llevan a cabo y desarrollan en el tiempo, con sujeción a unas
normas de procedimiento, y a través de la cual se realiza la actividad jurisdiccional, mediante el ejercicio por el
organo jurisdiccional penal de sus diversas potestades y la realización de las partes y terceros de la actividad
cooperadora que aquélla requiere". En este sentido, Vid. FENECH, M., El proceso penal, Madrid, 1982, pág. 5 .

${ }^{97} \mathrm{~A}$ su vez, CUELLAR SERRANO afirma que "es una obviedad afirmar que el proceso constituye un instrumento de actuación de la Jurisdicción que se basa en una articulación compleja de actos procesales, regido por determinados principios y destinado a satisfacer unos fines que la Constitución y la ley le asignan", Vid. GONZÁLEZ-CUELLAR SERRANO, N., "Investigación y prueba: los nuevos retos ante la reforma del proceso penal", VV.AA., Investigación y prueba en el Proceso Penal, Madrid, 2006, pág. 18.

${ }^{98} \mathrm{Cfr}$. SCHÖNKE, A., "Limites de la prueba en el derecho procesal", cit., pág. 374.

99 Vid. GOMEZ ORBANEJA, E., HERCE QUEMADA, V., Derecho Procesal Penal, 10ª edición, Madrid, 1984, pág. 8. En idéntico sentido, PRIETO-CASTRO y FERRÁNDIZ, L., GUTIERREZ DE CABIEDES Y FERNANDEZ DE HEREDIA, E., Derecho procesal penal, 2ª edición, Madrid, 1978, pág. 89.

100 Cfr. el articulo 117 de la Constitución española que tiene como objeto de estudio el Poder Judicial. El citado precepto de la Constitución abre el Título VI dedicado al Poder Judicial. De modo sintético este artículo de la CE dice respecto a algunos temas inherentes al Poder Judicial español, a ejemplo de su legitimación, la inamovilidad de Jueces y Magistrados, la exclusividad e integridad de la función jurisdiccional y la unidad jurisdiccional. 
acusación, la producción de pruebas, el ejercicio de la defensa y el fin de la cuestión penal vía de una decisión judicial101.

Sin embargo, la solución del citado conflicto de intereses, especialmente en el campo penal, se ejerce a través de la función jurisdiccional del Estado en lo que se denomina "proceso" y, en tratándose de una cuestión penal, de "proceso penal"102. Y el ius puniendi estatal en este contexto estaría representando el derecho del Estado de aplicar la sanción establecida en la norma penal, contra quien ha practicado la acción u omisión descrita en el precepto primario de la misma norma ${ }^{103}$.

Con una posición dogmática peculiar e intermedia respecto a esta discusión, sostiene ARMENTA DEU que el fin fundamental del proceso penal es la actuación del ius puniendi estatal, que obedece o proviene esencialmente de la atribución exclusiva al Estado de la facultad de imponer penas: el Estado tiene la facultad, pero también el deber, de castigar las conductas delictivas de las que tenga conocimiento; y esa facultad o deber sólo pueden ejercitarlo los Jueces y Tribunales a través del proceso penal. Hay que tener en cuenta, en todo caso, que el ejercicio de esta facultad o deber, por definición, ha de quedarse sujeto al principio de legalidad o necesidad; en tanto, por otro lado, su carácter público lo convierte en no disponibilidad para su titular, el Estado. Junto a esta finalidad de actuación del ius puniendi, se reconoce, sobre todo desde tiempos relativamente recientes, otros fines del proceso penal: la protección a la víctima del delito y la rehabilitación/reinserción social del delincuente ${ }^{104}$.

En sentido distinto a estas ideas, destacado seguimiento de la doctrina contemporánea ${ }^{105}$, con la cual estamos absolutamente de acuerdo, defiende que el proceso

101 En sentido crítico a esta concepción tradicional, SANTANA señala que "no se puede aceptar, sin reservas, la idea de que el proceso penal constituya mero instrumento de aplicación del Derecho Penal, restringiendo su función a la descubierta de la verdad material, exclusivamente. El proceso penal, amén de su carácter retrospectivo, direccionado a la reconstrucción de la verdad, debe estar conformado, llevándose en cuenta las peculiaridades de naturaleza político-criminal, en el contexto social de su aplicación, debiendo buscar una armonía entre las finalidades de política criminal de un determinado sistema jurídico-penal y el modelo de proceso penal en ello adoptado". Vid. SANTANA, S. P., "A tensão dialética entre os ideais de garantia, eficiência e funcionalidade", cit., nota 43, pág. 890.

102 Recuerda VALLEJO que "la función del proceso penal, aparte naturalmente de que tenga por objeto la aclaración del hecho punible y la eventual participación en el mismo del acusado, es la protección del imputado, que debe ser presumido inocente hasta el momento de la sentencia firme; de ahí precisamente el carácter excepcional y subsidiario de la medida de prisión provisional. Ello significa, básicamente, que debe respetarse la dignidad de la persona, la presunción de inocencia, y las reglas/garantías del debido proceso". Así, VALLEJO, M. J., Derechos fundamentales del proceso penal, 2a edición, Bogotá, 2006, pág. 20. En el mismo sentido, Vid. la STS 47/2000, de 17.2.2000. Además, no se puede olvidar, citando a VADILLO que "es innegable que el proceso penal es el único instrumento adecuado para la realización de la justicia penal, del llamado ius puniendi del Estado". Vid. VADILLO, E. R., Estudios de Derecho procesal penal, cit., pág. 37.

103 Jurídicamente suelen distinguirse dos manifestaciones del ius puniendi que, según la doctrina, tendrían, en cada caso, un fundamento autónomo: el derecho del Estado a establecer normas penales y el derecho del Estado a exigir el cumplimiento de éstas. En este sentido, Vid. RODRÍGUEZ DEVESA, J. M., Derecho Penal Español. Parte general, Madrid, 1949, pág. 35; RODRÍGUEZ MOURULLO, G., Derecho Penal. Parte general, Madrid, 1978, págs. 95 y ss.

104 ARMENTA DEU, T., Lecciones de Derecho Procesal Penal, 3a edición, Madrid-Barcelona, 2007, pág. 26. Sigue una orientación semejante a este, LÓPEZ BARJA DE QUIROGA al afirmar que 'las funciones del proceso penal se concretan en crear un marco en el que pueda realizarse en condiciones de justicia el ius puniendi, así como la protección de la víctima en tanto se atiende a la reparación civil de los efectos del delito". Vid. LÓPEZ BARJA DE QUIROGA, J., Tratado de Derecho Procesal Penal, cit., págs. 92-93.

105 Según, GRECO FILHO "es costumbre decir que el proceso penal es el modo por lo cual actúa la jurisdicción en materia penal. Esta, haciendo actuar el orden jurídica penal, debe definir, en relación a un caso concreto, si el imputado es culpado o inocente, o sea, si su conducta constituye, o no, ilícito penal, determinando la cantidad de sanción que a tal hecho corresponde". Y prosigue, señalando que "gran número 
no puede ser visto como un simple instrumento al servicio del poder punitivo (derecho penal), sino que desempeña el papel de limitador del poder y garante del individuo a él sometido. En este sentido, se puede comprender que el respeto a las garantías fundamentales de las personas sometidas al proceso no ha que confundirse con impunidad, y que jamás se ha defendido esto, pues el proceso penal es un camino necesario y casi obligatorio para llegarse, legítimamente, a la aplicación de una sanción. Desde ahí porque solamente se admite su existencia cuando a lo largo de este camino sean rigurosamente observadas las reglas y garantías constitucionalmente aseguradas (las reglas del debido proceso legal) ${ }^{106}$.

Siguiendo el mismo raciocinio, RODRÍGUEZ GARCÍA revela que el proceso penal, para ser efectivo, tiene que satisfacer dos fines esenciales: la disuasión, en el que sólo la rapidez en alcanzar la condena del culpable asegura la seriedad de la sanción penal; y la persuasión, debiendo garantizar por un lado una condena justa de los acusados culpables y por otro liberando lo más rápidamente posible a los que sean inocentes de la acusación que se les haya formulado ${ }^{107}$. Dicho en pocas palabras, ésta sería la representación de un proceso penal garantista.

En línea con esta doctrina no parece arriesgado afirmar que el proceso penal no es solamente un medio o instrumento de realización del Derecho penal, pues antes debe recibir él mismo una conformación directamente basada en propósitos de política criminal. Como dijimos antes, la búsqueda de la eficiencia penal deberá añadirse al deber estatal de punir, la tradicional dimensión garantista del proceso.

Delante de lo afirmado con anterioridad, cabe comprender que el proceso penal sirve para garantizar la seguridad pública, como un valor digno de especial protección, pues funciona precisamente como el elemento de cierre de la lucha contra la criminalidad y de las medidas de política criminal que deben adoptar los poderes públicos.

En síntesis, el proceso no sería un mero mecanismo de solución de conflictos.

Ello es, antes de todo, un locus para la discusión y desarrollo de políticas públicas, con espacio para la participación de las personas más directamente interesadas en el tema llevado a discusión ${ }^{108}$.

Frente a esta valoración, el proceso penal como instrumento para la concreción del Derecho penal material deberá seguir dos objetivos distintos: de un lado, posibilitar la viabilidad de la aplicación de la sanción por el Estado, y de otro, servir como verdadero instrumento de garantía de los derechos y libertades individuales, contra los posibles y emblemáticos actos abusivos practicados por el titular del derecho de punir.

En consecuencia, fácil es percibir que la función instrumental del proceso penal objetiva a la realización de la justicia que presupone la descubierta de la verdad material y

de doctrinadores del proceso penal ha olvidado la función procesal de garantía de los imputados". Vid. GRECO FILHO, V., Manual de Processo Penal, São Paulo, 1997, págs. 54-55.

106 LOPES JR, A., Direito Processual Penal e sua conformidade constitucional, cit., pág. 10. Corroborando lo dicho, en nuestra opinión, el proceso penal funciona en un Estado Constitucional de Derecho como un medio necesario e imprescindible de garantía de los derechos del imputado. No es un mero instrumento de concreción del Derecho Penal, sino, verdaderamente, un instrumento de satisfacción de derechos humanos fundamentales y, sobretodo, una garantía excepcional contra el arbitrio del Estado.

107 Cfr. RODRÍGUEZ GARCÍA, N., La justicia penal negociada. Experiencias de Derecho Comparado, Salamanca, 1997, pág. 134.

108 SILVA JUnior, W. N., Curso de Direito Processual Penal: Teoria (Constitucional) do Processo Penal, cit., pág. 276. 
el restablecimiento de la paz jurídica, incidiendo ésta tanto en el plan individual, del argüido y de la víctima, como en el plan más amplio de la comunidad jurídica. Pero, la realización de la justicia no puede ser un fin absoluto o único del proceso penal, siendo que la propia verdad material sólo puede ser buscada, en palabras de FIGUEIREDO DIAS, de modo procesalmente válido y admisible y, por lo tanto, con el integral respeto de los derechos fundamentales de las personas que en el proceso son sometidas ${ }^{109}$.

De lo expuesto, el proceso penal debe servir como un límite de la actividad jurisdiccional estatal, estructurándose de modo a garantizar la plena y real efectividad a los derechos y garantías constitucionalmente establecidos 110 .

¿Y cómo materializarse este objetivo? La receta es mantener la sensibilidad para percibir las afectaciones a la dignidad humana, recordando que el proceso penal administra violencia, violencia estatal, y aplica dolor, dolor que trasciende la persona del acusado ${ }^{111}$.

En efecto, citando palabras de ARAGONESES ALONSO, incluso tiene el Estado el deber de proteger al propio delincuente, pues esto también es una forma de garantizar el libre desarrollo de la personalidad, que es la función de la justicia112.

Es muy interesante dicha opinión, pues como es obvio, parece absolutamente equivocada la eventual defensa de que el titular del ius puniendi, no deba promover como meta institucional, la protección del ciudadano como forma de respeto a la dignidad humana.

En este orden de ideas, la función efectiva del proceso criminal, en esta línea del garantismo predominante en la doctrina procesal penal moderna, es la preservación de la dignidad de la persona humana contra el ejercicio del legítimo derecho del

109 Vid,. GONÇALVES, F; JOÃO ALVES, M; GUEDES VALENTE, M. M., Lei e Crime. O agente infiltrado Versus o agente provocador. Os princípios do processo penal, cit., pág. 14.

110 Cítese la presunción de inocencia, la defensa, de la contradicción, etc. A este respecto con más profundidad Vid. FALCONE, R. A., Las garantías del imputado frente a la persecución penal estatal, Buenos Aires, 2007.

111 Vid. SOLIMINE, M. A., "Praxis instructoria en un Estado de Derecho, Entre las garantías y la eficiencia", cit., pág. 133. Incluso, oportunas son las palabras de LOPES JR, en el sentido de que "considerando que riesgo, violencia e inseguridad siempre han de existir, es siempre mejor el riesgo con garantías procesales que el riesgo con autoritarismo. Es preferible un sistema que no funcione en algunos casos por falta de control (o de limitación de la esfera de la libertad individual) que un Estado policial y prepotente, pues los fallos siempre van a existir. El problema es que en este último caso, el riesgo de que inocentes paguen por el error es infinitamente mayor y éste es un costo que no se puede tolerar". Vid. LOPES JR, A., Introdução crítica ao Processo Penal, 4⿳亠丷a edição, Rio de Janeiro, 2006, pág. 68.

112 ARAGONESES ALONSO, P., Instituciones de Derecho Procesal Penal, 5a edición, col. S. Aragoneses Martínez, Madrid, 1984, págs. 7 y ss. Interesante mencionar citando a CARNELLUTI "que en el Estado Democrático de Derecho, la estructura del proceso penal debe ser tal que se reduzca a lo mínimo posible el riesgo de error y, en segundo lugar, el sufrimiento injusto que de ello deriva". Así, Vid. CARNELLUTI, F., Derecho Procesal Civil y Penal, trad. E. Figueroa Alfonso, México, 1997, pág. 308. En consecuencia, se puede afirmar que todos los mecanismos de protección que vengan a amenizar el sufrimiento y los riesgos que puedan ser provocados por el Proceso penal, son en verdad, imperativos de la justicia. Dicho lo anterior el paso siguiente tiene que consistir en reconocer que la realización de la justicia penal exige una importante dosis de garantías. Caso contrario, podrá caerse en un autentico terrorismo de Estado. A la total eficiencia, traducida en celeridad y economía de medios, tiene que ceder delante de la consideración de que al buscar punir todos los delincuentes, el Estado debe apartar el riesgo de punir personas que no sean criminosas, así como tendrá que tener siempre presente que el peor de los delincuentes, por el hecho que sea, nunca perderá la dignidad inherente a la condición de persona humana. 
Estado/sociedad perseguir la responsabilidad penal, sin descuidarse, por obvio, del papel que ello tiene de desempeñar cuanto al combate a la criminalidad ${ }^{113}$.

No estaría el proceso penal a servicio de la institución de la impunidad, alejándose de la función constitucional de protección de los derechos colectivos a la seguridad y la aplicación justa de la ley penal.

En definitiva, lo que se busca contemporáneamente es un proceso penal operativo, respetuoso con la dignidad humana, es decir, garantista y eficaz al tiempo. De otra parte, el proceso penal no puede transformarse en una eficaz herramienta para conspirar contra las garantías de los ciudadanos, buscándose una resolución penal a cualquier precio.

Muy al contrario, las garantías procesales fundamentales, tales como el derecho de no auto incriminarse y la no admisibilidad de las pruebas ilícitas, condicionan el descubrimiento de la verdad en el proceso penal, que no es, entonces, buscada a cualquier precio $^{114}$. Si bien puedan estos derechos permanecer restringidos de forma excepcional y basada en la proporcionalidad, como tendremos oportunidad de estudiar en capítulo posterior.

Siguiendo a esta línea de pensamiento, sostiene GIMENO SENDRA que a diferencia de los regímenes autocráticos, en un Estado de Derecho, la función del proceso penal no puede identificarse exclusivamente con la aplicación del ius puniendi, y ello, por la sencilla razón de que también está destinado a declarar el derecho a la libertad del ciudadano inocente ${ }^{115}$. Como defiende MARQUES DA SILVA: "que ningún responsable pase sin punición (impunitum non relinqui facinus) ni ningún inocente sea condenado (innocentum non condennari)"116.

Si el proceso penal regula el derecho deber de sancionar del Estado en la perspectiva democrática, ello es un instrumento de tutela de los derechos fundamentales del ciudadano. En esta visión, aunque el proceso sirva de instrumento para que el poder público, teniendo en vista mantener o restaurar la orden social, ejercite la persecución criminal con autoridad y legitimidad, por otro lado, ello tiene como misión establecer los límites del uso de la fuerza estatal en la búsqueda de la punición del agente infractor ${ }^{117}$.

113 SILVA JUnior, W. N., Curso de Direito Processual Penal: Teoria (Constitucional) do Processo Penal, cit., pág. 279.

114 Cfr. BALTAZAR JR, J. P., "Limites constitucionais à investigação. 0 conflito entre o direito fundamental a segurança e o direito de liberdade no âmbito da investigação criminal", cit., pág. 210.

115 Vid. GIMENo SENDRA, V., Derecho Procesal Penal, cit., pág. 43. Del mismo modo, defiende LORENTZ BLANK que "no habrá más condiciones para tolerarse un proceso penal autoritario, fomentado por políticas represivas de ley y orden, típicas de un estado policial. Esta perspectiva utilitarista deberá ser repudiada, mismo porque el proceso, en hipótesis alguna, puede ser transformado en instrumento de seguridad pública". Vid. LORENTZ BLANK, G., "Instrumentalidade garantista do processo penal", Revista do Ministério Público de Minas Gerais, Belo Horizonte, 2005, pág. 4.

116 MARQUES DA SILVA, G., Curso de processo penal, vol. 1, Lisboa, 2000, pág. 24.

117 SILVA JUNIOR, W. N., Curso de Direito Processual Penal: Teoria (Constitucional) do Processo Penal, cit., pág. 267. Pues bien, a partir de estas premisas, GOMÉZ COLOMER define que "las metas del proceso penal son varias y de similar importancia, aunque complejas: lograr la condena del culpable aplicando el llamado Derecho penal material, garantizar la protección del inocente evitando su condena y asegurando que tendrá el proceso debido, impedir cualquier forma de arbitrariedad en la actividad estatal, y llegar a una sentencia firme justa". Vid. GÓMEZ COLOMER, J. L., "Estado de Derecho y Policía Judicial Democrática: Notas sobre el alcance y límites de la investigación policial en el proceso penal, con consideración especial de los actos de mayor relevancia", VV.AA., El proceso penal en el Estado de Derecho (Diez estudios doctrinales), Lima, 1999, pág. 94. 
En nuestra opinión, como instrumento neutro de la jurisdicción, el proceso penal debe servir tanto a la efectividad del derecho de punir estatal, cuanto a la preservación de las garantías y derechos ${ }^{118}$ fundamentales de los ciudadanos.

Esto significa, sencillamente, que si el proceso penal es un instrumento que legitima el uso de la fuerza del Estado en el cumplimiento de su función punitiva, ello se manifiesta, por otro lado, como una limitación cuanto al uso de este poder-deber ${ }^{119}$.

En sentido semejante, señala FERRAJOLI que es posible afirmar que el proceso penal tiene como misión ejercer una tutela capaz de minimizar la violencia y de maximizar la libertad, así como crear un sistema de vínculos impuestos a la potestad punitiva del Estado en garantía de los derechos de los ciudadanos ${ }^{120}$, o sea, una auténtica e indiscutible representación garantista del proceso penal.

Entendido así, el proceso penal se dirige siempre a alcanzar un adecuado equilibrio entre eficacia y garantía. Habrá entonces de ser evitada, como anteriormente defendido, la tensión ${ }^{121}$ negativa de fuerzas que provoca un sinnúmero de situaciones de desigualdad en el ámbito penal.

Otra constatación de interés se refiere al hecho de que el Estado realiza su derecho de sancionar a través del proceso, verdadero e insustituible instrumento del que se vale para imponer la sanción al infractor de la norma penal. En consecuencia, en un Estado constitucional de Derecho, las garantías, comprendidas como la solidez o establecimiento del conocimiento verdadero, tanto de la sociedad, cuanto del individuo, están dentro del propio Estado.

\footnotetext{
118 Según ORÉ GUARDIA habrá que destacarse una clara distinción conceptual entre derechos y garantías. Señala en este sentido que los "derechos son las facultades que asisten al individuo para exigir el respeto o cumplimiento de todo cuanto se establece y reconoce en su favor en el ordenamiento jurídico vigente, Por su parte, las libertades abarcan un campo más amplio que el de los derechos, y su esencia es fundamentalmente política. Finalmente, las garantías son el amparo que establece la Constitución y que debe prestar el Estado para el efectivo reconocimiento y respetode las libertades y derechos de la persona individual, de los grupos sociales, e incluso del aparato estatal, para su mejor actuación y desenvolvimiento". Vid. ORÉ GUARDIA, A., Manual de derecho procesal penal, 2ª edición, Lima, 1999, pág. 28. En la doctrina brasileña, BARBOSA también reconoce una clara distinción entre los derechos y las garantías. Así, señala el jurista brasileño que "una cosa son las garantías constitucionales, otra cosa los derechos, que estas garantías traducen, en parte, la condición de seguridad, política o judicial. Los derechos son aspectos, manifestaciones de la personalidad humana en su existencia subjetiva, o en sus situaciones de relación con la sociedad, o los individuos que la componen. Las garantías constitucionales strictu sensu son las solemnidades tutelares de que la ley circunda algunos de estos derechos contra el abuso del poder". Vid. BARBOSA, R., Atos Inconstitucionais, São Paulo, 2003, pág. 154. En el mismo sentido, BONAVIDES conceptúa tal distinción, afirmando que "derecho es la facultad reconocida, natural o legal, de practicar o no practicar ciertos actos. Garantía o seguridad de un derecho, es el requisito de legalidad, que lo defiende contra la amenaza de ciertas clases de atentados de ocurrencia más o menos fácil", Así, BONAVIDES, P., Curso de Direito Constitucional, São Paulo, 1993, págs. 441-442.

119 Siguiendo este mismo raciocinio, señalan GONÇALVES y ALVES que "el proceso penal, como, también en todos los restantes procesos, de un Estado de Derecho democrático, basado en la dignidad de la persona humana, en el respeto y en la garantía de efetivación de los derechos y libertades fundamentales del ciudadano, en una perspectiva jurídico-procesal, visa la aplicación de la ley penal en los casos concretos, buscando garantizar que ningún responsable pase sin punición (impunitum non relinqui facinus) ni ningún inocente sea condenado (innocentum non condennari)". Vid. GONÇALVES, F; JOÃO ALVES, M., A prova do crime. Meios legais para a sua obtenção, Coimbra, 2009, pág. 13.

120 FERRAJOLI, L., Derecho y Razón, cit., págs. 851 y ss. Si lo anterior es correcto, entonces se puede afirmar sin miedo, que el proceso penal no puede ser concebido como un mero instrumento de pura rotulación, en que se pune no más por la sanción, pero si en razón del simple hecho de estar la persona siendo procesada.

121 La tensión aludida, en términos más vulgares, también aparece traducida como la disyuntiva entre el discurso "garantista" y el de "mano dura" o "tolerancia cero", por el que se quiere hacer aparecer a los primeros como cómplices de los delincuentes y de la impunidad, y a los segundos como garantes del castigo a los culpables.
} 
Dicho en palabras exactas, las garantías ${ }^{122}$ han de limitar la actuación de los órganos estatales protegiendo la eficacia, la aplicabilidad y la inviolabilidad de los derechos fundamentales de un modo particularmente especial123. Esta realmente es la función de las garantías procesales, o sea, legitimar, por el estricto control jurisdiccional, la intervención estatal en la esfera individual, de modo que, si cualquier restricción de derechos venga a ocurrir en la persecución penal, que sea la misma necesaria, adecuada y proporcional.

De esta suerte, queda establecido que el proceso penal en el marco del Estado constitucional de Derecho ${ }^{124}$, corresponde a la armonización del ius puniendi estatal junto a la preservación de las garantías de la persona sometida a la persecutio criminis. En tal sentido, el interés social debe enfrentarse al interés individual no en son de lucha sino de armonía $^{125}$.

Se evita con esto, como hemos visto, la indeseable tensión negativa entre eficacia y garantías $^{126}$, la cual podrá provocar un sinnúmero de situaciones de desigualdad, a la vez que uno u otro de estos dos intereses queda por aniquilarse sin cualquier criterio lógico ojurídico.

Por fin, para terminar este apartado, cabe citar la observación de ROXIN al señalar que el fin del proceso penal posee, entonces, una naturaleza compleja: la condena del inculpado, la protección del inocente, la formalidad del procedimiento alejada de toda arbitrariedad y la estabilidad jurídica de la decisión. Todas estas exigencias son igualmente significativas para una comunidad organizada desde el punto de vista del Estado de Derecho127. Estos factores son claramente difíciles de obtenerse de modo conjunto y armónico, demandando un esfuerzo sobremanera por parte de los órganos de persecución penal.

122 Vid. RAMOS MÉNDEZ desarrolla el tema de las garantías constitucionales del sistema procesal, subdividiendo en garantías de la actividad de las partes (igualdad de las partes, audiencia y contradicción, derecho de defensa y presunción de inocencia), garantías del juicio (el juicio con todas las garantías, principio de legalidad, acusación, tutela efectiva, prohibición de indefensión, eficacia del juicio y publicidad del juicio) y garantías de la actividad jurisdiccional (juez predeterminado por la ley y derecho a obtener una resolución fundada en derecho). Así, Vid. RAMOS MÉNDEZ, F., Enjuiciamiento Criminal, Octava lectura constitucional, cit., pág. 7. De su parte, BINDART CAMPOS al referirse a las garantías constitucionales, las considera como "el soporte de la seguridad jurídica y las define como el conjunto de seguridades jurídico-institucionales deparadas al hombre. Agrega que las garantías existen frente al Estado, en cuanto son medios o procedimientos que aseguran las vigencias de los derechos e ilustra que hay garantía cuando el individuo tiene a su disposición la posibilidad de movilizar al Estado para que lo proteja". Vid. BINDART CAMPOS, G., Manual de la Constitución Reformada, Tomo II, Buenos Aires, 2000, págs. 286-287.

123 De este modo, se percibe que no resulta sencillo deslindar el alcance y sentido de lo que se entiende por derechos fundamentales y sus garantías, pero lo que sí parece común en la doctrina científica es que "un derecho no garantizado no sería un verdadero derecho". Vid. FERRAJOLI, L., Derechos y garantías, Madrid, 2001, pág. 59.

124 Vid. MAIER, J. B., "¿Es posible todavía la realización del proceso penal en el marco de un Estado de Derecho?," VV.AA., Estudos em homenagem a professora Ada Pellegrini Grinover, F. L. Yarshell y M. Z. de Morais coords., São Paulo, 2005, págs. 353-364.

125CLARIÁ OlMEDO, J. A., Derecho Procesal Penal, Tomo 1, Buenos Aires, 1998, pág. 4.

126 En opinión de GUZMÁN FLUJA "no cabe ocultar que el proceso penal está sometido a una constante tensión entre la eficacia que se le exige como instrumento para el ejercicio del ius puniendi del Estado y la obligación de que se respeten los derechos señaladamente los de carácter fundamental, de toda persona imputada y acusada. Ya he expuesto que esta tensión se resuelve en una especie de zona de equilibrio que debe tener unos límites infranqueables dentro de los cuales unas veces el balance se inclinará hacia uno de los límites y otras veces hacia el otro". Vid. GUZMÁN FLUJA, V., " Anticipación y preconstitución de la prueba en el Proceso Penal ", cit., pág. 185.

127 ROXIN, C., Derecho procesal penal, Buenos Aires, 2000, pág. 4. 
Llegado a este punto, se concluye que la gran importancia del proceso en los días actuales es servir como hilo conductor entre estas dos fuerzas (eficacia y garantías) que provocan la controvertida tensión en el ámbito penal ${ }^{128}$.

I.1.2.2. ¿Es admisible una persecución sin límites en la búsqueda de la eficiencia penal o debe prevalecer un equilibrio procesal penal?

Hasta este punto de nuestro trabajo, hemos dejado inteligible que la búsqueda por un equilibrio procesal penal, o dicho en nuestra propia denominación, de una "armonía procesal penal", es imperativo que tenga que ser puesto en marcha a los fines de obtención de la consolidación del binomio eficiencia-garantías.

De otra parte, cabe considerar por lo tanto, que es aguda y perfecta la constatación de que delante de tiempos como los presentes, quedan evidenciadas las tensiones que abogan por el castigo a ultranza de los delincuentes y por el recrudecimiento de la represión. Pero en verdad, como sostiene RAMOS MÉNDEZ, el juicio penal es tan sólo un escenario de tutela de la libertad individual y colectiva con referencia al Código Penal129.

En suma, es algo normal que el Estado desarrolle toda actividad legítima tendiente a obtener los medios de convicción que le permitan respaldar en juicio su pretensión punitiva, toda vez que la comunidad tiene un poderoso interés en que quien cometa un ilícito sea sancionado con arreglo a las disposiciones penales vigentes.

$Y$ esto nos pone en presencia de una interesante cuestión: ¿Debemos admitir en pro de la contención del crecimiento de algunas de las graves especies de delincuencia, como ejemplo de la criminalidad organizada, una persecución penal a cualquier coste ${ }^{130}$ ?

Ya adelantamos que la respuesta debe ser negativa ${ }^{131}$, pues hay que construirse un proceso penal justo ${ }^{132}$ y eficiente ${ }^{133}$, tendente a la aplicación de la ley penal, pero basado

128 En este orden de ideas, ha dicho TIEDEMANN, que "la situación conflictiva en el proceso penal entre ciudadano y Estado, que resulta de la sospecha del hecho, exige una regulación jurídica, en la medida de lo posible escrupulosa, y una limitación de los poderes estatales, así como de los derechos y obligaciones de los sospechosos del hecho, pero también de otros participantes en el proceso penal, como testigos y perjudicados, peritos e intérpretes, pues también estas últimas personas vienen sujetas al poder soberano del Estado en el proceso penal, aunque en medida menos esencial". Vid. TIEDEMANN, K., Introducción al derecho penal y al derecho penal procesal, Barcelona, 1989, pág. 133. Hablando de la búsqueda de un equilibrio armónico de ponderación entre los valores eficacia y garantía, BARBOSA MOREIRA señala que "la mejor forma de cohibir un exceso y de impedir que ello se repita, consiste en no santificar el extremo opuesto". Así, BARBOSA MOREIRA, J. C., "A Constituição e as provas ilicitamente obtidas", Revista Forense, Rio de Janeiro, vol. 337, 1997, pág. 134.

129 RAMOS MÉNDEZ, F., Enjuiciamiento Criminal, Octava lectura constitucional, cit., pág. 30.

130 Un Estado que para reconstruir la posible verdad de lo ocurrido o denunciado, utiliza todos los medios a su alcance sin observar los límites impuestos por la Constitución (el "vale todo"), es un Estado que se ubica al mismo nivel del delincuente, y esa actitud resulta sumamente perjudicial para el mantenimiento de la forma de vida democrática, que tantas vidas, sufrimientos y exilios costaron desde nuestra última experiencia de un régimen de facto. Al respecto, Vid. CAFFERATA NORES, J., Cuestiones actuales sobre el proceso penal, $2^{a}$ edición, Buenos Aires, 1998, págs. 125-132 y 201-213. Además, cumple señalar que so pretexto de la eficacia no es de recibo desconocer, mistificar o lesionar la legalidad, sino exclusivamente y dentro del propio contexto normativo optar por las alternativas o variables más adecuadas y aptas al fin perseguido que, al mismo tiempo, sean las menos gravosas en razonable relación con las ventajas que derivarán tanto para el sujeto/s afectados como para la generalidad. Siguiendo este pensamiento, Vid. PEDRAZ PENALVA, E., Constitución, jurisdicción y proceso, Madrid, 1990, págs. 346-347.

131 En palabras de RODRÍGUEZ GARCÍA, "hay que ponderar el interés social en la persecución de los delitos y el interés individual de cada ciudadano en ver protegidos los derechos y libertades que la Constitución le garantiza". Vid. RODRÍGUEZ GARCÍA, N., "Medios de prueba restrictivos de derechos fundamentales. Las 
en el respeto a los derechos y garantías fundamentales de la persona, como veremos a continuación. Para esto, anticipamos que no existe otro modo: hay que armonizar y equilibrar la búsqueda de eficiencia con la defensa de las garantías, ablandándose la tensión ${ }^{134}$.

Además, observado que el proceso es garantía activa y pasiva, cabe referir al sistema constitucional de garantías del propio proceso, que lo establece como instrumento de justicia y de concreción de derechos ${ }^{135}$.

Interesante pues, también destacar que el fin fundamental del proceso penal es la averiguación de la verdad, sin perjuicio del valor ético de la condena del culpable, y del cumplimiento de las finalidades de la pena, sin perjuicio del valor ético de la absolución de un inocente, sin perjuicio del profundo significado del proceso como demostración de la vigencia del Derecho. Aunque es cierto que la pretensión de averiguar la verdad debe garantizarse con la misma convicción, debemos afirmar que no es lícito averiguar dicha verdad a cualquier precio. Es preferible permanecer en la duda antes que permitir que, para que se haga justicia, se lesione de modo innecesario y desproporcionado cualquier derecho fundamental ${ }^{136}$.

En palabras de GARCÍA RAMÍREZ, está más allá de toda duda que el Estado tiene el derecho y el deber de garantizar su propia seguridad. Tampoco puede discutirse que toda la sociedad padece por las infracciones a su orden jurídico. Pero por graves que puedan ser ciertas acciones y por culpables que puedan resultar los reos de determinados delitos, no cabe admitir que el poder pueda ejercerse sin límite alguno o que el Estado pueda valerse de cualquier procedimiento para alcanzar sus objetivos, sin sujeción al derecho o ala moral. Existe un amplio reconocimiento de la primacía de los derechos humanos, que el Estado no puede desconocer ni violentar ${ }^{137}$.

Entonces, a la vista de lo que se lleva dicho, nos parece que puede concluirse que es posible afirmar que el proceso penal debe ser la síntesis de las garantías fundamentales de

intervenciones telefónicas", cit., pág. 45. Caso contrario, tendremos que presenciar que una eficacia desmedida e irrazonable, cuando invocada, podría llevar a la erosión del orden constitucional en el proceso penal.

132 Respecto del proceso justo, describen con acierto, ARAÚJO CINTRA, GRINOVER y DINAMARCO que "la propia Constitución presta al derecho procesal la configuración no de mero conjunto de reglas accesorias de aplicación del derecho material, pero, científicamente, el instrumento publico de realización de la justicia". Vid. ARAÚJO CINTRA, A. C., GRINOVER, A. P y DINAMARCO, C. R., Teoria Geral do Processo, 5a edición, São Paulo, 1985, pág. 48. De su parte, señala CHIAVARIO que "la temática del derecho al proceso justo como derecho fundamental de la persona humana se presenta, así, como resultante de una pluralidad de aspectos, muchas veces consubstanciado en las garantías que desaguan en aquel derecho". Así, CHIAVARIO, M., Processo e garanzie della persona, Milano, 1982, págs. 4 y 13.

133 Por esta razón se puede afirmar que la eficiencia en el proceso penal no debe ser medida por el número de condenaciones impuestas, pero si por la conclusión en tiempo razonable, respetando los derechos fundamentales del acusado. En este sentido, Vid. FERNANDES, F., O Processo penal como instrumento de política criminal, Coimbra, 2001, págs. 829-834.

134 Es cierta esta afirmación, a partir de la constatación de que "esta aparente dicotomía ha ido generando, con el correr del tiempo, una suerte de divorcio entre la pretensión de eficiencia en el combate del delito y el modo en que el mismo debe llevarse a cabo, de tal forma que cada vez que se sanciona una transgresión a las disposiciones legales que ordenan los mecanismos de realización del derecho se produce un generalizado cuestionamiento que pone en crisis a aquellos que se han limitado a cumplir con sus respectivos deberes". Vid. RUBÉN AUED, N; JULIANO, M. A., La probation y otros institutos del Derecho Penal, cit., pág. 95.

135 GRECO FILHO, V., Manual de Processo Penal, cit., págs. 59-60.

136 Cfr. HERMIDA, Á. R., "El agente infiltrado y su regulación por el Derecho español", Periódico "El mundo", 31 de enero de 2008, pág. 4.

137 GARCÍA RAMÍREZ, S., "Algunas cuestiones del proceso penal", http://www.bibliojuridica.org. 
la persona y del derecho a castigar que tiene el Estado138. Éste además, debe tender a un equilibrio entre la libertad de la persona como derecho fundamental y la seguridad ciudadana como deber primordial del Estado ${ }^{139}$.

Luego, en realidad, se puede comprender que el mayor desafío de los operadores del derecho en el proceso penal moderno consiste en exactamente, hacer la ponderación entre las garantías fundamentales inherentes a un proceso penal democrático y la efectividad de este proceso, no perdiendo de vista que ésta también es una garantía fundamental, como componente del derecho de acceso a justicia y que, una vez completamente sacrificada, puede conducir a una impunidad que, en ultimo análisis y a largo plazo, tiende a comprometer la propia manutención del régimen democrático que se pretende preservar ${ }^{140}$.

Hemos visto hasta ahora, que actualmente, predomina en el proceso penal una indeseable tensión entre los derechos fundamentales y una persecución penal muchas veces sin límites, y además, que todo nos lleva a comprender la necesidad de que ambas las fuerzas en choque, sean armonizadas en pro de la concreción de una persecutio criminis eficiente y al mismo tiempo garantista. Se busca, pues, un proceso penal equilibrado.

Por otro lado, se percibe además, en la praxis, una preponderancia de búsqueda por la "eficacia" ${ }^{141}$ de la persecución criminal en disfavor de la defensa de las garantías ${ }^{142}$.

\footnotetext{
138 Corroborando esta idea, sostiene BINDER que "el orden jurídico es un instrumento de control social, y hablar de la eficiencia de los sistemas procesales supone que esa función puede ser canalizada con éxito a través de las normas jurídicas y otras rutinas que conforman esos sistemas. Pero, como el orden jurídico es también un instrumento de protección de la dignidad humana, cuando hablamos de garantías nos estamos refiriendo a todos los mecanismos jurídicos cuya misión sea impedir un uso arbitrario o desmedido de la coerción penal. Existirán normas que buscarán dotar al Estado de eficiencia en la coerción penal, al igual que existirán otras que buscarán proteger a las personas evitando la fuerza o el castigo injusto". Vid. BINDER, A. M., Introducción al derecho procesal penal, cit., pág. 59.

139 Es una verdad incontestable que "el presupuesto básico para buscarse la construcción de un modelo procesal se encuentra en la posibilidad de conciliar las necesidades de garantía del ciudadano con las, no menos necesarias, funcionalidad y eficiencia del sistema jurídico-penal". Así, Vid. SANTANA, S. P., "A tensão dialética entre os ideais de garantia, eficiência e funcionalidade", cit., págs. 891-892.

140 Con entendimiento en este sentido, RODRÍGUEZ GARCÍA de forma didáctica, señala que algunos aspectos de la crisis del Sistema Jurídico-Penal "conducen en última instancia a una peligrosa disociación entre dos ordenamientos procesales: un clásico, lento pero garantista, frente a otro de nuevo cuño, moderno, en que algunas de las garantías deben ceder ante las exigencias de eficacia que teóricamente son reclamadas por la sociedad. La experiencia de otros ordenamientos jurídicos de nuestro entorno viene demostrando como la justicia penal sólo estará en condiciones de poder salir de la crisis en que se encuentra si concilia equilibrada y coordinadamente los principios de garantía y eficacia, puesto que la primacía de cualquiera de ellos supondría agravar todavía más el problema". Vid. RODRÍGUEZ GARCÍA, N., "Análisis de la nueva regulación del principio del consenso en el procedimiento abreviado español", VV.AA., Líber Discipulorum para Jorge de Figueiredo Dias, Coimbra, 2003, págs. 1464-1465.

141 Hablamos aquí de la "eficacia" especificadamente en términos de pretensión acusatoria y de búsqueda por la celeridad procesal.

142 Vid. SILVEIRA FILHO, S. L., "Neoliberalismo, mídia e movimento de lei e ordem: rumo ao Estado de polícia", Discursos Sediciosos. Crime, direito e sociedade, núms. 15-16, Rio de Janeiro, 2007, págs. 345-358. De otra parte, suele decirse que "en el proceso ha prevalecido históricamente la tendencia a hacer prevalecer el fin de averiguación de la verdad, por encima de cualquier consideración. Pero esto es incierto en términos objetivos, porque es algo comprobado que el proceso penal inquisitivo, con la tortura como instrumento regular de investigación y, prácticamente, sin limitaciones en el desarrollo de ésta, no producía una verdad procesal de calidad, sino todo lo contrario". En este sentido, ANDRÉS IBÁÑEZ, P., "Sobre los derechos fundamentales del imputado en la investigación criminal", Revista de Derecho Penal, núm. 14, Montevideo, 2004, pág. 116. Importante además, señalar que "la eterna dicotomía entre garantías constitucionales y eficacia de la persecución penal parece resolverse mediante la aplicación de una solución que si bien se muestra ecléctica, tiene mucho de restrictiva de la primera a favor del robustecimiento de la segunda que se va revirtiendo a medida que avanza el desarrollo del proceso penal". Así, HIDALGO, M. J., "Conformación de la
} 
Desde esta perspectiva, se percibe en muchas ocasiones que el Estado presionado ante las exigencias de la sociedad, y muchas veces de los propios medios de comunicación, acaba por poner como prioridad, la meta de alcanzar el objetivo de aplicación del ius puniendi a todo costo, sin límites éticos y jurídicos, olvidándose que tal actitud puede llevar a desvirtuar una serie de postulados inherentes a un proceso penal garantista y marcado por el respetoa la esencia de un Estado constitucional de Derecho.

En especial cuando se trata de casos relativos a la delincuencia organizada, nos parece que en las últimas décadas, el procedimiento penal torna como prioritaria su eficacia en la comprobación de las conductas delictivas llevadas a cabo por estos clanes criminales, mientras que el procedimiento en sí mismo y su evaluación desde una óptica distinta del criterio funcional, incluyendo la dimensión del Estado de Derecho, cada vez más va pasando a segundo término ${ }^{143}$.

Como sintetiza CONTRERAS ALFARO, los particulares ven limitados sus derechos y garantías procesales a favor de la pretendida eficacia del sistema que parece irremediablemente condenado a encontrar de manera urgente, vías de escape a su insostenible situación. En definitiva, se constata con pesar una reducción del garantismo en el ámbito procesal y sustantivo frente a una expansión de los límites de la fuerza estatal para perseguir y sancionar conductas delictivas. La balanza del sistema de justicia que simboliza la búsqueda permanente del equilibrio entre derechos individuales y seguridad colectiva, se haya actualmente volcada a favor de la prevención general144.

Así las cosas, importante destacar que delante del "derecho penal del terror", implementado por las políticas represivas de ley y orden, tolerancia cero, etc., el proceso ha pasado a desempeñar una misión fundamental en una sociedad democrática, en cuanto instrumento de limitación del poder estatal y, al mismo tiempo, instrumento al servicio de la máxima eficacia de los derechos y garantías fundamentales ${ }^{145}$.

Esto supone reconocer el proceso como verdadero y destacable instrumento al servicio del orden constitucional. Dicho de otro modo, nos parece correcto referirse a una "tutela constitucional del proceso".

línea persecutoria en el proceso penal, Coherencia y continuidad", Exigencias actuales de la persecución penal, Propuestas, discusiones, práctica judicial, Córdoba, 2004, pág. 165.

143 En este sentido,Vid. ALBRECHT, H. J, Criminalidad transnacional, comercio de narcóticos y lavado de dinero, Bogotá, 2001, pág. 26 y ss.

144 Vid. CONTRERAS ALFARO, L. H., Corrupción y Principio de Oportunidad Penal. Alternativas en materia de prevención y castigo a la respuesta penal tradicional, cit., pág. 24. Importante además, señalar que el eterno conflicto entre la búsqueda de "más velocidad" (eficiencia) y menos garantías (efectividad), dentro del campo constitucional del proceso penal no corresponde tan sólo con el (des) respeto de los derechos individuales, pues percibiese que el interés colectivo es absolutamente preponderante en esta tensión de fuerzas.

145 LOPES JR, A., Introdução crítica ao Processo Penal, cit., pág. 1. Respecto a una visión moderna del proceso y de su real valor en el ámbito penal, señala SCARANCE FERNANDES que "el proceso es el escenario en el cual deben desarrollarse, en estructuración equilibrada y cooperadora, las actividades del Estado (jurisdicción) y de las partes (autor y reo). Ninguna de estas actividades deben ser el centro, prevaleciendo sobre las otras. El excesivo realce a la predominancia de la jurisdicción sobre las partes es reflejo del valor dado al intervencionismo estatal en la sociedad y en la vida de los ciudadanos. Prestigiar la acción es resaltar la actividad del autor en detrimento de la actuación del Estado y de la defensa. Colocar la defensa como razón del proceso es, también, valorizar una de las partes de la relación jurídica en perjuicio de la otra. El proceso es el punto de convergencia e irradiación. Es en el y por medio del mismo que alguien puede pleitear la afirmación concreta de su derecho. Es mediante el proceso que el Juez, como órgano soberano del Estado, ejerce su actividad jurisdiccional y busca, para el caso, la solución más justa". Vid. SCARANCE FERNANDES, A., Processo Penal Constitucional, cit., pág. 33. 
De esta apreciación valorativa del proceso, debe deducirse el entendimiento de que el proceso penal de hoy es en puridad, garantía ${ }^{146}$.

Esta es la tarea impuesta a los personajes de la persecución penal: preservar a tope los derechos fundamentales de la persona sometida al proceso penal, sin olvidarse del imperioso resguardo de la legitimidad del ius puniendi estatal.

Las garantías, en definitiva, serían la solidez o establecimiento del conocimiento verdadero. Por ello, es necesario, imprescindible, que el proceso penal no se sitúe por debajo de esas garantías ${ }^{147}$.

En aras de conseguir este objetivo, las garantías penales influyen marcadamente sobre la operación intelectual que subsume las conductas humanas a la norma penal presuntamente violada ${ }^{148}$. Sería ésta la regla principal necesaria al establecimiento de un proceso penal garantista.

Es cierto, no obstante, decir que el proceso penal contemporáneo debe ser entendido como un verdadero y hercúleo instrumento de efectividad de las garantías constitucionales ${ }^{149}$. En esta línea de pensamiento, el proceso penal funciona en un Estado constitucional de Derecho como un medio necesario e inderogable de garantía de los derechos del imputado 150 .

No es un mero instrumento de concreción del Derecho penal, pero si, verdaderamente, un instrumento de satisfacción de derechos humanos fundamentales y, más que esto, una garantía absoluta contra el arbitrio estatal.

Esto significa, sencillamente, que la omnipotencia jurídico-penal del Estado debe contar, necesariamente, con frenos o límites que vengan a resguardar los inviolables derechos fundamentales del ciudadano. Esta sería la señal que caracteriza el Derecho procesal penal de un Estado pluralista y democrático.

De otra parte las garantías constitucionales son espacios de lucha, en los que existen avances y retrocesos, y la justicia penal es, a su vez, un gran espacio de lucha en el que se

\footnotetext{
146 Vid. para mayor profusión respecto del tema de las garantías, FERRAJOLI, L., Derechos y garantías. La ley del más débil, 2ª edición, Madrid, 2001; PEÑA FREIRE, A. M., La garantía en el Estado Constitucional de Derecho, Madrid, 1997. Importante señalar que a nuestro modo de pensar, las garantías emergen, en el sentido amplio de la palabra, en los medios destinados a hacer valer el derecho. Son instrumentales o asecuratorias en relación a los derechos, o en otras palabras, son instrumentos por los cuales se aseguran el ejercicio y el gozo de los derechos.

147 Esta la opinión de GUZMÁN FLUJA, V. C., Anticipación y preconstitución de la prueba en el proceso penal, cit., pág. 21.

148 Cfr. PÉREZ MORENO, E. P., "Precisiones acerca de las garantías del imputado (A propósito de los Derechos ciudadanos)", Ejercicio concreto del poder pena. Límites, abusos, desafíos, cit., pág. 282.

149 En contra a la postura de que las garantías sólo pertenecen a lo adjetivo y no guardan más que una relación externa y episódica con lo sustantivo, defiende FERRAJOLI que "los diversos principios garantistas se configuran, antes que nada, como un esquema epistemológico de identificación de la desviación penal dirigido a asegurar ... el máximo grado de racionalidad y de fiabilidad del juicio, y por consiguiente de limitación de la potestad punitiva y de tutela de la persona contra la arbitrariedad". Vid. FERRAJOLI, L., Derecho y razón, Teoría del garantismo penal, cit., pág. 34. Sólo a modo de esclarecimiento, la citada obra del profesor italiano tiene un hilo conductor bastante claro: la limitación del poder.

150 Con riqueza de detalles, Vid. la reciente obra de AMBOS, K., Processo Penal Europeu, Preservação das garantias e direitos individuais (Princípios processuais e análise da Convenção Européia de Direitos Humanos), Rio de Janeiro, 2008. En esta obra, el autor habla del nuevo proceso penal europeo, que habrá de ser construido gracias a la influencia, cada vez más fuerte, de la jurisprudencia del Tribunal Europeo de Derechos Humanos, consolidando cada vez más un derecho procesal penal democrático y garantista, que no se preocupa tan sólo con la efectividad, pero también con la preservación de principios y derechos fundamentales.
} 
juega la dignidad de la persona. Lo importante es saber qué parte del juego quiere jugar cada uno 151.

Esta la cuestión central: conocer a fondo los intereses puestos en marcha cuando de la persecución penal, por cada uno de los actores del proceso.

Y no se puede olvidar además que la garantía presenta un carácter instrumental en relación a una norma de fondo que, en la esfera procesal penal, reposa en el campo de los derechos fundamentales ${ }^{152}$. De lo dicho se desprende que, todas y cada una de las garantías presentan, a un solo tiempo, instrumentos de protección de los destinatarios del proveimiento de la propia jurisdicción ${ }^{153}$.

De modo acentuadamente crítico, defiende ZAFFARONI, que las garantías penales y procesales penales no son productos de un capricho, sino del resultado de la experiencia de la humanidad acumulada en casi un milenio, en lucha constante contra el ejercicio inquisitorial del poder punitivo, propio de todas las invocaciones de emergencias conocidas en todos los siglos, en que el poder punitivo descontrolado emprendiendo empresas genocidas causó más muertes y dolor que las propias guerras ${ }^{154}$.

A la vista de estas reflexiones, resulta obvia la siguiente comprobación: eficiencia y garantías deben ser los dos vectores que demarcan el funcionamiento de la Justicia Criminal en este inicio del siglo XXI.

Retomando al tema de la tensión de fuerzas, debe resaltarse que la paradoja eficacia versus garantías, se presenta como uno de los temas más discutibles en la dogmática procesal penal. Es sin duda, el gran desafío del proceso penal moderno ${ }^{155}$.

Se trata, pues, de asunto que ha sido puesto en relieve en los últimos años por gran parte de la doctrina procesal penal156.

Pero la problemática no es de reciente aparición, pues ya en los años sesenta y setenta del siglo pasado, la doctrina norteamericana decantaba la tensión existente entre crime control versus due process ${ }^{157}$. 2007.

151 Monograficamente, Vid. RIBEIRO PLETSCH, N., Formação da prova no jogo processual penal, São Paulo,

152 HASSAN CHOUKR, F., Garantias constitucionais na investigação criminal, Rio de Janeiro, 2001, pág. 10. En este sentido, en verdad, las garantías individuales referidas al proceso penal configuran pautas establecidas por la Constitución que gobiernan la vigencia y hasta la interpretación de las leyes procesales comunes y que son, en verdad, decisiones políticas generales de cuyo contenido debe derivar, deductivamente, el reglamento procesal tendiente a hacerlas efectivas. Ya en opinión de HORACIO OBLIGADO, "las garantías son procedimientos y prohibiciones para asegurar los derechos, que se proyectan en los más diversos planes donde se concreta el poder penal". Así, HORACIO OBLIGADO, D., "Sobre la génesis de los principios y garantías del proceso penal", Garantías, medidas cautelares e impugnaciones en el proceso penal, Rosario, 2005, pág. 17.

153 GOMES FILHO, A. M., A motivação das decisões penais, São Paulo, 2001, pág. 34.

${ }^{154}$ Cfr. ZAFFARONI, E. R., "Globalización y crimen organizado", www.cienciaspenales.net.

155 Explanando respecto de la cuestión entre la libertad individual y el poder de intervención estatal, TAVARES señala que "garantía y el ejercicio de la libertad individual no necesitan de cualquier legitimación, en virtud de su evidencia". Vid. TAVARES, J., Teoría do injusto penal, 3a edición, Belo Horizonte, 2003, pág. 162. A su vez, complementa LOPES JR que "lo que necesita ser legitimado y justificado es el poder de punir, es la intervención estatal y no la libertad individual. La libertad individual, por resultar necesariamente del derecho a la vida y de la propia dignidad de la persona humana, está ampliamente consagrada en el texto constitucional y en tratados internacionales, siendo mismo un presupuesto para el Estado Democrático de Derecho en que vivimos". Vid. LOPES JR, A., Direito Processual Penal e sua conformidade constitucional, cit., pág. 13.

156 Vid. a respecto, SOUTO DE MOURA, J., "A protecção dos direitos fundamentais no processo penal", I Congresso de Processo Penal, Coimbra, 2005, pág. 39; MIRANDA RODRIGUES, A., "A defesa do argüido: uma garantia constitucional em perigo no admirável mundo novo", Revista Portuguesa de Ciência Criminal, núm. 12, Lisboa, 2002, págs. 549 y ss. 
Asume singular actualidad el debate relativo a esta colisión de intereses, pues de un lado se denota la obligatoriedad, en regla, de la actuación estatal a través del instrumental punitivo en la búsqueda de la eficacia de la pretensión acusatoria, y de otro, el necesario respeto a los derechos y garantías fundamentales inherentes a la condición de investigado o imputado en un proceso penal.

En un acercamiento directo al asunto, como premisa elemental, interesante señalar que la intervención estatal constitucionalmente admisible, a través de la actividad de persecución criminal representativa del proceso penal, acaba por imponer limitaciones en la esfera de las libertades individuales del imputado o investigado ${ }^{158 .}$

Así, el simple hecho de investigar por parte del órgano constitucionalmente competente para realizar tal tarea, puede directa o indirectamente provocar alguna forma de violación a derechos y garantías fundamentales del investigado ${ }^{159}$.

Esta la gran problemática, ejercer la tarea de persecución y al mismo tiempo, intentar vulnerar lo mínimo posible las garantías y los derechos fundamentales de la persona sometida al proceso o investigación criminal ${ }^{160}$. Se justifica esta afirmación, a partir de la necesidad de existencia de un conjunto mínimo de garantías y reglas sin las cuales no hay proceso penal en el Estado de Derecho democrático ${ }^{161 .}$

De lo dicho resulta como consecuencia lógica que los derechos fundamentales en virtud de que presentan papel de destaque en el mundo moderno ${ }^{162}$, siendo su efectividad

157 En este sentido, Vid. el trabajo científico de PACKER, H. L., "Two models of the criminal process", Pennsylvania Law review, 1964, págs. 153 y ss. Interesante también, la opinión de RIQUERT señalando que "es el nuevo escenario de una vieja tensión entre el derecho penal democrático y el autoritario (garantías/eficacia por un lado, interés individual/interés social, por el otro)". Vid. RIQUERT, M. A., Crisis Penal, Política Criminal, globalización y Derecho Penal, Buenos Aires, 2007, pág. 95. Además, según BINDER "en 1851, Karl Mittermaier planteaba la necesidad de fundar un sistema de procedimiento criminal que garantizara los intereses de la sociedad en la misma medida que los intereses de la libertad individual, generando seguridad en todos los buenos ciudadanos, al mismo tiempo que inspirando un terror saludable a todos los enemigos del orden público". Vid. BINDER, A. M., Introducción al derecho procesal penal, cit., pág. 56.

158 BECHARA, F. R., "Criminalidade Organizada e procedimento diferenciado: entre eficiência e garantismo", VV.AA., Direito Penal Especial, Processo Penal e Direitos Fundamentais, Visão Luso-Brasileira, J. Faria Costa y M. A. Marques da Silva coords., São Paulo, 2006, pág. 915.

159 Respecto a esta cuestión, cabe señalar la opinión de ORTIZ ÚRCULO en el sentido de que "es cierto, admite, que a veces se han limitado las garantías a favor de la eficacia y que otras el exceso de garantías ha propiciado una cierta impunidad", pero más que esto, "no creemos que las garantías y la eficacia deban ser conceptos permanentemente en tensión, de forma que a más garantías menor eficacia y viceversa. Nos gustaría pensar que el establecimiento de un sistema de garantías razonable y, sobre todo, posible en cuanto que realizable en la práctica, nada afectaría a la eficacia de la investigación siempre y cuando fuera llevada por sujetos suficientemente formados para ello". Vid. ORTIZ ÚRCULO, J. C., "Garantías del imputado en el proceso penal", Estudios Jurídicos. Ministerio Fiscal, Madrid, 2002, pág. 17.

160 Concretamente, se puede señalar que no se puede buscar la verdad en el proceso penal utilizándose de los adagios, "vale todo" o "los fines justifican los medios". En este sentido, las palabras de MUÑOZ CONDE: "el proceso penal de un Estado de Derecho no solamente debe lograr el equilibrio entre la búsqueda de la verdad y la dignidad de los acusados, sino que debe entender la verdad misma no como una verdad absoluta, sino como el deber de apoyar una condena sólo sobre aquello que indubitada e intersubjetivamente puede darse como probado. Lo demás es puro fascismo y la vuelta a los tiempos de la Inquisición, de los que se supone hemos ya felizmente salido". Vid. MUÑOZ CONDE, F., La búsqueda de la verdad en el proceso penal, cit., pág. 117.

161 Vid. GUZMÁN FLUJA, V. C., Anticipación y preconstitución de la prueba en el proceso penal, cit., pág. 21.

162 En palabras de PÉREZ LUÑO, "para cumplir sus funciones los derechos fundamentales están dotados de una especial fuerza expansiva, o sea, de una capacidad de proyectarse, a través de los consiguientes métodos o técnicas, a la interpretación de todas las normas del ordenamiento jurídico. Así, nuestro Tribunal Constitucional ha reconocido, de forma expresiva, que los derechos fundamentales son el parámetro de conformidad con el cual deben ser interpretadas todas las normas que componen nuestro ordenamiento". Así, PÉREZ LUÑO, A. E., Derechos Humanos, Estado de Derecho y Constitución, 3a edición, Madrid, 1990, pág. 318. 
y respeto perseguidos por administración de la justicia penal, y delante de su notoria naturaleza constitucional, deberán ser armonizados junto a la actuación punitiva estatal.

A esto es posible denominar de "equilibrio procesal penal"163, tema éste que tendremos la oportunidad de profundizar durante el desarrollo del trabajo, cuando trataremos de ofrecer una solución razonable a la tensión entre eficiencia versus garantías.

Al fin de este apartado, cabe concluir que en un abordaje garantista del proceso ${ }^{164}, \mathrm{y}$ específicamente del proceso penal, las garantías procesales deben ser inseridas como nuevos componentes de la concesión de los derechos fundamentales del Estado Constitucional. Así, las garantías procesales son los instrumentos que hacen valer los derechos fundamentales ${ }^{165}$.

En breve síntesis: en la búsqueda de establecimiento de una correcta y justa estrategia de eficacia de la aplicación de la ley penal, como forma legítima y concreta del ius puniendi estatal, incluso en la hipótesis de formas graves de criminalidad, no se puede aceptar el uso del "vale todo" para obtención de objetivos de preservación de la seguridad pública, pues el juego tiene que ser limpio, a la vez que se podrá obtener la eficacia persecutoria con respeto a las garantías y derechos fundamentales de las personas sometidas al proceso penal. El parámetro de la proporcionalidad es la principal clave para atingirse este objetivo, sin olvidarse de la imprescindible preservación del debido proceso penal ${ }^{166}$.

En congruencia con lo expuesto, se observa que las garantías procesales fundamentales, tales como el derecho de no auto incriminarse y la no admisibilidad de pruebas ilícitas han de condicionar la descubierta de la verdad en el proceso penal, que no es entonces, buscada a cualquier precio ${ }^{167}$.

163 Resaltando la necesidad de un equilibrio entre las fuerzas en tensión, y tratando específicamente del crimen organizado, CHIAVARIO señala que "el crimen organizado puede rejuvenecerse sea porla flaqueza, sea por una potencia excesiva y no sana del Estado. Y, recíprocamente, los derechos de la persona pueden sufrir sea a causa de los limites demasiadamente blandos, sea por los limites demasiadamente estrechos de los poderes estatales". Vid. CHIAVARIO, M., "Direitos humanos, processo penal e criminalidade organizada", Revista Brasileira de Ciências Criminais, núm. 5, São Paulo, 1994, pág. 28.

164 El proceso sin sus formas, sus reglas, sus principios, no es más un proceso; los actos fuera de reglas son operations sublimes, para utilizar la feliz expresión de Robespierre, pero no actos de justicia. En lugar del proceso penal y del derecho tenemos actos políticos subversivos. Vid. MOCCIA, S., "Emergência e defesa dos direitos fundamentais", Revista Brasileira de Ciências Criminais, núm. 25, São Paulo, 1999, pág. 67.

165 Vid. en este sentido, ABADE, D. N., Garantias do processo penal acusatório, cit., pág. 107.

166 Destacando su preocupación con la posible situación de deterioro del debido proceso en casos que traten de formas graves de violencia, a ejemplo del crimen organizado, sostiene GARCÍA RAMÍREZ que "la aparición de formas inaceptables y sumamente lesivas de delincuencia organizada, particularmente las que se valen de la mayor violencia y se vuelven contra personas inocentes, ha traído al debate la subsistencia del debido proceso. Hay ejemplos claros, fuera de toda, sobre la reanimación del arbitrio sustantivo y procesal para enfrentar conductas de esta naturaleza. En el trance padecen la legalidad penal, la independencia y objetividad de los tribunales, los principios de investigación y prueba, el derecho a la defensa, la garantía de impugnación, la publicidad procesal, para no mencionar sino algunos extremos de esta evidente retirada del debido proceso. Así se conforma otra versión del proceso, paralela a la versión ortodoxa, que pasa a ser tradicional y sustituible. Vale decir que la lucha contra la delincuencia organizada también ha traído consigo, en forma menos grave, pero no menos disolvente, hipótesis de exclusión del debido proceso". Vid. GARCÍA RAMÍREZ, S., "Algunas cuestiones del proceso penal", Memorias del Congreso Internacional de Culturas y Sistemas Jurídicos Comparados, http://www.bibliojuridica.org.

167 Siguiendo esta línea de pensamiento, Vid. BALTAZAR JR, J. P, "Limites constitucionais à investigação. 0 conflito entre o direito fundamental à segurança e o direito de liberdade no âmbito da investigação criminal", cit., pág. 210. 


\section{I.2. Eficiencia y garantías como vertientes del proceso penal equilibrado}

I.2.1. La abusiva instrumentalización de las garantías. Un peligro inminente a la preservación de la seguridad pública.

Hemos dejado claro que existe una tensión, pero que no debería ocurriri68 en términos negativos, entre derechos y garantías fundamentales y la estrategia punitiva estatal, muchas veces representada por una persecución penal sin límites.

Por lo demás, es necesario que sean beligerantes en defensa de las libertades y no permitir que se tuerzan los argumentos y el sentido de las normas para dar cabida a limitaciones de derechos que escapen de los supuestos constitucionalmente tasados ${ }^{169}$.

No con menor contundencia hemos sostenido también que esta disparidad sólo puede tener como consecuencia la búsqueda por una armonización de fuerzas, equilibrándose la eficacia y las garantías en la persecutio criminis.

El principal problema de fondo que impregna la adopción eficaz e inmediata de este equilibrio, nos conduce a un cuestionamiento esencial: ¿Es conveniente y adecuado la aplicación del proceso penal contemporáneo a los delitos no convencionales?170

En otras palabras, lo que se quiere plantear es en verdad, si la delincuencia transnacional puede ser combatida en el ámbito procesal del mismo modo que la criminalidad tradicional o la delincuencia callejera ${ }^{171}$.

¿La forma de encarar la preservación de las garantías y derechos de los investigados o imputados, puede ser de la misma intensidad en ambas situaciones? 0 dicho de otra forma, ¿es ilegitimo en el marco de un Estado de Derecho que existan normas penales y procesales específicas para los supuestos de delincuencia organizada?

Enfrentémonos estas duras cuestiones dogmáticas que despiertan el interés actual de gran parte de la doctrina mundial.

\footnotetext{
168 En sentido contrario, defiende SOLIMINE que "visualizar el proceso penal como una tensión de fuerzas antagónicas resulta sumamente útil para la comprensión de su correcta dinámica en un Estado de Derecho. Se trata de advertir que en cualquier persecución penal aparece una puja constante entre la necesidad de la sociedad de protegerse contra el delito, mediante un sistema de represión eficiente, y las garantías que amparan al imputado que actúan como límites que restringen y encauzan el poder estatal neutralizando el riesgo de su uso arbitrario". Vid. SOLIMINE, M. A., Praxis instructoria en un Estado de Derecho. Entre las garantías y la eficiencia, cit., pág. 130.

169 Vid. MOREno CATENA, V., "El enjuiciamiento de delitos de terrorismo y el derecho de defensa", Terrorismo y proceso penal acusatorio, cit., pág. 385. Además, DE LA OLIVA SANTOS dirá que "no es fácil atinar en el establecimiento de auténticas garantías para la justa defensa del acusado que, sin embargo, no obstaculicen insensatamente la eficaz represión de la delincuencia en defensa de la sociedad". Vid. DE LA OLIVA SANTOS, A., et alli., Derecho Procesal Penal, 5ª edición, Madrid, 2002, págs. 79-80.

170 La expresión "delitos no convencionales" en este caso se refiere a aquellas infracciones penales practicadas de modo muy especial por la delincuencia organizada, utilizándose de una estructura profesional y muchas veces con influencia en la política, en los medios de comunicación, en la administración pública, en el sistema de justicia y en la economía legítima, y que al contrario de los delitos comunes cometidos de forma aislada y sin un planeamiento organizativo, vienen a provocar serios daños sociales, como el blanqueo de capitales, el terrorismo, el narcotráfico, etc. Específicamente respecto a esta cuestión, Vid. PASTOR, D. R., Tensiones, ¿Derechos fundamentales o persecución penal sin límites?, cit., págs. 3-28.

171 Vid. respecto a esta discusión, ARAUJO DA SILVA, E., Crime organizado, Procedimento probatório, São Paulo, 2003, págs. 40 y ss. Específicamente en el ámbito del Derecho Italiano, Vid. SFERLAZZA, 0., Proceso acusatorio oral y delincuencia organizada, México, 2006.
} 
Empezamos por afirmar que es inevitable la constatación de la sociedad contemporánea, de que el enfoque tradicional dado a las garantías procesales viene mostrándose insuficiente para el combate de la criminalidad organizada postmoderna.

Y esto se explica de manera sencilla. Sin lugar a dudas, los investigadores de la delincuencia organizada necesitan de herramientas específicas y paciencia porque esta forma de actuación delictiva implica un estándar de actividad continua. Se trata de un grupo de personas que realizan actos delictivos de forma permanente o reiterada, que se meten en un arquetipo criminal. Ellos realizan actividades de corrupción y obstrucción a la justicia para impedir que sean sometidos a ella y evitar sus arrestos. También escapan de prisiones y amenazan a posibles testigos y sus familiares. Particularmente, se destaca que los miembros del grupo son amenazados para que no revelen la información de la organización ${ }^{172}$.

Como fácilmente puede deducirse, la criminalidad ha traspasado por una evolución nunca antes imaginada. No se sabe al cierto como combatir con éxito absoluto las nuevas vertientes del fenómeno delincuencial transfronterizo ${ }^{173}$. Y esto se explica de forma muy simple, a la vez que cada vez menos se conoce respecto a los aspectos más internos de los grandes grupos de delincuentes organizados.

En este particular, se nota que mientras los países deben mantener las características particulares de su sistema de justicia criminal, se ha desarrollado de conformidad con su cultura, su historia y su sociedad, la necesidad de una cooperación internacional cada vez más próxima demanda no sólo un mayor entendimiento de los distintos sistemas legales, también de una visión común sobre los problemas de las actividades delictivas organizadas ${ }^{174}$. Y este factor de actuación concertada y coordinada es complejo y por veces inviable delante de las diferencias culturales y territoriales de los distintos países atingidos por el fenómeno de la delincuencia organizada.

Actualmente, el principal problema quizás se encuentre en la magnitud de las complejas ramificaciones de las organizaciones criminales y en las dificultades para la persecución de estas actividades que hoy día se benefician de las limitaciones de nuestros ordenamientos tradicionales y, sobre todo, de las dificultades en la coordinación de una respuesta global y necesariamente cooperativa en la persecución penal por los Estados ${ }^{175}$.

Además, no se puede olvidar que los clanes más destacados en el mundo del crimen organizado, desde algunos años, han aprendido que para dificultar la persecución de los Estados, es importante dividirse en células esparcidas en distintos territorios. En la práctica, significa decir que a un solo tiempo, el grupo criminal puede estar actuando en distintos puntos estratégicos, hecho éste que dificulta la identificación por parte de las

172 VV.AA., Análisis, técnicas y herramientas en el combate a la delincuencia organizada con fundamento en la Convención de Palermo, M. Herrán; J. L. Santiago; S. González y E. Mendieta coords, México, 2007, pág. 60.

173 Por esta razón, deberá ser establecida una adecuada y eficaz política criminal de contención al desarrollo de las grandes organizaciones criminales, a la vez que contra este especie de delincuencia se exige de los operadores del derecho, una actualización de la técnicas de persecución penal y, más que esto, una especialización profesional de los órganos encargados de preservar la seguridad ciudadana.

174 VV.AA., Análisis, técnicas y herramientas en el combate a la delincuencia organizada con fundamento en la Convención de Palermo, cit., págs. 22-23.

175 BUJOSA VADELL, L. M., "Prólogo", a la obra La prueba testimonial ante la delincuencia organizada, DAGDUG KALIFE, A., México, 2006, pág. XXI. 
autoridades de persecución penal, de la localización del eje central de un determinado clan.

Lo más llamativo de esta realidad es que semejante a una estructurada empresa comercial, la organización criminal puede encontrarse dividida en distintas ramificaciones marcadas por segmentos sectoriales, hecho éste que lleva a perderse el rumbo del foco principal de las investigaciones.

Esta "nueva" delincuencia utiliza las lógicas y las potencialidades de la globalización para la organización del crimen, permitiendo que grupos criminales homogéneos aprovechen las ventajas que ofrece el nuevo espacio mundial, con la creación de zonas de comercio libre en algunas regiones del mundo, en las cuales se produce una permeabilización económica de las fronteras nacionales y se reducen los controles. Pero la gravedad de la alarmante situación generada en razón de la expansión del fenómeno de la delincuencia organizada transnacional no podrá ser entendida como una simple manifestación de una forma cotidiana de la violencia ${ }^{176}$.

Los grandes clanes organizados han aprendido incluso a trabajar con el mecanismo de contrainteligencia, de modo a buscar su infiltración en los poderes constitucionalizados ${ }^{177}$.

En este sentido es conveniente subrayar incluso el uso por parte de politólogos y juristas del término "captura del Estado" o "penetración del Estado", para tratar de la infiltración de la delincuencia en sectores como la política y la justicia.

La Captura del Estado se ha concebido usualmente como una forma de corrupción a gran escala que debilita la estructura económica de un país porque distorsiona la formulación de leyes, normas, decretos, reglas y regulaciones. Cuando la formulación de leyes y regulaciones tiene el propósito de favorecer intereses que contradicen el bienestar general, se generan fuertes distorsiones culturales, sociales y económicas ${ }^{178}$.

En este sentido los problemas identificados dicen respecto inicialmente a los actos de soborno que son continuos y periódicos, con el agente público ya encontrándose en la nómina del grupo delictivo. Esto asegura un flujo continuo de información confidencial y protección de las actividades policiales, permitiendo a las organizaciones mantener patrones de actividad ilegal y con esto permanecer siempre un paso adelante de la policía o de otras autoridades de persecución. También es algo frecuente la infiltración de criminales en las agencias gubernamentales dentro de posiciones oficiales de bajo rango.

\footnotetext{
176 BLANCO CORDERO, I., SÁNCHEZ GARCIA DE PAZ, I., "Principales instrumentos internacionales (de Naciones Unidas e la Unión Europea) relativos al crimen organizado: la definición de la participación en una organización criminal y los problemas de aplicación de la ley penal en el espacio", Revista Penal, núm. 6, 2000, pág. 4.

177 Cítese como ejemplo, la desconfianza de los órganos de persecución en Brasil de que en los últimos tiempos, grupos organizados de delincuentes vienen buscando reclutar jóvenes de poca o casi ninguna condición financiera, ofreciendo estudio y formación profesional altamente calificada, de modo a coger en el futuro, los frutos de su trabajo, generalmente como abogados, agentes bancarios, policías, políticos, etc., y direccionarlos al perfeccionamiento de las actividades ilícitas del clan criminal. Sobre esta problemática, señala DELGADO MARTÍN que "no hay que despreciar el reclutamiento de jóvenes y menores por parte de las bandas organizadas para realizar acciones constitutivas de delito, aprovechando el caldo de cultivo proporcionado por ambientes de marginalidad y alimentando la propia criminalidad". Vid. DELGADO MARTÍN, J., Criminalidad organizada, Barcelona, 2001, pág. 29.

178 Cfr. SALCEDO-ALBARÁN, E; LEÓN-BELTRÁN, I y GUERRERO, B., "La reconfiguración cooptada del Estado: Más allá de la concepción tradicional de captura económica del Estado", http://www.transparenciacolombia.org.co/Portals/0/Captura\%20del\%20Estad.pdf, pág. 5.
} 
Los miembros y asociados de los grupos delictivos obtienen empleos en las agencias bancarias, en oficinas del gobierno y en órganos de impartición de justicia, y desde estas instituciones, utilizándose de sobornos y chantajes, compran puestos de trabajo, al mismo tiempo que ofrecen a la organización criminal toda la información sobre datos que puedan neutralizar cualquier operación de persecución criminal179.

También en lo referente al tema de la "penetración o captación del Estado", es imprescindible señalar que en esta especie de infiltración delictiva, los grupos delictivos maximizan sus ganancias y utilizan el soborno y la extorsión para influenciar a la policía, los jueces y otros funcionarios clave, ganando incluso el control absoluto sobre diferentes sectores de la economía ${ }^{180 .}$

En virtud de lo anterior dicho, la preocupación es que en un futuro próximo la justicia de algunos países presenten un índice destacable de desconfianza respecto a sus miembros (jueces, fiscales y otros funcionarios), hecho éste que pondría la estabilidad y la seguridad de los ciudadanos y del propio Estado en situación de alarma. Y qué decir respecto a una ausencia de confiabilidad en la propia policía, órgano éste encargado justamente de propiciar tranquilidad a la sociedad.

Por fin, lo más grave en nuestra opinión es la infiltración política, donde los grupos de delincuencia organizada logran participar en campañas políticas financiando o apoyando a través de los medios de comunicación o comprando votos y corrompiendo los procesos democráticos. También logran influir coaccionando (mediante sobornos, amenazas o chantajes) a políticos para obtener su apoyo gracias a lazos familiares de éstos o a la existencia de "deudas" con algunos miembros de la delincuencia organizada. Por estos medios, la actividad criminal puede ser enmascarada o ignorada por la percepción pública favorable, ya que las alianzas con figuras políticas de alto nivel tienden a legitimar las actividades del grupo delictivo ${ }^{181}$.

$Y$ en este contexto, de alta complejidad, incluso donde presenciamos notables casos de infiltración de la delincuencia en los poderes del Estado, es inicialmente necesario destacar una vez más que los derechos humanos fundamentales no pueden ser utilizados como un verdadero escudo de protección a la práctica de actividades ilícitas, ni tampoco como argumento para alejarse o disminuir la responsabilidad civil o penal por actos criminales so pena de total consagración al no respeto a un verdadero Estado de Derecho ${ }^{182}$.

179 Con más detalles sobre esta forma de contrainteligencia practicada por la delincuencia organizada, Vid. SHELLEY, L., "The penetration of state and private sector strutures by criminal networks: It's impact on governance in Russia and others states of the former Soviet Union", Seminar on the impact of organizad crime and corruption on governance in the SADC region, Pretoria, 18-19 de abril, 2002.

180 Crf., VV.AA., Análisis, técnicas y herramientas en el combate a la delincuencia organizada con fundamento en la Convención de Palermo, cit., pág. 55.

181 Sobre esta problemática, Vid. VV.AA., Análisis, técnicas y herramientas en el combate a la delincuencia organizada con fundamento en la Convención de Palermo, cit., pág. 55.

182 Partiendo de una concepción de que un derecho garantista establece instrumentos para la defensa de los derechos de los individuos frente a su eventual agresión por otros individuos y (sobretodo) por el poder estatal, lo que tiene lugar mediante el establecimiento de límites y vínculos al poder a fin de maximizar la realización de esos derechos y de minimizar sus amenazas, no me parece arriesgado afirmar que, más que ser garantista, debemos antes de todo, buscar a tope defender con "uñas y dientes" la legalidad penal. Así lo ideal seria afirmar que en el ámbito procesal penal debemos buscar una mezcla entre el garantismo y la legalidad. En suma, debe prevalecer la defensa de la aplicación de la ley, añadida a la preservación de los derechos y de las garantías del ciudadano sometido al proceso penal (el equilibrio esencial de la persecución penal). 
En consecuencia de lo anteriormente afirmado, ninguna de las libertades fundamentales del individuo se reviste de un valor absoluto ${ }^{183}$ frente a la justicia penal ${ }^{184}$. Y la función del legislador constitucional es disciplinar de modo claro y objetivo todas las hipótesis de exigencia cautelar y probatoria, individualizando cada caso en concreto. Efectivamente, parece evidente la necesidad de utilización en la búsqueda del equilibrio procesal penal, del principio de proporcionalidad ${ }^{185}$, el cual será analizado con detalles en ulterior capítulo de este trabajo.

Uno de los temas más complejos es precisamente el de evitar que las garantías se conviertan en pretextos que priven al proceso de su eficiencia, que le impidan cumplir su objetivo, porque sin duda es difícil saber cuando se produce un abuso de las garantías causante de un injustificado perjuicio para el ordenado desenvolvimiento del proceso y del logro de sus fines ${ }^{186}$.

Como bien explica CHIAVARIO, el proceso penal se caracteriza por pertenecer irrenunciablemente a la cultura de las garantías, axioma que se debe "defender con uñas y dientes", que debe afirmarse y reafirmarse con toda la fuerza posible, y desde ahí es como se puede reprobar la abusiva instrumentalización de las garantías ${ }^{187}$.

183 A respecto, algún autor, así SILVA JUNIOR, defiende que "en la discusión sobre las características intrínsecas de los derechos fundamentales, ha quedado establecido que esta categoría de derechos, con cuanto reconocidos como esenciales a la condición humana, no puede ser visto como absoluta, por lo cuanto, a respecto de las observaciones que pueden constar del propio precepto constitucional, ellos poseen limitaciones que les son inmanentes". Vid. SILVA JUNIOR, W. N., Curso de Direito Processual Penal: Teoria (Constitucional) do Processo Penal, cit., págs. 289-290. Esta posición se puede observar estar en consonancia con el artículo 4ํㅜ de la Declaración de los Derechos del hombre y del ciudadano, hecha por el pueblo francés, constituida en 26 de agosto de 1789, donde han sido establecido los límites a los derechos fundamentales, desde que previstos en ley.

${ }^{184}$ Ante esta perspectiva, cabe señalar que en Brasil, el propio STF ha reconocido en materia de que los derechos y garantías individuales no tienen carácter absoluto, que "no existen, en el sistema constitucional brasileño, derechos o garantías que se revistan de carácter absoluto, mismo por que razones de relevante interés público o exigencias derivadas del principio de convivencia de las libertades legitiman, aunque de forma excepcional, la adopción, por parte de los órganos estatales, de medidas restrictivas de prerrogativas individuales o colectivas, desde que respetados los términos establecidos por la propia Constitución. El estatuto constitucional de las libertades públicas, al delinear el régimen jurídico a que éstas están obligadas, y considerando el sustrato ético que las informa, permite que sobre ellas incidan limitaciones de orden jurídica, destinadas, de un lado, a proteger la integridad del interés social y, de otro, la asegurar la coexistencia harmoniosa de las libertades, pues ninguno derecho o garantía puede ser ejercido en detrimento del orden público o con ausencia de respeto a los derechos y garantías de terceros" (MS n. 23.452-RJ, 2005, Ponente Celso de Mello).

185 Respecto del tema, Vid. GONZÁLEZ-CUELLAR SERRANO, N., Proporcionalidad y derechos fundamentales en el proceso penal, Madrid, 1990; BERNAL PULIDO, C., El principio de proporcionalidad y los derechos fundamentales, Madrid, 2003. En la doctrina brasileña, Vid. FEITOZA PACHECO, D., O princípio da proporcionalidade no Direito processual penal brasileiro, Rio de Janeiro, 2007. Interesante en este aspecto, señalar que aunque se defienda la tesis del garantismo (en el sentido de un garantismo responsable y racional), y de un proceso penal verdaderamente democrático, no se puede dejar de reconocer no sólo la posibilidad, pero la conveniencia en la utilización de la teoría de la ponderación de bienes (proporcionalidad penal), en cierta medida posible, para resolver los conflictos entre principios de naturaleza constitucional. En este sentido, se vislumbra en la doctrina de CHIAVARIO "la necesidad de aplicación del principio de proporcionalidad cuando estén en juego el interés persecutorio del Estado y la libertad del ciudadano". Vid. CHIAVARIO, M., "Direitos humanos, Processo Penal e criminalidade organizada", Revista Brasileira de Ciências Criminais, cit., pág. 35.

186 GUZMÁN FLUJA, V. C., "El agente encubierto y las garantías del proceso penal", VV.AA., La prueba en el Espacio Europeo de libertad, seguridad y justicia penal, Navarra, 2006, pág. 201.

187 En este sentido, Vid. CHIAVARIO, M., "Giustizia penale, Carta dei diritti e Corte europea dei diritti umani", Rivista di diritto processuale, 2002, págs. 21 y ss. Incluso otros autores a ejemplo de FRONDIZI y DAUDET hablan del "uso impropio de las garantías". Vid. FRONDIZI, R.J., DAUDET, M. G., Garantías y eficiencia en la prueba penal, cit; pág. 182. De gran importancia respecto al tema: BRAGE CAMAZANO, J., Los límites a los derechos fundamentales, Madrid, 2004. 
Nos parece significativo a este respecto, destacar que todo lo que excede la normalidad, mismo tratándose de preservación de derechos y garantías fundamentales puede provocar efectos perversos al proceso penal y a la sociedad en general. En razón de esta afirmación, destacado sector de la doctrina contemporánea defiende que habrá que evitarse el llamado "paroxismo garantista"188.

Incluso, observa BINDER que tampoco es imaginable un sistema procesal concreto que consista en puras garantías procesales y resguardos. Ellas, por su misma definición, se oponen a las normas que instrumentan la aplicación de la coerción penal y buscan su mayor eficiencia ${ }^{189}$.

La libertad personal es inviolable, pero esto no impide la adopción de restricciones, bajo el fundamento de tutela de la comunidad y del desarrollo de la vida en sociedad. Este es de modo primario el poder que el Estado ostenta de imponer límites que se concretizan en providencias coercitivas y restrictivas destinadas a impedir o a punir la práctica de delitos ${ }^{190}$.

En estrecha relación con lo anterior y otra vez más citando ideas de CHIAVARIO en lo que afirma respecto a las garantías procesales penales, señala que los derechos de la persona pueden sufrir restricciones sea a causa de los limites demasiadamente blandos, sea por los limites demasiadamente estrechos de los poderes estatales ${ }^{191}$.

Esta preocupación también es planteada también en la doctrina argentina, pues a quien se pregunte si la eficiencia de la justicia penal puede ser concebida como una finalidad que justifique restricciones a los derechos humanos, se ha de responder que las garantías son verdaderamente tales a condición de que se las salvaguarde aun en los momentos difíciles. Por otro lado tampoco ha de olvidarse el riesgo del abuso de las garantías $^{192}$.

En nuestro modo de comprender la cuestión, se nos parece razonable plantear la duda si por casualidad hubiera una preponderancia absurdamente sin proporción a favor de la preservación de las garantías, si los criterios de fiabilidad, veracidad y consistencia quedarían asegurados en una eventual decisión judicial. Es decir, no se puede desconocer que el derecho fundamental de la colectividad en verse apurada la infracción penal de acuerdo con los principios basilares del derecho procesal penal quedaría perjudicado, amén del surgimiento de una sensación de impunidad. No estaría además, clara la obediencia al principio de la simétrica paridad de armas, el cual establece como requisito esencial la igualdad de tratamiento en el proceso.

\footnotetext{
188 Cfr. DE LA OLIVA SANTOS, A., et alli, Derecho Procesal Penal, cit., pág. 80.

189 Vid. BINDER, A. M., Introducción al derecho procesal penal, cit., pág. 59.

190 Vid. con más profundidad respecto a esta idea, CUOCOLO, F., Principi di Diritto Costituzionale, 2ª edición, Milano, 1999, págs. 365-366.

191 CHIAVARIO, M., "Direitos humanos, Processo Penal e Criminalidade Organizada", cit., pág. 35. En este caso, habrá de ser aplicado el principio de proporcionalidad cuando estén en juego el interés persecutorio del Estado y la libertad del ciudadano.

192 FRONDIZI, R. J., DAUDET, M. G., Garantías y eficiencia en la prueba penal, cit., pág. 4. También en Portugal, la doctrina ha demostrado su preocupación con el tema de una posible y abusiva instrumentalización de las garantías, al destacar que "la radicalización de los derechos fundamentales, que conduciría a la eliminación de su dimensión objetiva, redundaría una paralización de la eficacia de la administración de la justicia, entendida ésta como una imposición al Estado de Derecho". Vid. ONETO, I., O agente infiltrado: contributo para a compreensão do regime jurídico das acções encobertas, Coimbra, 2005, pág. 170.
} 
Por su parte, SCARANCE FERNANDES aduce con claridad que son dos los derechos fundamentales del individuo que interesan especialmente al proceso criminal: el derecho a la libertad y el derecho a la seguridad. En consecuencia de estos dos derechos fundamentales, los individuos tienen derecho a que el Estado actúe positivamente en el sentido de estructurar órganos y crear procedimientos que, al mismo tiempo, les propicien seguridad y les defiendan la libertad. En otras palabras, tiene derecho a un sistema que haga actuar las normas del derecho represivo, necesarias para la concreción del derecho fundamental a la seguridad, y atribuya al acusado todos los mecanismos esenciales para a la defensa de su libertad. De forma resumida, un sistema que asegure eficiencia con garantismo ${ }^{193}$.

Queda muy claro, pues, que esta eventual y abusiva instrumentalización de las garantías puede originar efectos terribles al proceso penal, a punto de generar junto a la sociedad, una sensación de tolerancia pasiva al desarrollo y expansión de la criminalidad, además de provocar desaliento en las autoridades incumbidas de proceder al control de la seguridad colectiva.

En certera expresión, resumió GREVI que las garantías deben permitir el funcionamiento del proceso, es decir, deben conducirle al cumplimiento de su función, porque son el modo y el medio, de por sí imprescindibles, pero no el fin del proceso ${ }^{194}$.

De todo modo es cierto que, de cara a la eficiencia del proceso, se impone también la necesidad de reflexionar, y en cierto modo redimensionar, no ya las garantías tradicionales sino la amplitud y los alcances de las interpretaciones que se han hecho de algunas de ellas. Es un discurso éste de verificación de ciertos excesos ya sedimentados, que no aventajan sino perjudican a la tutela del núcleo esencial de las garantías ${ }^{195}$.

Queda muy claro, pues, la relevancia constitucional de las garantías, lo que nadie se le puede contestar. Esto, obviamente, se encuentra fuera de discusión ${ }^{196}$. Otra cosa es aclarar que hay límites en la interpretación de la instrumentalización y del uso de estas garantías, de modo a no poner en riesgo la seguridad colectiva ${ }^{197}$ buscada a través del ejercicio legítimo del ius puniendi estatal.

Esta idea adquiere especial relevancia en la doctrina italiana, donde VARI señala que los derechos han de encontrarse antes de la ley. El derecho puede ser desigual del momento en que la igualdad formal no es suficiente a garantizar la justicia necesaria o aquella posible, según aquellos mismos valores a los cuales se reconoce la tutela. La

193 SCARANCE FERNANDES, A., "O equilíbrio entre a eficiência e o garantismo e o crime organizado", cit., pág. 233.

194 Cfr. GREVI, V., "Garanzie individuali ed esigenze di difesa sociale nel processo penale(a cura di Lucio Lanfranchi)", Garanzie Costituzionali e Diritti Fondamentali, Roma, 1997, págs. 13 y ss y luego, 38 y ss. En nuestra opinión, de modo alguno deberán ser confundidas las ideas de "garantismo" y "impunidad". Muy al contrario, pues las garantías procesales deberán ser concebidas como legitimantes del propio poder punitivo, a la vez que fuera de los limites aceptables, se imponen como abusivas y peligrosas.

195 FRONDIZI, R. J., DAUDET, M. G., Garantías y eficiencia en la prueba penal, cit., pág. 182.

196 No se trata, como ya repetido tantas veces en este trabajo, de sustituir a una suerte de hipergarantismo intolerante por una aproximación groseramente eficientista, sino de dar espacio al equilibrio.

197 De este modo, "si el sistema pretende respetar plenamente los derechos de los imputados, pero no garantiza en medida razonable la seguridad del público, ni los ciudadanos ni los gobernantes lo aguantarán y tarde o temprano será rechazado", SOLIMINE, M. A., "Praxis instructoria en un Estado de Derecho, Entre las garantías y la eficiencia", cit., pág. 131. 
igualdad material refleja por esto las diversidades. Situaciones desiguales son tratadas de modos desiguales, pero las diversidades generan discontinuidad o incertidumbre ${ }^{198}$.

No se quiere defender aquí que se deba flexibilizar las garantías sin límites en caso de delitos graves como el caso de actuación de la criminalidad organizada ${ }^{199}$, muy al contrario, es nuestra intención, dejar claro que en ciertas situaciones de extrema gravedad e importancia institucional, los derechos de los investigados o imputados también deberán ser respetados, pero en caso de choque de bienes jurídicos en colisión, a ejemplo de la seguridad individual y la seguridad colectiva, tendrá primordial importancia, el análisis de la proporcionalidad 200 aplicada al caso concreto.

Así, a depender del examen del caso concreto, y delante de un análisis minucioso del mismo frente al principio de proporcionalidad, podrá o no ocurrir la restricción de derechos fundamentales del investigado o acusado201. Se trata en verdad, de una relativización de garantías a ser utilizada en carácter estrictamente excepcional y siempre que no se consiga a través de otras formas legales, obtener el éxito de la persecución penal.

Además, con relación a la preocupación con eventuales excesos en la actuación del poder estatal en la lucha contra la delincuencia, el derecho probatorio debería tener en cuenta los problemas del crimen organizado, pero no para llegar a lo que muchos denominan de un régimen de "doble vía", como si debieran existir dos códigos diferenciados y que para el crimen organizado se pudieran especificar normas más duras, pues son todos peligrosos criminales ${ }^{202}$.

Así, y otro modo, estaríamos aceptando o mejor legitimando el uso de las ideas arraigadas en un Derecho Penal o Procesal penal del enemigo, creador de reglas distintas para los "ciudadanos" y para los "enemigos".

Siendo el respeto a los derechos fundamentales la regla de un sistema criminal democrático, por lógico, la restricción a uno de estos derechos solamente debe ocurrir en situación de excepcionalidad, o sea, cuando demostrada la imprescindible necesidad de la medida, a fines de permitir el ejercicio de la pretensión acusatoria ${ }^{203}$. En este sentido, la flexibilización cuanto a un derecho de naturaleza fundamental, como consecuencia misma

198 Véase al respecto, VARI, M., "Acesso alla giustizia e tutela dei diritti e delle libertà fondamentali", Diritti di libertà e diritti sociali tra giudice costituzionale e giudice comune, Nápoles, 1997, pág. 66.

199 En el mismo sentido, MORENO CATENA, V., señala que "deben analizarse esas particularidades procesales y, si suponen restricción de derechos fundamentales, si se ajustan al marco constitucional". Vid. "El enjuiciamiento de delitos de terrorismo y el derecho de defensa", cit., pág. 385.

200 Respecto a una correcta interpretación del principio de proporcionalidad penal, GONZÁLEZ-CUELLAR SERRANO apunta la salida y también el peligro que de ella puede advenir: "El principio de proporcionalidad, en cuanto exige la ponderación de los intereses en conflicto, es, en cualquier país y con frecuencia, conscientemente o no, tomado en consideración en la regulación de las medidas limitativas de derechos y en el momento de su aplicación judicial, y así sucede incluso en el ámbito del Derecho comunitario europeo". Vid. GONZÁLEZ-CUELLAR SERRANO, N. G., Proporcionalidad y derechos fundamentales en el proceso penal, cit., pág. 21. Y complementa el citado autor, señalando que "el cumplimiento del principio de proporcionalidad, que prima la búsqueda de la justicia en el caso concreto sobre la automática aplicación de la ley, podría suponer un riesgo, si no es adecuadamente entendido, para la seguridad jurídica y la igualdad", cit., pág. 313.

201 Sosteniendo la idea de que no existen derechos fundamentales estrictamente ilimitables, Vid. ASENCIO MELADO, J. M., Prueba prohibida y prueba preconstituida, Madrid, 1989, págs. 92 y ss. En el mismo sentido, RODRÍGUEZ GARCÍA, N., "Medios de prueba restrictivos de derechos fundamentales. Las intervenciones telefónicas", cit., pág. 41.

202 Vid. CHIAVARIO, M., "La justicia penal italiana, a la búsqueda continua de un proceso justo", VV.AA., Terrorismo y Proceso Penal Acusatorio, Valencia, 2006, pág. 462.

203 Vid. SILVA JUNIOR, W. N., Curso de Direito Processual Penal: Teoria (Constitucional) do Processo Penal, cit., pág. 319. 
del principio de ponderación, tan sólo será aceptable en casos de delitos de destacada gravedad y repercusión social, demostrada la necesidad y la racionalidad de la medida restrictiva. Y más que esto, pues la regla principal será la excepcionalidad de adopción de esta postura.

A esto no se puede denominar de "análisis de excepción" en el sentido maléfico de la palabra, pero sí, de un modo de actuar de la justicia penal, proporcional y adecuadoa los fines de conseguir mantener los intereses sociales en situación de respeto incondicional a los preceptos esculpidos en la Constitución.

Respecto a esta intrigante cuestión, interesante la opinión de FEIJÓo SÁNCHEZ al contestar la pregunta acerca de ser ilegítimo en el marco de un Estado de Derecho que existan normas penales y procesales específicas contra el crimen organizado. Contesta señalando que la respuesta es que de partida no. Ello no significa que valga todo en la guerra o cruzada que se ha declarado políticamente (a nivel estatal y supraestatal) contra las organizaciones criminales, sino que la comisión de delitos vinculados a estructuras organizadas presenta determinadas particularidades que deben ser tenidas en cuenta. Ello tampoco significa que se autoricen intervenciones ilegítimas del Estado contra cualquier ciudadano al amparo de la justificación de que se trata de una actuación necesaria para combatir la delincuencia organizada (por ejemplo, realizar escuchas telefónicas indiscriminadas sin autorización judicial para descubrir pistas sobre organizaciones delictivas). Lo único que se debe afirmar es que es posible discutir en el marco del Estado de Derecho y de un Derecho penal de ciudadanos sobre la necesidad de crear normas especiales para la delincuencia relacionada con organizaciones criminales. Se trata de un fenómeno que puede justificar respuestas jurídicas específicas ${ }^{204}$.

Adoptándose un pensamiento diametralmente contrario al expuesto y aceptando que las garantías sean perpetuadas como escudo de protección de delincuencia, tendremos que convivir con la inseguridad y la frustración de los Estados, de la sociedad y de las autoridades encargadas del control penal de la criminalidad, quedando en abierto ataques desmedidos contra la paz, la seguridad y la estabilidad de las sociedades libres y democráticas.

Como consecuencia del pensamiento desarrollado hasta este punto del trabajo, la conclusión es que siempre que las medidas procesales que facilitan la aplicación del derecho de punir entren en colisión con el ius libertatis, deberán ser ponderados el interés estatal de persecución penal y los intereses de los ciudadanos en la manutención del más amplio grado de eficacia de los derechos fundamentales ${ }^{205}$. También que la respuesta estatal deberá llevar en cuenta una nueva realidad criminológica.

En congruencia con lo expuesto, aunque se adopte la tesis del garantismo y de un proceso penal verdaderamente democrático, no se puede reconocer no sólo la posibilidad, pero la conveniencia de la utilización de la ponderación de bienes, en cierta medida posible, para resolver los conflictos entre principios procesales penales de naturaleza constitucional.

\footnotetext{
204 FEIJÓo SÁNCHEZ, B., "El derecho penal del enemigo y el Estado democrático de Derecho", Revista Peruana de Ciencias Penales, núm. 18, Lima, 2006, págs. 148-149.

205 Esta idea ha sido desarrollada por BERNAL PULIDO, C., El principio de proporcionalidad y los derechos fundamentales, cit.
} 
De este modo, se evita la apariencia de cierta connivencia de los órganos de persecución penal, generadores de una sensación de impunidad y de falta de compromiso por parte del Estado en la tarea constitucional de manutención y preservación de la paz y de la seguridad ciudadana.

En síntesis, nuestro modo de pensar: garantías sí y siempre, pero a su medida ${ }^{206}$, pues no se puede olvidar que amén del hecho de que los delincuentes tengan garantizados sus derechos fundamentales, importante hacer hincapié en el sentido de que también la sociedad y las instituciones que pertenecen al conjunto de un Estado constitucional y democrático de Derecho, deben tener preservados sus derechos a la paz, a la tranquilidad y a la seguridad 207 .

Además, la delincuencia ha cambiado en los últimos años de forma muy significativa, ya que no se puede dispensar el mismo tratamiento procesal o político criminal a la criminalidad tradicional y a la organizada de carácter transnacional. Hay que evolucionar la respuesta penal en el sentido de hacer frente a los avances de la criminalidad moderna.

Si desde el punto de vista penal se ha ido produciendo una alteración de los componentes del sistema, en el ámbito estrictamente procesal penal se ha producido también un destacable deseo de buscar mecanismos que conviertan la justicia en eficiencia $\mathrm{y}$, por tanto, desde parámetros garantistas, parece que de modo pendular estamos adentrándonos en parámetros de celeridad para conseguir una económica justicia penal ${ }^{208}$.

Una última observación digna de destacarse se refiere al hecho de que es posible asumir ante el fenómeno de la delincuencia organizada, incluso de la mafia, una aproximación que no sea ni la del "enemigo" ni la que se realiza desde el garantismo exacerbado, sino más bien, una suerte de tercera vía, más crítica dialéctica, en la que se observe las novedades de la legislación de emergencia con mayor conciencia político criminal, que tenga en cuenta las características criminológicas de la criminalidad organizada $^{209}$. Y esto se trata de rescatar de la legislación de emergencia los aspectos que

206 Ajustándose a esta constatación, señala PÉREZ MORENO: "A decir verdad, las garantías son tan ajenas a nuestra conciencia de ciudadano como el enfermo que aún no conoce su dolencia por no haber concurrido aún al médico, quien le ha de prescribir la medicina para su enfermedad. Esto quiere decir que se hacen visibles o son necesarias sólo cuando se estima que una actividad estatal pondrá en riesgo un derecho o un comportamiento de esa administración que lo aniquile". Vid. PÉREZ MORENO, E. P., "Precisiones acerca de las garantías del imputado (A propósito de los derechos ciudadanos)", cit., pág. 279.

207 En este sentido, según MORENO CATENA "no cabe ninguna duda de que, junto al derecho de libertad, es también un valor digno de especial protección la seguridad pública, la impertubilidad de la tranquilidad personal y el disfrute de las libertades de cada individuo. Y precisamente la protección de la seguridad pública cuenta con el proceso como uno de sus más importantes elementos, pues es el dispositivo de cierre de lucha contra la criminalidad. Luego, el proceso penal es piedra angular de las políticas de seguridad pública, particularmente frente a la delincuencia, sobre todo frente a aquella especialmente dañosa y grave, como es la terrorista, que pretende o consigue poner en jaque a las legítimas estructuras de poder y la pacífica convivencia. Con el proceso se atribuye al Poder Judicial la administración del único medio legítimo a través del cual se puede imponer la sanción penal correspondiente al responsable de una acción delictiva". Vid. MORENO CATENA, V., "El enjuiciamiento de delitos de terrorismo y el derecho de defensa", cit., pág. 378.

208 En este sentido, Vid. BARONA VILAR, S., "Conformidad del acusado, paradigma de eficiencia de la Justicia Penal", cit., pág. 409.

209 Cfr. FIANDACA, G., "Lotta Allá criminalità organizzata di stampo mafioso nella legislazione penale italiana", Le estrategie di contrasto Allá criminalità organizzata nella prospettiva di diritto comparato, Gabriele Fornasari coord., Padua, 2002, pág. 3. 
han resultado eficaces rodeándolos de las garantías necesarias para que no desborden los derechos fundamentales ${ }^{210}$.

Nos parece muy interesante la solución apuntada, a la vez que consigue seguir la línea que hemos propuesto en nuestro trabajo de investigación, o sea, de mantenimiento de un equilibrio entre eficacia y garantías, al mismo tiempo en que se buscan respuestas jurídicas adecuadas al combate a la delincuencia organizada transnacional.

Delante de todos los argumentos coleccionados en este apartado, habrá que concluirse que lo más acertado es que la Justicia Penal como servicio público, y también en el ámbito de la delincuencia organizada, debe ser eficiente para que se alcance un proceso penal funcional y garante, apto a tratar con una nueva realidad criminal211.

A continuación, tendremos la oportunidad de analizar la importancia de un correcto entendimiento respecto a la eficiencia penal ${ }^{212}$.

\section{I.2.2. "Eficiencia penal": un concepto importante.}

Detengámonos otra vez más para resumir y clarificar lo anterior y una vez más seguir avanzando. Hasta el momento se ha intentado poner de manifiesto que para lograrse la obtención de eficiencia penal en sentido amplio, deberán ser armonizadas las dos fuerzas que se encuentran en tensión en el proceso penal (paradigma eficacia versus garantías).

También que los derechos y garantías fundamentales deben ser asegurados a tope, pero hay que observar que existen límites, principalmente cuando hablamos de una cierta delincuencia sui generis y marcada por la sofisticación, como sería la hipótesis de la criminalidad organizada ${ }^{213}$. Así, se vuelve imprescindible la idea de un proceso penal del equilibrio 214 .

De otra parte, es algo indubitable, que la proclamación de la eficacia de la justicia penal como una dimensión esencial del Estado constitucional de Derecho, protegiendo de forma autónoma el bien jurídico supraindividual, viene consolidándose en el derecho comparado.

La eficiencia funciona así como meta a ser buscada en el ámbito judicial215.

210 ZÚÑIGA RODRÍGUEZ, L., Criminalidad organizada y sistema de derecho penal, cit., pág. 197.

211 Cfr. BALTAZAR JR, J. P., Crime organizado e proibição de insuficiência, Porto Alegre, 2010, pág. 171.

212 Sobre el tema de la eficacia penal, Vid. GALINDO, J. J., "La eficiencia del sistema penal (poder y control)", http://www.insyde.org.mx.

213 En esta línea, sostiene ZÚÑIGA RODRÍGUEZ que "se trataría no de una relativización ni flexibilización de los principios, sino más bien de adaptabilidad de las categorías a las circunstancias criminológicas de la fenomenología de esta especial forma de criminalidad en la que se estructura una organización estable y permanente para delinquir". Vid. ZÚÑIGA RODRÍGUEZ, L., Criminalidad organizada y sistema de derecho penal, cit., págs. 204-205.

214 SCARANCE FERNANDES, A., "O equilíbrio na investigação criminal", VV.AA., Estudos em homenagem à Professora Ada Pellegrini Grinover, F. L. Yarshell y M. Zanoide de Moraes coords., São Paulo, 2005, págs. 319-330.

215 Para un estudio profundizado respecto a este tema, Vid. VARGAS VIANCO, J. E., "Eficiencia en la Justicia", Sistemas Judiciales, Buenos Aires, 2003, pág. 68-92. De otra parte, muy importante la afirmación hecha por GUZMÁN FLUJA al señalar que " estamos en un momento importante para el derecho procesal, un momento en el que surgen muchas interrogantes y en el que se debe hacer un esfuerzo por alcanzar soluciones que permitan al proceso mantener su eficacia y utilidad como mecanismo o instrumento componedor de conflictos". Vid. GUZMÁN FLUJA, V. C., Anticipación y preconstitución de la prueba en el proceso penal, cit., pág. 11. 
Por esta razón cabría afirmar que la ley procesal penal debe ser comprendida no sólo bajo la exigencia de la reserva de la ley, pero de reserva de la ley proporcional, que compatibilice los vectores antagónicos (eficiencia versus garantías) proporcionando la máxima eficiencia de la meta compleja del proceso. Especialmente en los procedimientos probatorios, la lectura proporcional conllevará a un análisis de la adecuación de las restricciones probatorias a los fines que se proponen, la efectiva necesidad de restricción delante de otras formas de control menos restrictivas y a la proporcionalidad entre la restricción probatoria y los demás intereses en colisión en el proceso penal, de entre los cuales, la eficiencia ${ }^{216}$.

Ahora bien. No se quiere defender que la eficiencia sea el criterio definitivo (del mismo modo como no habrá de defenderse que existen principios o derechos absolutos), pues el total abandono de las garantías individuales desarrolladas por el Estado liberal lleva a un irrazonable recrudecimiento del proceso, pero se destaca que la eficiencia es un principio que no puede simplemente ser objeto de negligencia, a la vez que también posee rango constitucional mismo que de forma indirecta.

Todavía, mucho se habla respecto de la eficiencia penal217. Pero ahora cabría plantear: ¿Qué significa eficiencia procesal penal en sentido general?

En la doctrina hay autores como PRADEL que defienden que el principio de eficiencia es un protector de la sociedad y que contiene dos otros principios: el de la busca de la verdad y el de la celeridad ${ }^{218}$. Así en esta línea de pensamiento el sistema es eficiente cuando permite la apuración de hechos criminales de manera célere.

Ciertamente, la verdadera eficiencia procesal sería a nuestro modo de pensar, más que célere, pero también aquella que incluye el reconocimiento de las garantías de los ciudadanos.

La eficiencia en el proceso penal, no debe, todavía, ser medida por el número de condenaciones impuestas, pero sí por su conclusión en tiempo razonable, respetando los derechos fundamentales del acusado ${ }^{219}$. Esta la lógica de una concepción garantista del Derecho procesal penal.

Por lo tanto, será eficiente el sistema penal compuesto por procedimientos que aseguren a todos los participantes del proceso oportunidad para una actuación en conformidad con sus misiones especificas $y$, en lo tocante a las partes, que proporcionen los medios para que ejerciten sus actividades, defiendan sus derechos y hagan respetar sus

\footnotetext{
216 Siguiendo esta línea de pensamiento, Vid. PIEROBOM DE ÁVILA, T. A., Provas ilícitas e proporcionalidade, Rio de Janeiro, 2007, págs. 68-69.

217 Algún autor, así MIRANDA COUTINHO, destaca que en realidad, dentro de una concepción contemporánea del Derecho procesal penal, y en especial delante del conflicto entre el "garantismo" versus "utilitarismo", adquiere extrema importancia la distinción entre efectividad y eficiencia. De este modo, sostiene el autor brasileño que "no es admisible, en hipótesis alguna, sinonimizar efectividad con eficiencia, principalmente por desconocimiento. Al sumo, aquella reclama un análisis de los fines; esta, la eficiencia, desde la base neoliberal, responde a los medios". Vid. MIRANDA COUTINHO, J. N., "Efetividade do processo penal e golpe de cena: um problema às reformas processuais", VV.AA., Escritos de Direito e Processo Penal em homenagem ao professor Paulo Cláudio Tovo, A. Wunderlich coord., Rio de Janeiro, 2001, págs 143 y ss.

218 PRADEL, J., Procédure pénale, 10aㅡ edición, Paris, 2000, pág. 300.

219 En este sentido, Vid. FERNANDES, F., O processo penal como instrumento de política criminal, cit., págs. 829-834; GOMES, M. G. M., "Devido processo legal e direito ao procedimento adequado", Revista Brasileira de Ciências Criminais, núm, 55, São Paulo, 2005, pág. 306.
} 
garantías 220 . Deberá ser respetado entonces, el principio de la paridad de armas tan bien elaborado dogmáticamente por FAZZALARI 221.

Como consecuencia, es posible afirmar que la eficiencia no es la de cualquier tipo de proceso con tal que haya una mayor represión, sino la de un proceso que permita alcanzar resultados creíbles en cuanto a su duración y a la eficacia de las sanciones, pero logrados de un modo justo desde el punto de vista del iter ${ }^{222}$.

Debe notarse, además, que la eficacia como imperativo a ser buscado para alcanzarse el proceso justo, no tiene nada que ver con la celeridad individualmente considerada, pues, muy al contrario, debe ser concebida como un conjunto de requisitos que deben ser agrupados de modo a que presenten el fin legítimamente a ser atingido: un proceso célere, formalmente estructurado y respetuoso con los derechos y garantías de la persona sometida a la persecución penal.

Puesto en otros términos, lo que se quiere decir es que en el ámbito de los derechos fundamentales, la eficiencia surge cuando son ellos realizados o rellenados, o sea, cuando son criadas las condiciones para su efectivo ejercicio, en relación al conjunto de los ciudadanos 223 .

En este sentido, si el proceso penal tiene por finalidad precipua asegurar el ejercicio del derecho de defensa del imputado o investigado, y al mismo tiempo, preservar el interés estatal de punir los autores del delito, será correcto interpretar que será eficiente cuando de modo global, consiga alcanzar el máximo en estas dos finalidades. Esta tarea sea estructurada a través de una ponderación como tendremos la oportunidad de estudiar en capítulos siguientes.

La eficiencia a la que nos referimos es la de un proceso que no gire sobre sí mismo, ni se agote sencillamente en un resultado formal224, sino que se proponga alcanzar en la medida de lo posible, la función esencial de absolver a los inocentes y de condenar a los culpables dentro de un marco intrínsecamente correcto y leal225.

El proceso eficiente es más que aquél destinado a la absolución de los inocentes y a la condena de los considerados autores del delito, es un proceso de forma intrínsecamente

220 SCARANCE FERNANDES, A., "O equilíbrio na repressão ao crime organizado", cit., pág. 11.

221 Vid. FAZZALARI, E., Istituzioni di diritto processuale, Padova, 1992. La paridad de armas en el plan estrictamente procesal, trata de asegurar que ambas partes en conflicto gocen de los mismos medios de ataque y de defensa y de la igualdad de armas para hacer valer sus alegaciones y medios de prueba. Vid. CORDÓN MORENO, F., Las garantías constitucionales del proceso penal, cit., pág. 145. En el mismo sentido la STC 90/1994, de 17.3.1994, donde se trata con este principio de garantizar el equilibrio entre ambas partes, de forma que "dispongan de las mismas posibilidades y cargas de alegación, prueba e impugnación".

222 A este respecto SCARANCE FERNANDES señala que "el vocablo eficiencia será utilizado de forma amplia, sendo superada la idea de eficiencia medida por el número de condenaciones. Será eficiente el proceso que, en tiempo razonable, permita atingirse un resultado justo, sea posibilitando a los órganos de persecución penal obrar para hacer actuar el derecho punitivo, sea asegurando al acusado las garantías del proceso legal". Vid. SCARANCE FERNANDES, A., "O equilíbrio entre a eficiência e o garantismo e o crime organizado", cit., pág. 234.

223 Vid. BALTAZAR JR, J. P., "Limites constitucionais à investigação. 0 conflito entre o direito fundamental a segurança e o direito de liberdade no âmbito da investigação criminal", cit., pág. 210.

224 En nuestra opinión el sentido de esta afirmación pone de manifiesto lo que se espera de un proceso eficiente y justo es que este no sea algo desprovisto de un contenido lógico jurídico, sino que al contrario, de forma fundamentada establezca los motivos de una condena o de una absolución.

225 En este sentido, Vid. FRONDIZI, R. J; DAUDET, M.G., Garantías y eficiencia en la prueba penal, cit., pág. 181. 
correcta y leal 226 , impregnado por el respeto a los derechos y garantías fundamentales. Si en cambio, la eficiencia del esquema se consigue con desapego de las garantías individuales ya no estaremos en un "Estado de Derecho", pues éste es inconcebible sin la salvaguarda de la dignidad humana, y en tal caso, el ius puniendi no tardará en tornarse $\operatorname{arbitrario}^{227}$.

Por esta razón, el proceso es el medio adecuado en virtud de su imparcialidad, para arribar un resultado justo, sin importar cuál es ese resultado. La declaración de inocencia o de culpabilidad es igualmente justa o correcta en tanto se respeten los límites del debido proceso.

Siguiendo por esta línea de raciocinio, la protección jurisdiccional de los derechos y libertades conforme garantizado por la Constitución debe obtenerse a través del proceso realizado en toda su integridad y desde que obedecidos los principios procesales y constitucionales aplicables.

En efecto, la noción de mayor eficiencia procesal, antes de excluir el concepto de las garantías del debido proceso penal, las presupone.

Desde esta perspectiva, se puede afirmar con conocimiento seguro y claro que el proceso penal resuelve el conflicto, lo elimina, sea cual sea su respuesta o resultado, que nunca puede ser prejuzgado de antemano. Es eficaz y eficiente tanto si se establece la existencia de un hecho delictivo como si se establece que no hay hecho alguno o que los hechos investigados y/o enjuiciados no constituyen delito; tanto si termina con una sentencia condenatoria como con una sentencia absolutoria ${ }^{228}$.

Esto nos pone en presencia de una interesante cuestión: el concepto general de eficiencia penal puede abarcar tanto una situación donde el fin del proceso termina en una condena, o en situación opuesta, donde en el fin del proceso apunta para una absolución. Lo que síimporta, es que el proceso haya respetado los principios procesales y constitucionales, en tiempo razonable. Esto es lo que podríamos denominar de un "proceso justo"229 o en nuestra denominación propia, de "armonía procesal equilibrada".

Lo justo en el sentido empleado, en nuestra opinión, significa encontrar el camino entre la necesidad de la investigación para la realización del derecho penal material y la protección de los derechos del imputado: esta es la misión constitucional del derecho procesal penal.

226 Vid. CHIAVARIO, M., "Garanzie individuali ed efficienza del processo", Il giusto processo, Milano, 1998, pág. 54.

227 SOLIMINE, M. A., "Praxis instructoria en un Estado de Derecho. Entre las garantías y la eficiencia", cit., pág. 131.

228 GUZMÁN FLUJA, V. C., "El agente encubierto y las garantías del proceso penal", cit., págs. 199-200. En el mismo sentido, señala VILLAR, que "en realidad, el proceso es el medio adecuado, en virtud de su imparcialidad, para arribar a un resultado justo, sin importar cuál es ese resultado. La declaración de inocencia o de culpabilidad son igualmente justas o correctas en tanto respeten los límites del debido proceso". Vid. VILLAR, M. A., "La libertad y el proceso penal. La garantía del máximo riesgo procesal aceptable", Doctrina Penal, núms. 59/60, Buenos Aires, 1992, pág. 483.

229 La noción de proceso justo, de la que se ocupó, quizás el primero entre los grandes estudiosos del derecho procesal de nuestro tiempo, ANDRIOLI, V., La convenzione europea dei diritti dell'uomo e il processo giusto, 1964, pág. 439, y que se ha desarrollado ampliamente en los días actuales por FERRUA, P., Il "giusto processo", Bologna, 2005 y MORELLO, A. M., El proceso justo, La Plata, 1994, no incluye solamente el tema de las garantías, sino el de éstas y el de la eficiencia al mismo tiempo. Y ello es particularmente así en el caso del proceso penal. También muy interesante respecto del proceso justo, SIRACUSANO, D., "Introduzione al giusto processo", Il giusto proceso, Milano, 1998 y CHIAVARIO, M., "La justicia penal italiana, a la búsqueda continua de un proceso justo", cit., págs. 451-465. 
De lo dicho resulta creíble que en la búsqueda de la eficiencia penal en los términos defendidos, las dos fuerzas que tensionan el proceso penal están necesariamente llamadas a equilibrarse, a entenderse y a armonizarse porque ambas son fines constitucionalmente dignos de protección ${ }^{230}$. Tanto la seguridad colectiva como la seguridad individual son por lo tanto, bienes jurídicos que encuentran protección en las Constituciones de los países avanzados y marcados por la democracia.

Efectivamente, parece evidente en este punto del trabajo, que las medidas de intervención en los derechos fundamentales, en la persecución criminal, sea en la fase de investigación preliminar o en el proceso penal stricto sensu, deben contribuir para finalidades inmediatas, o sea, en la perspectiva instrumental punitiva, ellas se justifican sivienen a contribuir para formar la convicción de la entidad que va a decidir la causa, iniciar el proceso penal en sentido estricto u obtener una sentencia condenatoria lato sensu respecto del hecho delictivo y su autoría.

Pero, no es más posible, teniendo en vista la contrariedad fundamental, que la persecución criminal cumpla apenas el principio instrumental punitivo, pues también debe satisfacer el principio instrumental garantista. Estas justificaciones teleológicas inmediatas "punitivas" son admitidas apenas prima facie y, por lo tanto, por ocasión del examen de proporcionalidad en sentido estricto, serán contrapuestas a las razones que van a garantizar los derechos fundamentales en razón de las medidas de intervención, cuando entonces podrán o no, ser definitivamente implementadas ${ }^{231}$.

Para la consecución de los fines de eficiencia y protección de los derechos fundamentales, es exigencia imprescindible la realización del debido proceso $^{232}$; un proceso que al mismo tiempo posea los requisitos de la eficiencia y de la legalidad, y que sea respetuoso conlas exigencias de la seguridad social y de las garantías individuales ${ }^{233}$.

Y con relación a las formas graves de criminalidad, ¿qué se puede esperar de la eficiencia?

Respecto a la delincuencia organizada, en especial, el estudio de la eficiencia puede ser efectuado de modo global, en razón del conjunto de las normas procesales que lo reglamentan. Fijada la idea de que no habrá de comprender eficiencia sin observancia de las garantías constitucionales, estas normas serán eficientes al permitir la represión al crimen organizado con respeto al núcleo esencial de las garantías, por medio del cual se va a garantizar la imparcialidad del juez, la amplia defensa y la contradicción.

De otra parte, no se puede olvidar que la eficiencia de la jurisdicción criminal en el ámbito de la criminalidad contemporánea, organizada o empresarial, depende de la adopción de nuevas posturas por parte de los operadores del derecho, bien como de adopción de nuevas técnicas de investigación ${ }^{234}$.

\footnotetext{
230 GUZMÁN FLUJA, V. C., "El agente encubierto y las garantías del proceso penal", cit., pág. 200. Véanse al respecto, las sentencias del Tribunal Constitucional Español (SSTC 166/1999, de 27.9.1999 y 130/2002, de 3.6.2002).

231 FEITOZA PACHECO, D., O princípio da proporcionalidade no Direito processual penal brasileiro, cit., pág. 167.

232 Vid. con amplitud respecto al tema, ESPARZA LEIBAR, I., El principio del proceso debido, Barcelona, 1995.

233 Vid. ABADE, D. N., Garantias do processo penal acusatório, cit., pág. 122.

${ }^{234}$ BALTAZAR JR, J. P., "Limites constitucionais à investigação. 0 conflito entre o direito fundamental a segurança e o direito de liberdade no âmbito da investigação criminal", cit., pág. 216.
} 
Delante de estos argumentos sólidos, se llega a la conclusión de que el objetivo debe ser concretar y no solamente reconocer la eficiencia del proceso penal, lo que se puede alcanzar por medio del respeto a las garantías constitucionales inherentes al debido proceso legal ${ }^{235}$.

En consecuencia, las garantías del proceso penal deben ser dirigidas a los fines de la justicia penal: protección de bienes jurídicos, restablecimiento de la paz, realización de la justicia en el caso concreto, manutención de la confianza de la sociedad en su propia eficacia, sin olvidar de las garantías individuales del imputado o investigado ${ }^{236}$. Y otras veces, como en la hipótesis de búsqueda de la preservación de la seguridad colectiva delante deataques del crimen organizado, deberá ser buscado el reconocimiento de un garantismo penal integral y proporcional como tendremos la oportunidad de defender en apartado siguiente.

En síntesis, mismo tratándose del combate a la criminalidad organizada, debe ser buscado el objetivo de equilibrar las fuerzas en tensión, evitándose por otro lado, toda suerte de actos que puedan configurar una abusiva instrumentalización de los derechos y garantías fundamentales. Y más, no se debe aceptar ideas típicas de un "estado de guerra" como forma aparentemente eficaz de eliminación de los problemas de contención de la violencia, extirpándose los "enemigos" de modo a neutralizarlos, pues este posicionamiento choca con la defensa de un Estado constitucional y democrático de Derecho.

I.2.3. La armonización de fuerzas y la búsqueda por un proceso penal equilibrado: una solución ideal.

Entre las tendencias contemporáneas del proceso penal, una viene manifestándose de forma intensa, la que busca el equilibrio entre la exigencia de asegurar al investigado, al acusado y al condenado la aplicación de las garantías fundamentales del debido proceso legal y la necesidad de mayor eficiencia del sistema persecutorio para la seguridad social. Con esto se intenta evitar los extremos del hipergarantismo o de movimientos como del Derecho penal del enemigo o de la ley y del orden ${ }^{237}$.

Ahora bien, si consideramos al proceso penal como el medio más idóneo y eficaz para la resolución de los conflictos de índole delictiva 238 , tendremos que señalar que su eficacia se pone en tela de juicio cuando factores externos alteran su curso normal: por ello los procesos penales nacionales se van ajustando para equilibrarse en su funcionamiento.

\footnotetext{
235 Respecto a esta conclusión, VILLAR señala que "el proceso confiable no surge sino de garantías que aseguren que tanto el inocente como el culpable cuenten con la posibilidad de triunfar frente a la persecución estatal". Vid. VILLAR, M. A., "La libertad y el proceso penal. La garantía del máximo riesgo procesal aceptable", cit., pág. 485.

236 Vid. GRINOVER, A. P., 0 processo em evolução, cit., págs. 226 y ss.

237 SCARANCE FERNANDES, A., "O equilíbrio entre a eficiência e o garantismo e o crime organizado", cit., pág. 231.

238 Así, aduce el profesor argentino CAFFERATA NORES que "el proceso penal sirve como instrumento para que el Estado intente demostrar y demuestre, si puede, bajo las condiciones (al intento y al logro) que como garantías individuales el sistema constitucional establece que una persona puede ser penada por un tribunal judicial como partícipe de un delito". Vid. CAFFERATA NORES, J. I., Cuestiones actuales sobre el proceso penal, cit., pág. 221.
} 
Al mismo tiempo, se percibe que la creciente y desenfrenada sofisticación de la delincuencia organizada, las diversas especies de tráfico, desde armas a seres humanos, pasando por la explotación sexual de niños y mujeres, la criminalidad económica y financiera hasta el blanqueo de capitales ${ }^{239}$, generan en las consciencias individuales el sentimiento de que la protección de la sociedad democrática exige altos grados de vigilancia y mayor control del Estado ${ }^{240}$.

Algún autor, así MOURAZ LOPES, incluso defiende que en tratándose del crimen organizado que presenta una realidad opaca, muchas veces casi blindada, que importa investigar, se obliga a la utilización de un conjunto de medios de obtención de prueba "pesados" de modo a posibilitar algún éxito en la investigación ${ }^{241}$.

El resultado originado de este conflicto lógicamente consiste en una obvia y compleja tensión entre valores, con la procura de un equilibrio que ha de permitir al Estado combatir eficazmente la criminalidad y al mismo tiempo garantizar la seguridad, pero no impidiendo, al mismo tiempo, que los individuos mantengan a su vida libre de intromisión estatal intensiva.

Este equilibrio ${ }^{242}$ debe permitir en nuestro modo de pensar, a la sociedad democrática, protegerse a sí propia, sin un regreso intolerable en los derechos y en las libertades.

Centrándonos en la cuestión de la paradoja eficacia versus garantías, se observa que en el proceso penal confluyen por lo tanto, entonces, dos grandes fuerzas: la del Estado como titular exclusivo del ius puniendi cuya aplicación es sólo posible en el proceso, y la de necesidad de que las personas sometidas al proceso penal queden a salvo de posibles abusos, mediante la adecuada garantía de sus derechos, sobre todo el de defensa ${ }^{243}$; ninguna de estas fuerzas es a priori menos importante que la otra ${ }^{244}$.

239 En este contexto importante señalar la existencia de una selección de conductas que se hace en el Tratado de Funcionamiento de la Unión Europea y que deriva en la cada vez mayor aprobación de normas penales y procesales penales en especial después del Tratado de Lisboa, quedando establecido en el artículo 83 que "el Parlamento Europeo y el Consejo podrán establecer, mediante directivas adoptadas con arreglo al procedimiento legislativo ordinario, normas mínimas relativas a la definición de las infracciones penales y de las sanciones en ámbitos delictivos que sean de especial gravedad y tengan una dimensión transfronteriza derivada del carácter o de las repercusiones de dichas infracciones o de una necesidad particular de combatirlas según criterios comunes". Y prosigue el apartado 1 del mismo artículo describiendo el rol de infracciones relativas a este ámbito delictivo: el terrorismo, la trata de seres humanos y la exploración sexual de mujeres y niños, el tráfico ilícito de drogas, el tráfico ilícito de armas, el blanqueo de capitales, la corrupción, la falsificación de medios de pago, la delincuencia informática y la delincuencia organizada.

240 Respecto a esta preocupación mundial, Vid. GÓMEZ DE LIAÑO FONSECA-HERRERO, M., Criminalidad organizada y medios extraordinarios de investigación, cit., págs. 29 y ss.

241 MOURAZ LOPES, J., "O crime econômico fiscal e o processo penal", II Congresso de Processo Penal, Coimbra, 2006, pág. 147. Aunque en nuestra opinión el término "pesados" deberá ser analizado con cuidado, pues se suele imaginarse que se trate de algo que viene en contra la legalidad. Preferíamos utilizar la denominación "medios contundentes" de producción de pruebas.

242 En este contexto, FRONDIZI y DAUDET exponen con claridad que "la profundización del valor eficiencia procesal lleva ante todo a entender que, desde ciertos puntos de vista, el refuerzo de la eficacia y el de las garantías, sobre todo de las fundamentales, no implica necesariamente antagonismo sino equilibrio armónico". Vid. FRONDIZI, R. J. y DAUDET, M. G., Garantías y eficiencia en la prueba penal, cit., pág. 181.

243 Monográficamente, Vid. CAROCCA PÉREZ, A., Garantía constitucional de la defensa procesal, Barcelona, 1997. En esta obra se recoge todo lo que concierne al término "defensa procesal", el cual constituye la implementación en el proceso de la participación de los propios interesados, es decir, de aquéllos que podrán verse afectados por la decisión jurisdiccional.

244 GUZMÁN FLUJA, V. C., "El agente encubierto y las garantías del proceso penal", cit., pág. 199. En la doctrina alemana puede citarse a ROXIN que señala cómo, "frente al poder estatal monopolizado de ejercicio 
Esta nos parece ser una idea razonable y digna de aceptación, a la vista que la primera fuerza (ius puniendi) no puede ser ejercitada sino a través de un proceso impregnado por las garantías y así, representativo de la segunda fuerza.

Pero, a partir de esta premisa, también es de resaltar que en ciertos momentos, el equilibrio entre un proceso garantista (perspectiva desde la óptica de los derechos fundamentales) y un proceso instrumentalmente dirigido a la aplicación del Derecho penal (perspectiva instrumental penal) debe ser encontrado, pero con la prevalencia del principio de protección de la libertad individual (perspectiva libertaria prevaleciente). Mejor diríamos que debe haber un desequilibrio ponderado, y no, un aniquilamiento de la perspectiva instrumental penal. Todo dependerá del estudio del caso concreto para apurarse cuál de las perspectivas representa adecuadamente el vector de la justicia.

Pues bien, para mejor comprender a esta cuestión conviene tener en cuenta que del mismo modo que es indiscutible la necesidad del ejercicio del derecho de punir del Estado a través del instrumental procesal, debe tenerse en cuenta que también es imprescindible la preservación de las garantías y derechos fundamentales de los ciudadanos investigados o imputados, los cuales fueron conquistados con mucho esfuerzo y lucha en los últimos siglos.

Deberá ser buscado por lo tanto, el equilibrio que en el proceso penal debe darse entre el principio de eficacia en la persecución de los delitos y el necesario respetode los derechos fundamentales que se encuentran reconocidos en la Constitución ${ }^{245}$.

De una parte, los actores estatales de la persecución criminal viven el drama, por ejemplo, de decidir, sin gradaciones, entre los extremos de la prisión provisional y la libertad, con lo que provocan las tragedias individuales y sociales que afectan negativamente no sólo la libertad de locomoción, pero también la educación, el trabajo, la convivencia familiar, la salud, el acceso a la cultura, etc ${ }^{246}$.

Tiene, en efecto, el Estado, la obligatoriedad de búsqueda de la aplicación del ius puniendi siempre que haya un hecho delictuoso, mismo teniendo en cuenta los posibles efectos negativos generados por el inicio de la persecución criminal.

Es innegable entonces que el derecho a la seguridad que es inherente a todas las personas, también constituye una de las muchas formas de realización de la dignidad de la persona humana, y, por tanto, de protección de todas estas en sus manifestaciones derivadas 247 .

En otras palabras, hay que buscar la proporcionalidad en el ámbito procesal penal desde la óptica de los derechos individuales del ciudadano, pero también de los derechos colectivos inherentes a la sociedad.

del ius puniendi, surge la necesidad de limitarlo para proteger a los inocentes frente a persecuciones injustas, mediante la formalización del proceso penal". Vid. ROXIN, C., Derecho Procesal Penal, cit., pág. 2.

245 Cfr. RIAÑO BRUN, I., La instrucción criminal en el proceso penal, cit., pág. 13.

246 En este sentido, Vid. FEITOZA PACHECO, D., O princípio da proporcionalidade no Direito processual penal brasileiro, cit., pág. 3.

247 BECHARA, F. R., "Criminalidade Organizada e procedimento diferenciado: entre eficiência e garantismo", cit., pág. 912. Esta también es la posición adoptada por BALTAZAR JR, al señalar que "el deber de garantía de la seguridad y el consecuente derecho del ciudadano a ella surgen como contrapartida al monopolio del uso de la fuerza por parte del Estado y de la prohibición de la autotutela". Vid. BALTAZAR JR, J. P., Crime organizado e proibição de insuficiência, cit., pág. 190. 
En este contexto, cobra singular relevancia la opinión de QUEIROZ acerca del principio de proporcionalidad bajo la óptica de la prohibición de insuficiencia de la intervención jurídico penal. Esto significa sencillamente, que deberá ser rechazada la idea de la desproporcionada reacción estatal, sin límites y ausente de una consistencia político criminal lógica. De otra parte, cumple evitar que la respuesta penal quede muy abajo de su efectivo merecimiento, dado su grado de ofensividad y significación político criminal, pues la desproporción tanto puede darse para más cuanto para menos ${ }^{248}$.

En realidad por fuerza del principio de la prohibición de la protección deficiente, ni la ley ni el Estado pueden presentar insuficiencia en relación a la tutela de los derechos fundamentales, o dicho en otras palabras, ello críaun deber de protección para el Estado que no puede abrir mano de los mecanismos de defensa, incluyéndose los de naturaleza penal, para asegurar o garantizar la protección de un derecho fundamental.

Como apunta BERNAL PULIDO, la prohibición de protección deficiente puede definirse como un criterio estructural para la determinación de los derechos fundamentales, con cuya aplicación puede determinarse si un acto estatal, por antonomasia una omisión, vulnera un derecho fundamental de protección ${ }^{249}$.

Del mismo modo, incontestable que el principio de la protección deficiente emana directamente del principio de proporcionalidad, el cual estaría siendo invocado para evitar la tutela penal insuficiente ${ }^{250}$.

El otro lado de la moneda, demuestra que los derechos fundamentales ${ }^{251}$, que en el plan teórico jurídico son identificados como derechos que están adscritos universalmente a todos en cuanto personas, o en cuanto ciudadanos o personas con capacidad de obrar, y que son por tanto indisponibles e inalienables, aunque no sean absolutos ${ }^{252}$, deben merecer toda la protección posible por parte del Estado253.

248 Vid. QUEIROZ, P. S., Direito Penal, Parte Geral, São Paulo, 2005, pág. 33. Importante también la opinión de INGO SARLET al afirmar que "la noción de proporcionalidad no se agota en la categoría de la prohibición de exceso, ya que contempla un deber de protección por parte del Estado, incluso cuanto a agresiones contra los derechos fundamentales oriundos de terceros, de tal suerte que se está delante de dimensiones que reclaman mayor densificación, notadamente en lo que dice respecto alos desdoblamientos de la llamada prohibición de insuficiencia en el campo jurídico-penal y, por consecuencia, en la esfera de la política criminal, donde encontramos un elenco significativo de ejemplos a ser explorados". Vid. SARLET, I. W., "Constituição e proporcionalidade: o direito penal e os direitos fundamentais entre a proibição de excesso e de insuficiência", Revista Brasileira de Ciências Criminais, núm. 47, São Paulo, 2004, pág. 67.

249 BERNAL PULIDO, C., El principio de proporcionalidad y los derechos fundamentales, cit., pág. 801.

250 La jurisprudencia del STF en Brasil también viene adoptando este mismo entendimiento, destacándose las palabras del Ponente Gilmar Mendes al señalar que "cuanto a la prohibición de protección deficiente, la doctrina viene apuntando para una especie de garantismo positivo, al contrario del garantismo negativo (que se basa en la protección contra los excesos del Estado) ya consagrado por el principio de proporcionalidad. La prohibición de la protección deficiente adquiere importancia en la aplicación de los derechos fundamentales de protección, o sea, en la perspectiva del deber de protección del derecho penal para garantizar la protección de un derecho fundamental". Vid. con detalles, STF, RE 418.376, de 09.2.2006.

251 En palabras de FERRAJOLI "son derechos fundamentales aquellos derechos subjetivos que las normas de un determinado ordenamiento jurídico atribuyen universalmente a todos con status de personas, ciudadanos y/o personas capaces de actuar". Vid. FERRAJOLI, L., Los fundamentos de los derechos fundamentales, 2ª edición, Madrid, 2005, pág. 291.

252 En esta línea de pensamiento, PARDO y BAQUER señalan que "los derechos y libertades, por reconocerse en el interior del ordenamiento jurídico, han de conciliarse con otros bienes que el ordenamiento protege y no pueden hacerse valer de modo absoluto frente a éstos". Vid. PARDO, I. 0; BAQUER, L. M. R., Derechos Fundamentales y Constitución, Madrid, 1988, pág. 110. Así, importante resaltar que la ponderación de bienes en confronto tiene siempre lugar por que ningúnderecho fundamental es absoluto, o sea, ningúnderecho es ilimitado. Todos encuentran límites en los demás derechos fundamentales. Es exactamente esto que sostiene la teoría de los límites inmanente de los derechos fundamentales. Respecto de esta citada 
Importante es tener presente que respetar a los derechos fundamentales en la respuesta a las nuevas amenazas provocadas especialmente por la delincuencia organizada ${ }^{254}$ y otras formas graves de criminalidad, no puede constituir obstáculo a un eficiente combate por las autoridades competentes, y tiene que ser posible, mismo delante del difícil equilibrio entre conciliar las exigencias de la defensa de la sociedad con la preservación de los derechos y libertades fundamentales en el proceso penal.

La propuesta que aquí se va a llevar a cabo pretende justamente, sostener la idea de que la identificación de una zona de "armonía procesal equilibrada" representaría, en lo que nos interesa en este estudio, un avance en la forma de adecuación y regulación de algunos medios o técnicas extraordinarias de investigación criminal en la lucha contra la delincuencia marcada por la gravedad de sus actuaciones.

Desde el planteamiento sostenido hasta este punto del trabajo, surge como premisa lógica que el equilibrio en el sentido de armonía procesal que se busca, no es fácil de obtenerse, pero se presenta como una fórmula casi ideal para la solución de la paradoja entre la eficacia del ius puniendi versus garantías y derechos del imputado. Así, un proceso penal equilibrado 255 y basado especialmente en el respeto a los principios de proporcionalidad y del debido proceso penal, sería el iter lógico para atingirse el status de un proceso justo y eficaz.

Eficacia y protección de los derechos fundamentales han de continuar a ser los puntos extremos de una tensión que alimenta las diferentes formas de realización de la justicia penal. Debe notarse, además, que el proceso penal democrático, construido con base en modelos diversos, se caracteriza, fundamentalmente, por la búsqueda de equilibrios (balances) y de la concordancia práctica entre valores en conflicto en la realización de las finalidades a que está determinado, la investigación de delitos, la identificación de sus agentes, y la aplicación, si posible, de la sanción penal prevista en la ley256.

teoría, Vid. BACIGALUPO SAGGESE, M., La aplicación de la doctrina de los "los límites inmanentes" a los Derechos Fundamentales sometidos a reserva de limitación legal. A propósito de la sentencia del Tribunal Administrativo Federal alemán de 18 de octubre de 1990, Revista Española de Derecho Constitucional, núm. 38, Mayo-Agosto, 1993, págs. 297-315.

253 En opinión de NARANJO DE LA CRUZ "los derechos fundamentales delimitan un ámbito de invulnerabilidad en el desarrollo de las personas en la vida jurídica y social que reclama protección frente a cualquier tentativa de intromisión por parte de los poderes públicos". Vid., NARANJO DE LA CRUZ, R., "Los límites de los derechos fundamentales en las relaciones entre particular y la buena fe", Boletín Oficial del Estado, Centro de Estudios Políticos y Constitucionales, Madrid, 2000, pág. 29.

254 Respecto a esto, muy interesante es la opinión de CHIAVARIO en el sentido de que "se debe, al contrario, admitir que hoy es la propia criminalidad organizada a dar cuerpo, especialmente en algunas de sus más sofisticadas formas multinacionales (frecuentemente jefe de vastísimos tráficos de armas y drogas), a las más formidables amenazas a los derechos más elementares de la persona humana, a empezar por aquello a la vida y a la seguridad individual y colectiva". Vid. CHIAVARIO, M., "Direitos humanos, processo penal e criminalidade organizada", cit., pág. 27.

255 Versando sobre la necesidad de reconocimiento de un Derecho penal del equilibrio, Vid. en la doctrina brasileña, vid.,GRECO, R., Direito Penal do Equilíbrio, Uma visão minimalista do Direito Penal, Niterói, 2005.

256 GASPAR, A. H., "Os novos desafios do processo penal no século XXI e os direitos fundamentais (um difícil equilíbrio)", Revista Portuguesa de Ciência Criminal, año 15, núm. 2, Coimbra, 2005, pág. 261. 
Como sintetiza GUZMÁN FLUJA, la tensión entre las dos fuerzas que ponen en constante tensión al proceso penal debe resolverse mediante la identificación de una zona de equilibrio, no tanto de un punto exacto de equilibrio ${ }^{257}$.

Entiende así el citado autor, que no cabe hablar de un sólo punto de equilibrio, cual si hubiera una solución exacta e indiscutible a esta tensión. La respuesta debe buscarse mediante esfuerzos dirigidos a establecer los "puntos límite" dentro de los cuales el proceso penal ofrece soluciones aceptables y fuera de los cuales ofrece soluciones inaceptables. Desde luego, se trata de una zona que debe estar definida de una manera restrictiva, pues las respuestas aceptables a la tensión de los elementos antedichos deben moverse en un margen estrecho, y se debe aceptar que la determinación de esta "zona de respuestas posibles" es difícil, como se ha dicho, pero no imposible ${ }^{258}$.

Nos parece interesante la idea de búsqueda de "puntos de equilibrio", vez que deberá el principio de proporcionalidad, como criterio de adecuación y necesidad, orientar de forma restrictiva, las posibilidades excepcionales de vulneración de derechos y garantías en pro de la seguridad colectiva y de la manutención del orden público.

Cuando del abordaje específico de la figura del agente encubierto, en capítulos siguientes, volveremos a tratar de los "puntos de equilibrio" y su relación especial con el principio de proporcionalidad.

Con el planteamiento expuesto hasta ahora, se llega a una constatación innegable: la búsqueda del equilibrio entre el derecho de punir estatal y la preservación de las garantías fundamentales, deberá ser intentado a tope ${ }^{259}$, pues que se presenta como la única solución plausible para la conformación de un proceso penal como instrumento democrático a servicio de la máxima eficacia persecutoria de un sistema respetuoso de las garantías y derechos fundamentales.

Así, transcribiendo palabras de GASPAR se puede afirmar que no obstante todos los riesgos, no hay construcción y salvaguardia de los valores sin un poco de utopía y algún trozo de tragedia ${ }^{260}$.

También se destaca la proficua constatación de que además de la dificultad de delimitarse una "zona de equilibrio"261 entre eficacia del derecho de punir estatal y el

257 GUZMÁN FLUJA, V. C., "El agente encubierto y las garantías del proceso penal", cit., pág. 201. En sentido contrario, de defensa de la necesidad de establecimiento de un único punto de equilibrio entre eficiencia y garantías, sin predominio absoluto de un plano sobre el otro, Vid. SOLIMINE, M. A., "Praxis instructoria en un Estado de Derecho, Entre las garantías y la eficiencia", cit., pág. 131. Algún otro autor, así BINDER prefiere defender la idea de que frente a la tensión y la búsqueda del equilibrio, deberá ser encontrado "más bien un punto de ebullición antes que un punto de equilibrio". Vid. BINDER, A. M., Introducción al derecho procesal penal, cit., pág. 59.

258 Cfr. GUZMÁN FLUJA, V. C., "El agente encubierto y las garantías del proceso penal", cit., pág. 201.

259 Según MOCCIA, "legitimidad e efectividad deben, por lo tanto, caminar juntas, iluminadas por la idea de subsidiariedad que, en el Estado social de Derecho, impone el recurso al sistema penal solamente como extrema ratio y respetándose todas las garantías establecidas. De modo diverso, aunquese consiga reprimir por un cierto tiempo un fenómeno criminal, se iba a producir otras ilegitimidades y otras víctimas, con grave perjuicio para la causa de la democracia". Vid. MOCCIA, S., "Emergência e defesa dos direitos fundamentais", cit., pág. 89.

260 GASPAR, A. H., "Os novos desafios do processo penal no século XXI e os direitos fundamentais (um difícil equilíbrio)", cit., pág. 274.

261 Compartiendo este pensamiento, respecto de la dificultad en la búsqueda del equilibrio, FRONDIZI y DAUDET señalan que el problema acuciante de la actualidad en el proceso penal es "la defensa a cualquier costo de los principios, inclusive a riesgo de caricaturizarlos, y los reclamos por una justicia eficiente, aun al precio de ser poco sensible al respeto por las garantías. No es fácil crear instrumentos concretos de un 
necesario respeto a las garantías fundamentales, otro grave problema ha surgido, tornándose más ardua la tarea de buscarse la armonía procesal penal: la regresión de las conquistas garantistas como ya anteriormente afirmado.

A continuación, tendremos la posibilidad de analizar un destacado factor de preocupación en tiempos de crisis de la administración de la justicia penal: la expansión y el desarrollo de los clanes de delincuentes organizados, partiendo del supuesto de que se trata de un problema mundial a ser resuelto a través de un programa de acciones y respuestas institucionales globalizadas, con vistas al restablecimiento de la paz y la tranquilidad internacional. En este contexto, importante observar que el punto de partida es la constatación de que la eficacia de la respuesta penal en la lucha contra el crimen organizado solamente será obtenida cuando del establecimiento de la protección de los derechos y de las libertades fundamentales de los ciudadanos, juntamente con el desarrollo de políticas públicas de seguridad y de una adecuada estructuración de nuevas técnicas de investigación criminal.

\section{I.3. El garantismo y la lucha contra el crimen organizado. La posible compatibilización de las garantías y la eficacia del derecho de punir estatal.}

\section{I.3.1.Consideraciones generales respecto a la delincuencia organizada.}

\section{I.3.1.1. Evolución histórica y desarrollo como fenómeno criminal.}

Aunque no sea nuestra meta principal estudiar con profundidad el tema de los agrupamientos de delincuentes que actúan de modo organizado y con similitud a una verdadera empresa formada para la práctica de delitos y obtención de lucros, se torna importante al menos entender sus principales características y las razones que puedan justificar su desarrollo, a los fines de comprensión de la esencia del método de investigación denominado "agente encubierto", objeto primordial de nuestro trabajo.

De inicio, en los días de hoy, se nota básicamente la existencia de dos principales especies de criminalidad; la primera calificada de criminalidad tradicional o convencional, practicada con modus operandi ya conocidos por las autoridades policiales y de control más o menos previsible frente a los retos de las fuerzas de seguridad pública, y la segunda, denominada criminalidad o delincuencia organizada ${ }^{262}$. La delincuencia más trascendente,

equilibrio razonable, como saben los cultores del derecho procesal penal, $\mathrm{y}$, sobre todo, quienes hayan tenido o tengan responsabilidades en la política criminal o en la administración de justicia". Vid. FRONDIZI, R. J; DAUDET, M. G., Garantías y eficiencia en la prueba penal, cit., pág. 4.

262 Como obra de referencia, Vid. ABADINSKY, H., Organized Crime, Chicago, 1997. Además, respecto al tema y para un completo estudio, Vid. ALMEIDA FERRO, A. L., Crime organizado e organizações criminosas mundiais, Curitiba, 2009; AVILÉS GÓMEZ, M., Criminalidad organizada: los movimientos terroristas, San Vicente (Alicante), 2004; CAPARRÓS, E. A. F., "Criminalidad organizada", VV.AA., El nuevo Código penal: primeros problemas de aplicación, Mạ. Luz Gutiérrez Frances y V. Sánchez López coords., Salamanca, 1997, págs. 169-181; CASTILlO BARRENTES, E., "Criminalidad organizada", Cuadernos de Política Criminal, núm. 50, 1993, págs. 493-512; CHOCLÁN MONTALVO, J. A., La organización criminal: tratamiento penal y procesal, Madrid, 2000; DAGDUD KALIFE, A., La prueba testimonial ante la delincuencia organizada, México, 2006; DAVIN, J., A criminalidad organizada transnacional. A cooperação judiciária e policial na UE, Coimbra, 2004; DELGADO MARTÍN, J., La criminalidad organizada (comentarios a la LO 5/99, de 13 de enero, de modificación de la Ley de Enjuiciamiento Criminal en materia de perfeccionamiento de la acción investigadora relacionada con el tráfico ilícito de drogas y otras actividades ilícitas graves),Barcelona, 2001; GÓMEZ DE LIAÑO FONSECA-HERRERO, M., Criminalidad Organizada y medios extraordinarios de investigación, Madrid, 2004; GARCÍA RIVAS, N., "Criminalidad organizada y tráfico de drogas", Revista Penal, núm. 2, 1998, págs. 23-33; GOMES, R. C., $O$ crime organizado na visão da Convenção de Palermo, Belo Horizonte, 2008; GREVI, V., Processo penale e criminalità 
por su nocividad para la sociedad en su conjunto, por el uso de alto nivel de violencia y sofisticación, es la constituida por la denominada "criminalidad organizada".

Como es sabido la delincuencia organizada atenta contra los principios básicos de la vida comunitaria y de la esencia estatal, generando descomposición social e inestabilidad política ${ }^{263}$.

Y lo más grave es que estos grupos criminales han aprendido a desarrollar sus actividades con una vocación empresarial 264 . Son muchas veces estructuras empresariales dignas de cualificarse como grupos altamente organizados y capacitados, con la finalidad específica de, a través de conductas delictivas, obtenerse el lucro y la estabilidad de algunas actividades generadoras del status de entidad a ser respetadapor el miedo que provoca junto a la sociedad.

Innegable es que la delincuencia organizada constituye hoy en día posiblemente el principal problema de seguridad para los gobiernos de las naciones en los que se asienta y desarrolla. Si bien y debido a su carácter de transnacionalidad 265 , es prácticamente

organizzata, Bari, 1993; IGLESIAS RÍO, M. A., "Criminalidad organizada y delincuencia económica: aproximación a su incidencia global", VV.AA., El nuevo derecho penal español: estudios penales en memoria del profesor José Manuel Valle Muñiz, Pamplona, 2001; JIMÉNEZ VILLAREJO, C., "Transnacionalización de la delincuencia y persecución penal", Crisis del sistema político, criminalización de la vida pública e independencia judicial, P. Andrés Ibáñez coord., Consejo General del Poder Judicial, Madrid, 1998, págs. 59-104; LÓPEZ BARJA DE QUIROGA, J., "Posición de la Unión Europea sobre el crimen organizado", número monográfico sobre "La criminalidad organizada. Aspectos sustantivos, procesales y orgánicos", Cuadernos de Derecho Judicial, núm. II, 2001, págs. 113-143; MENDRONI, M. B., Crime Organizado. Aspectos gerais e mecanismos legais, São Paulo, 2007; MONTOYA, M. D., Mafia y Crimen Organizado, Aspectos legales. Autoria mediata. Responsabilidad penal de los aparatos organizados de poder, Buenos Aires, 2004; PACHECO, R., Crime Organizado. Medidas de controle e infiltração policial, Curitiba, 2007; RAUFER, X, QUÉRÉ, S., Le crime Organize, 2a edición, Paris, 2001; ROSAL BLASCO, B. D., "Criminalidad organizada y nuevas tecnologías, algunas consideraciones fenomenológicas y político-criminales", número monográfico sobre "La criminalidad organizada. Aspectos sustantivos, procesales y orgánicos", Cuadernos de Derecho Judicial,núm. II, 2001, págs. 145-167; SÁNCHEZ GARCÍA DE PAZ, I., La criminalidad organizada: aspectos penales, procesales, administrativos y policiales, Madrid, 2005; SILVA, E. A., Crime Organizado. Procedimento probatorio, São Paulo, 2003; VV.AA., El desafío de la criminalidad organizada, Nieves Sanz Mula coord., Granada, 2006; ZAFFARONI, E. R., "Criminalidad y corrupción", Revue Internationale de Droit Penal, núms. 1-2, 1997, págs. 455-458; ZARAGOZA AGUADO, J., "Cuestiones penales y procesales relacionadas con la delincuencia organizada", Jornadas sobre delitos contra la salud pública en materia de drogas, Estudios jurídicos del Ministerio Fiscal, núm. VI, 1999, págs. 11-83; ZARAGOZA AGUADO, J., "Nuevos instrumentos procesales en la lucha contra la criminalidad organizada, La protección de testigos y peritos en causas criminales", Jornadas Internacionales de Derecho Procesal: Ponencias y comunicaciones, Málaga, 2001, págs. 7-33; ZARAGOZA AGUADO, J. A., "Tratamiento penal y procesal de las organizaciones criminales en el derecho español. Especial referencia al tráfico ilegal de drogas", número monográfico sobre "Delitos contra la salud pública y contrabando", Cuadernos de Derecho Judicial, núm. V, 2000, págs. 49-115; ZÚÑIGA RODRÍGUEZ, L., Criminalidad organizada y sistema de derecho penal. Contribución a la determinación del injusto penal de organización criminal, Granada, 2009. Para un proficuo entendimiento especifico respecto a la delincuencia organizada en actuación en España, Vid. GÓMEZ, L., España Connection. La implacable expansión del crimen organizado en España, Barcelona, 2005.

263 PÉREZ DAZA, A., "Sistema procesal acusatorio y delincuencia organizada", VV.AA., Análisis, técnicas y herramientas en el combate a la delincuencia organizada con fundamento en la Convención de Palermo, M. Herrán Salvatti., J. L. Santiago Vasconcelos., S. González Ruiz y E. Mendieta Jiménez coords., 1a edición, México, 2007, pág. 219.

264 En este sentido, la opinión de LUCAS MARTÍN, I., "La prueba en el proceso penal en el contexto de la Unión Europea", VV.AA., El proceso penal en la Unión Europea: garantías esenciales, M. Hoyos Sancho coord., Valladolid, 2008, pág. 424.

265En palabras de ZÚÑIGA RODRÍGUEZ, "el aspecto más sobresaliente de los últimos tiempos es sin duda el carácter transnacional de la criminalidad organizada, cómo ésta ha demostrado una extraordinaria capacidad de adaptación a los modernos fenómenos sociales, aprovechándose de las ventajas de la liberalización del comercio internacional y de los mercados financieros, de las facilidades de las comunicaciones propias de una sociedad de la información, potenciando su poder criminógeno en cuanto a la calidad y cualidad en dimensiones nunca antes vistas. Se estima que la internacionalización de las actividades criminales hace que las diversas organizaciones criminales establezcan alianzas, en lugar de combatirse, repartiéndose así 
inexistente el lugar del globo que se vea libre de su acción. Se puede decir que la delincuencia organizada ha entendido perfectamente la idea de MCLUHAN cuando acuñó el término de "aldea global". El mundo es un lugar globalizado y unitario donde los grupos criminales organizados realizan sus delitos y atentan contra la libertad y seguridad de los ciudadanos de todas y cada una de las naciones que lo componen ${ }^{266}$.

Por lo tanto, uno de los fenómenos que más ha producido comentarios y discusiones ha sido la criminalidad organizada o grupos organizados que practican determinados delitos marcados por la violencia.

Así, en los últimos años hubo una creciente preocupación de la sociedad respecto a este tipo de delincuencia, sobretodo por la violencia y por los sofisticados medios utilizados en la comisión de diferentes delitos, hecho éste que ha generado nuevas medidas de prevención y represión para la delincuencia organizada ${ }^{267}$.

Y esta preocupación ha provocado miedo y temor también junto a los Estados que han sido elegidos por las organizaciones criminales como área o territorio de actuación.

Frente a esta constatación, en un número cada vez mayor de ordenamientos contemporáneos, se dedica hoy día una parte importante del sistema penal a la lucha contra la criminalidad organizada y a las diversas formas ilegales en que se manifiesta ${ }^{268}$.

Pues bien, la obligación que asume el Estado democrático de derecho es la de garantizar a través del marco legal, con respeto al ordenamiento jurídico, que el modo de convivencia democrático otorgado por los ordenamientos constitucionales no se vea alterado por organizaciones criminales sea cualquierael método que utilicen con el objetivo de ocupar ilegítimamente el poder o parte de él269.

Según IGLESIAS RÍO, la preocupación actual en todos los órdenes, político-jurídico y económico-social, es de tal magnitud que produce una literatura incesante prácticamente inabarcable y motiva decisiones políticas, acuerdos intergubernamentales y planes de acción común a nivel internacional, con el difícil propósito de neutralizar esta lacra y armonizar métodos de lucha a través de reformas legislativas de naturaleza administrativa, procesal, penal y policial 270 .

Desde un punto de vista criminológico se constata que la delincuencia organizada se presenta con un potencial lesivo de gran magnitud (llamada por eso macrocriminalidad), y no crea sólo la inseguridad ciudadana de la tradicional delincuencia de la marginalidad, sino inseguridad de la propia clase política por su incidencia en el mismo sistema político

territorios y especialidades, teniendo en consideración los riesgos y las facilidades que presentan los diversos países". Vid. ZÚÑIGA RODRÍGUEZ, L., Criminalidad organizada y sistema de derecho penal. Contribución a la determinación del injusto penal de organización criminal, cit., pág. 3.

266 Cfr. PEÑA ECHEVERRÍA, M. J., "La delincuencia organizada y su problemática desde la óptica de la investigación policial", Criminalia, año LXVI, núm. 1, México, 2000, pág. 101.

267 CALLEGARI, A. L., "Controle social e criminalidade organizada", VV.AA., Crime Organizado. Tipicidade, Política Criminal, Investigação e Processo, Porto Alegre, 2008, pág. 14.

268 Cfr. MILITELLO, V., "Iniciativas supranacionales en la lucha contra la criminalidad organizada y el blanqueo en el ámbito de las nuevas tecnologías", Derecho Penal, sociedad y nuevas tecnologías, L. Zúñiga Rodríguez, C. Méndez Rodríguez y Mạ. R. Diego Díaz-Santos coords., Madrid, 2001, pág. 177.

269 Vid. GONZÁLEZ MOTA, V. J., "La especialización de la Fiscalía en la investigación de la criminalidad organizada", Corrupción y delincuencia económica, N. Rodríguez García y E. Fábian Caparrós coords, Bogotá, 2008, pág. 387.

270 IGLESIAS RÍO, M. A., "Criminalidad organizada y delincuencia económica: aproximación a su incidencia global", cit., págs. 1445-1446. 
(por ejemplo, conductas de corrupción de funcionarios) y en el sistema económico (desestabilización de los mercados) y social ${ }^{271}$. Se trata, pues de la verdadera criminalidad de la globalización caracterizada en especial, por el empleo de la sofisticación ${ }^{272}$ en favor de la eficacia delictuosa.

En este sentido, se habla con cierta frecuencia de la modernidad que ha impregnado las actuaciones de las bandas de delincuentes organizados. Modernidad ésta que según BAUMAN, se caracteriza por forzar las cosas para que sean distintas de lo que son ${ }^{273}$, de forma que el crimen organizado parece estar siempre adelantede la propia realidad, suscitando la adecuación de la justicia penal a los nuevos tiempos.

Por esta razón se torna necesaria la búsqueda de políticas públicas e instrumentos jurídicos compatibles con el actual nivel de estructuración logística presentada por los clanes de delincuentes organizados, de modo a establecer un cierto grado de eficiencia en la persecución penal de control al avance patológico de esta especie de criminalidad ${ }^{274}$.

En realidad, se percibe que la delincuencia organizada es un fenómeno delictivo que ha ido evolucionando en los últimos años, aunque sea algo indubitable que los delitos practicados por grupos de personas pertenecen a una parte de la historia no muy reciente ${ }^{275}$.

La verdad es que la criminalidad organizada no ha irrumpido de repente en la historia de la criminalidad sino que, por el contrario, ha evolucionado de forma paralela a la sociedad postindustrial 276 hasta presentarse, en los tiempos actuales, como un fenómeno "nuevo"277 y con sustanciales diferencias respecto de las formas tradicionales ${ }^{278}$.

Incluso, señala FABIÁN CAPARRÓS que la delincuencia organizada ha existido en casi todas las culturas a lo largo de la historia, pero el cúmulo de transformaciones que ha

\footnotetext{
271 Siguiendo este pensamiento, Vid. CHOCLÁN MONTALVO, J. A., La organización criminal: tratamiento penal y procesal, cit., pág. 5 .

272 En verdad, estos grupos de delincuentes organizados "han funcionado de forma cada vez más sofisticada, incorporando activamente todas las ventajas de la tecnología moderna, para acelerar sus actividades criminales. En caso de que tengan problemas usan el trípode de la protección: la violencia, la corrupción y la obstrucción a la justicia". Vid. VV.AA, Análisis, técnicasy herramientas en el combate a la delincuencia organizada con fundamento en la Convención de Palermo, cit., pág. 23.

273 BAUMAN, Z., "El eterno retorno de la violencia", Modernidad y violencia colectiva, Josetxo Beriain Razquin coord., Madrid, 2004, pág. 17.

274 Esta preocupación también es manifestada por PÉREZ DAZA, al señalar que "el crimen organizado es una amenaza, toda vez que altera la normalidad social; la sociedad queda sometida a las mafias y a la inseguridad; se instala una cultura criminal que imposibilita una convivencia civilizada afectando las vidas de miles de seres humanos, pero debido a que conserva escrupulosamente su invisibilidad, la sociedad no se percata de cuánto daña o afecta; por lo que es necesario adoptar estrategias político-criminales más adecuadas para enfrentarla eficazmente". Vid. PÉREZ DAZA, A., "Sistema procesal acusatorio y delincuencia organizada", cit., pág. 218.

275 Con una opinión distinta, ZAFFARONI aduce que "el organized crime como tentativa de categorización es un fenómeno del siglo XX, y poco vale que los autores se pierdan en descubrir sus supuestos precedentes históricos, mismo remotos, incluso en el dominio de una concepción popular". Vid. ZAFFARONI, R. E., "Crime organizado: uma categorização frustrada", Discursos sediciosos, crime, direito e sociedade, Rio de Janeiro, 1996, pág. 46.

276 DELGADO MARTíN, J., Criminalidad organizada, cit., pág. 21.

277 El término "nuevo" empleado en este sentido, significa que las organizaciones criminosas utilizan en los días actuales, métodos y estrategias cada vez más innovadoras.

278 Vid. KAISER, G., Organizaed crime, Kongressakten XIV, Internationaler Strafrechtkongress, Asociación Internacional de Derecho Penal, 1989, págs. 203-205.
} 
experimentado en los últimos tiempos ha hecho de ella algo realmente nuevo y diferente que cambia día a día ${ }^{279}$.

Esta es una de las grandes preocupaciones demostradas por los órganos de persecución penal, pues las transformaciones experimentadas por algunas organizaciones transnacionales, las cuales vienen a cambiar o hasta mismo a ensanchar el rol de sus actividades delictivas a todo momento, acaban por provocar un verdadero lío, confundiendo los agentes estatales y provocando dificultades operacionales en la investigación criminal.

En el mismo sentido, GÓMEZ DE LIAÑO FONSECA-HERRERO explica que la criminalidad organizada no constituye, en modo alguno, un problema de reciente aparición, toda vez que los precedentes del fenómeno delincuencial asociativo vienen cifrados en el siglo XV. Sin embargo, el crimen organizado presenta, en el actual contexto de la globalización, unos rasgos característicos muy particulares que lo configuran como una amenaza sin precedentes para el Estado y la sociedad 280 .

De otra parte, se suele considerar como antecedentes históricos de la criminalidad organizada las compañías de mercenarios que servían al Rey o a un caballero de la Edad Media, los bandoleros, las compañías de Condotieros del Renacimiento, las hermandades secretas del siglo XVIII, la Camorra Napolitana que se consolida en el siglo XIX ${ }^{281}$. También se encuentran antecedentes históricos de la mafia japonesa en los samuráis de la Edad Media $^{282}$.

Cierto es, que los vestigios organizativos se pierden en la historia. RADBRUCH los encuentra ya en la Roma republicana y en la protohistoria germánica. Más próximos a nosotros durante los siglos VIII y IX los feroces planes de concentración de poder político y económico de los reyes francos arrebatando en forma de "cesiones" para el pago de las costosas campañas bélicas los bienes de los campesinos, provocó un súbito empobrecimiento de éstos que debieron retirarse a los bosques formando núcleos de población indigentes de los que salieron bandas nómadas de pillaje que recorrieron toda Europa ${ }^{283}$.

${ }^{279}$ En este sentido, Vid. FABIÁN CAPARRÓS, E. A., El delito de blanqueo de capitales, Madrid, 1998, págs. 3536. Del mismo autor, Vid. "Criminalidad organizada", cit., págs. 173 y ss. Para una interesante y completa síntesis histórica de la criminalidad organizada, Vid. SCHWIND, H. D., Kriminologie. Eine praxisorientierte Einführung mit Beispielen 17. Auflage, Heidelberg, 2007; ALMEIDA FERRO, A. L., Crime Organizado e Organizações Criminosas Mundiais, cit., págs. 68-103.

280 GÓMEZ DE LIAÑO FONSECA-HERRERO, M., Criminalidad organizada y medios extraordinarios de investigación, cit., pág. 25. Incluso, algún autor a ejemplo de ANARTE BORRALLO, señala que "los antecedentes más cercanos a la criminalidad organizada actual se suelen buscar en la transformación de la delincuencia profesional en Estados Unidos, particularmente tras la prohibición total de alcohol en 1919, al pasar a protagonizar no delitos aislados e individualizados (robos o estafas), aunque repetidos, sino más bien actividades delictivas especializadas y estables (contrabando de alcohol, chantajes a empresarios, un incipiente tráfico de drogas ...)". Vid. ANARTE BORRALLO, E., "Conjeturas sobre la criminalidad organizada", VV.AA., Delincuencia organizada, Aspectos penales, procesales y criminológicos, J. C. Ferré Olivé y E. A. Borrallo Coords., Huelva, 1999, pág. 15.

281 RADBRUCH, G; GWINNER, E., Historia de la criminalidad (Ensayo de una criminología histórica), Barcelona, 1955, pág. 39.

282 ZÚÑIGA RODRÍGUEZ, L., Criminalidad organizada y sistema de derecho penal. Contribución a la determinación del injusto penal de organización criminal, cit., pág. 36.

283 CAFFARENA, B. M., "Problemas de la ejecución penal frente a la criminalidad organizada", VV.AA., La criminalidad organizada ante la Justicia, F. Gutiérrez-Alviz Conradi Coord., Sevilla, 1996, pág. 53. 
Independiente de la fuente histórica y partiendo de esta consideración inicial, se observa el surgimiento de una destacable preocupación del sistema legal para el control y combate de esta forma de delincuencia, generando un status y carácter propio de manifestación, afectando la sociedad contemporánea, desestabilizando la economía financiera de los Estados y en la gran mayoría de veces corrompiendo las instituciones políticas, judiciales y en especial los más altos niveles de la administración pública.

Con el avance de la ciencia, la tecnología, y la expansión del proceso de globalización de la economía, con la consecuente interconexión de los circuitos económico-financieros regionales y mundiales, se fueron creando las condiciones para el surgimiento de nuevas actividades delictivas, antiguamente impensadas, propiciándose la aparición de la llamada delincuencia internacional y la criminalidad organizada ${ }^{284}$.

En palabras de ANARTE BORRALLO, la criminalidad organizada constituye así un desafío sin precedentes para el Estado y la sociedad ${ }^{285}$.

Por otro lado, el proceso de globalización mundial 286 ha contribuido de forma fundamental para el desarrollo y crecimiento de las actividades practicadas por las bandas criminales organizadas.

Así se justifica la intensa y destacada relación entre la delincuencia organizada trasnacional y el mundo de la globalización. Y esto corresponde a la absoluta verdad, en razón de que el sistema de producción de libre mercado que se ha impuesto en el mundo desde la caída del muro de Berlín, aunado al espectacular desarrollo tecnológico principalmente en el ámbito de las telecomunicaciones, ha facilitado el movimiento de capitales, de bienes y servicios y ha incrementado notablemente el comercio internacional, pero también ha acercado a los grupos que se dedican al comercio ilícito, y ha facilitado los movimientos de capitales sucios, en suma, ha permitido a la criminalidad organizarse más y mejor. Las fronteras nacionales que se traspasan fácilmente con los medios modernos de comunicación, han sido también traspasadas por la criminalidad trasnacional, en la medida que puede mover personas, bienes, servicios y capitales, sin demasiadas complicaciones 287 .

En resumen, la globalización ha traído diversos efectos benéficos para el desarrollo del comercio de bienes y servicios, multiplicando las posibilidades de desarrollo de países y negocios. Pero, respecto a la delincuencia organizada, puede decirse que ha habido un

284 Vid. con profundidad respecto al tema de delincuencia organizada y su relación con el fenómeno de la globalización: SILVA SÁNCHEZ, J. M., La expansión del Derecho Penal. Aspectos de la política criminal en las sociedades postindustriales, $2^{a}$ edición, Madrid, 2001, págs. 85 y ss. Sin embargo, muy interesante la opinión de CALVO SÁNCHEZ al señalar que "Si la globalización de la delincuencia se producía y produce como consecuencia de la supresión de fronteras terrestres, lógico será dar también una respuesta globalizada tanto a la prevención como la persecución y al enjuiciamiento de sus delitos transfronterizo graves". Cfr. CALVO SÁNCHEZ, M. C., "Prólogo" a la obra Hacia un verdadero espacio judicial europeo, L. M, Bujosa Vadell coord.., Granada, 2008, pág. XII.

285 Vid. ANARTE BORRALLO, E., "Conjeturas sobre la criminalidad organizada", Delincuencia organizada, Aspectos penales, procesales y criminológicos, cit., pág. 13. Además, este mensaje es habitual en los discursos oficiales: véase, por ejemplo, a nivel internacional, la Convención de Naciones Unidas contra el tráfico ilícito de drogas, estupefacientes y sustancias psicotrópicas (Preámbulo), de 20 de diciembre de 1988.

286Para un completo estudio de esta problemática, Vid. HURTADO POZO, J., "Globalización y delincuencia organizada", cit., págs. 17 y ss.

287 ZÚÑIGA RODRÍGUEZ, L., Criminalidad organizada y sistema de derecho penal. Contribución a la determinación del injusto penal de organización criminal, cit., pág. 61. 
efecto que, precisamente por esa facilidad de intercambio de bienes y servicios, ha multiplicado la fuerza de las organizaciones criminales ${ }^{288}$.

En este sentido, la globalización creciente de la economía mundial ${ }^{289}$ basada en cambios comerciales más fáciles, en la interdependencia económica, en una circulación de capitales con un giro rápido como nunca antes imaginado, aliada a un desarrollo sin control de las nuevas tecnologías informáticas y telemáticas, conducirían lógicamente nuestras sociedades a presenciar un elogiable crecimiento del mercado financiero mundial, pero pagando en contrapartida un precio muy alto o sea el de soportar los efectos inherentes y perversos de este avanzo, a ejemplo de la incontrolable expansión de la delincuencia organizada.

Ocurre en efecto, que es una verdad incontestable que los delincuentes que operan en conjunto o en grupos organizados son más peligrosos que los que actúan aisladamente, porque disminuyen las posibilidades de la víctima defenderse o de poder evitar un perjuicio. Son personas profesionales que concentran sus esfuerzos y una total dedicación, al éxito de las operaciones ilícitas practicadas por los clanes organizados.

La organización criminal es por lo tanto una entidad colectiva ordenada en función de estrictos criterios de racionalidad. A modo de piezas que se integran en una sólida estructura, cada uno de sus miembros desempeña un determinado cometido para el que se encuentra especialmente capacitado en función de sus aptitudes o posibilidades personales. De este modo, la corporación alcanza los rasgos propios de una sociedad de profesionales del delito en la que se manifiesta un sistema de relaciones definidas a partir de deberes y privilegios recíprocos 290 .

Ciertamente, queda muy claro, pues, que el crimen organizado constituye uno delos fenómenos más característicos de la criminalidad desde el último tercio del siglo XX, fenómeno que según todos los indicadores va a ser igualmente dominante en el siglo que acabamos de comenzar.

Efectivamente, en las últimas décadas se han producido transformaciones de gran relevancia en la criminalidad en el ámbito mundial: mientras que las actividades delictivas clásicas eran llevadas a cabo básicamente de manera individual, se observa en la actualidad una evolución hacia una criminalidad conducida por grupos de delincuentes bien estructurados y que asumen el crimen como empresa, como negocio: esto es lo que se denomina a grandes rasgos crimen organizado 291.

Se percibe como ya afirmado, que estos grupos de delincuentes trabajan en régimen de total dedicación al engrandecimiento de la organización delictiva, bajo las orientaciones y órdenes de los jefes que mantienen exigencias de una rigurosa jerarquía y altísimo grado

288 VV.AA., Análisis, técnicas y herramientas en el combate a la delincuencia organizada con fundamento en la Convención de Palermo, cit., pág. 23.

289 En esta línea de pensamiento, Vid. DELGADO MARTíN, J., Criminalidad Organizada, cit., pág. 22. Según ARLACCHI, "el motor de este fenómeno ha sido el crecimiento del mercado de productos ilegales, a nivel local y a nivel internacional, que se ha producido de forma paralela al progresivamente acelerado desarrollo de la economía internacional". Vid. ARLACCHI, P., "Tendencias de la criminalidad organizada y de los mercados ilegales en el mundo actual", Poder Judicial, núm. 16, 1985, pág. 83.

290 Vid. FÁBIAN CAPÁRROS, E. A., El delito de blanqueo de capitales, cit., pág. 37.

291 SÁNCHEZ GARCÍA DE PAZ, I ., La criminalidad organizada. Aspectos penales, procesales, administrativos y policiales, cit., pág. 21. 
de profesionalización ${ }^{292}$ en los actos delictivos. Así, el comprometimiento de los miembros de estos clanes con la "empresa"293 se presenta como requisito imprescindible al crecimiento y desarrollo de los negocios ilícitos perpetrados en el seno del grupo criminal organizado.

Es evidente que la delincuencia se ha transformado con el caminar de los años, pasando de una actividad individual, aislada y sin estructuración a una forma de actuación colectiva, marcada por la unión de esfuerzos en pro del éxito en la práctica de infracciones y en especial, por la sofisticación.

Se torna pues importante destacar que la expansión o dicho de forma diversa, el crecimiento avasallador y patológico de este fenómeno criminal representa en los días actuales, sin duda, el gran peligro a la paz social y a la seguridad mundial294.

GARCÍA RIVAS incluso señala que la criminalidad organizada es un fenómeno sociológico que se ha venido incrementando significativamente de manera paralela al propio desarrollo de la sociedad postindustrial, que genera graves riesgos para la vida social y para el propio Estado de Derecho, y cuyo interés dogmático se extiende a distintos lugares del sistema penal ${ }^{295}$.

En apretada síntesis, representa el crimen organizado en la actualidad, el gran miedo de la sociedad y uno de los principales problemas de seguridad pública. Pasémonos a continuación a abordar el dilema de la búsqueda de una definición conceptual para esta forma de delincuencia globalizada, tema éste que ha sido la gran piedra de toque en las discusiones respecto a la delincuencia organizada y su expansión.

En otros términos, la lucha contra la delincuencia organizada transnacional se ha convertido en uno de los grandes desafíos que ha de afrontar la comunidad internacional. El incesante auge de lo que podemos denominar verdaderas multinacionales del crimen,

292 Analizando el aspecto de profesionalización de los grupos organizados, señala CASTRESANA FERNÁNDEZ que "han aprendido las características de las instituciones financieras, de los instrumentos jurídicos nacionales e internacionales, de las instituciones internacionales de cooperación, y en especial los de la legislación tributaria, penal y procesal de los Estados, y las normas de seguridad y control, y han adaptado su actividad a tales características centrando su interés en aquellas actividades menos controladas y por lo tanto más susceptibles de rentabilización, procurando optimizar los rendimientos y minimizar los riesgos". Vid. CASTRESANA FERNÁNDEZ, C., "Corrupción, globalización y delincuencia organizada", VV.AA., La corrupción en un mundo globalizado: Análisis interdisciplinar, N. Rodríguez García y E. A. Fabián Caparrós coords., Salamanca, 2004, pág. 214.

293 En consecuencia, se observa como rasgo característico de la delincuencia organizada, la adopción de una estructura similar a la de las empresas comerciales, en particular en lo que se refierea la configuración de diferentes esferas logísticas y niveles de jerarquía, generalmente separadas en compartimentos estancos. Vid. SÁNCHEZ GARCÍA DE PAZ, I., "Función político-criminal del delito de asociación para delinquir: desde el Derecho penal político hasta la lucha contra el crimen organizado", VV.AA., Libro homenaje al Dr. Marino Barbero Santos, in memorian, volumen II, Cuenca, 2001, pág. 664.

294 En palabras de DELGADO MARTíN, "La criminalidad organizada es extremamente dañina para la sociedad, para el correcto funcionamiento de las instituciones públicas y privadas". Vid. DELGADO MARTÍN, J., Criminalidad organizada, cit., págs. 29-30. Según SEOANE SPIEGELBERG, especialmente con relación al tráfico de drogas, "La Convención de Naciones Unidas sobre tráfico de estupefacientes y sustancias psicotrópicas celebrada en Viena el 20 de diciembre de 1988, refleja la grave preocupación que en todas las naciones provoca el incremento del tráfico ilegal de drogas. Tal clase de infracción delictiva se encuentra íntimamente relacionada con el ámbito propio de la delincuencia organizada, hasta el punto que se ha considerado que los delitos de tráfico de drogas constituyen la manifestación más genuina y arquetípica de tan peligrosa forma de delincuencia". Vid. SEOANE SPIEGELBERG, J. L., "Aspectos procesales del delito de trafico de drogas", Actualidad Penal, núm. 20, 1996, pág. 341.

295 GARCÍA RIVAS, N., "Criminalidad organizada y tráfico de drogas", cit., pág. 23. 
está causando efectos negativos en el orden socioeconómico de las sociedades a escala internacional, en el contexto de la globalización económica ${ }^{296}$.

\section{I.3.1.2. El concepto de delincuencia organizada. Una cuestión controvertible.}

Llegado a este punto del trabajo, interesante plantear una pregunta clave para una correcta comprensión del fenómeno criminológico de la delincuencia organizada: ¿sería posible un concepto unívoco y cerrado respecto al crimen organizado ${ }^{297}$ ?

Contestando a esta interrogante, inicialmente se puede señalar que una de las tareas más difíciles en relación al fenómeno de la delincuencia organizada es su definición, dada la dificultad de encontrar un concepto unívoco que abarque todos los fenómenos delictivos.

Ante la cuestión, se puede afirmar sin embargo que se torna necesaria la tarea conceptual, en especial, porque de ella dependería la misma eficacia del control del crimen organizado 298 . Dicho en términos coloquiales: "no se puede luchar contra lo que no se conoce", y, en nuestro saber racional, no se conoce lo que no se define ${ }^{299}$.

Se justifica este pensamiento en la medida en que no se puede perseguir el control de una especie de criminalidad, sin al menos conocerla en términos objetivos, lo que podría generar una ausencia de fuentes de informaciones que puedan delinear la búsqueda eficaz de su desarticulación a través de una persecución penal norteada por el respeto a los principios procesales penales, a ejemplo del debido proceso legal ${ }^{300}$.

296 ÚBEDA PORTUGUÉS, J. E., "Análisis de los efectos negativos de la delincuencia organizada en la sociedad internacional", Anales de la Universidad Metropolitana, vol. 9, núm. 2 (Nueva Serie), 2009, pág. 64.

297 Monograficamente respecto a esta discusión, Vid. MORAES PITOMBO, A. S. A., Organização Criminosa. Nova perspectiva do tipo legal, São Paulo, 2009.

298 Vid. BYNUM, T. S., "Controversies in the study of the organized crime", Organized Crime in America: Concepts and Controversies, 1987, pág. 70. Sobre esta realidad, señala SCARANCE FERNANDES que "la ausencia de definición de organización criminal imposibilita la restricción a derechos y garantías del investigado, del acusado, del condenado, con fundamento en el hecho de pertenecer a este tipo de entidad, por ofensa a los principios de la reserva legal y de la proporcionalidad". Vid. SCARANCE FERNANDES, A., "O equilíbrio na repressão ao crime organizado", cit., pág. 15. En el mismo sentido, SCHNEIDER afirma que "las instancias de persecución, cualesquiera que sean, necesitan disponer de una definición, toda vez que conviene saber, con precisión qué se está buscando, a qué y cómo hay que reaccionar y qué es lo que se quiere investigar". Vid. SCHNEIDER, H. J., "Recientes investigaciones criminológicas sobre la criminalidad organizada", cit., pág. 723.

299 ZÚÑIGA RODRÍGUEZ, L., Criminalidad organizada y sistema de derecho penal. Contribución a la determinación del injusto penal de organización criminal, cit., pág. 28. En la misma línea de pensamiento, señala ESPINOSA DE LOS MONTEROS que "para la correcta aplicación de las herramientas existentes tendentes a la eficaz lucha contra el crimen organizado, se requiere el conocimiento previo y lo más exhaustivo posible del fenómeno que se quiere combatir". Cfr. ESPINOSA DE LOS MONTEROS, R. Z., "Implicaciones del Tratado de Lisboa en la lucha contra la delincuencia organizada", Revista General de Derecho Penal, núm. 14, 2010, http:// www.iustel.com.

300 Según FABIÁN CAPARRÓS, respecto a la necesidad de mejor conocer el fenómeno del crimen organizado, "sería un error pensar que ahondar en el conocimiento de estas corporaciones es un trabajo inútil. Ciertamente, tal vez sea imposible definir con precisión el fenómeno; pero es indiscutible que la profundización en el estudio de la estructura, el funcionamiento, las motivaciones o las formas de actuación de estos clanes nos será de gran utilidad para encuadrar debidamente el problema y poder aventurar más tarde conclusiones de índole político-criminal dirigidas a la reforma del ordenamiento penal ante manifestaciones como éstas, dotadas de una extrema peligrosidad". Vid. CAPARRÓS, E. A., "Criminalidad Organizada", cit., pág. 171. La preocupación en razón de la ausencia de una definición conceptual es demostrada también por CHOCLÁN MONTALVO, al señalar que "esta imprecisión del concepto plantea problemas de legalidad (exigencia de determinación de los tipos penales) e interpretación por parte de los Tribunales. Vid. CHOCLÁN MONTALVO, J. A., La organización criminal: tratamiento penal y procesal cit., pág. 7. 
Por eso el concepto "delincuencia organizada" reúne una amplia variedad de estructuras, actividades y actores. Luchar contra la criminalidad organizada transnacional, demanda una clara identificación del oponente con el fin de escoger las armas adecuadas para neutralizarlo 301 .

Con esto no buscamos defender la idea de una "guerra" contra los "enemigos", sino tan sólo una lucha contra las personas, por lo tanto, "ciudadanos", envueltos con la práctica de actividades ilegales y delictuosas en moldes de una verdadera empresa creada para buscar lucros y ganancias.

De otra parte, no se puede confundir los datos históricos respecto al uso por primera vez del término "crimen organizado" con la aparición por primeras veces de grupos indicativos de constitución de los más antiguos delincuentes que actuaban de forma organizada.

De inicio, es necesario apuntar que según algunos autores, el concepto de "crimen organizado" es de origen norte americana, desde la escuela de Chicago, teniendo surgido en los años 20 del siglo $\mathrm{XX}^{302}$.

Por lo general, el término "criminalidad organizada" no es incorporado, como elemento normativo a las legislaciones que afectan al fenómeno descrito303. En otras oportunidades se encuentra una conceptuación creada para aplicación y conocimiento de un asunto en concreto ${ }^{304}$. Así, lo más frecuente es que tan sólo se utilice al explicar los

\footnotetext{
301Respecto a esta interesante cuestión, primordial la lectura de la clásica obra del pensamiento oriental sobre estrategia: TZU, S., A arte da guerra, São Paulo, 2007.

302 RAUFER, X, QUÉRÉ, S., Le Crime Organisé, cit., pág. 24. En el mismo sentido, FLORES PÉREZ señala que "el término crimen organizado es un concepto estadounidense. Su surgimiento y evolución están fuertemente identificados con la manera en que diversas instituciones de seguridad de ese país han concebido a la delincuencia profesional. El concepto comenzó a emplearse en 1919, en Estados Unidos, entre los miembros de la Comisión de Crimen de Chicago, una organización cívica que se creó en ese mismo año por banqueros y abogados que promovían cambios en el sistema de justicia criminal, con el objetivo de enfrentar mejor el problema del crimen". Vid. FLORES PÉREZ, C. A., Análisis, técnicas y herramientas en el combate a la delincuencia organizada con fundamento en la Convención de Palermo, VV.AA., México, 2007, pág. 143. De su parte, FOFFANI apunta que "el concepto de criminalidad organizada ha surgido por la primera vez en el léxico normativo de la Unión Europea, por vía del Tratado de Ámsterdam". Vid. FOFFANI, L., "Criminalidad organizada y criminalidad económica", Revista Penal, núm. 7, 2001, pág. 55.

303 Cítese como ejemplo, el caso brasileño, donde las Leyes 9.034/95 y 10.217/01, no ofrecen un concepto respecto de la criminalidad organizada.

304 Así en España, se encuentra previsto el tipo legal de criminalidad organizada en el art. 570 bis del CP (añadido por la LO 5/2010), donde se define por organización criminal "la agrupación formada por más de dos personas con carácter estable o por tiempo indefinido, que de manera concertada y coordinada se repartan diversas tareas o funciones con el fin de cometer delitos, así como de llevar a cabo la perpetración reiterada de faltas. También el legislador en el artículo 282 bis 4 de la LEcrim, describe un concepto de delincuencia organizada para los fines de comprensión de la figura del agente encubierto. A este respecto, de modo acentuadamente crítico, CHOCLÁN MONTALVO aduce que "en realidad no se define lo que es la organización sino que se presupone su concepto, pues la actuación de más de tres personas en grupo, que proyectan su actividad a una pluralidad de delitos más allá de una esporádica actuación, todavía no aclara en que consiste el plus de desvalor que resulta de una actuación llevada a cabo por una empresa criminal. El legislador español debería aclarar qué se entiende por organización criminal, estableciendo las notas características de la estructura organizativa (de la asociación), pues el art. 282 bis 4 ofrece un concepto exageradamente amplio de delincuencia organizada, de difícil delimitación con la conspiración para delinquir y la coautoría, que, desde luego, no puede extrapolarse a la interpretación, necesariamente restrictiva, de los tipos penales". Vid. CHOCLÁN MONTALVO, J. A., La organización criminal: tratamiento penal y procesal, cit., págs. 10-11. Otra dura crítica se puede observar en GÓMEZ DE LIAÑO FONSECA-HERRERO, M., Criminalidad organizada y medios extraordinarios de investigación, cit., págs. 67-68.
} 
motivos y objetivos de una ley en cuestión, viniendo a omitirse cuanto a laformulación de un concepto legal del crimen organizado aplicable en general 305 .

Además hay muy pocos acuerdos acerca de qué es la criminalidad organizada 306.

Respecto a esta situación, ROXIN destaca que no existe un concepto de criminalidad organizada jurídicamente claro con una mínima capacidad de consenso ${ }^{307}$. Por su parte, MUÑOZ CONDE se refiere al hecho de que el fenómeno en los días de hoy no ha sido claramente delimitado, ni definido con precisión, sea por la Criminología, sea por el Derecho Penal ${ }^{308}$.

Siendo así, las diversas perspectivas con las que ha sido tratada demuestran que es un fenómeno voluble, complejo, sumamente cambiante y, por tanto, difícil de aprehender en concepciones teóricas y, más aún, en leyes penales ${ }^{309}$.

Por esto resulta imposible enunciar un concepto unívoco de organización criminal que aúne al mismo tiempo la suficiente precisión y la necesaria generalidad. Hacerlo equivaldría a encorsetar en un rígido patrón una fenomenología cuyo dinamismo corre paralelo a la propia evolución de la sociedad actual ${ }^{310}$.

Aún interesante es la observación de RODRÍGUEZ GARCÍA, para quién la expresión "crimen organizado" designa una realidad compleja merecedora de ingentes esfuerzos institucionales, especialmente supranacionales a consecuencia de su habitual dimensión transfronteriza, plasmados en iniciativas preventivas, de investigación y represión, poco efectivas, a tenor de los resultados alcanzados ${ }^{311}$.

De lo dicho resulta que el crimen organizado constituye por sí mismo un fenómeno de difícil estudio y penetración incluso para la más sofisticada criminología. Dichas dificultades se derivan, en cierta medida, de la ambigua delimitación conceptual de lo que crimen organizado es, pero, posiblemente, están más relacionadas con tres factores de más hondo calado. Primero, la teoría criminológica tradicional y la mayor parte de de la teoría criminológica contemporánea resulta de más difícil aplicación al crimen organizado

305 En palabras de ALMEIDA FERRO, "la carencia de una definición normativa del crimen organizado ha servido de estimulo, por otro lado, para la elaboración de proyectos legislativos ostentando diferentes propuestas para la solución de la deficiencia apuntada, ni siempre en conformidad con la buena técnica jurídica y los principios garantistas constitucionalmente garantizados". Vid. ALMEIDA FERRO, A. L., Crime Organizado e Organizações Criminosas Mundiais, cit., pág. 622.

306 Sobre la dificultad de construcción de un concepto preciso del crimen organizado, Vid. GOMES, A. F., "Caracteres do crime organizado", Crime organizado e suas conexões com o Poder Público. Comentários a Lei 9.034/95: considerações críticas, Rio de Janeiro, 2000, pág. 4 y ss.

307 ROXIN, C., "Problemas de autoría y participación en la criminalidad organizada", Delincuencia organizada. Aspectos penales, procesales y criminológicos, J. C. Ferre Olive y E. A. Borallo coords., Huelva, 1999, pág. 198.

308 Vid. MUÑOZ CONDE, F., "¿Dominio de la voluntad en virtud de aparatos de poder organizados en organizaciones no desvinculadas del Derecho?, Problemas fundamentais de Direito Penal, libro homenaje a Claus Roxin, M. C. Valdágua coord., Lisboa, 2002, pág. 101.

309 ZÚÑIGA RODRÍGUEZ, L., "Criminalidad organizada, Derecho penal y sociedad. Apuntes para el análisis", VV.AA., El desafío de la criminalidad organizada, N. Sanz Mulas coord., Granada, 2006, pág. 39.

310 FABIÁN CAPARRÓS, E. A., El delito de blanqueo de capitales, cit., pág. 35. En opinión de FEIJÓo SÁNCHEZ, "el concepto de delincuencia organizada es un concepto normativo que debe ser dogmáticamente tratado como el dolo y la imprudencia o la autoria y la participación. Al igual que en estos casos problemáticos tradicionales, la distinción delincuencia organizada/no organizada puede determinar la mayor o menor gravedad de la sanción e, incluso, la necesidad de intervención del Derecho Penal". Vid. FEIJÓo SÁNCHEZ, B., "El derecho penal del enemigo y el estado democrático de derecho", cit., pág. 149.

311 Cfr. RODRÍGUEZ GARCÍA, N., "Prólogo" a la obra "Sistema penal y crimen organizado, Estrategias de aprehensión y criminalización del conflicto", cit., pág. I. 
en cuanto que su foco principal lo ha constituido la delincuencia callejera. En segundo lugar, más difícil resulta la aplicación de los métodos de investigación tradicionales al estudio del crimen organizado. Mientras que las encuestas de victimización y las encuestas autoincriminación abren una ventana al estudio de la delincuencia común, su aplicación al estudio del crimen organizado resulta mucho más limitada. En tercer lugar, la criminología dada sus carencias se ha desarrollado de una manera más notable en aquellas áreas en las que existe un mayor grado de conocimiento y una literatura más avanzada en el ámbito comparado 312 .

No cabe negar, incluso, que parte de la doctrina coincide en la necesidad, como punto de partida, de diferenciar la organización criminal de una simple asociación para delinquir ${ }^{313}$.

Hechas estas necesarias observaciones, se puede afirmar sencillamente que el crimen organizado puede ser entendido como un fenómeno que se caracteriza por ser evolutivo, mutable y polifacético ${ }^{314}$, características éstas que tornan difícil su identificación para un profundo y adecuado estudio.

Además, deberá ser registrado que el gran problema puede estar en el hecho de que el delito organizado tendrá una apariencia y realidad absolutamente distintas en cada sociedad, lo que dificulta el encuentro de una definición conceptual que contemple todas las situaciones peculiares e inherentes de cada país.

Mejor explicando, las características operacionales y el "poder de fuego" de un cartel de narcotraficantes en Colombia se presenta diametralmente opuesto al modus operandi de un grupo mafioso de Rusia que se dedica al tráfico de mujeres para la prostitución.

En este sentido, el crimen organizado debido a que constituye un fenómeno complejo no es un tema fácil de definir porque en cada país, en razón de particularidades locales y regionales, se desenvuelve de manera distinta ${ }^{315}$.

Profundizando la discusión acerca de la conceptuación del fenómeno delictivo denominado "crimen organizado", cítese incluso la aguda observación de CERVINI, para quien el fenómeno de la delincuencia organizada no debe considerarse como un mal nebuloso o un peligro efímero, sino más bien como una empresa ilícita totalmente tangible, con indicadores y características que son posibles de determinar analíticamente y con operaciones de amplio alcance que pueden y deberían ser combatidas. La tendencia a considerar a la delincuencia organizada como una amenaza abstracta se ha vinculado en

\footnotetext{
312 MEDINA ARIZA, J. J., "Una introducción al estudio criminológico del crimen organizado", VV.AA., Delincuencia Organizada. Aspectos penales, procesales y criminológicos, J. C. Ferré Olivé y E. Anarte Borrallo coords., Huelva, 1999, pág. 109.

313 En este sentido, Vid. SÁNCHEZ GARCÍA DE PAZ, I., La criminalidad organizada. Aspectos penales, procesales, administrativos y policiales, cit., pág. 27. En otro trabajo, la misma autora enseña que "la expresión crimen organizado aparece utilizada en la actualidad de modo inflacionista y expansivo en la literatura, de modo que sus contornos parecen coincidir con el de cualquier asociación criminal, eso sí, orientada por fines de carácter económico y no político. Falta, pues, claridad y unidad en la delimitación de estos conceptos, los de asociación criminal y organización criminal". Vid. SÁNCHEZ GARCÍA DE PAZ, I., "Función político-criminal del delito de asociación para delinquir: desde el Derecho penal político hasta la lucha contra el crimen organizado", cit., pág. 661.

314 DAGDUG KALIFE, A., La prueba testimonial ante la delincuencia organizada, cit., pág. 4.

315MONTOYA, M. D., "El agente encubierto en la lucha contra el crimen organizado en la Argentina", Revista de Derecho Penal, Procesal Penal y Criminología, vol. 1, núm. 2, Mendoza, 2001, pág. 293.
} 
parte a la falta de una definición clara, precisa y aceptable, de este fenómeno en el plano internacional e incluso en el nacional 316 .

No obstante el optimismo crítico del penalista uruguayo, de inmediato es importante advertirse que no se debe desconocer en todo caso, la opinión de parte de la doctrina criminológica radical o crítica que entiende no ser correcta la formulación de un concepto del crimen organizado ${ }^{317}$.

ZAFFARONI, uno de sus adalides, parte del supuesto de que el concepto tradicional de crimen organizado es en verdad una categoría frustrada, o sea, un rótulosin utilidad científica, carente de contenido jurídico-penal o criminológico ${ }^{318}$.

En dicha línea, se critica el concepto de crimen organizado, a la vez que funcionaría como discurso encubridor de la incapacidad política de reformas democráticas de los gobiernos locales. A esto se podría a vuela pluma denominar de "simbolismo penal"319, representado especialmente por la incompetencia política en razón de problemas comunitarios estructurales de empleo, habitación, escolaridad, salud y que sería compensada por la demostración de competencia administrativa en la lucha contra la delincuencia organizada.

Así, para esta corriente dogmática, nada mejor para un gobierno que apuntar el enemigo, aunqueimaginario, como causa de todos los males y aflicciones sociales, en determinado momento histórico ${ }^{320}$.

En síntesis, no es tarea fácil conceptuar lo que es una organización criminosa, puesto que bastaría un vistazo en la gran mayoría de los sistemas penales internacionales, para la constatación de que los legisladores y estudiosos no han encontrado una solución plausible para explicar la ausencia de unanimidad en la doctrina criminológica y penal para fornecer un concepto de delincuencia organizada, a la vez que ésta presenta contornos muy imprecisos y llena de relativismos.

Como señalado por RAMÍREZ BARBOSA, formular un concepto de criminalidad organizada no es asunto pacifico, bien por la propia complejidad que aparejan las conductas criminales de carácter organizado, y de otra parte, por las diversas normativas existentes en buena parte de los países ${ }^{321}$.

316 Vid. CERVINI, R; GOMES, L. F., Crime organizado. Enfoques criminológico, jurídico (Lei 9.034/95) e político-criminal, São Paulo, 1995, pág. 193.

317 Con profundidad respecto a este pensamiento dogmático, Vid. CIRINO DOS SANTOS, J., "Crime Organizado", Revista Brasileira de Ciências Criminais, núm. 42, 2003, págs. 214-224.

318 ZAFFARONI, E. R., "Crime organizado: uma categoria frustrada", cit., págs. 45-67. Pero, importante explicar que de modo alguno Zaffaroni niega la existencia de delitos practicados por organizaciones criminales. Así, señala que "de modo alguno se niega la existencia de la mafia, de la camorra, de bandas de criminales, de organizaciones que practican defraudaciones internacionales, que exportan sobrefacturando e importan subfacturando y que se hacen acreedoras de sí mismas en mercados lejanísimos, o decir que no existe la trata de personas ni de sustancias o servicios prohibidos, o que no hay organizaciones de secuestradores. Lo que defiende es que no hay un concepto que abarque todo eso y también, a veces, al terrorismo y que sirva para algo". Vid. ZAFFARONI, E. R., "En torno al concepto de crimen organizado", VV.AA., Nada personal. Ensayos sobre crimen organizado y sistema de justicia, cit., pág. 10. En el mismo sentido crítico, Vid. CIRINO DOS SANTOS, J., "Crime organizado", cit., págs. 214-224; ALBRECHT, P. A., Kriminologie, Munich, 1999, págs. 385 y 386.

319 Respecto al tema, Vid. DIEZ RIPOLLÉS, J. L., "El Derecho penal simbólico y los efectos de la pena", Crítica y justificación del Derecho penal en el cambio de siglo, Cuenca, 2003, págs. 147-172.

320 MORAES PITOMBO, A. S. A., Organização Criminosa, cit., pág. 119.

321 Vid. RAMÍreZ BARBoSA, P. A., Crime Organizado. Tipicidade, Política, Investigação e Processo, cit., pág. 67. 
Pero, al final, conviene preguntarse: ¿qué es la criminalidad organizada?

Para intentar buscarse una respuesta, preliminarmente se habrá de hacer mención al hecho de que a mediados de los años ochenta del siglo pasado, BOURDIEU advertía que no existen palabras inocentes, que toda locución puede revestir sentidos antagónicos, según la manera en que sea asumida por quien la expresa y quien la recibe ${ }^{322}$.

Pues bien, a partir de esta premisa, es de concluirse que la definición que se emplee al fenómeno del crimen organizado depende en gran medida del enfoque teórico que enmarque la reflexión sobre lo mismo, pues los intentos por unificar criterios para esta problemática no han sido muy exitosos y los esfuerzos que han prosperado se refieren al trabajo de organismos internacionales, a ejemplo de Naciones Unidas, que promueven la cooperación entre los países, con el objetivo de construir herramientas jurídicas y de política gubernamental que permitan enfrentar este fenómeno criminológico que tanto provoca miedo y inseguridad a todos.

De esta forma, si no es posible una definición completa o uniforme, siempre será posible $\mathrm{y}$, especialmente, útil, al menos para intentar armonizar las legislaciones nacionales o para efectos de operacionalización de la cooperación internacional, una descripción, a partir de algunas características comunes y dominantes, y además, en una perspectiva nacional, siempre sería importante y exigible una definición de lo que es el "crimen organizado" o los "grupos criminales", en la medida en que se prevean sanciones o consecuencias gravosas en función de la práctica de lo que se pretende con una de aquellas nociones. En fin, la definición, por más difícil o imposible que sea, significaría una garantía relacionadaa las exigencias de la legalidad en la aplicación de la pena ${ }^{323}$.

Todavía, a par de las consideraciones críticas acerca de la dificultad de búsqueda de un concepto que pueda corresponder a las expectativas generales, se puede buscar algunas definiciones en normas internacionales ${ }^{324}$ a ejemplo de la Convención de las Naciones Unidas contra la Delincuencia Organizada Transnacional, conocida como "Convención de Palermo" del año $2000^{325}$, a través de la cual se considera en su artículo 15.

322 BOURDIEU, P., ¿Qué significa hablar?, Economía de los intercambios lingüísticos, Madrid, 1985, págs. 14-

323 En este sentido, Vid. la opinión de CARLOS FONSECA, J., "Direitos, liberdades e garantias individuais e os desafios impostos pelo combate à criminalidade organizada. Um périplo pelas reformas penais em curso em Cabo Verde, com curtas paragens em Almagro e Budapeste", Liber Discipulorum para Jorge de Figueiredo Dias, M. Costa Andrade; J. Faria Costa; A. Miranda Rodrigues y M. João Antunes coords., Coimbra, 2003, págs. 163-164.

324 Anteriormente a la Convención de Palermo del año 2000, en el seno de la Unión Europea, ha sido adoptado una acción común sobre la base del K. 3 del Tratado de la Unión Europea (CE) 98/733/JAI relativa a la tipificación penal de la participación en una organización delictiva en los Estados miembros de la Unión Europea, de 21.12.1998, donde se definía la organización delictiva en el art. 1 como "una asociación estructurada, de más de dos personas establecida durante un cierto período de tiempo, y que actué de manera concertada con el fin de cometer delitos sancionables con una pena privativa de libertad o una medida de seguridad privativa de libertad de al menos 4 años como mínimo o con una pena más severa, con independencia de que estos delitos constituyan un fin en sí mismo o un medio para obtener beneficios patrimoniales y, en su caso, de influir de manera indebida en el funcionamiento de la autoridad pública". Para una mayor profusión respecto a las definiciones en el derecho comparado, Vid. SÁNCHEZ GARCÍA DE PAZ, I., $L a$ criminalidad organizada. Aspectos penales, procesales, administrativos y policiales, cit., págs. 35-39.

325 La Convención de las Naciones Unidas contra el crimen organizado transnacional es un documento normativo básico que en el plan internacional, reglamenta las acciones legales y las políticas institucionales de combate a la delincuencia organizada practicadas en gran parte de los países celebrantes de este Tratado Internacional. En efecto, es la Convención de Palermo que contiene los principios básicos, las directrices fundamentales que han de orientar la elaboración de leyes y la formulación de políticas de prevención y represión al crimen organizado, adoptados por los 147 países que hacen parte de la misma. En el sentido de utilización del concepto creado en la Convención de Palermo, Vid. la recomendación n. 3, de 30.5.2006, donde 
2.a, que por un grupo delictivo organizado se entenderá un grupo estructurado de tres o más personas que exista durante cierto tiempo y que actúe concertadamente con el propósito de cometer uno o más delitos graves o delitos tipificados con arreglo a la presente Convención con miras a obtener, directa o indirectamente, un beneficio económico u otro beneficio de orden material.

También muy bien acepto es el concepto adoptado por el Consejo de la Unión Europea, a partir de la Decisión Marco 2008/841/JAI, de 24 de octubre de 2008, por lo cual se comprende como crimen organizado "una asociación estructurada de más de dos personas, establecida durante un cierto período de tiempo y que actúa de manera concertada con el fin de cometer delitos sancionables con una pena privativa de libertad o una medida de seguridad privativa de libertad de un máximo de al menos cuatro años o con una pena aún más severa, con el objetivo de obtener, directa o indirectamente, un beneficio económico u otro beneficio de orden material"326.

Importante señalar que la citada Convención es un importante instrumento para ampliar la colaboración internacional y para determinar los mínimos necesarios para permitir la cooperación internacional contra la delincuencia organizada transnacional ${ }^{227}$. Se trata pues de un documento de Naciones Unidas que sirve como válvula de escape utilizado por varios países con vistas a encontrarse un modo razonable de definir lo que sea un grupo organizado tendente a la práctica de acciones ilícitas e que presentan una repercusión social notable.

La naturaleza o el carácter transnacional del delito o de las acciones del grupo criminoso constituyen elemento básico del concepto de crimen organizado, notadamente en razón de que así figura en el texto de la Convención de las Naciones Unidas contra el crimen organizado transnacional (Convención de Palermo) ${ }^{328}$. Sin embargo, la propia Convención propone una definición pragmática de lo que es un grupo delictivo organizado, con objetivo de sancionar la empresa criminal que tiene por fin obtener beneficios a partir de un patrón de actividad ilícita ${ }^{329}$.

Además, no se puede olvidar los importantes conceptos formulados por otras instituciones policiales de control de seguridad, especialmente en los Estados Unidos, dondela INTERPOL ${ }^{330}$ (International Criminal Police Organization) y el FBI (Federal Bureau of Investigation) han elaborado sus propias definiciones ${ }^{331}$.

el Consejo Nacional de Justicia en Brasil, recomienda a los Tribunales y jueces a lo utilizaren. También en la doctrina, como por ejemplo, PONTES, E. F; DEZEM, G. M., "Crime organizado e devido processo legal", Estudos de processo penal: o mundo à revelia, F. Hassan Choukr coord., Campinas, 2000, pág. 249 y ss.

326 Con más detalles sobre esta decisón, Vid. SANZ HERMIDA, Á. Mạ., "La lucha contra la delincuencia organizada: la Decisión Marco 2008/841/JAI, de 24 de octubre", Revista General de Derecho Procesal, núm. 17, 2009, http://www.iustel.com.

327 VV.AA., Análisis, técnicas y herramientas en el combate a la delincuencia organizada con fundamento en la Convención de Palermo, cit., pág. 28.

328 GOMES, R. C, O crime organizado na visão da Convenção de Palermo, cit., pág. 20.

329 VV.AA., Análisis, técnicas y herramientas en el combate a la delincuencia organizada con fundamento en la Convención de Palermo, cit., pág. 27.

330 Con más detalles respecto a la actuación de esta institución policial en la lucha contra el crimen organizado, véase, VV.AA., Análisis, técnicas y herramientas en el combate a la delincuencia organizada con fundamento en la Convención de Palermo, cit., págs. 127-129.

331 Para INTERPOL, "el crimen organizado es formado por cualquier grupo que tenga una estructura corporativa, cuyo principal objetivo sea el lucro de dinero a través de actividades ilegales, siempre subsistiendo por la imposición del temor y la práctica de la corrupción". Ya para el FBI, se trata de "cualquier 
De otra parte, se presenta también como alternativa, adoptar un concepto más general, que abarque los rasgos principales que caracterizan este fenómeno criminológico, a ejemplo de algunas definiciones encontradas en la doctrina penal. Cítese entonces, a modo de simple ejemplo, el concepto lanzado por BECCHI, cuando define la criminalidad organizada como una actividad delictiva colectivamente ejercitada con fines de lucro y orientada a conseguir beneficios de la producción de bienes y servicios prohibidos por la ley332.

En nuestra opinión, lo más adecuado será la búsqueda por los Estados de elaboración de un concepto a ser inserido en sus respectivas legislaciones penales, con la finalidad de definir con palabras exactas, los caracteres que demuestren la incidencia de actuación del crimen organizado. Cítese como buen ejemplo, España, que tras definir años atrás la criminalidad en la LECrim (art. 282 bis), ahora mismo ha cambiado este concepto al definir en el art. 570 bis 1 de la Ley Orgánica 5/2010 que se entiende por organización criminal "la agrupación formada por más de dos personas con carácter estable o por tiempo indefinido, que de manera concertada y coordinada se repartan diversas tareas o funciones con el fin de cometer delitos, así como de llevar a cabo la perpetración reiterada de faltas". Nótese en este último concepto que al no presentar un rol cerrado de delitos relativos al crimen organizado, deja la oportunidad para que se pueda incluir todos los entramados organizativos con independencia del delito cometido, aprovechándose de la verificación de otros requisitos característicos de esta especie de delincuencia (jerarquía, división del trabajo, uso de la violencia, uso de medios tecnológicos sofisticados para la práctica de delitos, etc), los cuales tendremos la oportunidad de analizar a continuación.

\section{I.3.1.3. Principales rasgos característicos.}

Es algo ya bastante conocido en lo relativo a la actuación de los grandes grupos de delincuentes organizados, el uso del poder y del dinero como forma de influencia en la máquina estatal, amén de una insidiosa capacidad corruptora. También es nota inherente a esta forma de criminalidad transnacional el alto poder de capacidad de intimidación a las víctimas y la destacable exigencia de una lealtad ciega por parte de sus miembros 333 .

Del mismo modo se percibe que estos clanes direccionados a la práctica de delitos de gran repercusión social practican una forma clara de justicia privada, con reglas propias, dictadas por la violencia y por la "ley del silencio", utilizándose de formas de actuación en moldes empresariales y marcadas por el "clientelismo"334.

Estas características dan forma a la estructura fundamental de actuación de un grupo organizado creado con la finalidad de cometer delitos de elevada desvalorización social y claro contenido económico.

grupo teniendo algún tipo estructura formalizada cuyo objetivo primario es la obtención de dinero a través de actividades ilegales. Tales grupos mantienen sus posiciones a través del uso de violencia, corrupción, estafas o extorsiones, y generalmente tienensignificante impacto sobre los locales y provincias del país donde actúan".

332 BECCHI, A., Criminalità organizata. Paradigmi e scenari delle organizzazioni mafiose in Italia, Roma, 2000, pág. 10.

333 Con detalles, vid., ALMEIDA FERRO, A. L., Crime Organizado e Organizações Criminosas Mundiais, cit., pág. 31.

334 Sobre el clientelismo, cfr., CACIAGLI, M., Clientelismo, Corrupción y Criminalidad Organizada. Evidencias empíricas y propuestas teóricas a partir de los casos italianos, Madrid, 2006. 
El crimen organizado se ha especializado en el comercio ilegal, es fenómeno que se extiende tanto a nivel regional como internacional. Las organizaciones criminales han transformado un mercado de los ingresos ilegales organizados con base artesanal en un mercado ilícito-empresarial gestionado internacionalmente ${ }^{335}$.

De otra parte, los avances tecnológicos en los sistemas de comunicación, de transmisiones de informaciones y de transportes han sido fundamentales para determinadas actividades del crimen organizado. De hecho, teniendo los medios, las estructuras y know how implicados, las organizaciones criminales transnacionales obtienen rápidos e ingentes beneficios sin precedentes, ya sea por el elevado número de clientes, ya sea por los escasos costes económicos y penales inferiores respecto a aquellas actividades antes tradicionales ${ }^{336}$.

En opinión de KELLENS, serian cinco las características básicas de una organización criminal o de un grupo de delincuencia organizada: organización jerárquica; leyes y sanciones internas; blanqueo del dinero criminal; intimidación y compra de funcionarios 337 .

Dicho en pocas palabras, se trata de una modalidad de delincuencia grave y que presenta como características destacadas su dimensión transfronteriza y su incomparable rasgo de sofisticación.

En nuestra opinión, otras innúmeras peculiaridades pueden ser visualizadas en el fenómeno del crimen organizado: es una forma de delincuencia formada por grupos de personas con objetivos comunes; se busca de todas las formas estar la organización en el centro del poder; poseen una rígida jerarquía y disciplina entre sus miembros lo que genera la conocida "ley del silencio"; presenta el clan criminal una fungibilidad interna, o sea, existe una obligatoria y constante sustitución de las funciones de sus miembros; es exigida una compleja profesionalidad de los miembros del grupo ${ }^{338}$, como forma de búsqueda por la eficiencia en la práctica de conductas ilícitas; busca la organización criminal conferir apariencia de legalidad a sus actividades, como forma de camuflaje y mantenimiento de las prácticas ilegales; realizan actividades marcadas por el carácter de

\footnotetext{
335 Por esto se habla del carácter de la "transnacionalización de la delincuencia", o sea, de "la colaboración de diversos grupos organizados de diversas nacionalidades con la finalidad de aumentar la variedad de hechos delictivos; cada vez es más frecuente que los grupos organizados colaboren entre sí, por ejemplo que una banda que trafica con drogas y armas coopere con otra que se dedique al blanqueo de capitales". Vid. en este sentido, POZO PÉREZ, M., "El agente encubierto como medio de investigación de la delincuencia organizada en la Ley de Enjuiciamiento Criminal española", Criterio Jurídico, vol. 6, Santiago de Cali, 2006, pág. 270. Así es que se ha percibido en los últimos tiempos una aproximación destacada entre los clanes criminales, con intercambio de informaciones y de mercancías ilícitas, buscando con esta actitud, ampliar el círculo de actuación negocial de la organización criminal. Para una mejor comprensión de esta problemática, Vid. WILLIANS, P., "Cooperación entre organizaciones criminales", Crimen transnacional organizado y seguridad internacional: cambio y continuidad, M. R. Berdal y M. Serrano coords., México, 2006, págs. 108-130.

336 PÉREZ CEPEDA, A. I., La seguridad como fundamento de la deriva del Derecho Penal postmoderno, Madrid, 2007, pág. 94.

337 KELLENS, G., "L'évolución de la theorie du crime organisé", Criminología y Derecho penal al servicio de la persona, Libro homenaje al profesor Antonio Beristain, San Sebastián, 1989, pág. 285.

338 Por este motivo, señala BLANCO CORDERO que "en este gigantesco mercado hacia el que evoluciona la economía mundial existe una demanda de bienes prohibidos que lo convierten en idóneo para la proliferación de organizaciones criminales. El delincuente organizado es un empresario, y la organización actúa como una auténtica empresa criminal, que asume los modelos y estructuras propias del mundo de la industria y de los negocios. Se habla de industria del crimen, de empresas criminales y, dado su carácter transnacional, de multinacionales del crimen". Véase al respeto, BLANCO CORDERO, I., "Criminalidad organizada y mercados ilegales", Eguzkilore, San Sebastián, 1997 págs. 214 y ss.
} 
internacionalidad, a la vez que no se respetan los limites de las fronteras físicas entre los países; y por fin, buscan la comisión de delitos de notoria gravedad y repercusión junto a las autoridades y la población en general.

Por otra parte, según describe DELGADO MARTíN, siete serían las principales características de la criminalidad organizada: la disposición de mayores medios personales y materiales, la cultura de la supresión de la prueba, el empleo de violencia, la influencia negativa sobre el sistema, la extensión a muchos ámbitos de la actividad económica, la internacionalización y transnacionalización y por fin, el reclutamiento de jóvenes en ambientes marginales ${ }^{339}$.

A los efectos de la lucha contra la criminalidad organizada y especialmente como documento para la Europol ${ }^{340}$, la Unión Europea ha elaborado el documento "Enfopol 161REV-3", en el que establece once indicadores para estimar que se está ante delito que se encuadra a la categoría de crimen organizado: 1) más de dos personas; 2) distribución de tareas entre ellas; 3) permanencia; 4) control interno; 5) sospechosas de la comisión de un delito grave; 6) actividad internacional; 7) violencia; 8) uso de estructuras comerciales o de negocios; 9) blanqueo de dinero; 10) presión sobre el poder público; 11) ánimo de lucro.

Se considera que como mínimo deben concurrir seis características de las arriba citadas y enumeradas, de las cuales son obligatorias mal menos tres: más de dos personas, sospechosas de la comisión de un delito grave y ánimo de lucro.

Lo importante en este momento es dejar claro que el rol de características de un grupo organizado para la práctica de delitos graves no se agota de modo a cerrar un listado de manifestaciones típicas de estos clanes, a la vez que a cada día se descubren nuevas formas de actuación, nuevos mercados ilícitos, nuevos métodos y modus operandi, nuevas tecnologías para perpetración de crímenes, etc.

Se percibe entonces, un sinnúmero de notas características del fenómeno de las organizaciones criminales, a depender de cual sea la especie de actividad ilícita y delictiva cometida ${ }^{341}$ : la criminalidad organizada "común", cuyo propósito sería la obtención primordial del beneficio del lucro; la asociación de tipo mafioso ${ }^{342}$, cuyo propósito consiste en lucro juntamente con la obtención del poder y el beneficio económico; y por fin, la organización de índole terrorista, cuya actuación es marcada por un fuerte contenido político y por el uso de una violencia diferenciada.

339 Con detalles acerca de cada una de estas características del crimen organizado, Vid. DELGADO MARTÍN, J., Criminalidad Organizada, cit., págs. 24-29.

340 La Europol (Servicio europeu de policía) tiene como función principal el tratamiento y intercambio de informaciones criminales. En el ámbito de la lucha contra la delincuencia organizada también debe buscar la mejora de la eficacia y la cooperación entre los Estados de la UE, en el dominio de la prevención y combate a formas graves de crimen organizado de dimensión internacional. Informaciones actualizadas respecto a Europol se puede encontrar en http://www.europol.europa.eu/.

341 Por lo tanto, acreditamos ser menester concluir que "la naturaleza y extensión del delito organizado varía en cada país y por lo tanto, de forma frecuente requiere respuestas específicas. La estructura y las actividades de los grupos organizados van a dictar las mejores estrategias para combatirlos". En este sentido, Vid. VV.AA., Análisis, técnicas y herramientas en el combate a la delincuencia organizada con fundamento en la Convención de Palermo, cit., pág. 22.

342 Vid. sobre el fenómeno criminal del tipo mafioso, MONTOYA, M. D., Mafia y crimen organizado. Aspectos legales, autoría mediata, responsabilidad penal de los aparatos organizados de poder, Buenos Aires, 2004. También interesante pero analizando la práctica de las actividades mafiosas, Vid. GAYRAUD, J. F., El G-9 de las mafias en el mundo. Geopolítica del crimen organizado, Barcelona, 2005. 
Otro factor que demuestra la distinción de los caracteres de los clanes organizados es la actuación territorial específica, pues a depender del lugar de perpetración de los delitos, habrán de cambiar las formas de actuar del crimen organizado, el cual presenta un fuerte poder de adaptación a las condiciones del mercado ilícito.

En conclusión, se trata pues de un problema grave para el sistema penal, necesitándose una respuesta estatal adecuada desde la óptica del Derecho penal sustantivo, de la política criminal ${ }^{343}$ y particularmente, en lo que nos interesa en este trabajo, del Derecho procesal, pues de nada le servirá al Estado definir tipos delictivos, en tanto estos no sean aplicables a los casos para los que se diseñaron ${ }^{344}$.

Estas respuestas son la clave central para el mantenimiento del control de la seguridad pública nacional e internacional, con vistas a frenar el crecimiento avasallador de nuevos y viejos grupos criminales que vienen infiltrándose en el seno del poder y de la sociedad, y vía de consecuencia, provocando riesgos y daños sin precedentes a un sinnúmero de bienes jurídicos.

\section{I.3.1.4. Breves apuntes sobre el tratamiento jurídico de la criminalidad organizada.}

En lo que se refiere a las herramientas vinculadas al combate del crimen organizado, es necesario aclarar que existen en la actualidad un elevado número de convenios y normas internacionales que prevén múltiples mecanismos excepcionales tendientes a agilizar las investigaciones sobre la delincuencia organizada, tales como el decomiso de bienes, la agilización de los procesos de extradición, las cláusulas de extraterritorialidad, la conformación de unidades que concentren información financiera y, en general, la implementación de amplios convenios de cooperación ${ }^{345}$.

Todavía, no me parece arriesgado afirmar en este momento, que el control preventivo y represivo de la delincuencia organizada deberá, simultáneamente, partir de tres ejes fundamentales, o sea, del tratamiento legislativo con relación al sistema de Derecho penal sustantivo, de una adecuada Política criminal y de medidas eficaces dentro del ámbito del Derecho procesal penal, en especial, actualizándose los medios de investigación criminal. Pasémonos a una síntesis de cada una de estos sectores.

\section{I.3.1.4.1. Medidas de Política-criminal.}

Desde un principio debe recordase una obviedad: la política criminal es ejercicio de la política y por lo tanto está atada a exigencias de racionalidad oproporción, en definitiva

343 En este particular, importante subrayar que ninguna respuesta político-criminal es válida si invade el sistema de garantías, aunque trate de solucionar un grave problema social. No existe razón política alguna que permita superar estos límites. A propósito y con riqueza de detalles respecto a una visión político-criminal del proceso penal, Vid. FERNANDES, F., O processo penal como instrumento de política criminal, Coimbra, 2001.

344 Corroborando esta afirmación, Cfr. FABIÁN CAPARRÓS, E. A., "Criminalidad Organizada", cit., pág. 181.

345Vid. con detalles, ORSI, O. G., Sistema penal y crimen organizado. Estrategias de aprehensión y criminalización del conflicto, Buenos Aires, 2007, págs. 135-136. Cítese como buen ejemplo, la Convención Internacional sobre Delincuencia Organizada Transnacional de las Naciones Unidas, también conocida como Convención de Palermo, del año 2000, la cual incluye medidas en materia de extradición, cooperación judicial, técnicas de investigación especiales, protección de testigos y víctimas, cooperación de los órganos encargados de la aplicación de la ley, recogida e intercambios de información, posibilidad de creación de órganos mixtos de investigación, formación y asistencia técnica, entre otros. 
de legitimidad en la búsqueda de sus fines ${ }^{346}$. En palabras de BINDER, y siguiendo las ideas lanzadas por DELMÁS-MARTY, sería el conjunto de métodos por medio de los cuales el cuerpo social organiza las respuestas al fenómeno criminal ${ }^{347}$.

Como ha puesto de manifiesto ZÚÑIGA RODRÍGUEZ, la política criminal permite la conexión del sistema penal a los principios básicos del Estado democrático de Derecho, a los valores constitucionales, que es el primer fundamento de racionalidad que se demanda. La política criminal en este ámbito de selección de los instrumentos para hacer frente a la criminalidad, plantea como principio fundamental el de subsidiariedad, expresión del principio general del Estado democrático de Derecho de proporcionalidad $^{348}$.

Respecto a un análisis político-criminal, podríamos afirmar a vuela pluma que la lucha contra la criminalidad organizada puede ser concretizada a través del empleo de algunas medidas preventivas imprescindibles a la reducción de ciertas desigualdades sociales ${ }^{349}$ bien como procediéndose al desestimulo de algunas personas que migran para los clanes criminales no en razón de una vocación profesional, pero sí, por necesidad de obtención de ganancias para sobrevivir.

En realidad, la delincuencia organizada ha tomado forma de una empresa y de una economía sumergida y paralela, que capta jóvenes debido a la carencia de desarrollo económico, social y educativo y, en particular, por la desocupación laboral, ofreciendo la posibilidad de ganancias rápidas ${ }^{350}$.

Es muy fácil a un grupo criminal proponer a una persona sin perspectivas económicas, un sinnúmero de ventajas financieras, dotándole de la posibilidad de obtención de grandes sueldos pecuniarios a corto plazo, en cambio de su participación en actividades ilícitas.

Queda muy claro, pues, que no sería correcto comprender el proceso penal como puro instrumento de combate a la criminalidad, pero sí, aprender a analizar los modos

\footnotetext{
346 YACOBUCCI, G. J., "Política criminal y delincuencia organizada", VV.AA., Crimen Organizado. Desafíos y perspectivas en el marco de la globalización, Buenos Aires, 2005, págs. 28-29.

347 BINDER, A. M., "Política criminal, derecho penal y sociedad democrática", Política criminal. De la formulación a la praxis, cit., pág. 33.

348ZÚÑIGA RODRÍGUEZ, L., Criminalidad organizada y sistema de derecho penal. Contribución a la determinación del injusto penal de organización criminal, cit., pág. 19. Vid. de esta misma autora, Política Criminal, Madrid, 2001.

349 La reducción de las desigualdades sociales se presenta a nuestro modo de pensar como uno de los factores esenciales a un proyecto de intento de control a los avances de la criminalidad organizada. Y es así en razón de que la desigualdad social limita el desarrollo y crecimiento de la sociedad civil, excluye de la participación democrática a parte importante de la sociedad y le otorga poder sin contrapeso significativos una minoría; también incrementa la probabilidad de conflictos sociales, lo que puede desembocar en la quiebra de las instituciones democráticas. Vid. con más detalles respecto a la problemática de la desigualdad social y su repercusión el en ámbito criminal, GARGARELLA, R., "Justicia penal y desigualdad social", Claves de razón práctica, núm. 188, 2008, Págs. 38-42.

350 Vid. MONTOYA, M. D., Mafia y crimen organizado. Aspectos legales. Autoría mediata. Responsabilidad penal de los aparatos organizados de poder, cit., pág. 107. Cítese como ejemplo de esta realidad, las noticias recientes de que grupos de traficantes de drogas de las "Favelas" brasileñas, estarían reclutando jóvenes para trabajar para el crimen organizado, ofreciendo la posibilidad de costear los estudios, hasta llegar a los exámenes preparatorios para ingreso en las carreras de la Magistratura, del Ministerio Fiscal, de la Policía, etc.
} 
sociales de controlar los problemas de la criminalidad, con los medios de un estudio interdisciplinar y a través de una política social global ${ }^{351}$.

Algún autor, como DÍEZ RIPOLLÉS, sostiene incluso que en materia de lucha contra la criminalidad organizada, el modelo tradicional del garantismo estaría obsoleto y se presentaría como ineficaz. Considera en contraposición a este modelo de actuación, se propone un modelo penal bienestarista que privilegie una aproximación social al problema de la delincuencia antes que un enfoque represivo. Esta perspectiva implica un abordaje experto de la criminalidad que apoye las decisiones político criminales en datos empíricos sociales fiables, que atienda a las causas de la criminalidad y que esté dispuesto a dar tiempo a las transformaciones sociales necesarias para afrontar determinadas disfunciones sociales, antes de orientarse a la reacción del sistema penal. Serían características del modelo propuesto: un abordaje experto de la criminalidad; indagación de las causas de la delincuencia más que en los síntomas; se orienta a favor de la modernización del derecho penal en un sentido de intervención a ámbitos socioeconómicos y de interés comunitario; exigencia de acreditación de la utilidad de la intervención penal por encima de otro tipo de intervenciones sociales; y el abandono del garantismo como modelo de intervención penal 352 .

Aunque estemos parcialmente de acuerdo con las afirmaciones arriba delineadas, deberá advertirse que como base fundamental de cualquier política preventiva o mismo represiva, importante y necesario, que sea implementada una propuesta educacional idónea en todos los niveles de enseñanza ${ }^{353}$, desde la fase inicial hasta la universidad, en la cual habrá de buscarse que se imponga una mentalidad basada en la ética de las relaciones personales, sociales, jurídicas, políticas y económicas, y en la valoración de los frutos del trabajo honesto, del esfuerzo personal y colectivo ${ }^{354}$. En suma, deberá ocurrir un cambio cultural apto a demostrar una mejor formación moral y educacional de los ciudadanos.

A la vista de las anteriores reflexiones, resulta comprensible que para el triunfo en la lucha contra la delincuencia organizada, es necesario que la sociedad se mantenga sensibilizada y consciente a respecto de la gravedad de este fenómeno criminal. Esta propuesta debe estar dirigida en especial a los jóvenes, futuros ciudadanos y formadores de opinión, que en la propia escuela han de recibir los conocimientos necesarios a la comprensión de la problemática, así como deberán ser indicados a los mismos, los valores y las bases sociales de orientación, rumbo a un saludable comportamiento en la vida ${ }^{355}$.

351 PALMA, Ma . F., "O problema penal do processo penal", Jornadas de Direito Processual Penal e direitos fundamentais, Maria Fernanda Palma coord., Coimbra, 2004, pág. 53.

352 Vid. con detalles, DÍEZ RIPOLLÉS, J. L., "El nuevo modelo penal de la seguridad ciudadana", Revista Electrónica de Ciencia Penal y Criminología, núm. 06, 06-03, 2004, http://criminet.ugr.es/recpc/.

353 Esta también es la opinión de MONTOYA, al defender que "combatir el fenómeno mafioso desde la escuela es la contribución decisiva en la lucha porque se le enseña al joven el amor a la libertad, el saber y la responsabilidad". Vid. MONTOYA, M. D., Mafia y crimen organizado. Aspectos legales. Autoría mediata. Responsabilidad penal de los aparatos organizados de poder, cit., pág. 114.

354 En este sentido, CACIAGLI acredita en un cambio cultural profundo, basado en la solución de los problemas económicos y sociales y en la "limpieza" de las instituciones, a la vez que "porque la cultura, a pesar de su capacidad de persistir, puede cambiar bajo la presión de poderosos factores, también exteriores. Pero sólo se producirá un cambio cultural radical cuando se eliminen las dificultades económicas y sociales y se limpien las instituciones". Vid. CACIAGLI, M., Clientelismo, Corrupción y Criminalidad Organizada. Evidencias empíricas y propuestas teóricas a partir de los casos italianos, cit., pág. 126.

355 Hay que tener presente la opinión de MAIEROVITCH, cuando destaca que "la cultura y el empeño comunes son dos factores necesarios para que cada individuo adquiera y comprenda el significado de su papel 
Es necesario según GUEDES VALENTE, exponer a la sociedad de que el crimen organizado es una enfermedad prolongada y devastadora para el desarrollo armonioso de la sociedad: hoy, puede dar trabajo a jóvenes pobres, además de dinero para buscarse fines personales y profesionales, oportunidades económicas, sociales y políticas, pero después, tienen ellos que pagar (y mucho) la ayuda antes fornecida como limosna ${ }^{356 .}$

Respecto a esta problemática, brillantes son las palabras de HASSEMER, al destacar que una reSpuesta inteligente y focalizada a la criminalidad organizada promete alivios sensibles en el campo de la seguridad interna. Las mejoras en la situación de los jóvenes (sobre todo en los nuevos Estados de la Federación), el progresivo desecamiento del mercado negro en el campo de las drogas (criminalidad dirigida a la obtención de los medios para la compra de los estupefacientes) o las medidas técnicas de prevención podrían hacer superfluas las agravaciones del derecho penal y lograr que el clima de la tranquila reflexión vuelva a imperar, como también lo necesita la política criminal ${ }^{357}$.

Así entendida la problemática, la mejor política para hacer frente al fenómeno social es la prevención mediante la educación y no sólo la represión de una organización criminal, que llega a introducirse en medios de escasos recursos y tener aceptación porque se hace cargo de las prestaciones sociales, sustituyendo en dicho segmento al Estado que carece de medios para ello ${ }^{358}$.

La cuestión todavía es compleja, pues como observa ZUÑIGA RODRÍGUEZ, no parece existir un programa de política criminal específico frente a este tipo de criminalidad organizada para realizar planteamientos apropiados de prevención según sus particulares características ${ }^{359}$. En verdad, la realidad demuestra que el problema reside, pues, en que es justamente frente a la criminalidad organizada que proviene de la exclusión social y los tráficos prohibidos contra la que el Estado de excepción cae con toda su fuerza ${ }^{360}$.

No se debe olvidar de todo modo, que la prevención contra la criminalidad organizada comprende también la prevención contra determinados fenómenos criminales, como el tráfico de drogas, el blanqueo de dinero, el tráfico de personas y demás tráficos ilícitos, o sea, dicho de otra forma, no sepuede desconocer, que cualquier política de prevención tiene que incidir en los fenómenos criminales concretos ${ }^{361}$.

Por fin, importante explicitar que la discusión político-criminal está presente en la regulación jurídico-penal del crimen organizado siendo los problemas dogmáticos muy numerosos, entre los que se destacan: la configuración de un bien jurídico que justifique una penalidad propia, los problemas de autoría y participación, referidos principalmente a

social y de sus responsabilidades en la relación a la sociedad en que vive, respetando los derechos y las libertades de sus semejantes". Vid. MAIEROVITCH, W., "A matriz terrorista do crime organizado e o fenômeno da eversão", Justiça Penal 3, O crime organizado (Itália e Brasil), J. C. Penteado coord., São Paulo, 1995, pág. 90.

356 GUEDES VALENTE, M. M., "A Investigação do crime organizado. Buscas domiciliárias, o agente infiltrado e intervenção nas comunicações", VV.AA., Criminalidade organizada e criminalidade de massa. Interferências e ingerências mútuas, Coimbra, 2009, págs. 161-162.

357 Cfr. HASSEMER, W., "Límites del Estado de Derecho para el combate contra la criminalidad organizada", Revista de la Asociación de Ciencias Penales de Costa Rica, núm. 14, http://www.cienciaspenales.org.

358 MONTOYA, M. D., Mafia y crimen organizado. Aspectos legales. Autoría mediata. Responsabilidad penal de los aparatos organizados de poder, cit., pág. 113.

359 ZÚÑIGA RODRÍGUEZ, L., "Redes internacionales y criminalidad., a propósito del modelo de participación en organización criminal", VV.AA., Derecho penal ante la globalización, Madrid, 2002, pág. 71.

360 Véase, PÉREZ CEPEDA, A. I., La seguridad como fundamento de la deriva del Derecho penal postmoderno, cit., pág. 107.

361Vid. ZUÑIGA RODRÍGUEZ, L., Criminalidad organizada y sistema de derecho penal, cit., pág. 169. 
la aplicación del principio de proporcionalidad en función de la concreta aportación de cada uno de los miembros de la organización y, también, no menos importantes, los problemas concursales con los otros delitos a los que la organización favorece.

En síntesis, las medidas de Política criminal deberán servir, o mejor, funcionar, como puente entre la realidad social y la norma penal en la lucha contra las formas graves de delincuencia.

\section{I.3.1.4.2. Medidas sustantivas.}

Una imprescindible observación preliminar: los Códigos Penales deberían ofrecer una delimitación conceptual sobre el fenómeno de la organización delictiva. Como hemos visto, ha sido demostrada a lo largo del tiempo, una gran dificultad en encontrarse un concepto "cerrado" y "unívoco" para el fenómeno criminológico del crimen organizado ${ }^{362}$.

Sin embargo, de modo concreto, con relación a las respuestas de Derecho penal sustantivo contra el crimen organizado, necesario sería optimizar y armonizar entre los Estados la legislación penal material que criminaliza tanto la pertenencia misma a una organización criminal como los comportamientos criminales más característicos de las mismas: así como perfilar algunas cuestiones propias de la parte general del Derecho penal, como las relativas a la responsabilidad de las personas jurídicas, la extensión de las reglas de aplicación extraterritorial del Derecho penal, el alcance de la sanción de confiscación, la previsión de incentivos penales para los coimputados que colaboran con la justicia, la imputación de delitos dentro del organogramade la organización, etc ${ }^{363}$.

Por su parte, FABIÁN CAPARRÓS señala que valorada la cuestión desde el punto de vista del injusto típico, el tratamiento de la criminalidad organizada podría girar, en torno a dos ejes: uno, la agravación de los actos delictivos ejecutados a través de la forma asociativa, tráfico de drogas, terrorismo, extorsión, estafa, etc., otro, la penalización de la creación y ulterior desarrollo de la asociación criminal per se $e^{364}$.

De nuestra parte, añadiéndose a las fundamentales cuestiones citadas arriba, sería importante además una adecuación normativa respecto a los tipos de peligro que puedan tener relación a las prácticas relativas a la formación de grupos de delincuentes organizados 365 y en especial, dentro del tema de la confiscación patrimonial de bienes, que

362 Así, "en todos los conceptos de las organizaciones internacionales emanados de Naciones Unidas, la Unión Europea o el Consejo de Europa, respecto a la delincuencia organizada, se coincide en la tipificación de los grupos criminales organizados como asociaciones estructuradas y concertadas con el fin de obtener beneficios lucrativos, por medios ilícitos que pueden incluir los medios violentos para la consecución de sus objetivos, y con capacidad de operar a nivel transnacional". Véase al respeto, ÚBEDA PORTUGUÉS, J. E., " Análisis de los efectos negativos de la delincuencia organizada en la sociedad internacional", cit., pág. 68.

363 SÁNCHEZ GARCÍA DE PAZ, I, La criminalidad organizada. Aspectos penales, procesales, administrativos y policiales, cit., págs. 101-102. La misma autora, además, apunta que "en el ámbito penal sustantivo la reacción frente al crimen como empresa pasa por el tipo penal de la asociación para delinquir, preferentemente por tipos adaptados a sus peculiares características, que aparecen ya en algunos ordenamientos como Suiza, Austria y Estados Unidos, así como por la represión del blanqueo de ganancias procedentes de la comisión de delitos por el grupo". Vid. SÁNCHEZ GARCÍA DE PAZ, I., "Función político-criminal del delito de asociación para delinquir: desde el Derecho penal político hasta la lucha contra el crimen organizado", cit., pág. 652.

364 Vid. FABIÁN CAPARRÓS, E. A., "Criminalidad Organizada", cit., pág. 179.

365 Ajustando a este entendimiento, se puede considerar que de esta suerte, interesante también sería a nivel legislativo, penalizar el simple hecho de participar de la organización criminal, sea a través de una agravante específica aplicada al caso concreto, o aún, criando un delito independiente de asociación criminal ilícita. 
es materia nítidamente penal, la reglamentación de la excepcional inversión de la carga de la prueba.

También, como ya afirmado, no se puede olvidar la imprescindible necesidad de utilización de la figura del arrepentido (derecho premial), a través de un programa estructurado e idóneo de protección de testigos y peritos, con la inclusión en las legislaciones de excusas absolutorias y consecuentes atenuaciones en las sanciones ${ }^{366}$.

Y la razón es sencilla, pues sólo a través de la prueba indiciaria ${ }^{367}$, en un sinnúmero de situaciones concretas, será posible el enjuiciamiento de los "capos"368 de las grandes organizaciones criminales.

Por fin, importante una persecución rígida al delito de blanqueo de capitales, en razón de su estrecha relación con el crimen organizado ${ }^{369}$, la cual podría inhibir el crecimiento y desarrollo de nuevos grupos que pasen a operar de forma organizada en la búsqueda de ganancias ilícitas, bien como de aquellos clanes antiguos que ya operan con experiencia en el reciclaje de bienes y servicios de origen ilícita.

Se justifica esta última medida, a la vez que la utilización del sistema bancario y financiero para reciclar los beneficios que se obtienen de distintas actividades delictivas ha sido una práctica extendida e impune durante muchos años, prácticamente en todo el mundo 370 .

Partiendo de cierta complicidad del sistema financiero, se ha utilizado dicho sistema para la transformación de capitales de origen ilícito, provenientes de la comisión de delitos graves, en dinero libre de sospecha ${ }^{371}$. Delante de esta constatación, una de las estrategias de lucha de mayor importancia contra el crimen organizado, será la destrucción de su poder económico ${ }^{372}$.

Pero en verdad, lo que debe quedar claro es que la respuesta sólo normativa, es una respuesta que exorciza el problema, que sirve para removerlo de nuestra conciencia; en realidad se trata de satisfacer emotivamente las ansias colectivas de justicia olvidando que

\footnotetext{
366 Monográficamente, Vid. BENÍTEZ ORTÚZAR, I. F., El colaborador con la justicia. Aspectos sustantivos procesales y penitenciarios derivados de la conducta del "arrepentido", Madrid, 2004; MAGRO SERVET, V., "Régimen legal de los testigos protegidos en el proceso penal", La Ley Penal, núm. 75, octubre/2010, págs. 113; RUDI, D. M., Protección de testigos y proceso penal, Buenos Aires, 2002.

367 Resaltando el carácter prioritario a ser elegido por el legislador, o sea, la prueba en la lucha contra el crimen organizado, Vid. FABIÁN CAPARRÓS, E. A., "Criminalidad Organizada", cit., pág. 181.

368 "Capos", palabra originaria de la mafia italiana, serian las personas que dirigen o comandan las grandes organizaciones criminales y que normalmente están en posición estratégica dentro del clan, de modo que su persona, por no participar directamente de las prácticas delictivas, se torna prácticamente inalcanzable.

369 En este sentido, con riqueza de detalles, Vid. CHOCLAN MONTALVO, J. A., La organización criminal: tratamiento penal y procesal, cit., págs. 13 y ss. También, FERRÉ OLIVÉ, J. C., "Blanqueo de capitales y criminalidad organizada", Delincuencia organizada. Aspectos penales, procesales y criminológicos, E. Anarte Borralo y J. C. Ferré Olive coords., Huelva, 1999, págs. 85-98.

370 Corroborando la idea de que la represión del blanqueo de ganancias ilícitas deberá ser una medida substantiva en la lucha contra el crimen organizado, Vid. SÁNCHEZ GARCÍA DE PAZ, I., "Función políticocriminal del delito de asociación para delinquir: desde el Derecho penal político hasta la lucha contra el crimen organizado", cit., pág. 652.

371 FERRÉ OLIVÉ, J. C., "Blanqueo de capitales y criminalidad organizada", Delincuencia organizada. Aspectos penales, procesales y criminológicos, cit., pág. 85.

372 Aprobando esta estrategia, Vid. BLANCO CORDERO, I., "Criminalidad organizada y mercados ilegales", cit., pág. 231; CHOCLÁN MONTALVO, J. A., La organización criminal: tratamiento penal y procesal, cit., pág. 13.
} 
para resolver los problemas de la delincuencia organizada no puede bastar la norma, sino requiere un real compromiso social 373 .

\section{I.3.1.4.3. Medidas procesales.}

Hemos analizado preliminarmente, las necesarias medidas de carácter penal y de política criminal, en la contención a la proliferación y al crecimiento de la delincuencia organizada.

Pero en lo que nos interesa directamente en nuestro trabajo de investigación, es de suma importancia un examen respecto a las medidas que deben ser adoptadas en el ámbito del Derecho procesal a los fines de obtención de resultados satisfactorios en la persecución penal a los clanes organizados ${ }^{374}$.

No se discute actualmente, que el teatro de operaciones más importante sobre el que el Estado debe combatir el fenómeno de la delincuencia organizada es, precisamente, el del proceso penal ${ }^{375}$.

Como medidas de contención a la delincuencia organizada en el ámbito procesal, las más destacadas serían la utilización de medios extraordinarios de investigación criminal $^{376}$, a ejemplo de las infiltraciones policiales, las entregas vigiladas, los equipos conjuntos de investigación, la prueba pericial de inteligencia ${ }^{377}$, etc. Del mismo modo, interesante y apropiada es la utilización de la videoconferencia en los supuestos relativos a casos de delincuencia organizada.

Pasémonos a un somero análisis de estas "nuevas" técnicas investigativas y de producción de pruebas en el ámbito penal.

De modo conciso, en razón de que tendremos la oportunidad adelante de profundizarnos en este tema, por infiltración policial en una organización criminal, se entiende la ocultación de la verdadera identidad de un agente, en aras a establecer una relación de confianza con la finalidad primordial, igualmente oculta, de obtener la información necesaria para satisfacer determinados intereses públicos y/o privados ${ }^{378}$.

\footnotetext{
373 En este sentido, Vid. STORTONI, L., "Criminalità organizzata ed emergenza: il problema delle garanzie", Criminalità organizzata e riposte ordinamentali. Tra efficienza e garanzia, S. Moccia coord., Nápoles, 1999, pág. 131.

374 Respecto a las medidas procesales orgánicas, o sea, las fiscalías y tribunales especializados en materia de delitos practicados por organizaciones criminales transnacionales como el terrorismo y el narcotráfico cuidaremos en apartado propio.

375 FABIÁN CAPARRÓS, E. A., "Criminalidad Organizada", cit., pág. 181.

376 Vid. para un estudio completo, GOMÉZ DE LIAÑO FONSECA-HERRERO, M., Criminalidad organizada y medios extraordinarios de investigación, Madrid, 2004. También, GASCÓN INCHAUSTI, F., Infiltración policial y "agente encubierto", Granada, 2001; MONTOYA, M. D., Informantes y técnicas de investigación encubiertas. Análisis Constitucional y Procesal Penal, 2ª edición, Buenos Aires, 2001; CARDOSO PEREIRA, F., "A moderna investigação criminal: infiltrações policiais, entregas controladas e vigiadas, equipes conjuntas de investigação e provas periciais de inteligência", Limites Constitucionais da Investigação, L. F. Gomes; P. Taques y R. Sanches Cunha coords., São Paulo, RT, 2009, págs. 98-146.

377 Respecto a su aceptación junto a jurisprudencia española, Vid. SSTS, 783/2007, de 1.10.2007, Ponente: Sánchez Melgar y 786/2003, de 29.5.2003, Ponente: Gimenez García. En la doctrina, Vid. SORIANO SORIANO, J. R., "El terrorismo y el Tribunal Supremo", VV.AA., Terrorismo y proceso penal acusatorio, Valencia, 2006, págs. 196 y ss; RODRÍGUEZ-MAGARIÑOS, F. G., "La presunta prueba pericial de inteligencia: análisis de la STS de 22 de mayo de 2009", La Ley Penal, núm. 64, 2009, págs. 5 y ss.

378 GOMÉZ DE LIAÑO FONSECA-HERRERO, M., "Infiltración policial y proceso penal", Investigación y prueba en el proceso penal, N. González-Cuéllar Serrano y Á. Sanz Hermida coords., Madrid, 2006, pág. 203.
} 
Nótese que, en este caso un agente estatal acaba por adentrar en las entrañas del grupo organizado, con vistas a obtener a través del uso de técnicas policiales, informaciones, datos y pruebas que puedan ayudar a las autoridades de persecución, a desarticular el clan criminal. El infiltrado no tiene la misión de provocación de delitos, muy al contrario, su objetivo es solamente colectar informaciones útiles al trabajo de desarticulación de la banda de delincuentes organizados.

Ya la circulación o entrega vigilada, podría ser definida como la técnica de investigación por la cual la autoridad judicial permite que remesas ilícitas o sospechosas de drogas tóxicas u otras substancias ilícitas, enviadas ocultamente en cualquier especie de transporte, puedan llegar a su destinación, sin recibir interferencia obstativa de la policía u otro órgano de seguridad, con la finalidad de identificación de la persona que ha enviado el producto ilícito, el destinatario y todas las demás personas que tengan participación en la actividad ilegal ${ }^{379}$.

Dicho en otras palabras, según nuestro entendimiento, la entrega vigilada es una técnica de investigación que permite que una mercancía o remesa ilícita pueda llegar a su lugar de destino sin ser interceptada, con la finalidad de determinar a sus principales partícipes, constituyendo una excepción al principio según el cual, ante situaciones de flagrancia, los funcionarios de policía deben intervenir inmediatamente de forma represiva ${ }^{380}$.

De este modo, esta forma extraordinaria de investigación criminal se torna una verdadera excepción al principio de que toda autoridad que tenga conocimiento de un delito en el ejercicio de sus funciones, deberá denunciarlo y proceder a su detención. Desde esta perspectiva, por una cuestión de política criminal, se considera más adecuado no interceptar inmediatamente la sustancia o producto enviado, con el objetivo de conseguir un resultado más eficaz y positivo, o sea, la desarticulación de toda la red de criminosos pertenecientes al grupo criminal.

Su propósito es entonces establecer quiénes son los responsables del delito (datos del remitente, destinatario, transportador, etc), las redes de distribución o contactos y las rutas de transporte, con el fin de golpear los más altos niveles de las organizaciones criminales, a partir de su identificación y obtención de elementos de prueba que sirvan para una posterior condena en juicio ${ }^{381}$.

Importante además, destacar que esta técnica de investigación deberá siempre que posible, ser conjugada con la infiltración de agentes policiales, con el objetivo de obtención de un resultado más eficiente y completo. Dicho en otras palabras, la armonización entre

379 Respecto a esta técnica policial, Vid. CARDOSO PEREIRA, F., "Meios extraordinários de investigação criminal: infiltrações policiais e entregas vigiadas (controladas)", Revista da Associação Brasileira de Professores de Ciências Penais, São Paulo, 2007, págs. 211-218; CÔRREA DE CARVALHO, J. T., Tráfico de drogas. Prueba penal y medidas restrictivas de derechos fundamentales, cit., págs. 443-47; DELGADO MARTÍN, J., Criminalidad Organizada, cit., págs. 135-174; SUITA PÉREZ, N., "La diligencia de investigación mediante la entrega vigilada", La actuación de la policía judicial en el proceso penal, Madrid, 2006, págs. 217-235.

380 Sin embargo, es común encontrar en la doctrina la siguiente clasificación de modalidades de ejecución delictiva que justifican la institución de las entregas vigiladas: 1) el envío mediante paquete postas; 2) la remisión del envío como equipaje o maleta a través de transportista o porteador; y 3) constituirse el remitente como correo personal en auto portador del envío o utilizar a un tercero para dicho fin. Cfr. con más detalles, SEQUEROS SAZATORNIL, F., El tráfico de drogas ante el ordenamiento jurídico, cit., pág. 700.

381 GONZÁLEZ MONGUÍ, P.E., La policía judicial en el sistema penal acusatorio, Bogotá, 2007, pág. 294. 
estos dos mecanismos se revela en los días actuales una eficaz providencia para el combate a las organizaciones criminales ${ }^{382}$.

Por su parte, en Europa especialmente, los equipos conjuntos de investigación consisten en una agrupación, temporal, de uno o más representantes de las autoridades competentes de los Estados miembros de la Unión Europea, en los que se lleva a cabo una investigación criminal contra una organización de delincuentes, con el fin de llevar a cabo, coordinadamente, medidas de investigación sobre la misma ${ }^{383}$.

Así una de las nuevas formas que, con toda seguridad, está llamada a ser una de las técnicas clave en el próximo futuro es el establecimiento de equipos conjuntos de investigación, integrados por policías de los países participantes en la misma con el apoyo analítico de Europol o sin él, dependiendo de la voluntad de los servicios implicados.

Presentan los equipos conjuntos de investigación, además, como principales requisitos o características, la temporalidad, la finalidad determinada y la ubiquidad 384 .

Por fin, en materia de combate al terrorismo, la prueba pericial de inteligencia, como variante de la prueba pericial tradicional, ha recibido aceptación por la jurisprudencia y la doctrina en España. De acuerdo con SORIANO SORIANO es aquella prueba realizada por expertos en lucha antiterrorista, que con apoyo abrumador en multitud de hechos objetivos, que a su vez reseñan y constatan, llegan a conclusiones que permiten evidenciar circunstancias que no se descubren en un primer examen ${ }^{385}$.

Se buscaría con esta técnica especial de investigación facilitar el esclarecimiento de los hechos al juzgador, apoyándose en informaciones o pareceres emitidos por especialistas, los cuales poseen conocimientos esenciales a la comprensión de los fenómenos criminológicos, especialmente con relación al terrorismo ${ }^{386}$.

Estas nuevas técnicas aparecen como medios que, con diferentes naturalezas jurídicas, pueden mejorar la eficacia policial en la dura tarea de desmantelar la estructuración de los grupos organizados y como tendremos la oportunidad de profundizar, deberán ser utilizadas y legalmente estructuradas de acuerdo a los parámetros de constitucionalidad, en especial, delante del reconocimiento de los principios de proporcionalidad y del debido proceso legal.

\footnotetext{
382 En este sentido, la opinión de MENDRONI al señalar que "parece sugestivo que ambas deban coexistir naturalmente en la investigación, la acción controlada o vigilada practicada por agentes infiltrados, de forma harmoniosa para que sea buscada la mejor obtención de informaciones necesarias al conocimiento de las actividades de la organización criminal". Vid. MENDRONI, M. B., Crime organizado. Aspectos Gerais e mecanismos legais, cit., pág. 49.

383 JIMÉNEZ FERNÁNDEZ, R., "Los equipos conjuntos de investigación", www.cienciaspenales.net. Para un estudio profundo sobre esta técnica de investigación, Vid. CARDOSO PEREIRA, F., "A moderna investigação criminal: infiltrações policiais, entregas controladas e vigiadas, equipes conjuntas de investigação e provas periciais de inteligência", cit., págs. 128-139; "As equipes conjuntas de investigação criminal", Revista jurídica do Ministério Público do Estado do Mato Grosso, ano 3, num. 5, julho/dezembro 2008, págs. 173-186; GARCÍA, E. V., Los equipos conjuntos de investigación penal, Madrid, 2006.

384 Con sobras respecto a estas características, Vid. nuestro trabajo, "A moderna investigação criminal: infiltrações policiais, entregas controladas e vigiadas, equipes conjuntas de investigação e provas periciais de inteligência", cit., pág. 132.

385 SORIANO SORIANO, J. R., "El Terrorismo y el Tribunal Supremo", Terrorismo y proceso penal acusatorio, cit., pág. 196.

386 Vid. CARDOSO PEREIRA, F., "A moderna investigação criminal: infiltrações policiais, entregas controladas e vigiadas, equipes conjuntas de investigação e provas periciais de inteligência", cit., pág. 139.
} 
Hechas las sucintas consideraciones conceptuales respecto a estas técnicas extraordinarias de investigación, en nuestra opinión, dentro del aspecto procesal, deberán también existir otras formas de facilitación de la prueba penal en los casos que tengan por investigación actuaciones de grupos de delincuentes organizados.

Y la razón es sencilla. Los delitos de organizaciones criminales, sean ellas del tipo violento o empresarial, presentan dificultades probatorias si comparadas con la criminalidad tradicional ${ }^{387}$.

La prueba en delitos de la criminalidad organizada es fragmentaria, dispersa, se asemeja a un verdadero mosaico, montado a partir de varias fuentes diversas, para permitir llegarse a una conclusión, sea por la pluralidad de agentes, por la utilización de estructura empresarial como base, por la jerarquía y compartimentación, y por la adopción sistemática de rutinas de secretos y destrucción de pruebas, de modo que son justificadas medidas para fines de asegurar la seguridad del proceso ${ }^{388}$.

Según nuestra opinión son tres las medidas de facilitación de la prueba en materia de delitos graves practicados por organizaciones criminales.

a) Protección de testigos, peritos y colaboradores.

Se trata también de una medida de carácter sustantivo penal, se destaca la casi obligatoria necesidad de una efectiva y eficaz protección de los testigos, peritos y colaboradores en el ámbito del Derecho Procesal penal. Un sinnúmero de países como España y Brasil ${ }^{389}$, han establecido reglas específicas respecto al tema.

Acerca de este asunto, es algo indubitable el hecho de que una de las situaciones más comunes que se producen en los casos del crimen organizado y de la delincuencia organizada es la del temor de los testigos que han conocido los hechos cometidos, o que han sido víctimas de ellos a declarar, bien ante la policía, ante el juez instructor o en el juicio oral ${ }^{390}$.

La consecuencia más que obvia es que en la gran mayoría de los juicios se percibe una ausencia significativa de los testigos principales, los cuales presentando alto grado de miedo y temor, y del mismo modo, no confiando en el propio Estado, acaban por imposibilitar la condena de los criminales.

Se justifica entonces la protección de estas personas en razón de que las garantías judiciales no solamente se limitan a las partes del proceso, sino que se expanden contemporáneamente a favor de los órganos de prueba y de las fuentes judiciales de información encubierta ${ }^{391}$.

Aprobando la imprescindible ayuda de protección a estas personas, señala SEOANE SPIEGELBERG, que la necesidad de obtener información a los efectos de desmantelar el

387 "El delito normal", violento, la injuria, el hurto, tiene espectadores reales o potenciales. La criminalidad de los poderosos ocurre en regla en el oscuro y sin posibilidad de observaciones. Aunque se presente para todos los crímenes una cifra negra, aquí ella es especialmente alta.

388 BALTAZAR JR, J. P., "Limites constitucionais à investigação. 0 conflito entre o direito fundamental a segurança e o direito de liberdade no âmbito da investigação criminal", cit., pág. 211.

389 Vid. en España la Ley Orgánica 19/1994, de 23.12.1994, de Protección a Testigos y Peritos en Causas Criminales y en Brasil la Ley 9807 de 13.7.1999.

390 Cfr. MAGRO SERVET, V., "Régimen legal de los testigos protegidos en el proceso penal", cit., http://revista-laleypenal.laley.es/

391 RUDI, D. M., Protección de testigos y proceso penal, cit., págs. 22-23. 
hermetismo y la cohesión interna de las organizaciones criminales dedicadas a tan ilícita actividad, lleva a los legisladores nacionales al establecimiento de tipos penales privilegiados con la finalidad de dar un tratamiento penal más benigno a quienes colaboren con los órganos jurisdiccionales a los efectos represivos de dichas organizaciones ${ }^{392}$.

Sólo con medidas eficaces y con un programa de protección idóneo y confiable, podrán los testigos, colaboradores y peritos prestar su ayuda en la persecución penal de hechos relativos a la actuación de la delincuencia organizada, sin cualquier miedo o temor de que sufran toda suerte de amenazas y atentados contra su vida y de su familia. Este el incentivo que se puede ofrecer a estas personas para que puedan venir a prestar su colaboración a las autoridades policiales y judiciales.

Importante además señalar que los actuales instrumentos de la Unión Europea, a saber, la Resolución relativa a la protección de los testigos en el marco de la lucha contra la delincuencia organizada internacional (1995) ${ }^{393}$ y la Resolución relativa a las personas que colaboran con el proceso judicial en la lucha contra la delincuencia internacional organizada (1996) ${ }^{394}$, son de alcance limitado por aplicarse únicamente a casos de lucha contra la delincuencia organizada y por consistir en instrumentos legislativos no vinculantes.

Por otra parte, en lo relativo a la Unión Europea, la Decisión Marco relativa al terrorismo ${ }^{395}$ y la Decisión Marco del Consejo relativa al estatuto de la víctima en el proceso penal ${ }^{396}$, ambos instrumentos legislativos vinculantes, prevén la posibilidad de reducción de penas a cambio de información. Son estos dos instrumentos normativos con carácter vinculante y que afectan el tema de la protección de testigos, denunciantes y peritos, aún no tienen aplicación directa en los Estados miembros pero sí obligan a su resultado ${ }^{397}$.

Incluso la mayoría de los Estados miembros de la Unión Europea disponen de normas sobre protección de testigos que están recogidas en un acto individual o forman parte del Código penal. Generalmente, estas normas establecen definiciones (testigo protegido, testigo anónimo, colaborador con la justicia), medidas procesales (modalidades de procedimiento de los pleitos, métodos alternativos de práctica de la prueba), medidas de otra naturaleza (protección física, traslado, cambio de identidad), y las estructuras de aplicación necesarias, así como las funciones de los diferentes órganos policiales antes, durante y después del juicio, y los derechos y obligaciones de las partes en el sistema de protección. Por fin, también suelen hacer referencia a la cooperación internacional en materia de protección de testigos, pero sólo de forma genérica ${ }^{398}$.

392 SEOANE SPIEGELBERG, J. L., "Aspectos procesales del delito de tráfico de drogas", cit., pág. 349.

393 Vid. DO C 327, 07.12.1995, pág. 5.

394 Vid. DO C 010 de 11.01.1997, pág. 1.

395 Vid. DO L 164 de 22.06.2002, pág. 3, artículo 6.

396 Vid. DO L 82 de 22.03.2001, pág. 1, artículo 8.

397 CUBILLO LÓPEZ, I. J., La protección de testigos en el proceso penal, Navarra, 2009, pág. 27.

398 Cfr. a respecto el DOCUMENTO DE TRABAJO DE LA COMISIÓN DE LAS COMUNIDADES EUROPEAS, sobre la viabilidad de la legislación de la UE en el ámbito de la protección de testigos y colaboradores con la justicia (Bruselas, 13.11.2007). 
b) El uso de la videoconferencia.

En segundo, importante es la utilización siempre que necesaria, de la videoconferencia ${ }^{399}$ como forma de preservar la prueba, en especial en la hipótesis de testigos y colaboradores que están amenazados por los miembros de los clanes criminales. Dicho de otro modo, se trata de una medida excepcional y que no deberá consistir en regla general para la celebración de juicios diversos.

Según indica CHOCLÁN MONTALVO, la videoconferencia constituye un sistema técnico que permite la percepción por el Tribunal y las partes, a través de la vista y el oído, del testimonio o declaración emitida a distancia, sin desplazamiento físico del declarante hasta la sede del Tribunal ${ }^{400}$. 0 dicho en otros términos, es un elemento más de las nuevas tecnologías de la información y la comunicación, cuya implantación responde al objetivo de hacer más fluidas las relaciones entre órganos jurisdiccionales y a mejorar las relaciones entre la Administración y sus ciudadanos, en este caso, la Administración de Justicia 401.

El desarrollo y aplicación de las nuevas tecnologías es un fenómeno presente en la sociedad actual y su uso cobra especial importancia en la tramitación de los procedimientos judiciales ${ }^{402}$.

Asimismo ha sido la videoconferencia acepta y refrendada en un sinnúmero de normativas internacionales, tales como el Estatuto de la Corte Penal Internacional aprobado en Roma el 17 de julio de 1998; en Naciones Unidas a través del apartado C del capítulo VII del "Informe sobre administración de justicia en las Naciones Unidas", en el año 2000; en el Convenio relativo a la asistencia judicial en materia penal entre los Estados miembros de la Unión Europea (Acto del Consejo de 29 de mayo de 2000); la decisión marco del Consejo de la Unión Europea de 15 de marzo de 2001, relativa al Estatuto de la víctima en el proceso penal; las Reglas de procedimiento y prueba aprobadas para los Tribunales internacionales ad hoc para la antigua Yugoslavia y Ruanda; en el Convenio de las Naciones Unidas contra la Delincuencia Organizada Transnacional (15 de noviembre de 2000), etc ${ }^{403}$.

399 Monográficamente, Vid. BARROS, M. A., LAVOURA ROMÃO, C. E., "Internet e videoconferência no processo penal", Revista do Centro de Estudos Jurídicos, núm. 32, Brasília, 2002, págs. 116-125; DE LA MATA AMAYA, J., "La utilización de la videoconferencia en las actuaciones judiciales", Actualidad Penal, núm. 47-48, 2002, págs. 1267-1286; GOMES, R. C, "A videoconferência ou interrogatório on-line, seus contornos legais e a renovação do processo penal célere e eficaz", Revista do Instituto Iob, Porto Alegre, 2007, págs. 42-50; MONTESINOS GARCÍA, A., La videoconferencia como instrumento probatorio en el proceso penal, Madrid, 2009. Interesante también respecto al tema, Vid. NEÑEZ, E. V., CUESTA, E. P., "Aspectos procesales de la videoconferencia", La Ley Penal, vol. 5, núm. 46, 2008, págs. 82-102; ORTIZ PRADILLO, J. C., "El uso de la videoconferencia en el proceso penal español", Revista Brasileira de Ciências Criminais, vol. 15, núm. 67, São Paulo, 2007, págs. 164-211.

400 Vid. CHOCLÁN MONTALVO, J. A., "Videoconferencia y proceso penal", Actualidad Jurídica Aranzadi, en 18.3.2002.

401 Cfr., CATOIRA, A.A., "La tecnologización de la prueba en el proceso penal. La videoconferencia: objetivos y ventajas", Anuario da Facultade de Dereito da Universidade da Coruña, núm. 13, 2009, pág. 18.

402 RODRÍGUEZ GARCÍA, N., "Asistencia judicial penal para luchar contra la corrupción, el blanqueo de capitales y la delincuencia organizada. Algunos apuntes sobre el convenio de Unión Europea de 2000", cit., pág. 344.

403 Para uma consulta más completa repecto de la regulación de la videoconferencia em el âmbito normativo interno español, Vid. MONTESINOS GARCÍA, A., La videoconferencia como instrumento probatorio en el proceso penal, cit., págs. 41-47. 
La audición por intermedio de la videoconferencia se presenta también como una estrategia excepcional y tecnológicamente ideal para servir como modalidad de ejecución de las comisiones rogatorias internacionales, bien como para obtención de declaraciones de acusados, testigos, agentes encubiertos, peritos, etc., que por distintos motivos, no pueden estar directamente frente al Juez en el Tribunal.

Las ventajas son muchas. De inicio, deberá ser destacado que el sistema de videoconferencia es una nueva forma de contacto directo (personal), no necesariamente en el mismo local ${ }^{404}$.

Además, es una forma de "reunión virtual", de carácter excepcional, a ser utilizada en casos relativos a delitos complejos practicados por personas dotadas de alta peligrosidad y que hagan parte de alguna organización criminal. En este sentido, además de no haber disminución de la posibilidad de si verificar las características relativas a la personalidad, condiciones socioeconómicas, estado psíquico del imputado, entre otros, por medio de la videoconferencia, es cierto que hace mucho la doctrina contemporánea y la jurisprudencia admiten el interrogatorio y las oídas de testigos y peritos por otros medios, como por ejemplo, las cartas rogatorias, donde la ausencia de contacto físico entre el juez de la causa y el imputado u otros personajes, también no ocurre.

A modo de descripción de otras ventajas con la utilización de la videoconferencia, cítese como ejemplos: se evita en muchos casos, las fugas o rescates de detenidos pertenecientes a grupos criminales; se reducen los gastos con el transporte de acusados a los tribunales, en especial cuando tienen que ser oídos en otra ciudad, provincia o país; se evita el contacto directo del miembro del grupo organizado con personas que están fuera de la cárcel y que puedan pasarle informaciones u objetos ilícitos, etc ${ }^{405}$.

Con opinión semejante, señala MONTESINOS GARCÍA, que se puede resumira ocho las grandes ventajas relativas al uso de esta nueva tecnología: agilización de la actividad de los jueces, reducción de desplazamientos, mayor seguridad, mejor organización del trabajo en los órganos judiciales, reducción de costes, evita el contacto físico víctima-agresor, mejora las condiciones de acceso a la Justicia y permite el seguimiento de un juicio oral ${ }^{406}$.

Podemos incluso afirmar que la utilización de las nuevas tecnologías aplicadas al buen desarrollo de las actividades judiciales, viene a promover la integración de los ciudadanos con la era de la globalización mundial, dejando un rastro de actualización y modernidad en la justicia que empieza este siglo.

${ }^{404 G O M E S, ~ L . ~ F ., ~ " V i d e o c o n f e r e ̂ n c i a: ~ L e i ~ n . ~ 11.900, ~ d e ~ 08.01 .2009 ", ~ h t t p: / / w w w . l f g . c o m . b r . ~ L a ~ l e y ~}$ $11.900 / 2009$ ha reglamentado en el ámbito penal brasileño el uso de la videoconferencia, estableciendo todos los requisitos y formalidades para su utilización en el proceso penal, especialmente en tratándose de casos que envuelvan criminalidad de alta potencialidad. Ya en la doctrina española, se destaca la opinión de ORTIZ PRADILLO, al señalar que "la utilización de la videoconferencia aporta un sinnúmero de aplicaciones prácticas al proceso. En este sentido, de acuerdo con la amplitud de supuestos previstos en el tenor literal del art. 229.2 LOPJ (declaraciones, interrogatorios, testimonios, careos, exploraciones, informes, ratificación de los periciales y vistas) y con la genérica mención de los arts. 325 y 731 bis LECrim, sobre los motivos legales que amparan el empleo de la videoconferencia (utilidad, seguridad o de orden público, y cuando se trate de una comparecencia particularmente gravosa o perjudicial), puede afirmarse que casi cualquier intervención que deba hacerse durante el proceso penal por medio de la palabra es susceptible de poder realizarse a través de la videoconferencia". Vid. ORTIZ PRADILLO, J. C., "El uso de la videoconferencia en el proceso penal español", cit., pág. 188.

405 Vid. en la práctica de los Tribunales Superiores en España, las STSS 644/2008, de 10.10.2008; 777/2009, de 24.6.2009; 940/2011, de 27.9.2011; STC 345/2006, de 11.12.2006.

406 Con detalles sobre cada uno de estos aspectos, Vid. MONTESINOS GARCÍA, A., La videoconferencia como instrumento probatorio en el proceso penal, cit., págs. 53-57. 
En conclusión, se suele afirmar que la videoconferencia se presenta como un instrumento procesal con un inmenso potencial que posibilita acortar las distancias que conspiran contra un modelo procesal eficiente ${ }^{407}$. Sin embargo, una observación es imprescindible respecto al tema.

La celebración de un juicio con la presencia mediante videoconferencia de los acusados debe ser entendida desde planteamientos restrictivos y requiere prestar inexcusable atención a criterios de proporcionalidad que relacionen el sacrificio de sus derechos con la relevancia de las causas que aconsejan semejante medida ${ }^{408}$.

c) La inversión excepcional de la carga de la prueba.

Aunque muy discutible, hemos dejado por último el análisis de una tercera medida que dice respecto a la inversión excepcional de la carga de la prueba en hipótesis de delitos graves practicados por organizaciones criminales.

Según nuestro entendimiento, éste es un tema muy peligroso y complejo a la vez que no siempre razones utilitaristas eventualmente invocadas son suficientes para legitimar la inversión de la carga de la prueba en razón de evidente violación a principios como la legalidad, la presunción de inocencia, etc ${ }^{409}$.

El gran problema surge a partir del establecimiento de presunciones en contra el reo, que representan una inversión de la carga de la prueba, que pasa así de la parte acusadora a la acusada. Serian propuestas cuya finalidad se dirige de modo directo al combate a delitos particularmente graves. Un buen ejemplo sería el de entender que la posesión de una determinada cantidad elevada de droga haga presumir, salvo prueba en contrario, que está destinada al tráfico o que la posesión de grandes cantidades de dinero sin explicación del origen de la fortuna haga presumir su origen ilegal o que estamos ante un enriquecimiento de origen delictivo ${ }^{410}$.

Se trata por lo tanto de admitir como posibles las presunciones en contra el reo, o la inversión de la carga de la prueba con carácter excepcional para delitos muy graves a ejemplo de las actuaciones de la delincuencia organizada, especialmente en materia de narcotráfico y blanqueo de capitales ${ }^{411}$. La razón para la defensa de esta idea sería sencilla, 57.

407 MONTESINOS GARCÍA, A., La videoconferencia como instrumento probatorio en el proceso penal, cit. pág.

408 Vid. la STS 1651/2005, de 16.3.2005.

409 Para demostrar la problemática relativa a esta discusión en los diferentes ordenamientos juridicos, cítesecomo ejemplo algún entendimiento oriundo de la jurisprudencia de la Corte Constitucional Colombiana (Sentencia C-740/2003): "Por otra parte, cuando el Estado ejerce la acción de extinción de dominio, en manera alguna se exonera del deber de practicar prueba alguna y que sin más, traslade al afectado el deber de acreditar la lícita procedencia de sus bienes. Por el contrario, aquél se encuentra en el deber ineludible de practicar las pruebas necesarias para concluir que el dominio ejercido sobre los bienes no tiene una explicación razonable derivaba del ejercicio de actividades lícitas. Satisfecha esta exigencia, al afectado, en legítimo ejercicio de su derecho de defensa, puede oponerse a esa pretensión y allegar los elementos probatorios que desvirtúen esa fundada inferencia estatal. De no hacerlo, las pruebas practicadas por el Estado, a través de sus funcionarios, bien pueden generar la extinción de dominio, acreditando, desde luego, la causaa la que se imputa su ilícita adquisición. De acuerdo con esto, lejos de presumirse la ilícita procedencia de los bienes objeto de la acción, hay lugar a una distribución de la carga probatoria entre el Estado y quien aparece como titular de los bienes, pues éstepuede oponerse a aquella".

410 Cfr. SÁNCHEZ GARCÍA DE PAZ, I., La criminalidad organizada. Aspectos penales, procesales, administrativos y policiales, cit., págs. 251-252.

411 Nótese que esta idea ha sido desarrollada especialmente en la jurisprudencia española, básicamente en máteria de prueba indiciaria en delitos de blanqueo de capitales (SSTS 7842/2004, de 2.12.2004; 57/2006, de 
pues las dificultades en la persecución probatoria en casos relativos al crimen organizado son incontestables. Cítese como ejemplo, la ley del silencio y la cultura de la supresión de la prueba ${ }^{412}$.

Muy importante con relación a este tema es señalar que las normas tradicionales de la carga de la prueba que rigen el proceso penal son muy distintas a las aplicables en el proceso civil. Del mismo modo los distintos principios que informan estos procesos.

Como se sabe, la carga de la prueba ha sido ideada fundamentalmente para los procesos regidos por el principio dispositivo como el proceso civil, y su fundamento se encuentra en los principios de la lógica, la justicia distributiva y la igualdad de las partes ante la ley y el proceso, esto es, en la necesidad de darle a todas las partes una adecuada oportunidad y un guía seguro para la defensa de sus derechos y de su libertad ${ }^{413}$.

De otra parte es incuestionable que en el proceso penal cada parte deberá probar lo que convenga a sus intereses ${ }^{414}$ : a) las partes acusadoras deben justificar la imputación (prueba de cargo), y b) las partes deberán desvirtuar aquélla (prueba de descargo); teniendo en cuenta el derecho a la presunción de inocencia y su carácter iuris tantum, que determina que, en cualquier caso, corresponda a los acusadores la carga de la actividad probatoria ${ }^{415}$.

Desde otra vertiente, una observación digna de interés es ofrecida por GIMENO SENDRA al diferenciar la carga de la prueba en sentido formal de la carga de la prueba en

13.1.2006; 3932/2007, de 4.6.2007; 4188/2009, de 22.5.2009 y 1645/2011, 10.3.2011). Para una compresión más profunda de este tema, Cfr. DELGADO GARCÍA, D., "Configuración jurisprudencial del delito de blanqueo de dinero procedente del tráfico de drogas. ¿Inversión de la carga de la prueba?, www.cej.justicia.es/pdf/publicaciones/fiscales/FISCAL07.pdf. Esta misma autora en otro de sus trabajos llega a apuntar que existen parámetros en los que deberían encuadrarse la inversión excepcional de la carga de la prueba, a saber: 1) Se trataría del comiso de ganancias obtenidas en el ámbito de la delincuencia organizada; 2) Exigencia de una previa declaración de culpabilidad, mediante una sentencia condenatoria, en el supuesto del comiso definitivo y 3) Aumento patrimonial enmarcado en el periodo de tiempo a que se refiere la actividad criminal (con independencia de la procedencia directa o indirecta de la misma). En tales supuestos procedería el comiso de todos los bienes que hayan ingresado en el patrimonio del condenado salvo que ésteacreditase la legitimidad de su procedencia. Cfr. DELGADO GARCÍA, Mํa. D., "La prueba indiciaria en el Delitos de Lavado de Activos. Perspectiva del Fiscal", www.juschubut.gov.ar/03_direcciones/9.../PruebaPerspectiva-Fiscal.pdf, pág. 27. También interesante destacar la posibilidad de la inversión de la carga de la prueba en el ordenamiento jurídico brasileño (art. 60 de la Ley 11.343/2006 - Ley de combate a drogas y art. $4^{\circ}$, § 2º, de la Ley 9.613/1998 -Ley del Blanqueo de Capitales).

412 Con más detalles, Vid. FASSONE, E., "La valorización de la prueba en los procesos de criminalidad organizada", Poder Judicial, núm. 48, 1997, págs. 417-464. No se puede todavía olvidar, que existen entendimientos de parte de la doctrina, en el sentido de que el principio de presunción de inocencia impediría la inversión de la carga de la prueba para cualquier fin, siendo responsabilidad del Ministerio Fiscal demostrar también el origen criminal de los bienes encontrados en poder de los miembros de organizaciones criminales o derivados de practicas de lavado de dinero. Sobre esta discusión, Vid. SCARANCE FERNANDES, A., "O equilíbrio na repressão ao crime organizado", Crime Organizado. Aspectos processuais, cit., págs. 20-21.

413 Cfr. DEVIS ECHAndíA, H., Módulo de Derecho Civil y Procesal Civil de la Academia de la Magistratura, Lima, 1998, pág. 511.

414 Vid. FENECH, M., El Proceso Penal, cit., págs., 117-118.

415 Las exigencias que la presunción de inocencia comporta en el orden penal han sido recogidas por el TC. Así: 1으 la carga de la prueba sobre los hechos constitutivos de la pretensión penal corresponde exclusivamente a la acusación, sin que sea exigible a la defensa una probatio diabólica de los hechos negativos; $2^{\circ}$ ) sólo puede entenderse como prueba la practicada en el juicio oral bajo la inmediación del órgano judicial decisor y con observancia de los principios de contradicción y publicidad; $3^{\circ}$ ) de dicha regla general sólo pueden exceptuarse los supuestos de prueba preconstituida y anticipada, cuya reproducción en el juicio oral sea o se prevea imposible y siempre que se garantice el ejercicio del derecho o la posibilidad de contradicción; y $4^{\circ}$ ) la valoración conjunta de la prueba practicada es una potestad exclusiva del juzgador, que éste ejerce libremente con la sola obligación de razonar el resultado de dicha valoración. Véase la STC 34/1996, de 11.3.1996. 
sentido material. En la primera las normas de la carga de la prueba nos establecen a cuál de las partes, si la acusación o a la defensa, le corresponde realizar la actividad de la prueba sobre tales hechos controvertidos. Ya en sentido material, interesa cuál de ellas ha de soportar los efectos desfavorables de la sentencia en el supuesto de que alguno de los citados hechos no resultara suficientemente probado en el juicio. La diferencia apuntada por este autor sirve para llegar a la conclusión de que en el proceso penal, debido, de un lado, a la vigencia del principio de investigación y a la obligación que tiene el tribunal, de esclarecimiento de los hechos, y de otro, a la sumisión del Ministerio Fiscal al principio de legalidad, que ha de vincularse, tanto a pedir la condena del culpable, como la absolución del inocente y, sobre todo, como consecuencia de la aplicación directa e inmediata de la presunción de inocencia, no existe carga de la prueba en sentido formal ${ }^{416}$.

Hechas las aclaraciones preliminares respecto al tema, debemos dilucidar que existen algunas recomendaciones internacionales que hacen eco a una tendencia de acogida de la inversión excepcional de la carga de la prueba en se tratando de delitos graves practicados por organizaciones criminales como el blanqueo de capitales, la corrupción y el tráfico de drogas.

Una de ellas sería el Convenio de Naciones Unidas sobre el crimen organizado de 2000 (Convención de Palermo), que recomienda en su artículo 12.7 la posibilidad de exigir a un delincuente que demuestre el origen del presunto producto del delito u otros bienes expuestos a decomiso, con observancia a los principios del Derecho interno.

La Unión Europea en el documento "Prevención y control de la delincuencia organizada: Estrategia de la UE para el comienzo del nuevo milenio" de 2000 recomienda estudiar la posibilidad de que una vez dictada condena contra un delincuente por un delito grave pueda mitigarse la carga de la prueba en lo que se refiere al origen de los activos en su posesión, de modo que sea ella quien tenga que demostrar que ha adquirido dichos activos lícitamente; si el Tribunal no queda convencido podría declarar que dichos activos son productos ilegales del delito y confiscarlos (Recomendación 19) ${ }^{417}$.

Además, la propia Convención de Viena del año 1988, posibilita en su artículo 5. 7, que "cada una de las partes considerará la posibilidad de invertir la carga de la prueba respecto del origen lícito del supuesto producto u otros bienes sujetos a decomiso, en la medida en que ello sea compatible con los principios de su derecho interno y con la naturaleza de sus procedimientos judiciales y de otros procedimientos".

También en materia de confiscación de bienes oriundos del blanqueo de capitales, cítese las 40 Recomendaciones del GAFI, al recomendar la adopción de medidas que "requieran que el imputado demuestre el origen lícito de los activos eventualmente sujetos a decomiso, en la medida en que ese requisito sea compatible con los principios de sus respectivas legislaciones nacionales".

Se observa actualmente que estas propuestas, especialmente en se tratando de la aplicación de la sanción de confiscación de las ganancias procedentes de actividades delictivas, comienzan a incorporarse en algunos ordenamientos jurídicos europeos, de modo muy destacable en lo que se refiere al combate a las formas más graves de criminalidad. Como ejemplos cítese en el Derecho comparado los ordenamientos suizo (\&

416 GIMENO SENDRA, V., Derecho Procesal Penal, cit., pág.674.

417 Vid. SÁNCHEZ GARCÍA DE PAZ, I., La criminalidad organizada. Aspectos penales, procesales, administrativos y policiales, cit., págs. 252-253. 
59.3 inciso 2 y \& 20 b 1 del StGB), italiano (art. 12 sexies del Decreto Ley 306/1992, modificado por la Ley 45/2001) y el danês (art. 76 a del CPe) ${ }^{418}$.

Amén de estas orientaciones sobre la posibilidad excepcional de la inversión de la carga de la prueba en el proceso penal, deberá ser esclarecido una vez más que la gran mayor parte de la doctrina internacional señala en el sentido de que la carga de la prueba cabría de modo innegable a la acusación.

En palabras de MAIER, la carga de la prueba de la inocencia no le corresponde al imputado o, de otra manera, que la carga de demonstrar la culpabilidad del imputado le corresponde al acusador y, también, que toda la teoría de la carga probatoria no tiene sentido en el procedimiento penal. El imputado no tiene necesidad de construir su inocencia, ya construida de antemano por la presunción que lo ampara, sino que, antes bien, quien lo condena debe destruir completamente esa posición, arribando a la certeza sobre la comisión de un hecho punible ${ }^{419}$.

También en sentido crítico a la tesis de inversión de la carga de la prueba y de modo muy específico al ámbito del ordenamiento jurídico español, señala SEOANE SPIEGELBERG que es evidente que una exigencia de tal tipo vulneraría nuestros postulados constitucionales (art. 24.2 de la Carta Magna), pues no ofrece duda que la carga de la prueba sobre los hechos enjuiciados compete, de forma exclusiva, a las partes acusadoras, sin que le corresponda al inculpado acreditar su inocencia cuando el proceso criminal se fundamenta, como no puede ser de otra forma, en la presunción de la misma $^{420 .}$

Frente a los argumentos citados, nos parece particularmente interesante la tendencia apuntada por algún autor ${ }^{421}$ en lo atinente al Derecho español, donde mismo no aceptando en su ordenamiento la excepcional inversión de la carga de la prueba, se apunta a una solución que a priori no entraría en conflicto directo con el principio de presunción de inocencia. Dicho de otro modo, se trata de admitir una práctica jurisprudencial ${ }^{422}$ que de algún modo viene a solventar los problemas de prueba que a menudo se suscitan en muchos procesos por crimen organizado sin entrar directamente en conflicto con el principio de presunción de inocencia. Estamos nos refiriendo a la admisión de la prueba

\footnotetext{
418 Con más detalles, Cfr. SÁNCHEZ GARCÍA DE PAZ, I., La criminalidad organizada. Aspectos penales, procesales, administrativos y policiales, cit., pág. 253.

419 Cfr. MAIER, J., Derecho Procesal Penal. Fundamentos, Tomo I, Buenos Aires, 1999, pág. 507. Así el que acusa ha de probar el hecho penal y las correspondientes participaciones; el acusado puede mantener una postura pasiva, salvo cuando quiera probar datos que él sólo conoce y sólo él conoce bien. No existe una presunción de inocencia invertida. Si no hay prueba de cargo, practicada conforme a las garantías establecidas en el sistema, hay que absolver. Adoptando este mismo pensamiento, Cfr. la STC 120/2009, de 18.5.2009.

420 Vid. SEOANE SPIEGELBERG, J. L., "Aspectos procesales del delito de trafico de drogas", cit., pág. 357. Opinión semejante se puede encontrar con DELGADO GARCÍA al afirmar que "en el proceso penal la prueba de la culpabilidad del acusado incumbe en todo caso a la acusación, incluyendo en la culpabilidad los elementos objetivos y subjetivos integrantes del delito. No caben presunciones legales contra el reo ni tampoco la inversión de la carga de la prueba. Ello es claro desde nuestros principios constitucionales y desde nuestro derecho interno. Pero también desde los Convenios y Tratados Internacionales. Ahora bien, diferente a la culpabilidad es la materia relacionada con el comiso y la incautación de los bienes procedentes del delito". Cfr. DELGADO GARCÍA, Mạ. D., "La prueba indiciaria en el Delito de Lavado de Activos. Perspectiva del Fiscal", www.juschubut.gov.ar/03_direcciones/9.../Prueba-Perspectiva-Fiscal.pdf, pág. 24.

421 Cfr. SÁNCHEZ GARCÍA DE PAZ, I., Criminalidad organizada. Aspectos penales, procesales, administrativos y policiales, cit., pág. 254.

422 Vid. la SAN 609/2012, de 28.2.2012; SSTS 3613/1997, de 23.5.1997; 4188/2009, de 22.5.2009; 4188/2009, de 22.5.2009; 962/2009, de 26.2.2009.
} 
por indicios, también llamada prueba indirecta, circunstancial, conjetural o de presunciones, que lleva a estimar probado un hecho delictivo siempre que ello pueda deducirse de indicios, "hechos base", que reúnan una serie de características concretadas por la jurisprudencia constitucional.

Por medio de la prueba indiciaria lo que se hace es probar directamente hechos mediatos para deducir de éstos, aquéllos que tienen una significación inmediata para la causa $^{423}$.

Incluso MIRANDA ESTRAMPES anota que la eficacia probatoria de la prueba indiciaria dependerá de la existencia de un enlace preciso y directo entre la afirmación base y la afirmación consecuencia, de tal forma que de no existir el mismo su valor probatorio sería nulo, no por el simple hecho de concatenación de las presunciones, sino porque faltaría uno de los elementos fundamentales integrantes de su estructura ${ }^{424}$.

En nuestra opinión es fundamental aceptar la viabilidad del reconocimiento de la prueba indiciaria en casos de actuación de la delincuencia organizada, a la vez que menos peligrosa que la inversión de carga de la prueba que en su esencia puede venir a provocar violaciones a principios básicos de un Estado Constitucional de Derecho, en especial a la presunción de inocencia ${ }^{425}$.

Esto se explica según RAMOS MENDES a partir del hecho de que para llegar a una condena es necesario que, mediante una adecuada actividad probatoria de cargo, realizada con todas las garantías, practicada en juicio para hacer posible la contradicción y sin que los medios probatorios traídos al proceso se hayan obtenido violentando derechos o libertades fundamentales, quede desvirtuada esa inocencia y que el órgano judicial pueda obtener de esas pruebas convicción jurídica de la existencia de los elementos fácticos que constituyen el delito. Si no han quedado probados estos elementos fácticos, el Tribunal no puede entender sustituida la inicial inocencia por la culpabilidad y debe absolver el enjuiciado 426 .

También a favor de la aceptación de la prueba indiciaria en casos de criminalidad organizada, ZARAGOZA AGUADO pone en claro que para manejar una prueba de esta especie o sea, para utilizarla como prueba en juicio, debe cumplir una serie de requisitos. Caso contrario, realmente no podremos hablar de prueba indiciaria. Son los siguientes los requisitos: en primer lugar, naturalmente, la legitimidad en la obtención de los indicios y en su incorporación al proceso. No se puede afectar al principio de presunción de inocencia, que es uno de los principios básicos del proceso penal moderno, y por eso es necesario que todo el tema de la prueba indiciaria sea objeto de especial control judicial, para evitar precisamente la infracción de ese principio básico del proceso penal. En segundo, la pluralidad de indicios de hechos básicos, para que nosotros establezcamos una deducción de culpabilidad respecto a alguien cuando no tengamos pruebas directas,

423 Cfr. MITTERMAIER, C. J. A., Tratado da prova em matéria criminal ou exposição comparada, Campinas, 2004, pág. 441. 242.

424MIRANDA ESTRAMPES, M., La mínima actividad probatoria en el proceso penal, Barcelona, 1997, pág.

425 En la misma línea de pensamiento, se suele afirmar la "importancia de la prueba indiciaria, ya que normalmente no será posible acreditar a través de prueba directa cuál es la estructura interna de la banda, los medios concretos con los que cuenta, las conexiones entre sus miembros, el cometido de cada sujeto o la jerarquización del grupo". Cfr. las SSTS 7391/1996, de 20.12.1996; 6903/2006, de 30.12.2006; 7783/2009, de 14.12.2009; 279/2010, de 27.1.2010; 3579/2011, de 15.6.2011; 2889/2011, de 6.5.2011.

426 Cfr. RAMOS MÉNDEZ, F., El proceso penal, Barcelona, 1993, págs. 359-360. 
porque parece que uno sólo no va a ser suficiente, salvo que ese dato tenga una singular potencia incriminadora. Por fin, deben estar acreditados por pruebas directas. Demostrado el hecho base, habrá que establecerse la deducción o el hecho de consecuencia que es la persecución del delito o la participación del delincuente ${ }^{427}$.

De todo modo, el Tribunal Constitucional español ha tenido la oportunidad de consolidar el entendimiento de que la prueba indiciaria puede ser compatible con la presunción de inocencia: "el derecho a la presunción de inocencia comporta el derecho a no ser condenado sin pruebas de cargo válidas, de modo que toda Sentencia condenatoria debe expresar las pruebas en las que sustenta la declaración de responsabilidad penal, dichas pruebas han de haber sido obtenidas con las garantías constitucionales, haberse practicado normalmente en el juicio oral y haberse valorado y motivado por los Tribunales con sometimiento a las reglas de la lógica y la experiencia, de modo que pueda afirmarse que la declaración de culpabilidad ha quedado establecida más allá de toda duda razonable. Por último, ha de tenerse en cuenta que la existencia de indicios puede no ser suficiente para destruir la presunción de inocencia cuando no puede establecerse un engarce suficiente entre los indicios y el hecho que ha de ser probado conforme a las reglas de la lógica y la experiencia; así, cuando el hecho base excluye el hecho consecuencia, o cuando del hecho base no se infiere de forma inequívoca la conclusión, de modo que la inferencia sea tan abierta que dé pie para albergar tal pluralidad de conclusiones que ninguna pueda darse por probada" 428 .

Hechas las observaciones necesarias sobre las medidas procesales que podrán ser empeladas en la lucha contra el crimen organizado, importante poner de relieve que en tales circunstancias esta especie de delincuencia constituye en estos momentos, cuando menos, desde el punto de vista policial, una de las mayores amenazas contra la seguridad y el orden público, llegando en muchos casos en sus distintas manifestaciones a afectar de manera directa los gobiernos de ciertas naciones, casi siempre las menos desarrolladas política y económicamente, si bien no debemos olvidar que incluso en los países más avanzados del occidente, sus perniciosos efectos se van notando al infiltrarse y afectar a las decisiones que se toman en las cúpulas y centros de decisión, tanto políticos como económicos ${ }^{429}$.

Todos estos factores van de encuentro a la absoluta necesidad de se establecer un tratamiento procesal específico y eficaz cuando del combate a las formas más graves de criminalidad, en el sentido de perfeccionamiento de nuevas tecnologías y técnicas de

427 ZARAGOZA AGUADO, J., "Las pruebas en los casos de Criminalidad Organizada: com énfasis en las pruebas indiciarias", Revista do Ministério Público, año 4, núm. 16, Santo Domingo, 2010, págs. 32-35. También en sentido semejante, Vid. la ATS 15843/2010: "la prueba indiciaria exige para su validez y consiguiente eficacia probatoria que el Tribunal exprese em su resolución los hechos o datos indiciários que há tenido em cuenta, y que haga explícito el razonamiento a través del cual, partiendo de ellos, ha llegado a la convicción sobre la realidad del hecho que declare expresamente probado. Los indícios deberán estar plenamente probados, ser plurales (aunque de modo excepcional podrá ser suficiente uno solo cuando tenga una especial potencia probatória); deberán también ser convergentes y estar interrelacionados".

428 Cfr. la STC 123/2002, de 20.5.2002. De otra parte, la STS 433/2000, de 10.1.2000 define que "en algunos delitos graves practicados por grupos organizados, lo usual será contar sólo con pruebas indiciarias y que el cuestionamiento de su aptitud para provocar el decaimiento de la presunción de inocência sólo produciría el efecto de lograr la impunidad respecto a las formas más graves de delincuencia entre las que debe citarse el narcotráfico y las enormes ganâncias que de él se derivan, las que se encuentren em íntima unión com él, como se reconoce expresamente en la Convención de Viena de 1988".

429 PEÑA ECHEVERRÍA, M. J., "La delincuencia organizada y su problemática desde la óptica de la investigación policial", cit., pág. 104. 
investigación, de modo a neutralizar la expansión y crecimiento de estas formas graves de expansión de la violencia.

\section{I.3.2. Crimen organizado y la teoría del garantismo.}

I.3.2.1. Algunas notas esenciales respecto del garantismo penal y procesal. La evolución hacia el garantismo "integral" en el proceso penal.

\section{I.3.2.1.1. El Garantismo y la contribución de FERRAJOLI.}

Como punto de partida, conviene preguntarse qué hay que entender por garantismo ${ }^{430}$.

De inicio, se deberá hacer hincapié en el sentido de que hablar del garantismo corresponde también, obligatoriamente, hablar de los derechos fundamentales. También que, garantismo en siendo sinónimo de derechos fundamentales, no puede ser confundido con el abuso de derechos y ni con la impunidad. Este es el punto de partida básico para la comprensión de este tema.

Así, es posible extraer una premisa elemental: el derecho existe para tutelar los derechos fundamentales.

De igual modo, nos cumple señalar que los derechos fundamentales tienen una base edificada en las distintas revoluciones burguesas inglesa, americana y francesa junto a diversos movimientos sociales que se han encargado de plasmar los valores jurídicos de igualdad, libertad y fraternidad; a partir de los cuales se ha erigido y construido el Estado liberal de derecho y posteriormente, el Estado constitucional 431.

Nótese que, en este caso, el garantismo es un sistema socio-cultural que establece instrumentos jurídicos para la defensa de los derechos y consecuente defensa del acceso a los bienes esenciales a la vida de los individuos o de colectividades, que puedan entrar en conflicto con intereses de otros individuos, u otras colectividades, y sobretodo, con intereses del Estado. Estos instrumentos jurídicos son las garantías, o sea, las armas jurídicas que tienen por finalidad proteger los ciudadanos que por ventura vengan a abrir mano de parcela de su autonomía en beneficio de la colectividad, entregando al Estado el poder para que ello propicie seguridad, salud, educación, trabajo, etc.

De otra parte, en el modelo tradicional del garantismo, garantizar significa afianzar, asegurar, proteger, defender, tutelar algo; y, cuando en la cultura jurídica se habla de garantismo, ese "algo" que se tutela son derechos o bienes individuales. Podría decirse pues, como primera aproximación, que un derecho garantista establece instrumentos para la defensa de los derechos de los individuos frente a su eventual agresión por otros individuos y (sobre todo) por el poder estatal; lo que tiene lugar mediante el

430 Respecto al tema, con profundidad, Vid. FERRAJOLI, L., Derecho y razón. Teoría del garantismo penal, trad. Andrés Ibáñez, Ruiz Miguel, Bayón Mohino, Terradillos Basoco y Cantarero Bandrés (del original de 1989), Madrid, 1995; GIANFORMAGGIO, L., "Diritto e ragione tra essere e dover essere", Le ragioni del garantismo. Discutendo com Luigi Ferrajoli, Torino, 1993; MORA MOLINA, J. J., El garantismo jurídico de Luigi Ferrajoli, Huelva, 2004; VV.AA., Garantismo y Derecho Penal, J. O. Sotomayor Acosta coord., Bogotá, 2006; VV.AA., Garantismo penal integral, Calabrich, B., Fischer, D., Pelella, E., coords., Salvador, 2010; VV.AA., Garantismo. Estudios sobre el pensamiento jurídico de Luigi Ferrajoli, M. Carbonell y P. Salazar coords., Madrid, 2005.

431 Cfr. AGUILLERA PORTALES, R. E; LÓPEZ SÁNCHEZ, R., "Los derechos fundamentales en la filosofía jurídica garantista de Luigi Ferrajoli", Revista Letras Jurídicas, núm. 4, 2007, pág. 1, http://letrasjuridicas.cuci.udg.mx/. 
establecimiento de límites y vínculos al poder a fin de maximizar la realización de esos derechos y de minimizar sus amenazas ${ }^{432}$.

Pero no sólo esto, pues para la comprensión del garantismo, en especial cuando tratamos del "garantismo penal integral", deberá ser procedido un análisis más amplio, incluyendo la defensa también de los derechos colectivos frente a las grandes amenazas. De esta idea trataremos en apartado posterior.

Volviendo a la teoría jurídica actual, hablar del garantismo remite necesariamente a la obra de FERRAJOLI ${ }^{433}$, denominada "Derecho y razón", y que lleva por subtítulo "Teoría del garantismo penal", la cual está sustentada en una teoría general del garantismo. En este sentido, esta teoría general es la teoría del derecho propio del Estado constitucional de Derecho ${ }^{434}$.

En efecto, el modelo de Estado de Derecho propuesto por el citado maestro italiano muestra la incidencia concreta de la presencia de las normas de derechos fundamentales en el Ordenamiento de un Estado de Derecho, y sirve para mostrar las implicaciones normativas y estructurales de la afirmación según la cual sin derechos fundamentales no se puede hablar de Estado de Derecho ${ }^{435}$.

Según los enseñamientos de ANDRÉS IBÁÑEZ, la figura de FERRAJOLI ocupa hoy un lugar central en la reflexión teórica sobre el derecho; y lo hace de manera muy singular, de un modo del que, diría, no existen precedentes en tal ámbito disciplinar. Porque en este

\footnotetext{
432 GASCÓN ABELLÁN, M., "La teoría general del garantismo. A propósito de la obra de L. Ferrajoli. Derecho y Razón", Garantismo y Derecho Penal, VV.AA, J. O. Sotomayor Acosta coord., Bogotá, 2006, pág. 13. Esta misma autora, en otro trabajo, también señala que es importante visualizar "como primera aproximación que un derecho garantista establece instrumentos para la defensa de los derechos de los individuos frente a su eventual agresión por parte de otros individuos y (sobre todo) por parte del poder estatal; lo que tiene lugar mediante el establecimiento de límites y vínculos al poder a fin de maximizar la realización de esos derechos y de minimizar sus amenazas". Vid. GASCÓN ABELLÁN, M., "La teoría general del garantismo: rasgos principales", Garantismo: estudios sobre el pensamiento jurídico de Luigi Ferrajoli, Carbonell, M; Salazar, P, coords., Madrid, 2005, pág. 21.
}

433 FERRAJOLI utiliza la expresión "garantismo" bajo tres acepciones: en la primera, designa un modelo normativo de derecho (el modelo del Estado de Derecho); en la segunda, el garantismo es una teoría jurídica (la del iuspositivismo crítico como opuesta al iuspositivismo dogmático); y en la tercera, el garantismo es una filosofía política (la que funda el Estado en el reconocimiento y la protección de los derechos). Ambos significados apuntarán al axioma sobre el derecho como garantía de limitación al poder de aquí se establece la ya celebre frase del jurista italiano que reza que "El derecho es la garantía de los más débiles frente a los más fuertes. El derecho es la ley del más débil". Vid. FERRAJOLI, L., Derecho y razón. Teoría del garantismo penal, cit., págs. 851 y ss. En palabras de AGUILLERA PORTALES y LÓPEZ SÁNCHEZ, "actualmente, existe una interesante, abundante y prolija bibliografía de divulgación y crítica sobre el garantismo de Luigi Ferrajoli, pues estamos hablando de uno de los autores más señalados y renombrados dentro del nuevo paradigma jurídico del neoconstitucionalismo, cuyas ideas siguen teniendo tanto una gran aceptación como una gran crítica en el mundo jurídico americano y europeo". Vid. AGUILLERA PORTALES, R. E; LÓPEZ SÁNCHEZ, R., "Los derechos fundamentales en la filosofía jurídica garantista de Luigi Ferrajoli", cit., pág. 2.

434 En este mismo sentido, FISCHER nos enseña que "el garantismo penal no es simplemente legalismo, pues la teoría está fundamentada en una visión teórica de un derecho propio de un Estado social y democrático". Vid. FISCHER, D., "O que é garantismo penal (integral)?", Garantismo Penal Integral, Salvador, 2010, pág. 26.

435 Incluso, sostiene con absoluta claridad AINAIGA VARGAS que "para hablar del Estado constitucional hemos de partir de una premisa indispensable. No todo Estado en la configuración moderna constituye en sí mismo un Estado constitucional, toda vez que se impone no sólo la existencia de un ordenamiento jurídico fundamental, que sea la norma de las normas, causa motor del Estado, sino que tal ordenamiento debe estar impregnado de valores humanistas a favor de los derechos y libertades fundamentales y de todo el conjunto de técnicas y procedimientos que hacen posible su existencia y disfrute ante la invasión, intromisión o actuaciones negatorias en su contra, sea del poder público o de algún sujeto privado en su dimensión física o jurídica". Vid. AINAGA VARGAS, Ma․ C., "Nota sobre el Estado Constitucional Democrático de Derecho", Revista Letras Jurídicas, vol. 7, 2003, http://www.letrasjuridicas.com. 
autor se da la más afortunada combinación de rigor lógico-formal y riqueza de contenidos, de formación filosófica y conocimiento jurídico (experiencia práctica incluida), de empeño cultural y compromiso civil ${ }^{436}$.

En la construcción de FERRAJOLI, nunca es demás destacar que las garantías son verdaderas técnicas insertas en el ordenamiento que tienen por finalidad reducir la distancia estructural entre la normatividad y la efectividad, posibilitando así, una máxima eficacia de los derechos fundamentales (pero de todos los grupos de derechos fundamentales) según determinado por la Constitución 437.

Destaca además el citado autor que el garantismo viene así a configurarse al mismo tiempo como doctrina de justificación y como teoría crítica del derecho vigente dirigida a identificar las carencias de garantías que deslegitiman políticamente y, cuando las garantías se hallen establecidas por las constituciones, también jurídicamente el derecho existente; y, por consiguiente, a poner de relieve los perfiles de injusticia y, a la vez, de invalidez respecto a los criterios axiológicos o constitucionales que valen como fuentes de justificación ${ }^{438}$.

De otro modo, deberá hacerse hincapié en el sentido que desde el modelo garantista el Estado de Derecho no solamente es un Estado legal sino que además es un Estado caracterizado por la funcionalización de todos los poderes del Estado a servicio de las garantías de los derechos fundamentales de los ciudadanos, mediante la incorporación limitativa en su constitución de los deberes públicos correspondientes, en donde cabe destacar la legalidad en sentido estricto. De esta forma, según la idea de garantismo propuesta por FERRAJOLI, el contenido de la ley deberá estar condicionado por los principios éticos que contienen el constitucionalismo.

Cabe considerar entonces que la acepción prevalente de la palabra "garantismo" es de "garantismo penal"439. Es, en efecto, en el ámbito del derecho penal donde el garantismo se ha desarrollado como teoría y como práctica jurídica, en oposición, primero, a los contundentes legados de la legislación fascista y, después, a las numerosas leyes excepcionales y de emergencia quehan reducido, en contra de los principios constitucionales, el ya débil sistema de garantías contra el arbitrio punitivo ${ }^{440}$.

${ }^{436}$ ANDRÉS IBÁÑEZ, P., "Luigi Ferrajoli: los derechos rigurosamente en serio", Revista Nexos, México, 2008, pág. 39.

437 Vid. FERRAJOLI, L., Derechos y garantías: la ley del más débil, cit., pág. 25. Como bien señalado por MARTÍ MÁRMOL, "el paradigma constitucional incluye asimismo, según Ferrajoli, los siguientes grupos de derechos fundamentales: derechos políticos (o de autonomía pública), derechos civiles (o de autonomía privada), derechos liberales (o de libertad) y derechos sociales". Vid. MARTí MÁRMOL, J. L., "El fundamentalismo de Luigi Ferrajoli: un análisis crítico de su teoría de los derechos fundamentales", Garantismo: estudios sobre el pensamiento jurídico de Luigi Ferrajoli, M. Carbonell y P. Salazar coords., Madrid, 2005, pág. 384.

438 Vid. FERRAJOLI, L., "El paradigma del Derecho Penal Mínimo", Garantismo y Derecho Penal, Juan Oberto Sotomayor Acosta coord., Bogotá, 2006, pág. 64.

${ }^{439}$ La expresión "garantismo", en su sentido estricto de "garantismo penal", surgió, en la cultura jurídica italiana de izquierda en la segunda mitad de los años setenta, como respuesta teórica a la legislación y a la jurisdicción de emergencia que, por aquel entonces, redujeron de diferentes formas el ya de por sí débil sistema de garantías procesales. En este sentido, el garantismo aparece asociado a la tradición clásica del pensamiento penal liberal. Vid. FERRAJOLI, L.,"Garantías", Democracia y garantismo, Madrid, 2008, pág. 61.

440 FERRAJOLI, L., "Garantías y Derecho Penal", Garantismo y Derecho Penal, J. O. Sotomayor Acosta coord., Bogotá, 2006, págs. 3-4. 
Desde el planteamiento que aquí se sostiene, en la perspectiva garantista del proceso penal ${ }^{441}$, aunque las eventuales estrategias en su discurso de aplicación, no se presten a inviabilizar la celeridad de los procedimientos y ni a la esperada eficacia del Derecho penal, pues, muy al contrario, el respeto a las garantías individuales y colectivas demuestra la consciencia de las limitaciones inherentes al conocimiento humano y la madurez social en la ardua tarea del ejercicio del poder.

No se puede negar que en los últimos años hemos presenciado una clara tendencia hacia el garantismo y hacia la toma en consideración del acusado como titular de derechos procesales, que ha conducido a un mayor grado de "humanización" del proceso penal ${ }^{442}$.

Pero, a nuestro juicio, hablar del garantismo no puede consistir en utilización de un radicalismo injustificable e irresponsable como ha sido defendido por algunas personas 443. El garantismo no se parece a una doctrina "cerrada" y blindada a la realidad criminológica actual por la cual vivimos, bien como no se puede considerarlo una concepción acabada y bien definida ${ }^{444}$.

Alguna autora, así GIANFORMAGGIO, al comentar respecto al garantismo defendido por FERRAJOLI, ha señalado que la teoría del garantismo no es reconducible, pese a las reiteradas profesiones de fe iuspositivista y utilitarista del autor, a una corriente o a una concepción bien definida, es más, las teorías a las que aparece más próxima no son aquellas de las que la teoría del garantismo es, y se declara, mayormente tributaria ${ }^{445}$.

En esta línea de pensamiento, el garantismo en sentido amplio, integral y proporcional, sería pues una forma de visualizar el derecho como sifuera algo preocupado con aspectos formales y sustanciales que deben siempre existir para que el derecho sea

441 Incluso es de suma importancia destacar lo que defiende el profesor IBÁÑEZ, al señalar que se debe analizar la existencia actualmente de un "garantismo dinámico, que es el que transciende el marco del proceso penal y también el de la mera garantía individual de carácter reactivo para ampliarse al aseguramiento de otros derechos y de los correspondientes espacios hábiles para su ejercicio". Vid. ANDRÉS IBÁÑEZ, P., "Garantismo: una teoría crítica de la jurisdicción", Garantismo: estudios sobre el pensamiento jurídico de Luigi Ferrajoli, Carbonell, M., Salazar, P, coords., Madrid, 2005, pág. 60.

442 En este sentido, Vid. GASCÓN INCHAUSTI, F., "Los procesos penales en Europa: líneas de evolución y tendencias", Revista de Derecho Procesal, 2009, pág. 471.

443 Por esta razón, en lo relativo a una visión crítica del garantismo, sostiene VÉLEZ RODRÍGUEZ que "desdeñoso de ofrecer alternativas para enfrentar los nuevos problemas se mantiene en una posición exclusivamente opositora de cualquier medida político criminal con la que se busque hacer frente a alguna disfunción social que de alguna manera entre en contradicción con los principios en los que se sustenta. Esto ocasiona que ante problemas reales, como lo es el crimen organizado, la postura garantista no encuentre comprensión dentro de una sociedad que reclama soluciones". Vid. VÉLEZ RODRÍGUEZ, L. A., "La lucha contra el crimen organizado como dilema para el Estado de Derecho. Aproximación a una alternativa", Revista Juridica, vol. 5, núm. 2, Caldas, 2008, pág. 101.

${ }^{444}$ Siguiendo esta línea de pensamiento, CARBONELL SÁNCHEZ es más incisivo y objetivo al defender que "la teoría garantista de Luigi Ferrajoli se presenta como un paradigma inacabado, como una obra en el medio del camino, carente de complementación y debida comprensión". Vid. CARBONELL SÁNCHEZ, M., "La garantía de los derechos sociales en la teoría de Luigi Ferrajoli", Garantismo: estudios sobre el pensamiento jurídico de Luigi Ferrajoli, Carbonell, M; Salazar, P, coords., Madrid, 2005, pág. 171.

445 GIANFORMAGGIO, L., "Diritto e ragione tra essere e dover essere", Le ragioni del garantismo. Discutendo con Luigi Ferrajoli, cit., pág. 26. Incluso, esta misma autora, Leticia Gianformaggio, resalta en concreto la similitud entre la teoría de la interpretación de la Constitución de Ferrajoli y la de Dworwin. Vid. GIANFORMAGGIO, L., "Diritto e ragione tra essere e dover essere", cit., págs. 34 y ss. Incluso GASCÓN INCHAUSTI ha sostenido con claridad que "que el camino del garantismo no es ni uniforme ni cerrado: no está cerrado, porque todavía existen piezas o aspectos, en todos los sistemas procesales penales, en que el sujeto pasivo se encuentra en posición de mayor debilidad; y no es un camino uniforme, porque no todos los ordenamientos lo han recorrido del mismo modo ni han llegado, movidos por esta tendencia, a resultados homogéneos". Vid. GASCÓN INCHAUSTI, F., "Los procesos penales en Europa: líneas de evolución y tendencias", cit., pág. 480. 
válido. Esa unión de estos dos aspectos tendría la función de rescatar la posibilidad de garantizarse, efectivamente, a los sujetos de derecho, todos los derechos fundamentales existentes y necesarios a su condición de vida como ser portador de dignidad humana.

El garantismo penal en realidad revela la necesidad de una precisa ponderación entre la indispensable tutela de la dignidad de la persona, mediante la protección de los derechos fundamentales individuales, y la adecuada preservación de los mecanismos e instrumentos investigatorios y procesales capaces de propiciar condiciones para que el Estado realice de modo eficaz el deber de prestar seguridad a los ciudadanos ${ }^{446}$.

\section{I.3.2.1.2. El Derecho Procesal penal y la teoría del garantismo.}

En un Estado democrático contemporáneo, la eficacia concreta de los derechos constitucionales y legalmente asegurados a los ciudadanos, depende de la garantía de la tutela jurisdiccional efectiva, en razón de que sin ella, el titular del derecho no dispone de la protección necesaria del Estado a su pleno derecho.

Entonces, la tutela jurisdiccional es, por lo tanto, no sólo una garantía, pero, ella misma, un derecho fundamental, cuya eficacia irrestricta es necesaria asegurar, en respeto a la propia dignidad humana ${ }^{447}$.

Nótese que, en este caso, la efectividad de la protección se encuentra en gran parte pendiente de la actividad jurisdiccional, principal responsable por dar o negar la tutela de los derechos fundamentales ${ }^{448}$. En consecuencia, el fundamento de la legitimidad de la jurisdicción y la independencia del poder judicial está en el reconocimiento de su función de garante de los derechos fundamentales resultantes de la Constitución. Y es por esto que se debe considerar que la función del juez es actuar como garantidor de los derechos de la persona sometida al proceso penal.

Partiendo de esta consideración, se concluye como premisa preliminar que existe una relación muy próxima y conexa entre las garantías y el proceso ${ }^{449}$. Pero, es importante destacar que el garantismo no tiene ninguna relación con el mero legalismo o formalismo.

Y más que esto, pues del reconocimiento de la existencia de un derecho sustancial a un proceso justo en las Constituciones y en los documentos de derecho internacional, se puede extraer la importancia que han asumido las garantías constitucionales del proceso en el pensamiento jurídico contemporáneo.

\footnotetext{
446 Del mismo modo dice GASCÓN INCHAUSTI respecto al garantismo en el proceso penal que "el centro de atención de desplaza hacia el sujeto pasivo del proceso penal y se asienta la idea de que la aplicación judicial del Derecho penal ha de ser respetuosa con una serie de garantías y de límites vinculados con la dignidad del ser humano, es decir, con los derechos fundamentales, cuyo alcance y contenido experimentan, por otra parte, un importante desarrollo, en especial en el ámbito de la administración de justicia". Vid. GASCÓN INCHAUSTI, F., "Los procesos penales en Europa: líneas de evolución y tendencias", cit., pág. 471.

447 Vid. GRECO, L., "Garantias fundamentais do processo: o processo justo", http://www.mundojuridico.adv.br.

448 Por esta razón, deberá ser destacada "la importancia que en el conjunto de las instituciones del Estado desempeñan los órganos judiciales, al ser los garantes últimos del respetoa las normas jurídicas por parte de ciudadanos y de poderes públicos, que, con la evolución histórica, se ha ido acentuando, por ejemplo, la necesidad de que los titulares de la potestad jurisdiccional gocen de independencia, o la de que sus actuaciones y su régimen jurídico se encuentren sometidos al principio de legalidad". Vid. LLOBREGAT, J. G, Constitución y Derecho Procesal. Los fundamentos constitucionales del Derecho Procesal, cit., págs. 40-41.

449 En este sentido, es correcto en nuestra opinión señalar que las garantías se prestan a preservar y asegurar los derechos fundamentales consagrados en la Constitución, ganando efectividad mediante el proceso, instrumento técnico y público de realización de derechos frente a los tribunales.
} 
Surge de este enlace, el tema del garantismo procesal ${ }^{450 .}$

Ante este escenario, siguiendo la doctrina defendida por PICÓ I JUNOY, deberá recordarse que durante la segunda mitad del siglo XX, surgió un fenómeno de especial relevancia para el derecho procesal, a saber, el de la "constitucionalización de las garantías procesales", que ha venido a asegurar, por vía de los textos constitucionales, en el ámbito nacional, y de tratados y convenios supra estatales de derechos humanos, en el ámbito internacional, un mínimo de garantías a favor de las partes, que deben presidir cualquier modelo de enjuiciamiento, Y a través del carácter normativo de estos textos, y de su aplicación directa e inmediata, esto es, su alcance jurídico-positivo, se pretendió evitar que el futuro legislador desconociese o violase tales garantías así como que el juzgador no se viese vinculado por las mismas en la dirección de los procesos ${ }^{451}$.

Partiendo de esta premisa del desarrollo del tema de las garantías constitucionales, es cierto afirmar que la doctrina garantista propone una visión alternativa para el moderno proceso penal, direccionando sus objetivos a la preservación de los derechos y garantías de los ciudadanos o hasta mismo de la propia sociedad.

Se busca pues, un proceso penal que siga los ideales de los preceptos constitucionales, poniendo las garantías y derechos fundamentales como pilares destacables en la búsqueda de un proceso justo.

Parte de la idea de que el Estado democrático fundamenta su legitimidad en el reconocimiento, en la defensa y en las garantías de las libertades de los ciudadanos, alejándose de la idea de que el Estado sea un instrumento de autoritarismo.

Efectivamente, parafraseando FERRAJOLI, parece evidente que de nada servirá un sistema formalmente garantista y efectivamente autoritario. Esta falacia garantista consiste en la idea de que son suficientes las razones de un "buen" derecho, dotado de sistemas avanzados y actuales de las garantías constitucionales, para contener el poder y poner los derechos fundamentales garantizados de los desvíos y arbitrariedades.

Con arreglo a lo anteriormente afirmado, se puede afirmar que no existen Estados democráticos que, por sus sistemas penales, puedan ser considerados plenamente garantistas o antigarantistas, sino que existen diferentes grados de garantismo y el punto central de esta cuestión estaría en el alejamiento entre el ser y el deber ser.

En palabras de uno de los defensores de la "escuela garantista" en España, LORCA NAVARRETE, el Derecho procesal es funcionalmente autónomo por cuanto que su

450 Para una comprensión más detallada del tema Vid. ALVARADO VELLOSO, A., Garantismo procesal contra actuación judicial de oficio, Valencia, 2005; LORCA NAVARRETE, A. Mà., Estudios sobre garantismo procesal. El derecho procesal conceptuado a través de la metodología del garantismo procesal: el denominado "Derecho de la garantía de la función jurisdiccional", San Sebastián, 2009. De se destacar que se percibe que en el momento actual, existe una intensa confrontación de ideas entre los procesalistas respecto a las bases del "garantismo procesal". Así se denota de los estudios de Lorca Navarrete, Montero Aroca y Picó I Junoy en España, Alvarado Velloso en Argentina, Barbosa Moreira en Brasil, Franco Cipriani y Girolamo Monteleone en Italia, Ariano Deho en Perú, etc.

451PICÓ I JUNOY, J., "El derecho procesal entre el garantismo y la eficacia: Un debate mal planteado", VV.AA., Proceso civil e ideología. Un prefacio, una sentencia, dos cartas y quince ensayos, Valencia, 2006, pág. 111. Para un estudio más proficuo, Vid. del mismo autor: Las garantías constitucionales del proceso, Barcelona, 1997. 
cometido es actuar la norma en tanto en cuanto se aplique la norma procesal con arreglo a su propio y autónomo sistema de garantías ${ }^{452}$.

Nosotros consideramos que cuando se habla de un garantismo procesal, en esencia, la cuestión se refiere a tratar de buscar un sistema procesal donde se compatibilice el respeto por las garantías del debido proceso y al mismo tiempo se obtenga la eficacia de dicho proceso. Sería el encuentro de la tan deseada "armonía procesal penal", marcada por el equilibrio entre la eficiencia y las garantías.

Y más que esto, pues el garantismo procesal supone, simplemente, la adecuación del procedimiento conforme al cual se deben desarrollar los procesos a las exigencias y mandatos que el legislador y especialmente la Constitución prescriben al consagrar y proteger la garantía del proceso judicial. Por lo tanto, es propio de un Estado de Derecho.

Presenta además este pensamiento dogmático, una fuerte carga de obediencia a la normativa constitucional, fundando sus pilares en un amplio mantenimiento de la vigencia de la Constitución ${ }^{453}$.

Así es que el garantismo procesal de justificación constitucional supone la puesta en práctica de las garantías que las leyes procesales se contienen, conjuntamente con las que poseen proyección constitucional, a través de una postura garantista plenamente comprometida con la realidad constitucional de aquí y ahora ${ }^{454}$.

Es licito así de esta forma, que comsideremos la importancia del garantismo procesal, sea como modelo normativo de la función jurisdiccional estatal, sea como una teoría jurídica, marcada por la búsqueda de un proceso vinculado a los valores éticos prestigiados por la Constitución, sea como base de la democracia sustancial.

Interesante por fin, dentro del ámbito estricto del garantismo procesal penal, destacar que él, como metodología, enseña que a la norma procesal penal no tanto le ha de interesar que la represión incumba a la jurisdicción ordinaria, cuanto que la norma procesal penal sea garantía de aplicación de la norma penal. En esencia: que el Derecho procesal penal no es represor y ha de ser garantista 455 .

Y más, para sí atingir el equilibrio en el proceso penal, deberá tener en cuenta que la eficacia del proceso sin garantismo es inadmisible desde un punto de vista constitucional, y el garantismo sin eficacia tampoco es aceptable si lo que se pretende es lograr la tutela judicial más justa posible, y no se puede olvidarque la "Justicia" también es un valor

452 LORCA NAVARRETE, A. Mํ.., Estudios sobre garantismo procesal. El derecho procesal conceptuado a través de la metodología del garantismo procesal: el denominado "Derecho de la garantía de la función jurisdiccional", cit., pág. 2.

${ }^{453}$ Como pone de manifiesto ALVARADO VELLOSO, "el garantismo procesal no tolera alzamiento alguno contra la norma fundamental; por lo contrario, se contenta modestamente con que los jueces -insisto que comprometidos sólo con la ley declaren la certeza de las relaciones jurídicas conflictivas otorgando un adecuado derecho de defensa a todos los interesados y resguardando la igualdad procesal con una clara imparcialidad funcional para, así, hacer plenamente efectiva la tutela legal de todos los derechos". Vid. ALVARADO VELLOSO, A., "El garantismo procesal", VV.AA., Activismo y garantismo procesal, Córdoba, 2009, pág. 85.

454 LORCA NAVARRETE, A. Mà., Estudios sobre garantismo procesal. El derecho procesal conceptuado a través de la metodología del garantismo procesal: el denominado "Derecho de la garantía de la función jurisdiccional", cit., pág. 4.

455 LORCA NAVARRETE, A. Mạa, "Garantismo procesal y participación ciudadana en la administración de justicia mediante la institución del jurado. El modelo español", Revista del Instituto de la Judicatura Federal, núm. 25, México, 2008, pág. 91. 
supremo en la mayoría de los textos constitucionales, ya venga proclamada expresamente o bien lo sea de forma implícita ${ }^{456}$.

Como conclusión y siguiendo esta línea del garantismo procesal penal, deberá ser deducido el entendimiento de que el moderno proceso penal tiene un doble fundamento que viene a justificar su plena existencia: instrumentalidad y garantismo. Por medio de estos dos postulados se hace viable la realización de la justicia correctiva y la aplicación de la sanción; y de otro, sirve como instrumento efectivo de garantía de los derechos y libertades individuales, protegiendo a los ciudadanos contra eventuales abusos.

\section{I.3.2.1.3. El punto ideal: el garantismo integral y proporcional.}

Hemos visto hasta ahora que el garantismo encuentra su antítesis en el Derecho penal máximo y en el utilitarismo procesal (eficacia antigarantista). Del mismo modo, que es la matriz constitucional garantista, un importante instrumento de resistencia al creciente movimiento de endurecimiento del Derecho penal y procesal penal, con sus manifestaciones basadas en la idea de guerra contra los enemigos.

Garantista, según nuestra opinión será el pensamiento que se presente de acuerdo con la consideración harmónica de todos (por esto se debería hablar en garantismo penal integral y proporcional) los valores, principios y reglas constitucionales, y no sólo en la consideración parcial de la necesaria protección de los derechos fundamentales individuales.

Como bien recordado por FELDENS, aunque sea innegable que la expresión "garantismo" permanezca ligada a la figura de FERRAJOLI, al contrario do que muchos piensan, el modelo del citado autor italiano es tan sólo uno de los modelos garantistas y más, ser garantista no significaría adoptar una postura inmune, en género, a la intervención jurídico-penal, y tampoco pugnar por la aplicación procesal más benéfica al acusado 457 .

Surge entonces la necesidad de comprender que al lado de las garantías penales y procesales del investigado o imputado, defendidas de forma brillante en la teoría de FERRAJOLI, surgen otros bienes jurídicos de la sociedad que deben ser igualmente tutelados por el proceso penal, en consecuencia de los mandamientos de protección estipulados en el propio ordenamiento constitucional, reforzados por los Tratados internacionales firmados por los Estados.

De gran importancia es también destacar que el argumento de que el derecho y el proceso penal tienen por función única la garantía del imputado, peca por el excesivo individualismo, olvidándose de la existencia de bienes jurídicos colectivos, del contenido objetivo-material de los derechos fundamentales y también de los intereses sociales ${ }^{458}$.

456 PICÓ I JUNOY, J., "El derecho procesal entre el garantismo y la eficacia: Un debate mal planteado", cit., pág. 112.

457 FELDENS, L., Direitos fundamentais e direito penal: garantismo, deveres de proteção, princípio da proporcionalidade, jurisprudência constitucional penal, jurisprudência dos tribunais de direitos humanos, Porto Alegre, 2008, pág. 66.

458 Vid. BALTAZAR JR, J. P., Crime organizado e proibição de insuficiência, Porto Alegre, 2010, pág. 92. El mismo autor incluso señala con absoluta claridad que "si el derecho y el proceso penal no prestasen para nada, del punto de vista de la protección de los bienes jurídicos, pero tuviesentan sólo la finalidad de garantizar losderechos de los acusados, la mejor solución, que no puede ser defendida seriamente, sería su abolición, caso en que tendríamos el grado máximo de protección del imputado. Más que esto, el derecho y el proceso penal 
Mismo estando de acuerdo en el sentido de que la función del proceso penal contemporáneo sea la de instrumentalidad garantista, nos parece incompleta la visión generalmente difundida, pues presenta demasiada relevancia a la defensa de los derechos y garantías individuales y concretas del ciudadano. Nos presenta así que al lado de las garantías del individuo sometido a la persecución penal, existen otros bienes jurídicos que del mismo modo deberán ser protegidos e igualmente merecedores de tutela. Cítese como ejemplo, los derechos de la colectividad a la seguridad plena en situaciones provocadas por la actuación de los grandes grupos de delincuentes organizados, a ejemplo de los delitos de narcotráfico y terrorismo.

Dicho en otros términos, no se debe privilegiar el garantismo tan sólo en el ámbito del ciudadano en el sentido individual, fortaleciendo este aspecto de modo a anular la necesaria defensa de los intereses de la colectividad, de suerte a crear un hipergarantismo en detrimento de los demás derechos de la sociedad.

Correcto pues, el establecimiento de un garantismo integral, buscando, como bien defendido por SCARANCE FERNANDES, un equilibrio entre la exigencia de asegurar al investigado, al acusado y al condenado, la aplicación de sus garantías fundamentales y la necesidad de mayor eficiencia del sistema persecutorio para la seguridad social, con el objetivo de proteger los demás intereses sociales tutelados ${ }^{459}$.

Pues bien, a partir de estas premisas deberá ser establecido un garantismo integral y proporcional, lo que significa alejar y abandonar una visión monocular e incompatible con la realidad, pautada en la protección de los bienes jurídicos únicamente del imputado, en cualquier situación. El garantismo integral significa la consideración equilibrada y proporcional de todos los intereses jurídicos envueltos en el proceso penal y garantizadoen la Constitución y en los tratados de derechos humanos. Y en este caso, el principio de la proporcionalidad justamente debe ser visto como el "fiel de la balanza", para auxiliar la interpretación adecuada a se buscar en el equilibrio, hace mucho ya perdido, entre los bienes jurídicos en juego, de suerte a se hablar en un garantismo integral y proporcional ${ }^{460}$.

El problema que se observa muchas veces en las discusiones respecto al garantismo penal, se refiere al hecho de que ha sido encontrado un sinnúmero de manifestaciones en la jurisprudencia y en la doctrina, con una simple referencia a los postulados del "garantismo penal", sin que se comprenda, en esencia, cuál la extensión real y los criterios verdaderos de su aplicación.

En muchas situaciones, se percibe una distorsión de los reales pilares fundantes de la doctrina de FERRAJOLI. Muchos han confundido el garantismo con la impunidad y con la abolición de todo el sistema de punición penal ${ }^{461}$. La verdad es que ha sido difundido un

perderían su legitimidad, que recurre justamente del pretender ser el resultado de una ponderación, que demuestre su adecuación, necesidad y proporcionalidad para una situación de colisión representada por la quiebra de la norma penal que pretendía mantener la paz jurídica". Cfr. BALTAZAR JR, J. P., Crime organizado e proibição de insuficiência, cit., pág. 93.

459 SCARANCE FERNANDES, A., "Equilíbrio entre a eficiência, garantismo e crime organizado", cit., pág. 231.

460 MENDONÇA, A. B., "A reforma do Código de Processo Penal sob a ótica do garantismo integral", Garantismo penal integral, Salvador, 2010, pág. 180.

461 Vid. como buen ejemplo, el trabajo de LARRAURI PIJOAN, E., "Criminología crítica: Abolicionismo y Garantismo", VV.AA., Garantismo y Derecho Penal, cit., págs. 65-103. 
garantismo penal únicamente monocular y hiperbólico ${ }^{462}$, evidenciando de forma aislada la necesidad de protección solamente de los derechos de los ciudadanos que se encuentran en posición de procesados o condenados por la justicia penal ${ }^{463}$.

Incluso, CHIAVARIO al referirse al tema del denominado "despertar garantista", ocurrido a principios de los años noventa, llega a afirmar que es un garantismo que, sin embargo, no es de todo cristalino, no es de todo positivo: garantismo que muchas veces se expresa en la acumulación de requisitos formales por parte de los jueces, las previsiones de nulidad se diseminan de nuevo, dando cabida a la sutil habilidad del abogado, más que a su capacidad de persuasión sobre la base de los hechos y los argumentos de fondo ${ }^{464}$.

Ahora bien, como pone de manifiesto DÍEZ RIPOLLÉS, de modo crítico, el garantismo no nos da las claves para interpretar los recientes cambios político-criminales, porque éstos obedecen a una nueva forma de configurar y modelar el control social 465 .

En esta línea de análisis, en particular en lo referente al combate al crimen organizado, se afirma que el garantismo tradicional se ha mantenido en el mundo de los ideales, y en el terreno de la crítica, sin plantear alternativas de solución viables. Además, la determinación de la línea de política penal contra la criminalidad organizada debe encuadrarse en la discusión de la modernización del Derecho penal, esto es, de la adaptación de las categorías a las nuevas formas de criminalidad de la sociedad moderna ${ }^{466}$.

Así, delante de las críticas planteadas, se pregunta: ¿Y los derechos sociales de los ciudadanos, que del mismo modo son violados, a ejemplo de la seguridad colectiva delante del crecimiento de la delincuencia organizada transnacional, no estarían amparados por el garantismo en los moldes defendidos por FERRAJOLI?

Nos parece que en la obra de FERRAJOLI esta idea no se presente puramente delimitada. De otra parte, una respuesta honesta a esta cuestión deberá basarse en el hecho de que una comprensión integral de los postulados garantistas, nos lleva a comprender que el Estado debe llevar en cuenta que en la aplicación de los derechos fundamentales (individuales y sociales), habrá la necesidad de garantizar también al

462 Terminología utilizada en la doctrina brasileña por FISCHER al señalar el equívoco cometido por algunos "falsos" garantistas. Vid. FISCHER, D., "Garantismo penal integral (e não o garantismo hiperbólico monocular) e o princípio da proporcionalidade: breves anotações de compreensão e aproximação de seus ideais", http://www.revistadoutrina.trf4.jus.br.

463 En opinión de PIEROBOM DE ÁVILA, "posee un razonable desarrollo en la doctrina la perspectiva del garantismo en sentido individual, estableciéndose garantías a los individuos de protección contra un resultado procesal que no lo degrade como objeto de un juicio, pero que permita al mismo una participación activa en el procedimiento, en la cualidad de sujeto de derechos". Vid. PIEROBOM DE ÁVILA, T. A., Provas ilícitas $e$ proporcionalidade, cit., pág. 62.

464 CHIAVARIO, M., "La justicia penal italiana, a la búsqueda continua de un proceso justo", cit., pág. 461. Del mismo modo, la opinión de BALTAZAR JR, al señalar que "es en estos casos, de los agentes con dinero y poder para el ejercicio de la defensa, que se vislumbra un apego excesivo a las garantías, dando una dimensión mayor que la efectivamente merecida, en el llamado hipergarantismo, una hipertrofia de la interpretación de los derechos de defensa, que compromete el andamiento de la persecución penal". Vid. BALTAZAR JR, J. P., "Limites constitucionais à investigação. 0 conflito entre o direito fundamental à segurança e o direito de liberdade no âmbito da investigação criminal", cit., pág. 213.

465 Vid. DÍEZ RIPOLLÉS, J. L., "El nuevo modelo penal de la seguridad ciudadana", Revista Electrónica de Ciencia Penal y Criminología, núm. 06, 06-03, 2004, http://www.criminet.ugr.es/recpc/. También interesante la opinión de ZÚÑIGA RODRÍGUEZ al señalar que "la aproximación a la política penal de la criminalidad organizada desde el garantismo tampoco es correcta". Vid. ZÚÑIGA RODRÍGUEZ, L., Criminalidad organizada y sistema de derecho penal, cit., pág. 193.

466 ZÚÑIIGA RODRÍGUEZ, L., Criminalidad organizada y sistema de derecho penal, cit., pág. 194. 
ciudadano la eficiencia y la seguridad, evitándose la impunidad. El deber de garantizar la seguridad no está en sólo evitar conductas delictuosas que atinjan derechos fundamentales de terceros, pero también en la debida apuración (con respeto a los derechos de los investigados o procesados) del acto ilícito y, en siendo el caso, en la punición del responsable. A este pensamiento dogmático se podría denominar "garantismo positivo" 467.

Incluso, STRECK utiliza las expresiones "garantismo negativo" (para la protección de las libertades negativas por la prohibición de exceso) y "garantismo positivo" (para la protección de las libertades positivas mediante la prohibición de insuficiencia), concluyendo por la posibilidad, incluso, de un control de constitucionalidad bajo la perspectiva del garantismo positivo ${ }^{468}$.

Sin embargo, muy importante a la exacta comprensión de este asunto, ha sido la opinión defendida por GOMÉZ DE LIAÑO, al sostener que el nuevo marco constitucional potencia las normas relativas a los derechos fundamentales de todas las personas y también de la sociedad como tal, ya que el enfoque cabal de esta cuestión debe hacerse teniendo en cuenta que en ella confluyen tres clases de intereses diversos: a) el orden social y la seguridad pública, que necesita la sociedad para su defensa y existencia; b) la dignidad y la libertad personal del "presunto culpable" al que asiste el sagrado derecho de defensa y c) los derechos de la víctima a que se restablezcan su integridad física, moral y demás derechos afectados por la infracción penal ${ }^{469}$.

Así es que delante de todo lo afirmado, en nuestro modo de pensar, el verdadero garantismo no comprende una protección ilimitada del individuo, pero también debe compatibilizar la necesidad de protección de la colectividad, pues en contrario, estaríamos delante de un "garantismo o de un minimalismo autista"470.

467 Vid. con más detalles, MENDES, G. F., "Os direitos fundamentais e seus múltiplos significados na ordem constitucional", Anuário Iberoamericano de Justicia Constitucional, núm. 8, 2004, págs. 131-142. Es por esta razón que no es adecuado hablar tan sólo de una función de protección negativa del Estado (garantismo negativo). Nótese que, en este caso, BARATTA ha utilizado el término "política integral de protección de los derechos", lo que significa definir el garantismo no solamente en sentido negativo como límitedel sistema positivo, o sea, como expresión de derechos de protección relativamente al Estado, sino también como garantismo positivo. Prosigue el citado autor sosteniendo que ese novo modelo de Estado deberá dar la respuesta para las necesidades de seguridad de todos los derechos, también los prestacionales por parte del Estado (derechos económicos, sociales y culturales) y no solamente de aquella parte de los derechos denominados de prestación de protección, en particular contra las agresiones provenientes de comportamientos delictivos de determinadas personas. Vid. BARATTA, A., "La política criminal y el Derecho Penal de la Constitución: Nuevas reflexiones sobre el modelo integrado de las Ciencias Penales", Revista de la Faculdad de Derecho de la Universidad de Granada, núm. 2, 1999, pág. 110.

468 STRECK, L., "A dupla face do principio da proporcionalidade: da proibição de excesso (übermassverbot) à proibição deficiente (untermassverbot) ou de como não há blindagem contra normas penais inconstitucionais", Revista da Associação dos Juízes do Rio Grande do Sul, núm. 97, Porto Alegre, 2005, págs. 171-202. En este significativo estudio, el citado autor desarrolla sus ideas partiendo de la constatación de que no parece difícil sostener la tesis por la cual solamente el acusado puede soportar el riesgo de restricción a la libertad, incidiendo, por esto, el principio de proporcionalidad como protección contra los excesos estatales (lo que se denomina de garantismo negativo). Por otro lado, en una perspectiva liberal-iluminista, no tiene sentido el proceso buscar garantir el derecho de libertad y al mismo tiempo, transformarse en causa de agresión al ciudadano.

469 GÓMEZ DE LIAÑO GONZÁLEZ, F., El proceso penal. Tratamiento Jurisprudencial, 7ạ edición, Oviedo, 2004, pág. 23.

470 Esta expresión ha sido utilizada por SARLET, I. W., "Constituição e proporcionalidade: o direito penal e os direitos fundamentais entre proibição de excesso e de insuficiência", cit., págs. 60-122. 
Por lo tanto, una visión unilateral del garantismo tan sólo individualista no es compatible con la efectiva protección de los derechos fundamentales como un todo, ni con la dignidad humana bajo la perspectiva personalista, y mucho menos con las ideas que impregnan el constitucionalismo moderno.

Siguiendo por esta línea, se puede defender sin miedo de equivocarse que el garantismo exacerbado puede originar la ineficacia del proceso, y la eficacia extrema puede propiciar la vulneración de las garantías básicas de la actividad del juez, con su deber de imparcialidad, y de las partes, con sus derechos a la defensa ${ }^{471}$.

En realidad, al lado de los bienes jurídicos individuales o dotados de referente individual y al mismo nivel de exigencia cautelar autónoma, existen auténticos bienes jurídicos sociales, transindividuales, transpersonales, colectivos, o como se quiera que nos exprimamos a propósito ${ }^{472}$.

De esta forma y de acuerdo con los postulados de un garantismo penal integral ${ }^{473}$, se puede afirmar que realidad innegable es que, al lado de los bienes individuales, existe un modelo en la actualidad de derechos sociales, con una prospección colectiva, producto de las funciones del Estado intervencionista, sobre todo, en políticas económicas ${ }^{474}$.

En palabras de FISCHER, del garantismo penal integral surge la necesidad de protección de los bienes jurídicos (individuales y también colectivos) y de protección activa de los intereses de la sociedad, de los investigados y de los procesados. Integralmente aplicado, el garantismo impone que sean observados rígidamente no sólo los derechos fundamentales (individuales y colectivos), pero también los deberes fundamentales (del Estado y de los ciudadanos), previstos en la Constitución. El Estado no puede actuar sin proporcionalidad: debe evitar excesos y, al mismo tiempo, no incurrir en deficiencia en la protección de todos los bienes jurídicos, principios, valores e intereses que posean dignidad constitucional, siempre buscando la proporcionalidad cuando necesaria a la restricción de alguno de ellos ${ }^{475}$.

Dicho de modo diverso, la tesis central del garantismo integral se resume en el hecho de que tendránque ser observados de modo rígido no sólo los derechos fundamentales individuales y también colectivos, pero también los deberes fundamentales del Estado y de los ciudadanos previstos en la Constitución ${ }^{476}$.

471 PICÓ I JUNOY, J., "El derecho procesal entre el garantismo y la eficacia: Un debate mal planteado", cit., pág. 126.

472 FIGUEIREDO DIAS, J., "O direito penal entre a sociedade industrial e a sociedade do risco", Revista Brasileira de Ciências Criminais, núm. 33, São Paulo, 2001, pág. 51.

473 Por esta denominación se quiere decir que el garantismo integral tiene la función de maximizar la protección del individuo directamente afectado por el proceso contra una irracionalidad punitiva, pero también de maximizar la realización práctica de los derechos de la colectividad mediante la protección penal. Así es que algún autor, cítese, PIEROBOM DE ÁVILA, señala que "una visión unilateral del garantismo tan sólo individualista no es compatible con la efectiva protección de los derechos fundamentales como un todo, ni con la dignidad humana desde la perspectiva personalista, tanpoco con la idea que rige la Constitución". Vid. PIEROBOM DE ÁVILA, T. A., Provas ilícitas e proporcionalidade, cit., pág. 61.

474 Vid. BARONA VILAR, S., "Conformidad del acusado, paradigma de eficiencia de la Justicia Penal", cit., pág. 401.

475 FISCHER, D., "O que é garantismo penal (integral)?", cit., pág. 48.

476 En este sentido, CARBONELL destaca que "la obligación de proteger significa que el Estado debe adoptar medidas destinadas a evitar que otros sujetos violen los derechos sociales, lo que incluye mecanismos no solamente reactivos frente a las violaciones (...), sino también esquemas de carácter preventivo que eviten que agentes privados puedan hacerse con el control de los recursos necesarios para la realización de un 
Tenemos pues que admitir que en la cúspide de los derechos humanos se encuentra la libertad y la dignidad personal, que los textos constitucionales proclaman como valores superiores del ordenamiento jurídico, que es necesario proteger. Pero nuestra libertad, es una libertad en convivencia, lo que significa pensar también en la de los demás. Y como tantas veces se ha puesto de manifiesto, la propia libertad tiene los límites que la marcan los derechos ajenos, y así cuando regulamos aquella convivencia a través del ordenamiento jurídico, se impone restricciones a aquella libertad ${ }^{477}$.

A respecto, cobra singular relevancia la opinión de RANGEL cuando señala que la teoría del garantismo penal defendida por FERRAJOLI es originaria de un movimiento del uso alternativo del derecho nacido en Italia en los años setenta por intermedio de jueces del grupo de la magistratura democrática (de entre ellos, FERRAJOLI), siendo una consecuencia de la evolución histórica de los derechos de la humanidad, que modernamente, considera el imputado no como un objeto de investigación estatal, pero sícomo sujeto de derechos, tutelado por el Estado, que pasa a tener el poder-deber de protegerlo, en cualquier fase del proceso (investigatorio o propiamente punitivo) ${ }^{478}$.

En síntesis, siguiendo a una línea integral del pensamiento garantista, deberá ser defendido con tenacidad que en un verdadero Estado Constitucional de Derecho, no se puede prescindir, directa o indirectamente, explícita o implícitamente, de la tutela penal como uno de sus marcos primarios, responsable por la protección de aquellos núcleos axiológicos fundamentales sobre los cuales se reposan sus estructuras.

De otra parte, deberá ser concluido que el garantismo integral o proporcional es aquél que respeta las garantías del acusado o investigado, no las violando de modo inadecuado, sin necesidad o sin proporcionalidad, al mismo tiempo en que asegura de modo eficiente la protección de otros bines jurídicos relevantes para la sociedad, como por ejemplo, el derecho a la seguridad, dentro de un doble enfoque del principio de proporcionalidad, o sea, incluyendo la prohibición de exceso, especialmente al establecer límites a los derechos y garantías del acusado, y también, la necesidad de establecer una tutela jurisdiccional penal efectiva y célere, que venga a asegurar la seguridad del ciudadano, de suerte a prestigiar los bienes jurídicos que son objeto de protección por la propia norma penal.

Llegado a este punto se hace imprescindible lanzar algunas palabras respecto al derecho a la seguridad como derecho fundamental a ser buscado para la manutención de la paz ciudadana y para la prevención de la delincuencia.

Una primera observación debe relacionarse con el hecho de que en gran mayoría de los Estados democráticos, no existe duda respecto al status constitucional del derecho a la seguridad por parte del ciudadano, con la necesaria contrapartida del deber por parte del Estado 479 .

derecho". Vid. CARBONELL SÁNCHEZ, M., "La garantía de los derechos sociales en la teoría de Luigi Ferrajoli", Garantismo: estudios sobre el pensamiento jurídico de Luigi Ferrajoli, cit., pág. 194.

477 En este sentido, Vid. GÓMEZ DE LIAÑO GONZÁLEZ, F., El proceso penal. Tratamiento Jurisprudencial, cit., pág. 19.

478 RANGEL, P., "O clone da inquisição terrorista", http://www.jusvi.com/artigos/1319.

479 Vid. como ejemplo, la jurisprudencia consolidada en el STF en Brasil, HC 87.310/SP, Ponente Carlos Britto, en 8.8.2006. Este mismo Tribunal Constitucional también ha reconocido al lado de los derechos fundamentales de garantía del acusado, como derechos de defensa contra la actuación estatal, también los derechos de la colectividad como el principio de la protección penal eficiente (STF, HC 90138/PR, Ponente 
En razón de que la transgresión hace parte de la vida, la manutención de niveles mínimos de seguridad requiere una persecución penal mínimamente eficaz, lo que, a su vez, depende de una investigación criminal dotada de medios capaces de hacer frente a la criminalidad tradicional y aquella que se presenta con contornos de modernidad, principalmente la criminalidad empresarial y organizada ${ }^{480}$.

Así, la prohibición de insuficiencia como tema correlato de la protección de los derechos fundamentales, al lado de la prohibición de exceso es especialmente relevante en relación al deber estatal de garantizar la seguridad 481, tanto en su sentido objetivo, de seguridad exterior, o sea, de protección a los riesgos y peligros efectivos, como en sentido subjetivo o interno, de ausencia de miedo, bien jurídico que conforma y condiciona el ejercicio de los derechos fundamentales ${ }^{482}$.

El deber estatal de garantizar la seguridad de los ciudadanos ${ }^{483}$ es uno de los fundamentos de la propia existencia y legitimación del Estado, cuya alternativa es la anarquía. La seguridad no es, sin embargo, un fin a ser buscado a cualquier precio como ya hemos visto, pues ni mismo se podría decirque existe una seguridad absoluta, lo que solamente sería obtenido a través de un alto grado de vigilancia, que comprometería la libertad general de acción, que es basilar para el libre desarrollo de la personalidad humana y que se confunde con la propia dignidad del hombre 484

La verdad es que la existencia del derecho a la seguridad, afirmada al tiempo del absolutismo y acepta en la época del liberalismo, mantiene en el modelo contemporáneo del Estado de Derecho democrático y social, con las adaptaciones decurrentes de las nuevas estructuras estatales, lo que acrecienta, sin excluir las demás acepciones de la seguridad, entre los ciudadanos y contra el Estado, la protección ofrecida por los derechos sociales para las necesidades de seguridad económica ${ }^{485}$.

Al fin de este apartado, es de concluirse con algunas ideas centrales.

En primero, que un factor de relevancia en esta tendencia hacia el garantismo en el proceso penal ha sido el hecho de convertirse el proceso penal en un proceso con mayor protagonismo de las partes, en el que quede más limitada la influencia del juez o del tribunal. Que el proceso penal sea cada vez más un proceso "de partes" conduce

Ricardo Lewandowski, en 27.2.2007). De otra parte, peculiar opinión es adoptada por parte de la doctrina española, al afirmarse que "la persecución penal no es un derecho fundamental, por más que el Estado deba garantizar la seguridad pública". Vid. MORENO CATENA, V., "La protección de los testigos y peritos en el proceso penal español", Delincuencia organizada. Aspectos penales, procesales y criminológicos, J. C. Ferré Olivé y E. Anarte Borrallo coords., Huelva, 1999, pág. 147.

480 BALTAZAR JR, J. P., "Limites constitucionais à investigação. 0 conflito entre o direito fundamental à segurança e o direito de liberdade no âmbito da investigação criminal", cit., pág. 184.

481 En este sentido, "es indiscutible que la seguridad interna y externa tiene un alto significado para las tareas estatales". Vid. GUSY, C., "Rechtsgüterschutz als Staatsaufgabe", Die öffentliche Verwaltung, 1996, pág. 573.

482 HABERLE, P., Die Wesensgehaltgarantie des Art. 19 abs. 2 Grundgesetz, Heidelberg, 1983, pág. 14.

483 En palabras de BULL, "ésta es la más antigua tarea impuesta al Estado y ha sido válida por muchos siglos como la única o la más importante justificativa del Estado en sí". Vid. BULL, H. P., Die Staatsaufgabennachdem Grundgesetz. 2, Kronberg, 1977, pág. 347.

484 BALTAZAR JR, J. P., "Limites constitucionais à investigação. 0 conflito entre o direito fundamental à segurança e o direito de liberdade no âmbito da investigação criminal", cit., pág. 215.

485 Vid. ISENSEE, J., Das Grundrecht auf Sicherheit, $\mathrm{Zu}$ den Schutzpflichten des freiheitlichen Verfassungsstaates, cit., págs. 3-5. 
inevitablemente a realzar la figura del acusado y fuerza la necesidad de reconocerle frente al acusador público una posición de igualdad en derechos y posibilidades procesales 486 .

Además, en consonancia con lo que se acaba de afirmar, que es posible entender la lucha contra la criminalidad organizada, con el debido respeto a los postulados garantistas, o sea, el garantismo como forma de prevalencia de los derechos fundamentales, debe estar presente cuando se trata del combate a esta grave forma de delincuencia.

Otra interpretación que se intente hacer sobre el tema, conducirá por cierto a una caótica situación de impunidad reforzada por una creciente y abusiva instrumentalización de las garantías. De lo dicho resulta que el garantismo penal no es en definitiva, sinónimo de impunidad. No puede significar deslealtad procesal ni mucho menos absolución o condenación a cualquier costo. Se lucha con vehemencia contra el abuso de poder de punir del Estado y se repiteel error con el abuso por veces del derecho de defensa, intentando difundir una equivocada concepción de un "garantismo negativo", utilizándose de maniobras procesales de procrastinación o aduciendo perjuicios para la defensa sin fundamentación jurídica consistente.

Esto significa sencillamente, que debe lograrse la mayor eficacia posible en la lucha contra la criminalidad, especialmente la organizada, pero siempre en el marco del Estado democrático de derecho, evitando una relativización innecesaria de los principios y garantías, y lo más grave, sin obedecer a criterios de proporcionalidad.

No se puede afirmar, por ejemplo, que los poderosos (autores de delitos de cuello blanco) o delincuentes pertenecientes a grandes grupos criminales no necesitan de garantías, porque ello, además, podría acabar afectando a la generalidad de los ciudadanos. La reducción de las garantías del proceso con el pretexto de combatir la criminalidad de poderosos, puede acabar convirtiendo la excepción en regla general, con el peligro de que finalmente se institucionalice el modelo del proceso como un instrumento del Estado de control social, frente al actual modelo del proceso como instrumento del Estado de Derecho ${ }^{487}$. Fruto de esta eventual desorientación, se podría estar legitimando un verdadero proceso penal del enemigo, asunto éste que tendremos la oportunidad de analizar en apartados siguientes.

También que la tarea del Estado es defender la sociedad, a partir de la conjunción de las varias dimensiones de los derechos, protegiendo la misma contra los varios tipos de agresión. O sea, el agresor no es solamente el Estado. Cítese como ejemplo las agresiones practicadas por la criminalidad organizada transnacional que impone obstáculos, en gran escala, a la realización de políticas públicas por parte del Estado, provocando miedo y sensación de inseguridad a toda la sociedad. Por fin, la conclusión final dice respecto a la necesidad de imponerse una recusa a la eficacia antigarantista ${ }^{488}$ demostrada muchas

\footnotetext{
486 En este sentido, Vid. GASCÓN INCHAUSTI, F., "Los procesos penales en Europa: líneas de evolución y tendencias", cit., págs. 473-474.

487 ECHARRI CASI, F. J; GONZÁLEZ GARCÍA, S., Aspectos procesales de la delincuencia económica, M. J. Vallejo y F. Bernate Ochoa coords., Bogotá, 2005, pág. 62.

488 Se puede utilizar la expresión "utilitarismo procesal" como sinónima de eficiencia antigarantista. Nótese que el término "utilitarismo" se encuentra relacionado a la idea del combate a la criminalidad a cualquier costo, a un proceso penal más célere y eficiente, en el sentido de disminuir las garantías procesales del ciudadano a nombre de los intereses estatales de más rápidamente apurar y aplicar sanciones. Es sinónimo de exclusión, supresión de derechos fundamentales para alcanzar la máxima eficiencia (antigarantista).
} 
veces por los órganos de persecución penal, pues en este caso, la eficacia invocada podría llevar a una erosión del orden constitucional 489 .

En síntesis, se trata de comprender la cuestión desde la opinión de BARATTA, el cual ha denominado la situación de "política integral de protección de los derechos", lo que significa definir el garantismo no solamente en sentido negativo como límite del sistema positivo, o sea, como expresión de los derechos de protección relativamente al Estado, sino que también como garantismo positivo ${ }^{490}$.

Del mismo modo, perfecta la observación de BAPTISTA MACHADO, para quien el principio del Estado de Derecho, en este punto de la historia contemporánea, no exige tan sólo la garantía de defensa de derechos y libertades contra el Estado: exige también la defensa de los mismos contra cualquier de los poderes sociales de hecho. Así, es posible afirmar que la idea del Estado de Derecho se pierde en su función cuando se abstiene de recurrir a los medios preventivos y represivos que se muestren indispensables a la tutela de la seguridad de los derechos y libertades de los ciudadanos ${ }^{491}$.

Por fin, es muy importante esclarecer una vez más que la lucha contra la delincuencia organizada no es incompatible con la más escrupulosa observancia de las garantías constitucionales. Todo lo contrario: su cumplimiento constituye la esencia del Estado de Derecho y la demostración más palpable de su superioridad ética frente a otros tipos de Estado 492 .

De este modo, con mayores o menores imperfecciones, la tendencia hacia el garantismo consiguió en los países de Europa Occidental, a finales del siglo XX, operar sistemas de proceso penal que reconocían y respetaban de forma amplia los derechos del imputado y del acusado, sobre todo si se compara con lo que sucedía en buena parte del resto del mundo ${ }^{493}$.

\footnotetext{
489 Para mejor entender el drama y la tragedia de los anhelos inmediatistas por la celeridad y rapidez en los juicios penales, es esencialmente recomendable que se vuelva a los clásicos, citando a CARNELUTTI que señalaba que "cuando oímos decir que la justicia debe ser rápida, he ahí una fórmula que se debe tomar en beneficio de inventario; el clisé de los llamados hombres de Estado que prometen a toda discusión del balance de la justicia que tendrá un desenvolvimiento rápido y seguro, plantea un problema análogo de la cuadratura del círculo. Por desgracia, la justicia, si es segura no es rápida, y si es rápida no es segura. Preciso es tener el valor de decir, en cambio, del proceso: quien va despacio, va bien y va lejos. Esta verdad transciende, incluso, de la palabra proceso, la cual alude a un desenvolvimiento gradual en el tiempo: proceder quiere decir, aproximadamente, dar un paso después del otro". Vid. CARNELUTTI, F., Cómo se hace un proceso, Bogotá, 1994, pág. 14.

490 Con detalles, Vid. BARATTA, A., "La política criminal y el Derecho penal de la Constitución: nuevas reflexiones sobre el modelo integrado de las Ciencias Penales", Revista de la Facultad de Derecho de la Universidad de Granada, núm. 2, 1999, pág. 110. Este mismo autor centraliza sus ideas al definir que no se puede más hablar tan sólo en una función de protección negativa del Estado, o dicho en otras palabras, en el garantismo negativo. Así es que llama la atención para la relevante circunstancia de que este nuevo modelo de Estado deberá dar la respuesta para las necesidades de seguridad de todos los derechos, también los prestacionales por parte del Estado (derechos económicos, sociales, culturales) y no solamente de aquella parte de los derechos denominados de prestación de protección, en particular contra agresiones provenientes de comportamientos delictivos de determinadas personas.

491 BAPTISTA MACHADO, J., Introdução ao Direito e ao discurso legitimador, Coimbra, 1998, pág. 131.

492 En este sentido, Cfr. GÁLVEZ MUNÕZ, L., La ineficacia de la prueba obtenida con violación de derechos fundamentales. Normas y jurisprudencia (TEDH, TC, TS, TSJ y AP) en los ámbitos penal, civil, contencioso administrativo y social, Navarra, 2003, pág. 67.

493 Vid. GASCÓN INCHAUSTI, F., "Los procesos penales en Europa: líneas de evolución y tendencias", cit., pág. 480 .
} 
I.3.2.2. La lucha contra el crimen organizado: Los derechos y garantías fundamentales no son siempre absolutos.

Una consideración inicial es imprescindible: los principios del proceso penal están particularmente relacionados con los derechos fundamentales ${ }^{494}$, y casi todos los actos procesales penales constituyen puentes entre las normas penales procesales y los derechos humanos. La incidencia del plano constitucional sobre el Derecho Procesal penal es contundente e indiscutible ${ }^{495}$. Incluso es posible citar RAMOS MÉNDEZ que señala que las normas y principios constitucionales relativos al ejercicio de la función jurisdiccional, considerados en su complejidad, permiten la posibilidad de diseñar un verdadero y propio esquema general del proceso, cuyo objeto nos viene suministrado por la denominada jurisdiccionalidad derivada del proceso, es decir, por el examen de su "deber ser" de conformidad con la normativa constitucional 496 .

De otra parte, la idea del Estado de Derecho se ha ido consolidando poco a poco dentro del proceso penal por medio de diversos mecanismos que aseguran el cumplimiento de las garantías del debido proceso e impiden situaciones que obstaculizan la impartición de justicia y merman los derechos humanos ${ }^{497}$.

Pues bien, a partir de esta premisa y en el marco de este bosquejo muy esquemático, se percibe hasta ahora que las estructuras criminales se han transformado desde hace apenas unas décadas de forma cualitativa y, al compás del gran incremento de los índices de delincuencia, viene operando un nuevo conjunto de actividades delictivas identificado con la expresión "criminalidad organizada"; fenómeno que, acompañado de un escenario de violencia y corrupción, presenta un problema mundial que se expande contagiosamente por cualquier ámbito de la realidad, de consecuencias y dimensiones apenas calculables, pero, desde luego, de una intensidad y peligrosidad sin precedentes ${ }^{498}$.

Como consecuencia, se percibe que la especial situación por la que atraviesa la delincuencia organizada y el crimen organizado obliga a la búsqueda de fórmulas de investigación que permitan asegurar el resultado del trabajo policial mediante la detención de los presuntos responsables criminales y más tarde por la condena penal por los Tribunales penales. Pero la especial idiosincrasia de esta delincuencia se ve rodeada de

494 En palabras de FERRAJOLI, "se entiende por derechos fundamentales, en oposición a los derechos patrimoniales, como la propiedad y él crédito, que son derechos singulares que adquiere cada individuo con exclusión de los demás, aquellos derechos universales y, por ello, indispensables e inalienables, que resultan atribuidos directamente por las normas jurídicas a todos en cuanto personas, ciudadanos o capaces de obrar: ya se trate de derechos negativos, como los derechos de libertad, a los que corresponden prohibiciones de lesionar; o de derechos positivos, como los derechos sociales, a los que corresponden de prestación por parte del los poderes públicos". Vid. FERRAJOLI, L., "Garantías", cit., pág. 61.

495 Monográficamente, Vid. las obras de GARBERÍ LLOBREGAT, J., Constitución y Derecho Procesal. Los fundamentos constitucionales del Derecho Procesal, Cizur Menor, 2009 y RAMOS MÉNDEZ, F., Enjuiciamiento Criminal, Octava lectura constitucional, Barcelona, 2006.

496 Cfr. RAMOS MÉNDEZ, F., "La influencia de la Constitución en el Derecho Procesal Civil", Revista de Derecho Procesal, número 1, 1983, pág. 11.

497 En este sentido, BLANCO ESCANDÓN, C., "El nuevo proceso penal en América Latina", http://www.bibliojuridica.org.

498 IGLESIAS RÍO, M. A., "Criminalidad organizada y delincuencia económica: aproximación a su incidencia global", cit., pág. 1145. 
circunstancias muy puntuales que han alterado la forma de afrontar, primero, la investigación policial y más tarde la propiamente judicial ${ }^{499}$.

Si lo anterior es correcto, entonces tratándose de problema crónico que impregna el mundo globalizado del siglo XXI, deberá el Estado buscar la implantación de programas político criminales de combate al crimen organizado, bien como dotar con condiciones materiales y personales los aparatos policial y judicial para el enfrentamiento de esta gravísima forma de criminalidad ${ }^{500}$. Pero la tarea no es sencilla, pues para el tratamiento de todas estas cuestiones hay que tener en cuenta, la grave constatación de que la organización del crimen dentro de su estructura de verdadera empresa para la práctica de actos delictuosos, muta constantemente las técnicas operativas y las estructuras que las sostienen, mediante un proceso de sofisticación que va siempre más alláde las técnicas policiales de dilucidación y persecución del delito.

Con todo, conviene también tener presente que ya es tradicional definir que el crimen organizado tiene sus operaciones delictivas concentradas en especial con relación a cierta clase de delitos, a ejemplo, del narcotráfico y de los delitos económicos y financieros. En este sentido, aunque se tenga una idea respecto a su correlación con algunas infracciones penales, a ejemplo del blanqueo de capitales, de las estafas, de la corrupción, no es posible obtener una comprensión exacta sobre el modus operandi de estos clanes criminales.

Es necesario destacar en este sentido la oportuna opinión de BOLLE, de que la criminalidad económica es como el cáncer: no hay nadie que sea capaz de definirla, pero genera perjuicios perfectamente perceptibles ${ }^{501}$. La misma idea se aplica a esta forma de delincuencia grave con dimensión transfronteriza denominada "crimen organizado", pues se sabe que existe, se tiene consciencia de sus perjuicios, al mismo tiempo en que no se tiene una idea concreta y segura respecto a su dimensión y estructura logística ${ }^{502}$.

No obstante, y sea como sea, en este punto hay que reconocer, sin ambages, que la realidad es que la criminalidad organizada como forma genuina de delincuencia globalizada, ha alcanzado grados de crecimiento inaceptables y en consecuencia de este desarrollo gigantesco, ha provocado un alarma de expectativas que viene generando una desorientación con respecto a la búsqueda y a la utilización de métodos eficaces en su

499 Vid. MAGRO SERVET, V., "Régimen legal de los testigos protegidos en el proceso penal", cit., http://revista-laleypenal.laley.es/.

500 La propia esencia del fenómeno de la delincuencia organizada y, en concreto, su difícil combate y control, nos conlleva a concluir sobre la necesidad de búsqueda de una adecuada y compleja estructuración de los aparatos policial y judicial, y en especial, teniendo la certeza de que la respuesta estatal desde el Estado Constitucional de Derecho, hay que venir mediante la especialización de los órganos de investigación y de persecución criminal, a ejemplo de la creación de las fiscalías especiales y de tipos penales y normas procesales conducentes con la realidad criminológica. Además, partiendo de la idea central de que no es correcto usar la reacción penal como ultima ratio en la lucha contra el crimen organizado, todo el arsenal de instrumentos y medidas que se van a adoptar, sean de carácter sustantivo, procesal o político criminal, deberán obligatoriamente estar en sintonía con los parámetros de constitucionalidad, de modo a que no se aniquilen de forma desmedida e irrazonable, derechos y garantías de las personas sometidas al proceso penal.

501 BOLLE, P. H., "La lutte contre la criminalité économique en Suisse", Schweizerische Zeitschrift für Strafrecht, Tomo 98, 1981, pág. 140.

502En definitiva, "asistimos en la actual sociedad internacional en el marco de la globalización, a un incesante incremento de las actividades de la delincuencia organizada, entendiéndola como criminalidad corporativa con carácter lucrativo, con capacidad plena para operar a escala transnacional, pudiendo llegar a constituir verdaderas "empresas transnacionales del crimen". Cfr. ÚBEDA PORTUGUÉS, J. E., " Análisis de los efectos negativos de la delincuencia organizada en la sociedad internacional", cit., pág. 71. 
combate. Si lo anterior es correcto, entonces llegamos al punto de la cuestión: habrá que existir una globalización de la respuesta institucional pero basada en el respetoa los derechos fundamentales del ciudadano ${ }^{503}$.

Nos interesa en este particular citar algunas normativas y documentos que presenten el objetivo de protección a los derechos de las víctimas: la Ley 32/1999, de 8 octubre (solidaridad con las víctimas del terrorismo), la Decisión Marco del Consejo de 15 de Marzo de 2001 (Estatuto de la Víctima en el Proceso Penal), la Directiva 2004/80/CE del Consejo de 29 de abril de 2004 (indemnización a las víctimas de delitos), la Instrucción 8/2005, 26 de julio de 2005 (deber de información en la Tutela y Protección de las Víctimas en el Proceso Penal) y las Conclusiones de las jornadas de las víctimas de León en 2010.

En el citado rol resulta imprescindible destacar la Decisión marco del Consejo 2001/220/JAI, de 15 de marzo de 2001504, relativa al estatuto de la víctima en el proceso penal. Esta establece por lo general, la asistencia a las víctimas de delitos antes, durante y después de los procesos penales. Así los Estados miembros garantizarán el respeto a la dignidad de las víctimas, y reconocerán sus derechos en el marco del proceso. Las víctimas especialmente vulnerables deberán recibir un trato que responda de la mejor manera posible a su situación ${ }^{505}$.

503 En se tratando de una especie de delincuencia que presenta la característica de fenómeno transfronterizo, deberá ser reconocido que a lo largo de las últimas décadas la criminalidad organizada se ha desarrollado de forma considerable como consecuencia de las transformaciones políticas y económicas globales. Los países de la Unión Europea son muy conscientes de esta realidad y están realizando esfuerzos por coordinar estrategias e impulsar la cooperación en la lucha contra esta problemática. El reto sería encontrar el denominador común de los derechos y garantías comunes a todos los países. De ahí la importancia del TEDH y la Corte Interamericana en definir qué es el debido proceso, bien como de resultar cumplidas sus decisiones. Respecto al primero, tal consideración debe ser completada con lo señalado por RIPOL CARULLA al afirmar que "no cabe olvidar que las SSTEDH no tienen únicamente como función definir, salvaguardar y desarrollar las normas contenidas en el Convenio de Roma, sino que también otorgan una justicia concreta y real al individuo que, después de haber agotado todos los recursos internos en su país, llega a Estrasburgo buscando la reparación definitiva". Vid. RIPOL CARULLA, S., El Sistema Europeo de Protección de los Derechos Humanos y el Derecho Español, Barcelona, 2007, pág. 141. Ya en lo relativo a la Corte Interamericana de Derechos Humanos, las sentencias de esta Corte como sentencias emanadas de un tribunal internacional o transnacional, son de obligatorio cumplimiento por los Estados parte y se deben ejecutar directamente por y en el Estado concernido, evidentemente sin que haga falta para ello ningún procedimiento de pase en el derecho interno o exequatur. En este sentido la Convención Americana es muy clara ya que incluso establece expresamente, que la parte del fallo que disponga indemnización compensatoria se podrá ejecutar em el respectivo país por el procedimiento interno vigente para la ejecución de sentencias contra el Estado (art. 63.1 de la CADH). Cfr. com más detalles, AYALA CORAO, C. M., "La ejecución de sentencias de la corte interamericana de derechos humanos", Estudios Constitucionales, año 5, núm. 1, Talca, 2007, págs. 127201.

504 Vid. para una mejor y más actualizada comprensión de este asunto, el importante Informe de la Comisión de 20 de abril de 2009 de conformidad con el artículo 18 de la Decisión marco del Consejo, de 15 de marzo de 2001, relativa al estatuto de la víctima en el Proceso penal. El citado Informe tiene en cuenta la aplicación de la Decisión marco a 15 de febrero de 2008 en 24 (de los 27) Estados miembros. La Comisión considera que dicha aplicación no ha sido satisfactoria. Ningún Estado miembro transpuso la Decisión marco en un único acto legislativo nacional; por el contrario, todos se basaron en disposiciones existentes o recientemente adoptadas. De hecho, los Estados miembros aplicaron determinadas posiciones a través de códigos no vinculantes, cartas y recomendaciones sin ninguna base legal.Tan sólo unos pocos Estados miembros aprobaron nueva legislación que abarca uno o más artículos. En consecuencia, la Comisión invita a los Estados Miembros a facilitar más información en relación con la aplicación, y a promulgar y presentar la legislación nacional pertinente que estén preparando.

505 La Decisión Marco 2001/220/JAI, de 15 de marzo de 2001 define algunas directrices a saber: 1) Las víctimas tendrán la posibilidad de ser oídas durante el proceso y de facilitar elementos de prueba. No obstante, las autoridades sólo las interrogarán en la medida necesaria para el proceso penal; 2) Las víctimas tendrán acceso, en particular desde el primer contacto con las autoridades policiales, a la información pertinente para 
En realidad, la Unión Europea ha percibido con alarma la expansión de la criminalidad organizada, y ha planteado la necesidad, a través de diversos documentos y acuerdos que se han establecido a lo largo de los últimos años, de desarrollar lazos más estrechos, a diversos niveles, con la finalidad de hacer frente a dicho fenómeno de forma coordinada. Estos avances se han registrado fundamentalmente en el ámbito policial y de la lucha contra el blanqueo de capitales ${ }^{506}$.

la protección de sus intereses; 3) Los Estados miembros deberán informar a las víctimas sobre el curso dado a su denuncia, el desarrollo del proceso (salvo en casos excepcionales) y la sentencia. En el caso de que pueda existir un riesgo para la víctima, también se le notificará la puesta en libertad de la persona inculpada o condenada por la infracción; 4) Los Estados miembros tomarán las medidas necesarias para reducir cuanto sea posible las dificultades de comunicación que afecten a la comprensión y a la participación de las víctimas en el proceso penal, cuando éstas sean testigoso parte en las actuaciones, en términos comparables a los aplicables a los procesados. Los Estados miembros también reembolsarán a las víctimas los gastos que les haya ocasionado su participación en el proceso penal; 5) Los Estados miembros garantizarán un nivel adecuado de protección a las víctimas y a sus familiares siempre que exista un riesgo grave de represalias o claros indicios de una intención clara de perturbar su vida privada; 6) Los Estados miembros garantizarán a la víctima de una infracción penal el derecho a obtener una resolución relativa a la indemnización en un plazo razonable, y adoptarán las medidas pertinentes para propiciar que el autor de la infracción indemnice a la víctima adecuadamente. Los objetos restituibles pertenecientes a la víctima y aprehendidos durante las actuaciones le serán devueltos sin demora cuando ya no sean necesarios para el proceso; 7) Los Estados miembros procurarán impulsar la mediación entre las víctimas y los inculpados para las infracciones que a su juicio se presten a este tipo de medida, y velarán para que pueda tomarse en consideración todo acuerdo entre ambas partes en las causas penales; 8) Los Estados miembros deberán mejorar la cooperación entre sí para mejorar la defensa de los intereses de las víctimas en el proceso penal. Además, los Estados miembros fomentarán la intervención de servicios que presten apoyo y asistencia las víctimas durante y después de las actuaciones. También propiciarán la formación de las personas que intervienen en las actuaciones o que tienen otro tipo de contacto con las víctimas, en especial de los agentes de policía y los profesionales del derecho. Por otro lado, los Estados miembros adoptarán las medidas necesarias para prevenir la victimación secundaria o evitar que las víctimas se vean sometidas a tensiones innecesarias durante las actuaciones, sobre todo en lo que respecta a los medios de que disponen los centros donde éstas pueden iniciarse.

506 En este sentido, la aprobación del Tratado de Maastricht en 1992 tuvo como consecuencia la incorporación de la Justicia y Asuntos Internos (JAI) a las competencias de la Unión, siendo, asimismo, oficialmente introducidas en la Agenda Europea. El resultado fue una mejora significativa del entendimiento policial entre las diversas fuerzas de seguridad europeas para hacer frente a problemas compartidos, entre los que se encontraba la criminalidad organizada, aunque no se cita ésta última expresamente. No será hasta el Tratado de Amsterdam, cuando se priorice explícitamente dicha criminalidad, profundizándose posteriormente en las conclusiones del Consejo Europeo de Tampere celebrado en 1999, a través de un programa concreto en el que se destacaba la lucha contra el crimen organizado en el ámbito de la Unión. Por su parte, el denominado Grupo de Lyon de expertos internacionales en criminalidad, integrado por los países del G8, impulsó el empleo de medios avanzados en la respuesta a la criminalidad organizada y la aplicación de instrumentos judiciales avanzados, promoviendo, asimismo, medidas en el ámbito financiero y de blanqueo de capitales. También el Consejo de Europa se ha ocupado de avanzar en este terreno a través de la promoción de buenas prácticas en el blanqueo de capitales y en la lucha contra la cibercriminalidad, aunque la Convención resulte excesivamente rígida. También el G6, al margen de las instituciones europeas, debate aspectos de la cooperación en materia de seguridad interior, y ha generado nuevas reflexiones y propuestas en la lucha contra la criminalidad organizada, entre otras temáticas. El proyecto de la Constitución europea realizaba asimismo aportaciones interesantes, que en parte han tenido que ser reformuladas para su adaptación al nuevo escenario político-institucional europeo tras el rechazo de su aprobación. Estas inquietudes expresadas en diversos foros de relevancia muestra la preocupación por este tipo de criminalidad. La imposibilidad de cumplir con el calendario previsto por el Plan de Acción de Tampere planteó la necesidad de impulsar todo el proceso a través del Programa de La Haya en 2004. Su principal y radical aportación fue aplicar el principio de disponibilidad a partir de enero de 2008. Este criterio suponía que las fuerzas policiales de los países miembros no tendrían que realizar tediosas y burocratizadas gestiones para obtener la información que necesitaran, puesto que ésta debía estar a su disposición, lo cual suponía penetrar en una dimensión desconocida de las relaciones policiales en el ámbito europeo. Las dificultades para aplicar este principio son ingentes, tanto de carácter legal como técnico, debido a las diferentes legislaciones, tradiciones culturales y prácticas policiales; en numerosas ocasiones, simplemente, no se dispone de la información solicitada. Espoleados por la necesidad de avanzar a un ritmo más intenso, se aprobó en 2005 el Tratado de Prüm, por el que se estrechaba la cooperación en materia de intercambio de información sobre terrorismo, criminalidad transfronteriza e inmigración ilegal, entre siete países signatarios, al margen de las instituciones de la UE. La crítica no se hizo esperar, al temerse que este acuerdo pudiera socavar los esfuerzos de la Comisión por 
Teniendo en cuenta todas estas consideraciones analizadas, se pone de manifiesto la necesidad de enfrentarse a la expansión y el crecimiento de la delincuencia organizada procediendo a neutralizar sus esquemas estructurales y sus modos operativos ${ }^{507}$.

A favor de esta solución se puede afirmar que una de las principales características del fenómeno delictivo denominado "crimen organizado" es su naturaleza depredadora o sea, el ánimo de lucro: su objetivo último es la consecución de beneficios normalmente pecuniariosy todas sus acciones convergen plenamente hacia el fin. De ello resulta que una de las armas más eficaces en la lucha contra el crimen organizado, bajo el aspecto represivo, es la sanción pecuniaria508, pues, debido a su racionalidad estructural, cabe esperar que esta especie de delincuencia deje de lanzarse a actividades criminales si éstas no resulten o no sean rentables debido a las fuertes multas, confiscación o comiso de sus productos ${ }^{509}$.

Pues bien, para dar respuesta a esta cuestión conviene destacar que destruyendo al aspecto financiero de los clanes criminosos, podrá el Estado obtener la clave de oro para el enfrentamiento de esta especie de macrocriminalidad, pero no es sólo, pues una serie de directrices políticas deberán ser adoptadas a ejemplo de una estratégica prevención de la penetración de la delincuencia organizada en el sector público y en el sector legítimamente privado, la revisión y perfeccionamiento de la legislación pertinente al tema, así como de las políticas reglamentarias y de control, a nivel nacional e internacional como en el caso de la Unión Europea y del Mercosur, y por fin, el incremento de la efectividad de los medios de investigación, con el debido respetoa los derechos y garantías fundamentales 510 .

avanzar mediante un proceso armonizado y uniforme. El éxito en el funcionamiento de este Tratado ha impulsado su ampliación al resto de los países, y en febrero de 2007 se acordó su incorporación a la estructura normativa de la UE. Su implementación efectiva implicará que a partir de 2011 todos los miembros de la UE puedan tener acceso automatizado a huellas de ADN, digitales y registro de vehículos, lo que supondrá un avance espectacular si todos los países gestionan correctamente el sistema. Asimismo, la propia UE también desarrolla su propia base de datos denominada SIS, la cual será ampliada. Continuando esta línea de compromiso en la lucha contra la criminalidad organizada, en 2005 se acordó el establecimiento del Modelo de Inteligencia Criminal Europeo (ECIM), que supuso la aplicación de la ampliamente difundida metodología intelligence-led policing, para lo cual resultaba necesario un considerable esfuerzo conjunto de diferentes recursos procedentes de las policías nacionales, de Europol y de la Task Force de Jefes de Policía. Resulta prematuro evaluar los resultados del proyecto, pero constituye un paso importante en el desarrollo de una metodología europea propia. Com más detalles, Vid. JAIME-JIMÉNEZ, Ó; CASTRO MORAL, L., " La criminalidad organizada en la Unión Europea. Estado de la cuestión y respuestas institucionales", Revista Cidob d'Afers Internacionals, núm. 91, 2010, págs. 178-184.

507 En este sentido, Vid. HERRERO HERRERO, C., Criminología, Parte general y especial, Madrid, 1997, pág. 500. El gran problema es que "por otra parte, surge de inmediato la crítica de la falta de capacidad del sistema penal y procesal tradicional para reaccionar ante tal forma de delincuencia, que, en los últimos años, se ha desarrollado extraordinariamente". Vid. SEOANE SPIELGELBERG, J. L., "Aspectos procesales del delito de trafico de drogas", cit., pág. 341.

508 Amén de otras medidas como el comiso y el aumento del quantum delas sanciones penales.

509 WEIGEND, T., "Los sistemas penales frente al reto del crimen organizado", International Review of Penal Law, vol. 68, 1997, pág. 550.

510 Por esto la importancia del combate al delito de blanqueo de capitales, a la vez que es sabido que el elemento dominante y que muchos consideran como la herramienta verdaderamente eficaz en la estrategia de combate al crimen organizado, tiene un carácter eminentemente preventivo y consiste en la persecución de las ganancias que se obtienen a través de la comisión de hechos delictivos, que constituyen el centro neurálgico de las organizaciones criminales. Es, por tanto, en el aspecto patrimonial de la lucha contra la criminalidad organizada en donde se encuadra la persecución del delito de blanqueo de capitales. De esta suerte, las investigaciones que se desarrollan en el ámbito financiero dentro de la lucha contra el lavado de dinero con miras a privar a la organización criminal de sus recursos económicos y de su "capital empresarial", tienen por objetivo, además, descubrir las estructuras organizativas internas e identificar a otros posible partícipes, a ser 
En opinión de MUSACCHIO, existen innúmeras formas de hacerse frente a la expansión de la criminalidad organizada; además es muy importante diseñar un modelo sancionatorio para empresas y otros entes colectivos con el fin de que los delincuentes no se sirvan de su impunidad para delinquir, ni aprovechen las lagunas legales que le brindan las incoherencias legislativas en los mercados comunes. Pero tan importante como sancionar incluso penalmente a las empresas en los casos graves, al aplicarles sanciones materiales aflictivas y preventivas, deben rodearse de principios y garantías, para racionalizar la intervención y cumplir a cabalidad con los fines preventivos de las incriminaciones ${ }^{511}$.

Importante además, destacar que de un sinnúmero de características peculiares presentadas por la criminalidad organizada, se destaca amén de otras, su carácter transnacional en la medida de que no respeta de forma alguna las fronteras y la soberanía de los países, denotándose su carácter de internacionalización ${ }^{512}$, sofisticación, con amplio cambio de informaciones entre los grupos criminosos, objetivando con esto, los fines de maximizar las ganancias obtenidas de forma ilícita a través de ciertas especies de delitos y de minimizar los riesgos cuanto a una posible pierda y quizás el comiso de bienes que hacen parte de la estructura de las verdaderas empresas del crimen.

Llegado a este punto nos cumple apuntar que el proceso penal no tiene como finalidad única y exclusiva, armar el Estado para enfrentar a la criminalidad, pero sí se trata de instrumento hábil y necesario para que se intente humanizar la función del ius puniendi.

También es sabido que los derechos fundamentales no son absolutos, lo que es propio de la vida en sociedad en la que se presenta permanentemente una colisión de los mismos motivada en diferentes factores. De allí que, una vez asegurado el derecho a nivel constitucional, viene a continuación toda una regulación para los casos en que es considerado necesario por el ordenamiento jurídico perturbar, restringir, flexibilizar o incluso in extremis, privar su ejercicio.

En apretada síntesis: la noción de un derecho fundamental ilimitado es imposible en la práctica y contradictoria en la teoría.

Silos derechos fundamentales no son absolutos, es inherente a la vida en sociedad la necesidad de restricciones, limitaciones o intervenciones, lo que es ampliamente admitido, hasta mismo delante de la necesidad de compatibilizar el ejercicio de los derechos fundamentales con otros bienes jurídicos protegidos por la Constitución, con el interés de la colectividad, o con derechos fundamentales de terceros, en la búsqueda de la concordancia práctica, que tensiona hacer con que los derechos fundamentales en colisión lleguen al punto óptimo posible de eficacia ${ }^{513}$.

posible de los niveles jerárquicos superiores. Al mismo tiempo, se pretende prevenir la planificación y comisión de futuros delitos.

511 MUSACCHIO, V., "Derecho penal económico, criminalidad organizada y Unión Europea", Revista Brasileira Ciências Criminales, núm. 60, 2006, pág. 218.

512 Sobre esta tendencia de la expansión e internalización del crimen organizado contemporáneo, Vid. SÁNCHEZ GARCÍA DE PAZ, I., La criminalidad organizada. Aspectos penales, procesales, administrativos y policiales, cit., págs. 73 y ss.

513 En este sentido, Vid. la opinión de BALTAZAR JR, J. P., Crime organizado e proibição de insuficiência, Porto Alegre, 2010, pág. 35. 
Siguiendo por este raciocinio, por lo general se suele afirmar que tan o más importante que el reconocimiento del derecho fundamental en las Constituciones es, precisamente, reglar y disciplinar las formas en que se considerará permitida su afectación ${ }^{514}$ en casos muy especiales y marcados por la actuación de una delincuencia sin fronteras ni limites, además de respetado siempre el postulado de la proporcionalidad.

De otra parte, es algo indiscutible que la criminalidad y, sobre todo, la de tipo violento y organizado no es un problema circunscrito a los países en particular, sino que constituye un flagelo que preocupa a todas las sociedades. La búsqueda de paz, seguridad y tranquilidad social es una aspiración universal515. Como ya decimos, habrá que buscarse una globalización de la respuesta institucional.

Consecuencia lógica es que tentativas aisladas de uno u otro país en definir una estrategia de lucha contra la delincuencia organizada es casi certeza de fracaso.

Y además no se puede olvidar que cada especie de delito exige, para su investigación, el recurso a técnicas especificas, en orden a obtener eficacia, certeza cuanto a la autoria del ilícito y prueba válida que posibilite la condenación ${ }^{516}$.

Cabe considerar también citando a ARAUJO DA SILVA, que el carácter multiforme del crimen organizado no ha repercutido tan sólo en el plan material, pues también en el proceso penal la tendencia verificada, sobretodo en la última década, es para que se desarrollen estrategias diferenciadas para reglamentar con más eficacia la obtención de la prueba y el tratamiento dispensado a los investigados y acusados por la práctica de infracciones relacionadas a la criminalidad organizada, en la búsqueda de eficiencia penal ${ }^{517}$.

Se habla incluso, de la necesaria estructuración de un Derecho penal de excepción en lo relativo a formas graves de criminalidad como en el caso del terrorismo, de la delincuencia organizada, etc 518 . No nos parece tan adecuada y correcta, la búsqueda de una legislación de excepción como forma de tratar los delincuentes organizados como verdaderos "enemigos" que necesitan ser eliminados.

La idea a ser desarrollada es diametralmente opuesta a esta última línea de pensamiento.

514 No se puede olvidar que los modos y formas en que se considerará permitida la afectación o flexibilización de un derecho fundamental en el campo de la persecución criminal estatal quedará ordinariamente reglamentada en los ordenamientos jurídicos penales (códigos procesales o leyes específicas) y su conjunto conforma el sistema de garantías estatuido para la protección del derecho puesto a prueba.

515 Respecto a la cuestión de la seguridad frente a los problemas originados a partir de la expansión patológica del la delincuencia organizada, Vid. FUMARULO, S., "Delincuencia organizada y seguridad: represión y prevención", Análisis, técnicas y herramientas en el combate a la delincuencia organizada y corrupción, México DF, 2007, págs. 231-258; DAGDUG KALIFE, A., La prueba testimonial ante la delincuencia organizada, cit., pág. 55; MOCCIA, S., "Seguridad y Sistema Penal", VV.AA., Derecho Penal del Enemigo, El discurso penal de la exclusión, vol. 2, Buenos Aires, 2006, págs. 298 y ss.

516 MARQUES, J., "Métodos de investigação da criminalidade económico-financeira", Revista do Ministério Público, núm. 110, año 28, Lisboa, 2007, pág. 88. El gran problema es que "para la prevención y represión de este tipo de delitos, todos los ordenamientos procesales adoptan prácticas y disposiciones especiales, intentando agilizar bien la actividad de la policía bien de los tribunales, pero que, al mismo tiempo, reducen las garantías del imputado y convierten en más aflictiva la condición del condenado". Vid. ORLANDI, R., "La lucha procesal penal contra la criminalidad organizada en Italia", VV.AA., Terrorismo y proceso penal acusatorio, Valencia, 2006, pág. 468.

517 ARAUJO DA SILVA, E., Crime organizado. Procedimento probatório, cit., pág. 40.

518 Monográficamente, con profundidad sobre el tema, Vid. VV.AA., Derecho Penal de Excepción, Terrorismo y Inmigración, P. Faraldo Cabana coord., Valencia, 2007. 
Partiendo de la premisa de que uno de los objetivos de nuestro estudio ha sido un análisis sucinto de la delincuencia organizada, como manifestación de la grave expansión del la criminalidad transnacional, frente al equilibrio entre el garantismo y la eficiencia del proceso penal, interesante señalar que a partir de la constatación de que el derecho a la seguridad se encuentra incluso en el rol de los derechos fundamentales descritos en las Constituciones de un sinnúmero de países, al lado del derecho a la vida, a la libertad y tantos otros, se hace necesaria la obtención de un difícil equilibrio entre la exigencia de asegurar a las personas sometidas a la persecución penal, la aplicación de las garantías constitucionales ${ }^{519}$ del debido proceso y la necesidad de una mayor y más concreta efectividad del sistema persecutorio para la seguridad social.

Sies verdad conforme señalado por FERRAJOLI, que el objetivo justificador del proceso penal se identifica con la garantía de las libertades del ciudadano, mediante la garantía de la verdad, una verdad no caída del cielo, pero sí, buscada mediante pruebas y debatida contra el abuso y el error, no menos cierto es afirmar que esta rama del Derecho se constituye en un verdadero instrumento al servicio de la máxima eficacia de las garantías constitucionales ${ }^{520}$.

Este el real valor que presentan los derechos y garantías fundamentales frente a la justicia penal, en el sentido de preponderación de una instrumentalidad constitucional del proceso, o sea, del proceso como instrumento a servicio de la máxima eficacia de un sistema de garantías mínimas.

Serian así los derechos y garantías fundamentales ${ }^{521}$ en el contexto del proceso penal, la conditio sine qua non del Estado constitucional y democrático de Derecho.

Queda muy claro, pues, que el proceso penal debe intentar abarcar el movimiento de medios y recursos destinados a combatir la delincuencia transnacional y superar las dificultades prácticas de una investigación de esta naturaleza e incluso las dificultades derivadas de las diferencias especificas entre las legislaciones de los distintos países. En lo relativo a esta última observación, resulta creíble la necesidad de una adecuada cooperación penal a nivel internacional522, dotándose los Estados de una estructura para

\footnotetext{
519 En este sentido, el examen de las garantías constitucionales aplicadas al proceso penal puede ser emprendido por dos prismas distintos, aunque conexos: el de la efectividad de las garantías y el de la ponderación entre las garantías, cuando de la ocurrencia de choque entre ellas o entre ellas y los demás derechos fundamentales.

520 A nuestro modo de pensar, merece aprobación y destaque la constatación de que de la función del proceso penal de imponer la pretensión punitiva del Estado a nombre de la protección de los bienes jurídicos del individuo y de la colectividad en un proceso judicial, garantiendo aquello sobre quien pesa la amenaza de sanción la protección eficaz de sus derechos fundamentales, procede, por fuerza de la Constitución, la tarea de garantizar el principio derivado de la dignidad de la persona humana en cuanto persona que actúa con autoresponsabilidad.

521 Respecto del valor constitucional de los derechos fundamentales, señala RODRÍGUEZ GARCÍA que "más allá de estar concebidos exclusivamente como derechos subjetivos de los individuos, los derechos fundamentales son los componentes estructurales básicos, tanto del conjunto del orden jurídico objetivo, como de cada una de las ramas que lo integran, puesto que son la expresión jurídica de un sistema de valores que, por decisión del constituyente, han de informar el conjunto de organización jurídica y política". Vid. RODRÍGUEZ GARCÍA, N., "Medios de prueba restrictivos de derechos fundamentales. Las intervenciones telefónicas", cit., págs. 35-36.

522 Adoptando esta línea de pensamiento, Vid. GÓMEZ DE LIAÑo FONSECA-HERRERO, M., Criminalidad organizada y medios extraordinarios de investigación, cit., págs. 32-36.
} 
cambios de informaciones en tiempo real entre varios países, bien como posibilitando la utilización incluso de los equipos conjuntos de investigación criminal523.

Del mismo modo, las garantías del proceso penal también deben acompañar este desarrollo.

Así, si en el Estado liberal, los valores básicos consistían en la defensa de la libertad, de la propiedad individual y de la igualdad, en el Estado constitucional de Derecho empiezan a tomar consciencia los conceptos de nuevos derechos fundamentales de carácter social y cultural, que van a sumarse a los viejos derechos individuales.

Hay que tener en cuenta, sin embargo, que cuando se trata del tema de la criminalidad globalizada y transnacional524, por lo tanto, de una especie de delincuencia sui generis, con características distintas si comparadas a la delincuencia tradicional, los derechos fundamentales deben ser analizados siempre con absoluto respeto, pero hay que matizar su análisis político-criminal y de respuesta procesal, por tratarse de realidades absolutamente diferentes. No se trata de establecer o legitimar un Derecho de excepción en lo relativo a esta forma globalizada ${ }^{525}$ y transfronteriza de delincuencia. Definitivamente no es este camino dogmáticamente correcto.

La cuestión que se discute hoy, al menos en el plan normativo, no es más saber si el Estado debe o no restringir derechos fundamentales ${ }^{526}$, pero en qué medida esta restricción debe ocurrir, pues como expone GREVI, frente al avance de la criminalidad organizada, el ordenamiento procesal debe saber reaccionar para salvar antes de todo a sí mismo, previendo instrumentos derogatorios y procedimientos alternativos que, sin ofender la sustancia de los derechos del imputado, permitan a la justicia seguir regularmente su curso ${ }^{527}$.

En estas condiciones, los derechos fundamentales pueden ser delimitados o restringidos, sea porque el propio texto constitucional los delimita; porque deben ser redimensionados cuando colisionan con otros derechos fundamentales, o porque las

523 Respecto del tema, Vid. en el ordenamiento español, la Ley 11/2003, de 21 de mayo, reguladora de los equipos conjuntos de investigación penal en el ámbito de la Unión Europea. Además, interesante una mirada en la doctrina de GORDILLO ÁLVAREZ-VALDÉS, I., Equipos conjuntos de investigación, La Ley Penal, Revista de derecho penal, procesal y penitenciario, vol. 1, núm. 2, 2004, págs. 75-78.

524 Para un estudio comparado del tema del crimen organizado en Brasil, España y Colombia, Vid. CALlEGARI, A. L; MELIÁ, M. C; RAMÍREZ BARBOZA, P. A., Crime organizado, tipicidade, política criminal, investigação e processo, Porto Alegre, 2008.

525 Un interesante análisis del fenómeno de la globalización y su relación con la delincuencia se puede encontrar en RODRÍGUEZ GARCÍA, N., "Globalización de la delincuencia versus globalización de la justicia penal: una lucha desigual", Revista Xurídica Galega, núm. 37, 2002, págs. 37-77.

526 Vid. para una visión global del tema de los derechos fundamentales, ALEXY, R., Teoría de los derechos fundamentales, Madrid, 2001; FERRAJOLI, L., Los fundamentos de los derechos fundamentales, 2a edición, Madrid, 2005; GIMENO SENDRA, V; TORRES DEL MORAL, A; MORENILLA ALLARD, P; DÍAZ MARTÍNEZ, M., Los Derechos Fundamentales y su protección jurisdiccional, Madrid, 2007; JIMÉNEZ CAMPO, J., Derechos fundamentales, Concepto y garantías, Madrid, 1999; NOGUEIRA ALCALÁ, H., Teoría y dogmática de los derechos fundamentales, México, 2003; PECES-BARBA, G., et alli., Lecciones de derechos fundamentales, Madrid, 2004; PÉREZ LUÑO, A. E., Los derechos fundamentales, Madrid, 1984; SARLET, I. W., A eficácia dos direitos fundamentais, 8aㅡ edición, Porto Alegre, 2007.

527 GREVI, V., Nuovo códice di procedura penale e procesi di criminalità organizzata: un primo bilancio, Processo penale e criminalitá organizzata, Roma/Bari, 1993, págs. 40-41. 
normas infraconstitucionales pueden estar autorizadas a reducir su ámbito de actuación en algunas situaciones 528 .

De otra parte, en la búsqueda de una solución razonable para la resolución del conflicto establecido entre eficacia y garantías, tensión esta como ya hemos visto, sóloaparente, es necesario saber si los derechos fundamentales admiten límites o si pueden ser restringidos en algunas situaciones excepcionales.

En opinión de RODRÍGUEZ GARCÍA, los derechos fundamentales, o concretamente, su ejercicio, está sujeto tanto a los límites que expresamente la propia Constitución prevé en su articulado, así como a otros que puedan fijarse para proteger o preservar otros derechos o bienes constitucionalmente protegidos, después de haber llevado a cabo una adecuada ponderación de los bienes en conflicto ${ }^{529}$.

Por lo tanto, los derechos y libertades, por reconocerse en el interior del ordenamiento jurídico, han de conciliarse con otros bienes que el ordenamiento protege y no pueden hacerse valer de modo absoluto frente a éstos ${ }^{530}$.

En sentido semejante, CAFFERATA NORES considera que los derechos que las garantías tutelan no son absolutos, pues están limitados por los derechos de los demás por la seguridad de todos y por las justas exigencias del bienestar general y del desenvolvimiento democrático ${ }^{531}$.

Como se observa en la estructura y naturaleza de los derechos fundamentales, sin lugar a dudas éstos no pueden ser absolutos e ilimitados. Tres son los fundamentos básicos para justificar la limitación de los derechos: porque son de titularidad múltiple; porque su dimensión no es infinita ya que se chocan con otros derechos igualmente fundamentales y, finalmente, porque la propia norma que los positiva crea situaciones de restricción o autoriza que las normas legales las creen ${ }^{532}$.

528 CORRÊA DE CARVAlHO, J. T., Tráfico de drogas. Prueba penal y medidas restrictivas de derechos fundamentales, Curitiba, 2009, pág. 87. En opinión de ORTELLS RAMOS, "la naturaleza de las medidas restrictivas de derechos fundamentales en general puede ser de tres tipos: las relacionadas con la imposición de una pena; las que tienen por causa actuaciones para prevenir delitos y para su investigación y enjuiciamiento; y las medidas cuya causa no está relacionada con la ley penal". Vid. ORTELLS RAMOS, M., "Exclusividad jurisdiccional para la restricción de derechos fundamentales y ámbitos vedados a la injerencia jurisdiccional", Cuadernos de Derecho Judicial, núm. 12, Madrid, 1996, pág. 18.

529 RODRÍGUEZ GARCÍA, N., "Medios de prueba restrictivos de derechos fundamentales. Las intervenciones telefónicas", cit., pág. 39. Como sostiene ASENCIO MELLADO, "no existen derechos fundamentales estrictamente ilimitables, puesto que lo contrario supondría privar de éxito cualquier investigación penal, si bien, del mismo modo, las restricciones a las que pueden ser sometidos en cada caso concreto tienen que cumplir los siguientes requisitos: a) reserva jurisdiccional en el establecimiento de las limitaciones de los derechos fundamentales, puesto que también los órganos jurisdiccionales son los titulares de la potestad jurisdiccional en todo tipo de proceso; b) proporcionalidad, como criterio equilibrador de las controversias entre los derechos individuales y las necesidades sociales; c) garantías en la ejecución de la vulneración". Vid. ASENCIO MELLADO, J. M., Prueba prohibida y prueba preconstituida, cit., págs. 92 y ss.

530 Vid. OTTO Y PARDO, I., Derechos fundamentales y Constitución, Madrid, 1988, pág. 110.

531 CAFFERATA NORES, J. I., Proceso penal y derechos humanos. La influencia de la normativa supranacional sobre derechos humanos de nivel constitucional en el proceso penal argentino, Buenos Aires, 2000, pág. 18. Por su parte, señala GRANDINETTI CARVALHO que "la ponderación tiene lugar porque ningún derecho fundamental es absoluto, ninguno es ilimitado. Todos encuentran limitación en los demás derechos fundamentales". Vid. GRANDINETTI C. DE CARVALHO, L. G., "Garantias Constitucionais-Processuais Penais (A efetividade e a ponderação de garantias no processo penal)", cit., pág. 195. También siguiendo el mismo pensamiento de que no existen derechos fundamentales absolutos, Vid. DÍAZ CABIALE, J. A., La admisión y práctica de la prueba en el proceso penal, Madrid, 1992, pág. 133.

532 CORRÊA DE CARVAlHo, J. T., Tráfico de drogas. Prueba penal y medidas restrictivas de derechos fundamentales, cit., pág. 79. La propia jurisprudencia española del Tribunal Constitucional confirma este 
Incluso ni siquiera el derecho a la vida tiene carácter absoluto, pues se admite en algunos países la aplicación de la pena de muerte en casos de guerra declarada533, así como se admite como lícita y constitucional la muerte ajena en una situación de legítima defensa. Lo mismo se puede afirmar de las situaciones en que excepcionalmente se admite el aborto ${ }^{534}$.

Más compleja además, delante de la problemática del fenómeno de la delincuencia organizada es la constatación de que los denominados "nuevos" instrumentos o técnicas de investigación criminal, a ejemplo de las operaciones encubiertas 535 , son, a su vez, por definición más agresivos con las garantías procesales que los "tradicionales".

Modernamente, en especial en los últimos años, hemos presenciado una notable expansión de los medios e instrumentos a disposición de los Estados y de sus poderes, para invadir, cada vez con más intensidad, derechos fundamentales de los individuos, con los riesgos que desde ahí surgen para la libertad de las personas investigadas o acusados en un proceso.

Puntualizando desde una vertiente diversa, con un enfoque desde la perspectiva de la seguridad versus libertad, como una eterna confrontación en el ámbito de la seguridad ciudadana, PÉREZ CEPEDA destaca que el énfasis en el riesgo/peligro crea un alarmismo no justificado ni probado en materia de seguridad, cuya utilidad no parece ser otra que la de generar alarma social, y con ella reclamo de mayor presencia de las instancias de control y conformismo ante un recorte de derechos y libertades basadas en criterios de eficacia de la lucha contra la criminalidad organizada, el terrorismo, el tráfico de drogas, etc 536 .

Prosigue señalando que el riesgo, una vez que aparece, tiende a proliferar. Así, de modo retroalimentativo, se generan nuevas demandas securitarias, se aprueban normas fundamentadas en la lógica de la seguridad, aun a costa de otros valores políticos fundamentales, como la libertad. Por tanto, tenemos que preguntarnos si estamos dispuestos a renunciar a determinados espacios de libertad (en forma de derechos frente a pretensiones de intervención estatal) a favor de una mayor seguridad537. Esta es una buena cuestión a ser debatida y enfrentada por la doctrina penal.

Pero la verdad única e incontestable es que el crecimiento de la violencia y el surgimiento y perfeccionamiento de las nuevas formas de criminalidad han provocado un

entendimiento, al afirmar que "no existen derechos ilimitados. Todo derecho tiene sus límites que establece la Constitución por sí misma en algunas ocasiones, mientras en otras el límite deriva de una manera mediata o indirecta de tal norma, en cuanto ha de justificarse por la necesidad de proteger o preservar no sólo otros derechos constitucionales, sino también otros bienes constitucionalmente protegidos". Vid. STC, 2/1982, de 29.1.1982.

533 Vid. art. 5o, XLVII, "a", de la CRFB.

534 Incluso hubo una reciente aprobación del proyecto de ley que trata de la cuestión del aborto en España. Vid. "Aprobada de forma definitivay sin cambios h kydel aborto",El país, 24/02/2010, www.elpais.com.

535 En sentido amplio, el término "operación encubierta" puede servir para designar diversas formas o métodos de investigación especiales, como por ejemplo la entrega y circulación controlada de drogas y el uso de la figura del agente encubierto o infiltrado.

536 PÉREZ CEPEDA, A. I., La seguridad como fundamento de la deriva del derecho penal postmoderno, cit., págs. 388-389.

537 PÉREZ CEPEDA, A. I., La seguridad como fundamento de la deriva del derecho penal postmoderno, cit., pág. 389. 
miedo social 538 que, aliado a las históricas razones que manipulan este sentimiento irreflexivo de la sociedad y a la falta de credibilidad del Estado en ofrecer políticas sociales efectivas, han venido a fomentar loque se puede denominar de Derecho penal o procesal penal de emergencia. De este tema trataremos en posterior apartado. A continuación, analizaremos la interesante discusión relativa a la necesaria obediencia a los reglamentos procesales y constitucionales en la lucha contra el crimen organizado, evitándose la vulneración innecesaria a los postulados inherentes a la construcción de las bases de un Estado Constitucional de Derecho.

I.3.2.3. El proceso penal garantista y la búsqueda de un enfrentamiento eficiente al crimen organizado.

Una constatación previa respecto al contexto garantista del proceso penal contemporáneo: a través del proceso penal, el Estado debe asegurar la libertad (del imputado o investigado) y la seguridad (de la sociedad) ${ }^{539}$.

Por esta razón el proceso penal debe ser un filtro del derecho penal máximo (garantismo) y realizador del derecho penal mínimo necesario (funcionalismo). Desde ahí es posible afirmar que el proceso penal posee una instrumentalidad garantista-funcional como expresión del debido proceso penal proporcional, representando el imperativo de ponderación entre la necesidad de establecer garantías procesales de legitimidad del sistema como una ponderación razonable de la expectativa social de eficiencia del proceso penal (funcionalidad) y la respectiva realización de la función social de la pena según la dirección de una política criminal basada en la protección personalista de la dignidad humana.

De otra parte, es hecho comprobado que el debate garantismo-eficacia no debe plantearse en términos de prevalencia de uno sobre otro, sino de compatibilidad, esto es, debe buscarse la máxima eficacia del proceso respetando las garantías procesales del juez y de las partes ${ }^{540}$.

Partiendo de estas consideraciones básicas, se puede afirmar que el proceso es el instrumento creado por el Estado para garantizar la restricción legal, necesaria y adecuada

\footnotetext{
538 Por esta razón "se ha observado, en ocasiones, como son las propias instituciones gubernamentales las que provocan esa sensación de miedo en la ciudadanía, con el interés de conseguir la fácil aprobación de una futura reforma legislativa o, incluso, impulsar la sociedad a demandar leyes más duras". Vid. RODRÍGUEZ, A. D., "Seguridad, Derechos Humanos y Garantías Penales: ¿Objetivos comunes o aspiraciones contrapuestas?", VV.AA., Derecho penal de la democracia vs seguridad pública, I. B. Gómez de la Torre y N. Sanz Mulas, coords., Granada, 2005, pág. 217.

539 Se habla de una necesaria seguridad de la colectiva en razón de que en la sociedad contemporánea, todavía, las fuentes de peligro y agresión a los derechos fundamentales no advienen exclusivamente del Estado, pero también de otros centros del poder, privados, en relación a los cuales no da respuesta adecuada a la visión tradicional de los derechos fundamentales como derechos de defensa. Siendo así, los derechos fundamentales pasaron a desempeñar, al lado de sus funciones tradicionales, también una función de defensa contra amenazas y agresiones a los derechos fundamentales con origen en otros centros de poder, no estatales.

540 Cfr. PICÓ I JUNOY, J.,"El derecho procesal entre el garantismo y la eficacia: Un debate mal planteado", cit., pág. 126. En opinión de LOPES JR "es importante comprender que la represión y las garantías procesales no se excluyen, sino que coexisten". Vid, LOPES JR, A., Introdução crítica ao Processo Penal. Fundamentos da instrumentalidade constitucional, cit., pág. 68.
} 
de los derechos y libertades por parte de las autoridades que tienen encomendada, con mayor o menor amplitud, la investigación preprocesal y procesal del crimen ${ }^{541}$.

Del mismo modo, es algo lógico aducir que pensar en la eficacia del proceso penal presenta un significado doble, pues en una primera acepción, deberá ser idealizada la persecutio criminis como actividad desarrollada y estructurada por el Estado con la meta optata de intentar bajar los niveles de impunidad ${ }^{542}$, o sea, para poner en práctica un ideal punitivo que promueva la seguridad colectiva. Todavía, no se puede olvidar el otro lado de la moneda, donde se destaca la obligación del mismo Estado en mantener intacto el sistema de garantías, respetando a tope los derechos humanos fundamentales del ciudadano.

Nos parece incontestable que la idea de eficacia procesal penal no tiene la pretensión de significar un aumento del contenido violento del ius puniendi. Muy al revés, pues debe representar un ideal de buscarse el control de la criminalidad con el menor contenido de violencia posible. Y la razón es sencilla: no se combate la violencia con el uso de más violencia ${ }^{543}$.

Por esta línea de pensamiento, es lógico comprender que considerando que riesgo, violencia e inseguridad siempre van a existir, es siempre mejor el riesgo con garantías procesales que el riesgo con autoritarismo. Todavía, el gran problema que se puede afrontar dice respecto a la constatación práctica e indiscutible de que las fundadas objeciones que delinean la teoría garantista tradicional defendida en especial por FERRAJOLI, hacia las políticas de lucha contra la criminalidad organizada, presentan la característica de parecer un peso muerto frente a las crecientes demandas de seguridad en la sociedad contemporánea y, en el caso de estudio, de cara a los retos que para el normal funcionamiento de los Estados democráticos plantea el crimen organizado, pues no se puede desconocer que este fenómeno posee unas características que escapan a los paradigmas dentro de los cuales se ha comprendido la delincuencia clásica.

Pero, hechas estas consideraciones, cabe plantear una duda: ¿cómo conciliar este ideal garantista del proceso penal delante de formas graves de delincuencia, a ejemplo de los crimines practicados por los grupos organizados de actuación transnacional?

Para empezar a comprender este dilema, habrá que reafirmarse que estas organizaciones criminales, especialmente por su poder económico y su carácter transnacional, poseen un potencial especialmente perjudicial para las instituciones

541MARTÍNEZ GARCÍA, E., Actos de investigación e ilicitud de la prueba. El derecho al proceso y sus garantías como límite a la actuación de los poderes públicos en la investigación del delito, Valencia, 2009, pág. 24. Respecto al tema, señala GÓMEZ DE LIAÑo GONZÁLEZ que "el proceso penal, es pues un mecanismo complejo, que como todos los procesos jurisdiccionales, tiene la misión fundamental de aplicar el ordenamiento jurídico, y proporcionar los elementos de juicio suficientes para determinar cual es el derecho aplicable al supuesto concreto sometido a consideración, y al objeto de conseguir la que se ha denominado piedra angular jurídica: la tutela judicial efectiva". Vid. GÓMEZ DE LIAÑO GONZÁLEZ, F., El proceso penal. Tratamiento Jurisprudencial, cit., pág. 25.

542 Deberá ser recordado que la impunidad como factor criminológico resultante de la ineficacia de la actuación estatal es una preocupación social, pues la ineficacia casi absoluta del Estado en algunas situaciones puntuales es el eje central de la pierda de confianza de la sociedad en el modelo persecutorio establecido para la represión a los avancesde la criminalidad.

543 Para un estudio más proficuo y general respecto al tema del uso de la violencia, Vid. DELGADO AGUADO, J et alli, VV.AA., Estudios sobre la violencia, J. Delgado Aguado coord., Madrid, 2006; MICHAUD, Y., La violencia, Madrid, 1998; SAN MARTÍN, J., La violencia y sus claves, Barcelona, 2000. 
sociales y democráticas ya que aprovechan la jurisdicción limitada de los países para lograr impunidad; su compleja estructura organizativa y los códigos internos de lealtad y silencio por los que se rigen hacen con que las posibilidades de detección de los responsables de dirigir la asociación criminal sean reducidas o que, aun reconociéndolos, puedan ser sujetos imputables en calidad de autor mediato o partícipe de un delito concreto, dadas las grandes dificultades probatorias de establecer el nexo causal entre el sujeto y la comisión del hecho ${ }^{544}$.

Se percibe, pues, la complejidad en encontrarse un modelo ideal que consiga al mismo tiempo, mantener el control sobre la expansión de las formas más graves de delincuencia, satisfacer los anhelos de la sociedad atemorizada con la violencia practicada por los clanes organizados de criminales y aún, buscar la punición de los culpables que pertenecen al crimen organizado, sin violentar de modo irrazonable y sin criterios jurídicos, los derechos y garantías fundamentales inherentes a los mismos.

Y en este camino de búsqueda de soluciones para compatibilizar la situación expuesta, surgen como respuestas mágicas, las tesis basadas en la represión dura y con contornos de guerra, a ejemplo de la idea de defensa de un Derecho penal y procesal penal de enemigos, como forma de resolución de todos los males y como fantasiosa clave para se exterminar las personas que no quieren seguir las reglas de convivencia ciudadana ${ }^{545}$.

No se puede olvidar además, la idea de que la delincuencia organizada obedece a una categoría criminal especial frente a otros fenómenos de delincuencia clásica, traza los contornos de la necesidad de establecer excepciones al sistema de derechos y garantías de los imputados y condenados con la finalidad de facilitar la demostración de la responsabilidad penal y, en consecuencia, la prevención y represión del fenómeno ${ }^{546}$.

Como ya adelantamos, mismo en se tratando de actividades perpetradas por la delincuencia organizada, con todas las características que le son inherentes, como la violencia exacerbada y el uso del poder financiero y de la corrupción, no se puede admitir que el Estado utilice de medios inmorales, ilegales y violentos para atingir la finalidad de obtención de la punición de sus miembros.

Entonces, quizás la gran cuestión sería comprender lo que se debe entender por "medios inmorales", a la vez que la ilegalidad y la violencia ya son por nosotros claramente comprendidos como términos antigarantistas y que no deben prevalecer en las respuestas persecutorias del Estado. Cuando del estudio de la problemática de la ética en las operaciones encubiertas, tendremos la oportunidad de aclarar si el uso de medios extraordinarios de investigación podría ser considerado como medio inmoral de búsqueda por la eficiencia en la investigación.

544 Vid. VÉLEZ RODRÍGUEZ, L. A., "La lucha contra el crimen organizado como dilema para el Estado de Derecho. Aproximación a una alternativa", cit., pág. 95.

${ }^{545}$ En este contexto, no podemos dejar de recordar la teoría hobbesiana, en el sentido de que quien no acepta las normas que surgen del contrato social, puede ser "eliminado sin injusticia". La noción del Derecho Penal del Enemigo se emparenta con este extremo al negarle el carácter de "personas" a quienes pertenecen a cierto subgrupo de "delincuentes". Todavía, como tendremos oportunidad de constatar en el desarrollo de nuestro trabajo, con la construcción teórica denominada "Derecho Penal o Procesal penal del Enemigo" se está violando palmariamente derechos fundamentales pacíficamente consagrados, lo que a nuestro modo de pensar es incompatible con el modelo ideal de un Estado constitucional de Derecho.

546 En este sentido, Vid. VÉLEZ RODRÍGUEZ, L. A., "La lucha contra el crimen organizado como dilema para el Estado de Derecho. Aproximación a una alternativa", cit., pág. 97. 
Al fin de este apartado, habrá que concluirse que la disputa procesal habrá que ser legalista y ética, pues el arma más poderosa que podrá ser utilizada por los órganos de persecución penal es el empleo de la legalidad en sus actitudes de investigación, bien como el respeto al criterio de proporcionalidad como forma dedistinguirse las situaciones concretas donde deberán excepcionalmente quedar flexibilizadas algunas de las garantías inherentes a aquellas personas envueltas en prácticas criminales de destacada gravedad y repercusión social ${ }^{547}$.

Se adquiere a nuestro modo de pensar, con esta postura, el rescate de la credibilidad de la administración de la justicia penal junto a la sociedad, bien como la eficiencia en la lucha contra las formas más graves de actuación de la criminalidad.

547 Confirmando este pensamiento, deberá ser citado el famoso y controvertido caso denominado "Naseiro", donde la Sala Segunda del Tribunal Supremo, ATS de 18 de junio de 1992, dejó claro que "no se puede obtener la verdad a cualquier precio. No todo es lícito en el descubrimiento de la verdad. Sólo aquello que es compatible con la defensa del elemento nuclear de los derechos humanos, así la dignidad, la libertad, etc., dentro de los parámetros fijados por la ley". Para más conocimiento respecto del citado caso Naseiro, Vid. ANDRÉS IBÁÑEZ, P., "El caso Naseiro en el país de las garantías", http://www.juecesdemocracia.es. 


\section{CAPÍTULO SEGUNDO: LA "EMERGENCIA" PENAL Y EL DERECHO PENAL DEL ENEMIGO COMO POSIBLES SOLUCIONES CONTRA EL CRIMEN ORGANIZADO TRANSFRONTERIZO. UNA AFRONTA AL ESTADO CONSTITUCIONAL DE DERECHO.}

\section{II.1. El proceso penal de "emergencia" y su relación con el tratamiento jurídico de la delincuencia organizada}

II.1.1. Los derechos fundamentales y la "emergencia" como respuesta en la lucha contra la delincuencia organizada.

\section{II.1.1.1. La atención hacia la eficacia y la seguridad.}

Si desde el punto de vista penal se ha ido produciendo una alteración de los componentes del sistema, en el ámbito estrictamente procesal penal se ha producido también un obsesivo deseo de buscar mecanismos que conviertan la justicia en eficiencia $\mathrm{y}$, por tanto, desde parámetros garantistas parece que pendularmente estamos adentrándonos en parámetros de celeridad para conseguir una económica justicia penal ${ }^{548}$. En realidad, se busca más celeridad y rigor en la aplicación de la ley penal, disminuyendo el respeto por las garantías y derechos fundamentales de las personas sometidas a la persecución penal 549.

Esta triste constatación lógicamente no es compatible con el marco garantista que impregna el Derecho procesal penal contemporáneo. Y lo más grave es que nos encontramos delante de la consolidación de discursos de emergencia, a ejemplo de propuestas como la del derecho penal y procesal penal del enemigo. Sin embargo, el derecho penal de la emergencia se traduce en una propuesta de derecho penal máximo con un claro recorte de garantías constitucionales y procesales y se viene repitiendo a lo largo de la historia.

En cualquier caso, deberá reconocerse que la sociedad de la post modernidad vienecreando la figura de los "enemigos", los cuales son concebidos como sujetos que deben estar desprovistos de las garantías propias del Estado de Derecho, porque ya mediante su comportamiento individual o como parte de una organización criminal (nadie duda que vivimos la era de la tecnocriminalidad y de la delincuencia organizada trasnacional), abandonan el Derecho de manera irreversible pues no se tratarían de delincuentes ocasionales. Esta la esencia del pensamiento dogmático defendido por JAKOBS550 en Alemania y extendido a otros países europeos y especialmente iberoamericanos.

\footnotetext{
548 En este sentido, Vid. BARONA VILAR, S., "Conformidad del acusado, paradigma de eficiencia de la Justicia Penal", cit., pág. 409.

${ }^{549}$ A esta situación podríamos cualificar como representativa de un "utilitarismo procesal antigarantista".

550 Aunque se va a tratar del tema del "Derecho penal del enemigo" de forma bastante detallada en apartados siguientes, no es de todo inútil señalar en este momento que nos encontramos con un derecho penal incluso de la anticipación a los hechos criminales, como una propuesta de protección penal, que va a conllevar un discurso de aumento de penas, la transformación de la legislación penal en un arma de lucha contra el enemigo, al que hay que enfrentar socavándole sus garantías procesales, desconociéndole hasta el derecho al reclamo mediante instituciones como las del amparo de libertad. El derecho penal de la emergencia termina por legitimar el abuso frente a lo que se considera una situación excepcional, que creada por el enemigo es castigada de inicio con la propia renuncia a sus garantías personales. El recorte de garantías y beneficios de excarcelación se trasladan al propio derecho procesal penal, con la creación de institutos como la prisión preventiva no excarcelable ni sustituible frente a cierto tipo de delitos como los de criminalidad organizada,
} 
Pues bien, eso quiere decir sin ninguna duda que "el vale todo" para conseguir lograr los objetivos persecutorios de la justicia penal es una realidad incontestable. Según esta línea de pensamiento, la reducción de las garantías y derechos fundamentales sería una forma de contener el avance de ciertas formas graves de violencia. Sin embargo, esta situación viene a chocarse con el ideal garantista de defensa de una armonía procesal penal, la cual tiene por finalidad precipua, ablandar los efectos negativos de la tensión de fuerzas entre los vectores de las garantías y la eficiencia.

De otra parte, es acertada la afirmación de GASCÓN INCHAUSTI, en el sentido de que delante del contexto actual en que vivimos, es una realidad que el Estado se va viendo cada vez más indefenso ante el terrorismo y la delincuencia organizada, porque los instrumentos clásicos o tradicionales de que dispone para combatirlos se han quedado insuficientes, con la consiguiente sensación de inseguridad ciudadana y la percepción social de que ciertas modalidades delictivas son impunes; esta situación hace con que resulte imprescindible lograr que la persecución penal sea más eficaz. Siendo así, esta exigencia, a su vez, descansa sobre otro postulado, en el que también han tenido una influencia decisiva los medios de comunicación, y que afecta a la propia concepción de lo que ha que ser la función del proceso penal: no sólo instrumento para la aplicación del Derecho penal, sino una herramienta más para la consecución de un bien colectivo como es la "seguridad"551.

En este contexto, la búsqueda de eficacia en la persecución penal conduce a otra vertiente provocadora de serias preocupaciones al bien estar ciudadano y colectivo: la ausencia de seguridad representada por la alarma provocada por las actuaciones de los grupos de delincuentes organizados. En siendo verdad esta afirmación, importante señalar que justamente desde estos parámetros, deberá ser afirmado que el Derecho Procesal penal es instrumento idóneo para alcanzarse la eficiencia de la persecutio criminis contra el crimen organizado, proporcionando a la sociedad, desde un "proceso justo", la seguridad como forma de certeza respecto a la aplicación de la ley penal552.

A este propósito, nos interesa señalar que la seguridad es uno de los objetivos prioritarios que la gran mayoría de los gobiernos se han propuesto para mejorar la calidad de vida de las personas, siendo todavía, de modo claro, una condición indispensable para el libre ejercicio de los derechos fundamentales de los ciudadanos.

Desde este punto de vista, es lógico comprender que si bien la seguridad es una necesidad humana y una función del sistema jurídico, no tiene, sin embargo, un contenido propio, es una necesidad secundaria sobre todo si se la incardina en el sistema de derechos o necesidades básicas que son realmente de naturaleza primaria. Tales supuestos nos conducen a reconocer que es importante "desconstruir" el sentimiento de

terrorismo, delincuencia macro-económica, tráfico de drogas ilegales, pornografía infantil, etc., en estos casos se pretende encontrar su legitimación a partir de la necesidad de la eliminación de un peligro potencial o futuro, la punibilidad se adelanta y la pena se dirige hacia el aseguramiento frente a hechos futuros. Véase a respecto, ZAMBRANO PASQUEL, A., "Derecho Penal del Enemigo y Amparo de Libertad", http://www.revistajuridicaonline.com. 485.

551 GASCÓN INCHAUSTI, F., "Los procesos penales en Europa: líneas de evolución y tendencias", cit., pág.

552 Monográficamente respecto al tema de la seguridad ciudadana y el Derecho penal, Vid. con detalles, RUBIO LARA, P. A., Derecho penal y seguridad ciudadana, 1ae edición, Madrid, 2009; JIMENEZ DIAZ, Mạ. J., Seguridad ciudadana y Derecho penal, Madrid, 2006. 
inseguridad ${ }^{553}$ y reconstruirla pero desde políticas de inclusión social y no de exclusión, a saber: mediante políticas dirigidas a la atención de los débiles y excluidos, políticas criminales como elemento subsidiario de política integral de seguridad de los derechos, política pública de seguridad, y derecho penal mínimo, entre otras ${ }^{554}$.

Así, en nuestro modo de pensar, todo es posible, habiendo posibilidad de buscarse grados aceptables de seguridad ciudadana, mismo en situaciones de extrema necesidad de ejercitarse el ius puniendi estatal contra determinadas formas más graves de criminalidad. Bastaría, pues, encontrarse la deseada armonía procesal penal, compatibilizándose la seguridad y la eficiencia.

Pongamos atención: seguridad y eficiencia deben seguir el mismo rumbo, a la vez que la credibilidad de la sociedad en la administración de la justicia penal solamente podrá ser rescatada a partir del momento en que, a través del cumplimiento y observancia de los principios constitucionales y procesales penales, consiga el Estado proporcionar un juicio justo y marcado por el respetoa las garantías y derechos fundamentales.

II.1.1.2. La "emergencia" penal como posible solución para el fin de la criminalidad organizada.

En un sentido histórico, la invocación de la emergencia ${ }^{555}$ y la necesidad de medidas excepcionales para combatirla (así como su inutilidad para resolverla), tiene una larga tradición en la vida desarrollada por los hombres a partir del momento en que han empezado a vivir en sociedad.

Esto significa, sencillamente, que la realidad es que el estudio del fenómeno de la emergencia en el ámbito penal revela la incoherencia y la insensatez de un sistema penal que se imagina racional. Junto a la situación de emergencia, viene casi como una consecuencia, la adopción de un derecho de excepción ${ }^{556}$.

Al tratar de modo específico del tema de la represión a la delincuencia organizada, que a cada día se aproxima más en dirección a este derecho especial o de excepción, destaca ADRIASOLA que esta postura no importa en aceptar la renuncia a las garantías del derecho clásico, pero sólo reconocer su insuficiencia delante de la nueva realidad penal. Se trata en último análisis, de una decisión de política criminal que los legisladores y operadores del derecho deberán adoptar o repudiar, no dejando de reconocer que el derecho emergencial quiebra todo el paradigma del derecho penal y procesal penal liberal,

553 Para un estudio profundizado véase, COMAS ARNAU, D., "Delincuencia e inseguridad ciudadana", VV.AA., España, sociedad y política, S. G. San Julián coord., Madrid, 1990, págs. 613-632.

554 Véase, BARATTA, A., "Diritto alla sicurezza o sicurezza del diritto", La bilancia e la misura. Democracia e diritto, núm. 5, 2001, págs. 19 y 27.

555 Como obra de referencia respecto al tema de la emergencia en el ámbito propiamente penal, Vid. MOCCIA, S., La perenne emergenza. Tendenze autoritarie nel sistema penale, Nápoles, 1995. También destacado y con profundidad dogmática, Vid. BARATTA, A; SILBERNAGL, M., "La legislación de emergencia y la cultura jurídica garantista en el proceso penal", Cuadernos de política criminal, núm. 28, 1986, págs. 157-191.

556 En esta línea de pensamiento, GOMES y CERVINI esclarecen que "la característica principal del derecho de excepción reside en la formación de un derecho paralelo, poco ajustado a los derechos y garantías fundamentales y a los principios básicos del Estado Constitucional de Derecho. Es guiado, de otro lado, por la política criminal sólo preocupada con la eficiencia del sistema, con el éxito funcional, en fin, con tener respuestas (inmediatas, aunque muchas veces simbólicas) para la criminalidad, dentro de una concepción criminológica neoclásica". Vid. GOMES, L. F., CERVINI, R., Crime organizado: enfoque criminológico, jurídico (Lei 9.034/95) e político-criminal, cit., pág. 67. 
destinado a garantir la esfera de libertad del individuo delante del Estado557. En consecuencia, como afirma FERRAJOLI, la "razón del Estado" pasa a prevalecer sobre la "razón jurídica"558.

Todavía, es cierto que las leyes penales son uno de los medios preferidos del Estado que promueve el espectáculo del "simbolismo penal" y de sus operadores showman, en razón de que son baratas, de propaganda fácil y la opinión se engaña ${ }^{559}$ con suficiente frecuencia sobre su eficacia. Se trata de un recurso que otorga alto rédito político con bajo costo financiero, pues la simple aprobación de un acto legislativo presentará a la clase política un retorno o recompensa destacable en términos de exaltación pública ${ }^{560}$. De allí la reproducción de leyes penales, la descodificación, la irracionalidad legislativa y, sobre todo, la condena a todo el que dude de su eficacia ${ }^{561 .}$

De otra parte, en palabras de HASSAN CHOUKR, la emergencia significa algo que huye de los padrones tradicionales del tratamiento por el sistema represivo, constituyendo un subsistema de derogación de los principios culturales empleados en la normalidad. En un cierto sentido, la criminología contemporánea da guarida a este subsistema, lo poniendo en la escala más elevada de la gravedad criminosa a justificar la adopción de mecanismos excepcionales a combatirla, aunque siempre defienda el modelo del Estado democrático de Derecho como límite máximo de la actividad legislativa en este campo ${ }^{562}$.

De lo dicho resulta que es en la emergencia ${ }^{563}$ del confronto entre la democracia y la hipercriminalidad, que más se manifiesta la tentación de los gobiernos y de los

557 ADRIASOLA, G., El nuevo derecho sobre tóxicos y el lavado de dinero, Montevideo, 1994, pág. 97. Para un proficuo estudio de la emergencia en el proceso penal, Vid. BARATTA, A., SILBERNAGL, M., "La legislación de emergencia y la cultura jurídica garantista en el proceso penal", cit., págs. 157-191. Como ha puesto de manifiesto ZÚÑIGA RODRÍGUEZ, "dentro del ámbito académico, la aproximación a la legislación excepcional contra la criminalidad organizada ha sido, fundamentalmente crítica por la abolición de principios que ella supone, fundamentalmente, adelantamiento de la intervención, medios extraordinarios de investigación, formas de comiso de las garantías obtenidas, pérdida de beneficios penitenciarios y cumplimiento íntegro de las penas". Vid. ZÚÑIGA RODRÍGUEZ, L., Criminalidad organizada y sistema de derecho penal, cit., pág. 191.

558 FERRAJOLI, L., Derecho y razón, Teoría del garantismo penal, cit., pág. 814.

559 En el sentido de crear leyes simbólicas, con carácter de emergencia, con el objetivo de demostrar que el Estado se preocupa con el bien estar de los ciudadanos.

560 La justificativa del "bajo costo" puede ser fácilmente explicada en razón de que la promulgación de una ley no impone significativos gastos financieros al legislador que la edita. Por otro lado, el valor simbólico de una ley acredita al Estado un fuerte carácter emocional junto a la sociedad que se siente más segura.

561 Vid. ZAFFARONI, R. E., "Globalización y sistema penal en America Latina: de la seguridad nacional a la urbana", Revista Brasileira de Ciências Criminais, vol. 5, núm. 20, São Paulo, 1997, págs. 19-20.

562 HASSAN CHOUKR, F., Processo Penal de Emergência, Rio de Janeiro, 2002, pág. 6. Ya en la opinión de BERGALLI, "por emergencia se puede entender la aparición de ciertas situaciones que tienen por efecto, modificar o influir en el ámbito de las relaciones habidas entre la sociedad civil y el Estado. Desde este punto de vista es posible hablar de una cultura de emergencia". Vid. BERGALLI, R., "Emergencia: una cultura específica", presentación de la monografía "Emergencia y crisis del Estado social. Análisis de la excepcionalidad penal y motivos de su perpetuación", Barcelona, 1988, págs. 1 y ss.

563 Vid. respecto de la creciente legislación penal y los discursos de emergencia: STORTONI, L., Criminalità organizzata e legislazione di emergenza, Dei delitti e delle pene, 1992, págs. 39-51; VV.AA, Teorías actuales en el Derecho Penal, 75o aniversario del Código Penal, Buenos Aires, 1998, págs. 613-668; MOCCIA, S., "Emergência e defesa dos direitos fundamentais", cit., págs. 58-91; PAREDES, E. A., Los discursos de emergencia y los procesos de criminalización, Revista de Derecho penal, procesal penal y criminología, Mendoza, 2002, págs. 435464; HASSAN CHOUKR, F., Processo Penal de Emergencia, Rio de Janeiro, 2002; SICA, L., Direito penal de emergência e alternativas à prisão, São Paulo, 2002; GONZÁLEZ, H. R., Estado de no derecho, emergencia y derechos constitucionales, Buenos Aires, 2007. 
parlamentos, presionados por la opinión pública564, que exige seguridad y eficacia, en combatir el fuego con el fuego, con retroceso en las garantías que son la base de una sociedad democrática. Pero, mismo aquí, y por mayoría de razón en otras formas de criminalidad amenazadoras de valores esenciales a la estabilidad de las sociedades democráticas, el combate no puede ser ejecutado al margen del respetopor los derechos fundamentales. Es precisamente en situaciones de crisis que el respeto por los derechos fundamentales se revela más incisivo y exige mayor vigilancia ${ }^{565}$.

Se denota entonces, que es una tendencia habitual, delante de los discursos de emergencia, que la represión venga a aumentarse sin fronteras y sin límites en el seno cultural de la normalidad, con evidentes perjuicios, pues esta cultura de emergencia y la práctica de excepción, antes de transformaciones legislativas, son, a bien de la verdad, responsables por un retroceso en la evolución de un determinado ordenamiento punitivo.

Cítese como ejemplo práctico en los días de hoy, las discusiones respecto de la tesis del Derecho Penal del enemigo566 o la posibilidad de utilización de la tortura567, como formas de reacción a algunas de las graves especies de criminalidad como el terrorismo y la delincuencia organizada.

Obviamente, y como no podía ser de otra forma, en este contexto de surgimiento de indicativos de un proceso penal de emergencia, fruto del alarma de inseguridad despertada desde los últimos años, se observa que la política criminal de algunos países viene esquivándose del modelo garantista, dando a su vez, espacio para el crecimiento de los anhelos inmediatistas, ofreciendo así, respuestas fuera de un contexto razonable y actuando en conformidad con las presiones sociales, y lo más grave, olvidándose de la verificación de su eficacia instrumental como medio de prevención del delito.

Se instala según BINDER, una "concepción bélica" del proceso penal, donde tiene amplio predominio la ausencia de respeto a las garantías constitucionales, pues que para el Estado lo que se busca es sólo ganar el juego, a cualquier precio ${ }^{568}$.

Pensamos de modo distinto, pues en la disputa procesal penal, habrá que actuarse siempre de modo eficiente, mismo que tenga que utilizarse de estrategias y mecanismos investigativos más agresivos con los derechos fundamentales, pero lógicamente, obedeciendo a los parámetros de legalidad y de proporcionalidad.

Después de concluir que en los días actuales se presenta incontestable una cultura de emergencia como forma de solucionar los problemas de la criminalidad, lo que a nuestro modo de ver consiste en una verdadera falacia política, puede afirmarse que si la

\footnotetext{
564 Como afirma RODRÍGUEZ, "ante esta fuerte presión mediática, los partidos políticos suelen responder con promesas o propuestas de intervenciones rápidas y efectivas que aborden las disfunciones de forma tajante, dura y radical. En el momento que los poderes públicos deciden intervenir reformando la Ley, la disfunción pasa ha convertirse en un problema social, generándose una sensación de miedo, inseguridad, intranquilidad en la ciudadanía". Vid. RODRÍGUEZ, A. D., "Seguridad, Derechos Humanos y Garantías Penales: ¿Objetivos comunes o aspiraciones contrapuestas?", cit., pág. 217. BARONA VILAR es más contundente y afirma que "a los políticos se les llena la boca de compromisos de seguridad ciudadana, de control callejero o limpieza de calles, de aplicación del sistema penal". Vid. BARONA VILAR, S., Seguridad, celeridad y justicia penal, cit., pág. 55.

565 GASPAR, A. H., "Os novos desafios do processo penal no século XXI e os direitos fundamentais (um difícil equilíbrio)", cit., pág. 260.

566 Vid. con profundidad, APONTE CARDONA, A., Guerra y Derecho Penal del enemigo, Bogotá, 2006.

567 Vid. AMBOS, K., Terrorismo, tortura y Derecho penal. Respuestas en situaciones de emergencia, Barcelona, 2009.

568 CAFFERATA NORES, J., Cuestiones actuales sobre el proceso penal, cit., pág. 222.
} 
búsqueda del equilibrio entre las fuerzas en tensión ya se presentaba como de difícil concreción, hemos acompañado en los últimos años, el surgimiento de situaciones demostrativas de un retroceso increíble del proceso penal rumbo al pasado, delante de la constatación de violaciones típicas de una negación pura de los derechos fundamentales. De este tema, trataremos a continuación.

II.1.1.3. El triste retorno a un pasado sombrío. El cambiar de las cosas después del 11 de septiembre de 2001.

Ahora nos cabe tratar del tema relativo a un determinado retroceso incontestable de las conquistas garantistas del Derecho procesal penal y su repercusión frente al tema de la tensión de fuerzas en el ámbito penal.

Mejor explicando, no se puede negar que en los últimos tiempos, el proceso penal ha atingido grados altísimos de evolución cuanto al respeto a las garantías y derechos fundamentales de las personas sometidas a la persecución penal ${ }^{569}$. Ha sido, pues, un desarrollo sin precedentes.

Nótese que, en este caso, hasta un pasado reciente, la doctrina, la jurisprudencia y la ley, no hacían referencia especial y destacada al valor de principios como la presunción de inocencia ${ }^{570}$, o la contradicción en el contexto de la simétrica paridad de armas ${ }^{571}$, o mismo con referencia a la necesidad de respeto a un plazo razonable ${ }^{572}$ para la realización de los actos procesales. Estos son algunos sencillos ejemplos. Sin ambages y directo al punto: no se defendía con uñas y dientes la preservación de derechos y garantías fundamentales.

En este aspecto, de evolución del sistema de garantías en el ámbito penal, hay que tener en cuenta la importancia, de entre otros, de los estudios desarrollados especialmente por FERRAJOLI respecto del garantismo ${ }^{573}$ y de BARATTA respecto a la criminología crítica ${ }^{574}$.

Pero, la verdad es que actualmente, hemos presenciado movimientos que ponen de manifiesto que ese hermoso historial se ha paralizado o se ve en retroceso, algo cuya justificación se ve influida por la generalización de un "efecto alarma" provocado por acontecimientos ciertamente indeseables y horribles (atentados terroristas ocurridos en

\footnotetext{
569 Para un adecuado entendimiento respeto a la apertura de un nuevo camino en la concepción del proceso, vide MONTERO AROCA, J., Proceso y Garantía Civil y Penal. El proceso como garantía de libertad y de responsabilidad, Valencia, 2006.

570 Vid. con profundidad sobre este tema, OVEJERO PUENTE, A. M., Constitución y Derecho a la presunción de inocencia, Valencia, 2007; PASTOR ALCOY, F., Prueba de indicios, credibilidad del acusado y presunción del inocente, Valencia, 2003.

571 Con riqueza de detalles, Vid. FAZZALARI, E., Istituzioni di diritto processuale, Padova, 1992.

572 Monograficamente, véase, LANZAROTE MARTINEZ, P., Vulneración del Plazo Razonable en el Proceso Penal, Madrid, 2005; LOPES JR, A., BADARÓ, G. H., Direito ao Processo Penal no Prazo Razoável, Rio de Janeiro, 2006.

573 Vid. FERRAJOLI, L., Derecho y razón. Teoría del garantismo penal, cit. Este magnifico libro analiza la crisis de los fundamentos del derecho penal expresada en la profunda falta de correspondencia que existe entre el sistema normativo de las garantías y el funcionamiento efectivo de las instituciones punitivas. Hace un recorrido teórico por las raíces del modelo garantista recogido por la tradición ilustrada, así como por la oposición que contra dicho modelo han ejercido desde finales del siglo pasado la continua emergencia de arquetipos penales premodernos y la interminable tentación de autoritarismo. Ilustra las múltiples formas de ilegitimidad e injusticia provocadas por la inadecuación del modelo o por las lesiones contra las garantías individuales. Frente a la crisis del modelo, propone una reformulación política en el marco de una teoría general del garantismo.

574 Vid. BARATTA, A., Criminología crítica y crítica del Derecho Penal, México, 2000.
} 
2001 en Nueva York y Washington, en 2004 en Madrid, en 2005 en Londres, o los de menor repercusión como los atentados de Bali o Egipto, por recordar algunos de los de mayor impacto $)^{575}$.

De se destacar que después de los últimos grandes atentados ocurridos en Londres en 2005, hemos presenciado a bien de la verdad actos terroristas de menor intensidad, debiendo citarse como ejemplos, la continuidad de las acciones del grupo separatista ETA en España y de los rebeldes en Irak y Afganistán. También el ataque ocurrido en 24 de enero de 2011 en el aeropuerto de Moscú-Domodédovo.

La verdad es que el 11 de septiembre de $2001^{576}$ ha inaugurado un nuevo período de inseguridad e intranquilidad. Según ORÉ GUARDIA, el atentado del 11 de septiembre en Nueva York constituye un hito de carácter cultural, histórico y político que, como no podía ser de otro modo, ha tenido su correlato en el ámbito de la vigencia de los derechos fundamentales y, en particular, en la configuración de un nuevo proceso penal. Piénsese, por ejemplo, en la denominada Acta Patriótica577 aprobada un mes después del atentado a los Estados Unidos de América, que contiene una serie de normas que inciden directamente en la afectación de derechos fundamentales y que tienen relación con normas procesales penales ${ }^{578}$.

Ya en opinión de BARONA VILAR, en esta evolución globalizada de la justicia penal es especialmente remarcable la crisis que, tras el 11 de septiembre y los atentados terroristas contra las Torres Gemelas y el Pentágono, el mundo de las libertades ha sufrido, y aún está sufriendo. De ahí que se haya afirmado que la luna de miel entre el mundo y los derechos humanos se ha quebrado desde este momento ${ }^{579}$.

Como respuesta580, se han empezado a producir situaciones que deben ser calificadas de indeseables, que deben ser rechazadas y repudiadas con total vigor y

575 En este sentido, RIQUERT pone de relieve que "a comienzo del tercer milenio, una sucesión de hechos terroristas de gran escala en distintos países ha provocado la adopción de medidas contra el crimen en general y el terrorismo en particular, que ponen en crisis reconocidas garantías de raigambre constitucional". Vid. RIQUERT, M. A., Crisis Penal, Política Criminal, globalización y Derecho Penal, cit., pág. 96.

576 De acuerdo con MANNA, "los atentados a las Torres Gemelas y al Pentágono del 11 de septiembre de 2001 han supuesto un momento de importancia notable en la historia mundial, y, obviamente, en la historia estadounidense". Vid. MANNA, A., "Erosión de las Garantías individuales en nombre de la eficacia de la acción de lucha contra el terrorismo: La privacy", VV.AA., Derecho Penal del Enemigo, El discurso penal de la exclusión, vol. 2, Buenos Aires, 2006, pág. 257. De su parte, FERRAJOLI al comentar sobre el terrible acto terrorista del 11 de septiembre de 2001, ha señalado con absoluta propiedad que "esta horrible masacre puso en crisis la ilusión de la seguridad y de la invulnerabilidad de nuestro mundo". Vid. FERRAJOLI, L., "Por una esfera pública del mundo", Democracia y garantismo, Madrid, 2008, pág. 328.

577 El Acta patriótica es un documento de 119 páginas y 128 secciones aprobado por la Cámara y el Senado norteamericano a menos de dos semanas de producido el atentado de 11 de septiembre. Se sabe también que la inmensa mayoría de los legisladores que lo aprobaron ni siquiera lo habían leído. Su nombre completo es "Acta del 2001: Uniendo y fortaleciendo a los Estados Unidos al dotarlo de las herramientas adecuadas para interceptar y obstruir al terrorismo", conocido por las siglas en inglés USAPA y fue puesto en vigencia desde el 26 de octubre de 2001. Vid. con profundidad respecto del acta patriótica norteamericana, SALAS CALERO, L., "La Ley Patriótica USA", VV.AA., Terrorismo y proceso penal acusatorio, J. L. Gómez Colomer y J. L. Gonzáles Cussac coords., Valencia, 2006, págs. 255-309; PÉREZ CEBADERA, Mà Á., "Las medidas antiterroristas en Estados Unidos de Norteamérica al final de la presidencia Bush", VV.AA., Terrorismo y Estado de Derecho, J. R. Serrano Piedecasas y E. Demetrio Crespo coords., Madrid, 2010, págs. 482 y ss.

578 ORÉ GUARDIA, A., "Panorama del Proceso Penal Peruano y reformas urgentes", http://www.incipp.org.pe.

579 BARONA VILAR, S., "Conformidad del acusado, paradigma de eficiencia de la Justicia Penal", cit., págs. 404-405.

580 A nuestro modo de pensar, una respuesta absolutamente desmedida, fruto de la sensación de inseguridad ampliamente difundida y sostenida en algunas situaciones por el propio Estado, el cual frente a la 
convicción, por cuanto suponen la negación pura de derechos fundamentales ${ }^{581}$. Cítese, por ejemplo, la situación degradante de los talibanes detenidos en la prisión de Guantánamo en Cuba o las reglas de restricción a derechos fundamentales de los ciudadanos contenidas en la Patriot Act norteamericana ${ }^{582}$ o en otras leyes antiterroristas en el ámbito de la Unión Europea.

La consecuencia de esta situación viene dada a través del resurgimiento por intermedio de JAKOBS de la tesis de un Derecho penal del enemigo, de índole nítidamente contraria al Derecho penal liberal y al Estado de Derecho.

Como sintetiza MUÑOZ CONDE, en estos últimos cinco años y, sobre todo, desde los atentados terroristas del 11 de septiembre de 2001 en Nueva York y Washington, se observa, no sólo en los Estados Unidos de Norteamérica, sino también en otros muchos países, una tendencia creciente hacia lo que el penalista alemán GÜNTHER JAKOBS denomina un "Derecho penal del enemigo". Con él, dice el citado penalista germánico, el legislador no dialoga con sus ciudadanos, sino que amenaza a sus enemigos, conminando sus delitos con penas draconianas más allá de la idea de proporcionalidad, recortando las garantías procesales y ampliando las posibilidades de sancionar conductas muy alejadas de la lesión de un bien jurídico ${ }^{583}$.

Esta tesis sostenida y ahora legitimada y justificada a partir del año 2003 por JAKOBS584, visualiza el delincuente no como un ciudadano que debe ser respetado, pero sí, como un inminente peligro a ser neutralizado. Nótese que, en este caso, los miembros de grupos de delincuentes organizados, los terroristas, los autores de delitos sexuales o de delitos de genocidio, reciben un tratamiento especial como enemigos del Estado, y así como en la guerra, deben ser sumariamente eliminados o puestos fuera de circulación, no teniendo derecho alguno.

De esta suerte, el tráfico de drogas, el terrorismo y el fantasma de la criminalidad organizada han sido los problemas que han dado y están dando lugar a un Derecho penal excepcional que bien podría calificarse como "Derecho penal del enemigo". Son estos delitos y sus autores la principal preocupación de los gobiernos actuales, que proceden de la forma más dura y eficaz posible para combatirlos, incluso más allá de los parámetros admisibles en el Estado de Derecho585.

Respecto a este pensamiento dogmático, volveremos en apartado posterior, en el que tendremos la oportunidad de ofrecer una mayor profusión del tema, incluso

presión sufrida delante del crecimiento de la criminalidad, hace una opción por respuestas estatales típicas de un Derecho penal máximo.

581 GUZMÁN FLUJA, V., "El agente encubierto y las garantías del proceso penal", cit., pág. 202.

582 Vid., un análisis más profundo de esta especie de legislación de emergencia, en VERVAELE, J. A. E, $L a$ legislación antiterrorista en Estados Unidos, ¿Inter arma silent leges?, Buenos Aires, 2007. Interesante señalar respecto de la Patriot Act, que "dos semanas después del atentado en la Zona Cero, el Senado estadounidense aprobó, con un solo voto en contra, la Uniting and Strengthning America by Providing Tools Required to Intercept and Obstruct Terrorism Acto 2001, más conocida con el significativo acrónimo de la USA Patriot Act, convertida en ley, con la firma del presidente George W. Bush, el 26 de octubre de 2001". Véase, MANNA, A., "Erosión de las Garantías individuales en nombre de la eficacia de la acción de lucha contra el terrorismo: La privacy", cit., pág. 259.

583 MUÑOZ CONDE, F., De nuevo sobre el Derecho penal del enemigo, Buenos Aires, 2005, pág. 25.

584 Vid. JAKOBS, G., CANCIO MELÍA, M., Derecho Penal del Enemigo, 1a edición, Madrid, 2003.

585 MUÑOZ CONDE, F., De nuevo sobre el Derecho Penal del Enemigo, cit., pág. 39. 
preocupándonos en mejor definir el origen y el actual sentido que se debe emplear al discutible "derecho penal del enemigo".

En este punto podemos apuntar algunas conclusiones:

a) Primera, una vez más reafirmar que el proceso penal deberá denotar una estructura legal de equilibrio entre el derecho de punir del Estado y el derecho de los individuos a la libertad y a la seguridad.

b) Segunda, que la eficacia del Derecho penal depende, en gran medida, no de la gravedad de las penas que establezca, sino de la percepción ciudadana respeto de la certeza de su aplicación y de la celeridad en su concreción, lo que se puede lograr a partir de la instrumentalización de un proceso penal justo, en tiempo razonable y que venga a establecer como esencial el respetoa los derechos y garantías fundamentales de las personas sometidas a la persecutio criminis.

Además, deberán ser mejor estructurados nuevos medios de investigación criminal.

Esta es nuestra aposta, en el sentido de búsqueda de estructuración de un Derecho procesal penal del equilibrio, donde las dos fuerzas (eficacia y garantías) deberán ser llamadas a armonizarse en pro del mantenimiento de la credibilidad de la justicia penal.

Posible además comprender que el 11 de septiembre se haya convertido en la excusa de determinadas normas que pretenden paliar un aparente desorden, y justifican las políticas legislativas en la inseguridad callejera, la necesidad de control social a través de un sistema punitivo por razones de seguridad 586 .

En este sentido, señala FERRAJOLI que por una especie de inercia mental, casi un reflejo condicionado irracional, esta terrible masacre fue interpretada no como un crimen ante el cual era necesario reaccionar con la captura y castigo de los culpables y con el descubrimiento y la neutralización de la red compleja y ramificada de sus cómplices, sino como un acto de guerra, como Pearl Harbor, al cual era necesario responder, simétricamente, con la guerra ${ }^{587}$.

Así, se busca con toda fuerza, a través de legislaciones de emergencia y con carácter excepcional, instalar un clima de alarmismo, a sea, una tendencia a propagar rumores sobre peligros imaginarios o a exagerar los peligros reales, de modo a suprimir principios y reglas propias de un verdadero Estado Constitucional de Derecho. Y lo peor, se pasa a esparcir la cultura de la guerra, donde la figura del "enemigo" se transforma en un trofeo de caza.

En síntesis, sostener el exterminio de los "enemigos" como meta optata a ser atingida en la lucha contra las formas más graves de criminalidad, nos parece una involución sin precedentes, teniendo en cuenta las dificultades que fueron traspasadas en los últimos tiempos para se consolidar un Estado Constitucional de Derecho, incompatible con las premisas desarrolladas y defendidas por JAKOBS588.

\footnotetext{
586 Sosteniendo este entendimiento, Vid. BARONA VILAR, S., "Conformidad del acusado, paradigma de eficiencia de la Justicia Penal", cit., pág. 407.

587 FERRAJOLI, L., "Por una esfera pública del mundo", Democracia y garantismo, cit., pág. 329.

588 Se justifica esta proposición a partir de la constatación de los defensores de la tesis del Derecho penal del enemigo, de que el atentado del 11 de septiembre de 2001 a los Estados Unidos de América, el atentado del 11 de marzo de 2004 en la central ferroviaria de Atocha, España y las recientes demostraciones de fuerza de parte del terrorismo el 7 y 21 de julio de 2005 en Londres, Gran Bretaña, han colocado al terrorista como el "enemigo" primordial del nuevo milenio.
} 


\section{II.1.2. La concepción dogmática del Derecho Penal o Procesal penal del enemigo.}

II.1.2.1. La búsqueda del fin de la delincuencia a través del imperativo de ley y orden.

De todo lo expuesto hasta ahora, es una obviedad necesaria afirmar que la existencia de delitos es, lamentablemente, un hecho cierto. También lo es que la sociedad debe reaccionar frente a esos delitos, persiguiendo a quienes los han cometido y castigándolos, encargando de esa función a unas personas determinadas, los Jueces y Magistrados, y precisamente sólo a través del proceso penal589.

Por otro lado, queda muy evidente que se establece claramente en la dogmática moderna, una disputa muy interesante, pero peligrosa, entre el "garantismo penal" y "la política de mano dura", como modelos de actuación penal.

Todavía, no se puede olvidar que la noticia de la posible alteración del orden jurídico mediante la comisión de un hecho delictivo, genera una inmediata reacción del Estado que invocando el interés social en el castigo del delincuente, intentará esclarecer la verdad y actuar la ley penal en el caso concreto. Pero el mismo orden jurídico establece (o debe establecer) la necesidad de asegurar que la satisfacción del interés social en la represión del delito, se logre respetando los derechos de la persona que resulte sospechosa de su comisión. Este el interés individual que radicará en lograr el reconocimiento, por las leyes y en la práctica procesal, de los derechos inherentes a la persona humana como tal y los acordados como garantías especificas frente a la persecución penal ${ }^{590}$.

Es algo incontestable entonces que el proceso penal en una visión moderna debe ser utilizado en estrecha y profunda relación de respetocon los derechos y garantías fundamentales previstas en la Constitución.

Ciertamente, en la búsqueda de la eficiencia en el control de las formas más graves de criminalidad, a ejemplo de la delincuencia organizada, habrá según nuestro modesto entendimiento, que obedecerse los principios rectores de un proceso penal de índole garantista y más que todo, preservándose la incontestable fuerza de la ley penal.

Propugnamos así, como ya explicitado anteriormente, por un modelo de "garantismo integral y proporcional"591, responsable y respetuoso con la soberanía del monopolio estatal que es a nuestro modo de pensar, irrenunciable.

Frente a esta necesidad de poner frenos a la gravísima situación de la expansión de la delincuencia organizada, demostrando el poder de eficiencia penal del Estado, han surgido en los últimos tiempos, algunas discutibles orientaciones doctrinales en el sentido de endurecer la lucha junto a determinadas especies de criminalidad trasnacional y otros delitos de suma gravedad. Y lo más grave, sin preocuparse con el resguardo de las garantías constitucionales de aquellas personas sometidas a la persecución penal.

\footnotetext{
589 Véase, GOMÉZ COLOMER, J. L., "Estado de Derecho y Policía Judicial democrática: notas sobre el alcance y límites de la investigación policial en el proceso penal, con consideración especial de los actos de mayor relevancia", cit., pág. 97. En este sentido, como gráficamente expresara CASSEL "un sistema que no se preocupa por combatir de manera eficaz la delincuencia, no es nada más que una especie de suicidio institucional". Vid. CASSEL, D., "El derecho Internacional de los Derechos Humanos y la detención preventiva", Revista Instituto Interamericano de Derechos Humanos, núm. 21, San José, enero-junio 1995, pág. 36.

590 CAFFERATA NORES, J. I., Derechos individuales y proceso penal, Córdoba, 1984, pág. 13.

591 Si bien a primera vista pueda parecer una incoherencia, sostenemos la idea de un modelo normativo del derecho, estructurado a partir de los principios de legalidad y proporcionalidad, que es en verdad, la base del Estado Constitucional de Derecho. Así, el Estado a través de su potestad punitiva, deberá respetarun elenco sistémico de garantías que han de ser efectuados por él.
} 
La idea rectora de estos pensamientos antigarantistas se basa en la reducción de las garantías del proceso penal y en el endurecimiento de las reglas de aplicación del Derecho penal material, incluyendo así, de modo paradojo, la flexibilización de los derechos fundamentales que reglamentan la incidencia del derecho punitivo en carácter excepcional y en los límites de lo estrictamente necesario ${ }^{592}$.

Se impone así, según algunos entendimientos ideológicos de origen de la política de "manos duras"593, al Derecho procesal penal, a cualquier precio, la tarea de dar fin a las prácticas delictuosas más graves que vienen provocando alarma en nivel mundial, mismo que se tenga que vulnerar los más destacables derechos y garantías individuales establecidas en el texto constitucional.

En lo que nos interesa, cabe resaltar que en los procesos penales nacionales frecuentemente se reflejan fenómenos de violencia e inseguridad ciudadana que preocupan a la sociedad contemporánea ${ }^{594}$. Los fenómenos de la criminalidad organizada y la criminalidad violenta han tenido una respuesta en mecanismos procesales que han limitado las garantías de los procesados y han fortalecido la potestad persecutoria del Estado. El marco teórico para este tipo de legislación es lo que ha venido a llamarse Derecho penal o procesal penal del enemigo ${ }^{595}$, tema ésteque será analizado a continuación.

Ha empezado entonces en la doctrina penal, con considerable intensidad, la discusión sobre la legitimación y existencia de un Derecho penal y procesal penal del enemigo, como forma de describir un modus de actuación contra la criminalidad acentuadamente grave y de dimensión transfronteriza.

Más grave es que dos de las discusiones actuales en el ámbito penal, en especial en Alemania, se refieren en primero al tema relativo a si la prohibición absoluta de la tortura puede realmente mantenerse en situaciones extremas en las cuales su uso podría ser el único medio de obtenerse la información necesaria para prevenir daños (de aún mayor gravedad) a personas inocentes. $Y$ en segundo, si una prueba obtenida por medio de tortura en el extranjero lleva consigo una prohibición absoluta de utilización de la misma en el proceso nacional596. Es lógico que nuestra opinión sea contraria a la admisión de estas formas de logro de las pruebas, en razón de su absoluta incompatibilidad con el Estado Constitucional de Derecho.

Y en este sentido, como consecuencia, en los últimos años ha venido a defenderse y consolidarse, un determinado modelo de enemigo, una legislación de guerra, a la postre, como han calificado algunos autores, que justifica y legitima un Derecho penal y un

\footnotetext{
592 En este sentido, Vid. PRADO, G., "Proceso penal e Estado de Direito no Brasil: considerações sobre a fidelidade do juiz à lei penal", Revista de Estudos Criminais, Sapucaia do Sul, 2004, pág. 104.

593 Vid. GARGARELlA, R., "Mano dura sobre el castigo. Igualdad y comunidad", Nueva Doctrina Penal, Buenos Aires, 2007, págs. 451-472.

${ }^{594}$ Con amplitud respecto a la globalización y la sociedad del riesgo mundial, Vid. BECK, U., Sobre el terrorismo y la guerra, Barcelona, 2003.

595 Vid. ORÉ GUARDIA, A., "Panorama del Proceso Penal Peruano y reformas urgentes", http://www.incipp.org.pe.

596 Para mejor comprender la discusión sobre la utilización de la tortura como medio de obtención de pruebas en los procesos relativos al terrorismo, véase, AMBOS, K., Terrorismo, tortura y Derecho penal. Respuestas en situaciones de emergencia, Barcelona, 2009. También, los recientes trabajos de LLOBET ANGLÍ, M., Derecho penal del terrorismo. Límites de su punición en un Estado democrático, Madrid, 2010; HUSTER, S; GARZÓN VÁLDES, E y MOLINA, F., Terrorismo y Derechos Fundamentales, Madrid, 2010.
} 
proceso penal sin garantías ${ }^{597}$. Y lo más preocupante, es que la propia clase política, por veces, ha intentado sostener frente a la sociedad, que la aceptación de un derecho de excepción, a ejemplo del tratamiento dispensado a los "enemigos" por JAKOBS, sería la solución para se resolver los problemas de agravación de la violencia y de la criminalidad 598 .

\section{I.2.2. Origen histórico de la concepción del "enemigo".}

Como preludio es importante dilucidar que la discusión sobre el Derecho penal del enemigo en la doctrina penal contemporánea ha venido de la mano de los trabajos dogmáticos del profesor alemán GÜNTHER JAKOBS, primero de manera referencial en su trabajo de 1985 sobre la criminalización en el estado previo a la lesión del bien jurídico y luego de manera abierta en su conferencia en el Congreso de Profesores de Derecho Penal de 1999 en Berlín. A partir de entonces este autor se ha encargado de desarrollar los presupuestos filosóficos para explicar dogmáticamente el llamado Derecho penal del enemigo, llegando a concluir esta labor de forma rigurosa en el trabajo titulado Derecho Penal del enemigo, aparecido en lengua castellana en el año 2003.

Esto nos pone en presencia de dos interesantes cuestiones preliminares: ¿Cuál sería el origen de esta concepción de la figura del "enemigo"? ¿Sería JAKOBS el creador de la idea de los "enemigos" como seres distintos a los "ciudadanos"?

En la búsqueda de estas respuestas se nos impone necesario explorar mismo que a vuela pluma, algunos antecedentes históricos. Pasémonos a un análisis respecto al desarrollo temporal de esta discusión ${ }^{599}$.

Primero punto: la propuesta de JAKOBS no es una verdadera novedad. A través del estudio de la historia del nacimiento del poder punitivo se evidencia la construcción de enemigos que, en distintas épocas han servido para canalizar la persecución a las minorías, o sea, a los grupos considerados nocivos para la sociedad 600 .

Esto es especialmente importante para dejar claro que la figura del "enemigo" siempre ha existido en la historia, a partir del momento en que los hombres han decidido vivir en colectividad, defendiendo cada uno sus propios intereses en contraposición a sus oponentes.

Segundo punto: la noción de "enemigo" podrá ser buscada principalmente en los trabajos de HOBBES y ROUSSEAU. Ya en el Contrato Social, por ejemplo, hace ROUSSEAU algunas consideraciones sobre el Derecho penal, en las que introduce el concepto de enemigo, que hoy resulta tan discutido en la dogmática penal. Precisamente alude a él al 403.

597 BARONA VILAR, S., "Conformidad del acusado, paradigma de eficiencia de la Justicia Penal", cit., pág.

598 Cítese como ejemplo, la posición adoptada por el Congreso español, al defender que debería ser aplicada la tesis del Derecho penal del enemigo al maltrato. Vid. sobre el asunto: "El Congreso propone aumentar la condena a quien maltrate borracho. Aplicaría el derecho penal del enemigo para individuos especialmente peligrosos", El mundo, Castilla León, núm. 7.268, del 11 de noviembre de 2009, pág. 8.

599 Monográficamente, Vid. DEL VALLE, C. P., "Sobre los orígenes del Derecho penal del enemigo. Algunas reflexiones en torno a Hobbes y Rousseau", Cuadernos de Política Criminal, núm. 75, Madrid, 2001. También de gran importancia, la reciente publicación de MUÑOZ CONDE, F., "Los orígenes ideológicos del Derecho penal del enemigo", Revista Penal, núm. 26, 2010, págs. 139-150.

600 En este sentido, Vid. ZAFFARONI, E. R., "Buscando o inimigo: de satã ao Direito penal cool", Criminologia e subjetividade, Rio de Janeiro, 2006, pág. 5. 
justificar la pena de muerte: Por otra parte, todo malhechor, cuando ataca el derecho de la sociedad, se convierte por sus crímenes en rebelde y traidor a la patria; él cesa de ser miembro de ella violando sus leyes, e incluso le hace morir al culpable, menos como ciudadano que como enemigo. Los procesos, el juicio, son las pruebas y la declaración de que él ha roto el tratado social y, en consecuencia, ya no es miembro del Estado601.

Siendo así, el punto de partida de la polémica se puede visualizar en otras ramas de la Filosofía del Estado y del Derecho, a ejemplo de los trabajos de filósofos y pensadores como HOBBES o ROUSSEAU.

En verdad este repaso histórico cobra especial significación en pensadores ilustrados ${ }^{602}$.

De esta manera, en varios autores se encuentra una línea constante que, desde una perspectiva objetiva, diferencía entre unos hechos y otros, atendiendo para ello a criterios cuantitativos. Por ejemplo, merecerían un desvalor que excede el ordinario, el asesinato premeditado (FICHTE), los crímenes de lesa majestad y los que atentan contra leyes fundamentales (HOBBES), y las infracciones esenciales del contrato social (ROUSSEAU). Las citas de estos precedentes se repiten en otros autores, en particular en referencia a HOBBES y ROUSSEAU, aunque tampoco falten las reseñas a C. SMIDTH, o GARÓFALO, e imprecisas y controvertidas alusiones a diversos pasajes de las obras de KANT603.

No se debe desconocer, en todo caso, los fundamentos filosóficos del Derecho penal del enemigo: a) el enemigo, al infringir el contrato social, deja de ser miembro del Estado y está en guerra contra ello; luego, debe morir como tal (ROUSSEAU); b) quien abandona el contrato de ciudadano pierde todos sus derechos (FICHTE); c) en casos de alta traición contra el Estado, el criminoso no debe ser castigado como súbditos, pero si como enemigo (HOBBES); d) quien amenaza constantemente la sociedad y el Estado, quien no acepta el "estado-comunitario-legal", debe ser tratado como enemigo (KANT) ${ }^{604}$.

En síntesis, para comprender integralmente el modelo ahora defendido contemporáneamente por JAKOBS, de un Derecho penal dirigido a los "enemigos" de la sociedad y del Estado, se impone un proficuo conocimiento de la doctrina clásica de HOBBES, ROUSSEAU, KANT, FICHTE, LUHMANN y otros, a la vez que estos autores a su respectivo tiempo, han abordado el tema de relación de la figura del enemigo con el Estado.

Hechas estas consideraciones necesarias, se percibe que definitivamente no ha sido JAKOBS el creador de la concepción de la figura del enemigo en contraposición al

601 DEL VALLE, C. P., "Sobre los orígenes del Derecho penal del enemigo. Algunas reflexiones en torno a Hobbes y Rousseau", cit., pág. 597.

602 GONZÁLES CUSSAC, J. L., "El renacimiento del pensamiento totalitario en el seno del Estado de Derecho: la doctrina del derecho penal del enemigo", Revista Penal, núm. 19, Barcelona, 2007, pág. 56.

603 Así, pueden verse los trabajos de GRACIA MARTÍN, L., "Consideraciones críticas sobre el actualmente denominado Derecho penal del enemigo", Revista Electrónica de Ciencia Penal y Criminología, núm. 7, 2005, http://criminet.ugr.es/recpc; ZAFFARONI, E. R., "¿Es posible un Derecho penal del enemigo no autoritario?, VV.AA., Libro en homenaje al Profesor Dr. Gonzalo Rodríguez Mourullo, Navarra, 2005, págs. 1077- 1091.

604 GOMES, L.F; GARCÍA-PABLOS DE MOLINA, A., BIANCHINI, A., Direito Penal. Introdução e princípios, vol. 1, São Paulo, 2007, pág. 295. 
ciudadano y al Estado. El citado autor alemán, a su tiempo, ha sido tan sólo responsable por la reapertura de la discusión en el ámbito penal605.

I.2.3. Qué significa el Derecho penal o procesal penal del enemigo. La polémica contribución de JAKOBS.

Una observación preliminar al tema: para JAKOBS, el modelo penal y procesal penal que debe defenderse es aquél que prima la defensa de la seguridad del Estado por encima de cualquiera de los valores y principios liberales606.

Como ya hemos visto, la tesis más comentada y debatida en los días de hoy, cuya difusión actual de la cuestión viene de las manos del citado penalista alemán, versa sobre la justificación y legitimidad de un Derecho penal del enemigo ${ }^{607}$, del cual deriva como corolario lógico, la idea de un Derecho procesal penal del enemigo ${ }^{608}$.

En este sentido, la referida polarización entre Derecho penal del ciudadano y Derecho penal del enemigo habrá de permear igualmente el Derecho procesal penal. Así las cosas, el proceso penal del enemigo no traduce la actividad cognitiva basada en la imparcialidad del Estado democrático de Derecho.

Sólo como recordación, interesante apuntar que el concepto de Derecho penal del enemigo fue introducido en el debate por JAKOBS a partir de una primera fase en un congreso celebrado en Frankfurt en el año 1985, en el contexto de una reflexión sobre la tendencia en Alemania hacia la "criminalización en el estadio previo a una lesión" del bien jurídico. En esta ponencia, el citado autor manifiesta la necesidad de separar en caso excepcional al Derecho penal del enemigo del Derecho penal de los ciudadanos con el fin de conservar el Estado liberal; tesis que en aquel momento no tuvo mayor trascendencia. Y es, a partir del Congreso de Berlín de 1999 que surge una segunda fase orientada hacia delitos graves contra bienes jurídicos individuales. Diferente fue la reacción crítica entre los juristas alemanes después de la intervención de JAKOBS en este Congreso, principalmente por la diferenciación que el autor propone entre el Derecho penal del ciudadano dirigido a personas y el Derecho penal del enemigo destinado a no personas y que es, según él, necesario para combatir por ejemplo el terrorismo ${ }^{609}$.

¿Pero qué es el Derecho penal del enemigo?

605 Según KAI AMBOS, "la recuperación del derecho penal del enemigo por parte de Günther Jakobs ha generado olas de gran altura no sólo en la discusión jurídico-penal de habla alemana, sino principalmente de habla española, portuguesa e italiana". Vid. AMBOS, K., Derecho penal el enemigo, trad. C. Gómez-Jara Díez y M. Lamadrid, Bogotá, 2007, pág. 7.

606 Esta la opinión general en la doctrina penal. Vid. por ejemplo, BARONA VILAR, S., "Conformidad del acusado, paradigma de eficiencia de la Justicia Penal", cit., pág. 404.

607 Para una comprensión actual del tema, Vid. el trabajo de FEIJÓo SÁNCHEZ, B., "El derecho penal del enemigo y el estado democrático de derecho", cit., págs. 115-158. Interesante todavía es la observación hecha por GOMES CANOTILHO al afirmar que en realidad lo más correcto sería denominar esta construcción dogmática como "Derecho penal contra el enemigo". Vid. GOMES CANOTILHO, J. J., Terrorismo e Direitos fundamentais, Coimbra, 2009, pág. 22.

608 En nuestro modo de pensar, la terminología "Derecho procesal penal del enemigo" al revés de "Derecho penal del enemigo", es la que mejor se encaja en los términos dogmáticos defendidos por Jakobs, a la vez que presenta este modelo, como característica primordial, la reducción y la consecuente pérdidadel valor de algunos derechos y garantías fundamentales de las personas sometidas a la persecución penal.

${ }^{609}$ En este sentido, Vid. VÍQUEZ, K., "Derecho penal del enemigo ¿Una quimera dogmática o un modelo orientado al futuro?", Política Criminal, núm. 3, 2007, pág. 2. 
Bajo la denominación "Derecho penal del enemigo" se hace referencia al Derecho penal que trata a los infractores como enemigos, es decir, como meras fuentes de peligro que deben ser neutralizadas del modo que sea ${ }^{610}$. Este Derecho Penal se opone al Derecho penal del ciudadano, en donde la imposición de una pena se hace necesariamente en el marco de un procedimiento rodeado de garantías.

Esta concepción dogmática ahora recientemente desarrollada por JAKOBS viene recibiendo duras y fuertes críticas, oriundas en especial de la mayoritaria doctrina alemana, española, italiana, brasileña, argentina, etc 611.

Según se percibe, se han escrito un sinnúmero de artículos y libros referentes al debate que se desarrolla en Alemania y en varios países, especialmente en Europa y en América del Sur, en torno a la eventual legitimidad de un Derecho penal de enemigo, expresión con la que JAKOBS alude a un Derecho penal de índole peculiar que se diferencia nítidamente del Derecho penal de ciudadanos: "el Derecho penal de enemigos optimiza la protección de bienes jurídicos, el Derecho penal de ciudadanos optimiza las esferas de libertad"612.

Respecto a esta polémica e instigadora discusión dogmática acerca de este modo de búsqueda de eficiencia penal a través de lucha contra los "enemigos", pasémonos a una exposición de los fundamentos básicos a la comprensión del tema.

Previamente, importante citar las palabras de ZAFFARONI, en el sentido de que las emergencias no son nuevas en los discursos legitimantes del poder punitivo ya que con la Inquisición aquéllosse fundaban en el ataque de Satán y de las brujas ${ }^{613}$.

Como premisa lógica de esta realidad enfrentada por las sociedades modernas, se percibe que en consideración al estado de vulnerabilidad que se denota actualmente en las comunidades internacionales, incluso en se tratando de países desarrollados 614 , fruto de lo que se ha denominado de "sociedad de riesgos"615, surge la consecuente inseguridad entre

610 Vid. Cancio Meliá, M., "Derecho penal del enemigo y delitos de terrorismo: algunas consideraciones sobre la regulación de las infracciones en materia de terrorismo en el código penal español después de la LO 7/2000", Revista Peruana de Ciencias Penales, núm. 13, Lima, 2003, pág. 155.

611 Vid. como buenos ejemplos los trabajos de ALMEIDA DE MORAES, A. R., Direito Penal do Inimigo. A terceira velocidade do Direito Penal, Curitiba, 2008; DONINI, M., "El derecho penal frente al enemigo", VV.AA., Derecho penal del enemigo, M. Cancio Meliá y C. Gómez-Jara Díez coords., Madrid, 2006, págs. 603-684; GÖSSEL, K. H., "Réplica del Derecho Penal del Enemigo. Sobre seres humanos, individuos y personas del derecho", Revista Penal, núm. 20, 2007, págs. 89-100; GRACIA MARTÍN, L., El horizonte del finalismo y el derecho penal del enemigo, Valencia, 2005; ZAFFARONI, E. R., El enemigo en el derecho penal, Buenos Aires, 2006.

612JAKOBS, G., "Criminalización en el estadio previo a la lesión de un bien jurídico", VV.AA., Bases para una teoría funcional del Derecho penal, Lima, 2000, pág. 215. Vid. también la caracterización del Derecho penal de ciudadanos y del Derecho penal de enemigos que realiza DENCKER, F., "Gefährlichkeitsvermutung statt Tatschuld -Tendenzen der neueren Strafrechtsentwicklung-", StV 6/1988, págs. 263-264, quien en las páginas siguientes ejemplifica en la historia del Derecho penal alemán los avances y retrocesos del Derecho penal de enemigos.

613 ZAFFARONI, E. R., "La creciente legislación penal y los discursos de emergencia", VV.AA., Teorías Actuales en el Derecho Penal, Buenos Aires, 1998, pág. 618.

614 Vid. por ejemplo los actos de terrorismo ocurridos en Nueva York, Washington, Madrid y más recientemente en Londres, cuya autoría se puede imputar con seguridad a bandas criminales organizadas de índole terrorista.

615 Fue el sociólogo Beck quien desarrolló esta caracterización de las modernas sociedades resultando un tópico fructífero para entender el moderno Derecho penal. Vid. a respecto del tema, BECK, U., La sociedad de riesgo. Hacia una nueva modernidad, Barcelona, 1998; MENDOZA BUERGO, B., El Derecho Penal en la sociedad de riesgos, Madrid, 2001; MACHADO, M. R. A., Sociedade do risco e Direito Penal. Uma avaliação de novas tendências político-criminais, São Paulo, 2005. 
los ciudadanos y mismo de los Estados, frente a la actuación de las bandas criminales de carácter transnacional y que presentan un potencial criminógeno de altísimo nivel, especialmente en lo que se refiere a sus actuaciones de signo terrorista.

A partir de ahí, de entre las peculiares manifestaciones del Derecho penal de la sociedad moderna, denominada sociedad de riesgo (para algunos sociedad postmoderna), ha merecido destaque la construcción teórica, muy en relieve en la actualidad, del llamado Derecho penal del enemigo, relacionada a la tendencia expansiva del Derecho penal y esencialmente atribuida a las formulaciones de JAKOBS, pero que constituye, en realidad, expresión o reformulación de un pensamiento autoritario616, hace mucho presente en el desarrollo de la civilización, además de presentar determinados principios y reglas delineados en formulaciones bien más antiguas, especialmente la doctrina de HOBBES ${ }^{617}$.

En consecuencia de lo afirmado y frente a esta factible constatación, llegamos al punto irrazonable de presenciar la defensa por JAKOBS, de un "Derecho penal del enemigo" 618, o indirectamente de un "Derecho procesal penal del enemigo"619, donde se establece que estos infractores pertenecientes a la delincuencia organizada deberían ser considerados como enemigos del Estado y por tanto, pasibles de recibir respuesta del mismo por medios no convencionales, incluso sin tener derecho a las garantías constitucionales y procesales comunes a todos los ciudadanos que sufren con una imputación penal.

El mencionado penalista alemán que ha sido discípulo de HANS WELZEL, se presenta preocupado frente a los peligros provocados por la nueva sociedad de riesgos, y partiendo de las construcciones del Estado de HOBBES y KANT, de entre otros, propone el Derecho penal del enemigo en oposición al de los ciudadanos.

El Derecho penal del enemigo, calificado por gran parte de la doctrina europea como "el tema de moda" en la dogmática reciente, puede caracterizarse, entre otras notas, por un amplio adelantamiento de la punibilidad, la adopción de una perspectiva fundamentalmente prospectiva, un incremento notable de las penas, y la relajación o supresión de determinadas garantías procesales individuales ${ }^{620}$.

Algún autor, así DEMETRIO CRESPO, sostiene que el "Derecho penal del enemigo" es consecuencia, entre otros factores, del uso simbólico del Derecho Penal y de la propia crisis del Estado Social ${ }^{621}$.

616 Cfr. GONZÁLEZ CUSSAC, J. L., "El renacimiento del pensamiento totalitario en el seno del Estado de Derecho: la doctrina del derecho penal del enemigo", cit., pág. 52.

617 PRADO, L. R., Curso de Direito Penal, vol. 1, 8ª edición, São Paulo, 2008, pág. 106.

618 En sentido critico a esta tesis, cítese como buen ejemplo, GRACIA MARTíN, L., El horizonte del finalismo y el Derecho penal del enemigo, Valencia, 2005.

619 Vid. MORENO, J. D., ¿Un derecho procesal de enemigos? VV.AA., Derecho penal del enemigo, El discurso penal de la exclusión, M. Cancio Meliá y C. Gómez-Jara Díez Coords., Buenos Aires, 2006; PORTILLA CONTRERAS, G., "El derecho penal y procesal del enemigo: las viejas y nuevas políticas de seguridad frente a los peligros internos-externos", cit., págs. 693-720; MALAN, D. R., "Processo Penal do inimigo", Revista Brasileira de Ciências Criminais, Vol. 14, núm. 59, São Paulo, 2006, págs. 223-259.

620 Vid. CANCIO MELIÁ, M., "Derecho penal del enemigo y delitos de terrorismo. Algunas consideraciones sobre la regulación de las infracciones en materia de terrorismo en el Código Penal español después de la LO 7/2000", cit., págs. 19 y ss.

621 DEMETRIO CRESPO, E., "Del Derecho penal liberal al Derecho penal del enemigo", Revista de Derecho Penal Y Criminología, núm. 14, Madrid, 2004, págs. 90 y 91. 
Vista desde esta "nueva" perspectiva, la idea de JAKOBS consiste en la defensa de que los enemigos (por ejemplo, los delincuentes organizados ${ }^{622}$, los terroristas o los autores de delitos sexuales graves) son aquellas personas quienes se alejan de modo permanente del Derecho y no ofrecen garantías cognitivas de que van acontinuar fieles a las normas. Así es que estos individuos que no admiten ingresar en el estado de ciudadanía, no pueden participar de los beneficios del concepto de persona, y en la condición de verdaderos enemigos del Estado, no son sujetos procesales, luego, no podrán contar con los derechos procesales inherentes a la condición de ciudadanos, mereciendo no la aplicación de penas, sino de medidas de seguridad.

Según esta línea de pensamiento, la existencia de un Derecho penal del enemigo de estas características lo que persigue, en definitiva, es tratar de legitimar el derecho de la sociedad a reaccionar ante determinados fenómenos delictivos cuando se constata que la respuesta penal convencional existente respecto a ciertos delitos, resulta manifiestamente insuficiente.

Respecto al tema, defiende PORTILLA CONTRERAS que en los últimos años, se observa una acentuada tendencia que, basándose en el modelo del "enemigo", en una legislación de guerra, justifica e intenta legitimar la estructura de un Derecho penal y procesal penal sin garantías. Esta es la dirección seguida por diversos autores, destacando aquellos que interpretan el Derecho penal material y el Derecho procesal según la óptica del estructuralismo-funcional de LUHMANN. Conforme a ella, lo que realmente importa es la conservación de los intereses del sistema, la capacidad funcional de sus órganos y la defensa del Estado a través de las garantías del propio Estado ${ }^{623}$.

Nos parece correcto entonces, afirmar que el rasgo más característico de la construcción dogmática de JAKOBS, o sea, la reducción o quizás la pérdidaabsoluta de las garantías, nos conduce al reconocimiento en verdad, de un Derecho procesal penal del enemigo.

¿Y qué debemos esperar bajo este epígrafe "Derecho procesal penal del enemigo"?

Esta construcción denominada "Derecho procesal penal del enemigo"624 se caracteriza por la aceleración de los procedimientos y por la brevedad del proceso, características estas inherentes a las tendencias expansivas del Derecho penal y de la política criminal. Este proceso penal al provocar profundas transformaciones en eltiempo instituidor del proceso, reduce inevitablemente las garantías del investigado o acusado.

622 Respecto específico a relación entre esta tesis dogmática y la criminalidad organizada, Vid. FARALDO CABANA, P., "Un derecho penal de enemigos para los integrantes de organizaciones criminales: la ley orgánica $7 / 2003$, de 30 de junio, de medidas de reforma para el cumplimiento íntegro y efectivo de las penas", Política criminal y sistema penal, I. Rivera Beiras coord., Barcelona, 2005, págs. 395-433.

623 PORTILla CONTRERAS, G., "El Derecho penal y procesal del enemigo. Las viejas y nuevas políticas de seguridad frente a los peligros internos-externos", Dogmática y Ley penal, cit., págs. 694- 695.

${ }^{624}$ Aún según opinión de PORTILLA CONTRERAS, "el Derecho penal-procesal del enemigo ha sido una constante en la lucha contra la criminalidad organizada alusiva al tráfico de drogas". Vid. PORTILLA CONTRERAS, G., "El Derecho penal y procesal penal del enemigo. Las viejas y nuevas políticas de seguridad frente a los peligros internos-externos", cit., pág. 709. En otro de sus trabajos, el mismo autor ha puesto de relieve que el Derecho penal del enemigo que describe (y legitima) Jakobs puede dar lugar también a un Derecho procesal penal del "enemigo". Vid. PORTILLA CONTRERAS, G., El Derecho penal entre el cosmopolitismo universalista y el relativismo posmodernista, Valencia, 2008, págs. 208-266. 
De esta forma, se destaca por la brevedad y celeridad, desencadenando la maximización del riesgo endógeno, comprometiendo la instrumentalidadgarantista del proceso penal.

A respecto, cobra singular relevancia la constatación de que el "proceso penal del enemigo" puede ser identificado como un modelo de crime control625, semejante a un esquema totalizante del poder penal, que tiene su origen en la edificación de un arquetipo social del alarma, de urgencia, pasando a dibujar institutos jurídicos que expresamente se encuentran consustanciados en el principio del bien y del mal626.

Sin embargo, se nota en el discurso del proceso penal del enemigo una inexorable tendencia a la arbitrariedad por la celeridad, axioma éste que en palabras de DANIEL PASTOR se traduce en la comprobación de que un procedimiento arbitrario por celeridad es el que asegura una rápida resolución del caso pero sin permitir el desenvolvimiento de las facultades básicas del inculpado ${ }^{627}$.

Se trata a nuestro modo de ver, de una construcción dogmática controvertible que de cierto modo, se choca con la actual lectura constitucional del proceso penal, que al empezar del siglo XXI, presenta como marco destacable la imperiosa necesidad de tutela de los derechos y garantías fundamentales.

Y lo más grave es que a la hora de justificar esta creación de un "Derecho Procesal penal del enemigo", no es infrecuente que se traiga a colación el argumento de que precisamente el exceso en las garantías concedidas a los imputados ha sido aprovechado por la delincuencia organizada para alcanzar las cotas de presencia y de impunidad que han generado la actual situación de alarma social. Además, se destaca el peligro que estas técnicas de "Derecho Procesal del enemigo" puedan encontrar justificación cuando se trata de persecución del terrorismo y de otras formas graves de delincuencia organizada, y que se vayan extendiendo al resto de ámbitos y vayan "contaminando" otros sectores de persecución criminal o incluso al proceso penal en su conjunto ${ }^{628}$.

\section{I.2.4. Visión crítica respecto a este pensamiento dogmático.}

Según FERRAJOLI, el esquema del derecho penal del enemigo no es otra cosa que el viejo esquema del "enemigo del pueblo" de estaliniana memoria y, por otra parte, el modelo penal nazi del "tipo normativo de autor". Y enlaza con una tradición antigua y recurrente de despotismo penal inaugurada con los crimina maiestatis. Con la agravante de que aquél se ha perfeccionado mediante su abierta identificación con el esquema de la guerra, que hace del delincuente y del terrorista un enemigo a suprimir y no a juzgar629.

\footnotetext{
625 En el modelo de crime control, el proceso penal se justifica frente la delincuencia como combate, control, cuya idea central reside en la pura represión, sin preocupación con la preservación de derechos y garantías fundamentales.

${ }^{626}$ Respecto al discurso del bien y del mal, Vid. BARATTA, A., Criminología crítica y crítica del Derecho Penal, México, 2000.

627 PASTOR, D. R., El plazo razonable en el Proceso del Estado de Derecho: una investigación acerca del problema de la excesiva duración del proceso penal y sus posibles soluciones, Buenos Aires, 2002, pág. 94.

628 Vid. en este sentido, la preocupación lanzada por GASCÓN INCHAUSTI, F., "Los procesos penales en Europa: líneas de evolución y tendencias", cit., págs. 486 y 490.

629 FERRAJOLI, L., "El Derecho Penal del Enemigo y la disolución del Derecho Penal", Democracia y garantismo, Madrid, 2008, pág. 237.
} 
En tanto a las consideraciones descritas, cabe señalar, sin embargo, que no se encuentran con facilidad, argumentos que demuestren la coherencia de la postura dogmática defendida por JAKOBS630, pues respecto a esta "novedosa"631 pero polémica tesis, entendemos que un Derecho penal o procesal penal del enemigo, en la forma propuesta, contraria al significado del Derecho penal o procesal del ciudadano, simboliza claramente un retroceso o una involución a un Derecho penal del autor, incompatible con el Estado social y democrático de Derecho y con el garantismo penal que fundamentan la moderna Ciencia Penal632.

Pero, ¿cuales serían las principales críticas formuladas por la mayoritaria doctrina procesal penal contemporánea?

Un gran número de estudiosos del Derecho penal y del proceso penal han defendido la idea que considera al Derecho penal del enemigo como pasible de una crítica analítica de valor ${ }^{633}$. En otros términos, esta construcción dogmática viene siendo contestada por gran parte de la doctrina mundial, por presentar según se percibe, rasgos que denotan la prevalencia de un derecho penal del autor en detrimento de un derecho penal del hecho634.

630 En sentido contrario, encontrando fundamentos lógicos y razonables en la tesis de Günther Jakobs, Vid. POLAINO-ORTS, M., Derecho penal del enemigo. Desmitificación de un concepto, Córdoba, 2006. También, en la obra de LESCH, el cual defiende que "sólo en la medida en que el individuo acepta el orden social constituido adquiere el status de persona; por el contrario, de no aceptarlo, se convierte en una criatura animal y en consecuencia, el ordenamiento carece de razones para defender sus intereses". Vid. LESCH, H. H., "Hörfalle und Kein Ende - Zur Verwertbarkeit von Selbstbelastenden Angaben des Beschuldigten in der Untersuchungshaft", GA, núm. 141, 2000, págs. 355 y 362. También como discípulos de Jakobs en Alemania, citese, PAWLIK y MÜSSIG.

631 No se puede todavía olvidarse que en uno de sus más recientes libros (Derecho penal del enemigo), Jakobs ha abandonado su postura descriptiva del denominado Derecho Penal del Enemigo (posición esta divulgada primeramente en 1985, en la Revista Zeitschrift für die gesamte Strafrechtswissenschaft, núm. 97, págs. 753 e siguientes), pasando a defender (desde 1999, pero con más contundencia a partir de 2003) la tesis afirmativa, legitimadora y justificadora de esta línea de pensamiento. Vid. JAKOBS, G., Derecho Penal del Enemigo, cit., pág. 47.

632 A este respecto, apunta FEIJÓo SÁNCHEZ que "el derecho penal del enemigo tal y como está planteado en sus fundamentos por Jakobs es contrario a los fundamentos de nuestro Estado democrático de Derecho". Vid. FEIJÓo SÁNCHEZ, B., "El derecho penal del enemigo y el Estado democrático de Derecho", cit., pág. 117. También interesante la obra de BECK, F. R., Perspectivas de controle ao crime organizado e crítica à flexibilização das garantias, São Paulo, 2004.

633 En contra de esta tesis, se pude citar LUÍS GRECO, al señalar que "la carga de la valoración, por una parte, y su agudeza, por el otro lado, condicionan que la etiquetación de una regulación como Derecho penal del enemigo no traen ni una ganancia de la exactitud analítica, ni tampoco dejan libre una potencialidad crítica". Vid. GRECO, L. F, "Sobre o chamado Direito penal do inimigo", Revista da Faculdade de Direito de Campos, núm. 7, 2005, págs. 211 y ss. Con más detalles sobre este posicionamiento dogmático, Vid. SCHÜNEMANN, B., "Derecho penal del enemigo: crítica a las insoportables tendencias erosivas en la realidad de la administración de justicia penal y de su insoportable desatención teórica", VV.AA., Derecho Penal del Enemigo, M. Cancio Meliá y C. Gómez-Jara Díez coords., Madrid, 2006, págs. 963-984.

634 Vid. con amplitud, GONZÁLES CUSSAC, J. L., "El renacimiento del pensamiento autoritario en el estado de derecho: la doctrina del derecho penal del enemigo", cit., págs. 52-69; LASCANO, C. J., "La insostenible modernización del derecho penal basada en un derecho penal para enemigos: como manifestación de un nuevo derecho penal autoritario", Pensamiento Penal del Sur, Buenos Aires, 2004, págs. 179-209. Interesante además la opinión de CAFFERATA NORES en el sentido de que "como expresión de varias o de todas estas posibles desviaciones, se puede visualizar un suerte de concepción bélica del proceso penal, consistente en entenderlo como un "arma" para enfrentar y a ganar la "guerra" contra manifestaciones delictivas que generan especial inquietud y reprobación social (delito organizado, tráfico de estupefacientes, terrorismo, corrupción de funcionarios públicos, delincuencia económica, financiera, impositiva, etc.). Esta concepción se inspira (quizás sin darse plena cuenta) en categorías de derecho penal del autor y entiende que el proceso existe para combatir a los "mafiosos", "narcotraficantes", "terroristas", "corruptos", "evasores", etc., es decir, para vencer a estos peligrosos "enemigos" de la sociedad, respecto de los cuales se postula expresamente o se tolera complacientemente la violación de la constitución, mientras sea útil a tal empeño. No se trata ya de juzgar 
Se justifica este pensamiento, a partir del análisis de la ambigüedad presentada por esta tesis (falta de definición de quien sería el enemigo, la ausencia de claridad de quiénesson los defensores de este modelo dogmático). Además, por fuerza del principio constitucional de igualdad 635 , somos todos ciudadanos y así no se puede aceptar la idea de que algunos de nosotros sean tratados como enemigos. No existe así, normatividad que no comporte violación.

En el plano dogmático, SCHÜNEMANN ha pronunciado críticamente frente a la formulación de un Derecho penal del enemigo, considerándola incorrecta ya desde el plano analítico y reprochándole ser consecuencia de aquella circularidad propia de la dogmática penal a la que califica de ausente de consecuencias ${ }^{636}$.

Con menos adjetivos y con mayor profundidad analítica se pronuncia CANCIO MELIÁ, quien enmarca la actual configuración del Derecho penal del enemigo dentro del fenómeno de expansión del Derecho penal que acusara ya SILVA SÁNCHEZ con suma claridad, precisando que se trata del resultado de la fusión de dos líneas de desarrollo de las legislaciones penales modernas: el Derecho penal simbólico y el resurgimiento del punitivismo. Además, se pone de manifiesto la irracionalidad o incoherencia del llamado Derecho penal del enemigo, para a partir de ello negarle el carácter de verdadero Derecho penal: "Sólo el Derecho penal del ciudadano es Derecho penal"637.

En este sentido, algún autor defiende que la dicotomía entre ciudadanos y enemigos plantea serios problemas de compatibilidad con el principio del hecho como principio básico de un Derecho de penas propio de un Estado de Derecho, inclinándose más bien hacia un Derecho penal de autor, aunque no se pueda negar que se trata de un Derecho penal de autor de características distintas a los modelos que conocíamos hasta ahora638.

Como apunta GRACIA MARTÍN, el Derecho penal democrático y del Estado de Derecho ha de tratar a todo hombre como persona responsable, y no puede ser lícito ningún ordenamiento que establezca reglas y procedimientos de negación objetiva de la dignidad de ser humano en ningún caso 639 .

Destacada también es otra vez la opinión de FERRAJOLI respectoal tema, cuando afirma que el "derecho penal del enemigo" es una contradicción que contradice y, por tanto, niega la idea misma del derecho penal. Así, el derecho penal, más bien el derecho tout court, es la negación del enemigo; porque es el instrumento, el medio por el que las relaciones de convivencia pasan del estado salvaje al estado civil y cada uno es reconocido

imparcialmente a un ciudadano: se procura sólo combatir y derrotar a un enemigo". Vid. CAFFERATA NORES, J. I., Cuestiones actuales sobre el proceso penal, cit., pág. 222.

635 En este sentido, Vid. SOLOZÁBAL ECHAVARRÍA, J. J., La igualdad en la aplicación de la ley, libro Homenaje al Profesor Dr. Gonzalo Rodríguez Mourullo, Navarra, 2005, págs. 2197-2208; RONCONI, D. R., "O princípio constitucional da igualdade e a desigualdade (i) legal deste princípio na legislação brasileira”, Novos Estudos Jurídicos, núm. 12, Itajaí, 2001, págs. 71-83; CUNHA, E. M; FRISONI, V. B., "Igualdade: extensão constitucional", Cadernos de direito constitucional e ciência política, vol. 4, núm. 16, São Paulo, 1996, págs. 249267. 211.

636 Vid. Schünemann, B., Die deutsche Strafrechtswissenschaft nach der Jahrtausendwende, GA 2001, pág.

637 JaKobS, G., CAncio Meliá, M., Derecho penal del enemigo, cit., pág. 55, 61-62.

638 FEIJÓo SÁNCHEZ, B., "El derecho penal del enemigo y el estado democrático de derecho", cit., pág. 133.

639 GRACIA MARTÍN, L., "Consideraciones críticas sobre el actualmente denominado Derecho penal del enemigo", cit., pág. 42. 
como persona. En este sentido, la pena es la negación de la venganza, del mismo modo que el derecho en general es la negación de la guerra640.

En nuestro modo de pensar, independientemente de la gravedad de la conducta del agente, éste, habrá de ser punido criminalmente como transgresor de la norma penal, como individuo, como una persona que ha practicado un delito, y no como un guerrero, como un enemigo del Estado y de la sociedad. La conducta, por más deshumana que sea, no autoriza el Estado a tratar el ser humano como sifuera un irracional. El infractor sigue sosteniendo la condición de ser humano, de ciudadano, de persona portadora de dignidad.

Hay que deslegitimar cualquier propuesta a favor del Derecho penal del enemigoporque el mismo constituye la más perversa negación del Estado de Derecho, y permite consolidar un Estado policial inadmisible, ni aun con el pretexto de que el enemigo se ha auto excluido voluntariamente y que en consecuencia ha renunciado a cualquier derecho. Esta exclusión es un acto de barbarie y totalitarismo, y hay que impedir que tome carta de ciudadanía una propuesta que termina convirtiéndose en auténtico terrorismo de Estado.

Una cosa es tener la consciencia y certeza de que un Derecho penal o procesal del enemigo, en los moldes planteados por JAKOBS, aparezca ya claramente dibujado por la situación, por ejemplo, de los presos talibanes en Guantánamo ${ }^{641}$. Estos siguen siendo tratados como verdaderos "enemigos" de los Estados Unidos de América ${ }^{642}$, sin derechos a las garantías básicas de todos los ciudadanos. Pero, al que parece, el gobierno de Obama en los Estados Unidos ha intentado cambiar esta situación, promoviendo mismo que de forma lenta, la transferencia de algunos prisioneros a otros sitios para que sean debidamente juzgados.

Pero otra es aceptar este modelo o construcción teórica como algo eficaz en la lucha contra la criminalidad organizada y otras formas graves de delincuencia, a costo de la supresión de las garantías del procedimiento en función de las características peculiares de los autores (llamados de enemigos). Se trata pues, de la más pura y cristalina demostración de la irracionalidad funcional de un Estado que un día pretende ser comprendido como democrático y desarrollado en materia de respetoa los derechos humanos.

En nuestra opinión, existen otros tantos caminos más próximos de la legalidad y del derecho para el control y freno del desarrollo y crecimiento avasallador de la delincuencia organizada y además, de sus más destacadas vertientes, el narcotráfico y el terrorismo.

640 FERRAJOLI, L., "El Derecho Penal del Enemigo y la disolución del Derecho Penal", cit., pág. 241.

641 Para una profunda comprensión del drama de los detenidos en la prisión de Guantánamo, Vid. DEUTSCHMANN, D; RICARDO, R., Guantánamo: A Critical History of the Us Base in Cuba, Melbourne, 2008; SMITH, C. S., The Eight O'Clock Ferry to the Windward Side: Fighting the Lawless World of Guantanamo Bay, New York, 2007; BOUCHARD, M., "Guantánamo: morte do processo penal e início do apocalipse", Revista do Ministério Público, ano 25, núm. 97, Lisboa, jan/mar 2004, págs. 61-72; RUKHSANA KHAN, M., Diário de Guantánamo, 1a edición, São Paulo, 2008.

642 De observarse que el actual Presidente de los Estados Unidos, Barack Obama, recientemente ha declarado que muy pronto la prisión de Guantánamo en Cuba, quedará cerrada de forma definitiva y deberán ser todos los detenidos sospechosos de participación en actos terroristas y en supuestos de criminalidad organizada, sometidos a un Tribunal para juicio. Vid. "Jornal Folha de São Paulo", 10/06/2009, www.estadao.com.br. Además. cítese respecto a la "rectificación en el comienzo del mandato del Presidente Obama", la reciente obra de PÉREZ ROYO, J et alli., Terrorismo, democracia y seguridad en perspectiva constitucional, cit., págs. 44-47. 
Pensamos de forma diametralmente opuesta a la tesis enunciada por JAKOBS, pues a partir de la adopción eficaz de algunas medidas de política criminal, incluso de medidas de política social (por ejemplo, erradicando las desigualdades), arreglando puntos débiles en el Derecho penal sustantivo, y además, en lo que nos interesa, perfeccionando el aspecto procesal, con nuevos métodos legales de investigación, en especial en lo tocante a la utilización de agentes encubiertos, de las entregas vigiladas, de los equipos conjuntos de investigación y tantas otras técnicas, con vistas a la identificación de los métodos empleados en las practicas delictuosas, bien como de las personas envueltas en estas operaciones delictivas, podrá valerse de estas preciosas informaciones y pruebas eventualmente producidas, con el fin de buscar con respeto a las garantías y derechos fundamentales de los sospechosos, el desmantelamiento del grupo criminoso, culminando con la condena penal de los mismos en la forma descrita en ley 643 .

Bastaría entonces, solamente encuadrar la actuación de estos medios extraordinarios de investigación dentro de la pretendida "zona de equilibrio", buscándose con esto, armonizar la paradoja eficacia del ius puniendi estatal y la imprescindible garantía de los derechos fundamentales del investigado.

Analizándose caso a caso, a la luz del principio de proporcionalidad, no se podrá argumentar en el sentido de que las "nuevas" técnicas policiales de investigación del crimen vengan a constituirse siempre en demostraciones de un proceso penal marcado por el carácter de emergencia y contrario al ordenamiento constitucional, en el sentido de ausencia de respeto a los derechos fundamentales de las personas investigadas o imputados en un proceso.

De ninguna manera, debemos marchar hacia construcciones jurídicas que buscan "proteger" mejor a la sociedad mediante la ilimitada y desmedida flexibilización o vulneración de principios clásicos de Derecho penal o del proceso penal, porque no debemos olvidar que en la postura de JAKOBS, el mayor riesgo lo representa la incertidumbre de las pautas y él órgano-persona encargado de determinar quién es el "enemigo".

En apretada síntesis, la conclusión es que deberá rechazarse, por lo tanto, la tesis jakobsiana del Derecho Penal o procesal penal del enemigo, caracterizada por una

\footnotetext{
643 Un sencillo ejemplo, aunque no revestido totalmente del carácter de respeto al garantismo penal, a la vez que ocurrido en los años setenta, puede servir para ilustrar lo que se acaba de decir: el real y concreto éxito en la utilización del medio investigativo de infiltración, si bien podría denominarse de colaboración policial, en razón del infiltrado no pertenecer originariamente a los cuadros de la Policía Judicial, pero si al servicio de inteligencia español, en la interesante narrativa hecha por CERDÁN, M., RUBIO, A., Lobo, un topo en las entrañas de ETA, 9a edición, Barcelona, 2004. En este libro, un caballo de troya perfecto, fue introducido en el corazón de ETA. Gracias a este agente infiltrado pudieron evitarse sangrientas campañas de la organización terrorista. Pero "Lobo" finalmente fue olvidado por quienes lo contrataron, y condenado a sobrevivir bajo nueva identidad. También, ya con connotación especifica de infiltración policial, Vid. MADRID, D., Insider, Un policía infiltrado en las grades ultra, Madrid, 2005. Por fin, otras interesantes narrativas son hechas por CABEZAS, J., Infiltrados de ETA a Al Qaeda, Barcelona, 2004, donde se cuenta la historia de los infiltrados en la organización terrorista ETA a través de dos ejes principales: la historia de la mujer policía infiltrada en el comando Donosti y las escuchas del CESID en la sede de Herri Batasuna en Vitoria. Queda en esta obra evidenciado como se forma un infiltrado, desde la captación, formación y control hasta las operaciones finales. Tanbién, la historia real de un periodista infiltrado en la violenta mafia napolitana en Italia. Así Vid. SAVIANO, R., Gomorra, 3aㅡ edición, Rio de Janeiro, 2009.
} 
destacable restricción de las garantías constitucionales a los individuos considerados "enemigos" del Estado644.

Se destaca aún que bajo la creciente legislación de excepción encuadrada dentro de la construcción teórica denominada "Derecho penal del enemigo", se están violando palmariamente derechos fundamentales pacíficamente consagrados.

Y en respetoal Estado Constitucional de Derecho, no se puede admitir que el clima punitivista alardeado por esta construcción dogmática, haga con que se pierda los nervios frente a la expansión del fenómeno del crimen organizado.

Hay como ya afirmado, medios legales de investigación que siutilizados en conformidad a los límites constitucionales a se establecer, muy pronto servirán como las armas más eficientes para la contención a esta modalidad de delincuencia.

Por más increíble que parezca, hay por ejemplo, discutible seguimiento de la doctrina penal que considera el uso de operaciones encubiertas en la lucha contra la delincuencia organizada, como verdadera manifestación de un derecho procesal penal del enemigo, pues que con tal legalización de esta tarea de investigación mantenida por el Estado, quedaría establecido que la propia ley exoneraría de responsabilidad criminal a los agentes encubiertos por las actuaciones que sean consecuencia necesaria para el desarrollo de sus funciones 645 . Como consecuencia, podría afirmarse que restarían por veces violados o flexibilizados algunos derechos y garantías fundamentales de sospechosos e imputados.

Incluso, PORTILLA CONTRERAS llega a afirmar que en nombre de una simbólica represión penal al tráfico de drogas se ha apoyado un sistema procesal penal de carácter excepcional que conculca gran parte del contenido de las garantías constitucionales. En efecto, ciertos funcionarios llevan a cabo comportamientos ilegales que no suelen sancionarse: pago con droga a confidentes de las Fuerzas y Cuerpos de Seguridad del Estado, la utilización de agentes infiltrados, agentes provocadores, la práctica de cacheos, entradas en domicilios, interceptaciones ilegales, etc ${ }^{646}$.

Aunque tengamos la oportunidad de tratar de este tema con cierta profundidad en el desarrollo de nuestro trabajo, no nos parece dogmáticamente convincente tal argumentación, pues lo que se busca con la implementación de nuevos medios extraordinarios de investigación criminal, a ejemplo de las operaciones encubiertas, desde que respetados a su límite los derechos y garantías fundamentales del investigado o imputado, de modo proporcional, es justamente, evitarse las prácticas abusivas e ilegales que desde años han sido utilizadas clandestinamente por la policía en la lucha contra la

\footnotetext{
644 En este sentido, LOBO DA COSTA defiende que "todas las veces donde en que surge alguna propuesta política basada en el terror penal, en la diferenciación entre enemigo y ciudadano, es preciso quedarnos atentos, pues esto no resuelve la erosión del Estado de Derecho, como la pone en nivel insoportable". Vid. LOBO DA COSTA, H. R., "Os rumos da política criminal cinco anos depois do 11 de setembro. Política criminal e dogmática penal: entre a judicialização e a administrativização", VV.AA., Repressão penal e crime organizado, São Paulo, 2009, pág. 65.

645 Vid. en este sentido, por ejemplo, MASSON, C. R., "O Direito penal do inimigo", VV.AA., Processo Penal e garantias constitucionais, M. A. Marques da Silva coord., São Paulo, 2006, págs. 145 y 148; MORENO, J. D., “¿Un Derecho procesal de Enemigos?”, cit., pág. 467; JAKOBS, G., CANCIO MELIÁ, M., Direito Penal do Inimigo, Noções e críticas, Trad. A. Luís Callegari y N. José Giacomolli, Porto Alegre, 2005, pág. 40; VALLEJO, M. J., Derechos fundamentales del proceso penal, cit., pág. 21.

646 Así Vid. PORTILLA CONTRERAS, G., "El Derecho penal y procesal penal del enemigo. Las viejas y nuevas políticas de seguridad frente a los peligros internos-externos", cit., págs. 709-710.
} 
criminalidad. Del mismo modo, denominar como "comportamientos ilegales" las actuaciones de los agentes infiltrados nos parece una idea equivocada, partiendo del fundamento de que este medio de investigación se encuentra legalmente previsto en gran parte de los ordenamientos penales.

Además, la búsqueda de establecimiento de una "zona de equilibrio" como idea defendida inicialmente por GUZMÁN FLUJA, con vistas a armonizar la tensión entre eficacia y garantías, se presentajustamente como instrumento de neutralización de esta supresión absurda y radical de las garantías y de los derechos de las personas sometidas al proceso penal.

Incoherente del mismo modo, es inserir el tema del Derecho penal del enemigo como una "tercera" velocidad del Derecho penal.

Sobre esta discusión, FARALDO CABAÑA analizando la consideración de existencia de dos velocidades en el Derecho Penal, señala que más allá de la propuesta de esas dos velocidades, a su juicio suficientemente contestada por MARTÍNEZ-BUJÁN647 y GRACIA MARTÍN ${ }^{648}$, se ha cuestionado si puede admitirse una tercera velocidad del Derecho penal, en la que el Derecho penal de la cárcel concurra con una amplia relativización de garantías político-criminales, reglas de imputación y criterios procesales, llegándose a la conclusión de que la existencia de un espacio de Derecho penal de privación de libertad con reglas de imputación y procesales menos estrictas que las del Derecho penal de la primera velocidad es, seguramente, en algunos ámbitos excepcionales y por tiempo limitado, inevitable. Se quiere limitar este Derecho penal de tercera velocidad a la consideración de un instrumento de abordaje de hechos "de emergencia", siendo expresión de una especie de "Derecho de guerra" en el que la sociedad, ante la gravedad de la situación excepcional de conflicto, renuncia de modo cualificado a soportar los costes de la libertad de acción ${ }^{649}$.

Repelidas estas infundadas argumentaciones, importante resaltar que el carácter multiforme del crimen organizado no ha repercutido tan sólo en el plan material, pues también en el proceso penal la tendencia verificada, sobretodo en la última década, es para que se desarrollen estrategias diferenciadas para reglar con más eficacia la obtención de la prueba y el tratamiento dispensado a los investigados y acusados por prácticas de infracciones relacionadas a la criminalidad organizada, en la búsqueda de la eficiencia penal 650 .

La realidad diaria indica que los instrumentos procesales tradicionales para apuración de la criminalidad individualizada no se demuestran suficientes para el tratamiento del fenómeno de la delincuencia organizada, que en razón de sus

\footnotetext{
${ }^{647}$ Quien pone de relieve la incorrección que cometen la Escuela de Francfort y Silva Sánchez al proceder a la deslegitimación global de los delitos económicos. Cfr. MARTíNEZ-BUJÁN PÉREZ, C., Algunas reflexiones sobre la moderna teoría del Big Crunch en la selección de bienes jurídico penales (especial referencia al ámbito económico)", La Ciencia del Derecho Penal ante el nuevo siglo, Madrid, 2002, págs. 395 y ss.

648 Autor que se ha lanzado a la defensa de una modernización del Derecho penal sin renunciar a los principios no ya del Estado de Derecho, sino del Estado social y democrático de Derecho. Vid. GRACIA MARTíN, L., "¿Qué es modernización del Derecho penal?", La Ciencia del Derecho penal ante el nuevo siglo, Madrid, 2002, págs. 349 y ss. Del mismo autor, Vid. Prolegómenos para la lucha por la modernización y expansión del Derecho penal y para la crítica del discurso de resistencia, Valencia, 2003, cit., págs. 164 y ss.

${ }^{649}$ SILVA SÁNCHEZ, J. M., La expansión del Derecho Penal. Aspectos de la política criminal en las sociedades postindustriales, cit., pág. 163-164 y 166.

650 Vid. ARAUJO DA SILVA, E., Crime organizado. Procedimento probatório, cit., pág. 40.
} 
características peculiares tiene comprometido la actividad estatal de persecución criminal 651 .

Si creemos en un proceso penal justo y en la obediencia irrestricta a los principios que rigen el Estado Constitucional de Derecho, no existe razón lógica-científica para la aceptación de un Derecho procesal penal de emergencia, marcado por la absurda distinción entre los ciudadanos y los enemigos del sistema ${ }^{652}$.

De observarse siempre que en el proceso penal la protección de las garantías para todos, sin cualquier excepción, ha de ser pieza fundamental.

Al fin, inferimos que el Derecho penal o procesal penal del enemigo como negación pura de los más elementares derechos fundamentales de los ciudadanos, es por lo tanto, una real y efectiva afronta al Estado Constitucional de Derecho, presentándose como un retroceso inaceptable a los tiempos de tristes recuerdos de la época del nacionalsocialismo653.

\section{2. El proceso penal y su lectura constitucional: una realidad innegable}

II. 2.1. El camino único para obtención de eficacia con garantías: Constitución y proceso penal.

II.2.1.1. El proceso penal y su fórmula ideal: legitimación del ius puniendi con respeto a las garantías.

Con lo visto hasta el presente momento, a priori es imprescindible señalar que el proceso penal es, junto con el Derecho penal, el sector del ordenamiento en que mayores poderes se conceden al Estado para la restricción de los derechos fundamentales que la Constitución reconoce a los ciudadanos ${ }^{654}$.

Por esto hay que manejar estas dos ramas de la ciencia jurídica con mucha responsabilidad y siempre teniendo como clave el principio de proporcionalidad, a la vez

651 Sin embargo, señala GARRIDO GENOVÉS que "desgraciadamente las modalidades de crimen organizado gozan de buena salud. La comunidad internacional no parece contar con buenos reflejos para adelantarse a los acontecimientos y su tecnología muchas veces está retrazada en relación a los métodos que emplean estos criminosos. El imperio de la ley parece vacilar ante estos gigantes del crimen, ya que muchas veces los intereses políticos parecen ser predominantes ante el bien estar de los ciudadanos que dicen proteger". Vid. GARRIDO GENOVÉS, V., Principios de criminología, Valencia, 1999, pág. 655.

652 Vid. con más profundidad respecto de este tema, FARALDO CABANAS, P., "Un derecho penal de enemigos para los integrantes de organizaciones criminales. La Ley Orgánica 7/2003, de 30 de junio, de medidas de reforma para el cumplimiento íntegro y efectivo de las penas", cit., págs. 395-432.

653 En sentido similar, señala CARO CORIA que "las bases garantistas del proceso penal, que solo liminarmente se alcanza a exponer, expresan la vinculación de la legislación y la práctica procesal a la Constitución y a los diversos instrumentos de derechos humanos que vinculan al Estado. Se busca que el proceso penal sea plausible no sólo porque es más eficaz, especialmente ante la criminalidad grave o no bagatelar, sino porque preserva el núcleo duro de principios que permite que los culpables respondan ante la ley de modo civilizado y que los inocentes, pese a las deficiencias del sistema, pueden hallar una justa absolución. Sólo la vigencia de estos principios garantistas permitirá el destierro de ese derecho penal del enemigo y la construcción de un derecho penal del ciudadano que a la vez no sea débil con las formas de criminalidad que enfrenta nuestra sociedad, aun más graves y violentas que demandan el efectivo despliegue preventivo del derecho penal". Vid. CARO CORIA, D. C., "Las garantías constitucionales del proceso penal", cit., pág. 1045.

654 Acertadamente expone RAMOS MÉNDEZ que "el juicio penal aparece así como el mecanismo más drástico para la tutela de la convivencia en libertad en las diversas esferas de la vida". Vid. RAMOS MÉNDEZ, F., Enjuiciamiento criminal, Octava lectura constitucional, cit., pág. 30. 
que entra en juego uno de los bienes jurídicos más destacados, cual sea, la libertad del ciudadano. Además, necesaria una interpretación de ellos en consonancia con la normativa constitucional.

De otra parte, importante señalar que las gravísimas intromisiones de los poderes públicos en el ámbito de los derechos más preciados del individuo, justificadas por las necesidades de persecución penal en aras de la tutela de los bienes esenciales de la comunidad protegidos por las normas penales, deben ser limitadas en la medida en que su práctica no sea útil, necesaria o proporcionada, atendiendo a los intereses en conflicto, según las particulares circunstancias del caso concreto655.

Esta reflexión propugnada por GIMENO SENDRA resume toda la problemática que se pretende abordar durante el desarrollo de nuestra investigación respecto del tema del agente encubierto y las garantías del proceso penal.

Pues bien, buscar establecer los límites constitucionales que deberán ser observados con relación a la utilización de algunos instrumentos o medios extraordinarios de investigación criminal, muy especialmente del agente encubierto, es nuestra finalidad principal en los subsecuentes capítulos que componen este trabajo.

Hechas estas consideraciones preliminares, enfrentémonos la labor científica.

Nos parece indiscutible que el proceso penal es considerado generalmente un instrumento necesario de protección de valores recogidos por el Derecho penal, cuya función primordial consiste en dotar al Estado de un cauce preestablecido para la aplicación del ius puniendi656. Esta la realidad que hemos visto con relación al Derecho procesal penal tradicional.

Ocurre, en efecto, que como ya visto anteriormente, la función del proceso penal moderno no se resume solamente a esto, a la vez que cumple además, la tarea de declarar el derecho a la libertad del ciudadano inocente. Esta idea adquiere especial relevancia frente a la necesidad de protección de los derechos y garantías fundamentales de las personas sometidas a una persecución criminal y también de los derechos colectivos. Esto es lo que defienden acertadamente los adeptos del garantismo penal integral.

Como es sabido, en el proceso penal contemporáneo, fruto de las grandes revoluciones liberales europeas, la Constitución adquiere una gran relevancia, no sólo atendiendo a un criterio formal, según el cual la Ley Fundamental ocupa en el ordenamiento una posición jerárquica de supremacía, sino también desde un punto de vista material, desde el que se observa que, en el proceso penal, los derechos en conflicto adquieren la naturaleza de fundamentales, ya que vienen integrados, de un lado, por el "derecho de penar" que ejercitan las partes acusadoras, a través del derecho a la tutela, y, de otro, por el derecho a la libertad del imputado que hace valer la defensa ${ }^{657}$.

655 GIMENO SENDRA, V., "Prologo" a la obra: Proporcionalidad y Derechos Fundamentales en el Proceso Penal, cit., pág. 7. Del mismo modo, muy interesante la observación de BERNAL CUÉLLAR y MONTEALEGRE LYNETT en el sentido de que "el Estado está obligado a hacer extensiva la fuerza vinculante de los derechos constitucionales a sus relaciones con los asociados; el Estado legislador debe dar eficacia a los derechos constitucionales en el proceso publico; y el Estado investigador, acusador y juez, debe interpretar el derecho siempre a través de la óptica de los derechos constitucionales". Vid. BERNAL CUÉLLAR, J., MONTEALEGRE LYNETT, E., El proceso penal, 4⿳亠丷a edición, Bogotá, 2002, pág. 23.

656 GÓMEZ ORBANEJA, E., HERCE QUEMADA, V., Derecho Procesal Penal, cit., págs. 1- 2.

657 Véase, GIMENO SENDRA, V., Derecho procesal penal, cit., pág. 59. 
Sin embargo, no se puede olvidar que mismo delante de la constatación del establecimiento de algunos derechos de los ciudadanos como "fundamentales", podrán ocurrir sin cualquier nota de violación al texto constitucional, ciertas restricciones en pro de la seguridad colectiva o del Estado. Recordémonos, que no existen derechos fundamentales dotados de valor absoluto y por lo tanto, "intocables"658.

Hablamos en este caso, de una necesaria y siempre excepcional flexibilización de algunos de los derechos fundamentales del investigado o imputado, desde que se llegue hasta esta conclusión después de un análisis del caso concreto en consonancia con el principio de proporcionalidad.

En este caso, se destaca una vez más, importante establecer la regla de "eficacia con garantías".

La finalidad, sin embargo, de las medidas restrictivas de derechos fundamentales susceptibles de ser adoptadas en el proceso penal se orientaría así, en principio, a permitir a los órganos del Estado la satisfacción de los fines propios del Derecho material, dando de este modo respuesta al interés de persecución penal que anima su actuación en este ámbito y que se opone al ius libertatis de los ciudadanos ${ }^{659}$.

Tomando como partida este estado de cosas, habrá de ser esclarecido que delante de esta constatación real e indiscutible, este aspecto señalado representa tan sólo un lado de la moneda. Así, de otra parte, no hay posibilidad de comprender el proceso penal de modo justo y eficiente, sin la consideración de que no puede ejercitarse el derecho de punir del Estado sino a través de un proceso con todas las garantías ${ }^{660}$, porque el proceso penal no sólo es la forma en la que el Estado ejerce de manera más severa tal derecho, sino que afecta al derecho de libertad del acusado y a otros derechos fundamentales ${ }^{661}$.

No obstante, y sea como sea, la realidad es que en el ámbito procesal penal, es irrenunciable el ideal de posibilitar mecanismos de concreción de los derechos

658 En este sentido, Vid. la STC 2/1982, de 29.1.1982, que dispone que: "En efecto, no existen derechos ilimitados. Todo derecho tiene sus límites que en relación con los derechos fundamentales, establece la Constitución por sí misma en algunas ocasiones, mientras en otras el límite deriva de una manera mediata o indirecta de tal norma, en cuanto ha de justificarse por la necesidad de proteger o preservar no sólo otros derechos constitucionales, sino también otros bienes constitucionalmente protegidos". También, la STC 254/1988, de 21.12.1988 que declara que "como ya ha declarado en anteriores ocasiones este Tribunal, es cierto que los derechos fundamentales no son absolutos, pero no lo es menos que tampoco puede atribuirse dicho carácter a los límites a que ha de someterse el ejercicio de los mismos. Todas las normas relativas a tales derechos se integran en un único ordenamiento inspirado por los mismos principios; y tanto los derechos individuales como sus limitaciones, en cuanto éstas derivan del respeto a la Ley y a los derechos de los demás, son igualmente considerados por el art. 10.1 de la Constitución como "fundamento del orden político y de la paz social". Se produce así, en definitiva, un régimen de concurrencia normativa, no de exclusión, de tal modo que tanto las normas que regulan el derecho fundamental como las que establecen límites a su ejercicio vienen a ser igualmente vinculantes y actúan recíprocamente. Como resultado de esta interacción, la fuerza expansiva de todo derecho fundamental restringe, por su parte, el alcance de las normas limitadoras que actúan sobre el mismo; de ahí la exigencia de que los límites de los derechos fundamentales hayan de ser interpretados con criterios restrictivos y en el sentido más favorable a la eficacia y a la esencia de tales derechos".

659 GONZÁLEZ-CUÉLlAR SERRANO, N., Proporcionalidad y Derechos Fundamentales en el Proceso Penal, cit., pág. 243.

660 En este contexto, importante señalar que lo importante no es solamente destacar que las garantías del imputado, que son, verdaderamente, garantías del proceso y de la jurisdicción, fueran elevadas a nivel constitucional. A nuestro modo de ver, más que esto, necesario e imprescindible es leer las normas procesales a la luz de los principios y de las reglas constitucionales. Seria, pues, verificar la adecuación de las leyes a la letra y al espíritu del texto constitucional, o en otras palabras, proceder a la interpretación de la norma en conformidad con la Constitución.

661 Vid. STC 130/2002, de 3.6.2002. 
fundamentales como forma de evitarse el ilimitado y por veces arbitrario monopolio estatal 662 .

En su momento, ya advertía BOBBIO que el problema más grave de nuestro tiempo, con relación a los derechos del hombre, no era más el de fundamentarlos, sino que de protegerlos. Con efecto, el problema que tenemos delante de nosotros no es filosófico, pero sí jurídico y, en un sentido más amplio, político. No se trata de saber cuáles y cuántos son estos derechos, cuál es su naturaleza y su fundamento, si son derechos naturales o históricos, absolutos o relativos, pero sí cuál es el modo más seguro para su garantía, para impedir que, además de las solemnes declaraciones, ellos sean continuamente violados ${ }^{663}$.

Desde esta perspectiva de obediencia y respeto irrestricto a los derechos, independientes de su naturaleza, como ha resaltado BOBBIO, el proceso debe ser una garantía de verdad y justicia, pues su finalidad precipua es la búsqueda de la verdad en el establecimiento de los hechos y la justicia en la aplicación del derecho.

Además, según la opinión de GONZÁLEZ-CUÉLLAR SERRANO, es necesario destacar también que el proceso no es un simple instrumento al servicio de fines ajenos que le serían impuestos por normas materiales. Pero, no sólo el interés de persecución penal justifica la restricción de los derechos de los particulares en el proceso, pues la actuación de los órganos del Estado puede ir dirigida a la satisfacción de otros intereses constitucionalmente protegibles. Y prosigue el citado autor señalando que como ejemplo cabría citar el interés del Estado en la protección de los derechos fundamentales de los ciudadanos o de otros valores constitucionalmente protegibles y el interés por el correcto desarrollo del proceso y el adecuado funcionamiento de las instituciones procesales. En todos estos casos el interés del Estado y los intereses de los ciudadanos cuyos derechos son restringidos, deben ponderarse y limitarse recíprocamente en la aplicación del principio de proporcionalidad 664 .

\section{II.2.1.2. La necesidad de una lectura constitucional del proceso penal.}

La Constitución de un país es la norma fundamental que unifica y da validez a todas las legislaciones que constituyen un orden jurídico determinado: es decir, unifica la pluralidad de codificaciones que componen el Derecho positivo de un Estado. De ahí su calidad de Ley Suprema665. Esta debe ser la base para una comprensión del tema de la constitucionalización del proceso penal.

\footnotetext{
662 Por esto, cierta es la apreciación de que las garantías individuales referidas al proceso penal configuran pautas establecidas por la Constitución que gobiernan la vigencia y hasta la interpretación de las leyes procesales comunes y que son, en verdad, decisiones políticas generales de cuyo contenido debe derivar, deductivamente, el reglamento procesal tendiente a hacerlas efectivas. Incluso, algún autor, así VEIGA, sostiene que "el interés de la perseguición penal (interés que la comunidad siente en punir el culpado) acaba por ser puesto en el mismo plan de los principios de proceso penal de un Estado de Derecho, pero surge orientado por reglas y principios que defienden la libertad y dignidad de la persona humana $\mathrm{y}$, simultaneamente, visan una correcta administración y aplicación de la justicia". Vid. VEIGA, C., Considerações sobre a relevância dos antecedentes criminais do arguido no proceso penal, Coimbra, 2000, pág. 26.

663 Vid. BOBBIO, N., A era dos direitos, Rio de Janeiro, 1992, pág. 25.

664 GONZÁLEZ-CUELLAR SERRANO, N., Proporcionalidad y Derechos Fundamentales en el Proceso Penal, cit., págs. 243 y 245.

665 MANCILla OVANDO, J. A., Las garantías individuales y su aplicación en el proceso penal, Estudio constitucional del proceso penal, México, 1988, pág.13. En palabras de BINDER "la Constitución se preocupa especialmente por establecer resguardos o garantías frente al posible uso arbitrario del poder penal del Estado". Vid. BINDER, A. M., Introducción al derecho procesal penal, cit., pág. 79.
} 
De otra parte, como ya hemos apuntado anteriormente, la protección judicial de los derechos y libertades debe obtenerse a través del proceso y en lo que nos interesa, del proceso penal ${ }^{666}$. Desde esta perspectiva, se denota la imprescindible necesidad de establecimiento de un Derecho procesal penal constitucional.

Los trabajos de comparación en derecho constitucional y derecho procesal muestran como tendencia la constitucionalización del procedimiento en todas las ramas del derecho. En la norma superior de la mayoría de los Estados, incluso de aquellos con mayor tradición jurídica, se consagra un catálogo de las garantías mínimas que debe reunir todo proceso judicial, con el fin de impedir que el futuro legislador desconozca los derechos fundamentales de las personas $y$, de otra parte, lograr la verdadera materialización de dichos derechos, alcanzando de esta forma la pretendida justicia, reconocida como valor superior de todo ordenamiento jurídico ${ }^{667}$.

Así dentro del tema especifico del proceso penal y su lectura constitucional ${ }^{668}$, un aspecto inicial que se debe plantear es relativo al hecho de que en el panorama de la persecución penal transcurren cotidianamente en un escenario formado por dos fuerzas directivas que se chocan tensamente (eficacia versus garantías), provocando la contrariedad fundamental de la persecutio criminis: cuanto más intensamente se busca demostrar la existencia del hecho criminoso y su respectiva autoría (principio instrumental punitivo) más se queda lejos de las garantías de los derechos fundamentales; y cuanto más intensamente se garantiza los derechos fundamentales (principio instrumental garantista), más difícil se torna la búsqueda y la producción de pruebas que podrán comprobar la existencia del delito practicado y su autoría669.

Esto significa, sencillamente, que esta colisión fundamental entre un principio instrumental punitivo y un principio instrumental garantista es la esencia de una persecución penal de índole constitucional. Queda muy claro, pues, que la seguridad colectiva y también la seguridad individual, constituyen el núcleo central de este aparente conflicto entre bienes constitucionalmente protegidos.

Pues bien, es incontestable que el proceso penal es el instrumento jurídico necesario para la resolución de los conflictos de naturaleza penal, de modo que si se ha de perseguir una conducta delictiva, el proceso es el instrumento imprescindible para ello. Al propio tiempo, representa probablemente el principal campo de tensión entre la exigencia ciudadana de seguridad y el derecho a la libertad de quien se ve sometido al proceso ${ }^{670}$.

666 Vid. GÓMEZ DE LIAÑO GONZÁLEZ, F., El proceso penal. Tratamiento Jurisprudencial, cit., pág. 25.

667 Seguiendo esta orientación, véase, BERNAL CUÉLLAR, J; MONTEALEGRE LYNETT, E., El Proceso Penal, cit., pág. 23. De modo semejante, la opinión de GÓMEZ COLOMER cuando defiende que "las relaciones entre el Derecho Procesal Penal y el Derecho Constitucional tienen una conexión ideológica evidente, puesto que el proceso penal acoge siempre en su seno las condiciones políticas de la sociedad en que se ha de desarrollar, lo que significa que nuestro proceso penal es el espejo en el que se miran los preceptos constitucionales, reflejando la verdadera naturaleza del régimen político imperante". Vid. GÓMEZ COLOMER, "Estado democrático y modelo policial: una propuesta de diseño de cara a lograr una investigación eficaz del crimen", La policía en los Estados de Derecho Latinoamericanos, Un proyecto internacional de investigación, Bogotá, 2003, pág. 12.

668 Vid. con riqueza de detalles, HASSAN CHOUKR, F., "A ordem constitucional e o processo penal", Revista Brasileira de Ciências Criminais, núm. 8, São Paulo, 1994, págs. 57-68.

3.

669 FEITOZA PACHECO, D., O princípio da proporcionalidade no Direito processual penal brasileiro, cit., pág.

670 MORENO CATENA, V., "Los elementos probatorios obtenidos con la afectación de derechos fundamentales durante la investigación penal", cit., pág. 75. 
Es perceptible entonces que el problema de fondo que impregna el proceso penal en los días actuales es representado por esta tensión de fuerzas aparentemente contrapuestas y que por veces provoca efectos drásticos y perjudiciales en el desarrollo de la persecución criminal.

Esta la constatación que se puede observar respecto del proceso penal moderno, pues que ha venido a pasar en los últimos tiempos por sensibles variaciones y cambios oriundos de las varias influencias provocadas por movimientos extrajurídicos, en especial en razón de la valorización de los derechos humanos y de las garantías de los derechos fundamentales de los ciudadanos.

En esta evolución de la relación entre individuo y Estado, hubo una concreta e imperiosa necesidad de establecimiento de normas que vendrían a garantizar los derechos fundamentales del ciudadano, contra el fuerte poder estatal intervencionista ${ }^{671}$.

Como consecuencia, la gran mayoría de los países democráticos, han introducido recientemente en sus ordenamientos constitucionales reglas y disposiciones de índole garantista, las cuales imponen al Estado y por vía refleja a la propia sociedad, el respeto incondicional a los derechos fundamentales en su grado máximo.

Cabe considerar también la comprobación de que el proceso penal contemporáneo es fruto del avanzo del proceso de civilización de la humanidad, resultante del reconocimiento del carácter jurisdiccional del poder punitivo estatal. Aunque el Derecho penal presente un matiz represivo, el Derecho procesal penal es comprometido con la cuestión de la libertad 672 .

Esto nos pone en presencia de otra cuestión: ¿En la actualidad debe ser el proceso penal considerado como instrumento de concreción de las garantías constitucionales?

Según nuestro modo de pensar y delante de todos los argumentos ya expuestos anteriormente, la respuesta deberá necesariamente ser positiva, pues en la búsqueda de las garantías de tales derechos fundamentales inherentes a la condición de ciudadano en un Estado Constitucional de Derecho, es necesario e imprescindible la obediencia a la base de principios del procesal penal ${ }^{673}$, que muchas veces, por no decir casi siempre, presenta rango constitucional explícita o implícitamente.

Ocurre, en efecto, que el ejercicio de coerción estatal a través de la justicia penal debe ser legitimado, destacándose el bien estar social, no sólo colectivo como distributivo.

Necesaria pues, la institucionalización de los principios de justicia en la forma de un Estado constitucional democrático y social, permitiéndose que las controversias puedan

\footnotetext{
671 Se destacan en este sentido, como documentos fundamentales en la lucha para el fortalecimiento de los derechos fundamentales, la Declaración de los derechos universales del hombre, producida por Naciones Unidas, en 1948, la Convención europea para la salvaguardia de los derechos del hombre y de las libertades fundamentales, hecha en Roma en 1950, el Pacto internacional de los derechos civiles y políticos, en Nueva York en 1966, la Convención de los derechos humanos, el conocido Pacto de San José de Costa Rica, en 1969, la Carta de los derechos fundamentales de la Unión Europea, en el año 2000, el Tratado de Lisboa, del año 2007, etc.

672 SILVA JARDIM, A., "Bases Constitucionais para um Processo Penal Democrático", Direito Processual Penal, 7a edición, Rio de Janeiro, 1999, pág. 317.

673 Sobre el tema, Vid. OBLIGADO, D. H., "Sobre la génesis de los principios y garantías del proceso penal", Garantías, medidas cautelares e impugnaciones en el proceso penal, C. A. Chiara Díaz coord., Rosário, 2005, págs. 15-19; ARMENTA DEU, T., "Principios y sistemas del proceso penal español", El nuevo derecho penal español: estudios penales en memoria del profesor José Manuel Valle Muñiz, G. Quintero Olivares y F. Morales Prats coords., Pamplona, 2001, págs. 57-80; ROMERO COLOMA, A. M., "Alcance de los principios del proceso penal español a la luz del ordenamiento constitucional", Actualidad Penal, Madrid, 1995, págs. 297-316.
} 
ser llevadas a los Tribunales. Esta la importancia del proceso penal como forma de expresión judicial de los principios procesales y constitucionales.

Por otro lado, como ya hemos visto, el Derecho Procesal penal como instrumento para la realización del Derecho penal debe cumplir su doble función: de un lado, tornar viable la aplicación de la sanción, y, de otro, servir como efectivo instrumento de garantía de los derechos y libertades individuales, asegurando a los individuos contra los actos abusivos del Estado.

En este sentido, debe servir como instrumento de limitación de la actividad estatal, estructurándose de modo a garantizar plena efectividad a los derechos individuales constitucionalmente previstos, como la presunción de inocencia, la contradicción, el derecho de defensa, etc 674 .

Queda muy claro, pues, que el proceso penal debe recibir una lectura constitucional ${ }^{675}$ y no al contrario, a la vez que los dispositivos de la ley procesal penal es que deben ser objeto de una interpretación hecha en consonancia con los postulados democráticos y garantistas de la Constitución.

En consecuencia, se nos parece algo lógico afirmar que casi todas las ramas jurídicas han recibido en los últimos tiempos, una relectura constitucional, o mejor, bajo la óptica de la Constitución, fenómeno que deberá ser reconocido como un filtro constitucional.

Esto significa, sencillamente, según GÓMEZ COLOMER, que el Derecho Procesal penal se muestra hoy ante los ojos de la generalidad, consecuentemente, como el producto de un compromiso público entre eficacia de la persecución penal y respetoa la dignidad humana, lo que interrelaciona definitivamente el Derecho procesal penal con la Constitución676.

En la hipótesis especifica del proceso penal, señala GRECO FILHO que el proceso constitucionalmente estructurado, por lo tanto, actúa como indispensable garantía pasiva contra el arbitrio del que eventualmente representa el Estado, cabiendo al Poder Judicial la concretización de esta garantía677.

Otra constatación de interés es que el proceso penal, sin cualquier duda, es una de las expresiones más típicas del grado de cultura alcanzado por una nación en el curso de su historia, y los principios de política procesal de una nación no son otra cosa que segmentos de la política estatal en general678.

En esta línea, una Constitución democrática debe orientar la democratización sustancial del proceso penal, y eso demuestra la transición del derecho pasado al derecho del futuro. Obsérvese, pues, que siendo el Derecho Penal un Derecho de protección individual y social de bienes jurídicos entroncados con principios básicos de todas las

674 LOPES JR, A., Introdução crítica ao Processo Penal. Fundamentos da instrumentalidade constitucional, cit., pág. 38.

675 Una lectura lineal del proceso penal constitucional, habrá de nos conducir a la siguiente conclusión: las leyes del proceso son el complemento necesario de las leyes constitucionales; al mismo tiempo en que las formalidades del proceso son las actualidades de las garantías constitucionales.

676 En este sentido, Vid. GÓMEZ COLOMER, J. L., "Estado de Derecho y Policía Judicial democrática: Notas sobre el alcance y límites de la investigación policial en el proceso penal, con consideración especial de los actos de mayor relevancia", cit., págs. 94-95.

677 GRECO FILHO, V., Manual de Processo Penal, cit., pág. 54.

678 Cfr. GOLDSCHMIDT, J., Problemas jurídicos y Políticos del Proceso Penal, Barcelona, 1935, pág. 67. 
Constituciones democráticas, el Derecho Procesal se convierte en el garante del Estado de Derecho consagrado por esa misma Constitución 679 .

De igual forma nos cumple destacar que el Estado está obligado a hacer extensiva la fuerza vinculante de los derechos constitucionales a sus relaciones con los asociados; el Estado legislador debe dar eficacia a los derechos constitucionales en el proceso público; y el Estado investigador, acusador y juez, debe interpretar el Derecho siempre a través de la óptica de los derechos constitucionales ${ }^{680}$.

Lógicamente, frente al Estado Constitucional de Derecho, no se puede tolerar un proceso penal autoritario y típico de un Estado-policial, pues el proceso penal debe adecuarse a la Constitución y no viceversa como hemos visto anteriormente.

En este sentido, dentro de una perspectiva garantista, la protección de los derechos fundamentales según HENKEL681 ha transformado el proceso penal en un Derecho constitucional aplicado, o, en expresión de metáfora muy destacada, "sismógrafo" de su efectiva protección ${ }^{682}$. Como consecuencia, en el estudio de los institutos del proceso, una vez ignorada su conexión con el Derecho Constitucional, éste se convierte en "tedioso y estéril", siendo solamente un "cómputo de formalidades y términos", adquiriendo su verdadero significado cuando es entendido como el estudio del aparato de garantías establecidas para la defensa de los derechos fundamentales del hombre ${ }^{683}$.

En este contexto, la tendencia es fijar en la Constitución las reglas mínimas de un debido proceso penal ${ }^{684}$, es decir, como afirma BINDER, "un diseño constitucional del proceso penal"685. Dicho en otros términos, el Derecho procesal penal se muestra hoy ante los ojos de la generalidad, consecuentemente, como el producto de un compromiso público entre eficacia de la persecución penal y el respeto a la dignidad humana, lo que interrelaciona definitivamente el Derecho procesal penal con la Constitución ${ }^{686}$.

El proceso penal es en realidad un instrumento de garantía de la libertad y del status dignitatis de los investigados o imputados. Además, necesario reafirmar que la justicia penal es, por su vez, un gran espacio de lucha en el que juega la dignidad de la persona.

\footnotetext{
679 Vid. GÓMEZ COLOMER, J. L., "Estado democrático y modelo policial: una propuesta de diseño de cara a lograr una investigación eficaz del crimen", cit., pág. 12.

${ }^{680}$ En este sentido, BERNAL CUÉLLAR, J., MONTEALEGRE LYNETT, E., El proceso Penal, cit., pág. 27.

681 Véase, HENKEL, H., Strafverfahrensrecht, Stuttgart/Köln, 1953, pág. V.

682 ROXIN, C., Derecho Procesal Penal, cit., pág. 2.

683 Cfr. LIEBMAN, E. T., "Diritto costizionale e processo civile", Rivista di diritto processuale, Padova, 1952, págs., 328-329.

${ }^{684}$ De este modo, las normas y principios constitucionales relativos al ejercicio de la función jurisdiccional, considerados en su complejidad, permiten la posibilidad de diseñar un verdadero y propio esquema general del proceso, cuyo objeto nos viene sumistrado por la denominada jurisdiccionalidad derivada del proceso, es decir, por el examen de su deber ser en conformidad con la normativa constitucional. Vid. con más detalles, RAMOS MÉNDEZ, F., Enjuicamiento criminal. Octava lectura constitucional, cit., págs. 29 y ss.

685 Vid. BINDER, A. M., Introducción al derecho procesal penal, cit., pág. 70.

686 GOMÉZ COLOMER, J. L., "Estado de Derecho y Policía Judicial Democrática: Notas sobre el alcance y límites de la investigación policial en el proceso penal, con consideración especial de los actos de mayor relevancia", cit., págs. 94-95.
} 
A su vez GREVI, refiriéndose a Italia, afirma que el modelo constitucional impregna el proceso penal687. Como fácilmente puede deducirse, la base constitucional siempre estaría influyendo profundamente en la ciencia del Derecho Procesal penal.

Este matiz constitucional nos permite constatar que el Derecho Procesal penal conforma y disciplina al proceso penal de acuerdo con una serie de principios y garantías ${ }^{688}$, que sólo pueden entenderse desde el marco de los derechos fundamentales de la persona, de su respeto máximo, y es por esto que se afirma el entronque directo del Derecho procesal penal con el Derecho constitucional y, más exactamente, como se afirma que el proceso penal y el Derecho procesal penal son hijos directos de la Constitución de un Estado de Derecho689.

Con arreglo a lo anteriormente afirmado, no cabe duda, que un Derecho procesal liberal, a diferencia del que corresponde a una sociedad autoritaria, ha de reconocer con la mayor amplitud las garantías procesales del acusado, con carácter de derecho fundamental, asumiendo incluso el riesgo de absolución de un culpable, pues se entiende que esta posibilidad siempre es menos mala que la que supone el riesgo contrario, esto es, el riesgo de condenar a un inocente.

A la vista de las anteriores reflexiones, cabe entender que a una Constitución autoritaria va a corresponder siempre un proceso penal autoritario, utilitarista (eficacia antigarantista). Sin embargo, a una Constitución democrática, como la mayoría de las Constituciones de nuestro entorno, necesariamente debe corresponder un proceso penal democrático, visto como instrumento al servicio de la máxima eficacia del sistema de garantías constitucionales del ciudadano690.

Solamente a partir de la consciencia de que la Constitución debe efectivamente constituir la base del proceso penal, es que se puede comprender que el fundamento legitimante de su existencia se da a través de su instrumentalidad constitucional. Significa decir que el proceso penal contemporáneo solamente se legitima en la medida que se democratiza y desde que sea construido a partir de la Constitución.

De esta suerte, debemos hacer hincapié en el sentido de que la ciencia del proceso penal al menos en los países avanzados y que buscan defender con "uñas y dientes" el Estado social y democrático de Derecho, ha empezado el siglo XXI con una gran pretensión de certeza: la de que no es más posible emprender cualquier pesquisa dogmática alejada del referencial constitucional691.

No nos parece arriesgado afirmar entonces que cuando se cuida de establecer un sistema procesal penal cuya teoría tiene raíces en la propia teoría de los derechos

\footnotetext{
687 GREVI, V., "Garanzie individuali ed esigenze di difesa sociale nel processo penale(a cura di Lucio Lanfranchi)", cit., págs. 3 y ss.

688 Vid. HASSEMER, W., Fundamentos del Derecho Penal, cit., págs. 149-150.

689 Vid. en este sentido, GUZMÁN FLUJA, V. C., "El agente encubierto y las garantías del proceso penal", cit., pág. 200.

690 Esta idea adquiere especial relevancia a partir del entendimiento de que a través de la Constitución procesal penal, el Estado se autodefine como liberal o autoritario, y revela su respecto o no a la persona individualmente considerada o por el contrario, a los intereses colectivos.

691 Concretamente, se quiere exponer claramente algo indiscutible: muchos de los derechos, principios y garantías que conforman el derecho al debido proceso, tienen reconocimiento constitucional. Este reconocimiento constitucional de algunos de estos derechos, principios y garantías se vincula con la relación conflictiva que suele existir entre el proceso penal y los derechos fundamentales. En síntesis, de allí que se aluda en la actualidad a una "relación mutuamente y necesaria" entre Constitución y Derecho procesal.
} 
fundamentales, no se pretende proponer la construcción de un orden impotente para enfrentar la macrocriminalidad o las acciones ilícitas que exigen más rigidez en la respuesta del Estado.

Muy al contrario, lo que se quiere dejar claro es que el tratamiento adecuado y eficaz de delitos que reclaman actuación más contundente del Estado en el combate a la criminalidad no habrá de confundirse con el maltrato a los derechos fundamentales. Y esto se explica, en razón de que por más grave que sea la actuación criminal, en la persecución penal el Estado tiene que pautar su forma de actuar de acuerdo con el perfil democrático dibujado en la Constitución, cuya espina dorsal son los derechos fundamentales.

No se puede ignorar actualmente la prevalencia de un proceso penal de índole garantista en razón del necesario respeto al Estado constitucional de Derecho, marcado por la defensa de los derechos y garantías fundamentales de los ciudadanos.

Es también significativo, a nuestro juicio, que cualquier análisis del proceso penal, además de estar basado en la normativa constitucional, debe hacer referencia también a los diversos Tratados Internacionales ${ }^{692}$ que puedan influir en la preservación de las garantías y en los derechos humanos de los ciudadanos.

Al finalizar este apartado, debemos concluir que cualquier análisis del proceso penal en días de hoy, tiene que estar en la Constitución y además basado en los Tratados y Convenciones Internacionales ${ }^{693}$, en especial, aquellos establecidos para el combate a la criminalidad transnacional ${ }^{694}$.

Del mismo modo, no hay como dudar que el Derecho Procesal penal venga a presentar un alto y representativo contenido constitucional, pues que es inherente a la esencia del conflicto entre el ius puniendi estatal sancionador y los derechos y garantías fundamentales de los ciudadanos.

692 Vid. más ampliamente sobre este asunto, PÉREZ DE NANCLARES, J. M., Tratado de Lisboa, Madrid, 2008; ALONSO GARCÍA, R; SARMIENTO, D., La carta de los Derechos Fundamentales de la Unión Europea explicaciones, concordancias, jurisprudencia, Madrid, 2006; FERNÁNDEZ TOMÁS, A., La Carta de los Derechos Fundamentales de la Unión Europea, Valencia, 2002.

693 En lo relativo a esta cuestión, nos parece imprescindible dentro del ámbito normativo español, señalar algunos aspectos sobre los artículos 10 y 96 de la Constitución española. Así, estableciendo una conexión entre el ordenamiento jurídico interno y el Derecho Internacional, dispone la Constitución española en su artículo 96, I, que los Tratados internacionales, luego que sean publicados oficialmente, formarán parte del orden interno español, disponiendo también que "las normas relativas a los derechos fundamentales y a las libertades que la Constitución reconoce se interpretarán de conformidad con la Declaración Universal de Derechos Humanos y los Tratados y acuerdos internacionales sobre las mismas materias ratificados por España" (art. 10.2). Versando sobre la interpretación del artículo 10.2 de la CE, AGUDO ZAMORA señala que "no se trata, por lo tanto, de una duplicación superflua, inconveniente, inútil o perturbadora, ya que hay diferencia entre la aplicación directa de un Tratado y la disposición de que las normas sobre derechos fundamentales deben ser interpretadas de conformidad con los Tratados debidamente suscritos por España respectode los derechos humanos". Cfr. AGUDO ZAMORA, M. J., "La interpretación de los derechos y libertades constitucionales a través de los tratados internacionales: la técnica del artículo 10.2", Estudios Penales y Jurídicos, Córdoba, 1996, pág. 39. Del mismo modo, el artículo 96, I de la CE deberá ser interpretado de modo que los Tratados internacionales relacionados con los derechos fundamentales no solamente constituyan parte del ordenamiento interno, sino que "son además, un patrón básico a la hora de interpretar cualquier precepto constitucional o legal relativo a derechos fundamentales". Vid. GARCÍA MORILLO, J., La protección judicial de los derechos fundamentales, Valencia, 1994, págs., 32-33.

694 Vid. como buenos ejemplos, la Convención de Naciones Unidas contra el tráfico ilícito de estupefacientes y sustancias psicotrópicas aprobada en Viena el 19 de diciembre de 1988; la Convención de las Naciones Unidas contra la Delincuencia Organizada Transnacional y sus protocolos, suscrita y firmada por 124 países en la ciudad de Palermo (Italia), el 15 de diciembre de 2000 y el Tratado de Lisboa, firmado el 13 de Diciembre de 2007, por el que se modifican el Tratado de la Unión Europea y el Tratado constitutivo de la Comunidad Europea. 
II.2.1.3. Garantías procesales fundamentales en los pactos y convenios internacionales de derechos humanos.

Ostentando los derechos humanos un carácter preferente en la gran mayoría de los sistemas jurídicos, la actividad de los poderes públicos en el seno del proceso penal, no obstante estar imbuida por la finalidad de lograr la búsqueda de la verdad material, se encuentra modulada por la necesaria tutela a los derechos fundamentales de la constelación de personas que, en su papel de inculpados o víctimas, se encuentran inmersos en las diversas fases del proceso. El respeto que el Estado está obligado a otorgar a la dignidad humana debe estar latente en todos los momentos en los que se desenvuelve el ejercicio de su potestad punitiva, desde que emerge la sospecha del hecho criminal hasta que se ejecuta la condena, impidiendo, en todo caso, la degradación de la persona a la condición de mero instrumento de la política criminal695.

Así, con mucha vehemencia en los últimos años, las garantías inherentes a la condición de persona portadora de dignidad humana han sido puestas de relieve como condicio sine qua non para la configuración del Estado de Derecho.

Y en este sentido, la libertad y la seguridad como requisitos básicos para la vida del hombre en sociedad han recibido de los Estados un respeto destacable. Del mismo modo han sido objetos de tratamiento en los Pactos Internacionales de Protección a los Derechos humanos.

Atinente a esta última consideración es necesario partir de la premisa de que cualquier atentado contra los derechos y libertades de la persona no es una cuestión doméstica de los Estados, sino un problema de relevancia internacional696. Así se justifica la importancia de la notoriedad adquirida por el tema de la dignidad de la persona humana bajo el aspecto de la libertad y de la seguridad frente a varios documentos internacionales.

No bastaría la previsión expresa de las garantías esenciales del ciudadano en las Constituciones de cada país, a la vez que la armonización de estos derechos necesitaba estar claramente delineada en documentos de rango internacional ${ }^{697}$.

Desde esta perspectiva se destacan los siguientes textos:

a) La Declaración Universal de los Derechos Humanos, de 10 de diciembre de 1948, donde se acoge el derecho a la libertad personal en su artículo $3^{\circ}$, señalando que "Toda persona tiene derecho a la vida, a la libertad y a la seguridad personal". Proscribe la práctica de la tortura, tratamiento o castigo cruel, inhumano o degradante (art. V) y la práctica de la discriminación (art. VII), la prisión arbitraria (art. IX). Reconoce el derecho de la persona sobre la cual pese una acusación criminal a una audiencia pública y justa por parte de un Tribunal independiente e imparcial que decidirá sobre sus derechos y deberes (art. X), así como el de ser considerada inocente hasta que su culpabilidad haya sido probada de acuerdo con la ley, en juicio público y rodeado de garantías para su defensa (art. XI). Asegura también la libertad de locomoción y residencia (art. XIII) y garantiza a

695 Cfr. SUBIJANA ZUNZUNEGUI, I. J., "Policía Judicial y el Derecho a la intimidad em el seno de la investigación criminal", Cuaderno del Instituto Vasco de Criminología, San Sebastián, núm. 10 Extraordinario, 1997, pág. 123.

696 Vid. PÉREZ LUÑO, A. E., Los derechos fundamentales, Madrid, 1984, pág. 41.

697 Para una comprensión integral del tema, en especial frente al Derecho Procesal penal, Vid. VV.AA., El proceso penal en la Unión Europea: garantías esenciales, M. Hoyos Sancho coord., Valladolid, 2008. 
toda persona, como miembro de la sociedad, derecho a la seguridad social y a la realización de los derechos sociales indispensables para su dignidad y el libre desarrollo de su personalidad (art. XXII). Por último, establece además que "En el ejercicio de sus derechos y libertades, toda persona estará sujeta simplemente a las limitaciones determinadas por la ley, exclusivamente con el fin de asegurar el debido reconocimiento y respetode los derechos y libertades de otros, y de satisfacción a las justas exigencias de la moral, del orden público y del bienestar de una sociedad democrática (art. XXIV) ${ }^{698 ;}$

b) El Pacto Internacional sobre Derechos Civiles y Políticos de Nueva York, de 16 de diciembre de 1966, el cual establece el derecho de toda persona a no ser sometida a tratamiento inhumano o cruel (art. $7^{\circ}$ ). Asegura este documento que "Toda persona tiene derecho a la libertad y a la seguridad personal. Así, nadie podrá ser privado de su libertad, salvo por los motivos previstos en ley y en conformidad con los procedimientos en ella establecidos (art. 9o, I). A favor de la persona privada de su libertad, hipótesis admitida solamente a título excepcional cuando anterior a la condena definitiva, establece una serie de derechos y garantías, como el de ser, sin demora, informada de las razones de la prisión y acusaciones contra ella formuladas; la conducción inmediata de la persona presa a la presencia de la autoridad judicial; la celebración del juicio en un plazo razonable o ser puesta en libertad; recurrir a fin de cuestionar la legalidad de la prisión, así como el derecho a la reparación (art. 9으, apartados 2, 3, 4 y 5). Por fin, asegura a toda persona privada de libertad el derecho a un tratamiento humanitario respeto a la dignidad inherente a la persona humana (arts. 9o e 10 ) y al principio de la presunción de inocencia (art. 14.2);

c) El Convenio Europeo para la protección de los Derechos y Libertades Fundamentales, de 4 de noviembre de 1950, el cual define una amplia protección del derecho a la libertad y a la seguridad en su artículo 5으, al determinar el reconocimiento que toda persona tiene del derecho a la libertad y que nadie podrá ser de ella privada, excepto de acuerdo con el procedimiento establecido por ley y presentándose alguna de las hipótesis que contempla ( $\operatorname{art.} 1^{\mathrm{o}}$ ), como la condena criminal definitiva dictada por un Tribunal competente o la "detención preventiva o internamiento" en los casos legalmente previstos (art. 1ํa, a, b, c, d).Pero, siempre fundamentado con las garantías, como la de ser informada sobre los motivos de su detención o acusación (art. $2^{\circ}$ ). También de ser la persona conducida sin dilaciones a la presencia de la autoridad competente y a un juicio en plazo razonable o de ser puesta en libertad durante el procedimiento (art. $3^{\circ}$ ). Por fin, el derecho a la interposición de un recurso frente a un órgano judicial a fin de que se pronuncie sobre la legalidad de la privación de la libertad (art. $4^{\circ}$ ), el derecho a la reparación (art. 5을 y a la presunción de inocencia (art. 6.2) ${ }^{699}$;

d) La convención Americana sobre Derechos Humanos (Pacto de San José de Costa Rica), de 22 de noviembre de 1969. Este importante documento señala con claridad

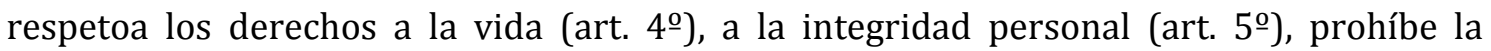

698 Con más detalles, Vid. GARCÍA VITORIA, I., "La Declaración Universal de los Derechos Humanos y el sistema europeo de protección de los Derechos Fundamentales", Los derechos humanos sesenta años después: (1948-2008), Valladolid, 2009, págs., 83-94.

699 Cfr. con más profundidad sobre este tema, GARCÍA SAN JOSÉ, D. I., "Alcance de las obligaciones internacionales asumidas por los estados europeos en materia de derechos y libertades de los nacionales y extranjeros a la luz del artículo 1 del Convenio Europeo para la Protección de los Derechos y Libertades Fundamentales", Migrantes y derecho: problemas actuales de la coordinación comunitaria de las prestaciones sociales en España, A. María Chocrón Giráldez coord., Murcia, 2006, págs., 49-64. 
tortura, penas o tratos crueles, inhumanos o degradantes, garantizando el "derecho de toda persona privada de su libertad a ser tratada con el debido respeto a la dignidad inherente al ser humano" (art. 5ㅜㅡ, II). Del mismo modo, define que "Toda persona tiene derecho a la libertad y a la seguridad personales" y que "Nadie puede ser privado de su libertad física, salvo por las causas y en las condiciones previamente fijadas por las Constituciones políticas de los Estados partes o por las leyes de acuerdo con ellas promulgadas" (art. 7ํㅜ 2). Prohíbe la detención de la persona o su encarcelación arbitrarias (art. 7으, 3). A favor de la persona privada de su libertad establece un rol de garantías, a ejemplo del respeto al derecho de ser informado de las razones de la custodia y de la acusación (art. 7ํㅜ 4); la conducción inmediata a la autoridad responsable, a un juicio en plazo razonable o a su liberación (art. 7으, 5). Del mismo modo, establece como garantía el derecho a recurrir frente a un Juez o Tribunal competentes para decidir respecto a los aspectos de legalidad de su prisión o detención (art. 7ํㅜ 6), bien como prohíbe la prisión por deudas (art. 7ํㅜ 7). Por fin, define una serie de garantías judiciales como el derecho a ser juzgado en plazo razonable por un Juez competente, independiente e imparcial, desde que establecida la competencia con anterioridad (art. 8ㅇ, 1); el reconocimiento de la presunción de inocencia (art. 8oㅜ 2); la previa comunicación de la acusación formulada contra la persona, la concesión de tiempo y medios adecuados para el ejercicio de la defensa personal o a través de abogado, de ser asistido por defensor ofrecido por el Estado, el derecho de interrogar testigos, incluso los que sean presentados por el imputado, el derecho a no auto incriminarse, el de recurrir de las decisiones para un

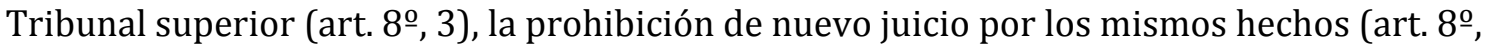

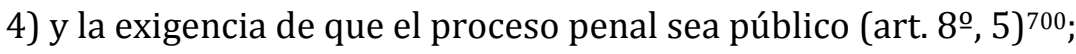

e) Por fin, el documento más reciente: el Tratado de Lisboa. Ha sido firmado en Lisboa, Portugal, el 13 de diciembre de $2007^{701}$ y presenta como claro objetivo la mejora del funcionamiento de la Unión Europea y del Tratado constitutivo de la Comunidad Europea. En su esencia, define de forma expresa que son valores de la Unión Europea la paz, la democracia, el respeto a los derechos humanos, la justicia, la igualdad y el Estado de Derecho. Además, garantiza las libertades y los principios enunciados en la Carta de los Derechos Fundamentales (art. 6º).

Imprescindible destacar citando palabras de GARCÍA RIVAS que la entrada en vigor del Tratado de Lisboa supone un importante cambio en la estructura institucional de la Unión Europea, que se aborda con la finalidad de afianzar su cohesión política. A estas alturas de la integración europea, no cabe duda de que uno de los factores estructurales de dicha cohesión es el que se refiere a la consolidación del "espacio de libertad, seguridad y justicia", un reto en el que la Unión está empeñada desde hace años y que expresa la tendencia a la disolución de las barreras nacionales para lograr una mayor eficiencia en la lucha contra la delincuencia ${ }^{702}$.

700 Monográficamente sobre este asunto, Vid. GOMES, L. F; MAZZUOLI, V. O., Comentários a Convenção Americana de Direitos Humanos. Pacto de San José da Costa Rica, São Paulo, 2010.

701 Todavía, importante destacar que el Tratado de Lisboa solamente ha entrado en vigor el 1 de diciembre de 2009 y dota a la Unión Europea de instituciones modernas y perfecciona sus métodos de trabajo para poder afrontar con eficacia los desafíos del mundo de hoy.

702 Cfr. GARCÍA RIVAS, N., "La tutela de las garantías penales tras el Tratado de Lisboa", Revista General de Derecho Penal, núm. 14, 2010, http::/www.iustel.com. 
En un planeta que cambia con rapidez, los europeos vuelven su mirada a la Unión Europea para resolver problemas como la globalización, el cambio climático, la evolución demográfica, la seguridad y la energía. El Tratado de Lisboa refuerza la democracia en la Unión Europea y mejora su capacidad de defender día a día los intereses de sus ciudadanos.

Con el Tratado de Lisboa, la Carta de los Derechos Fundamentales pasa a ser jurídicamente vinculante, teniendo el mismo valor jurídico que los Tratados. Esta la clave para una exacta comprensión respecto a la relación entre estas dos normativas.

En realidad, el paso de la Carta de los Derechos Fundamentales de la Unión Europea a Derecho vinculante para los Estados miembros (y sus ciudadanos) a través de su inclusión en el Tratado de Lisboa, suscita muchos temas de interés, entre ellos, el referido a los mecanismos de articulación en la protección de los derechos fundamentales, consecuencia de la coexistencia de diversos sistemas jurídicos reguladores de tales derechos y, por tanto, de varias jurisdicciones que habrán de dar solución a las eventuales situaciones de conflicto en su interpretación 703 .

De todo modo, si nota que al otorgarse el mismo valor jurídico a la Carta de los Derechos Fundamentales que a los textos de derecho originario, ésta pasa a tener plenos efectos jurídicamente vinculantes.

Se convierte, según reconocida doctrina ${ }^{704}$ e incluso el propio Gobierno español en el documento de ratificación por las Cortes del Tratado de Lisboa y de la propia Carta, en un Tercer Tratado.

Al fin, nos cumple destacar que aunque la mayoría de la doctrina termine por reconocer los avances de la nueva regulación 705 , algunos autores lamentan la falta de previsión de un recurso específico de protección de los derechos fundamentales considerando que las previsiones del Tratado de Lisboa en la materia recortan el vigor democrático de la Unión Europea y su acercamiento jurídico a los ciudadanos ${ }^{706}$. Son de prever, por tanto, enormes dificultades en la práctica en relación con la interpretación "concordante" de las garantías de los derechos fundamentales en su conjunto e individualmente considerados ${ }^{707}$.

\footnotetext{
703 Vid. con detalles, el reciente y destacado trabajo de PAREJO NAVAJAS, T., "La Carta de los derechos fundamentales de la Unión Europea", Derechos y Libertades, Revista del Instituto Bartolomé de las Casas, año 14, núm. 22, 2010, págs. 205-239.

704ALDECOA LUZÁRRAGA, F., La Europa que viene: el Tratado de Lisboa, Madrid, 2008, pág. 149.

705Esta sería la opinión por ejemplo de ESPINOSA DE LOS MONTEROS al señalar que "tras la grave crisis sufrida en el ámbito de la Unión Europea, tras el fracaso de la Carta de los Derechos Fundamentales, el Tratado de Lisboa ha servido como empuje para la creación de una verdadera institución europea en la que prime la unión de los Estados que la componen. Desde este momento, la unión se aprecia como una verdadera institución supra estatal con intereses, derechos y obligaciones comunes a todos los Estados miembros". Vid. ESPINOSA DE LOS MONTEROS, R. Z., "Implicaciones del Tratado de Lisboa en la lucha contra la delincuencia organizada", Revista General de Derecho Penal, núm. 14, 2010, http://www.iustel.com.

706 Vid. ALDECOA LUZÁRRAGA, F., La Europa que viene: el Tratado de Lisboa, cit., pág. 151.

707 En este sentido, Vid. la opinión de HÄBERLE, P., "El Tratado de Reforma de Lisboa de 2007", Revista de Derecho Constitucional Europeo, núm. 9, 2008, pág. 15. Otros autores, así ESPINOSA DE LOS MONTEROS, con un matiz más optimista, defiende que "con el Tratado de Lisboa, se pretende la unión de todos sus Estados miembros bajo una organización supraestatal. Esta situación, que puede parecer contraria a los planteamientos del principio de soberania, es necesaria para poder hacer frente a una criminalidad cada vez más peligrosa que atenta contra los intereses de la comunidad internacional". Vid. ESPINOSA DE LOS MONTEROS, R. Z., "Implicaciones del Tratado de Lisboa en la lucha contra la delincuencia organizada", Revista General de Derecho Penal, núm. 14, 2010, http://www.iustel.com.
} 


\section{CAPITULO TERCERO: LA INVESTIGACIÓN CRIMINAL COMO PIEZA CLAVE EN LA PERSECUCIÓN PENAL}

\section{III.1. La investigación criminal: algunas consideraciones generales}

\section{III.1.1. Observaciones preliminares respecto a la esencia de la investigación}

Por más que parezca obvio, debemos realizar algunas consideraciones respecto al tema de la investigación criminal, partiendo del presupuesto de que nuestro objeto principal de estudio, el agente encubierto, consiste en un medio extraordinario de investigación utilizado en la lucha contra la delincuencia organizada.

En una primera observación debemos señalar que en el proceso penal quien de verdad soporta el peso de la investigación es la policía: son los verdaderos especialistas en este aspecto, dotados de una estructura preparada, especialización, etc.708. De ahí la relevancia que en la práctica tienen los equipos de investigación policial.

Tratándose de un órgano con actividad directa de descubrir la verdad de los hechos, la responsabilidad de una investigación policial en orden al descubrimiento de un delito y sus autores del que se poseen indicios, corresponde en general a la policía judicial, antes de que se haya abierto el procedimiento judicial sobre esos hechos, siempre que no se necesite la autorización del juez para algún acto de intromisión en la esfera de los derechos fundamentales de las personas investigadas, necesarios para la incoación o prosecución de la labor investigativa ${ }^{709}$.

De otra parte, es perceptible que la comisión de todo delito de acción pública impone como regla al Estado, en forma necesaria, obligatoria e indispensable la promoción y desarrollo de un proceso que, como instrumento de Administración de Justicia, tiene por finalidad aplicar al caso concreto la ley penal sustancial e imponer al responsable una pena que luego el mismo Estado tiene el derecho de ejecutar. Lógicamente, respetando los derechos y garantías del imputado o investigado.

Pero antes del ejercicio de la acción penal, tendrá el órgano oficial del Estado, que alcanzar en la fase de investigación ${ }^{710}$ el descubrimiento del delito y sus respectivos responsables a través de la búsqueda de pruebas y otros datos de interés al esclarecimiento del hecho ${ }^{711}$.

708 Cfr. PÉREZ GIL, J., "Entre los hechos y la prueba: reflexiones acerca de la adquisición probatoria en el proceso penal", Revista Jurídica de Castilla y León, núm. 14, 2008, pág. 226; SÚAREZ-BÁRCENA, E. L., El modelo constitucional de investigación penal, Valencia, 2001, pág. 199; RIAÑO BRUN, I., La Instrucción Criminal en el Proceso Penal, Navarra, 2008, págs. 81 y ss; GÓMEZ DE LIAÑO FONSECA-HERRERO, M., Criminalidad organizada y medios extraordinarios de investigación, cit., pág. 103. Además, respecto a la importancia del trabajo policial, Vid. con monógraficamente, GRECO, R., Atividade Policial. Aspectos Penais, Processuais Penais, Administrativos e Constitucionais, Niteroi, 2009.

709 Cfr. la STS 1221/2007, de 6.3.2007.

710 Monográficamente, Vid. DE LLERA SUÁREZ-BÁRCENA, E., El modelo constitucional de investigación penal, Valencia, 2001; GUTIÉRREZ ZARZA, Á., Investigación y enjuiciamiento de los delitos económicos, Madrid, 2000; HASSAN CHOUKR, F., Garantias constitucionais na investigação criminal, Rio de Janeiro, 2006; MORAS MOM, J. R., La investigación en el proceso penal. Técnica del descubrimiento, Buenos Aires, 1998. Más reciente, un trabajo específico respecto al tema de la investigación policial en el ámbito español. Vid. PEDRAZ PENALVA, E., "Actividad policial preprocesal", Revista de Derecho Procesal, año 2009, págs. 763-888.

711 En la doctrina española, ha sido tratada con absoluto destaque la controversia respecto a diferencia existente entre actos de investigación y actos de prueba. Así, MONTERO AROCA; GÓMEZ COLOMER; MONTÓN REDONDO y BARONA VILAR, afirman que "El problema inicial que plantea el estudio de los actos de investigación es que son prácticamente coincidentes con los actos de prueba, y ello a pesar de que ambas 
De acuerdo Con IBÁÑEZ, una aproximación intelectualmente honesta a la realidad de la investigación criminal, y del proceso penal en general, no puede dejar de partir de una clásica constatación de CARNELUTTI: en ellos no solamente se hace sufrir a los hombres porque son culpables sino también para saber si son culpables o inocentes ${ }^{712}$.

En este sentido, el proceso penal sin la investigación preliminar es un proceso irracional, una figura inconcebible según la razón y los postulados de la instrumentalidad garantista.

Y es así porque se debe preparar, investigar y reunir elementos que justifiquen el proceso. Es un grave error que primero se acuse para después investigar y al fin juzgar ${ }^{713}$. Siendo así las cosas, resulta que los elementos obtenidos a través de la investigación criminal, sujetos a procesos intelectuales de análisis, correlación y síntesis, resultan en una conclusión, tendencialmente correspondiente a la realidad objetiva que, cualificada penalmente, es sometida a la apreciación del juzgador ${ }^{714}$.

Todavía, frente a esta constatación, el punto de partida para la comprensión de la magnitud e importancia de la investigación en el proceso penal moderno, deberá originarse de la constatación inicial de que la delincuencia contemporánea se caracteriza como una criminalidad no convencional, cuyo perfil asume innumerables formas de manifestación, exigiendo, del aplicador del Derecho, la ardua y desafiadora misión de rever conceptos tradicionales ${ }^{715}$, adecuando los mismos al tiempo y al espacio, a través del filtro de la eficiencia penal 716 .

instituciones son distintas porque cumplen finalidades muy diversas". Y además, describen algunas de las distinciones: 1a. El acto de investigación se dirige a averiguar o descubrir algo que se desconoce; el acto de prueba se dirige a verificar la verdad de una afirmación de hecho realizada por la parte; $2^{\mathrm{a}}$. El acto de investigación se realiza en el procedimiento preliminar; el acto de prueba, salvo los casos de prueba anticipada, en el juicio oral; 3a . La fundamental diferencia consiste en la función que cumplen enel proceso: El acto de investigación, aunque de resultados no ciertos sino probables, puede fundar las resoluciones interlocutorias que es preciso ir dictando en el procedimiento preliminar para que el proceso penal avance (por ejemplo, con base en esos actos se decide si se dicta auto de procesamiento o si se abre el juicio oral); estos actos no sirven para fundar la sentencia sobre la culpabilidad o inocencia del acusado. Los actos de prueba son los que sirven para determinar la convicción del juzgador sobre la existencia del hecho punible y la participación en él del acusado, de modo que la presunción de inocencia ha de ser desvirtuada precisamente en el juicio oral y por los actos de prueba". Vid. MONTERO AROCA, J., GÓMEZ COLOMER, J. L., MONTÓN REDONDO, A., BARONA VILAR, S., Derecho Jurisdiccional III, Proceso Penal, 12ª edición, Valencia, 2004, pág. 155.

712 ANDRÉS IBÁÑEZ, P., "Sobre los derechos fundamentales del imputado en la investigación criminal", cit., pág. 115.

713 LOPES JR, A., Sistemas de investigações preliminares no Processo Penal, cit., pág. 1.

714 Vid. MARQUES, J., "Métodos de investigação da criminalidade económico-financeira", cit., págs. 92-93.

715 En este sentido, FASSONE afirma que "si el reo siempre ha buscado el no dejar huellas de su delito, o hacerlas desaparecer, las asociaciones criminales han elevado a ciencia este empeño, inscribiéndolo programáticamente en sus designios complejos. Ello comporta que, no sólo la ciencia recíproca (la investigación) está obligada a seguir con modernidad la cultura de la supresión de la prueba, sino que también la ciencia jurídica viene obligada a hacer lo mismo con la evolución de sus propias categorías dogmáticas tradicionales". Vid. FASSONE, E., "La valoración de la prueba en los procesos de criminalidad organizada", cit., pág. 419. Por esto, en el ámbito español se ha afirmado que "el sistema actual es claramente insuficiente, tanto desde una perspectiva normativa como de los órganos policiales y judiciales para reprimir este tipo de delincuencia" y por ello se destacala necesidad de "diseñar una política criminal que permita investigar estas organizaciones delictivas, penetrando en su propia estructura, con la finalidad de conocer su funcionamiento, sus integrantes y su financiación". Vid. Diario de Seciones del Congreso de Diputados, núm. 126, año 1997, pág. 6604.

716 BECHARA, F. R., "Criminalidade organizada e procedimento diferenciado: entre eficiência e garantismo", cit., pág. 911. 
Esto lo que se busca hoy a través del proceso penal: eficacia y efectividad en la tarea de concretización del ius puniendi. Una vigorosa y concreta repuesta del Estado a la proliferación de los fenómenos delictivos considerados de mayor gravedad, adecuándose la misma al necesario respetoa los derechos fundamentales de los investigados o imputados. Como hemos visto, esto es lo que se podría denominar sintéticamente como eficiencia penal a través de la armonía procesal penal.

En principio esta reflexión remite a un análisis más detallado respecto de temas como la tutela de la defensa social en el proceso penal, las limitaciones a los derechos fundamentales, los fines del Derecho Penal y del Derecho Procesal penal y, finalmente, la necesidad de desarrollo de un procedimiento de investigación especifico y adecuado al combate a las nuevas formas de criminalidad, en especial, la delincuencia organizada, compatibilizando los valores de la eficiencia y las garantías individuales.

Resulta particularmente interesante destacar que el hecho de que un sistema de Administración de Justicia penal funcione en un Estado de Derecho de base democrática, no significa para nada que deba ser "blando", mucho menos que pueda favorecer la impunidad. Por el contrario, tiene que ser eficiente para lograr igualitariamente (o sea, tanto para "enemigos" como para "amigos") el castigo del delito en todos los casos que así lo establezca la ley; pero especialmente en los relacionados con sus expresiones más violentas y perversas, con la criminalidad organizada, con el ilícito financiero y económico, y la corrupción gubernamental y administrativa (anterior y contemporánea) ${ }^{717}$.

Pues bien, a partir de estas premisas, se puede afirmar que lograr la simultánea vigencia de esta eficacia y de aquellas garantías es el desafío mayor al que debe enfrentar el sistema de procuración y administración de justicia penal en una democracia ${ }^{718}$. Y en esta tarea cumplirá un rol decisivo la investigación, porque a través de ella se deberá procurar la obtención de las pruebas indispensables para lograr la condena de una persona por la comisión de un delito, e imponerle la sanción correspondiente.

Por esto se afirma en la doctrina que los actos de investigación son los que se realizan en la fase preparatoria o preliminar del proceso penal para descubrir los hechos criminales que se han producido y sus circunstancias, y la persona o personas que los hayan podido cometer, de manera que una vez investigado todo ello, se pueda proceder a formular una acusación o, al contrario, a terminar el proceso penal por sobreseimiento ${ }^{719}$.

Una última observación general al tema de la investigación se refiere a la opinión de CAFFERATA NORES al afirmar que la verdad que buscará la investigación penal es la "verdad sobre la culpa", la verdad sobre lo contrario a lo presunto por el orden constitucional. Si el acusado es inocente hasta que se pruebe lo contrario, lo que el Estado debe probar es "lo contrario": la verdad que se busca es la verdad sobre la culpabilidad del acusado en el delito que se le atribuye. Quizás podría decirse, para una mayor

717 CAFFERATA NORES, J. I., "Crisis de eficacia de la investigación penal: causas, peligro, soluciones", cit., pág. 17.

718 En el mismo sentido dice, con toda razón, HASSAN CHOUKR que "la investigación criminal encierra, quizás, el dilema fundamental del proceso penal, que es el enlace y balance entre los valores seguridad y libertad. Vid. HASSAN CHOUKR, F., Garantias constitucionais na investigação criminal, cit., pág. 8.

719 GÓMEZ COLOMER, J. L., "La investigación criminal: problemas actuales y perspectivas de unificación internacional", Revista del Poder Judicial, núm. 64, 2001, págs. 223-224. 
comprensión, que la investigación buscará, más que probar una verdad (la culpabilidad del acusado), probar una falsedad: la de la presunción de inocencia720.

De esta forma se consigue un puente entre la investigación y el principio de presunción de inocencia.

\section{III.1.2. Contenido de la investigación criminal.}

Etimológicamente, el término "investigare" proviene de la palabra vestigium (vestigio, es la señal, huella o rastro que queda de algo) y supone el descubrir lo que está oculto, a través de medios que permitan alcanzar dicha información ${ }^{721}$.

La investigación en una visión ya tradicional sería así la etapa de la persecutio criminis que tiene por objeto consignar y asegurar todo cuanto conduzca a la comprobación de un hecho presuntamente ilícito y a la identificación de quienes hayan participado, para que el órgano público de persecución penal y el sujeto particular legitimado puedan decidir si deducen acusación en contra de una determinada persona, pidiendo al tribunal correspondiente la aplicación de una sanción penal, previo un juicio oral, público y con todas las garantías.

Presenta como objetivo establecer la efectividad del hecho imputado, con todas las circunstancias de personas, cosas o lugares, identificar a los testigos del hecho investigado y consignar sus declaraciones, y, en general, recoger todos los antecedentes que puedan servir para tomar la decisión acerca del curso de la persecución penal722.

La investigación comprende de esta forma todos los actos del órgano competente encaminados a verificar la existencia de un hecho conocido que tenga apariencia de delito, de sus circunstancias y de sus posibles autores, para concluir la conveniencia o no de promover la incoación del proceso penal mediante la correspondiente acción penal, identificando para ella los elementos probatorios, tanto de cargo como de descargo ${ }^{723}$.

En este punto debe enfatizarse que el iter de la investigación presenta como característica destacable el hecho de que cualquier intromisión restrictiva del contenido esencial de derechos y libertades fundamentales, habrá que realizarse dentro de un marco de constitucionalidad, manteniéndose la salvaguardia del núcleo garantista de la persecución penal ${ }^{724}$.

720 Vid. CAFFERATA NORES, J. I., "La eficacia de la investigación penal en el Estado de Derecho", Revista Brasileira de Ciencias Criminais, núm. 35, 2001, pág. 30. Sobre el tema de la investigación criminal, muy especialmente en lo relativo a esta fase del proceso penal, Vid. CALVO SÁNCHEZ, M. C., "La fase de investigación en el nuevo proceso penal abreviado regulado por la Ley Orgánica 7/1988 de 28 de diciembre”, La Ley, tomo 2, 1990, págs. 1085 y ss.

721 URBANO CASTRILLO, E., "La investigación tecnológica del delito", Los nuevos medios de investigación en el proceso penal. Especial referencia a la tecnovigilancia, Cuadernos de Derecho Judicial, Madrid, 2007, pág. 25.

${ }^{722}$ Por esto se puede afirmar que "en la medida en que toda investigación criminal tiene por objeto la obtención de información sobre unos hechos y su presunto autor, todos los rastros pueden ser decisivos en orden a la persecución y eventual enjuiciamiento". Vid. PÉREZ GIL, J., "Entre los hechos y la prueba: reflexiones acerca de la adquisición probatoria en el proceso penal", cit., pág. 233.

723 En este mismo sentido, Vid. BENITO LÓPEZ, A. Mạ; SÁEZ VALCÁRCEL, R., "La investigación penal", VV.AA., Hacia un nuevo proceso penal, Madrid, 2006, pág. 205.

724 Incluso, alguna autora, así MARTÍNEZ GARCÍA, sostiene que "existen otros derechos implicados en una investigación, que si bien no forman parte de este reducido núcleo de derechos (por ejemplo, la propiedad de un documento), nada obsta para pensar que su violación durante una investigación policial dificultaría 
Además, como señala BINDER, la investigación es una actividad eminentemente creativa, se trata de superar un estado de incertidumbre mediante la búsqueda de todos aquellos medios que puedan aportar la información que acabe con esa incertidumbre. Se trata, pues, de la actividad que encuentra o detecta medios que servirán de prueba ${ }^{725}$.

Sería así una fase relevante en el proceso criminal tanto para la acusación, como para la defensa; quien acusa, de ella depende para poder aparejar la imputación y obtener los elementos que han de permitir la producción de la prueba; en cuanto a la defensa, la previa investigación es esencial para evitarse acusaciones apresadas e injustas, por lo tanto, sin justa causa ${ }^{726}$.

En cualquier caso, en este abordaje introductorio respecto a la investigación criminal es importante destacar que la fase preliminar en el proceso penal, sea cual nombre le impongan ${ }^{727}$, procedimiento preliminar en España, enquête préliminaire 0 instruction préparatoire en Francia, indagini preliminari en Italia, ermittlungsverfahren o vorverfahren en Alemania, procedimento judicial pré-processual en Portugal o inquérito policial en Brasil, presenta destacable importancia en la búsqueda de la eficiencia penal.

La experiencia procesal penal en sentido amplio, es decir, comprendida la investigación policial cuando se da, comienza a partir de un hecho que rompe gravemente la normalidad, al punto de interesar al Derecho Penal. En el origen de cualquier actuación de esa clase, para que no sea arbitraria, tiene que existir lo que aparece, prima facie, como resultado de una acción humana que pueda ser criminalmente relevante. Es, pues, el criterio de la relevancia jurídica lo que, a partir de un cierto dato fáctico, desencadena el proceso institucional 728.

En virtud de lo expuesto cabe afirmar que la regla general es la imposibilidad de empezar un proceso penal sin previamente pensar, diligenciar e investigar un hecho criminoso que haya ocurrido. La excepción estaría en las hipótesis en las que el órgano acusador ya poseyera, sin necesidad de investigaciones, datos o pruebas que puedan comprobar la práctica del crimen, estando así en condiciones de empezar la acción penal ${ }^{729}$.

Parece claro de otra parte, que un sistema de investigación dotado de instrumentos, técnicas y normas legales adaptadas a la realidad del mundo contemporáneo, representa

gravemente su consideración, aunque no afecte a derecho fundamental debiéndose derivar las responsabilidades oportunas para el que sustrae dichos documentos". Vid. MARTínEZ GARCÍA, E., Actos de investigación e ilicitud de la prueba, cit., pág. 22, nota 5. En el mismo sentido, veáse la STC 69/2001, de 17.3.2001.

725 BINDER, A., Introducción al derecho procesal penal, cit., pág. 236. En este mismo sentido la opinión de GIMENO SENDRA al señalar que "los actos de investigación asumen la función de comprobar la verosimilitud de la notitia criminis". Vid. GIMENO SENDRA, V., Derecho Procesal Penal, cit., pág. 455.

726 Cfr. SCARANCE FERNANDES, A., "O equilíbrio na investigação criminal", cit., pág. 319.

${ }^{727}$ Para un estudio comparativo respecto a los diversos modelos de investigación, con sus respectivas particularidades, Vid. LOPES JR, A., Sistemas de investigação preliminar no processo penal, cit.

${ }^{728}$ ANDRÉS IBÁÑEZ, P., "Sobre los derechos fundamentales del imputado en la investigación criminal", cit., pág. 120.

729 Esta excepción en nuestra opinión no se aplica por supuesto a los casos de delincuencia organizada, o de otras formas graves de criminalidad, donde la investigación tiene una tarea de evidente y singular importancia. 
sin duda un gran avance en la lucha contra la expansión sin frenos de las formas más graves de criminalidad 730 .

En esta línea de pensamiento, de gran importancia señalar que definir y plantear una estrategia de investigación, en función de realidad que se pretende apreciar, asume una inequívoca prioridad en el dominio de la investigación criminal. Si la definición de una estrategia de investigación es fundamental, su concreción asiente en un adecuado e inequívoco rol de medios y recursos humanos significativos y aún un conjunto de medios de obtención de prueba adecuados, lo que configura el cierne de una investigación eficaz ${ }^{731}$. Consecuencia lógica es que en la medida en que toda investigación criminal tiene por objeto la obtención de información sobre unos hechos y su presunto autor, todos los rastros pueden ser decisivos en orden a la persecución y eventual enjuiciamiento ${ }^{732}$.

No obstante, sea cual sea el sistema de investigación preliminar adoptado, el modelo policial como en Brasil, donde la policía es quien ejerce toda la labor de la apuración de los hechos criminosos, o el modelo del Juez instructor, en que el actor principal de la investigación es la figura del juez, como en España y Francia, o aún el modelo del fiscalinvestigador, donde quien dirige la investigación y la actuación de la policía es el Ministerio Fiscal, como en Alemania, Italia y Portugal, la verdad es que el resultado final de la búsqueda de datos, informaciones y pruebas del hecho delictuoso, deberá ser eficiente de modo a proporcionar al órgano titular del poder de acusar o al particular por excepción en los delitos privados, la oportunidad de dar inicio a un proceso penal justo y sin riesgos de eventuales alegaciones de violaciones a los derechos fundamentales de los investigados ${ }^{733}$.

Queda así claro, como ya hemos tenido la oportunidad de analizar, que la exigencia de eficacia no puede dar base a una "concepción bélica de la investigación", que busque lograr la prueba "cueste lo que cueste"734.

Por la misma razón, debe concluirse que la investigación de un hecho delictivo, por tratarse de una cuestión que afecta a los derechos de las personas, en particular a su

\footnotetext{
730 Vid. con abundancia de detalles, GÓMEZ COLOMER, J. L., "Estado democrático y modelo policial: una propuesta de diseño de cara a lograr una investigación eficaz del crimen", La policía en los Estados de Derecho Latinoamericanos, Un proyecto internacional de investigación, Bogotá, 2003.

731 MOURAZ LOPES, J., "O crime económico fiscal e o processo penal", cit., pág. 146.

732 Véase a respecto, PÉREZ GIL, J., "Entre los hechos y la prueba: reflexiones acerca de la adquisición probatoria en el proceso penal", cit., pág. 233.

733 Resaltando la finalidad de la investigación, señala GIMENO SENDRA que "los actos de investigación asumen la función inmediata de comprobar la verosimilitud de la notitia criminis". Vid. GIMENO SENDRA, V., Derecho Procesal Penal, cit., pág. 455. Y esta realidad puede ser apurada delante de la constatación de que la violación de un derecho fundamental sólo puede estar justificada por un estado de necesidad o por el ejercicio legítimo de otro derecho.

734 Esclarece además CAFFERATA NORES que "la concepción bélica de la investigación penal consiste en entenderla como un arma para enfrentar y ganar, de cualquier forma, la "guerra" contra manifestaciones delictivas que generan especial inquietud y reprobación social, respecto de las cuales, y esto es lo importante de advertir, se postula expresamente o se tolera complacientemente la violación de la Constitución, mientras sea útil a tal empeño. Con sólo utilizar con inteligencia y corrección el enorme poder del Estado en sus variadas formas, incluso clandestinas para obtener legalmente datos probatorios para cualquier investigación, se podrá lograr descubrir la verdad sobre delitos y partícipes en la inmensa mayoría de los casos y aplicarles la ley". Vid. CAFFERATA NORES, J. I., "Crisis de eficacia de la investigación penal: causas, peligros, soluciones", cit., pág. 21, nota 10.
} 
libertad y derechos constitucionales, debe realizarse revestida de una serie de garantías ${ }^{735}$. Esta idea es la rectora de un proceso penal garantista y conectado al ideal de la justicia.

A los efectos que ahora interesa tratar, es importante poner de manifiesto que conceptualmente la investigación criminal es un conjunto de saberes interdisciplinarios y acciones sistemáticas, integrados para llegar al conocimiento de una verdad relacionada con el fenómeno delictivo ${ }^{736}$.

Sin embargo, en un abordaje más teórico, la investigación criminal seria un conjunto de actividades realizadas concatenadamente por órganos del Estado, a partir de una notitia criminis o actividad de oficio, con carácter previo y de naturaleza preparatoria con relación al proceso penal, que pretende averiguar la autoría y las circunstancias de un hecho aparentemente delictivo, con el fin de justificar el ejercicio de la acción penal o el sobreseimiento ${ }^{737}$.

Como sintetiza OCHOA MONZÓ la investigación es una fase que existe en todo proceso penal como fase previa al enjuiciamiento encaminada a determinar y descubrir las circunstancias que rodean el hecho delictivo y a su posible autor, donde se practican variados actos de investigación y se adoptan medidas de distinta naturaleza ${ }^{738}$.

Sería así, la investigación, dentro de la etapa instructora del proceso penal, la actividad específica que ante el hallazgo del hecho encara lo desconocido y en función de "descubrimiento" busca, acredita, junta elementos y va abriendo bases de conocimiento para que sobre ellos trabajen los medios de prueba, conformándose así la instrucción propiamente dicha, con aspiración final de certeza ${ }^{739}$.

Se nos parece correcto afirmar que la investigación del delito en su fase preliminar es la base fundamental de todo el procedimiento penal, pues a partir de su concreción fáctica, el persecutor público está en posibilidad de acopiar todo el material probatorio de cargo, destinado a la probanza del injusto penal y de la responsabilidad criminal del imputado, o a contrario sensu promover la abstención del poder punitivo del Estado, cuando de dicha Investigación se demuestre la irrelevancia jurídico-penal de la conducta imputada, $o$ ante una inminente insuficiencia de pruebas.

Efectivamente, delante de todo lo expuesto, parece evidente que la investigación del delito ha venido a constituirse en la columna vertebral del proceso penal moderno. Todo el

735 URBANO CASTRILLO, E., "La investigación tecnológica del delito", cit., pág. 49. En la misma línea de raciocionio, defiende PÉREZ GIL que "la búsqueda de mecanismos eficientes para afrontar la persecución de modalidades complejas de criminalidad (terrorismo, tráfico de drogas, de seres humanos, blanqueo de capitales, etc) lleva consigo la adopción de medidas que implican un profundo cambio estructural en el diseño del proceso penal". Vid. PÉREZ GIL, J., "Entre los hechos y la prueba: reflexiones acerca de la adquisición probatoria en el proceso penal", cit., pág. 230.

736 LÓPEZ CALVO, P., GÓMEZ SILVA, P., Investigación criminal y criminalística, cit., pág. 55. En el mismo sentido de esta idea clásicamente aceptada por un sinnúmero de manuales al uso, sostiene SÚAREZ-BÁRCENA que: "En una primera aproximación la actividad investigadora supone pues un conjunto de acciones encaminadas a verificar información sobre un hecho presuntamente cometido, es decir, que se ha podido cometer o sobre las circunstancias de él ya se tiene noticia cierta de haberse cometido. La actividad investigadora se cifra únicamente en esto, aunque la adquisición de información que constituye el contenido de la investigación criminal no sea un fin en si misma y se halle legalmente dirigida a posibilitar el ejercicio del ius puniendi del Estado a través del proceso penal". Vid. SÚAREZ-BÁRCENA, E. L., El modelo constitucional de investigación criminal, cit., pág. 17.

737 LOPES JR, A., Sistemas de investigação preliminar no processo penal, cit., pág. 40.

738 Vid. OCHOA MONZÓ, V., "Sujetos de la investigación en el proceso penal español", cit., pág. 101.

${ }^{739}$ En este sentido, Cfr. MORAS MOM, J. R., La investigación en el proceso penal, Técnica de descubrimiento, cit., págs. 12-13. 
iter procesal y la consecuente aplicación de la ley penal al caso concreto dependerán en buena parte del desarrollo de la fase de investigación del hecho delictuoso.

\section{III.1.3. Fundamentos y naturaleza del procedimiento de investigación.}

Analizándose esta fase de la persecución criminal, no es interesante solamente ofrecer un concepto de investigación, sino también, contestar a la siguiente pregunta clave: ¿Cuáles serían los fundamentos de la existencia de la investigación criminal preliminar?

La respuesta a priori no puede ser calificada como sencilla. El proceso penal no puede concebirse como una desorganizada e imprevisible secuencia de actos. Muy al contrario, es el conjunto de reglas que disciplinan la realidad social, obligando a los actos que componen el proceso a desarrollarse en una y otra forma ${ }^{740}$. No es más que el cauce a través del cual se desarrolla el proceso ${ }^{741}$. En síntesis, es el conjunto de normas que regulan la procesión de los actos en el proceso penal, de modo que la dinámica procesal, o sea, el avance hacia un resultado querido por la norma, debe realizarse con arreglo a los preceptos procedimentales correspondientes ${ }^{742}$.

Dicho lo anterior, es claro asimismo que el fin del proceso penal es hallar la verdad material (averiguar lo que realmente ha ocurrido) y obtener una sentencia justa (de absolución o de condena), respetando los derechos de los ciudadanos y actuando a través del proceso debido ("juicio limpio") 743 .

Pero, como hemos tenido la oportunidad de afirmar, generalmente habrá de empezarse con una fase preliminar de descubierta de los hechos ocurridos, seguida de la formación efectiva del juicio penal a través del debido proceso legal. Esteconjunto es lo que se denomina persecutio criminis $^{744}$.

Incluso se sostiene que el proceso penal tiene como fundamento de su existencia la instrumentalidad garantista y esto sería también el punto de partida para justificar la investigación preliminar ${ }^{745}$. Pero hubo en la historia del Derecho procesal muchas opiniones distintas a esta concepción dogmática.

Por ejemplo, BELING en una visión un tanto tradicional, pero correspondiente a su época, afirmaba que la fase preprocesal ha de servir al esclarecimiento del supuesto hecho en la medida necesaria para hacer posible la resolución sobre la apertura o no del juicio oral (fase procesal) ${ }^{746}$.

De su parte, con una construcción dogmática más consistente a nuestro modo de pensar, CARNELUTTI ha defendido que la investigación preliminar no se hace para la

740 Vid. SERRA DOMÍNGUEZ, M., Jurisdicción, Acción y Proceso, Barcelona, 2008, pág. 233.

741 RAMOS MÉNDEZ, F., Derecho y Proceso, Barcelona, 1978, pág. 38.

742 FENECH, M., El proceso penal, Madrid, 1982, pág. 184.

743 Vid. GOMÉZ COLOMER, J. L., "Estado de Derecho y Policía Judicial Democrática: Notas sobre el alcance y límites de la investigación policial en el proceso penal, con consideración especial de los actos de mayor relevancia", cit., pág. 97.

744 Vid. RIGHI, E., "Los límites de la persecución penal y la tutela de derechos fundamentales", Cuadernos de Doctrina y Jurisprudencia Penal, Buenos Aires, 1996, págs. 191-208.

745 LOPES JR, A., Sistemas de investigação preliminar no processo penal, cit., pág. 49.

746 Vid. la clásica obra de VON BELING, E. L., Derecho Procesal Penal, Trad. Miguel Fenech, Barcelona, 1943, pág. 271. 
comprobación del delito sino solamente para excluir una acusación aventurada. Incluso afirma que para evitar equívocos la función del procedimiento preliminar no debe ser entendida en el sentido de una preparación del procedimiento definitivo, sino al contrario, como un obstáculo a ser superado antes de poder abrir el procedimiento judicial ${ }^{747}$.

Así es que del mismo modo que el proceso no tiene como único fundamento la instrumentalidad, la investigación preliminar también atiende a un patente interés garantista, para evitar las acusaciones y los procesos infundados.

Otra orientación claramente distinta y que de cierto modo corrobora la tesis de BELING, viene expresada por MANZINI, quien ha sostenido que la investigación tiene la finalidad característica de recoger y seleccionar el material que habrá de servir para el juicio, eliminando todo lo que resulte confuso, superfluo o inatendible. Con esto, se evitarían los debates inútiles y se prepararía un material seleccionado para los debates necesarios ${ }^{748}$.

En sentido más actualizado, resulta interesante mencionar la opinión de algunos autores en el sentido de que por fuerza del art. 299 de la LECrim, el procedimiento preliminar tiene, pues, finalidades muy complejas. No sólo sirve para preparar el juicio oral, pues puede llegar a servir para impedir que ese juicio oral se celebre; así como el proceso civil empieza con la presentación de la demanda por el actor, y no existe control por parte del juez respecto a las posibilidades de éxito de la misma, en el proceso penal existe, primero, una fase pública de preparación y, también, un control judicial de que el verdadero proceso, el juicio oral, sólo se abre cuando existen posibilidades de éxito. El imputado no puede sufrir el juicio sólo porque exista la acusación, aunque ésta sea imprescindible para que se abra el juicio ${ }^{749}$.

Todas estas opiniones ya citadas, desde las más tradicionales hasta las actuales, o sea, un verdadero mosaico doctrinal, aunque con distintos sentidos, defendidos dogmáticamente a su tiempo, a nuestro modo de pensar han sido importantes para el desarrollo del tema de la investigación como pieza clave para la persecutio criminis.

A modo de conclusión, según nos parece más acertado, se puede afirmar que la tesis de la instrumentalidad garantista ${ }^{750}$ es la ideal para justificar en la actualidad, el gran fundamento que habrá de sostener la importancia de esta fase de la persecución criminal. La verdad es que el proceso es y siempre ha sido el medio para llegarse a la satisfacción jurídica de la pretensión acusatoria, a la pena y a la justa aplicación de las leyes.

Así, en la actual situación de la evolución científica del derecho procesal habrá de prevalecer ampliamente en la doctrina y en la jurisprudencia la visión de instrumentalidad del proceso penal.

En efecto, el proceso como instituto estructural del derecho procesal es el medio para que se pueda llegar a un cierto fin. Nos cumple de este modo destacar cuales son las finalidades que habrán de ser perseguidas por el proceso penal digno de un Estado

\footnotetext{
747 Veáse, CARNELUTTI, F., Derecho Procesal Civil y Penal, cit., págs. 338 y 346.

748 MANZINI, V., Tratado de Derecho Procesal Penal, trad. S. Sentís Melendo y M. Ayerra Redin, Buenos Aires, 1951, págs. 173 y ss.

749 Vid. MONTERO AROCA, J et alli, Derecho Jurisdiccional III, Proceso Penal, cit., pág. 119.

750 En sentido contrario, vide la opinión de LEONI, G., Tratado de Derecho Procesal Penal, trad. S. Santís Melendo, vol. II, Buenos Aires, 1963, pág. 86. Este autor considera la autonomía de la instrucción preliminar como incompatible con cualquier carácter instrumental respecto a la fase judicial.
} 
Constitucional y democrático de Derecho. De otra parte, no hay más espacio para se tolerar un proceso penal de índole autoritaria, fomentado por políticas represivas de ley y orden. Esta perspectiva utilitarista a priori debe ser repelida en razón de que el proceso en ninguna hipótesis, puede ser transformado en instrumento exclusivo de preservación de la seguridad ciudadana.

Dicho en pocas palabras: un auténtico proceso debe merecer el calificativo de sistema coherente ${ }^{751}$.

Desde el punto de vista de dinámica criminal, la investigación es una fase previa, pero que no tiene como fundamento la pena y mucho menos la satisfacción jurídica de una pretensión. No hace en sentido propio, justicia, si no que tiene como objetivo inmediato garantizar el eficaz funcionamiento de la justicia. Puede síser un instrumento para formar o mismo introducir elementos necesarios para el ejercicio de la pretensión, esto es, instrumentalizar la propia pretensión acusatoria ${ }^{752}$.

Es lógico por lo tanto afirmar que es fundamental comprender que la instrumentalidad de la persecución criminal no significa que ella sea un instrumento a servicio de una única finalidad, cual sea, la satisfacción de la pretensión acusatoria. Al lado de ella, se encuentra la función política de la persecución penal, y en especial del proceso, como instrumento a servicio de la realización del proyecto democrático. Es dentro de esta dimensión que está destacada la finalidad constitucional y garantidora de la máxima eficacia de los derechos y garantías fundamentales, en especial en el plan de las libertades individuales.

Cuestión actual y de interés en el estudio de la investigación penal es lo relativo a la naturaleza jurídica de la actividad instructora.

Así, el tema de la naturaleza jurídica del procedimiento preliminar es polémico en la doctrina 753

Y es así particularmente en el ordenamiento jurídico español cuando se está discutiendo si debe ser competente para instruirlo un Juez o el Ministerio Fiscal.

De un lado, autores defienden que el sumario tiene un indubitable carácter procesal en cuanto que constituye un presupuesto necesario para entrar en el proceso decisorio. Como dice FENECH, el sumario constituye la fase instructora del procedimiento entendido

\footnotetext{
751 Vid. GONZÁLEZ-CUÉLLAR SERRANO, N., "Investigación y prueba: los nuevos retos ante la reforma del proceso penal", cit., pág. 18.

752 LOPES JR, A., Sistemas de investigação preliminar no processo penal, cit., pág. 47.

753 Incluso, importante señalar que sin lugar a dudas puede decirse que el punto nuclear en las discusiones de los trabajos preparatorios en la elaboración de un nuevo código de proceso penal en España radica en el rol que quiere atribuírsele al Ministerio Fiscal. Vid. entre otros muchos, GIMENO SENDRA, V., "La reforma de la Ley de Enjuiciamiento Criminal y la posición del Ministerio Fiscal en la investigación penal", AA.VV., $L a$ posición del fiscal en la investigación penal: la reforma de la Ley de Enjuiciamiento Criminal, Instituto Elcano, 2005; ANDRÉS IBÁÑEZ, P., "El fiscal en la actual regresión inquisitiva del proceso penal", Teoría \& Derech Revista de Pensamiento Jurídico, núm. 1, 2007; BASTARRECHE BENGOA, T., Constitución y Ministerio Público: Holanda, Italia y España, Cizur Menor, 2010; DÍEZ-PICAZO PONCE DE LEÓN, L. M., "Siete tesis sobre la idea de Fiscal investigador", Teoría \& Derecho - Revista de Pensamiento Jurídico, núm. 1, 2007; ESPINA RAMOS, J. A., "La instrucción por el Ministerio Fiscal: La reforma eternamente pendiente", AA.VV., La reforma de la Justicia penal. Aspectos materiales y procesales, Valladolid, 2008; FUENTES SORIANO, O., "La instrucción por el Fiscal en un nuevo proceso penal", AA.VV., Nuevos retos de la Justicia penal, Madrid, 2008; GARBERÍ LLOBREGAT, J., "¿Fiscal instructor?: Pocas ventajas y un gran inconveniente", Revista Jurídica de Castilla y León, núm. 14, 2008. En sentido más general y crítico sobre el futuro del ordenamiento procesal penal español, Vid. ASENCIO MELLADO, J. Mํ.., La reforma del Proceso Penal, 1ํㅡㄹ edición, Madrid, 2011.
} 
en sentido amplio, y tiene un indubitable carácter procesal en cuanto que constituye un presupuesto necesario para entrar en el proceso decisorio ${ }^{754}$.

Desde este punto de vista el procedimiento preliminar tiene naturaleza jurisdiccional por el fundamental argumento siguiente: Con base únicamente en el sumario se puede resolver la absolución o condenación, tanto penal como civil, del acusado, cuando se conforma con la pena solicitada en la calificación provisional, pues entonces no hay juicio oral. Es más, cuando se sobresee libremente, con efectos de cosa juzgada, también se actúa con base únicamente a diligencias sumariales, lo que sería inconcebible si el procedimiento preliminar no tuviera naturaleza jurisdiccional755.

Una segunda corriente doctrinal entiende que la instrucción preliminar tiene un carácter predominantemente administrativo, aun cuando esté encomendada la instrucción a un órgano judicial 756 .

El argumento a favor de la naturaleza administrativa de la instrucción judicial, según VIADA, se apoya en la consideración de que en tal actividad el órgano instructor carece de la nota institucional del proceso, de la imparcialidad, porque no opera sobre datos que le son proporcionados por otros sujetos situados en un plano inferior y a través de una actividad contradictoria, sino que es el propio instructor el que investiga o inquiere los hechos pasados, para, en base de ellos, formalizar la acusación. El instructor, se mantiene por los partidarios de esta dirección, sea cual sea el nombre con el que se le designe, no es un juzgador en sentido propio, es decir, un sujeto que está colocado formal y materialmente por encima de la contienda que en todo proceso subyace, sino que es un sujeto que interviene directamente en la misma y que realiza una función característica de parte 757 .

Y la razón sería sencilla, pues entendido que el procedimiento preliminar investigatorio integra la realización de uno de los actos practicados por el Estado soberano (por lo tanto, un acto administrativo), se percibe que se trata de un procedimiento de índole meramente administrativa, de carácter informativo, preparatorio de la acción penal 758 .

La razón para la defensa de esta concepción dogmática también se encuentra en el hecho de que hay actos del Juez que son administrativos, porque intervienen en órganos no jurisdiccionales, es decir, administrativos, como la Policía Judicial, y porque ninguna de sus decisiones tiene el carácter de definitiva, sino que son revocables ${ }^{759}$.

Y por fin, con menos intensidad, otros autores atribuyen al sumario un carácter mixto predominantemente procesal760. Incluso HERCE QUEMADA ha apuntado que el sumario es un proceso cautelar o un proceso autónomo, y de este modo, cumple

754 En este sentido, por todos. Vid. FENECH NAVARRO, M., El proceso penal, cit., pág. 220.

755 Vid. GOMÉZ COLOMER, J. L et alli., Derecho Jurisdiccional III, cit., pág. 120.

756 Vid. VIADA LÓPEZ-PUIGCEVER, C; ARAGONES ALONSO, P., Curso de Derecho Procesal Penal, 2ª edición, Madrid, 1968-1970. También en el mismo sentido, Cfr. IBAÑEZ Y GARCÍA VELASCO, M., Curso de Derecho Procesal Penal, Madrid, 1969.

757 Vid. Vid. VIADA LÓPEZ-PUIGCEVER, C; ARAGONES ALONSO, P., Curso de Derecho Procesal Penal, cit., pág. 254.

758 Cfr. RANGEL, P., Direito Processual Penal, 5ae edición, Rio de Janeiro, 2001, pág. 67.

759 GOMÉZ COLOMER, J. L et alli., Derecho Jurisdiccional III, cit., pág. 120.

$760 \mathrm{Al}$ respecto, véase PASTOR LÓPEZ, M., El proceso de persecución. Análisis del concepto, naturaleza y específicas funciones de la instrucción criminal, Valencia, 1979. 
importantes funciones cautelares respecto a las personas, a los bienes y a las pruebas, lo que permite concebir a la fase de instrucción como un proceso autónomo, de naturaleza cautelar ${ }^{761 .}$

Por fin, opinión muy interesante sobre esta discusión es presentada por GIMENO SENDRA al señalar que la determinación de la naturaleza jurídica de la fase instructora no es una cuestión baladí, ni una polémica bizantina, toda vez que conlleva importantes consecuencias de lege ferenda. Y, así, de mantener la viabilidad de la tesis administrativa, ningún inconveniente existiría en conferir la totalidad de los actos instructores al Ministerio Fiscal, como ha sido preconizado en la gran reforma del proceso penal alemán de 1975 o la de los Códigos Procesales penales portugués de 1988 e italiano de 1989. De otra parte, predominando la teoría jurisdiccionalista, la fase instructora se integraría en el principio de exclusividad jurisdiccional, sustentada por el artículo 117.3 de la Constitución española e impediría dicha delegación de actos instructorios en el Ministerio Fiscal762.

III.1.4. La búsqueda de una investigación eficiente. Hay límites en la investigación preliminar.

El gran objetivo que hoy se impone a la investigación criminal es obtener la eficiencia.

De este modo, se trata del desafío de la búsqueda de equilibrios que han de conciliar el discurso de la legalidad (oponiéndose al abuso y a la arbitrariedad, en el respeto por un conjunto de garantías fundamentales que constituyen patrimonio ético-jurídico a preservarse) con el discurso de la eficiencia (oponiéndose al amateurismo y la incompetencia, con el profesionalismo y la utilización de las metodologías y procedimientos técnicamente adecuados a cada situación) ${ }^{763}$.

Partiendo de esta constatación, importante señalar que respecto a los fundamentos básicos de la investigación criminal, resulta obvio por otro lado, afirmar que los órganos de persecución no se utilizando de medios aptos al descubrimiento de las pruebas y actuando sin criterios científicos en la búsqueda de informaciones y datos relevantes, ciertamente restará difícil encontrarse la verdad de los hechos, lo que podrá perjudicar el ejercicio de una eventual acción penal764

Quizás ni exista el proceso o juicio penal. Naturalmente, una vez que se obtiene el conocimiento de la probable comisión de un delito, se inicia a través de la autoridad competente, la búsqueda de informaciones, datos y pruebas, con el correspondiente desarrollo de una investigación preliminar, la que por su importancia llega a ocupar posición de relieve en la persecución penal.

\footnotetext{
761 HERCE QUEMADA, V; GÓMEZ ORBANEJA, E., Derecho Procesal Penal, Madrid, 1984, pág. 142.

762 Cfr. GIMENO SENDRA, V., Derecho Procesal Penal, cit., pág. 291.

763 BRAZ, J., Investigação Criminal. A organização, o método e a prova. Os desafios da nova criminalidade, Coimbra, 2009, págs. 342-343.

764 Importante recordar que "el derecho de acción penal es un derecho fundamental, que asiste a todos los sujetos de derecho, y se ejercita mediante la puesta en conocimiento del Juez de Instrucción de una notitia criminis, haciendo surgir en el órgano jurisdiccional la obligación de dictar una resolución motivada y fundada sobre su inadmisión o sobre la finalización del proceso penal". Vid. GIMENO SENDRA, V., Derecho Procesal Penal, cit., pág. 201.
} 
Por esto, volvemos a afirmar que la investigación criminal debe ser considerada como la columna vertebral del proceso penal moderno, teniendo en cuenta su importancia para la búsqueda de la eficiencia penal 765 .

Y además, no se puede negar que en este contexto es de suma importancia la necesidad de un aparato policial estructurado y en condiciones de hacer frente a la expansión de la criminalidad.

Así, en expresión de HELIE, la policía es el ojo de la justicia766, y es que, normalmente, es el primer elemento de control social que entra en contacto con el delito.

Es la policía judicial el "brazo armado de la justicia penal"767.

En este punto, resulta que una deficiente investigación criminal no logrará recolectar los suficientes medios de prueba que hagan razonable para el Estado invertir tiempo, recursos y esfuerzos en llevar a una persona a un juicio formal. Por esto la importancia y necesidad de una satisfactoria investigación en la búsqueda de pruebas y datos que puedan corroborar la acusación formal.

Pero no se puede olvidar, recuérdese, que la búsqueda de informaciones, datos y pruebas en la investigación preliminar no pude ser obtenida con ausencia de respeto a las bases constitucionales que son inherentes a esta fase de la persecución criminal, y además, sin respetar especialmente la dignidad humana de la persona investigada ${ }^{768}$.

Por todo ello, lo que queda evidenciado es que la investigación procesal penal puede concebirse en dos sentidos: en un sentido restringido, la investigación criminal seria la actividad técnica $y$ científicaque realizan los órganos del Estado delegados para ello, con el fin de recolectar los medios de prueba que permitan conocer y comprender un hecho delictivo. En un sentido amplio, puede ser comprendida como una fase del proceso penalen la que se desarrolla la actividad de búsqueda de informaciones y se liga al proceso penal a una persona determinada con base en los hallazgos primarios que la investigación va aportando. Este último sentido nos interesa sobremanera en este presente estudio.

Resulta claro entonces que la investigación criminal antecede el ejercicio de la acción penal y tiene por objetivo fundamental preparar la acción penal, a través de la dinámica e incesante búsqueda de medios de prueba que viabilicen la reconstrucción de los hechos delictuosos ocurridos, siendo importante observar que, desde la fase de investigación, ya se aplica el básico principio de la búsqueda de la verdad real769.

765 Por esta razón, se justifica la opinión de GUEDES VALENTE, al señalar que "la investigación criminal debe presentarse como el primer patamar de la tutela de los derechos y libertades individuales contra los abusos del ius puniendi del Estado". Vid. GUEDES VALENTE, M.M., Regime Jurídico da Investigação Criminal. Comentado e anotado, 3a edición, Coimbra, 2003, pág. 43. 45.

766 HELIE, M. F., Traté de l'instruction criminelle ou théorie du Code di instruction criminelle, Paris, 1866, pág.

767 Vid. SÚAREZ-BÁRCENA, E. L., El modelo constitucional de investigación criminal, cit., pág. 199.

768 Así, es de concluirse que en la investigación, el objetivo último será el de evitar menoscabo en términos de derechos y garantías fundamentales pero, simultáneamente, habremos de conseguir que el proceso satisfaga sus finalidades. Vid. PÉREZ GIL, J., "Entre los hechos y la prueba: reflexiones acerca de la adquisición probatoria en el proceso penal", cit., pág. 230.

769 LEMES JÚNIOR, A. P., "A investigação criminal diante das organizações criminosas e o posicionamento do Ministério Público", Caderno Jurídico: Novas formas de criminalidade, ano 1, vol. 1, núm. 3, São Paulo, 2001, pág. 57. 
Así las cosas, el descubrimiento de la verdad constituye medio y modo para reconstrucción de los hechos que deben ser juzgados, y consecuentemente, de la aplicación de la ley penal.

Además, en una visión típica de la instrumentalidad garantista, la investigación preliminar normalmente realizada por la autoridad policial770 sirve para una tutela mediata, cuyo objetivo como ya anteriormente afirmado, no es hacer justicia y sí garantizar el eficaz funcionamiento de la justicia.

Y en tratándose de una investigación policial, como ocurre en regla general en la gran mayoría de los ordenamientos penales, es imprescindible que exista una policía judicial con una actuación respetable, es decir, dotada de una ubicación institucional y de un estatuto que la haga apta para operar de manera efectiva conforme a las reglas procesales del juego y bajo la dependencia funcional de la autoridad judicial; por tanto, a salvo de cualquier posible instrumentalización en función de otros intereses que no sean los del proceso ${ }^{771}$.

Además, con la expansión del fenómeno de la criminalidad organizada, la importancia de la investigación criminal ha sido destacada. El modelo de investigación tradicional, efectivamente, no haalcanzado el objetivo buscado: el control (comprendidos la prevención y la represión) al crecimiento patológico de los fenómenos de criminalidad macroeconómica.

No obstante, ciertamente deberá ser comprendido que es un logro del iluminismo haber establecido reglas muy claras para poder castigar las personas. Este logro ha de ser respetado integralmente. Sin embargo, esto no implica que no podamos advertir que en el caso de la delincuencia organizada, la tarea de obtener las pruebas necesarias para sancionar las personas se convierta en un muy difícil cometido ${ }^{772}$.

Hay que tener en cuenta, sin embargo, que el carácter solidario en los fenómenos criminales torna necesaria la predisposición de actividades de investigación inspiradas por rigurosos criterios de secreto y estructuradas de modo a asegurar el efecto sorpresa de la operación 773 .

Allí se encuentra, según nuestro criterio, el centro de la cuestión, desarrollar una investigación basada en las más actuales técnicas de inteligencia policial774, con la finalidad de descubrir a través del uso, por ejemplo de agentes infiltrados, los secretos, la estructura y las actividades ilícitas perpetradas por las organizaciones criminales, neutralizándose la espina dorsal de estos clanes ${ }^{775}$.

\footnotetext{
770 Se dice "normalmente", en razón de la posibilidad, por excepción, de investigación por otro órgano distinto de la policía, a ejemplo del Ministerio Fiscal o del Juez.

771 ANDRÉS IBÁÑEZ, P., "Sobre los derechos fundamentales del imputado en la investigación criminal", cit., pág. 124.

772 Vid. BUSCAGLIA, E; GOECKENJAN, I; GONZÁLEZ RUIZ, S; MENDIETA JIMÉNEZ, E; MERLE, A., "Delincuencia organizada y derechos humanos: ¿Cómo controlar el uso de las técnicas modernas de investigación? El caso de las intervenciones de comunicaciones privadas", VV.AA., Reflexiones en torno a la Delincuencia Organizada, E. Buscaglia y S. González Ruiz coords., México, 2005, pág. 35.

773 BECHARA, F. R., "Criminalidade organizada e procedimento diferenciado: entre eficiência e garantismo", cit., pág. 920.

774 Respecto a las técnicas o procedimientos de inteligencia policial, Vid. MORAS MOM, J. R., La investigación en el proceso penal. Técnica del descubrimiento, cit., págs. 35-52.

775 Y esta idea se puede perfectamente poner en práctica, a la vez que según MARTÍNEZ GARCÍA, "el interés público propio de la investigación de un delito y, más en concreto, la determinación de hechos relevantes para
} 
En defensa de esta postura se argumenta que la investigación procesal penal, como actividad a cargo en exclusiva del órgano competente, consiste pues en buscar pruebas del delito y de sus partícipes, incorporándolos al juicio y procurar demostrar su eficacia para acreditar la verdad de la acusación.

Ella será eficaz cuando, respetando el marco axiológico y normativo del Estado de Derecho, logre proporcionar a los jueces (sobre la base de las pruebas necesarias) la convicción firme, fundada y demostrable racionalmente exigida por la normativa supranacional sobre derechos humanos para condenar a los culpables de la comisión de delitos, satisfaciendo así el derecho a la justicia que tienen las víctimas776.

Investigar es por lo tanto la tarea más complicada a ser desarrollada por los órganos encargados por el Estado para asegurar la manutención de la tranquilidad y paz social.

De una eficaz y completa investigación como ha sido afirmado, dependerá toda la suerte del juicio penal, dado el valor que tienen las pruebas e informaciones recogidas cuando de la práctica del crimen.

Por otro lado, nadie duda que haya límites en la búsqueda de la eficacia penal ${ }^{777}$. La investigación criminal no puede realizarse vulnerando la dignidad personal y demás derechos del acusado, ni tampoco pretende basarse en la idea, explícita o implícita, de que el acusado debe colaborar con la actividad de investigación ${ }^{778}$.

No es de todo absurdo afirmarse que en un Estado de Derecho la investigación del crimen debe estar supeditada al respeto de los derechos y libertades fundamentales, que puedan entrar en conflicto con los actos de averiguación de la verdad que llevan a cabo la policía y los órganos jurisdiccionales ${ }^{779}$.

De otra parte, es importante destacar el hecho de que es lógico que por su propia voluntad, no haya ningún interés por parte del investigado o del imputado en la eficacia investigativa de un hecho delictuoso practicado por él o por terceros. La excepción serían los casos de los arrepentidos quienes normalmente tienen, pues, otros intereses en juego.

el proceso penal son, desde luego, causa legítima que puede justificar la diligencia restrictiva de un derecho fundamental, siempre y cuando prevista por la ley". Véase a respecto, MARTÍNEZ GARCÍA, E., Actos de investigación e ilicitud de la prueba, cit., pág. 98.

776 CAFFERATA NORES, J. I., "La eficacia de la investigación penal en el Estado de Derecho", cit; pág. 36.

777 Respecto de los límites en las investigaciones, pone de relieve RAMOS MÉNDEZ que "La investigación sólo puede realizarse a través de medios lícitos. No son lícitas las diligencias practicadas con coacción, violencia o vulneración de cualquier otro derecho fundamental. Se exige, por lo tanto, un fair play absoluto. Sin perjuicio de ello, la ley se ha encargado de reforzar las garantías en ciertas diligencias de averiguación de los hechos, que pueden afectar a derechos fundamentales". Vid. RAMOS MÉNDEZ, F., Enjuiciamiento Criminal, Octava lectura constitucional, cit., pág. 157.

778 CAFFERATA NORES, J. I., "La eficacia de la investigación penal en el Estado de Derecho", cit; pág. 32. En este sentido, particularmente con relación al combate a la delincuencia organizada, GUEDES VALENTE defiende que "la investigación criminal en el ámbito del crimen organizado no puede socorrerse de instrumentos procesales penales delatores de los derechos humanos fundamentales del ser humano, mismo en el espacio europeo se impone el equilibrio entre la libertad, la justicia y la seguridad, en especial la vida, la integridad física y moral, la libertad, la reserva de la intimidad de la vida privada y familiar". Vid. GUEDES VALENTE, M. M., "A Investigação do crime organizado. Buscas domiciliárias, o agente infiltrado e intervenção nas comunicações", cit., págs. 162-163.

779 MARTÍNEZ GARCÍA, E., Actos de investigación e ilicitud de la prueba, cit., pág. 21. 
Importante también destacar en el presente momento de nuestro análisis del tema, que no se puede visualizar el investigado como un mero y despreciable objeto de la investigación, sino que debe ser considerado como sujeto de derechos ${ }^{780}$.

Analizando el tema de los necesarios y obligatorios límites que serán impuestos a la investigación criminal, señala GÓMEZ COLOMER que el Estado de Derecho no permite que en la investigación del crimen se utilice de forma irrestricta de todos los medios posibles. El juego procesal debe ser limpio ${ }^{781}$ desde la óptica del respeto al Estado de Derecho. Por ello en su actuación la policía judicial debe vigilar estrechamente, en la fase de investigación del crimen, no sólo que las garantías procesales se cumplan y que los derechos fundamentales consagrados en la Constitución, sobre todo los del imputado, se respeten, sino que también y ante todo, ella misma debe cumplirlas y respetarlos ${ }^{782}$.

A la vista de las precedentes reflexiones, resulta que la eficacia de la investigación quedará entonces patentizada en el momento en que los jueces acepten el fundamento de la parte acusadora al sentenciar imparcialmente y en forma motivada teniéndola por verdadera, porque pudieron se apoyar en pruebas de cargo aportadas por el acusador gracias a su tarea de investigación, y que no fueron enervadas por alguna de descargo que pueda haber sido ofrecida por el imputado y su defensor y recibidas en las mismas condiciones, prestando igual atención a las argumentaciones y enfoques diversos y enfrentados que todos ellos realicen sobre su fuerza conviccional. Este será su "control de calidad"783.

Pero estos límites no quieren de cualquier forma significar la imposibilidad absoluta de flexibilización o relajación, a modo de excepción, de algunos de los derechos fundamentales de los investigados o imputados, en pro del éxito de las investigaciones en la lucha contra ciertas formas graves de criminalidad.

Imagínese por ejemplo, la necesidad de la preservación del secreto de algunos actos de investigación. La respuesta a esta cuestión viene dada, a nuestro juicio, por el obligatorio análisis del caso concreto a luz del principio de proporcionalidad ${ }^{784}$.

De fundamental importancia señalar, además, que según el Tribunal Constitucional español respecto de la investigación criminal, "la finalidad perseguida no es otra que la realización de las diligencias esenciales para poder determinar los hechos, las personas participantes en los mismos y, en su caso, el órgano competente para formular la acusación, sino también las que apreciada su esencialidad por el Juez, puedan favorecer al imputado. Es por ello, que para el cumplimiento de tales fines, basados en un indubitable

780 Cfr. RANGEL, P., Direito Processual Penal, cit., pág. 66. Con más profundidad sobre este tema, Vid. HUERTAS MARTÍN, Mạ. I., El sujeto pasivo del proceso penal como objeto de la prueba, 1a edición, 1998.

781 Seguiendo esta línea de raciocinio, sostiene GUEDES VALENTE que "los derechos fundamentales imponen una actitud contra el ejercicio del poder autoritario en el sentido de que se exigen que todo y cualquier proceso se ejecute según las reglas de transparencia democratica. El proceso-crimen, en especial la investigación criminal debe transcurrir de forma transparente sin cualquier subterfugio posible de conducir el ciudadano más incauto a actos ilícitos".Vid. GUEDES VALENTE, M. M., Regime Jurídico da Investigação Criminal. Comentado e anotado, cit., pág. 44.

782 GÓMEZ COLOMER, J. L., "Estado democrático y modelo policial: una propuesta de diseño de cara a lograr una investigación eficaz del crimen", cit., pág. 10.

783 CAFFERATA NORES, J. I., "La eficacia de la investigación penal en el Estado de Derecho", cit; pág. 36.

784 Para un conocimiento más profundo respecto a este principio en el proceso penal, Vid. GONZÁLESCUEllar SERRANO, N., Proporcionalidad y Derechos Fundamentales en el Proceso Penal, cit., FEITOZA PACHECO, Denílson, O princípio da Proporcionalidade no Direito Processual Penal Brasileiro, cit. 
interés público, por lo que la Ley autoriza con las garantías necesarias la imposición de determinadas restricciones en los derechos fundamentales, de manera que se posibilite la investigación y se impida la frustración de los fines que la misma persigue"785.

Se puede concluir entonces que aunque no sea una fase obligatoria en la persecución criminal, en se tratando de ciertas formas más graves de criminalidad, a ejemplo de la delincuencia organizada, se torna imprescindible una investigación basada en la utilización de técnicas especiales que se utilicen de los principios de inteligencia criminal 786, con el objetivo de prevenir, detectar y controlar las actividades ilegales que desarrollan los clanes criminales. Basta con utilizarlas en conformidad con los preceptos contenidos en la base constitucional de los ordenamientos jurídicos, proporcionando a las personas sometidas a la persecución penal, oportunidades de hacer valer sus derechos conquistados como condición inherente al status de ciudadano.

De otra forma, prevaleciendo el hipergarantismo y la abusiva instrumentalidad de las garantías, el miedo impuesto por las organizaciones criminales continuará imponiendo su fuerza, perpetuándose la cultura de la corrupción y llevando la justicia penal al total descrédito junto a la sociedad.

Además, no se debe olvidar que el Estado no puede reaccionar contra el delito igualándose al delincuente, incluso actuando como él, sino mediante un juicio debido, ordenado, objetivo, imparcial y justo ${ }^{787}$.

Al fin se puede concluir citando ARMENTA DEU, que no debe prevalecer el interés de protección y de castigo de las conductas infractoras si para ello se lesionan injustificadamente o desproporcionalmente los derechos (fundamentales o no sólo éstos) tanto de contenido material como los que determinan el carácter justo y equitativo del proceso (derecho de contradicción, de defensa, de asistencia letrada, a utilizar los medios de prueba pertinentes, etc) ${ }^{788}$.

\section{III.1.5. Investigación criminal y delincuencia organizada.}

Respecto al tema de la investigación preliminar en el proceso penal, debemos centrar nuestro estudio en la relación existente entre la necesidad de una eficaz investigación criminal ante los avances de la delincuencia organizada ${ }^{789}$.

785 Vid. STC 32/1994, de 31.1.1994.

786 La inteligencia aplicada al ámbito de la lucha contra la criminalidad organizada cobra especial relevancia en aras a neutralizar su capacidad de eludir, cuando no enfrentar con éxito, la acción del Estado. Congruentemente, para afrontar con solvencia las manifestaciones más elaboradas del fenómeno criminal, la inteligencia criminal está abocada a recurrir a la Criminología. Un recurso extremadamente valioso, que permite conocer qué ha sucedido en el escenario criminal, qué está sucediendo y por qué, y en un esfuerzo prospectivo, quees lo más probable que suceda en el futuro. En suma, elaborar el conocimiento para la aprehensión global de la amenaza en un contexto de seguridad polimorfo y en continua transformación. Monógraficamente, Vid. RUBERT PASCUAL, D. S., Inteligencia criminal. El surgimiento de un actor global, 1aㅗ edición, Madrid, 2008. También, MINGARDI, G., "O trabalho da Inteligência no controle do Crime Organizado", http://www.scielo.br/pdf/ea/v21n61/a04v2161.pdf.

787 Vid. GÓMEZ COLOMER, J. L., "Estado democrático y modelo policial: una propuesta de diseño de cara a lograr una investigación eficaz del crimen", cit., pág, 10.

788 ARMENTA DEU, T., "La verdad en el filo de la navaja (nuevas tendencias en materia de prueba ilícita)", Revista Ius Et Praxis, año 13, núm. 2, 2007, pág. 348.

${ }^{789}$ Sobre el asunto, para mayor profusión, Vid. PEÑA ECHEVERRÍA, M. J., "La delincuencia organizada y su problemática desde la óptica de la investigación policial", cit., págs. 101-165. 
En efecto, el gran dilema consiste exactamente en la búsqueda de formas alternativas y especiales para luchar contra un tipo sui generis de delincuencia denominada como "organizada", la cual es caracterizada como de muy difícil comprobación y persecución.

Una observación inicial es imprescindible: la delincuencia organizada utiliza el trípode violencia, corrupción y obstrucción de la justicia para impedir la aplicación del Derecho. Estos factores vienen a dificultar la puesta en práctica de las acciones de persecución penal, a la vez que se destaca la ya mencionada "cultura de supresión de la prueba", corroborada por una implacable "ley del silencio" entre los miembros del clan.

En virtud de lo anterior, es frecuente que se carezca de pruebas suficientes contra los jefes y contra los demás miembros de este tipo de organizaciones criminales ${ }^{790}$. Nótese que, en este caso, particularmente difícil es obtenerlas respecto a los líderes que casi nunca están en contacto con las mercancías ilícitas ni cometiendo los delitos instrumentalizados por ellos mismos ${ }^{791}$.

No se debe desconocer en todo caso que este blindaje al centro neurálgico de la organización criminal conlleva consecuencias irreparables al desarrollo de una eficaz persecución criminal, al no se conocer la estructura del grupo delictivo, hecho este que torna complicada y dificultosa la tarea de enfrentamiento en la lucha contra la expansión del crimen organizado.

Y más, desde el punto de vista de dinámica criminal, se nota que mientras que la persecución de la criminalidad convencional está caracterizada por la investigación aislada que realizan las agencias de policía para lograr la presentación de las pruebas ante los Tribunales, la investigación del crimen organizado requiere un modelo más complejo. Desde el planteamiento que aquí se sostiene, debido al hecho de la sofisticación de muchos grupos de delincuencia organizada transnacional, al usar dispositivos de comunicaciones avanzados y redes aparentemente extensas de asociados criminales subsidiarios, requiere una respuesta eficaz en la aplicación de la ley, incluyendo la utilización de técnicas especiales de investigación.

Y no es otra la consecuencia, pues, cualquier modelo que se asuma en relación con este tipo de delito debe ser puesto en el contexto de una estrategia de investigación cuyas metas van más allá de la solución de un caso concreto. Estas investigaciones deben ser planificadas, supervisadas y llevadas a cabo con un personal de formación especializada.

Ciertamente, esta afirmación nos conduce a imaginar que los marcos de investigación deben ser análogos aunque no necesariamente idénticos en se tratando de las diversas formas de delincuencia, sea organizada o tradicional. Lo que ocurre es que para ambas las hipótesis el punto clave consiste en la obtención de informaciones y datos relativos al objeto de investigación. Estos informes podrán venir de distintas fuentes, siendo las más usuales, los agente infiltrados, los testigos colaboradores, las interceptaciones telefónicas, las unidades de inteligencia policial, etc.

\footnotetext{
790 Por esto se afirma que "en estas organizaciones no es frecuente encontrar a los jefes directamente en contacto con los productos ilícitos ni cometiendo ellos mismos, las actividades delictivas". Vid. BUSCAGLIA, E; GOECKENJAN, I; GONZÁLEZ RUIZ, S; MENDIETA JIMÉNEZ, E; MERLE, A., "Delincuencia organizada y derechos humanos: ¿Cómo controlar el uso de las técnicas modernas de investigación? El caso de las intervenciones de comunicaciones privadas", cit., págs. 35-36.

791 En este sentido, cfr. VV.AA., Análisis, técnicas y herramientas en el combate a la delincuencia organizada con fundamento en la Convención de Palermo, cit., pág. 60.
} 
En este punto cabe recordar las palabras de PEÑA ECHEVERRÍA, cuando señala que es una obviedad que los jefes de los grupos de delincuentes organizados no realizan de manera directa los elementos de los distintos tipos penales. Ellos dan sus instrucciones y otros delincuentes, más abajo en el escalafón, se encargan de la ejecución material del delito. Tampoco se puede olvidar que los elementos criminales de los escalones más bajos, dependen económica, social e incluso familiarmente de la organización que cubrirá sus necesidades básicas mientras esté en la prisión, por lo que es muy difícil que estos individuos incriminen de manera directa a sus jefes, unido además al miedo a la venganza, que entre estos individuos no es cosa infrecuente ${ }^{792}$.

Luego, acercarse a los miembros más fuertes del clan criminal no es tarea sencilla, exigiéndose de los cuerpos policiales un gran esfuerzo en el desarrollo de estrategias basadas en especial en el uso de las técnicas de inteligencia policial ${ }^{793}$.

Además, es factible que cada especie de delito exija, para su investigación, el recurso a técnicas específicas, en orden a obtener eficacia, certeza cuanto a la autoría del ilícito y la prueba válida que venga a posibilitar la condenación de los culpables ${ }^{794}$.

Entonces, se percibe que el desarrollo y complejidad de la criminalidad organizada, han hecho necesaria la regulación adecuada por parte de las autoridades que se haga efectiva la lucha contra este tipo de delincuencia. El delito tiende a cometerse de forma clandestina, y sus autores suelen intentar eliminar las huellas y vestigios de su comisión, por lo que la policía encuentra dificultades en la función de investigar sus circunstancias y responsables. Para mejorar los resultados en la persecución penal, el Estado utiliza nuevos medios de investigación, cada vez más sofisticados aprovechando los avances tecnológicos ${ }^{795}$.

Importante también es señalar que para hacer más eficaz la actividad represiva es oportuno reestructurar el aparato de investigación, intentando adecuarlo a las características de la criminalidad organizada (especialmente a las de carácter mafioso y terrorista) ${ }^{796}$.

Sin embargo, la prevención de las actividades criminales desarrolladas por el crimen organizado es una consecuencia de la ausencia de adaptación y la no adecuación de los instrumentos jurídicos y operativos, para hacer frente a las estructuras criminales humanas y materiales supranacionales ${ }^{797}$.

792 Cfr. PEÑA ECHEVERRÍA, M. J., "La delincuencia organizada y su problemática desde la óptica de la investigación policial", cit., pág. 159.

793 Con razón entonces, afirmarse que en una investigación criminal, podemos tener muchísima información acerca de las personas, hechos y lugares, etc, pero hay que vincular toda esta información para poder establecer si estas personas son miembros del grupo criminal y cául es el modus operandi de esteclan, además si tiene relaciones con otros grupos delincuenciales o redes transnacionales. Para más conocimiento respecto a esta idea, cfr. VV.AA., Análisis, técnicas y herramientas en el combate a la delincuencia organizada con fundamento en la Convención de Palermo, cit., págs. 263 y ss.

${ }^{794}$ Esta la opinión de MARQUES, J., "Métodos de investigação da criminalidade económico-financeira", cit., pág. 88.

795 DELGADO MARTÍN, J., Criminalidad Organizada, cit., pág. 43.

796 Vid. ORLANDI, R., "La lucha procesal penal contra la criminalidad organizada en Italia", cit., pág. 473.

797 GUEDES VALENTE, M. M., "A Investigação do crime organizado. Buscas domiciliárias, o agente infiltrado e intervenção nas comunicações", cit.,, págs. 159-160. 
El gran problema es que la mayoría de las legislaciones procesales penales son consideradas desde la perspectiva policial como obsoletas en algunas facetas, y escasas o inexistentes en otras.

De otra parte, la búsqueda de mecanismos eficientes para afrontar la persecución de modalidades complejas de criminalidad (terrorismo, tráfico de drogas, de seres humanos, blanqueo de capitales, etc.) lleva consigo la adopción de medidas que implican un profundo cambio estructural en el diseño del proceso penal ${ }^{798}$. Este el gran dilema actual.

En este sentido, estas normas especiales han servido para incorporar al proceso penal las llamadas "nuevas técnicas de investigación", que suelen ir acompañadas de dos factores adicionales: una mayor intromisión en la esfera de los derechos fundamentales de las personas objeto de una investigación y una mayor atribución de poderes de actuación autónoma a la policía799.

Así, existen derechos fundamentales que cabe comprobar fácilmente que pueden ser vulnerados por una investigación policial ${ }^{800}$. Cítese como ejemplos las intromisiones en la integridad física, en la intimidad, en la libertad individual, etc. El nivel de afectación dependerá como ya hemos señalado, de un análisis concreto de los criterios de proporcionalidad.

En razón de lo afirmado, se espera de un modelo acusatorio en un Derecho procesal penal de índole garantista, que se oriente por una investigación preparatoria que dé base para el juicio y no que se convierta en la fase central o de búsqueda exhaustiva de la verdad o acreditación de los hechos, pues su función es sólo preparatoria, para fundar la eventual acusación, y nada más. Y lo principal, deberá imperar un modelo de investigación que consiga disminuir la tensión entre eficacia y garantías, equilibrándose de forma armónica la persecución penal.

De hecho, con el fenómeno del crimen organizado, la importancia de la investigación criminal se ha destacado. El modelo de investigación criminal tradicional no ha logrado el objetivo buscado. La situación de un equipo de dos o tres investigadores de policías saliendo a las calles en búsqueda de informaciones sobre el delito, o la utilización de informantes de policía, es sin duda alguna, útil para el esclarecimiento de crímenes sin cualquier complejidad, tales como algunos asaltos, homicidios, hurtos, etc.

Como norma de oro en este tipo de investigaciones, hay que estar sensibilizados y convencidos de que no deben de ir dirigidas únicamente al esclarecimiento del delito puntual cometido por la organización criminal, que en determinadas ocasiones se trata de un robo con fuerza en las cosas o un hurto, con lo que la respuesta penal es muy escasa, sino que la principal finalidad tiene que ser la desarticulación de toda la estructura criminal, con detención de todos los integrantes de la misma, incautación del total de los medios utilizados (vehículos, sistemas de comunicación, beneficios obtenidos, etc) y la

\footnotetext{
798 Véase con detalles, PÉREZ GIL, J., "Entre los hechos y la prueba: reflexiones acerca de la adquisición probatoria en el proceso penal", cit., pág. 230. 488.

799 GASCÓN INCHAUSTI, F., "Los procesos penales en Europa: líneas de evolución y tendencias", cit., pág.

800 Vid. NIEVA FENOLL, J., "La protección de derechos fundamentales en las diligencias policiales de investigación del proceso penal", La Ley Penal, núm. 50, 2008, pág. 84.
} 
aportación de suficientes pruebas de su participación en un número de delitos más o menos elevado 801.

Si lo anterior es correcto, entonces la persecutio al crimen organizado debe, mismo que no sea eficaz, basarse en los principios y valores propios de la cultura jurídica de un Estado respetuoso de la dignidad de la persona humana y de la voluntad popular. No se previne y persigue el crimen organizado sólo con medios sofisticados ${ }^{802}$, que, debido a su naturaleza excepcional y perniciosa, pueden ser generadores de nuevos tipos legales del crimen o violadores de la legalidad constitucional del Estado803. Habrá por lo tanto que exigirse de las autoridades de persecución penal, una actuación marcada por la técnica profesional, por el respeto a la ley, además de un comportamiento ético.

Las organizaciones de delincuencia organizada tienen un halo de protección interno fundado en las reglas de sigilo de la organización, y un halo de protección externa fundado en el trípode violencia, corrupción y obstrucción de la justicia. Para investigar estos elementos es necesario utilizar técnicas eficientes de investigación para conseguir la obtención de informaciones que se encuentran cerradas en el círculo de protección del clan criminal. Sólo de esta manera se puede desarrollar una investigación contra estos fenómenos delictivos complejos ${ }^{804}$.

Probablemente es la técnica de las operaciones encubiertas a través de agentes infiltrados una de las formas más eficaces de enfrentamiento a esta especie opaca y peligrosa de criminalidad, idea que será desarrollada en los apartados siguientes.

Por fin, en cuanto a los aspectos de Derecho procesal penal para lograr la investigación de la delincuencia organizada y de los fenómenos de corrupción que le rodean es necesario utilizar nuevos medios de investigación y nuevas estrategias. Desde ahí surge la consecuente y necesaria actuación de los legisladores, en el sentido de legalización uniforme y proporcional de nuevas técnicas de investigación criminal.

En síntesis, si no hay una buena legislación, adecuada, moderna y al mismo tiempo garantista, restará la labor policial con evidentes perjuicios en su puesta en práctica.

Para terminar este apartado cabe concluir con una frase el objetivo de una correcta y proporcional investigación criminal en la lucha contra el crimen organizado: el reto es lograr un menor abuso de poder sin perder la eficacia en las medidas ${ }^{805}$.

801 HERNANDO MARTíN, F., "La guardia civil en la lucha contra el crimen organizado: técnicas de información, metodología operativa y directrices policiales en las investigaciones", www.cej.justicia.es.

802 Habrán que ser empleadas en la ardua tarea de investigar los hechos criminales, también técnicas de inteligencia policial basadas en un proficuo analisis de datos e informaciones. De conformidad con lo afirmado, afirmarse en la doctrina que "la investigación de delincuencia organizada es, en sí misma, la acción de ligar pruebas y evidencias mediante un proceso que relaciona unos con los otros, para obtener las redes". Vid. VV.AA., Análisis, técnicas y herramientas en el combate a la delincuencia organizada con fundamento en la Convención de Palermo, cit., pág. 263.

803 GUEDES VALENTE, M.M., "A investigação do crime organizado. Buscas domiciliárias nocturnas, o agente infiltrado e intervenção nas comunicações", cit., pág. 165.

${ }^{804 B U S C A G L I A, ~ E ; ~ G O E C K E N J A N, ~ I ; ~ G O N Z A ́ L E Z ~ R U I Z, ~ S ; ~ M E N D I E T A ~ J I M E ́ N E Z, ~ E ; ~ M E R L E, ~ A ., ~ " D e l i n c u e n c i a ~}$ organizada y derechos humanos: ¿Cómo controlar el uso de las técnicas modernas de investigación? El caso de las intervenciones de comunicaciones privadas", cit., pág. 40. Se justifica delante de esta asertiva, la necesidad de utilización de medios extraordinarios de investigación, a ejemplo de las operaciones encubiertas, como forma de combatir de modo eficiente la expansión de la delincuencia organizada.

805 Respecto a la difícil labor de los cuerpos de policía en la lucha contra la criminalidad, señala con claridad NIEVA FENOLL que "una parte esencial del proceso penal es la investigación, pero, pese a ello, ésta ha sido tradicional y sistemáticamente olvidada. Los agentes policiales de la investigación penal, acuciados por las 


\section{III.2. Sociedad de riesgos y la insuficiencia de los actuales medios de investigación criminal.}

III.2.1. ULRICH BECK y la sociedad de riesgos.

Hemos visto hasta ahora, en primer término, que la investigación criminal preliminar se presenta como absolutamente imprescindible a la persecución penal respecto a la delincuencia en general, particularmente en se tratando de delitos perpetrados por ciertas manifestaciones más graves de la criminalidad. Y en segundo que la delincuencia organizada es una realidad incontestable, aunque se perciba la ausencia de un concepto unívoco, hecho este que la transforma en una de las principales preocupaciones de los gobiernos, de la policía y de la sociedad organizada.

De otra parte, es hecho incontestable la creciente preocupación que ha tenido y tiene en la sociedad este tipo de delincuencia, sobre todo por la violencia y los sofisticados medios utilizados en la comisión de los diferentes tipos penales; se ha reflejado también en el proceso de adopción de decisiones políticas orientadas a la previsión de determinadas medidas para la represión y la prevención de la delincuencia organizada ${ }^{806}$.

Así las cosas, debemos acentuar que la constante y vertiginosa evolución de la tecnología y de la criminalidad en los últimos años, nos ha introducido en un mundo novedoso, diferente y mucho más complejo de lo imaginado.

Respecto a estos cambios de la delincuencia, describe FASSONE con absoluto sentido de humor, que si Arthur Conan Doyle escribiera hoy sus historias detectivescas, Sherlock Holmes se vería obligado a cambiar radicalmente su bagaje profesional: colillas de cigarrillos, residuos de tierra en los zapatos, examen de las ruedas de coche, huellas de tinta en las yemas de los dedos, en suma, todos los indicios clásicos han desaparecido de la historia delictuosa de hoy, al menos en los delitos llevados a cabo por la criminalidad organizada 807.

No se debe desconocer, en todo caso, que en este reciente y dinámico contexto se ha desarrollado, como pieza clave, una nueva sociedad, denominada "sociedad de riesgos", que se manifiesta según BECK ${ }^{808}$, quien ha incrementado fundamentalmente este modelo teórico, como una verdadera y real institucionalización de la inseguridad. Vivimos entonces en una verdadera sociedad del "miedo"809 y del "riesgo"810.

necesidades propias de ésta, y de la consiguiente persecución, nunca acaban de saber con gran precisión cuál es el espacio cubierto por el derecho fundamental y que, en consecuencia, hay que respectar, ni, sobre todo, qué cautelas hay que adoptar para conseguir que la investigación sea eficaz sin que al mismo tiempo se vulneren derechos fundamentales". Vid. NIEVA FENOLL, J., "La protección de derechos fundamentales en las diligencias policiales de investigación del proceso penal", cit., pág. 82.

${ }^{806}$ Vid. PLANET ROBLES, S., "Políticas de seguridad y prevención en el Estado español en materia de delincuencia organizada", VV.AA., La seguridad en la sociedad del riesgo. Un debate abierto, Barcelona, 2003, pág. 155.

807 FASSONE, E., "La valoración de la prueba en los procesos de criminalidad organizada", págs. 418-419.

808 Vid. además de las ya citadas obras de ULRICH BECK y MENDOZA BUERGO, B., el trabajo de SILVA FERNANDES, P., Globalização, "Sociedade de risco" e o futuro do Direito Penal. Panorâmica de alguns problemas comuns, Coimbra, 2001, sin olvidarse de la clásica obra de LUHMANN, W., Soziologie des Risikos, Berlin, 1991.

${ }^{809}$ Lógico es concluirse que después del atentado de 2001 contra los Estados Unidos, "el miedo, entendido como el sentimiento de vulnerabilidad, se ha convertido en un condicionante importante de las políticas de seguridad, siendo utilizado tras el atentado para la creación de un enemigo con el objetivo de eliminar toda resistencia a la estrategia de las posiciones dominantes". Vid. OLÁSOLO ALONSO, H; PÉREZ CEPEDA, A. N., Terrorismo internacional y conflicto armado, Valencia, 2008, pág. 45. 
Según las expresivas palabras de FIGUEIREDO DIAS, estamos en presencia de una sociedad exasperadamente tecnológica, masificada y global, donde la acción humana, muchas veces anónima, se revela susceptible de producir riesgos también globales, los cuales son susceptibles de ser producidos en tiempo y en lugar largamente alejados de la acción que los han originado o que para ellos han contribuido y que pueden tener como consecuencia, pura y simplemente, la extinción de la vida ${ }^{811}$.

La verdad es que la moderna teoría social estudia y analiza lo que se conoce como "globalización" y "sociedad de riesgo"812, siendo que en esta última, en palabras de BECK, los riesgos se relacionan con la capacidad de perjuicio o daños causados por decisiones humanas, que son ilimitados, globales y a menudo de consecuencias irreparables ${ }^{813}$.

En esta medida, es innegable por lo demás la vinculación del progreso técnico y el desarrollo de las formas de criminalidad organizada, que operan a nivel internacional, y constituyen claramente uno de los nuevos riesgos para los individuos y para los Estados 814 .

Cuando se está aludiendo al riesgo para caracterizar la sociedad postindustrial no se está pensando en riesgos procedentes de causas o fenómenos naturales, sino de riesgos que tienen su origen en decisiones y comportamientos humanos producidos con ocasión del uso y manejo de los referidos avances tecnológicos. Según el modelo sociológico al que estamos aludiendo, se configura el "riesgo de procedencia humana" como "fenómeno social estructural"815.

Sin querer profundizar en el tema, es interesante destacar como BECK describió la sociedad mundial del riesgo como una solución sistémica de manejo de los riesgos e inseguridades introducidas por la modernización, que han alterado durante el proceso las dinámicas de la organización social. Para él, el riesgo representa la anticipación de la catástrofe, una percepción que a menudo ignora las mismas precondiciones que lo generan. En este marco, considera que la sociología debería estudiar estas percepciones si no se concretan en un riesgo proyectado en lo real.

En el contexto de las sociedades modernas, BECK cree necesario debatir, prevenir y aprender a manejar satisfactoriamente el riesgo, con el fin de hacer frente a la inducida

810 En palabras de BRANDARIZ GARCÍA, "el riesgo de amenaza, generalmente en forma de enemigo es presentado, $\mathrm{y}$ vivido como una emergencia, como un peligro ante el que hay que responder de forma urgente $\mathrm{y}$ excepcional". Vid. BRANDARIZ GARCÍA, J. A., "Itinerarios de evolución del sistema penal como mecanismo de control social en las sociedades contemporáneas", VV.AA., Nuevos retos del Derecho penal de la globalización, P. Faraldo Cabana coord., Valencia, 2004, pág. 59.

811 FIGUEIREDO DIAS, J., Algumas reflexões sobre o Direito penal e a Sociedade de Risco, Lisboa, 2000, pág. 7. También em otro de sus trabajos, Temas básicos da Doutrina Penal, Coimbra, 2001, pág. 158.

${ }^{812 E n ~ p a l a b r a s ~ d e ~ B E C K, ~ " p u e d e n ~ d i f e r e n c i a r s e ~ t r e ̂ s ~ d i m e n s i o n e s ~ d e l ~ p e l i g r o ~ e n ~ l a ~ s o c i e d a d ~ d e l ~ r i e s g o ~}$ mundial que desarrollan conflictos diferentes según la lógica que sigan, que resaltan o eliminan otros temas, que derrocan o entronizan prioridades: en primer lugar, las crises ecológicas; em segundo, las crisis financieras globales; y, em tercero, desde el 11 de septiembre, el peligro de las redes terroristas transnacionales". Vid. BECK, U., Sobre el terrorismo y la guerra, cit., pág. 19.

813 Vid. en este sentido, PLANET ROBLES, S., "Políticas de seguridad y prevención en el Estado español en materia de delincuencia organizada", VV.AA., La seguridad en la sociedad del riesgo. Un debate abierto, cit., pág. 157.

814 SILVA SÁNCHEZ, J. M., La expansión del Derecho Penal. Aspectos de la política criminal en las sociedades postindustriales, cit, pág. 28.

815 RODRÍGUEZ MOURULlO, G., "Prólogo" a la obra: El Derecho Penal en la sociedad del riesgo, cit; pág. 15. 
histeria política y a la percepción del miedo, difundida, a menudo, a través de prácticas comunes utilizadas por los medios de comunicación de masas.

Interesante además, en lo que nos interesa, destacar que la amenaza terrorista, como traz o destacable de la actuación del crimen organizado, percibida y políticamente instrumentalizada provoca las demandas de seguridad y anula la libertad y la democracia. En realidad, para el citado sociólogo alemán, lo que importa no es el riesgo en sí, sino la percepción del mismo ${ }^{816}$. Incluso, se defiende que los atentados de Nueva York, Bali, Madrid y Londres de comienzos de siglo han significado un reforzamiento y una transformación de la incertidumbre y la angustia que eran el sustrato emocional de la sociedad del riesgo ${ }^{817}$.

De lo afirmado, es lógico inferir que la emergencia de nuevas modalidades de la criminalidad organizada han contribuido con la configuración de un nuevo escenario de inseguridad en el que, a las problemáticas tradicionales de carácter estatal, se suman asuntos y riesgos que aparecen como novedosos y que se desenvuelven en una ambiente cuyo rasgo saliente está dado por la globalización de los procesos políticos, sociales, económicos y culturales.

Nótese también, que la actual gravitación política, económica y cultural de estas problemáticas en sus expresiones transnacionales impacta significativamente sobre el sistema de seguridad supranacional así como sobre el ámbito doméstico de la seguridad de los Estados. Estas nuevas amenazas no son protagonizadas por agencias estatales sino, más bien, por organizaciones o grupos no estatales $\mathrm{y}$, aunque su accionar no parezca poner en jaque la existencia misma de los Estados, si vulneran importantes áreas de la vida social, económica e institucional del sistema internacional y de los Estados que lo componen, al mismo tiempo que cercenan notoriamente la capacidad de éstos para prevenirlos y conjurarlos.

De lo dicho resulta que las formas de perturbaciones de la seguridad social y del orden público pueden manifestarse según diversos niveles de intensidad, de tal suerte que el tratamiento estatal a ser puesto en práctica debe mostrarse igualmente proporcional a la realidad presentada ${ }^{818}$.

Hechas estas sucintas consideraciones respecto al tema de las sociedades del riesgo mundial, el próximo paso es concluir una vez más por el fracaso de los medios tradicionales de investigación frente al combate a la expansión de la delincuencia organizada.

Así, ante la delincuencia organizada, los medios tradicionales de investigación se muestran insuficientes, al menos para llegar al corazón de las organizaciones y acercarse a los auténticos jefes y promotores. Por ello en los últimos años se estáempleando, especialmente en las investigaciones relativas a casos de narcotráfico organizado, la

\footnotetext{
816BECK, U., "El mundo despúes del 11-S", Diario El país, 19 de octubre de 2001. También ha sido desarrollada esta idea con profundidad por el mismo autor, en la obra: Sobre el terrorismo y la guerra, Barcelona, 2003.

817 OLÁSOLO ALONSO, H; PÉREZ CEPEDA, A. N., Terrorismo internacional y conflicto armado, cit., pág. 19. Y lo peor es que "la realidad demuestra que los excesos en materia de seguridad producen el efecto contrario al perseguido: crean inseguridad". Vid. CORCOY BIDASOLO, M., "La perspectiva jurídico-penal", VV.AA., La seguridad pública ante el Derecho penal, Buenos Aires, 2010, pág. 3.

818 BECHARA, F. R., "Criminalidade organizada e procedimento diferenciado: entre eficiência e garantismo" cit., pág. 918.
} 
técnica de investigación consistente en que funcionarios de Policía Judicial penetren de forma encubierta o se infiltren en el entramado organizativo de estos grupos ${ }^{819}$ al objeto de obtener pruebas sobre la ejecución de los hechos delictivos, determinar la estructura de la organización, los campos delictivos en que opera, los circuitos de distribución de la sustancia estupefaciente y de las ganancias obtenidas, para finalmente proceder a la aprehensión de la droga, la incautación del dinero y la detención de los autores ${ }^{820}$.

\section{III.2.2. La insuficiencia de los actuales medios de investigación criminal.}

En el panorama de la sociedad actual, donde se ha empezado a implementar las llamadas "técnicas de investigación encubiertas", mediante las cuales se ha intentado acomodar y flexibilizar las garantías mínimas del proceso penal, ante las exigencias de una política criminal eficientista que busca enfrentar las recientes formas de perpetuación del delito, especialmente cuando la delincuencia proviene de organizaciones criminales que cuentan con un poder en aumento, por lo que se dice que el Estado se vería en aprietos al seguir con los métodos tradicionales de persecución penal, para lograr enjuiciar y condenar tales conductas ${ }^{821}$.

Así es que la aparición del fenómeno de la criminalidad organizada, vinculado especialmente a distintos factores, tales como la libre circulación de personas, la desaparición de fronteras o el uso de nuevas tecnologías ha creado en la sociedad la necesidad de recurrir a nuevos instrumentos y técnicas de investigación que puedan ofrecer cumplida respuesta a la implantación de grupos de criminalidad organizada ${ }^{822}$.

No podemos olvidar que no importa la rapidez con la que el Derecho, y en particular el Derecho Penal y procesal, arbitran estos instrumentos, pues que la criminalidad organizada siempre va un paso más adelante823.

Ejemplo de esta afirmación se puede extraer de la hipótesis de persecución al narcotráfico, donde se percibe que la policía casi siempre se encuentra en una posición de inferioridad, pues, mientras no se descubre la nueva técnica empleada, difícilmente se desconfía de un objeto, de una ruta o de una persona con características que todavía no han sido utilizadas.

\footnotetext{
819 A favor de esta solución se argumenta que "las investigaciones de delincuencia organizada pueden requerir el uso de una, todas o ninguna de las técnicas especiales de investigación. Sin embargo, el uso de estas técnicas no debe ser rechazado por los investigadores como poco realistas, complejas o excesivamente sofisticadas". Vid. VV.AA., Análisis, técnicas y herramientas en el combate a la delincuencia organizada con fundamento en la Convención de Palermo, cit., pág. 91.

820 DELGADO GARCÍA, Mà. D., "El agente encubierto: técnicas de investigación. Problemática y legislación comparada", VV.AA., La criminalidad organizada ante la justicia, F. Gutiérrez-Alviz y Conradi coord., Sevilla, 1996, pág. 69.

821 Vid. para un completo estudio sobre el tema, PORTILLA, E., "El agente encubierto en la ley de drogas: la lucha contra la droga en la sociedad de riesgo", Política Criminal, año 2, núm. 2, 2006, págs. 1-17.

822 Siguiendo esta línea de pensamiento, señala POZO PÉREZ que "en el ámbito internacional se ha sostenido que, dada la gravedad de los delitos cometidos por organizaciones criminales que cuentan con un poderío en cuanto a nivel de estructuras, desplazamiento, disponibilidad de recursos humanos y materiales, influencia corruptora, y que son muy hábiles en eliminar las pruebas o rastros de sus ilicitos, facilitándoseles tanto la perpetuación como la impunidad de sus actividades, es necesario otorgar a las autoridades las facultades de investigación excepcionales o extremas para enfrentar adecuadamente a estos grupos". Vid. POZO PÉREZ, M., "El agente encubierto como medio de investigación de la delincuencia organizada en la ley de enjuiciamiento criminal española", cit., pág. 280.

823 En este sentido, la opinión de LUCAS MARTíN, I., "La prueba en el proceso penal en el contexto de la Unión Europea", cit., pág. 424.
} 
Aunque en teoría, los Estados tengan en general medios materiales más eficaces que los traficantes, llega a impresionar que en algunos casos los delincuentes estén mejor armados que los policías o que incluso en los países ricos, los policías sean incapaces de frenar el flujo de drogas en sus fronteras o en los centros penitenciarios. Eso indica que incluso en los sitios más vigilados es posible burlar los sistemas de seguridad ${ }^{824}$.

Según nuestro modo de ver las cosas, la situación descrita se encuentra cristalinamente demostrada, pues es lógico que los grandes grupos de delincuentes organizados tienen mucho más poder financiero para su estructuración si comparados al Estado que siempre posee dificultades en materia de inversiones en estructura logística y de los cuerpos policiales. Y en este punto debemos preguntarnos si es normal presenciar inversiones financieras por parte de la clase política en materia de incremento de la seguridad ciudadana.

De este modo hay que tener presente que actualmente denota gran destaque en el ámbito procesal penal, el tema de los medios o técnicas de investigación criminal en la búsqueda de alejarse el estado de inseguridad provocado por la actuación de grupos de delincuentes organizados 825 .

Es hecho comprobado que la gran mayoría de las legislaciones procesales penales son consideradas desde la perspectiva policial como obsoletas en algunas facetas y escasas o inexistentes en otras, en especial cuando se trata de combate al crimen organizado ${ }^{826}$, deja un rastro demostrativo de la gravedad de la situación actual.

Vivimos en la era de las comunicaciones, todo el mundo habla de autopistas de información, comunicación digital, utilización de satélites, etc. Y lo que el ciudadano considera una nueva conquista para mejorar nuestro sistema de vida, es utilizado ilícitamente por los grandes grupos criminales, sin que las legislaciones sean capaces de ponerle freno ${ }^{827}$. Es a nuestro modo de pensar, la más destacable demostración de la superioridad, al menos financiera, del poder logístico y estructural de los grandes grupos de criminales organizados.

La incriminación de estas organizaciones tendría el objetivo de producir un efecto de desestabilización tomando por cuenta el grave desorden provocado al sentimiento de intimidad y fidelidad de los ciudadanos a los valores propuestos en el ordenamiento. En esta perspectiva, la atención del legislador al peligro de perturbación del orden público tiene por función resaltar la justificativa de represión en razón de su daño social, no siendo tolerable que los ciudadanos soporten las sensaciones del mal estar, repulsa o

824 Vid. CORRÊA DE CARVALHO, J. T., Tráfico de drogas. Prueba penal y medidas restrictivas de derechos fundamentales, cit., pág. 67.

825 Monograficamente sobre el tema, Vid. GÓMEZ DE LIAÑO FONSECA-HERRERO, M., Criminalidad organizada y medios extraordinarios de investigación, Madrid, 2004. También nuestro trabajo: PEREIRA, F. C., "A moderna investigação criminal: infiltrações policiais, entregas controladas e vigiadas, equipes conjuntas de investigação e provas periciais de inteligência", cit., págs. 98-146.

826 En este sentido, se torna clara la necesidad de que "debe producirse un desarrollo creciente en la colaboración entre Estados y en la asistencia mutua, realizándose una sustitución de los tradicionales instrumentos de cooperación internacional, que devienen ineficaces en la nueva realidad al responder a parámetros de Derecho Internacional clásico, por unas nuevas formas de cooperación internacional y por medios de investigación diferentes de los tradicionales, que resultan inútiles para luchar contra este peligroso y complejo fenómeno delictivo". Vid. POZO PÉREZ, M., "El agente encubierto como medio de investigación de la delincuencia organizada en la Ley de Enjuiciamiento Criminal española", cit., pág. 270.

827 PEÑA ECHEVERRÍA, M. J., "La delincuencia organizada y su problemática desde la óptica de la investigación policial", cit., p. 159. 
indignación, que, todavía, puedan perjudicar a su postura de fidelidad a los valores culturales mantenidos como parte integrante de las condiciones generales que promueven y favorecen la consolidación de la compañía social ${ }^{828 .}$

Mantener el orden público es una meta institucional que debe ser buscada por los Estados, como forma de defensa del postulado constitucional de la seguridad colectiva ${ }^{829}$. Como derechos fundamentales descritos en gran parte de las Constituciones ${ }^{830}$, la tranquilidad y el bienestar social hacen parte del rol de las garantías inherentes a condición de ciudadano que vive en sociedad.

De la misma forma que no se concibe que el Estado se utilice de los mismos instrumentos de los cuales se valen los criminosos, no se puede negar la postura del exegeta, por ocasión de la interpretación y aplicación de las normas incidentes, el cual deberá buscar la precisión y la forma más adecuada de establecer la respuesta estatal, que debe ser más enérgica y, por lo tanto, proporcional a la gravedad de la situación presentada 831 .

No obstante, esta realidad habrá de conducir inevitablemente al estrangulamiento y a la posibilidad, por excepción, en casos extremos, de una mayor flexibilización de los derechos fundamentales que obligan a las libertades públicas individuales. Tal flexibilización es justificada a partir de la indiscutible necesidad de preservación del orden público y obligatoriamente deberá pautarse en el principio de proporcionalidad.

Con meridiana claridad, habrá de observarse que delante de este contexto no se puede reaccionar con el instrumental investigatorio tradicional por la sencilla razón de que no será el mismo eficiente en la lucha contra la criminalidad organizada. Ciertamente es hecho comprobado que los grupos de delincuencia organizada y del terrorismo llegan a tal nivel de sofisticación que las técnicas antiguas de investigación criminal ya no dan el resultado requerido. Por eso es necesario desarrollar los métodos y diseñar las estrategias adecuadas para que la investigación tenga éxito832.

Como es sabido los medios de investigación en el proceso penal, denominados tradicionales tienen por misión inmediata introducir los hechos en el procedimiento (esclarecer los hechos) y contribuir a formar en el Juez el juicio de probabilidad suficiente para disponer la imputación y adoptar las oportunas medidas cautelares y como mediata la de poder decidir acerca del juicio oral, en tanto que los actos de prueba presupongan la entrada de los hechos y tiendan a formar la certeza o evidencia suficiente para lograr la

828 DE VERO, G., Tutela penale dell'ordine pubblico, Milano, 1988, pág. 292.

829 Obsérvese que en las sociedades modernas, la vida social descansa sobre la normalidad jurídica. Uno de los principios más arraigados del derecho es el que se denomina "seguridad jurídica", que implica la pervivencia en el tiempo de una serie de normas y que los individuos conozcan hasta donde se extiende su esfera de libre actuación y donde comienza la de los demás. La seguridad colectiva viene garantizada por un Estado Constitucional de Derecho que asegura el imperio de la ley. Esta ley se ocupará de la protección de las personas y bienes (seguridad en sentido estricto) y el mantenimiento de la tranquilidad u orden ciudadano. La seguridad para la realización de los derechos y deberes está garantizada por la actuación de las Fuerzas y Cuerpos de Seguridad.

830 Vid. MEDINA, J. L., "El derecho a la seguridad colectiva: un derecho fundamental en permanente expansión y progresión", La Ley, núm. 5, 2005, págs. 1170-1178.

831 DE VERO, G., Tutela penale dell'ordine pubblico, cit., pág. 277.

${ }^{832} \mathrm{Cfr}$. VV.AA., Análisis, técnicas y herramientas en el combate a la delincuencia organizada con fundamento en la Convención de Palermo, cit., pag. 263. 
convicción del Tribunal sobre la preexistencia de los hechos y participación en ellos del acusado 833 .

Es necesario pues hacer hincapié en el sentido de la importancia y necesidad actual de que los ordenamientos procesales penales prevean en sus estructuras, la posibilidad de utilización de medios y técnicas de investigación criminal conducentes a la realidad en que vivimos; que sean al fin, aptos al logro de la eficiencia penal.

Ante este panorama, en general, se observa que el proceso penal no viene modernizándose en ritmo equivalente al desarrollo de las nuevas formas de criminalidad, pues que también utiliza habitualmente medios de investigación criminal poco avanzados para hacer frente a la expansión del crimen organizado. Como consecuencia inmediata, los sujetos responsables por la investigación criminal, del mismo modo, no consiguen estar en el mismo grado de especialización y modernidad que los miembros del crimen organizado ${ }^{834}$.

Como bien destaca GASCÓN INCHAUSTI, tenemos un proceso penal que se encuentra de espaldas a los adelantos científicos del último siglo y que, con su retraso, desaprovecha las ventajas que los mismos pueden conllevar para los sujetos activos del proceso penal 835 .

Sin embargo, en realidad, es asimismo incontrovertible la afirmación de que los métodos convencionales de investigación en el proceso penal son insuficientes para combatir ciertas formas de delincuencia, motivo por lo cual las autoridades recurren a técnicas policiales "novedosas"836, a ejemplo de las infiltraciones policiales, estableciendo relación con los autores previsibles de los delitos, con el objetivo de controlar e intervenir en el propio proceso de realización de la actividad criminosa.

Constituyen así los denominados actos o medios de investigación encubierta las actuaciones que realiza con carácter general la Policía Judicial, encaminadas al esclarecimiento de hechos presuntamente delictivos, determinando la participación en los mismos de los presuntos responsables.

Partiendo de ello, surge nuestro interés en estudiar la figura del agente encubierto, un personaje que despierta la curiosidad de los profanos, pues estamos acostumbrados a que en las películas de espías se utilicen de trampas y simulaciones, acaban por infiltrarse en las entrañas de grupos criminales con la meta de desmantelar estos clanes.

Lejos de afirmar que sea un asunto indiscutible que se encuentre libre de críticas, no se puede olvidar como recuerda GRANADOS PÉREZ que la infiltración policial como

833 GIMENo SEndRA, V; CORTÉZ DOMíngUEZ, V; MOREno CATENA, V. M., Derecho Procesal Penal, 2a edición, Madrid, 1997, pág. 372.

834 Es lamentable y al mismo tiempo preocupante, cuando en la prensa es divulgado que los cuerpos de seguridad y policías están recibiendo nuevos incentivos financieros del Estado, a fin de poner en practica algunas modernas técnicas de investigación criminal, como por ejemplo, cuando son adquiridos nuevos aparatos electrónicos para interceptarse comunicaciones telefónicas. Y razón es sensilla, pues en realidad se sabe que esta tecnología tenida como novedosa para la policía, seguramente ya viene siendo utilizada y desarrollada como forma de contrainteligencia por los grandes grupos de delincuentes organizados. En síntesis, el crimen organizado, como detentor de un fuerte poder económico y financiero, oriundos de sus actividades ilícitas, siempre tendrá más poder de fuego en comparación con los cuerpos de seguridad estatales. El poder de inversión en seguridad del Estado siempre quedará inferior a las inversiones de los clanes organizados en búsqueda de perfeccionamiento de sus actividades ilegales.

835 GASCÓN INCHAUSTI, F., Infiltración policial y agente encubierto, cit., pág. 2.

836 La "novedad" no es ya la técnica en sí, sino su utilización o su regulación en la gran mayoría de los ordenamientos penales. 
técnica de investigación viene utilizándose desde hace años y venía protegida por la causa de justificación de obrar en cumplimiento de un deber o en el ejercicio legítimo de un derecho, oficio o cargo. Pero no cabe duda que la incorporación de esta figura al sistema penal y su estricta regulación aporta seguridad jurídica y está en consonancia con otros países que ya vienen usando, con específico apoyo legal, estos instrumentos que pueden reportar una mayor eficacia en la lucha contra graves manifestaciones del crimen organizado ${ }^{837}$.

La cuestión es aprovecharse de esta técnica de investigación, desde que respetados los principios del debido proceso legal y de la proporcionalidad.

Afirmada la curiosidad que el tema despierta y partiendo de la premisa de que la sofisticación de las técnicas empleadas por la criminalidad de la globalización (delincuencia organizada), traspasa los límites de tolerancia, lo ideal sería la puesta en práctica de una política criminal de prevención y represión a la expansión de esta forma de criminalidad, buscándose con este cambio de actitud, mantener la paz social, preservando la soberanía del Estado.

Pero la tarea que se busca concretizar no es sencilla. Para lograr este propósito, en regla como contraposición a la búsqueda de la eficiencia penal en la lucha contra el crimen organizado, podrán quedar comprometidas las garantías procesales inherentes a los investigados, como por ejemplo la intimidad, la privacidad, etc.

Con acierto GUZMÁN FLUJA sintetiza que el problema está en el hecho de que estos nuevos medios de investigación son, a su vez, por definición más agresivos con las garantías procesales que los "tradicionales"838. Al jugarse con estas técnicas, se impone extremada cautela en razón de que presentan una fuerte carga de invasión o violación a derechos fundamentales de los ciudadanos investigados.

Del mismo modo surge una preocupación respecto a la validad de las pruebas obtenidas a través de operaciones encubiertas ${ }^{839}$, y en este sentido, hemos decidido analizar en el cuerpo del trabajo, específicamente, la situación de estas problemáticas a luz del principio de proporcionalidad, desde una perspectiva fáctica y jurídica, en el entorno de la eficacia de eventuales pruebas consideradas ilícitas.

Volviendo al tema de la insuficiencia de los actuales medios de investigación criminal, tenemos que destacar que la criminalidad organizada en realidad es opaca o, al menos, resistente a la observación, tanto del científico como del sistema penal y policial. Una de las tareas más destacadas en el ámbito de los grupos organizados es orientar su estructura, actividades y recursos, de modo a provocar dificultades en lo relativo a su investigación y persecución penal.

Así, como consecuencia lógica, de la delincuencia clásica individual y tradicional se viene pasando sobre todo en determinados delitos a una delincuencia de múltiples personas organizadas con fines de enriquecimiento ilícito. Semejante criminalidad

837 GRANADOS PÉREZ, C., "Instrumentos procesales en la lucha contra el crimen organizado. Agente encubierto. Entrega vigilada. El arrepentido. Protección de testigos. Posición de la jurisprudencia", VV.AA., La criminalidad organizada. Aspectos sustantivos, procesales y orgánicos, C. Granado Pérez coord., Madrid, 2001, pág. 91.

838 GUZMÁN FLUJA, V. C., "El agente encubierto y las garantías del proceso penal", cit., pág. 206.

839 Respecto a este asunto, Vid. MORA MORA, L. P., "La prueba como derecho fundamental", Revista Iberoamericana de Derecho Procesal Constitucional, núm. 4, 2005, págs. 169-187. 
corporativa, que ha evolucionado hacia fórmulas de organización internacional, se presenta con estructura de empresa del crimen y con la utilización de mecanismos de la más alta sofisticación, con formas novedosas de actuación, con intervenciones que combinan lo legal con lo ilegal y con influencias de gran alcance que pueden condicionar importantes sectores de la vida económica, social e incluso institucional y de la administración pública ${ }^{840}$.

Cuando se está delante de la denominada criminalidad organizada, protagonizada por acciones de grupos, cuyas personas se asocian con la finalidad de practicar delitos de gravedad y por consecuencia violar el Estado de Derecho, es indiscutible que la situación de intranquilidad generada sugiere la adopción de una serie de posturas y providencias que de alguna forma puedan minimizar el riesgo acarreado ${ }^{841}$.

No cabe incluso olvidar que frente a la criminalidad postmoderna, el Estado necesita de un refinamiento del instrumental persecutorio, lo cual deberá ser equilibrado por la protección de las garantías tradicionales y de la eficiencia delante de las nuevas demandas, so pena de no hacerse frente al imperativo de protección de la dignidad del hombre en pleno siglo XXI. Esta perspectiva también impone una rediscusión de los criterios políticos criminales de incentivo a la formación de la verdad, con el respeto a las garantías mínimas de eticidad del proceso.

La actuación de personas en conjunto, con unidad de esfuerzos, ha provocado en la comunidad internacional preocupación intolerable vez que aumenta la potencialidad de actuación de los grupos criminosos ${ }^{842}$. Se percibe que son creadas y estructuradas verdaderas empresas para ejercer la labor de formular prácticas delictivas.

Queda muy claro, pues, que el Derecho penal clásico o nuclear, vinculado al hecho del individuo aislado y el Derecho procesal penal que en un sinnúmero de veces aún hoy se utiliza de medios de investigación del siglo XIX, deben ser convenientemente adaptados a la nueva realidad criminológica.

De todo lo anterior, parece desprenderse, al menos como planteamiento lógico, que no es posible la labor policial tradicional para luchar contra la expansión de la delincuencia organizada.

840 MORILLAS CUEVA, L., "El delito de tráfico de drogas en sentido estricto", VV.AA., Estudios jurídicopenales y político-criminales sobre tráfico de drogas y figuras afines, Lorenzo Morillas Cueva coord., Madrid, 2003, pág. 25.

841 BECHARA, F. R., "Criminalidade organizada e procedimento diferenciado: entre eficiência e garantismo", cit., pág. 918.

842 Por este motivo, "la finalidad de los instrumentos celebrados a nivel internacional tienen, entre otros, como objetivos: en primer lugar, la lucha contra todas las actividades ilícitas que suponen una vulneración de los derechos humanos; en segundo lugar, la preservación del orden socioeconómico en las sociedades, impidiendo que las actividades ilícitas de la criminalidad organizada contribuyan a desestabilizar las economías de los estados, a través de la evasión de capitales procedentes del blanqueo de capitales o a través de la actuación ilícita de tales redes criminales en la economía sumergida e incluso en amplios sectores de la economía legal; y en tercer lugar, el incremento de la cooperación internacional para la lucha contra las modalidades de la delincuencia organizada transnacional a través del desarrollo de la cooperación internacional en los ámbitos judicial y policial. Y por supuesto, a través de la eficaz aplicación de los más avanzados instrumentos jurídicos internacionales en materia de lucha contra el crimen organizado". Cfr. ÚBEDA PORTUGUÉS, J. E., "Análisis de los efectos negativos de la delincuencia organizada en la sociedad internacional", cit., págs. 79-80. 
Hay que buscar contender el problema del crimen organizado utilizándose de medios y técnicas de investigaciones policiales adecuados a nuestra realidad y que han de presentarse como eficientes a los fines propuestos.

No se puede aceptar como satisfactoria la simple utilización de medios policiales ya bastante conocidos, a ejemplo de las interceptaciones telefónicas o las grabaciones convencionales, para llegarse a la tan buscada eficiencia penal o policial en la lucha contra la delincuencia organizada. Desde el punto de vista de dinámica criminal, combatir esta forma de criminalidad macroeconómica exige del Estado, un cambio de estrategias de investigaciones, de modo a permitir un control de la grave situación por la que pasa la comunidad internacional.

Este raciocinio debe ser trasladado a la discusión respecto a la necesidad de sustituir o hasta mismo introducirse nuevos medios de investigación con eficacia en la lucha contra el crimen organizado ${ }^{843}$. Como se anticipaba, cada ordenamiento procesal debe proporcionar a los operadores del Derecho, formas o técnicas de reaccionar de modo a actuar a través del uso de respuestas penales correctas y adecuadas al grave problema de la expansión de la delincuencia organizada. De modo contrario, quedará el Estado desmoralizado y sin condiciones de imponer su poder de soberanía en la manutención de la paz social.

Ante los nuevos interrogantes que sobre investigación y prueba se plantean a la justicia penal del siglo XXI, nuestros ordenamientos penales ofrecen, según GONZÁLEZCUÉLLAR SERRANO, casi siempre, respuestas decimonónicas y, en ocasiones, defectuosas disposiciones impropias de un sistema de justicia penal que sea digno de tal nombre ${ }^{844}$.

Y el problema en el caso de la delincuencia organizada se agrava, en la medida en que analizamos la cuestión desde la óptica de la disciplina de las pruebas, pues que el crimen organizado también incluye en sus actividades aquello que FASSONE denomina la "cultura de la supresión de la prueba", destruyendo documentos, amenazando o eliminando testigos, restringiendo conversaciones telefónicas, etc., por lo que es esencial que los órganos de investigación dispongan de medios más eficaces de obtención de pruebas, sea porque en la búsqueda de esta necesaria eficacia muchas veces chocan con los valores mayores de protección a la persona proclamados por la Constitución ${ }^{845}$.

En síntesis, hay que aceptar la realidad de que los medios de investigación criminal hasta hoy utilizados no sirven eficazmente en el combate contra la delincuencia organizada, necesitándose, pues, de un giro radical en el sentido de la búsqueda de la eficiencia penal.

843 Estos "nuevos" medios o técnicas de investigación tienen la función de proporcionar una igualdad en términos de enfrentamiento de la delincuencia organizada, en razón del escenario actual donde los órganos de persecución no consiguen acompañar el desarrollo logístico, estructural y empresarial de las grandes organizaciones criminales. Caminando siempre de espaldas y sin conocimiento más profundo sobre estos grupos delictivos, el aparato estatal de prevención y represión del crimen no vienen obteniendo gran resultados en la persecución penal contra la delincuencia organizada, y lo más grave, pues muchas veces, acaban por practicar acciones vulneradoras de derechos y garantías fundamentales de las personas sometidas a investigación, sin cualquier criterio de proporcionalidad o legalidad.

844 GONZÁLEZ-CUÉLLAR SERRANO, N., "Investigación y prueba: Los nuevos rectos ante la reforma del proceso penal", págs. 17-18.

845 GOMES FILHO, A. M., "Prológo" a la obra de ARAÚJO DA SILVA E., Crime Organizado. Procedimento probatório, cit., pág. 13. 
De otra parte, importante señalar la necesidad de adecuar estos mecanismos extraordinarios de investigación a los principios del Estado de Derecho y en este sentido, velar para que la búsqueda de medios eficaces no comporte detrimento de la plena vigencia de los principios, derechos y garantías constitucionales, cuya preservación exige, siempre que exista conflicto, inclinarse a favor de los derechos y garantías aun renunciando a la eficacia y garantizando el control jurisdiccional de estas actuaciones ${ }^{846}$.

Implementar nuevas formas de investigar a las formas más graves de criminalidad importa en la obligatoriedad de los Estados en estructurar los cuerpos de seguridad policiales, dotándolos de aparatos tecnológicos de última generación, además de una preparación adecuada y especializada de sus miembros, medidas estas que si concretadas han de posibilitar la utilización de medios y técnicas avanzadas de investigación criminal.

Así, si es verdad que los actuales medios de investigación se encuentran de espaldas a la realidad criminológica, vamos a continuación tratar de analizar la introducción en muchos ordenamientos penales, de medios o técnicas extraordinarias de investigación más eficaces en la lucha contra la delincuencia organizada.

III.2.3. Una necesidad irrenunciable: la implantación de nuevas técnicas de investigación penal.

Llegado a este punto hay que ser reconocido que un proceso penal marcadamente garantista, concebido y modelado para soportar la acción penal relativa a la criminalidad común, teniendo por base límites y valores que hoy, en muchos casos, están traspasados, parece no tener capacidad para enfrentar las amenazas criminales emergentes ${ }^{847}$.

Se sostiene entonces que hoy día, los procedimientos tradicionales de investigación policial y de instrucción judicial se muestran ineficaces para enfrentar con éxito el grave problema social que representa la moderna criminalidad, especialmente cuando se trata de la delincuencia organizada. La capacidad de actuación que tienen estos grupos delictivos, su sólida estructura (compuesta por un entramado de instrumentos personales, materiales y patrimoniales), su ilimitada fuente de recursos y medios (principalmente de comunicación y de alta tecnología) y, sobre todo, el de que tales clanes criminales maniobren con sofisticadas técnicas de ingeniería financiera, fiscal y contable (generalmente usadas para reciclar los capitales ilícitos producto de sus operaciones delictivas), provoca que las habituales medidas de investigación penal resulten obsoletas y, por tanto, fácilmente vencidas ${ }^{848}$.

Esta es una realidad incontestable en razón del miedo provocado a la sociedad y al propio Estado, por las actuaciones de los más destacados grupos de delincuentes organizados, a ejemplo de los clanes mafiosos en Italia, Rusia, y en países africanos como

846 Por esta razón, es lógico concluir que "el impulso que se deriva del ánimo de combatir el terrorismo y otras formas graves de criminalidad abre la puerta a la introducción de medidas que suponen un alto grado de injerencia en los derechos fundamentales". Vid. PÉREZ GIL, J., "Investigación penal y nuevas tecnologías: Algunos de los retos pendientes", Revista Jurídica de Castilla y León, núm. 7, 2005, pág. 219.

847 Vid. BRAZ, J., Investigação criminal. A organização, o método e a prova. Os desafios da nova criminalidade, cit., pág. 293.

848 NÚÑEZ PAZ, M. A; GUILLÉN LÓPEZ, G., "Entrega vigilada, agente encubierto y agente provocador. Análisis de los medios de investigación en materia de drogas", Anuario de Derecho Penal y Ciencias Penales, Tomo LXI, Madrid, 2008, págs. 90-91. 
Nigeria, además de los carteles de drogas en Colombia y de grupos terroristas como el ETA en España.

Sin embargo, si es verdad como hemos visto que la criminalidad organizada, y especialmente la narcocriminalidad ${ }^{849}$, ha evolucionado extraordinariamente en los últimos tiempos y que las organizaciones criminales se tratan de complejas estructuras, que disponen de ingentes medios financieros de origen ilícito, y cuya capacidad operativa supera a la de las clásicas organizaciones de delincuentes ${ }^{850}$, se torna imprescindible la implantación y estructuración en los ordenamientos penales de los distintos países afectados por este fenómeno delictivo, de modernas y actuales técnicas de investigación para la obtención de la desarticulación de estos clanes de delincuentes y la posterior detención de las personas que integran los mismos.

De otra parte, es importante señalar que las nuevas formas de comisión de delitos y el poderío económico existente detrás, que alcanza muchas veces al corazón político del Estado, hace que la lucha en contra del crimen organizado tenga matices diversos, con características particulares y distintas, así como también las técnicas que se utilizan para contrarrestar sus principales ilícitos, tales como tráfico de drogas, espionaje, corrupción, terrorismo, blanqueo de capitales, que mueven capitales muchas veces superiores al presupuesto de un país ${ }^{851}$.

Esta conclusión, nos demuestra la complejidad del crimen organizado transnacional, el cual presenta, dependiendo de su localización y área de actuación, características distintas y modus operandi diversos, hecho que dificulta importantemente la actuación de los órganos de persecución criminal.

Así las cosas, resulta que la forma de actuación de las organizaciones criminales, conjugando violencia, astucia y sofisticación en sus prácticas delictuosas, por una parte sugiere la adopción de respuestas estatales más firmes para su represión, de otra, exige objetividad y equilibrio por parte del legislador y de los operadores jurídicos, de modo que no provoquen violaciones inútiles a las garantías individuales de los investigados o imputados.

De esta apreciación debe deducirse el entendimiento de que la delincuencia organizada asume un sentido político-jurídico, cuando los fenómenos criminosos asumen niveles elevados de intolerancia social. Es a partir de la reacción social que se busca definir una determinada realidad como criminalidad organizada, y no a partir de sus características intrínsecas ${ }^{852}$.

En consecuencia de lo afirmado, se denota que las formas de perturbaciones de la seguridad social y del orden público pueden manifestarse según diversos niveles de

\footnotetext{
${ }^{849}$ Respecto a la problemática especifica del tráfico de drogas, Vid. con profundidad el trabajo de CORRÊA DE CARVALHO, J. T., Tráfico de drogas. Prueba penal y medidas restrictivas de derechos fundamentales, Curitiba, 2009.

850 DELGADO GARCÍA, M. D., "El agente encubierto: técnicas de investigación. Problemática y legislación comparada", cit., pág.. 69.

851 MONTOYA, M. D., Informantes y técnicas de investigación encubiertas. Análisis constitucional y procesal penal, cit.,pág. 29.

852 PAVARINI, M., "Lo sguardo artificiale sul crimine organizzato", AA. VV., Lotta alla criminalità organizzata: gli strumenti normativi (a cura di Giostra e Insolera), Milano, 1993, pág. 78.
} 
intensidad, de tal suerte que el tratamiento estatal que podrá ser empleado debe mostrarse igualmente proporcional a la realidad presentada 853 .

La criminalidad organizada es un fenómeno criminal que tieneraíces culturales, económicas y políticas, que deben ser examinadas para programar una política criminal eficaz que no centre toda su carga en el Derecho Penal854. Entra en juego entonces, la necesidad de un tratamiento procesal con reglas especiales y adecuadas a la realidad criminológica, como forma de establecerse el control de esta forma de delincuencia, el cual tiene que presentar ciertas características diferenciadas, en razón de su especificidad.

De otra parte, cumple a los Estados hacerfrente a las modernas manifestaciones delictivas y a sus complejas formas de desenvolvimiento, como asimismo a los distintos problemas sociales, económicos y culturales, que encierran esas ilicitudes.

Así, la respuesta sustantiva debe estar acompañada de otros mecanismos extraordinarios de investigación, detenidamente regulados para salvaguardar el equilibrio entre derechos fundamentales y la protección de la sociedad ${ }^{855}$.

Un interesante ejemplo se puede extraer de España, donde en 1975, parte de la cúpula del grupo ETA (Euskadi Ta Askatasuna), organización terrorista independentista vasca, acabó detenida gracias a la persona de Mikel Legarza, alias "lobo", un joven vasco sin formación política que se convirtió en el primer topo o infiltrado que los servicios secretos españoles lograron colocar en el comité ejecutivo de esta organización ${ }^{856}$.

La realidad cotidiana puede así exigir nuevas fórmulas para potenciar la acción policial en la detección y conocimiento de ciertas conductas delictivas especialmente complejas, así como en la obtención de pruebas para detener e inculpar a sus responsables ${ }^{857}$.

En nuestra opinión deberá entonces el Estado reaccionar de una forma también innovadora, utilizándose de técnicas y métodos de inteligencia criminal que presenten una real posibilidad de confrontarse con la gran modernidad que caracterizalas prácticas delictuosas perpetradas por las organizaciones criminales.

De esta apreciación debe deducirse el entendimiento de que la moderna delincuencia organizada y transnacional ${ }^{858}$ obliga a una adecuación de las figuras

853 Vid. BECHARA, F. R., "Criminalidade organizada e procedimento diferenciado: entre eficiência e garantismo" cit., pág. 918.

854 ZÚÑIIGA RODRÍGUEZ, L., "Criminalidad organizada, Derecho penal y sociedad. Apuntes para el análisis", cit., pág. 67.

855 Por esta razón, sostiene GASCÓN INCHAUSTI que "resulta ya más tópico insistir en la idea de que en el proceso penal, como institución jurídica, se enfrentan siempre dos impulsos o tendencias contrapuestos: de un lado, se encuentra una exigencia de eficacia, pues el proceso penal es el único instrumento admisible para hacer valer el interés público en la persecución penal, al servicio de la preservación de la seguridad y de la paz social; de otro, el encuadre del proceso penal dentro de un modelo constitucional que comporte la exigencia de que se desarrolle respetando los derechos fundamentales de todos los sujetos que puedan verse implicados en él. De una adecuada ponderación de ambas exigencias depende que el Estado pueda reaccionar ante el fenómeno delictivo de forma legítima". Vid. GASCÓN INCHAUSTI, F., "Prólogo" a la obra: Tráfico de drogas. Prueba penal y medidas restrictivas de derechos fundamentales, CORRÊA DE CARVALHO, J. T., cit., pág. 9.

856 Vid. la historia completa de esta operación de infiltración en CERDÁN, M; RUBIO, A., Lobo. Un topo en las entrañas de ETA, Barcelona, 2004.

857 MONTERO AROCA, J., GÓMEZ COLOMER, J. L., MONTÓN REDONDO, A., BARONA VILAR, S; Derecho Jurisdiccional III, cit., pág. 210.

858 Como punto de partida para la comprensión del tema del carácter "transnacional" del crimen organizado resulta de gran utilidad señalar que la lucha contra esta especie de delincuencia no ha tenido el éxito esperado, ya que es necesario que exista una cooperación coordinada entre las agencias responsables de 
procesales y penales, no sólo en Europa, sino incluso a nivel internacional, al objetivo de poder luchar con eficacia contra las nuevas formas de delincuencia que conviven en nuestra sociedad 859 .

Los medios tradicionales de averiguación del delito, en la actualidad, se muestran a menudo ineficaces en la lucha contra el crimen organizado. Ello se debe a varias causas, siendo las principales dos: la transnacionalidad real y virtual, propia de la globalización económica en la que se desenvuelve la sociedad del siglo XXI acelerada por una tecnología que permite actuar en tiempo real en cualquiera economía local en cualquier momento desde cualquier lugar, y una abundancia de medios en la perpetración del delito y perfección en la estructura organizativa, que en muchos casos, hace inviables e insuficientes las técnicas de investigación tradicionales ${ }^{860}$.

Por otro lado, debido a la complejidad de las organizaciones criminales, con eslabones directivos profesionalizados y con frecuencia asesorados por expertos en materias técnicas como la informática o la economía. La organización además suele disponer de medios materiales y técnicos, por ejemplo, medios de transmisión de comunicaciones cada vez más sofisticados para desarrollar su trabajo sin ser detectados. Se muestran además opacas e impermeables al exterior, como consecuencia de los fuertes códigos de jerarquía y disciplina por los que se rigen sus miembros. Tampoco es fácil contar con testigos externos 861 .

Con la evolución y desarrollo de la criminalidad, se impone la correspondiente adecuación de la respuesta estatal, la cual tieneque contar con la utilización y estructuración de medios y técnicas de investigación criminal eficaces para hacer frente a la profesionalización de la delincuencia organizada.

La sofisticación inherente a la actividad de las organizaciones criminales impide que los métodos tradicionales de investigación tengan resultados efectivos, mientras que la integración de un agente en su estructura, participando en sus actividades, puede aportar abundante información sobre su esquema y funcionamiento ${ }^{862}$.

De este modo, deberá el titular del ius puniendi, implementar estudios para la estructuración de una política criminal rica en instrumentos útiles para la persecución de

combatirlo, esto es, compartiendo la información disponible, facilitando las investigaciones, incluso con el empleo de medios extraordinarios a ejemplo de agentes encubiertos, dictando leyes armonizadas entre todos los países involucrados y estableciendo apoyos técnicos mutuos entre todos los organismos especializados en este fenómeno. Los Estados en general no han acertado con las soluciones para enfrentar esta amenaza, ya sea porque no tienen los medios apropiados, porque las autoridades no aplican con firmeza las leyes, porque no hay intercambio de informaciones o porque no hay coordinación cooperativa. Dentro de una estrategia global es necesario considerar la tipificación internacional del delito, mediante acuerdos bilaterales o multilaterales. Para más detalles sobre la transnacionalización e internacionalización del crimen organizado, Cfr. GOMÉZ DE LIAÑO FONSECA-HERRERO, M., Criminalidad organizada y medios extraordinarios de investigación, cit., págs., 54-55 y 112 y ss.

${ }^{859}$ En este sentido, cfr. PEÑA ECHEVERRÍA, M. J., "La delincuencia organizada y su problemática desde la óptica de la investigación policial", cit., pág. 159.

860 BENÍTEZ ORTÚZAR, I. F., El colaborador con la justicia. Aspectos sustantivos, procesales y penitenciarios derivados de la conduta del "arrepentido", cit., pág. 14. También, al respecto, Vid. DELGADO MARTíN, J., Criminalidad organizada, cit., pág. 30.

861 SÁNCHEZ GARCÍA DE PAZ, I., La criminalidad organizada. Aspectos penales, procesales, administrativos y policiales, cit., pág. 218.

862 DELGADO MARTÍN, J., "El proceso penal ante la criminalidad organizada. El agente encubierto", Actualidad Penal, núm. 1, 2000, pág. 6. 
toda forma de delincuencia y en especial de aquella típicamente transnacional como es la propia del crimen organizado.

Se trata, lógicamente, no de emplear formas o medios más invasivos a los derechos fundamentales, para a través del uso de la arbitrariedad y de la violación sin proporción de las garantías de los investigados, desarticularse el crimen organizado, pero sí de utilizar técnicas de investigación más adecuadas a la búsqueda del objetivo primordial del Estado que es proporcionar a la colectividad seguridad y preservación del orden público, con la obtención de datos y pruebas que puedan en el futuro llevar a la condena de los miembros de estos clanes organizados. Pero esto con obediencia a los principios constitucionales y siempre teniendo en cuenta la necesidad de la preservación in totum, siempre que sea posible, de los derechos fundamentales de los investigados o imputados. Por esto las operaciones encubiertas tienen que revestirse del carácter de ultima ratio.

Así, ante el fracaso de los medios tradicionales de investigación se hace patente la necesidad de estudiar la posibilidad de implementación y reglamentación de nuevos métodos de esclarecimiento del delito. Sólo de este modo la acción de la justicia criminal podrá ejercerse de forma segura y adecuada a los objetivos que se propone alcanzar.

A modo de conclusión es importante apuntar que en materia procesal penal numerosas recomendaciones de organismos internacionales van en la línea de potenciar nuevos medios de investigación criminal calificados de proactivos ("proactive") y encubiertos ("undercover") que resultan más invasivos que los tradicionales en parcelas como la libertad personal o la intimidad en sus diferentes manifestaciones, como la intimidad del domicilio, el secreto de las comunicaciones o la privacidad de los datos bancarios. Se tratan de técnicas como la vigilancia electrónica de las comunicaciones, la toma de imágenes, la investigación de datos financieros sin el límite del secreto bancario, el uso de agentes encubiertos y la autorización de la circulación o entrega vigilada de determinados efectos delictivos, entre otras ${ }^{863}$. En todo caso, nos interesa de modo especial el estudio del tema del "agente encubierto".

863 SÁNCHEZ GARCÍA DE PAZ, I., La criminalidad organizada. Aspectos penales, procesales, administrativos y policiales, cit., pág. 219. 


\section{CAPÍTULO CUARTO: EL AGENTE ENCUBIERTO COMO MEDIO EXTRAORDINARIO DE INVESTIGACIÓN CRIMINAL}

\section{IV.1. Consideraciones generales y puntos críticos.}

IV.1.1. Agente encubierto: orígenes históricos y marco conceptual.

IV.1.1.1. Un medio de investigación necesario para combatir el crimen organizado.

Normalmente cuando ocurre una infracción penal, se tiene que poner en marcha una investigación, con el objetivo de rehacer, con cierta fiabilidad, la reconstrucción de los hechos tal como aproximadamente se produjeron en larealidad.

Se empieza, por lo tanto, el procedimiento de persecución penal, donde se observa que el Estado, como acusador, parte de una posición de desventaja inicial con respecto a la persona del delincuente y a las circunstancias del hecho delictivo, lo que provoca que el Estado deba utilizar todas las armas legítimas para luchar contra la delincuencia que cada vez es más poderosa ${ }^{864}$. Se necesita, incluso y principalmente, una actualización de las técnicas procesales de investigación ${ }^{865}$.

Siguiendo esta tendencia, la expansión de la criminalidad organizada, violenta y transnacional, debidamente potenciada con grandes recursos económicos ha obligado a los Estados contemporáneos a trasladar algunos modelos que han sido puestos en práctica en el sistema anglosajón ${ }^{866}$ y que han tenido éxito en la oportuna detección de los focos criminógenos y de las redes delictivas que operan en gran escala mundial.

Luego, como forma de lograrse éxito contra las más destacadas formas de actividades delictivas, cada vez más complejas y sofisticadas, en particular contra la delincuencia transfronteriza, sólo se podrá alcanzar este objetivo mediante el uso de técnicas modernas de investigación igualmente complejas.

Queda claro, pues, que es cierto que "nuevos" medios de investigación ${ }^{867}$, por lo extraños que resultan al sistema y por la contaminación que puedan recibir, deben ser aceptados con mucho cuidado y cautela, previa verificación y práctica bajo la vigilancia, control y autorización del funcionario de instrucción ${ }^{868}$.

No menos importante es señalar que la delincuencia y sus actores principales, los delincuentes, están en constante evolución. Se adaptan a cada tiempo, utilizando todos los adelantos técnicos útiles para el uso normal de la sociedad. De la misma forma se ha

864 Cfr. ESPINOSA DE LOS MONTEROS, R. Z., El policía infiltrado. Los presupuestos jurídicos en el proceso penal español, Valencia, 2010, pág. 22.

865 En este sentido, vid. GÓMEZ DE LIAÑO FONSECA-HERRERO, M., "El agente encubierto como medida de investigación del terrorismo en el contexto internacional", VV.AA., Terrorismo y Estado de Derecho, J. $R$. Serrano-Piedecasas y E. Demetrio Crespo coords., Madrid, 2010, pág. 417.

866 Siguiendo esta posición, señala ONETO que "el recurso al agente infiltrado, sea en el ámbito de acciones de prevención criminal, sea de represión criminal, es una práctica corriente en la mayoría de los países, pero es el los Estados Unidos que esta figura atinge mayor dimensión como técnica de investigación". Vid. ONETO, I., o Agente infiltrado. Contributo para a compreensão do regime jurídico das acções encobertas, cit., pág. 79.

867 De modo específico sobre el tema de la búsqueda de la eficiencia en la persecución contra el crimen organizado, a través de un tratamiento distinto desde el plan procesal penal, vid. ARAÚJO DA SILVA, E., Crime organizado. Procedimento probatório, cit., págs. 40 y ss.

868 Se justifica de este modo el carácter excepcional del empleo de los medios extraordinarios de investigación penal. Excepcionalidad esta que encuentra fundamentación en razón de las características destacadas por la fuerte carga de restricción de derechos fundamentales inherentes a las técnicas de operación encubierta. 
adaptado miméticamente a todos los cambios sociales, políticos y estructurales de nuestros días ${ }^{869}$. Consecuencia lógica es que los más destacados grupos criminales se coordinan con una enorme rapidez, escogen y seleccionan países para refugiarse y finalmente planifican, desde un territorio nacional, la práctica de un sinnúmero de actividades delictivas.

Efectivamente, parece evidente que para incrementar la eficiencia de la lucha contra la criminalidad organizada, existe una tendencia a crear instrumentos extraordinarios ${ }^{870}$, entendiendo por tales aquéllos que suponen una alteración de los principios inspiradores tanto del Derecho penal material como del propio proceso justo. Todavía, muchos de ellos pueden estar justificados en las dificultades inherentes a dicha lucha, vistas las especiales características de las organizaciones criminales ${ }^{871}$.

Con esta afirmación, queremos poner de manifiesto que delante de los avances del crecimiento de las nuevas formas de delincuencia, marcadas por el carácter transnacional y por la sofisticación en materia logística, se hace necesaria una actualización de las técnicas que deberán ser empleadas para el combate a las acciones de estos grupos organizados ${ }^{872}$.

De otro lado, como ya hemos afirmado, la realidad criminológica actual nos enseña que el modelo tradicional de investigación criminal no se encuentra en condiciones aptas para hacerse eficiente en la resolución y control de los casos más graves de delincuencia, especialmente aquella caracterizada por la violencia desmesurada y por el uso notable de su poder financiero y logístico.

Siendo así, es necesario afirmar que las operaciones bajo cobertura o técnicas de investigación encubiertas son algunas de las armas más eficaces que los órganos encargados de aplicar la ley tienen para atacar la delincuencia organizada y los problemas de corrupción pública y privada ${ }^{873}$. Ahora bien, tendrán que ser utilizadas siempre de conformidad con las reglas y principios establecidos en los ordenamientos jurídicos, de modo que no provoquen, de modo injustificado, vulneración de derechos y garantías fundamentales.

En esencia, como resulta inviable afrontar la represión del crimen organizado mediante el recurso a las vías legales arbitradas para la delincuencia tradicional874, ha

869 Vid. PARDO MATEOS, R. J., "Fenomenología del delito: delincuencia tradicional y nuevas formas de delincuencia", VV.AA., Teoría y práctica de la investigación criminal, J. Collado Medina coord., Madrid, 2009, pág. 46.

870 Monográficamente, vid. GOMÉZ DE LIAÑO FONSECA-HERRERO, M., Criminalidad organizada y medios extraordinarios de investigación, Madrid, 2004. También nuestro trabajo, CARDOSO PEREIRA, F., Meios extraordinários de investigação criminal: infiltrações policiais e entregas vigiadas (controladas), cit., págs. 199226.

871 DELGADO MARTÍN, J., "El proceso penal ante la criminalidad organizada. El agente encubierto", cit., pág. 5. En el mismo sentido, señala AROCENA que "esa nueva forma de delincuencia requiere la debida actualización del sistema penal, a efectos de que la respuesta sea acorde a la gravedad y complejidad del fenómeno". Vid. AROCENA, G. A., "El agente encubierto. Consideraciones político-criminales", cit., pág. 110.

872 Esta "actualización" todavía, deberá de modo imprescindible, se operar en consonancia con la concepción dogmática garantista del proceso penal, ajustando sus contornos a los parámetros de conformidad constitucional.

873 Vid. VV.AA., Análisis, técnicas y herramientas en el combate a la delincuencia organizada con fundamento en la Convención de Palermo, cit., pág. 93.

${ }^{874}$ En este sentido, vid. SCHNEIDER, H. J., "Recientes investigaciones criminológicas sobre la criminalidad organizada", cit., pág. 724. 
tenido lugar una especialización ${ }^{875}$ de la normativa procesal penal contra la delincuencia asociativa. Dicho en otras palabras, se ha llegado a la conclusión de que la lucha estaría quedando desigual en términos de combate al crimen organizado, especialmente en razón de que en la gran mayoría de las veces, se intenta luchar contra un oponente imaginario, por veces desconocido respecto a su estructura y logística,y además, de lo cual no se tiene un completo conocimiento con relación a los aspectos internos de su modus operandi.

Este es un punto muy importante a tener en cuenta, en la medida en que se puede afirmar con seguridad que uno de los métodos más antiguos de control de la criminalidad consiste en que el agente investigador realice una búsqueda de datos e informaciones ocultando su pertenencia al poder público, con lo que consigue el acceso a ambientes sociales y a personas que tendría vedado si no actuara de forma subrepticia.

Así nos encontramos de esta forma, con la figura del agente encubierto en su modalidad más sencilla. Posteriormente, y sobre esa elemental base, podrá adoptar perfiles más complejos dependiendo de la mayor sofisticación de la delincuencia y de la duración de la operación de infiltración; el agente deberá integrarse en el ambiente investigado, adoptar una identidad supuesta y también utilizar medios técnicos visuales y auditivos cada vez más desarrollados.

Ocurre, en efecto, que las necesidades de la investigación establecerán el marco de actuación del agente encubierto, su mayor o menor grado de infiltración en el ambiente o subcultura, los medios técnicos u operativos que utilice, así como la eventual adopción de una identidad supuesta ${ }^{876}$.

Así es que cada operación encubierta de infiltración presentará detalles distintos y forma de actuación adecuada a la situación en concreto. El análisis y montaje del plan de infiltración dependerá de un rol de informaciones básicas previamente recabadas respecto a la organización criminal que se pretende mejor conocer, que después de debidamente estudiadas ${ }^{877}$, iban a servir como línea de investigación respecto a las actuaciones de este clan.

Surge entonces la figura del agente encubierto o infiltrado ${ }^{878}$.

\footnotetext{
875 Véase a respecto, ANARTE BORRALLO, E., "Conjeturas sobre la criminalidad organizada", cit., pág. 20.

876 Vid. DELGADO J., Criminalidad Organizada, cit., pág. 43.

877 A este modo particular de actuar se suele denominar de "actividad de inteligencia criminal". Esta tarea policial consiste en la obtención de conocimiento que ayudea la adopción de decisiones con relación a la represión y prevención criminal, de modo muy especial en se tratando de la delincuencia organizada. Para un completo estudio del tema, cfr. MINGARDI, G., "0 trabalho da Inteligência no controle do Crime Organizado", Revista Estudos Avançados da Universidade de São Paulo, núm. 61, SãoPaulo, 2007, págs. 51-69.

878 Vid. como significativos trabajos respecto al tema, AROCENA, G. A., "El agente encubierto. Consideraciones político-criminales", VV.AA., Temas de derecho procesal penal (Contemporáneos), J. I. Cafferata Nores y G. A. Arocena coords., Córdoba, 2001; BERNARD CORBOZ, L., "L'agent infiltré", Revue Penale Suisse, núm. 111, 1993, págs. 307-342; CARMONA SALGADO, C., "La circulación y entrega vigilada de drogas y el agente encubierto en el marco de la criminalidad organizada sobre narcotráfico", VV.AA., Estudios jurídicopenales y Político-criminales sobre tráfico de drogas y figuras afines, L. Morillas Cueva coord., Madrid, 2003; CASSANI, B., "Agentes encubiertos e informantes como medios de prueba contra el crimen organizado", VV.AA., El crimen organizado. Desafíos y perspectivas en el marco de la globalización, Buenos Aires, 2005; DELGADO GARCÍA, Ma a D., "El agente encubierto: técnicas de investigación. Problemática y legislación comparada", VV.AA., La criminalidad organizada ante la justicia, Sevilla, 1996, págs. 69-84; DELGADO MARTíN, J., "El proceso penal ante la criminalidad organizada. El agente encubierto", Actualidad Penal, núm. 1, 2000; EDWARDS, C. E., El arrepentido, el agente encubierto y la entrega vigilada, Buenos Aires, 1996; ESPINOSA DE LOS MONTEROS, R. Z., El policía infiltrado. Los presupuestos jurídicos en el proceso penal español, Valencia, 2010; FERNÁNDEZ APARICIO, J. M., "El delito provocado y el agente encubierto", Actualidad Penal, núm. 44, Madrid, 2002; GÓMEZ DE LIAÑO FONSECA-HERRERO, M., "Infiltración policial y proceso penal", VV.AA.,
} 
Como punto de partida, el análisis que haremos a continuación parte de una concepción general de que el agente encubierto se trata de un medio procesal utilizado hoy por el orden jurídico de muchos países, siendo ciertamente en los Estados Unidos de América y muy particularmente en el ámbito de la lucha contra el tráfico de estupefacientes en el que el recurso sistemático a esta técnica de investigación ha adquirido históricamente, mayor relevancia, a partir de los años ochenta del siglo pasado 879, aunque se podrá constatar que el origen natural de este personaje tiene mucho que ver con el periodo del antiguo régimen en Francia 880.

Téngase presente, además, que el argumento político-criminal es bastante significativo, puesto que la actuación del infiltrado tiene por objeto afrontar actuaciones criminales graves, con respecto a las garantías constitucionales, especialmente en lo relativo a problemas que plantea la delincuencia organizada en materia de drogas, tráficos ilícitos de personas, sustancias o animales, o delitos en materia de propiedad intelectual e industrial, entre otros. Se justifica por la ineficacia de las técnicas de investigación tradicionales en la lucha contra la criminalidad organizada, ante la dimensión internacional de estas organizaciones, la abundancia de recursos con los que cuentan, y la dificultad de conocer su estructura y funcionamiento dado la opacidad y relativa discreción de sus actividades ${ }^{881}$.

Lo cierto es que la búsqueda de eficacia en la represión delictiva ha hecho tener al agente infiltrado como una institución necesaria para la consecución de tal cometido ${ }^{882}$.

Investigación y prueba en el proceso penal, N. González-Cuéllar Serrano y A. Sanz Hermida coords., Madrid, 2006; GASCÓN INCHAUSTI, F., Infiltración policial y agente encubierto, Granada, 2001; GONÇALVES, F., JOÃO ALVES, M., GUEDES VALENTE, M. M., Lei e Crime. O agente infiltrado Versus o agente provocador. Os princípios do processo penal, Coimbra, 2001; GONZALEZ-CASTELL, A. C., "El agente infiltrado en España y Portugal. Estudio comparado a la luz de las garantías y de los principios constitucionales", VV.AA., Criminalidade organizada e criminalidade de massa. Interferências e ingerências mútuas, M. M. Guedes Valente coord., Coimbra, 2009; GUZMÁN FLUJA, V. C., "El agente encubierto y las garantías del proceso penal", VV.AA., La prueba en el Espacio Europeo de libertad, seguridad y justicia penal, Navarra, 2006; MOLINA MANSILLA, Mạ. C., Mecanismos de investigación policial: entrega vigilada y agente encubierto, Barcelona, 2009; MONTÓN GARCÍA, M. L., "Agente provocador y agente encubierto: ordenemos conceptos", La Ley, año XX, núm. 4826, 1999; MONTOYA., M. D., Informantes y técnicas de investigación encubiertas. Análisis Constitucional y Procesal Penal, 2ª edición, Buenos Aires, 2001; MOSCATO DE SANTAMARIA, C. B., El agente encubierto en el Estado de Derecho, Buenos Aires, 2000; ONETO, I., $O$ agente infiltrado. Contributo para a compreensão do regime jurídico das acções encobertas, Coimbra, 2005; PACHECO, R., Crime Organizado. Medidas de controle e infiltração policial, Curitiba, 2007; POZO PÉREZ, M., "El agente encubierto como medio de investigación de la delincuencia organizada en la Ley de Enjuiciamiento Criminal española", Revista Criterio Jurídico, vol. 6, Santiago de Cali, 2006; RIFÁ SOLER, J. M., "El agente encubierto o infiltrado en la nueva regulación de la LECrim", Poder Judicial, núm. 55, 1999.

879 BRAZ, J., Investigação Criminal. A organização, o método e a prova. Os desafios da nova criminalidade, cit., pág. 320. Es este sentido es imprescindible afirmar que "las primeras operaciones encubiertas en los Estados Unidos eran típicamente operaciones con fachadas ficticias o negocios de escaparate comprometidos en la compra de objetos o partes de vehículos robados. Conforme se fue adquiriendo experiencia en el uso de la técnica, se fueron generando operaciones más sofisticadas, como las operaciones con compañías constructoras, negocios de camiones de transporte, actuando como vendedores de bienes raíces o servicios a representantes gubernamentales o comprando agentes, y en la operación de clubes nocturnos o establecimiento de juegos y apuesta ilegal". Cfr. VV.AA., Análisis, técnicas y herramientas en el combate a la delincuencia organizada con fundamento en la Convención de Palermo, cit., pág. 95.

880 A este respecto la infiltración de agentes tiene su origen en el período del absolutismo francés, especialmente en la época del Rey Luís XIV, él cual con objetivo de fortalecer el Ancien Régime, ha creado la figura del agent provocateur o "delatores".

881 Vid. RIFÁ SOLER, J. M; RICHARD GONZÁLEZ, M; RIAÑO BRUN, I., Derecho procesal penal, Pamplona, 2006, pág. 285.

882 Por esto, algún autor como QUINTANAR DIEZ, señala que "la figura del agente encubierto supone la positivización de un instrumento esencial en la lucha contra el denominado crimen organizado". Vid. QUINTANAR DIEZ, M., "El agente encubierto", Revista Letras Jurídicas, núm.1, 
Se justifica la anterior opinión en razón de que, siguiendo las orientaciones de Naciones Unidas, varios países han regulado en los últimos años la posibilidad de las investigaciones encubiertas ${ }^{883} \mathrm{y}$, en concreto, la figura de la infiltración de agentes en organizaciones criminales de carácter transnacional.

Siendo así las cosas, el fenómeno de la narcocriminalidad, la sofisticación de las modalidades comisivas, la transnacionalidad de organizaciones criminales, el terrorismo y otros delitos graves vienen a justificar el empleo de agentes encubiertos con el propósito de desplegar una eficaz tarea de prevención y represión del delito. Sería pues, una de las pocas oportunidades de intentar conocer profundamente la estructura y logística de los grandes grupos organizados de delincuentes que actúan a nivel transnacional y con base en estas informaciones, poner en práctica el procedimiento de desarticulación de estos clanes delictivos.

Aunque deberá tener por regla que la técnica de infiltración deba consistir en la ultima ratio, siendo el recurso final a ser utilizado en materia de búsqueda de informaciones y pruebas contra un determinado grupo organizado de criminales, no se puede olvidar que dependiendo de la magnitud del grupo de delincuentes, no existirá otra forma de descubrir su modus operandi y su verdadera y real estructura humana y material ${ }^{884}$.

http://letrasjuridicas.cuci.udg.mx/. Además, las Naciones Unidas, a través de la Oficina contra la Droga y el Delito, ha dejado establecido que "las técnicas especiales de investigación constituyen un componente esencial de la práctica moderna de aplicación de la ley y revisten suma importancia para una labor policial e investigación fructífera. En la actualidad, las medidas son una parte intrínseca de los procedimientos operativos". Cfr. la Recomendación 3, del Grupo de Trabajo Oficioso de Expertos sobre Técnicas Especiales de Investigación (Prácticas óptimas y recomendaciones sobre los obstáculos jurídicos a las entregas vigiladas y las operaciones encubiertas), septiembre, 2005.

883 Importante destacar que existen nítidas diferencias de tratamiento penal del "agente encubierto" en los diversos ordenamientos jurídicos. En este sentido, hay un primer grupo de Estados que regula de forma expresa y directa en sus legislaciones el uso de agentes encubiertos. Esto ocurre, sin ánimo de ser completamente exhaustivo, en España, Alemania, Dinamarca, Perú y Argentina. Hay otro grupo de Estados que no regula en sus ordenamientos de manera directa la infiltración policial, pero su admisibilidad se deduce de forma implícita, bien de normas que contemplan técnicas de investigación que exigen de la participación de agentes infiltrados, a ejemplo de las entregas controladas de elementos ilícitos, bien, y de manera más común, a través de preceptos que exoneran de responsabilidad penal a los agentes policiales por los delitos cometidos en la investigación de determinados delitos. Ésta es la situación normativa existente en Italia Francia y Portugal. Y finalmente, algunos Estados no regulan la infiltración policial, ni di manera directa, ni deducible, y ha sido la jurisprudencia la que le ha dado carta de naturaleza. Tal es el caso de Suiza, Austria, Bélgica y Países Bajos, donde la admisión de la infiltración aparece relacionada con la cuestión de la licitud de la provocación policial como instrumento de obtención de pruebas. Vid. con más detalles, GOMÉZ DE LIÃNO FONSECAHERRERO, M., "El agente encubierto como medida de investigación del terrorismo en el contexto internacional", cit., págs. 418-420.

${ }_{884}$ En este orden de cosas, es correcto se concluir que la figura del agente encubierto no puede ser considerada per se inconstitucional, ni por el contrario puede afirmarse de manera general, que la figura esté revestida de total constitucionalidad, ya que dependerá en cada caso de cómo se haya desarrollado la actuación policial; y su aceptación o no, devendrá como ha quedado repetido y reiterado, de haber o no, ocurrido violación a derechos fundamentales, debiendo tenerse en cuenta que su violación, no puede ser permitida en un Estado que de cumplimiento a su norma suprema, ni en el afán más profundo de controlar y combatir las organizaciones criminales, sacrificando para ello derechos fundamentales en los casos que se investiguen hechos delictivos; ya que para ello existen las regulaciones legales que deben controlar tales actuaciones, así como límites constitucionales que orienten el desarrollo de las mismas. No admite duda alguna lo alarmante del alto grado de criminalidad que golpea sociedades enteras sin discriminación; y ese tipo de prácticas, se realizan con el fin de salvaguardar intereses colectivos, amenazados frente a peligros concretos o abstractos, y con el objeto de controlar la proliferación de las organizaciones criminales que atentan a diario, gracias al comercio de las drogas, con una serie de bienes jurídicos, por ser una actividad no aislada, sino en relación dependiente de una gran cantidad de padecimientos de la sociedad, que difícilmente lograrán disminuirse sino es entre otros combatiendo los conductos por los que se filtra, a través de la investigación especializada, requerida como respuesta a una criminalidad moderna e incontrolable. Sin 
Regístrese una vez más que el recurso a la utilización del agente infiltrado para la investigación de determinados delitos es algo que ha sido naturalmente admitido por un sinnúmero de ordenamientos jurídicos ya que, a pesar de tratarse de una técnica claramente restrictiva de derechos fundamentales, es considerada necesaria para luchar contra un tipo de criminalidad cada vez más desarrollada y sofisticada, y fruto de la actual sociedad globalizada, en la mayoría de los casos de carácter transnacional, lo que sin duda justificó su inclusión entre las técnicas de asistencia judicial previstas en el Convenio de Asistencia Judicial en materia penal entre los Estados miembros de la Unión Europea, de 29 de mayo de 2000, que en su artículo 14.1 apuntalo que ha de entenderse por investigación encubierta, al describir que: "El Estado miembro requirente y el Estado miembro requerido podrán convenir en colaborar para la realización de investigaciones de actividades delictivas por parte de agentes que actúen infiltrados o con una identidad falsa" 885 .

Incluso GUEDES VALENTE ha afirmado que el recurso al agente infiltrado, además del recurso a la vigilancia electrónica u otras formas de vigilancia, es una de las obligaciones de los Estados Parte de la Convención de Naciones Unidas contra la criminalidad organizada transnacional, conocida como Convención de Palermo (art. 20). Pero, esta obligación solo se impone cuando el ordenamiento jurídico del Estado Parte permite el uso de técnicas especiales de investigación ${ }^{886}$; se trata, pues, de un imperativo correspondiente a la obediencia al principio de legalidad, con la previsión detallada, circunstanciadae inteligible del uso de este medio de investigación.

En cualquier caso, uno de los temas más controvertidos en él ámbito del Derecho procesal, especialmente en la parte de la investigación criminal, se refiere a la cuestión de la actuación de los agentes encubiertos o infiltrados y por consecuencia, la valorización de las pruebas producidas a través de este método extraordinario de investigación y también indirectamente, de búsqueda de la prueba penal 887 .

Se cuestiona incluso la eventual violación de derechos constitucionales del investigado, como por ejemplo el de su intimidad y el derecho a no autoincriminarse.

Es necesario hacer hincapié en este sentido, afirmando una vez más que para el combate a la expansión del fenómeno de la delincuencia organizada, su avance u difusión social, se presenta la figura del agente encubierto como uno de los más destacables instrumentos de enfrentamiento a esta forma de criminalidad.

embargo, y a pesar de ello, no puede sacrificarse el fiel y estricto cumplimiento de los derechos fundamentales, ni por el logro de tan alto objetivo.

885 Cfr. GONZALEZ-CASTELL, A. C., "El agente infiltrado en España y Portugal. Estudio comparado a la luz de las garantías y de los principios constitucionales", cit., págs. 185-186.

886 Vid. en este sentido, GUEDES VALENTE, M. M., "A investigação do crime organizado. Buscas domiciliárias nocturnas, o agente infiltrado e intervenção nas comunicações", cit., págs. 168-169.

887 Interesante es reconocer que aunque sea un tema que viene despertando el interés de los estudiosos del Derecho procesal penal, no se percibe una producción bibliográfica compatible, a la vez que pocas son las obras especificas respecto al tema del agente encubierto, permaneciendo el asunto restricto a un sinnúmero de artículos doctrinales, de los cuales muchos presentan la misma esencia, sin mayores novedades. Cítese como ejemplos de obras de referencia específica del tema del agente infiltrado: ESPINOSA DE LOS MONTEROS, R. Z., El policía infiltrado. Los presupuestos jurídicos en el proceso penal español, Valencia, 2010; GASCÓN INCHAUSTI, F., Infiltración policial y "agente encubierto", Granada, 2001; MONTOYA, M. D., Informantes y técnicas de investigación encubiertas. Análisis Constitucional y Procesal Penal, 2a edición, Buenos Aires, 2001; ONETO, I., $O$ agente infiltrado. Contributo para a compreensão do Regime Jurídico das Acções Encobertas, Coimbra, 2005; PACHECO, R., Crime Organizado. Medidas de controle e infiltração policial, Curitiba, 2007. 
Su utilización y empleo como es lógico, estaría condicionado a la normativa constitucional y en especial, en razón del reconocimiento en el caso concreto, de los principios de subsidiariedad, especialidad, proporcionalidad y del respecto al debido proceso legal 888 .

Conviene anotar que como método de introducción de un infiltrado en las entrañas del grupo delictivo, su ingreso en este grupo criminal puede consistir en cualquier actuación imaginable, siempre que no se conculquen de modo irrazonable y sin criterios de proporcionalidad los derechos constitucionales de los sujetos investigados ${ }^{889}$.

Por eso, se hace necesario centrar la cuestión, partiendo del criterio de análisis de la hipótesis concreta a la luz de los principios de proporcionalidad y del debido proceso legal ${ }^{890}$. Sólo de este modo se podría aceptar el uso de este medio extraordinario de investigación como forma "limpia" y "legal" de combate a la delincuencia más destacada y de carácter transnacional.

Desde la anterior perspectiva, se reconoce que la regulación de las operaciones encubiertas se hace extremamente necesaria a los fines obtención de armonización de su previsión legal en el ordenamiento penal y en la disciplina constitucional de los derechos fundamentales. Ello es debido a que la utilización del engaño por el Estado ${ }^{891}$ en la obtención de informaciones que se convertirán en pruebas de cargo contra los investigados puede plantear algunos problemas de compatibilidad constitucional ${ }^{892}$.

Siguiendo esta línea de pensamiento, uno de los mecanismos universalmente aceptados en orden a la averiguación de los hechos consiste en la actuación de personas que se introducen en la organización delictiva, o que de algún modo se interfieren en el camino del delito, en orden a hacerlo constar y a permitir su persecución y castigo ${ }^{893}$.

Pero en realidad, como método sui generis y excepcional de investigación de delitos graves, la figura del infiltrado encuentra dificultades en su operatividad práctica. No se

888 A este respecto, con detalles, vid. nuestro trabajo, "A investigação criminal realizada por agentes infiltrados", Revista Jurídica do Ministério Público de Mato Grosso, ano 2, núm. 2, 2007, pág. 173 y ss. Por esta razón, se vuelve obligatoria la observación inicial en el sentido de que el análisis de la figura del agente infiltrado implica que se haga un encuadramiento constitucional relativamente a los derechos fundamentales aplicables en esta materia en particular. Así es que, efectivamente, el recursoala Constitución es indispensable,enlaexacta medida en que elderecho procesal penal camina estrechamente asociado a la Constitución, desde el origen del constitucionalismo, a punto de ya haber sido considerado el verdadero "sismógrafo" de una ley fundamental: la cada nueva orden constitucional, unnuevoderecho procesal penal.

889 Vid. la STS 7815/2007, de 15.11.2007. En lo mismo sentido, el Tribunal Supremo considera la infiltración policial como un procedimiento de investigación que se realiza de incógnito, sin revelar la identidad ni condición de policías con el fin de, una vez introducido en el ambiente criminal, poder conocer los planes y así abórtalos, y también para poder descubrir a los autores del hecho y procurar su detención. Cfr. la STS 1575/1998, de 9.3.1998.

890 Así lo concibe GOMÉZ DE LIÃNO FONSECA-HERRERO, respecto a la actuación de los agentes encubiertos, al señalar que "debe efectuarse, en todo caso, con un escrupuloso respecto al principio de proporcionalidad y al proceso debido, excluyentes de cualquier forma de oportunismo". Cfr. GOMÉZ DE LIAÑO FONSECA-HERRERO, M., "Límites y garantías procesales en la investigación mediante agente encubiertos", La Ley, año XXV, núm. 6142, 7 de diciembre de 2004, http://diariolaley.laley.es.

891 En lo que se refiere a la figura del agente encubierto, la utilización de la técnica del "engaño" se debe al hecho de que el infiltrado solamente conseguirá alcanzará su objetivo dentro del procedimiento de investigación, a partir del momento en que a través del uso de una identidad falsa, consiga obtener la confianza de los otros miembros de la organización criminal.

892 En este sentido, vid. CORRÊA DE CARVALHO, J. T., Tráfico de drogas. Prueba penal y medidas restrictivas de derechos fundamentales, cit., 311.

${ }^{893}$ REDONDO HERMIDA, A., "El agente encubierto en la jurisprudencia española y en la doctrina del Tribunal Europeo de Derechos Humanos", La Ley Penal, núm. 45, Madrid, 2008, pág. 95. 
trata de una operación de bajos costos, llevándose en consideración el entrenamiento de los eventuales infiltrados, la estructura material y logística relativa al plan de elaboración de la técnica de investigación, etc.

Se percibe incluso que el considerable aumento de las actividades de las organizaciones criminales ha supuesto un incremento y una flexibilización ${ }^{894} \mathrm{en}$ el empleo del agente encubierto como modalidad de investigación, con el consiguiente nacimiento de graves problemas tanto de Derecho Penal material, como procesales ${ }^{895}$. Tendremos la oportunidad más adelante, de analizar las más destacadas críticas a esta forma de investigación criminal delante de su empleo muchas veces ilegal y sin proporcionalidad por algunos Estados a través de sus agentes de seguridad.

Sin embargo, esta técnica de investigación solo tendrá eficacia y proporcionará resultados positivos a los fines de la pretensión persecutoria, a la vez que utilizada de forma legal, obedeciendo a los marcos teóricos del Estado Constitucional de Derecho, y en todo caso, no provocando vulneración innecesaria e injustificada a los derechos y garantías fundamentales de los investigados o imputados 896 .

El agente encubierto investiga el crimen desde el interior de la organización criminal, y según nuestro modo de pensar, actuando sin exceder el marco de las garantías constitucionales, se utiliza de técnicas de investigación para recabar datos, informaciones y pruebas que comprobé la práctica de delitos graves por los miembros de un determinado grupo de delincuentes ${ }^{897}$.

Dicho de otro modo, no tiene el infiltrado la intención de crear en la mente de la persona, algún propósito delictivo, a la vez que su objetivo consiste tan solo en ingresar en

894PÉREZ ARROYO M. R. "La provocación de la prueba, el agente provocador y el agente encubierto: la validez de la prueba y del delito en la lucha contra la criminalidad organizada desde el sistema de pruebas prohibidas en el Derecho penal y procesal penal", La Ley, números 4987, 4988 e 4989, 8-10 de febrero de 2000, págs. 1 y ss.

895Vid. DELGADO MARTíN, J., Criminalidad Organizada, cit., pág. 44.

896 Esta idea ha sido desarrollada con detalles en nuestro trabajo: "A moderna investigação criminal: infiltrações policiais, entregas controladas e vigiadas, equipes conjuntas de investigação e provas periciais de inteligência", cit., págs. 98-146.

897 En este orden de ideas, se justifica que la labor de agente encubierto "consiste en infiltrarse en organizaciones delictivas, desempeñando un papel que confunda a sus integrantes, permitiéndoles suponer que se trata de uno de ellos, para obtener información o pruebas que sirvan para impedir el delito o sancionarlo una vez producido". Cfr. la STS 4287/2002, de 12.06.2002. Se destaca también la importante opinión de MOLINA PÉREZ cuando señala que "y es precisamente en la actuación del agente encubierto en dónde hay que distinguir dos casos: 1ํ. La actuación policial que sirve para descubrir una infracción, ya consumada, del delito; $2^{\circ}$. La infiltración policial. En cuanto al primero, los supuestos que se pueden presentar son muy diversos, y habrán de interpretarse en cada caso concreto. En todo caso, existe un elemento en común dentro de la gran variedad de ellos, y es que la Policía solamente hace aflorar un delito que previamente ya se había cometido. Por tanto, si el delito ya se ha iniciado, la actuación policial sólo va a influir en el grado de perfección o agotamiento del mismo, bien porque se limita a su descubrimiento y constatación en la fase consumativa, bien porque origina su frustración si la intervención se produce antes de que el delito se consume. Todas estas actuaciones nos conducen a considerar que se trata de una técnica policial para descubrir a aquellos que han delinquido. La Policía actúa ejerciendo aquellas funciones que le otorgan las Leyes, porque el delito nace libremente de la voluntad del autor y se desarrolla conforme a esta ideación, hasta que la intervención policial se cruza. Es por tanto un medio de investigación cuya finalidad es descubrir una actividad delictiva prexistente. En cuanto al caso segundo, para poder descubrir a quiénes integran una organización de narcotraficantes, en muchos casos internacional, para poder desarticular esa red se necesita que los agentes policiales realicen una actividad de relación con los narcotraficantes, aparentando estar interesados en algún aspecto de esa actividad, para así descubrir el delito y a sus autores. Y esta es la única función que realiza el agente infiltrado. Vid. MOLINA PÉREZ, T., "Técnicas especiales de investigación del delito: el agente provocador, el agente infiltrado y figuras afines (y II)", Anuario Jurídico y Económico Escurialense, XLII, 2009, págs. 155-156. 
el seno de la organización criminal, y aprovechándose de la confianza adquirida, recabar informaciones, datos y pruebas que puedan ayudar a las autoridades de persecución penal al desbaratamiento del grupo de delincuentes.

Esto lo diferencia como ya veremos adelante, de la figura del agente provocador.

Se trata además, de uno de los más eficaces e interesantes instrumentos adoptados por la reacción penal estatal frente al rígido código de silencio impuesto en el seño de las organizaciones criminales. Funcionaría, pues, el procedimiento de infiltración, principalmente como forma preventiva ${ }^{898}$ de evitarse la práctica de delitos de significativa gravedad, lo que por cierto traería una seguridad destacada a las sociedades que conviven actualmente con el miedo y temor de las acciones violentas practicadas especialmente por grupos pertenecientes al terrorismo y al narcotráfico internacional.

Sin embargo, se observa que la figura del agente encubierto no es novedosa, pero sí su introducción totalmente innovadora en la mayoría de las normativas respeto de mecanismos de represión a delincuencia organizada ${ }^{899}$.

Es una realidad que casi todos los países del mundo disponen de agentes infiltrados, aunque en algunos ordenamientos esta figura no esté positivada ${ }^{900}$ y en este último caso, se producen hipótesis de actuaciones ilícitas, vulneradoras de garantías y derechos fundamentales, creando un ambiente para el desarrollo de ideas basadas enun Derecho Procesal penal del enemigo ${ }^{901}$.

Así mismo, la ambigüedad que muchas veces tiene caracterizado a sus funciones, y mismo su definición, permite en ocasiones, que bajo referencia a agentes encubiertos, o mismo de provocadores, se clasifiquen también de operaciones de espionaje de carácter absolutamente político. E incluso más grave, que bajo el pretexto de una operación encubierta se objetive alcanzar aspectospolíticos ${ }^{902}$. En este punto, ya dejamos afirmada

898 Dentro de este contexto, es correcto señalar que si en las funciones de la Policía se encuentran las de prevenir el delito o descubrir su perpetración, para conseguirlo, uno de los medios de investigación utilizado es el de la infiltración, cuyo fin es conocer los planes delictivos, abortarlos y detener a los autores. Así es que el agente encubierto, se constituye como una técnica de investigación necesaria para enfrentar cierto tipo de delincuencia especialmente grave, que se desarrolla en forma altamente organizada. Incluso según la jurisprudencia española la intervención policial dirigida a la obtención de pruebas y a la detención de los autores, puede darse en cualquier fase del itercriminis, tanto en las fases iniciales de preparación del delito, como una vez cometido. Cfr. Las SSTS, 4287/2002 de 12.6.2002, 4107/2003 de 13.6.2003 y 772/2007 de 25.1.2007.

899 Por esta razón, afirma CORRÊA DE CARVALHO que "la práctica de que los agentes gubernamentales disimulen sus actividades y objetivos en la investigación y prevención de la delincuencia no es nueva y empezó a ser utilizada con más frecuencia cuando los grupos criminales pasaron a contar con estructuras propias, a veces extremamente complejas, dotadas de medios humanos y materiales verdaderamente importantes y cerradas al exterior hasta el punto de extenderse en la sociedad la convicción de que eran inmunes a los métodos tradicionales de investigación". Vid. CORRÊA DE CARVALHO, J. T., Tráfico de drogas. Prueba penal y medidas restrictivas de derechos fundamentales, cit., pág. 312 .

900 Cítese como información de derecho comparado que de los 27 países miembros de la Unión Europea, 26 utilizan esta técnica de investigación, y además, de otros 18 países de Europa, 15 utilizan la figura del agente encubierto (excepción a Andorra, Mónaco y Ucrania).

901 En la concepción dogmática del "Derecho penal o procesal penal del enemigo", sostenida actualmente por Günther Jakobs y sus discípulos, se defiende con vigor la restricción inmoderada y irrazonable de los derechos y garantías fundamentales de aquellas personas consideradas como "enemigas" del Estado, y que a su vez han optado por actuaren de modo alejado de las normativas legales, justificando así, un tratamiento bélico contra estos delincuentes. Vid. con profundidad sobre este pensamiento dogmático, JAKOBS, G., Derecho Penal del Enemigo, Madrid, 2003.

902 ONETO, I., $O$ agente infiltrado. Contributo para a compreensão do Regime Jurídico das Acções Encobertas, cit., pág. 11. 
nuestra repulsa delante de la posibilidad de agentes de inteligencia estatal figuraren como infiltrados en una operación encubierta contra un determinado grupo de delincuentes organizados, afirmación esta que habremos de fundamentar en apartado siguiente.

Por fin, es importante recoger la cita de una de las importantes conclusiones extraídas de la Reunión del Grupo de Expertos para el control de Lavado de Activos de la Organización de los Estados Americanos (OEA): los métodos usados por las organizaciones criminales en sus actividades ilícitas, sea narcotráfico, crimen organizado o lavado de dinero, se han convertido en más sofisticadas y son en la mayoría de los casos, extremamente difíciles de detectar, lo que hace necesario el uso de las técnicas especiales de investigación para la obtención de medios probatorios que lleven a una efectiva condena ${ }^{903}$.

\section{IV.1.1.2. El origen histórico de la figura del "agente encubierto".}

Preliminarmente, en lo que aquí interesa, es fundamental en el contexto histórico destacar que en la antigüedad no se percibía una distinción clara y objetiva entre las figuras del agente encubierto y el agente provocador, confundiéndose estos dos personajes: en la practica el infiltrado en muchas ocasiones provocaba el delito en la búsqueda de obtención de informaciones para el control de la criminalidad.

Partiéndose de este enfoque se puede afirmar que el origen de la figura del agente encubierto o infiltrado puede ser encontrado en tiempos pasados. Las técnicas encubiertas tales como espías, informantes, agentes encubiertos, etc., fueron utilizadas en todas las fases de la historia de la humanidad. Los pueblos de la antigüedad utilizaban dichas técnicas con respecto a sus enemigos, generalmente los pueblos vecinos que pretendían conquistar ${ }^{904 .}$

Se trataba de una forma de conocer el oponente, conociendo los detalles de su estructura, con la finalidad dedescubrir el poderíodel grupo superiormente más fuerte, hecho este que vendría más tarde a facilitar el logro de obtención de la ocupación del territorio adversario.

El antecedente histórico más importante del agente encubierto es por lo tanto, la institución conocida como agent provocateur. Según MONTOYA, hay informaciones que sitúan por primera vez su existencia en el Génesis (III, 1-7), algunos en la antigüedad griega (Esopo, III, fábula V, Aesopuset petulans) y otros que consideran que dicho concepto proviene de la expresión francesa agent provocateur y está relacionado con las actividades de espionaje político llevadas a cabo en Francia, donde las instancias del poder organizaban atentados, se promovían disturbios, a fin de crear un clima psicológico para

\footnotetext{
903 Vid. el Informe de la Secretaria Ejecutiva sobre las Técnicas Especiales de Investigación, originario de la Reunión del Grupo de Expertos para el control del Lavado de Activos, Marzo 16-18, Washington DC, 2005, http://www.cicad.oas.org.

904 MOSCATO DE SANTAMARIA, C. B., El agente encubierto en el Estado de Derecho, cit., pág. 5. Esta idea también es desarrollada, con especial destaque para la cuestión de la estrategia, en la clásica obra de TZU, S., $A$ arte da guerra, São Paulo, 2007. En este libro, considerado como el "mayor tratado de guerra de todos los tiempos", queda claro que en tiempos pasados una de las estrategias más utilizadas en los conflictos consistía en estudiar los "enemigos" para aprender como combatirlos.
} 
fundamentar medidas persecutorias contra los enemigos políticos del régimen absolutista ${ }^{905}$.

En realidad, existe un gran número de opiniones respeto al origen histórico de los primeros personajes que actuaban como agentes provocadores y encubiertos ${ }^{906}$.

Como no había en la antigüedad una construcción dogmática y técnica para poner en claro las distinciones entre el agente provocador y el infiltrado, estas dos figuras han recibido el mismo calificativo de medio de búsqueda de informaciones por parte de un determinado grupo de personas para hacer frente a sus oponentes en la incesante lucha por el poder.

Asimismo, merece destacar que conocer el oponentesiempre ha sido una gran estrategia dentro del juego de la disputa por la supremacía de fuerzas.

Según la opinión de ONETO, la reciente autonomía conceptual del agente encubierto, marcada por la necesidad político criminal de su consagración legal, ha impuesto su cotejo con el agente provocador, figura esta creada en el ámbito doctrinario que, a cubierto de una carencia de tipificación legal, tiene visto garantizada su castigo. Cierto es que, hasta la efectiva separación dogmática de las dos figuras, su distinción ha sido puramente nominal, refiriendo indistintamente a la misma realidad; o sea, ambas se han movido históricamente bajo la designación de agent provocateur. Esta raíz común fue descrita en la literatura francesa y se reporta al período del Ancien régimen ${ }^{907 .}$

Desde esta concreta perspectiva, se puede afirmar que ha sido muy provechosa la separación conceptual de estas dos figuras, a la vez que en esencia, presentan características absolutamente distintas y con consecuencias jurídicas muy peculiares ${ }^{908}$.

De su parte, ALVES MEREIS recuerda que los primeros agentes provocadores de la historia europea fueron contratados por inspectores de la policía parisiense, en fines del siglo XVIII. Así, la policía distinguía entre aquellos que trabajaban encubiertos en la clandestinidad, a los que se les llamaba eufemísticamente "observateurs", y aquellos que son abiertamente contratados, a quien, en lenguaje popular, se denominaba de "mouches", o "sous-inspecteurs" o "préposés"909.

En sentido semejante, apunta DE MAGLIE que las primeras muestras de una práctica institucionalizada de infiltraciones se encuentran mismo en Francia del Antiguo Régimen,

905 Vid. MONTOYA, M. D., Informantes y técnicas de investigación encubiertas. Análisis Constitucional y Procesal Penal, cit., págs. 39-40. Además, como sostiene DELL'ANDRO, "en aquella época los agentes de policía inducían a otros a cometer delitos políticos con el fin de deshacerse de individuos vistos como peligrosos por el gobierno, ya sea para obtener una recompensa, para quedarse con sus bienes o con su mujer. Fue conocida la provocación con fines políticos en la época del Cardenal Richelieu y sobre todo en tiempos de Luis XIV, con la organización policial a las órdenes del Marqués de Argenson, cuya finalidad era, por una parte, la realización de acciones criminales con tintes políticos y por otra la creación de un clima en el cual se pudiera desarrollar la toma de medidas coercitivas desde el punto de vista social. La institución pasó del espionaje a la provocación". Cfr. DELL'ANDRO, R., "Agente provocatore", Enciclopedia del Diritto, Milano, 1958, pág. 864.

906 Por lo que se refiere al ordenamiento español, Cfr. sobre el origen de esta medida de investigación, RUIZ ANTÓN, L.F., El agente provocador en el Derecho Español, Madrid, 1982, págs. 5-6 y MUÑOZ SÁNCHEZ, J., El agente provocador, Valencia, 1995, págs. 21-22.

907 Vid. ONETO, I., O agente infiltrado. Contributo para a compreensão do Regime Jurídico das Acções Encobertas, cit., pág. 21.

908 Para una comprensión de esta distinción, vid. MONTÓN GARCÍA, M. L., "Agente provocador y agente encubierto: ordenemos conceptos", La Ley, año XX, núm. 4826, 1999.

909 Cfr. ALVES MEREIS, M. A., O regime das provas obtidas pelo agente provocador em Processo Penal, Coimbra, 1999, pág. 21. 
especialmente en la organización de la Policía de Paris durante el siglo XVIII, donde los inspectores de Policía, para obtener información sobre determinados delitos (hurtos, juego ilegal, conjuras políticas, imprentas clandestinas), se servían de los denominados "mouches" o "mouchards", sujetos que pertenecían a los entornos en que se cometían tales conductas (normalmente, detenidos que recuperaban su libertad a cambio de la cooperación), se trataba, por tanto, de infiltraciones controladas por la policía, aunque ejecutadas por sujetos particulares ${ }^{910}$.

$\mathrm{Al}$ respecto, se percibe entonces que el origen de las figuras actuales del arrepentido y del informante o colaborador de la justicia ha sido el mismo, o sea, el agent provocateur.

Destaca todavía MUÑOZ SÁNCHEZ que la utilización del agente provocador "como técnica de lucha contra la criminalidad" ha sido registrada anteriormente y ha sido una constante fija en las medidas táctico-policiales de los diversos regímenes políticos. El origen de esta institución se encuentra en el periodo del absolutismo francés, durante el cual, para reforzar el régimen, es criada la figura del delator, compuesta por ciudadanos que descubrían los enemigos políticos para recibir favores del príncipe. En esta época su actividad se limitaba a espiar y a dar conocimiento de los hechos a las autoridades sin que se realice una actividad de provocación ${ }^{911}$.

Por fin, recuerda ALVES BENTO que el primer registro histórico respecto de un programa organizado de infiltración de agentes ha sido empleado en Francia por EUGÈNE FRANÇOIS VIDOCQ ${ }^{912}$ en 1800, el cual fue considerado uno de los primeros infiltrados cuya actuación fuera en forma de particular' ${ }^{913}$.

Existen también informaciones que en Reino Unido ha sido instituido un programa de infiltración policial denominado "Special Irish Branch", en 1883 y que en Estados Unidos, en el año 1906, ha sido creado el "Italian Squad", después que diversos agentes federales han empezado a efectuar sus propias acciones de infiltración en el crimen organizado, sin un control judicial ${ }^{914}$.

De otra parte, adoptando un posicionamiento extremamente crítico, ZAFFARONI se refiere al recurso de esta figura durante la Inquisición, sustentando que la institución del agente encubierto, a la par de otras medidas que están preordenadas a aumentar la eficacia policial, se inscribe en un presupuesto genérico inmutable durante cierto tiempo, que tiene por objetivo la legitimación de coacción estatal ante la amenaza de un mal que 13.

910 DE MAGLIE, C., L'agent provocatore. Un'indagine dommatica e politico-criminale, Milano, 1991, págs. 7-

911 Véase, MUÑOZ SÁNCHEZ, J., La moderna problemática jurídico penal del Agente Provocador, Valencia, 1995, pág. 21.

912 Este ciudadano francés ha tenido un pasado envuelto con delitos, y según los historiadores, tendría inspirado Victor Hugo para la obra "Los miserables".

913 Cfr. ALVES BENTO, R., "Agente infiltrado. Busca pela legitimação constitucional", Limites Constitucionais da Investigação, cit., pág. 344.

914 Vid. MARX, G., Undercover: Police surveillance in America, Berkeley, 1988. En opinión de MONTOYA, respecto de los antecedentes de la figura del infiltrado en Inglaterra y en los Estados Unidos, se puede afirmar que "en la historia inglesa es dificultoso encontrarlo pero puede ser identificado con los Watchman. La primera clara evidencia del uso de agentes encubiertos en Inglaterra proviene de 1869 cuando el Chief Contable de Warwickshire solucionó el problema de la vagancia usando este tipo de individuos". También, "en los Estados Unidos su origen se remonta a la Agencia Pinkerton, que tenía gente encargada de infiltrarse en las bandas en el oeste americano. Después de la guerra civil, la Oficina Postal y el Departamento del Tesoro (Post Office y el Treasury Departament) usaron detectives encubiertos para luchar contra los robos de correos y falsificaciones. En 1930 el F.B.I comenzó a utilizar esta técnica". Vid. para más detalles, MONTOYA, M. D., Informantes y técnicas de investigación encubiertas. Análisis Constitucional y Procesal Penal, cit. págs. 82-83. 
recae sobre la humanidad. Así, la idea de que existe un mal continuo como legitimación de un poder policial que apela a cualquier medida para salvar la especie es propio de la Inquisición o sea, es preilustración, ha renacido con el positivismo que ha desembocado en regímenes autoritarios entre las dos grandes guerras y, en América Latina, en la llamada "doctrina" de la seguridad nacional que, basada en una hipótesis de una guerra total entre dos fuerzas, cuya manifestación regional era una "guerra sucia", ha legitimado métodos igualmente "sucios" como único recurso ${ }^{915}$.

Se puede concluir de modo general, por lo tanto, que el origen natural de la figura específica del agente encubierto puede ser buscado especialmente en la antigüedad, mas precisamente en Francia del siglo XVII.

IV.1.1.3. El marco conceptual del agente encubierto y de la técnica de infiltración.

En los más diversos diccionarios de la lengua española, de modo especial, el Diccionario de la Real Academia Española, es común se definir el acto de infiltrarse como "penetrar subrepticiamente en territorio ocupado por fuerzas enemigas a través de las posiciones de éstas" o "introducirse en un partido, corporación, medio social, etc., con propósito de espionaje, propaganda o sabotaje"916.

Esta definición muy general no esclarece integralmente lo que se debe entender por la figura del "agente infiltrado o encubierto" o mismo por el procedimiento de investigación denominado "infiltración", necesitando entonces de una inmersión en el ámbito del Derecho comparado.

Asimismo, merece destacar como punto de partida que en la jurisprudencia española ha sido consolidado que el infiltrado "es el agente de la autoridad que conoce o tiene noticias de la existencia de una actividad delictiva y se infiltra entre quienes la llevan a cabo en busca de información y pruebas que permitan impedir o sancionar el delito"917.

Agente encubierto sería entonces el policía judicial, especialmente seleccionado, que bajo identidad supuesta, actúa pasivamente con sujeción a la Ley y bajo el control del Juez, para investigar delitos propios de la delincuencia organizada y de difícil averiguación, cuando han fracasado otros métodos de la investigación o estos sean manifiestamente insuficientes, para su descubrimiento y permite recabar información sobre su estructura y modus operandi, así como obtener pruebas sobre la ejecución de hechos delictivos.

El Tribunal Supremo español también ha conceptuado la infiltración de un agente encubierto policial como un procedimiento de investigación que se realiza de incógnito, sin revelar la identidad ni condición de policías con el fin de, una vez introducido en el ambiente criminal, poder conocer los planes y así abortarlos, y también para poder descubrir a los autores del hecho y procurar su detención ${ }^{918}$.

915 ZAFFARONI, E. R., "Impunidad del agente encubierto y del delator: Una tendencia legislativa Latinoamericana", Révue Internationale de Droit Penal, año 67, Toulouse, 1996, pág. 726.

916 Diccionario de la lengua Española, Real Academia Española, 22a edición, http://www.rae.es.

917 Vid. la STS de 1316/2011, de 1.3.2007.

918Vid. STS 1575/1998, de 9.3.1998. 
Sin embargo, ha sido la doctrina quien más se ocupó de elaborar distintos conceptos sobre el denominado "agente encubierto"919, aportando diferentes elementos en su construcción.

Desde esta concreta perspectiva han sido elegidas algunas características o elementos que cuando son añadidos auna situación individualizada vienen formar el concepto del agente encubierto o de la técnica de infiltración.

De inicio, con relación al agente infiltrado, deberá ser un sujeto, ordinariamente integrado en las fuerzas de seguridad del Estado, especialmente un agente de Policía, que utilizará de una "identidad supuesta" a los fines de conseguir se infiltrar y obtener la confianza de los otros miembros de la organización criminal ${ }^{920}$. También deberá poseer el designio de investigar y descubrir una conducta delictiva en marcha o desarrollo, buscando pruebas, datos e informaciones que ayuden en la desarticulación de una concreta organización criminal ${ }^{921}$.

Asimismo, merece destacar la existencia de un requisito imprescindible a la actuación del infiltrado: la investigación de delitos graves, especialmente aquellos practicados por la delincuencia organizada de carácter transnacional ${ }^{922}$.

Por fin, algunos otros datos de interés pueden ser destacados en la búsqueda del establecimiento del concepto del infiltrado: el policía u otro agente de seguridad del Estado tiene que ser especialmente preparado y entrenado para esta concreta tarea de investigación y actuar bajo el control de una autoridad superior ${ }^{923}$, se sujetando a la obediencia de la ley y evitando al máximo la práctica de delitos que no presenten relación con el objeto de la investigación ${ }^{924}$.

También la doctrina extranjera ha realizado aportes dignos de mención. Partiéndose de este enfoque, podríamos citar algunos ejemplos de países donde la doctrina ha

\footnotetext{
919 Otras denominaciones pueden ser encontradas en el derecho comparado: Agente infiltrado (Brasil), Agente encoberto o homem de confiança (Portugal), Undercover (EEUU), Verdeckter Ermittler (Alemania), Agenti infiltrati di polizia o Agenti infiltrato (Italia), etc.

920 Vid. CARMONA SALGADO, C., "La circulación y entrega vigilada de drogas y el agente encubierto en el marco de la criminalidad organizada sobre narcotráfico", cit., págs. 181-182; DELGADO MARTíN, J., "El proceso penal ante la criminalidad organizada. El agente encubierto", cit., pág. 6; GASCÓN INCHAUSTI, F., Infiltración policial y agente encubierto, cit., pág. 10; PAZ RUBIO, J. M; MENDOZA MUÑOZ, J; MORICHE, R. R; OLLÉ SESÉ, M., La prueba en el proceso penal. Su práctica ante los Tribunales, Madrid, 1999, pág. 395; RIFÁ SOLER, J. M., "El agente encubierto o infiltrado en la nueva regulación de la LECrim", cit., pág. 164; RIVES SEVA, A. P., La prueba en el proceso penal. Doctrina de la Sala Segunda del Tribunal Supremo, 3a a edición, Navarra, 1999, págs. 60-61; RODRÍGUEZ FERNÁNDEZ, R., "Comentarios a la LO 5/1999, de 13 de enero: la entrega vigilada y el agente encubierto", Actualidad Jurídica Aranzadi, núm. 380, 1999, pág. 5.

921 Cfr. por todos, PÉREZ ARROYO, M. R., "La prueba provocada como supuesto de prueba prohibida en el proceso penal", Revista Jurídica de Castilla la Mancha, núm. 27, 1999, pág. 228; SEÖANE SPIEGELBERG, J. L., "Aspectos procesales del tráfico de drogas", cit., pág. 342; SOTO NIETO, F., El delito de tráfico ilegal de drogas: su relación con el delito de contrabando, 1a edición, Madrid, 1989, pág. 31; RIVES SEVA, A. P., La prueba en el proceso penal. Doctrina de la Sala Segunda del Tribunal Supremo, 3ª̣ edición, Navarra, 1999, págs. 60-61.

922 Vid. DELGADO MARTíN, J., "El proceso penal ante la criminalidad organizada. El agente encubierto", cit., pág. 6; PAZ RUBIO,J. M et alli., La prueba en el proceso penal. Su práctica ante los Tribunales, cit., pág. 395; RIFÁ SOLER, J. M., "El agente encubierto o infiltrado en la nueva regulación de la LECrim", cit., pág. 164.

923 Vid. ESPINOZA DE LOS MONTEROS, R. Z., El policía infiltrado. Los presupuestos jurídicos en el proceso penal español, cit., pág. 349-354; PAZ RUBIO, J. M et alli., La prueba en el proceso penal. Su práctica ante los Tribunales, cit., pág. 395.

924 En este sentido, dispone el artículo 282-bis 5 I de la LECrim que "El agente encubierto estará exento de responsabilidad criminal por aquellas actuaciones que sean consecuencia necesaria del desarrollo de la investigación, siempre que guarden la debida proporcionalidad con la finalidad de la misma y no constituyan una provocación al delito".
} 
desarrollado interesantes estudios sobre la figura del agente encubierto. Así, en Portugal, algunos autores apuntan que el agente infiltrado es el funcionario de la investigación criminal o tercera persona, por ejemplo, el ciudadano particular, que actúe bajo el control de la Policía que con la ocultación de su cualidad e identidad, y con el fin de la obtención de pruebas para la incriminación del sospecho, o sospechosos, gana su confianza personal, para mejor observar, en orden a obtener informaciones relativas a las actividades criminosas de que es sospecho y pruebas contra él, con las finalidades exclusivas de prevención o represión criminal, sin todavía, determinar a la práctica de nuevos delitos ${ }^{925}$.

Otra opinión es presentada por ALVES MEREIS, el cual define el agente infiltrado como aquello agente de la autoridad o ciudadano particular (pero que actúe de forma concertada con la policía) que, sin revelar su identidad o cualidad y con el fin de obtener pruebas para la incriminación de los sospechosos o entonces, simplemente para la obtención de la notitia criminis, gana la confianza personal, se manteniendo a la par de los acontecimientos, acompañando la ejecución de los hechos, practicando actos de ejecución si necesario, de forma a conseguir la información necesaria al fin que se propone ${ }^{926}$.

La nota de interés que se observa en estos conceptos extraídos de la doctrina portuguesa, igual que en la colombiana ${ }^{927}$, consiste en admitirse como agentes encubiertos tanto a policías como a particulares.

Otra observación respeto al aspecto conceptual de este medio extraordinario de investigación criminal puede también ser extraída de la doctrina portuguesa, opinión que no compartimos, donde se acepta la diferenciación entre las figuras del "agente encoberto" y del "agente infiltrado".

Así, el "agente encoberto" sería el agente de policía o un tercero concertado con aquello que, sin revelar su identidad o calidad y sin conquistar la confianza de los posibles infractores, frecuenta los sitios connotados con el crimen, v.g., bares, cafés, hipermercados, estaciones de tren, barrios de tráfico o de receptación de productos hurtados o robados, etc., con la finalidad de identificar y detener, caso exista flagrante delito de un crimen, posibles sospechosos de práctica de delitos, más o menos graves, públicos o semi públicos, sin que exista la determinación de la práctica de cualquier crimen. El "agente encoberto" no necesita de autorización judicial para actuar en el ambiente criminal y no está relacionado a un rol "cerrado" de delitos que pueden ser investigados ${ }^{928}$.

Ya el agente infiltrado posee naturaleza y funcionalidad distinta, pues éste es el funcionario de investigación criminal o un tercero, por ejemplo, un ciudadano particular, que actúe bajo el control de la Policía Judicial que, después de una autorización jurisdiccional, con ocultación de su calidad e identidad y con el fin de obtener pruebas para la incriminación del sospecho o sospechosos, gana su confianza personal para mejor observarlo mejor, en orden a obtener informaciones relativas a las actividades criminales de que es sospecho, así como obtener pruebas, reales o personales, contra ello (s), con las

925 Vid. GONÇALVES, F; JOÃO ALVES, M; GUEDES VALENTE, M. M., Lei e Crime. $O$ agente infiltrado versus o agente provocador. Os Princípios do Processo Penal, cit., pág. 264.

926 Cfr. ALVES MEREIS, M. A., O regime das provas obtidas pelo agente provocador em Processo Penal, cit., págs. 163-164.

927 Véase, por todos, RAMÍREZ JARAMILLO, A. D., El agente encubierto frente a los derechos fundamentales a la intimidad y a la no autoincriminación, Medellín, 2010, pág. 33; MARTÍNEZ PABÓN, S. J., La labor del agente encubierto en el sistema penal acusatorio, Bogotá, 2009. También sobre el tema, Cfr. la Sentencia de Constitucionalidad núm. 543/08 de la Corte Constitucional, de 28.5.2008 y el artículo 242 de la Ley 906/2004.

928 GUEDES VALENTE, M. M., Teoria Geral do Direito Policial, Tomo I, Coimbra, 2005, pág. 301. 
finalidades de prevención o represión criminal, sin que, por cualquier medio material o psicológico, determine aquellos a la práctica de nuevos delitos ${ }^{929}$.

A nuestro modo de pensar no sería muy técnica y pedagógica esta diferenciación ${ }^{930}$, puesto que el término "agente encoberto", que corresponde en Portugal la labor de un Policía que trabaja con un disfraz, sin el uniforme, acaba por provocar cierta confusión con el infiltrado, lo que nos lleva a comprender que mejor sería adoptar las definiciones de "agente encoberto" y "agente infiltrado" como sinónimos, dejando la denominación de "policía paisano" o "informante"931 para referirse a esa labor policial de investigar delitos callejeros de poca o ninguna gravedad, sin infiltrarse efectivamente en organizaciones criminales.

A su vez, en Argentina, otro país donde la doctrina ha desarrollado muy bien el tema del agente encubierto, MONTOYA considera que los agentes encubiertos son agentes de policía especialmente seleccionados que actúan dentro del marco legal vigente y a largo plazo con una asignación concreta para combatir delitos especialmente peligrosos y/o de difícil esclarecimiento, provistos de una leyenda y manteniendo en secreto su identidad, toman contacto con la escena delictiva para lograr puntos de apoyo informativos con la finalidad de repeler el peligro y/o llevar a cabo la persecución penal cuando han fracasado otros métodos de investigación o estos no aseguren el éxito buscado ${ }^{932}$.

Del mismo modo, CAFFERATA NORES, define el agente encubierto como un funcionario público que fingiendo no serlo (simulando ser delincuente) se infiltra, por disposición judicial, en una organización delictiva (por ejemplo, de narcotraficantes), con el propósito de proporcionar "desde adentro" información que permita el enjuiciamiento de sus integrantes y, como consecuencia, el desbaratamiento de esa asociación ilícita933.

Por fin, en la doctrina brasileña, siguiendo la misma tendencia adoptada por España y Argentina, el agente infiltrado sería aquél que oculta su identidad y calidad para los fines de obtención de pruebas para incriminar el sospechoso, de forma a ganar su confianza y, así, pasar a observar para obtener informaciones sobre la actividad criminosa934.

929 GUEDES VALENTE, M. M., Teoria Geral do Direito Policial, cit., págs. 169-170. Con una posición peculiar, negando la necesidad de distinción entre estos dos personajes, pero admitiendo se tratar el "agente encoberto", de una sub especie de "agente infiltrado", vid. ONETO, I., O agente infiltrado. Contributo para a compreensão do regime jurídico das acções encobertas, cit., págs. 138-140.

930 También sosteniendo la ausencia de necesidad en se proceder la distinción entre las figuras del "agente infiltrado" y el "agente encoberto" en la legislación portuguesa, vid. PEREIRA, S., "A recolha da prova por agente infiltrado", VV.AA., Prova Criminal e Direito de Defesa. Estudos Sobre Teoria da Prova e Garantias de Defesa em Processo Penal, F. L da Costa Pinto y T. Pizarro Beleza coords., Coimbra, 2010, pág. 143.

931 Incluso, cuando el suministro de información es meramente ocasional, y no se prolonga en el tiempo, algunos emplean el nombre de "informante". Así lo hace GUARIGLIA, F., "El agente encubierto. ¿Un nuevo protagonista en el procedimiento penal?", Revista Jueces para la Democracia, núm. 23, 1994, pág. 50, nota 6.

932 Véase, MONTOYA, M. D., Informantes y técnicas de investigación encubiertas. Análisis Constitucional y Procesal Penal, cit., pág. 155. En sentido semejante, Cfr. MOSCATO DE SANTAMARIA, C. B., El agente Encubierto en el Estado de Derecho, cit., pág. 1 y CASSANI, B., "Agentes encubiertos e informantes como medios de prueba contra el crimen organizado", cit., págs. 237-238.

933 Cfr. CAFFERATA NORES, J. I., La prueba en el proceso penal, Buenos Aires, 2003, pág. 223.

934 FRANCO, A. S., Leis penais especiais e sua interpretação jurisprudencial, 7ạ edición, SãoPaulo, 2001, pág. 584; POLASTRI LIMA, M., Processo penal Europeu. Preservação e direitos individuais (Princípios processuais e análise da Convenção Européia de Direitos Humanos), Rio de Janeiro, 2008, págs. 47-48. 
No menos dispares son las aportaciones relacionadas con el trabajo de investigación denominado "infiltración"935.

Como técnica de investigación, la infiltración tiene como objeto central la utilización de una persona que ingresada en un determinado ambiente de una organización criminal, habrá que utilizar de las más diversas formas de obtención de informaciones, con la finalidad de recabar pruebas que puedan interesar a los órganos de persecución penal.

En este sentido, el trabajo de infiltración consiste en la ocultación de la verdadera identidad, en aras a establecer una relación de confianza con la finalidad primordial, igualmente oculta, de obtener la información necesaria para satisfacer determinados intereses públicos y/o privados ${ }^{936}$.

Sin embargo, esta técnica se refiere a uno de los procedimientos de obtención encubierta de informaciones más complejos y arriesgados, pues supone preparar y posteriormente posibilitar que un agente estatal pueda adentrarse en un entorno grupal netamente hostil, a fin de que permanezca por un cierto lapso de tiempo en busca del conocimiento sobre los secretos y formas de actuación de una determinada organización criminal.

En palabras de GASCÓN INCHAUSTI la infiltración sería concretamente la acción de aquél que, para obtener una información que no es de acceso general y que le es necesaria para un propósito concreto, oculta tanto su identidad real como sus intenciones y, bien directamente bien a través de un tercero, entra en contacto con las personas aparentemente susceptibles de suministrársela, estableciendo con ellas una falsa relación de confianza que, con el transcurso del tiempo, le permita obtener la información deseada ${ }^{937}$.

Ante esta diversidad de opiniones cabe preguntarse si existe un concepto ideal y cerrado para definir la figura del agente encubierto, e incluso el medio extraordinario de investigación denominado infiltración.

Contestando a esta interrogante, hay que destacar en general que la mezcla o la fusión de algunos de los aspectos recogidos en los varios conceptos anteriormente citados podrían presentar una satisfactoria respuesta a estas dudas.

Así es que hechas las debidas consideraciones sobre la ausencia de univocidad respecto a la conceptuación del agente encubierto en la doctrina internacional y como colofón importante del debate doctrinal desplegado en torno a esta cuestión, exponemos nuestro concepto personal sobre lo que puede se considerar como un agente encubierto en el marco de un Estado constitucional y democrático de Derecho.

\footnotetext{
935Nos cumple en este momento distinguir entre el agente encubierto y la operación de infiltración, pues el primero consiste en el medio por el que se hace efectiva la infiltración, a la vez que la segunda sería la técnica de investigación criminal.

936 Vid. GOMÉZ DE LIAÑO FONSECA-HERRERO, M., Criminalidad organizada y medios extraordinarios de investigación, cit., pág. 125.

937 Véase, GASCÓN INCHAUSTI, F., Infiltración policial y agente encubierto, cit., pág. 10. En el mismo sentido, Cfr. ARAÚJO DA SILVA, E., Crime organizado. Procedimento probatório, cit., pág. 86; FEITOZA PACHECO, D., Direito Processual Penal. Teoria, crítica e praxis, 3a edición, Niterói, 2005, pág. 967; GOMÉZ DE LIAÑO FONSECA-HERRERO, M., Criminalidad organizada y medios extraordinarios de investigación, cit., pág. 125; MENDRONI, M. B., Crime organizado. Aspectos gerais e mecanismos legais, cit., págs. 69-70; RAMÍREZ JARAMILLO, A. D., El agente encubierto frente a los derechos fundamentales a la intimidad y a la no autoincriminación, Medellín, 2010, pág. 29.
} 
El agente encubierto, infiltrado o "topo" en lenguaje coloquial, es la figura representada por la persona que ejerce una función policial, debidamente entrenada para esta actuación, que bajo la subordinación de las autoridades competentes, y contando con autorización judicial fundamentada en el principio de proporcionalidad y, utilizando de una identidad supuesta, consigue se introducir en las entrañas de una determinada organización criminal, utilizandolas varias técnicas encubiertas de investigación, incluso con actos de engaño y disimulación, con la finalidad específica de obtener pruebas, informaciones y datos de la comisión de delitos graves por los miembros del clan criminoso y por consecuencia, con el ofrecimiento de las informaciones necesarias a las autoridades, con el objetivo de ayudar en la desarticulación de toda la estructura de macrocriminalidad a través de una sentencia condenatoria de los delincuentes.

De lo dicho resulta que el infiltrado deberá pautar su actuación en el respecto a los principios del Estado constitucional de Derecho, muy especialmente en el debido proceso legal y en la proporcionalidad 938 .

Deberá también el agente aceptar esta tarea libre y voluntariamente, dado el enorme riesgo personal que su ejecución conlleva, incluso a la familia del infiltrado.

Entendemos del mismo modo, que la infiltración policial como técnica es un medio extraordinario de investigación criminal ${ }^{939}$, dónde se posibilita a un funcionario de las fuerzas policiales (el agente encubierto), mediante un cierto control por las autoridades competentes $^{940}$, la oportunidad a través del uso de técnicas de inteligencia criminal y bajo el uso de identidad supuesta, para adentrar en el seno de la organización criminal, buscando con esta tarea, levantar datos e informaciones que pueden ser útiles a la eventual desarticulación del grupo criminal.

También hay que dejar indicación de una clasificación sui generis en la doctrina penal, donde DELGADO MARTÍN distingue entre "agente meramente encubierto", "agente encubierto infiltrado" y "agente encubierto infiltrado con identidad supuesta", según que el agente esté actuando de forma breve y externa en relación a la organización (encubierto de corta duración), esté efectivamente infiltrado de forma duradera y manteniendo su

938 En esta línea de pensamiento, advierte ARAUJO DA SILVA, que "es necesario identificar un punto de equilibrio entre los intereses estatales y los principios orientadores del Estado de Derecho, pues si de un lado el Estado debe buscar reprimir con eficiencia la criminalidad organizada, de otro, no pueden sus agentes practicar cualquier infracciones penales, que eventualmente pueden ser más gravosas que las cometidas por la organización criminal. Habría inevitable contrasentido, pues naturalmente no se presenta razonable concebir que el estado pueda, por sus agentes, en la actividad de persecución criminal, practicar conductas más graves que las apuradas. El análisis de la proporcionalidad entre la conducta del policía infiltrado y el fin buscado por la investigación es el camino a ser buscado". Cfr. ARAUJO DA SILVA, E., Crime organizado, Procedimento probatório, cit., pág. 90.

939 Se Justifica este calificativo, "en atención a que dos notas inherentes a la figura determina graves repercusiones desde el inicio en derechos y principios constitucionales: el engaño y la identidad falsa facilitada por el Estado al policía que voluntariamente asume la condición de infiltrado". En este sentido, vid. GOMÉZ DE LIAÑO FONSECA-HERRERO, M., "El agente encubierto como medida de investigación del terrorismo en el contexto internacional", cit., pág. 421.

940 Por esto se afirmar que "es necesario un eficaz control judicial, no solo en la autorización de la medida, sino también en el desarrollo de la misma". Vid. GONZÁLEZ-CASTELL, A. C., "El agente infiltrado en España y Portugal. Estudio comparado a la luz de las garantías y de los principios constitucionales", cit., pág. 207. En el mismo sentido, MORENO CATENA; GIMENO SENDRA y CORTÉS DOMÍNGUEZ al señalaren que "el cumplimiento de los presupuestos necesarios para la adopción de una medida restrictiva de derechos fundamentales carecería de sentido y trascendencia, como garantía y protección del derecho fundamental, si la actuación judicial se limitara a ordenar la diligencia, sin preocuparse del posterior desarrollo y cese de la medida de intervención". Véase, MORENO CATENA, V; GIMENO SENDRA, V; CORTÉS DOMÍNGUEZ, V., Derecho Procesal Penal, cit., pág. 456. También la STS 49/1996, de 26.3.1996. 
identidad original, o, finalmente, cuando esté actuando infiltrado de forma duradera y con identidad supuesta941. A nuestro juicio parece un poco confusa esta distinción, a la vez que se debe considerarinadecuado el uso del calificativo "encubierto" para designar funciones absolutamente dispares.

Algún sector de la doctrina define además la actuación del agente encubierto como una forma de infiltración pública directa. Dos serian los motivos claros para esta definición. En primer lugar, porque el sujeto activo de la operación ha de ser, por prescripción legal, un funcionario público, policía judicial en sentido estricto, que aparte de esconder su relación laboral, opera bajo una identidad falsa proporcionada por el Estado. En segundo, porque el poder público es el último interesado en la información averiguada ${ }^{942}$.

Tendremos la oportunidad de profundizar sobre las distintas especies de infiltración en apartado propio.

Para finalizar, importante dejar constancia del exitoso concepto elaborado por el grupo de trabajo oficioso de expertos sobre "Técnicas especiales de investigación" de las Naciones Unidas: las operaciones policiales encubiertas consisten en un proceso planificado de investigación y vigilancia en el que los funcionarios de policía utilizan disfraces y subterfugios para obtener información y pruebas respecto de presuntos delincuentes o delitos penales, en especial cuando se trata de situaciones y personas que escapan a los métodos tradicionales de aplicación de la ley ${ }^{943}$.

IV.1.2. El agente infiltrado en tratados y acuerdos internacionales.

El reconocimiento de las técnicas de investigaciones encubiertas en las más importantes recomendaciones internacionales demuestra la importancia del personaje denominado "agente encubierto" o "infiltrado" en el actual contexto de contención del desarrollo de la delincuencia organizada transnacional.

Y es así en razón de que tradicionalmente la actuación de las organizaciones criminales ha desestabilizado los pilares básicos de los Estados. Ahora, tras los cambios cuantitativos (desde el punto de vista territorial) y cualitativo (desde el punto de vista de la especialización de las técnicas delictivas y de sus miembros) que ha experimentado, su actuación afecta a los bienes e intereses de la comunidad internacional ${ }^{944}$.

Nótese que en los últimos tiempos ha sido en Europa ${ }^{945}$ donde el desarrollo del tema fue destacado con intensa preocupación por los países que se vieron afectados por las

941 DELGADO MARTÍN, J., Criminalidad organizada, cit., págs. 47-48.

942 Cfr. GOMÉZ DE LIAÑO FONSECA-HERRERO, M., "El agente encubierto como medida de investigación del terrorismo en el contexto internacional", cit., pág. 421.

943Véase a respecto, el informe elaborado por el grupo de trabajo oficioso de expertos sobre técnicas especiales de investigación, prácticas óptimas y recomendaciones sobre los obstáculos jurídicos a las entregas vigiladas y las operaciones encubiertas, subscrito por Naciones Unidas (Oficina contra la Droga y el Delito), septiembre de 2005, pág. 20.

944 Vid. ESPINOSA DE LOS MONTEROS, R. Z., "Implicaciones del Tratado de Lisboa en la lucha contra la delincuencia organizada", Revista General de Derecho Penal, núm. 14, 2010, http://www.iustel.com.

945 En los Estados Unidos de América también ha sido muy intensa la utilización de agentes encubiertos, en especial después de los actos terroristas del 11 de septiembre de 2001, donde nació el término "guerra contra el terror". Todavía, como tendremos la oportunidad de analizar, en este país la actuación del personaje undercover agent, cuyas atribuciones son distintas del infiltrado objeto de nuestro estudio, ha sido destacada incluso en la forma preventiva, como se observa con relación a los agentes de la policía antiterrorista 
actuaciones de grandes grupos criminales, las que han provocado preocupaciones y perjuicios a lo largo de los años, llegando hasta hoy sus actividades. Sirvan como ejemplos, las acciones perpetradas por las mafias italianas y rusas o las actuaciones terroristas de ETA en España y el IRA en Irlanda.

Así, en los diversos foros internacionales, desde las Naciones Unidas hasta la Unión Europea y pasando por el Consejo de Europa, se ha desarrollado una ingente y continua labor de regulación normativa de variados niveles (acuerdos, tratados internacionales, convenios, directivas, recomendaciones), que han tomado como elemento clave la prevención y represión de la delincuencia organizada, especialmente en materia de tráfico de drogas, terrorismo y blanqueo de capitales ${ }^{946}$.

Regístrese que la Convención de Naciones Unidas contra el crimen organizado de 15 de noviembre de 2000 al tratar del tema de las "técnicas especiales de investigación", determina siempre que lo permitan los principios fundamentales del ordenamiento jurídico del Estado, el reconocimiento de técnicas de investigación especial como las operaciones encubiertas (art. 20.1) ${ }^{947}$; también la Convención de la ONU contra la Corrupción de 2003 (art. 50.1) ${ }^{948}$, en el que además se añade que los Estados tomarán las medidas necesarias para permitir la admisibilidad de las pruebas derivadas de esta técnica.

Respecto a la citada Convención de Naciones Unidas contra el Crimen Organizado, señala GUZMÁN FLUJA que se aprecia que el texto se limita a regular la posibilidad de utilizar operaciones encubiertas como medio especial de investigación de la criminalidad organizada, pero no se establece ninguna condición material sobre cómo o con qué requisitos pueden llevarse a cabo, algo que se deja a los Derechos internos de los Estados $^{949}$.

Importante también en el escenario europeo ha sido la Recomendación Rec (2001) 11 del Comité de Ministros del Consejo de Europa sobre los principios y directrices en la lucha contra el crimen organizado, en el que se estableció que "deben desarrollarse nuevos métodos de trabajo policial que muden su foco deatención de una policía reactiva

norteamericana dentro de los aviones comerciales, con la finalidad de vigilar de forma general y intensificada los pajareros y personas sospechosas de pertenecieren a grupos terroristas.

946GUZMÁN FLUJA, V. C., "El agente encubierto y las garantías del proceso penal", cit., pág. 208.

947 "Siempre que lo permitan los principios fundamentales de su ordenamiento jurídico interno, cada Estado Parte adoptará, dentro de sus posibilidades y en las condiciones prescritas por su derecho interno, las medidas que sean necesarias para permitir el adecuado recurso a la entrega vigilada y, cuando lo considere apropiado, la utilización de otras técnicas especiales de investigación, como la vigilancia electrónica o de otra índole y las operaciones encubiertas, por sus autoridades competentes en su territorio con objeto de combatir eficazmente la delincuencia organizada".

948"Con la finalidad de combatir eficazmente la corrupción, cada Estado Parte, en la medida en que lo permitan los principios fundamentales de su ordenamiento jurídico interno y conforme a las condiciones prescritas por su derecho interno, adoptará las medidas que sean necesarias, dentro de sus posibilidades, para prever el adecuado recurso, por sus autoridades competentes en su territorio, a la entrega vigilada y, cuando lo considere apropiado, a otras técnicas especiales de investigación como la vigilancia electrónica o de otra índole y las operaciones encubiertas, así como para permitir la admisibilidad de las pruebas derivadas de esas técnicas en sus tribunales".

949 Cfr. GUZMÁN FLUJA, V. C., "El agente encubierto y las garantías del proceso penal, cit., pág. 209. En estrecha relación con lo anterior, pensamos que la ausencia de explicación en esta Convención de los requisitos mínimos para la implantación de estas técnicas de investigación genera la posibilidad de que ocurra una notable discrepancia entre los distintos ordenamientos jurídicos-penales de los países afectados por el problema de la expansión del crimen organizado, dificultando incluso una cooperación penal internacional entre varios Estados. 
(reactive policing), a una policía proactiva (proactive policing), incluyendo el uso de inteligencia estratégica y análisis del crimen".

Del mismo modo, en el ámbito europeo comunitario el Convenio entre los Estados miembros de la Unión Europea de asistencia judicial penal de $2000^{950}$ (Acto del Consejo 2000/C 197/01, de 29.5.2000) regula las operaciones encubiertas internacionales (art. 14). Establece este Convenio la posibilidad de que los Estados convengan su realización, así como el régimen jurídico a que deban atenerse los funcionarios implicados. Además en el artículo 15 se establece que en el desarrollo de estas operaciones los funcionarios de un Estado miembro que actúen en territorio de otro se asimilarán a los funcionarios públicos del Estado en que se desarrolle en lo que respecta a su responsabilidad penal.

Con este Convenio, la Unión Europea se ha querido sumar a la actuación legislativa en que en otros organismos internacionales se viene desarrollando contra determinadas formas de delincuencia grave con dimensión transfronteriza, en especial Naciones Unidas y el Consejo de Europa ${ }^{951 .}$

Importante además apuntar que en este texto, de modo semejante a la Convención de Naciones Unidas contra el Crimen Organizado Transnacional, tanto la duración, como las condiciones concretas y el régimen de los agentes encubiertos quedan confiados a las legislaciones nacionales, sin que se regulen en el convenio condiciones comunes mínimas. En este sentido, las regulaciones nacionales son muy variadas, y se encuentran desde Estados que no las contemplan o regulan, hasta Estados que las regulan con cierta flexibilidad y otros que lo hacen con mayor rigurosidad 952 .

También tiene que ser mencionado el Convenio celebrado sobre la base del artículo K.3 del Tratado de la Unión Europea, relativo a la asistencia mutua y la cooperación entre las Administraciones aduaneras, hecho en Bruselas el 18 de diciembre de 1997, el cual establece una serie de formas especiales de cooperación entre las que figura, en el artículo 23 , las investigaciones encubiertas 953 .

950 Este Convenio regula las operaciones encubiertas internacionales, estableciendo la posibilidad de que los Estados convengan su realización y que los funcionarios de un Estado que sean autorizados a actuar en territorio de otro sean beneficiarios de las reglas de exención de responsabilidad como si fueran agentes nacionales.

951 FABIÁN CAPARRós, E. A.; MERCHÁn MATEOS, J. F; RODRÍGUEZ GARCÍA, N; ZARAGOZA AGUADO, J. A., Delincuencia económica y blanqueo de capitales, Salamanca, 2005 (inédito), pág. 415.

952 Vid. GUZMÁN FLUJA, V. C., "El agente encubierto y las garantías del proceso penal", cit., págs. 210-211. En el mismo sentido, señala RODRÍGUEZ GARCÍA que "el Convenio impone la colaboración entre los Estados interesados para garantizar la preparación y supervisión de la investigación, así como la adopción de medidas de seguridad de los agentes infiltrados. La duración de la investigación encubierta, condiciones concretas y régimen jurídico de los agentes se regulará por los acuerdos alcanzados por los distintos Estados miembros de acuerdo con su respectiva legislación interna y procedimientos nacionales". Vid. RODRÍGUEZ GARCÍA, N., "Asistencia judicial penal para luchar contra la corrupción, el blanqueo de capitales y la delincuencia organizada. Algunos apuntes sobre el convenio de la Unión Europea", cit., pág. 363.

953 Artículo 23: 1. A petición de la autoridad requirente, la autoridad requerida podrá autorizar que operen en el territorio del Estado miembro requerido funcionarios de la Administración aduanera del Estado miembro requirente o funcionarios que actúen por cuenta de dicha Administración, con identidad supuesta (investigadores infiltrados). La autoridad requirente sólo presentará la solicitud en el caso de que fuera extremadamente difícil aclarar los hechos sin proceder a las medidas de investigación consideradas. Los funcionarios mencionados estarán autorizados, en el marco de su misión, a recoger información y establecer contactos con sospechosos u otras personas del entorno de los sospechosos. 2. Las investigaciones encubiertas en el Estado miembro requerido tendrán una duración limitada. La preparación y dirección de las investigaciones se realizará en estrecha cooperación entre las autoridades correspondientes del Estado miembro requerido y del Estado miembro requirente.3. La autoridad requerida determinará, de acuerdo con su Derecho nacional, los requisitos de autorización de la investigación encubierta, así como las condiciones en 
En el escenario del ámbito de las normativas internacionales, hay que hacer hincapié sobre la importancia de la jurisprudencia europea, la cual ha admitido la utilización de las operaciones encubiertas, pudiendo citarse la inédita Sentencia del Tribunal Europeo de Derechos Humanos, de 15.6.1992, caso Lüdi versus Suiza ${ }^{954}$, la cual ha sido posteriormente vencida por la sentencia Teixeira de Castro c. Portugal, de 9.6.1998955.

Antes de finalizar este apartado, aunque el tema de los medios extraordinarios de investigación no es contemplado de modo detallado en algunas normativas internacionales, nos parece importante realizar alguna observación respecto a la Carta de los Derechos Fundamentales de la Unión Europea y su intima relación con el reciente Tratado de Lisboa, el cual también es conocido como "Tratado reformador"956.

Todavía, para comprender mejor el sentido del citado Tratado, es necesario ubicarlo en el marco de la lucha contra la delincuencia transnacional, esclareciendo que uno de los inconvenientes que se encuentra en la aplicación de las técnicas de lucha contra el crimen organizada consiste en la falta de armonización de las legislaciones de los diferentes Estados miembros que dificulta, en gran parte, la cooperación policial y judicial frente a una delincuencia cada vez más peligrosa, más sofisticada, que avanza muy rápidamente, y que, en definitiva, no recibe el castigo merecido a sus conductas criminales. Esta falta de armonización supone que los miembros de las organizaciones criminales, encuentren

las que ésta se realizará. Cuando en el transcurso de una investigación encubierta se obtenga información sobre una infracción distinta de la indicada en la solicitud original, la autoridad requerida también determinará, de acuerdo con su Derecho nacional, las condiciones de utilización de esa información.4. La autoridad requerida prestará la asistencia necesaria tanto de personal como de medios técnicos. La autoridad requerida asumirá todas las medidas de protección de los funcionarios a que se refiere el apartado 1 cuando éstos operen en el Estado miembro requerido. 5. Todo Estado miembro podrá declarar, con ocasión del depósito de su instrumento de adopción del presente Convenio, que no está vinculado por el presente artículo o parte del mismo. Dicha declaración podrá retirarse en cualquier momento". Sobre el tema, señala ESPINOSA DE LOS MONTEROS que "en el ámbito de la Unión Europea y bajo el auspicio del Tercer Pilar (cooperación judicial y policial entre los Estados miembros), estas operaciones encuentran su origen legal en el Convenio celebrado sobre la base del artículo K.3 del Tratado de la Unión Europea, relativo a la asistencia mutua y la cooperación entre las Administraciones aduaneras, conocido como Nápoles II (DOCE C 24 de 23 de noviembre de 1998). En este Convenio, firmado el 18 de diciembre de 1997, se encuentra, en su precepto número 23 la primera regulación legal del agente encubierto. No obstante, el plano interno, países como Dinamarca y Alemania se revelan como las pioneras en el reconocimiento legal de la intervención de un agente encubierto al regularla desde 1986 y 1992 respectivamente". Vid. ESPINOSA DE LOS MONTEROS, R. Z., El policía infiltrado. Los presupuestos jurídicos en el proceso penal español, cit., pág. 25.

954En este caso, un agente de policía infiltrado en una supuesta red de narcotraficantes había grabado las conversaciones telefónicas sostenidas por un también supuesto integrante de tal red con quien había trabado amistad interesada. El TEDH estimó innecesaria la habilitación legal, con base en la siguiente argumentación: "el recurso a un agente encubierto no afecta por sí, ni en combinación con las escuchas telefónicas a la esfera privada del demandante en el sentido del art. 8º del CEDH, pues desde el momento en que el Sr. Lüdi aceptó la transacción sobre la droga debía darse cuenta de que cometía un acto criminal por aplicación del art. 19 de la ley sobre estupefacientes y corría el riesgo, en consecuencia, de encontrar un funcionario policial encargado de desenmascararlo (FJ 40)". Todavía, en cualquier caso, esta primera y única doctrina del Tribunal Europeo fue completamente desterrada por la posterior sentencia Teixeira de Castro c. Portugal, de 9.6.1998, donde el Tribunal tuvo ocasión de recordar que "la intervención de agentes encubiertos debe estar circunscrita y rodeada de garantías incluso en el tráfico de estupefacientes, En efecto, si la expansión de la delincuencia organizada lleva a no dudar de la adopción de medidas apropiadas, no queda más que, en una sociedad democrática, el derecho a que una buena administración de justicia ocupe un lugar tan preeminente, que no podamos sacrificarla por conveniencia (FJ 36)". Vid. GÓMEZ DE LIAÑO FONSECA-HERRERO, M., "Límites y garantías procesales en la investigación mediante agente encubiertos", cit., http://diariolaley.laley.es.

955 Para un completo estudio respecto a esta significada Decisión vid. LOUREIRO, J., Agente infiltrado? Agente provocador! Reflexões sobre o $1^{o}$ acórdão do T. E. D. Homem - 9 junho 1998. Condenação do Estado Português, Coimbra, 2007.

956 Terminología esta ampliamente utilizada por la doctrina española. Cfr. VV.AA., Carta de los derechos fundamentales de la Unión Europea: comentario artículo por artículo, A. Mangas Martín y L. N. González Alonso coords., Madrid, 2008. 
verdaderos paraísos jurídico-penales (en donde no encuentran reproche a sus acciones ilícitas) ${ }^{957}$.

Así, la conclusión según ESPINOSA DE LOS MONTEROS es que la existencia de un sistema procesal común, o al menos homogéneo, conllevaría la satisfacción de las necesidades que la sociedad reclama en materia de libertad, seguridad y justicia ${ }^{958}$.

Relacionado con ello, según el art. 52.1 de la Carta de los Derechos Fundamentales de la Unión Europea959, "cualquier limitación del ejercicio de los derechos y libertades reconocidos por la presente Carta deberá ser establecida por la ley y respectar el contenido esencial de dichos derechos y libertades. Dentro del respeto del principio de proporcionalidad, sólo podrán introducirse limitaciones cuando sean necesarias y respondan efectivamente a objetivos de interés general reconocidos por la Unión o a la necesidad de protección de los derechos y libertades de los demás".

En análisis al citado precepto legal, sostiene MANGAS MARTíN que el apartado 1 del art. 52 de la Carta reconoce que los derechos garantizados por esta pueden presentar limitaciones y que éstas sólo son admisibles si se han acordado en una ley, responden a objetivos de interés general o de respecto de otros derechos, no desnaturalizan o hacen imposible el propio derecho de libertad y si son proporcionadas ${ }^{960}$.

Siguiendo esta posición, importante destacar que el llamado "espacio de libertad, seguridad y justicia"961 es uno de los ámbitos de actuación de la Unión Europea en el que

957 Al respecto, señala HOYOS SANCHO que "La fiducia reciproca ha de constituir sin duda el punto de partida de las relaciones interestatales en la UE, en el ámbito de la cooperación judicial penal también; sin embargo, la presunción de que cada actuación procesal se ha llevado a cabo en el supuesto concreto con arreglo a los principios rectores de un Estado de Derecho sería absolutamente irreal". Cfr. HOYOS SANCHO, M., "La armonización de los procesos penales, reconocimiento mutuo y garantías esenciales", VV.AA., El proceso penal en la Unión Europea: garantías esenciales, M. de Hoyos Sancho coord., Valladolid, 2008, pág. 68.

958 Cfr. ESPINOSA DE LOS MONTEROS, R. Z., "Implicaciones del Tratado de Lisboa en la lucha contra la delincuencia organizada", Revista General de Derecho Penal, núm. 14, 2010, http://www.iustel.com.

${ }^{959}$ La Carta de los Derechos Fundamentales de la Unión Europea es un documento que contiene provisiones de derechos humanos proclamado por el Parlamento Europeo, el Consejo de la Unión Europea y la Comisión Europea el 7 de diciembre de 2000. Desde esta concreta perspectiva, la citada Carta reafirma, respetando las competencias y misiones de la Comunidad y de la Unión, así como el principio de subsidiariedad, los derechos reconocidos especialmente por las tradiciones constitucionales y las obligaciones internacionales comunes de los Estados miembros, el Tratado de la Unión Europea y los Tratados comunitarios, el Convenio Europeo para la Protección de los Derechos Humanos y de las Libertades Fundamentales, las Cartas Sociales adoptadas por la Comunidad y por el Consejo de Europa, así como por la jurisprudencia del Tribunal de Justicia de las Comunidades Europeas y del Tribunal Europeo de Derechos Humanos. Con más detalles, vid. GONZÁLEZ RIVAS, J. J., "La importancia de la Carta de Derechos Fundamentales de la Unión Europea en los ámbitos civil y penal: Reflexiones sobre la Conferencia de Presidentes de Tribunales Supremos y Fiscales Generales de la Unión Europea, celebrada en Madrid en 2010", Noticias de la Unión Europea, núm. 315, 2011, págs. 127-132; MARTíN DIZ, F., "Garantías procesales básicas en la Carta de Derechos Fundamentales de la Unión Europea", VV.AA., La Carta de Derechos Fundamentales de la Unión Europea : una perspectiva pluridisciplinar, A. A. Herrero de la Fuente coord., 2003, págs. 211-245; POZ0 RUÍZ, F., "La Carta de los Derechos Fundamentales de la Unión Europea: Un paso más en la protección de los derechos humanos", Ciudadanía: dinámicas de pertenencia y exclusión, Logroño, 2003, 173-193; RODRÍGUEZ, A., " Sobre la naturaleza jurídica de la Carta de Derechos Fundamentales de la Unión Europea", Revista de Derecho Político, núm. 51, 2001, págs. 37-56.

960 MANGAS MARTÍN, A., Carta de los derechos fundamentales de la Unión Europea: comentario artículo por artículo, VV.AA., A. Mangas Martín y L. N. González Alonso coords., Madrid, 2008, pág. 833.

961 Para profundizar en el tema, vid. SIMANCAS, M., "El espacio de libertad, seguridad y justicia", Ciencias Policiales, núm. 67, Madrid, 2003, págs. 7-19. Respecto a esta cuestión, señala FERNÁNDEZ ROZAS que "con el fin de aumentar la confianza en el espacio judicial europeo, el Tratado de Lisboa ha reconocido el principio de reconocimiento mutuo como la piedra angular de la cooperación penal. Este principio supone, que una decisión judicial de un Estado miembro debe ser efectiva en cualquier otro Estado miembro sin que pueda ser sometida a controles adicionales de conformidad con el orden jurídico del Estado miembro receptor, y su 
más avances se producen con el Tratado de Lisboa. Respecto a este aspecto del Tratado, es imprescindible señalar que lo mismo pretende afianzar el "espacio de libertad, seguridad y justicia" mediante la atribución a la unión de nuevas competencias que son especialmente intensas en el ámbito de la delincuencia transfronteriza, es decir aquélla más proclive a la limitación de los derechos fundamentales ${ }^{962}$.

Así, en materia de cooperación policial, el Tratado de Lisboa prevé la adopción de medidas sobre recogida, análisis e intercambio de información, apoyo a la formación del personal y técnicas comunes de investigación, a través del procedimiento legislativo ordinario. Si bien para adoptar medidas relativas a la cooperación operativa entre las autoridades competentes se exigirá la unanimidad del Consejo, previa consulta al Parlamento Europeo. En este caso, si no se alcanza la unanimidad, un grupo de al menos nueve Estados podrá solicitar la remisión del proyecto al Consejo Europeo para que, en el plazo de cuatro meses, decida si debe continuarse con la tramitación del proyecto, en cuyo caso devolverá el texto al Consejo para su adopción, o si inicia una cooperación reforzada por esos nueve Estados miembros interesados en su adopción. En este caso la autorización se considerará concedida tras la comunicación pertinente al Parlamento Europeo, al Consejo y a la Comisión (art. 87 del Tratado sobre el Funcionamiento de la Unión Europea) ${ }^{963}$.

Las normas sobre la cooperación policial se completan con la regulación de Europol y la posibilidad de que las autoridades competentes de un Estado miembro puedan actuar en el territorio de otro Estado miembro en contacto y de acuerdo con las autoridades de dicho Estado (arts. 88 y 89 TFUE).

En este sentido, esta cooperación cuenta con el refuerzo de Europol para facilitar la colaboración mutua en la prevención y lucha contra la delincuencia grave que afecte a dos o más Estados miembros, del terrorismo y de las formas de delincuencia que lesionen un interés común que sea objeto de una política de la Unión ${ }^{964}$.

No se debe desconocer en todo caso, que está bastante extendida la idea de que Europol es el principal instrumento comunitario de apoyo a las investigaciones en materia de delincuencia organizada transnacional, pues recaba y analiza información de inteligencia sobre diversos delitos, desde narcotráfico hasta falsificaciones y terrorismo. Su oficina se organiza mediante una estructura radial: todos los Estados miembros envían agentes de policía a su sede en La Haya, que actúan como radios, compartiendo información directamente con los demás policías y con un núcleo de analistas de Europol. Estos analistas rastrean el corpus común de inteligencia criminal europea en busca de vínculos y tendencias transnacionales que puedan haber sido pasados por alto por los

fundamento se basa en una confianza compartida que se justifica en la existencia de unos valores y objetivos jurídicos comunes en todos los Estados miembros". Vid. FERNÁNDEZ ROZAS, J. C., "El espacio de libertad, seguridad y justicia consolidado por la Constitución Europea", La Ley, núm. 6097, 2004, http://www.laley.es.

962 GARCÍA RIVAS, N., "La tutela de las garantías penales tras el Tratado de Lisboa", Revista General de Derecho Penal, núm. 14, 2010, http::/www.iustel.com.

963 Vid. MATÍA SACRISTÁN, A., "El Tratado de Lisboa en el proceso de construcción europea", Boletín de Información del Ministerio de Justicia, año 62, núm. 2058, 2008, pág. 1035.

964 MANGAS MARTÍN, A; LIÑÁN NOGUERAS, D. J., Instituciones y Derecho de la Unión Europea, 6ª edición, Madrid, 2010, pág. 107. 
cuerpos de policía nacionales o regionales, más centrados en lo que sucede en su propio terreno 965 .

Desde otro punto, en el ámbito de la cooperación judicial penal hay que destacarque la remodelación que el Tratado de Lisboa realiza en esta materia resultaba urgente para adaptar el estado de los Tratados a las medidas tomadas para la creación del espacio de libertad, seguridad y justicia y, singularmente, la asunción del reconocimiento mutuo como su "piedra angular"966 por el Consejo Europeo de Tampere. En efecto, la consecución del espacio de libertad, seguridad y justicia se ha pretendido sobre la base de una elevada confianza mutua entre los Estados miembros que permite que se produzca el reconocimiento de las resoluciones judiciales aun careciendo de un sustrato armonizado en un discretísimo remedo de la cláusula constitucional norteamericana full faith and credit. Sin embargo, esta opción convierte en instrumentales al reconocimiento mutuo todas las medidas de armonización penal sustantiva y procesal, cuyas dificultades de adopción se han puesto de manifiesto mientras ha estado vigente la normativa surgida del Tratado de Amsterdam.

Conviene para finalizar este análisis anotar que el Tratado de Lisboa no incluye un catálogo de Derechos Fundamentales que le habrían otorgado carácter constitucional material, pero sí opta por otorgarle a la Carta de Derechos Fundamentales plena eficacia y valor jurídico con una referencia expresa en este sentido en el propio articulado del Tratado. La existencia y obligatoriedad jurídica de este catálogo, a pesar de no incluirse expresamente en el Tratado, supone un gran avance para la defensa de los Derechos fundamentales pues aporta visibilidad al compromiso europeo frente a los ciudadanos y con ello, un refuerzo a la identidad europea. Asimismo, el catálogo de derechos otorga a los ciudadanos europeos mayor seguridad jurídica y una mejor y más completa protección, en la medida en que se regulan nuevos derechos no recogidos ni en las Constituciones nacionales ni en el CEDH ${ }^{967}$.

\section{IV.1.3. Sujeto activo en las operaciones de infiltración.}

Nos cabe en este punto afirmar inicialmente que cuando la actividad del agente encubierto está dirigida al mero descubrimiento del delito ya cometido previamente, o que se está cometiendo, y definitivamente con su actuación no se hace nacer la decisión de delinquir en la persona o personas investigadas ${ }^{968}$, la misma es totalmente lícita, siendo punible el delito investigado y válidos los medios de prueba obtenidos ${ }^{969}$. Sin embargo,

965 Vid. BRADY, H., "Europol y el Modelo europeo de inteligencia criminal: una respuesta no estatal a la delincuencia organizada", Real Instituto Elcano, núm. 126/2007, pág. 4, http://www.realinstitutoelcano.org.

966 La idea fue asumida por el Consejo Europeo de Tampere de octubre de 1999, que consideró que el reconocimiento mutuo de las relaciones judiciales debía convertirse en la "piedra angular" de la cooperación judicial tanto en materia civil como en materia penal en el seno de la Unión (puntos 33 a 37). Cfr. LUCAS MARTÍN, I., "La prueba en el proceso penal en el contexto de la Unión Europea", VV.AA., El proceso penal en la Unión Europea: garantías esenciales, M. de Hoyos Sancho coord., Valladolid, 2008, pág. 424.

967 Cfr. PAREJO NAVAJAS, T., "La Carta de los derechos fundamentales de la Unión Europea", cit., pág. 236.

968 Es así en razón de que quien obra siempre persiguiendo un fin de signo contrario al que en apariencia aspira y por ello provoca la comisión de un hecho como medio necesario para conseguir la reacción en el sentido deseado, cuando incita a otro a cometer un delito no lo hace con el fin de lesionar o poner en peligro el bien jurídico afectado, sino con el propósito de que el provocado se haga acreedor de una pena, recibe el cualificativo de "agente provocador". Vid. con profundidad sobre esta figura absolutamente distinta del infiltrado, RUIZ ANTÓN, L. F., El agente provocador en el Derecho penal, Madrid, 1982.

969 Vid. DELGADO MARTíN, J., Criminalidad Organizada, cit., pág. 56. 
eventuales excesos y actos arbitrarios deberán ser imputados a los infiltrados responsables por tales conductas.

También, que deben ser obedecidos los parámetros de proporcionalidad y legalidad en el análisis concreto del contexto de una operación encubierta.

Además, en el aspecto procesal, se debe observar que la técnica de la infiltración es a la vez un medio de investigación y un medio de adquisición y aseguramiento de fuentes de prueba que serán utilizadas posteriormente en el juicio oral ${ }^{970}$.

Siendo así las cosas podemos preguntarnos quién puede, o mejor, quién debe figurar como infiltrado en una investigación encubierta.

La respuesta exacta sobre el sujeto activo de la infiltración dependerá de la normativa u ordenamiento penal que reglamentar la posibilidad de utilización de operaciones encubiertas para el fin de introducirse en organizaciones criminales y hacer aflorar, sin provocarse, conductas delictivas que, de otro modo, resultarían difícilmente perseguibles.

Existen países que aceptan el uso de particulares ${ }^{971}$, otros solo agentes de policía e inclusode miembros de grupos de actividad de inteligencia estatal ${ }^{972}$.

A nuestro juicio nos parece más acertado defender que el agente infiltrado en el seno de la organización criminal debe de forma obligatoria pertenecer a las fuerzas de seguridad policiales ${ }^{973}$.

Siguiendo esta perspectiva, es importante señalar que cada país presenta una división interna de los cuerpos policiales ${ }^{974}$, siendo que en regla todos aquéllos que poseen

970 Con riqueza de detalles, véase, CORRÊA DE CARVALHO, J. T., Tráfico de drogas. Prueba penal y medidas restrictivas de derechos fundamentales, cit., pág. 315.

971Por ejemplo, en Alemania se otorga el nombre de V-Mann a aquella persona privada que, sin ser un funcionario de la Policía, trabaja para ella. También pueden ser agentes encubiertos en condición de particulares, en Portugal, Colombia, Perú, etc.

972 Véase el ordenamiento brasileño por fuerza del art. 2oㅡ, V, de la Ley 9.034 de 1995.

973 De acuerdo con la opinión más destacada de la doctrina española, siguiendo la regla dispuesta en el 282 bis, 1, de la LECrim, los agentes encubiertos han de tratarse de miembros de la Policía Judicial (Barja de Quiroga, Delgado Martín, Rifa Soler, Pérez Arroyo, Espinosa de los Monteros). En sentido contrario, admitiendo erróneamente, en nuestra opinión, la utilización del particular (Muñoz Sánchez, Montón García). En la doctrina portuguesa, algunos autores basados en el art. 1으, no 2, de la Ley 101/2001, admiten la figura del particular como agente encubierto (Gonçalves, Alves y Valente). En Brasil, el infiltrado habrá que ser miembro de la fuerza policial, aunque la propia ley permita la infiltración por agentes de inteligencia (Ley 9.034/1995, artículo $2 \stackrel{\circ}{\circ}, \mathrm{V}$ ).

974 Véase el caso de España, dónde "no existe una auténtica Policía Judicial, sino que a falta de un cuerpo específico sus funciones generales pueden ser desempeñadas por todos los miembros de las Fuerzas y Cuerpos de Seguridad del Estado, cualquiera que sea su naturaleza y dependencia, tanto nacionales, Policía Nacional y Guardia Civil, de las Comunidades Autónomas, o de Entes Locales, Policía local". Cfr. OCHO AMONZÓ, V., "Sujetos de la investigación en el proceso penal español", cit., pág. 109. Otro tema de discusión en la dogmática española se refiere a la cuestión en torno a si los funcionarios de vigilancia aduanera tienen la condición de Policía Judicial para la investigación del delito de contrabando y aquellos que se encuentren en conexión con él. Vid. Consulta de la FGE 2/1999, de 1 de febrero; SSTS 1001/2003, de 17.2,2003; 4157/2003, de 16.6.2003 y 5749/2003, de 25.9.2003. En opinión de POZO PÉREZ, podrían estos agentes, en teoría actuar como agentes encubiertos puesto que se le atribuye en la legislación la condición de funcionarios de Policía Judicial en relación con los delitos de contrabando (Ley Orgánica 12/1995, de 12 de diciembre, de Represión del contrabando - B.O.E.núm. 97, 13 de diciembre de 1995), sin embargo, no se puede olvidar que al no estar incluido el delito de contrabando en el listado del art. 282 bis de la LEcrim, no habrá lugar a la utilización de esta figura para la investigación del mismo. Vid. POZO PÉREZ, M., "El agente encubierto como medio de investigación de la delincuencia organizada en la Ley de Enjuiciamiento Criminal española", cit., pág. 288. Algún otro sector de la doctrina, señala además que la polémica en torno a si los funcionarios de vigilancia aduanera tienen la condición de Policía Judicial para la investigación del delito de contrabando y conexos, lejos 
el denominado "poder de policía" y previsión de actuación y estructuración en la ley tendrían capacidad y condiciones de trabajar a priori como agentes encubiertos.

Conviene en este punto de nuestro trabajo apuntar algunas notas esenciales para una adecuada comprensión de la función ejercida por la Policía Judicial en la actualidad ${ }^{975}$.

Inicialmente, se puede conceptuarla Policía Judicial como una función específica dentro las funciones de la Policía general, basada en los criterios de la policía científica, destinada a la investigación de los hechos punibles, la persecución y aseguramiento de los delincuentes, poniendo a disposición de la autoridad judicial y eventualmente, del Ministerio Fiscal, los resultados de su averiguación ${ }^{976 .}$

Hay que hacer notar que la creación de la Policía Judicial constituye de alguna manera la culminación de un proceso lógico en una sociedad moderna: la necesidad de institucionalizar, a través del proceso jurisdiccional-penal, el instrumento de la coacción que cualquier Estado tiene derecho a imponer a sus ciudadanos para preservar valores superiores ${ }^{977}$.

Desde esta concreta perspectiva, la función de Policía Judicial no es sino la función de policía criminal represiva o encaminada a la represión de las infracciones criminales ${ }^{978}$.

De esta suerte, dice MORENO CATENA que la Policía Judicial es una Policía para el enjuiciamiento penal, en el desempeño de funciones que se inscriben dentro del proceso

de resolverse con el paso del tiempo, está cada vez más viva. En realidad, junto con otros niveles de Policía Judicial, existe un nivel intermedio representado por el Servicio de Vigilancia Aduanera como Policía Judicial genérica con una función específica o propia, que ha de auxiliar a la justicia en la represión del delito de contrabando y conexos, absteniéndose de intervenir más allá de la práctica de las diligencias indispensables por su urgencia, con traslado inmediato a las Fuerzas y Cuerpos de Seguridad, que ostentan la cualidad de Policía Judicial específica que al servicio le falta. Cfr. por todos, MORENO CATENA, V.; COQUILLAT VICENTE, Á; DE DIEGO DÍEZ, L. A; JUANES PECES, Á; LLERA SUÁREZ-BÁRCENA, E., El proceso penal. Doctrina, jurisprudencia y formularios, Valencia, 2000, pág; 833. También importante respecto al tema es la opinión de MORENO CATENA y CASTILLEJO MANZANARES, al señalaren que "en el ámbito de la Unión Europea, se previó en el Convenio de Nápoles II, sobre asistencia mutua y la cooperación entre las administraciones aduaneras, la actuación de los agentes del servicio de vigilancia aduanera como agentes encubiertos". Crf. MORENO CATENA, V; CASTILLEJO MANZANARES, R., La persecución de los delitos en el Convenio de Schengen, Valencia, 1999, págs. 63 y ss. En resumen, nos parece acertada la posición adoptada por ESPINOZA DE LOS MONTEROS, al señalar que basado en criterios de política criminal, en España es posible la actuación de los miembros del servicio de vigilancia aduanera como infiltrados, en virtud del Convenio de Nápoles II, a ejemplo de las investigaciones encubiertas en los casos de tráfico ilícito de drogas y sustancias psicotrópicas, armas, municiones, explosivos, bienes culturales, residuos peligrosos y tóxicos, materiales nucleares o materiales y equipos destinados a la producción de armas nucleares biológicas y químicas, tráfico de sustancias precursoras o cualquier otro comercio de mercancías sometidas a prohibición por las normativas aduaneras comunitaria o nacionales. Cfr. ESPINOSA DE LOS MONTEROS, R. Z., El policía infiltrado. Los presupuestos jurídicos en el proceso penal español, cit.,pág. 248.

975 El en escenario jurídico español, la normativa actual de la Policía Judicial la conforman: el art. 126 de la CE, los arts. 547 a 550 de la LOPJ, el Título III del Libro II de la LECrim, los arts. 29 a 36 de la LO 2/1986, de 13 de marzo, de Fuerzas y Cuerpos de Seguridad del estado (LOFCSE), y muy especialmente, el Real Decreto 769/1987, de 19 de junio, sobre Policía Judicial (RDPJ). Véase el reciente trabajo publicado por LÓPEZ RODRÍGUEZ, donde este autor defiende que La Ley de Enjuiciamiento Criminal española quedó derogada en lo relativo a la Policía Judicial tras la aprobación de la Constitución y de la Ley Orgánica del Poder Judicial. Así, hoy constituyen Policía Judicial, sólo determinados miembros de las Fuerzas y Cuerpos de Seguridad, es decir, determinados «policías», que además y tal y como se aprobó en el diseño constitucional, deberían depender plenamente, y no sólo «funcionalmente» del Poder Judicial. Vid. LÓPEZ RODRÍGUEZ, J. A., "Resumen de La Policía Judicial y la obsoleta Ley de Enjuiciamiento Criminal", La Ley, núm. 7637, 2011, págs. 1-8.

976QUERALT, J. J., Introduccióna la policía judicial, Barcelona, 1999, pág. 13.

977 En este sentido, véase, NAVAJAS RAMOS, L., "Policía Judicial, composición, funciones y principios de actuación. Unidades Orgánicas de la Policía Judicial: su dependencia funcional y orgánica", Eguzkilore, núm. 13, San Sebastián, 1999, pág. 119.

978 Cfr. LLERA SÚAREZ-BÁRCENA, E., El modelo constitucional de investigación penal, cit., pág. 333. 
penal, del ejercicio de la jurisdicción en este orden al objeto de castigar los hechos constitutivos de delito, bien por medio de actuaciones preliminares a la intervención judicial, bien a través de diligencias practicadas en el curso del proceso ${ }^{979}$.

Esta idea defendida anteriormente, aunque verdadera, no puede ser alejada del necesario reconocimiento de una actuación policial marcada por el respecto a los principios de un proceso penal garantista, basado estrictamente en la valorización de los derechos fundamentales.

Siguiendo esta posición, se exige que las actuaciones policiales estén revestidas del más escrupuloso respecto a los principios constitucionales de dignidad de la persona y a su libre y espontánea determinación, y se prohíbe toda acción coactiva sobre la voluntad ajena, así como la utilización de medios ilícitos o éticamente reprobables, aunque su finalidad fuera la de llegar a lograr la mayor efectividad en el cumplimiento de las leyes atinentes a la represión y prevención de la delincuencia. Es decir, la absoluta legalidad o licitud es exigible tanto para los fines como para los medios utilizados para lograrlos ${ }^{980}$.

Pero lo cierto es que a día de hoy no hay lugar para actividades de investigación policial donde la búsqueda de la eficacia se sobreponga a las garantías constitucionales inherentes a la condición de ciudadano en un Estado de Derecho.

Incluso se puede afirmar que la Policía necesita de profesionales emocionalmente equilibrados, que tengan gran estima a todo lo que suponga la defensa de la dignidad de la persona humana y que se someta en sus actuaciones al marco legal, adecuando los fines a conseguir y los medios a emplear. Aunque la Ley suponga una "servidumbre", es el medio que reúne las garantías de ser producto de una técnica jurídica puesta al servicio del bien común ${ }^{981}$.

En otro orden de cosas, por lo que se refiere a la legislación española, como caso particular, existe la consideración de reconocer una doble función a la Policía Judicial. De esta forma, en primer término, se observa un carácter general donde se incluyen todos los integrantes de las fuerzas y Cuerpos de Seguridad del Estado, los cuales podrán desempeñar funciones de Policía Judicial. De otra parte, se reconoce al Cuerpo Nacional de Policía, a la Guardia Civil y a los Cuerpos de Policía Autonómica el carácter específico para actuar como agentes de Policía Judicial ${ }^{982}$. Partiendo de estas consideraciones, se puede comprender que para los fines de actuación como agentes encubiertos con base en el artículo 282 bis LEcrim estarían aptos los policías que se encuadran en las dos funciones, genérica y específica.

Como última observación al tema de la Policía Judicial, resulta patente su efectivo valor en cuanto institución estatal encargada de mantener la seguridad frente a los graves ataques cometidos por destacadas organizaciones criminales. En consecuencia de lo afirmado, se suele afirmar que en momento presente y en la lucha contra el crimen

979 Vid. MOREno CATENA, V., "Dependencia orgánica y funcional de la Policía Judicial", Revista del Poder Judicial, núm. Especial VIII (Seguridad ciudadana), 1989, pág. 143.

980 Cfr. en este sentido, la STS 953/1991, de 20.2.1991.

981 NAVAJAS RAMOS, L., "Policía Judicial, composición, funciones y principios de actuación. Unidades Orgánicas de la Policía Judicial: su dependencia funcional y orgánica", cit., pág. 125.

982 Cfr. ESPINOSA DE LOS MONTEROS, R. Z., El policía infiltrado. Los presupuestos jurídicos en el proceso penal español, cit., pág. 235-236. 
organizado el contar con unidades de Policía Judicial resulta absolutamente imprescindible 983 .

Retomando el tema del agente encubierto, normalmente se habla de infiltración policial, pero también es posible incluso hablar de infiltrado judicial ${ }^{984}$, toda vez que la infiltración la ejecuta un concreto miembro de la Policía Judicial al servicio del órgano jurisdiccional encargado de la fase de instrucción.

¿Y cuál sería la justificación para la actuación de los agentes de policía como únicos sujetos activos de la infiltración policial?

Nos parece más acertado empezar demostrando la inviabilidad del nombramiento de la figura de un particular para ejercer el trabajo de infiltración.

Desde esta concreta perspectiva, el particular como regla general no tiene conocimientos prácticos de vivencia junto al entorno criminal, y por esta razón no tendrá condiciones psicológicas y físicas parasoportar la convivencia junto al ambiente criminal de una banda de delincuentes organizados.

A estos efectos se debe recordar que cobra singular relevancia sostener la exclusión de la participación de particulares en el trabajo de infiltración ${ }^{985}$ por las razones que a continuación pasaremos a exponer.

En la hipótesis de los particulares ${ }^{986}$ que pueden ser aceptados como infiltrados en países como Portugal, Dinamarca y Colombia, la razón para nuestro reproche consiste en la constatación lógica de que los mismos no poseen conocimientos y habilidades

983 Asumiendo esta idea, veáse, GÓMEZ DE LIAÑO FONSECA-HERRERO., Criminalidad organizada y medios extraordinarios de investigación, cit., pág. 103.

984Vid. GASCÓN INCHAUSTI, F., Infiltración policial y"agente encubierto", cit, págs. 14 y 16.

985 En Este sentido se afirma que "no ostentarán la cualidad de agente encubierto, aquellos que no revistan la condición de funcionario público-confidentes, arrepentidos, seguridad privada u simples ciudadanos. Tampoco podrán intervenir en una operación de infiltración, aquellos que siendo funcionarios policiales no constituyan Policía Judicial en sentido estricto". Vid. GOMÉZ LIAÑO FONSECA-HERRERO, M., Criminalidad organizada y medios extraordinarios de investigación, cit., pág. 178. Del mismo modo, la opinión de EDWARDS, al afirmar que "otro de los elementos caracterizantes del agente encubierto consiste en que debe tratarse de un empleado o funcionario público, descartándose la infiltración de un particular: debe ser un agente estatal". Vid. EDWARDS, C. E., El arrepentido, el agente encubierto y la entrega vigilada. Modificación a la Ley de Estupefacientes. Análisis de la Ley 24.424, cit., pág. 60. En sentido idéntico, cfr. ESPINOSA DE LOS MONTEROS, R. Z., El policía infiltrado. Los presupuestos jurídicos en el proceso penal español, cit., págs. 79 y 232.

986 Vid. con más profundidad respecto de la imposibilidad del particular actuar en la función de agente encubierto, JESUS, D. E., "¿Particular pode atuar como agente infiltrado?", http://www.damasio.com.br; SEÖANE SPIEGELBERG, J. L., "Aspectos procesalesdel delito de tráfico de drogas", cit., pág. XXI. También respecto a la actuación de particulares en operaciones encubiertas, vid. el texto de la Ley 906/2004, del ordenamiento penal Colombiano y la Ley 101/2001 reguladora de las acciones encubiertas en Portugal. En este sentido, esclarece RAMÍREZ BARBOSA que "en Colombia, el agente encubierto es el funcionario de policía judicial o particular, que se infiltra en una organización criminal, previa orden del Fiscal a cargo de la investigación y con la perspectiva autorización del Director Nacional de Fiscalías o del Director Seccional de Fiscalías correspondiente. Su objeto es establecer las características de la organización, sus miembros, funciones de los mismos, modus operandi, y toda información que permita desmantelar la organización". Vid. RAMÍREZ BARBOSA, P. A., Crime Organizado. Tipicidade, Política criminal, Investigação e Processo, cit., págs. 9091. En el mismo sentido, la Corte Suprema de Justicia Colombiana al establecer que "los agentes encubiertos son funcionarios de la policía judicial o particulares especialmente seleccionados que actúan dentro del marco legal vigente y a largo plazo con la misión especifica de combatir delitos peligrosos o de difícil esclarecimiento, quienes manteniendo en secreto su identidad, entran en contacto con la escena delictiva en orden a obtener información para neutralizar acciones delictivas y llevar a cabo la persecución penal cuando otras técnicas de investigación han sido frustradas o no aseguran el éxito perseguido" (Sala de Casación Penal, Sentencia del 13 de febrero de 2008, proceso n. 28888, Ponente Julio Enrique Salamanca). 
específicaspara participaren de un trabajo tan emblemático y peligroso ${ }^{987}$ como es la infiltración en una banda criminal organizada.

En torno a esta afirmación, cabe precisar que la infiltración como técnica de investigación policial conllevará al agente encubierto a adoptar diariamente medidas y practicar conductas cuyas consecuencias dependerán en gran parte del conocimiento y experiencia de vida del profesional. En este punto, le faltarán al particular condiciones prácticas que deberían haber sido adquiridas en la labor junto al ambiente de combate a la criminalidad 988 .

De otra parte, no cabe duda de que las posibilidades de que este agente particular se entregue a la corrupción ${ }^{989}$, por miedo, necesidad financiera y otros factores, son suficientemente elevados. Y el motivo para esto es sencilla: como no son personas formadas en un ambiente policial, no tienen una responsabilidad profesional adecuada que les posibilite resistir a tentación de ceder al soborno y ni mismo conocimientos técnicos sobre la tarea de persecución criminal. Además no son entrenados con técnicas policiales, lo que generaría su vulnerabilidad absoluta en situaciones de extrema tensión psicológica.

En este orden de cosas, se debe destacar que el Estado no puede asumir el riesgo de que los particulares se infiltren en determinados entramados criminales pues su actuación podría implicar la limitación o vulneración de los derechos fundamentales, y ello conllevar a declarar nula toda la información obtenida durante la investigación viéndose afectadas todas las expectativas de declarar a los sujetos investigados culpables por no haber conseguido la enervación de la presunción de inocencia ${ }^{990}$.

Siguiendo el mismo raciocinio, podemos mencionar la opinión de GONZÁLEZCASTELL cuando refiriéndose a la regulación portuguesa señala que no se puede aceptar que se permita que un tercero, no vinculado con ningún cuerpo policial, pueda desarrollar

\footnotetext{
987 Por esta razón, "hay que estimar que cuando un agente entra en el entramado organizativo son muchas las posibilidades de que tenga que cometer delitos, de que tenga que consumir drogas, lo que supone un riesgo inmenso para un particular no preparado". Vid. ESPINOSA DE LOS MONTEROS, R. Z., El policía infiltrado. Los presupuestos jurídicos en el proceso penal español, cit., pág. 233, nota 24. Prosigue la autora afirmando que "si la peligrosidad es un factor para declarar la voluntariedad de infiltrarse en el seno de la organización, creemos que éste debe ser fundamento suficiente para que el Estado, no pueda reclamar la intervención de particulares para infiltrarse en el seno de la organización criminal". Cfr. ESPINOSA DE LOS MONTEROS, R. Z., El policía infiltrado. Los presupuestos jurídicos en el proceso penal español, cit., pág. 80.

988 En este punto habremos de esclarecer que en situaciones muy excepcionales podrán ser encontrados agentes particulares que tengan alguna experiencia práctica en combate a la criminalidad, a ejemplo de una persona que tenga servido al cuerpo del ejército o hasta mismo un policía jubilado. Lo que es pacifico en nuestro modo de pensar es que como regla general, deberán funcionar como agentes encubiertos, policías que presenten preparo psicológico, físico y moral aptosa ayudaren el desarrollo de su nueva vida con una identidad supuesta.

989 En verdad, "la corrupción del agente infiltrado, debe ir orientado a una extralimitación de sus funciones como investigador, es decir, la comisión de hechos delictivos o bien, que la operación encubierta se vuelva en contra del Estado. Esta situación puede provocar la aparición de agentes dobles, es decir, aun actuando bajo el amparo de la operación encubierta, facilitan información relevante a la organización criminal con el fin de que estas eludan la acción de la justicia y por tanto todas sus actuaciones delictivas queden impunes". Cfr. ESPINOSA DE LOS MONTEROS, R. Z., El policía infiltrado. Los presupuestos jurídicos en el proceso penal español, cit., pág. 272. Además, es posible afirmar que en la gran mayoría de los casos, la actuación corrupta podrá estar motivada por "una recompensa económica indebida".

990 Cfr. ESPINOSA DE LOS MONTEROS, R. Z., El policía infiltrado. Los presupuestos jurídicos en el proceso penal español, cit., pág. 79. Prosigue además esta autora, señalando con precisión que "la participación en la investigación penal realizando labores de infiltración, se deben calificar como infiltraciones semipúblicas o infiltraciones sobrevenidas practicadas por los confidentes y arrepentidos con el consentimiento y bajo el control y dirección de los poderes públicos".
} 
esta actividad, mucho menos cuando las personas utilizadas para este fin pueden ser incluso otros delincuentes o personas que tengan algún tipo de deuda con la justicia991.

Estamos de acuerdo con esta opinión en razón de que tal restricción pretende evitar, de un lado, la perdida de la confiabilidad del trabajo de investigación, excluyéndose la posibilidad de la inversión de valores, cuando el agente particular pasa a entregarse a actos de corrupción, actuando junto a la organización criminosa; y de otro, que la policía trabaje soportando interferencias de terceras personas extrañas a los cuadros de las fuerzas de seguridad públicas.

En resumen, se puede afirmar que son cinco las objeciones que el empleo de civiles como infiltrados podrán ocasionar: el grave peligro que corre su seguridad y la seguridad de terceros, así como la propia investigación; el riesgo de que no haya control de los civiles, concretado en una ausencia de jerarquía de mando; el grave peligro de perder el control de las actividades encubiertas de los civiles; la falta de capacitación y competencia de los particulares; y la utilización problemática de las pruebas recabadas por particulares en una operación encubierta, especialmente en los casos de operaciones transfronterizas.

Expuesta de este modo la cuestión, sería dogmáticamentecorrecto afirmar que la figura del particular mejor se encaja con el confidente o colaborador policial (informante), figura ésta totalmente distinta del agente encubierto.

De otra parte, relativamente a los agentes de servicios de inteligencia (normalmente agentes secretos o espías), aunque se perciba su aceptación en alguna legislación de combate a criminalidad organizada992, es cuestionable su condición de actuación como agente encubierto ${ }^{993}$. En este caso se puede incluso plantear un problema de constitucionalidad sobre los dispositivos legales que tratan de esta forma de actuación, a la vez que tales agentes no poseen en regla atribuciones de poder de Policía Judicial y, en consecuencia, no tendrían legitimación para proceder a la búsqueda de pruebas con el fin de una futura utilización procesal como medio de comprobación de los hechos investigados ${ }^{994}$.

Pese a lo dicho, la mayoría de las legislaciones internacionales, por ejemplo de España ${ }^{995}$ y tantos otros países europeos como Alemania, Bélgica y Francia, no tratan de la

\footnotetext{
${ }^{991}$ Cfr. GONZALEZ-CASTELL, A. C., "El agente infiltrado en España y Portugal. Estudio comparado a la luz de las garantías y de los principios constitucionales", cit., pág. 192. En sentido contrario, opinando favorable a aceptación de particulares en la tarea de infiltración, vid. PÉREZ ARROYO, M. R., "La provocación de la prueba, el agente provocador y el agente encubierto: la validez de la prueba y del delito en la lucha contra la criminalidad organizada desde el sistema de pruebas prohibidas en el Derecho penal y procesal penal", cit., pág. 1785.

992 En este sentido, Vid. el art. $2^{\circ}$, V, de la Ley 10.217/2001 (que ha modificado la Ley 9.034/95): "En cualquier fase de la persecución criminal son permitidos, sin perjuicio de los ya previstos en ley, los siguientes procedimientos de investigación y formación de pruebas: V - infiltración por agentes de policía o de inteligencia, en tareas de investigación, constituida por los órganos especializados pertinentes, mediante circunstanciada autorización judicial". Criticando la equiparación de la figura del agente de inteligencia con el agente policial, Vid. FRANCO, A. S., Leis penais especiais e sua interpretação jurisprudencial, cit., pág. 584.

993 Para un estudio más detallado de esta cuestión véase ESTEBAN NAVARRO, M. A., "Contrainteligencia y operaciones encubiertas", VV.AA., Inteligencia, Valencia, 2012, págs. 183 y ss.

994 Vid. la misma opinión en PACHECO, R., Crime organizado, medidas de controle e infiltração policial, cit., pág. 115. También ALVES BENTO, R., "Agente infiltrado. Busca pela legitimação constitucional", cit., pág. 346.

995 Vid. art. 282 bis de la LECrim: "A los fines previstos en el artículo anterior y cuando se trate de investigaciones que afecten a actividades propias de la delincuencia organizada, el Juez de Instrucción competente o el Ministerio Fiscal dando cuenta inmediata al Juez, podrán autorizar a funcionarios de la Policía Judicial, mediante resolución fundada y teniendo en cuenta su necesidad a los fines de la investigación, a
} 
figura del agente de inteligencia como persona habilitada a trabajar en infiltraciones, restando la labor a los miembros de las fuerzas policiales. Del mismo modo en la práctica totalidad de los países del sudamericanos (Argentina, Chile, Uruguay, Perú, Colombia, etc.).

Por lo que se refiere a la doctrina española ${ }^{996}$ en cuanto a las infiltraciones llevadas a cabo por los servicios de inteligencia del Estado, no parece necesario esforzarsedemasiado para poner de relieve su especial naturaleza y función, totalmente alejadas del ámbito procesal penal ${ }^{997}$. Asimismo, debe ser resaltada la diferencia entre las actividades de inteligencia del Estado y las actividades de inteligencia criminal, donde se incluye la figura del agente infiltrado. Así, la inteligencia de Estado, cuyo objetivo es la salvaguardia de la seguridad estatal, aunque se utilice de las infiltraciones como técnica de obtención de datos "cerrados", no tiene por finalidad la producción de la prueba obtenida para utilización en futuro proceso penal.

Partiéndose de este enfoque de exclusión de posibilidad de actuación de particulares o agentes de inteligencia como infiltrados en una determinada operación encubierta, nos cumple ahora finalizar exponiendo nuestra opción por la exclusividad de la Policía para actuar como sujeto activo de las infiltraciones.

En el proceso penal la policía cumple una función de seguridad o de prevención de la criminalidad y, por otro lado, una función de apoyo judicial o de investigación de los delitos.

La policía es que, normalmente, es el primer agente de control que entra en contacto con el delito.

En efecto, la existencia de una Policía Judicial es, en primer lugar, una exigencia del Estado Democrático de Derecho consagrado por la Constitución'998. En segundo, es consecuencia de la necesidad social de garantizar la eficaz persecución de los delitos, ya que el éxito de la justicia penal, como mecanismo para la defensa de la sociedad frente al delito, depende en gran medida de la actividad policial. ${ }^{999}$. Su actuación, además, constituye un referente ineludible para evaluar la conformidad constitucional del proceso penal ${ }^{1000}$.

actuar bajo identidad supuesta y a adquirir y transportar los objetos, efectos e instrumentos del delito y diferir la incautación de los mismos ...". Del mismo modo, la posición asumida por la jurisprudencia española: "la condición de agente encubierto sólo puede ostentarla los agentes de la policía y como medio para infiltrarse en organizaciones criminales y hacer aflorar conductas delictivas que de otro modo serían difícilmente perseguibles". Vid. la STS 8380/2001, de 29.10.2001.

996 Según la opinión de DELGADO MARTín, al tratar del tema del sujeto activo de las operaciones encubiertas, "tampoco pueden ser autorizados los agentes de los servicios de inteligencia del Estado, ya que no reúnen la condición de Policía Judicial". Vid. DELGADO MARTín, J., Criminalidad Organizada, cit., pág. 66.

997 Véase a respecto GASCÓN INCHAUSTI, F., Infiltración policial y “agente encubierto", cit, pág. 17. Todavía, en opinión de GOMÉZ DE LIAÑO FONSECA-HERRERO, "mención aparte merecen los miembros del Centro Nacional de Inteligencia que, aun cuando no tengan la condición de agentes de la autoridad, pueden recurrir al uso de medios bajo cobertura en aras a prevenir y evitar cualquier amenaza para la seguridad del Estado". Vid. GOMÉZ DE LIAÑO FONSECA-HERRERO, M., Criminalidad organizada y medios extraordinarios de investigación, cit., págs. 179-180.

998 Cfr. los artículos 126 y 104.1 CE.

999 Sobre la cuestión, vid. SUÁREZ-BARCENA, E. L., El modelo constitucional de investigación penal, cit., pág. 199. Cfr. los artículos 126 y 104.1 CE.

1000 Así, AMBOS, K., "Breves comentarios sobre la reforma judicial en América Latina", Política Criminal, núm. 2, 2006, pág. 3; también en http://www.politicacriminal.cl. Por esta razón, "se presume de su trabajo diario, un conocimiento de las reglas básicas del proceso penal, en cuanto al significado de la limitación de derechos fundamentales. Y estas reglas son desconocidas por la mayoría de los ciudadanos". Vid. ESPINOSA DE LOS MONTEROS, R. Z., El policía infiltrado. Los presupuestos jurídicos en el proceso penal español, cit., pág. 79. 
La policía es sin duda, el órgano especifico, preparado y entrenado para llevar a cabo las investigaciones típicas de una persecución penal, con la meta de obtención de informaciones, datos y pruebas que puedan ayudar en la formación de la opinio delicti del órgano encargado de proceder a la acusación contra la persona o las personas autoras de un crimen.

No se puede olvidar que uno de los más destacados valores constitucionales inherentes a la actividad policial ${ }^{1001}$ consiste en garantizar el libre ejercicio de los derechos y libertades de los ciudadanos, bien como en la garantía de la seguridad ciudadana1002. Por esto la eficacia policial nunca puede superar el principio general de sometimiento de los poderes públicos a la ley1003.

Como señala BOSSARD, las funciones ejercidas por la policía en los distintos países tienen un carácter extremamente variado; no obstante, del estudio de tales misiones pueden obtenerse conclusiones útiles para la definición de la función policial1004.

Conviene anotar que la gran mayoría de los ordenamientos jurídicos penales que reglamentan las operaciones encubiertas han optado por la exclusividad de la policía como agentes específicos aptos a infiltrarse en las entrañas de las grandes organizaciones criminales. Cítese como buenos ejemplos, las legislaciones francesas, alemana, belga, española, argentina y chilena.

Reseñar aquí también la opinión de MARTÍNEZ PÉREZ quien se afirma que se debe exigir que el agente encubierto sea un miembro del servicio policial puesto que ello implica que su actuación necesariamente se ve revestida de las facilidades que esta condición les permite, así como los límites que los principios y deberes de actuación que las mismas llevan implícitas ${ }^{1005}$. Se justifica este posicionamiento, en razón de la constatación de que la policía es una institución imprescindible del engranaje articulado para la persecución del delito por el Estado, siendo indiscutiblemente en todos los países, una autoridad pública de persecución ${ }^{1006}$. Son personas altamente capacitadas y de ahí que presentan nociones y experiencias básicas sobre cómo proceder en ambientes frecuentados por delincuentes.

Asimismo, merece poner de relieve el valor e importancia de las funciones asumidas por la policía en la actualidad, destacando las diligencias fundamentales de investigación

1001 Por esta razón, señala PEDRAZ PENALVA que "el término policía abarca una ingente y variada pluralidad de conceptos de la que sólo interesa destacar que es una actividad administrativa, y en cuanto tal plenamente sometida a la ley y al derecho (art. $103 \mathrm{CE}$ ) que, orientada al pleno respecto y potenciación de las libertades y derechos fundamentales (art. 9o $\mathrm{CE}$ ), ha de regirse por las constitucionales exigencias a que está sujeta la Administración". Vid. PEDRAZ PENALVA, E., "Actividad policial preprocesal", cit., pág. 763. 225.

1002 En este sentido, vid. SUÁREZ-BARCENA, E. L., El modelo constitucional de investigación penal, cit., pág.

1003 Cfr. RUIZ ANTÓN, L. F., "La provocación policial como forma de reprimir el tráfico ilícito de droga", La problemática de la droga en España, Madrid, 1986, pág. 335.

1004 BOSSARD, A., "Las funciones policiales", Policía y Sociedad Democrática, Madrid, 1983, págs. 99 y 232 233.

1005 Vid. MARTÍNEZ PÉREZ, R., Policía Judicial y Constitución, Navarra, 2001, pág. 399. Vid. también la STS 8380/2001, de 29.10.2001: "La condición de agente encubierto sólo pueden ostentarla los agentes de la policía y como medio para infiltrarse en organizaciones criminales y hacer aflorar conductas delictivas que de otro modo serían difícilmente perseguibles".

1006GOMÉZ COLOMER, J. L., "Estado democrático y modelopolicial: Una propuesta de diseño de cara a lograr una investigación eficaz del crimen", cit., pág. 1. Respecto a la importancia del trabajo policial en la lucha contra el crimen organizado transnacional, Vid. PEÑA ECHEVERRÍA, M. J., "La delincuencia organizada y su problemática desde la óptica de la investigación policial", cit., págs. 101-166. 
acometidaa esta institución estatal, la cual posee como objetivo el esclarecimiento de los hechos delictivos que presenten violación a las reglas previstas en ley para la convivencia en sociedad.

Dicho lo anterior el paso siguiente tiene que consistir en reconocer que la responsabilidad de una investigación policial en orden al descubrimiento de un delito y sus autores del que se poseen indicios corresponde, o mejor debería corresponder, en general, de forma exclusiva, a la policía judicial, antes de que se haya abierto el procedimiento judicial sobre esos hechos, siempre que no se precise la autorización del órgano judicial para algún acto de intromisión en la esfera de los derechos fundamentales de las personas investigadas, necesarios para la incoación o prosecución de la labor investigadora.

Pero la posición activa de agente encubierto no puede ocuparla cualquier miembro de policía, sino, que como medida de protección y seguridad, los llamados a desempeñar la infiltración han de revestir la condición de miembros de la policía con entrenamiento y preparación específica para ejercer esta tarea1007. Por supuesto, resulta que el infiltrado deberá ser un funcionario de la policía judicial y sólo puede desarrollar sus investigaciones mientras se mantenga en vigor la autorización por parte del órgano competente ${ }^{1008}$.

En razón de la constatación de que en cada país el cuerpo de policía tiene sus competencias y divisiones internas, deberáconcluirse que en principio todos estos policías tendrían legitimidad para actuar como infiltrados desde que presente el "poder de policía" previsto en la ley.

En otro orden de cosas, se percibe que los infiltrados deben ser agentes de policía especialmente seleccionados para actuar dentro del marco legal vigente y a largo plazo con una asignación concreta para combatir delitos especialmente peligrosos y/o de difícil esclarecimiento, utilizando una "leyenda"1009 y manteniendo en secreto su identidad, tomando contacto con la escena delictiva para lograr puntos de apoyo informativos con la finalidad de repeler el peligro y/o llevar a cabo la persecución penal cuando han fracasado otros métodos de investigación o estos no aseguren el éxito buscado1010.

En conclusión, aunque dependerá de cada texto legal la atribución para actuar como agente encubierto, se espera que el infiltrado sea un miembro de los cuerpos policiales, debidamente entrenado, y que tenga experiencia con el ambiente criminal, sin constituirse en un delincuente, a la vez que las dificultades que podrán ser encontradas en un puesto de infiltración presentan un alto grado de riesgo a su integridad y a su propia vida y de sus familiares.

1007De este modo, es imperativa la consecuencia de que "esto requiere que el agente sea maduro en el juicio y extremamente experto en el campo especializado de la actividad encubierta. Se recomienda la realización de pruebas psicológicas que aseguren que pueden hacer frente a la tensión y a las demandas que recaen en un oficial o un agente que desarrolle este tipo de operaciones". Vid. VV.AA., Análisis, técnicas y herramientas en el combate a la delincuencia organizada con fundamento en la Convención de Palermo, cit., pág. 99.

1008 Vid. STS 3388/2007, de 25.04.2007. En la misma línea de entendimiento, sostiene ESPINOSA DE LOS MONTEROS que "la dificultad que entraña la lucha contra la delincuencia organizada es motivo suficiente para exigir que la función de agente encubierto sea desempeñada por un agente de policía que cuente con la oportuna especialización". Véase, ESPINOSA DE LOS MONTEROS, R. Z., El policía infiltrado. Los presupuestos jurídicos en el proceso penal español, cit., pág. 234.

1009 Denominación propia utilizada en el derecho alemán para referirse a la "identidad supuesta".

1010 MONTOYA., M. D., Informantes y técnicas de investigación encubiertas. Análisis Constitucional y Procesal Penal, cit., pág. 155. 
Operativamente, parece adecuada la posición anteriormente mencionada en razón de que la seguridad ciudadana, constitucionalmente, se encuentra protegida delante de la estructuración de un cuerpo policial entrenado y legalmente establecido para este fin específico.

IV.1.4. Distinción junto a otras figuras de interés: los informantes (confidentes), los denunciantes anónimos, los agentes secretos, los "undercover agents" y los agentes provocadores.

Conviene ahora tratar del tema referente a la importante cuestión de la distinción entre las figuras del agente encubierto y otras similares.

Esta tarea de diferenciación de estas figuras presenta como finalidad demostrar que el agente infiltrado posee una tarea única y distinta de otros institutos penales y procesales, y que podrá ser notada con relación a las consecuencias de su actuación y la correspondiente responsabilidad penal, civil y disciplinaria1011.

El agente infiltrado o encubierto deberá ser un funcionario de la Policía Judicial, cuya actuación ha de contar con la autorización previa de la autoridad competente en las operaciones que realiza con identidad supuesta o falsa, con el objetivo de obtención de informaciones sobre trampas $\mathrm{u}$ operaciones ilícitas practicadas por miembros de organizaciones criminales, posibilitando posteriormente la concreta desarticulación del grupo de delincuentes.

En razón de se tratarde una figura de grandes complejidades no sólo técnicas, sino también prácticas, de la que resulta conveniente acotar sus líneas características para diferenciarla de otras figuras afines ${ }^{1012}$.

Por lo tanto, esta figura creada en el ámbito de la investigación criminal presenta características y particularidades inherentes a su actuación, las cuales no se confunden con otras similares ${ }^{1013}$.

\footnotetext{
1011 Todavía, se observa la opinión contraria de GISBERT POMATA al señalar que "el infiltrado una vez que está dentro de la organización actúa también como confidente o bien como agente provocador". Vid. GISBERT POMATA, M., "La circulación o entrega vigilada y el agente encubierto", Revista de las Facultades de Derecho y Ciencias Económicas y Empresariales, núm. 55, 2002, págs. 35-58.

1012 Cfr. GÓMEZ DE LIAÑO FONSECA-HERRERA, Criminalidad organizada y medios extraordinarios de investigación, cit., pág. 131.

1013 Nótese que en el sistema procesal penal alemán existe la previsión de algunos personajes muy semejantes al infiltrado, pero que poseen atribuciones absolutamente distintas. Así, existe en primero lugar, el denominado Nichtoffenoperierender Polizei beamtero agentes policiales de investigación encubierta o disfrazada, muy típico de la región de Bavaria. Son investigadores de policía que actúan de forma muy semejante a los agentes encubiertos, con la diferencia básica de que no tienen autorización para trabajaren de modo encubierto por un largo período de tiempo. En segundo, cítese la figura del Informante o simplemente informantes, o sea, que generalmente no son policías y conocen algún detalle o alguna información puntual con respecto de una situación o delito especifico de una organización criminal. Por fin, el personaje denominado Vertrauenspersonen o V-Personen, que serían también conocidos como hombres de confianza. Diferentemente de los informantes, estos sirven a la policía por un periodo más largo de tiempo, no solamente con relación a una información o situación criminal, pero también de diversos modos que pueden relacionarse con la organización criminal. No son agentes policiales y por lo tanto en la mayoría de las veces provienen del seno del propio clan criminal. Son delincuentes que continúan se manteniendo en la organización criminal, bajo el acompañamiento de la policía y en este periodo prestan informaciones. Hechas estas consideraciones, cumple destacar la figura del agente infiltrado propiamente dicho, que en la legislación alemana recibe la denominación de Verdeckter Ermittler y se encuentra previsto en el § 110 de la StPO (Strafprozessordnung). Vid. con más detalles, MENDRONI, M. B., Crime organizado. Aspectos Gerais e mecanismos legais, cit., págs. 140-
} 


\section{IV.1.4.1. El informante.}

En la lucha contra la criminalidad, ya sea la delincuencia convencional o la organizada, las declaraciones de los informantes o confidentes ${ }^{1014}$ pueden resultar primordiales en la investigación ${ }^{1015}$.

Sin embargo, en razón de ausencia de tratamiento legal de este personaje en la casi absoluta totalidad de los ordenamientos penales la utilización de las informaciones obtenidas conllevará la sospecha de violación de derechos y garantías de las personas investigadas.

De inicio, no se debe confundir el "infiltrado" o "agente encubierto", cuya misión es detectar la comisión de posibles delitos y obtener las necesarias pruebas inculpatorias, con la figura del "informante"1016 que es aquella persona cuyos datos son reservados y que confidencialmente brinda material informativo acerca de ilícitos, prestando una valiosa ayuda a los funcionarios policiales en la investigación del delito ${ }^{1017}$. Sin embargo, el infiltrado, al contrario del informante, ejecuta su labor en razón de su previsión legal en el ordenamiento jurídico y respetando los requisitos estipulados por la ley penal.

Los confidentes pueden provenir de los ambientes delictivos, es decir, delincuentes de pequeña escala que a cambio de ciertos favores dicen a las autoridades todo lo que saben sobre la organización objeto de investigación. 0 bien es un ciudadano cuyo objetivo es proteger la seguridad ciudadana ${ }^{1018}$.

No se debe desconocer en todo caso que en la hipótesis de los informantes no existe la entrada de este personaje en las entrañas del grupo criminal, y del mismo modo, el grado de aproximación junto a los delincuentes es reducible a una sencilla observación del entorno o ambiente exterior donde se desarrollan actos de criminalidad.

Para comprender mejor la necesidad de la utilización del personaje denominado "informante", importante apuntar que es evidente que una persona normal y corriente no va a tener información sobre las actividades de una organización criminal, sino que tiene que ser un individuo cercano a este grupo ${ }^{1019}$.

Desde esta concreta perspectiva se puede llegar a conclusión de que el recurso a los confidentes o colaboradores policiales constituye una práctica policial corriente ${ }^{1020}$ y

141 y 143. También, el interesante trabajo de GUARIGLIA, F., "El agente encubierto ¿Un nuevo protagonista en el procedimiento penal?", cit., págs. 49-60.

1014 Monográficamente, vid. VELASCO NUÑEZ, E., “El confidente", La Ley, núm. 3, 1993, págs. 823-830.

1015SSTS 7219 de 8.11.2006 y 4520 de 6.7.2005.

1016Respecto a la actuación en la práctica del personaje denominado "Confidente" o "Informante", vid. EICHENWALD, K., El confidente: una historia real, 1a edición, Barcelona, 2009. De acuerdo con el relato descrito en esta obra, por lo tanto, una historia real, a principios de los años noventa, Mark Whitacre, un joven alto ejecutivode una multinacional estadounidense se dedica a denunciar reuniones secretas de su empresa al FBI.

1017 MONTOYA, M. D., Informantes y técnicas de investigación encubiertas. Análisis Constitucional y Procesal Penal, cit., pág. 199.

1018 ESPINOSA DE LOS MONTEROS, R. Z., "El agente encubierto en el ordenamiento jurídico español", cit., pág. 232.

1019 Vid. HERNANDO MARTíN, F., "La guardia civil en la lucha contra el crimen organizado: técnicas de información, metodología operativa y directrices policiales en las investigaciones", http://www.cej.justicia.es.

${ }^{1020}$ En este sentido, afirma MONTOYA que "los datos de los clásicos informantes como por ejemplo, meseros, taxistas, porteros de hotel, casas de comida o prostitutas, son útiles pero muchas veces insuficientes para hacer frente a las grandes organizaciones que trabajan en el mundo de la droga. Con los aludidos colaboradores la policía mantiene contactos confidenciales sobre sus conocimientos acerca de las negociaciones que se efectúan con estupefacientes, así como también, sobre la ubicación y actuación de 
según la opinión de ciertos autores, carente de respaldo legal alguno y, en la medida en que se pueden vulnerar derechos fundamentales, supone una confesión del fracaso de los medios de reacción estatales ${ }^{1021}$.

En palabras de GÓMEZ DE LIAÑO FONSECA-HERRERO, la utilización de la información suministrada por el confidente en el proceso penal, origina, en su esencia, dos problemas de gran trascendencia relacionados directamente con la salvaguarda de derechos constitucionales. Se refiere a la manifestación de las limitaciones policiales y a la proscripción del testimonio de referencia de los confidentes anónimos ${ }^{1022}$.

Ocurre en efecto, que no se puede negar que la revelación de información por el confidente a la policía en un sinnúmero de veces ha tenido una gran importancia en la investigación penal1023, principalmente en lo relativo a casos de la delincuencia considerada tradicional o común.

El informante normalmente tiene cierta proximidad con los cuadros de la policía, prestando su colaboración con relación a la obtención de datos que puedan auxiliar en una posible investigación y posterior persecución. En ocasiones, las informaciones prestadas por los informantes o confidentes son las únicas aportadas inicialmente a las autoridades policiales para se empezar una investigación criminal.

También denominado de "confidente" o "colaborador policial", se trata por lo tanto de persona de confianza de las autoridades de persecución penal que recoge información en el ambiente criminal para la policía ${ }^{1024}$. Después, entrega los resultados de su

potenciales delincuentes, puntos de reunión de los integrantes de asociaciones delictivas y trabajos que realizan las organizaciones que se dedican al tráfico de drogas a fin de prevenir y reprimir este tipo de actividades. Las informaciones que se reciben pueden ser o no pagadas". Vid. MONTOYA, M. D., Informantes y técnicas de investigación encubiertas. Análisis Constitucional y Procesal Penal, cit., pág. 149.

1021 Cfr. MORENO CATENA, V; CORTÉS DOMÍNGUEZ; GIMENO SENDRA, V., Lecciones de Derecho Procesal Penal, Madrid, 2003, pág. 218. En sentido opuesto a esta idea, matiza RODRÍGUEZ FERNÁNDEZ que "se trata de una práctica perfectamente válida y legítima desde el punto de vista de los derechos fundamentales, que sirve para mejorar el nivel de eficacia en la represión penal". Vid. RODRÍGUEZ FERNÁNDEZ, R., "El agente encubierto y la entrega vigilada", Criminalidad organizada: reunión de la sección nacional española preparatoria del XVI Congreso de la Asociación Internacional de Derecho Penal, Toledo, 1999, pág. 95. Con una posición intermedia, DELGADO GARCÍA señala que "no existe ninguna razón para excluir del proceso penal los datos fácticos aportados por el confidente, pero sí para mostrar cierta desconfianza". Vid. DELGADO GARCÍA, J., Criminalidad organizada, cit., pág. 45.

1022 Con más detalles, vid. GÓMEZ DE LIÃNO FONSECA-HERRERO, M., Criminalidad organizada y medios extraordinarios de investigación, cit., págs. 148-153.

1023 Vid. SSTS, 6355 de 30.9.2002; 3078 de 30.4.2002; 5500 de 30.9.1998 y 6338 de 14.11.1996.

1024 Un interesante caso de colaboración entre confidentes policiales y agentes encubiertos ha sido tratado en la STS 1575 de 9.3.1998: "Los acusados, antes de contactar con otras personas, entre las que se encontraba un confidente de la Guardia Civil y, posteriormente, un agente infiltrado, ya habían adoptado la determinación de efectuar el tráfico de una importante cantidad de hachís. La actividad de aquéllos, cualquiera que fuera, no hizo nacer la idea criminal en los recurrentes". Comentando sobre esta sentencia, REDONDO HERMIDA aduce que "ello significa que, en el sentir del Tribunal Supremo, existe un amplio abanico de posibilidades de intervención en la organización delictiva, tanto de los confidentes policiales, como de los agentes encubiertos, sin que deba necesariamente confundirse un tan amplio espectro con la incitación al crimen realizada por confidentes o agentes, cuestión distinta que no tiene por qué suponerse, cualquiera que haya sido aquella intervención secreta". Vid. REDONDO HERMIDA, A., "El agente encubierto en la jurisprudencia española y en la doctrina del Tribunal Europeo de Derechos Humanos", cit., pág. 96. Otra nota de interés dice respecto a la diferente situación encontrada en el ordenamiento jurídico alemán donde se prevé la actuación de confidentes particulares que no pertenecen a los bajos fondos criminales. De este modo, es posible que las autoridades alemanas acudan a personas privadas, que no son miembros de la policía, pero que trabajan para ella y que se les conoce con el nombre de V-Mann. Cfr. ESPINOSA DE LOS MONTEROS, R. Z., El policía infiltrado. Los presupuestos jurídicos en el proceso penal español, cit., pág. 133. 
observación bajo la garantía de confidencialidad y con una expectativa de recibimiento de contraprestación material o inmaterial.

Al respeto el confidente es una persona de confianza de las autoridades de persecución penal. Es el clásico "soplón" o "chivato" cuya actividad siempre estará premiada, ya sea con ventajas materiales y/o procesales (en caso de estar también procesado, aunque no necesariamente por el mismo delito) ${ }^{1025}$.

Queda muy claro, pues, que el informante es justamente la persona que no infiltra en la organización criminal, viniendo solo a ofrecer a las autoridades, datos o informaciones respecto de determinado ambiente criminal ${ }^{1026}$.

En definitivo, la destacable diferencia presentada por el informante si comparado al infiltrado, es que el primer tiene que cumplir solo con la obligación de entregar informaciones a las autoridades policiales, no se tratando de infiltración destinada a investigación de una actividad delictiva concreta y practicada por un grupo de delincuentes organizados; el segundo tiene un encargo más técnico y específico junto a la función policial, con vistas a profundizar en las investigaciones y alcanzar el objetivo de desbaratamiento de la organización criminal ${ }^{1027}$.

Además, el infiltrado deberá desempeñar las tareas de represión y prevención a la criminalidad organizada, siempre contando con previa autorización y actuando bajo el control judicial, requisito este que no es exigido de los confidentes o informantes.

En ocasiones la tarea de informante simplemente da lugar al inicio de la investigación, obteniendolas pruebas directamente a través de la misma. La cuestión aquí es si la ocultación de dicho confidente en el atestado podría ser considerado ocultamiento de datos y vulnerar al menos, el derecho de defensa ${ }^{1028}$. Es complejo el planteamiento

1025 Véase, PÉREZ ARROYO, M. R., "La provocación de la prueba, el agente provocador y el agente encubierto: la validez de la provocación de la prueba y del delito en la lucha contra la criminalidad organizada desde el sistema de pruebas prohibidas en el Derecho Penal y Procesal Penal", cit., pág. 2. Una observación interesante y distinta viene expresada por parte de la doctrina argentina, en el sentido de tratar la figura tradicionalmente acepta como "informante", con la eufemística denominación de "agente paraencubierto", haciendo así un paralelo con el personaje ya conocido del agente encubierto. Se trata del sujeto que sin formar parte de ninguna institución pública es inadmisiblemente encargado o autorizado por el Estado (por lo general, mediante un precio) para cumplir tareas similares a las del agente encubierto, o directamente para realizar misiones de espionaje particular. Por cierto que su actividad es disfrazada, como si sólo se tratara de un mero aprovechamiento, por parte del Estado, de conocimientos que aquél hubiere obtenido en forma accidental, o de averiguaciones que hubiese realizado por su cuenta. En este sentido, vid. CAFFERATA NORES, J. I., La prueba en el proceso penal, cit., pág. 224.

1026 En opinión de HERNANDO MARTÍN, "en esta orden de las cosas, la mera ocultación de la condición de policía en el desarrollo de una investigación, sin que el agente se infiltre en la organización criminal, es una antigua técnica frecuentemente utilizada, que por sí misma, no afecta a ningún derecho fundamental del investigado ni supone injerencia en su vida privada". Vid. HERNANDO MARTÍN, F., "La guardia civil en la lucha contra el crimen organizado: técnicas de información, metodología operativa y directrices policiales en las investigaciones", http://www.cej.justicia.es.

1027 De este modo "a la hora de determinar su idoneidad, como medio de investigación o como auténtica prueba para el acto del juicio oral, debe rechazarse la equiparación entre la infiltración policial, la infiltración de ciudadanos controlada por el poder público y la simple infiltración de particulares o informantes, entendidos, estos últimos, como aquellas personas que de manera ocasional y esporádica facilitan información sobre hechos punibles sin interferencia y al margen de las autoridades penales". Cfr. GOMÉZ DE LIAÑO FONSECA-HERRERO, M., Criminalidad organizada y medios extraordinarios de investigación, cit., pág. 160.

1028 CERRO ESTEBAN, J. A., "El sistema de garantías constitucionales en los procesos judiciales sobre criminalidad organizada", http://www.cej.justicia.es. Nos parece claro que la situación jurídica del informante es quizás más cuestionable bajo el aspecto ético que la del agente encubierto, a la vez que su labor se pasa de forma absolutamente sin control judicial y muchas veces sus informaciones son caracterizadas por la clandestinidad del origen de la fuente de obtención. Ya en opinión de BARCELONA LLOP, "el fundamento de la 
expuesto, pues delante de una estructura garantista del proceso penal, estarían palmariamente vulnerados derechos y garantías de los investigados por un simple motivo: la ausencia de reglamentación legal de este trabajo ejercido por el informante.

Todavía, cabe considerar también en este análisis respecto a la figura del informante o confidente que es habitual que la identidad del mismo quede salvaguardada, de manera que sólo sea conocida por la autoridad con la que colabora ${ }^{1029}$. De esta suerte, la información obtenida mediante la colaboración del confidente será elaborada y tratada en instancias policiales ${ }^{1030}$ y servirá como línea de investigación o bien como prueba de cargo cuanto estos testifiquen en el juicio oral1031.

Esclarecidas de este modo las diferentes características del informante, o sea, de mero colaborador junto a la actividad de investigación policial, a través de la obtención y consecuente repaso de las informaciones imprescindibles al desarrollo del trabajo policial, no necesitando por supuesto, de autorización judicial para proceder a la búsqueda de informaciones. Su objetivo consiste en algo más particular: la obtención de privilegios o algún tipo de remuneración por parte de las autoridades ${ }^{1032}$.

En síntesis, se puede terminar citando a RODRÍGUEZ FERNANDES, para quien la función de los confidentes no es otra que la aportación de información que, posteriormente, es elaborada en otras instancias y sirve para mejorar el nivel de eficacia de la persecución de la criminalidad dentro del área en que trabajan; concluyendo que es perfectamente válida para la lucha contra el crimen y legítima desde el punto de vista de los derechos fundamentales ${ }^{1033}$.

En nuestra opinión no es tan sencilla la cuestión anteriormente apuntada, pues amén de su reconocido valor para la aportación de relevantes informaciones relacionadas con la investigación, no se puede olvidar que la ausencia de un reglamento jurídico sobre las funciones y límites de la actuación del informante en el contexto de la persecución penal podrá sugerir vicios de inconstitucionalidad por violación al principio de legalidad.

ocultación de la identidad del confidente se debe, fundamentalmente, a la salvaguarda de su derecho a la intimidad cuanto por la de su vida o integridad física". Cfr. para más detalles, BARCELONA LLOP, J., "El secreto policial. Acceso a archivos y registros de la policía. Los ficheros automatizados de las fuerzas y cuerpos de seguridad", Cuadernos del Consejo General del Poder Judicial, volumen dedicado a Acceso judicial a la obtención de datos, núm. 25, Madrid, 1997, págs. 157-222.

1029 Cfr. ESPINOSA DE LOS MONTEROS, R. Z., " El agente encubierto en el ordenamiento jurídico español", La prueba en el Espacio Europeo de Libertad, Seguridad y Justicia Penal, cit., págs. 232-233.

1030 En este sentido, vid. MAPELLI CAFFARENA, B.; GONZÁLEZ CANO, M. I.; AGUADO CORREA, T., Estudios sobre la delincuencia organizada. Medios, instrumentos y estrategias de la investigación criminal, cit., pág. 67.

1031 Deberá ser esclarecido que en gran mayoría de los casos, el colaborador policial que aporta y facilita información no acaba testificando en el juicio oral, de modo que sus informaciones prestadas a la policía acaban por no presentaren valor probatorio, prestando solamente como fuente indicativa de datos de investigación a ser aprovechada por los cuerpos policiales. En caso de testificaren, advierte DELGADO MARTíN que "El Tribunal valorará su declaración de conformidad con las normas de la sana crítica, pero con la precaución lógica en aquellos supuestos en los que su colaboración con la justicia obedece a una retribución económica o procesal, o a un motivo espurio o de mera venganza". Vid. DELGADO MARTín, J., Criminalidad organizada, cit., pág. 46.

1032 ESPINOSA DE LOS MONTEROS, R. Z., "El agente encubierto en el ordenamiento jurídico español", cit., pág. 233. Cuando se refiere la autora a "la obtención de privilegios o algún tipo de remuneración por parte de las autoridades", se busca referirse a "contraprestación de tipo material (entrega de dinero, droga, protección) o de tipo procesal (empleo del principio de oportunidad para la punibilidad o para una disminución de la pena)". En este mismo sentido, vid. MUÑOZ SÁNCHEZ, J., La moderna problemática jurídico penal del agente provocador, cit., pág. 40.

1033 RODRÍGUEZ FERNÁNDEZ, R., "Comentarios a la LO 5/99, de 13 de enero: la entrega vigilada y el agente encubierto", cit., pág. 4. 
Desde esta perspectiva, dependerá la valoración de las pruebas aportadas por los informantes en un concreto caso, del análisis de la autoridad judicial sobre la eventual vulneración derechos fundamentales de la persona investigada.

\section{IV.1.4.2. El denunciante anónimo.}

El anonimato como forma de iniciarse una investigación no es un fenómeno contemporáneo, ni producto de la globalización, y tampoco una herramienta nacida para combatir el crimen organizado ${ }^{1034}$.

Según explica GASCÓN INCHAUSTI, el denunciante anónimo suele ser, como regla, un particular que pone en conocimiento de la autoridad la comisión de hechos delictivos y que, a menudo, conduce a ésta hacia algún elemento probatorio de relevancia, pero cuya identidad se mantiene oculta en el proceso penal, bien por desconocerla todos aquéllos que en él intervienen, bien porque quien la conoce no la revela, amparándose, con o sin fundamento, en alguna modalidad de secreto profesional ${ }^{1035}$.

Esta figura enun sinnúmero de ocasiones presenta un cierto temor en mostrar su verdadera identidad, a la vez que presenta miedo en exponer sus datos personales a los fines de servir en el futuro, como testigo en un proceso penal. Pese a lo dicho, deberá hacerse hincapié en el sentido de que sus informaciones, aunque mantenga el anonimato, podrán servir como pauta para orientar la actuación de investigación de la policía, especialmente en las hipótesis de descubrimiento de los delitos más comunes donde la dificultad probatoria no es destacada.

Generalmente es un particular quien informa a la autoridad la comisión de hechos delictivos y que, comúnmente, guía a ésta hacia algún elemento probatorio, pero cuya identidad se conserva oculta en el proceso penal, ya sea porque es desconocida por todos aquellos que en él intervienen, o porque quien la conoce no la desvela, albergándose, con o sin fundamento, en alguna modalidad de secreto profesional ${ }^{1036}$.

Se explica este temor del denunciante anónimo en servir como testigo de cargo en razón de que la gran mayoría de las personas no tienen plena confianza en la eficacia de los programas de protección de víctimas y testigos.

En otro orden de cosas, esta figura no es normalmente utilizada en las investigaciones relacionadas con la criminalidad organizada ${ }^{1037}$, quedando su función restringida en la práctica a casos de identificación de delincuentes callejeros, sirviendo de

\footnotetext{
${ }^{1034}$ En este sentido, vid. FEDERICO DELGADO, J., La denuncia anónima, Buenos Aires, 1999, pág. 21.

1035 Vid. GASCÓN INCHAUSTI, F., Infiltración policial y “agente encubierto”, cit., pág. 21. Sobre los problemas que plantea la denuncia anónima como instrumento para motivar la apertura de un proceso penal, Vid. la opinión de MONTERO AROCA, J., "La denuncia anónima y su eficacia como acto de iniciación del procedimiento preliminar penal", VV.AA., Primeras Jornadas sobre Problemas Actuales de la Justicia Penal, Granada, 1994, págs. 15 y ss. Con más profundidad, Cfr. MORENO CATENA, V., El secreto en la prueba de testigos del proceso penal, Madrid, 1980.

1036 Vid. entre otros, ALONSO PÉREZ, F., Medios de investigación en el proceso penal. Legislación, comentarios, jurisprudencia y formularios, $2^{\text {a }}$ edición, Madrid, 2003, págs. 553 y ss.

1037 Sobre este aspecto es imprescindible señalar que "en los casos de delincuencia organizada el denunciante anónimo proporcionará información sobre un acto delictivo concreto, pero será imposible que proporcione la información sobre la actuación de la banda, el modus operandi, funcionamiento y composición". Cfr. ESPINOSA DE LOS MONTEROS, R. Z., El policía infiltrado. Los presupuestos jurídicos en el proceso penal español, cit., pág. 141.
} 
forma excepcional para obtener en algunas situaciones informaciones sobre la ubicación de los lugares en donde se comercializan estupefacientes.

Otra cosa es, sin embargo, que la delación anónima no es acepta integralmente por gran parte de los regímenes constitucionales modernos, en razón de exponer y colocar en riesgo la integridad del sistema de derechos fundamentales ${ }^{1038}$. Dejando de lado la utilidad de la notitia criminis anónima para el éxito de la investigación, no se puede olvidar que la libertad de manifestación de pensamiento tiene su carga en el hecho de tener el denunciante que identificarse, asumiendo claramente la autoría del producto del pensamiento manifestado para, según las hipótesis, responder por eventuales daños causados a terceros. Esto sería el motivo para la prohibición del anonimato en muchas de las Cartas Constitucionales.

La única consecuencia que se puede extraerde esta afirmación es que la prueba originada de una denuncia anónima no estará libre de desconfianzas respecto a su licitud y su valor probatorio.

Por fin, nos cabe señalar que la diferencia clara entre esta figura del denunciante anónimo ${ }^{1039} \mathrm{y}$ el agente encubierto es que este último, además de ser miembro de la Policía Judicial, es un sujeto que, al contrario del denunciante anónimo, disfruta de una identidad, aunque sea supuesta; asimismo, su identidad real es conocida por el órgano jurisdiccional $\mathrm{y}$, en cualquier caso, el peculiar anonimato que en cierta medida le proporciona la identidad supuesta está sujeto a la autorización y al control del órgano judicial ${ }^{1040 .}$

Siguiendo esta misma posición, LÓPEZ ORTEGA afirma que no hay que confundir el denunciante anónimo, cuya identidad se oculta a los mismos investigadores, con el informador o el agente encubierto, cuya identidad es conocida, por los órganos encargados de la persecución penal, pero se mantiene oculta para el Tribunal sentenciador y para la defensa. Mientras que, en el primer caso, la denuncia no puede ser utilizada como un medio de prueba y no puede servir como fundamento de la acusación, ni de una sentencia condenatoria, en el segundo el testimonio del informador o del agente encubierto puede ser introducido en el proceso indirectamente a través de un testimonio de referencia ${ }^{1041 .}$

\footnotetext{
1038 Se conclui que un problema fundamental que conlleva la denuncia anónima, es que bajo el anonimato, pueden se ocultar propósitos vengativos que conlleven a la puesta en conocimiento de información falsa para poder menoscabar el honor a la persona del denunciado. Es decir, pueden perseguir ánimos irreconciliables con la justicia penal y en concreto con la investigación del hecho delictivo. Esta circunstancia ha sido puesta de manifiesto en España por la Instrucción de la Fiscalía General del Estado de 16 de marzo de 2003: "bajo el anonimato pueden llegar a ocultarse espurios propósitos encaminados a la descalificación pública y al descrédito social del denunciado".

${ }^{1039} \mathrm{Al}$ respeto, "la figura del confidente anónimo es diferente a la del denunciante anónimo. Se trata de un colaborador o informante de la policía siendo ésta la que mantiene su identidad en el anonimato". Vid. la STS 4209 de 17.6.2003.

1040 Cfr. GASCÓN INCHAUSTI, F., Infiltración policial y “agente encubierto”, cit, pág. 21. Monográficamente respecto a este personaje denominado "arrepentido", vid. BENÍTEZ ORTÚZAR, I. F., El colaborador con la justicia. Aspectos sustantivos procesales y penitenciarios derivados de la conducta del "arrepentido", Madrid, 2004.

1041 Cfr. LÓPEZ ORTEGA, J. J., "Prueba y proceso equitativo. Aspectos actuales en la jurisprudencia del Tribunal Europeo de Derechos Humanos", Derechos y Libertades, Revista del Instituto Bartolomé de las Casas, año 1, núm. 2, 1993-1994, pág. 616.
} 


\section{IV.1.4.3. El agente secreto.}

El agente secreto es la persona que generalmente a servicio de los intereses estatales (servicios de inteligencia), promueve el trabajo de descubrir e investigar hechos que presenten relevancia e interés para la parte interesada en las informaciones hasta entonces ocultas.

Se trata de un espía, un miembro de los servicios de inteligencia de un determinado Estado, que si bien utiliza la técnica de infiltración para obtener información no tiene vinculación con las funciones del proceso penal ${ }^{1042}$.

Como hemos señalado anteriormente, el agente encubierto no es un agente secreto o espía, aunque en ambos los casos, el objetivo final sea la investigación y búsqueda de informaciones cerradas.

Siguiendo esta tendencia, las tareas del agente de inteligencia estatal son diametralmente distintas del trabajo de infiltración policial, careciendo el primero de vinculación con las funciones del proceso penal ${ }^{1043}$. Por esto se podría tratar incluso de una hipótesis de dudosa constitucionalidad por no pertenecer lo mismo a los cuerpos de seguridad policial.

Nos parece acertado señalar que no se puede de modo alguno confundir el trabajo del agente encubierto que utiliza recursos de inteligencia policial y criminal ${ }^{1044}$, con la finalidad derecabar datos e informaciones que serán entregadas a las autoridades de persecución criminal; con la tarea ejercida por los agentes secretos o de inteligencia, cuya misión institucional es a través del empleo de técnicas inherentes a la inteligencia estatal, promover la defensa de la soberanía de un determinado territorio, evitando que informaciones confidenciales y secretos de Estado sean descubiertos, poniendo en riesgo la seguridad nacional. 0 dicho en pocas palabras: el trabajo de los servicios de inteligencia nada tiene que ver con el proceso penal.

También es importante afirmar que al contrario del agente infiltrado, el cual funciona como uno de los medios de investigación eficaz contra el crimen organizado, los servicios secretos presentan como encargo la tarea de conocer e informar al gobierno de todo aquello que amenaza y puede afectar a la seguridad, estabilidad y defensa de un Estado.

Así es que se concluye que el agente secreto se encuentra en lugar distinto al agente encubierto dentro del organigrama administrativo, y sus infiltraciones van orientadas a

1042 Vid. NÚÑEZ PAZ, M. A; GUILLÉN LÓPEZ, G., "Entrega vigilada agente encubierto y agente provocador. Análisis de los medios de investigación en materia de drogas", cit., pág. 120, nota 102.

1043 En este sentido, vid. GASCÓN INCHAUSTI, F., Infiltración policial y “agente encubierto", cit, pág. 28. Además, "los servicios de inteligencia ya no son simples servicios de información que se dedican a espiar, sino que investigan, analizan y estudian la información que obtienen para que los gobiernos adopten las decisiones correctas, actuando bajo el principio de coordinación con otros servicios del Estado". Cfr. ESPINOSA DE LOS MONTEROS, R. Z., El policía infiltrado. Los presupuestos jurídicos en el proceso penal español, cit., págs. 142-143.

${ }^{1044}$ Incluso, con una opinión peculiar, sostiene UGARTE que "la actividad de inteligencia policial no debe se confundir entonces con la actividad de investigación criminal, ya que en ésta última se procura esclarecer el hecho, obtener pruebas, descubrir y detener a los responsables y someterlos a la acción de la justicia, mientras que en la primera, más que realizar arrestos de personas que pueden sólo constituir los eslabones más pequeños y débiles de la cadena, se procura establecer la existencia, características, dimensiones, delitos cometidos y los que pretenden se cometer, medios materiales a disposición, modus operandi de una determinada organización delictiva". Vid. UGARTE, J. M., Legislación de inteligencia, legitimidad y eficacia, Guatemala, 2000, pág. 72. 
proteger otros intereses como la seguridad institucional de un país, no estando definitiva vinculado directamente al proceso penal ${ }^{1045}$.

\section{IV.1.4.4. Undercover agent.}

De forma efectiva, otro personaje que no se confunde con el agente encubierto es la figura conocida por "undercover agent"1046 de los modelos policiales angloamericanos. Se trata de un Policía con trabajo semejante al agente encubiertoque se infiltra en esferas y organizaciones delictivas sin que su tarea esté subordinada desde su inicio a una investigación criminal en particular concreta ${ }^{1047}$.

Se justifica esta distinción, según GASCÓN INCHAUSTI, en razón de que el undercover agent aunque sea un policía como el agente encubierto se infiltra de modo genérico en ámbitos y organizaciones diversas, sin que su labor obedezca desde un principio a una investigación delictiva concreta. Es por ello, una especie de equivalente policial del colaborador o del confidente ${ }^{1048}$.

En sentido contrario, expresa DELGADO MARTÍN que el agente infiltrado extiende su investigación a toda la actividad criminal de la organización y no solamente a un hecho delictivo concreto. De acuerdo con este autor, no existiría distinción conceptual entre las figuras del agente encubierto y del undercover agent ${ }^{1049}$, debiendo estos dos términos ser empleados de modo indistinto ${ }^{1050}$.

Nos parece más acertada la primera posición expuesta, en razón de la especialidad que caracteriza la actuación de un infiltrado en una operación encubierta. Así es que pensamos que es técnicamente correcta la diferencia apuntada por GASCÓN INCHAUSTI, pues el infiltrado es designado para trabajar en una operación encubierta, que tiene como objeto una determinada investigación, lo que posibilita la exigencia de obediencia a los criterios de proporcionalidad y racionabilidad, bien como facilita el obligatorio control jurisdiccional. Con relación a los undercovers agents, ellos no tienen una actuación específica de obtención de un resultado concreto en una determinada investigación, trabajando de modo general, lo que convierte el control judicial en especialmente dificultoso, además de provocar la vulneración del principio de especialidad que es inherente a las actuaciones del agente encubierto.

IV.1.4.5. El agente provocador.

Cuestión especialmente sensible es proceder a un análisis de la figura que más dudas conceptuales provoca cuando es comparado con el agente encubierto: el agente provocador.

1045 Con más detalles, Cfr. NÚÑEZ PAZ, M. A; GUILLÉN LÓPEZ, G., "Entrega vigilada, agente encubierto y agente provocador. Análisis de los medios de investigación en materia de drogas", cit., pág. 121.

1046 Vid. monográficamente respecto a esta figura, REID, I., Undercover Agent, Adelaide, 1978.

1047 NÚÑEZ PAZ, M. A; GUILLÉN LÓPEZ, G., "Entrega vigilada agente encubierto y agente provocador. Análisis de los medios de investigación en materia de drogas", pág. 120, nota 101.

1048 Cfr. GASCÓN INCHAUSTI, F., Infiltración policial y “agente encubierto”, cit., pág. 28.

1049 DELGADO MARTÍN, J., Criminalidad Organizada, cit., págs. 44-45 y 59.

1050 Siguiendo esta posición, vid. SUITA PÉREZ, N., "La diligencia de investigación por medio del agente encubierto", cit., pág. 243; PAZ RUBIO, J. M, et alli., La prueba en el proceso penal. Su práctica ante los tribunales, cit., pág. 395. 
Y la razón es histórica a la vez que como hemos tenido la oportunidad de afirmar anteriormente en la antigüedad los vocablos "agente encubierto" y "agente provocador" eran considerados sinónimos.

Como punto de partida, hay que tener en cuenta que la especie denominada "agente provocador" se engloba dentro del tema de las formas de "investigaciones encubiertas" 1051.

Acentuando este aspecto, el antecedente histórico más importante del agente encubierto es la institución conocida como agent provocateur, expresión esta originaria del idioma francés. Conviene entonces notar que el origen del agente provocador se encuentra en el periodo del absolutismo francés, en tiempos de Luis XIV, donde para reforzar el régimen se crea la figura del delator, compuesta por ciudadanos que descubrían a los enemigos políticos a fin de recibir favores del príncipe, si bien en esta época su labor se limitaba a espiar y poner los hechos en conocimiento de la autoridad, sin que se realizara una actividad de provocación. Con el paso del tiempo, la actividad de vigilar no sería suficiente para neutralizar la oposición al régimen y se pasa del espionaje a la provocación ${ }^{1052}$.

Estábamos delante de los comúnmente conocidos "delatores" cuya actividad consistía en el mero espionaje con el objeto de descubrir a los enemigos del régimen para aportar posteriormente los resultados de su investigación en conocimiento de las autoridades. Sin embargo, con el paso del tiempo el espionaje se hizo insuficiente para la defensa del sistema y los agents provocateurs han pasado del simple espionaje a la provocación, aunque los motivos por los cuales actuaban fueron casi exclusivamente políticos y como remedio de lucha contra la criminalidad ${ }^{1053}$.

Por todo lo indicado consideramos importante conceptuar qué es un agente provocador.

MUÑOZ SÁNCHEZ ha definido al agente provocador como aquél sujeto que provoca a otro a la comisión de un delito con el fin de que el autor provocado sea castigado precisamente a causa de ese hecho, sin que tenga voluntad de consumación del delito y poniendo para ello las medidas necesarias ${ }^{1054}$.

Dicho en otras palabras, el agente provocador es quien, particular o agente policial, instiga o induce con engaños a un tercero para que realice una infracción penal que, sin su provocación, no hubiera cometido 1055 .

\footnotetext{
1051 Conviene observar que la STS 571/1998 de 31.1.1998 ha distinguido el infiltrado de otros personajes: "Hay que distinguir entre confidente o infiltrado y agente provocador, ya que, mientras éste incide directa y principalmente en la comisión delictiva con anterioridad a su realización, viciando así la voluntad de quien lo lleva a cabo de modo material y directo, los dos primeros actúan con una misión simplemente investigadora para conseguir el descubrimiento de la acción criminal ya realizada".

1052 PÉREZ ARROYO, M. R: "La provocación de la prueba, el agente provocador y el agente encubierto: la validez de la provocación de la prueba y del delito en la lucha contra la criminalidad organizada desde el sistema de pruebas prohibidas en el Derecho Penal y Procesal Penal", cit., pág. 1. En el mismo sentido, señala MONTOYA que "el agente provocador fue una presencia constante en la historia de la política francesa, durante el l'Ancien Regimen, en la fase revolucionaria y pos revolucionaria". Vid. MONTOYA, M. D., Informantes y técnicas de investigación encubiertas. Análisis Constitucional y Procesal Penal, cit., pág. 40.

1053 PAZ RUBIO, J. M et alli., La prueba en el proceso penal. Su práctica ante los Tribunales, cit, pág. 387. 43.

1054 Cfr. MUÑOZ SÁNCHEZ, J., La moderna problemática jurídico penal del agente provocador, cit., págs. 38-

1055 MONTÓN GARCÍA, M. L., "Agente provocador y agente encubierto: ordenemos conceptos", cit., pág. 2130. Nos parece que el "agente provocador" actúa instigando, generando en el autor la propia voluntad
} 
Mención aparte merece la opinión de RUIZ ANTÓN cuando señala que el agente provocador es aquella persona que incita a realizar un determinado hecho o crea las circunstancias fácticas que impulsan a otro a ejecutarlo, persiguiendo un fin de signo contrario al que en apariencia se aspira con la acción provocadora ${ }^{1056 .}$

La actuación del agente provocador se caracteriza entonces por la estructura contradictoria en que se desarrolla su conducta: por una parte quiere el castigo del delincuente a través de un hecho que con su conducta provoca, pero no desea la lesión del bien jurídico al que va dirigida la acción del provocado ${ }^{1057}$.

En sentido tradicional, el delito provocado surge por obra y estímulos de provocación, de suerte que consiste en resultado de la actividad de dos individuos: un agente provocador y un sujeto provocado, cualquiera que sea la condición personal de uno u otro, y cualquiera que sea la naturaleza del delito provocado ${ }^{1058}$.

El agent provacateur, al instigar o inducir otra persona a cometer un delito con el fin de que este pueda ser detenido y puesto a disposición de la Justicia, no puede en consecuencia, al contrario del agente encubierto, invocar para si la posibilidad de plantear la concurrencia de una causa de justificación ${ }^{1059}$. Por esto se puede afirmar que el agente provocador en razón de ser representado por un individuo que conduce su actividad de forma a inducir o instigar la persona sospechosa a practicar actos delictuosos por los cuales habrá de responder penalmente, con el objetivo principal de obtención de pruebas que vengan a perjudicar el mismo, acaba por violar las garantías esenciales de un Estado social y democrático de Derecho.

En consecuencia, se observa un gran rechazo legal, doctrinal y jurisprudencial a esta forma de investigación policial ${ }^{1060}$.

delictiva, o sea, el dolo, determinándolo a realizar la conducta con el fin ulterior de someterlo a un proceso judicial, circunstancia que no resiste el menor análisis constitucional.

1056 Cfr. RUIZ ANTÓN, L. F., El agente provocador en el Derecho penal, Madrid, 1982, págs. 5-6.

1057 Cfr. MONTOYA, M. D., Informantes y técnicas de investigación encubiertas. Análisis Constitucional y Procesal Penal, cit., pág. 41. De otra parte, interesante citar que un tratamiento penal distinto al agente provocador ocurre en Estados Unidos de América donde "el problema de la provocación se ha enfocado en la defensa del entrampamiento, la cual puede ser invocada cuando son los agentes del gobierno los que crean la idea de la comisión del delito en la persona investigada. El entrampamiento o entrapment se presenta en investigaciones proactivas que utilizan la inducción con el propósito de si conseguir que un sujeto, dispuesto a cometer delitos, pero que de otra manera no sería fácilmente identificable, muerda el anzuelo, tendido por agentes policiales, lo que en una visión caricaturesca sería como cuando se pone un queso en una trampa, donde se pretende, no que el ratón se lo coma, sino que caiga en ella para exterminarlo". Vid. RAMíREZ JARAMILLO, A. D., El agente encubierto frente a los derechos fundamentales a la intimidad y a la no autoincriminación, cit., pág. 52. Para una visión más profundizada respecto a la doctrina dedicada a la provocación policial como defensa o entrapment, Cfr. MUNÕZ NEIRA, O., Sistema penal acusatorio de Estados Unidos, Bogotá, 2006, págs. 245-259.

1058 FERNÁNDEZ APARICIO, J. M., "El delito provocado y el agente encubierto", cit., pág. XLV.

${ }^{1059}$ Sobre esta cuestión, FURTADO destaca que "aun el agente infiltrado trabaja en un medio en que delitos ya fueron practicados, o están en ejecución o en la inminencia de ocurrieren, el agente provocador incita, instiga otra persona a la práctica del crimen, tornándose autor mediato de este". Vid. FURTADO, F., "O agente infiltrado", Direito e Cidadania, ano V, números 16-17, Praia, 2002-2003, pág. 12.

1060 Incluso en España, a pesar de ser una técnica de investigación habitual en la práctica policial y de disfrutar de la aquiescencia de la Jurisprudencia, la figura del agente provocador no tiene reconocimiento legal expreso. De esta forma, la actuación del agente provocador, tal y como es entendida por la Jurisprudencia, debe ser considerada legítima, pero siempre que la preparación del delito haya comenzado y el agente actúe sólo con la finalidad de descubrir los cauces y medios por los que se desarrollan los hechos delictivos, o incluso, como parte de la doctrina señala, para poner al descubierto delitos ya cometidos con anterioridad a la provocación. En este sentido, crf., ESPINOSA DE LOS MONTEROS, R. Z., El policía infiltrado. Los presupuestos jurídicos en el proceso penal español, cit., pág. 105; RIFÁ SOLER, J. M., "El agente encubierto o infiltrado en la 
Por su importancia conviene señalar la posición adoptada por GRANADOS PÉREZ, al señalar que una cosa es el delito provocado que ha de ser enérgicamente rechazado porque no existiendo culpabilidad, ni habiendo tipicidad propiamente dicha, se llega a la lógica conclusión de que el sujeto no hubiera actuado de la manera que lo hizo si no hubiere sido por la provocación previa y eficaz del agente incitador. La impunidad es entonces absoluta. No hay dolo criminal independiente y autónomo, como tampoco hay verdadera infracción penal, sólo el esbozo de un delito imposible. Es distinta la conducta que, sin conculcar legalidad alguna, se encamina al descubrimiento de delitos ya cometidos, generalmente de tracto sucesivo como suelen ser los de tráfico de drogas, porque en tales casos los agentes no buscan la comisión del delito sino los medios, las formas o canales por los que ese tráfico ilícito se desenvuelve, es decir, se pretende la obtención de pruebas en relación a una actividad criminal que ya se está produciendo pero de la que únicamente se abrigan sospechas. Conclui afirmando que en el primer caso no se da en el acusado una soberana y libre decisión para cometer el delito, mientras que en el segundo supuesto la decisión criminal es libre y nace espontáneamente1061.

En otro orden de cosas y como punto de partida para demostrar las diferencias entre el agente encubierto y el provocador, se observa que este último puede ser un particular, pues en la gran mayoría de las acciones encubiertas de esta especie, cuanto más el agente presentar apariencia de ciudadano común y sin sospechas, mayores serán las posibilidades de inducción o instigación del agente criminoso para la práctica del delito, en especial cuando se tratade una simulada compra de estupefacientes.

Queda muy claro entonces que no deberán ser confundidas las figuras del "agente encubierto" y "agente provocador", pues el primero recibe órdenes y acepta voluntariamente la tarea de infiltrarse en el seno de la organización criminal con el objetivo primario de mantener activa observación sobre los pasos efectuados por los miembros del clan de criminosos, recogiendo informaciones y pruebas que podrán servir para una futura persecución criminal; además su actuación es permitida legalmente; ya la segunda figura, presenta un aspecto de actividad positiva de "provocar" la práctica criminosa, sin todavía infiltrarse o integrarse en la organización criminal, pero se utilizando de los artificios de la instigación o inducción, con vistas a hacer con que el agente criminoso venga efectivamente practicar el delito. Se trata pues, de forma de ausencia de respecto a los derechos fundamentales de la persona que acaba siendo engañada ${ }^{1062}$ y llevada a practicar un delito que a principio no estaría dispuesto a cometer.

nueva regulación de la Ley de Enjuiciamiento Criminal", cit., pág. 161 y MUÑOZ SÁNCHEZ, J., La moderna problemática jurídico penal del agente provocador, cit., pág. 116. También, las SSTS 9730/2001 de 12.12.2001 y 312/2001 de 23.1.2001. En contra, afirmando que la figura del provocador induce a la comisión de un delito que no habría tenido lugar sin la actuación instigadora del policía, la cual hace surgir la concreta voluntad delictiva en quien no había resuelto cometer ese determinado delito, vid. la STS 1969/1996 de 30.3.1996. Más reciente, Cfr. la STS 7467/2009 de 19.11.2009: "La provocación delictiva es una inducción engañosa, es decir, supone injertar en otra persona el dolo de delinquir, y cuando esto se hace con la colaboración policial, se produce el efecto perverso de que la policía lejos de prevenir el delito, instiga a su comisión - elemento subjetivo - bien que sin poner en riesgo ningún bien jurídico, pues en la medida que lo apetecido es la detención del provocado, elemento objetivo, toda la operación está bajo el control policial por lo que no hay tipicidad ni culpabilidad, ya que los agentes de la autoridad tienen un control absoluto sobre los hechos y sus eventuales consecuencias".

1061 GRANADOS PÉREZ, C., "Instrumentos procesales en la lucha contra el crimen organizado. Agente encubierto. Entrega vigilada. El arrepentido. Protección de testigos. Posición de la jurisprudencia", cit., pág. 93.

${ }^{1062} \mathrm{Al}$ respeto, se denota que "el agente infiltrado es una figura bien más suave cuando comparada con el agente provocador, pues nunca podrá ello instigar o determinar al crimen, bajo pena de convertirse en un 
En opinión de ONETO, la gran diferencia entre estos dos personajes estaría en el hecho de que en el agente provocador se cuestiona la instigación del crimen; en el agente encubierto, se cuestiona la práctica de delitos ${ }^{1063}$.

Por otra parte, la conducta del agente encubierto no puede se calificar como provocación ni a su autor de agente provocador ${ }^{1064}$, ya que no provoca la comisión del delito por un tercero, sino que a veces llega a cometer él mismo en el desarrollo de la investigación. Debemos pues distinguir estas dos figuras ya que integran una realidad distinta y son acreedores de un dispar tratamiento, máxime en el caso español, tras la llegada de la Ley Orgánica 5/1999, que prevé expresamente la figura del agente encubierto eximiéndole de cualquier responsabilidad por los actos que llevar a cabo, pero no la del agente provocador ${ }^{1065}$.

En resumen, se puede afirmar que la esencial diferencia existente entre las dos figuras analizadas es que el agente provocador es quien induce a cometer un delito para condenar al provocado, y por su vez, el agente encubierto es aquél que es utilizado como parte de una técnica especial para combatir ciertos delitos que presentan gravedad, como sucede con la actuación de la delincuencia organizada1066. En el primer caso, hay una actitud activa por parte del provocador que incita a cometer el delito; mientras que en el supuesto del agente encubierto su postura es pasiva, recibiendo información ${ }^{1067}$.

Del mismo modo, se concluye que mientras el agente provocador incita con engaños a un tercero para que cometa un hecho delictivo imposible, el agente encubierto actúa sólo cuando está convencido de la existencia de una actividad delictiva consumada o que se está cometiendo, y cuyo descubrimiento pretende1068. Así es que a diferencia del provocador, el agente infiltrado con su actuación, no determina el nacimiento del hecho delictivo, sino que lo que hace es introducirse en una organización criminal para poder descubrir a aquellos que son partícipes de ella ${ }^{1069}$. Dicho de otro modo, aunque actúe con las estrategias del engaño y de la disimulación, el infiltrado no estimula y no determina el nacimiento del deseo de delinquir por parte del agente provocado.

verdadero agente provocador, pues la provocación siendo una forma no autorizada de investigación policial, y no estando autorizada por ley, consumaría la infiltración". Vid. AUGUSTO MEIREIS, M., 0 regime das provas obtidas pelo agente provocador em processo penal, Coimbra, 1999, pág. 164.

1063 ONETO, I., O agente infiltrado. Contributo para a compreensão do regime jurídico das acções encobertas, cit., pág. 12.

${ }^{1064 E n ~ r e a l i d a d ~ l a ~ a c t u a c i o ́ n ~ d e l ~ i n f i l t r a d o ~ n o ~ s u p o n e ~ u n a ~ a u t e ́ n t i c a ~ p r o v o c a c i o ́ n, ~ y a ~ q u e ~ e l ~ d e l i t o ~ a r r a n c a ~ d e ~}$ la determinación del sujeto activo libre, voluntaria y anterior a la intervención del agente policial.

1065 PALMA HERRERA, J. M., Los delitos de blanqueo de capitales, Madrid, 2000, pág. 509.

1066 Por esto sería correcto afirmar la "inexistencia de delito provocado cuando los acusados tienen voluntad y decisión criminal desde el principio, respondiendo a un serio proyecto previamente elaborado, con lo que tal decisión no viene determinada por la intervención del agente encubierto" (STS 1242/2009 de 06.02.2009); y también la "inexistencia de delito provocado al no considerar que la intervención de los agentes encubiertos condujera a la consumación del delito" (STS 99/2009 de 08.01.2009).

1067 EDWARDS, C. E., El arrepentido, el agente encubierto y la entrega vigilada. Modificación a la Ley de estupefacientes. Análisis de la Ley 24.424, cit., pág. 57. Además, la STS 5414 de 25.6.2007, dispone que "no existe delito provocado cuando los agentes tienen indicios de la existencia de una actividad delictiva y se infiltran entre quienes la llevan a cabo en busca de información o prueba que permitan impedir la progresión de aquella o facilitar la sanción; la intervención policial puede producirse en cualquier fase, aunque consista en tareas de fingidos auxilio o colaboración, siempre que no impida la evolución libre de la voluntad del sujeto".

2.

1068 Cfr. MONTÓN GARCÍA, M. L., "Agente provocador y agente encubierto: ordenemos conceptos", cit., pág.

${ }^{1069}$ MOLINA PÉREZ, T., "Técnicas especiales de investigación del delito: el agente provocador, el agente infiltrado y figuras afines (y II)", cit., pág. 155 
Desde las perspectivas anteriormente analizadas, opinamos en el sentido de que la hipótesis de acción inducida por un agente provocador afronta los derechos fundamentales del sospechoso, principalmente el principio de dignidad de la persona humana, y, en caso de utilización policial, se constituiría en ilegalidad estatal, o sea, verdadera prueba ilícita, por actuación ilegitima, además de provocar la atipicidad del hecho ${ }^{1070 .}$

De lo dicho resulta que en algunos casos el agente encubierto se podrá comportar como un agente provocador, recibiendo el tratamiento legal dispensado a esta última figura. De este modo, el agente encubierto es un agente de policía con identidad supuesta y que ya no sólo puede se agenciar de información relativa a la organización criminal en donde se introduce, sino también actuar incluso como agente provocador. Así mismo, si actuar de modo a provocar o crear la voluntad de cometer un delito, viniendo a inducir la práctica delictuosa por el investigado, el agente encubierto podrá dejar de se beneficiar de las justificantes legales y puede además responder como agente provocador con las consecuencias jurídicas inherentes a la actuación de este personaje.

Por fin, no sería conveniente cerrar este apartado sin observar dos temas muy importantes sobre la figura del agente provocador y que en cierto modo interesan al estudio del infiltrado.

En primer término, la jurisprudencia del Tribunal Supremo español propone una imprescindible diferenciación entre el delito provocado y el agente provocador: "el delito provocado se trata de una rechazable e inadmisible actuación policial que traspasa claramente los límites de la legalidad que deben constituir una barrera infranqueable para todo agentepolicial, en cuanto determina la nulidad de las pruebas obtenidas, directa o indirectamente, violentando los derechos y libertades públicas, devendría de inexcusable aplicación, siendo por tanto nulo todo lo obtenido por esta vía. Nada hay más desmoralizador que el funcionario policial, garante del ordenamiento jurídico, se convierta en su infractor. Ninguna eficacia policial puede predicarse de esta actitud. No existen atajos. La policía debe prevenir el delito no instigar a su comisión. Figura distinta sería la figura del agente provocadortendente a poner de manifiesto y por tanto a acreditar una situación o actividades criminales ya existentes sin que el agentehaya insertado o creado el dolo en tercera persona, sino que esta ya tiene decidido un actuar delictivo de forma libre y autónoma y la actividad del agentesolo tiene por finalidad sacar a la luz tal actividad"1071.

La segunda, corresponde a la actuación del agente provocador en los Estados Unidos, donde se utilizan los términos "entrampamiento" o "celada legal"1072.

1070 Siguiendo esta tendencia, Cfr. POLASTRI LIMA, M., Processo Penal Europeu. Preservação e direitos individuais (Princípios processuais e análise da Convenção Européia de Direitos Humanos), cit., pág. 49.

1071 Vid. la STS 5038/2008 de 25.9.2008. También en la doctrina, alguna autora, así MOLINA MANSILLA defiende que "ha de diferenciarse el delito provocado de la provocación policial, que actúa sobre un delito ya iniciado, influyendo tan sólo en el grado de perfección del mismo, en función del momento del iter criminis en que se produjo aquella intervención". Cfr. MOLINA MANSILLA, Mạ , C., El delito de narcotráfico, Barcelona, 2008, pág. 305.

1072 Vid. con más detalles, MURCHISON, K. M., "The Entrapment Defense in Federal Courts: Modern Developments", Mississippi Law Journal, núm. 47, 1976, págs. 573-619. 
Según MONTOYA, la defensa de entrampamiento es oponible cuando un agente del gobierno o alguien trabajando para éste, como por ejemplo un informante pagado o un condenado que busca disminuir su condena, lo induce a cometer un crimen ${ }^{1073}$.

De este modo, el entrampamiento seria la concepción y planificación de un delito por un agente del gobierno a fin de procurar su comisión por alguien que no lo hubiera perpetrado a no ser por la persuasión o fraude por parte del funcionario.

Ahora bien, esbozadas las debidas consideraciones sobre la figura del agente provocador, no se debe olvidarque si hay algo que tiene gran importancia en el comportamiento del agente provocador es la contradicción existente entre el objeto que aparentemente persigue con su provocación (un resultado criminal) y el fin que realmente pretende (la condena del delincuente). Es esta contradicción la base a la hora de entender el propio concepto de agente provocador y de diferenciarlo del resto de las conductas criminales ${ }^{1074}$.

\section{IV.1.5. Una referencia esencial: el "pentiti" en Italia.}

Otra figura de interés y que nada tiene que ver con el agente encubierto es la figura conocida en nuestro entorno como "arrepentido" 1075 o "colaborador con la justicia penal".

Se justifica esta afirmación en razón de que el infiltrado no se refiere a un miembro antiguo de la banda criminal que se arrepiente y resuelve blindar a las autoridades de persecución criminal con informaciones respecto a datos secretos e internos de un determinado grupo de delincuentes organizados, a cambio de alguna recompensa.

Sin embargo, en razón de la importancia de esta figura denominada "arrepentido" y su historia en la lucha contra el crimen organizado ${ }^{1076}$, en especial en Italia, nos cumple apuntar algunas observaciones importantes en relación a sus principales características.

1073 MONTOYA, M. D., Informantes y técnicas de investigación encubiertas. Análisis constitucional y procesal penal, cit., pág. 117.

1074 PAZ RUBIO, J. M et alli., La prueba en el proceso penal. Su práctica ante los Tribunales, cit, pág. 387.

1075 En otros idiomas, "Pentito" en Italia, "Kronzeuge" o "Kronzeugenregelungen" en Alemania, Suiza y Austria, "Arrependido" en Brasil, "Witness of the crown" en Estados Unidos de America o "Repentis" o "Collaborateurs de justice" en Francia. Monográficamente respecto al tema del "arrepentido", vid. BENÍTEZ ORTÚZAR, I. F., El colaborador con la justicia. Aspectos sustantivos procesales y penitenciarios derivados de la conducta del "arrepentido", Madrid, 2004; EDWARDS, C. E., El arrepentido, el agente encubierto y la entrega vigilada. Modificación a la Ley de Estupefacientes. Análisis de la Ley 24.424, Buenos Aires, 1996. También, BEERNAERT, M. A., "Repentis o collaborateurs de justice: quelle légitimité dans le système pénal?, Droit et société, núm.55, 2003, págs.693-711; DÍAZ-MAROTO Y VILLAREJO, J., "Algunos aspectos jurídicos -penales y procesales de la figura del arrepentido", La Ley, núm. 05, 1996, págs. 1463-1467; NÚÑEZ PAZ, M. A y GUILLÉN LÓPEZ, G., "El arrepentido en el ámbito del crimen organizado y en el tráfico de drogas: el artículo 376 del Código Penal español", Revista de Derecho de Extremadura, núm. 5, 2009, págs. 132-150; SÁNCHEZ GARCÍA DE PAZ, I., "El coimputado que colabora con la justicia penal (con atención a las reformas introducidas en la regulación española por las Leyes Orgánicas 7 y 15/2003)", http://criminet.ugr.es/recpc.

1076 La verdad es que "el fenómeno de la colaboración con la Justicia no es una coyuntura inédita en la historia del Derecho penal ni, a la sazón, un instrumento procesal inane en el descubrimiento del delitoyla lucha contra el crimen organizado. Será, pues, en este contexto en el que la colaboración con la Justicia cree ese pasto fértil de pesos y contrapesos: la averiguación y descubrimiento de los delitos que afectan al magma social, que nutre de legitimidad a los derechos y libertades de los ciudadanos al socaire del patrocinio de actividades de desistimiento y arrepentimiento eficaz del germen criminal, especialmente latente en el seno de organizaciones criminales altamente especializadas". Cfr. JORDÁN DÍAZ-RONCERO, Ma. J; COMES RAGA, I., "El arrepentimiento postdelictual en España: un ensayo acerca de su viabilidad como instrumento combativo del crimen organizado", La Ley Penal, núm. 77, 2010, http://revista-laleypenal.laley.es. 
De inicio es usual la referencia a la existencia de un "Derecho penal premial"1077 cuando se tratan de colaboradores de justicia (arrepentidos).

El punto de partida para un adecuado análisis del derecho premial deberá consistir en proceder una aproximación a sus orígenes históricos ${ }^{1078}$.

Es de estimar que el origen del Derecho penal premial, no obstante sea antiguo, se remonta al menos al Derecho Romano, a propósito de los delitos de lesa majestad (en la Lex Cornelia de sicarios et veneficiis) para pasar después al Derecho Canónico y Común medieval. Los filósofos juristas ilustrados se pronunciaron, después de sopesar beneficios e inconvenientes de esta figura (son paradigmáticas las reflexiones de Beccaria al respecto en Dei deliti e delle pene), en contra de premiar la delación con beneficios penales, práctica común en el antiguo régimen en los procedimientos seguidos ante la Inquisición. En la literatura encontramos una de las primeras referencias favorables a este tipo de instituciones en la obra de Bentham, paradigma del pensamiento utilitarista anglosajón aplicado al ámbito jurídico-penal quien por entender preferible "la impunidad de uno de los cómplices que la de todos", se mostraba partidario de las disposiciones premiales para el delator. Todo ello siendo consciente de sus riesgos, al percibir el peligro de que "entre muchos criminales, el más malo no sólo quedará sin castigo, sino podrá ser también recompensado" 1079 .

En la jurisprudencia inglesa, según palabras de AMODIO, la figura del colaborador ha pasado a ser tratada con base en una sentencia dictada en el caso Rudd (1775), en la cual el Juez ha declarado admisible el testigo del imputado (crownwitness) contra los cómplices en cambio de su impunidad, después de su confesión. Posteriormente, otras decisiones semejantes han sido dictadas en el campo de los delitos contra la personalidad del Estado (caso Blunt - 1964), en la lucha contra el terrorismo norte irlandés (1982), en casos de criminalidad económica (1972) y en relación a la criminalidad organizada (caso Smith 1982) ${ }^{1080 .}$

1077 La expresión "Derecho premial" indica un fenómeno observado en la legislación de los últimos años por el cual a la pena correspondiente a un delito se le puede aplicar un premio consistente en la despenalización. El derecho premial responde a una política criminal que puede observarse desde el punto de vista tanto científico como político. Vid. MONTOYA, M. D., Informantes y técnicas de investigación encubiertas. Análisis Constitucional y Procesal Penal, cit. pág. 225.

1078 Todavía, deberá ser esclarecido que han sido Jeremy Bentham y Melchiorre Gioia, las personas consideradas como fundadores del "derecho al premio o a la recompensa". Bentham, con su obra "Teoría de las penas y de las recompensas", publicada en 1811 y Gioia que ha escrito en la primera mitad del siglo XVIII (1818), la obra "Del merito e delle ricompenze", han tenido importancia fundamental en el proceso histórico que ha culminado con la configuración del instituto del arrepentimiento. Para una mayor profusión, vid. PISANI, M., "Diritto premiale e sistema penale: rapporti e intersezioni", VV.AA., Diritto premiale e sistema penale, Milano, 1983, pág. 30.

${ }^{1079}$ SÁNCHEZ GARCÍA DE PAZ, I., "El coimputado que colabora con la justicia penal (con atención a las reformas introducidas en la regulación española por las Leyes Orgánicas 7 y 15/2003)", cit., págs. 02-03. También interesante las opiniones de NÚÑEZ PAZ y GUILLÉN LÓPEZ, al afirmaren que "dentro del derecho penal histórico, el derecho premial ha estado presente en sus instituciones: en las Partidas del Rey Alfonso X, El Sabio, otorgaba cartas de gracia por merecimiento de servicio que haya alguno fecho, o por bondad que haya en sí, aquel a quien la gracia fase". Vid. NÚÑEZ PAZ, M. A; GUILLÉN LÓPEZ, G., "El arrepentido en el ámbito del crimen organizado y en el tráfico de drogas: el artículo 376 del Código Penal español", cit., pág. 133, nota 5.

1080 Vid. Con riqueza de detalles, AMODIO, E., "I pentiti nella commow law", Rivista Italiana di Diritto $e$ Procedura Penale, núm. 4, 1986, págs. 991-993. Además, sobre las referencias de Cesare Beccaria en su clásica obra "De los delitos y de las penas", a respecto del derecho a la recompensa, Vid. PISANI, M., Attualità di Cesare Beccaria, Milano, 1998, págs. 44 y ss. 
Ya en Estados Unidos de América, los acuerdos entre acusación y defensa (pleabargaining) también están incorporados a la cultura jurídica, hecho este que viene a facilitar la obtención de la colaboración premiada a través de los arrepentidos ${ }^{1081}$.

Todavía, es en Italia donde históricamente su marco referencial ha sido profundamente destacado.

El origen histórico del fenómeno de los "colaboradores de la justicia" es de difícil identificación, aún su adopción ha sido incentivada en los años setenta para el combate a los actos de terrorismo ${ }^{1082}$, sobretodo con relación a la extorsión mediante secuestro, culminando por alcanzar hasta el periodo actual un prestigio alcanzado en los años ochenta cuando ha demostrado su eficacia en los procesos instaurados para la persecución de la criminalidad mafiosa ${ }^{1083}$.

Todavía, de modo muy particular, la historia de la legislación premial en Italia se refiere al año de 1974, siendo emblemática la Ley sobre los arrepentidos. Tal como el resto de la legislación de emergencia, las leyes sobres arrepentidos tanto desde el punto de vista sustancial como procesal se insertan en un marco caracterizado por evidentes deformaciones de la legalidad penal ${ }^{1084}$.

Así, en Italia este personaje ya consagrado es conocido como "colaboratori della giustizia" o "pentiti". Ha tenido esta figura suma importancia en el contexto de la legislación excepcional dictada en los años setenta y ochenta en Italia, al acaso del terrorismo y el levantamiento de estructuras organizadas de mafiosos, en especial en el sur del país.

Se puede entonces afirmar que en Italia, los pentiti son mejores definidos como colaboradores de la justicia en razón de la contribución blindada a la policía o a la autoridad judicial en la individualización de responsables de delitos de terrorismo. Nadie puede desconocer, como ya afirmado, la importancia que han tenido en la lucha contra el terrorismo y contra la mafia ${ }^{1085}$. Por esto, en ocasiones, aquel que desea colaborar, para merecer el premio tiene en el juego una puesta alta, por cuanto no debe brindar 1 y ss.

1081 En detalle vid. ALSCHULER, A. W., "Plea bargaining and his history", Columbia Law Review, 1979, págs.

1082 Incluso advierte MUÑOZ CONDE que "el caso de Italia es conocido, en donde surge la figura del pentito o los pentiti, de los arrepentidos, sobre todo a partir de finales de los años setenta, cuando, por ejemplo, en 1978 hubo 2.785 atentados terroristas (uno de ellos nada más y nada menos que el secuestro y posterior asesinato de uno de los políticos más carismáticos e importantes de la democracia cristina, Aldo Moro)". Vid. MUÑOZ CONDE, F., "Los arrepentidos en el caso de la criminalidad o delincuencia organizada", La criminalidad organizada ante la justicia, F. Gutiérrez-Alfiz y Conradi coord., Sevilla, 1996, pág. 148.

1083 ARAÚJO DA SILVA, E., Crime organizado. Procedimento probatório, cit., pág. 79. En efecto, "no solamente ha permitido abrir amplios espacios al conocimiento acerca de un mundo hasta entonces cubierto por el espeso velo de la complicidad mafiosa, sino que ha permitido realizar y culminar con un éxito antes impensable los grandes procesos atingentes a los fenómenos criminales más aguerridos, violentos y gigantescos". Vid. FRONDIZI, R. J., DAUDET, M. G., Garantías y eficiencia en la prueba penal, cit. Pág. 114.

1084 Vid. MONTOYA, M. D., Informantes y técnicas de investigación encubiertas. Análisis Constitucional y Procesal Penal, cit. 226.

1085Deberá ser destacado el hecho de que el primer gran desertor de la mafia siciliana fue Tommaso Buscetta, el conocido arrepentido, colaborador del Juez Giovanni Falcone al revelar la estructura de la mafia organizada (Cosa Nostra). Su testimonio fue usado en el primer maxi proceso contra la mafia iniciado en Palermo en 1986. Vid. MONTOYA, M. D., Informantes y técnicas de investigación encubiertas. Análisis Constitucional y Procesal Penal, cit. pág. 237. 
declaraciones falsas, ya que al ser descubierto lo harían perder un beneficio en el cual tiene cifrado una esperanza de vida1086.

Desde otra perspectiva, el denominado pentitismo ${ }^{1087}$ del tipo mafioso ha permitido a las autoridades una visión concreta sobre la capacidad operativa de las mafias, determinando la ampliación de su previsión legislativa y la creación de una estructura administrativa para su gestión operativa y logística (sector de los colaboradores de la justicia).

Es obvio que el término "pentitismo" no se usa en su dimensión ética, sino en su acepción menos noble, en el sentido hoy en uso en la comunidad social, en el significado vulgar que se limita a indicar simplemente el hecho objetivo de la admisión de la propia responsabilidad por uno o más delitos, acompañado de la ayuda proporcionada a los investigadores para el conocimiento del mundo criminal al que pertenece ${ }^{1088}$.

Dentro del contexto presentado, Italia que presenta serios problemas con relación a actuación de clanes organizados de mafiosos, tiene una experiencia de más de veinte años con los "arrepentidos" y la "colaboración con la justicia"1089. En 1979 aparece la primera disposición normativa que establece descuentos de la pena a los responsables de los delitos cometidos con finalidades terroristas o de subversión del ordenamiento constitucional, dispuestos a ayudar concretamente a la autoridad de la Policía y la autoridad judicial en la recogida de pruebas decisivas para la captura de los participantes ${ }^{1090}$.

1086 DOMINIONI, O., "L'esperienza della legislazione sui pentiti opinioni a confronto", Legislazione sui pentiti. Legislazione Penale, 1983, pág. 604. También del mismo autor italiano y versando sobre el tema del pentiti, vid. "La valutazione delle dichiarazioni dei pentiti", Rivista di Diritto Processuale, Padova, vol. 41, núm. 4, 1986, págs. 740-767.

1087 Para una mejor compresión del tema del "pentitismo", Vid. MUSCO, E., "Los colaboradores de la justicia entre el pentitismo y la calumnia: problemas y perspectivas", Revista Penal, núm. 2, 1998, págs. 35-47. Interesante ennoblecer que la denominación "pentito", que ha dado origen al fenómeno del "pentitismo", ha sido creada por la prensa en los años setenta, para designar la figura jurídica prevista en el Derecho italiano, en la ley 304/82, en su artículo 3oㅡ, o sea, el sujeto que, sometido a proceso penal, confesaba su propia responsabilidad y fornecía a las autoridades noticias útiles a la reconstitución de los hechos criminales (conexos con el terrorismo o con la violación del ordenamiento constitucional) y a la individualización de los respectivos responsables. En esta legislación, el arrepentido o pentiti podría ser beneficiado con hipótesis de no punibilidad y disminución de penas; todavía, la protección podría ser revocada en caso de las declaraciones ser consideradas reticentes o provocasen la desconfianza.

1088 Vid. MUSCO, E., "Los colaboradores de la justicia entre el pentitismo y la calumnia: problemas y perspectivas", cit., pág. 35. Para una proficua comprensión de la legislación italiana sobre los "arrepentidos" y su evolución en el tiempo, vid. CHELAZZI, G., La dissociazione dal terrorismo, Milano, 1981; RESTA, E., "I'l diritto penale premiale: nuove estrategie di controlllo sociale", Dei delitti e delle pene, núm. 1, 1983, págs. 41 y ss; FERRACUTI, F., "Legislación sobre el arrepentimiento en los delitos terroristas. Un primer análisis de los problemas planteados y de los resultados obtenidos en Italia", Revista de la Facultad de Derecho de la Universidad Complutense de Madrid, número monográfico 11, Homenaje al Prof. L. Jiménez de Asúa, 1986, págs. 303 y ss.

1089 Por esto, GARCÍA VALDÉS se refería a la República Italiana como "país exportador" de legislación en materia de arrepentidos. Vid. GARCÍA VALDÉS, C., "La legislación antiterrorista. Derecho vigente y proyectos continuistas", Temas de Derecho Penal (penología, parte especial, proyectos de reforma), Madrid, 1992, pág. 257.

1090 ORLANDI, R., "La lucha procesal penal contra La criminalidad organizada en Italia", VV.AA., Terrorismo y Proceso Penal acusatorio, cit., págs. 477-478. De su parte SÁNCHEZ GARCÍA DE PAZ, indica que "el origen de esta legislación premial se sitúa en los años 70, concretamente en un Decreto-Ley de 21 de marzo de 1978 seguido de otras posteriores, en el contexto de las Brigadas Rojas (la ley se dictó días después del secuestro de Aldo Moro, aunque no logró salvar su vida), y posibilitó en su momento gran número de procesos y condenas y un cierto acaso de la delincuencia terrorista". Vid. SÁNCHEZ GARCÍA DE PAZ, I., "El coimputado que colabora con la justicia penal (con atención a las reformas introducidas en la regulación española por las Leyes Orgánicas 7 y 15/2003)", cit., pág. 5. Actualmente, en materia de combate a la criminalidad organizada, dispone la legislación italiana respecto del uso de los arrepentidos: a) El artículo 8 del decreto ley de 13 de 
Sin embargo, mismo en Italia, donde la legislación premial ha encontrado mayor desarrollo y aplicación, se han constatado resultados contradictorios: mientras por un lado ha sido un factor decisivo en materia de lucha contra el terrorismo, por otro lado su empleo en el contexto de la lucha contra las asociaciones mafiosas ha sido controvertido.

En síntesis, en contexto del Derecho Italiano se puede afirmar que el arrepentimiento es un instrumento desde el punto de vista del arrepentido para obtener el premio, desde la óptica del Estado es útil para obtener información sobre una organización terrorista o la mafia1091.

¿Y cuál sería la razón para dar un tratamiento diferenciado a esa persona que se torna en un delator?

Con la previsión de un mejor tratamiento punitivo al delincuente arrepentido, se trataría de incluir, junto al castigo como consecuencia legítima de la comisión de la conducta constitutiva de delito, la del premio por la contra conducta consistente en la colaboración con la justicia ${ }^{1092}$.

En realidad, la necesidad de obtener información a los efectos de desmantelar el hermetismo y la cohesión interna de las organizaciones criminales dedicadas a tan ilícita actividad lleva a los legisladores nacionales a establecer tipos penales privilegiados con la finalidad de dar un tratamiento penal más benigno a quienes colaboren con los órganos jurisdiccionales a los efectos represivos de dichas infracciones ${ }^{1093}$.

mayo de 1991, número 152, de medidas urgentes en materia de criminalidad organizada y de transparencia y buen funcionamiento de la actividad administrativa, que posteriormente sería convertido en Ley de 12 de julio de 1991, número 203, prevé una disminución de la pena (de cadena perpetua a prisión de 12 a 20 años y para el resto de las penas la mitad) para el culpable de delitos de asociación mafiosa que se separa de la asociación actuando para evitar que la actividad delictiva llegue a consecuencias ulteriores, también ayudando concretamente a la autoridad judicial en la búsqueda de elementos decisivos para la reconstrucción de los hechos y para individualizar o capturar a los autores del delito; b) La Ley de 19 de marzo de 2001, número 92, modifica la normativa concerniente a la represión del contrabando de tabaco elaborado, recogida en el texto único de las disposiciones legislativas en materia de aduanas, aprobado por Decreto del Presidente de la República de 23 de enero de 1973, número 43, incluyendo en el mismo un nuevo artículo 291, con la previsión de disminución de pena de un tercio a la mitad al imputado que, separándose de los otros, actúa para evitar que la actividad delictuosa llegue a consecuencias ulteriores también ayudando concretamente a la autoridad de policía o a la autoridad judicial en la recolección de elementos decisivos para la reconstrucción de los hechos y para la individualización de los medios relevantes para la comisión de los delitos.

1091 MONTOYA, M. D., Informantes y técnicas de investigación encubiertas. Análisis Constitucional y Procesal Penal, cit. pág. 227.

1092 En este sentido, vid. BENÍTEZ ORTÚZAR, I. F., El colaborador con la justicia. Aspectos sustantivos procesales y penitenciarios derivados de la conducta del "arrepentido", cit., pág. 21. También sobre el tema, afirma SEOANE SPIEGELBERG que "la necesidad de obtener información a los efectos de desmantelar el hermetismo y la cohesión interna de las organizaciones criminales dedicadas a tan ilícita actividad lleva a los legisladores nacionales al establecimiento de tipos penales privilegiados, con la finalidad de dar un tratamiento penal más benigno a quienes colaboren con los órganos jurisdiccionales a los efectos represivos de dichas organizaciones". Vid. SEOANE SPIEGELBERG, J. L., "Aspectos procesales del delito de tráfico de drogas", cit., pág. 349.

1093 Vid. SEOANE SPIEGELBERG, J. L., "Aspectos procesales del delito de tráfico de drogas", cit., pág. 349. Sosteniendo una posición doctrinal semejante, JORDÁN DÍAZ-RONCERO y COMES RAGA afirman que "razones de pragmatismo político-criminal han inducido al legislador a conceder beneficios penales y penitenciarios a todos aquellos que colaboren activamente en la evitación de futuros delitos, y el descubrimiento de los ya cometidos". Cfr. JORDÁN DÍAZ-RONCERO, Mạ. J; COMES RAGA, I., "El arrepentimiento postdelictual en España: un ensayo acerca de su viabilidad como instrumento combativo del crimen organizado", cit., http://www.revista-laleypenal.laley.es. 
Llegado a este punto del análisis, cabría preguntar cuál sería el concepto más adecuado para una comprensión del personaje denominado arrepentido ${ }^{1094}$.

Se puede conceptuar esta figura como el sujeto que arrepentido de su intervención en un acto delictuoso, o con el único afán de gozar del nuevo beneficio que le brinda la ley, suministra datos que contribuyen o permiten una más adecuada y eficaz actuación de la justicia ${ }^{1095}$.

Por su parte BENÍTEZ ORTÚZAR denomina de colaborador de la justicia o arrepentido como aquél miembro o ex miembro de la organización delictiva que aporta elementos que pueden ser usados para la incriminación de otros miembros de la organización, o para impedir la comisión de nuevos delitos. Prosigue este autor señalando que normalmente esta colaboración va a fomentarse con una expectativa de disminución en la pena impuesta o en la obtención privilegiada de beneficios penitenciarios ${ }^{1096}$.

También la Fiscalía Especial para la Prevención y Represión del Tráfico de Drogas en España define al colaborador con la justicia o arrepentido como aquél que, con su colaboración, contribuye, esté o no iniciado el proceso, a evitar la comisión de hechos delictivos, a descubrir los ya cometidos y a identificar a los responsables, y en función de ese comportamiento, de la trascendencia o colaboración prestada, del momento en que se realiza, se hace beneficiario en el ámbito jurídico penal de cláusulas de reducción ${ }^{1097}$.

Tomadas en cuenta estas opiniones, podemos conceptuar al confidente o arrepentido como aquella persona que ya teniendo hecho parte de una organización criminal, conociendo profundamente la estructura, el poder logístico y el grado de jerarquía del clan de delincuentes, decide "cambiar de puesto", pasando a trabajar para el órgano de persecución penal, y con esa actitud, acaba por ayudar a través de sus valiosas informaciones prestadas, la desarticulación del grupo criminal. En consecuencia, al final siempre el arrepentido termina por recibir alguna contraprestación a cambio de su declaración.

Todavía, es preciso recordar que en realidad el problema del arrepentido surge de un pacto entre dos partes interesadas: de un lado, los órganos encargados de la persecución penal, que necesitan de "colaboradores de la justicia" para obtener un conocimiento suficiente acerca del funcionamiento interno de complejas estructuras criminales; de otro, el arrepentido, que busca un beneficio personal y la vuelta a la normalidad social en régimen de libertad ${ }^{1098}$.

1094 Respecto a las recomendaciones internacionales, en especial en el ámbito de la Unión Europea y Naciones Unidas, versando sobre el instrumento denominado "arrepentido", vid. con riqueza de detalles: SÁNCHEZ GARCÍA DE PAZ, I., "El coimputado que colabora con la justicia penal (con atención a las reformas introducidas en la regulación española por las Leyes Orgánicas 7 y 15/2003)", cit., págs.11-13.

1095 Siguiendo esta posición, señala EDWARDS, que el arrepentido es aquella persona a quien se le imputa cualquier delito referido a estupefacientes, y que brinda a la autoridad judicial información significativa sobre la identidad de los autores, coautores, partícipes o encubridores del tráfico ilícito de estupefacientes, o que permita el secuestro de sustancias, bienes, etc., pertenecientes a este tipo de delincuencia, se beneficiando en la reducción de pena. Cfr. EDWARDS, C. E., El arrepentido, el agente encubierto y la entrega vigilada, cit., pág. 31.

1096 Cfr. BENÍTEZ ORTÚZAR, I. F., El colaborador con la justicia. Aspectos sustantivos procesales y penitenciarios derivados de la conducta del "arrepentido", cit., pág. 21.

1097Vid. Memoria Fiscalía Especial, 1990, pág. 66, http://www.fiscal.es/. También, la STS 34/1999 de 11.1.1999.

1098 CHOCLÁN MONTALVO, J. A., La organización Criminal. Tratamiento penal y procesal, cit., págs. 65-66. 
Efectivamente, parece evidente que el arrepentido, igual que el informante ${ }^{1099}$, no es nada más que una forma de colaboración con la justicia. El objetivo a ser alcanzado por el arrepentido en este "cambio de favores", mediante realización de un pacto de cooperación, consiste en la obtención por parte del mismo junto a los órganos judiciales, de un beneficio relativo a una posible reducción o reconocimiento de una eximente de la sanción penal.

Los arrepentidos, dada su anterior vinculación con los grupos investigados y su conocimiento interno, pueden resultar de gran ayuda a la hora de desmantelar redes de crimen organizado ${ }^{1100}$. En realidad, nada mejor que el testimonio de una persona que ha participado del entramado criminal para que posibilite a los órganos de persecución criminal conocer a fondo las informaciones y datos sigilosos que vengan a ayudar en el desmantelamiento del grupo de delincuentes organizados.

Esta figura del arrepentido es muy utilizada en las hipótesis de investigaciones de grupos organizados relacionados con el tráfico de estupefacientes ${ }^{1101}$, o con el terrorismo, en los cuales existe la posibilidad de un arrepentimiento de alguno de los autores o coautores del delito con la clara intención de obtener un privilegio judicial.

Hechas las consideraciones generales sobre esta figura, no sobran dudas sobre la imposibilidad de confundir la misma con el agente encubierto, pues este último exactamente realiza el camino contrario al del arrepentido, ya que se adentra en la organización criminal a través de una infiltración. El arrepentido justamente sale del entorno criminal del grupo delictivo para prestar colaboración a las autoridades de persecución penal.

IV.1.6. Las principales características de la figura del agente encubierto.

Hasta aquí se ha comprobado que el agente encubierto o infiltrado se puede catalogar como un medio extraordinario de investigación de determinados delitos graves cuya comisión se encuadra en la actividad de una organización criminal, que consiste en integrar o incorporar a la estructura de dicha organización a un funcionario de policía, a quien, a tales efectos, se le otorga una identidad supuesta o ficticia, para poder recabar, desde esa posición y ante las dificultades de hacerlo mediante los medios de investigación ordinarios, información y datos sobre los hechos delictivos investigados, así como otros que puedan conducir a conocer la estructura, integrantes, financiación y funcionamiento de la organización criminal que puedan conducir a su desmantelamiento o a lograr su inoperancia ${ }^{1102}$.

1099 Todavía, esclarece EDWARDS que la diferencia principal entre el informante y el arrepentido consiste en hecho de que "mientras el informante puede recibir un incentivo económico, el arrepentido se favorece únicamente con la reducción o eximición de pena". Vid. EDWARDS, C. E., El arrepentido, el agente encubierto y la entrega vigilada, cit., pág. 34.

1100 MEDINA ARIZA, J. J., "Una introducción al estudio criminológico del crimen organizado", cit., pág. 128. Como señalan algunos autores, aparte de la novedad que como método de investigación supone, la figura del arrepentido destaca por su importante efecto penológico, ya que permite bajar la pena en uno o dos grados. Vid. en este sentido, CLIMENT DURÁN, C; GARCÍA GONZÁLEZ, J; PASTOR ALCOY, F; PÉREZ MARTÍNEZ, A., Las drogas en el nuevo Código penal. Doctrina, jurisprudencia y formularios, Valencia, 1998, pág. 51; NÚÑEZ PAZ, M. A., "Consideración critica en torno al Código penal español", Anuario de Derecho Penal y Ciencias Penales, vol. LII, 1999, págs. 265 y ss.

1101 Véase como ejemplo en Argentina, la Ley 24.424, artículo 5o.

1102 GUZMÁN FLUJA, V. C., "El agente encubierto y las garantías del proceso penal", cit., pág. 215. 
A estos efectos debe se recordar que esta técnica de investigación criminal ha sido adoptada en los últimos tiempos por varios ordenamientos jurídicos, los cuales han presentado una enorme preocupación con el crecimiento de la delincuencia organizada de carácter transnacional, factor este que se agrava de modo considerable en razón de la ineficiencia de los medios tradicionales de investigación.

Queda muy claro, pues, que si la criminalidad organizada y especializada utiliza de unos medios de actuación que se encuentran totalmente cerrados al exterior, la intervención de la Policía exige, a menudo, trasladar la investigación a ese ambiente ${ }^{1103}$. Al respeto, se declara que la figura del agente encubierto supone la puesta en práctica de un instrumento esencial en la lucha contra el crimen organizado siempre y cuando sea utilizado de conformidad constitucional, respetando especialmente los requisitos de legalidad y de proporcionalidad.

A la vista de las anteriores reflexiones es necesario en este punto esclarecer cuáles serían las finalidades básicas inherentes a este personaje central de esta técnica extraordinaria de investigación.

Para una comprensión más adecuada de la situación hay que tener en cuenta que nos hallamos inmersos en un mundo globalizado, el cual se encuentra impregnado por las actuaciones de organizaciones criminales de carácter transnacional especializadas en delitos graves como el narcotráfico, el terrorismo, el blanqueo de capitales, la corrupción y otros. En este sentido, es una verdad incuestionable que el fenómeno de la delincuencia no se detiene; al contrario, se encuentra siempre en constante y vertiginosa expansión, viniendo a crear constantemente medios y técnicas nuevase innovadoras para el acometimiento de ilícitos ${ }^{1104}$

Siguiendo esta realidad, se hace imprescindible que las autoridades involucradas en la persecución penal no permanezcan en situación de inferioridad frente al desarrollo de la delincuencia, a la vez que en este caso estaría omitiendo su deber constitucional de protección y preservación de la paz y de la seguridad ciudadana.

Se busca, pues, un modo eficiente, adecuado y legalmente establecido para descifrar el funcionamiento de una estructura organizada de actores criminales. Y sería en este momento en el que surgiría la necesidad del empleo de la técnica de infiltración a través de agentes encubiertos.

Como consecuencia, la intervención de un agente encubierto tiene su sede en la fase de investigación de un determinado proceso penal que se suscita contra un concreto entramado organizativo ${ }^{1105}$. Como señala MARTÍNEZ PÉREZ, tendrá que perseguir el fin

1103 Cfr. MOLINA PÉREZ, T., "Técnicas especiales de investigación del delito: el agente provocador, el agente infiltrado y figuras afines", Anuario Jurídico y Económico Escurialense, XLI, 2008, pág. 185.

1104 Un excepcional ejemplo del grado de profesionalismo y modernización del modus operandi de estos clanes de criminales se puede extraer del uso en los últimos años en Colombia, de submarinos para el transporte de drogas para otros países, en especial para los Estados Unidos. Se trata del denominado "narcosubmarino", el cual consiste en una embarcación especializada para operar de forma sumergida, y que se utilizada para fines del tráfico de drogas, y en razón de ausencia de un control policial sobre los sitios más profundos de los océanos, acaba por frustrar los intentos de obtención de pruebas contra estas organizaciones de delincuentes transnacionales. Vid. con más detalles y riqueza de informaciones sobre este modo de actuar de los carteles de droga en Colombia, el video de la cadena Discovery Channel denominado "Narcosubmarinos", http://citytv.com.co/videos/148298/narcosubmarinos-especial-de-discovery-channel.

1105 Cfr. ESPINOSA DE LOS MONTEROS, R. Z., El policía infiltrado. Los presupuestos jurídicos en el proceso penal español, cit., pág. 93. 
mediato centrado en el conocimiento interno de la organización, procurando así llegar a su desarticulación total1106.

Por tanto, se puede señalar que la finalidad de la infiltración policial a través de agentes encubiertos es permitir que los delitos que impliquen delincuencia organizada sean investigados de una forma más efectiva para identificar a todos sus miembros, su estructura y actuación, generando una obtención de pruebas que culmine con la sanción del mayor número posible de integrantes del grupo ${ }^{1107}$.

Dicho de otro modo, la finalidad concreta de la intervención del agente encubierto seria la de conseguir información relevante y suficiente ${ }^{1108}$ para llegar a la desarticulación de la organización y la prevención y combate de los hechos delictivos cometidos por la misma ${ }^{1109}$.

Una última observación relativa al objetivo buscado a través de una operación encubierta a través de agentes infiltrados podemos hacerla respecto a la necesaria referencia distintiva entre la finalidad preventiva y represiva de la infiltración policial. La primera hace alusión a la evitación de la consumación de delitos, mientras que la segunda modalidad, con el fin represivo se configura como un modo de obtener información para facilitarse a las autoridades penales en cuanto a delitos ya consumados ${ }^{1110}$.

Finalizado el análisis respecto a la finalidad primordial de esta técnica de investigación, nos cabe ahora explicitar cada una de sus principales características.

IV.1.6.1. El carácter de "medio extraordinario de Investigación criminal".

En principio, se suele afirmar que se trata de un "medio extraordinario de investigación criminal", justificando tal denominación en razón de que el agente encubierto no es parte del rol de las técnicas comunes o tradicionales de descubrimiento de delitos.

Como consecuencia se tiene muy claro que el infiltrado como personaje de la persecución e investigación penal no posee la tarea de laborar en la búsqueda del enfrentamiento legal a todas las especies de delitos, pues como medio extraordinario y excepcional de actuación estatal estaría encargado de servir solamente en casos de gran repercusión social, especialmente en hipótesis de combate a delitos graves practicados por delincuentes organizados.

Sin embargo, el agente encubierto merece el calificativo de "medio de control extraordinario"1111 al conllevar una alteración de principios constitucionales básicos y un fuerte "ataque" a determinados derechos fundamentales, razones ambas determinantes de

\footnotetext{
1106 MARTÍNEZ PÉREZ, R., Policía judicial y Constitución, cit., pág. 398.

1107 En este sentido, CORRÊA DE CARVALHO, J. T., Tráfico de drogas. Prueba penal y medidas restrictivas de derechos fundamentales, cit., pág. 318.

1108 Vid. RIVES SEVA, A. P., La prueba en el proceso penal. Doctrina de la Sala segunda del Tribunal Supremo, cit., pág. 75.

1109 RIFÁ SOLER, J. Mํa-, "El agente encubierto o infiltrado en la nueva regulación de la LECrim", cit., pág. 158.

1110 Cfr. ESPINOSA DE LOS MONTEROS, R. Z., El policía infiltrado. Los presupuestos jurídicos en el proceso penal español, cit., pág. 67. Dentro de esta temática, importante destacar que en Alemania y Portugal se regulan tanto la finalidad represiva como la preventiva, al paso que en España y Brasil sólo los fines represivos.

1111 Vid. FERRAJOLI, L., Derecho y razón. Teoría del garantismo penal, cit., pág. 701; DELGADO MARTíN, J., "El proceso penal ante la criminalidad organizada. El agente encubierto", cit., págs. 5-6.
} 
que su empleo quede sometido al cumplimiento de estrictos requisitos legales, paliativos de los riesgos para las garantías procesales vigentes en un Estado de Derecho1112.

En nuestra opinión, aquí se instala la solución para la adopción de este medio de investigación: trabajar siempre asentado en la obediencia a los principios fundamentales del Estado de Derecho, en especial, se observando el criterio de proporcionalidad.

No se debe en todo caso olvidar que la técnica de investigación a través del uso de agentes infiltrados es actualmente un instrumento imprescindible en la lucha contra las nuevas y complejas formas de delincuencia transnacional, pero deberá ser utilizada como medida excepcional y obedeciendo a los postulados de un proceso penal garantista.

En síntesis, el calificativo "extraordinario" se debe al hecho del personaje del agente encubierto o infiltrado no figurar entre los medios tradicionales o comunes de investigación criminal, siendo reglamentado en los ordenamientos penales de un sinnúmero de países solamente en tiempos recientes para hacer frente al crecimiento de la delincuencia organizada transnacional. Así es que se trata de una técnica de investigación no tradicional, como no tradicional es, el marco en el que está llamada a operar, cual sea, el de la criminalidad organizada ${ }^{1113}$.

Se concluye que por ser considerado como un medio extraordinario de investigación, el recurso a las infiltraciones de agentes se torna especialmente delicado, a la vez que deberá ser empleado en consonancia con las exigencias del respecto a las garantías procesales. Por así decirlo, el uso de esta clase de medios de investigación, en opinión de GUZMÁN FLUJA, es como "jugar con fuego", y por ello se entra en una zona donde resultará fácil "quemarse"1114.

Significa este presupuesto que debe existir entonces la búsqueda del establecimiento de una zona de equilibrio en donde se puedan encontrar los puntos que tendrán la función de ablandar la tensión existente entre la necesidad y obligatoriedad de aplicación del ius puniendi estatal y la imprescindible tutela y defensa de las garantías fundamentales del ciudadano. A estos efectos, se debe recordar una vez más la importancia destacada del principio de la proporcionalidad y de sus consecuentes requisitos de ponderación.

\section{IV.1.6.2. Utilización restricta a la investigación de la delincuencia organizada.}

Otra característica peculiar al agente infiltrado es que su actuación deberá ocurrir, en general, cuando se trate de investigaciones que afecten a actividades propias de la

1112 Cfr. MONTÓN REDONDO, A et alli., Derecho jurisdiccional III, cit., pág. 207. También, GÓMEZ DE LIAÑO FONSECA-HERRERO, M., Criminalidad organizada y medios extraordinarios de investigación, cit., pág. 129. Esta última autora en otro trabajo, ha tenido la oportunidad de complementar que "el agente encubierto merece ser cualificado como un medio extraordinario de investigación, en atención a que dos notas inherentes a la figura determina graves repercusiones desde el inicio en derechos y principios constitucionales: el engaño y la identidad falsa facilitada por el Estado al policía que voluntariamente asume la condición de infiltrado". Vid. "El agente encubierto como medida de investigación del terrorismo en el contexto internacional", cit., pág. 421. En este mismo sentido, afirma CORREAA DE CARVALHO que "la investigación por medio de agentes encubiertos sin lugar a dudas puede restringir derechos fundamentales de los investigados; por lo tanto, debe ser autorizada en situaciones excepcionales y proporcionales en las que su utilización sea justificable por la naturaleza de la investigación llevada a cabo". Vid. CORRÊA DE CARVALHO, J. T., Tráfico de drogas. Prueba penal y medidas restrictivas de derechos fundamentales, cit., pág. 319.

1113QUINTANAR DIEZ, M., "El agente encubierto", Revista Letras jurídicas, núm. 1, México, 2005, http://letrasjuridicas.cuci.udg.mx/.

1114 Vid. GUZMÁN FLUJA, V. C., "El agente encubierto y las garantías del proceso penal", cit., pág. 216. 
delincuencia organizada1115. Incluso más, pues esto dependerá de la constatación de la gravedad de las conductas delictivas cometidas por estos grupos.

Dicho en otras palabras, en razón de la fuerte carga de restricción de derechos y garantías fundamentales en que podrá verse envuelta la persona investigada, el recurso al agente encubierto deberá siempre estar relacionado con la práctica de delitos marcados por extrema gravedad y por el empleo de sofisticación y violencia, como ocurre por ejemplo con los actos criminales practicados por los grandes clanes de narcotraficantes y terroristas que actúan a nivel internacional.

Pues bien, a partir de estas premisas resulta clara la necesidad de los ordenamientos jurídicos penales y de la jurisprudencia en conceptuar lo que se debe entender por "organización criminal"1116.

En torno a esta cuestión, cabe precisar que ya hemos tenido la oportunidad, con ocasión del análisis del tema de las organizaciones criminales, de explicitar las principales dificultades encontradas para la búsqueda de un concepto cerrado y unívoco que pueda servir a los fines de persecución penal.

Lo que si interesa en este momento es poner en claro que la Policía Judicial que conozca o sospeche de la existencia de una actividad delictiva propia de la delincuencia organizada puede, desde que resulte autorizada por un órgano judicial, infiltrar a un agente encubierto en el seno de la organización para proceder a una detallada investigación en busca de informaciones y pruebas que permitan impedir o sancionar la actividad ilícita, e incluso proceder a desarticular el grupo ${ }^{1117}$. Para ello, el agente se introduce en los canales de la organización criminal, procurando desvelar su estructura para llegar hasta sus mandos ${ }^{1118}$.

Partiendo de este enfoque, es necesario plantearnos una importante duda: ¿siempre deberá ser empleada la infiltración policial para casos de investigaciones que tengan por objeto actuaciones de grupos de delincuentes organizados? O planteado de otra forma, ¿el simple hecho de tratarse de actuaciones relacionadas con el crimen organizado justificaría la adopción de esta técnica de investigación?

Como respuesta concreta a esta cuestión se puede contestar aduciendo que la aplicación de esta medida debe ser entendida con carácter excepcional, sólo para aquellas manifestaciones graves y dañinas para la sociedad no pudiéndose, por ende, aplicarse de

\footnotetext{
1115 Ciñéndonos al ordenamiento procesal penal español, MOLINA MANSILLA señala que: "la explicación de que el legislador haya contemplado unas herramientas de investigación en la lucha contra la delincuencia organizada se halla en los siguientes motivos: 1) la organización genera un efecto delincuencial multiplicador, puesto que potencia las posibilidades de realización de actividades delictivas, posibilitando asimismo la protección entre los integrantes del grupo (STS 1631, de 10.03.2006); 2) la organización posee una naturaleza clandestina y una complejidad que favorece su opacidad dificultando su persecución (SSTS, 1294 de 26.02.2004 y 1407 de 08.03.2005)". Vid. MOLINA MANSILLA, Ma. C., Mecanismos de investigación policial: entrega vigilada y agente encubierto, cit., pág. 30.

1116 Relativo a esta problemática, en opinión de GUZMÁN FLUJA, "es necesario determinar con la mayor claridad posible qué se debe entender por organización criminal. Claro que es una tarea especialmente compleja, pero cuando menos hacerse procurando ser estrictos, huyendo de definiciones generales, o poco precisas, evitando que cualquier asociación o concurrencia de dos o más personas pueda ser considerada como organización criminal". Vid. GUZMÁN FLUJA, V. C., "El agente encubierto y las garantías del proceso penal", cit., pág. 217.

1117 Vid. la STS 7815 de 15.11.2007.

1118 MOLINA MANSILLA, Mạ. C., Mecanismos de investigación policial: entrega vigilada y agente encubierto, cit., pág. 30.
} 
manera generalizada a todas las organizaciones criminales puesto que si así fuera este medio de investigación se convertiría en una medida de carácter policial propia de los Estados autoritarios ${ }^{1119}$.

Demostración inequívoca de lo anteriormente afirmado se encuentra en la consideración fáctica de que es perfectamente posible que un grupo de delincuentes organizados practiquen conductas delictuosas de escasa gravedad y que pueden ser perseguidas y sancionadas con fundamento en la obtención de informaciones y pruebas conseguidas a través del uso de medios tradicionales de investigación criminal, sin necesidad del uso in extremis de una operación de infiltración de agentes.

A tenor de esta consideración, fácil es deducir que los clanes organizados también pueden incluir en el rol de sus actividades ilícitas la consecución de delitos de poca expresión económica y limitada repercusión social, los cuales estarán sujetos a la utilización de medios tradicionales de investigación y producción de la prueba. De otra parte, en hipótesis de perpetración de delitos complejos y de destacada peligrosidad como el caso del tráfico de estupefacientes, tendría la infiltración el objeto de descubrir las acciones delictivas pasadas, prevenir las futuras y lograr la desaparición y el castigo de la banda con todos los elementos que la integran ${ }^{1120}$.

En síntesis, la intervención del agente encubierto requiere que se trate de investigación de delitos graves ${ }^{1121}$, atendiendo no sólo a la previsión legal de una pena privativa de libertad alta, sino además a la trascendencia social del delito que se trata de investigar ${ }^{1122 .}$

Por fin, resulta imprescindible dejar sentado que violaría el principio de proporcionalidadla utilización del medio de investigación a través de agentes infiltrados, a los fines de buscarse pruebas, datos e informaciones respecto a delitos sin destacada gravedad y practicados por delincuentes callejeros, incluso aunque actúen de forma mínimamente organizada. Y la explicación es sencilla, pues al tratarse de una técnica policial que presenta una alta carga de restricción de derechos fundamentales su utilización deberá ocurrir en situaciones extremas, cuando las otras formas tradicionales de investigación se demostraren ineficaces u obsoletas.

\footnotetext{
${ }^{1119}$ Sosteniendo este entendimiento, vid. ESPINOSA DE LOS MONTEROS, R. Z., El policía infiltrado. Los presupuestos jurídicos en el proceso penal español, cit., pág. 312. Incluso llega a afirmar que "a los efectos de la intervención de los agentes encubiertos, hay que señalar que sólo podrá recurrirse a ellos, cuando estemos ante organizaciones realmente lesivas para el Estado de Derecho y cuando sus conductas criminales, supongan graves consecuencias para la paz social y seguridad de los ciudadanos". Cfr. ESPINOSA DE LOS MONTEROS, R. Z., El policía infiltrado. Los presupuestos jurídicos en el proceso penal español, cit., pág. 312.

1120 Vid. MORENO CATENA, V., "Los agentes encubiertos en España", Revista Ilustre Colegio de Abogados de Madrid, núm. 10, 1999, pág. 40.

1121 Se justifica la exigencia de la gravedad de la conducta investigada, a la vez que como medio de ponderar los intereses públicos y privados en conflicto, la justificación de esta medida también debe versar sobre si el delito que pretende aclararse resulta grave de por sí. Esto tiene relación con la proporcionalidad entre la magnitud de la injerencia estatal y la gravedad del delito a investigar, donde para determinar dicha gravedad se necesitaría, además de que el delito se lleve a cabo en el seno de una organización criminal, evaluar otros factores como la cuantía de la pena señalada y que esa conducta sea suficiente por sí misma para afectar sensiblemente la tranquilidad o el sentimiento de seguridad jurídica de la población. Con más detalles, véase GUERRERO PERALTA, O. J., Fundamentos teóricos constitucionales del nuevo proceso penal, Bogotá, 2007, pág. 395.
}

1122 Vid. la STS 4533 de 27.06.2007. 


\section{IV.1.6.3. Uso de identidad ficticia o supuesta y el engaño.}

La utilización de laidentidad supuesta, junto con la estrategia del engaño, son elementos consustanciales a la infiltración policial ${ }^{1123}$. Sin el empleo de estas técnicas policiales jamás se podrá esperar un éxito en las tareas de investigación del infiltrado, a la vez que no tendría como se conquistar la confianza de los demás miembros de la organización criminal.

De otra parte está bastante extendida la idea de que los órganos de persecución penal no vienen consiguiendo obtener informaciones, datos y pruebas contra los grandes clanes de delincuentes organizados, en razón de que a cada día aumenta de forma sensible la opacidad de sus actuaciones y el cierre de la organización al mundo exterior ${ }^{1124}$, encontrándose el Estado de Derecho con una fuente cerrada de actos ilícitos de significativa gravedad.

Asimismo, la justificación para que se acepte el uso del engaño en una técnica de investigación criminal se debe a la clandestinidad, sofisticación y alta peligrosidad que representan las nuevas formas de criminalidad organizada ${ }^{1125}$.

El secreto sobre la efectiva identidad del infiltrado representa una conditio sine quo non para que pueda cumplirse una acción encubierta de penetración en el seno de una determinada organización de delincuentes, con la finalidad fundamental de establecer una relación de confianza e intimidad con los presuntos delincuentes que le permita obtener información que sirva para la persecución penal de los mismos ${ }^{1126}$.

La identidad ficticia sería en síntesis un instrumento excelente para infiltrar a un agente en una organización delictiva,otorgando credibilidad al agente y provocando dificultades en lo relativo al descubrimiento la su verdadera identidad. Sin embargo, la creación de una identidad ficticia puede provocar un problema legal. Así, tal vez se necesite modificar los registros oficiales para poder emitir documentos de identidad, licencias de conducir y establecer una historia creíble de la persona ${ }^{1127}$.

Amén de las dificultades anteriormente apuntadas, la identidad supuesta es una simulación que permite el ordenamiento jurídico para introducirse en las organizaciones criminales, en donde el agente ha de desempeñar un "papel" que confunda a los integrantes de tal organización y les permita suponer que se trata de "uno de ellos". Luego,

1123 En este sentido, ESPINOSA DE LOS MONTEROS, R. Z., El policía infiltrado. Los presupuestos jurídicos en el proceso penal español, cit., pág. 69. Nos parece lógico y en conformidad con los parámetros fundamentales de las técnicas de investigación encubiertas, que el agente que va a se infiltrar en un determinado grupo criminal, no deje aclarar su verdadera identidad, pues que estaría poniendo en riesgo su propia vida, además de despertar el rígido control del código del silencio establecido entre los miembros de la organización criminal.

1124 En nuestra opinión la causa es única: el código del silencio impuesto a losmiembros del clan criminal, lo cual se roto por alguien, podrá generar consecuencias irreparables llegando hasta mismo a la muerte del delator.

1125 Vid. ESPINOSA DE LOS MONTEROS, R. Z., El policía infiltrado. Los presupuestos jurídicos en el proceso penal español, cit., pág. 74.

1126 Véase GONZÁLEZ-CASTELL, A. C., "El agente infiltrado en España y Portugal. Estudio comparado a la luz de las garantías y de los principios constitucionales", cit., pág. 187. Se trata además "de una figura de grandes complejidades no sólo técnicas, sino también prácticas, de la que resulta conveniente acotar sus líneas características para diferenciarla de otras figuras afines". Vid. GOMÉZ DE LIAÑO FONSECA-HERRERO, M., Criminalidad organizada y medios extraordinarios de investigación, cit., pág. 131.

1127 Cfr. la Recomendación 37 del Grupo de Trabajo Oficioso de Expertos sobre Técnicas Especiales de Investigación (Prácticas óptimas y recomendaciones sobre los obstáculos jurídicos a las entregas vigiladas y las operaciones encubiertas), de Naciones Unidas, septiembre de 2005. 
si la ley permite tal simulación con objeto de desarticular la organización, no se puede aceptarse criticas, mismo porque no hay otro modo de penetrar en una determinada organización criminal. Sin embargo, por cierto será la utilización de la identidad falsa el aspecto más complicado de toda esa operativa policial. En consecuencia, respetados los derechos fundamentales en tal infiltración, cualquier otra actuación para la penetración en la trama organizada debe considerarse legal ${ }^{1128}$.

En torno a esta afirmación, cabe precisar otra vez más que no existe otra forma de un agente estatal ingresar en la organización criminal, sino que poniendo en práctica técnicas policiales de engaño y simulación, las cuales por cierto conllevaran a los demás miembros del grupo a formar lazos de confianza junto al infiltrado, se empezando a partir de este momento el trabajo encubierto de obtención de las informaciones imprescindibles al éxito de una futura la acción penal contra los autores identificados como pertenecientes a este grupo de delincuentes.

Es evidente que no sólo la identidad sino también las investigaciones deben ser mantenidas en secreto mientras no termine la investigación, pues si el investigado, incluso sin conocer la identidad del infiltrado, es consciente de que hay una persona infiltrada, todo el trabajo estaría en altísimo riesgo.

Queda muy claro que sin una identidad ficticia o falsa no habrá éxito en la infiltración como operación encubierta, a la vez que no hay otra forma de obtener la confianza de otros miembros del grupo criminal para satisfacer el objetivo de conocer a fondo las características del grupo o clan de delincuentes ${ }^{1129}$.

En realidad, el agente infiltrado ha de desempeñar un papel que confunda a los integrantes de la organización y les permita suponer que se trata de uno de ellos ${ }^{1130}$; por lo tanto, mientras ostente la identidad falsa, queda legítimamente habilitado para participar en las actividades desarrolladas por la organización delictiva, realizando las tareas que le sean encomendadas, teniendo en cuenta que su actuación la realiza bajo la identidad supuesta ${ }^{1131}$.

Más que todo esto, según estudios de expertos de las Naciones Unidas, el marco jurídico de cada país debería permitir la creación y la utilización de esta identidad con anterioridad a la operación encubierta para asegurar la credibilidad de la identidad ${ }^{1132}$.

1128 STS 975/2007, de 15.11.2007.

1129 Del mismo modo, sería en razón del "engaño' que algunos autores determinan el agente encubierto como una mentira viviente que crea relaciones, penetra en la intimidad, percibe confidencias y presencia escenas a las que en absoluto hubiera tenido acceso de conocerse su verdadera identidad. Cfr. GASCÓN INCHAUSTI, F., Infiltración policial y "agente encubierto", cit., pág. 102; SEQUEROS SAZARTORNIL, F., El tráfico de drogas ante el ordenamiento jurídico. Evolución normativa, doctrinal y jurisprudencial, Madrid, 2000, pág. 756.

1130 Vid. la STS 4107/2003 de 13.6.2003.

1131MOLINA MANSILLA, Ma. C., Mecanismos de investigación policial: entrega vigilada y agente encubierto, cit., pág. 34. Importante también señalar que "el riesgo que correría el entorno del agente encubierto si se conociera la verdadera identidad se minimiza al otorgar la identidad supuesta". Cfr. ESPINOSA DE LOS MONTEROS, R. Z., El policía infiltrado. Los presupuestos jurídicos en el proceso penal español, cit., pág. 70.

${ }^{1132}$ Cfr. la Recomendación 38 del Grupo de Trabajo Oficioso de Expertos sobre Técnicas Especiales de Investigación (Prácticas óptimas y recomendaciones sobre los obstáculos jurídicos a las entregas vigiladas y las operaciones encubiertas), de Naciones Unidas, septiembre de 2005. Se puede concluir que el resultado de una operación encubierta depende principalmente de la credibilidad en la identidad presentada por el agente. Crear una identidad con un fin específico puede ir en contra del éxito de la operación, dado que los delincuentes pueden averiguar con facilidad la identidad y detectar que el agente es en realidad un funcionario encargado de tareas de investigación. 
Nos parece muy acertada esta posición, pues el procedimiento de preparación de un agente que iba a trabajar como infiltrado sugiere un tiempo razonable de adaptación de esta persona junto a su "nueva" identidad, hecho este primordial al éxito de la operación donde no hay espacio para vacilación o equívocos que podrán costar la vida del agente encubierto.

En este contexto el agente encubierto no se limitará al uso público de un nombre supuesto, sino que necesitará de una "leyenda" que afecte a múltiples aspectos de la vida social, con la finalidad de conseguir la confianza de los miembros de la organización delictiva investigada, así como para burlar los controles (contra vigilancia) que la misma pueda establecer. Debe se tener en cuenta que cuanto más sofisticada sea la organización criminal, cuantos más medios materiales tenga a su disposición, más extensa y cuidada debe ser la "leyenda" del agente encubierto ${ }^{1133}$.

Deberá ser destacado que la identidad supuesta no consiste simplemente en otorgarle un nombre falso, ocultando la propia personalidad, sino que se legaliza la posibilidad de crear un personaje inseparable en un contexto social donde se comporta de acuerdo con las cualidades, profesión, apetencias y conductas preestablecidas de antemano para garantizar el éxito de la misión cual es la investigación y represión de la actuación delictiva de la organización criminal1134.

Es la clave para el éxito del uso de la identidad supuesta, o sea, que se ponga en práctica una nueva identidad psicológica en el infiltrado, el cual deberá cambiar su modo de comportarse habitualmente en sociedad, pasando a adoptar las nuevas características que le fueron asignadas por fuerza de su "nueva" identidad.

Mismo siendo justificado el uso excepcional de estas técnicas policiales dentro del contexto de la infiltración del agente estatal, no se puede olvidar la cristalina constatación de que en regla general las notas del engaño y de la identidad falsa que se consiente al agente encubierto determinan desde el inicio de la operación bajo cobertura, graves repercusiones en derechos y principios constitucionales ${ }^{1135}$. A consecuencia de ello, surgen algunas dudas importantes: ¿por cuánto tiempo puede el infiltrado valerse de la falsa identidad otorgada por la autoridad competente?, o ¿quién detiene la función de conceder la identidad supuesta?

Se puede afirmar que la competencia para autorizar el uso de la identidad supuesta o falsa, y también para determinar el plazo de duración, dependerá una vez más del respectivo ordenamiento jurídico, vez que existen casos como de la legislación brasileña donde aunque no exista disposición legal sobre el tema la tiene el Juez de Instrucción, sin un plazo estipulado para utilización, o aún, el Ministerio del Interior como ocurre en

1133DELGADO MARTíN, J., Criminalidad Organizada, cit., pág. 80. Incluso, en la operación de infiltración deberá el agente "contar con el respaldo documental que acrediten esta nueva identidad: DNI, pasaporte, permiso de conducir, incluso cuando sea necesario para salvaguardar los resultados de la investigación y garantizar la protección del agente, se le podrá proporcionar antecedentes penales y policiales necesarios según las actividades y características de la organización con el objetivo de no levantar sospechas". Vid. ESPINOSA DE LOS MONTEROS, R. Z., El policía infiltrado. Los presupuestos jurídicos en el proceso penal español, cit., págs. 70-71.

1134 Vid. SEQUEROS SAZATORNIL, F., El tráfico de drogas ante el ordenamiento jurídico. Evolución normativa, doctrinal y jurisprudencial, cit., pág. 756.

1135 Esta la precisa y clara opinión de GÓMEZ DE LIAÑO FONSECA-HERRERO, M., "Límites y garantías procesales en la investigación mediante agente encubiertos", La Ley, año XXV, núm. 6142, 7 de diciembre de 2004, http://diariolaley.laley.es. 
España1136, donde el infiltrado puede se utilizar de la identidad supuesta por un plazo de seis meses. En este último caso, la misma será otorgada por el Ministerio del Interior por el plazo de seis meses prorrogables por períodos de igual duración, quedando legítimamente habilitados para actuar en todo lo relacionado con la investigación concreta y a participar en el tráfico jurídico y social bajo tal identidad ${ }^{1137}$.

Otro punto de interés se refiere al hecho de que en la infiltración policial son utilizadas varias técnicas encubiertas para obtención de pruebas contra la organización criminal, las cuales son previamente determinadas bajo la óptica de aplicación de una política de inteligencia criminal.

Luego, resulta en este punto imprescindible aclarar que lo más importante con relación a la utilización de los medios o técnicas encubiertas es definir la necesidad de la exigencia de producción de pruebas obtenidas a través de medios lícitos, con respecto a los derechos constitucionales, en especial, a la intimidad y a la privacidad de los ciudadanos investigados. Al respeto no ignoramos como será tratado en los apartados siguientes, la posibilidad del aprovechamiento de algunas pruebas pro societa obtenidas ilícitamente, de modo absolutamente excepcional, por fuerza del principio de proporcionalidad o racionalidad, en especial en lo que se refiere a la actuación de los agentes encubiertos en el combate a la proliferación y expansión de la delincuencia organizada.

Abordado y delimitado el tema de la identidad supuesta a ser concedida al agente encubierto, cumple ahora analizar la problemática de la utilización del engaño y de la disimulación por el infiltrado en aras de se conseguir proximidad y confianza junto a miembros de una organización criminal.

Dentro de la perspectiva de puesta en práctica de una operación de infiltración el agente encubierto obligatoriamente tendrá que se utilizar de la estrategia del engaño ${ }^{1138}$ para conseguir demostrar seguridad y lazos de amistad a los demás miembros del grupo criminal.

Demostrando cierta preocupación, sostiene GUZMÁN FLUJA que el problema está en que en las operaciones de infiltración policial el engaño de la identidad ficticia abre un enorme abanico de posibilidades de actuar afectando derechos fundamentales de las personas investigadas, porque colocar al infiltrado en la organización criminal exigirá que

\footnotetext{
1136 Vid. art. 282 bis, 1, de la LEcrim. En cumplimiento a este precepto legal, algunos autores apuntan que "el auto por el que se otorgue dicha identidad deberá consignar el nombre verdadero y el supuesto con el que actuará y será reservada. Por su parte, el órgano judicial o Ministerio Fiscal han de limitarse a ratificar la identidad supuesta previamente otorgada por el Ministro del Interior". Vid. ESPINOSA DE LOS MONTEROS, R., "El agente encubierto en el ordenamiento jurídico español", cit., pág. 238. También GASCÓN INSCHAUSTI, F., Infiltración policial y "agente encubierto", cit., pág. 209 y RIFÁ SOLER, J. M., "El agente encubierto o infiltrado en la nueva regulación de la LECrim", cit., pág. 162.

1137 En sentido crítico a esta disposición legal, defiende MOLINA PÉREZ que "si el agente infiltrado con identidad supuesta está obligado a facilitar la información que vaya obteniendo a quién le autorizó, no se entiende muy bien cuál es la razón por la que deba pedirse prórroga cada seis meses. Hubiera sido deseable que la identidad supuesta se mantuviera, sin necesidad de ampliación, hasta que finalizase la investigación, o hasta que fuera necesario mantenerla, puesto que en definitiva tal facultad la tiene otorgada el Juez de Instrucción". Vid. MOLINA PÉREZ, T., "Técnicas especiales de investigación del delito: el agente provocador, el agente infiltrado y figuras afines (y II)", cit., pág. 166.

1138 Nos parece lógico que deberá ser acepta la licitud de algunas actuaciones de agentes infiltrados en las que hayan utilizado medios engañosos,siempre que con ellas no se haya originado un delito antes inexistente (lo que trasformaría la actuación del infiltrado en acto de provocación del delito) sino que se haya limitado a descubrir una infracción cometida con anterioridad.
} 
éste trabe amistad, confraternice, o simplemente trabaje, con diversos sujetos a los que terminará conociendo, y ello supone que conversará con ellos, en ocasiones tendrá que entrar en lugares cerrados, incluso domicilios de estas personas, podrán conocer sus comunicaciones, etc., lo que significa que de un solo golpe, el engaño pone el infiltrado ante la posibilidad de afectar diversos derechos fundamentales como la intimidad, la inviolabilidad del domicilio, el secreto de las comunicaciones, etc. Y esto conduce a tener que plantear el valor que puedan tener las informaciones obtenidas por el agente encubierto, así como a ver qué alcance probatorio pueden tener ${ }^{1139}$.

Todavía, es inherente a la actividad del agente encubierto laprevalencia de la confianza que ha generado sus actitudes junto a los miembros de la organización ${ }^{1140}$, lo que puede ser valorado negativamente desde el punto de vista ético. Sin embargo, se trata de un medio de investigación admitido por varios ordenamientos jurídicos, sin perjuicio de que alguno de los actos realizados por el agente encubierto puedan contravenir las exigencias del proceso penal con todas las garantías ${ }^{1141}$.

En efecto, el engaño de que se sirve el Estado a través del agente encubierto le permite acceder a determinadas facetas de la intimidad personal de las personas objeto de investigación ${ }^{1142}$ e incluso de personas que no ostentan la cualidad de sospechosos o encausados ${ }^{1143}$. En este contexto, el agente infiltrado convive y comparte de la intimidad del sospecho, tiene acceso a las informaciones familiares y personales que nunca hubiera tenido se no ganase su confianza, además, comparte la mesa de comida, comparte y accede a la vida privada y familiar del sospecho o sospechosos ${ }^{1144}$.

En definitiva, no tenemos la pretensión de negar que el engaño del Estado en principio vulnera el derecho a la intimidad como derecho vinculado con el libre desarrollo

1139 Vid. GUZMÁN FLUJA, V. C., "El agente encubierto y las garantías del proceso penal", cit., pág. 216. En sentido contrario, afirmando la imposibilidad de que la actuación del infiltrado pueda ser entendida como atentatoria a la dignidad de la persona humana, puesto que en nada ha contribuido para cualquier instrumentalización del agente del crimen, vid. FURTADO, F., "O agente infiltrado", cit., pág. 12.

${ }^{1140}$ Afirma en este sentido SEQUEROS SAZATORNIL que "es contrario a la dignidad de la persona que se utilicen precisamente las buenascualidades que puedan restarle a un presunto delincuente, como pudieran ser la apertura al otro, el culto a la amistad, la solidaridad o, tal vez, el deseo de ayudar, como medios para el descubrimiento del delito". Vid. SEQUEROS SAZATORNIL, F., El tráfico de drogas ante el ordenamiento jurídico (evolución normativa, doctrinal y jurisprudencial), cit., pág.756.

${ }^{1141}$ Sobre esta situación concreta, señala DELGADO MARTín que "así ocurrecuando lo manifestado por el imputado ante el agente encubierto en relación con un dato fáctico incriminatorio se ha obtenido mediante una treta capciosa, o mediante la puesta en escena de una maniobra engañosa que va más allá de la ocultación de la mera condición de policía; o cuando el agente encubierto instala secretamente micrófonos en el domicilio de los sospechosos; o cuando accede al contenido del e-mail (correo electrónico) de un miembro de la organización sin su consentimiento". Cfr. DELGADO MARTíN,J., Criminalidad Organizada, cit., pág. 60. Además, se suele afirmar que "el Estado de Derecho permite la utilización de una técnica de investigación y averiguación del delito basada en la identidad supuesta y el uso del engaño para ganar la confianza de los integrantes de la organización". Vid. ESPINOSA DE LOS MONTEROS, R.Z., El policía infiltrado. Los presupuestos jurídicos en el proceso penal español,cit., pág. 73; CHOCLÁN MONTALVO,J. A., La organización criminal. Tratamiento penal y procesal, cit., págs. 60 y ss.

1142 Según DELGADO MARTíN, es precisamente el derecho a la intimidad el que se ve restringido por la actuación del agente encubierto; utiliza, sin embargo, un concepto de derecho a la intimidad muy amplio, configurado como el poder de control sobre las informaciones que son relevantes para cada sujeto, muy semejante, como puede apreciarse, a lo que la doctrina alemana ha conceptuado como derecho de autodeterminación informativa. Vid. DELGADO MARTÍN, J., "El proceso penal ante la criminalidad organizada. El agente encubierto", cit., págs. 8-9.

1143 Vid. GASCÓN INCHAUSTI, F., Infiltración policial y "agente encubierto", cit., pág. 103.

1144 Vid. GUEDES VALENTE, M.M., "A investigação do crime organizado. Buscas domiciliárias, o agente infiltrado e intervenção das comunicações", cit., pág. 170. 
de la personalidad, dignidad y calidad de vida1145. Sin embargo, lo que deseamos en este momento es dejar claro que ninguno de los derechos fundamentales, inclusoel derecho a la intimidad, presenta carácter absoluto, a la vez que podrá se ver restringido en situaciones excepcionales, cuando de la puesta en práctica de la tarea de ponderación de bienes a través del principio de proporcionalidad ${ }^{1146}$.

Desde esta concreta perspectiva, cuando exista un orden judicial autorizando la práctica de alguna conducta, será posible la verificación de vulneración de derechos fundamentales en pro de algún otro interés relevante.

Por lo tanto, la autorización judicial permite la infiltración legítima de las acciones de investigación del agente encubierto que aunque afecten a derechos fundamentales, reposen únicamente en el engaño en el que se recurre para la infiltración ${ }^{1147}$. En cambio, las actuaciones del infiltrado que rebasen la esfera del engaño en que se funda la infiltración no quedan cubiertas dentro de la autorización judicial recibiendo su debida sanción en dado caso de que ocurriese ${ }^{1148}$.

Por esta razón, nos parece muy adecuada la observación de DELGADO MARTín al señalar que mediante una maniobra engañosa que excediendo de la sagacidad policial utiliza acciones y omisiones constitutivas del delito, el Estado accede a la intimidad de los miembros de la organización criminal investigada; esto es, resulta afectado el derecho fundamental a la intimidad de los miembros de la organización. De esta forma, la actuación de un agente infiltrado con identidad supuesta debe ser considerada como una medida de investigación restrictiva de un derecho fundamental, con el consiguiente sometimiento estricto al principio de proporcionalidad, y con la jurisdiccionalización tanto de su autorización previa como del control de su actividad 1149 .

En este punto reside la clave para armonizar el empleo de medidas restrictivas de garantías fundamentales y al mismo tiempo no menospreciar el valor del derecho de punir inherente a las actividades de persecución penal. En tal tarea de equilibrio de fuerzas, ocupa fundamental posición el postulado de la proporcionalidad.

Una última observación sobre el tema nos conduce a comprender que toda actividad de infiltración conlleva un engaño para la persona sometida a la investigación. En este contexto, nos parece imprescindible aclarar la distinción entre los términos "secreto" y "engaño".

1145 Vid. las SSTC 119/2001 de 24.5.2001 y 186/2000 de 10.7.2000. Por esto se afirma que la intimidad es el modo de ser de la persona y siempre que fuere dificultado el desarrollo de la personalidad, ésta ha de merecer la protección dispensada al derecho del artículo 18.1 de la CE. Con más detalles, Cfr. HERRERO TENEDOR, F., La intimidad como derecho fundamental, Madrid, 1998, págs. 19 y ss.

1146 Este modo de actuar con engaño y disimulación es el punto clave en la operación de infiltración, pues no habrá otro modo del agente adentrar en el grupo criminal. Y lo más importante es destacar una vez más que no debe se confundir la provocación del delito por parte del agente encubierto, con una actuación de aparente conformidad, que no incita a delinquir, pero que puede engañar al delincuente, engaño este que debe ser considerado lícito, y por ello, incapaz de romper la eficacia probatoria del eventual testimonio del agente.

1147 Aceptando este criterio, se justifica "la entrada en domicilios ajenos, la inspección de los lugares en que se ha entrado, la aportación de los objetos entregados al agente encubierto de forma voluntaria, así como las fotografías y grabaciones efectuadas en aquellos lugares, la promoción y participación en conversaciones de contenido incriminatorio con imputados y testigos, bien como grabaciones cuando el agente encubierto las protagonice". En este sentido, Vid. GASCÓN INCHAUSTI, F., Infiltración policial y "agente encubierto", cit., pág. 244.

1148 Vid. NÚÑEZ PAZ, M. A; GUILLÉN LÓPEZ, G., 'Entrega vigilada, agente encubierto y agente provocador. Análisis de los medios de investigación en materia de tráfico de drogas", cit., pág. 126.

1149 Vid. DELGADO MARTíN, J., Criminalidad organizada, cit., pág. 79. 
Así, el secreto está muy presente en la investigación criminal, en el desarrollo de un proceso penal, pues se puede decretar el secreto de la investigación. De otra parte, en las infiltraciones policiales, la actividad se desarrolla bajo el paraguas del engaño. Este engaño puede suscitarse en un doble plano: en primer lugar, con respecto a la identidad real que se materializa a través del uso de la identidad supuesta por la que el infiltrado accede al entramado organizativo y forja relaciones de confianza con los miembros de la organización. Y en segundo lugar, respecto a la verdadera intención de la relación que el agente encubierto mantiene con las personas objeto de la investigación ${ }^{1150 .}$

\section{IV.1.6.4. La voluntariedad del infiltrado en la operación encubierta.}

Es regla que presenta carácter irrenunciable el hecho de que el infiltrado no puede ser obligado a aceptar la tarea de adentrarse en una banda criminal, aunque bajo ordenes de un oficial jerárquico. Y es así porque se trata de una función que no debe ser forzada, debiendo fundarse la infiltración en la voluntad libre y consciente del agente de aceptar la labor de infiltrarse en un ambiente peligroso y tenso como sucede en la hipótesis de hacerlo en el seno de un grupo organizado de delincuentes ${ }^{1151 .}$

En cualquier caso, ningún agente estatal, por más especializado y cualificado que sea, está obligado a actuar como infiltrado. Tal disposición se justifica por la naturaleza ardua del trabajo a ser ejecutado por el agente encubierto. No se trata sólo de ejercer una profesión, sino de abdicar de su vida y de sus relaciones personales para hacerse pasar por otra persona. Y lo que es peor, por una persona involucrada en el mundo de la criminalidad donde los riesgos inherentes son enormes. No sería razonable que los mandos policiales o el Juez pudieran determinar que un concreto agente de Policía realizara tal función en contra su voluntad ${ }^{1152}$.

Para un mejor entendimiento sobre esta problemática, basta con fijarse en la dificultad que el Estado tendrá que enfrentar al elegir el agente para se infiltrar en la banda criminal, o sea, de encontrar una persona con vocación y disponibilidad para esta tarea de investigación, que esté debidamente formado incluso en técnicas y habilidades no comunes, y que presente una fuerte carga de voluntad y profesionalismo para conseguir laborar de forma satisfactoria, en orden a alcanzar las metas de la operación encubierta. Y

1150 Cfr. ESPINOSA DE LOS MONTEROS, R. Z., El policía infiltrado. Los presupuestos jurídicos en el proceso penal español, cit., pág. 73.

1151 En nuestra opinión es absurda la situación del Estado obligando a uno de sus funcionarios, a trabajar exponiendo su vida y de sus familiares, al se infiltrar en el seno de una organización criminal. Se justifica esta afirmación, pues no tendría el agente encubierto el animus y la tranquilidad para ejecutar sus tareas de investigación, hecho esto que podría poner en riesgo el éxito de toda la operación policial. Incluso estarían los órganos de persecución penal sujetos a presenciar el cambio de motivación del infiltrado, el cual no satisfecho con su obligación de se infiltrar, podría empezar a trabajar para el grupo criminal, promoviendo verdaderos actos de contrainteligencia.

1152 Vid. CORRÊA DE CARVAlHO, J.T., Tráfico de drogas. Prueba penal y medidas restrictivas de derechos fundamentales, cit., pág. 332. Esta justificativa es percibida en art. 282, bis 2 de la LECrim y justificada según NICOLÁS MARCHAL ESCALONA en razón de que "el legislador, consciente de los riesgos que este tipo de operaciones implica, unidos incluso a la reserva personal que pueden tener ciertos agentes a adoptar nombres falsos (que puede traer consigo consecuencias imprescindibles tanto en su ámbito profesional como personal), ha dispuesto que ningún funcionario de Policía Judicial podrá ser obrigado a actuar como agente encubierto. Por lo tanto, de disponerse cualquier operación de esta índole, deberá contarse on la anuencia del agente actuante que, a ser posible, es conveniente que de la misma quede constancia por escrito". Cfr. NICOLÁS MARCHAL ESCALONA, A., Manual de lucha contra la droga, Cizur Menor (Navarra), 2011, pág. 758. 
por supuesto, estas virtudes que deberán ser buscadas en el infiltrado son incompatibles con la selección obligatoria del funcionario estatal.

Se pone de relieve incluso que el agente encubierto debe expresar formalmente su consentimiento para ser nombrado como tal, por cuanto se trata de una función difícil y peligrosa, a por ejemplo de se infiltrar en una organización delictiva dedicada al tráfico de estupefacientes, en la que debe se utilizar de una falsa identidad, cambiar sus hábitos de vida, se separar de su núcleo familiar e incluso llegar a delinquir para ganarse la confianza de la organización en la cual pretende infiltrarse ${ }^{1153}$.

Por fin, la prohibición de obligar ${ }^{1154}$ a título individual, a los concretos funcionarios de la Policía Judicial a operar como agentes encubiertos alcanza tanto a los mandos policiales en el diseño de la operación, como al Juez de Instrucción y al Ministerio Fiscal cuando la aconsejan y autorizan ${ }^{1155}$.

\section{IV.1.6.5. La necesidad de justificación para una acción encubierta.}

Efectivamente, analizadas las principales características de la figura del agente encubierto, se indaga sobre cual sería la justificativa para la aceptación de la técnica de infiltración policial para combatir ciertas formas graves de delincuencia.

Se puede decir que la respuesta se encuentra en reconocer la necesidad de introducir en un determinado ordenamiento jurídico medidas legales y especiales que permitan a los miembros de la Policía Judicial participar del entramado organizativo, detectar la comisión de delitos e informar sobre sus actividades, con el fin de obtener pruebas inculpatorias y proceder a la detención de los autores, respetando el fin del proceso penal que no es otro que el descubrimiento de la verdad real y la aplicación de la ley penal al caso concreto, sin olvidar que los límites de las técnicas propuestas de investigación se encuentren en el sistema de derechos y garantías que la Constitución reconoce a todo imputado, ya que por más abyectos que sean las formas de delincuencia que se tratan de combatir, ello no justificaría la utilización de medios investigadores que puedan violentar garantías constitucionales ${ }^{1156}$.

Nos parece clara la necesidad de aceptación de la técnica de investigación policial a través de agentes encubiertos, la cual dependerá para obtención de éxito en su

1153 Cfr. MONTOYA, M. D., "El agente encubierto en la lucha contra el crimen organizado en la Argentina", cit., págs. 318-319. Así deberán actuar como agentes encubiertos aquellos que voluntariamente quieran prestar dichos servicios y que a su vez, reúnan una serie de cualidades, tales como una formación adecuada, con conocimientos jurídicos, técnicos y psicológicos, que permita velar por los aspectos de seguridad del agente. A dicha conclusión se llegó durante el Seminario Internacional sobre Agentes Encubiertos, organizado por el Consejo General del Poder Judicial español en Madrid en octubre de 1999.

1154 En el ordenamiento español, la prohibición de obligar a alguien a actuar como agente encubierto obedece a proposición de ley del Grupo PSOE (BOCG, Congreso de los Diputados, VI Legislatura, Serie B, 23 de septiembre de 1997, núm. 116-1, pág. 2), así como la Enmienda núm. 10 presentada por el PSOE al proyecto del PP (BOCG, Congreso de los Diputados, Serie B, VI Legislatura, 6 de marzo de 1998, núm. 89-6, pág. 18).

1155GOMÉZ DE LIAÑO FONSECA-HERRERO, M., Criminalidad organizada y medios extraordinarios de investigación, cit., pág. 177.

1156 GONZÁLEZ-CASTELL, A. C., "El agente infiltrado en España y Portugal. Estudio comparado a la luz de las garantías y de los principios constitucionales", cit., pág. 189. Según nuestro modo de comprender la cuestión, en realidad es algo loable la intención de los Estados en buscar combatir la delincuencia organizada transnacional a través del uso de técnicas modernas y eficaces de investigación, mismo teniendo en cuenta la necesidad de imponer límites a las operaciones encubiertas, sea a través de la obediencia a los principios de proporcionalidad y del debido proceso legal, sea imponiendo la regla de que estas técnicas sean utilizadas como ultima ratio. 
funcionamiento de una regulación específica y detallada sobre los presupuestos, amén de límites que deberán ser observados. También resulta imprescindible que el Estado ponga a disposición de los cuerpos policiales de una adecuada estructura logística, con objetivo de enfrentarse de forma eficaz contra los actos graves practicados por la delincuencia organizada.

Téngase presente que la obediencia a los postulados garantistas de protección a los derechos fundamentales de las personas sometidas a la persecutio criminis servirá como forma de justificar frente al Estado constitucional de Derecho, la limitación excepcional y necesaria de algunas de las garantías violadas cuando de la puesta en acción de una operación a través de agentes infiltrados.

En la doctrina se observa la existencia de autores que defienden la existencia necesaria de requisitos o elementos objetivos y subjetivos que deberán ser obedecidos para el correcto y adecuado funcionamiento de un plan de infiltración policial. Nos parece muy didáctica esta proposición.

Así es que MOLINA PÉREZ sostiene que el elemento subjetivo en el agente infiltrado está representado por un elemento intencional que se dirige a descubrir los delitos ya cometidos, o que se están cometiendo. No busca la comisión del delito, sino descubrir los medios y las formas a través de los cuales el delito se desenvuelve, porque la penetración o infiltración en tales grupos criminales permite recabar información sobre su estructura y su modus operandi, así como obtener pruebas sobre la ejecución de hechos delictivos. El agente infiltrado no induce a la comisión del delito, por lo que el elemento objetivo lo constituye su actuación, que no tiene influencia en la resolución delictiva del autor, ni en la consumación, ya producida del delito ${ }^{1157}$.

Queda muy claro, pues, que en cuanto dichas intervenciones policiales puedan afectar en grado diverso a derechos fundamentales, tales como la libertad ambulatoria, la intimidad y la dignidad personal o la integridad física u moral, se han de realizar sólo en aquellas hipótesis en que siendo menester para la tutela de un interés prevalente, sea necesario y adecuado su desconocimiento constituyendo la medida menos gravosa y soportable para el sujeto1158.

En opinión de GOMÉZ DE LIAÑO FONSECA-HERRERO los elementos subjetivos en la actuación del infiltrado se podrían se resumir a dos: los autores materiales de la operación y las autoridades competentes para acordar el inicio de la medida1159.

1157 Vid. MOLINA PÉREZ, T., "Técnicas especiales de investigación del delito: el agente provocador, el agente infiltrado y figuras afines (y II)", cit., pág. 163-164. Con una posición peculiar sobre la actuación preventiva del infiltrado, sostiene RAMÍREZ JARAMILLO que "una constatación indiscutible se refiere al hecho de que es una condición necesaria para la intervención del agente encubierto, la existencia de una investigación en curso por la realización de un delito; es decir, no es posible su actuación en el campo previo a la efectiva comisión de un delito por parte del investigado, y además se requiere que existan serios indicios para concluir que dicha actividad delictiva puede seguir desarrollándose en el tiempo". Vid. RAMÍREZ JARAMILLO, A. D., El agente encubierto frente a los derechos fundamentales a la intimidad y a la no autoincriminación, cit., pág. 44.

1158 Cfr. PEDRAZ PENALVA, E., "Actividad policial preprocesal", cit., pág. 791.

1159 Vid. GOMÉZ DE LIAÑO FONSECA-HERRERO, M., 'Límites y garantías procesales en la investigación mediante agente encubiertos", La Ley, año XXV, núm. 6142, 7 de diciembre de 2004, http://www.diariolaley.laley.es. 
En relación al primero ya hemos dejado sentada nuestra opinión en el sentido de la exclusividad en favor de los miembros de la Policía Judicial, los cuales deberán recibir un adecuado entrenamientopara las tareas en la operación encubierta.

La Policía Judicial estando en condiciones de ofrecer una preparación adecuada y rígida al agente que voluntariamente se predispone a se ingresar en una organización criminal, ocupa así el puesto principal de figura clave para el éxito de la operación de infiltración.

El segundo elemento subjetivo dice respecto al rol de las autoridades que poseen competencia para acordar el inicio de un plan estructurado de infiltración policial. A depender del reglamento del ordenamiento jurídico, quedaría a cargo del Juez de Instrucción.

Más que esto, según nuestro modo de pensar y desde una perspectiva amplia, deberá hacerse hincapié en la necesidad de que existan motivos razonablemente fundados. Así es que sería evidente que para esto no bastan las simples conjeturas o sospechas sobre la actuación de un grupo de delincuentes, sino que es necesario que la investigación esté bastante adelantada y que los elementos materiales probatorios, evidencias físicas e informaciones recolectadas por la Policía Judicial se presenten suficientemente fiables para se reconocer que el investigado está realizando actividades delictivas relacionadas con una organización criminal.

Por fin el elemento objetivo deberá se relacionar con el objeto de esta diligencia de investigación, que debe corresponder a fuertes y significativos indicios de actuación de la delincuencia organizada.

IV.1.7. Principios básicos en una actuación de un agente infiltrado.

Además de las características ya analizadas y que son inherentes al trabajo del agente encubierto, se observa que en la actuación de esta figura deberán ser obedecidos los principios reguladores del proceso justo, añadido a un rígido control judicial con la finalidad de preservación delas garantías y derechos fundamentales constitucionalmente reconocidos a las personas investigadas.

En este sentido, algunas directrices deberán ser reconocidas para el buen éxito de una operación encubierta a través del uso de agentes infiltrados, especialmente teniendo en cuenta que los derechos y garantías fundamentales de las personas investigadas o imputadas no podrán ser flexibilizadas sin criterios razonables y proporcionales en razón del carácter estrictamente excepcional de esta medida.

De modo general a través de principio de legalidad, debe la infiltración ser un medio de investigación previsto en la ley. Por la subsidiariedad, debe ser utilizado únicamente cuando no se puede obtener la finalidad de investigación de la banda organizada con otro medio que sea menos restrictivo. En respeto al principio de proporcionalidad, únicamente se puede emplear esta medida para el descubrimiento de supuestos delictivos de naturaleza graves. Por fin, deberá ser observado el principio de autorización, intervención y control judicial de la medida de investigación encubierta1160.

1160 Vid. POZO PÉREZ, M., "El agente encubierto como medio de investigación de la delincuencia organizada en la Ley de Enjuiciamiento Criminal española", cit., pág. 280. 
Pasemos a realizar un análisis específico de cada uno de estos principios, y su consecuente repercusión frente a la actuación del agente encubierto.

\section{IV.1.7.1. Principio de legalidad.}

En nuestra opinión, el más elemental principio de actuación del infiltrado lo constituye la legalidad ${ }^{1161}$. Queremos decir que la obediencia a la ley se configura como requisito imprescindible y obligatorio a cualquier actividad desarrollada en un Estado de Derecho.

El principio de legalidad significa que los actos y comportamientos de todos los ciudadanos, e inclusodel propio Estado, deben estar justificados en una ley previa y de carácter general.

En lo que nos interesa, es importante destacar que el procedimiento para la obtención de autorización para empezar una operación de infiltración policial quedará detallado por el ordenamiento jurídico, evitándose situaciones que no se encuentren previstas y reglamentadas, y por lo tanto, sin previsión legal.

Sin embargo, hay que tomar cuidado con este tema puesno se podrá exigir que la reglamentación de un medio extraordinario y caracterizado por el engaño y el secreto revele el modo de actuar del agente encubierto en el seno de la organización pues esto conllevaría no sólo el fracaso de la investigación sino que además las organizaciones criminales quedarían en alerta para captar a posibles "topos" de la policía, lo que conllevaría un especial riesgo para la integridad del infiltrado ${ }^{1162}$.

Así, como ya se ha puesto de manifiesto, es hecho demostrado que la infiltración policial atenta contra derechos fundamentales y así, la habilitación legal de la diligencia de investigación es la primera de las condiciones bajo las cuales resulta admisible tal restricción ${ }^{1163}$.

Sobre esta cuestión, la verdad es que admitido que la infiltración policial afecta a derechos fundamentales hay que precisar las condiciones y los requisitos bajo los cuales resulta admisible tal restricción, y como es lógico, la primera de ellas no es otra que la habilitación legal de la medida ${ }^{1164}$. Esto no significa que sería obligatoria la necesidad de se exponer en la ley el modus de actuar del infiltrado en la operación encubierta, bien como las técnicas de inteligencia criminal que se utilizará para los fines de mejor conocer la estructura interna y operacional de la organización criminal.

Corresponde el precepto constitucional de la legalidad al hecho de que este medio extraordinario de investigación encuentre previsión explicita y circunstanciada en el

1161 Para un estudio esencial y profundo respecto al principio de legalidad, vid. RUBIO LLORENTE, F., "El principio de legalidad", Revista española de derecho constitucional, año 13, núm. 39, 1993, págs. 9-42.

1162 ESPINOSA DE LOS MONTEROS, R. Z., El policía infiltrado. Los presupuestos jurídicos en el proceso penal español, cit., págs. 375-376.

1163 En este sentido, vid. GÓMEZ DE LIAÑO FONSECA-HERRERO, M., "El agente encubierto como medida de investigación del terrorismo en el contexto internacional", cit., pág. 423. Incluso, tanto el TEDH, como el TC han declarado que la previsión legal de una medida limitativa de derechos es premisa básica de su legitimidad constitucional, además de garantía de seguridad jurídica y certeza del derecho (SSTEDH, 18 de febrero de 2003, 16 de febrero de 2000 y 4 de mayo de 2000; SSTC, 169/2001, de 16.7.2002 y 49/1999, de 5.4.1999).

${ }^{1164 C f r . ~ G O ́ M E Z ~ D E ~ L I A N ̃ O ~ F O N S E C A-H E R R E R O, ~ M ., ~ " I n f i l t r a c i o ́ n ~ p o l i c i a l ~ y ~ p r o c e s o ~ p e n a l ", ~ c i t ., ~ p a ́ g . ~} 139$. 
ordenamiento jurídico ${ }^{1165}$. Por esta razón, el principio de legalidad como presupuesto formal del principio de proporcionalidad constituye el principal requisito que ha de cumplir toda actuación limitativa de derechos fundamentales ${ }^{1166 .}$

El principio de legalidad exige que todo medio extraordinario y limitativo de derechos fundamentales se presente descrito en el ordenamiento jurídico, pero más que esto, que la ley en cuestión sea accesible y previsible ${ }^{1167}$. Deberán los aspectos que caracterizan la labor del infiltrado quedar explícitamente definidos en el ordenamiento jurídico, en especial, las informaciones respecto al plazo de duración de la operación encubierta, la posibilidad de eventuales prórrogas, la atribución para se infiltrar(quien debe figurar como sujeto activo), la competencia para autorizar la medida de investigación, la responsabilidad penal, civil y disciplinaria del agente encubierto, y las diligencias de investigación permitidas al infiltrado.

Siendo así las cosas, se puede afirmar que la legalidad es la base de aceptación de cualquier instituto en un Estado constitucional de Derecho, teniendo en vista que su no obediencia repercutirá en la puesta en práctica de otros tantos principios reguladores de la actuación del agente infiltrado. Si lo anterior es correcto, entonces se puede concluirseñalando que es preciso que las operaciones encubiertas reciban un adecuado tratamiento legislativo, ya sea por ley, disposiciones normativas o directrices administrativas. Sea cual fuere la medida que se utilice, lo importante es orientar y vigilar el modo en que se realiza la actividad del agente encubierto ${ }^{1168}$.

\section{IV.1.7.2. Principio de especialidad.}

El segundo de los principios corresponde al de especialidad, el cual establece que la intervención del infiltrado debe estar relacionada con la investigación de un delito

\footnotetext{
1165 Esto significa, sencillamente, que "la actuación del infiltrado ha de ser conforme a la Constitución y a ley ordinaria". Vid. MOLINA MANSILLA, Ma ${ }^{\text {a }}$.., Mecanismos de investigación policial: entrega vigilada y agente encubierto, cit., pág. 36. Como forma de respecto al principio de legalidad, cítese como ejemplo el caso español. Como se observa en la redacción legal del artículo 282 bis de la Ley de Enjuiciamiento Criminal (Ley 5/1999), al disciplinar la actividad de investigación y aseguramiento de las fuentes de prueba del agente encubierto, el legislador se preocupó especialmente en regular el ámbito de aplicación del método a determinados delitos, entre ellos el tráfico de drogas; en garantizar el respecto a los derechos fundamentales; y del uso de la identidad falsa del agente, su protección personal y su exención de responsabilidad. Según SEQUEROS SAZATORNIL, "las innovaciones tienen un triple objetivo: incrementar la eficacia policial posibilitando a sus agentes el acceso a una identidad supuesta sin quebrantar la legalidad, así como utilizarla para unos fines concretos y determinados; blindar su protección sin solución de continuidad; y establecer, por último, un status de inmunidad reglada ante las posibles responsabilidades legales en que pudiera haber incurrido con su actuación. Todo ello para que su testimonio y las informaciones derivadas de su labor puedan operar como pruebas hábiles para enervar el derecho de presunción de inocencia del investigado". Vid. SEQUEROS SAZATORNIL, F., El tráfico de drogas ante el ordenamiento jurídico, cit., pág. 735.

1166GÓMEZ DE LIAÑO FONSECA-HERRERO, M., "Infiltración policial y proceso penal", cit., pág. 208.

1167 Vid. SSTEDH, 33129/96 de 4.6.2002 (caso Oliveira); 28802/95 de 21.1.1999 (caso Tsavachidis) y 19776/92 de 25.6.1996 (caso demandantes somalíes).

1168 Cfr. la Recomendación 24 del Grupo de Trabajo Oficioso de Expertos sobre Técnicas Especiales de Investigación (Prácticas óptimas y recomendaciones sobre los obstáculos jurídicos a las entregas vigiladas y las operaciones encubiertas), de Naciones Unidas, septiembre de 2005. Justificase el tenor de esta recomendación en razón de que las operaciones encubiertas son de naturaleza invasiva; un agente policial que emplea una identidad ficticia se infiltra en el hogar, la empresa y la vida privada de una persona con el fin de obtener información o pruebas. De allí la importancia de que esas operaciones estén sujetas a directrices y a una vigilancia adecuada.
} 
concreto, sin que puedan autorizarse mecánicamente, de modo genérico, ante cualquier solicitud policial1169.

Se evita con la exigencia de este requisito la puesta en práctica de operaciones encubiertas que dificulten el trabajode la autoridad responsable por la expedición de la resolución para inicio de la infiltración, a la vez que el control de los actos de investigación ejecutados por el agente encubierto, si indeterminados y genéricos, exigiría un esfuerzo sobremanera para la evitación de práctica de abusos y violaciones a derechos y garantías fundamentales de las personas sometidas a la persecución penal.

En palabras de SUITA PÉREZ tal principio no es más que la determinación de los delitos, cuya comisión se sospecha, habida cuenta que no son válidas las autorizaciones genéricas ${ }^{1170}$. Prosigue señalando que el auto que autoriza la actuación del agente infiltrado determinará concretamente y en forma específica cual es el delito que se investiga y cuáles son las personas que son objeto de esa investigación ${ }^{1171}$.

La obediencia a este principio tiene su razón de ser en especial por la búsqueda de una solución plausible y justa con relación al tema de los descubrimientos casuales o hallazgos accidentales, forzando a la autoridad de persecución, en caso de adquisición fortuita de conocimiento de pruebas sobre otros delitos o nuevos imputados, no comprendidos en el ámbito de la autorización judicial originaria, a iniciar una nueva investigación formal, de modo a se obtener una nueva y específica autorización judicial para extenderse el objeto de análisis criminal.

Todavía es factible reconocer que este requisito estaría íntimamente conectado con la existencia de indicios suficientes para la imputación de un delito determinado, que permitan afirmar la probabilidad de que el sujeto esté cometiendo o haya cometido un delito ${ }^{1172}$.

De esta forma, sólo se adoptará esta medida investigativa cuando previamente exista la sospecha cierta y sólida de que el hecho delictivo se cometerá y nunca con la finalidad de descubrir de modo indiscriminado cualquier conducta delictiva ${ }^{1173}$.

Siguiendo esta tendencia, se deberá evitar la presencia de agentes encubiertos en los ambientes criminales de modo permanente y por tiempo indeterminado, sin cualquier criterio definidor de su específica actuación.

Otro aspecto inherente a la obediencia a este postulado, dice respecto al hecho de que la investigación obligatoriamente deberá recaer sobre supuestos relacionados a casos

1169 MOLINA MANSILLA, Mạ. C., Mecanismos de investigación policial: entrega vigilada y agente encubierto, cit., pág. 32.

1170 Todavía se observa que en algunos países como los Estados Unidos de América, la actuación del undercover agent presenta justamente la característica de involucrarse en operaciones de infiltración policial genéricas, sin un objeto de investigación específico, factor este que lo diferencia del personaje del agente encubierto.Por esta razón, se afirma que en los países anglosajones "los sujetos también tienen la condición de policía pero su investigación no se ciñe a un caso concreto sino que la infiltración en el ambiente criminal es de carácter genérico". Cfr. GASCÓN INCHAUSTI, F., Infiltración policial y “agente encubierto”, cit., pág. 88.

1171 Vid. SUITA PÉREZ, N., "La diligencia de investigación por medio del agente encubierto", cit., págs. 249250. No se puede olvidar que las "autorizaciones genéricas" y sin criterios específicos acaban por provocar graves violaciones al principio de proporcionalidad, pues imposibilitan el análisis del caso concreto a la luz de una zona de equilibrio. También que delante de esta ausencia de especialidad, quedaría violado el principio de la seguridad jurídica del investigado.

1172 SUITA PÉREZ, N., "La diligencia de investigación por medio del agente encubierto", cit., págs. 249-250.

1173 PAZ RUBIO, J. Mae et alli., La prueba en el proceso penal. Su práctica ante los tribunales, cit., pág. 398. 
de delitos graves practicados por miembros de grupos de delincuentes organizados. De esta suerte, importante subrayar que si en el curso de la investigación acometida por agentes encubiertos, se descubriese que la actividad de los investigados es distinta a aquellas conductas tipificadas como actuación de crimen organizado, deberá cesar inmediatamente el cometido de los infiltrados, se comunicando lo más breve posible al Juez que ha dictado la resolución autorizante, se buscando de este modo interrumpir la operación encubierta por violación al principio de especialidad.

\section{IV.1.7.3. Principio de subsidiariedad.}

La subsidiariedad 1174 o excepcionalidad como principio rector de las actuaciones encubiertas consiste en la defensa de que el método de infiltración policial sea utilizado siempre que sean agotadas previamente todas las posibilidades de utilización de técnicas y métodos de investigación menos invasivos y restrictivos de derechos y garantías.

Dicho en otras palabras, el órgano de persecución penal no deberá utilizar la técnica de infiltración de un agente encubierto en un entramado organizado de delincuentes como prima ratio; muy al contrario, siempre como ultima posibilidad, o sea, en carácter de ultima ratio.

Esta medida procesal de utilización de agentes encubiertos sólo se adoptará cuando no exista otro medio de investigación del delito menos gravoso. La intervención del infiltrado habrá que se relacionar directamente con la proporcionalidad del hecho, de tal suerte que sólo se autorizará en aquellos casos en que las informaciones y pruebas sólo puedan obtenerse, por esta técnica. En definitiva, la excepcionalidad significa que las finalidades de la investigación no puedan lograrse de otro modo ${ }^{1175}$.

Así es que a esta figura debe recurrirse sólo de forma excepcional1176, o sea, deberá ser buscada la alternativa menos gravosa.

Por esta razón, se puede admitir que como toda medida susceptible de restringir un derecho fundamental, deberá tener un carácter excepcional y sólo se adoptará cuando no exista otro medio de investigación del delito menos gravoso para los imputados, lo que normalmente se traduce en que el mismo sea la ultima ratio ${ }^{1177}$.

La excepcionalidad se deriva, pues, del hecho de que en razón de constituirse en un medio extremamenteinvasivo en las libertades del investigado, y que puede incluso enervar los pilares del Estado constitucional de Derecho, deberá limitarse su empleo a

\footnotetext{
1174 Incluso se habla como corolario de este principio, del postulado de la necesidad, que según palabras de GÓMEZ DE LIAÑO FONSECA-HERRERO, describe que "en el recurso a la figura de los agentes encubiertos, atendidas siempre las circunstancias específicas del caso, existen en verdad dos claves para fundamentar la culminación del principio de necesidad: de un lado, comprobar si el ordenamiento jurídico proporciona otras formas de investigación igualmente idóneas para luchar eficazmente contra la delincuencia organizada, y de otro, verificar, en su caso, si estos otros medios no suponen una lesión de derechos del mismo calibre". Vid. GÓMEZ DE LIAÑO FONSECA-HERRERO, M., "Infiltración policial y proceso penal", cit., pág. 208.

1175 Cfr. PAZ RUBIO, J. Ma et alli., La prueba en el proceso penal. Su práctica ante los tribunales, cit., pág. 399.

1176 Debiendo se condicionar por lo tanto, en forma explícita su utilización al principio de subsidiariedad, reservándola sólo para cuando resulte evidente que el esclarecimiento de los gravísimos delitos respecto de los que teóricamente admiten su uso, no será posible de lograr por las vías probatorias ordinarias.

1177 SUITA PÉREZ, N., "La diligencia de investigación por medio del agente encubierto", cit., págs. 247-248.
} 
situaciones graves y que vengan a exigir una actuación incisiva del Estado de modo a se buscar la preservación de la seguridad colectiva ${ }^{1178 .}$

Significa en términos objetivos y concretos que para acudir a la utilización de un agente infiltrado deberán ser utilizados y agotados otros medios de investigaciones y que los mismos resulten ya ineficaces o inoperantes y que llegados a este punto de la investigación se haga necesario restringir un derecho fundamental. Todas estas cuestiones son inherentes al trabajo de la policía que deberá poner en conocimiento del Juez todas las diligencias que se han practicado, las pruebas que se han obtenido, y la necesidad de que no exista otra forma de poder llegar a descubrir los canales por los cuales se está cometiendo un delito o varios ${ }^{1179}$.

En síntesis, lo que se quiere dejar claro es que no se debe utilizar un medio extraordinario de investigación con fuerte carga de restricción de derechos fundamentales como las operaciones encubiertas, dejando previamente de se intentar lograr éxito en las investigaciones a través de otros medios menos agresivos con relación a las garantías inherentes a la condición de investigado.

Se adoptando estas observaciones anteriormente mencionadas, se evitaría labanalización del empleo de esta técnica de investigación, hecho este que de forma lamentable viene siendo percibido en muchos ordenamientos jurídicos, viniendo a provocar el desencadenar de fuertes críticas por parte de cierto sector de la doctrina procesal penal. Efectivamente, lo que se quiere evitar es que esta técnica o medio extraordinario de investigación criminal sea utilizada como prima ratio, provocando violaciones innecesarias a derechos y garantías fundamentales de la persona investigada.

\section{IV.1.7.4. Principio de proporcionalidad.}

Este principio es esencial para dotar de armonía al proceso penal y consecuentemente para alcanzar el equilibrio en la tensión de fuerzas entre la eficacia estatal y los derechos y garantías fundamentales del ciudadano.

En buena lógica el principio de proporcionalidad debe figurar como postulado necesario de las actuaciones del agente encubierto ${ }^{1180}$, de modo que su utilización como medio extraordinario de investigación permanezca restringida a casos de extrema y diferenciada gravedad como son las hipótesis del terrorismo fundamentalista, el narcotráfico, la criminalidad financiera, la corrupción y el blanqueo de capitales.

Significa este presupuesto que no sería adecuado el recurrir a esta técnica policial para lograr éxito en la persecución e investigación de algunos delitos sin contenido económico y ausente de peligrosidad, como sucede por ejemplo el intento de desarticular un simple grupo de ladrones callejeros que hurtan productos expuestos en las puertas de las tiendas. No sería proporcional la movilización del aparato policial, con entrenamiento

1178 En consecuencia de lo afirmado y respecto al ámbito de intervención del agente encubierto, se suele afirmarse que se circunscribe a la criminalidad organizada y que fuera de este ámbito el infiltrado no puede actuar. En este sentido, Cfr. ESPINOSA DE LOS MONTEROS, R. Z., El policía infiltrado. Los presupuestos jurídicos en el proceso penal español, cit., pág. 68.

1179 SUITA PÉREZ, N., "La diligencia de investigación por medio del agente encubierto", cit., págs. 250-251.

1180 En este sentido, es primordial señalar que "en modo alguno puede obviarse que cualquier medida de investigación restrictiva de derechos fundamentales deben declinar la observancia del principio de proporcionalidad". Vid. GÓMEZ DE LIAÑO FONSECA-HERRERO, M., "Infiltración policial y proceso penal", cit., pág. 205. 
específico de agentes y elaboración de un plan de actuación para buscar la detención de estos delincuentes, a la vez que en este caso los medios tradicionales de investigación deberán solucionar estaproblemática, sin enfrentar las dificultades con relación a la aceptación de la prueba obtenida a través de empleo de agentes encubiertos ${ }^{1181}$. Del mismo modo, no sería proporcional la eventual flexibilización de las garantías y derechos de estas personas afectadas por la medida de infiltración.

Asimismo, cabe señalar que este principio conecta directamente con los denominados límites al ius puniendi del Estado. De ahí queeste poder estatal no se puede ejercer de cualquier forma, ni a cualquier precio, sino que se encuentra limitado por los principios informadores del Derecho penal, entre ellos, el de proporcionalidad ${ }^{1182}$.

Pese a las consideraciones precedentes, el principio de proporcionalidad se manifiesta como un criterio para establecer los límites a la intervención estatal en la búsqueda de la verdad, equilibrándose los intereses del Estado y los derechos de las personas objeto de la investigación ${ }^{1183}$.

De este modo, como ya anteriormente hemos estudiado, la tensión de fuerzas actualmente tan discutible en la dogmática procesal penal (eficacia versus derechos y garantías fundamentales) podrá verse resuelta delante de la visualización de una zona de equilibrio, donde en función del caso concreto, se analizará la viabilidad de la restricción fundamentada y proporcional de algún o algunos derechos fundamentales del investigado en casos excepcionales, y todo ello en pro de la eficacia de la investigación criminal.

Por fin, en lo que nos interesa ahora, el principio de proporcionalidad aplicado a la infiltración policial no sólo responde a la idea de limitación de derechos fundamentales sino a las peculiaridades de este medio de investigación. En este sentido, el uso del engaño efectivo a través de la identidad supuesta, su consideración de medio extraordinario y su determinación como más agresivo con las personas objeto de investigación, son causas suficientes para hacer que el principio de proporcionalidad no sólo tenga que estar presente en la adopción de la medida sino en la actuación del agente encubierto con respecto a los demás integrantes de la organización criminal ${ }^{1184}$.

\section{IV.1.7.5. Principio del control jurisdiccional.}

Este último principio está referido a la autorización, intervención y control judicial de la medida de investigación encubierta.

Ya adelantamos en el apartado anterior la necesidad e importancia del control judicial de la operación encubierta mediante la utilización de agentes infiltrados. Sin cualquier forma de control por las autoridades de persecución, y principalmente por parte de aquélla que ha concedido la autorización para el inicio de la operación de ingreso de un agente encubierto en un determinado entorno criminal, las consecuencias han de caminar

\footnotetext{
1181 Por esta razón, se impone reconocer que la actuación de agentes encubiertos debidamente autorizados y con respecto a los principios de proporcionalidad y debido proceso legal, es un mecanismo importante de investigación criminal, especialmente en lo que se refiere a la criminalidad organizada y sus graves actuaciones.

1182 Véase, SUITA PÉREZ, N., "La diligencia de investigación por medio del agente encubierto", cit., pág. 249.

1183 Vid. PEDRAZ PENALVA, E., "El principio de proporcionalidad y principio de oportunidad", Constitución, jurisdicción y proceso, Madrid, 1990, pág. 342.

1184 ESPINOSA DE LOS MONTEROS, R. Z., El policía infiltrado. Los presupuestos jurídicos en el proceso penal español, cit., págs. 367-368.
} 
rumbo a la verificación de excesos, actos de arbitrariedad y especialmente de situaciones de ausencia de legalidad 1185 .

En otras palabras, la intervención judicial es indispensable para otorgar el debido valor probatorio a las actuaciones llevadas a cabo por el agente encubierto ${ }^{1186}$, particularmente cuando las acciones de éste afecten derechos procesales objeto de protección constitucional. Y la razón es sencilla, pues la confirmación de que la sola presencia de un agente encubierto afecta a la intimidad de los investigados yace en la exigencia de someter el inicio de la operación a una autorización del Juez de Instrucción o del Ministerio Fiscal, este último dando cuenta inmediata al Juez ${ }^{1187}$.

Sin embargo, es fundamental la participación del Ministerio Fiscal una vez que en su actuación deberá acompañar todo el desarrollo operativo de la infiltración, y acaso perciba que las disposiciones contenidas en la resolución judicial no vienen siendo obedecidas, bien como en caso de ausencia de respecto a alguno de los principios procesales penales o constitucionales aplicables, deberá de forma obligatoria solicitar con ahínco ante la autoridad responsable la resolución, la invalidación y la cancelación de la orden para la ejecución del plan de infiltración.

Si el control legalmente establecido no puede garantizar que no ocurran situaciones de excesos y arbitrariedad, imagínese en la hipótesis de una total ausencia de cualquier medida de verificación relativa al desarrollo del procedimiento de infiltración. Sería la institucionalización de aceptación de las irregularidades y abusos de actuación que pueden configurar violaciones de derechos y garantías de aquellas personas sometidas al proceso penal: un auténtico Derecho Procesal penal del enemigo, donde las garantías son relegadas a un plano inferior, instituyéndose una inaceptable situación de negación de los derechos fundamentales del ciudadano.

Así, la necesidad de control se debe centralizar en la protección y tutela de los derechos del investigado porque al desconocer éste la ejecución de la actividad autorizada no puede impugnarla ni autodefenderse de ella, por lo que en garantía de sus derechos el Juez y el Fiscal deben ser especialmente rigurosos ${ }^{1188}$.

El agente encubierto deberá poner en conocimiento de la autoridad competente todas las cuestiones que se vayan planteando y máxime cuando se afectan otros derechos fundamentales como puede ser por ejemplo la intervención de una comunicación telefónica, que afecta al secreto de las comunicaciones, o cualquier otro tipo de situación o

\footnotetext{
$1185 \mathrm{Al}$ respeto, interesante señalar que "el control judicial en todo momento, tiene que ser riguroso y en grado sumo, desde el inicio hasta el final, prórrogas incluidas, vigilando que en todo momento se cumpla el ordenado". Vid. PAZ RUBIO, J. Ma et alli., La prueba en el proceso penal. Su práctica ante los tribunales, cit., pág. 399.

1186 Vid. DELGADO MARTíN, J., La criminalidad organizada, cit., págs. 93-94.

1187 Esta la opinión ya consolidada en la doctrina española. Vid. con riqueza de detalles, GÓMEZ DE LIAÑO FONSECA-HERRERO, M., "El agente encubierto como medida de investigación del terrorismo en el contexto internacional", cit., pág. 424.

${ }^{1188}$ Cfr. MONTÓN GARCÍA, M. L., "Agente provocador y agente encubierto: ordenemos conceptos", cit., págs. 2 y ss. Respecto a la necesidad de un control sobre la actuación del infiltrado, es importante destacar que existen técnicas donde el control debe ser ejercido en todas las etapas. Este es caso del agente encubierto donde el comienzo de una operación debe estar sujeta a indicios razonables; durante la operación, informes periódicos deben ser presentados y finalmente, una descripción específica de la conducta del agente será el control ex post para enfrentar los problemas de provocación.
} 
circunstancia que se presente como ajena al delito, o incluso la diligencia que surge paralelamente con el hecho delictivo que se está investigando ${ }^{1189}$.

La problemática surge cuando se analiza la cuestión de los riesgos en el procedimiento de transmisión de las informaciones y datos entre el agente infiltrado y las autoridades de persecución. Al mismo tiempo que se exige la máxima cautela del agente para no poner en peligro la integridad de la operación y su propia vida, se intenta forzar que el agente encubierto ponga en conocimiento de sus superiores jerárquicos o del Juez, con la mayor brevedad posible, todas las informaciones y pruebas obtenidas junto al grupo delictivo1190.

En síntesis, en cuanto a la resolución por la que se adopta la medida restrictiva, tendrá la forma de auto, y en consecuencia deberá estar motivado. Dicha motivación se hará sobre los hechos suministrados por la Policía Judicial1191.

Por fin, se hace imprescindible mencionar que en caso de inobservancia de los preceptos señalados, por cierto conllevará la prohibición de valoración de la prueba obtenida en razón de la violación a los derechos y garantías fundamentales de los investigados, bien como de los postulados básicos del Estado constitucional de Derecho' ${ }^{1192 .}$

1.8. La responsabilidad penal, civil y disciplinaria del agente encubierto: conductas justificadas y conductas punibles.

\subsubsection{La responsabilidad en el ámbito penal.}

Partiendo de la consideración de que la finalidad del trabajo de infiltración como medio extraordinario de investigación en la lucha contra el crimen organizado es de permitir la persecución de destacados grupos de delincuentes, importanteen este momento es analizar el tema relativo a las consecuencias jurídicas de las eventuales conductas delictivas practicadas por el infiltrado en el contexto de la operación encubierta.

Las actividades lícitas e ilícitas del agente encubierto deben tener como límite el respecto a los derechos fundamentales de las personas, principalmente de aquéllas investigadas, pues como servidor público tiene el infiltrado la obligación de respetar la

\footnotetext{
1189 SUITA PÉREZ, N., "La diligencia de investigación por medio del agente encubierto", cit., pág. 253. En este sentido, el dispuesto en el artículo 282 bis 1 de la LECrim. También muy importante señalar que hasta donde hemos conseguido pesquisar, tan solo España contiene disposición normativa imponiendo al agente encubierto o su superior jerárquico, la obligación de comunicar a la autoridad judicial competente, las posibles violaciones a derechos fundamentales de la persona sospechosa o investigada. En este sentido, dispone el art. 282 bis. 3 de la LECrim que: "Cuando las actuaciones de investigación puedan afectar a derechos fundamentales, el agente encubierto deberá solicitar del órgano judicial competente las autorizaciones que al respecto establezcan la Constitución y la Ley, así como cumplir las demás previsiones legales aplicables". Incluso dispone ESPINOSA DE LOS MONTEROS que "En cualquier caso, la contravención de esta disposición conlleva la nulidad de todo lo obtenido mediante dichas actuaciones, y por tanto, la imposibilidad de utilizarlas en el juicio oral como pruebas aptas para desvirtuar la presunción de inocencia, conforme el artículo 11.1 LOPJ". Vid. ESPINOSA DE LOS MONETEROS, R. Z., "Las reglas de exclusión probatoria al hilo del desarrollo de la infiltración policial", cit., pág. 97.

1190 Vid. el art. 282 bis. 1 de la LECrim: "La información que vaya obteniendo el agente encubierto deberá ser puesta a la mayor brevedad posible en conocimiento de quien autorizó la investigación. Asimismo, dicha información deberá aportarse al proceso en su integridad y se valorará en conciencia por el órgano judicial competente".

1191 Vid. SUITA PÉREZ, N., "La diligencia de investigación por medio del agente encubierto", cit., pág. 248.

1192 Véase la STS 9283/2000 de 7.11.2000.
} 
vida, honra, bienes y demás derechos fundamentales de las personas, razón por la cual esos derechos no son comerciables, a menos que por razón de la investigación y para garantizar su éxito se contara con la participación y consentimiento de la persona titular del derecho, que estuviera dispuesta a sacrificarlo, en los casos que puede haber disposición sobre el mismo ${ }^{1193}$.

Este es un punto muy importante tener en cuenta que toda actividad persecutoria del Estado, sea en aras de prevención o represión contra la delincuencia, deberá estar limitada con el propósito de mantener libre de riesgos los presupuestos reveladores de un verdadero Estado constitucional de Derecho. Se busca con esta tendencia ejecutar una persecución penal contra la delincuencia fundamentada en el respeto a los postulados de un proceso penal garantista ${ }^{1194}$.

Otra observación importante se refiere al hecho de ser la actividad del agente encubierto claramente peligrosa. No resulta difícil imaginar que puede verse durante su actuación, compelido a cometer un ilícito, ya sea para ganar la confianza de los integrantes de la organización delictiva o incluso como una manera de que su vida no corra riesgo, pues el implemento de una orden de los integrantes de estas bandas delictivas le puede significar un serio peligro a su identidad física ${ }^{1195}$.

Además, es notoria la constatación de que el peligro de que el agente cometa un delito o participe en el cometido por otro es directamente proporcional al grado de infiltración en el grupo criminal: cuanto mayor es la integración en la organización, mayor la posibilidad del riesgo de verse obligado a realizar actos para ganarse la confianza de sus miembros ${ }^{1196 .}$

También estará propenso a acciones que puedan facilitar el consumo de drogas tóxicas, estupefacientes o sustancias psicotrópicas y, por tanto, constitutivos de algún

1193 GONZÁLEZ MONGUÍ, P. E., La policía judicial en el sistema penal acusatorio, cit., págs. 287-288.

1194 Sobre la cuestión sobre se el acto de "simular" o "engañar" por parte del agente encubierto, podrá generar alguna responsabilidad penal, señala REDONDO HERMIDA que "las actividades de colaboración simuladas, por medio de las cuales el agente encubierto lleva a engaño a la organización criminal, están exentas de perseguibilidad penal, previa autorización judicial de dichas actuaciones, en la medida en que consistan en operaciones solo aparentemente delictivas, las cuales en todo caso tienen como límite infranqueable la necesidad de las mismas, la proporcionalidad respecto de la gravedad del delito perseguido y el respecto irrestricto de los derechos fundamentales de los investigados. En síntesis, la autorización judicial se convierte así en una cláusula general de exclusión de la antijuridicidad, al establecer un deber de actuar de un modo determinado". Cfr. REDONDO HERMIDA, A., "El agente encubierto en la jurisprudencia española y en la doctrina del Tribunal Europeo de Derechos Humanos", cit., pág. 101. En torno a esta afirmación, cabe precisar que a partir del momento de otorga de una resolución motivada por la autoridad competente, quedaría el agente encubierto ya en condiciones de iniciar el plan de infiltración, pudiendo incluso, como ya previsto, practicar delitos de poca o escasa gravedad y que tengan estrecha relación con el objeto de la operación encubierta, sin cualquier responsabilidad penal, administrativa o disciplinaria, desde que observado el postulado de la proporcionalidad y sus vertientes (necesidad, idoneidad y proporcionalidad en sentido estricto).

1195 Vid. EDWARDS, C. E., El arrepentido, el agente encubierto y la entrega vigilada, cit., pág. 85. Incluso DELGADO MARTíN destaca que "a mayor mimetización en la organización, mayores pruebas de fidelidad habrá de satisfacer el policía infiltrado para obtener el respecto, la credibilidad como auténtico criminal de los componentes del grupo delictivo y, de este modo, no levantar sospechas sobre su verdadera condición e intenciones". Vid. DELGADO MARTÍN, J., Criminalidad organizada, cit., pág. 108.

1196 Véase DELGADO MARTÍN, J., Criminalidad organizada, cit., pág. 108. El mismo autor se refiere en todo caso a los actos necesarios para simular la pertenencia a la subcultura en la que se mueve la organización investigada, como puede ser la práctica de conductas de receptación de objetos robados, o de uso de documentos falsos, y similares; y, en segundo lugar, a las denominadas "pruebas de castidad", esto es, pruebas impuestas por el grupo criminal para probar la fidelidad y disposición de sus miembros o candidatos a serlo. 
delito contra la salud pública1197; y a omisiones de sus específicos deberes de impedir la comisión de delitos y de socorrer a las víctimas que se encuentren en claro peligro; de participar en escuchas ilegales y registros ilícitos, etc.

Para una correcta comprensión de la eventual responsabilidad penal del sujeto activo de la operación encubierta esimprescindible esclarecer que la recepción legislativa de la figura del infiltrado no significa la introducción de una pretendida figura del "agente autorizado para delinquir", sino la aceptación de una actuación policial necesaria para simular actuaciones delictivas de colaboración, actividades destinadas a engañar a una organización criminal y así descubrir delitos en cuya ideación el agente no tiene parte ${ }^{1198}$.

No significa del mismo modo que el Estado entregue al infiltrado una "carta en blanco" para que este la utilice sin cualquier criterio y con fines ajenos a la investigación criminal. Ningún agente estatal empieza la operación de infiltración previamente determinado a practicar delitos de toda especie, sino que muy al contrario, lo que sucede es que el agente encubierto tiene consciencia en el inicio de la operación de que en determinadas situaciones podrá ser compelido o mismo por las circunstancias, obligado a cometer algún crimen, y que estos tienen que presentar total relación con el objetivo ya determinado para la investigación encubierta.

Este seria el punto ideal, o sea, mantener el propósito de que la eventual y consecuente práctica de delitos se acaba por convertir en parte inherente al trabajo del infiltrado, pero desde que esta conducta criminal presente una fuerte y directa relación con la investigación que se busca realizar. Y más, que está conducta delictiva presente correlación con las vertientes del principio de proporcionalidad (necesidad, adecuación y ponderación).

Partiéndose de este enfoque, la infiltración policial supone que el Estado se inserta dentro de la propia delincuencia organizada ${ }^{1199}$, aun cuando sea con la paradójica intención de combatirla, lo cual supone que el mismo asume y tolera la comisión de delitos por parte de sus agentes. De este modo, el agente policial infiltrado puede participar en la comisión de ciertos delitos ${ }^{1200}$, desde que a modo de excepción y con respecto al criterio de la proporcionalidad.

Debemos ser honestos en el análisis del tema pues es notorio que el hecho de que el infiltrado venga a utilizaralgunas maniobras de inteligencia policial, como el uso del engaño y de la disimulación a través del uso de una identidad supuesta, para conseguir la confianza de los miembros del clan criminal, conduce a la práctica casi obligatoria de

1197 A tal efecto, véase el trabajo de SEQUEROS SAZARTORNIL, F., El tráfico de drogas ante el ordenamiento jurídico, cit., págs. 79 y ss.

1198 Vid. REDONDO HERMIDA, A., "El agente encubierto en la jurisprudencia española y en la doctrina del Tribunal Europeo de Derechos Humanos", cit., pág. 100. En este sentido, es correcto afirmar que "la exclusión de la antijuridicidad es evidente pues habiendo autorización para la infiltración del agente, que significa integrar la banda criminal, pero para fines de investigación, ello no estaría en la verdad integrando la organización criminal, pero si disimulando su integración con la finalidad de buscar informaciones y mejor viabilizar su combate". Vid. MENDRONI, M. B., Crime organizado. Aspectos gerais e mecanismos legais, cit., págs. 54-55.

1199 Dentro de este contexto, importante la advertencia de PACELLI DE OLIVEIRA al destacar que "cómo es el propio Estado que estará inserido en las acciones criminales, es preciso que se establezcan los limites de tal inserción, para que se sepa, con un mínimo de certeza posible, la frontera que iba a separar la acción lícita de la ilícita". Vid. PACELLI DE OLIVEIRA, E., Curso de Proceso Penal, cit., pág. 302.

1200 Cfr. CERRO ESTEBAN, J. A., "El sistema de garantías constitucionales en los procesos judiciales sobre criminalidad organizada", http://www.cej.justicia.es/. 
algunas conductas delictivas. Imagínese que la aceptación por parte del agente encubierto de una invitación para frecuentar la casa de un investigado, puede significar la práctica de un delito de invasión del domicilio pues sólo ha sido él mismo invitado en razón del engaño perpetrado a través de la disimulación de ser el agente un nuevo miembro del clan criminal ${ }^{1201 .}$

No debe se desconocer en todo caso que sin el recurso a esta técnica policial del engaño y disimulación, jamás el agente encubierto tendría acceso a las informaciones "cerradas" sobre el grupo criminal, tornando la investigación en este caso prácticamente infructífera.

Conviene anotar todavía quesólo serán admitidas y aceptadas como justificadas las conductas ejecutadas por el agente encubierto que mantengan relación directa e imprescindible con el desarrollo de la investigación, que no sean consideradas delitos graves $^{1202}$ y que obedezcan el criterio de la proporcionalidad ${ }^{1203}$.

Siguiendo esta posición sostiene CERRO ESTEBAN que por lo que se refiere a las posibles actuaciones delictivas que pueda cometer el agente encubierto para la apreciación de la exención de responsabilidad, la actuación del infiltrado debe reunir tres requisitos: primero,que sea consecuencia necesaria del desarrollo de la investigación; segundo, que guarde la debida proporcionalidad con la finalidad de la investigación; y tercero,que no constituya una provocación al delito ${ }^{1204 .}$

1201 Respecto a esta concreta situación, "cuando la entrada en un domicilio no va precedida de consentimiento del titular, autorización judicial o situación de delito flagrante, se considera indebidamente restringido el derecho a la inviolabilidad del domicilio". También que "está claro que cuando el agente encubierto entra en un domicilio, mediando o no invitación, podrá observar y escuchar todo lo que acontezca a su alrededor. Esta información podrá ser valorada por el órgano judicial sentenciador. Y aquí es donde reside toda la problemática de aquellas entradas que se realizan mediante únicamente el consentimiento de uno de los titulares de la organización". Vid. ESPINOSA DE LOS MONTEROS, R. Z., El policía infiltrado. Los presupuestos jurídicos en el proceso penal español, cit., págs. 194-195. En nuestra opinión estaría claramente demostrada una violación de domicilio se acaso el infiltrado adentrase en el ambiente domiciliar de los miembros del clan criminal sin cualquier especie de invitación, sea explícita o implícita. Sin embargo, desde que el agente encubierto posee una autorización judicial para a través del uso de técnicas policiales de inteligencia, a ejemplo del engaño y de la disimulación, penetrar en el domicilio del investigado, el cual ha hecho una invitación basada en un equívoco de pensar que el infiltrado sería una persona de confianza o un nuevo miembro de la banda criminal, no estaría la prueba obtenida viciada por cualquier ilicitud y ni mismo tipificado el mencionado delito. En razón de la prueba haber sido obtenida con conocimiento de una autoridad que ha ditado una resolución, donde supuestamente ya había el infiltrado le comunicado previamente esta situación de violación de un derecho fundamental - por cuenta de la invasión del domicílio - la información obtenida será objeto de análisis por el juzgador, a través de aplicación del principio de proporcionalidad.

1202 No sería lógico y razonable se admitir que estuviera autorizado el infiltrado a practicar actos ajenos a su tarea de investigación encubierta o que no tengan guardada relación con la debida proporcionalidad. Imagínese la conducta de matar a alguien durante una investigación. Todavía, a modo de excepción, no se puede dejar de considerar la hipótesis en que el infiltrado en un determinado contexto dentro de la operación encubierta, venga a quitar la vida de un integrante de la banda criminal actuando en legítima defensa o en estado de necesidad.

1203 En este sentido "los actos delictivos que pueden estar cubiertos por la causa de exclusión de antijuridicidad serán los tradicionalmente practicados por el grupo criminal, los referidos a la propia investigación, los referidos a generar fiabilidad a la infiltración y las omisiones del deber de acción y protección de un policía frente a la criminalidad". Vid. CORRÊA DE CARVALHO, J.T., Tráfico de drogas. Prueba penal y medidas restrictivas de derechos fundamentales, cit., pág. 337.

1204 Cfr. CERRO ESTEBAN, J. A., "El sistema de garantías constitucionales en los procesos judiciales sobre criminalidad organizada", cit. Ya en opinión de LÓPEZ BARJA DE QUIROGA, serian cuatro los requisitos con relación a la exención de responsabilidad del infiltrado: a) agente encubierto: la exención de responsabilidad no sería aplicable a cualquier funcionario de Policía Judicial que se encontrara en las mismas circunstancias que el agente encubierto y hubiera actuado de idéntica forma, pues, es preciso que formalmente le haya sido otorgada la licencia de trasgresor legal; b) consecuencia necesaria: las actuaciones del infiltrado que generan 
Desde esta perspectiva se torna muy importante señalar que no todo acto delictivo cometido por un infiltrado queda amparado in extremis por la exención de responsabilidad. Antes al contrario, para que un acto constitutivo de infracción penal imputable al agente encubierto venga beneficiado por la exención de responsabilidad, deben concurrir de manera simultánea ${ }^{1205}$ una serie de presupuestos de inexcusable observancia. La actuación delictiva ha de ser consecuencia necesaria del desarrollo de la investigación, guardar la debida proporcionalidad con la finalidad de la misma y no constituir una provocación al delito ${ }^{1206}$.

La obediencia a estos citados requisitos se hace imprescindible en razón de que no hay como dudar que la medida de investigación a través de la utilización del agente encubierto posea un nítido carácter intrusivo en la vida cotidiana del investigado, vulnerando algunas garantías constitucionales a ejemplo de la intimidad o del derecho a la autodeterminación.

Resulta claro que la actuación del funcionario autorizado para figurar como agente encubierto se encuentra penalmente protegida, pero solo en tanto y cuanto no se violen de forma abusiva los derechos fundamentales y se actúe estrictamente en el marco de la autorización judicial y en la medida absolutamente necesaria para la obtención de información ${ }^{1207}$. Aunque imprescindible es que la responsabilidad penal del infiltrado haga parte de la reglamentación específica contenida en el ordenamiento jurídico.

Dicho en pocas palabras, las actuaciones que generan la responsabilidad criminal han de ser consecuencia inexcusable del desarrollo de la investigación. Es decir, si no son una consecuencia necesaria no habrá la exención de responsabilidad ${ }^{1208}$.

Ante esta posibilidad de no punición al infiltrado, desde que obedecidos los requisitos ya mencionados surge una interesante cuestión: ¿conductas justificadas o conductas punibles? ${ }^{1209}$

En principio, deberá partirse de la regla general de que debe ser eximido de sanción penal el agente infiltrado, sea porque actúo en cumplimiento de un deber, en ejercicio de

responsabilidad penal han de ser consecuencia necesaria del desarrollo de la investigación; c) proporcionalidad: la cual será averiguada tomando en consideración la actuación del agente encubierto y la finalidad de la investigación; d) no provocación: refiérese al hecho de la responsabilidad criminal del agente provocador por tentativa. Vid. LÓPEZ BARJA DE QUIROGA, J., Tratado de Derecho Procesal Penal, cit., págs. 532534.

1205 GASCÓN INCHAUSTI, F., Infiltración policial y “agente encubierto”, cit., pág. 279.

1206 Esta la opinión de GÓMEZ DE LIAÑO FONSECA-HERRERO, M., Criminalidad organizada y medios extraordinarios de investigación, cit., pág. 258.

1207 Vid. REDONDO HERMIDA, A., "El agente encubierto en la jurisprudencia española y en la doctrina del Tribunal Europeo de Derechos Humanos", cit., pág. 101.

1208 En este sentido, vid. el art. 282 bis, 5, de la Ley de Enjuiciamiento Criminal española: "El agente encubierto estará exento de responsabilidad criminal por aquellas actuaciones que sean consecuencia necesaria del desarrollo de la investigación, siempre que guarden la debida proporcionalidad con la finalidad de la misma y no constituyan una provocación al delito. También, LÓPEZ BARJA DE QUIROGA, J., "El agente encubierto", Revista Jurídica La Ley, Diario 4778, Madrid, 1999, pág. 1955.

1209 Interesante opinión respeto al tema es ofrecida por MOLINA PÉREZ en el sentido de que "cuando el agente se limita a dar información bien sobre delitos ya cometidos, bien sobre la observación de determinadas personas, no se plantea problema alguno, puesto que no existe implicación alguna en la comisión de ese delito. El problema surge, por tanto, cuando el agente infiltrado se introduce para buscar pruebas, pues en la medida en que participe o realice hechos delictivos habrá de determinarse si esa actuación es impune, o si, por el contrario, es partícipe de ella". Vid. MOLINA PÉREZ, T., "Técnicas especiales de investigación del delito: el agente provocador, el agente infiltrado y figuras afines", cit., pág. 186. 
una orden legítima de autoridad competente, en el legítimo ejercicio de un cargo, o por un estado de necesidad 1210 .

Para una exacta comprensión de esta cuestión es necesario esclarecer que la conducta del infiltrado puede se manifestar de diversas formas cuando de la infiltración policial en una organización criminosa: en primero, puede ser que el agente encubierto venga a provocar la acción u omisión de una o más personas que integran la organización criminosa, vino a inducir e interferir directamente en el ánimo de las mismas, y en este caso, hablaríamos de un flagrante preparado o de un delito provocado. Así, el agente infiltrado podría ser responsabilizado penalmente por el abuso cometido, pero no habría que responder por la práctica del delito en sí mismo considerado.

La segunda posibilidad sería aquella donde el agente encubierto viniese a actuar conjuntamente con uno o más integrantes del grupo organizado en una determinada trama criminal. De la misma forma, si el agente policial infiltrado ingresa en una organización de delincuentes, la cual ya viene practicando una determinada especie de delitos, antes de su entrada. En esta hipótesis su intervención no significa la creación inductora de la voluntad del sujeto provocado, que ya prexistía, de suerte que la actuación del agente viene simplemente a facilitar la práctica del crimen y no inducir a su concretización. En este caso, se verifica la anterioridad de la acción criminosa en relación a la intervención del agente. Se trata de caso clásico de concurso de agentes, sea por participación o en coautoría y el agente encubierto no respondería por el delito practicado, desde que su conducta presentase conexión con el objeto de la investigación y que no se presentase alta gravedad.

En este último caso, se hace necesario analizar la naturaleza jurídica de la exención de responsabilidad penal del agente infiltrado.

El ámbito de la exención de responsabilidad queda indeterminado, toda vez que resulta frecuente que se exija por la organización al agente encubierto la llamada "prueba de castidad", consistente en la ejecución de acciones delictivas en señal de fidelidad a la organización ${ }^{1211 .}$

Como dice JESCHECK, frecuentemente el agente encubierto resulta obligado a cometer acciones delictivas para cumplir su misión de investigación e incluso para ganarse

\footnotetext{
1210 Esta opinión se fundamenta en la exención de responsabilidad penal del infiltrado siempre que lo mismo actúe dentro de los límites establecidos por el principio de proporcionalidad y respetándose la legalidad penal. Véase. ARCINIEGAS MARTíNEZ, G. A., Policía judicial y sistema acusatorio, Bogotá, 2007, págs. 38-43.

1211 Vid. CHOCLÁN MONTALVO, J. A., La Organización Criminal. Tratamiento penal y procesal, cit., pág. 64. Ya existen noticias de que algunos clanes criminales en razón de la profunda desconfianza respecto de los "nuevos" miembros, vienen exigiendo como prueba de aceptación, la práctica de al menos un delito grave, a ejemplo de un homicidio, asesinato o una violación sexual. Incluso ha sido noticiado recientemente por la prensa que en Japón, algunas organizaciones criminales han instituido una prueba escrita y rígida como modo de acceso al grupo delictivo. 0 sea, habrán que pasar por un examen para saber se están o no aptos a participar del grupo delictivo. Respeto a esta noticia, vid. LESSA, I., "Na senda vestibular do crime", http://www.bbc.co.uk/portuguese/noticias/2009/09/090914_ivanlessa_tp.shtml. En este articulo, el periodista de la BBC-Brasil, hace un análisis critico sobre la información divulgada en septiembre de 2009, de que la mafia japonesa, la Yakuza, estaría instituyendo un sistema de examen escrito de admisión para que la persona pueda se tornar miembro de este grupo criminal.
} 
la confianza de los miembros de la organización; piénsese en el transporte de drogas, determinadas falsedades documentales, escuchas ilegales, registros ilícitos, etc.1212.

Se percibe entonces que forma parte de las notas características del actuar del infiltrado el hecho de verse envuelto ante las posibilidades de perpetración de delitos, sin bien sea algo incontestable que en un principio, no tiene el agente la idea preconcebida de que deba practicar algún crimen, a excepción de los que sean inherentes a su actividad de investigación como en el caso del uso de un documento falso (identidad supuesta).

Pero lo importante ahora es dejar sentado que el agente encubierto estará exento de responsabilidad criminal por aquellas actuaciones que sean consecuencia necesaria del desarrollo de la investigación, siempre que guarden la debida proporcionalidad con la finalidad de la misma y no constituyan una provocación al delito. Esta es la regla1213. Por otro lado, es evidente que existe una prohibición de cometer hechos delictivos, por lo que todo exceso, extralimitación o trasgresión de la ley se debe examinar caso por caso determinando si la actuación fue necesaria y proporcional a los fines de la investigación ${ }^{1214}$.

Se concluye, por lo tanto, que la operación encubierta debe estar encaminada a descubrir el entramado criminal, el delito y la responsabilidad penal de los sujetos involucrados en la organización criminal; y en mérito a la necesidad, proporcionalidad y su vinculación a los fines de la investigación de la actividad el agente está exento de responsabilidad penal. Sin embargo, tal exención de responsabilidad está condicionada a que el agente no provoque el delito1215.

Llegados a este punto podemos preguntarnos cuál sería la justificación para la exención de la responsabilidad penal del infiltrado.

La exención de responsabilidad le vendrá otorgada en virtud del cumplimiento del deber encomendado, lo que excluye la antijuridicidad del hecho'1216, o por concurrir excusa

1212 Cfr. JESCHECK, H. H., "Entre dogmatisme et pragmatismo: l'evolution des expérienses contemporaines de codification et des pratiques legislatives", Nouvelles Éstudes Pénales, núm 17, Toulouse, 1998, pág. 463.

1213 De este modo, en la gran mayoría de los países que emplean esta técnica policial se ha decidido eximir de responsabilidad penal al agente por aquellos delitos a los que se vea compelido para lograr la aceptación y confianza de los miembros de la organización, garantizar su seguridad y la de la operación, siempre que su participación resulte ineludiblemente necesaria, racional y proporcionada. Confirmando esta tendencia, vid. ARCINIEGAS MARTÍNEZ, G. A., Policía judicial y sistema acusatorio, cit., págs. 319-320.

1214 Vid. POZO PÉREZ, M., "El agente encubierto como medio de investigación de la delincuencia organizada en la Ley de Enjuiciamiento Criminal española", cit., pág. 308.

1215 PÉREZ ARROYO, M. R., "La provocación de la prueba, el agente provocador y el agente encubierto: la validez de la provocación de la prueba y del delito en la lucha contra la criminalidad organizada desde el sistema de pruebas prohibidas en el Derecho Penal y Procesal Penal", cit., pág. 3.

1216 Adoptando este entendimiento, y de modo específico en relación a la actuación del agente encubierto en la lucha contra el blanqueo de capitales, señala CÁLIX VALLECILLO que "el agente encubierto que realiza actos típicos en el ámbito del delito de blanqueo de capitales, como puede ser el de adquirir los efectos procedentes de un delito grave puede ver justificada su conducta en tanto en cuanto cumple con el deber que genéricamente la misma ley atribuye a los miembros de la Policía Judicial, esto es el de practicar, averiguar los delitos públicos, practicar según sus atribuciones las diligencias necesarias para comprobarlos y descubrir a los delincuentes, y recoger todos los efectos e instrumentos del delito de cuya desaparición hubiere peligro, poniéndolos a disposición de la autoridad policial (art. 282 bis LECrim). De esta manera, el funcionario de la Policía Judicial que acepta su nombramiento como agente encubierto y realiza actos típicos de blanqueo como la adquisición de bienes procedentes de un delito grave podrá justificar su comportamiento alegando que lo ha realizado en el ejercicio legítimo de su deber de comprobar la existencia del delito y de descubrir a los intervinientes en la comisión del mismo". Y concluye el citado autor afirmando que "en nuestra opinión el cumplimiento de un deber derivado de su oficio es lo que permite excluir la antijuridicidad de la conducta típica del agente encubierto". Vid. CÁLIX VALLECILLO, C. D., "Actuaciones del agente encubierto en el ámbito 
absolutoria, siendo que en cualquier caso su actuación tendrá que ajustarse a los principios de necesidad y proporcionalidad.

En definitiva, podría ser permitido muy excepcionalmente la comisión de ilícitos penales de escasa entidad o faltas, rigiendo como norma general la carencia de facultades para perpetrar delitos. Luego, se le exige al agente encubierto dos requisitos positivos y uno negativo: necesidad de su actuación, proporcionalidad de ésta y que no constituya delito provocado1217. Esta trilogía justificaría la exención de responsabilidad penal al infiltrado como medida de política criminal.

La actuación del infiltrado deberá corresponder a una efectiva e indiscutible necesidad relativa a la dinámica del procedimiento de investigación. Así, el primer límite a la actuación de agente encubierto es que el delito sea consecuencia necesaria del desarrollo de la investigación, ya que la exención no se refiere a cualquier delito que él pueda cometer, sino que éste debe cometerse para lograr los fines de la investigación.

Respecto de otros delitos en que se incurra y que no guarden relación con la investigación, el infiltrado deberá responder según las reglas generales por la práctica abusiva del crimen.

Del mismo modo, se exige que el trabajo del agente encubierto presente relación de respeto al postulado de la proporcionalidad. Dicho en otras palabras, su actuación debe ser proporcional y razonable, y el eventual delito practicado en medio al procedimiento de la operación encubierta tendrá que guardar relación de finalidad con el objeto de la investigación. En el desempeño de su tarea de investigación, deberá el funcionario estatal respetar las reglas impuestas a la operación, quedando expresamente prohibido la práctica de delitos graves y la provocación del crimen ${ }^{1218}$.

Sin duda alguna, en los requisitos de necesidad y proporcionalidad se encuentra el factor decisivo para la exención de responsabilidad del agente encubierto. Una interpretación amplia va a determinar una mayor aplicación de esta exención,pero también puede conllevar un aumento de los riesgos de las arbitrariedades policiales ${ }^{1219}$.

Por fin, aunque sea necesaria y proporcional, la excepcional práctica de delitos por el infiltrado no deberá consistir en un acto de provocación ${ }^{1220}$, lo que significa que el agente encubierto no puede incitar o instigar a otro a cometer un delito, quedando su

del blanqueo de capitales. Conductas típicas y su posible justificación", Revista Letras Jurídicas, núm. 1, 2005, http://letrasjuridicas.cuci.udg.mx/.

1217 PAZ RUBIO, J. Ma et alli., La prueba en el proceso penal. Su práctica ante los Tribunales, cit., págs. 401 y ss.

1218 Por esta razón de suele afirmar que "la actuación del agente encubierto está sujeta a límites infranqueables que unido con el principio de que, en el proceso penal la verdad no puede conseguirse a cualquier precio por más graves que sean las formas de criminalidad, hacen necesario el estudio de la responsabilidad en que pueda incurrir el infiltrado por las actuaciones que haya realizado en el transcurso de la investigación puesto que algunas ocasiones la labor desarrollada por éste se escapa de su ámbito de actuación legítima". Vid. ESPINOSA DE LOS MONTEROS, R. Z., El policía infiltrado. Los presupuestos jurídicos en el proceso penal español, cit., pág. 395.

1219 Vid. DELGADO MARTÍN, J., Criminalidad organizada, cit., pág. 115.

${ }^{1220}$ Cfr. la STS 6729/1998 de 14.11.1998. También la Recomendación 29 de Grupo de Trabajo Oficioso de Expertos sobre Técnicas Especiales de Investigación de Naciones Unidas (Septiembre de 2005), donde se ha dejado establecido que: "En todos los ordenamientos jurídicos, la instigación, provocación o incitación por parte de un agente de policía o infiltrado puede afectar la admisibilidad del caso o debilitar la causa ante el Tribunal". Y se justifica esta afirmación en razón de que el delincuente puede sostener que no habría participado en ningún acto delictivo si el agente infiltrado no hubiera provocado esa conducta $y$, fundamentalmente, si no lo hubiera tentado a cometer el delito. 
actuación restricta a su infiltración en la organización criminal con el objetivo de mantener actividad pasiva de observancia y análisis de la estructura del grupo criminal, pasando secundariamente a actuar activamente, en conjunto o en apoyo con los otros miembros.

Parece bastante claro entonces que la ausencia de inducción delictiva, que no de provocación, por parte del agente encubierto constituye una condición sine qua non para la estimación de la exención de responsabilidad ${ }^{1221 .}$

Hechas estas consideraciones, lo más Importante es destacar que el incumplimiento de los requisitos mencionados puede dar lugar a responsabilidades penales, civiles y administrativas del agente encubierto por las infracciones que hubiera podido cometer.

A priori dos serían las principales posibilidades dogmáticas de resolución del problema de exención de la responsabilidad penal del agente encubierto.

Inicialmente, una primera posición es de concurrencia de una excusa absolutoria, en la medida en que por razones de política criminal no es razonable y ni lógico admitir la responsabilidad penal del infiltrado. La importancia de su actuación está directamente asociada a la impunidad del delito perseguido. Sosteniendo esta tendencia, LÓPEZ BARJA DE QUIROGA plantea la posibilidad de que la exención sea una excusa absolutoria en lugar de una causa de justificación, en cuyo caso habría responsabilidad penal y civil de los partícipes y la responsabilidad civil subsidiaria del Estado, salvo que se conformara como excusa absolutoria de carácter objetivo, en cuyo caso la responsabilidad penal de los partícipes podría quedar excluida ${ }^{1222}$.

EDWARDS también justifica la impunidad del agente encubierto a la concurrencia de una excusa absolutoria, lo que significa que el hecho que comete el agente encubierto es típico, antijurídico y culpable, no imponiéndosele pena por una cuestión de política criminal, que radica en la propia esencia de esta técnica de investigación por la cual el agente se infiltra en la propia estructura de la organización dedicada a cometer delitos referidos al narcotráfico ${ }^{1223}$.

En torno a esta afirmación, cabe precisar que se considera que todo exceso o extralimitación de la ley debe examinarse caso por caso; se ha pensado que resulta conveniente eximir de responsabilidad al agente encubierto, bien sea aplicando por cuestiones de política criminal una excusa absolutoria, la cual consiste en una causa personal que excluye la aplicación de la pena de carácter netamente individual y

1221 Vid. GOMÉZ DE LIAÑO FONSECA-HERRERO, M. G. L., Criminalidad organizada y medios extraordinarios de investigación, cit., pág. 261.

1222Cfr. LÓPEZ BARJA DE QUIROGA, J., "El agente encubierto", cit., pág. 1956. En cualquier caso, según este mismo autor, "es claro que la responsabilidad civil do Estado existe por el funcionamiento normal o anormal de los servicios públicos". Vid. LÓPEZ BARJA DE QUIROGA, J., Tratado de Derecho Procesal Penal, cit., pág. 536. También interesante la observación en el sentido de que "las consecuencias últimas derivadas de la consideración de la exención como excusa absolutoria serían que la exención, a fin de quedar impune el delito cometido, únicamente resultaría aplicable al sujeto policial autorizado para desempeñar el papel de agente encubierto, y habría responsabilidad penal y civil de los participes, además del Estado a título subsidiario, en quienes no concurra la circunstancia personal de contar con la autorización judicial legitimadora del proceder encubierto". Vid. GÓMEZ DE LIAÑO FONSECA-HERRERO, M., Criminalidad organizada y medios extraordinarios de investigación, cit., pág. 256.

1223 En este sentido, vid. EDWARDS, C. E., El arrepentido, el agente encubierto y la entrega vigilada, cit., pág. 88. Del mismo modo la opinión de OCHOA, C.A.,"El agente encubierto", Semanario jurídico Fallos y Doctrina, núm. 1057, 1995, pág. 367. 
considerando la conducta típica, antijurídica y culpable, pero sin aplicarle pena, o una causa de justificación, por la cual la conducta será típica, pero no antijurídica.

Sin embargo, la doctrina mayoritaria considera que se trata de una causa de exclusión de la ilicitud, una vez que el infiltrado actúa en el estricto cumplimento de un deber legal ${ }^{1224}$ o que el agente encubierto estaría obrando en cumplimiento de un deber o en el ejercicio legítimo de un derecho, oficio o cargo ${ }^{1225}$.

Esta conclusión apunta en el sentido de que considerada la naturaleza jurídica de la exención de la responsabilidad criminal como una causa de justificación, esto implica que la exención ampara a los partícipes, tanto en el ámbito de la responsabilidad civil, incluyendo en este extremo la responsabilidad civil subsidiaria del Estado ${ }^{1226}$.

Nos parece más acertada la posición de considerar reconocida una causa de justificación pues el infiltrado al ejecutar la misión de acuerdo con el plan de la operación encubierta estará actuando bajo el "estricto cumplimiento de un deber", el cual ha sido determinado por la autoridad competente, tratándose de un deber legal de descubrir las actividades perpetradas por la organizacióncriminal, bien como de informaciones respecto al numero de miembros de la misma, sus contactos ilícitos, su forma de actuar, su ámbito territorial de trabajo y otros datos de interés ${ }^{1227}$.

Dicho de otro modo, al ejecutar la infiltración de acuerdo con el plan de operación, el agente encubierto estará actuando en estricto cumplimiento de un deber legal de encontrar la verdad respecto de las actividades de la organización criminal, sus integrantes y redes de contacto, su modus operandi, su área geográfica de actuación, sus objetivos de corto, medio y largo plazo, la cantidad de recursos financieros, materiales y humanos que posee, etc. ${ }^{1228}$.

Con el planteamiento expuesto queda muy claro que desde que el agente infiltrado venga a laborar dentro de los parámetros establecidos en la resolución judicial, representando el Estado en la lucha contra la criminalidad, resultaría justificada su

1224 Vid. monográficamente, TOLEDANO TOLEDANO, J. R., "La actuación policial y la eximente del cumplimiento de un deber", Ciencias Policiales, núm. 92, Madrid, 2009, págs. 73-86; SANZOBRODT, L. A., Do estrito cumprimento de dever legal, Porto Alegre, 2005.

1225 En este sentido, LAJE ANAYA sostiene que "la naturaleza de la impunidad del agente encubierto estriba en una causa de justificación que aquél actúa en el legítimo ejercicio del cargo y actúa, en consecuencia, la ley". Vid. LAJE ANAYA, J., Narcotráfico y derecho penal argentino, Córdoba, 1998, 331. Adoptando la posición de reconocimiento de una causa de justificación véase por todos CARMONA SALGADO, C., "La circulación y entrega vigilada de drogas y el agente encubierto en el marco de la criminalidad organizada ante el narcotráfico", cit., pág. 188; CHOCLÁN MONTALVO, J. A., La organización criminal: tratamiento penal y procesal, cit., pág. 62; GONZÁLEZ, R. L.,"Cuestiones referidas a la utilización deagentes encubiertos en la represión del narcotráfico", Doctrina Judicial, núm. 33, 1996, págs. 316 y ss.; NÚÑEZ PAZ, M. A; GUILLÉN LÓPEZ, G., "Entrega vigilada, agente encubierto y agente provocador: Análisis de los medios de investigación en materia de tráfico de drogas", cit., pág. 123; REY HUIDOBRO, L. F., El delito de tráfico de drogas. Aspectos penales y procesales, Valencia, 1999, pág. 352; RIFA SOLER, J. Ma.., "El agente encubierto o infiltrado en la nueva regulación de la LEcrim", cit., pág. 172. Todavía, con una posición peculiar sobre esta discusión, algún autor defiende que "la impunidad del agente encubierto es un caso de estado de necesidad no justificativo, sino exculpante, motivo por el cual aquél comete acción típica, antijurídica e inculpable". Vid. TORRES, C., "El agente encubierto", Cuadernos del Departamento de Derecho Penal y Criminología, núm. 2, Córdoba, 1998, pág. 301.

1226 Vid. LÓPEZ BARJA DE QUIROGA, J., Tratado de Derecho Procesal Penal, cit., pág. 536.

1227 Vid. en este sentido la STS 571/1998 de 31.01.1998.

1228FEITOZA PACHECO, D., Direito processual penal. Teoria, critica e práxis, cit., pág. 968. 
actuación con fundamento en la causa de exclusión de la responsabilidad penal denominada "estricto cumplimiento de un deber legal"1229.

Además, cuando se trata de este medio extraordinario de investigación, dicha causa de justificación está vinculada a la existencia de una situación de necesidad en que haga imperioso recurrir a la infiltración policial encubierta en una organización de delincuencia organizada. Es decir, que el encubrimiento aparezca como la única técnica utilizable para conseguir pruebas de cargo contra dicha asociación criminal ${ }^{1230}$ y que exista incondicional respeto a los principios de proporcionalidad y subsidiariedad.

Estas restricciones apuntadas anteriormente tienen por finalidad buscar que se optimice el criterio de utilidad y velar por el menor perjuicio de las garantías del Estado de Derecho. De esta manera, para poner en práctica la medida se exige que se traten de delitos graves y de difícil comprobación, presentando la técnica de infiltración como la única vía para la investigación y esclarecimiento de los tales comportamientos criminales ${ }^{1231 .}$

Lo más importante es que independientemente de la justificativa para la exención de la responsabilidad penal del infiltrado, deberá ser registrado que toda la actuación del mismo en el contexto de la operación encubierta exige la compatibilidad con el principio de proporcionalidad ${ }^{1232}$.

Respecto a esta cuestión, LÓPEZ BARJA DE QUIROGA señala que la proporcionalidad se averiguará tomando en consideración la actuación del agente encubierto y la finalidad

\footnotetext{
1229 Por lo que se refiere al ordenamiento penal español, existen autores que han defendido que se trata de la especificidad de una causa de justificación genérica del Código Penal español, en concreto, la recogida en el número 7 del artículo 20: "el que obre en cumplimiento de un deber o en el ejercicio legitimo de un derecho, oficio o cargo". En este sentido, vid. QUERALT JIMÉNEZ, J. J., "Recientes novedades legislativas en materia de lucha contra la criminalidad organizada: Ley Orgánica 5/1999 de 14 de enero", La Ley, 1999-6, pág. 1824; RIFÁ SOLER, J.M., "El agente encubierto o infiltrado en la nueva regulación de la LECrim", cit., pág. 172; REY HUIDOBRO,L.F., El delito de tráfico de drogas. Aspectos penales y procesales, Valencia, 1999, págs. 335-336; ZARAGOZA AGUADO, J. A., "Tratamiento penal y procesal de las organizaciones criminales en el Derecho español. Especial referencia al tráfico ilegal de drogas", VV.AA., Delitos contra la salud pública y contrabando, cit., pág.109. Dentro de esta postura hay un sector que limita a priori la aplicación de dicha eximente a determinados supuestos: en primer lugar, señala este sector que el legislador sólo exime cuando exista la debida proporcionalidad entre los delitos que cometa el agente y la finalidad perseguida por la investigación; en segundo lugar, cuando se trata de infracciones graves cometidas por el agente encubierto como atentados contra a la vida, la integridad o libertad de las personas, no cabe exonerarle porque estos casos constituyen límites a la citada cláusula de exención, salvo circunstancias muy especiales que habría que valorar detenidamente en cada supuesta en particular. Cfr. por todos, CARMONA SALGADO, C., "La circulación y entrega vigilada de drogas y el agente encubierto en el marco de la criminalidad organizada sobre narcotráfico", cit., pág. 188; MARTíN PALLÍN, J. A., "Impacto social, criminológico, político y normativo del tráfico de drogas", Delitos contra la salud pública, Cuadernos de Derecho Judicial, Madrid, 2000, pág. 167.

1230Vid. RODRÍGUEZ FERNANDES, R., "El agente encubierto y la entrega vigilada", cit., pág. 106.

1231 Lo afirmado viene a significar que en los demás supuestos en que la participación del infiltrado en la ejecución de conductas delictivas no emerja como necesaria para la protección de los bienes jurídicos en juego, y por ende, vaya más allá del ámbito de su justificación inicial, se puede considerar quedicho comportamiento podráser comprendido como delictivo, noobstante, en el casodel funcionario policial infiltrado en un grupo de delincuencia organizada, cuya propia seguridad personalpuede verse en peligro por no ejecutar algunos de estos ilícitos, debe se aceptar la posibilidad de una exculpación por miedo insuperable o fuerza irresistible. Vid. MATUS ACUÑA, J. P; GÚZMAN, R., Lecciones de Derecho penal Chileno. Parte especial, 2ª edición, Talca, 2002, pág. 250.

1232 Por esta razón "la exigencia formal referente a que la conducta del agente encubierto dentro de la investigación ha de guardar la debida proporcionalidad con la finalidad de la misma, determina que sólo cabe consentir un quebranto de la legalidad cuando los logros de la investigación retribuyan los daños que comporta". Vid. NÚÑEZ PAZ, M. A; GUILLÉN LÓPEZ, G., "Entrega vigilada, agente encubierto y agente provocador: Análisis de los medios de investigación en materia de tráfico de drogas", cit., pág. 138.
} 
de la investigación. Por ejemplo, si el agente encubierto mata por la espalda a un secuestrador (de la organización en la que se ha infiltrado) para liberar a siete rehenes, no hay que examinar si la muerte se ha llevado a cabo justificadamente (legítima defensa) sino si es proporcional matar (actuación del agente encubierto) para liberar siete rehenes bajo la amenaza seria de muerte (finalidad de la investigación). También se puede imaginar el agente encubierto que se ha infiltrado en una organización y que para se ganar la confianza de sus compañeros o para se mantener infiltrado tenga que matar o ayudar a matar, o secuestrar o ayudar a secuestrar. Surgiría la duda de si son proporcionadas estas actuaciones en razón a la finalidad de la investigación ${ }^{1233}$.

De otra parte, cabe plantearse cómo justificar la actuación del infiltrado que sea obligado por los otros miembros del grupo criminal a matar a alguien.En una situación extrema en que el agente encubierto se vea en situación de cumplir un orden de matar a una determinada persona como respuesta al desafío de una prueba de castidad, se puede esperar que el mismo actúe al menos de tres modos: inicialmente, es de esperar que el infiltrado vislumbre la posibilidad de alejarse de la esfera de vigilancia de los miembros de la banda y consiga salir del ambiente criminal, abandonándose la operación de infiltración $y$, por lo tanto, no practicando el delito ${ }^{1234}$. La segunda posibilidad consiste en el hecho de que el agente infiltrado simule el cumplimiento del orden, emprendiendo un engaño de modo que provoque en los miembros del clan criminal la sensación de que el mismo ha cumplido con su obligación; así, podría seguir actuando normalmente en el plan de infiltración, contando con la confianza de la organización criminal. Por fin, como tercera posibilidad, puede verse en la situación de tener que matar la persona a que le ha sido encomendada, hipótesis esta merecedora de una atención especial.

Sobre esta situación concreta, recuerda CORRÊA DE CARVALHO que sólo en la excepcional situación de encontrarse en un ambiente controlado por el grupo, sería razonable que cumpliese el orden de matar como medida de estado de necesidad, cuando sea previsible que del incumplimiento del orden resultase su propia muerte. Además, no se está afirmando con esto que sea legítimo matar para investigar. Sucede que en situaciones límite la confrontación entre bienes de igual magnitud puede justificar la muerte lícita de otra persona, como sucede en los casos de legítima defensa o estado de necesidad ${ }^{1235}$.

Incluso es previsible la posibilidad de que un policía infiltrado que actuando con el objetivo de investigar la organización criminal acabe por verse con un arma apuntada a la cabeza por el delincuente y obligado a disparar contra una tercera persona. Nos parece

1233 Cfr. LÓPEZ BARJA DE QUIROGA, J., "El agente encubierto", cit., pág. 1955.

1234 Nos parece que existe un equívoco al se pensar que el infiltrado no tiene tiempo para adoptar una actitud positiva, de actuar conforme le ha sido determinado, o negativa, alejándose del ambiente criminal y abandonando el procedimiento de infiltración. Cuando se le pide o se determina la práctica de una "prueba de castidad", es normal que se le conceda un cierto tiempo para ponerla en marcha. Esto lo que ocurre en la práctica de las infiltraciones de agentes policiales en bandas criminales. Pero no se desestima la posibilidad excepcional de que el infiltrado sea obligado a ejecutar su prueba de castidad de inmediato, sin tiempo hábil para adoptarse alguna medida de improviso.

1235 Vid. CORRÊA DE CARVALHO, J. T., Tráfico de drogas. Prueba penal y medidas restrictivas de derechos fundamentales, cit., págs. 337-338. También se puede considerar legítimo por ejemplo, un ajuste de cuentas entre miembros de la banda con resultado muerte. En este sentido, Cfr. RIFÁ SOLER, J. M., "El agente encubierto o infiltrado en la nueva regulación de la LECrim", cit., pág. 172. 
razonable y de acuerdo a los principios básicos del Derecho Penal que sea aplicable la causa de exclusión de la culpabilidad en razón de una coacción moral irresistible1236.

De esta forma, se observa como premisa básica que el agente infiltrado no deba cometer hechos delictivos en su actividad encubierta, en razón de no recibir una "carta en blanco" de la autoridad judicial que lo autoriza a delinquir. Muy al contrario, es posible que de modo excepcional se produzcan situaciones en que el infiltrado dentro de la trama de la operación encubierta se vea obligado a cometer una acción delictuosa que se presente como consecuencia del desarrollo de la investigación y que deberá ser entendida como una causa justificada en razón del ejercicio de un estricto cumplimiento de un deber legal, a la vez que estaría laborando para el Estado, y por lo tanto, ejecutando un trabajo de investigación en la persecutio criminis ${ }^{1237}$.

Cuestión especialmente interesante versando sobre el tema de la responsabilidad penal del infiltrado se refiere al hecho de que el ordenamiento jurídico podrá establecer una "condición de procedibilidad" como requisito para la exención de responsabilidad.

En España, el párrafo 2o del apartado 5o del artículo 282 bis de la LECrim contiene una condición de procedibilidad consistente en que para poder proceder penalmente contra el agente encubierto es preciso que el Juez competente requiera informe de quien hubiere autorizado la identidad supuesta. De esta manera, el informe aparece como una condición para que pueda se perseguir al agente encubierto.

Según BARJA DE QUIROGA, la mecánica de esta cuestión es sencilla: el Juez competente para el conocimiento de las acciones delictivas, cuando tenga conocimiento de que el responsable de ellas es un agente encubierto, debe pedir el informe a la persona que ha autorizado la exigencia del agente encubierto. Una vez con el informe en su poder resolverá lo procedente ${ }^{1238}$.

En nuestra opinión, se trata de una exigencia totalmente viable y positiva pues tiene por finalidad la posibilidad de poner en conocimiento de la autoridad que va a proceder contra el infiltrado, autor del delito, toda suerte de informaciones sobre los detalles de la operación encubierta, y en especial, dando oportunidad de conocerse las razones que llevaron a la práctica de la infracción penal.

$\mathrm{Al}$ fin de este apartado, se torna imprescindible mencionar la Recomendación 28 del Grupo de Trabajo Oficioso de Expertos sobre Técnicas Especiales de Investigación de Naciones Unidas, en la que se propone que la legislación relativa a las operaciones encubiertas debería contemplar la posibilidad de que los agentes infiltrados comentan ciertos delitos penales dentro de parámetros definidos. Según el ordenamiento jurídico aplicable de que se trate, ello puede lograrse: estableciendo exenciones específicas en la legislación; sentando jurisprudencia en la que se determine que el agente no tiene la intención requerida para la comisión del delito, o recurriendo a la doctrina o directrices

1236 Adoptando esta posición vid. MENDRONI, M. B., Crime organizado. Aspectos gerais e mecanismos legais, cit., pág. 56. Nos parece una situación semejante cuando con base en el principio de proporcionalidad, un agente encubierto estuviera en una situación en que tenga que admitir el recibimiento de alguno dinero originado de acto de corrupción, aceptando entonces repasar la cuantía a las autoridades en la primera oportunidad, acompañado de un informe circunstanciado, para que sea debidamente aprehendido y documentado.

1237 Vid. SEOANE SPIEGELBERG, J. L., "Aspectos procesales del delito de trafico de drogas", cit., pág. 342.

1238 Vid. LÓPEZ BARJA DE QUIROGA, J., Tratado de Derecho Procesal Penal, cit., pág. 534. 
según las cuales no se iniciará juicio en esos casos ya que no hay perspectiva razonable de que se dicte condena y esos procedimientos no serían de interés público ${ }^{1239}$.

\section{IV.1.8.2. La responsabilidad civil}

En términos generales se puede recordar que una vez finalizada la infiltración policial, tendrán que verificarse las eventuales responsabilidades penales y civiles por los actos cometidos por el agente encubierto durante la investigación ${ }^{1240}$.

Y aunque normalmente surge una destacada preocupación con los aspectos que permean la responsabilidad del agente encubierto con relación a eventual práctica de delitos durante el período de infiltración en una organización criminal. Pero deberán ser analizadas del mismo modo los aspectos civiles y disciplinarios que puedan presentar conexión con la actuación del infiltrado.

En realidad, la lógica nos impone a considerar que los Estados también deberían reconocer que la inmunidad que se concede eventualmente a los agentes debería contemplar la posible responsabilidad civil, además de la penal, a la que quizás se vea expuesto el agente.

En ocasiones, amén de la incidencia de actos de responsabilidad penal sobre actuaciones practicadas por el agente encubierto en el desarrollo del plan de infiltración podrán surgir dudas sobre la necesidad de se reconocer alguna repercusión civil originaria de alguna conducta ejecutada pelo agente también durante la tarea encubierta.

Con relación al tema sería muy interesante la dotación de recursos financieros para hacer frente a los gastos previsibles,así como contratar seguros de responsabilidad civil en nombre del agente encubierto. Nos parece una idea digna de alabanza y que viene de encuentro a la imperiosa necesidad de preventivamente minimizar los perjuicios que podrán ser provocados por alguna conducta involuntaria del infiltrado y que venga a repercutir en la esfera civil ${ }^{1241}$.

Desde esta concreta perspectiva, surge una cuestión sensible sobre quién deberá soportar la responsabilidad de indemnizar a algún acto cometido por el infiltrado ${ }^{1242}$.

${ }^{1239}$ Cfr. con detalles, el Informe del Grupo de Trabajo Oficioso de Expertos sobre Técnicas Especiales de Investigación (Prácticas óptimas y recomendaciones sobre los obstáculos jurídicos a las entregas vigiladas y las operaciones encubiertas), Septiembre de 2005. El citado grupo de especialistas de la Oficina contra la Droga y el Delito de las Naciones Unidas, al analizaren la citada recomendación, hacen hincapié en el sentido de que para que las operaciones se lleven a cabo con éxito y el agente pueda ganarse la confianza de los cabecillas de la organización, éste debe gozar de flexibilidad para cometer ciertos actos sin que exista la posibilidad de que se lo procese penalmente. En esta línea de pensamiento, es necesario que se pueda aplicar la prueba de la proporcionalidad y establecer restricciones claras al alcance de la protección que se les ha de conceder, para que no haya inmunidad general respecto de todas las clases de conductas delictivas.

1240 En este sentido, Vid. ESPINOSA DE LOS MONTEROS, R. Z., El policía infiltrado. Los presupuestos jurídicos en el proceso penal español, cit., pág. 424.

${ }^{1241 E n ~ c u a n t o ~ a ~ e s t a ~ r e s p o n s a b i l i d a d ~ d e ~ c a r a ́ c t e r ~ c i v i l, ~ e s ~ d a b l e ~ q u e ~ s e g u r a m e n t e ~ s u r g i r a ́ ~ e n ~ l a ~ i n v e s t i g a c i o ́ n ~}$ de grandes entramados delictivos o incluso en delitos de carácter internacional cometidos por grandes mafias u organizaciones delictivas. Cfr. SUITA PÉREZ, N., "La diligencia de investigación por medio del agente encubierto", cit., pág. 264.

1242 Ciñéndonos al ordenamiento penal portugués, según el dispuesto en el Decreto-Ley n. 48.051, de 21 de noviembre de 1967, y en el ámbito de su responsabilidad extracontractual, debe el Estado proceder el pago de la correspondiente indemnización siempre que durante una acción infiltrada exista un evidente daño a una tercera persona, independiente de la licitud de la conducta del agente encubierto. En palabras de CANOTILHO, "la asunción por parte del Estado sobre esta responsabilidad se impone cuando entre la relación de esta actividad y la cualidad del agente público del sujeto que provoca la lesiones es de tal modo estrecha que ella no 
Aunque sea una hipótesis plenamente posible y que deberá ser analizada de modo concreto en lo referente a una situación real y compleja, no se puede dejar de reconocer que en ningún caso se podrá considerar la exención de responsabilidad civil del agente encubierto cuando los actos civiles y mercantiles que haya realizado tengan el fin de lucrarse. En estos supuestos, el tercero perjudicado podrá reclamar al agente en primera persona $^{1243}$.

Esta posición anteriormente descrita viene de encuentro a la correcta comprensión de que el Estado no puede soportar perjuicios financieros por actos individuales e independientes practicados dolosamente por sus funcionarios, que presentan como característica central el hecho de tener sido realizados con intenciones de índole personal y con objetivos y propios, nada teniendo que ver con las tareas de investigación encargadas al infiltrado en la operación encubierta.

De otra parte, ciñéndonos al ordenamiento procesal penal español,consideramos interesante señalar que a diferencia de la existencia de una regulación expresa del sistema de modulación de la responsabilidad penal del agente encubierto, no hay en el ordenamiento procesal precepto alguno que fije límites a una futura responsabilidad civil de los infiltrados ${ }^{1244}$. La razón es bien sencilla pues mientras que la titularidad exclusiva del ius puniendi corresponde al Estado y, por ello, puede hacer concesiones legislativas respecto a la penalidad de los delitos, en la responsabilidad civil la titularidad de la pretensión es exclusivamente privada, sucumbiendo ante el Estado la posibilidad de efectuar cualquier tipo de renuncia ${ }^{1245}$.

\section{IV.1.8.3. La responsabilidad disciplinaria.}

La ejecución por parte de un agente encubierto de un delito en el devenir de una operación de infiltración no sólo puede generar responsabilidad penal y civil, sino que también puede dar lugar a responsabilidad administrativa o disciplinaria1246.

Imagínese una hipótesis de responsabilidad disciplinaria del agente que se infiltra en una banda criminal donde ocurre un orden superior de interrupción de la operación encubierta por motivos de seguridad y el infiltrado no viene a atender este comando por nítido acto de rebeldía. La omisión de este funcionario estatal podrá generar una suerte de aplicación de una grave sanción disciplinaria en razón de su falta administrativa en razón de su actitud rebelde.

Efectivamente, parece evidente que esta especie de responsabilidad a ser imputada al agente se encuentra vinculada a la constatación de una acción motivada por una

podría ter sido realizada en la forma y modalidades adoptadas se el agente no estuviera investido de un munus público". Vid. CANOTILHO, J. J. G., O problema da responsabilidade do Estado por actos lícitos, Coimbra, 1983, pág. 65.

1243 Cfr. con más detalles, ESPINOSA DE LOS MONTEROS, R. Z., El policía infiltrado. Los presupuestos jurídicos en el proceso penal, cit., pág. 421.

${ }^{1244}$ GÓMEZ DE LIAÑO FONSECA HERRERO, M., Criminalidad organizada y medios extraordinarios de investigación, cit., pág. 269. Tal previsión legislativa ocurre en la gran mayoría de los ordenamientos penales de nuestro entorno, principalmente en Europa y en America del Sur.

1245 Véase, GASCÓN INCHAUSTI, F., Infiltración policial y “agente encubierto”, cit., pág. 289.

1246En España, por ejemplo, el art. 6.2 del Reglamento de Régimen Disciplinario del Cuerpo Nacional de Policía aprobado mediante el Real Decreto 884/1989, de 14 de julio, en consonancia con el art. 27.3 de la LOFCSE, preceptúa como falta disciplinaria muy grave la comisión de cualquier conducta constitutiva de delito doloso. 
ausencia de respecto a un orden jerárquicamente superior. En este caso, es algo normal que esta conducta del infiltrado presente íntima relación con algún propósito personal del agente, o sea, alguna finalidad que venga exclusivamente a traer beneficios propios a esta persona.

La irrogación de la sanción administrativa queda condicionada a la decisión final tomada en el proceso penal, surgiendo de este modo una cuestión prejudicial devolutiva administrativa en el proceso penal ${ }^{1247}$.

Ante esta situación expuesta no podemos cuestionar si en este caso de sanción penal y administrativa concomitantes se estaría violando la regla del principio del non bis in idem.

No hay una respuesta unívoca para contestar esta pregunta. Obsérvese que en España el Tribunal Constitucional ha considerado ajustado al non bis in idem que la legislación funcionarial permitiera a la Administración, tras la condena de un funcionario, imponerle una sanción administrativa ${ }^{1248}$, en tanto en cuanto hubiera lugar a una compensación de las sanciones. De acuerdo con la jurisprudencia constitucional, refrenda en este concreto punto de la compensación por la Sentencia del Pleno 2/2003, de 16.1.2003, no existe infracción del principio non bis in idem siempre y cuando se proceda a un descuento de las sanciones penales y administrativas, pues no basta la mera declaración de la imposición de la sanción ${ }^{1249}$. Todavía, la posición del Tribunal Constitucional sobre la compensación difiere radicalmente de la jurisprudencia asentada en el Tribunal Europeo de Derechos Humanos ${ }^{1250}$, para el cual da por completo igual en los casos de vulneración del non bis in idem que se haya efectuado una compensación de sanciones, así como que la sanción penal sea anterior o posterior a la sanción administrativa, ya que debe irrefutablemente el Tribunal superior anular siempre la última ${ }^{1251 .}$

En torno a esta intrigante cuestión nos parece que más acertada sería la primera posición, teniendo en cuenta que es algo indudable que las responsabilidades penales y administrativas son distintas y autónomas, presentando cada cual sus propias especificidades y particularidades, no siendo correcta la invocación del principio de la prohibición del non bis in idem ${ }^{1252}$.

1247Vid. GÓMEZ DE LIAÑO FONSECA-HERRERO, M., Criminalidad organizada y medios extraordinarios de investigación, cit., pág. 271.

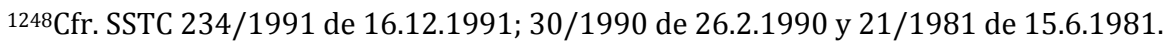

${ }^{1249}$ GÓMEZ DE LIAÑO FONSECA-HERRERO, M., Criminalidad organizada y medios extraordinarios de investigación, cit.,pág. 272.

1250Vid. SSTEDH, caso Sallen c. Austria, de 6.6.2002 (TEDH 2002/35), caso CF c. Austria, de 30.5.2002 (TEDH 2002/35) y Franz Fischer c. Austria, de 29.5.2001 (TEDH 2001/352).

1251Vid. GIMENO SENDRA, V., "Cuestiones prejudiciales devolutivas y non bis in idem en el proceso penal", Revista La Ley, núm. 5817, 2003, pág. 6.

1252 Sobre esta cuestión, señala ESPINOSA DE LOS MONTEROS "que los actos cometidos por el agente encubierto sean objeto de un proceso penal, no impide que se inicie la tramitación del procedimiento disciplinario por los mismos hechos. Sin embargo, la resolución del expediente disciplinario no se producirá en tanto cuanto la sentencia recaída en elprocesopenal adquiera firmeza, vinculando la declaración de los hechos probados en el ámbito penal, a la Administración". Cfr. ESPINOSA DE LOS MONTEROS, R. Z., El policía infiltrado. Los presupuestos jurídicos en el proceso penal español, cit., pág. 419. 
IV.1.9. Algunas críticas respecto al agente encubierto.

Hemos visto anteriormente que la actuación del agente encubierto podrá generar una responsabilidad no solo penal, sino que en ciertos casos también civil y administrativa o disciplinaria. Y las razones son claras, pues resulta que para la obtención de datos relevantes no bastará al infiltrado solo la maniobra engañosa consistente en la mera ocultación de la condición de policía, sino que deberá utilizar otras series de mecanismos destinados a lograr la confianza de los miembros de la organización, muchos de los cuales se sitúan en los límites del Estado de Derecho y otros son constitutivos de delito. De esta forma, la infiltración policial genera importantes riesgos de imputar al agente la comisión de infracciones penales (perspectiva material) y de provocar la existencia de pruebas nulas por contradecir las exigencias del proceso debido constitucionalmente diseñado (perspectiva procesal) ${ }^{1253}$.

A la vista de las anteriores reflexiones han surgido en el ámbito doctrinal algunos posicionamientos críticos que apuntan imperfecciones respecto a este medio de investigación criminal, el cual podría en su utilización enervar principios del Estado de Derecho.

Sobre esta cuestión no menos importante es señalar que la actividad del agente infiltrado crea múltiples problemas de carácter material y de carácter procesal que se relacionan con su actividad, ya que ésta se extiende a una amplia gama de actuaciones que abarcan desde la mera observación del ambiente criminal hasta la participación en determinados delitos ${ }^{1254}$.

Aunque se defienda que el uso de agentes encubiertos en las entrañas de grupos de delincuentes organizados sea una medida imprescindible en los días actuales, esto no conlleva a una conclusión de que esta técnica de investigación se encuentre lejos de recibir críticas. Todavía nos parece más acertado el planteamiento de críticas constructivas a esta técnica de búsqueda de datos, informaciones y pruebas que se encuentran cerrados en el centro de algunos grupos criminales.

La visión crítica que defendemos sería aquella que busca proponer soluciones que vengan a promover una reglamentación y consecuente interpretación de este medio extraordinario de investigación de acuerdo con los parámetros de constitucionalidad y en especial obedeciendo el postulado de proporcionalidad con la finalidad de evitarse la innecesaria violación de derechos y garantías fundamentales.

Dicho de otro modo, teniendo en cuenta que la utilización de un agente infiltrado presenta alta carga de riesgo en el sentido de provocar violaciones graves a los derechos y garantías fundamentales de los investigados, se torna necesaria la adopción de medidas de

1253 Cfr. DELGADO MARTín, J., Criminalidad Organizada, cit., pág. 60.

1254 MOLINA PÉREZ, T., "Técnicas especiales de investigación del delito: el agente provocador, el agente infiltrado y figuras afines", cit., pág. 186. Siguiendo esta posición, señala GARCíA SÁNCHEZ que "la razón fundamental de la polémica gira en torno a una premisa: la utilización de tales mecanismos supone, en muchos casos, la vulneración de derechos fundamentales, cuando no, la comisión por parte de los sujetos encargados de la persecución delictiva de conductas tipificados en el Código Penal; es decir, los policías para perseguir, por ejemplo, el tráfico de drogas, tienen a su vez que, en algunas ocasiones, cometer delitos de tráfico de drogas". Vid. GARCÍA SÁNCHEZ, B., "Técnicas de investigación de la delincuencia organizada: perspectiva penal", Revista Letras Jurídicas, vol. 20, 2009, http:://www.letrasjuridicas.com. 
reglamentación de esta figura ${ }^{1255}$, de modo a que su actuación pueda ser aceptada como eficaz y al mismo tiempo correspondiente a un proceso penal garantista.

Básicamente son tres las principales objeciones planteadas contra la figura del agente encubierto: la utilización del infiltrado a través de una autorización del propio Estado, pudiendo incluso cometer delitos; la exención de responsabilidad penal del agente con relación a su actuación; y la violación del principio de lealtad con graves repercusiones sobre la valoración de la prueba obtenida en la operación encubierta.

La primera y principal crítica se refiere a la cuestión del uso de un agente funcionario del propio Estado para que practicando delitos, como eluso de una identidad supuesta, pueda ingresar en el seno de una organización criminal con objetivo de proceder a un verdadero engaño sobre terceros, buscando al fin la desarticulación de la misma. El problema de fondo que impregnaría esta actuación policial estaría en que no se podrá aceptar en la actualidad la idea de que "los fines justifican los medios"1256.

Desde esta perspectiva, el Estado a través de acciones cometidas por uno o más de sus funcionarios estaría practicando conductas ilícitas y delictuosas que iban a provocar en los ciudadanos la sensación de descontrol por parte de los órganos de persecución, a la vez que estos demostrarían desespero y anhelo por encontrar alguna forma, incluso contraria a la ética y a los principios del Estado de Derecho, para contener o frenar las actividades de un determinado grupo criminal organizado.

Pues bien, a partir de estas premisas señala NERIA que el agente encubierto involucra por parte del Estado la traición y el engaño. En una sociedad que mira con desconfianza a las fuerzas de seguridad, estas son, justamente las encargadas de engañar a los ciudadanos, con el fin de escudriñar sus actos y buscar su culpabilidad; además, puede crear una situación de inseguridad, ya que se justifica a las fuerzas de seguridad cuando realizan las mismas conductas que se intenta investigar ${ }^{1257}$.

Partiendo de este enfoque, sería sumamente malo el ejemplo empleado por quien debiera como meta principal combatir la delincuencia con rigor y no al contrario, pactar con la práctica de actos criminales.

Incluso se destaca que en realidad el agente encubierto se infiltra de una manera engañosa en el contexto social, valiéndose de la falacia; y se añade que en esa mentira viviente que es, él mismo crea relaciones humanas, amistades, penetra en intimidades, percibe confidencias, presencia escenas a las que en absoluto hubiera tenido acceso de conocerse su verdadera condición ${ }^{1258}$.

\footnotetext{
1255 La razón consiste en el hecho de que para combatir las organizaciones criminales con eficacia no sólo depende de la excelente disponibilidad demostrada por las instituciones, sino que también hay que dotar los ordenamientos jurídicos de normas que garanticen la legalidad de las actuaciones de los órganos de investigación y así evitando que el crimen organizado salga victorioso en los procesos judiciales en consecuencia de ausencia de pruebas inculpatorias, generando pues una sensación de absoluta impunidad.

1256 En este sentido, AROCENA señala que "la indiferencia del Estado en la persecución y represión de la criminalidad ante aquel elemental principio ético, encierra un potencial peligro, que estriba en la creencia de que todo medio está justificado para la consecución de la anhelada seguridad ciudadana, cimentada en la persecución y castigo de todos los delitos". Vid. AROCENA, G. A., "El agente encubierto. Consideraciones político-criminales", cit., pág. 129.

1257 Vid. NERIA, C., "El arrepentido y el Agente encubierto: reflexiones acerca de un proyecto de ley contra las actividades terroristas", La Ley, Tomo 1997-B, pág. 1431.

1258 Vid. SEQUEROS SAZATORNIL, F., "El tráfico de drogas ante el ordenamiento jurídico (evolución normativa, doctrinal y jurisprudencial), cit., pág. 756.
} 
Por consiguiente el Estado no debería actuar de modo facineroso, adoptando las mismas estrategias empleadas por los criminales y utilizando de medios incompatibles con su status de órgano gubernamental de enfrentamiento a la delincuencia.

El inconformismo oriundo de este sector doctrinal reposaría fundamentalmente en la dudosa cuestión ética de sus actuaciones ${ }^{1259}$, siendo cuestionable que en nombre de la eficiencia del sistema punitivo guardara legitimidad el juicio criminal que apoyarse en la actuación de un infiltrado, o mejor, si en nombre de esta misma eficiencia debe reconocerse como racional y justo que el propio Estado en vez de ejercer función de prevención penal, practique actos desviados, igualándose al delincuente ${ }^{1260}$.

De lo dicho resultaría que el Estado que posee la función de combatir las prácticas criminosas, estaría pues, desde sus propios cuadros, promoviendo un excepcional y desastroso incentivo a la violación de las leyes, ejemplo este de preocupante repercusión en la sociedad ${ }^{1261 .}$

Además, un sinnúmero de principios constitucionales estarían siendo violados en razón de la actuación del agente encubierto, entre otros la legalidad penal y procesal ${ }^{1262}$. Del mismo modo, algunos derechos fundamentales del inculpado, en especial la intimidad, la privacidad y el derecho a la autodeterminación informativa ${ }^{1263}$ serían frontalmente violados.

${ }^{1259}$ En este sentido,GUEDES VALENTE señala que "la eticidad de este medio excepcional de obtención de prueba es dudosa, mucho más se el agente infiltrado ha sido un ciudadano oriundo o próximo al mundo del crimen". Vid. GUEDES VALENTE, M. M., "A investigação do crime organizado. Buscas domiciliárias, o agente infiltrado e intervenção das comunicações", cit. pág. 171.

1260 Vid. FRANCO, A. S., Leis penais especiais e sua interpretação jurisprudencial, cit., pág. 583. En contra a esta crítica, Pozo Pérez, afirma que este modo de actuar del agente encubierto es ético; se utiliza el mismo como medio subsidiario de investigación, cuando no existe otro modo, menos lesivo, de averiguar todo lo relacionado con las redes organizadas violentas, que corrompen y tratan de conseguir a cualquier precio su impunidad. La ética no se pierde en ningún momento de la utilización de esta técnica de indagación puesto que existe control jurisdiccional y están prohibidas las conductas poco respetuosas con los derechos fundamentales. Cualquier actuación que quebrante las garantías fundamentales, no podrá ser utilizada en el proceso penal, pudiendo incluso generar responsabilidades, disciplinarias o penales para el agente. Vid. POZO PÉREZ, M., "El agente encubierto como medio de investigación de la delincuencia organizada en la Ley de Enjuiciamiento Criminal española", cit., pág. 286. También interesante mencionar la STEDH de 9.6.1998, Caso Teixeira Castro contra Portugal, cuando se indica que "la intervención de agentes encubiertos debe estar circunscrita y rodeada de garantías incluso en el tráfico de estupefacientes. En efecto, si la expansión de la delincuencia organizada lleva a no dudar de la adopción de medidas apropiadas, no queda más que, en una sociedad democrática, el derecho a que una buena administración de justicia ocupe un lugar tan preeminente, que no podamos sacrificarla por conveniencia".

1261 Respecto a esta crítica, algún autor, así MONTOYA, ha defendido que "el empleo de la técnica encubierta debe enfrentarse con el viejo principio de que el Estado no puede ser partícipe en delitos bajo ningún concepto. Ello hace a las reglas mínimas que conforman una sociedad, donde la ética debe imperar y en la cual el ciudadano, por otra parte, no está dispuesto a pagar impuestos para que se financien grandes operaciones, en que se utilicen fondos para teatralizar una investigación, por más que ésta tenga como fin detener un flagelo que de otra forma es muy difícil de combatir por los medios ordinarios de lucha contra el crimen". Vid. MONTOYA, M. D., Informantes y técnicas de investigación encubiertas. Análisis constitucional y procesal penal, cit., pág. 29.

1262 En este sentido, BRAUM apunta que "los presupuestos para la intervención del investigador encubierto son contrarios al principio de legalidad procesal". Vid. BRAUM, S., "La investigación encubierta como característica del proceso penal autoritario", VV.AA., La Insostenible situación del Derecho Penal, Instituto de Ciencias Criminales de Frankfurt, Granada, 2000, pág. 7.

1263 El derecho a la autodeterminación informativa ha sido reconocido, bajo la denominación de derecho a la protección de datos de carácter personal, en la Carta de los Derechos Fundamentales de la Unión Europea. También ha sido reconocido como derecho fundamental por el TC (STC 292/2000, de 30.11.2000). Monográficamente sobre el tema, Cfr., MURILLO DE LA CUEVA, P. L., "Perspectivas del derecho a la autodeterminación informativa", Revista de Internet, Derecho y Política, núm. 5, 2007, pags. 18-32. 
La segunda crítica al agente encubierto destaca que el legislador no puede eximir de pena a sus funcionarios, en razón de equiparar arbitrariamente bienes jurídicos de diferentes valores como sucede al evaluar del mismo modo el éxito de una investigación criminal y la propiedad, la intimidad, la autoridad legítima del mismo Estado o el riesgo previsible para la vida de una persona. Si se entendiese que el legislador puede operar de esta manera, no quedaría derecho alguno tutelado ni garantizado, pues su garantía dependería del valor que quisiera asignarle cada Estado, subordinándolo a la eficacia de sus agencias policiales, que operarían como valor supremo. No es función del Estado autorizar a sus agentes a cometer delitos contra sus habitantes sino, precisamente, tratar de protegerlos contra los que pretenden cometerlos. Al menos hasta ahora así lo ha entendido en el Estado moderno y no se cree que el estado posmoderno invente nada nuevo si postula el contrario ${ }^{1264}$.

Frente a esta opinión, la introducción legal de la figura del agente encubierto renunciaría a límites éticos, propios del Estado de Derecho, invocando un pragmatismo policial que ni siquiera es el pragmatismo tradicional, sino que reduce a un pragmatismo sectorial burocrático.

Se observa una vez más que se pone de relieve la cuestión de la ausencia de ética por parte del órgano estatal de persecución penal, pues la infiltración de agentes en el crimen organizado se trata de un procedimiento cuya legitimidad ética y jurídica es cada vez más contestada en las sociedades avanzadas pues sería incompatible con la reputación y la seriedad de la Justicia penal que agentes estatales se presten a envolverse con las mismas prácticas delictuosas que se presuponen a combatir ${ }^{1265}$.

En síntesis, la impunidad de agentes encubiertos, y también de los arrepentidos, constituiría una seria lesión a la eticidad del Estado, o sea, al principio que forma parte esencial del Estado de Derecho. En pocas palabras: el Estado no puede valerse de medios inmorales para evitar la impunidad ${ }^{1266}$.

Desde esta óptica, estaría siendo objeto de crítica la posibilidad de la exención de responsabilidad penal del infiltrado, mismo cuando su actuación presente relación directa con el objeto de la investigación encubierta.

Se suele incluso afirmar que la investigación encubierta, según se deriva de la dimensión crítica del principio de Estado de Derecho, resultaría contraria a la Constitución. Como consecuencia necesaria se derivaría la interdicción de valorar la prueba obtenida mediante la investigación encubierta ${ }^{1267}$.

1264 Vid. ZAFFARONI, E. R., "Impunidad del agente encubierto y del delator: Una tendencia legislativa en Latinoamérica", cit., pág. 735.

1265 GOMES FILHO, A. M., "Também em matéria processual provoca inquietação a Lei anti-crime organizado", Boletim do Instituto Brasileiro de Ciências Criminais, núm. 13, São Paulo, 1994, pág. 1.

1266 Cfr. ZAFFARONI, E. R., "El crimen organizado: una categorización frustrada", cit., pág. 279. Incluso en otro de sus trabajos, señala este mismo autor que "se ha podido además, argumentar que en verdad, con la introducción de la figura del agente infiltrado en la ley, el Estado a través de sus operadores políticos pretenden en realidad legitimar medidas penales antiliberales en función de todas las guerras que emprenden y pierden, y en este sentido, no están más que apelando a un recurso teorizado hace más de medio milenio de modo estructuralmente no superado hasta el presente y que es propio del Estado pre moderno o Estado de terror y de sus reapariciones". Cfr. ZAFFARONI, E. R., "Impunidad del agente encubierto y del delator. Una tendencia legislativa latino americana", cit., pág. 727.

1267 BRAUM, S., "La investigación encubierta como característica del proceso penal autoritario", cit., pág. 24. Siguiendo esta posición señala DAMIÁN MORENO que "la normalidad procesal y su compromiso con la defensa de las libertades es lo que, en el fondo, caracteriza el Estado de Derecho. No en vano, la lealtad institucional 
Una última crítica, todavía menos dura, dice respeto al hecho de que la lealtad es un principio inherente a la estructura del proceso penal, pues pretende imprimir una actitud de respecto por la dignidad de las personas y de la justicia y en esta perspectiva es fundamento de prohibición de prueba y dificulta la necesaria legitimación por el proceso penal y así el recurso a agentes informadores y agentes infiltrados violaría el principio de la lealtad produciendo como consecuencia la prohibición de pruebas obtenidas por esta vía.

El problema estaría en que las operaciones de infiltración policial el engaño de la identidad ficticia abre un abanico de posibilidades de actuar afectando derechos fundamentales de las personas investigadas, porque colocar el infiltrado en la organización criminal exigirá que éste trabe amistad, confraternice, o simplemente trabaje con diversos sujetos a los que terminará conociendo, y ello supone que conversará con ellos, en ocasiones tendrá que entrar en lugares cerrados, incluso en los domicilios de estas personas, podrán conocer sus comunicaciones, etc., lo que significa que de un solo golpe el engaño pone al agente infiltrado ante la posibilidad de afectar diversos derechos fundamentales como la intimidad, la inviolabilidad del domicilio, el secreto de las comunicaciones, etc. Y esto conduce a tener que plantear el valor que pueden tener las informaciones obtenidas por el agente encubierto, así como a ver qué alcance probatorio pueden tener ${ }^{1268}$

Sin embargo, la cuestión de los agentes informadores e infiltrados no tienen la misma tensión de los agentes provocadores; éstos son siempre inadmisibles, porque agentes del propio crimen y en circunstancia alguna se puede admitir que la justicia actúe por medios ilícitos y que el combate a la criminalidad se haga a través de medios criminosos; los agentes informadores e infiltrados no participan en la práctica del delito y su actividad no es constitutiva del crimen pero tan solo informativa y es por eso que se puede admitir, que en el límite, se pueda recurrir a estos medios de investigación ${ }^{1269}$.

Siguiendo esta tendencia, se observa un cierto repudio a la utilización de operaciones encubiertas al argumento de que el engaño del infiltrado respecto a los miembros del grupo criminal podría generar violaciones al derecho de estos en una conversaciónde no autoinculparse o de no declarar contra sí mismo ${ }^{1270}$. También que la privacidad y la intimidad de estas personas estarían en total estado de vulnerabilidad.

exige que sean los poderes públicos los primeros a respectar los principios y valores que inspiraron los movimientos surgidos en defensa de las garantías constitucionales". Vid. DAMIÁN MORENO, J., ¿Un Derecho Procesal de Enemigos?, Derecho Penal del Enemigo. El discurso penal de la exclusión, vol. 1, Buenos Aires, 2006, pág. 472.

1268 En este sentido, Cfr. GUZMÁN FLUJA, V., "El agente encubierto y las garantías del proceso penal", cit., pág. 216.

${ }^{1269}$ Cfr. MARQUES DA SILVA, G., Curso de proceso penal II, Lisboa, 1999, pág. 258.

1270 En sentido contrario, POZO PÉREZ señala que "por la propia naturaleza de la figura del infiltrado, se le exonera, de trasladarse la imputación y de realiza una lectura de derechos a cada miembro de la organización con el que entable una conversación antes de su inicio; si no resultaría absurdo; pues debería revelar su condición que es precisamente lo que deseamos ocultar, es evidente, y es precisamente uno de los objetivos de la infiltración, que así puede obtener datos relevantes acerca de la organización delincuencial. Si no permitimos al agente mantener charlas con sus compañeros de banda criminal, no tiene ningún sentido la infiltración porque resultará completamente estéril". Vid. POZO PÉREZ, M., "El agente encubierto como medio de investigación de la delincuencia organizada en la Ley de Enjuiciamiento Criminal", cit., pág. 304. Incluso, es de destacarse que de igual modo, no se ve por que razón el engaño que el agente infiltrado corporiza deba ser censurado como un ataque a la integridad moral del agente del crimen, cuando se aceptan, pacíficamente, 
Teniendo en cuenta el tenor literal de las críticas anteriormente presentadas, según nuestro modo de pensar deberán ser analizadas con cierta prudencia, a la vez que no representan factores aptos a superar la necesidad del Estado de estructurarsede modo eficaz para el enfrentamiento contra la criminalidad organizada.

Así, delante de algunas críticas impuestasa la figura del agente encubierto, nos parece acertadoemprender esfuerzos para a través de elaboración de criterios para una armonización procesal penal y utilizándose especialmente de los criterios de necesidad, adecuación y ponderación, establecer esta técnica de investigación en nivel confiable, presentando condiciones de aplicabilidad en razón de obediencia a los parámetros de constitucionalidad.

Pero esnecesario señalarla constatación de que la naturaleza del agente encubierto puede se presentar problemática, atento a los dos valores en pugna. Por un lado, el empleo de un agente infiltrado evidencia que el Estado se vale de un medio aparentemente "inmoral" en la represión de delitos graves, ya que el infiltrado utilizará la mentira y la traición como técnicas para descubrir los delitos y desarticular una determinada organización. A su vez, puede incluso llegar a cometer delitos en consecuencia de la investigación de las actividades delictivas del grupo criminal o incluso para ganar la confianza de los integrantes del mismo.

Como contrapeso a la situación anteriormente descrita, importante es destacar que nos encontramos también frente al valor eficacia de la persecución penal. Si queremos luchar eficazmente en la represión del crimen organizado debemos contar con medios idóneos para penetrar y conocer la intimidad de una delincuencia tan compleja, sofisticada y ramificada como son el narcotráfico o el terrorismo ${ }^{1271 .}$

Y dentro de este contexto, se observa que las organizaciones criminales utilizan todo tiempo del engaño y de la violencia frente a las autoridades de persecución, actuando de modo a conseguir sus objetivos a cualquier precio.

En este punto surge la cuestión de si sería correcto no admitir el engaño excepcional y legalmente justificado en una operación encubierta permitida por una autoridadjudicial a través del criterio de la proporcionalidad

Negar la aceptación de este medio extraordinario de investigación denotaríaque la simétrica paridad de armas quedaría quebrantada de forma injustificada; y más que esto, de manera a poner en riesgo el derecho fundamental de los ciudadanos con relación a la seguridad colectiva frente a las formas más graves de delincuencia.

Por fin, se constata que es tarea fácil criticar y aniquilar el empleo de esta técnica de investigación, defendiendo de forma radical la obligatoria necesidad de una actuación ética del Estado en el combate a la delincuencia. Todavía, nos cabe en este estudio no sólo reconocer la procedencia de un sinnúmero de críticas presentadas y que sin duda corresponden parcialmente a la verdad, pero también intentar presentar soluciones o modos de interpretación diversos con vistas a matizar los problemas imputados a esta

otros métodos como el de las escuchas telefónicas, la interceptación de correspondencia, etc. Vid. FURTADO, F., "O agente infiltrado", cit., pág. 13.

1271 Vid. EDWARDS, C. E., El arrepentido, el agente encubierto y la entrega vigilada., cit., págs. 53-54. 
técnica de investigación de modo que se pueda concebir la figura del agente encubierto como aceptable y respetuosa con las directrices constitucionales ${ }^{1272}$.

Dicho de otro modo, habrá que concluir afirmando que dependerá la aceptación de esta técnica de investigación a través de agentes infiltrados, de cómo ha sido prevista en el respectivo ordenamiento jurídico, bien como del reconocimiento especial de los principios de proporcionalidad y del debido proceso legal. Con esta actitud, quedarían cimentados al menos en parte, los argumentos críticos que se han puesto en relieve en este apartado ${ }^{1273}$.

\section{IV.2. Las operaciones encubiertas en la praxis.}

IV.2.1. Operaciones encubiertas: especies y finalidad.

Para comprender de una forma más accesible el trabajo de infiltración, conviene aprovechándose del texto de la Exposición de Motivos de la Ley Orgánica 5/1999, de 13 de enero, conceptuar una vez más este medio extraordinario de investigación como una medida legal especial que permite a los miembros de la Policía Judicial participar del entramado organizativo de un grupo criminoso, detectar la comisión de delitos e informar sobre sus actividades, con el fin de obtener pruebas inculpatorias y proceder a la detención de sus autores ${ }^{1274}$.

1272 También de gran significado para el correcto análisis de la cuestión mencionar que las SSTS 4796 y 9543 de 2.7.1993 apuntan que "la actuación policial, si bien utiliza un procedimiento engañoso, fingiendo intenciones irreales, sin embargo no origina un delito antes inexistente, sino que solo sirve para descubrir aquel que ya había cometido con anterioridad. El comportamiento del agente se encuentra dentro de los límites que la Constitución y la Ley le imponen en el ejercicio de sus funciones de averiguación del delito y descubrimiento y aseguramiento del delincuente, que es la propia de la policía judicial. El simulado obrar del funcionario está justificado por el cumplimiento de los deberes de su cargo, por tanto, el comportamiento policial es lícito".

1273 Así en un Estado Social, Democrático y de Derecho la actuación de los poderes públicos, incluso en la persecución de los delitos más graves, debe estar presidida por el respeto de los derechos fundamentales y, ante todo, de la Constitución. De ahí que la gran polémica que gira en torno al agente encubierto y a las demás técnicas de investigación policial se centre en perfilar con precisión los límites de la actuación de dicho sujeto para que se resienta lo menos posible los derechos fundamentales de los individuos y para que su actuación se ajuste a los principios reinantes en un Estado de Derecho y a los principios del Derecho penal. Y ello es así, porque, como se ha reconocido, la figura del agente encubierto genera gravísimos problemas materiales y procesales, pues supone un medio extraordinario de investigación que quiebra la aplicación de algunos principios propios del Estado de Derecho; de ahí que se permita, a través de la regulación expresa de la figura, dicha quiebra, siempre que se cumplan determinados requisitos constitucionales. Veáse en este sentido, DELGADO MARTÍN, J., "El proceso penal ante la criminalidad organizada. El agente encubierto", cit., págs. 2 y ss.

1274 Importante destacar que la infiltración de personas en una organización criminal, ocultando su identidad y su finalidad, para la investigación de los sujetos que forman parte de dicho entramado de cara a su futuro enjuiciamiento y con el fin de obtener pruebas para la investigación de los delitos ha existido en España desde hace tiempo, incluso antes de la regulación de esta figura por la Ley de Enjuiciamiento Criminal en el artículo 282 bis. Pero en opinión de GARCÍA SÁNCHEZ "esa existencia, su admisión y construcción jurisprudencial presentaba numerosos problemas en un Estado de Derecho. En primer lugar, atentaba contra el principio de seguridad jurídica, ya que la ley no permitía dicha vulneración de derechos fundamentales que se realizaba con la actividad policial; también las sentencias vacilaban entre su admisión sometidas a determinados límites no precisos y su no admisión; y además, la no regulación de la figura del agente encubierto planteaba para los agentes policiales numerosos problemas para afirmar su impunidad o su punibilidad por las actuaciones realizadas en dicha labor investigadora. En segundo lugar, no había una delimitación precisa de las distintas actuaciones que pueden llevar a cabo tanto los agentes policiales como los particulares en la investigación: así, se hablaba de agente provocador -pero no en el sentido de la provocación definida en el Código Penal-, de delito provocado, de confidente, de undercover agent, del denunciante anónimo, aunque no se distinguían éstos del ahora conocido y regulado como agente encubierto. En tercer lugar, toda la construcción jurisprudencial, y por ello también doctrinal, giraba en torno a la intervención del agente policial consistente en la provocación del delito, mejor expresado, en la inducción al delito, y olvidaba otras posibles intervenciones de estos agentes infiltrados en el entramado de una organización criminal". Vid. 
Así, en una operación de infiltración ocurriría la entrada y permanencia más o menos intensa de un agente encubierto en un determinado entorno u organización criminal, para lo cual resulta imprescindible la ocultación de la identidad y condición policial de quien se infiltra ${ }^{1275}$.

A estos efectos se debe recordar que son características principales de las infiltraciones policiales, amén de otras tantas, el hecho de que el agente encubierto puede participar de la comisión de ciertos delitos que mantengan relación directa con los objetivos de la operación encubierta y que se presenten como consecuenciadel trabajo de investigación, desde que respetado el principio de proporcionalidad, y además que esta técnica se funda en el engaño, para lo que el agente policial ha que estar dotado de una cobertura o identidad falsa1276 que le proporciona el propio Estado.

Acentuando este aspecto, lo esencial de toda infiltración es la ocultación de la identidad, rectius, de la condición policial y/o de las intenciones del infiltrado como punto de partida para establecer con el paso del tiempo una relación de confianza que permita el acceso a una información; es decir, el engaño y el abuso de la confianza1277.

De otra parte, como fácilmente se puede observar, la ratio última de una operación de infiltración policial reside en los perjuicios ocasionados a toda la sociedad por el crimen organizado y las dificultades propias de su erradicación ${ }^{1278}$.

Sentadas estas premisas, puede afirmarse que algunas clasificaciones sobre las diferentes especies de infiltración han sido elaboradas por la doctrina contemporánea.

Ciñéndonos al ordenamiento procesal penal español, GÓMEZ DE LIAÑO FONSECAHERRERO afirma que las infiltraciones pueden ser de variadas formas: públicas, semipúblicas, semiprivadas y privadas ${ }^{1279}$.

Cuando se oculta la condición de policía para poder entablar una relación de cordialidad con personas pertenecientes a ambientes delictivos, y de este modo acceder a estructuras criminales, resulta factible hablar de infiltración "pública", y ello por dos razones esenciales: primero, porque el sujeto activo de la infiltración es un funcionario público, que en virtud de su relación laboral recibe el encargo de los poderes públicos, últimos interesados en la información procurada; y segundo, porque la finalidad

GARCÍA SÁNCHEZ, B., "Técnicas de investigación de la delincuencia organizada: perspectiva penal", Revista Letras Jurídicas, vol. 20, 2009, http:://www.letrasjuridicas.com. En este mismo sentido, Cfr. OLMEDO CARDENETE,M. "La provocación al delito y el Agente Provocador en el tráfico de drogas", VV.AA., Estudios jurídico-penales y político criminales sobre el tráfico de drogas y figuras afines, Madrid, 2003, págs. 199-200

1275 En este sentido, vid. GASCÓN INCHAUSTI, F., Infiltración policial y “agente encubierto”, cit, pág. 20.

${ }^{1276 E s}$ evidente que cuanto mejor esté construida, respaldada y documentada la "leyenda" del agente infiltrado, éste la utilizará con las suficientes garantías lo que evitará el recelo o desconfianza de la organización ante la posibilidad de estar tratando con un policía. Vid. POZO PÉREZ, M., "El agente encubierto como medio de investigación de la delincuencia organizada en la Ley de Enjuiciamiento Criminal española, cit., pág. 292.

1277 GASCÓN INCHAUSTI, F., Infiltración policial y "agente encubierto", cit, pág. 10. Como ya hemos tenido oportunidad de afirmar, la identidad supuesta concedida por el Estado al agente encubierto es condición esencial para se conseguir penetrar en el nucleo de la organización criminal, a la vez que los criminales de este grupo de delincuentes solo tendrán confianza para recibir el infiltrado como un "nuevo" compañero a partir del momento en que este demostre su gana de tornarse miembro de la banda. Y esto intento solo se consigue a través del uso de técnicas de inteligencia policial, especialmente por medio del engaño y de actos de dismulación.

1278 Vid, DELGADO MARTÍN, J: Criminalidad organizada, cit., pág. 31.

1279 GÓMEZ DE LIAÑO FONSECA-HERRERO, M., Criminalidad organizada y medios extraordinarios de investigación, págs. 126 y ss. 
perseguida con lo averiguado obedece a un interés público de carácter represivo, preventivo, o político. Como ejemplos de esta forma de infiltración se puede citar la figura del agente encubierto, el agente provocador miembro de la policía y los agentes de los servicios de inteligencia del Estado.

Ya en la infiltración "semipública", los sujetos activos, aun siendo particulares, cuentan con la aquiescencia y el respaldo del poder público para llevar a cabo la infiltración en la estructura criminal y proporcionar información, ocasional o continua, guiados por diferentes leitmotiv. En esta clasificación la integran: el confidente, el arrepentido, y el agente provocador no policía.

Por infiltración "semiprivada", cabe entender la actuación de los detectives privados y de los reportajes periodísticos de investigación que, adentrándose en un ambiente social-empresarial para cubrir una finalidad privada, principalmente económica, ponen de manifiesto ilícitos con indudables repercusiones públicas, tales como estafas a empresas y consumidores o sospechas de movimientos de blanqueo de capitales.

Por fin, en la última forma de infiltración, denominada de "privada", los sujetos particulares acometen una investigación para satisfacer una finalidad exclusivamente personal. Se trata de los supuestos comunes de los detectives privados, que investigan sobre situaciones concernientes a la esfera de relaciones personales, familiares, afectivas, económicas y empresariales de sus clientes.

Ya otra clasificación de interés ha sido elaborada por DIAS FERREIRA ${ }^{1280}$, quien distingue las operaciones encubiertas en función del grado de envolvimiento del agente en el medio criminoso y de la duración de la operación de infiltración. En esta medida, se dividen las operaciones en dos especies básicas, las llamadas lightcover (infiltraciones "leves") ${ }^{1281}$ y las deepcover (infiltraciones "profundas") ${ }^{1282}$.

Adoptando una clasificación muy semejante a la anteriormente mencionada, ESPINOSA DE LOS MONTEROS apunta una distinción entre las operaciones de larga duración y de corta duración. En las primeras de "larga duración", efectivamente ocurre la verdadera entrada del agente encubierto en las entrañas de una organización criminal, con la finalidad de desde dentro de este entorno aportar a las autoridades de persecución las informaciones y pruebas necesarias a la desarticulación de la misma, con la consecuente detención de las personas culpables. En esta especie, es algo indudable que las actuaciones policiales iban a limitar derechos y garantías fundamentales. Ya en las segundas, denominadas de operaciones de "corta duración", la actuación llevada por el agente no supone una conquista en las relaciones personales con respecto a los miembros de la

1280 Cfr. DIAS FERREIRA, V. P., "Problémes poses par la mise en oevre dês opérations undercover dans les domaine de la lutte contre lê trafic de stupéfiants", Revue de droit pénal et de criminologie, núm. 76, 1996, págs. 557-588.

1281 Se caracterizan por el acto de no presentaren una duración superior a seis meses y además, por exigieren un menor grado de planeamiento, de supervisión y de experiencia por parte del agente, que mantiene su identidad y su lugar en la estructura policial. Estas operaciones implican un menor riesgo para el agente y tiene un objetivo preciso,que puede consistir en una transacción o tan sólo en un encuentro o cita para recogimiento de informaciones. Una característica de estas operaciones lightcover, con importantes consecuencias es la no exigencia de permanencia continua en el medio criminoso.

1282 Estas operaciones tienen una duración superior a seis meses y en ellas, los agentes son totalmenteinmersos en el medio criminoso. El agente policial asume una identidad falsa y los contactos con su anterior medio social y familiar pasan a ser irregulares o poco frecuentes, llegando mismo a se suspender totalmente. Estas operaciones son más peligrosas para el agente y plantean problemas logísticos, éticos y humanos. 
organización, ya que tan sólo se mantienen contactos más o menos esporádicos y siempre relacionados con la conducta delictiva y en ningún caso se entra en la esfera íntima de la persona $^{1283}$.

Con todo, conviene tener presente que nos interesa en momento analizar las operaciones de larga duración, donde el agente infiltrado consigue penetrar en el grupo delictivo a través de la obtención de confianza de los otros miembros, permaneciendo por un lapso de tiempo razonable, momento en que podrá con paciencia y cautela recoger las informaciones y pruebas útiles al trabajo de las autoridades de persecución penal. Sin embargo, no significa que la operación encubierta pueda extenderse a periodos indeterminables, pudiendo la autoridad judicial correr el riesgo de perder el control sobre la actuación del infiltrado ${ }^{1284}$.

Volviendo a la clasificación ideada por DIAS FERREIRA1285, subdivide las operaciones lightcover en seis modalidades: la decoy operation o operation leurre, la pseudos-achat, la pseudos-vente, el flash roll, la livraison surveillée y la livraison contrôlée 1286.

Por su vez, las operaciones deepcover presentan también una subdivisión en las siguientes especies: stingoperations, honey-potoperation, buy-bustoperation e infiltration de réseaux ${ }^{1287}$.

1283 Con más informaciones sobre esta clasificación, vid. ESPINOSA DE LOS MONTEROS, R. Z., El policía infiltrado. Los presupuestos jurídicos en el proceso penal español, cit., pág. 160.

1284 Siguiendo esta posición, señala DELGADO MARTín que "la labor del agente infiltrado se prolonga necseariamente en el tiempo, no siendo una actuación meramente esporádica, porque solamente así conseguirá la mínima integración necesaria en el grupo criminal". Cfr. DELGADO MARTíN, J., Criminalidad organizada, cit., pág. 60.

1285Vid. DIAS FERREIRA, V. P., "Problémes poses par la mise em oevre dês opérations undercover dans les domaine de la lutte contre lê trafic de stupéfiants", cit., pág. 809 y ss.

1286 En la primera especie denominada decoy operation, el agente hace el papel de víctima potencial: un vagabundo, un comerciante, un borracho, o un conductor de taxi, de entre otros papeles. Su misión consiste en colocarse en sitios conocidos por su actividad criminosa, esperando ser atacado por un delincuente, instante en que otros agentes policiales surgen, deteniendo el agresor. El recurso al uso de la decoy operation tanto puede tener por objetivo una comunidad específica como un determinado sospecho. El pseudo-achat y el pseudo-vente solo se distinguen llevándose en cuenta el lado pasivo o activo en que el agente policial se coloca. En el primero caso, presentase como potencial comprador de productos de transacción ilícita; en el segundo, surge como un ladrón proponiendo a venda de bienes hurtados o otros productos de venda ilícita. El flash-roll es una variante del pseudo-achat, en que el agente exhibe cuantías en dinero a los potenciales vendedores de mercaderías prohibidas o de origen ilícito, con el objetivo de "cerrar un negocio". Por fin, la livraison surveillée consiste en uno procedimiento de espionaje, que puede desencadenar en una operación de pseudo-achat o en uno flash-roll. Tratase de vigilar el pasaje, en determinado territorio, de mercaderías prohibidas o de origen ilícita, rechazándose la interpelación de los intermediarios, con la finalidad de detener los responsables por el tráfico. Al contrario, en la livraison contrôlée, son los propios agentes policiales que transportan la mercadería, encargándose de la entrega.

1287 En la modalidad sting operations, el agente policial, bajo identidad falsa, constituí una empresa o toma de arrendamiento un establecimientocomercial y hace constar entre sus clientes que efectivamente el mismo compra mercaderías de origen ilícita, generalmente de hurtos o robos. Estas mercaderías generalmente son joyas, armas o tarjetas de crédito. En el ámbito de esta operación, desarrollase la técnica conocida como "scouting", que consiste en agentes policiales que se pasan por ladrones y, nos medios frecuentados por rateros y otros delincuentes, anuncian la existencia del establecimiento, de modo a que los sospechosos les compren o vendan mercaderías robadas. La operación honey-pot no es muy distinta de la anterior. En esto caso, los agentes abren un bar u otro comercio con el objetivo de transformar lo mismo en centro de delincuentes y de organizaciones criminosas. La operación de buy-bust es una técnica de infiltración y así no sería correcto llamarla de modalidad de deep cover. El agente policial va adquiriendo pequeñas cantidades de drogas, sin que el vendedor sea detenido. De este modo, efectúa a su inserción en el medio criminoso, al mismo tiempo que gana la confianza de los sospechosos y va obteniendo informaciones respecto del tráfico de drogas. A partir del momento en que su actividad ilícita está definitivamente reconocida en el medio policial, el agente 
Para encauzar el objeto de nuestro estudio, centrémonos en una última clasificación donde se diferencian las infiltraciones preventivas y represivas, siendo factor relevante la finalidad pretendida con la información obtenida. En la infiltración "preventiva" lo averiguado sirve para acordar medidas que eviten la realización definitiva del delito planificado. Ya en la segunda modalidad, denominada "represiva", viene configurada como una diligencia instructora dirigida a facilitar a las autoridades información de trascendencia penal ${ }^{1288}$.

Analizadas algunas de las principales clasificaciones respecto de las modalidades de operaciones encubiertas de infiltración, importante destacar que las actuaciones de agentes encubiertos se adoptarán cuando previamente existan indicios ciertos y sólidos, en satisfacción del test de proporcionalidad, de que se ha cometido o se cometerá un hecho delictivo, pero nunca con la finalidad de descubrir indiscriminadamente cualquier conducta delictiva. Caso contrario, podrá restar violado el principio de presunción de inocencia.

Por fin, nos cumple destacar que la finalidad determinante de la técnica de infiltración policial a través de agentes encubiertos consiste en penetrar en un determinado ambiente criminal, buscando recoger datos, informaciones y pruebas para una eventual condena de los miembros de la organización de delincuentes. Sin embargo, el hecho de adentrarse en el seno del grupo exige la utilización de una identidad falsa por el infiltrado, bien como el empleo de maniobras de engaño y disimulación con el objetivo de obtener la confianza de sus "nuevos" compañeros. Además, esta finalidad inherente a la técnica de infiltración será incompatible con la violación a principios del Estado de Derecho.

Acentuando este aspecto, deberá se concluir que dentro del contexto de un proceso penal garantista, la actuación de los poderes públicos, incluso en la persecución de los delitos más graves, debe estar presidida por el respeto de los derechos fundamentales y, ante todo, de la Constitución ${ }^{1289}$.

\section{IV.2.2. Presunción de inocencia e infiltración policial.}

IV.2.2.1. Elementos básicos del principio de presunción de inocencia.

\section{IV.2.2.1.1. Origen histórico.}

A modo de introducción al estudio del principio de la presunción de inocencia, es importante poner de manifiesto que los derechos fundamentales son aquellos derechos, libertades, igualdades o inviolabilidades que, desde la concepción, fluyen de la dignidad humana y que son intrínsecos de la naturaleza singular del titular de esa dignidad. Tales

policial busca comprar una cuantidad considerable de estupefacientes, siendo esta operación detalladamente planeada por la entidad policial con el objetivo de detener los traficantes criminosos. En la operación sell-bust, ocurre el contrario del anterior, o sea, el objetivo son compradores de significativas cuantidades de drogas. Por fin, y encerando esta clasificación, la infiltration de réseaux o de groupes, es una operación de infiltración más o menos larga del agente policial en uno determinado medio criminoso teniendo por objetivo recoger informaciones y pruebas sobre la preparación de un crimen o de su consumación. Los agentes adoptan una identidad falsa y el papel que desarrollan depende igualmente del medio criminoso en que se insertan (tráfico de drogas, de armas, corrupción o otros delitos).

1288 En este sentido, vid. GÓMEZ DE LIAÑO FONSECA-HERRERO, M., Criminalidad organizada y medios extraordinarios de investigación, cit., pág. 127.

1289 En este sentido, Cfr. GARCÍA SÁNCHEZ, B., "Técnicas de investigación de la delincuencia organizada: perspectiva penal", Revista Letras Jurídicas, vol. 20, 2009, http:://www.letrasjuridicas.com. 
atributos, facultades o derechos públicos subjetivos son, y deben ser siempre, reconocidos y protegidos por el ordenamiento jurídico, permitiendo al titular exigir su cumplimiento con los deberes correlativos.

Este concepto es muy importante en razón de que después de la Segunda Guerra Mundial se produjo en Europa la constitucionalización de los derechos fundamentales de la persona humana, y la tutela de las garantías mínimas que deben permear todo el proceso judicial y administrativo.

Consecuencia lógica es que los derechos fundamentales presuponen la existencia de una Constitución que posea fuerza normativa, esto es, que se cumpla razonablemente en la práctica. En realidad los derechos fundamentales son interpretados a la luz de los principios del Estado de Derecho y este se nutre de la interpretación de los derechos fundamentales.

De otra parte, en lo que nos interesa en este momento, es especialmente importante señalar que uno de los más destacados derechos fundamentales en el proceso penal contemporáneo es representado por el principio de la presunción de inocencia ${ }^{1290}$.

De estas consideraciones se deriva que la presunción de inocencia es la expresión abreviada del conjunto de derechos fundamentales que definen el estatuto jurídico del imputado, cuyo respecto ha de ser el primer criterio rector del contenido y de la estructura del proceso penal ${ }^{1291 .}$

En síntesis se puede afirmar que se refiere a una garantía del ciudadano de no ser puesto en condiciones de condenado desde el principio de la imputación, sin el desarrollo por completo del debido proceso legal.

Por otro lado, en lo relativoal aspecto histórico de este principio, cabe precisar que este postulado de rango constitucional remonta al Derecho Romano, particularmente a los escritos de Trajano, pero ha sido seriamente atacado y repudiado en la inquisición de la edad media. Consistía en verdad en una presunción de culpabilidad ${ }^{1292 .}$

1290 Para mejor comprehender esta relación, vid. DOÑATE I SANGLAS, I., "Derechos fundamentales: presunción de inocencia", Iuris: actualidad y práctica del derecho, núm. 19, 1998, págs. 31-36. En palabras de VÁZQUEZ SOTELO, "la presunción de inocencia constituye la primera garantía que el vigente proceso penal, ahora abajo la tutela de las normas constitucionales, establece a favor de todo ciudadano que se encuentra sometido o implicado en él. Y tal garantía se establece y protege como un derecho fundamental de rango constitucional". Vid. VÁZQUEZ SOTELO, J. L., Presunción de inocencia del imputado e íntima convicción del Tribunal, Barcelona, 1984, pág. 268.

1291Vid. VIVES ANTÓN, T.S., "El proceso de la presunción de inocencia", VV.AA., Jornadas de Direito Processual Penal e Direitos Fundamentais, Coimbra, 2004, pág. 30. Sobre este tema, VEGAS TORRES presenta tres distintos significados para el enunciado "presunción de inocencia": 1ํํㄱ la presunción de inocencia podría ser el concepto fundamental en torno al cual se construye todo unmodelo de proceso penal, concretamente el proceso penal de corte liberal, en el que se mira fundamentalmente a establecer garantías para el imputado frente a la actuación punitiva estatal; $2^{\circ}$ ) la presunción de inocencia podría ser un postulado directamente referido al tratamiento del imputado durante el proceso penal, conforme el cual habría de partirse de la idea de que el inculpado es inocente y, por tanto, reducir al mínimo las medidas restrictivas de derechos en el tratamiento del imputado durante el proceso; $3^{\text {}}$ ) la presunción de inocencia podría ser una regla directamente referida al juicio de hecho de la sentencia penal, con incidencia en el ámbito probatorio, conforme a la cual, la prueba completa de la culpabilidad del imputado debe ser suministrada por la acusación, imponiéndose la absolución del inculpado si la culpabilidad no queda suficientemente demostrada". Vid. para más detalles, VEGAS TORRES, J., Presunción de inocencia y prueba en el proceso penal, Madrid, 1993, págs. 3536.

1292 Vid. LOPES JR, A., Introdução crítica ao Processo Penal. Fundamentos da instrumentalidade constitucional, cit., págs. 184-185. Para un completo y amplio estudio respecto a los orígenes del reconocimiento y protección del derecho a la presunción de inocencia, vid. OVEJERO PUENTE, A. M., Constitución y derecho a la presunción de inocencia, cit., págs. 21-34. 
BECCARIA a su tiempo, ya llamaba la atención para el hecho de que un hombre no podría ser considerado culpable antes de la sentencia del Juez y la sociedad solo le podría quitar la protección pública después que fuera decidido que ello había violado las condiciones sin las cuales esta protección le ha sido concedida1293.

También imprescindible afirmar que otro dato importante se refiere al hecho de que el principio de presunción de inocencia ha sido uno de los atributos constituidos por la Revolución Francesa a través del cual no se admite que se presuma la culpa del acusado sin que exista un regular y justo proceso tramitado dentro de las reglas judiciales aplicables.

Como acaba de verse, la idea fundamental de este principio corresponde a un límite a la acusación penal que debe ser probada a través de elementos serios de convicción, siendo que no cumple al imputado demostrar su inocencia, muy al contrario, es deber del órgano estatal laconcreción de esta tarea.

Además, aunque el origen del postulado in dubio pro reo ${ }^{1294}$ pueda ser observada desde el Derecho Romano, muy especialmente en razón del cristianismo, lo que no se pone en duda es que el principio de la presunción de inocencia, regla tradicional del sistema de la common law, deberá ser considerado como uno de los pilares fundamentales que han influenciado la reforma del sistema represivo emprendido por la revolución liberal del siglo XVIII.

Por fin, importante señalar que el principio de la presunción de inocencia ha adquirido notoriedad en el escenario mundial principalmente después de la Declaración Universal de los Derechos Humanos de 10 de diciembre de 1048, la cual estableció en su artículo 11.1 que "toda persona acusada de delito tiene derecho a que se presuma su inocencia mientras no se pruebe su culpabilidad, conforme a la ley y en juicio público en el que se le hayan asegurado todas las garantías necesarias para su defensa".

También el Pacto Internacional de Derechos Civiles y Políticos aprobado por la Asamblea General de las Naciones Unidas en 16 de diciembre de 1966, destaca en su artículo 14.2 que "toda persona acusada de un delito tiene derecho a que se presuma su inocencia, mientras no se pruebe su culpabilidad conforme la ley".

Por fin, el Convenio para la Protección de los Derechos Humanos y de las Libertades Fundamentales de 4 de noviembre de 1950 en su artículo 6.2 define que "toda persona acusada de una infracción se presume inocente hasta que su culpabilidad haya sido legalmente declarada".

\section{IV.2.2.1.2. Concepto y finalidades.}

De inicio nos cumple conceptuar el principio de la presunción de inocencia con la siguiente frase: nadie puede ser penado sin que exista un proceso en su contra, seguido de

\footnotetext{
1293 Vid. BECCARIA, C., De los delitos y de las penas, trad. J. Antonio de las Casas, Madrid, 1996, pág. 35.

1294 Conviene esclarecer que la presunción de inocencia no se confunde con el principio in dubio pro reo. Y la razón es sencilla, pues mientras la primera despliega su eficacia cuando existe falta absoluta de pruebas o cuando las practicadas no reúnen las garantías procesales, el principio in dubio pro reo sólo se hace jugar si, después de valoradas las pruebas obtenidas y practicadas con observancias de aquellas garantías, restan dudas al juzgador sobre la comisión del delito o sobre la participación que en éste pudo tener el acusado. Cfr. ARMENTA DEU, T., Lecciones de Derecho Procesal Penal, cit., pág. 269. Sobre el verdadero fundamento de la distinción jurisprudencial entre la presunción de inocencia y el principio del in dubio pro reo, vid. MIRANDA ESTRAMPES, M., La mínima actividad probatoria en el proceso penal, Barcelona, 1997, págs. 6 y ss.
} 
acuerdo a los principios de la ley procesal vigente. Ahora bien, a este postulado corresponde agregar lo que en realidad constituye su corolario natural, esto es, la regla de la presunción de inocencia, la cual se resuelve en el enunciado que expresa que todo imputado debe ser considerado como inocente antes de comprobada su culpabilidad.

Se trata pues de una garantía esencial y fundamental del ciudadano al empezar del siglo XXI ${ }^{1295}$. En este sentido, es válidamente oportuna la observación de SANCHIS CRESPO al señalar que si se considera erróneamente un proceso penal eficaz a aquél que proporciona un elevado número de condenas, habrá de colegirse que la tentación de vulnerar este derecho a la presunción de inocencia aparece como opción atractiva. Desde ese inadecuado punto de vista, la presunción de inocencia se erige en una especie de obstáculo que impide que se haga "verdadera justicia"1296.

De todo modo, se puede afirmar que la presunción de inocencia1297 como garantía fundamental sobre la cual se erige el proceso penal de corte liberal sostiene que el fundamento del ius puniendi del Estado se basa en el anhelo de los hombres por tener un sistema equitativo de justicia que proteja los derechos fundamentales del individuo frente a la arbitrariedad y el despotismo de la autoridad que han existido a lo largo de la historia; prerrogativas que adquieren significado jurídico y político a partir de la Revolución Francesa y el pensamiento predominante del movimiento de la Ilustración del siglo XVIII, de los que derivaron los conceptos de Estado con poder limitado y de derecho como instrumento de defensa de los valores primigenios de la sociedad, frente a las violaciones graves de los mismos bajo el imperio de la ley. De esta manera, se propone prescindir del Estado totalitario en el que pueden restringirse al máximo los derechos fundamentales del individuo ${ }^{1298}$.

\footnotetext{
1295 Importante señalar la opinión de MONTERO AROCA, en el sentido de que "debe advertirse que no estamos realmente ante una presunción en sentido técnico, sino ante algo mucho más transcendente para la justicia penal, pues puede decirse que esa llamada presunción es realmente un concepto fundamental que sirve para identificar cuando estamos ante un proceso penal que podemos calificar liberal". Vid. MONTERO AROCA, J., Proceso penal y libertad. Ensayo polémico sobre el nuevo proceso penal, Navarra, 2008, págs. 413-414. En el mismo sentido, VÁSQUEZ SOTELO, J. L., Presunción de inocencia del imputado e íntima convicción del Tribunal, cit., págs. 268-279.
}

1296 Vid. SANCHIS CRESPO, C., "La justicia en la Constitución Europea: Aproximación al derecho a la presunción de inocencia a través de la doctrina del Tribunal Europeo de Derechos Humanos", cit., pág. 159. En consecuencia, tornase imperiosa la necesidad de reconocerse que "la presunción de inocencia es también una regla de tratamiento del imputado durante el proceso penal, que obliga a reducir al mínimo estrictamente necesario las medidas restrictivas del imputado en el proceso ${ }^{1296}$. Destacable afirmar además que se vulnerará este derecho "cuando no haya pruebas de cargo válidas, es decir, cuando los órganos judiciales hayan valorado una actividad probatoria lesiva de otros derechos fundamentales o carente de garantías, o cuando no se motive el resultado de dicha valoración, o, finalmente, cuando por ilógico o insuficiente no sea razonable el iter discursivo que conduce de la prueba al hecho probado". Cfr. STC 220/1998, de 16.11.1998. También en la misma línea de pensamiento, las SSTC 202/2000, de 24.7.2000 y 155/2002, de 22.7.2002.

1297Monográficamente respecto al tema de la presunción de inocencia, Vid. la destacada obra de VEGAS TORRES, J., Presunción de inocencia y prueba en el proceso penal, Madrid, 1993. También como buenas obras de referencia, Vid. OVEJERO PUENTE, A. M., Constitución y derecho a la presunción de inocencia, Valencia, 2006; FERNÁNDEZ LÓPEZ, M., Prueba y presunción de inocencia, Madrid, 2005; ROMERO ARIAS, E., La presunción de inocencia. Estudio de algunas consecuencias de la constitucionalización de este derecho, Pamplona, 1985; VÁSQUEZ SOTELO, J. L., Presunción de inocencia del imputado e íntima convicción del Tribunal, Barcelona, 1984.

1298Vid. AGUILAR LÓPEZ, M. Á., "Presunción de inocencia", pág. 10, http://www.reformapenal.inacipe.gob.mx. Importante además, destacar que el principio de presunción de inocencia, como es sabido (SSTC 17/2002 de 28.1.2002 y 213/2002 de 14.2.2002), da derecho a no ser condenado sin prueba de cargo válida, que es la obtenida en el juicio (salvo las excepciones constitucionalmente admitidas), que haya sido racional y explícitamente valorada, de forma motivada, en la sentencia, y se refiera a los elementos nucleares del delito. Por otra parte, cuando se trata de la prueba habitualmente conocida como indiciaria, para que la conclusión incriminatoria pueda ser tenida por válida es 
Dicho en otras palabras, la presunción de inocencia, calificada también como un estado jurídico, constituye hoy un derecho fundamental reconocido constitucionalmente. Lejos de ser un mero principio teórico de derecho, representa una garantía procesal insoslayable para todos; es la máxima garantía del imputado y uno de los pilares del proceso penal acusatorio.

Esta garantía constitucional representa así, en opinión de SOTO NIETO, un pilar básico e inestimable en el proceso penal, constituyéndose en barrera que impide todo pronunciamiento de condena de quien se presume iuris tantum inocente, mientras no exista una prueba de cargo que, revestida con las garantías exigidas, venga a poner en evidencia su participación en el hecho delictivo ${ }^{1299}$.

En cualquier caso, la presunción de inocencia debe ser considerada como una regla de tratamiento del imputado durante el proceso penal, que obliga a reducir al mínimo estrictamente necesario las medidas restrictivas del imputado en el proceso ${ }^{1300}$.

Este matiz nos permite constatar que la presunción de inocencia dentro del proceso penal moderno exige que la condena se funde en pruebas lícitamente obtenidas y practicadas con las debidas garantías procesales, que contengan suficientes elementos inculpatorios respecto a la participación del imputado en los hechos delictivos sometidos a la resolución del tribunal, que formen convicción en éste último sobre la responsabilidad del acusado en el delito, posibilitando su condena ${ }^{1301}$.

Significa este presupuesto que debe existir un mínimo de notas características de la participación del individuo en la práctica delictuosa, constatación esta que podrá servir al juzgador como fundamento para enervar la presunción de inocencia. Y más, pues no se

preciso que los hechos indicadores o hechos-base sean varios y viertan sobre el hecho principal u objeto de imputación; estén bien probatoriamente acreditados, mediante prueba de la llamada directa; y que la inferencia realizada a partir de aquéllos sea racional, fundada en máximas de experiencia fiables, y cuente con motivación suficiente.

1299 SOTO NIETO, F., "Ética profesional y su proyección en la prueba penal", La Ley, 1994-2, pág. 1116. Siguiendo esta opinión señala FERRAJOLI que "es la culpa y no la inocencia la que debe ser demostrada, y es la prueba de la culpa y no la de la inocencia, que se presume desde el principio, la que forma el objeto del juicio". Vid. FERRAJOLI, L., Derecho y razón. Teoría del garantismo penal, cit., pág. 549. También importante considerar que el derecho a la presunción de inocencia en el ordenamiento español (artículo24.2 de la Constitución), supone "el derecho a no ser condenado sin pruebas de cargo válidas, de modo que toda Sentencia condenatoria debe expresar las pruebas en las que sustenta la declaración de responsabilidad penal, dichas pruebas han de haber sido obtenidas con las garantías constitucionales, haberse practicado normalmente en el juicio oral y haberse valorado y motivado por los Tribunales con sometimiento a las reglas de la lógica y la experiencia, de modo que pueda afirmarse que la declaración de culpabilidad ha quedado establecida más allá de toda duda razonable". En este sentido, de modo muy especial, la STS 123/2002 de 20.5.2002. También las SSTC 81/1998 de 2.4.1998; 7/1999 de 8.2.1999; 171/2000 de 26.6.2000; 222/2001 de 5.11.2001; 147/2002 de 15.7.2002.

1300 MONTAÑES PARDO, M. Á, La presunción de inocencia. Análisis doctrinal y jurisprudencial, Pamplona, 1999, pág. 41. Incluso destaca GIMENO SENDRA que "se trata de un derecho presente a lo largo de todo el proceso penal". Vid. GIMENO SENDRA, V., "Los derechos de acción penal, al juez legal y de defensa y sus derechos instrumentales", VV.AA., Comentarios a la legislación penal, Tomo 1, M. Bajo Fernández coord., Madrid, 1982, pág. 188.

1301 Cfr. NOGUEIRA ALCALÁ, H., Consideraciones sobre el derecho fundamental a la presunción de inocencia, Revista Ius et Praxis, vol.11, núm.1 Talca, 2005, http://www.scielo.cl. Como sostiene VEGAS TORRES, "la presunción de inocencia como derecho fundamental del inculpado, actúa en una sola dirección, poniendo condiciones a la determinación de la certeza de la culpabilidad y al consecuente pronunciamiento condenatorio e imponiendo la absolución cuando no se dan tales condiciones; pero la presunción de inocencia no impone la condena en ningún caso". Vid. VEGAS TORRES, J., Presunción de inocencia y prueba en el proceso penal, cit., pág. 184. 
puede olvidar que este principio representa la regla, quedando la restricción a la presunción de inocencia como excepción a ser acatada en situaciones concretas.

Además, es necesario hacer hincapié en la constatación de que el citado postulado forma parte del bloque constitucional de derechos ${ }^{1302}$, porque está asegurado y garantizado tanto en la Convención Americana de Derechos Humanos como en el Pacto Internacional de Derechos Civiles y Políticos ${ }^{1303}$.

La presunción de inocencia representa de este modo el derecho que tienen todas las personas a que se considere a priori como regla general que ellas actúan de acuerdo a la recta razón, comportándose de acuerdo a los valores, principios y reglas del ordenamiento jurídico, mientras un tribunal no adquiera la convicción, a través de los medios de prueba legal, de su participación y responsabilidad en el hecho punible determinada por una sentencia firme y fundada, obtenida respetando todas y cada una de las reglas del debido y justo proceso, todo lo cual exige aplicar las medidas cautelares previstas en el proceso penal en forma restrictiva, para evitar el daño de personas inocentes mediante la afectación de sus derechos fundamentales, además del daño moral que eventualmente se les pueda producir.

Esta cuestión es importante en la medida en que la presunción de inocencia constituye un estado jurídico de una persona que se encuentra imputada, debiendo orientar la actuación del Tribunal competente, independiente e imparcial prestablecido por ley, mientras tal presunción no se pierda o destruya por la formación de la convicción del órgano jurisdiccional a través de la prueba objetiva, sobre la participación culpable del imputado o acusado en los hechos constitutivos de delito, ya sea como autor, cómplice o encubridor, condenándolo por ello a través de una sentencia firme fundada, congruente y ajustada a las fuentes del derecho vigentes ${ }^{1304}$.

Por lo demás, la presunción de inocencia1305, como principio rector del proceso penal, deberá ser maximizado en todos sus aspectos, en especial en lo relativo a la carga de

\footnotetext{
1302 Incluso, su consagración constitucional, como señala VÁZQUEZ SOTELO, "no supone renunciar a un proceso penal eficaz. Por el contrario, se entiende que la eficacia del proceso penal deriva ahora de su carácter de medio civilizado de persecución y represión de la delincuencia; civilizado en tanto respecta los derechos y libertades básicas de los ciudadanos, lo que le convierte en el proceso con todas las garantías". Vid. VÁZQUEZ SOTELO, J. L., "La presunción de inocencia", Los principios del proceso penal y la presunción constitucional de inocencia, Cuadernos de Derecho Judicial, núm. V, Madrid, 1992, págs. 115-116. Para una análisis más completo respecto a la configuración constitucional de la presunción de inocencia, muy especialmente en lo relativo al dispuesto en el artículo 24.2 de la CE, vid. GÓRRIZ ROYO, E. Mà-, "La presunción de inocencia como criterio de aplicación del Derecho penal", VV.AA., Constitución, Derechos Fundamentales y Sistema Penal. Semblanzas y estudios con motivo del setenta aniversario del profesor Tomás Salvador Vives Antón, M. L. Cuerda Arnau Coord., Valencia, 2009, págs. 844-853.

1303 El Pacto Internacional de Derechos Civiles y Políticos de Nueva York, de 16 de diciembre de 1966, ratificado por España el 13 de abril de 1977, dispone en su art. 14.2 que toda persona acusada de un delito tiene derecho a que se presuma su inocencia mientras no se pruebe su culpabilidad conforme la ley.

1304 Véase al respecto, NOGUEIRA ALCALÁ, H., Consideraciones sobre el derecho fundamental a la presunción de inocencia, Revista Ius et Praxis, vol.11, núm.1, 2005, http://www.scielo.cl.

1305 Interesante también la opinión de SANCHIS CRESPO al apuntar respecto a la presunción de inocencia que "su conocimiento forma parte de la cultura media de una persona en una sociedad actual, siempre y cuando nos refiramos a aquellos países que se goce del llamado Estado de derecho y se reconozcan las consiguientes libertades públicas y derechos fundamentales a sus ciudadanos". Vid. SANCHIS CRESPO, C., "La justicia en la Constitución Europea: Aproximación al derecho a la presunción de inocencia a través de la doctrina del Tribunal Europeo de Derechos Humanos", VV.AA., Garantías fundamentales del proceso penal en el espacio judicial europeo, A. de la Oliva Santos; T. Armenta Deu y M. a Pía Calderón Cuadrado coords., Madrid, 2007, pág. 159.
} 
la prueba (regla del juicio), a las reglas del imputado (límites a la publicidad abusiva) y por fin, cuanto a la limitación del abuso en las detenciones provisionales.

En consecuencia a lo afirmado, se concluye que como parte integrante del derecho a una investigación y procedimiento justo y racional o un debido proceso ${ }^{1306}$ establece la obligación de conformar el sistema jurídico en el sentido de que es el órgano acusador el que debe acreditar los cargos, impidiendo la inversión de la carga de la prueba o estableciendo la prueba de hechos negativo; en otras palabras, no existe nunca como carga del imputado probar su inocencia o la ausencia de participación en los hechos, conducta que dependerá siempre de la libre decisión que adopte su defensa, derecho que debe ser siempre preservado o restablecido en su caso ${ }^{1307}$.

Debido a complejidad del tema, nos parece correcto afirmar que este postulado acaba por repercutir en diferentes dimensiones en el proceso penal. Sin embargo, la esencia de la presunción de inocencia puede ser sintetizada en la siguiente expresión: deber de tratamiento. Este deber de tratamiento actúa en dos dimensiones del proceso, interna y externa. Dentro del proceso, la presunción de inocencia implica un deber de tratamiento por parte del juez y del acusador, los cuales deberán efectivamente tratar el imputado como a priori inocente, no abusando de las medidas cautelares y, principalmente, no olvidando que a partir de ella, se atribuye a la carga de la prueba integralmente al acusador. En la dimensión externa al proceso, la presunción de inocencia impone límites a la publicidad abusiva y al acto de crear un estigma en contra el imputado, delante del deber de considéralo como inocente ${ }^{1308}$.

IV.2.2.2. Valoración de las actuaciones del agente infiltrado a la luz de la garantía de la presunción de inocencia.

Analizadas algunas cuestiones generales respecto al tema de la presunción de inocencia, se hace necesario destacar que dentro del contexto de nuestro trabajo es imprescindible destacar que la lucha contra el crimen y la delincuencia manifiesta su superioridad ética en el Estado de Derecho en razón del respeto por las garantías efectivas de los derechos fundamentales de todas las personas, muy especialmente de los imputados sometidos a un proceso penal.Además, el conjunto de derechos fundamentales están protegidos por el sistema de garantías constitucionales y del sistema de protección internacional de los derechos humanos, tanto el derivado del sistema interamericano (Comisión y Corte Interamericana de Derechos Humanos) como el sistema de protección internacional de Naciones Unidas.

Incluso la Corte Interamericana de Derechos Humanos ha establecido queel derecho a la presunción de inocencia constituye un fundamento de las garantías que no perturba la persecución penal, pero sí la racionaliza y encausa. Así, la presunción de inocencia es una garantía básica y vertebral del proceso penal, constituyendo un criterio normativo del

1306 Del mismo modo, como bien señalado por OVEJERO PUENTE, "el derecho a la presunción de inocencia es en origen una garantía de la libertad personal frente al ejercicio del ius puniendi del Estado que está relacionada con la garantía jurisdiccional de los derechos y con el derecho al procedimiento debido (due process of law)". Vid. OVEJERO PUENTE, A. M., Constitución y derecho a la presunción de inocencia, cit., pág. 391.

1307 Cfr. NOGUEIRA ALCALÁ, H., Consideraciones sobre el derecho fundamental a la presunción de inocencia, Revista Ius et Praxis, vol.11, núm.1 Talca, 2005, http://www.scielo.cl.

1308 Siguiendo este raciocinio, vid. LOPEZ JR, A., Direito processual penal e sua conformidade constitucional, cit., pág. 518. 
Derecho Penal sustantivo y procesal, descartando todo reglamento que implique una presunción de culpabilidad y establezca la carga al imputado de probar su inocencia1309.

Obviamente, la prueba obtenida con violación de derechos fundamentales, vulnera el derecho a una investigación y a un procedimiento racional y justo con todas sus garantías y el derecho de igualdad de las partes en el proceso ${ }^{1310}$.

$Y$ en este punto, debemos preguntarnos qué especie de relación tiene la actuación del agente encubierto con el principio de presunción de inocencia.

Respecto a esta cuestión y buscando un análisis más profundo, deberá ser analizado a priori el hecho de la cantidad de prueba necesaria para enervar la presunción de inocencia 1311.

Este aspecto, según RIVERA MORALES, se refiere a la cantidad de prueba necesaria para que la presunción de inocencia pueda considerarse suplantada con licitud constitucional y procesal. Se trata de un problema fundamentalmente de valoración de la prueba que debe realizar el juzgador. En consecuencia de lo afirmado, se observa que la presunción de inocencia para que pueda ser remplazada por la culpabilidad es necesario que, con las debidas garantías constitucionales y procesales, se haya practicado en el juicio una mínima actividad probatoria lícita y que pueda estimarse de cargo ${ }^{1312 .}$

Pero además, las exigencias de una "mínima actividad probatoria" y la "producción de la misma con todas las garantías" implicaría que la valoración de actos de investigación sumariales vulneraría la presunción de inocencia en dos hipótesis: al no existir una verdadera actividad probatoria y al carecer ésta de las debidas garantías ${ }^{1313}$.

Y llegados a este punto planteamos qué significado tiene la expresión "mínima actividad probatoria".

1309 Vid. NOGUEIRA ALCALÁ, H., Consideraciones sobre el derecho fundamental a la presunción de inocencia, Revista Ius et Praxis, vol.11, núm.1, Talca, 2005, http://www.scielo.cl.

1310 Respecto a este importante postulado procesal penal señala CASSANI que "el principio de igualdad de armas es el que consagra la igualdad de condiciones de todos los que intervienen en el proceso. Este implica una igualdad en las oportunidades de ofrecimiento de pruebas, pero también exige que el marco de producción y control de aquellas sea equitativo". Vid. CASSANI, B., "Agentes encubiertos e informantes como medios de prueba contra el crimen organizado", cit., pág. 240.

1311 Todavía interesante destacar las palabras de JAÉN VALLEJO al apuntar que "la presunción de inocencia, que versa sobre los hechos, pues solos éstos pueden ser objeto de prueba, es una presunción iuris tantum que exige para ser desvirtuada la existencia de un mínimo de actividad probatoria de cargo producida con las debidas garantías procesales". Vid. JAÉN VALLEJO, M., Los principios de la prueba en el proceso penal, Bogotá, 2006, pág. 38. También en el mismo sentido, las SSTC 150/1989, de 25.9.1989 y 157/1998, de 13.7.1998.

1312 Cfr. RIVERA MORALES, R., Actos de investigación y pruebas en el proceso penal, Barquisimeto, 2008, págs. 66-67. Incluso MARTÍNEZ GARCÍA señala que "la presunción de inocencia solo puede verse desvirtuada por pruebas legales de cargo. La valoración de las pruebas obtenidas directa o derivadamente de la violación de un derecho fundamental, lesiona el derecho al proceso celebrado con todas las garantías y la presunción de inocencia en caso de condena". Vid. MARTÍNEZ GARCÍA, E., Actos de investigación e ilicitud de la prueba. El derecho al proceso y sus garantías como límite a la actuación de los poderes públicos en la investigación del delito, cit., pág. 21.

1313 Adoptando esta posición vid. DÍAZ CABIALE, J. A., La admisión y práctica de la prueba en el proceso penal, cit., pág. 27. 
La respuesta es sencilla y al mismo tiempo comporta cierta profundidad en su interpretación, pues sería aquella actividad que razonablemente puede formar convicción en el Juez sobre la culpabilidad del imputado1314.

Véase que este aspecto es extremamente subjetivo, quedando a criterio del órgano jurisdiccional la mejor forma de hacerse valorar el material probatorio.

En nuestra opinión la presunción de inocencia no puede ser destruida por cualquier actividad probatoria, por mínima que sea. Tiene que exigirse un grado superior de probabilidad a la prueba lícitamente practicada. Es decir, la prueba de cargo, independiente de la cantidad de prueba, debe ser suficiente para que se forme la racional convicción sobre la culpabilidad del imputado y que pueda ser expuesta coherente y científicamente en la sentencia condenatoria.

Traspasada esta cuestión fundamental, y adentrando al tema del agente encubierto, nos cumple mencionar que la actividad de los agentes infiltrados en el marco de las investigaciones de delincuencia organizada y la eficacia posterior en el proceso de los elementos de prueba obtenidos quedará condicionada por el respecto a ciertos principios del proceso penal, esencialmente el derecho de defensa y la presunción de inocencia ${ }^{1315}$.

Pero no es sencillo en la práctica, el perfecto encaje legal de este método excepcional de investigación con la presunción de inocencia o con el derecho de defensa de la persona sometida al proceso penal.

Sobre esta intrigante cuestión, MOSCATO DE SANTAMARIA plantea la duda sobre que ocurre cuando alguien efectúa declaraciones autoincriminadoras al agente encubierto, sin conocer su verdadero rol, y luego, dichas manifestaciones son introducidas al proceso de alguna manera. En esta hipótesis sostiene que el agente encubierto al ocultar su calidad y al inducir a engaño también puede conseguir pruebas e introducirlas de algún modo al proceso (su testimonio, prueba documental, etc.) con clara violación al principio de presunción de inocencia,el cual también contempla la prohibición de obligar a una persona a suministrar prueba que pueda perjudicarla1316.

En nuestra opinión, la cuestión debe ser analizada en el plan de las garantías individuales del investigado, de entre ellas, la intimidad, la privacidad y la dignidad del ciudadano. 0 mejor explicado, siendo la infiltración de agentes un medio de obtención de pruebas invasivo, con riesgos para la privacidad y la intimidad del investigado, deberá ser utilizado de modo excepcional, cuando no exista posibilidad de probar o de obtener datos a través de otros medios.

No se tiene que admitir entonces que el Juez autorice la medida a través de una resolución, o el Fiscal ponerse de acuerdo con el pedido, por considerar el investigado culpable desde luego (como es culpable, no debo preocuparme por su vida, su intimidad o privacidad). Del mismo modo, el agente que actúa de forma infiltrada deberá observar los límites legales de su labor de investigación encubierta. En otras palabras, en un Estado constitucional de Derecho, las autoridades y sus agentes de persecución no pueden tratar

1314 En este sentido, vid. OVEJERO PUENTE, A. Mª., Constitución y derecho a la presunción de inocencia, cit., pág. 140. Todavía, para un estudio completo y profundizado respecto al tema, Vid. MIRANDA ESTRAMPES, M., La mínima actividad probatoria en el proceso penal, Barcelona, 1997.

1315 Vid. RIFÁ SOLER, J. M; RICHARD GONZÁLEZ, M; RIAÑO BRUN, I., Derecho procesal penal, cit., pág. 285.

1316 Cfr. MOSCATO DE SANTAMARIA, C. B., El agente encubierto en un Estado de Derecho, cit., pág. 74. 
las personas sometidas a investigaciones criminales como a priori ya culpadas o condenadas ${ }^{1317}$.

Según MAIER, presumir "inocente", "reputar inocente" o "no considerar culpable" significan exactamente lo mismo; y, al mismo tiempo, estas declaraciones formales remiten el mismo principio que emerge de la exigencia de un "juicio previo" para infligir una pena a una persona. Se trata, en verdad, de un punto de partida político que asume, o debe asumir, la ley de enjuiciamiento penal en un Estado de Derecho; punto de partida que constituyó, en su momento, la reacción contra una manera de perseguir penalmente que, precisamente, partía desde o extremo contrario ${ }^{1318 .}$

En el caso de las infiltraciones policiales en las bandas organizadas de delincuentes, uno de los requisitos fundamentales para que el Estado pueda predisponer de los medios personales para el descubrimiento de hechos ilícitos se encuentra precisamente en el conocimiento previo por parte de la autoridad que haga suponer la existencia de una organización que se encuentra cometiendo, de forma permanente, actividades criminales graves.

Esto es, ante la existencia de una notitia criminis y de elementos suficientes que hagan suponer la actividad delictiva, el cumplimiento de estos requisitos impide que se vulnere el derecho a la libertad y el principio de presunción de inocencia, ya que no se puede irrumpir en la esfera personal del sospechoso, ni siquiera para investigar, si no hay, por lo menos, los requisitos mencionados, dándole al individuo, en principio, certeza jurídica para los efectos de la persecución estatal.

Cabe aclarar entonces que para que la autoridad pueda emplear medios extraordinarios de investigación como la técnica del agente encubierto es necesario que concurran requisitos previos, como son el conocimiento de un hecho delictivo grave e indicios racionales de su existencia; luego en el momento de poner en marcha estos medios sui generis de investigación, sí se puede hablar de los límites que el principio pro civitate impone a la propia presunción de inocencia. Es decir, primero la presunción de inocencia limita la intervención estatal (con los citados requisitos previos) y después el principio pro civitate limita la misma presunción de inocencia (para la adecuada eficacia procesal) ${ }^{1319}$.

Importante también señalar que en definitiva, la presunción de inocencia es, en afortunada expresión, una verdad interina, una presunción iuris tantum, que deberá ser recusada mediante la aportación al proceso de los elementos de juicio que la desvirtúen, precisamente, por las partes acusadoras, que son las que imputan al inculpado la conducta ilícita jurídicamente sancionable1320.

Para que sea válidamente desvirtuada la presunción de inocencia, deben existir pruebas firmes y válidas de la responsabilidad de los imputados, de lo que resulta que uno

\footnotetext{
1317Siguiendo esta posición, la palabra "inocente", en la acepción académica del término es aquel que se halla libre del delito que se le imputa: todo hombre tiene derecho a ser considerado inocente mientras no se pruebe que es culpable.

1318 Véase, MAIER, J. B., Derecho Procesal Penal, tomo I, Buenos Aires, 2002, págs. 491-492.

1319 DAGDUG KALIFE, A., La prueba testimonial ante la delincuencia organizada, cit., págs. 336-338. En este sentido, Vid. el artículo 282 bis 1, de la LECrim cuando señala que los medios predispuestos para la obtención de fuentes de prueba serán autorizados por la autoridad competente "... cuando se trate de investigaciones que afecten a actividades propias de la delincuencia organizada".

1320 Vid. SEOANE SPIEGELBERG, J. L., "Aspectos procesales del delito de trafico de drogas", cit., pág. 357.
} 
de los temas más importantes del proceso penal corresponda a la búsqueda de las pruebas que puedan informar al Juez acerca de los hechos que se examinan ${ }^{1321}$.

Por todo lo expuesto, es necesario destacar que en principio existe una compatibilidad entre el principio de presunción de inocencia y la actividad del agente infiltrado ${ }^{1322}$, en la medida en que el trabajo de investigación del mismo solo encontrará amparo legal y constitucional a partir del momento en que han sido agotadas todas as posibilidades de utilización y empleo de otros medios de investigación menos invasivos de derechos y garantías del ciudadano para la obtención de pruebas u otros datos que puedan llevar a la desarticulación del grupo criminal. Y más, solo después que la autoridad competente ejercite el análisis respecto a la proporcionalidad de la medida restrictiva de derechos fundamentales, procediendo a un estudio profundo de la necesidad e idoneidad de la utilización de la técnica policial es que tendrá inicio la operación encubierta.

De este modo, tratándose de existencia de indicios fuertes de práctica de delitos graves por parte de una organización criminal y, además, constatado el empleo del método de investigación del agente encubierto como ultima ratio, no estaríamos delante de un caso de violación irrazonable y sin criterios al postulado de presunción de inocencia. Al contrario, tal principio restaría enervado en la hipótesis de una resolución judicial sin observancia de los citados criterios, a la vista que en este caso el Juez estaría presumiendo la culpabilidad del investigado al permitir la infiltración del agente encubierto.

En síntesis, desde que observada la necesidad de combatir a una determinada organización criminal practicante de delitos de suma gravedad (con existencia de indicios seguros de la actuación delictiva), amén de la utilización de la técnica de infiltración como último recurso de investigación, agotados otros medios menos invasivos a los derechos y garantías fundamentales, no ocurrirá violación a la presunción de inocencia de las personas investigadas en la persecución penal.

IV.2.3. Algunas hipótesis de actuación de agentes encubiertos.

Las líneas que siguen se dedican a un análisis de algunas de las principales formas de actuaciones del agente infiltrado, dejándose claro que este rol es meramente enunciativo y no se agota de modo alguno en las posibilidades analizadas a continuación.

Por lo demás, el agente encubierto tendrá siempre una participación determinante e imprescindible en diversas hipótesis, toda vez que se observe que los órganos de persecución estatal no consiguieron a través del uso de técnicas tradicionales de investigación del delito, desmantelar el núcleo central de la organización criminal practicante de infracciones graves y con destacada repercusión social.

\section{IV.2.3.1. Narcotráfico.}

La droga representa la más brutal forma de exterminio voluntario de personas. Mismo que parezca un comentario muy drástico, corresponde a la realidad con la cual convivimos, significando la verdad que atormenta las sociedades modernas.

1321 CORRÊA DE CARVAlHO, J. T., Tráfico de drogas. Prueba penal y medidas restrictivas de derechos fundamentales, cit., pág. 68.

1322 Vid. respecto a la compatibilidad concreta de la actuación de agentes encubiertos y el principio de presunción de inocencia, la reciente STS 99/2009, de 2.2.2009. 
En una primera observación al tema del narcotráfico o tráfico ilícito de estupefacientes, se suele afirmar que se trata en realidad de un fenómeno cuya erradicación está lejos de lograrse, pese a los anuncios espectaculares, principalmente de los órganos de persecución, que nos quieren convencer de lo contrario. Del mismo modo, la clase política al dictar leyes de carácter de emergencia, viene a plantear una hipotéticavictoria contra el narcotráfico objetivando la credibilidad junto a los ciudadanos electores, muy especialmente en momentos que anteceden a una disputa para cargos públicos. A este modo de actuar denominase de "simbolismo penal".

En razón de lo afirmado, se considera que la globalización ha contribuido para que el narcotráfico se haya convertido en un problema de escala mundial1323. En torno a esta afirmación, cabe precisar que al empezar del siglo XXI, el tránsito de las personas se encuentra cada vez más facilitado en razón de la minimización de las barreras y fronteras físicas entre los países ${ }^{1324}$.

Consecuencia lógica es que esta libre circulación de personas y bienes acaban por dificultar los controles policiales en lo relativo a la entrada y salida de estupefacientes de un determinado país.

La situación se torna más grave a partir del momento en que se denota que la investigación sobre esta especie de delito se constituí en una de las más dificultosas posibles. Justificase tal afirmación a la vez que la gran delincuencia de carácter organizado y como paradigma, el llamado "narcocrimen", vienen dando incontables muestras de su capacidad de aprovechar la agilidad y el anonimato que ofrecen, tanto las tradicionales o clásicas, cuanto las modernas vías de comunicación, por no hablar de su habilidad para burlar los mecanismos de control estatal a partir del empleo de sofisticadas técnicas, pero, fundamentalmente, amparándose de forma escandalosa en la protección que el propio Estado confiere a los derechos y libertades básicas de sus ciudadanos, en particular, el derecho a la libertad y secreto de las comunicaciones privadas ${ }^{1325}$.

De otra parte, denotase que el poder del tráfico de drogas y la ineficacia de los sistemas de investigación tradicionales para frenar las "narcobandas" ha llevado las autoridades a reflexionar sobre los límites de los derechos fundamentales en la persecución de la delincuencia organizada ${ }^{1326}$.

\footnotetext{
1323 Vid. MOLINA MANSILLA, Maㅡ, C., El delito de narcotráfico, cit., pág. 21.

1324 Véase el Acuerdo de Schengen firmado el 14 de junio de 1985 que prevé la supresión gradual de los controles en las fronteras comunes entre algunos países de Europa.

1325 Cfr. LÓPEZ YAGÜES, V., "Circulación o entrega vigilada de drogas u otros efectos", VV.AA., Investigación y prueba en el proceso penal, Madrid, 2006, pág. 224.

1326 Cfr. CORRÊA DE CARVALHO, J. T., Tráfico de drogas. Prueba penal y medidas restrictivas de derechos fundamentales, cit., pág. 311. Incluso el Tribunal Supremo español recientemente ha reconocido esta necesidad, al afirmar en la STS 4142/2000 de 22.5.2000 que: "Una cosa es el delito provocado que ha de ser enérgicamente rechazado y otra cosa bien distinta es la conducta que, sin conculcar legalidad alguna, se encamina al descubrimiento de delitos ya cometidos, generalmente de tracto sucesivo como suelen ser los de tráfico de drogas, porque en tales casos los agentes no buscan la comisión del delito sino los medios, las formas o los canales por los que ese tráfico ilícito se desenvuelve, es decir, se pretende la obtención de pruebas en relación a una actividad criminal que ya se está produciendo pero de la que únicamente se abrigan sospechas. En este caso la decisión criminal nace libre y espontáneamente. En este caso la intervención de los agentes encubiertos es consecuencia del ofrecimiento de venda de sustancias estupefacientes por quienes dicen tener la disponibilidad unos cien kilos de cocaína y cuando resulta abortada la primera entrega, son los acusados y en concreto el presente recurrente el que estupefaciente cuya posesión y disponibilidad dicen tener". Monográficamente y analizando la labor de los infiltrados en el narcotráfico, Cfr. MOLINA MANSILLA, Ma $=$ C., El delito de Narcotráfico, 1aㅡ edición, Madrid, 2008. De modo más específico, tratando de la actuación del infiltrado
} 
Dicho en apretada síntesis, no cabe duda de que uno de los problemas de mayor magnitud con el que la sociedad actual se enfrenta, es el de la droga y su repercusión social.

Además, desde las reacciones prohibicionistas más radicales hasta las propuestas más firmes de actuaciones y reformas antiprohibicionistas que pretenden defender la libertad y la responsabilidad individual en esta materia, los matices, las valoraciones e incluso las regulaciones concretas presentan múltiples $\mathrm{y}$ heterogéneas manifestaciones ${ }^{1327}$.

Lo más grave es que se hace imprescindible en la persecución y represión a esta especie de delito, conseguir la descubierta de informaciones y otros datos de interés que puedan facilitar los intentos de un control policial sobre la venta y el tráfico de las sustancias estupefacientes, con el objetivo de punir de acuerdo con la ley y obedeciendo a los postulados garantistas del proceso a estos agentes criminales que comandan el comercio denominado narcotráfico.

Con todo, conviene tener presente la existencia de ciertas dificultades en el combate a la expansión del tráfico de estupefacientes, donde se destacan dos problemas cruciales en la persecución penal: la problemática de la obtención de pruebas sobre el comercio ilícito de la droga con la identificación de los concretos traficantes y las mutaciones relativas al modus operandi de este delito ${ }^{1328}$.

En este contexto presentado anteriormente, el agente infiltrado constituye una parte esencial e integral de cualquier investigación sobre estupefacientes, en razón de que sus valiosas informaciones difícilmente podrían ser obtenidas de otra forma ${ }^{1329}$.

en la lucha contra el tráfico de drogas, vid. DUARTES-DELGADO, E., "El agente encubierto en los delitos de narcotráfico", http://www.uaca.ac.cr/actas/2008/Acta42/juridica/agenteEncubierto.pdf.

1327Vid. MORILLAS CUEVA, L., "El delito de tráfico de drogas en sentido estricto", cit., pág. 23. Por esta razón, es importante destacar que "la globalización puede ofrecer a la humanidad oportunidades inexploradas y beneficiosas. Por desgracia permite también que muchas actividades antisociales se conviertan en problemas sin fronteras. Entre ellas se encuentran el consumo de drogas que lleva la desdicha a millones de familias en todo el mundo, y el narcotráfico, que promueve y explota esa fatalidad en su provecho". Vid. MAGAZ ÁLVAREZ, R., "Respuestas político-criminales a la delincuencia internacional: narcotráfico y terrorismo", VV.AA., Elementos básicos de investigación criminal, J. Collado Medina coord., Madrid, 2007, pág. 125.

1328 Véase como ejemplo la hipótesis de utilización de "narcosubmarinos" para proceder el tráfico de estupefacientes desde Colombia hasta países de Europa y a los Estados Unidos de América. En esta operación delictiva, los traficantes de drogas envían sus productos para venda en otros países a través de submarinos, los cuales navegan por las partes más profundas de los océanos, buscándose así, fugir de la fiscalización policial hecha normalmente por aire, por tierra y en la superficie acuática. Con más detalles sobre estas modalidades delictivas vid. la noticia publicada por la CNN en México: "Los narcosubmarinos avanzan con el desarrollo tecnológico y de seguridad", http:://www.cnn.mx/nacional/2010/07/16/pwlos-narcossubmarinos-avanzancon-el-desarrollo-tecnologico-y-de-seguridad. Otra novedad en relación a nuevas formas de tráfico de drogas consiste en el surgimiento de las "narcomodelos" en Bolivia, donde algunas jóvenes modelos son utilizadas como "mulas de lujo" para el transporte de la cocaína. Cfr. el reportaje "Narcomodelos", periódico La estrella del Oriente, 24 de julio de 2011, Santa Cruz de la Sierra, págs. 3 y ss.

1329 GARCIA, J. E., La droga, problema de vigencia universal: perspectiva policial, Madrid, 1993, pág. 60. Vid. respecto al uso de agentes encubiertos en operaciones contra la expansión del tráfico de drogas, algunas sentencias recientes del Tribunal Supremo español: SSTS 1316/2011, de 1.3.2011; 1156/2010, de 9.3.2010; 99/2009, de 8.1.2009 y 7815/2007, de 15.11.2007. Todavía, en relación al ordenamiento penal español, advierte REY HUIDOBRO que "la participación del agente encubierto en operaciones de tráfico de drogas, nos sitúa en los límites del agente provocador, penado con carácter genérico en el 368 CP y agravado en el 369.1 $\mathrm{CP}$ por su calidad de funcionario público. Luego de aquí se deduce que el infiltrado tendrá que limitarse en todo caso a tareas informativas, identificando autores y posibles que los mismos vayan a verificar, con un claro norte: el aseguramiento de la prueba. Por lo que no debe confundirse la provocación con la investigación". Vid. REY HUIDOBRO, L. F., "La entrega vigilada de drogas. El artículo 263 bis de la Ley de Enjuiciamiento Criminal", Revista del Ministerio Fiscal, no 2, 1999, pág. 194. 
Quizás sea posible afirmar sin miedo de equivocarse, que la tarea más usual de actuación de agentes encubiertos posee relación con el combate contra la venta de estupefacientes $^{1330}$. Y además consiste en una de las más peligrosas tareas de investigación, teniendo en cuenta el alto nivel de violencia imperante en los clanes de traficantes, lo que podría significar que en caso de descubierta de la infiltración del agente en el grupo criminal, la consecuencia inevitable sería la muerte de él.

En esta tarea de investigación el infiltrado en el clan organizado de narcotraficantes actuará como los demás integrantes del grupo delictivo, es decir, si la banda está dedicada al tráfico de sustancias psicotrópicas, comprará drogas, la transportará, las venderá sin que se pueda ser imputado el respectivo delito, pues estará cubierto por la exención de responsabilidad penal cuando prevista en la ley y condicionada su actuación a los parámetros de proporcionalidad.

Deberá el agente encubierto vivir cotidianamente muy cerca de los demás miembros del grupocriminal, pasando a conocer el cotidiano y el rol de cada uno de ellos, de modo a poder ingresar en el escenario de venta de la droga ${ }^{1331}$, al mismo tiempo en que obligatoriamente tendrá la responsabilidad de enviar informes a las autoridades de persecución penal, presentando las informaciones, datos y pruebas dirigidas contra los narcotraficantes.

Sin embargo, en este envío de los informes reside el gran momento de peligro para la vida del infiltrado, a la vez que cualquier error que pueda desvelar su real identidad, podrá costar la propia vida. Así es que salir del entorno criminal en una fase de paralización parcial del trabajo de infiltración, con el consecuente retorno al seno del grupo, tras el repaso de los informes, pasa a ser el instante de tensión más destacable en la tarea de investigación.

En realidad la actuación del agente encubierto no supone una auténtica provocación, ya que el delito arranca de la determinación del sujeto activo libre, voluntaria y anterior a la intervención del agente policial, que se desarrolla conforme a aquella ideación, de modo que la actuación del agente policial se limita a realizar tareas de auxilio o colaboración, por iniciativa del autor, simulando una disposición a delinquir, que permite una más efectiva intervención policial ${ }^{1332}$. Luego, el resultado de este mecanismo es que cuando la intervención policial frustra la operación de tráfico de drogas que se estaba desarrollando, todos los actos previos a esa intervención policial son válidos para surtir los efectos penales que le son propios, según el grado de desarrollo delictivo alcanzado, y sólo a partir de la actuación simulada de los agentes los actos realizados serán irrelevantes por la imposibilidad de producción de sus efectos ${ }^{1333}$.

\footnotetext{
1330Monográficamente véase NÚÑEZ PAZ, M. A;GUILLÉN LÓPEZ,G., "Entrega vigilada agente encubierto y agente provocador. Análisis de los medios de investigación en materia de drogas", cit., págs. 89-164. Merece destaque además, el importante y destacadolabordel DEA (Drug Enforcement Administration) enlos EstadosUnidos, órgano este que tiene mucha experiencia en operaciones encubiertas contra el narcotráfico.

1331 Incluso el Tribunal Supremo español admite que la labordel agente infiltrado puede extenderse a la realización de actividades de colaboración con el delincuente investigado (STS 6971/2006 de 13.11.2006), cuando por iniciativa del autor de la infracción criminal, llegue a ejecutar labores de adquisición o transporte de los efectos del delito, u otras tareas de auxilio o colaboración similares (STS 4107/2003, de 13.6.2003) tendentes a conseguirla confianza del delincuente.

1332 Vid. MOLINA MANSILLA, Mạ, C., El delito de narcotráfico, cit., pág. 302.

1333 Cfr. Otra vez más, la STS 4107/2003 de 13.6.2003. Interesante además señalar que la jurisprudencia española admite la figura del delito comprobado en los supuestos de tendencia preordenada para el tráfico, al
} 
Por fin, dos cuestiones prácticas merecen una atención especial dentro del análisis de la actuación del agente encubierto en los delitos de tráfico de drogas.

La primera como ya hemos tenido oportunidad de mencionar se refiere al hecho de que los grupos relacionados con la venda de estupefacientes se encuentran en constante cambio de modus operandi en lo relativo al transporte de la droga, situación esta que viene a dificultar la labor policial de combate al tráfico. Desde ahí, surge la necesidad de que el Estado proporcione a algún funcionario, a través de una identidad supuesta, la posibilidad de estar dentro de la organización criminal, conociendo desde el interior del grupo, todas las informaciones y formas de contrainteligencias relativas a la represión policial.

La segunda observación dice respecto a la necesidad de compatibilizarse el uso de las técnicas policiales de entrega vigilada y del agente encubierto, con la finalidad de obtenerse más éxito en la operación de infiltración. Se justifica esta posición a partir del momento en que en la entrega vigilada se posibilita la circulación de una sustancia o producto sin actitud obstativa alguna de las autoridades competentes, con la meta de aguardarse el exacto instante para descubrir o identificar a las personas involucradas en la comisión de algún delito relativo al narcotráfico. Y para este propósito, es de suma importancia para acompañar la circulación o entrega vigilada, la actuación y participación de un agente infiltrado, el cual podrá a todo tiempo repasar a las autoridades de persecución, informaciones sobre personas envueltas en la práctica delictiva, las rutas elegidas por el grupo, las tácticas para burlar y transportar la sustancia ilícita y otros datos de interés.

\section{IV.2.3.2. Blanqueo de capitales.}

Una observación preliminar sobre el tema apunta en el sentido de que la necesidad de blanquear dinero surge cuando no es posible justificar su procedencia porque es la contraprestación a la ejecución de una actividad delictiva; si se reconoce la existencia del dinero se reconoce la existencia del delito. Esto obliga a quienes acumulan grandes cantidades de dinero de origen ilícito a encontrar las vías que les permitan introducirlo en lo que podría llamarse "circuito monetario", de modo que puedan reconocer su existencia, es decir, obtener una rentabilidad, sin justificar su procedencia ${ }^{1334}$.

De este modo, la delincuencia organizada a través de grandes y poderosos grupos criminales, en razón de la constante necesidad de hacerse "girar" el gran volumen de capitales de origen ilícito, busca a todo costa reciclar y limpiar estos importes, con la finalidad de darles apariencia de absoluta legalidad. Tal situación justifica los esfuerzos de los órganos de persecución penal en la lucha contra los agentes que practican actos de blanqueo de capitales ${ }^{1335}$.

tratarse de un tipo penal de resultado cortado y consumación anticipada, que supone una conducta criminal tipificada en el art. 368 CP ya consumada, de manera que la actuación de funcionarios policiales sobre el sujeto que detenta la sustancia ilícita no provoca el delito, sino que única y exclusivamente saca a luz un delito preexistente. En este sentido, Cfr. STS, de 8 de julio de 1999.

1334 Vid. MONTALVO SANTAMARÍA, A., "La prevención del blanqueo de capitales de origen ilícito", Información Comercial Española, núm. 741, Madrid, 1995, pág. 84. De este modo, por se tratar de una actividad ilícita de gran complejidad en su operacionalidad, se afirma que "el reciclaje de capitales ilícito es un proceso". Cfr. con detalles, CAPARRÓS, E. F., El delito de blanqueo de capitales, cit., págs. 49-54.

1335 Sobre esta cuestión CASSANI señala que "golpeando la blanqueador de dinero sucio se busca golpear en primer término a las organizaciones criminales; prohibir el blanqueo es luchar contra el crimen organizado". Vid. CASSANI, U., "Le blanchissage d'argent", Fiches Jurídiques Suisses, Genève, 1994, pág. 2. 
El blanqueo de capitales supone la introducción en el sistema económico legal de ingentes cantidades de dinero procedentes de actividades ilícitas lucrativas. Muchos son los ámbitos de actividad económica legal en los que opera la delincuencia organizada a través del reciclaje de bienes ilícitos, especialmente en las áreas de inversión del sector terciario, a través de la creación de empresas, inversiones inmobiliarias y otros diversos campos de actividad económica legal. El blanqueo de capitales aparece, así, como un agente distorsionador del bien jurídico a proteger, como es el orden socioeconómico de los países. Es por ello por lo que los Estados disponen de órganos públicos de control y supervisión encargados de la lucha contra el mismo. En síntesis, este delito es la piedra angular de la delincuencia organizada transnacional ${ }^{1336}$.

Delante de esta situación, se observa que las operaciones encubiertas a través de infiltraciones policiales ${ }^{1337} \mathrm{se}$ presentan como métodos de investigación de gran importancia en la contención al desarrollo de los procesos de reciclaje de capitales de origen ilícita.

Basta con decir que el lavado de dinero y otros bienes ilícitos es el motor de funcionamiento de los grandes grupos de delincuentes organizados, los cuales necesitan de poder financiero para ejecutar sus actividades criminales.

Así, en razón de la expansión de la criminalidad organizada a nivel transnacional, surge la necesidad de que los Estados y sus respectivos órganos de persecución penal acudan a nuevos instrumentos de investigación, o mejor dicho, en mayor medida, a mecanismos ya existentes y considerados eficaces, a ejemplo de las figuras del agente provocador ${ }^{1338}$ y del agente encubierto. En palabras de PALMA HERRERA, esto explica el empuje adquirido por estas técnicas en materia de narcotráfico, y que su conveniencia comience también a constatarse como mecanismo para combatir el blanqueo de capitales, una vez comprobada la limitada eficacia de las técnicas policiales ordinarias ${ }^{1339}$.

De otra parte, en lo relativo a la actuación práctica del infiltrado, señala ARÁNGUEZ SÁNCHEZ que quien pretende integrarse en una organización dedicada al blanqueo de capitales no puede, por ejemplo, cometer un homicidio para ganarse la confianza de quienes conforman la asociación ilícita, pero ¿podría cometer un delito de coacciones sobre un empleado de banca? La respuesta sin duda dependerá del caso en concreto, pero al menos deberían haberse delimitado los criterios con los que juzgar tan delicada cuestión ${ }^{1340}$. A tenor de esta hipótesismencionada anteriormente, una vez más queda clara

1336 Cfr. ÚBEDA-PORTUGUÉS, J. E., "Análisis de los efectos negativos de la delincuencia organizada en la sociedad internacional", Anales de la Universidad Metropolitana, vol. 9, núm. 2, 2009, pág. 77.

1337 De forma específica sobre o tema, vid. CÁLIX VALLECILLO, C. D., "Actuaciones del agente encubierto en el ámbito del blanqueo de capitales. Conductas típicas y su posible justificación", Revista Letras Jurídicas, núm. 1, 2005, http://www.letrasjuridicas.cuci.udg.mx/. Sobre la actuación del agente encubierto en casos de blanqueo de capitales, vid. la STSS 3388/2007, de 25.4.2007 Y 1156/2010, de 9.3.2010.

1338 En este sentido señala BLANCO CORDERO que "el recurso a la técnica del agente provocador para luchar contra la criminalidad organizada en general y contra el blanqueo de capitales en particular, se configura como uno de los nuevos métodos policiales frente a los tradicionales, no demasiado eficaces ante este tipo de criminalidad. Es ilustrativo el supuesto real de la operación Green Ice, en la que se desarticuló una importante banda dedicada al narcotráfico y al blanqueo de capitales. Para ello, agentes de policía se infiltraron en la banda y consiguieron realizar actividades de blanqueo de dinero controlado tendentes a conocer su origen y su destino". Vid. BLANCO CORDERO, I., El delito de blanqueo de capitales, Navarra, 2002, pág. 539.

1339 Cfr. PALMA HERRERA, J. M., Los delitos de blanqueo de capitales, cit., pág. 510.

1340 Cfr. ARÁNGUEZ SÁNCHEZ, C., El delito de blanqueo de capitales, Madrid/Barcelona, 2000, pág. 254. 
la necesidad de la incorporación del principio de proporcionalidad a las operaciones encubiertas, fijando los límites que deberán balizar la actuación del agente infiltrado.

Otra hipótesis nos parece perfecta para ilustrar la eventual labor del infiltrado en una investigación sobre blanqueo de capitales: hay conocimiento por indicios e informaciones que un determinado grupo de delincuentes, contando con el apoyo de funcionarios de unaentidad bancaria, constantemente realizan envíos de cuantías sospechas para paraísos fiscales como forma de limpiar el dinero "sucio", sin sujetarse a los controles administrativos exigidos por ley. Debido a la ley del silencio, incluso a consecuencia también del poder de la corrupción imperante, la única posibilidad para descubrir de forma segura toda la operación delictiva será ingresar a un agente estatal infiltrado para que desde el ambiente bancario pueda ganar la confianza de los otros miembros del grupo y obtener, con el pasar del tiempo, las informaciones y pruebas respecto a los actos de blanqueo de capitales así como el modus operandi utilizado para los procesos de reciclaje de bienes de origen ilícito. Se busca con esta tarea de investigación hacer frente al surgimiento a todo momento de nuevas formas de blanquear los capitales ilícitos originarios de actividades criminales, neutralizando la actuación de los delincuentes especializados en procesos de reciclaje de bienes "sucios".

\section{IV.2.3.3. Paidofilia o pedofilia.}

Un tema de moda dentro de los problemas enfrentados por las sociedades modernas es el de la pedofilia, lo que se justifica en razón del incremento y crecimiento de los medios tecnológicos,en especial de Internet. De este modo, se suele utilizarse de esta forma de contacto virtual para empezar sin riesgo una amistad con una víctima menor de edad, con el objetivo de mantener con ella en un futuro próximo, actos de satisfacción de lascivia sexual.

Los durísimos golpes sufridos por las redes de pornografía infantil en los últimos años han hecho que los pederastas sean cada vez más cautos a la hora de intercambiar material en la red, lo que ha obligado a la policía a empezar a utilizar agentes encubiertos en sus investigaciones en Internet ${ }^{1341}$.

La búsqueda por personas practicantes de actos de paidofilia ${ }^{1342}$ y que pueden también ser denominadas de "pedófilos", ha despertado la atención de los cuerpos policiales y de otras autoridades de persecución penal, en razón de su expansión irrazonable en la "red de las redes"1343.

La pedofilia ${ }^{1344}$ es así un rasgo multifactorial en la personalidad del que la padece, y se compone de aspectos mentales, institucionales, de actividad, de educación sexual, de

1341 Sobre esta preocupación relativa a la expansión de los delitos de pedofilia por medio de la internet, el gobierno brasileño está a punto de aprovar una ley que viene a permitir de forma específica la infiltración de agentes policiales en la internet. Con más detalles, Cfr., el preyecto de ley del Senado Federal n. 100/2010. Disponible en http://www.senado.gov.br.

1342 Monográficamente, Vid. OLIVEIRO FERRARÍS, A; GRAZIOSI, B., ¿Qué es la pedofilia?, 1ạ edición, Barcelona, 2004. Además, para un análisis jurídico y actual del problema, vid. SANZ MULA, N., "Pornografía en la web. El reto del Derecho penal ante el más vergonzoso uso de las nuevas tecnologías", Ciencia Policial, núm. 86, Madrid, 2008, págs. 57-104.

1343 Expresión sinónima utilizada en el Derecho Informático para denominar la rede de Internet.

${ }^{1344}$ Desde un punto de vista médico, la paidofilia o pedofilia es una parafilia que consiste en que la excitación o el placer sexual se obtienen, principalmente, a través de actividades o fantasías sexuales con niños 
violencia y de control de las pulsiones. En este sentido, se suelen distinguir dos tipos de pedofilia: una primaria o esencial, muy arraigada en el sujeto, y otra secundaria (u otras), que aparecería motivada por factores circunstanciales.

Nos cabe en este momento señalar de modo introductorio que la pornografía infantil es una de las aberrantes formas a través de las cuales se violan los derechos de los niños, niñas y adolescentes. Constituye un abuso cometido por adultos contra estos seres humanos en pleno desarrollo de la personalidad, considerándose un delito grave en muchas legislaciones nacionales ${ }^{1345}$.

De otra parte, la pornografía infantil no es un fenómeno nuevo, y sus formas de difusión tradicionales han sido las revistas y videos tanto artesanales como "industriales", comerciales o no comerciales, difundidos en forma reducida dadas las propias limitaciones de los medios y de las distintas épocas de su realización. La aparición hace 35 años de Internet, y su posterior desarrollo en los últimos 15 años, ha permitido que la pornografía, y en particular la infantil, encuentren en ella un medio privilegiado para su difusión dándole además la posibilidad de su extensión al mundo entero. La transformación de Internet y algunos de sus medios conexos, como el correo electrónico, en medios muy baratos y de fácil acceso para cualquier persona, grupo u organización han hecho que en la actualidad sea ésta un medio imprescindible para la comunicación ${ }^{1346 .}$

También importante destacar que la difusión de pornografía infantil en Internet tiene fines distintos; es posible distinguir una finalidad comercial y otra no comercial. Sin embargo ambas pueden estar relacionadas, ya que se comercian materiales que se pueden obtener en la propia red y que han sido realizados por pedófilos para su consumo personal, no para su venta.

La gran dificultad de la actuación policial contra esta especie de delito se refiere al hecho de que en la gran mayoría de los ordenamientos jurídicos la ley impide, aunque sea de modo indirecto, que los agentes encubiertos puedan distribuir ellos mismos vídeos o fotos de contenido pedófilo para intentar congraciarse con sus interlocutores, aunque sí les permite intercambiar material simulado que en realidad está protagonizado por actores pornográficos mayores de edad ${ }^{1347}$. Estaríamos delante de la prohibición de la práctica de un delito grave en medio a la actuación del infiltrado, pues el hecho de que el mismo utilice fotos o películas con participación de menores de edad no estaría en correspondencia con la exigencia de la proporcionalidad en la investigación.

Todavía, pese a las dificultades de persecución, han sido recientemente noticiadas actuaciones de infiltrados en la red de Internet para conseguir identificar a los pedófilos ${ }^{1348}$.

de, generalmente, entre 8 y 12 años. En este sentido, vid. ECHEBÚRUA, E; GUERRICAECHEVARRÍA, C., Abuso sexual en la infancia, Barcelona, 2005, pág. 79.

1345 Véase por ejemplo, la legislación brasileña que pune de forma rígida los actos de paidofilia en los artículos 240 y 241 A, B, C, D, E, de la Ley 8.069/90.

1346 Vid. el informe "Pornografía infantil en Internet", elaborado en Uruguay por el Ministerio del Interior a través de la Dirección Nacional de Prevención Social del Delito, Montevideo, 2004, http://www.iin.oea.org/proy_trafico_ninos_internet/iintpi/pornog.uruguay.pdf.

1347 Vid. con detalles respecto a esta problemática, el Blog de la Red Peruana contra la pornografía infantil, http://nopornoinfantil.blogspot.com.

1348 Un buen ejemplo sería la STS 6202/2007, de 3.10.2007, la cual contempla un caso de infiltración policial para la persecución a delitos de pornografia infantil practicado en la Internet. 
Importante mencionaralgunos casos recientes y que tuvieron una repercusión internacional respecto al combate a esta forma de expansión de la pornografía infantil. El periódico digital argentino "Adnmundo" en su edición de 3.11.2006 ha noticiado que la policía canadiense detuvo a un hombre de 34 años dos horas después de que transmitiese por Internet en directo la violación de una niña a un policía que actuaba encubierto. Este detective que forma parte de la Unidad de Crimines Sexuales de la policía de Toronto ha creado junto con Microsoft un sofisticado programa informático para rastrear pederastas en Internet, destacando que las fuerzas de seguridad están constantemente vigilando y adaptándose a los cambios de tecnología ${ }^{1349}$.

También en Chile, en marzo del año 2010, ha sido detenido un sujeto que comercializaba las grabaciones pornográficas a Europa y a otros países. El involucrado fue detenido tras un operativo del departamento OS9 de la Policía uniformada, en que además se capturó a otros tres sujetos. Para la investigación se utilizó un agente encubierto, que se contactó con el sospechoso. El supuesto pedófilo (infiltrado) se mostró interesado en la producción de material y logro que el acusado confesara sus delitos. Se investigan sus nexos en España, Gran Bretaña, Italia, Alemania, Estados Unidos y México, entre otros países ${ }^{1350}$. En estos dos casos, ha sido muy importante la utilización de agentes infiltrados, los cuales, sin promover actos de provocación, ya que los delitos estaban siendo ya practicados por los pedófilos, han obtenido pruebas que llevaron a la detención de estos delincuentes pertenecientes a organizaciones criminales que actúan en el comercio internacional de materiales pornográficos.

En España han sido creados departamentos específicos en los diferentes cuerpos policiales para luchar contra la pornografía infantil: la Brigada de Investigación Tecnológica (BIT) de la Policía Nacional y el grupo de delitos telemáticos de la Guardia Civil ${ }^{1351}$. Y en consecuencia, es frecuente en España la actuación de agentes encubiertos en la represión a la pornografía infantil practicada a través de medios telemáticos ${ }^{1352}$.

Sin embargo, otro gran problema enfrentado por las autoridades de persecución es la ausencia de reglamento especifico de actuación policial en el ambiente virtual para la responsabilización de las personas usuarias de material pornográfico, bien como para la punición de pedófilos.

Respecto a esta cuestión, y analizando la realidad del ordenamiento penal español, es significativa la opinión de VELASCO NÚÑEZ al señalar que se puede concluir que la imprevisión legislativa para con la realidad actual de la delincuencia por Internet, y el denostable sistema de lista cerrada, en que, por meros dictados de la moda, ha incurrido el legislador, recluye la aplicación de este método de investigación a los fraudes en banda organizada y la distribución de pornografía infantil, además a ciertos otros delitos

1349 Vid. para más detalles, "Arrestan a pedófilo luego de mostrar su abuso por Internet", http://www.adnmundo.com/contenidos/politica/pedofilo_internet_menor_canada_pi03112006.html.

1350 Con abundante informaciones sobre esta investigación encubierta, vid. la noticia "Detienen a líder de banda dedicada a producción de pornografía infantil en Chile", http://latercera.com/contenido/680_232206_9.shtml.

1351 Cfr. SANZ MULA, N., "Pornografía en la web. El reto del Derecho penal ante el más vergonzoso uso de las nuevas tecnologías", cit., pág. 92.

1352 Cfr. la STS 767/2007, de 3.10.2007. 
convencionales (como el terrorismo, la distribución y tráfico de drogas, las extorsiones, etc.), siempre que se vehiculasen a través de las nuevas tecnologías 1353.

En resumen, nos cabe afirmar que la presencia de agentes estatales que utilizándose del engaño y de disimulación, permanecen conectados a Internet, navegando como se fueran personas "normales", sirve no sólo como una vía para perfeccionar la detección de pedófilos en la Internet sino que también presenta un carácter de efecto disuasorio para una persona que esté navegando en la red para captar a un menor y no sepa si está hablando con este o con un agente de la autoridad ${ }^{1354}$.

Desde que el referido trabajo sea consecuencia de una resolución judicial motivada y tras ser objeto de análisis frente al principio de proporcionalidad, amén del obligatorio respecto a la legalidad, tenemos como perfectamente idóneo la actuación del infiltrado como medio extraordinario legítimo para el combate a la pedofilia. Por fin, importante destacar que en España, el acceso a Internet y a las pistas y rastros que el delincuente abandona en el, no afecta a derechos fundamentales, pues ni es privado ni íntimo (art. 18.1 CE) lo que se deja allí, ni se trata de una telecomunicación formalmente protegida (art. 18.3 CE) cuyo secreto deba guardarse, ni son datos protegidos automatizadamente (art.18.4 CE) los que se realizan a colgar en Internet ofertas, más o menos camufladas de objetos de circulación delictiva ${ }^{1355}$.

\section{IV.2.3.4. Terrorismo.}

Partiendo de la consideración general de que el concepto de terrorismo posee dos elementos integradores, cuales sean, el estructural y el teleológico, se suele definir como la realización de actos de violencia política organizada1356. Así es que se constituye en nuestros días el fenómeno más evidente de hostilidad al sistema ${ }^{1357 .}$

Dentro de este escenario, la idea es provocar el terror en la población por medio de la realización de actos de violencia, para poder así exigir algún objetivo o concesión de carácter político como condición para el cese de la violencia ${ }^{1358}$.

Siendo una modalidad de crimen organizado, a la vez que los grupos terroristas actúan en general dotados de una gran estructura personal de funcionamiento y siempre

1353 Cfr. VELASCO NÚÑEZ, E., "Entregas vigiladas, infiltración y agente encubierto en internet", Justicia Revista de Derecho Procesal, núms., 1-2, 2010, pág. 258.

1354 Incluso, en España, el PP (Partido Popular) ha propuesto en julio de 2008 que se cree la figura del agente encubierto para atrapar a los ciberpedófilos, pues podrían entablar contacto directo con estos criminales, pero también tendrían que manejar e intercambiar archivos de porno infantil. Cfr. la publicación "Policías disfrazados de pedófilos para acabar con la pornografía infantil en internet", http://www.adn.es/ciudadanos/20080711/NWS-2052-pedofilos-internet-agente-encubierto-congreso.html.

1355 Cfr. la opinión de VELASCO NÚÑEZ, E., "Entregas vigiladas, infiltración y agente encubierto en internet", Justicia, Revista de Derecho Procesal, cit., págs. 258 y ss.

1356 En este sentido, vid. LAMARCA PÉREZ, C., "Sobre el concepto de terrorismo (a propósito del caso Amedo)", Anuario de Derecho Penal y Ciencias Penales, 1993, pág. 536. Para una comprensión profunda, actual y garantista del fenómeno del terrorismo, Vid. VV.A.A., Terrorismo y Estado de Derecho, J. R. SerranoPiedecasas; E. Demetrío Crespo coords., Madrid, 2010.

1357 Esta la posición de CARBONELL MATEU, J. C., "Terrorismo: algunas reflexiones sobre el concepto y el tratamiento penal", VV.AA., Terrorismo y proceso penal acusatorio, J. L. Gómez Colomer; J. L. González Cussac coords., Valencia, 2006, pág. 49.

1358 Con más detalles respecto a esta característica del terrorismo, Cfr. MIRÓ LLENARES, F., "Democracias en crisis y Derecho penal del enemigo: política criminal frente al terrorismo en los Estados democráticos antes y después del 11 de septiembre de 2001", Cuadernos de Política Criminal, núm. 87, 2005, págs. 185-228, nota 5. 
contando con un aparato logístico por detrás, se puede concluir que también presentan la característica del mantenimiento de la ley del silencio como forma de asegurar el éxito de sus operaciones ilícitas.

Surge, pues, la dificultad de conocer más profundamente el modus operandi y la estructura jerárquica de estos grupos de criminales como forma de sancionar a sus miembros y preventivamente evitar la práctica de nuevos actos que puedan quitar la vida de un sinnúmero de personas inocentes.

Delante de este contexto, surge la imprescindible necesidad del uso de la figura delagente encubierto como medida de investigación del terrorismo en el contexto internacional ${ }^{1359}$, con el objetivo de que el Estado a través de personas infiltradas, que elegidas actuarán en operaciones encubiertas, pueda penetrar en las entrañas de un determinado grupo terrorista y, enconsecuencia, consiga obtener el mayor número de informaciones, datos y pruebas posibles, con la finalidad de que los órganos de persecución penal puedan desarticular la organización terrorista, principalmente con la detención de sus principales miembros ${ }^{1360}$. Se evita con esta actitud la pérdida de un sinnúmero de vidas inocentes cuando se realizan actos terroristas.

En España han sido muy interesantes los resultados de infiltración de agentes estatales en el contexto terrorista, a ejemplo del caso del ETA. La actuación del agente "lobo", alias de Mikel Legarza en este grupo, ha podido demostrar que el trabajo con un agente encubierto puede aportar una cantidad excepcional de informaciones que puedan llevar a la policía a la detención de un gran número de miembros de terroristas ${ }^{1361 .}$

En este caso citado anteriormente se percibe que después de la actuación del agente "lobo" hubo un claro enflaquecimiento de la organización terrorista, a la vez que fueron detenidos en aquellos momentos gran parte de los miembros de la cúpula de la banda terrorista ${ }^{1362}$.

Por último, dejar indicación de que se trata, juntamente con la investigación del narcotráfico, de una de las tareas más arriesgadas a las que puede enfrentarse el agente encubierto si tomamos en consideración la violencia empleada por los terroristas, especialmente aquellos denominados "fundamentalistas".

1359 Para un conocimiento especifico del tema, Cfr. GÓMEZ DE LIÃNO FONSECA-HERRERO, M., "El agente encubierto como medida de investigación del terrorismo en el contexto internacional", cit., págs. 417-433. También la STS 5441/2007 de 25.6.2007.

1360 Utilizándose de esta especie de actividad persecutoria preventiva, se busca descubrir a tiempo planes de ataques terroristas y por consecuencia, evitando la muerte de víctimas inocentes.

1361 Vid. CERDÁN, M; RUBIO, A., Lobo. Un topo en las entrañas de ETA, Barcelona, 2004. Otro interesante ejemplo, se refiere a la labor del agente estatal español del CESID, Francisco Lerena Zambrano, conocido en los medios policiales por los apodos "Alejandro" o "lobo azul", el cual ha sido infiltrado en la cúpula de extrema derecha, en los años 84 y 85, teniendo evitado atentados muy graves como la muerte del diputado de Euskadiko Ezquerra Juan María Bandrés, el preparado contra un autobús lleno de familiares de ETA, cerca de Alcalá Meco, la voladura de un cine Alphaville en Madrid, repleto de espectadores durante la proyección de la película "Je vous salue marie", y muy especialmente, controló, para frustrarlo desde dentro, el atentado contra la Familia Real y el gobierno de Felipe González en un desfile en la ciudad de A Coruña. Para más detalles, vid. "Los secretos del lobo azul", Periódico El Mundo, 4.7.2005; "La historia de lobo azul, el topo que evitó el asesinato del Rey", http://www.elreservado.es, en 2.9.2010.

1362 Recuérdese que a finales de 1975, "el lobo" consiguió con su sangre fría la caída de la cúpula de ETA y de la mayor parte de los terroristas que estaban de España. Hasta hoy este agente estatal que se infiltró en ETA encuéntrase en la "lista negra" de esta organización terrorista, a la vez que según sus miembros, este infiltrado les había infringido un daño irreparable y por esto deberá pagar con su vida. 
IV.2.4. Valoración crítica del control de la criminalidad organizada a través de la utilización de agentes encubiertos.

De todo lo dicho hasta ahora se deducen algunas conclusiones preliminares: que la delincuencia organizada es una realidad incontestable ${ }^{1363}$ y por tanto para combatirla la utilización de medios extraordinarios de investigación policial, en especial de infiltraciones a través de agentes encubiertos, se presenta como una potencial forma de enfrentamiento a la expansión de este fenómeno criminológico.

Todavía, la criminalidad organizada, especialmente el narcotráfico, exige que su combate sea, también, organizado y complejo. Si los jefes ni siquiera tocan la droga y llevan una vida de aparente integración en la sociedad legalizada, es evidente que deben cambiarse las técnicas empleadas para sacar a la luz sus actividades ocultas, identificar a todos los miembros del grupo criminal, descubrir su modus operandi y, consecuentemente, impedir su impunidad. Sin lugar a dudas, el sistema de persecución estatal puede ser muchísimo más fuerte que las organizaciones delictivas, pero es indispensable que la fuerza sea empleada con técnica e inteligencia y que, en todo caso, se mantenga dentro de los límites que marcan la exigencia de respeto hacía los derechos fundamentales ${ }^{1364}$.

De las consecuencias del crimen organizado en el plan procesal penal, se observa una innegable tendencia de restricción de ciertos derechos fundamentales de los investigados e imputados en la búsqueda de una mayor eficiencia penal. Para justificar esta tendencia, se entiende que la lucha frentea la delincuencia organizada exige medidas diferenciadas de las utilizadas para la represión de la criminalidad tradicional, lo que podrá conducir a violaciones de derechos y garantías constitucionales ${ }^{1365}$.

De esta forma, es innegable que estas modalidades más graves de criminalidad constituyen hoy en día, posiblemente, el principal problema de seguridad para los gobiernos de las naciones en los que se asienta y desarrolla. Si bien y debido a su carácter de transnacionalidad, es prácticamente inexistente el lugar del globo que se ve libre de su acción.

Podemos decir que esta delincuencia ha encajado perfectamente a las ideas del sociólogo y teórico de la comunicación de masas MCLUHAN cuando acuño el término de "aldea global". El mundo es un lugar globalizado y unitario donde los grupos criminales organizados realizan sus delitos y atentan contra la libertad y seguridad de los ciudadanos de todas y cada una de las naciones que lo componen ${ }^{1366}$.

\footnotetext{
1363 Es correcto entonces ponerse de acuerdo con el hecho de que el fin de la Guerra Fría y el aumento de la globalización han contribuido simultáneamente con el crecimiento de los nuevos grupos de delincuencia transnacional. Estos grupos se han convertido en actores cada vez más importantes dentro de la economía ilícita global, concentrados en los Estados débiles, mientras que la intervención del Estado en los países con gobiernos fuertes ha frenado el crecimiento de la mafia en Italia y Estados Unidos, los boryokudan en Japón, y ha contribuido con el colapso del Cartel de Medellín en Colombia.

1364 Vid. CORRÊA DE CARVALHO, J. T., Tráfico de drogas. Prueba penal y medidas restrictivas de derechos fundamentales, cit., pág. 73.

1365 Vid. en este sentido, ARAUJO DA SILVA, E., Crime organizado. Procedimento probatório, cit., pág. 47. Del mismo modo, GARRIDO GENOVÉS señala que "los Estados democráticos están siendo obligados a tratar de sus policías y sistemas de justicia con medidas especiales para hacer frente aquellos que no respectan ninguna regla". Vid. GARRIDO GENOVÉS, V et alli., Principios de criminología, cit., pág. 647.

1366 PEÑA ECHEVERRÍA, M. J., "La delincuencia organizada y su problemática desde la óptica de la investigación policial", cit, pág. 101.
} 
Como es bien sabido, el crimen organizado es un verdadero desafío no sólo a la estructura tradicional del sistema penal, sino también a todo el esquema fundamental del poder político, administrativo y económico sobre el que se construye la noción de lo público, sea este de nivel estatal, internacional o global ${ }^{1367}$.

Como todo problema a ser enfrentado, sería necesaria la estructuración de un plan político criminal de combate al foco intangible de estas redes criminales: su organización estructural. Todavía, la clave principal está en encontrar una formula ideal de control a esta especie de criminalidad ${ }^{1368}$, y al mismo tiempo, a través del uso de medios operacionales de índole de investigación, vulnerar lo mínimo posible las garantías inherentes a la condición de dignidad del ciudadano investigado ${ }^{1369}$.

Hechas estas preliminares consideraciones y con la finalidad de encauzar el objeto de nuestro estudio, centrémonos en la intrigante cuestión de analizarse concretamente si sería plausible y fiable hablar de un control de la delincuencia organizada.

No debe desconocerse, en todo caso, la opinión pesimista de ZIEGLER, el cual entiende que la represión a la delincuencia organizada va bien más allá de la búsqueda de la eficiencia penal, pues se trata de una cuestión de Estado. En este sentido, afirma que por su gigantesco poder financiero, la criminalidad organizada influye secretamente el área económica, el orden social, la administración pública y la justicia. En algunos casos llega a dictar su ley y sus valores a la política, desembocando en una auténtica "captura del Estado". De este modo, la independencia de la justicia, la credibilidad de la acción política y, por fin, la función protectora del Estado de Derecho, van desapareciendo. La corrupción se torna en un fenómeno aceptado. El resultado es la institucionalización progresiva del crimen organizado, con el riesgo concreto del Estado verse incapaz de garantizar los derechos y libertades cívicas de los ciudadanos. En síntesis, el peligro para el Estado de Derecho no reside en el acto criminoso en sí mismo, y sí en la real posibilidad de la delincuencia organizada para influir en los procesos de decisiones democráticas. El pronóstico de esta situación, según el autor, ya puede ser notado en Rusia, donde las organizaciones criminosas dominan ramos enteros de la economía y controlan largos sectores de la administración pública. Aunque en Rusia, el crimen organizado es responsable del control del 85\% de las empresas privadas. Más de 40.000 empresas de dimensión nacional son por ello mantenidas y, a partir de 1991, pasaron a controlar más 2000 conglomerados estatales, garantizando su transferencia para el sector privado ${ }^{1370}$.

Otras constataciones del efectivo peligro de las grandes organizaciones criminales se refieren al hecho de que la planificación de los sucesos del 11 de Septiembre de 2001 se llevó a cabo en Hamburgo, Alemania. También que los terroristas que accionaron las

1367 Cfr. YACOBUCCI, G. J., "Los tipos penales relacionados con el crimen organizado", El crimen organizado. Desafíos y perspectivas en el marco de la globalización, cit, pág. 73.

1368 Nos parece que desde este esfuerzo, constatamos a priori la legitimidad del empleo de técnicas especiales de investigación criminal frente al Estado de Derecho, sin todavía olvidarse que su incidencia no podrá deformar los pilares del proceso penal garantista. Así, las intervenciones necesarias que puedan atingir derechos y garantías individuales solamente podrán ser ejercidas dentro de los estrictos límites formulados por la Constitución y además, se justificaran cuando presentaren el objetivo de realización de otros derechos y garantías de rango constitucional, como sería la hipótesis de la seguridad colectiva.

1369 Esta preocupación ha sido puesta en relieve por BECK, F. R., Perspectivas de controle ao crime organizado e crítica à flexibilização das garantias, Instituto Brasileiro de Ciências Criminais, SãoPaulo, 2004.

1370 Vid. con más detalles sobre esta problemática, ZIEGLER, J. Os senhores do crime: novas máfias contra a democracia, trad. Manuela Torres, Lisboa, 1999, págs. 17, 99 y 253. 
bombas en los trenes en Madrid en Marzo de 2004 se mantenían a través del delito y los contrabandistas chinos conocidos como snakeheads (cabezas de culebra) han desarrollado relaciones de protección y comercio con el Ejército Republicano Irlandés.

Con esto se quiere decir que los grandes clanes de delincuentes organizados han pasado en los últimos años a mantener contactos profesionales entre ellos, fortaleciendo los vínculos de lealtad entre los grupos criminales y lo que es peor, pasando a cambiar informaciones y a enseñar el knowhow sobre el funcionamiento de los negocios ilícitos practicados.

Nos parece algo muy preocupante, pues al mismo tiempo en que se percibe un enflaquecimiento de los retos de la cooperación penal internacional, muchas veces en razón de que los Estados no cumplen lo pactado en las Convenciones y Tratados por ellos firmados, y de otra parte los grandes clanes de delincuentes organizados vienen aproximándose en sus contactos, intercambiando informaciones logísticas y expandiéndose a cada día el abanico de posibilidades para delinquir.

Y no se puede olvidar de mencionar que los vínculos peligrosos de los nuevos grupos de delincuencia transnacional no tienen lugar únicamente en los países en vías de desarrollo y en transición, pues se visualiza incluso en las regiones que carecen de instituciones estatales fuertes donde este tipo de delincuencia asume su forma más potente ${ }^{1371}$.

El peligro y la gravedad apuntados representan una verdad incontestable, pero esto no puede funcionar como un obstáculo a la eficiencia de la persecución penal, a la vez que nos cumple mantener la esperanza en concretar un control eficaz y riguroso del crimen organizado.

Hoy en día tiende a reconocerse un escenario criminológico y político criminal nuevo al que se le atribuyen rasgos capaces de generar un salto cualitativo en la evolución de los mecanismos de control de la criminalidad ${ }^{1372}$.

Se dice en este sentido, que el reto de mantener la seguridad colectiva ${ }^{1373}$ frente al crecimiento del crimen organizado constituye un desafío sin precedentes para el Estado y la sociedad.

1371 Desde este punto de vista y acentuando el carácter de internacionalización de esta especie de delincuencia, se puede destacar que "las oportunidades para operar de forma transfronteriza de que disfrutan los bajos fondos de la delincuencia se multiplican a medida que se va multiplicando también la disponibilidad de las tecnologías de la información y las comunicaciones, aumenta la movilidad de personas, bienes y servicios entre los distintos países y surge una economía globalizada. Actualmente, las bandas criminales venden armas, realizan contrabando de inmigrantes y trata de personas, trafican con droga y cometen fraudes en distintos países de todo el mundo". Cfr. BRADY, H., "Europol y el Modelo europeo de inteligencia criminal: una respuesta no estatal a la delincuencia organizada", Análisis del Real Instituto Elcano, núm. 126, 2007, pág. 1, http://www.realinstitutoelcano.org.

1372 Por esta razón, tornase importante señalar que la lógica del crimen organizado se sostiene en la medida en la que la actividad ilícita represente mayores beneficios que cualquier actividad legal a la que el grupo de sujetos pueda dedicarse. El sujeto maximiza sus beneficios interactuando continuamente con otros actores dentro y fuera de la legalidad, creando y concluyendo multitud de asociaciones interpuestas sobre bases temporales más o menos prolongadas y empresas ilegales informales.

1373 Sobre la necesidad de preservación de la seguridad colectiva, se puede señalar que "las actividades ilícitas de la delincuencia organizada suponen la vulneración de la dignidad de toda persona reconocida por los instrumentos del derecho internacional de los derechos humanos. En este sentido, los protocolos $1^{\circ}$, $2^{\circ}$ y y $3^{\circ}$ a la Convención de Palermo contra la Delincuencia Organizada Transnacional, que versan respectivamente contra la trata de personas, la explotación de los trabajadores migrantes y el tráfico ilícito de armas, supone la concienciación, por parte de la comunidad internacional, alguno de los efectos que están presentes en la actual 
En cuanto al control, se propugna usualmente un modelo diferenciado y agravado que afronte estos peligros, supere las especiales dificultades que plantea su descubrimiento y persecución, y calme la alarma que provocan, tanto en la opinión pública como en las instancias formales de mantenimiento de la seguridad pública. Igualmente, la terminología al uso muestra claramente esta singularidad, cuando se habla de "guerra o cruzada contra la criminalidad organizada".

Con todo, conviene tener presente que cualquier forma de control estatal deberá mantenerse próximo de la concepción de un proceso penal garantista, donde se destaca la imperiosa e imprescindible defensa de los derechos y garantías fundamentales de las personas sometidas a la persecución penal.

Tomando como punto de referencia los valores e instituciones del Estado de Derecho, esta peculiaridad radicaría, en síntesis, en que tanto la criminalidad organizada como el control que de ella se pretende representan graves peligros para dichos valores e instituciones ${ }^{1374}$.

Lejos de imaginarse que la tarea de establecimiento del dominio estatal sobre los niveles de seguridad sea algo sencillo, pues en ocasiones, la búsqueda por la implementación de un control a la criminalidad podrá representar una serie de situaciones dignas de una negación pura de los derechos fundamentales. De esta forma, la arbitrariedad y los abusos son características inherentes a los sistemas penales y procesales que no consiguen concretizar esta labor de equilibrar la tensión existente entre la busca de eficacia y la defensa de las garantías de los ciudadanos.

Hechas estas consideraciones preliminares, deberemos concluir que el crimen organizado, en definitiva, constituye por sí mismo un fenómeno de difícil estudio y penetración incluso para la más conceptuada doctrina. Por otro lado, la investigación policial y persecución de esta especie de delito es y siempre ha sido problemática. La naturaleza extendida de sus actividades, el tamaño y complejidad de algunos grupos, y los límites de la propia legislación penal son algunas de las barreras que impiden un mayor éxito en la lucha contra el crimen organizado1375.

Y de ninguna manera sería posible medir ni combatir el crimen organizado si no nos ponemos de acuerdo en la realidad que esta etiqueta captura1376.

Dada su naturaleza conspiratoria y secreta, es muy difícil penetrar en el mundo del crimen organizado utilizando las técnicas de investigación ordinarias de los cuerpos policiales.

sociedad internacional. En los desarrollos jurídicos internacionales posteriores a la Declaración Universal de los Derechos Humanos, también aparece recogida tal vulneración de derechos que sufren, especialmente las mujeres y los niños, pero también los trabajadores migrantes por parte de las redes de delincuencia organizada transnacional". Cfr. ÚBEDA-PORTUGUÉS, J. E., "Análisis de los efectos negativos de la delincuencia organizada en la sociedad internacional", Anales de la Universidad Metropolitana, vol. 9, núm. 2, 2009, pág. 74.

1374 Cfr. ANARTE BORRALLO, E., "Conjeturas sobre la criminalidad organizada", Delincuencia organizada: aspectos penales, procesales y criminológicos, cit, pág. 13. En el mismo sentido, vid. WEIGEND, T., "Los sistemas penales frente al reto del crimen organizado", cit. págs. 547 y ss.

1375 MEDINA ARIZA, J. J., "Una introducción al estudio criminológico del crimen organizado", cit., pág. 127. Las principales dificultades se derivan, en cierta medida, como ya observado, de la ambigua delimitación conceptual de lo que es la delincuencia organizada y además, en razón de la imposibilidad real de obtenerse en fuentes abiertas informaciones respecto del efectivo de participantes del grupo criminoso, de la estructura logística, del poder centralizado en las manos de estos clanes jerárquicos, etc.

1376 Vid. MALTZ, M., "Defining Organizad Crime", Handbook of Organized Crime in the United States, Westport, 1994. 
A nuestro juicio los grupos criminales tienden a perpetuar la implicación de sus miembros en actividades criminales por medio del apoyo logístico y psicológico de sus actos criminales y, así mismo, mediante la creación de barreras contra el abandono de la empresa criminal. Como acto consecuente, si se viola algún secreto o se quebranta la ley del silencio el delator pagará con su propia vida o con la de alguno de sus familiares.

Hacer parte de una organización criminal en los días actuales representa concretamente la obtención de un empleo eterno y sin derecho a pedido de dimisión voluntaria. Este es un problema grave, puesto que a partir del momento en que el delincuente decide dejar el clan es obligado a permanecer, a la vez que el temor de la organización criminal es que esta persona después de su salida exponga los secretos logísticos y operacionales de la estructura del grupo, volviéndose el mismo vulnerable a los ojos de los órganos de persecución penal. Disminuyen así las posibilidades de la puesta en práctica de la figura del arrepentido, incluso teniendo en consideración la existencia de programas de protección de testigos.

Ante esta trascendental realidad, con carácter eminentemente práctico, es preciso plantear un interrogante básico: ¿cómo proceder a un efectivo control de estetipo de criminalidad, a partir del momento en que los miembros de estos grupos se encuentran prisioneros de una implacable ley del silencio que no permite que las informaciones y actividades de estos clanes vengan a conocimiento de las autoridades públicas?

Antes de contestar de forma directa a este cuestionamiento, se nos impone señalar que de la imposición de esta "ley del silencio"1377se presenta otra característica del fenómeno que es la impersonalidad de sus miembros, pues como actúan en las sombras de la clandestinidad, generalmente sus actuaciones no son perceptibles ${ }^{1378}$. Esta afirmación se aplica en especial a la figura de los "jefes" o "capos", personas estas que se encuentran en la cúspide de la estructura jerárquica de la organización criminal ${ }^{1379}$.

Ahora bien, en concatenación con esta problemática, no debemos olvidar un importante dato verosímil presentado por MAPELLI CAFFARENA, en el sentido de que cuando los miembros de una organización criminal son detenidos y condenados e ingresan en una prisión, por lo general, aquélla no se desentiende sino que pone en marcha sus mecanismos, sus contactos con las agencias de control para evitar que el sujeto pueda sentirse en algún momento desprotegido y también para garantizar que no suministrará ningún tipo de información. Este comportamiento no se da frente a quienes han sido delatores o han infringido las normas internas dejándose, por ejemplo, apresar por

1377 Ley del silencio que resulta establecida dentro de la jerarquía del grupo criminal como forma de sepultar todos los secretos internos del mismo. De esta forma, en la apuración de delitos practicados por la criminalidad organizada, ha pasado a ser frecuente el clamoroso silencio, la retratación o el improviso en la reconstitución de los hechos por los testigos en juicio, en razón de condicionamientos externos como el empleo de la violencia física y psicológica, la oferta de dinero y otras promesas.

1378 La baja visibilidad del crimen organizado ha contribuido para la expansión de esta forma de delincuencia en el contexto contemporáneo, pues estos clanes de criminosos laboran sin cualquier alarde, imperando pues el secreto entre sus integrantes. Conviene recalcar, sin embargo, que la imposición de esto silencio por las organizaciones criminales y el empleo de violencia en contra sus violadores resultaran en la tutela de sistemas de protección de las víctimas y testigos en los modernos ordenamientos jurídicos. Cfr. ARAUJO DA SILVA, E., Crime organizado. Procedimento probatório, cit, pág. 44.

1379 De este modo, "el entramado estructural está preparado para proteger a los dirigentes de la organización, que son los que deciden, y a los cuales resulta altamente complicado acceder. Estos "cerebros de la organización" distribuyen los "roles" en función de las aptitudes de cada uno de los individuos, que se encuentran sometidos a una férrea jerarquía, disciplina y control interno". Cfr. GÓMEZ DE LIAÑO FONSECAHERRERO, M., Criminalidad organizada y medios extraordinarios de investigación, cit., pág. 48. 
imprudencia. Tampoco se da esta protección cuando se trata de organizaciones funcionales creadas sólo con carácter temporal para la comisión de determinados delitos, como ocurre en el ámbito de la criminalidad económica, en cuyo caso la organización se disuelve o actúa tan solo para el exterior. A resulta de esta protección exterior los condenados pertenecientes a asociaciones delictivas reciben una asistencia, asesoramiento jurídico, información, visitas, medios, materiales (alimentación, ropas, libros, prensa, televisión) muy superior al resto de la población penitenciaria ${ }^{1380}$.

En consecuencia, estos privilegios conllevan a los miembros de los clanes criminales organizados a un status de seguridad y blindaje distinto de la mayoría de los infractores de la ley, lo que fortalece la manutención de los secretos e informaciones respecto de la organización, dificultando la eficacia de los medios convencionales de investigación llevados a efecto por las autoridades públicas responsables por las fuerzas de seguridad ${ }^{1381}$.

Pues bien, la verdad es que aunque con tonos diversos, la mayoría de los teóricos, juristas, criminólogos y especialistas en política criminal, los operadores jurisdiccionales y policiales, la opinión pública, los responsables públicos y políticos, a nivel nacional, europeo o internacional, mantienen un discurso coincidente en sus líneas básicas: la lucha contra la criminalidad organizada requiere medidas excepcionales en todos los ámbitos, que sin duda alguna, conllevan restricciones significativas para los derechos constitucionales, pero que deben aceptarse en la medida que dicho fenómeno representa hoy mismo un grave e inminente peligro para los sistemas de organización social, política y económica vigentes ${ }^{1382}$.

A este argumento se añade otro con perspectiva de futuro: si estas medidas no se adoptan ya, se corre el riesgo de que más adelante sería irremediable o bien, en un clima social mucho más crispado, habría que tomar decisiones mucho más radicales y perjudiciales para los derechos y libertades públicas y las instituciones constitucionales ${ }^{1383}$.

Sentadas estas premisas, puede afirmarse sin miedo de equivocarse, que una selección cuidadosa de las figuras delictivas miradas para golpear sobre los fenómenos delictivos realmente expresivos de la delincuencia organizada juntamente con una política de prevención que invierta recursos para corregir los desequilibrios sociales y de

1380 Vid. MAPELLI CAFFARENA, B., "Problemas de la ejecución penal frente a la criminalidad organizada", La Criminalidad Organizada ante la Justicia, F. Gutiérrez-Alviz Conrado coord., Sevilla, 1996, pág. 57.

1381 Prueba concreta de lo afirmado se puede extraer de la constatación de que siempre que es detenido un miembro de un clan criminal, por más que sea una persona sin destaque en la estructura jerárquica del grupo, de forma inmediata es oferta al mismo un fuerte aparato jurídico compuesto por competentes abogados, a los fines de procedieren a su defensa procesal.

1382 Desde esta concreta perspectiva se observa que "el incesante auge de lo que podemos denominar verdaderas multinacionales del crimen, está causando efectos negativos en el orden socioeconómico de las sociedades a escala internacional, en el contexto de la globalización económica". Vid. ÚBEDA-PORTUGUÉS, J. E., "Análisis de los efectos negativos de la delincuencia organizada en la sociedad internacional", cit., pág. 64.

1383 Vid. ANARTE BORRALLO, E., "Conjeturas sobre la criminalidad organizada", Delincuencia organizada: aspectos penales, procesales y criminológicos, cit., pág. 48. Además, si estas medidas no fueren adoptadas a un corto plazo, habrá el riesgo de que en el futuro ocurran iniciativas mucho más radicales y prejudiciales a los derechos y libertades públicas y a las instituciones constitucionales a ejemplo de la institucionalización y legalización por parte del Estado de un Derecho penal y procesal penal del enemigo. Sería en verdad, la llegada al caos jurídico, con la pierda de la validad y fiabilidad del texto constitucional. Véase al respecto, ARAUJO DA SILVA, E., Crime organizado. Procedimento probatório, cit., pág. 47. 
mercado, debe representar entonces el leitmotiv de las legislaciones futuras para el control a la expansión de esta forma de macrodelincuencia.

No obstante estas medidas, deberán los gobiernos fortalecer a los sistemas de obtención y análisis de datos sobre la delincuencia organizada, prevenir la penetración de la criminalidad organizada en el sector público y en el sector legítimamente privado, y en especial no que nos interesa, fortalecer las estructuras de investigaciones respecto a esta forma de criminalidad ${ }^{1384}$, incrementándose la efectividad de los medios extraordinarios de investigación, en especial con relación a las infiltraciones realizadas por agentesencubiertos, con el debido respecto a los derechos humanos fundamentales y con profunda observación a los principios del debido proceso legal y de proporcionalidad.

Otro factor de extrema importancia en materia de búsqueda de un control a la criminalidad dice respecto al hecho de que no se puede contentar con la simple introducción de la figura del agente encubierto en las legislaciones modernas, olvidándose que su tarea no será eficaz si no fuera propiciado al infiltrado las mínimas y adecuadas condiciones de trabajo y de protección de su vida y de su familia en el período pos infiltración. Del mismo modo, la reglamentación de las infiltraciones de agentes estatales tiene que seguir los parámetros constitucionales, evitándose la flexibilización desnecesaria de derechos y garantías fundamentales de los investigados.

Con lo dicho hasta ahora hemos buscado poner de manifiesto que un control de la criminalidad organizada, aunque demuestre ser de difícil concreción, es algo factible y necesario a los imperativos de seguridad pública, principalmente a partir de la adopción de iniciativas gubernamentales en el sentido de mejor estructurar la actuación de los agentes que reciben oportunidad para infiltrarse en bandas criminales con objetivos de recabar pruebas, planes de ejecución de crímenes graves y otras informaciones y al fin, posibilitar a los órganos de persecución, el desmantelamiento del grupo criminoso ${ }^{1385}$.

Del mismo modo, deberán ser mejor estructuradas las operaciones policiales de entregas vigiladas, de grabaciones ambientales, de actuación de equipos conjuntos de investigación y de otros tantos medios extraordinarios de investigación criminal, amén de las otras soluciones direccionadas a permitir un control de la criminalidad. Tal medida visaría minimizar la constatación de que el crimen organizado siempre quedará financieramente a frente de los poderes públicos de seguridad en materia de estructura material, logística y personal ${ }^{1386}$.

1384 Y tiene que ser de este modo pues "en este gigantesco mercado hacia el que evoluciona la economía mundial existe una demanda de bienes prohibidos que lo convierten en idóneo para la proliferación de organizaciones criminales. El delincuente organizado es un empresario, y la organización actúa como una auténtica empresa criminal, que asume los modelos y estructuras propias del mundo de la industria y de los negocios. Se habla de industria del crimen, de "empresas criminales" y, dado su carácter transnacional, de "multinacionales del crimen". En este sentido, BLANCO CORDERO, I., "Criminalidad organizada y mercados ilegales", Eguzkilore, núm. 11, San Sebastián, 1997, págs. 214 y ss.

1385 Siguiendo esta tendencia, se suele afirmar que "la eficacia técnica de los funcionarios policiales y la capacidad por parte de los estados para no interpretar los síntomas como causas resultará fundamental, pero el compromiso colectivo permitirá suprimir espacios políticos, económicos y simbólicos ambiguos, sentando las bases para construir sociedades más equilibradas y confiadas en sus propias capacidades como proyecto colectivo". Cfr. JAIME-JIMÉNEZ, 0; CASTRO MORAL, L., "La criminalidad organizada en la Unión Europea. Estado de la cuestión y respuestas institucionales", cit., pág. 193.

1386Uno de sus principales potenciales de algunas organizaciones criminales es su capacidad corruptora y de infiltración, estableciendo definitivamente su influencia a través de reinversiones significativas en negocios legales. Todo ello permite expandir su ascendiente e impulsar, a su vez, de forma directa o indirecta, las actividades ilegales con poderosas coberturas y apoyos, no necesariamente clandestinos. En la actualidad, se 
Con lo dicho hasta ahora, hemos buscado poner de manifiesto que la tarea de hacer un control de la expansión de la delincuencia organizada es de gran complejidad, necesitando pues, de una política criminal desarrollada y específica para alcanzar tal objetivo.

Del mismo modo, se impone como premisa básica, en lo que nos interesa en este estudio, la formulación de leyes que establezcan de forma clara y objetiva todos los trámites procesales relativos a legalidad de la infiltración policial y la eficacia de las pruebas obtenidas a través de este medio de investigación procesal penal.

Caso contrario, al no adoptarse estas medidas de control, se incrementa la expansión del fenómeno criminológico, fortaleciendo las organizaciones criminales y quedando todo el trabajo policial perjudicado con la descalificación de las pruebas quizá obtenidas, amén de otros tantos efectos graves, a ejemplo de la exposición de la vida del agente encubierto y de su familia a peligro ${ }^{1387}$.

Desde esta perspectiva crítica, hablar de un "control" de la delincuencia organizada justificase a nuestro modo de pensar, también en razón de que sería algo utópico se admitir que es posible en los días actuales, exterminar o poner un fin definitivo a este fenómeno globalizado de criminalidad. Trataría pues de un discurso simbólico y lejos de veracidad hablar de métodos eficaces y aptos a establecieren un fin en definitivo a los problemas relativos a la actuación de grupos de criminales organizados ${ }^{1388}$.

De esta forma, un control a los niveles de aceptabilidad y tolerancia natural a la expansión del crimen organizado nos parece algo más factible, como ya ocurre desde muchos años con el tráfico de estupefacientes, donde se intenta con políticas públicas y criminales, bajar los altos índices de proliferación de esto comercio ilegal de drogas, de modo a no provocar efectos destructivos a la sociedad y al Estado.

Ya cerrando este apartado, importante destacar que teniendo en cuenta los riesgos que una mala utilización de los poderes de emergencia (formas de control) puede ocasionar, es preciso que la respuesta penal y procesal sea absolutamente necesaria desde el plan de la política criminal que se pretenda llevar a cabo y siempre bajo la consideración de que se tratan de medidas de carácter excepcional. Esta sería, sin duda, la clave para lograr la tan buscada eficiencia penal en el combate a la delincuencia organizada.

La solución sería entonces, como ya hemos afirmado, la búsqueda de un equilibrio procesal penal a través del criterio de la proporcionalidad, que consiga poner en situación

percibe como los grupos criminales más influyentes y sofisticados intentan eludir la atención pública y la ostentación. Ya no se trata de controlar el territorio, sino de establecer espacios de influencia económicos que trasciendan la dimensión geográfica. Cfr. JAIME-JIMÉNEZ, O; CASTRO MORAL, L., "La criminalidad organizada en la Unión Europea. Estado de la cuestión y respuestas institucionales", cit., pág. 178.

1387 Sin embargo, quedaría el poder del Estado en este caso colocado en posición de descrédito junto a la sociedad, en el especial junto a estas organizaciones criminales. Por fin, los miembros de los cuerpos de policía que serán llamados a actuar como infiltrados, deberán de forma obligatoria, pasaren por un período de preparación física y psicológica, con la finalidad de soportaren los obstáculos y dificultades que podrán ser encontrados durante el período de infiltración en el clan criminoso.

1388 Y los motivos son claros, pues la criminalidad organizada está permanentemente explorando nuevos nichos de expansión y formas novedosas de explotación y penetración, que en la mayoría de los casos resultan finalmente detectados por las autoridades, pero con ingentes recursos y siempre con un sensible retraso, lo que condiciona intensamente la eficacia final de la respuesta. Véase al respecto, JAIME-JIMÉNEZ, 0; CASTRO MORAL, L., "La criminalidad organizada en la Unión Europea. Estado de la cuestión y respuestas institucionales", cit., pág. 191. 
de compatibilidad, la efectividad y la eficiencia estatal junto a la preservación de los derechos y garantías fundamentales de aquellas personas sometidas a un proceso penal.

\section{IV.2.5.Las operaciones encubiertas: lectura desde la realidad actual.}

De todo lo expuesto hasta este punto del trabajo parece desprenderse, al menos como planteamiento inicial, que no es posible el tratamiento policial y judicial tradicional para la lucha contra la expansión de la delincuencia organizada ${ }^{1389}$. Hay que buscar frenarel problema de la delincuencia organizada utilizando medios y técnicas de investigaciones policiales adecuados a nuestra realidad.

No se puede admitir como satisfactoria la simple utilización de medios policiales ya bastante conocidos como las interceptaciones telefónicas 0 las grabacionesaudiovisualesconvencionales para llegar a tan buscada eficiencia penal. Sería una utopía sin posibilidad de alcanzarse la finalidad de combatir los avances de la delincuencia organizada de carácter transnacional ${ }^{1390 .}$

De otra parte, debemos mostrarnos críticos contra el "vale todo" en la búsqueda de obtención de la eficacia de la investigación, pues deberán ser obedecidos ciertos requisitos que corresponden a una actuación policial adecuada al Estado Constitucional de Derecho' ${ }^{1391 .}$

Esto significa sencillamente que principios y reglas de limitación son las balizas del aceptable dentro del contexto de la autorización para el inicio de una medida restrictiva de derechos como son las operaciones encubiertas a través de agentes infiltrados ${ }^{1392}$.

Desde el punto de vista de la dinámica criminal, combatir estas formas graves de criminalidad transnacional exige del Estado un cambio de estrategias de investigación, de modo a permitir un control de la grave situación de inseguridad por la que pasa la comunidad internacional.

\footnotetext{
1389 Mientras que la persecución de la criminalidad convencional está caracterizada por la investigación aislada que realizan las agencias de policía para lograr la presentación de las pruebas ante los Tribunales, de otra parte, la investigación del crimen organizado requiere un modelo más complejo y adecuado para poner limites a esta especie de actuación delictiva.

${ }^{1390}$ De este modo resulta claro que es evidente que ante un fenómeno como la delincuencia organizada no podemos utilizar para su investigación los medios tradicionales a los que estamos acostumbrados, de ahí que ante una situación grave como de la actuación del crimen organizado y de las dimensiones y peligrosidad correspondientes, debemos acudir a medios de investigación extraordinarios o extremos, los cuales se califican así a la vez que pueden suponer una alteración de los principio reguladores del proceso justo, pero siempre con control judicial y respeto, como límite a la garantía de los derechos fundamentales constitucionalmente reconocidos. Cfr. POZO PÉREZ, M., "El agente encubierto como medio de investigación de la delincuencia organizada en la Ley de Enjuiciamiento Criminal española", cit., pág. 280.

1391 Esta la preocupación destacada por PÉREZ GIL al señalar que "el impulso que se deriva del ánimo de combatir el terrorismo y otras formas graves de criminalidad abre la puerta a la introducción de medidas que suponen un alto grado de injerencia en los derechos fundamentales. Con ello, y sin atisbo de crítica, pueden hacer su entrada en las normas procesales disposiciones de carácter excepcional habilitadas por ejemplo para la persecución de gravísimos delitos socialmente muy dañosos, pero que subrepticiamente podrían llegar a generalizarse para cualesquiera modalidades delictivas". Cfr. PÉREZ GIL, J., "Investigación penal y nuevas tecnologías: algunos de los retos pendientes", Revista Jurídica de Castilla y León, núm. 7, 2005, pág. 219.

1392Incluso la infiltración policial, como medio de investigación que es, tendrá una eficacia normal, producirá todas aquellas consecuencias si se cumplen los requisitos establecidos para ella. La eficacia anormal de la infiltración policial se produce cuando el agente infiltrado, con el fin de detener y poner a disposición judicial, así como también con el de obtener pruebas irrefutables de la comisión de un delito induce al sujeto provocado a cometerlo. Vid. MOLINA PÉREZ, T., "Técnicas especiales de investigación del delito: el agente provocador, el agente infiltrado y figuras afines (y II)", cit., pág. 166.
} 
Sin embargo, lo preocupante de todo esto es que esta tarea de investigación criminal se presente en conformidad constitucional, o sea, respetando a su medida, los derechos y garantías fundamentales de las personas, lo que se convierte en un verdadero proceso penal del equilibrio.

Corroborando esta situación, afirma GASCÓN INCHAUSTI que es ya acuciante la necesidad de que el legislador provea a las autoridades de persecución penal con unas técnicas de investigación, forzosamente "nuevas", ante la insuficiencia de las existentes, que se adapten mejor al descubrimiento y obtención de pruebas respecto de las nuevas formas de criminalidad y, en especial, de la organizada ${ }^{1393 .}$

De esta forma, no se puede olvidar que la delincuencia organizada tiene por característica común explotar los tejidos del comercio internacional para lograr ganancias ilícitas, las cuales se acrecientan en la medida que tienen que corromper las relaciones legales para utilizar las ilegales. Hay una correspondencia entre aumento de las ganancias ilícitas con la corrupción de las relaciones económicas lícitas y empleo de las ilícitas ${ }^{1394 .}$

Esta cuestión es importante, en la medida en que para se combatir este fenómeno criminoso, cuyas características son de todo especiales y distintas de la delincuencia habitual, habrá que buscarse el incremento de las estructuras de investigación policial, con vistas a la obtención de resultados eficientes en la desarticulación de las bandas criminales organizadas. Por lo demás, nos parece que tendría el Estado que planificar y establecer una política criminal de repuesta penal y procesal, es decir, ejercitar una política atada a las exigencias de racionalidad y proporción, en definitiva de legitimidad, en la búsqueda del fin de enfrentarse este fenómeno a nivel global.

Desde el planteamiento que aquí se sostiene,la delincuencia organizada responde a parámetros de ocultación de su actividad y desaparición de las huellas y vestigios del delito, y por ello es útil y necesaria la figura del agente encubierto, que por medio de actos de engaño se infiltra en una banda organizada para descubrir sus actividades ${ }^{1395}$, con la finalidad de recoger datos, informaciones y pruebas que puedan ayudar en la desarticulación del agrupamiento criminal, con la detención y punición de las personas pertenecientes al grupo delictivo.

Justificando la elección de la técnica de investigación de las operaciones encubiertas para el combate al crimen organizado destaca D'AMICO que el contraste entre el envejecimiento de los instrumentos de investigación a disposición de las autoridades y el éxito de aquéllos experimentados en los países del common law determinaron la

1393 Vid. GASCÓN INCHAUSTI, F., Infiltración policial y “agente encubierto", cit, pág. 4. Con relación al uso de "nuevas" técnicas policiales invasivas a derechos fundamentales, deberá se hacer hincapié en el sentido de que estas restricciones deben ser adecuadas para lograr el fin perseguido; necesarias, en el sentido de que no exista un medio menos gravoso en términos de afectación de otros principios constitucionales y deben ser proporcionales stricto sensu, esto es, que no se afecten excesivamente valores y principios que tengan un mayor peso que el fin constitucional que se pretende alcanzar.

1394 ZÚÑIGGA RODRÍGUEZ, L., "Criminalidad organizada, Unión Europea y sanciones a empresas", VV.AA., Criminalidad organizada, Almagro, 1999, págs. 58-59.

1395 Cfr. POZO PÉREZ. M., "El agente encubierto como medio de investigación de la delincuencia organizada en la Ley de Enjuiciamiento Criminal española", cit., pág. 280. Caso contrario, tendremos que convivir con la insoportable situación de la "cultura de la supresión de la prueba", que según defendido por ELVIO FASSONE, significaría una contante y casi profesional actividad del crimen organizado en la búsqueda de hacer desaparecer las huellas y cualquier otro señal del delito practicado. Con riqueza de detalles sobre esta problemática probatoria, vid. FAZZONE, E., "La valorización de la prueba en los procesos de criminalidad organizada", cit., págs. 417-464. 
introducción de algunas innovaciones en las legislaciones cuanto a la apuración del crimen organizado, entre los cuales merecen destacarse la acción vigilada, la infiltración de agentes y la protección de los colaboradores de la justicia ${ }^{1396}$.

Puesto que en la actualidad no se cuestiona la insuficiencia de los mecanismos penales vigentes, como tampoco la de los medios tradicionales de investigación policial existentes para luchar contra el fenómeno criminal de la delincuencia organizada, tanto si opera dentro como si lo hace fuera de nuestras fronteras, cuya capacidad de actuación e ilimitados medios de los que dispone supera con creces la infraestructura y las estrictas posibilidades de funcionamiento, propias de cualquier otra manifestación delictiva común, se ha suscitado en los últimos años un debate en torno a la conveniencia de adoptar nuevas soluciones respecto de esta problemática, no solo a nivel interno, penal y procesal, sino también en el marco de la cooperación internacional entre los diversos Estados implicados ${ }^{1397}$.

Como consecuencia, la búsqueda por nuevas soluciones y estrategias de prevención al crimen llevaron a una movilización a nivel mundial, en el sentido de unir esfuerzos para el enfrentamiento de las nuevas formas de criminalidad 1398 .

El problema radica en que la actuación individual de un Estado en tal contexto, sin vinculación con la cooperación internacional, parece expresar insuficiencia e inferioridad frente a realidad que se presenta actualmente ${ }^{1399}$.

Desde otro punto, se observa que en realidad una política criminal eficiente no puede propiciar seguridad solamente a las garantías individuales del investigado en perjuicio del combate a la criminalidad organizada que expone a peligro toda una sociedad. Nos parece que toda regla presenta excepciones, pues deberá por veces, predominar la necesaria salvaguardia a los intereses de la colectividad en detrimento a los derechos individuales de algunos ciudadanos comprometidos con bandas de delincuentes organizados. Se evitaría de este modo la subsistencia de una maléfica y abusiva

\footnotetext{
1396 Cfr. D’AMICO, S., Il collaboratore della giustizia, cit., págs. 86-87.

1397 CARMONA SALGADO, C., "La circulación y entrega vigilada de drogas y el agente encubierto en el marco de la criminalidad organizada sobre narcotráfico", cit., pág.165.

${ }^{1398}$ Basicamente la estrategia de lucha contra la delincuencia organizada se ha definido en la Unión Europea en los siguientes instrumentos: los planes de acción de 1997 y 1998 de lucha contra la delincuencia organizada; las conclusiones del Consejo Europeo extraordinario celebrado en Tampere los días 15 y 16 de octubre de 1999, sobre la creación de un espacio de libertad, seguridad y justicia en la Unión Europea, y la estrategia de 27 de marzo de 2000 para el principio del nuevo milenio sobre la prevención y el control de la delincuencia organizada. Además, la UE coopera con el Centro para la Prevención del Delito y participa activamente en la Comisión de Prevención del delito y participa activamente en la Convención de Prevención del delito y Justicia Penal. En este contexto, la UE apoya los convenios celebrados por las Naciones Unidas para luchar contra la delincuencia organizada. La Comunidad Europea ha firmado el Convenio de las Naciones Unidas contra la Delincuencia Organizada Transnacional y sus protocolos sobre introducción clandestina de inmigrantes, trata de personas y tráfico de armas de fuego. Favorece la ratificación de estos instrumentos y su rápida entrada en vigor, y los utiliza como orientación para la acción dentro de la Unión Europea y para la cooperación de la Comunidad Europea con terceros países. El 19 de julio de 2002, el Consejo de la UE adoptó una decisión marco sobre la trata de personas como complemento del protocolo de las Naciones Unidas sobre el tema.

1399 Por esta razón, con relación a la necesidad de una cooperación internacional en la lucha contra la delincuencia organizada, ha sido muy importante la opinión de PIERO VIGNA al afirmar que "las asociaciones criminales ya no tendrán la posibilidad de insertarse en los espacios vacíos dejados por esta o aquella legislación, eligiendo, para sus operaciones o su refugio, los territorios regidos por la ley que les es más favorable". Vid. VIGNA, P. L., "La cooperación judicial frente al crimen organizado", El crimen organizado. Desafíos y perspectivas en el marco de la globalización, Buenos Aires, 2005, pág. 234.
} 
instrumentalización de las garantías, la cual viene a propiciar una fuerte sensación de inseguridad colectiva ${ }^{1400}$.

A grandes rasgos, éste es el planteamiento seguido por Naciones Unidas y por la Unión Europea, que solventan el eventual conflicto que surja entre la tutela de los derechos fundamentales de los individuos y la eficacia de la investigación penal alegando que se trata de una confrontación más que aparente que real, ya que ambos son valores esenciales del Estado de Derecho que hay que intentar compatibilizar entre sí a partir de la primacía del primero de ellos, si bien que la proliferación del citado fenómeno criminal en su versión transnacional ha puesto de manifiesto la inevitable necesidad de que los Estados y la propia comunidad internacional hayan tenido que crear para repelerlo nuevos instrumentos penales y técnicas de investigación que conllevan altas dosis de intromisión en el ámbito de los derechos personales de los ciudadanos ${ }^{1401}$.

En este contexto, ante el temor de no poder controlar razonablemente la proliferación de los ataques al orden social, merced a la limitación instrumental de instituciones pensadas para una sociedad de características distintas, se volvió necesario apelar a una "legislación de emergencia", que introdujera nuevas técnicas de investigación para luchar contra este tipo de delincuencia, signada por su difícil persecución y comprobación. De este modo, se abrieron paso en el sistema penal de nuevas formas de investigación que involucran a agentes encubiertos, testigos de identidad reservada e informantes.

En aras de conseguir este objetivo,en los últimos tiempos han ido apareciendo en las legislaciones de varios paíseslos denominados "medios extraordinarios de investigación", los cuales, justificados originariamente por la necesidad de reforzar la apuración de hechos delictivos también "extraordinarios" (no sólo por su inusitada gravedad, sino también por los serios problemas que presentan para su persecución), encierran el grave riesgo de legitimar la ilegalidad en la averiguación penal, por violar derechos fundamentales de los investigados.

\footnotetext{
1400 Esta inseguridad colectiva es inherente no solo a las autoridades policiales o judiciales, sino a todos los ciudadanos, pues que la criminalidad y la violencia hacen parte de nuestras vidas. De esta suerte, "la preocupación por la seguridad, exacerbada por el miedo a amenazas criminales ciertas, nos viene a situar en una dimensión novedosa: lo que importa es recoger información, cuanta más mejor, con independencia de su origen público o privado y de que no se sepa a ciencia cierta para qué puede ser utilizada en el futuro. La extensión de medidas preventivas propiciada por la técnica determina que todos nos hayamos transformado en sospechosos, por lo que podemos ser objeto de atención en todo momento. La conservación de datos relativos al tráfico telefónico, al correo electrónico, a los accesos a Internet se encomienda a sujetos privados, pero ello se hace con fines de persecución del delito (o al menos así se justifica). Los poderes públicos se sirven con esa finalidad de quienes ya han puesto su atención sobre nosotros (bien porque hemos prestado nuestro consentimiento expreso o tácito, bien porque la ley nos obliga), requiriendo su colaboración cuando sea preciso". Vid. PÉREZ GIL, J., "Investigación penal y nuevas tecnologías: algunos de los retos pendientes", cit., pág. 219.

1401 En el sentido del texto, ZARAGOZA AGUADO, J., "Tratamiento penal y procesal de las organizaciones criminales en el Derecho español. Especial referencia al tráfico ilegal de drogas", cit., pág. 113 y nota 56. Señala este autor que " quizá por dicha razón, y sin perder de vista los diferentes contextos sociojurídicos, así como la mayor o menor gravedad del problema a combatir, algunos países han probado, con más o menos éxito, una serie de mecanismos legales de excepción o emergencia, cual fue el caso del "Derecho Penal de Excepción o Emergencia", surgido en Italia a finales de los años 70 y primero de los 80 a través de novedosos mecanismos penales y procesales, como sucediera con la figura de los arrepentidos (pentiti) y los privilegios establecidos para los mismos; legislación de emergencia objeto de severa crítica por destacados sectores de la doctrina italiana al haberla calificado de contraria a la normalidad constitucional y resultar absolutamente incompatible con la legislación democrática".
} 
Se hizo imprescindible la adaptación de las técnicas de investigación a la clandestinidad y sinuosidad de la delincuencia1402, o según nos explica la Exposición de Motivos de la Ley 5/1999, las medidas de investigación "parten de la insuficiencia de las técnicas de investigación tradicionales en la lucha contra este tipo de criminalidad organizada, que generalmente actúa en ámbitos transnacionales y con abundancia de medios conducentes a la perpetración de los delitos"1403.

En consecuencia de todo lo anteriormente expuesto, se denota que la motivación de incorporación de la figura del agente encubierto en las legislaciones de muchos países tiene que ver directamente con la insuficiencia de las técnicas de investigación tradicionales en la lucha contra la macrocriminalidad, que generalmente actúa en ámbitos transnacionales y con abundantes medios conducentes a la perpetración de los delitos.

En congruencia con lo expuesto,la gran mayoría de los ordenamientos jurídicos internacionales han previsto formas especiales de investigación que permitan que los organismos especializados se infiltren en los circuitos criminales ${ }^{1404}$.

Efectivamente, parece evidente que una de las más importantes y eficaces técnicas de investigación consiste en las denominadas "operaciones encubiertas", que tienen la finalidad de permitir en regla que el personal especializado de las fuerzas de policía se infiltre en los circuitos ilícitos con el objetivo de lograr descubrir las distintas ramificaciones de la organización criminal, apuntando "los cerebros del grupo" y recogiendo pruebas e informaciones para la desarticulación de la misma.

De outra parte, resulta inteligible que en esto caso, los órganos de persecución penal han validado la figura del agente infiltrado, dándole status de legalidad. En realidad se trata,según CHOCLÁN MONTALVO, de dar cobertura formal al empleo del engaño como método válido y eficaz en la lucha contra la delincuencia organizada1405.

En estrecha relación con lo anterior, la introducción de preceptos legales de creación de la figura del agente infiltrado se justifica en parte por la necesidad que se buscaba de dar cobertura legal a un sinnúmero de operaciones de investigaciones policiales que en la práctica se llevaban a cabo con total normalidad, todavía sin obedecer a criterios y reglas de limitación establecidos en ley.

\footnotetext{
1402 Cfr. la STS 6268/1987 de 9.10.1987.

1403 Para paliar estas deficiencias se introducen en el ordenamiento jurídico medidas legales especiales que permitan a los miembros de la Policía Judicial participar del entramado organizativo, detectar la comisión de delitos e informar sobre sus actividades, con el fin de obtener pruebas inculpatorias y proceder a la detención de sus autores.

1404 Todavía, es muy importante señalar que "en verdad, muchos de los nuevos instrumentos procesales previstos en la legislación en vigor no están todavía debidamente consolidados y direcionados en la law in action, siendo perceptible una cierta ausencia de ajustes en su utilización, situación esta que es relevante en la medida en que se violan, claramente, los principios de proporcionalidad y de necesidad". Vid. BRAZ, J., Investigação Criminal. A organização, o método e a prova. Os desafios da nova criminalidade, cit., pág. 334.

1405 CHOCLÁN MONTALVO, J. A., La Organización Criminal, Tratamiento penal y procesal, cit., pág. 60. Desde esta perspectiva "la dimensión alcanzada en determinadas formas de criminalidad, obliga a los Estados a coordinarse, no sólo en el plano legal sino también en el operativo judicial/policial, para hacerlas frente sin violentar los principios y garantías constitucionales. Es precisamente en este contexto donde debe ser incluida la actividad de infiltración policial (directa o indirecta) en determinados ámbitos delictivos, para conocer, controlar y, en su caso, desbaratar las pretensiones criminales de los responsables, procurando su detención y puesta a disposición judicial. En su opinión, el fundamento del agente encubierto hay que buscarlo en la insuficiencia de las técnicas de investigación tradicionales, motivo por el cual se deben poner en manos de los responsables de la persecución y represión de tales conductas, los instrumentos que legítimamente tengan encuadre en un Estado de Derecho". Véase al respeto, MARTínEZ PÉREZ, R., Policía Judicial y Constitución, cit., pág. 398.
} 
Con la inclusión de preceptos que regulan las infiltraciones policiales se pretende evitar, de un lado, que en la práctica existan actuaciones que aunque aceptadas por la jurisprudencia, y por lo tanto, adecuadas socialmente, puedan violar derechos fundamentales, y de otro, que tales operaciones encubiertas no sean autorizadas sin obediencia a los principios de proporcionalidad y del debido proceso legal ${ }^{1406}$.

Efectivamente, parece evidente que la introducción de nuevas técnicas operativas como las operaciones encubiertas deberán ser admitidas con normalidad, pues incluso la el Tribunal Europeo de Derechos Humanos (caso Teixeira de Castro) ${ }^{1407}$ ha reconocido que el Convenio Europeo de Derechos Humanos "no impide apoyarse, en la fase de la instrucción preparatoria y siempre que la naturaleza de la infracción lo pueda justificar, sobre medios tales como confidentes ocultos", si bien la intervención de agentes infiltrados debe estar circunscrita y rodeada de garantías ${ }^{1408}$.

En este orden de cosas conviene recordar que la intervención del Derecho Penal o Procesal penal en determinadas actividades criminales, por graves que éstas sean, no puede justificar el sacrificio ilimitado de ciertos derechos fundamentales y garantías constitucionales reconocidas por el Estado de Derecho a todos los ciudadanos en general, constituyendo su tutela la esencia de cualquier sistema democrático.

De ello se deriva la necesidad de basar la lucha contra la delincuencia organizada en la rigurosa utilización de medios legítimos que respeten esos valores fundamentales, motivo por el que las técnicas excepcionales de investigación empleadas que conllevan una mayor o menor limitación de los derechos individuales, deben se aplicar en base a criterios restrictivos y bajo estricto control judicial asegurándose de este modo una solución lo más equitativa posible a los intereses en conflicto ${ }^{1409}$.

Dentro del contexto analizado, la figura del agente encubierto responde a una política legislativa tendente a la articulación de medios extraordinarios de investigación al servicio de la fase de instrucción del proceso penal. El problema de fondo que impregna su actuación se relaciona a la necesaria obediencia de requisitos y límites que deberán ser preestablecidos con anterioridad en la ley que autorizar su empleo como técnica de investigación.

Esta figura merece el calificativo de medio de control extraordinario ${ }^{1410}$, al conllevar una alteración de principios constitucionales básicos y una fuerte restricción de derechos fundamentales, razones ambas determinantes de que su empleo quede sometido al

1406 Ciñéndonos al ordenamiento procesal penal español, es importante esclarecer que las SSTS 13233/1982, de 4.3.1992, 1828/1992, de 4.3.1992, 4346/1993 de 21.6.1993 y 7382/1993 de 3.11.1993, ya consideraban lícita la actuación policial, aunque se utilicen procedimientos engañosos y se finjan intenciones irreales, cuando no se origina un delito inexistente, sino que tal proceder sirve para descubrir aquel que ya se había cometido con anterioridad y por tanto, la infiltración es práctica policial que no ofrece ningún reparo.

1407 Véase la STEDH de 9 de junio de 1998. Monograficamente, Cfr. LOUREIRO, J., "Agente infiltrado? Agente provocador! Reflexões sobre o 1o acórdão do T.E.D.Homem - 9.junho.1998. Condenação do Estado Português", Coimbra, 2007.

1408 Respecto a los detalles de la jurisprudencia europea sobre el caso "Teixeira de Castro", vid. CASSANI, B., "Agentes encubiertos e informantes como medios de prueba contra el crimen organizado", Crimen Organizado. Desafíos y perspectivas en el marco de la globalización, cit, pág. 241.

1409 CARMONA SALGADO, C., "La circulación y entrega vigilada de drogas y el agente encubierto en el marco de la criminalidad organizada sobre narcotráfico", cit, pág. 168.

1410 Vid, FERRAJOLI, L., Derecho y razón. Teoría del garantismo penal, cit., pág. 701; DELGADO MARTíN, J., "El proceso penal ante la criminalidad organizada. El agente encubierto", cit., págs. 5-6. 
cumplimiento de estrictos requisitos legales, paliativos de los riesgos para las garantías procesales vigentes en un Estado de Derecho1411.

Efectivamente, parece evidente que la necesidad de se utilizar esta técnica policial como instrumento eficaz de lucha contra algunas modernas formas de criminalidad se somete ineludiblemente a las exigencias del principio de proporcionalidad, cuyo análisis se llevará a cabo en capítulo propio, donde se analizará la trascendental cuestión de la valoración de las pruebas obtenidas durante operaciones realizadas por agentes encubiertos.

Sin embargo, nos encontramos ante un planteamiento legal expuesto a continencias yexigente de una cuidadosa regulación al tenerse que desarrollar en condiciones tales que, haciendo prevalecer el descubrimiento de la verdad material y la aplicación de la ley, deben quedar preservadas debidamente las garantías constitucionales y procesales propias de toda investigación penal en un Estado de Derecho.

De modo contrario, los riesgos ${ }^{1412}$ que suponen las actuaciones de este tipo para el infiltrado y para la propia justicia, no quedarían compensados si la efectividad de lo conseguido quedara sin eficacia procesal por la vulneración de aquellas.

Por fin, aunque se reconozca que la gran mayoría de los ordenamientos jurídicos han reglamentado en los últimos tiempos esta forma de investigación policial, no menos cierto es considerar que el tema de las infiltraciones por agentes encubiertos en el crimen organizado no ha sido tratado en muchas ocasiones con la necesaria seriedad por el legislador, de modo a quedar explicitada la obligatoriedad de respecto a los principios básicos de un proceso penal garantista, en especial el debido proceso legal y la proporcionalidad. Del mismo modo, muchas veces no se establecen límites a la actuación del infiltrado. Así, nos parece que estas imperfecciones vienen a contribuir para las dificultades operacionales en la práctica de las actividades encubiertas, bien como sirviendo de motivo para el aparecimiento de duras críticas contra este medio extraordinario de investigación.

\section{IV.3. La espera por soluciones eficaces en el control de la criminalidad.}

IV.3.1. La necesidad impostergable de establecer un tratamiento procesal adecuado en relación a la criminalidad organizada.

Del mismo modo que no se concibe que el Estado utilice las mismas conductas empleadas por los criminosos, no se puede negar que el mismo deberá dotarse de todos los recursos financieros, materiales y humanos necesarios al cumplimiento de su obligación legal de mantenimiento de la seguridad colectiva, desde que respetado el núcleo esencial de los derechos fundamentales. No obstante, el intérprete y el aplicador de

\footnotetext{
1411 Vid. MONTÓN REDONDO, A et alli., Derecho jurisdiccional III, cit., pág. 207.

1412Versando sobre este aspecto, señala MONTOYA que "se debe tener en cuenta que el hombre que actúa en forma encubierta ha sido debidamente entrenado, que es un experto no solamente como investigador, sino que también debe moverse con una identidad distinta, que abarca los diversos aspectos de su vida de relación, que tiene datos personales ficticios que comprenden distintos hechos que se extienden desde su nacimiento al día en que entra en una operación, en la cual todos los detalles tienen que ser observados cuidadosamente. Sin olvidar que debe vivir lejos de su familia, de sus conocidos y de todo aquello que lo ligue a su vida de todos los días, a fin de que la cobertura no sea descubierta". Vid. MONTOYA, M. D., Informantes y técnicas de investigación encubiertas. Análisis constitucional y procesal penal, cit., pág. 30.
} 
la ley deberán buscar la precisión y la forma más adecuada de establecer la respuesta estatal 1413 .

Con arreglo a lo anteriormente afirmado, cabe señalar que de la misma forma que es totalmente inadmisible el vaciamiento de los derechos fundamentales, es absolutamente inadmisible la preservaciónirrestricta y absoluta de los derechos individuales de los acusados, lo que tornaría imposible o inviable cualquier actividad de represión ${ }^{1414}$. A esta última situación se suele denominar de "abuso de garantías" 1415.

Esto nos pone en presencia de una interesante cuestión donde el proceso algunas veces no es utilizado para la satisfacción de los intereses de la defensa, pero tan solo como consecuencia de una actitud de deslealtad procesal. Así, es imprescindible observar que la amplia libertad que es concedida a las partes en el proceso para la demostración de su pretensión no legitima al exceso y a la abusiva instrumentalidad de las garantías ${ }^{1416}$.

Por esta razón se puede afirmar que los derechos fundamentales, por más esenciales que parezcan, no son dotados de un valor absoluto ${ }^{1417}$, pudiendo ser restringidos 0 flexibilizados en situaciones extremas, como forma de se equilibrar la tensión entre la eficacia y las garantías.

Partiendo de esta línea de pensamiento, la actuación penal represiva del Estado sólo se puede justificar en tanto en cuanto haya seguido escrupulosamente las reglas del respecto a esos derechos y garantías, pero tampoco se puede dejar inerme al Estado, ni a los ciudadanos que sufrirían los efectos de las formas más grave de criminalidad. Es absolutamente necesario que los ciudadanos no puedan sentirse amenazados por el propio Estado a través de sus leyes y actos, pero es también seguro que los ciudadanos no pueden estar sometidos a amenazas genéricas e indiscriminadas, sorpresivas de ser víctimas de delitos especialmente graves ${ }^{1418}$.

1413 En este sentido, BECHARA, F. R., "Criminalidade organizada e procedimento diferenciado: entre eficiência e garantismo", cit., pág. 921.

1414 Vid. RODOVALHO PODVAL, M. F; PODVAL, R., "Das restrições aos direitos e garantias individuais para combate ao terrorismo", Revista Brasileira de Ciências Criminais, núm. 23, 1994, pág. 2.

1415 Vid. con detalles, HASSEMER, W., "Sobre el Ejercicio Abusivo de los Derechos" VV.AA., El Penalista Liberal, J. L. Guzmán Dalbora coord., Buenos Aires, 2004, pág. 119; LUCAS SOSA, G., "Abuso de Derechos Procesales", VV.AA., Abuso dos Direitos Processuais, J. C. Barbosa Moreira coord., Rio de Janeiro, 2000, pág. 46; SOUZA, A. A., O Abuso do Direito no Processo Penal, Rio de Janeiro,2007, pág. 214.

1416 En este sentido, la garantía del debido proceso legal debe ser establecido como un fin útil al proceso penal y no para el ejercicio abusivo de derechos. Sin embargo, se considera un abuso de la defensa cuando se elige el modo más oneroso para la obtención de un determinado resultado, incidiendo en figuras delictivas o en fraudes procesales. Del mismo modo, existe un acto abusivo cuando este se desvía de su finalidad, se utilizando para conseguir este objetivo de una evidencia ausencia de rectitud y lo más grave, se amparando en principios como la amplia defensa y la contradicción.

1417 En España el Tribunal Constitucional ha dejado bien claro que no existen derechos absolutos o ilimitados: "En efecto, no existen derechos ilimitados. Todo derecho tiene sus límites que (...) en relación con los derechos fundamentales, establece la Constitución porsí misma enalgunas ocasiones, mientras en otras el límite deriva de una manera mediata o indirecta de tal norma, en cuanto ha de justificarse por la necesidad de proteger o preservar no sólo otros derechos constitucionales, sino también otros bienes constitucionalmente protegidos" (STC 2/1982, de 29.1.1982). Cfr. también la STC 254/1988, de 21.12.1988 en su Fundamento Jurídico $3^{\circ}$.

${ }^{1418}$ Cfr. GUZMÁN FLUJA, V. C., "El agente encubierto y las garantías del proceso penal", cit., pág. 215. No cabe negar, sin embargo, que desde que la seguridad emergió como problema social y político significativo, no ha dejado de ser una de las cuestiones sociales más preocupantes, siempre con nuevos desafíos a enfrentar. En especial, los albores del siglo XXI se han visto caracterizados por una serie de fenómenos que han puesto en primera línea la discusión sobre la problemática de la seguridad, tanto a nivel nacional como a nivel internacional. La aparición de nuevas formas de delincuencia, la mayor movilidad de personas y bienes en el 
Este contenido anteriormente defendido es la síntesis del proceso penal garantista y comprometido con la defensa de los derechos y garantías fundamentales de los ciudadanos y con el eficaz cumplimiento del reglamento punitivo penal ${ }^{1419}$. Desde este contexto surge como necesidad imperiosa el establecimiento de un proceso penal del equilibrio, ablandándose la tensión entre la eficiencia y las garantías.

Téngase presente, además, que la respuesta estatal debe ser más enérgica y, por lo tanto, proporcional a la gravedad de la situación presentada ${ }^{1420}$, cuya medida y límites se habrán de concretar a partir del respecto a las garantías individuales. Esta noción conducirá inevitablemente al estrangulamiento y a la posibilidad de una mayor flexibilización de los derechos fundamentales que abrigan las libertades públicas individuales, pero jamás el total vaciamiento del núcleo de las garantías constitucionales ${ }^{1421}$.

Conviene en este punto, esclarecer que en ninguno momento de nuestro trabajohemos sostenido una posición radical y cerrada en el sentido de que en la lucha contra las formas más graves de la criminalidad deban los derechos fundamentales inherentes a los ciudadanos quedar expuestos a toda suerte de violación y ausencia de respecto sin un análisis proporcional y legalista del caso en concreto ${ }^{1422}$.

Muy al contrario, hemos defendido que en ciertas situaciones excepcionales, agotado en lo posible todas las formas de investigación ordinarias para se desarticular una organización criminal practicante de delitos de alto grado de afectación social, desde que obedecidos los parámetros de proporcionalidad, deban ser utilizados de forma especialmente cautelosa, medios extraordinarios de investigación como son los agentes encubiertos.

En realidad,con el mayor valor dado al ser humano, existe una característica común a las legislaciones penales consistente en la necesidad de acotar el posible excesivo poder del Estado en beneficio del reconocimiento de las garantías ciudadanas, especialmente en un ámbito como el penal, donde su conculcación puede llevar a consecuencias de difícil

espacio europeo de seguridad y libertad, entre otras muchas cuestiones, han generado nuevos desafíos para la seguridad ciudadana. Cfr. en este sentido, MENDOZA BREMAUNTZ, E., Delincuencia global, Córdoba, 2005, pág. 64; BENEYTO PÉREZ, J. M., "Identidad y conflictos culturales. La nueva perspectiva de laseguridad", VV.AA., La seguridad de la Unión Europea: Nuevos factores de crisis, Cuadernos de Estrategia, núm. 134, Madrid, 2007, págs. 17 a 46.

1419 Quedaría entonces establecida la tan deseada armonía procesal penal. Así, "sólo de ese modo puede alcanzarse el necesario equilibrio de intereses opuestos, siempre presentes en materia criminal, la persecución y castigo del delito, de un lado, y la salvaguarda de la esfera de derechos del sometido al proceso como partícipe en su comisión, de otro sin el cual no puede hablarse de efectiva realización de la Justicia Penal". Cfr. LÓPEZ YAGÜES, V., "Circulación o entrega vigilada de drogas u otros efectos", cit., pág. 244.

1420 DE VERO, G., Tutela penale dell'ordine pubblico, cit., pág. 277.

1421 Vid. BECHARA, F. R., "Criminalidade organizada e procedimento diferenciado: entre eficiência e garantismo", cit., pág. 922.

1422 Siguiendo esta tendencia, señala RUIZ RUIZ que "el que las colisiones entre principios deban resolverse mediante ponderación en cada caso concreto no significa que la solución de la colisión sea solamente significativa para ese mismo caso, sino que pueden establecerse relaciones de prioridad que son importantes para la decisión de nuevos casos. Sin embargo, como pueden surgir nuevos casos con nuevas características que deben ser evaluadas, no es posible construir ningún orden que establezca en cada caso justamente una decisión". Cfr. RUIZ RUIZ, R., " La ponderación en la resolución de colisiones de derechos fundamentales. Especial referencia a la jurisprudencia constitucional española", Revista Telemática de Filosofía del Derecho, núm. 10, 2006/2007, pág. 61. 
reparación ${ }^{1423}$. No cabe negar, sin embargo, que en la misma proporción, cumple al Estado a través de los órganos encargados de la persecutio criminis, la obligación de garantizar la seguridad y la tranquilidad de los ciudadanos, siendo ésta una responsabilidad tanto del propio gobierno como del resto de los poderes públicos, buscando defender la libertad y la seguridad desde la firmeza de nuestros valores democráticos y la fortaleza del Estado de Derecho ${ }^{1424}$.

Llegado a este punto, el razonamiento que se busca plantear dice respecto al hecho de que esnecesario dispensar un tratamiento distinto y con rasgos específicos en el ámbito procesal, frente a la necesidad de se luchar contraa la criminalidad organizada en el marco de su expresivo grado de expansión. Pero esta afirmación no quiere significar un tratamiento de excepción a esta especie de delincuencia, en especial delante de nuestro repudio a cualquier idea basada en los preceptos y fundamentos de un proceso penal del enemigo ${ }^{1425}$.

Teniendo en consideración que el arma a ser utilizada sería el instrumental penal y procesal penal, hay que buscar el exacto punto de equilibrio entre el uso de la fuerza represiva estatal y el debido respecto a las garantías individuales de los investigados.

Como bien explica GÓMEZ COLOMER, el Derecho procesal penal se muestra hoy ante los ojos de la generalidad, consecuentemente, como el producto de un compromiso público entre eficacia de la persecución penal y respeto a la dignidad humana, lo que interrelaciona definitivamente el Derecho procesal penal en la Constitución ${ }^{1426}$. Significa, en otras palabras, más eficiencia penal y en contrapartida más garantías de los derechos constitucionales de los investigados o imputados, todo esto dentro de una zona de equilibrio que venga a demostrar la finalidad instrumental y garantista del proceso penal contemporáneo.

En síntesis, es correcto concluir en un primero momento que el proceso penal es un instrumento democrático y justo donde se puede buscar medios legales para cohibir la proliferación de especies graves de macrocriminalidad, sin el menoscabo irrazonable de los derechos humanos fundamentales.

Lo preocupante de todo esto es que desde la óptica de la mayoría de los miembros de los cuerpos policiales, personas que tienen un largo conocimiento y experiencia respecto de esta problemática, es algo incontestable que la lucha contra la criminalidad organizada en los albores del siglo XXI es muy difícil y deviene en muchas ocasiones

\footnotetext{
1423 Vid. MORILLAS CUEVA, L., Derecho penal. Parte general, fundamentos conceptuales y metodológicos del Derecho penal, Madrid, 2004, pág. 114.

1424 Vid. al Plan de Lucha contra la Delincuencia presentado por el Gobierno español en 12 de septiembre de 2002.

1425 Por este motivo, señala PORTILLA CONTRERAS que "actualmente el sistema procesal penal contra la criminalidad organizada se ha caracterizado por una constante restricción de los principios básicos que rigen el tradicional funcionamiento tanto del Derecho penal como del Derecho procesal penal". Cfr. PORTILLA CONTRERAS, G., "El Derecho penal y procesal del enemigo. Las viejas y nuevas políticas de seguridad frente a los peligros internos-externos", cit., pág. 693. También necesario destacar que "en torno de la ilegitimidad de la razón dictada por la emergencia hobbesiana, el estado de guerra justifica políticamente la ruptura de las reglas del juego". Vid. FERRAJOLI, L., Derecho y Razón, Teoría del garantismo penal, cit., págs 829 y ss.

1426 Vid. GOMÉZ COLOMER, J. L., "Estado de Derecho y Policía Judicial democrática: notas sobre el alcance y límites de la investigación policial en el proceso penal, con consideración especial de los actos de mayor relevancia", cit, pág. 95.
} 
totalmente ineficaz, con instrumentos legislativos en la mayoría de las ocasiones del pasado siglo XIX ${ }^{1427}$.

Desde esta perspectiva, cabe entender que el Derecho Procesal penal contemporáneo contando con técnicas de investigación inadecuadas a la realidad criminológica actual, no responde eficaz y satisfactoriamente al desarrollo y crecimiento de los grupos que integran la denominada "delincuencia organizada transnacional"1428.

Como fácilmente puede deducirse, las características que presentan las nuevas formas de criminalidad organizada, referidas sobre todo a aquellos grupos dedicados a la comisión de delitos relacionados con tráficos ilícitos de todo tipo, con el terrorismo y con la corrupción, ponen de actualidad, por lo menos desde el punto de vista policial, la obligatoriedad de contar con un elemento necesario, y en muchos casos imprescindible para luchar contra los mismos: modernas y eficaces técnicas policiales de búsqueda de datos, informaciones y pruebas contra los clanes criminales.

Este elemento según nuestro entendimiento, amén de otras formas extraordinarias de investigación, estaría constituido por la figura del agente encubierto o infiltrado, procedente de los cuerpos policiales. Sería, pues, la forma más próxima de obtenerse informaciones y datos reales respecto al funcionamiento de una determinada organización criminal $^{1429}$.

Desde esta tendencia, la figura del agente encubierto o infiltrado en una organización criminal, tiene por objeto conseguir pruebas que la desarticulen, de forma que introducirse en la misma puede consistir en cualquier actuación que se imagine, siempre que no se conculquen derechos constitucionales ${ }^{1430}$, o sea, el único objetivo, o finalidad, es el de desvelar y poner de manifiesto el proceder delictivo de los infractores ${ }^{1431}$.

La única consecuencia que se puede arrojarse de lo anteriormente afirmado es que la investigación penal utilizándose de agentes encubiertos, presenta entonces una importancia destacable en la lucha contra la expansión de la criminalidad organizada.

Importante en este momento es señalar que la propuesta que aquí se va a llevar a cabo pretende demostrar que una de las más formidables alternativas en materia de técnicas de investigación, desde que utilizada en consonancia con los principios procesales del debido proceso legal y de la proporcionalidad, es la utilización de las denominadas

1427 Vid. PEÑA ECHEVERRÍA, M. J., "La delincuencia organizada y su problemática desde la óptica de la investigación policial", cit., pág. 163.

1428 En realidad, frente al aumento de las nuevas formas de criminalidad, bien como en razón de la globalización que ha favorecido el crimen organizado, se percibe la aparición de organizaciones criminales que pueden desarrollar actividades delictivas que, cualitativa y cuantitativamente, suponen ataques más agresivos contra la paz social y contra la integridad física y moral de los ciudadanos. Para estos casos, parece lógico que se articulen medios de defensa que sean adecuados a esos mayores niveles de agresión. Y en este punto es donde aparece el recurso a nuevas formas de investigación criminal que tratan de adecuar la respuesta del Estado a las nuevas formas de delincuencia. En este sentido, Cfr. GÚZMAN FLUJA, V., "El agente encubierto y las garantías del proceso penal", cit., pág. 205.

${ }^{1429}$ Esta actuación deberá cumplir con dos requisitos básicos: una regulación expresa de su actuación tras una ponderación legal de intereses, marcando los límites que deberán ser obedecidos durante la infiltración y también se permitirá tal actuación siempre que la misma esté sometida al control jurisdiccional, por poder suponer dichas actuaciones vulneración de derechos fundamentales.

1430 Vid. la STS 7815/2007 de 15.11.2007.

1431 MOLINA PÉREZ, T., "Técnicas especiales de investigación del delito: el agente provocador, el agente infiltrado y figuras afines (y II)", cit., pág. 161. 
operaciones encubiertas a través de infiltración de agentes policiales en el seno de las organizaciones criminales. Desde ahí se podrá obtener todo el conocimiento de informaciones repasadas por los miembros del grupo criminal al agente infiltrado, teniendo en vista el fuerte lazo de confianza y amistad que será firmado entre los mismos.

Sin embargo, teniendo clara la necesidad de se utilizar un agente estatal infiltrado en una determinada organización criminal, surge un gran problema a ser solucionado desde las consecuencias del crimen organizado en el plan procesal penal: la innegable tendencia de restricción de ciertos derechos fundamentales de los investigados e imputados, en la búsqueda de una mayor eficiencia penal.

Para justificar esta tendencia, se entiende que la apuración de la criminalidad organizada exige medidas diferenciadas de las utilizadas para la represión de la criminalidad tradicional, lo que podrá conducir a restricciones de derechos constitucionales ${ }^{1432}$. Esta es una verdad que deberá ser matizada y analizada desde la óptica del establecimiento de un proceso penal equilibrado.

Con el planteamiento expuesto, la infiltración policial ya saltaría a los ojos como una medida que podrá restringir o mejor, provocará siempre fuertes y concretas violaciones a los derechos fundamentales de los investigados ${ }^{1433}$.

Para dar una adecuada respuesta a esta problemática, puntualiza ARMENTA DEU que la tutela de los derechos fundamentales y la limitación de cualquiera de ellos, como medida necesaria para los fines investigadores, debe efectuarse salvaguardando un conjunto de garantías, que en el caso de los respectivos derechos fundamentales, precisamente por carecer de la condición de derechos absolutos, puede legitimar o no la prevalencia sobre otros fines como la investigación penal y la sanción de los delitos. Para juzgar si la priorización fue correcta o aun habiéndolo sido debe prevalecer el efecto devastador de su ilegítima limitación, se examinarán la injerencia en la esfera de los derechos fundamentales y el respeto a toda una serie de requisitos graduados a través de un rosario de consecuencias, anudadas a la relevancia otorgada a cada uno de los mismos. En otras palabras, el análisis de los diferentes presupuestos y requisitos que deben concurrir a la hora de una legítima limitación de un derecho fundamental actuará como criterio relevante en el juicio ponderativo correspondiente sobre las necesidades de tutela del derecho fundamental afectado por la ilicitud ${ }^{1434}$.

También no debe olvidarse que las exigencias de una mayor eficacia al proceso penal y a la represión del delito siempre chocan con la barrera de los derechos

1432 Respecto a esta cuestión, observa SILVA SÁNCHEZ que, "frente al fenómeno de la criminalidad organizada, se impone que algunas garantías procesales sean de nuevo interpretadas, razón por la cual, en los días actuales, entiende inevitable reformas antigarantistas para la apuración de ciertas formas de crimen". Vid. SILVA SÁNCHEZ, J. Màa, La expansión del Derecho Penal. Aspectos de la política criminal en las sociedades postindustriales, cit., págs. 17-18 y 41-42. En la misma tendencia, GARRIDO señala que "los Estados democráticos están siendo obligados a tratar de sus policías y sistemas de justicia con medidas especiales para hacer frente aquellos que no respetan a ninguna regla". Vid. GARRIDO, V., Principios de criminología, cit., pág. 647.

1433 Nos parece tratarse de una realidad indiscutible, si bien que la clave estaría en se consolidar el binomio eficacia-garantías de modo a que los eventuales derechos fundamentales violados no significasen una ponderación irrazonable, sin idoneidad e innecesaria.

1434 Vid. ARMENTA DEU, T., "Exclusionary rule: convergencias y divergencias entre Europa y América", Revista de Estudios de la Justicia, núm. 11, 2009, pág. 90. 
fundamentales y libertades de los ciudadanos ${ }^{1435}$. Este aparente conflicto, a priori irresoluble, deberá ser el gran desafío a ser enfrentado por los órganos de persecución penal, sin todavía consistirse en una misión utópica o imposible.

Luego, lo que se pretende poner de manifiesto es la necesidad de adaptar los instrumentos procesales de investigación al mismo nivel del desarrollo tecnológico atingido por la delincuencia organizada y en condiciones de enfrentar las alteraciones de los padrones de comportamiento adoptados por las organizaciones criminales en las últimas décadas. No se trata de suprimir garantías procesales arduamente conquistadas ensiglos pasados, pero sí compatibilizarlas o flexibilizarlas ${ }^{1436}$ al nuevo paradigma criminal impuesto por las más destacadas formas de criminalidad.

Corresponde esta propuesta en considerar el crimen organizado como una forma de delincuencia sui generis y que demanda soluciones y estrategias distintas, o sea, no diferenciadas en el sentido peyorativo de la palabra, lo que destacaría la idea de privilegio o prejuicio de tratamiento en comparación a la criminalidad clásica o tradicional.

Se puede entonces afirmar que la producción u obtención de la prueba en los procesos que tratan de la criminalidad organizada tornase una tarea compleja, justificándose la necesidad de un tratamiento procesal específico y distinto al utilizado por el proceso penal tradicional.

En virtud de lo expuesto, se percibe en los últimos tiempos una gran dificultad enla obtención de pruebas en los procesos de apuración de actuación de grupos organizados, fruto de la ley del silencio impuesta a los delincuentes pertenecientes al grupo criminal.

Dicho lo anterior, el paso siguiente consiste en reconocer que hubo un cambio en varios ordenamientos jurídicos en la búsqueda de admitirse y por veces reglamentar de forma detallada las medidas de interceptación telefónica y ambientales ${ }^{1437}$, amén de la quiebra del sigilo bancario y fiscal de los investigados y de las infiltraciones policiales.

Y dentro de este contexto de buscarse un tratamiento penal y procesal especifico y diferenciado para los procesos relativos al crimen organizado, estas medidas solo tendrán eficacia jurídica se previamente obtenida la debida autorización judicial, pues así quedarán respetados los principios del debido proceso legal y en especial, de la proporcionalidad, lo que podrá minimizar o justificar las eventuales violaciones a derechos fundamentales como la intimidad, la privacidad y otros derechos de los ciudadanos investigados.

Otra demostración de que debe haber un tratamiento procesal distinto en relación a la persecución de delitos practicados por la delincuencia organizada, desde que respetados los derechos fundamentales del sujeto sometido al proceso penal, sería la

1435 Vid. GASCÓN INCHAUSTI, F., Infiltración policial y “agente encubierto”, cit., pág. 9. Por esta razón, señala DELGADO MARTÍN que "no puede pagarse cualquier precio para conseguir resultados contra las organizaciones criminales. La vía para la regularización existe y su uso dependerá de la voluntad política de los más altos mandos policiales, configurándose como un test sobre el auténtico respeto a las reglas básicas de un Estado de Derecho". Cfr. DELGADO MARTín, J., Criminalidad Organizada, cit., pág. 64.

1436 Cfr. SILVA SÁNCHEZ, J. Måa., La expansión del Derecho Penal. Aspectos de la política criminal en las sociedades postindustriales, cit., pág. 21.

1437 La Recomendación n. 10 del VIII Congreso de la Organización de Naciones Unidas, realizado en la Habana, en el año 1991, ya disponía que "la interceptación de las telecomunicaciones y el uso de métodos de vigilancia electrónicos son también importantes y eficaces" para la apuración del crimen organizado. 
utilización del sistema de videoconferencia ${ }^{1438}$. Se trata, en verdad, de un instrumento y no de un objeto de prueba procesal penal ${ }^{1439}$.

La experiencia internacional demuestra la lógica evidencia de que la adopción del sistema de videoconferencia para la búsqueda y producción de pruebas en el juicio de instrucción criminal, optimiza y acelera la prestación jurisdiccional, en razón de la eliminación de la burocracia y demora de las comunicaciones entre jueces de locales distintos, amén de la contribución para una económica y significativa reducción de los gastos con el dinero público, vez que no habrá necesidad del transporte de los detenidos a la sala de juicios.

De otra parte, si no se utiliza esta técnica, los testigos no van a prestar sus declaraciones libres del temor de venganza por parte de los miembros de la organización criminal. El peligro de fugas de algunos criminales quedará más lejos, vez que a través de la comunicación audiovisual, se impide los rescates de detenidos.

Por fin, las propias autoridades (jueces, fiscales y policías) quedarían más protegidas y a priori, libres de venganzas y actos de intimidación por parte de los delincuentes.

Todavía que se esclarezca que no somos favorables a la utilización del sistema de videoconferencia de modo indiscriminado, muy al contrario, como excepción en las hipótesis de trato con una criminalidad diferenciada y peligrosa como el terrorismo, el narcotráfico y otras formas graves de delincuencia organizada ${ }^{1440}$.

No tendría por justificado que el interrogatorio de un imputado de un simple hurto de unas botellas de agua o mismo de un coche fuera realizado con sistema audiovisual, privando el contacto visual directo del imputado con el Juez de Instrucción, pues que en este caso quedarían sumariamente violados los principios del derecho fundamental de defensa y del debido proceso legal. Además, el costo financiero de esta operación tecnológica no sería adecuado y proporcional a la baja gravedad de la infracción apurada en el proceso penal ${ }^{1441}$.

Como colofón respecto al tema de la busca de establecimiento de un tratamiento especial en la persecución a delitos graves, importante destacar que la aplicación del proceso penal clásico, sin disponer de algunas garantías procesales, que por veces estarán en juego cuando del conflicto entre los derechos fundamentales en las dimensiones colectiva e individual, dificultará por cierto una persecución efectiva y eficaz de las formas de criminalidad organizada.

\footnotetext{
1438 Respecto de la interesante y necesaria utilización de esta técnica, vid. MAGRO SERVET, V., La viabilidad legal del uso de la videoconferencia para la celebración de los juicios penales", Actualidad Jurídica Aranzadi, núm. 519, 2002, págs. 1-5.

${ }^{1439}$ De se destacar que "la utilización de esta técnica no suprime la presencia judicial sino que, bien al contrario, la duplica para que tanto en el lugar en que se encuentran los declarantes como en el lugar del visionado se encuentre una autoridad judicial garante de los derechos fundamentales de la persona". Vid. PENÍN ALEGRE, C., "Nuevos instrumentos de cooperación jurídica internacional con Iberoamérica", VV.AA., Investigación y prueba en el proceso penal, N. González-Cuellar Serrano y A. S. Hermida coods., Madrid, 2006, pág. 405.

1440 Así lo permite el artículo 24, 2 "b", de la Convención de Naciones Unidas contra la Delincuencia Organizada Transnacional.

1441 Destacando este aspecto, la STS 6586/2005 de 16.5.2005 declara que "la celebración de un juicio con la presencia mediante videoconferencia de los acusados debe ser entendida desde planteamientos rigurosamente restrictivos y requiere prestar inexcusable atención a criterios de proporcionalidad que relacionen el sacrificio de sus derechos con la relevancia de las causas que aconsejan semejante medida".
} 
Se llega a una conclusión al fin de este apartado en el sentido de que debe haber un tratamiento no excepcional o menos garantista contra la delincuencia organizada, pero si más eficiente, especializado y adecuado a larealidad actual en cuanto al combate a la expansión del fenómeno criminológico mundial.

Deberá, pues, el Estado promover la utilización de medios y técnicas de investigación y de producción de pruebas, con vistas a la desarticulación de los grupos organizados de delincuentes pero siempre sin olvidarse del necesario e imprescindible respecto a los principios procesales básicos en un proceso penal fundamentado en un Estado constitucional de Derecho. En otras palabras, las sociedades democráticas actuales no pueden vivir y desarrollarse atemorizadas por esas amenazas, tienen que enfrentarse al miedo con valentía, usando los instrumentos que tiene a su alcance, sin olvidar que el primero de ellos es el respeto a la dignidad humana, que constituye el cimiento del edificio sobre el que se construyen las mismas. No vale cualquier método de defensa ${ }^{1442}$.

IV.3.2. La especialización de los órganos de persecución criminal, en especial delMinisterio Fiscal.

IV.3.2.1. Consideraciones generales sobre el Ministerio Fiscal.

Dentro del rol de los sujetos necesarios parael buen funcionamiento de la administración de la Justicia penal destaca por encima de las demás la figura del Parquet ${ }^{1443}$, representada en los días de hoy por la institución del Ministerio Público, Fiscalía o Ministerio Fiscal.

El Ministerio Fiscal no ha aparecido en forma natural en la realidad jurídica, sino que se ha formado con el transcurso de los siglos asumiendo un gran número de funciones que se han ido depurando y al propio tiempo acrecentando, hasta al punto de resultar muy difícil estudiar la institución fuera de unos límites históricos determinados ${ }^{1444}$.

Queda muy claro, pues, que el moderno perfil institucional del Ministerio Publico traduce de modo muy especial uno de los aspectos más importantes de su destinación constitucional, ahora que posee una destacable atribución de velar por la intangibilidad e integridad del orden democrática del Estado.

En este contexto, se puede afirmar que desde la función primitiva de acusador penal, en la actualidad se configura como un auténtico custodio de la legalidad, debiendo intervenir, por lo tanto, siempre que estén en juego normas de carácter imperativo o los derechos fundamentales de los ciudadanos ${ }^{1445}$.

El Ministerio Fiscal es un órgano colaborador de la jurisdicción regido por los principios de legalidad, imparcialidad, unidad y dependencia jerárquica. Incluso el art. 124

1442CONDE-PUMPIDO TOURÓN, C., "El Ministerio Fiscal frente a la nueva criminalidad", Cuaderno del Instituto Vasco de Criminología, San Sebastián, núm. 20 , 2006, págs. 98-99. roi).

1443Terminología originaria del idioma Francés que significaba el órgano del Ministerio Fiscal (les gens $d u$

1444 SERRA DOMíngUEZ, M., "El Ministerio fiscal", Revista de Derecho Procesal Iberoamericano, núms. 3 y 4 , Madrid, 1979, pág. 611. Monográficamente respecto al desarrollo de la institución del Ministerio Fiscal en España, muy especialmente en cuanto a su ubicación constitucional, vid. FLORES PRADA, I., El Ministerio Fiscal en España, Valencia, 1999.

1445 Cfr. PÉREZ-CRUZ MARTíN, A. J.; FERREIRo BAAMONDE, X. X; PIÑOL RODRÍGUEZ, J. R; SEOANE SPIEGELBERG, J. L., Derecho Procesal Penal, 1aㅡ edición, Navarra, 2009, pág. 106. 
de la Constitución española1446le otorga la función de "promover la acción de la justicia en defensa de la legalidad", lo que, en el ordenamiento procesal penal se traduce en la obligación de ejercitar la acción penal ante la sospecha de la comisión de un delito público y con la sola excepción de los dependientes de la instancia privada (art. 105 LECrim) ${ }^{1447}$.

De todo modo, es común afirmarse que la actuación del Ministerio Fiscal en el proceso penal resulta trascendente, ya que es parte necesaria en los procedimientos penales por delito público que se desarrollan ante los tribunales de justicia1448. Y más que esto, pues la sujeción a la legalidad se erige en canon fundamental de la actuación de este órgano ${ }^{1449}$.

Efectivamente, parece evidente que en el ámbito de un proceso penal garantista deberá esta institución buscar la protección de los derechos humanos, procurando evitar la ocurrencia de abusos cometidos por el Estado cuando de la persecución penal. Del mismo modo, deberá prestar especial atención a la defensa de los derechos y garantías fundamentales en sentido amplio, objetivando la manutención del respeto a la libertad y la dignidad de la persona sometida al proceso penal.

De lo dicho resulta que se trata de un órgano que representa la sociedad, monopolizando parcialmente el ejercicio de la acción penal ${ }^{1450}$, y teniendo la obligación de pautar sus actuaciones en el respeto al debido proceso legal, manteniendo de esta forma los pilares del Estado de Derecho.

Si lo anterior es correcto, entonces el Ministerio Fiscal defiende la legalidad exigiendo responsabilidades a los infractores de las normas de convivencia. Para ello ejercita ante los Tribunales la acusación pública ${ }^{1451}$.

Con el planteamiento expuesto, queda muy clara la importancia del Ministerio Fiscal en el contexto de la justicia penal, a la vez que al mismo tiempo en que deberá ejercer su legítima función de dominus litis de la acción penal, posee la tarea de evitar la violación innecesaria y sin racionabilidad de las garantías procesales previstas en el ordenamiento constitucional.

Por fin, importante destacar que en casi todos los ordenamientos jurídicos marcados por el respecto al Estado constitucional de Derecho ha sido muy discutible la cuestión en torno a si el Ministerio Fiscal debe dirigir la investigación ${ }^{1452 .}$

1446 El art. 124 de la CE atribuye al Ministerio Fiscal la misión de promover la acción de la justicia en defensa de la legalidad, de los derechos de los ciudadanos y del interés público tutelado por la ley, así como de velar por la independencia de los Tribunales y procurar ante estos la satisfacción del interés social.

1447GIMENO SENDRA, V., Derecho procesal penal, cit., pág. 182.

1448 Vid. con más detalles, RICHARD GONZÁLEZ, M., "La competencia del Ministerio Fiscal para la investigación de actos delictivos. Diligencias preliminares y competencias de instrucción en el procedimiento de menores", VV.AA., Estudios sobre prueba penal. Actos de investigación y medios de prueba en el proceso penal: competencia, objeto y límites, volumen I, Madrid, 2010, pág. 249 y ss.

${ }^{1449}$ STC 115/1994, de 14.4.1994.

1450 Mejor explicando, en varios ordenamientos penales como el caso de España, el Ministerio Fiscal no goza del principio del "monopolio de la acción penal", sino que ha de compartirla con los particulares. Cfr. GIMENO SENDRA, V., Derecho procesal penal, cit., pág. 202.

1451 Vid. CONDE-PUMPIDO TOURÓN, C., "El Ministerio Fiscal frente a la nueva criminalidad", cit., pág. 99.

${ }^{1452}$ Cfr. DEL MORAL GARCÍA, A., "Ministerio Fiscal y reforma de la justicia", Jueces para la democracia, núm. 43, 2002; FUENTES SORIANO, O., "La instrucción por el fiscal en un nuevo proceso penal", VV.AA., Nuevos retos de la justicia penal, J. Mạ. Asencio Melado y O. Fuentes Soriano coords., Madrid, 2008, págs. 163-192. 
El gran problema que se observa es que la asunción por el Ministerio Fiscal de la dirección de la fase de investigación de las causas penales ha venido siendo considerado como una de las cuestiones puntales de la futura reforma integral del enjuiciamiento penal en España ${ }^{1453}$. Esta controversia se erige en tema de moda en el proceso penal cuando se tratan de cuestiones relacionadas a la investigación criminal.

Lejos de consistir en nuestro propósito profundizar en este asunto, dado que nuestro objetivo en la investigación es distinto, nos cabe al menos antes de tratarnos de la especialización de las fiscalías en la lucha contra el crimen organizado referirnos al hecho de que cierto es que el Ministerio Fiscal en los últimos tiempos ha visto ampliadas de manera notable no sólo sus funciones, sino también sus posibilidades de intervención en la fase de instrucción de los procesos penales.

$Y$ en este sentido, el trabajo de las fiscalías ha tenido una importancia muy fundamental en los casos que tratan de delitos practicados por grupos criminales organizados, especialmente en relación al terrorismo y al narcotráfico ${ }^{1454}$. De este modo, el Ministerio Fiscal ha sido considerado en un sinnúmero de ordenamientos jurídicos ${ }^{1455}$ como un órgano con capacidad para operar competentemente en la coordinación de la fase de investigación, si bien que siempre en cooperación con la policía que sería la institución ya históricamente reconocida como titular del labor de la investigación.

En España, cierto segmento de la doctrina apunta en el sentido de que resulta indudable que la posición del Ministerio Fiscal en el sistema institucional le garantiza una especial posición que le habilita y permite investigar los hechos delictivos que, posteriormente y en caso de que proceda, fundarán las acciones penales que la fiscalía interponga ante los tribunales de justicia ${ }^{1456 .}$

1453 Para una visión critica respeto a esta discusión, vid. CABEZUDO RODRÍGUEZ, N., "Sobre la conveniencia de atribuir la instrucción penal al Ministerio Fiscal", Revista Jurídica de Castilla y León, núm. 14, 2008, págs. 187 y ss.

1454 Incluso habrá que registrarse que el Tratado de Lisboa prevé en su texto la creación de una Fiscalía Europea, la cual tendrá como antecedente lógico la implantación efectiva de Eurojust, para combatir las infracciones que perjudiquen a los intereses financieros de la Unión Europea. Con respecto a las funciones de esta Fiscalía especial, establece incluso el artículo 86 del Tratado de funcionamiento de la Unión Europea, que asumirán las funciones de investigar, incoar un procedimiento penal o solicitar la apertura de juicio y órganos jurisdiccionales competentes de los Estados miembros la acción penal relativa a dichas infracciones. Vid. RODRÍGUEZ GARCÍA, N., "Cooperação judicial penal e Ministério Público Europeu", Revista dos Tribunais, núm. 834, 2005, págs. 456 y ss.

${ }^{1455}$ Efectivamente, parece evidente el éxitoobtenido por la figura del Fiscal investigador en losmodelos francés, alemán e italiano, que suelen tomarse como referencia, bien como es preciso tomar en cuenta modelos como el holandés, el polaco o el austriaco. También a favor del poder de investigación del Fiscal, véase en Brasil, la jurisprudencia reciente del STF: HC 87610/2009 y HC 83492/2010.

1456 En este sentido, Cfr. RICHARD GONZÁLEZ, M., "La competencia del Ministerio Fiscal para la investigación de actos delictivos. Diligencias preliminares y competencias de instrucción en el procedimiento de menores", cit., pág. 262. También importante señalar que aunque la investigación criminal nunca ha sido atribuida explícitamente al fiscal, a pesar de los arts. 284 y 295 de la LECrim, se puede extraer de la Constitución española, en el art. 126, el poder de investigar al Ministerio Fiscal. Del mismo modo, destacable es la opinión de RIFÁ SOLER al afirmar que "en la actualidad corresponde al ministerio fiscal la dirección y coordinación de la investigación preprocesal. También dirigirá la investigación policial y podrá acordar por propia iniciativa las diligencias preliminares de investigación del hecho punible que estime adecuadas". Cfr. RIFÁ SOLER, J. M., "Actos de investigación, actos de instrucción y actos de prueba", VV.AA., Estudios sobre prueba penal. Actos de investigación y medios de prueba en el proceso penal: competencia, objeto y límites, Madrid, 2010, pág. 124. 
En este contexto, la dirección de la investigación sumarial por parte del Ministerio Fiscal supondría no sólo un incremento del principio acusatorio, sino también la celeridad de la fase instructora, donde actualmente se concentran la mayoría de las dilaciones indebidas. El Juez de Instrucción vería reducida su competencia a las funciones estrictamente jurisdiccionales, de modo que la práctica de los actos de investigación sería encomendada al Ministerio Fiscal y a la Policía Judicial, mientras el Juez conservaría sus atribuciones en todo lo relativo a la adopción de medidas limitativas de los derechos fundamentales, medidas cautelares y actos de prueba anticipada y preconstituida ${ }^{1457}$.

Sin embargo, de otra parte se defiende en la doctrina que no sería el Ministerio Fiscal la persona idónea para asumir la investigación, por ser esta función ajena a los cometidos del mismo. Además, la configuración constitucional de esta Institución cifra su campo de actuación en el ámbito del proceso y no fuera del mismo ${ }^{1458}$.

También en sentido crítico al otorgamiento de la instrucción al Ministerio Fiscal, se suele destacar que la asunción de dicha competencia le impediría en realidad desarrollar otras funciones, y entre ellas la de vigilar la actividad investigadora que en el proceso penal se desarrolla para comprobar si la misma se ajusta a la legalidad vigente y sobre todo, si la misma es respetuosa con los derechos de los ciudadanos. Por tanto, si asume la investigación mal podrá observar sus defectos y tratar de corregirlos, y por ende, le resultará sumamente difícil defender derechos y libertades de los implicados contra las posibles desviaciones derivadas de su propia actividad ${ }^{1459}$.

1457 Presentando detalladamente su opinión sobre la cuestión, con aportes significativos sobre la posición del Fiscal en el derecho comparado, vid. GIMENO SENDRA, V., El Ministerio Fiscal - Director de la Instrucción, 1aㅡ edición, Madrid, 2006. En breve resumen, defiende este autor que hay que cambiar el modelo e instaurar la figura del fiscal director de la investigación, porque sin ese modelo no hay posibilidad de mitigar la dilación en la instrucción de las causas. Ahora bien, hay distintos modelos de fiscales investigadores, y no todos son igual de adecuados para el caso español. A su juicio, no se puede aplicar el sistema anglosajón porque es un modelo de justicia de clase, en el que la investigación la hacen las partes. En España debería se elegir el modelo de fiscal europeo continental y, dentro de él, el de fiscal imparcial, y descartar el modelo de fiscal independiente, que ha dado malos resultados y provocado cientos de condenas por dilación indebida en la experiencia italiana, por ejemplo. Imprescindible además, señalar que durante la realización del Seminario "La posición del Fiscal en la investigación penal: la reforma de la ley de enjuiciamiento criminal", ocurrido en el Centro de Estudios Jurídicos, en Madrid, el 26 de abril de 2005, las posiciones a favor de la creación del Fiscal investigador fueron mayoritarias (Moscoso del Prado, Pantoja, LópezBarja, Quintero, Asencio, Vives y Tejada) y se apoyaron en diversas razones, pero entre ellas especialmente la necesidad de separar la persona que investiga de quien tutela los derechos de los investigados (Moscoso del Prado), para que quien en sus investigaciones, sea Fiscal o sea Juez, tenga que alterar algún derecho fundamental, deba pedirle permiso al otro. Y si la investigación la realiza un Juez (instructor), haría falta otro juez (un Juez de garantías), así que lo lógico es que la investigación la lleve a cabo elFiscal, y que sea el juez quien autorice los pasos de la investigación cuando éstos afecten a derechos. LópezBarja justificó la atribución al Fiscal de la investigación en la necesidad de proteger el principio acusatorio en el proceso penal, puesto que el Juez Instructor tiene naturaleza inquisitiva, desde sus orígenes y hoy también, y si el sistema que establece la Constitución se basa en el principio acusatorio, entonces la instrucción también, y es preciso que se dé esa separación entre quien investiga y quien decide sobre derechos fundamentales.

1458LLERA SÚAREZ-BÁRCENA, E, El modelo constitucional de investigación penal, cit., pág. 123. Siguiendo este pensamiento, señala FAIRÉN GUILLÉN que "la instrucción dirigida por el Ministerio Fiscal puede predicarse en aquellos países en que dicho Cuerpo sea autónomo o mejor, independiente del Poder Ejecutivo. Pero si no los es (como sucede en España) el hacerlo instructor es exponernos a que instruya el Ministro de Justicia por medio de órdenes. Y si le autorizamos además, a sobreseer, resultará que habremos creado un nuevo modelo de proceso penal no jurisdiccionalizado a disposición de la policía". Cfr. FAIRÉN GUILLÉN, V., " Imagen preliminar y fragmentaria de la Reforma Procesal Penal a fines de 1991", Revista de Derecho Procesal, núm. 1, 1992, pág. 14.

1459Vid. de modo crítico, ECHARRI CASI, F. J., "Las partes en el proceso penal. Alcance de la responsabilidad subsidiaria", http://www.cej.justicia.es/pdf/publicaciones/secretarios_judiciales/SECJUD19.pdf. Siguiendo esta línea de pensamiento, señala GARBERÍ LLOBREGAT que "toda la fase de investigación conducente al 
Frente a estas posiciones anteriormente citadas, nos parece más correcto comprender la cuestión partiendo de la consideración de que el modelo del fiscal investigador introduce una mayor agilidad al evitar la duplicidad de diligencias, y además sitúa la investigación en su verdadera dimensión al atribuírselas tanto al órgano público de acusación, que debe promover la acción de la justicia y el aseguramiento del delincuente.

\section{IV.3.2.2. La creación de fiscalías especiales.}

La delincuencia organizada transnacional es el principal reto al que se enfrenta en su trabajo el Ministerio Fiscal. Ha invadido la actual economía globalizada, a la que limita su eficacia y competitividad; corroe las instituciones del Estado democrático, que pone a su servicio en detrimento de los ciudadanos; y pervierte las instituciones financieras al utilizar sus circuitos para disfrutar de sus intensos beneficios. Así, el Ministerio Fiscal tiene que combatirla con absoluta decisión y empleando todos sus medios ${ }^{1460}$.

Frente a los avances en términos de crecimiento de las formas más graves de delincuencia, han sido creadas en algunos países, fiscalías especiales con la finalidad de laborar directamente en los casos de delitos practicados por los grupos de criminales organizados, especialmente con relación al terrorismo y al narcotráfico.

Un buen ejemplo se observa en España, donde la especialización del Ministerio Fiscal ha sido decisiva en las investigaciones complejas a ejemplo del terrorismo, del blanqueo de capitales y del narcotráfico.

Esta actuación de la fiscalía contra la delincuencia organizada se ha concretado mediante la creación de tres fiscalías especiales o especializadas que confluyen en numerosos procedimientos en la Audiencia Nacional: la Fiscalía de la Audiencia Nacional, la Fiscalía Antidroga y la Fiscalía contra la Corrupción y la Criminalidad Organizada.

Sin embargo, según GONZÁLEZ MOTA, debe hacerse una doble precisión: existe delincuencia organizada distinta de la del narcotráfico, corrupción o terrorismo, y no todos los procedimientos atribuidos a la competencia de estas fiscalías se refieren a crimen organizado; en el caso de la Fiscalía de la Audiencia Nacional, por ejemplo, se conocen de acuerdo a las normas de competencia española de procedimientos como los relativos a españoles cometidos en el extranjero que no guardan relación con la criminalidad organizada ${ }^{1461 .}$

A continuación, serán expuestos algunos aspectos generales delas principales fiscalías especiales en actuación en el ordenamiento español vigente.

esclarecimiento de los hechos típicos y a la determinación de la culpabilidad del presunto responsable no debería poder llevarla a cabo el Ministerio Fiscal instructor sin que previamente haya solicitado al Juez la apertura del correspondiente proceso penal, y sin que éste, valorando la existencia de indicios racionales de criminalidad, como sucede en el momento presente, decida dictar el correspondiente auto de incoación del proceso penal (y ello incluso en los supuestos en los que no se manifestase imprescindible, ni adoptar medidas cautelares, ni acordar diligencias de prueba anticipada o de investigación restrictivas de derechos). Cfr. GARBERÍ LLOBREGAT, J., "¿Fiscal Instructor? Pocas ventajas y un enorme inconveniente", Revista Jurídica de Castilla y León, núm. 14, 2008, pág. 175.

${ }^{1460} \mathrm{Cfr}$. la Instrucción 4/2006 de la Fiscalía General del Estado, http:://www.fiscal.es.

1461 GONZÁLEZ MOTA, V. J., 'La especialización de la Fiscalía en la investigación de la criminalidad organizada", VV.AA., Corrupción y delincuencia organizada, cit., págs. 387-388. 
La primera de las fiscalías que componen la estructura del Ministerio Fiscal en España es la Fiscalía de la Audiencia Nacional. Este Tribunal especializado en materia de delitos graves practicados por la delincuencia organizada ya sido creado por el Real Decreto-Ley 1/1977, y tiene como competencia conocer entre otros de los delitos de falsificación de moneda, monetarios y relativos al control de cambio (art. 65.1 b LOPJ), defraudaciones y maquinaciones para alterar el precio de las cosas en los casos más graves (descritos en el art. 65.1 c LOPJ), terrorismo (delitos de los arts. 571 a $580 \mathrm{CP}$ ); y tráfico de drogas con efectos en varias provincias (art. 65. $1 \mathrm{~d}$ LOPJ) ${ }^{1462}$.

Importante destacar según SÁNCHEZ GARCÍA DE PAZ que existen en la Audiencia Nacional dos fiscalías especiales ${ }^{1463}$ : la Fiscalía Especial para la evitación y la lucha contra el tráfico de drogas, creada por la Ley 5/1988 y la Fiscalía Especial para la evitación y la lucha contra los delitos económicos conectados a la corrupción, creada por la Ley 10/1995 (ésta última importante con relación al delito de blanqueo de capitales) ${ }^{1464}$.

Ya la denominada "Fiscalía Antidroga", interviene en los procesos penales por delitos relativos al tráfico de drogas, estupefacientes y sustancias psicotrópicas o blanqueo de capitales relacionado con dicho tráfico, que sean competencia de la Audiencia Nacional.

De este modo, la Fiscalía Antidroga esta adscrita a la Audiencia Nacional, presentando como funciones en la lucha contra la delincuencia organizada, lo descrito en al art. 18 bis E.O.M.F ${ }^{1465}$ y en la Instrucción 1/1995.

Esta Fiscalía interviene habitualmente en reuniones con diversos organismos nacionales; en unos casos, Comité Permanente y Comisión de Prevención del Blanqueo de Capitales, por estar prevista expresamente la presencia de un miembro de esta Fiscalía en ambos organismos. En otros casos se ha tratado de reuniones ad hoc, a las que ha sido convocada la Fiscalía Especial para tratar cuestiones de interés común, o conocer la opinión de la misma sobre determinadas materias, especialmente con la Delegación del Gobierno en el Plan Nacional Contra las Drogas.

1462 Según BALACLOCHE PALAO y ZARZALEJOS NIETO, sería así la Audiencia Nacional "un conjunto de Tribunales unipersonales y colegiados, integrados en los órdenes penal, social y contencioso-administrativo, que extienden su jurisdicción a todo el territorio nacional (arts. 62 y 64 LOPJ)". Vid. BALACLOCHE PALAO, J; ZARZALEJOS NIETO, J., Aspectos fundamentales de Derecho Procesal Penal, Madrid, 2010, pág. 52. Importante también es destacar que el panorama competencial de la Fiscalía de la Audiencia Nacional se ha visto sustancialmente modificado tras la reforma del artículo 23.4 de la LOPJ. por la Ley Orgánica 1/2009, de 3 de noviembre. La modificación legal superó el último trámite parlamentario en el Congreso de los Diputados el día 15 de octubre de 2009, y ha sido publicada en el «Boletín Oficial del Estado» (BOE) del miércoles 4 de noviembre de 2009. La novedad más importante es la introducción de criterios que legitimen el ejercicio de la jurisdicción española para enjuiciar los crímenes cometidos en cualquier parte del mundo, y la conclusión a la que se llega al examinar la nueva regulación es que la reforma está inspirada en la doctrina plasmada por el Tribunal Supremo en las resoluciones dictadas en los casos Guatemala y Caso Falun Gong. En síntesis, el Alto Tribunal desarrollaba una interpretación del anterior artículo 23.4 LOPJ armonizando las exigencias del principio de jurisdicción universal con otros principios de derecho internacional, como el principio de no intervención en los asuntos de otros Estados previsto en el artículo 2.7 de la Carta de Naciones Unidas, el principio de proporcionalidad o el principio de la necesidad de un punto de conexión legitimante. Cfr. la Memoria de la Fiscalía Especial del año 2010, http:://www.fiscal.es.

1463 De esto modo, "las Fiscalías Especiales, constituyen, sin lugar a dudas, órganos especializados por razón de la materia". Vid. FLORES PRADA, I., El Ministerio Fiscal, cit., pág. 683.

${ }_{1464}$ SÁNCHEZ GARCÍA DE PAZ, I., La criminalidad organizada. Aspectos penales, procesales, administrativos y policiales, cit., pág. 286.

1465 Estatuto Orgánico del Ministerio Fiscal (Ley 50/1981). 
En estrecha relación con lo anterior, la Fiscalía Especial Antidroga ha tenido una amplia actuación en el ámbito internacional, con la asistencia de sus miembros a numerosas reuniones y cursos de formación relativos a cuestiones de su competencia.

De otra parte, la Fiscalía contra la corrupción y la criminalidad organizada, investiga y conoce de los procesos penales de especial trascendencia, relativos a los delitos económicos u otros cometidos por funcionarios públicos en el ejercicio de sus cargos relacionados con el fenómeno de la corrupción. También asume las investigaciones de los delitos económicos cometidos por grupos organizados ${ }^{1466}$.

Así, esta Fiscalía conocida también como "Fiscalía Anticorrupción", no esta vinculada a ninguno órgano jurisdiccional y de hecho, actúa en todo el territorio español por razón de la competencia por la materia. Además, importante aducir que en el desarrollo de la Ley 10/1995, el Fiscal General del Estado estableció en la Instrucción n. 1/96, actualizada por la Instrucción n.․ 4/2006 "sobre atribuciones y organización de la Fiscalía Especial para la represión de los delitos económicos relacionados con la corrupción y sobre la actuación de los fiscales especialistas en delincuencia organizada", las normas de funcionamiento de la misma ${ }^{1467}$.

Por lo tanto la Fiscalía cuenta con el apoyo de unidades de la Guardia Civil y de la Policía Nacional, así como el asesoramiento de funcionarios de la Agencia Tributaria y de la Intervención General de la Administración del Estado que asesoran y colaboran con el Ministerio Público en la persecución de estos delitos ${ }^{1468}$.

Por fin, deberá hacerse hincapié respecto a la creación de una Fiscalía especial coordinadora de urbanismo, medio ambiente y ordenación del territorio, la cual tiene incluso competencia para actuar en casos de corrupción ${ }^{1469}$.

Las funciones que desempeña esta Fiscalía especializada se encuentran explicitadas en el art. 20.2 del E.O.M.F, de entre las cuales se destacan la coordinación de las diversas Fiscalías en materias de medio ambiente y urbanismo, unificando los criterios de actuación, para lo cual podrá proponer al Fiscal General del Estado la emisión de las correspondientes instrucciones y reunir cuando proceda, a los Fiscales integrantes de las Secciones especializadas, bien como ejercitar la acción pública en cualquier tipo de procedimiento, directamente o a través de instrucciones impartidas a los delegados, cuando aquella venga prevista en las diferentes leyes y normas de carácter medio ambiental, exigiendo las responsabilidades que procedan. Si bien que la más destacable atribución institucional de esta Fiscalía especializada consiste en practicar las diligencias a que se refiere el art. 5 del E.O.M.F, e intervenir directamente o a través de instrucciones impartidas a los delegados, en aquellos procesos penales de especial transcendencia apreciada por el Fiscal General del Estado, referentes a los delitos relativos a la ordenación del territorio, la protección del patrimonio histórico, los recursos naturales y el medio ambiente, la protección de la flora, fauna y animales domésticos y los incendios florestales.

\footnotetext{
1466 Con más detalles, en la página oficial del Ministerio Publico español, http://www.fiscal.es.

1467 Vid. GONZÁLEZ MOTA, V. J., "La especialización de la Fiscalía en la investigación de la criminalidad organizada", cit., pág. 393.

1468Vid. GONZÁLEZ MOTA,V. J., "La especialización de la Fiscalía en la investigación de la criminalidad organizada, cit., pág. 395.

1469 Monográficamente, vid. VERCHER NOGUERA, A., "Reflexiones sobre ministerio fiscal y la lucha contra la corrupción en medio ambiente", VV.AA., Corrupción y delincuencia económica, N. Rodríguez García y E. Fabián Caparrós coords., Bogotá, 2008, págs. 447-466.
} 
Importante dentro del tema de la actuación de las fiscalías especiales es destacar que en España el Ministerio Fiscal recomienda a sus miembros la utilización de medios extraordinarios de investigación, a ejemplo de las entregas vigiladas y del agente encubierto, insiriendo estas técnicas en la investigación criminal patrimonial en el ámbito del proceso penal. En este sentido, la Circular 4/2010 de la Fiscalía General del Estado define que: "También el Fiscal podrá autorizar la técnica del agente encubierto, en los casos y con las formalidades previstas en el art. 282 bis LECrim, en su redacción dada por LO 5/1999, de 13 de enero, modificada por LO 15/2003, de 25 de noviembre y LO 5/2010 de 22 de junio. En su virtud, en estos supuestos habrá que procederse a la inmediata judicialización del expediente, en tanto el apartado primero de este precepto exige del Fiscal que cuando autorice la técnica de investigación dé cuenta inmediata al Juez. A tales efectos, aun cuando la Ley no lo especifica habrá de entenderse que tal dación de cuenta con remisión de las diligencias de investigación hasta el momento tramitadas habrá de darse al Juzgado de Instrucción o Central de Instrucción de Guardia competente, con el fin de cumplir esa legalmente exigida inmediatez en la dación de cuentas".

También en Italia ha sido muy importante la creación de fiscalías especiales en la lucha contra la delincuencia organizada. En este sentido, se destacan la Dirección Nacional Antimafia y el Procurador Nacional Antimafia (art. 371 bis del Código Procesal Penal).

El papel de la Dirección Nacional Antimafiaes la coordinación investigativa en materia de criminalidad organizada, tanto nacional como internacional. Se compone del Procurador Nacional y de veinte magistrados del Ministerio Público ${ }^{1470}$. A su vez, están las Direcciones Distritales Antimafia, veintiséis en todo el país, que son las que investigan y la Dirección investigativa antimafia que depende del Ministerio del Interior, y en la que forman parte la Policía del Estado, Carabineros y la Guardia de Finanzas, y que está encargada de coordinar la investigación preventiva de las actividades del crimen organizado y realizar las indagaciones propias de la policía judicial.

Todas las actividades emprendidas por estos organismos tienen como eje central la centralización y la especialización. Es la única forma de enfrentar adecuadamente determinadas estructuras organizativas de orden criminal. Además, en el plan internacional su trabajo se coordina con otras instituciones policiales y judiciales ${ }^{1471}$.

Para cerrar esta presente sección, deberá concluirse que la creación y estructuración de fiscalías específicas para el enfrentamiento a la delincuencia organizada reflecte la necesidad de especialización de los órganos de persecución penal, con vistas a poner en práctica el principio de igualdad de armas, donde la eficacia estatal podrá ser buscada con más éxito en razón de la complejidad de los asuntos que serán objeto de tratamiento judicial.

Ahora bien, para el combate a los delitos originados de una verdadera empresa creada para la práctica de delitos graves que provocan repercusión social y destacados perjuicios al Estado y a la sociedad, tornase imperiosa la instalación de estas fiscalías dotadas de miembros con una formación especializada, amén de una estructura logística y

1470 En Italia no hay separación entre magistrados y Ministerio Público, pues ambos forman parte del Poder Judicial. Con más detalles sobre esta distinción, Cfr. TONINI, P., Diritto processuale penale. Manuale breve, Milán, 2009.

1471 Vid. con detalles, CARNEVALI RODRÍGUEZ, R., "La criminalidad organizada. Una aproximación al derecho penal italiano, en particular la responsabilidad de las personas jurídicas y la confiscación", Revista Ius et Praxis, año 16, núm. 2º 2010, pág. 289. 
humana diferenciada y en condiciones de buscarse la condena de los miembros de una determinada organización criminal. 


\section{CAPÍTULO QUINTO: BÚSQUEDA DE UNA REGLAMENTACIÓN IDEAL Y ESPECÍFICA DE LA FIGURA DEL AGENTE ENCUBIERTO}

\section{V.1. Los requisitos básicos para ponerse en práctica la infiltración de un agente encubierto.}

Hasta ahora hemos tenido la oportunidad de enfrentar un vasto rol de cuestiones que rodean el entorno de la figura denominada agente encubierto o infiltrado. Así es que desde la conceptuación y origen histórico, pasando por los principios y características más destacadas de este medio extraordinario de investigación criminal, llegamos hasta los puntos críticos levantados por parte del seguimiento doctrinal.

Además, ha sido analizada la controvertida cuestión de la responsabilidad penal, civil y disciplinaria del agente infiltrado, amén de los rasgos prácticos de las operaciones encubiertas de infiltración policial y las más usuales actuaciones de esta figura en la lucha contra la criminalidad organizada y sus formas más graves de perpetración de delitos.

Nos cabe ahora ofrecer nuestra opinión respeto al modelo más correcto para elaborar la reglamentación de esta técnica policial de investigación contra los delitos practicados por la delincuencia organizada de nivel transnacional.

Se tratan de algunos puntos que reputamos esenciales a la actuación del infiltrado, de modo a obtener su encuadramiento en la zona de equilibrio procesal, evitándose la indeseable tensión de fuerzas entre la eficacia del poder punitivo estatal y la necesaria tutela de los derechos y garantías fundamentales.

\section{V.1.1. La estructuración de un plan eficaz de infiltración.}

Como es sabido,la delincuencia organizada y sus manifestaciones más destacadas como el terrorismo, el tráfico de estupefacientes y la criminalidad financiera se encuentran en expansión, siendo necesaria una respuesta estatal adecuada con el objetivo de poner frenos a estosfenómenos delictivos ${ }^{1472}$.

Frente a esta drástica conclusión, se observa que el crecimiento y desarrollo de algunas especies delictivas vienen provocando una sensación de inseguridad y miedo, hecho este comprobable en gran dosis en razón de que algunas organizaciones criminales han ido progresivamente perfeccionándose en forma cualitativa y cuantitativa, sobre todo con la utilización de medios sofisticados para la práctica de delitos. Con esto, los órganos de persecución penal se ponen en situación de desventaja, no logrando muchas veces actuar contra el núcleo central de estos grupos de delincuentes.

Un medio eficaz de lucha contra esta clase de bandas es mediante la utilización de agentes infiltrados en la organización criminal1473. Esta técnica presenta una gran

\footnotetext{
1472 De este modo, es lógico afirmar que "la realidad de nuestros tiempos parece demostrar que se trata de un problema creciente que se torna ordinario $\mathrm{y}$, por tanto, que requiere de instrumentos que respondan eficientemente". Vid. ALEO, S., Sistema penale e criminalità organizzata. Le figure delittuose associative, Milán, 1999, págs. 2-5.

1473 A través de esta técnica de investigación criminal es posible obtener el conocimiento necesario a las autoridades de persecución, con la finalidad de utilizar las informaciones sobre el funcionamiento y la estructura de la organización criminal, para su desmantelamiento y consecuente detención de los miembros del grupo.
} 
complejidad, ya que requiere la utilización de una persona extraordinariamente motivada y capacitada profesionalmente, así como una detallada planificación que va a requerir un período de tiempo relativamente prolongado ${ }^{1474}$.

Queda muy claro que en realidad la implementación de una operación encubierta a través de infiltrados implica un vasto dispositivo operacional, desarrollado por personas o equipos entrenados para estos fines, cuya actividad debe ser exhaustivamente demarcada y sujeta a rigurosos mecanismos de control y fiscalización, sea de naturaleza operacional y jerárquica, sea de naturaleza judicial ${ }^{1475}$.

Sin embargo, para asegurar la licitud de su actuación el trabajo del agente infiltrado debe venir adornado de determinadas cualidades o desprovisto de determinadas tachas insalvables, que desvirtúan procesalmente su eficacia1476. Por esta razón, según DELGADO MARTÍN, la disponibilidad de agentes dispuestos a actuar como infiltrados dependerá no solamente de la existencia de una adecuada selección y formación (tendente a la profesionalización de la figura) ${ }^{1477}$, sino también de los medios logísticos de cobertura que concurran (destinados a garantizar su seguridad física1478), así como del efectivo mantenimiento de la identidad reservada durante toda la tramitación del proceso judicial y posteriormente ${ }^{1479}$.

A partir de ahí se percibe que una de las cuestiones que se echa en falta en gran parte de los ordenamientos jurídicos que permiten la utilización de las operaciones encubiertas consiste en el necesario establecimiento de un apoyo logístico y humano durante la labor encubierta, bien como de condiciones post infiltración con la finalidad de mantener la identidad ficticia del agente y preservar su integridad física o su propia vida y de sus familiares.

Si lo anterior es correcto, entonces cabría concluir que la actividad ejercida por el agente encubierto es altamente peligrosa. No resulta difícil imaginar que puede verse durante su actuación compelido a cometer un ilícito, ya sea para ganar la confianza de los integrantes de la organización delictiva o incluso, como una manera de que su vida no corra peligro, pues el incumplimiento de una orden de los integrantes de estas bandas delictivas le puede significar un serio riesgo para su integridad física ${ }^{1480}$.

1474 Cfr. HERNANDO MARTÍN, F., "La guardia civil en la lucha contra el crimen organizado: técnicas de información, metodología operativa y directrices policiales en las investigaciones", http://www.ces.justicia.es.

1475 BRAZ, J., Investigação Criminal. A organização, o método e a prova. Os desafios da nova criminalidade, cit., pág. 327.

1476 Vid. REDONDO HERMIDA, A., "El agente encubierto en la jurisprudencia española y en la doctrina del Tribunal Europeo de Derechos Humanos", cit., pág. 97.

1477La primera de las conclusiones de carácter formativo del Seminario Internacional sobre uso de agentes encubiertos en la lucha contra el crimen organizado (realizado en Madrid en los días 26 a 29 de octubre de 1999 y organizado por la Dirección General de la Policía española), se refiere a que "sería recomendable que el agente encubierto recibiera, con carácter obligatorio y continuo, una formación general, que debe contemplarse desde un triple enfoque: jurídico, técnico y psicológico".

1478 En este sentido sería correcto afirmar que frente al objetivo operativo buscado, siempre deberá prevalecer la seguridad del agente encubierto. El éxito de la operación de infiltración vendría como una consecuencia a esta prioridad de mantenimiento del aspecto humano envuelto en esta especie de labor policial.

1479 Cfr. DELGADO MARTÍN, J., Criminalidad Organizada, cit., pág. 81.

1480 EDWARDS, C. E., El arrepentido, el agente encubierto y la entrega vigilada, cit., pág. 85. Por este motivo nos parece claro que la técnica del agente encubierto requiere un tratamiento muy especial con relación al planeamiento de la operación, pues su función es extremamente delicada y supone en todo caso la puesta en riesgo de un bien jurídicamente tutelado de mayor jerarquía como es la vida. 
Incluso deberá hacerse hincapié en la constatación verídica de que el costo de planificación de una operación encubierta, por más corta que sea, genera un sinnúmero de gastos financieros y de personal de apoyo, hechos estos que provocan una ausenciade estímulo al Estado en la tarea de combatir de modo eficaz las formas más graves de criminalidad.

Respecto a la infiltración como forma de técnica policial de investigación, DELGADO GARCÍA señala la necesidad de definición de dos fases distintas en el procedimiento de estructuración del plan de actuación de los agentes encubiertos. En la primera fase, denominada "fase previa a la infiltración", deberán ser analizados los siguientes puntos: los supuestos en que se puede permitir la actividad encubierta; la autoridad competente para autorizarla; y las personas que pueden actuar como agentes encubiertos. En la fase posterior, denominada de "fase de desarrollo de la infiltración", del mismo modo, deberán ser analizados otros tres requisitos: la autoridad competente para su control, así como el modo de ejércelo; la posible afectación de derechos fundamentales; y los posibles delitos cometidos por el agente encubierto ${ }^{1481}$.

El problema de fondo que impregna este tema corresponde saber a quién cumple la iniciativa de planificar una operación encubierta, bien como se deberá estructurarel modo de actuar del infiltrado dentro de la perspectiva de utilización de los medios inherentes a la actividad de inteligencia policial.

Ciñéndonos al ordenamiento procesal penal español, no hay duda en afirmar que la iniciativa tiene que ser policial, aunque la norma del artículo 282 bis LECrim no la establezca explícitamente. De todos modos, señala MARCHAL ESCALONA, que para justificar este entendimiento deberá valerse del hecho de que éste sea el sentido por lo cual se decanta el apartado 1 del artículo 282 bis, ya que si la infiltración policial supone el estudio y diseño de una estrategia investigadora ante unos indicios de delincuencia organizada, tales tareas previas, entre las que se incluye la selección y adiestramiento del agente, siempre corresponde a la labor policial. Ni el órgano judicial ni fiscal están capacitados o poseen los conocimientos técnicos y prácticos para arreglar por sí solos una operación de tal magnitud. Por eso, ha de entenderse que la iniciativa para proceder a una infiltración es propiamente policial: es la Policía Judicial quien está más habilitada para valorar la factibilidad de una infiltración ${ }^{1482}$.

Delante de lo expuesto, se puede afirmar que existe dentro del plan de elaboración de una operación de infiltración algunas fases establecidas y que presentan gran importancia al éxito de la misma. A esto se le podría denominar de "estructura operacional básica".

1481Vid. DELGADO GARCÍA, Ma․ D., "El agente encubierto: técnicas de investigación. Problemática y legislación comparada", cit., pág. 70.

1482 En este sentido, MARCHAL ESCALONA, A. N., "Drogas. Actuación policial. Problemas en la investigación", Drogodependencia y Derecho, Cuadernos de Derecho Judicial, Vol. VIII, 2003, pág. 257 y ss. También destacando de forma muy compleja las funciones policiales y su valor para la Justicia Penal, Cfr. PEDRAZ PENALVA, E., "Notas sobre Policía y Justicia Penal", Revista Jurídica de Castilla y León, núm. 14, 2008, págs. 15-109. 
Desde el planteamiento que aquí se sostiene siete serian las fases necesarias al éxito de una operación de infiltración: el reclutamiento, la formación, la inmersión, la infiltración propiamente dicha, el seguimiento-refuerzo, la exfiltración y la reinserción ${ }^{1483}$.

Pasemos a analizar individualmente cada uno de estos principales momentos.

La primera fase sería la de reclutamiento ${ }^{1484}$, o sea, el instante en que se decide quién, cómo encontrar y cuál es el perfil debe presentar la persona que va infiltrarse en una banda criminal. Se suele afirmar que existen dos procedimientos básicos en esta fase: la captación y la selección. La primera, llamada "captación", sería un procedimiento en sentido abajo-arriba, que sitúa su eje en las peculiaridades de un sujeto (abajo) para sustanciar las necesidades institucionales (arriba). Esta opción suele partir de la existencia de un perfil prototípico del candidato, que una vez encontrado en un sujeto particular acciona iniciativas institucionales de contacto y propuesta a esta persona específica.

En este caso, las autoridades de persecución estatales establecen el perfil que buscan en un agente, y a partir del momento en que surge alguien que les demuestren rellenar los requisitos deseables, desencadena una inmediata propuesta de la labor, con las debidas explicaciones al presunto candidato acerca de la responsabilidad de la operación encubierta, los riesgos, etc.

La segunda forma de reclutamiento consiste en la "selección", que sería justamente al contrario de la captación, o sea, un procedimiento arriba-abajo, en donde el órgano estatal difunde de un modo más o menos restringido sus necesidades especializadas de recursos humanos, eligiéndose los candidatos de entre un repertorio de personas preseleccionadas en base al cumplimiento de unas características personales y profesionales tasadas ${ }^{1485}$.

Ya seleccionado el candidato a ser infiltrado, parece lógico que el elegido deberá presentar algunas características básicas tales como perfil psicológico adecuado a los objetivos propuestos, o sea, estabilidad emocional, perfil físico, inteligencia aguzada y facilidad para actuar de improvisto, aptitudes específicas de la misión de infiltración y por fin, sintonía étnica y cultural con el entorno donde se va a ingresar ${ }^{1486}$.

1483 Cfr. MONTERo GÓMEZ, A., "Doctrina de infiltración para inteligencia contraterrorista", Revista Athena Paper, vol. 2, núm. 3, 2007, págs. 1-24, http://www.athenainteligence.org.

${ }^{1484} \mathrm{El}$ reclutamiento de un agente es simplemente la base, inicio o fundamento operativo para la obtención de información y cumplimentar las necesidades de un servicio de infiltración. Se buscan quienes son las personas que tienen acceso a las informaciones que necesitan los órganos de persecución penal, se analizan los candidatos, se seleccionan, se eligen y comienzan los trabajos para saber si resuelven las necesidades de información y si llenan todos los requisitos adecuados para convertirse en un agente. Se determinan si tienen o no debilidades aprovechables, se destacando las cualidades pertenecientes al agente y que se encajan a las finalidades de la operación. Por fin, se busca un policía adecuado a la personalidad y características culturales, educativas y raciales relativas al entorno criminal donde se va a infiltrar y comienza el arduo trabajo de caracterizarlo, de medirlo, estudiarlo y conocerlo, para saber como se le va a utilizar, para que sirve y en que será más eficiente.

1485 MONTERO GÓMEZ, A., "Doctrina de infiltración para inteligencia contraterrorista", cit., pág. 7. De entre otras características a ser buscadas en el infiltrado, se destaca la motivación para la misión, la tolerancia a frustraciones, el equilibrio familiar, el histórico de trabajo en actividades policiales, la baja ansiedad, etc.

${ }^{1486}$ Con relación a este aspecto, imagínese la necesidad de infiltración de un agente en una mafia rusa que actúa en el tráfico de mujeres para prostitución en España. Podría pensarse que la clave estaría en buscarse un policía que tuviera ascendencia rusa y por lo tanto, que conociera el idioma ruso y algunos datos básicos de esta nación. Pero en realidad, amén de este requisito esencial, deberá el agente seleccionado poseer un vasto conocimiento sobre los aspectos culturales del pueblo ruso, bien como saber con actitudes de improviso, demostrar que tiene una sintonía étnica compatible para ganar la confianza de los miembros de la banda 
A continuación, se sigue la fase de formación del agente, en la cual se impone a las autoridades penales la labor de capacitar al mismo ${ }^{1487}$. Esta capacitación está dirigida a desarrollar las cualidades consideradas diferenciales de un infiltrado y que se corresponden con el ideal definido en el perfil prototipíco del candidato. La capacitación está además concebida para dotar el agente de toda una serie de habilidades instrumentales y profesionales que contribuirán a incrementar su repertorio de recursos accionables en los escenarios que encontrará, y resolverá, en su labor lo que hará dentro del ámbito operacional ${ }^{1488}$.

Sobre este particular, habrá que incrementar las habilidades psicológicas del infiltrado, en especial con relación a un entrenamiento sobre la dinámica del engaño y de la disimulación ${ }^{1489}$, pues estas serán las armas cruciales para que ello consiga demostrar a los otros miembros del grupo criminal, su voluntariedad y capacidad para hacer parte del entramado delictivo de la organización criminal.

Terminada la formación del agente, se impone su inmersión en el entorno criminal, incluso empezándose a acostumbrar lo mismo con su nueva identidad, la cual en razón de ser ficticia, será concedida por el Estado. Se puede afirmar que se trata de la parte más compleja del procedimiento de estructuración de un plan de infiltración, teniendo en cuenta que no es tarea sencilla demostrar al candidato que a partir de aquello momento, tendrá que acostumbrarse con sus nuevos datos personales so pena de no conseguir estar a punto de ingresarse en la organización criminal.

En la fase de inmersión deberá el infiltrado pasar por un verdadero lavado cerebral ${ }^{1490}$, donde aprenderá que a partir de aquellos momentos deberá sostener un nuevo nombre, nuevos datos familiares, una nueva profesión, nuevos hábitos alimentarios, etc. Además, iba a incorporar a su mente su actual perfil biográfico, su perfil psicológico y profesional, amén de un vasto repertorio de conductas inherentes a su nueva identidad supuesta.

Traspasado este período de inmersión, empieza el agente encubierto a infiltrarse propiamente en el grupo criminal objeto de la investigación. Es la parte práctica de la

criminal. Caso contrario, en una acción descuidada, podrá demostrar una falta de habilidad o conocimiento sobre algún aspecto inherente a esta cultura y acabar pagando con su propia vida.

1487 Es en este instante donde el agente que se va a infiltrar recibe todas las orientaciones institucionales, tales como planes de entrada y salida del entorno criminal, formas de repaso de informaciones, apuntes prácticos sobre técnicas de obtención de datos y pruebas, informaciones sobre la cultura y hábitos de los miembros del grupo criminal, etc.

1488 Vid. MONTERO GÓMEZ, A., "Doctrina de infiltración para inteligencia contraterrorista", cit., pág. 10.

1489 Recuérdese que el engaño aunque sea esencial al éxito de la operación, encuentra fuerte carga crítica por parte de la doctrina. En este sentido, GUZMÁN FLUJA señala que "el problema está en que las operaciones de infiltración policial el engaño de la identidad ficticia abre un enorme abanico de posibilidades de actuar afectando derechos fundamentales de las personas investigadas, porque colocar al infiltrado en la organización criminal exigirá que éste trabe amistad, confraternice, o simplemente trabaje, con diversos sujetos a los que terminará conociendo, y ello supone que conversará con ellos, en ocasiones tendrá que entrar en lugares cerrados, incluso domicilios de estas personas, podrán conocer sus comunicaciones, etc., lo que significa que de un solo golpe, el engaño pone al agente infiltrado ante la posibilidad de afectar diversos derechos fundamentales como la intimidad, la inviolabilidad del domicilio, el secreto de las comunicaciones, etc". Cfr. GUZMÁN FLUJA, V., "El agente encubierto y las garantías del proceso penal", cit., pág. 216.

1490 Se trata de un conjunto de procedimientos o técnicas utilizadas con la finalidad de control de la mente, del comportamiento y del raciociniológico de una persona. 
operación donde el agente tiene la oportunidad de poner en acción todo lo que ha aprehendido en su preparación anterior a su ingreso junto a los miembros del clan ${ }^{1491}$.

A partir de ahí el agente construye una imagen delante de los otros miembros del grupo criminal, momento en que deberá estar predispuesto a estrechar lazos de amistad y confianza con la finalidad de obtener conocimiento sobre como funciona internamente la estructura de la organización, bien como para a través de estos datos, ayudar en la prevención de la práctica de nuevos delitos.

En realidad la piedra angular de este momento de la operación puede ser buscada en el hecho de que el infiltrado debe mantener sus propósitos y objetivos, no dejando que la situación dibujada durante su permanencia junto al grupo pueda llevarlo a practicar actos de provocación de delitos o hasta mismo, a la práctica de delitos que no tengan relación ninguna con las metas previstas para el buen éxito de su trabajo. En lo relativo a este último aspecto, tendrá importancia fundamental la obediencia a los preceptos del principio de proporcionalidad, el cual delimitará cuando estará el infiltrado exento de responsabilidad criminal por eventuales delitos cometidos durante su labor ${ }^{1492}$.

Resulta útil para una mejor comprensión de la fase de la infiltración propiamente dicha, dejar claro una vez más que cumple al agente encubierto, desde que autorizado por resolución judicial motivada, ingresar en el seno de una determinada organización criminal, con la finalidad única y exclusiva de obtener sin violar injustificadamente derechos y garantías de los investigados, los datos, pruebas e informaciones que puedan llevar a las autoridades de persecución a desmantelar determinado grupo de delincuentes organizados que se dedican a la práctica de infracciones graves.

Cumplido el objetivo ya señalado, tiene el infiltrado que enfrentar casi al fin de la operación encubierta, la fase de seguimiento-refuerzo. En este momento de la operación, articulase el compromiso institucional de lograr cuatro objetivos básicos: asegurar la cobertura del agente infiltrado, recoger inteligencia, reforzar en el agente las conductas y procedimientos tácticos apropiados, y contrarrestar los efectos de la clandestinidad ${ }^{1493}$.

La propuesta que va a llevar a cabo el infiltrado consiste entonces en hacer un repaso en todo el plan de la operación, contando por supuesto con la ayuda del personal de apoyo policial, de modo a intentar mejorar su labor y muy especialmente valorar sus actitudes y las posibilidades de éxito en la búsqueda de informaciones y pruebas útiles a los fines de imputación penal de las personas pertenecientes a la organización criminal.

\footnotetext{
1491 Por esta razón, destaca la jurisprudencia que "la labor del agente no pretende la comisión del delito, limitándose a comprobar la actuación del delincuente, recogiendo pruebas de delitos ya cometidos o que se están cometiendo". Vid. la STS 4107/2003, de 13.6.2003.

1492 En este sentido, señala POZO PÉREZ que "el agente debe valorar en cada momento si existe o no proporcionalidad con la finalidad de la investigación en las actuaciones que va a llevar a cabo que deben ser una consecuencia necesaria del desarrollo de la misma". Cfr. POZO PÉREZ, M., "El agente encubierto como medio de investigación de la delincuencia organizada en la Ley de Enjuiciamiento Criminal española", cit., pág. 299. Además, véase el art. en el artículo 282 bis de la LECrim: "El agente encubierto estará exento de responsabilidad criminal por aquellas actuaciones que sean consecuencia necesaria del desarrollo de la investigación, siempre que guarden la debida proporcionalidad con la finalidad de la misma y no constituyan una provocación al delito".

1493 MONTERO GÓMEZ, A., "Doctrina de infiltración para inteligencia contraterrorista", cit., pág. 14. Nos parece de gran importancia esta fase denominada "seguimiento-refuerzo", en razón de que podrán en este momento ser conformadas las tareas encargadas al infiltrado, corrigiéndose las imperfecciones y quedando a cargo de las autoridades responsables por la operación encubierta, eventuales cambios de estrategias de investigación.
} 
Surge incluso en este momento la oportunidad del agente encubierto de opinar, junto a sus superiores jerárquicos, respeto al proseguimiento o el abandono de la operación.

Con la obtención del material probatorio necesario, ya saliendo del entorno criminal, pasa el agente encubierto por la fase de exfiltración, la cual consiste en adecuar y buscar un modo de salida seguro y eficiente del infiltrado desde la organización criminal, de modo a evitarse que se descubra su verdadera identidad y sus propósitos en la operación.

Se trata de un momento de mucha ansiedad y temor por parte no sólo del infiltrado, pero también de sus superiores jerárquicos, teniendo en cuenta que un simple error en esto momento crucial, podrá costar la vida del policía, bien como frustrará el objetivo de procederse a la detención de los miembros del grupo criminal.

En términos operacionales prácticos, se le impone al infiltrado una salida con cautela y precaución, a la vez que a nadie podrá sospechar de una persona que poco a poco se va desvinculando del clan, no provocando la desconfianza de algún miembro de la organización. Se justifica este procedimiento de cautela en razón de la posibilidad de que el infiltrado pueda volver al seno del grupo en otra oportunidad con el objetivo de complementar su trabajo de búsqueda de pruebas contra los sospechosos ${ }^{1494}$.

Llegado a este punto de la operación, con el agente ya fuera de peligro y absolutamente lejos de los delincuentes con quien ha convivido, es obligación del Estado proceder a la reinserción del infiltrado, proporcionando al mismo ayuda psicológica para que este vuelva a convivir junto a su familia, rescatando sus hábitos de vida e incluso, si es necesario, concediéndole el ingreso en un programa eficiente de protección de testigos.

Aunque se pueda pensar que ésta sería la fase más sencilla y menos dolorosa de la operación, muy al contrarionos parece que se refiere a un momento de gran importancia en la vida del agente. Volver a ser uno mismo, después de un período de convivencia en un entorno hostil y peligroso, podrá presentar marcas psicológicas que se quedarán sin borrar en la mente del infiltrado. Dependiendo del tiempo de permanencia junto a la organización criminal, el agente encubierto quedará con más o menos dificultades de relacionarse en el ámbito familiar del cual ha sido privado, amén de verse en situación de desconfianza en cuanto a su futuro y el de su familia.

Hechos los comentarios respecto a las fases de montaje del plan de infiltración, nos cumple analizar como se cumple la garantía de la protección de la identidad del agente encubierto al fin de la operación de infiltración.

MAGRO SERVET, con fundamento en el ordenamiento jurídico español (art. 282 bis, 2 LECrim), señala incluso que se permite que no conste la identidad del infiltrado en las diligencias judiciales y que figure tan sólo un número o identificación clave. Además, se le permite puedaadoptar otra identidad y también los medios económicos necesarios para cambiar su residencia o lugar de trabajo ${ }^{1495}$.

\footnotetext{
1494 Un ejemplo puede aclarar esta posibilidad. Imagínese que el infiltrado no éste seguro de que ha conseguido todas las informaciones del grupo y al mismo tiempo tenga dificultades en el repaso de las mismas a sus superiores jerárquicos. Podría entonces intentar una salida discreta del entorno criminal y después de recibir órdenes para complementar su labor de investigación, retornar al grupo simulando que había hecho un viaje lejano para resolver problemas particulares. De otro modo, se concluye que se hubiera una salida abrupta de la organización, tornaría el retorno del infiltrado muy peligroso en razón de las desconfianzas que podrían surgir en razón de su desaparecimiento repentino.

1495 Cfr. a respecto, MAGRO SERVET, V., Manual práctico de actuación policial-judicial en medidas de limitación de derechos fundamentales, Madrid, 2006, pág. 191.
} 
La cuestión seráanalizada con más profundidad en el apartado propio cuando analicemos la problemática del testigo del agente encubierto en la instrucción criminal.

De otra parte, POZO PÉREZ opina en el sentido de que no sólo controles judiciales deberán ser utilizados en el proceso de infiltración policial, sino en la práctica operativa, razón por la cual se crea la figura del controlador o supervisor como pieza clave. Este sería el responsable directo del agente, siendo una especie de "protector" del funcionario, y tendrá contacto con él y deberá saber interpretar las señales de alarma que aproximen su comportamiento al de los delincuentes que investiga1496.

El propósito del denominado "protector" del infiltrado ${ }^{1497}$ consiste en la función esencial de acompañar muy cerca las actividades del mismo con vistas a garantizar que en situaciones de extrema gravedad pueda el infiltrado tener un contacto directo y urgente con los responsables por la elaboración del plan de infiltración, bien como con la autoridad responsable por la expedición de la resolución para el inicio de la operación.

En síntesis, será el responsable directo de la actuación del funcionario infiltrado, será el que controle sus actividades, marque el camino a seguir, sirva de interlocutor con el resto de investigadores que pueden tener que participar en la realización de determinadas diligencias, coordinará el dispositivo de seguridad, trasmitirá al agente todo aquello que sea necesario y recogerá de éste la información y fuentes de prueba obtenidas para ponerlas en conocimiento del instructor que autorizó la operación y, por último, tendrá que interpretar las alertas sobre el peligro que el encubierto esté sufriendo en cada momento concreto, convirtiéndose a un mismo tiempo en su jefe, su enlace y su protector ${ }^{1498}$.

El equipo de apoyo presenta una imprescindible importancia en el contexto de la operación encubierta, debiendo estar siempre atento a la aparición de situaciones que expongan el infiltrado a riesgos o peligros inminentes. Todas las informaciones sobre hechos relativos a la organización criminal infiltrada deberán ser transmitidas al infiltrado, de forma que con ello conozca perfectamente las posibles situaciones que tendrá que enfrentar dentro de la labor de la operación.

Del mismo modo, deberá prestar atención a la seguridad de la familia del infiltrado, evitándose que en caso de ser descubierta su verdadera identidad ocurra un inmediato ataque a las personas que hagan parte del entorno familiar del agente.

Por fin,hay que concluir que el análisis de la realidad práctica conduce a tener que abandonar la idea del agente encubierto legendario que actúa en solitario. En consecuencia, el Estado debe proporcionar los medios adecuados para la creación de cada leyenda, otorgando al agente una infraestructura que le proporcione cobertura con la finalidad de conseguir la confianza de los miembros de la organización, objetivando

1496 Vid. POZO PÉREZ, M., "El agente encubierto como medio de investigación de la delincuencia organizada en la Ley de Enjuiciamiento Criminal española", cit., pág. 282.

1497 Esta figura tendrá una fundamental importancia en términos de definir las mejores tácticas operacionales a ser utilizadas por el agente encubierto, buscando de este modo, permitir al funcionario estatal la seguridad para laborar dentro de situaciones de riesgos controlables, evitándose así, la exposición innecesaria de su vida o integridad física a peligro. Del mismo modo que el infiltrado, este coordinador operacional deberá ser entrenado para buscar en un curto espacio de tiempo y con cierta margen de razonabilidad, soluciones para el buen desarrollo de la operación encubierta.

1498Vid. POZO PÉREZ, M., "El agente encubierto como medio de investigación de la delincuencia organizada en la Ley de Enjuiciamiento Criminal, cit., pág. 301. 
garantizar la seguridad física del agente y de canalizar la información que éste vaya consiguiendo ${ }^{1499}$.

V.1.2. Necesidad legal de una autorización fundamentada. Ponderación de intereses y principio de proporcionalidad.

V.1.2.1. La exigencia de una autorización motivada para empezar la infiltración.

La exigencia legal de someter el inicio de la infiltración a una previa autorización judicial, o en algunos casos convalidación judicial posterior de la autorización del fiscal, demuestra como el solo hecho de la intervención de un agente encubierto, sin acciones concretas, conlleva una vulneración de derechos fundamentales; en concreto, del derecho a la intimidad latu y estricto sensu, en la medida en que el recurso a la figura del infiltrado descansa sobre la base de todo un engaño proveniente del aparato estatal, habilitante de un falso consentimiento para penetrar en la esfera privada de las personas sometidas a investigación ${ }^{1500}$.

Así, como regla general, dependiendo del ordenamiento jurídico, corresponde al Juez de Instrucción o al Ministerio Fiscal, este último dando cuenta inmediatamente al Juez, conceder la autorización pertinente para que funcionarios de la Policía Judicial u otros agentes puedan actuar como infiltrados bajo identidad supuesta1501.

Y no podría ser de otra forma, pues el trabajo ejercido por el infiltrado habrá de ser valorado previamente a su ingreso en la organización criminal, momento este donde las autoridades de persecución van a montar un plan general de actuación, analizando especialmente las ventajas de poner en curso la operación de investigación. Se quiere decir con esto que siempre habrá una autoridad jerárquicamente superior al agente encubierto, la cual después de iniciado el trabajo del mismo continuará ejerciendo el control sobre sus actuaciones, evitándose la ocurrencia de situaciones que no presenten relación con el objeto de la investigación.

Cuando la ley menciona que la resolución debe ser fundada significa la exigencia de un auto motivado de la autoridad judicial, pero si al mismo tiempo tiene contemplada la intervención del Ministerio Fiscal no debe quitar que el acuerdo que se tome debe estar

1499 Vid. DELGADO MARTíN, J., Criminalidad Organizada, cit., pág. 80. Por esta razón y siguiendo esta tendencia, señala MENDRONI que "parece incontestable que para cada policía infiltrado deberá corresponder el acompañamiento próximo de una equipe de policías de apoyo y protección, dispuestos a actuar en situaciones extremas y de emergencia. Evidentemente que la participación del agente policial como infiltrado en la organización criminal exige el constante acompañamiento de sus actividades por parte de la policía, de modo a viabilizarse protección en hipótesis de ocurrencia de situaciones de dificultad que puedan venir a surgir". Vid. MENDRONI, M. B., Crime organizado. Aspectos gerais e mecanismos legais, cit., págs. 61-62. Además, un buen ejemplo de acompañamiento de una operación encubierta se puede encontrar en el sistema norteamericano, donde el infiltrado siempre queda acompañado por un equipo policial que lo escolta a través de cameras y micrófonos, instalados en vehículos aparcados próximo al sitio de la infiltración, los cuales son altamente preparados con modernos equipamientos (surveillence cars).

${ }^{1500} \mathrm{Cfr}$. GÓMEZ DE LIÃNO FONSECA-HERRERO, Criminalidad organizada y medios extraordinarios de investigación, cit., pág. 181.

${ }^{1501}$ En este sentido, "La autorización judicial de actuación del agente clarifica la situación jurídico-penal del mismo, confiriendo seguridad procesal a su gestión investigadora". Vid. REDONDO HERMIDA, A., "El agente encubierto en la jurisprudencia española y en la doctrinadel Tribunal Europeo deDerechos Humanos", cit., pág. 100. 
igualmente fundado, pues se debe evitar, en todo momento, la arbitrariedad por parte de los órganos del Estado1502.

Dicho en otras palabras, independiente de la autoridad encargada de otorgarla, la motivación de la resolución deberá siempre estar presente, tornándose regla obligatoria a los fines de respecto a los criterios de legalidad y proporcionalidad. El contenido de la resolución debe mostrar tanto el propio convencimiento del Juez como la explicación de las razones dirigidas a las partes, pues ha de explicar el proceso de su decisión y las razones que motivaron la misma. La ausencia de este requisito de motivación conduce a la arbitrariedad, impidiendo una justificación racional del acto jurisdiccional1503.

\section{V.1.2.2. La competencia autorizante.}

En la gran mayoría de las legislaciones, pudiendo citarse Portugal, Francia, Brasil, Argentina, Colombia y otros tantos, habrá de ser exclusivamente el Juez la persona encargada de autorizar una operación encubierta mediante el uso de agentes infiltrados. Es así en razón de que la autorización del agente encubierto debe ser otorgada por un órgano estatal ajeno a la propia organización policial, como única forma de garantizar la adecuación del juicio de proporcionalidad ${ }^{1504}$.

Sin embargo, otros ordenamientos jurídicos adoptaron la opción legislativa de también otorgar al Ministerio Fiscal la competencia para autorizar el inicio de la medida de investigación encubierta1505. En este sentido, recoge el apartado 1 del artículo 282 bis de la LECrim una doble, indistinta e indiferente competencia en la autorización básica de la investigación ${ }^{1506}$.

1502Vid. MARTÍN PALLÍN, J. A., "Impacto social, criminológico, político y normativo del tráfico de drogas". VV.AA., Delitos contra la salud pública y contrabando, Cuadernos de Derecho Judicial, Madrid, 2000, pág. 164. De todo modo, importante destacar que la obligatoriedad de motivación de las decisiones encuentra fundamento en el artículo 120.3 de la CE.

1503 Con detalles sobre este tema, vid. GARCÍA VARELA, R., "La motivación de la sentencia", La Ley, núm. 6, 2000, pág. 1996-1997.

1504 En este sentido, PALAZZO constata el potenciamiento del componente jurisdiccional como elemento sustitutivo y compensatorio de la disminución que las otras garantías del Estado de Derecho soportan en el campo de la prevención ante delictum, recordando el creciente papel garantista asumido por el poder judicial. Vid. PALAZZO, F., "Estado constitucional de derecho y derecho penal (consideraciones comparadas a propósito de la reforma constitucional argentina de 1994)", Revista Penal, núm. 2, 1998, pág. 51.

1505 Tratando de esclarecer la posibilidad de una autorización por el Ministerio Fiscal, señala GASCÓN INCHAUSTI que "la Ley alemana parece distinguir dos fases diversas en la infiltración: una primera fase, en la que las labores del agente son más difusas y consisten en una toma de contacto con el entorno delictivo objeto de investigación, para lo cual resulta suficiente la autorización de la Fiscalía, y una segunda, en la que la investigación toma un rumbo definido y se dirige contra persona determinada. Sólo a partir de ese segundo momento puede considerarse la infiltración restrictiva del derecho fundamental a la informationelle selbstbestimmung". Vid. GASCÓN INCHAUSTI, F., Infiltración policial y "agente encubierto", cit., pág. 193. De otra parte, analizando la ley de enjuiciamiento criminal española, interesante la opinión de MUERZA ESPARZA en el sentido de que "depende de la fase del proceso en la que se encuentren las investigaciones. En efecto, si la autorización se produce con carácter previo a la incoación de un proceso, el tenor literal do precepto permite sostener que es el Ministerio Fiscal el encargado de conceder la autorización. Sin embargo, si el proceso ya se inició, y se han producido actuaciones judiciales, debe ser éste el encargado de realizar la autorización". Cfr. MUERZA ESPARZA, J., "Instrumentos procesales en la lucha contra la criminalidad organizada", VV.AA., Derecho Procesal Penal Económico, Madrid, 2003, pág. 562.

1506 Cuando se trate de investigaciones que afecten a actividades propias de la delincuencia organizada, el Juez de Instrucción competente o el Ministerio Fiscal dando cuenta inmediata al Juez, podrán autorizar a funcionarios de la Policía Judicial, mediante resolución fundada y teniendo en cuenta su necesidad a los fines de la investigación, a actuar bajo identidad supuesta y a adquirir y transportar los objetos, efectos e instrumentos del delito y diferir la incautación de los mismos. La identidad supuesta será otorgada por el 
La autorización de la medida de infiltración en estos casos como no podría ser de otra manera, dado que este medio de investigación puede afectar a derechos fundamentales ${ }^{1507}$, deberá contener una resolución debidamente motivada y prestar una especial atención al principio de proporcionalidad, entendido en el sentido de que sólo será concedida cuando se considere absolutamente imprescindible, por lo que si es de prever que no es posible conseguir los mismos objetivos por otros medios menos gravosos ${ }^{1508}$. En síntesis, como ya anteriormente afirmado, deberá ser la infiltración ser utilizada solo en hipótesis especiales, como ultima ratio.

La resolución por la que se acuerde la actuación del agente encubierto deberá consignar el nombre verdadero del agente, así como la identidad supuesta con la que actuará en el caso concreto. Por lo tanto, las autoridades competentes deberán argumentar las razones que conducen al Juez a restringir un derecho fundamental ${ }^{1509}$, volviendo a recalcar aquí la importancia que juega el papel de la Policía a la hora de suministrar al Juez Instructor aquellos datos, hechos, indicios racionales de criminalidad para que se realice correctamente la motivación de la resolución autorizante ${ }^{1510}$. A esto se podría llamarse de "motivación del auto".

Como consecuencia, la autorización debe concederse mediante una "resolución fundada", es decir, una resolución en la que el órgano correspondiente debe expresar la necesidad de utilizar este instrumento procesal a los fines de la investigación. Por lo demás, la resolución será reservada y deberá conservarse fuera de las actuaciones con la debida seguridad 1511 .

Desde esta perspectiva, el Juez de Instrucción debe dictar el auto motivado en el que se explicite por qué concede este título al agente policial para infiltrarse en la organización criminal. Debe existir proporcionalidad entre la medida concedida y el fin pretendido; es decir, si no hubiere otra vía de conseguir obtener pruebas para los fines de la investigación, lo que se deberá explicar por la fuerza actuante en el oficio dirigido al Fiscal o Juez de guardia1512.

Ministerio del Interior por el plazo de seis meses prorrogables por períodos de igual duración, quedando legítimamente habilitados para actuar en todo lo relacionado con la investigación concreta y a participar en el tráfico jurídico y social bajo tal identidad.

1507 Sobre el tema, véase la STC 1199/2006 de 16.2.2006, que sostiene que "la habilitación judicial justifica la actuación de los agentes encubiertos en aras de la necesaria investigación criminal". Y además, que "la investigación por medio de los agentes encubiertos constituye un medio de investigación permitido en relación con las actividades de la delincuencia organizada, siempre que se respecte el correspondiente marco legal. La conducta de los agentes encubiertos que han intervenido en este caso no han implicado la vulneración de ningún derecho fundamental".

1508 Véase al respecto, ALONSO PÉREZ, F., Medios de investigación en el proceso penal. Legislación, comentarios, jurisprudencia y formularios, cit., págs. 557-558.

1509 En este sentido, apunta NIEVA FENOLL respecto a la necesidad de autorización judicial para la actuación de agentes infiltrados que "ello es plenamente lógico, no sólo porque el agente deberá realizar, o tolerar la realización, de actividades prohibidas por la ley, sino porque, además, siendo la actuación de los agentes encubiertos algo que debe prolongarse en el tiempo para establecer los debidos lazos de confianza, no hay ningún inconveniente para que deba esperarse a que el juez decida sobre la cuestión". Vid. NIEVA FENOLL, J., "La protección de derechos fundamentales en las diligencias policiales de investigación del proceso penal", cit., pág. 85.

1510 Cfr. SUITA PÉREZ, N., "La diligencia de investigación por medio del agente encubierto", cit., pág. 250.

1511 Vid. MUERZA ESPARZA, J., "Instrumentos procesales en la lucha contra la criminalidad organizada", cit., pág. 562.

1512 Vid. MAGRo SERVET, V., Manual práctico de actuación policial-judicial en medidas de limitación de derechos fundamentales, cit., pág. 190. 
También es de gran importancia explicitar que en razón de que la orden judicial tiene que ser motivada, deberá el agente infiltrado tener conocimiento personal del contenido de la resolución, la cual va a fijar los límites de su actuación ${ }^{1513}$.

Nótese que, en este caso, es imprescindible que el infiltrado conozca profundamente las limitaciones a su actuación así como los objetivos de la operación, debiendo, sin embargo, seguir integralmente lo que ha sido determinado en la resolución judicial, pues de otra forma podrá responder y ser sancionado por sus actos en las esferas penal, civil y disciplinaria, tal y como hemos expuesto.

Además, el contenido de la resolución del Juez de Instrucción competente a la vista de las acciones delictivas realizadas por el agente encubierto, y teniendo en cuenta el informe emitido por la persona que autorizó la existencia del agente encubierto, tiene que ir referido a determinar si se debe o no proceder penalmente contra el agente encubierto ${ }^{1514}$.

\section{V.1.2.3. El control de la operación encubierta.}

Ya se percibe a través de los argumentos hasta aquí colacionados la importancia de un efectivo control de la operación de infiltración por los órganos de persecución penal, con la meta prestablecida de dejar claramente delineado en la resolución autorizante del ingreso del agente encubierto en una determinada organización criminal todos los límites y objetivos que deberán ser alcanzados en su labor.

Se trata de una medida que obligatoriamente deberá ser adoptada para evitar que una vez autorizado el plan de infiltración se pierda el rumbo de las acciones permitidas al agente encubierto, hecho que conllevará la práctica de actos violadores a los principios del debido proceso legal y de la proporcionalidad. La consecuencia en esta hipótesis será la invalidación de todo el contenido de la operación encubierta, perdiéndose el valor de las pruebas obtenidas y provocando innúmeros prejuicios a la persecución penal.

En todo caso, para admitirse una autorización para que un agente encubierto pueda ingresar se infiltrando en una organización criminal deberá la autoridad competente utilizarse de un juicio de proporcionalidad respeto a esta medida de investigación, valorando como regla la existencia de indicios suficientes, la idoneidad de la medida, la necesidad o subsidiariedad de la medida, la gravedad de la conducta investigada y, por fin, la debida motivación para la resolución ${ }^{1515}$.

\footnotetext{
1513 Respecto a la importancia de la autorización judicial para una operación encubierta, vid. CARRIÓ, A. D., "Agente encubiertos y testigos de identidad reservada: armas de doble filo, ¿confiadas a quién?", Cuadernos de Doctrina y Jurisprudencia Penal, vol. 3, núm. 6, Buenos Aires, 1997, págs. 311-322.

1514 Véase a respecto, LÓPEZ BARJA DE QUIROGA, J., "El agente encubierto", cit., pág. 1956. También el art. 282 bis 5 de la LECrim: "El agente encubierto estará exento de responsabilidad criminal por aquellas actuaciones que sean consecuencia necesaria del desarrollo de la investigación, siempre que guarden la debida proporcionalidad con la finalidad de la misma y no constituyan una provocación al delito. la investigación, el Juez competente para conocer la causa deberá, tan pronto tenga conocimiento de la actuación de algún agente encubierto en la misma, requerir informe relativo a tal circunstancia de quien hubiere autorizado la identidad supuesta, en atención al cual resolverá lo que a su criterio proceda".

1515 En este sentido, vid. POZO PÉREZ, M., "El agente encubierto como medio de investigación de la delincuencia organizada en la Ley de Enjuiciamiento Criminal española", cit., pág. 295. Otros autores también vienen a destacar la importancia del principio de proporcionalidad en la valoración de la necesidad de dictarse una resolución autorizante de una infiltración policial, aduciendo que "el juicio de proporcionalidad cobrará una importancia radical en la valoración de los indicios concurrentes. Sólo serán aptos para obtener una resolución autorizante los indicios o sospechas fundadas y contrastables por un tercero con la finalidad de que
} 
Por indicios suficientes ${ }^{1516}$ deberá ser comprendida la posibilidad de existencia de informaciones y datos reales en el sentido de que el grupo criminal ha estado planeando y ejecutando conductas graves que han de tipificar infracciones delictivas inherentes al crimen organizado.

También se exige un grado de imputación suficiente de la comisión de un hecho delictivo, y el órgano jurisdiccional ha de verificar la existencia de datos objetivos determinantes para deducir que resulta más que probable que dichos individuos están llevando a cabo conductas delictivas ${ }^{1517}$. Como se puede entender, se trata de un requisito de seguridad fundado en la racionalidad de la actuación estatal, de modo a evitarse la planificación de operaciones inocuas e innecesarias, factor este que puede venir a colaborar para la banalización del uso de esta técnica de investigación criminal.

Pero amén de la exigencia de indicios suficientes de la práctica de delitos graves por una determinada organización criminal, deberá de forma obligatoria ser visualizada la idoneidad de la medida de infiltración de un agente encubierto1518. Así, es necesario que el órgano jurisdiccional determine que la introducción en una banda organizada de un funcionario de Policía de manera encubierta va a resultar apta para obtener datos relevantes para la investigación del grupo delictivo; es decir, que la medida adoptada, en este caso la investigación con un funcionario infiltrado, va a contribuir al desarrollo de la investigación, sirviendo para averiguar todos los extremos posibles relacionados con la organización delincuencial ${ }^{1519}$.

Si lo anterior es correcto, entonces la medida de autorización para el inicio de la operación encubierta deberá presentar ventajas bajo al aspecto de la investigación, a la vez que se presupone en este caso que no hubieron otras técnicas aptas o adecuadas a proporcionar a los órganos de persecución penal resultados eficientes sobre el modus operandi y estructura de un determinado grupo criminal. También es imprescindible destacar que no bastaría la idoneidad de la medida delante de situaciones de menoscabo innecesario de las garantías y derechos fundamentales de la persona investigada.

su control pueda ser efectivo y no incurrir en automatismos o remisiones a solicitudes policiales absurdas e irreales, además de esos indicios o sospechas bastantes habrá que inferir racionalmente que se está cometiendo o se va a cometer un delito. Se impone, en consecuencia, desterrar las meras suposiciones, conjeturas vanas o imaginaciones de los funcionarios instantes, así como las desgraciadas y frecuentes valoraciones de las personas investigadas que con frecuencia se vienen realizando el deplorable derecho penal del autor". Vid. PAZ RUBIO, J. Ma et alli., La prueba en el proceso penal. Su práctica ante los tribunales, cit., pág. 397.

1516 Según MOLINA MANSILLA, deberá se comprobada la "existencia de indicios suficientes de que se está produciendo una actividad delictiva organizada y no meras sospechas: una vez comprobada la veracidad de una información, corresponde la solicitud de aplicación de este mecanismo a los responsables de la dirección de una investigación de la Policía Judicial, que elaborarán los informes oportunos, conteniendo la exposición de indicios que demuestren que se trata de una organización criminal y que serán entregados al órgano competente, para que valore la necesidad y la proporcionalidad de aplicación de la medida". Vid. MOLINA MANSILLA, Ma - C., Mecanismos de investigación policial: entrega vigilada y agente encubierto, cit., págs. 31-32.

1517 Cfr. POZO PÉREZ, M., "El agente encubierto como medio de investigación de la delincuencia organizada en la Ley de Enjuiciamiento Criminal española", cit., pág. 292. Como ejemplo, el ATS 3773 de 18 de junio de 1992, indica que "resulta indispensable que existan indicios, lo que ni puede equivaler jamás a sospechas o conjeturas".

1518 Como afirma el fundamento jurídico 4o de la STS 207/1996, de 16.12.1996, la medida debe ser "idónea (apta, adecuada) para alcanzar el fin constitucionalmente legítimo perseguido con ella (art. 8 CEDH), esto es, que sirva objetivamente para determinar los hechos que constituyen el objeto del proceso penal.

1519 POZO PÉREZ, M., "El agente encubierto como medio de investigación de la delincuencia organizada en la Ley de Enjuiciamiento Criminal española", cit., pág. 293. 
Constatada la existencia de los indicios de práctica de delitos graves por el grupo criminal, bien como la idoneidad de la medida de infiltración, deberá ser analizada la necesidad de empleo de este medio extraordinario de investigación ${ }^{1520}$.

La necesidad corresponde de forma sencilla al inevitable recurso a este medio extraordinario de investigación para acercarse a los secretos internos de la organización criminal; o dicho de otro modo, impone reconocer la importancia de tener a alguien, en este caso un agente de policía, dentro del entramado criminal para conseguir informaciones imprescindibles al éxito de la persecución penal.

En torno a esta afirmación cabe precisar que la clave se encuentra en reconocer la importancia de situarse la utilización del infiltrado como último recurso a ser empleado en la fase de investigación ${ }^{1521}$. Sería el reconocimiento del criterio de la ultima ratio, o sea, esencialmente que esta técnica de investigación criminal debe ser el último instrumento al que los órganos de persecución recurren para proteger determinados bienes jurídicos, siempre y cuando no haya otras formas de control menos lesivas "formales e informales". Si se logra la misma eficacia disuasiva a través de otros medios menos gravosos, deberá inhibirse de recurrir a un instrumento más intenso y que venga a violentar derechos y garantías fundamentales.

Desde el planteamiento que aquí se sostiene, la necesidad o subsidiariedad de la medida autorizante de una infiltración policial representa el actuar del agente encubierto siempre de modo imprescindible y como ultima ratio, siempre que la obtención de datos acerca de la red criminal no se pueda obtener, en ningún caso, a través de otro medio de investigación que resulte menos gravoso, restrictivo o lesivo para los derechos fundamentales implicados ${ }^{1522}$.

Por fin, se hace importante dejar claro respecto al requisito de la gravedad de la conducta investigada que la delincuencia organizada presenta como modus operandi el uso de actos violentos para conseguir alcanzarsus objetivos: el poder y las ganancias ilícitas ${ }^{1523}$.Sin embargo, la violencia extrema puede ser ejercida en cualquiera de sus formas, ataques físicos, terrorismo, coerción y soborno a los poderes públicos para la consecución de sus objetivos, hechos estos que caracterizan de forma singular esta forma de delincuencia.

La valoración de la gravedad de la conducta debe realizarse de manera conjunta, no únicamente por la pena del delito presuntamente cometido, sino que hay que determinar

1520 Explícitamente así lo exige el primer inciso del artículo 282 bis 1 de la LECrim, al disponer que la autorización judicial del agente encubierto se otorgará "teniendo en cuenta su necesidad a los fines de la investigación".

1521 A este respecto, interesante la opinión de PRIETO SANCHÍS la disponer que "la necesidad de la intervención lesiva, supone la acreditación de que no existe otra medida que, obteniendo en términos semejantes la finalidad perseguida no resulte menos gravosa o restrictiva". Cfr. PRIETO SANCHÍS, L., "Observaciones sobre las antinomias y el criterio de ponderación", Cuadernos de Derecho Público, núm. 11, 2000, pág. 23.

1522 En este sentido, vid. POZO PÉREZ, M., "El agente encubierto como medio de investigación de la delincuencia organizada en la Ley de Enjuiciamiento Criminal española", cit., pág. 294.

1523 Por esta razón, "el Juez deberá valorar las concretas características de la organización criminal investigada, teniendo en cuenta los efectos corruptores sobre componentes de entidades públicas y privadas; el ámbito geográfico abarcado por sus actividades, que podrá ser transnacional; su estabilidad en el tiempo; el empleo de un velo corporativo (ley del silencio) para aislar a sus miembros, especialmente a los líderes; la utilización de empresas interpuestas o corporaciones falsas, sobre todo con la finalidad de blanquear dinero; y otras similares". Vid. DELGADO MARTÍN, J., Criminalidad Organizada, cit., págs. 91-92. 
si la conducta resulta grave de por sí, aunque se refiera a robos de vehículos o tráfico de obras de arte, por ejemplo, si tenemos en cuenta que va a ser llevada a cabo por una organización criminal ${ }^{1524}$.

En congruencia con lo expuesto, señala ESPINOSA DE LOS MONTEROS que la gravedad de la conducta será un elemento relevante y a tener en cuenta para estimar la adopción o no de la infiltración policial. Pero en ningún caso podrá por sí sola ser elemento suficiente para estimar la necesaria intervención de un agente encubierto, sino que deberá ir acompañada de otros factores como el carácter cerrado de la estructura o la infiltración de la organización en las instituciones públicas y en los mercados económicos y financieros ${ }^{1525}$.

Llegado a este punto y a modo de recapitulación, hacemos hincapié en el hecho de la importancia de que la actuación policial no traspase los límites asegurados por los principios procesales de dignidad de la persona humana y de legalidad, sin perjuicio de evitar los frecuentes abusos de autoridad practicados por los ejecutores de estas especies de medidas 1526 .

Se puede incluso afirmar de forma amplia que la efectividad de la medida invasiva de derechos fundamentales exige un control judicial en la ordenación, desarrollo y cese de la intervención.

En el ámbito de las medidas que puedan violar derechos fundamentales del sospechoso, se suele destacar que la infiltración policial no autoriza la restricción policial de derechos fundamentales; es necesario que el agente encubierto recabe la oportuna resolución judicial limitativa de derechos que pondere adecuadamente la concurrencia de los presupuestos generales para la restricción válida de determinados derechos

1524 Cfr. POZO PÉREZ, M., "El agente encubierto como medio de investigación de la delincuencia organizada en la Ley de Enjuiciamiento Criminal española", cit., pág. 294. En este mismo sentido, GÓMEZ DE LIAÑO FONSECA-HERRERO señala que "de entre los criterios a tomar en cuenta para acreditar la proporcionalidad en sentido estricto, la gravedad del delito plantea no pocos problemas. Nuestro legislador, a la hora de acreditar la gravedad de la infracción, desterró el parámetro de la pena abstracta, y optó por hacerla depender de otra serie de factores, comisión del hecho punible en el seno de un grupo criminal, habida cuenta que forman parte del objeto de la medida delitos menos graves desde el punto de vista penológico. Con la clara intención de salvaguardar el precepto, en el marco del crimen organizado, la gravedad no debiera venir fijada sólo por una pena numérica, y habría que atender a extremos como la dimensión geográfica y relevancia social del delito. Cualquier delito, por insignificante pena que conlleve, susceptible de producir un lucro económico elevado, será cometido por organizaciones criminales, y buena prueba de ello son, por poner ejemplos de actualidad, el robo de objetos de arte para su posterior venta a sectores adinerados de la sociedad, los robos de vehículos de lujo para su comercialización en los mercados de segunda mano, o los delitos contra la propiedad intelectual cometidos mediante la reproducción e masa de obras artísticas". Vid. GÓMEZ DE LIAÑO FONSECA-HERRERO, M., Criminalidad organizada y medios extraordinarios de investigación, cit., pág. 4.

1525 ESPINOSA DE LOS MOTEROS, R. Z., El policía infiltrado. Los presupuestos jurídicos en el proceso penal español, cit., pág. 313.

1526Por esta razón, señala MONTOYA que "no solamente nos encontramos con los problemas que hacen al adiestramiento de un hombre y a todo lo que pueda rodarlo y colocarlo en escena, sino también con lo que es más importante, como es controlar al agente en la vida diaria a fin de que utilice todo aquello que se le entrega para llevar a cabo su trabajo, de acuerdo con lo que se espera de él. Por una parte, que brinde la información que permita la detención del crimen, y por otra, que no cometa delitos. No tiene licencia para matar o robar e incluso usar su identidad o cobertura para desligarse de una conducta irregular con la simple invocación de ésta para escapar de las autoridades. El juez o el fiscal deben controlar qué hace el individuo, en qué casos está trabajando, cómo prospera la investigación, todo ello con un máximo de seguridad, por cuanto no sólo está en juego el éxito sino la vida del hombre que trabaja bajo una cobertura en constante riesgo". Vid. MONTOYA, M. D., Informantes y técnicas de investigación encubiertas. Análisis constitucional y procesal penal, cit., pág. 30. 
fundamentales con la finalidad de acopio de medios de prueba (limitación del secreto de las comunicaciones, inviolabilidad domiciliaria, etc.) ${ }^{1527}$.

Y después de concedido el auto motivado por la autoridad competente, la siguiente cuestión que surge es si debe controlar el Juez la actuación del agente encubierto. Y en caso de que la respuesta fuera afirmativa, hay que fijar la manera conforme a la cual el agente tendría que entregar las informaciones obtenidas al Juez o al Ministerio Fiscal.

El agente encubierto, en la medida que le sea posible, y lejos de exponer a peligro su vida, su integridad física y el éxito de la operación de infiltración, debe volcar toda la información de la que vaya disponiendo al Juez de guardia o al Fiscal ${ }^{1528}$. Sin embargo, los agentes encubiertos tendrán que poner a disposición del órgano que les autorizó la infiltración, en su integridad, toda la información que vayan obteniendo de sus averiguaciones, al objeto de que éste acuerde las resoluciones correspondientes, según convenga a las necesidades de la instrucción, por lo que está vedado para el infiltrado seleccionar a su libre arbitrio la información que le presentará al Juez de Instrucción ${ }^{1529}$

Respecto a esta problemática fase de la infiltración, MAGRO SERVET cita las siguientes notas características, con las cuales concordamos plenamente:

a)Aunque haya sido el Ministerio Fiscal el que lo haya autorizado y éste se lo haya comunicado al Juez de guardia, el agente encubierto debe comunicarlo a quien autorizó su infiltración, sea Juez de Instrucción o Fiscal;

b)El agente debe facilitar la información a medida que entienda que la obtenida es susceptible de ser remitida y, además, debe serlo en su totalidad, por lo que no se puede valorar qué se envía y qué no se remite. Hay que hacerlo en su integridad.

c) Todos estos cauces y cautelas se establecen para que sea el órgano judicial el que valore la información que se vaya recibiendo.

d) No hay que olvidar que con posterioridad el agente encubierto será testigo del proceso penal que, en su caso, se celebre, por lo que con carácter previo debe haber facilitado toda información de la que disponga, con lo que habrá vulnerado esta obligación si luego en el juicio declara alguna cuestión que no fue facilitada en su momento a la Fiscalía o al Juez.

e) Por último, no es el agente el que debe seleccionar lo que debe remitir, ya que debe hacerlo con toda la información,tal y como ocurre con los resultados de las intervenciones telefónicas ${ }^{1530}$.

Como se acaba de exponer, el envío de las informaciones obtenidas durante el periodo de actuación del agente encubierto presenta una importancia destacada, representando en realidad un inicio de la producción de las pruebas que servirán como

1527 CHOCLÁN MONTALVO, J. A., La Organización Criminal. Tratamiento penal y procesal, cit, pág. 63.

1528 En este sentido, vid. art. 282 bis.1, último párrafo, de la LECrim.

1529 PAZ RUBIO, J. Ma et alli., La prueba en el proceso penal. Su práctica ante los Tribunales, cit., págs. 399400. De otro modo, "el agente tiene la obligación de solicitar autorización, ahora ya exclusivamente a la autoridad judicial, para la práctica de diligencias complementares de investigación limitativas de derechos fundamentales. Por otra, tiene el deber de comunicar al juez las averiguaciones verificadas". Vid. GÓMEZ DE LIAÑO FONSECA-HERRERO, M., "El agente encubierto como medida de investigación del terrorismo en el contexto internacional", cit., pág. 428.

1530 MAGRO SERVET, V., Manual práctico de actuación policial-judicial en medidas de limitación de derechos fundamentales, cit., págs. 190-191. 
fundamento para la acción penal y la consecuente condena de las personas pertenecientes al grupo de delincuentes organizados.

\section{V.1.2.4. El contenido de la resolución autorizante.}

De otra parte, es una cuestión especialmente sensible el análisis del real contenido de la resolución que autoriza el empleo de la técnica de investigación encubierta a través de agentes infiltrados 1531 .

La autorización judicial puede consistir simplemente en la autorización para la actuación bajo identidad supuesta, o puede comprender, además, que el agente encubierto pueda adquirir y transportar los objetos, efectos e instrumentos del delito y diferir la incautación de los mismos ${ }^{1532}$. Quedará, por lo tanto, libre al ordenamiento penal describir los límites que iban a conformar la actuación del agente estatal, todavía, atendiendo a criterios de racionabilidad y proporcionalidad con el objetivo de evitarse la arbitrariedad y posibles excesos en el ejercicio de la actividad estatal de combate a la criminalidad.

Y en dicha línea, declara DELGADO MARTíN1533 en el sentido de que el auto autorizante podrá establecer, entre otras, las siguientes formas de ejercicio del control jurisdiccional:

a) Contemplando las vías a través de las cuales el agente encubierto deberá cumplir con su deber de información. A estos efectos, podrá designarse un segundo agente, que puede ser un superior jerárquico, para que traslade la información al Juez cuando la salvaguarda de la integridad física del agente encubierto lo aconseje.

b) Fijando momentos o tiempos para el traslado de la información que se vaya obteniendo, sin perjuicio de la obligación de la comunicación inmediata de todos los datos relevantes para la información.

c) Estableciendo un concreto periodo de duración de la medida, sin perjuicio de que, a la vista de los resultados que se vayan obteniendo, puedan decretarse una o sucesivas prórrogas. En caso de prórroga, debe tenerse en cuenta que la resolución que la disponga debe reunir los mismos requisitos, sobre todo de motivación, que la autorizó inicialmente la medida, y que la misma puede denegarse si el Juez considera que es inoperante o innecesaria.

Particularmente el ordenamiento procesal penal español dispone en el artículo 282 bis 1ํㅡㄹ LECrim que la autorización será mediante "resolución fundada". Resolución que acordada por el Juez y distinta de la del Ministerio del Interior, acordando la identidad supuesta, no podrá adoptar otra forma que la de auto, por los derechos fundamentales

\footnotetext{
1531 En realidad la gran mayoría de los ordenamientos jurídicos no determina explícitamente el contenido de la resolución judicial para una operación de infiltración policial. Una interesante excepción sería la ley procesal penal belga $(\S 47)$ donde se determina el contenido básico del auto mediante el que se adopta la infiltración, a saber: los delitos en que se justifica la necesidad de adoptar la infiltración; los motivos por los que la infiltración se considera indispensable para el caso concreto; si son conocidos los nombres o descripción de la persona objeto de investigación; el procedimiento mediante el que se realizará la infiltración policial; la duración de la medida (que no podrá exceder de 3 meses) y el nombre y la calidad del policía judicial que dirige la ejecución de la infiltración. También el Código Procesal Penal francés (artículo 706-83) disciplina claramente el contenido de la resolución, exigiendo las infracciones que justifican el recurso de la infiltración; la identidad del agente bajo cuya responsabilidad se desarrolla la operación y la duración de la medida que no podrá exceder de 4 meses.

1532 CHOClÁn MONTALVO, J. A., La Organización Criminal. Tratamiento penal y procesal, cit., pág. 63.

1533 Cfr. DELGADO MARTín, J., Criminalidad Organizada, cit., págs. 93-94.
} 
afectados y por la necesaria e imprescindible motivación ${ }^{1534}$ que además impone el propio texto legal.

Aunque se tenga dejado claro la vigencia del principio de exclusividad de la figura del Juez para autorizar una operación encubierta, hay que tener en cuenta, sin embargo, que la posibilidad de que el Ministerio Fiscal en algunos ordenamientos jurídicos ${ }^{1535}$ autorice la actividad del agente encubierto, en cuanto venga afectar al derecho fundamental de la intimidad de los investigados, debe ser objeto de una interpretación restrictiva, de tal forma que solo puede existir en aquellos supuestos en los que la urgencia impida solicitar la autorización al Juez de Instrucción ${ }^{1536 .}$

Incluso nos cumple observar que se el sujeto autorizante $a b$ initio de la medida es el Ministerio Fiscal, dictará igualmente resolución motivada, que dará cuenta inmediata al Juez, el cual mediante auto motivado lo confirmará o denegará, sin poder hacer remisión a las razones expuestas por el Ministerio Fiscal. De este modo se impone como requisito constitucional la motivación del auto autorizante de las técnicas de investigación encubierta 1537.

La razón de que sea el Ministerio Fiscal el autorizante en un primer momento ${ }^{1538}$ será por las facultades de investigación que le otorga la legislación procesal penal, y la urgencia que puede surgir en un determinado momento, pero inmediatamente dando cuenta al Juez. No debe desconocerse, en todo caso, la necesidad de existencia previa de un procedimiento penal antes de la autorización para actuación del agente encubierto.

La propia actuación pasiva del agente encubierto, como agente infiltrado dentro de la delincuencia organizada, requiere que bien antes de la adopción de la medida e incluso paralelamente a la adopción se incoen diligencias instructoras con la finalidad de evitar la clandestinidad del procedimiento y reforzar el control de legalidad del Ministerio Fiscal y del propio imputado una vez notificada la resolución y después de levantado el secreto de sumario.

Si el sujeto autorizante ha sido el Ministerio Fiscal con base en la investigación que esté llevando a cabo, o por previa solicitud policial, no existiendo previamente

\footnotetext{
${ }^{1534}$ Con relación a la exigencia de la motivación en la autorización, explica MOLINA MANSILLA que "en la resolución deberían hacerse constar, preferiblemente, los datos fácticos en los que el órgano autorizante apoya su valoración, e incluso en función de las circunstancias puede ser conveniente realizar una valoración explícita de la situación, que recoja las razones que aconsejan la intervención policial". Vid. MOLINA MANSILLA, M. ․ C., Mecanismos de investigación policial: entrega vigilada y agente encubierto, cit., pág. 32 .

1535 Hay dos posibilidades concretas: una donde el Ministerio Fiscal podrá autorizar la infiltración policial dando cuenta inmediata al Juez de Instrucción (art. 282 bis 1 de la LECrim), y otra en Alemania donde el Ministerio Fiscal tiene legitimidad para autorizar una infiltración policial, independientemente de cualquier comunicación al Juez ( $\$ 110$ b StP0).

1536 Con más detalles, sobre la excepcionalidad de autorización por el Ministerio Fiscal, vid. DELGADO MARTÍN, J., Criminalidad organizada, cit., pág. 65.

1537 PAZ RUBIO, J. Ma et alli., La prueba en el proceso penal. Su práctica ante los Tribunales, cit., pág. 396.

1538 Profundizando sobre esta posibilidad de autorización otorgada por el Ministerio Fiscal, destaca con extrema claridad ESPINOSA DE LOS MONTEROS que "en definitiva, considerando que en la infiltración policial, la limitación de derechos fundamentales no se producirá desde el primer momento de la operación, afirmamos que es factible la facultad otorgada al Ministerio Fiscal para autorizar la infiltración policial. Ahora bien, debido al carácter extraordinario de la medida, junto con la limitación de derechos fundamentales producida en el segundo momento, es necesario que la autorización del Fiscal vaya seguida de un control judicial efectivo y a la menor brevedad posible. Sólo así podremos considerar que la operación se situará en los parámetros del Estado de Derecho". Vid. ESPINOSA DE LOS MONTEROS, R. Z., El policía infiltrado. Los presupuestos jurídicos en el proceso penal español, cit., pág. 336.
} 
procedimiento penal, la ley prescribe que el Fiscal dará cuenta inmediata al Juez para que éste, necesariamente, incoe el procedimiento penal1539.

Del análisis respecto al tema de la autorización para una infiltración, se deduce con seguridad que sólo se adoptará la medida de infiltración cuando previamente exista la sospecha cierta y sólida de que el hecho delictivo se cometerá, y nunca con la finalidad de descubrir de modo indiscriminado cualquier conducta delictiva.

\section{V.1.2.5. El contenido original de la resolución y otras diligencias necesarias.}

En línea de principio nos tenemos que plantear cómo hay que proceder en la hipótesis de que durante el periodo de infiltración el agente encubierto tuviera la necesidad de practicar diligencias complementarias, no previstas de forma expresa en la resolución judicial previa autorizante.

Se puede despejar este interroganteseñalando que elagente infiltrado tiene la obligación de solicitar autorización, ahora ya exclusivamente a la autoridad judicial, para la práctica de diligencias complementarias de investigaciones limitativas de derechos fundamentales. Por otra parte, tiene el deber de comunicar al Juez las averiguaciones verificadas.

La necesidad de recabar autorización para efectuar una diligencia adicional va a depender del contenido conferido, ante el silencio de la ley, a la autorización de inicio ${ }^{1540}$. Se quiere con esta exigencia demostrar que la labor del agente encubierto, amén de las críticas sobre su contenido contrario a la ética a ser empleada por el Estado en la lucha contra la criminalidad, debe obedecer a un principio de transparencia por parte de los órganos de persecución, no admitiéndose la práctica de diligencias genéricas y sin parámetros de proporcionalidad, hecho este que estaría rompiendo con la obligación de respeto del Estado a la dignidad humana de las personas sujetas a una investigación criminal.

En esencia, se trata del reconocimiento del principio básico de la seguridad jurídica ${ }^{1541}$, donde se busca evitar que una autorización a través de una resolución pueda servir como una "carta en blanco" genérica y sin límites con relación al objeto de la investigación criminal ${ }^{1542}$. Por lo tanto, la seguridad jurídica es un valor estrechamente ligado al Estado de Derecho que se concreta en exigencias objetivas de "corrección estructural" (formulación adecuada de las normas del ordenamiento jurídico) y "corrección funcional" (cumplimiento del Derecho por sus destinatarios y especialmente

${ }^{1539}$ Cfr. PAZ RUBIO, J. Ma et alli., La prueba en el proceso penal. Su práctica ante los Tribunales, cit., pág. 398.

1540 Vid. GÓMEZ DE LIAÑO FONSECA-HERRERO, M., "Infiltración policial y proceso penal", cit., págs. 215216. Incluso es una verdad irrenunciable que "el número de agentes encubiertos y los cambios que se vayan produciendo a lo largo de la investigación tendrán que ser autorizados por el Juez competente". En este sentido, Vid. PAZ RUBIO, J. Mae et alli., La prueba en el proceso penal. Su practica ante los tribunales, cit., pág. 396.

1541 Respecto al principio de seguridad jurídica, Cfr. GÓMEZ DE LIAÑO FONSECA-HERRERO, M., Criminalidad organizada y medios extraordinarios de investigación, cit., págs. 138-139. También los destacados trabajos de PÉREZ LUÑO, A. E., "Seguridad jurídica", El derecho y la justicia, vol. 2, 1996, págs. 481-492 y MARCOS DE CANO, A. M., "La seguridad jurídica. Su configuración actual", Estudios en homenaje al profesor Gregorio Peces-Barba, vol. 2., 2008, págs. 763-786.

1542 Se acaso fuera acepto el aprovechamiento de la resolución original para el inicio de la operación de infiltración policial, con la finalidad de practicarse otras diligencias complementarias no previstas anteriormente, estaría la labor del agente encubierto siendo utilizada como un instrumento de negación pura de los derechos fundamentales de la persona investigada. 
por los órganos encargados de su aplicación). Junto a esta dimensión objetiva, la seguridad jurídica se presenta, en su acepción subjetiva, encarnada por la certeza del Derecho, esto es, como la proyección en las situaciones personales de las garantías estructurales y funcionales de la seguridad objetiva ${ }^{1543}$.

Conforme a ello, cuando más allá de la observación del entorno el agente quiera obtener información por otros cauces, restrictivos de otros derechos fundamentales, en lo que se cabe llamar de "segundo momento de la infiltración", debe solicitar autorización específica para tales efectos ${ }^{1544}$.

Ya encerrando este apartado, nos cumple señalar que cada autorización concedida en el caso concreto, independiente de la persona autorizante (Juez o Fiscal), deberá presentar sus particularidades, denotándose en especial los contornos específicos de cada operación encubierta y estipulando los respectivos límites que deberán ser obedecidos ${ }^{1545}$.

\section{V.1.3. El plazo de duración de la operación encubierta.}

V.1.3.1. La necesidad de fijar un plazo determinado para la duración de la infiltración.

Otro de los temas que reputamos como de gran importancia se refiere al plazo de duración de una operación de infiltración policial, al cual se ha dedicado específicamentela doctrina especializada ${ }^{1546}$, ya que tienen mucho que ver con el incremento del riesgo para el infiltrado, a la vez que cuanto más tiempo permanezca dentro de la organización criminal mayor será el riesgo de ser descubierto por los miembros del clan de delincuentes ${ }^{1547}$.

Además de ello, nos preocupa también la necesaria limitación de que no pueda ser admitido un plazo indefinido y abierto, sin controles, respecto a la duración de esta medida investigativa de carácter excepcional.

A nuestro modo de comprenderla importancia del factor temporal debe ser valorado a partir de la aplicación del principio de proporcionalidad. En este sentido, explica GASCÓN INCHAUSTI que permitir una duración excesiva de estas medidas puede llegar a ser, dado el caso, desproporcionado en relación con los fines que a través de ellas se pretende alcanzar ${ }^{1548}$.

1543 PÉREZ LUÑO, A. E., "La seguridad jurídica: una garantía del Derecho y la Justicia", Boletín de la Facultad de Derecho de la Universidad Nacional de Educación s Distancia, núm.15, 2000, pág. 28.

1544 Vid. GÓMEZ DE LIAÑO FONSECA-HERRERO, M., "Infiltración policial y proceso penal", cit., pág. 216.

1545 En este sentido, en España, el Circular no 4/2010 de la Fiscalía General del Estado define claramente que "tanto las autorizaciones de entregas vigiladas como las de utilización de la figura del agente encubierto, presentan numerosas particularidades en cada supuesto concreto, por lo que es difícil establecer pautas concretas de actuación más allá de las que se refieren al estudio pormenorizado de cada una de las situaciones y la prudencia en la adaptación de las mismas".

1546 Véase al respecto, GASCÓN INCHAUSTI, F., Infiltración policial y “agente encubierto", cit., págs. 217 y ss; GÓMEZ DE LIAÑO FONSECA-HERRERO, M., Criminalidad organizada y medios extraordinarios de investigación, cit., págs. 196 y ss; ESPINOSA DE LOS MONTEROS, R. Z., El policía infiltrado. Los presupuestos jurídicos en el proceso penal español, cit., págs. 355 y ss.

1547 En nuestra opinión, es algo indudable que la labor del infiltrado no es una tarea fácil. Muy al contrario, exige mucha determinación y entrenamiento, pues además de ser una labor que exige un alto grado de paciencia, también es notadamente arriesgado. Quizá por estas razones las infiltraciones de largo plazo y por lo tanto duraderas sean cada vez más escasas en la práctica.

1548 Cfr. GASCÓN INCHAUSTI, F., Infiltración policial y “agente encubierto”, cit., pág. 138. 
Así, en aras de un proceso penal de índole marcadamente garantista, permeado por el respecto a los derechos y garantías de los ciudadanos, no es viable ni permisible aceptar una duración sin límite ${ }^{1549}$ de la medida judicial de infiltración de un agente encubierto en una determinada banda de delincuentes organizados.

Esto significa, sencillamente, que un plazo en abierto de una diligencia invasiva para los derechos y garantías fundamentales conllevará una dificultad extrema de control por la autoridad encargada de evitar abusos y actos de arbitrariedad que no presenten relación directa con la investigación encubierta.

Por fin, es importante señalar que la duración efectiva de la infiltración será evaluada por las fuerzas policiales de seguridad desde que sean autorizadas por el órgano jurisdiccional competente en atención a la necesidad, la posibilidad y los riesgos presentes. Reseñar que el plazo inicial de duración de la identidad supuesta varía en cada ordenamiento penal ${ }^{1550}$.

Dentro de este contexto, se infieren algunas consecuencias prácticas importantes: el distinto tratamiento del asunto en el Derecho comparado, los riesgos oriundos de la operación, y la posibilidad de prórrogas de la infiltración policial.

\section{V.1.3.2. El límite temporal de la infiltración policial.}

Cada ordenamiento jurídico posee autonomía legislativa para establecer un tratamiento específico de cada institución o trámite procedimental a desarrollar. Por esta razón podemos encontrar algunas posiciones dispares en lo relativo al plazo de duración de una operación através del uso de agentes encubiertos.

Lo que debe quedar lejos de cualquier discusión como ya hemos visto es la necesidad de que la investigación tenga una duración limitada en el tiempo ${ }^{1551}$, tanto en la autorización inicial como en la eventual prórroga que se pudiere acordar.

Sin pretensión de agotar el asunto, analizaremos algunos ordenamientos que han optado por definir distintos criterios para la fijación de límites temporales.

Comenzando por España, el art. 282 bis 1 LECrim dispone que el Ministerio del Interior puede conceder al agente encubierto, por seis meses, una identidad ficticia como presupuesto elemental para conseguir adentrarse en la organización criminal. Lo que ocurre en este caso particular es que se aprovecha el quantum del plazo de seis meses

1549 Refiriéndose al tema de la duración razonable del proceso y que puede mutatis mutandis ser trasladada a la discusión sobre el plazo de duración de una infiltración policial, denotase que el proceso en sí es un acto de coerción o bien un conjunto de actos cuya realización es asegurada por medidas de coerción, que siempre intervienen en los derechos fundamentales de las personas, entonces su duración misma debe estar establecida por la ley con precisión. Vid. con más detalles respecto a esta cuestión, PASTOR, D. R., El plazo razonable en el Proceso del Estado de Derecho: una investigación acerca del problema de la excesiva duración del proceso penal y sus posibles soluciones, Buenos Aires, 2002.

1550 Vid. CORRÊA DE CARVALHO, J.T., Tráfico de drogas. Prueba penal y medidas restrictivas de derechos fundamentales, cit., pág. 329. En la gran mayoría de los ordenamientos penales que tratan de la reglamentación del uso de agentes encubiertos, a ejemplo de Brasil, Alemania y Portugal, no poseen un plazo específico para el uso de la identidad ficticia, y mucho menos de la duración de una infiltración por agentes estatales en un clan criminal.

1551 También defendiendo esta posición, véase GASCÓN INCHAUSTI, F., Infiltración policial y “agente encubierto", cit., pág. 218. 
concedido al infiltrado por el Ministerio de Interior para uso de la identidad supuesta como límite máximo de plazo inicial para la duración de la infiltración ${ }^{1552}$.

En este contexto, si el Juez instructor o el Ministerio Fiscal estiman necesaria o conveniente esta forma de investigar, podrán acordar fundadamente que un miembro de la Policía Judicial se infiltre, en los lugares o ambientes que consideren adecuados, durante un periodo de tiempo de hasta seis meses, prorrogables por otros de igual duración en función de sus resultados.

De esta forma, en la normativa reguladora del agente infiltrado se asienta el criterio de no estipular plazo de duración para el ejercicio de la investigación encubierta, lo que nos lleva a deducir que deberá esta actividad perdurar por tiempo razonable y proporcional a los fines objetivados en la resolución judicial. Cabrá, por tanto, al Juez de Instrucción redactar el auto que autorice o ratifique la infiltración policial, señalando el plazo de duración de la medida y tomando en consideración la opinión de los mandos policiales que diseñaron la operación 1553 .

Sin embargo, a grandes rasgos, se puede afirmar que los ordenamientos penales en general no definen criterios temporales de duración de la medida, dejándose la determinación de la misma a la prudencia del órgano judicial una vez apreciada las circunstancias del caso ${ }^{1554}$.

Otra situación se observa en la legislación portuguesa, en la que si bien expresamente no hace referencia al plazo de duración de una operación de infiltración, si se establece que las acciones encubiertas deben ser adecuadas a los fines de prevención y represión criminal identificadas en concreto, especialmente el descubrimiento de material probatorio, debiendo ser proporcional a aquellas finalidades y a la gravedad del crimen que está siendo objeto de investigación ${ }^{1555}$. En concreto, de forma directa no hace referencia al periodo de duración de la actuación del agente encubierto si bien que define el plazo para la utilización de una identidad ficticia por un plazo de seis meses prorrogables por igual plazo, cuya competencia recae sobre el Ministro de Justicia (art. 5으, 2 y 3 de la Ley 101 de 25 de agosto de 2001). Dentro del contexto analizado se percibe que esta decisión sobre el límite temporal de duración de la operación quedará al criterio del Juez.

1552 Vid. ESPINOSA DE LOS MONTEROS, R. Z., El policía infiltrado. Los presupuestos jurídicos en el proceso penal español, cit., pág. 357. De otra contraria, señala PAZ RUBIO que "la autoridad judicial no está sujeta al plazo que concede la autoridad administrativa sobre la identidad supuesta, sino que el Juez, en función del necesario juicio de proporcionalidad, la información que vaya obteniendo y el curso de la investigación ordenará el cese o la prórroga de la investigación encubierta". Cfr. PAZ RUBIO, J. Ma et alli., La prueba en el proceso penal. Su práctica ante los Tribunales, cit., págs. 400-401. Con una opinión también crítica respeto al plazo para la operación de infiltración en España, señala HERNANDO MARTíN que "una operación de infiltración no puede estar sujeto a plazos ( 6 meses prorrogables en la normativa española) ni a una valoración inmediata de sus resultados (dice la ley que la información obtenida deberá ser puesta a la mayor brevedad posible en conocimiento de quién autorizó la investigación)". Vid. HERNANDO MARTÍN, F., "La guardia civil en la lucha contra el crimen organizado: técnicas de información, metodología operativa y directrices policiales en las investigaciones", www.ces.justicia.es.

1553 Vid. GÓMEZ DE LIAÑO FONSECA-HERRERO, M., Criminalidad organizada y medios extraordinarios de investigación, cit., pág. 197.

1554 GUZMÁN FLUJA, V. C., "El agente encubierto y las garantías del proceso penal", cit., pág. 215. Y en este caso, "ante al silencio legal, de un límite máximo, tendrá que ser el mínimo imprescindible y necesario para el desarrollo de la investigación, de lo contrario se conculcarían losderechos de los investigados". Vid. en este sentido, PAZ RUBIO, J. Mª et alli., La prueba en el proceso penal. Su práctica ante los tribunales, cit., pág. 401.

1555 Cfr. el artículo 3oㅡ n. 1 de la ley 101/01. 
Si nos referimos a Brasil, a consecuencia de una omisión legislativa, no se tiene fijado en ley ningún plazo establecido para la duración de la infiltración policial. Por esta razón, parte de la doctrina utiliza una solución sui generis frente a la problemática de ausencia de un plazo legal: ante la precariedad de este cuadro y con el objetivo de asegurar el respecto a las garantías del investigado deberá aplicarse, por analogía, el procedimiento establecido en la Ley 9.296/96 que disciplina la interceptación de las comunicaciones telefónicas, refiriéndose de este modo a la moderna concepción del principio de proporcionalidad en relación a una materia que igualmente puede resultar en restricción a derechos fundamentales como la privacidad y la intimidad ${ }^{1556 .}$

Con un planteamiento divergente en otros ordenamientos jurídicos como el francés y el belga la duración de la medida se hace expresamente. En Francia, el artículo 706-83 de la Ley Procesal Penal establece que dicha autorización fijará la duración de la operación de infiltración, que no podrá exceder de cuatro meses, habiendo incluso la posibilidad de renovación del plazo. Y en Bélgica el artículo 87 del Código Procesal Penal dispone que el período en que se pueda desarrollar una operación a través de agente encubiertos tendrá como límite temporal el plazo de tres meses desde la concesión de la autorización.

Hechas las consideraciones generales respeto a algunas formas de tratamiento del tema del aspecto temporal de una operación encubierta a través de agentes infiltrados, nos parece claro el acierto de las legislaciones francesa y belga en definir claramente el plazo de duración de la operación, respetando el principio de legalidad y evitando interpretaciones analógicas que pueden terminar siendo objeto de cuestionamiento judicial. Además, podrán quedar establecidas situaciones de prórrogas del plazo inicial de la operación encubierta, hecho este que servirá como complemento para lograr el fin objetivado de búsqueda de datos, informaciones y pruebas sobre las actuaciones del grupo delictivo.

\section{V.1.3.3. Los riesgos en la operación y su repercusión en la duración de la medida.}

Es algo común afirmar que la práctica demuestra que una mayor infiltración del agente determina un aumento del propio ámbito de la investigación, es decir, se incrementan las actividades de la organización que son sometidas a la acción policial, una más larga duración del propio periodo de infiltración, un incremento y una diversificación de los mecanismos destinados a lograr la confianza de los miembros de la organización, así como una intensificación de esa confianza. Así las cosas, cuanto más intenso es el grado de infiltración del agente, con la consiguiente acentuación de sus elementos característicos, mayor es el riesgo de que se produzcan infracciones procesales que determinen la nulidad del acto de investigación o la exclusión de valoración de su resultado, y también es mayor el peligro de que el agente encubierto cometa actos constitutivos de infracción penal1557.

1556 Vid. ARAÚJO DA SILVA, E., Crime organizado, Procedimento probatório, cit., págs. 87-88. En sentido contrario a esta idea, en razón de no ser racional la invocación de la analogía, vid. PACHECO, R., Crime organizado. Medidas de controle e infiltração policial, cit., pág. 120. Nos parece dogmáticamente correcta esta segunda posición, pues como ya señalado por JULIO MAIER "en el Derecho procesal penal se prohíbe recurrir a la analogía, como consecuencia del mandato de interpretar restrictivamente la ley, en los mismos casos designados inmediatamente antes: reglas que restringen la libertad del imputado o que limitan el ejercicio de una facultad que la ley le confiere, y reglas que limitan un poder concedido a cualquiera de los intervinientes en el procedimiento". Vid. MAIER, J. B., Derecho procesal penal. Fundamentos, Buenos Aires, 2004, pág. 236.

1557 Esta la opinión de DELGADO MARTíN, J., Criminalidad Organizada, cit., pág. 61. La regla general es fácil de entenderse, partiendo de la idea central de que cuanto más tiempo venga a perdurar la operación de 
Se trata de una cuestión lógica en razón del grado de compromiso asumido por el infiltrado junto a otros miembros del grupo criminal. Cuando se estrechan los lazos de amistad y de confianza entre el agente y sus nuevos "compañeros" surgen algunas consecuencias naturales, o sea, una referente al fortalecimiento del vinculo afectivo entre los miembros de la organización y el nuevo participante (el infiltrado), hecho este que posibilitará la obtención de informaciones esenciales sobre el modus operandi del clan, y de otra parte, a partir de la formación de este mismo vínculo, el peligro de que en caso de descubierta de la verdadera identidad del agente la traición podrá costarle la propia vida.

Desde esta concreta perspectiva, cuanto mayor sea el grado de infiltración mejores serán las expectativas de obtener datos útiles sobre la estructura de la organización, sus actividades y sus auténticos dirigentes. Pero paralelamente también aumentará de forma significativa el peligro de que el agente cometa actos constitutivos de infracción penal, lo que significa que nacerán riesgos reales para el adecuado respeto de los postulados del Estado de Derecho, máxime en unos tiempos caracterizados por el desarrollo de las nuevas tecnologías sobre la información, las comunicaciones y el tratamiento automatizado de los datos personales ${ }^{1558}$.

Esta cuestión es importante a la vista que toda actividad de investigación que pueda restringir derechos del ciudadano, por lo que deberá en regla contener plazos o limitaciones temporales para su ejercicio o al menos quedar bajo un rígido control jurisdiccional basado en el criterio de proporcionalidad y razonabilidad adecuados al caso concreto. Esta segunda opción nos parece en los días actuales la más plausible teniendo en cuenta la ausencia casi unívoca de previsión de plazos para la infiltración en los ordenamientos jurídicos de nuestro entorno ${ }^{1559}$.

En esta dirección surge la preocupación con el tema de una posible duración en abierto del plazo de infiltración de un agente en las entrañas de una organización criminal, incluso justificando este hecho por la necesidad de un periodo mayor para conocimiento de los hábitos y modus operandi del clan de delincuentes.

Así es que afortunadamente, según GUZMÁN FLUJA, no se contempla la posibilidad de medidas de duración indeterminada (lo que sería incompatible con el propio presupuesto de la existencia de un proceso penal abierto, porque cerrado éste, en concreto su fase de investigación, debe cesar la medida). Esto supone, incluso, la posible existencia de un marco de indefinición o de falta de concreción temporal que no cuadra con las garantías del proceso penal ${ }^{1560}$.

infiltración del agente, lógicamente serán mayores las posibilidades de errores operacionales por parte del infiltrado, a punto de exponer su propia vida, también más destacada será la necesidad de práctica de delitos para la manutención de su confianza junto a los otros miembros del clan criminal, y al fin, crecen las posibilidades de prácticas de actos restrictivos de derechos y garantías fundamentales de las personas investigadas.

1558 Cfr. DELGADO MARTín, J., Criminalidad Organizada, cit., pág. 47.

1559 Como ya hemos tenido oportunidade de mencionar, algunas excepciones se pueden buscar en las leyes penales francesa y belga donde la duración de la medida se hace expresamente. En Francia, la autorización fijará el plazo que no podrá exceder a cuatro meses, aunque sea posible la prorroga (art. 706-83). Ya en Bélgica, el plazo no podrá superar los tres meses (artículo 47).

1560 Vid. GUZMÁN FLUJA, V. C., "El agente encubierto y las garantías del proceso penal", cit., pág. 214. 
Otro factor de destaque se da respecto al hecho de que la labor del agente infiltrado se prolonga necesariamente en el tiempo, no siendo una actuación meramente esporádica, porque solamente así conseguirá la mínima integración necesaria en el grupo criminal ${ }^{1561}$.

Es casi imposible que el agente consiga en un corto lapso de tiempo obtener los datos e informaciones que puedan servir integralmente a los objetivos establecidos para el éxito de la operación encubierta. Dicho en otras palabras, solamente el tiempo de convivencia prolongado, junto a los miembros del grupo criminal, podrá ofrecer las respuestas que interesan a las autoridades que coordinan el funcionamiento de esta técnica de investigación.

Parece imprescindible un tiempo mínimo de contacto del infiltrado con los otros miembros de la organización criminal en razón de que la confianza no se adquiere de modo automático, sino que es conquistada diariamente a través de la participación del agente en la rutina del clan ${ }^{1562}$. Sus opiniones, gestos y actitudes serán evaluados por sus nuevos compañeros y solo a partir de este momento empieza a fortalecerse un lazo de amistad y confianza sobre el infiltrado.

De manera más concreta algún autor, como GÓMEZ DE LIAÑO FONSECA-HERRERO, defiende incluso que es fácil imaginar que el éxito de estas operaciones depende, en gran medida, del mantenimiento en secreto de la propia investigación y de una duración razonable, sin duda mayor a un mes ${ }^{1563}$.

Ante el silencio legal de un límite máximo, tendrá que ser el mínimo imprescindible y necesario para el desarrollo de la investigación, pues de lo contrario se conculcarían los derechos de los investigados ${ }^{1564}$.

Lo más imprescindible en estos casos corresponde evitar que la operación con la infiltración de un agente encubierto en una determinada organización criminal permanezca por tiempo indeterminable, sin límites preestablecidos, a la vez que estarían aumentando en gran escala las posibilidades de violaciones innecesarias a algunos derechos y garantías de las personas investigadas ${ }^{1565}$.

Una observación interesante se refiere al número de agentes encubiertos y los cambios que se vayan produciendo a lo largo de la investigación, los cuales tendrán que

1561DELGADO MARTíN, J., Criminalidad Organizada, cit., pág. 60.

1562 Siguiendo esta línea de pensamiento, sostiene ESPINOSA DE LOS MONTEROS que "debemos tener en cuenta que la infiltración policial no es un medio que se pueda programar completamente y que necesita un tiempo de maturación para poder llegar a obtener el fin perseguido". Cfr. ESPINOSA DE LOS MONTEROS, R. Z., El policía infiltrado. Los presupuestos jurídicos en el proceso penal español, cit., pág. 356.

1563 Cfr. GÓMEZ DE LIAÑO FONSECA-HERRERO, M., "Infiltración policial y proceso penal", cit., pág., 215. El análisis práctico de las operaciones encubiertas más destacadas y noticiadas por la prensa internacional no presenta una conclusión de que el plazo mínimo para la obtención de resultados exitosos sería de al menos seis meses, lapso este suficiente para conocerse la estructura y la jerarquía del grupo criminal. Dicho en otros términos, no se consigue muchos datos y informaciones en un mes de infiltración, salvo en situaciones excepcionales.

1564 PAZ RUBIO, J. Ma et alli., La prueba en el proceso penal. Su práctica ante los Tribunales, cit., pág. 401.

1565 La razón entonces para el establecimiento de un plazo "cerrado" para la duración de la operación encubierta tiene fundamento en el hecho de que en esta especie de investigación criminal, a todo tiempo habrán posibles violaciones de derechos fundamentales, lo que no permitiría la permanencia de un infiltrado por tiempo indeterminado dentro de una organización criminal, exponiendo la seguridad jurídica a riesgos de alto grado, bien como dificultando también el control de la operación. 
ser autorizados por el Juez competente ${ }^{1566}$. A esto se denomina control operacional y legal de la operación encubierta.

Sin embargo, si en el curso de la investigación por parte de los agentes encubiertos, se descubriese que la actividad de los sujetos sospechosos es distinta del rol en numerus clausus establecido para esta especie de investigación, deberá cesar inmediatamente el cometido de los agentes infiltrados y, adoptar el Juez la resolución que proceda en atención a las circunstancias concurrentes ${ }^{1567}$.

En congruencia con lo expuesto, llegase a conclusión una vez más de que la medida procesal de infiltración mediante uso de agentes encubiertos, sólo se adoptará cuando no exista otro medio de investigación del delito menos gravoso. La intervención del agente encubierto habrá que relacionarla directamente con la proporcionalidad del hecho, de tal suerte, que sólo se autorizará en aquellos casos en que las informaciones y las pruebas sólo puedan obtenerse, por esta técnica. En definitiva, la excepcionalidad significa que las finalidades de la investigación no puedan lograrse de otro modo ${ }^{1568}$.

Desde otro ángulo, deberá ser exigido en las hipótesis de infiltración policial un destacado y serio control judicial con el objetivo de evitar violaciones a preceptos básicos de un Derecho Procesal penal garantista.

El control judicial en todo momento tiene que ser riguroso y en grado sumo, desde el inicio hasta el final, incluyéndose las excepcionales prórrogas, con el objetivo de vigilar para que en todo acto se cumpla el ordenado y sin provocar perjuicios a los derechos fundamentales de los sospechosos.

A demás, se hace imprescindible que los agentes encubiertos pongan en conocimiento del Juez, en su integridad, toda la información que vayan recabando de sus investigaciones ${ }^{1569}$. Es el Juez quien en función de la integridad de la información acordará, las resoluciones procedentes, según lo que sea útil para la instrucción, y desechando lo irrelevante, por lo que le está vedado al agente seleccionar a su libre arbitrio que información le transmitirá al Juez instructor. El problema será la fiscalización por la autoridad judicial sobre la totalidad de las informaciones. Si no es "íntegra", lo que será casi imposible de comprobar, afecta a las garantías del acusado y al requisito

1566 Cfr. PAZ RUBIO, J. Ma et alli., La prueba en el proceso penal. Su práctica ante los Tribunales, cit., pág. 396. El control de la operación de infiltración policial es fundamental a los fines de posibilitar que la búsqueda de pruebas y informaciones contra los miembros de una determinada organización criminal, se presente en consonancia con los postulados procesales y constitucionales inherentes a la actividad probatoria. Dicho en otras palabras, si no hay control respecto a la legalidad de los actos de investigación del infiltrado, lógicamente se estará delante de posibles y inevitables excesos y abusos que iban a impregnar la idoneidad de la prueba obtenida.

1567 Esta actitud mantiene el órgano autorizador de la resolución en condiciones de imparcialidad y con el status de mantenedor de la legalidad, a la vez que mismo teniendo otorgado de forma motivada el inicio de la operación encubierta, podrá en caso de no observancia del cumplimiento de los requisitos contenidos en al autorización o en la hipótesis de violación a los reglamentos jurídicos, adoptar una posición de anulación de los efectos de su anterior decisión, determinándose el fin de la operación policial.

1568 Vid. PAZ RUBIO, J. Ma et alli., La prueba en el proceso penal. Su práctica ante los Tribunales, cit., pág. 399.

1569 De este modo, en nuestra opinión, el plazo no puede ser definido de una forma muy rígida y especificada, debiendo el infiltrado atentarse a la obligación de poner las informaciones y datos con la mayor brevedad posible a las autoridades de persecución, evitándose riesgos desnecesarios y la pérdida de oportunidad de acciones de desarticulación del clan criminal. Además, todo dependerá del riesgo presentado, de la importancia del contenido de la información y del modo como será repasada los informes. En sintesis, deberán ser obedecidas las cautelas y los procedimientos de seguridad para que el infiltrado no venga a ser descubierto y expuesto a toda suerte de actos de venganza. 
constitucional de la motivación y consecuentemente de la necesaria proporcionalidad a la hora de mantener o prorrogar la medida acordada 1570.

Al fin, deberá concluirse que amén de la ausencia explícita de un plazo de duración de la infiltración, hecho este frecuente en la gran mayoría de los ordenamientos jurídicos que han recientemente reglamentado el uso de esta técnica investigativa, nos parece más correcto interpretar que la mejor solución en estos casos será dejar al criterio de la autoridad competente para otorgar la resolución la determinación de un lapso temporal máximo para la conclusión de la investigación, debiendo el Juez de Instrucción, a través de los criterios de proporcionalidad y razonabilidad, fijar en cada caso concreto la duración exacta del periodo en que podrá el agente encubierto laborar con vistas a la obtención de datos, informaciones y pruebas que puedan llevar a la desarticulación del grupo de delincuentes organizados.

\section{V.1.3.4. La posibilidad de prorrogar las operaciones encubiertas.}

De manera clara y directa queremos cuestionar si son aceptables y justificables las prórrogas de las infiltraciones por sucesivos periodos, tomando en consideración la afectación que esta actuación policial supone para un buen conjunto de derechos y garantías procesales.

De inicio deberá ser esclarecido que la prórroga consiste en la extensión del plazo anteriormente establecido por la autoridad judicial para el desarrollo de la operación de infiltración de un determinado agente encubierto en una organización criminal1571.

A priori, puede ser justificada esta ampliación en razón de que el infiltrado no haya conseguido dentro del lapso temporal previsto poner en práctica toda su labor, necesitando de más tiempo para obtener las informaciones imprescindiblespara el éxito de la operación. 0 dicho de otro modo: en razón de que el plan está consiguiendo ser fructífero, existirá la necesidad de instar un nuevo plazo para el cumplimiento integral de las finalidades buscadas a través de la introducción del agente estatal en el seno del grupo criminal.

Como regla general, en caso de silencio de la ley, la prórroga del plazo de infiltración de un agente encubierto en una determinada banda criminal podrá ocurrir tantas veces sea necesario a los fines de la investigación. En última instancia, dependerá de la concreta forma como el tema ha sido disciplinado en un determinado ordenamiento jurídico, pues incluso podrá estar restringida en la ley la posibilidad de prórrogas del lapso temporal para la infiltración policial, bien sea en su totalidad o ya sea en cuanto al número de las prórrogas.

En linea de principiose puede afirmar que el Juez decretará la prórroga cuando la investigación no haya arrojado los resultados deseados, o acordará la extinción de la

1570 Vid. PAZ RUBIO, J. Ma et alli., La prueba en el proceso penal. Su práctica ante los Tribunales, cit., págs. $399-400$

1571 Por esta razón, "será tarea primordial de los mandos policiales constatar, en función de los resultados obtenidos hasta el momento, si tiene sentido prolongar la infiltración o si no lo tiene (bien ante el fracaso, bien porque ya se ha obtenido de ella todo lo que se esperaba)". Vid. GASCÓN INCHAUSTI, F., Infiltración policial y "agente encubierto", cit., págs. 119-120. 
medida, sin prórroga alguna, cuando la diligencia haya satisfecho las pretensiones investigadoras ${ }^{1572}$.

De este modo, señala ESPINOSA DE LOS MONTEROS refiriéndose al ordenamiento español, que si la autoridad competente decide que el resultado de la infiltración en la primera fase es fructífero, podrá autorizar la prórroga de la infiltración policial que al igual que la autorización inicial no tendrá porque ser de seis meses, sino que se podrá autorizar por el tiempo que se estime oportuno ${ }^{1573}$.

La solución presentada nos parece lógica si pensamos en términos de una estrategia policial eficaz para conseguir el objetivo de desarticular el clan criminal, debiendo quedar el infiltrado insertado en la organización criminal por un tiempo razonable y ajustado a la obtención de las informaciones y pruebas necesarias a la persecutio criminis.

Lo más importante es que la posibilidad y el plazo de una eventual prórroga se encuentre previsto expresamente en la ley, como forma de respeto a los principios de legalidad y proporcionalidad.

En este contexto, aunque normalmente no exista en los distintos ordenamientos jurídicos un número máximo de prórrogas susceptibles de concesión, el criterio de proporcionalidad exige del órgano judicial una resolución motivada sobre la necesidad de extender la duración de la medida1574.

En torno a esta afirmación, cabe precisar que se quiere decir que el plazo de la prórroga no tiene que ser obligatoriamente el mismo concedido en la autorización inicial, sino que su quantum dependerá de las necesidades exigidas por la investigación. Entra en juego, una vez más, la necesidad del análisis del caso concreto a la luz de la proporcionalidad, donde tendrá destaque un estudio pormenorizado de la idoneidad, de la adecuación y de la ponderación aplicable. Dicho en pocas palabras, la prórroga deberá sujetarse al principio de proporcionalidad para evitar la actuación desmedida y arbitraria de los poderes públicos ${ }^{1575}$.

Al fin de este apartado, cabe señalar que se percibe en la práctica que en algunas situaciones es previsible que las prórrogas sean varias y sucesivas, pero puede suceder en otros casos que la organización sea desarticulada en el plazo original o que no se trate de un grupo delictivo, o que se torne inviable seguir con la infiltración sin que los fines pretendidos sean alcanzados: compete entonces a la Policía poner fin a la actuación cuando, por cuestiones de seguridad o interés, no quepa mantenerla, comunicándolo inmediatamente al Juez ${ }^{1576 .}$

En breve síntesis: cada operación de infiltración analizada concretamente, tomara un rumbo distinto, con consecuencias y adopción de medidas necesarias al logro de sus fines. Así, la prórroga de la ejecución de la técnica de investigación de agente encubierto

1572 GÓMEZ DE LIANO FONSECA-HERRERO, M., "Infiltración policial y proceso penal", cit., pág. 215.

1573 Vid. ESPINOSA DE LOS MONTEROS, R. Z., El policía infiltrado. Los presupuestos jurídicos en el proceso penal español, cit., pág. 361.

1574 Cfr. GÓMEZ DE LIAÑO FONSECA-HERRERO, Criminalidad organizada y medios extraordinarios de investigación, cit., págs. 196-197. Véase también, STEDH caso Lambert de 24.8.1998 (TEDH 1998/40); SSTC 299/2000, de 11.12.2000 y 236/1999, de 20.12.1999.

1575 Cfr. ESPINOSA DE LOS MONTEROS, R. Z., El policía infiltrado. Los presupuestos jurídicos en el proceso penal español, cit., pág. 362.

1576 Cfr. CORRÊA DE CARVALHO, J .T., Tráfico de drogas. Prueba penal y medidas restrictivas de derechos fundamentales, cit., pág. 329. 
podrá ocurrir desde que autorizada en consonancia con los postulados del principio de proporcionalidad y con expresa previsión legal.

V.1.4. Preparación adecuada de los agentes que van a infiltrarse en una organización criminal.

Es hecho comprobable que hay dificultades enprobar la existencia de actuación de grupos relacionados al crimen organizado e incluso la participación individualizada de las personas pertenecientes a estos clanes.

De otra parte, es algo incontestable que este tipo de organizaciones criminales tienen la suficiente experiencia para conocer o intuir los procedimientos utilizados por las Fuerzas de Seguridad y adoptan una serie de contramedidas para dificultar la investigación, como son las acciones para detectar seguimientos policiales, el uso limitado de teléfonos con empleo de lenguaje encubierto y frecuente cambio de tarjeta, uso de cabinas telefónicas para conversaciones importantes, el trato sólo con personas de absoluta confianza, etc., que hacen necesario un sobreesfuerzo y una mayor imaginación por parte de los grupos policiales de investigación 1577 .

En este contexto, la técnica de agente encubierto requiere de un tratamiento muy especial, pues su función es en extremo delicada y supone en todo caso la puesta en riesgo de un bien jurídicamente tutelado de mayor jerarquía como es la vida del infiltrado.

Esto significa, sencillamente, que la formación de los responsables en la lucha contra la criminalidad organizada es fundamental se si pretende alcanzar resultados positivos en dicha tarea. Debido a la idiosincrasia de este fenómeno, los agentes responsables deben recibir no sólo una formación específica que les permita mejorar los conocimientos sobre los fenómenos de la delincuencia organizada, sino también una formación jurídica sobre la regulación penal y procesal vigente ${ }^{1578}$.

Esta ha sido incluso una de las Recomendaciones del Grupo de Trabajo Oficioso de Expertos sobre Técnicas Especiales de Investigación de Naciones Unidas, al determinar que "los agentes infiltrados deberían recibir formación especializada, que debería incluir formación sobre la ley aplicable, en especial énfasis en la instigación, provocación o incitación. También es preciso formar a los fiscales, magistrados y jueces en el uso y la metodología de las operaciones encubiertas"1579.

\footnotetext{
1577 Véase a respecto, HERNANDO MARTÍN, F., "La guardia civil en la lucha contra el crimen organizado: técnicas de información, metodología operativa y directrices policiales en las investigaciones", pág. 1390, http://www.cej.justicia.es. Por esto, explica POZO PÉREZ que "no basta ser funcionario de la Policía Judicial, y prestarse voluntario para ejercer dicho papel en la investigación criminal, sino que deberá gozar de un perfil determinado y tener una formación adecuada; no hay que olvidar que además de tener que cumplir una fundamental misión de investigación de una organización criminal deberá proteger su vida, seguridad personal e integridad, que en algún momento puede verse en peligro". Vid. POZO PÉREZ, M., "El agente encubierto como medio de investigación de la delincuencia organizada en la Ley de Enjuiciamiento Criminal española", cit., pág. 289.

1578 Cfr. MAPELLI CAFFARENA, B; GONZÁLEZ CANO, Mà. I., AGUADO CORREA, T., Estudios sobre Delincuencia Organizada. Medios, instrumentos y estrategias de la investigación policial, cit., pág. 45.

${ }^{1579} \mathrm{Cfr}$. la Recomendación n. 33 del Grupo de Trabajo Oficioso de Expertos sobre Técnicas Especiales de Investigación de Naciones Unidas (Prácticas óptimas y recomendaciones sobre los obstáculos jurídicos a las entregas vigiladas y las operaciones encubiertas), elaborada por la Oficina contra la droga y el delito en septiembre de 2005. Justificase esta recomendación en razón de que dado que las actividades encubiertas quizá requieran que el agente infiltrado incurra en conducta delictiva, es de vital importancia que los
} 
Entrenar y preparar a un futuro agente encubierto nos parece ser una de las tareas más arduas encargadas al Estado, que empieza desde el reclutamiento de esta persona, pasando por una adecuada y rígida programación de las funciones que serán objeto de la labor investigativa. Y dentro de este proceso de formación del agente infiltrado destaca la preparación psicológica del mismo, teniendo en cuenta que podrá permanecer lejos de su familia y de sus actividades cotidianas por un largo plazo, y lo más grave, conviviendo en un ambiente hostil y peligroso.

Por esta razón, desde el punto de vista metodológico y técnico-policial, las acciones encubiertas constituyen procedimientos complejos, donde el alto grado de riesgo y la gran presión psicológica son características destacadas. Su desempeño exige una elevada disciplina funcional, especialización técnica e intenso entrenamiento ${ }^{1580}$.

Observa también POZO PÉREZ que en España, para infiltrarse en un grupo criminal, se recurre a funcionario de policía que desea voluntariamente hacerlo, y se le dota de esa identidad supuesta, se le forma y se le infiltra. Sin embargo, esto no es así en otros países como Estados Unidos, con gran tradición y experiencia en esta materia, donde lejos de ser la infiltración una técnica de investigación de uso puntual poseen auténticas unidades orgánicas de agentes encubiertos o undercovers de las que se van obteniendo los funcionarios para infiltrar en los ambientes criminales ${ }^{1581}$.

Una vez determinado el funcionario de Policía Judicial que va a ejercer como agente encubierto en una determinada investigación, es necesario dotarle de una formación específica e integral donde se aborden todos los aspectos relacionados con su futura actividad ${ }^{1582}$. Es ineludible afianzar sus conocimientos sobre sus actuaciones,

funcionarios estén bien informados y al tanto de los límites de su autoridad, así como del marco jurídico en el que actúan.

1580 En este sentido, vid. BRAZ, J., Investigação Criminal. A organização, o método e a prova. Os desafíos da nova criminalidade, cit., pág. 327.

1581 Vid. POZO PÉREZ, M., "El agente encubierto como medio de investigación de la delincuencia organizada en la Ley de Enjuiciamiento Criminal española", nota 36, cit., pág. 281. Incluso citada autora manifiesta su admiración por el modelo estadounidense de infiltración, al señalar que "yo soy más partidaria del sistema americano, es decir, de tener una unidad especializada y específica de potenciales agentes encubiertos que deseen formar parte de la misma por supuesto voluntariamente, que superen un concurso y cursos de formación y que se preparen durante un tiempo para ser, llegado al caso, un infiltrado. A mi juicio esto garantizaría mejor el éxito de las operaciones, tanto en lo referente a la protección y garantía de la vida e integridad del agente, como en todo lo que tiene que ver con la obtención de todos los datos posibles relacionados con la investigación de la organización ilícita". Vid. POZO PÉREZ, M., "El agente encubierto como medio de investigación de la delincuencia organizada en la Ley de Enjuiciamiento Criminal española", nota 36, cit., pág. 281

1582Una observación peculiar ha sido hecha por MONTOYA en el sentido de que "cuando los policías regulares son usados como agentes, algunas veces se suele preferir utilizar a aquellos que se han agregado recientemente a la fuerza, inclusive sin entrenamiento académico sobre las prácticas encubiertas. En otros casos los policías enlistan a estudiantes, por cuanto hay ocasiones en las cuales se requiere que el hombre elegido no tenga ciertos modismos propios de los integrantes de los cuerpos ya formados, que revelarían su verdadero carácter". Pero, concluye e citado autor argentino que en su opinión, "el éxito de la intervención del agente encubierto depende de algunas condiciones fundamentales. La selección de las personas a emplear requiere gran cuidado y experiencia. Por razones de seguridad los oficiales que actúan como agentes encubiertos deben descartar la colaboración con las personas de confianza. Al utilizar la técnica encubierta se tomará contacto en forma independiente con el medio criminal". Además, no se puede contestar que "los agentes encubiertos son agentes de policía especialmente seleccionados que actúan dentro del marco legal vigente y a largo plazo con una asignación concreta para combatir delitos especialmente peligrosos y/o de difícil esclarecimiento, provistos con una leyenda y manteniendo en secreto su identidad, toman contacto con la escena delictiva para lograr puntos de apoyo informativos con la finalidad de repeler el peligro y/o llevar a cabo la persecución penal cuando han fracasado otros métodos de investigación o éstos no aseguren el éxito buscado". Vid. MONTOYA, M. D., Informantes y técnicas de investigación encubiertas. Análisis constitucional y procesal penal, cit., págs. 32 y 154-155. A nuestro modo de pensar, es perfecta y ideal esta idea esbozada por 
personalidad, utilización de medios técnicos, contra-vigilancias, técnicas de entrevista e interpretación; estudio de la legislación, planificación y ejecución operativa, integridad moral, autocontrol, intercambio de experiencias con otros compañeros que hayan podido estar infiltrados antes, etc. Además de la citada formación, que sin duda ha de superarse antes de ser infiltrado, debe completarse la misma con conocimientos jurídicos, técnicos y psicológicos, una formación específica para velar por los aspectos de seguridad y prácticas de campo ${ }^{1583}$.

Resalta entre nosotros la necesidad imperiosa de creación, en un futuro próximo, de centros especializados con la finalidad de preparar personas que puedan laborar como agente encubiertos en infiltraciones en las grandes redes de delincuencia organizada1584.

Todavía no se puede desconocerse que en los países más avanzados en términos de técnicas de investigación estas operaciones tienen en sus Unidades Especializadas de agentes encubiertos, un departamento de infraestructura, con medios técnicos avanzados y personal cualificado que tiene como cometido único facilitar los medios y documentos necesarios para que el agente pueda aportar a la organización esa identidad ficticia si fuera necesario ${ }^{1585}$.

A la vista de las anteriores reflexiones, resulta creíble la necesidad de que la persona que desarrolle estas funciones sea un profesional lo suficientemente preparado y que reúna una serie de cualidades excepcionales tanto en el plano operativo como en el plano ético, ya que sí la ética de la utilización de este medio de investigación puede estar en algún momento en entredicho lo estará mucho más si quienes actúan como agente infiltrado proceden del mundo de la delincuencia y del crimen ${ }^{1586 .}$

Montoya, y la razón es sencilla, pues debido al riesgo que se expone el agente infiltrado, cuando de su inserción el ambiente criminal de un grupo de delincuentes organizados, mejor será entrenar personas (agentes policías) para soportaren la presión psicológica y física de una operación de infiltración, y de preferencia, utilizándose de policías con larga experiencia con la criminalidad.

1583 Cfr. POZO PÉREZ, M., "El agente encubierto como medio de investigación de la delincuencia organizada en la Ley de Enjuiciamiento Criminal española", cit., pág. 290. Incluso respecto a necesaria formación psicológica del infiltrado, deberá citarse la Recomendación n. 34 del Grupo de Trabajo Oficioso de Expertos sobre Técnicas Especiales de Investigación de Naciones Unidas (Prácticas óptimas y recomendaciones sobre los obstáculos jurídicos a las entregas vigiladas y las operaciones encubiertas), elaborada por la Oficina contra la droga y el delito en septiembre de 2005. que define que "los Estados quizá deseen emplear exámenes y estudios psicológicos para determinar la idoneidad de un individuo para este tipo de trabajo". La explicación lógica para esta recomendación es que los agentes infiltrados están expuestos a situaciones de gran presión y enfrentan condiciones de vida que exigen determinada aptitud mental para este tipo de trabajo. Como garantía para el organismo encargado de hacer cumplir la ley y. al mismo tiempo, por el bien de los agentes infiltrados, se debería llevar a cabo un análisis psicológico con frecuencia, especialmente antes de organizar una operación.

1584 Tendrían estos centros de formación la misión institucional de entrenar y preparar personas que presenten un perfil prototipo ideal para actuar como infiltrado en una determinada operación encubierta, dotándoles de un sinnúmero de conocimientos y recursos materiales y humanos, buscando de este modo, dejar estos agentes en condiciones de se acaso necesario, puedan laborar de forma segura y con suficientes medios para sostener su identidad supuesta durante el periodo en que permanecieren dentro del ámbito de actuación del clan criminal.

1585 Cfr. POZO PÉREZ, M., "El agente encubierto como medio de investigación de la delincuencia organizada en la Ley de Enjuiciamiento Criminal española, nota 53, cit., pág. 291.

1586 En este sentido, vid. GONZÁLEZ-CASTELL, A. C., "El agente infiltrado en España y Portugal. Estudio comparado a la luz de las garantías y de los principios constitucionales", cit. pág. 193. En el mismo sentido, MOSCATO DE SANTAMARIA defiende que "se debe contar con personal altamente capacitado y con pleno conocimiento de las limitaciones que tienen su accionar, tratando de prevenir cualquier tipo de abuso en el ejercicio de su función". Vid. MOSTATO DE SANTAMARIA, C. B., El agente encubierto en un Estado de Derecho, cit., pág. 55. 
Importante además es esclarecer que el agente encubierto, aparte de respetar las formalidades que le impone el ordenamiento, deberá contar con un grado de formación y preparación que le permita llevar a cabo con éxito su actuación (que se da por supuesto dentro de la causa penal); si no cumple con las cualidades acabadas de mencionar, difícilmente se podrá considerar como viable su investigación durante el proceso penal ${ }^{1587}$.

Por fin, deberá ser reconocido que eventuales errores y una mala preparación de estos agentes podrán resultar en perjuicios muy grandes a los objetivos de la investigación criminal, si bien que lo más terrible es que podrá costar incluso el precio de la vida del infiltrado o de algún de sus familiares o amigos en caso de descubierta su verdadera identidad y de su vinculación con los órganos de persecución penal.

Intuitivamente este argumento parece muy plausible, puesto que es natural esperar del Estado, la puesta en práctica de la persecutio criminis a través de medios de investigación dotados de estructura humana y material adecuada a provocar efectos positivos y a obtener resultados eficientes en cuando a desarticulación de las grandes redes de delincuencia organizada transnacional.

V.1.5. La búsqueda de un equilibrio procesal penal y la actuación de los agentes encubiertos. Especial referencia a los "puntos de equilibrio" que deberán ser alcanzados.

Nos parece oportuno en este momento demostrar de modo claro, objetivo y lejos de dudas, como funcionaría el encaje de la técnica de utilización del agente encubierto en la zona de equilibrio procesal, la cual presenta como finalidad minimizar los efectos de la tensión existente entre el derecho de punir estatal (eficacia) y la defensa de los derechos fundamentales de la persona sometida a la persecutio criminis (garantías).

En este sentido, se deberá establecer como punto inicial que en el Derecho Procesal penal está latente la tensión entre seguridad ciudadana y los derechos fundamentales frente al ejercicio del ius puniendi estatal a través de la búsqueda de una eficaz represión de la criminalidad.

En realidad, hemos visto que la actuación del agente encubierto en las entrañas de una organización criminal conlleva un sinnúmero de situaciones de peligro, no solo para la vida del infiltrado, sino que podrá afectar seriamente derechos y garantías fundamentales de las personas investigadas, poniendo en riesgo el mantenimiento del Estado de Derecho ${ }^{1588}$.

Así es que se revela que esta técnica de investigación se mueve precisamente en la zona de frontera que intercepta el binomio seguridad/libertad, una tensión dialéctica resultante de la constante búsqueda del equilibrio entre los objetivos de prevención y

1587 Cfr. MARCHAL ESCALONA, A. N., "Drogas. Actuación policial. Problemas en la investigación", cit., págs. 270-271.

1588 Por esta razón es que "la actividad de los agentes infiltrados en el marco de las investigaciones de delincuencia organizada y la eficacia posterior en el proceso de los elementos de prueba obtenidos, quedará condicionada por el respeto a los principios del proceso penal, esencialmente el derecho de defensa y la presunción de inocencia". Cfr. RIFÁ SOLER, J. Mạa; RICHARD GONZÁLEZ, M; RIAÑO BRUN, I., Derecho procesal penal, cit., pág. 285. 
represión al crimen y la observancia rigurosa de los principios inherentes a un Estado de Derecho democrático ${ }^{1589}$.

De hecho, en el plan teórico, deberíamos comprender que la clave para el establecimiento de una zona de equilibrio procesal penal estaría en reconocer ante cada caso concreto de una solicitud de infiltración policial la intensidad de la amenaza concreta al derecho fundamental, la medida violadora del peligro de vulneración de la garantía, y por fin, el grado de afectación del interés general por la situación puesta en análisis ${ }^{1590}$. Pero esta idea no parece adecuada y de posible concreción a menos que se considere la importancia del análisis de estas vertientes o "puntos de equilibrio" bajo la óptica del principio de proporcionalidad.

A estos efectos debe recordarse preliminarmente que la proporcionalidad significa la ponderación de principios o intereses constitucionales en conflicto en el modelo de un Estado que centraliza los derechos fundamentales en su orden jurídica.

Se puede incluso afirmar que este principio, presente explícitamente o implícitamente en la gran mayoría de las Constituciones de los países democráticos, no puede ser considerado en puridad como una norma jurídica, sino más bien como un principio heurístico de la interpretación constitucional ${ }^{1591}$.

Al fin, tiene por finalidad primordial la preservación de los derechos fundamentales, viniendo a coincidir pues con la "esencia y destinación misma de una Constitución de un Estado de Derecho democrático", lo que le confiere la característica de "principio de los principios", verdadero principium ordenador del Derecho ${ }^{1592}$.

Volviendo al tema de los requisitos exigibles para el perfecto análisis de una petición de autorización para una determinada operación encubierta, pasemos a presentar algunas observaciones que reputamos de suma importancia.

El primer requisito, referido a la intensidad de la amenaza concreta al derecho fundamental se refiere a la constatación de que la actuación específica del agente encubierto infiltrado en una organización criminal viene de forma indudable a provocar serias restricciones a las garantías de la persona investigada.

Sobre esta cuestión, nos parece muy lógico que la autoridad responsable para analizar la solicitud de expedición de una resolución para la operación encubierta, cuando tenga que manifestarse, tiene la obligación de ponderar los intereses en juego ${ }^{1593}$,

1589 Vid. ONETO, I. O agente infiltrado. Contributo para a compreensão do regime jurídico das acções encobertas, cit., págs. 12-13.

1590 No se debe olvidar de que sólo se podrá establecerse la "zona de equilibrio procesal" a partir del cumplimiento impositivo de los postulados inherentes a la proporcionalidad.

1591 En palabras de GIMENO SENDRA, "la incidencia de los actos procesales, fundamentalmente a lo largo de la fase instructora, sobre los derechos fundamentales ocasiona que deba aplicarse la doctrina emanada del TC sobre el principio de proporcionalidad, según el cual no es suficiente que el acto de investigación, lesivo de un derecho fundamental, haya emanado de la autoridad competente, sino que es también necesario, en primer lugar, que esté previsto en la Ley, en segundo, que objetivamente se justifique y, en tercero, que la resolución judicial que ordena la limitación del derecho fundamental esté minuciosamente motivada, de tal suerte que, en ella, se plasme el ineludible juicio de necesidad del que se desprenda el sacrificio del derecho fundamental, objeto de la medida". Vid. GIMENO SENDRA, V., Derecho Procesal Penal, cit., pág. 61.

1592 De acuerdo con esta opinión, Cfr. GUERRA FILHO, W. S., Processo constitucional e direitos fundamentais, São Paulo, 1999, págs. 61-62.

${ }^{1593}$ Desde una perspectiva amplia, no se puede desconocer que en la ponderación entre valores no se debe dejar de concluir que la inclinación de la balanza se hará por el mayor o menor despertar del consenso, consecuencia típica de un procedimiento valorativo. En la metódica estructurante, al contrario, la ponderación 
buscando con esta actitud vislumbrar el nivel de amenaza que se puede provocar al derecho del ciudadano en caso de que seaconcedida la autorización. Dicho en otras palabras, tiene normalmente el Juez de Instrucción la tarea de, utilizando sus conocimientos jurídicos y haciendo uso de su sensibilidad como representante estatal en aquél acto, promover la adecuación de la solicitud a los fines de la investigación y a los postulados de la razonabilidad.

Se destaca entonces la necesidad de que la amenaza provocada por las conductas delictivas de un determinado grupo de criminales organizados sea de tal magnitud que venga a justificar el empleo de una medida excepcional y violadora de derechos fundamentales, como es el caso de la infiltración a través de agentes encubiertos.

No se justificaría, por supuesto, la emisión de una autorización para el inicio de una operación encubierta en hipótesis de simples hurtos practicados por un pequeño grupo de delincuentes callejeros contra peatones. Y la razón es sencilla, pues ausente estaría la gravedad de la amenaza provocada a los derechos fundamentales de estas personas, siendo esta especie de actuación delincuencial resuelta a través del simple uso de otros medios de investigación menos invasivos a las garantías constitucionales, como por ejemplo a través del control de las calles mediante el uso de cámaras de videovigilancia o incluso a través del incremento del efectivo policial en los puntos más vulnerables de algunas calles.

El segundo requisito se predica respeto de la medida violadora del peligro de vulneración de la garantía. La propia técnica de infiltración deberá también ser objeto de un estricto análisis por la autoridad encargada de expedir la autorización.

Se quiere decir con esto que tendrá el Estado, titular de la persecutio criminis, que ponderar la necesidad de utilización de esta medida de introducción de un agente encubierto en las entrañas de una determinada organización criminal, sin olvidarse que referida técnica es representativa de un modus de actuar que podrá provocar graves violaciones a derechos y garantías de las personas investigadas ${ }^{1594}$.

En este punto del examen, la autoridad competente procederá a un estudio de la situación dibujada en la solicitud, buscando de esta forma encontrar fundamentos que vengan a justificar la existencia de idoneidad del uso de este medio extraordinario de investigación criminal.

Por fin, cabe además, como tercero requisito, proceder a un estudio sobre el grado de afectación del interés general delante de la situación puesta en análisis. Desde este punto de vista, se hace imprescindible la aplicación de la regla de ponderación de los bienes en conflicto. Es la tensión establecida: ¿seguridad a través de la búsqueda de eficacia represiva o libertad como garantía fundamental del ciudadano?

entre derechos, no obstante carretada de valoraciones del Juez, buscará, mediante los principios de concordancia práctica y de la proporcionalidad, utilizar referenciales diversos. En consecuencia, será el valor más prestigiado que prevalecerá. Los referidos principios iban a servir, antes, para restringir, en la menor medida posible el otro valor en juego". Con riqueza de detalles respecto a esta concepción dogmática, Vid. ALEXY, R., "Colisão de direitos fundamentais e realização de direitos fundamentais no Estado Constitucional Democrático", Revista de Direito Administrativo, núm. 217, 1999, págs. 67-79.

1594 En este sentido, "hay que fundamentar la necesidad de que el Estado recurra a medidas de investigación en cuya base se encuentre el recurso a un engaño". Cfr. GUZMÁN FLUJA, V., "El agente encubierto y las garantías del proceso penal", cit., pág. 217. 
La ponderación, en palabras de MARTÍNEZ ZORRILLA, se puede considerar como un mecanismo para poder dar una respuesta a problemas de colisión o conflicto normativo, y en este sentido se asemeja a los clásicos criterios de resolución de antinomias, como por ejemplo lex superior ${ }^{1595}$.

Esta regla de ponderación, aplicada al caso concreto, significa que el Juez cuando del análisis de los principios en conflicto, y en la búsqueda de la solución de compromiso en la cual se respeta más en una determinada situación una de las vertientes, buscando el mínimo de ausencia de respecto al otro, no violando los respectivos núcleos esenciales, deberá tener en cuenta lo que sea el peso que iba a permitir la elección de uno u otro principio.

Cuando se tiene que decidir sobre el hecho de autorizar o no el inicio de una operación de infiltración policial deberá quedar inteligible y lejos de cualquier duda los provechos que se pueden obtener a través del empleo de esta técnica de investigación, de modo que el beneficio general de preservación de la seguridad colectiva afectada por la actuación de una organización criminal sea superior a la restricción sufrida o soportada en razón de la restricción o vulneración de las garantías constitucionales individuales inherentes a aquellas personas sometidas a la persecución penal.

En resumen, serían tres reflexiones o indagaciones ${ }^{1596}$ las que deberán ser contestadas o analizadas por el Juez de Instrucción -o por excepción por el Ministerio Fiscal- antes de dictar la resolución que autorice la puesta en práctica del plan operacional de infiltración:

$\left.1 .^{-}\right)$¿Es justificable la autorización para ingreso de un agente encubierto en un clan de delincuentes organizados, en razón del nivel de peligrosidad de la amenaza a los derechos y garantías fundamentales de las personas investigadas?

2.ํ) ¿Sería adecuada y necesaria la utilización de esta técnica policial para obtención de los fines de desarticulación de un grupo de delincuentes organizados?

3.ํ) ¿La repercusión de la concesión de autorización para la infiltración policial puede ser compatible con el sacrificio de determinadas garantías del investigado en pro de la manutención de la seguridad colectiva?

Contestadas de forma positiva estas tres cuestiones, estaría la actuación del agente encubierto situada de forma razonable y proporcional en la zona de armonía procesal penal, quedando las vertientes de la eficacia y de las garantías sopesadas y compatibilizadas, y por lo tanto, minimizados los efectos de la tensión de fuerzas.

Dentro de este contexto y estrechamente relacionado con la tan mencionada zona de equilibrio, la intervención del agente encubierto hay que circunscribirla en el campo de tensión existente entre el deber de los poderes públicos de realizar una eficaz represión de la conducta delictiva y la protección de que tales derechos deben dispensar el Estado ${ }^{1597 .}$

1595 Vid. MARTÍNEZ ZORRILLA, D., Conflictos constitucionales, ponderación e indeterminación normativa, Madrid, 2007, pág. 236.

1596 Serian estos los puntos de equilibrio que deberán ser buscados con el objetivo de establecimiento de la zona de armonía procesal penal, la cual tendrá como finalidad precipua el ablandamiento de la tensión de fuerzas imperante en la ciencia procesal penal moderna.

1597 Vid. MORENO CATENA, V., "Garantías de los derechos fundamentales en la investigación penal", Revista del Poder Judicial, número especial II, 1997, pág. 133. 


\section{V.2.Límites a la actuación del agente encubierto: el criterio de la última ratio.}

Como toda actividad que puede generar restricción o flexibilización de derechos y garantías fundamentales, la actuación del agente encubierto deberá ser marcada por algunos límites.

Uno de los más importantes está referido a la obediencia al criterio de la ultima ratio, el cual impone el empleo del medio extraordinario del agente encubierto como último recurso a ser empleado después de agotadas todas las otras formas de investigación ya ampliamente utilizadas por las autoridades de persecución penal ${ }^{1598}$.

Se justifica esta afirmación debido al hecho de que las limitaciones son parte esencial del establecimiento del principio de restricción a los abusos y arbitrariedades practicados normalmente por parte del Estado, o en situaciones excepcionales por los individuos así considerados aquellos portadores de derechos y garantías fundamentales.

Aplicando este conocimiento al tema de las infiltraciones, se percibe que la actuación del agente encubierto debe ir orientada a la comprobación de la actividad delictual, no a su provocación o inducción. La actividad desplegada por el agente infiltrado debe ir destinada al descubrimiento, averiguación y constancia de los delitos que investiga, nunca contribuyendo a su comisión ${ }^{1599}$.

Como técnica excepcional el agente encubierto, ya sea por razones de orden moral o ética, ya sea por razones de seguridad del propio infiltrado, solamente debe ser utilizado cuando todos los otros medios de obtención de prueba no fueron suficientemente capaces y eficaces para la averiguación de la verdad ${ }^{1600}$.

Significa este presupuesto que el agotamiento de todas las posibilidades de investigación a través de los medios tradicionales es un imperativo que tiene que ser seguido e impuesto con todo rigor, objetivando dejar para un ulterior momento la utilización de esta técnica policial que con toda seguridad podrá provocar vulneraciones a los derechos y garantías fundamentales de los delincuentes organizados investigados en una determinada operación encubierta.

Efectivamente, parece evidente que en la función de conseguir datos necesarios en la investigación, que no pudieran lograrse por cualquier otro medio, la técnica de la infiltración de agentes se trata de una medida de carácter excepcional e idónea, que sólo debe autorizarse cuando no exista posibilidad de aplicar otras medidas menos gravosas para los derechos fundamentales del investigado ${ }^{1601 .}$

\footnotetext{
1598 También considerando el criterio de la ultima ratio como requisito imprescindible a la actuación del agente encubierto, véase ARMENTA DEU, T., "Exclusionary rule: convergencias y divergencias entre Europa y America", cit., pág. 85.

1599 Vid. REDONDO HERMIDA, A., "El agente encubierto en la jurisprudencia española y en la doctrina del Tribunal Europeo de Derechos Humanos", cit., pág. 97. En este sentido procede recordar la sentencia del STS 262/2003, de 19.2.2003, donde se ha afirmado que: "No cabe identificar ni confundir el delito provocado con el que ha venido denominarse delito comprobado, que tiene lugar cuando la actividad policial, sin quebrar legalidad alguna, pretende descubrir delitos ya cometidos. En estos supuestos el agente infiltrado no busca ni genera la comisión del delito, sino allegar las pruebas de una ilícita actividad ya cometida o que se está produciendo, pero de la que únicamente se abrigan sospechas. En el delito provocado no se da en el acusado una decisión libre y soberana de delinquir. En el delito comprobado esa decisión es libre y nace espontáneamente".

1600 GUEDES VALENTE, M. M., Teoria Geral do Direito Policial, cit., pág. 285.

1601 Adoptando este pensamiento, vid. MOLINA MANSILLA, Mạe, C., Mecanismos de investigación policial: entrega vigilada y agente encubierto, cit., pág. 32.
} 
Por esta razón, el órgano policial de persecución penal deberá poner en conocimiento del Juez, previamente a la solicitud de una resolución para la operación encubierta, todas las diligencias que se han practicado, las pruebas que se han obtenido y la necesidad de que no existe otra forma de poder llegar a descubrir los canales por los cuales se están cometiendo uno o varios delitos ${ }^{1602}$. Con esta exigencia, la autoridad judicial tendrá condiciones de valorar si efectivamente han sido intentados por la policía otros medios de investigación para lograr el descubrimiento de las informaciones sobre la organización criminal, impidiendo que la técnica del agente infiltrado sea utilizada equivocadamente como prima ratio.

A la vista de las anteriores reflexiones, resulta quetres serían los límites impuestos al infiltrado. En primer lugar, con relación a las actuaciones que afecten a derechos fundamentales se requiere la intervención judicial autorizando la medida, todo ello de acuerdo a la exigencia legal. También, se realiza una prohibición expresa de la provocación al delito. Por fin, el agente encubierto debe valorar en cada momento si existe o no proporcionalidad con la finalidad de la investigación en las actuaciones que va a llevar a cabo que deben ser una consecuencia necesaria del desarrollo de la misma ${ }^{1603 .}$

De otra parte, destacando el carácter de ultima ratio de este medio extraordinario de investigación, MATA-MOUROS señala que es incuestionable la excepcionalidad de estos procedimientos, pues con ellos, se invade inevitablemente el campo peligroso del desvío a cualquier regla. Así, para combatir prácticas excepcionales, habrá de exigirse medios excepcionales. Pero más que eso, para los medios excepcionales habrá que adoptar cautelas excepcionales ${ }^{1604}$. En este orden, el Estado debe apreciar y valorar si el quantum de violencia a derechos y garantías que emplea delante de la actuación de órganos de persecución se relaciona con la necesaria eficacia disuasiva en su actuación. Así, resulta esencial determinar criterios que permitan jerarquizar los medios de investigación a ser empleados y con ello, racionalizar los recursos de manera que la respuesta frente al delito sea eficaz y al mismo tiempo correspondan a un proceso penal de índole garantista.

Reforzando la idea de que el criterio de ultima ratio deberá nortear la actuación del agente encubierto, basta citar como ejemplo la legislación argentina, la cual dispone de forma clara que la designación del agente queda reservada para los casos en que las finalidades de la investigación no pudieran lograrse de otro modo ${ }^{1605}$.

A los fines de concluir esta parte de nuestro trabajo, se destaca que el carácter excepcional de este medio extraordinario de investigación presenta una íntima relación con el principio de necesidad en el sentido de que, a los fines de la investigación, deberá ser revelada la importancia del delito investigado, bien como las posibilidades de

1602 Cfr. SUITA PÉREZ, N., "La diligencia de investigación por medio del agente encubierto", cit., pág. 251.

1603 Cfr. POZO PÉREZ, M., "El agente encubierto como medio de investigación de la delincuencia organizada en la Ley de Enjuiciamiento Criminal, cit., pág. 299.

1604 Vid. MATA-MOUROS, F., "O agente infiltrado", Revista do Ministério Público, ano 22, núm. 85, Lisboa, 2001, pág. 108.

1605 Vid. Art. 31 bis, de la ley 27.737/89. Debiendo condicionarse en forma explícita su utilización al "principio de subsidiariedad, reservándola sólo para cuando resulte evidente que el esclarecimiento de los gravísimos delitos respecto de los que teóricamente admiten su uso, no será posible de lograr por las vías probatorias ordinarias". Vid. CAFFERATA NORES, J. I., "Medios extraordinarios de investigación y desnaturalización bélica del proceso penal", Cuestiones actuales del proceso penal, Buenos Aires, 1998, págs. 209-210. 
vigilancia del mismo, permitiendo la actuación del agente encubierto en el marco de un procedimiento penal ${ }^{1606}$. 


\section{CAPÍTULO SEXTO: VALORACIÓN DE LAS PRUEBAS OBTENIDAS A TRAVÉS DE LA ACTIVIDAD DEL AGENTE ENCUBIERTO}

\section{VI.1. El derecho probatorio y el agente encubierto.}

VI.1.1. La búsqueda de la verdad en el proceso penal.

De inicio se observa una constatación muy obvia al empezar del siglo XXI: el proceso penal, a través de la actividad probatoria, busca afanosamente reconstruir los hechos históricos acontecidos ${ }^{1607}$. Sin embargo, esta búsqueda no puede realizarse a cualquier precio, con sacrificio a los derechos y libertades fundamentales ${ }^{1608}$.

Tomando como presupuesto que por medio del proceso no se puede obtener la verdad a toda costa, premisa que constituye una reivindicación fundamental de la protección del individuo frente al poder punitivo estatal, el Estado tiene, en consecuencia, que respetar y ceñirse a lo legalmente establecido, respetando con ello la dignidad de la persona, la estricta vigilancia en los requisitos de restricción de los derechos fundamentales y los principios reguladores de la prueba, que intentan lograr un juicio justo y con todas las garantías ${ }^{1609}$.

La justificaciónde las anteriores afirmaciones puede ser buscada en la imperiosa e imprescindible constatación de que el Derecho Procesal penal contemporáneo presenta un rasgo de índole garantista y fundamentalmente relacionado con la defensa de los derechos y libertades fundamentales. A partir de ahí, señala ROXIN que todo Derecho Procesal penal enmarcado dentro de los parámetros de un Estado constitucional de Derecho se halla en la necesidad de armonizar por un lado, el interés de la búsqueda de la verdad y, por otro lado, el interés del procesado en la salvaguarda de sus derechos fundamentales ${ }^{1610}$.

Esto significa, sencillamente, en palabras de RAMOS MÉNDEZ, que para llegar a la condena en un determinado proceso es necesario que, mediante una adecuada actividad probatoria de cargo, realizada con todas las garantías, practicada en juicio para hacer posible la contradicción y sin que los medios probatorios traídos al proceso se hayan obtenido violentando derechos y libertades fundamentales, quede desvirtuada esa inocencia y que él órgano judicial pueda obtener de esas pruebas convicción jurídica de la existencia de los elementos fácticos que constituyen el delito ${ }^{1611 .}$

1607 La justificativa sería el hecho de que "el proceso penal suele estar en principio presidido por la pretensión de saber qué ha pasado, a partir de la constatación de un hecho perturbador de la normalidad que, al menos prima facie, se presenta como resultado de una acción humana, posiblemente delictiva. Es lo que dota a aquél de una inequívoca dimensión cognoscitiva". Vid. ANDRÉS IBÁÑEZ, P., Prueba y convicción judicial en el proceso penal, Buenos Aires, 2009, pág. 181.

1608 En este sentido, afirman URBANO CASTRILLO y TORRES MORATO que "en efecto, la experiencia histórica nos ha dado abundantes ejemplos de pavorosas aberraciones contra la dignidad y los derechos humanos que partían indefectiblemente, de criterios dogmáticos de verdad prestablecidos (la inquisición, los procesos de Moscú, la justicia hitleriana...) y que nos han enseñado que la verdad material no puede ser conocida en todo caso y con cualquier medio". Cfr. URBANO CASTRILLO, E; TORRES MORATO, A., La prueba ilícita penal, cit., pág. 33.

1609 Cfr. DAGDUG KALIFE, A., La prueba testimonial ante la delincuencia organizada, cit., pág. 339.

${ }^{1610}$ ROXIN, C., "La protección de la persona en el Derecho procesal penal alemán", trad. de M. García Cantizano, VV.AA, La evolución de la Política criminal, el Derecho penal y el Proceso penal, Valencia, 2000, pág. 121.

1611 Véase en este sentido, RAMÓS MÉNDEZ, F., El proceso penal, Barcelona, 1993, págs. 359-360. 
De lo dicho resulta, como ya hemos afirmado, el hecho de que en el proceso penal se busca la verdad como marco de reconstrucción histórica de un hecho delictivo ${ }^{1612}$. Si bien es verdad que si ni siquiera en el campo de la filosofía ha dado una respuesta consensuada a qué es la verdad, no puede pretenderse en la esfera procesal sentar las bases de la verdad material como la verdad absoluta de los hechos. Lo que ocurre en realidad es que la verdad que se alcanza en el proceso es una verdad relativa, particular del propio proceso, pero que por exigencias del sistema procesal y el orden jurídico ese pronunciamiento jurisdiccional se considera como verdad procesal ${ }^{1613}$.

Solamente esta verdad podrá repercutir en aras de conseguirse el éxito de un proceso justo, donde el Juez en la búsqueda de la reconstrucción de los hechos ${ }^{1614}$ debe actuar imparcialmente, con idoneidad y transparencia, permitiendo a las partes el ejercicio de sus derechos y garantías procesales.

Pero insistimos que la problemática de la búsqueda de la verdad no es sencilla ${ }^{1615}$. Según las enseñanzas de CHAUÍ, es la exigencia de la verdad que da sentido a la existencia humana ${ }^{1616}$. Es decir, que toda actividad filosófica del ser humano está ligada al valor de la verdad mientras se considere como el motor constante del desarrollo de la humanidad. La verdad es, pues, prerrequisito esencial para la libertad del hombre.

Se observa entonces que la prueba posee ligación íntima con esta constante actividad del ser humano en la búsqueda de la verdad. Si bien que un destacado sector de la doctrina defiende que la averiguación de la verdad no es un valor absoluto en el proceso

1612 Monográficamente, vid. BARROS, M. A., A busca da verdade no processo penal, 2. a edición, São Paulo, 2010. En este aspecto resulta muy destacado el papel del Ministerio Fiscal, a la vez que ante la imposibilidad de obtener certeza en el proceso de reconstrucción de los hechos, resulta fundamental que el fiscal verifique la corrección material de los argumentos relacionados con el componente fáctico, esto es, que se convenza a sí mismo y luego le demuestre al juez, que cada una de las conclusiones principales o secundarias, están fundamentadas en premisas válidas, y que la conexión lógica entre premisas y conclusiones es tal, que sugiere una alta probabilidad de que estas sean ciertas.

1613 Vid. HUERTAS MARTÍN, M. I., El sujeto pasivo del proceso penal como objeto de la prueba, cit., pág. 279. También en este sentido, afirmando que en el ámbito del proceso se puede hablar sensatamente de verdad (relativa) de los hechos como aproximación a la realidad, vid. TARUFFO, M., La prueba de los hechos, Madrid, 2002, pág. 181.

1614 En palabras de GRECO, "la sociedad de nuestro tiempo es más exigente. Ella no se pone contenta con cualquier reconstrucción de los hechos, pero solo con aquella que la consciencia colectiva asimila y acepta como auténtica, porque la exacta reconstitución de los hechos es un presupuesto fundamental de las decisiones justas". Vid. GRECO, L., "O conceito de prova", Revista da faculdade de Direito de Campos, ano IV, núm. 4, 2003, págs. 214-215, http://www.fdc.br/Arquivos/Mestrado/Revistas/Revista04e05/Docente/13.pdf.

1615 Incluso con una opinión distinta, defiende NIEVA FENOLL que dentro "del tema de la verdad, es obvio que en el proceso se puede dictar sentencia sin que el resultado haya sido el averiguamiento de la verdad. Eso ha sido así desde la época de las ordalías, y no constituye ninguna novedad. Ahora bien, deben destacarse dos cuestiones. En primer lugar, que en ocasiones en el proceso sí que es posible alcanzar la verdad. Y en segundo lugar, que no es preciso alcanzarla para poder dictar sentencia". Vid. NIEVA FENOLL, J., La valoración de la prueba, Madrid, 2010, págs. 146-147.

1616 CHAUÍ, M., Convite à filosofia, São Paulo, 2003, pág. 103. Interesante del mismo modo son las clásicas ideas defendidas por MALATESTA, al afirmar que "la verdad, en general, es la conformidad de la noción ideológica con la realidad; la creencia en la percepción de esta conformidad es la certeza. Ella es, por lo tanto, un estado subjetivo del alma, pudiendo no corresponder a la verdad objetiva. Certeza y verdad ni siempre habrán de coincidir: por veces, se tiene certeza de lo que objetivamente es falso; por veces, dudase de lo que objetivamente es verdadero. Y es la misma verdad que aparece cierta a unos, a otros parece dudosa, $\mathrm{y}$, por veces, hasta mismo falsa a otros". Vid. MALATESTA, N. F. D., A lógica das provas em matéria criminal, trad. PaoloCapitanio, SãoPaulo, 1996, pág. 21. 
penal; antes al contrario, el propio proceso penal está impregnado por las jerarquías éticas y jurídicas del Estado 1617.

Así, la realización de la justicia constituye una función, primordial para el Estado de Derecho, y estructural en el Estado social y democrático. Y dentro de un contexto constitucional, la búsqueda de la verdad en el proceso penal no es sólo una norma informadora del ordenamiento jurídico como garantía de justicia parael imputado o para la sociedad, sino también es un instrumento de protección de la víctima y de eficacia de derechos de especial relevancia constitucional. Por este motivo, según IBAÑEZ, la verdad cumple una doble función de garantía en tanto la acusación, como simple hipótesis, debe ser objeto de prueba por parte de quien la sostiene -plano epistemológico- y la dirigida a evitar la anticipación de los efectos de una eventual sentencia condenatoria -plano éticopolítico-1618.

Amén de los citados planteamientos dogmáticos, cabe plantear ahora la duda sobre lo que significa probar en Derecho Procesal penal.

De modo objetivo y sin divagaciones, apunta ROXIN que probar significa convencer el Juez sobre la certeza de la existencia de un hecho ${ }^{1619}$. Significaría el procedimiento tendente a formar la libre convicción del órgano juzgador desde que sean obedecidas las reglas procesales y respetado el orden constitucional.

Esta idea adquiere especial relevancia en la medida en que la convicción de la autoridad juzgadora será formada a partir del momento en que la certeza de los argumentos ofrecidos por la parte interesada vengan a representar una reconstrucción más próxima de la verdad de los hechos.

Con un abordaje más en profundidad, sostiene FLORIÁN que probar significa añadir al proceso el conocimiento de cualquier hecho, de manera que se adquiera para sí o se engendre en otros la convicción de la existencia o verdad de este hecho. En este sentido, los elementos de hecho deben ser alegados, introducidos y comprobados en el proceso a través de los medios de prueba, para que sean examinados y criticados por las partes antes de la apreciación y valoración del Juez ${ }^{1620}$.

No con menor contundencia sostiene MITTERMAIER que la prueba sería la suma de los motivos generadores de la certeza de los hechos en la consciencia del Juez ${ }^{1621}$.

1617 En este sentido, vid. ROXIN, C., Derecho procesal penal, cit., pág. 191. Sobre este tema, son absolutamente sensatas las palabras de JULIO MAIER y GUARIGLIA al señalaren que "el descubrimiento de la verdad es sinónimo de persecución penal desde que el procedimiento adquirió naturaleza de inquisición, pero hoy esa dirección hacia la verdad funciona también no sólo como meta del proceso en un sentido formal bastante distinto al histórico se prefiere el método dialéctico de contraposición de intereses para descubrirla, en lugar de una nuda investigación estatal, sino que, además, funciona también como garantía de quien es perseguido en él, como seguridad de que no sufrirá la pena estatal si no se alcanza la certeza acerca de la comisión de un hecho punible y de su participación en él (in dubio pro reo), de allí que alcance su fin a pesar del desconocimiento de la verdad histórica". Vid. MAIER, J. B; GUARIGLIA, F., "Las prohibiciones de valoración probatoria en el procedimiento penal", Revista de Ciencias Penales, núm. 4, Montevideo, 1998, pág. 181.

1618 Cfr. ANDRES IBAÑEZ, P., "Ni fiscal instructor ni Habermas procesalista", Revista Jueces para la Democracia, núms. 16-17, 1992, pág. 57.

1619 Vid. ROXIN, C., Derecho procesal penal, cit., pág. 185. Importante en este sentido la opinión de SENTÍS MELENDO, al señalar que la prueba "constituye la zona neurálgica del proceso". Vid. SENTÍS MELENDO, S., El proceso civil, Buenos Aires, 1959, pág. 10.

1620 Vid. FLORIAN, E., De las pruebas penales, trad. J. Guerrero, 3ª̣ edición, vol. I, Bogotá, 1982, págs. 44 y 95.

1621 Cfr. MITTERMAIER, C. J. A., Tratado da prova em matéria criminal ou exposição comparada, Campinas, 2004, pág. 74 . 
Dentro de una concepción más actual del derecho probatorio, se puede destacar la posición de TARUFFO al defender que es posible un concepto de prueba que tiene alcance general y que se formula como elemento de confirmación de conclusiones referidas a aserciones sobre hechos o bien como premisas de inferencias dirigidas a fundamentar conclusiones consistentes en aserciones sobre hechos ${ }^{1622}$.

Dicho lo anterior el paso siguiente tiene que consistir en reconocerque la verdad procesal es revelada por la prueba. Es de esta forma que el Estado debe actuar para que las informaciones acerca del delito sean obtenidas por sus agentes de modo que puedan ser presentadas como pruebas validas y eficaces en el juicio oral.

En síntesis, la prueba sería el vínculo esencial entre la realidad, lo que existe, y la realización de la justicia, objetivo fundamental del Derecho ${ }^{1623}$.

Se denota del mismo modo que aventurarse en el estudio de temas relacionados con el denominado "derecho probatorio" y, concretamente, en el estudio de la prueba referida a un proceso jurisdiccional, supone entrar de lleno en la parte más delicada y a la vez más esencial del proceso y de las normas que lo disciplinan, esto es, el Derecho Procesal ${ }^{1624}$.

Sin la certeza de los hechos probados, la justicia no será presentada como resultado de un juicio justo y posiblemente se estará muy cerca de una respuesta estatal marcada por la ausencia de seriedad y de compromiso social con la dignidad del ciudadano.

Asentado el presupuesto del principio de la búsqueda de la verdad en el proceso penal, una verdad procesalmente limitada, pero teleológicamente dirigida a una mayor aproximación posible con la realidad de los hechos sometidos a la apreciación jurisdiccional, se llega a la conclusión de que las partes participantes en el proceso deben tener el derecho de producir las pruebas ${ }^{1625}$ necesarias para influenciar la formación de la convicción del juzgador. En esta actividad, el proceso debe estar teleológicamente abierto a que, obedecida el orden constitucional, sea recepcionado todo material probatorio verosímil que sea pertinente y relevante a la dilucidación del hecho controvertido ${ }^{1626 .}$

Efectivamente, parece evidente que la prueba es el alma del proceso ${ }^{1627}$ en cuanto es el instrumento a través del cual se logra la formulación del juicio de hecho, la

1622 Cfr. TARUFFO, M., La prueba de los hechos, Madrid, 2002, pág. 327. Incluso el citado jurista italiano reconoce en su obra que este no es un punto de llegada sino un punto de partida, dado que la cuestión no está completamente cerrada dada su complejidad. Siguiendo la misma línea de pensamiento, señala CAFERRATA NORES que "en sentido amplio, cabe decir que prueba es lo que confirma o desvirtúa una hipótesis o afirmación precedente". Vid. CAFERRATA NORES, J. I., La prueba en el proceso penal, Buenos Aires, cit., pág. 3.

1623 Cfr. MARTÍ MINGARRO, L., "Prólogo" a la obra La prueba ilícita penal, estudio jurisprudencial, Navarra, 2003, pág. 19.

1624 GUZMÁn FLUJA, V. C., Anticipación y preconstitución de la prueba en el proceso penal, cit., pág. 25. De otra parte, deberá considerarse que la prueba constituye la zona neurálgica del proceso, demostrando carácter al proceso, y desde ahí puede colegirse si un proceso es más o menos autoritario en razón de la libertad o el autoritarismo que dominan la materia de la prueba. Vid. en este sentido, SENTIS MELENDO, S., El proceso civil, cit., pág. 10.

1625 En este particular, deberá ser observado el principio de la simétrica paridad de armas, manteniendo las mismas oportunidades en grado de absoluta igualdad entre las partes del proceso. Con más detalles, vid. FAZZALARI, E., Instituições de Direito Processual, 1aㅡ edición, Campinas, 2006.

1626 Todavía, según nuestro modo de pensar, deberá ser matizado que no siendo los derechos fundamentales absolutos como ya hemos visto en apartados anteriores, mismo el derecho a la prueba podrá ser limitado cuando ocurrir la colisión con otros principios constitucionales.

1627 Y así puede citarse a BENTHAN cuando afirma que "el arte del proceso no es esencialmente otra cosa que el arte de administrar las pruebas". Vid. BENTHAN, J., Tratado de las Pruebas Judiciales, Vol. I, trad. Osorio Florit, Buenos Aires, 1959, págs. 4 y 11. Sin embargo, lo que debe quedar claro es que "el reconocimiento de la 
determinación del relato fáctico en que consiste un caso concreto y sobre el cual debe procederse a la aplicación del derecho ${ }^{1628}$.

Incluso en opinión de ANDRÉS IBÁÑEZ, la valorización de las pruebas debe hacerse con métodos que en la cultura común se consideran racionales. Deben tenerse en cuenta todos los datos empíricos disponibles, y no prescindirse arbitrariamente de algunos. Por otra parte, es bien sabido que las pruebas son tanto más eficaces cuanto mayor sea el contenido empírico de la información que producen ${ }^{1629}$.

Con ello se pretende evitar que el órgano juzgador a través de la obligación de motivar en la sentencia los argumentos que justifiquen la aceptación de determinado dato probatorio, acabe por preservar la integridad del principio de la seguridad jurídica de quien se encuentra en posición de imputado en un proceso penal. Con esta actitud, no habrá que confundirse la actividad discrecional ${ }^{1630}$ del Juez en la formación de su íntima convicción con la arbitrariedad en el acto de valorar la esencia de una determinada prueba.

Sin embargo, no se puede olvidar que el fenómeno de la prueba no es ni propio ni específico del proceso, sino que es algo más amplio que pertenece en general al comportamiento humano, con aplicación y predicamento en otras ciencias extrajurídicas, e incluso en el desarrollo normal de la vida de cualquier persona ${ }^{1631}$.

Piénsese en la posibilidad de que una persona necesite probar a sí mismo, que tiene fuerza y disposición para luchar y conseguir alcanzar sus objetivos particulares en el desarrollo de su vida profesional.

Por fin, se hace necesario destacar que la prueba no es en ningún caso una actividad de averiguación o de investigación, ya que como acertadamente estableció SENTÍS MELENDO averiguar o investigar son actividades anteriores a la prueba, necesarias para ésta pero ajenas y previas a ella1632.

VI.1.2. El concepto de prueba penal y su carácter de derecho fundamental.

Empezamos por poner de relieve que los hechos alegados como sucesos reales de la vida son siempre e inevitablemente el punto de partida, constituyendo tanto el objeto de la prueba a realizar durante el proceso como el objeto de la calificación jurídica

verdad no es por tanto, en sí y para sí, el fin último del proceso, sino el presupuesto para poder adecuadamente decidir cuál es la ley aplicable en el caso concreto". Véase al respeto de esta afirmación y con más detalles, UBERTIS, G., "La prueba penal. Perfiles jurídicos y epistemológicos", https://www.ucursos.cl/derecho/2008/1/D124T0763/31/material_docente/bajar?id_material=160283.

${ }^{1628}$ En este sentido con mayor detenimiento, vid. DEVIS ECHANDÍA, H., Teoría general de la Prueba Judicial, Tomo I, 6a edición, Buenos Aires, 1988, pág. 13.

1629 Cfr. ANDRÉS IBÃ̃̃EZ, P., "Garantismo y Proceso Penal", Garantismo y Derecho Penal, J. O. Sotomayor Acosta coord., Bogotá, 2006, pág. 154.

${ }^{1630}$ Frente al problema de la discrecionalidad nos encontramos ante una perplejidad: El derecho se ha mostrado insuficiente para resolver aquellos casos de la vida para los que no prevé una solución y, lo que es más grave, la existencia de casos complejoses inevitable y consustancial al derecho, tanto porque la vida es rica y las situaciones que puede plantear son infinitas y es imposible preverlas todas, como porque el hombre y la aplicación del derecho son productos de la historia que es cambiante, como también porque las reglas jurídicas, así como las palabras, siempre tendrán una zona de penumbra inevitable.

1631 GUZMÁN FLUJA, V. C., Anticipación y preconstitución de la prueba en el Proceso Penal, cit., pág. 28. Con el mismo entendimiento, DEVIS ECHANDÍA, H., Teoría general de la Prueba Judicial, cit., págs. 20 y ss.

1632 Vid. con riqueza de detalles, SENTÍS MELENDO, S., La prueba, Buenos Aires, 1979, págs. 50-59. 
correspondiente a partir de la que se extrae la consecuencia jurídica prevista en la norma aplicada 1633 .

Todavía más: no es tarea fácil conceptuar lo que se considera como prueba, pues como bien ha señalado RAMOS MÉNDEZ, todo el mundo tiene un concepto intuitivo de lo que es la prueba. Sin embargo, comenzamos el estudio de la misma con la siguiente afirmación: sin duda, uno de los capítulos más controvertidos de la ciencia jurídica es el relativo a la prueba, y su concepto transciende al Derecho Procesal, aunque hoy en día la mayoría de los autores se inclinan por encuadrar la prueba en una disciplina estrictamente procesal 1634 .

En cualquier caso, la prueba en sentido más amplio sería todo medio o instrumento que permite introducir en el proceso y hacer llegar al Juez los elementos necesarios para poder decidir sobre el juicio del hecho ${ }^{1635}$. 0 dicho en otros términos, la prueba penal consiste en el medio a través del cual las partes y el propio Estado, por intermedio de los órganos de acusación, buscan reconstruir la verdad de los hechos y, así, alcanzar la decisión mas justa. En este contexto, sería la demostración que se hace a través de los medios admitidos en ley, de la existencia o veracidad de un determinado hecho o de un concreto acto jurídico con la finalidad de propiciar al órgano juzgador una idea próxima a la verdad real ${ }^{1636}$.

Según NAVAJAS RAMOS, la prueba no es sino aquella actividad, llevada a cabo por cualquiera de las partes intervinientes en un proceso, encaminada a demostrar o a acreditar ciertos hechos o a lograr la convicción psicológica del Juez sobre los mismos, llevada a cabo mediante un procedimiento reglado que ha de someterse a las pautas de los principios de publicidad, oralidad, inmediación, igualdad y contradicción, y con sujeción siempre, en el proceso penal, al necesario respeto a los derechos del imputado bajo el prisma del principio de presunción de inocencia, que impone siempre la carga probatoria a las partes acusadoras ${ }^{1637}$.

Por consiguiente, se pone a disposición del juzgador todas las informaciones y datos necesarios a la formación libre y consciente de su valoración racional de la verdad reconstruida y presentada en forma de prueba.

Sin embargo, la prueba en el proceso penal representa la actividad procesal de las partes y del juzgador, dirigida a formar la convicción de éste último sobre la verdad o

1633 CLIMENT DURÁN, C., La Prueba Penal,Valencia, 1999, pág.42.

1634 Cfr. RAMÓS MÉNDEZ, F., Derecho procesal civil, tomo 1, 3aㅡ edición, Barcelona, 1986, pág. 535.

1635 En este sentido, Cfr. ASENCIO MELLADO, J. M., Prueba prohibida y prueba preconstituida, cit., pág. 15. Por esta razón es que se afirma que la finalidad que en el proceso penal persigue con la actividad probatoria es "desentrañar los hechos no admitidos o notorios, aclarar las posiciones procesales, descubrir la verdad real, aunque en multitud de ocasiones quede relegada a la verdad legal, en definitiva, formar un estado de consciencia en el juzgador frente a la resolución que habrá que dictar". Vid. PALACIOS LUQUE, D., "Introducción a la prueba en el proceso penal", Planes provinciales y territoriales de formación, Consejo General del Poder Judicial, vol. II, año 1992, pág. 1112.

1636 Incluso advierten algunos preocesalistas que "la actividad procesal del juez y de las partes, y la finalidad perseguida son dos elementos importantes en el concepto de prueba penal". Cfr. BUJOSA VADELL, L; HUERTAS MARTÍN, I; POZO PÉREZ, M; VICENTE JIMÉNEZ, C., Derecho procesal penal, Salamanca, 2007, pág. 252.

1637 NAVAJAS RAMOS, L., "La prueba videográfica en el proceso penal: su valor y límites para su obtención", Eguzkilore, núm. 12, San Sebastián, 1998, pág. 148. 
certeza de los hechos afirmados por las partes, que se desarrolla, fundamentalmente, en el juicio oral 1638 .

De este modo, el derecho a la prueba se encuadra dentro de los principios constitucionales de la contradicción, amplia defensa, debido proceso legal, dignidad humana y otros tantos postulados ${ }^{1639}$, una vez que permite a las partes titulares del derecho de acción y de defensa, se manifestaren respeto de las pruebas producidas en el juicio.

Con el planteamiento expuestose denota que el derecho a la prueba puede ser definido como aquél que posee el litigante consistente en la utilización de los medios probatorios necesarios para formar la convicción del órgano jurisdiccional acerca de lo discutido en el proceso ${ }^{1640}$. Amén de esta consideración, no se puede olvidar que esta búsqueda de informaciones aptas a la formación de la convicción judicial deberá presentar como premisa elemental el respeto por las garantías fundamentales y por los principios propios del Estado de Derecho, evitándose así actos motivados por la arbitrariedad.

En lo que nos interesa ahora, la prueba de carácter penal tiene la pretensión de hacer llegar al juicio del juzgador todo el arquetipo histórico representativo de la verdad sobre los hechos que fundamentaron la práctica del delito ${ }^{1641}$, con vistas a la formación y construcción de la íntima convicción de la autoridad encargada de dictar la sentencia judicial.

Se buscan así los argumentos o motivos que se desprenden de las fuentes o medios de conocimiento de los que hacen uso las partes o los interesados en el proceso para conformar la convicción del Juez sobre los hechos que son los presupuestos de sus intereses materiales perseguidos.

Y en dicha línea resalta entre nosotros la indiscutible constatación de que para que una prueba pueda ser tomada en consideración por el Juez o Tribunal llamado a juzgar no sólo ha de practicarse en el acto del juicio oral sino que ha de ser lícita, es decir, debe hacerse obtenida con respecto al conjunto de derechos y libertades fundamentales ${ }^{1642}$.

Otra cuestión especialmente sensible se refiere al derecho de la prueba como derecho fundamental ${ }^{1643}$. Se busca dejar claro que el derecho de toda persona de presentar

1638 DE LA OLIVA SANTOS, A; ARAGONESES MARTÍNEZ, S; HINOJOSA SEGOVIA, R; MUERZA ESPARZA, J; TOMÉ GARCÍA, J. A., Derecho Procesal Penal, Octava edición, Madrid, 2007, pág. 475.

1639 Al respeto de esta íntima relación principiológica, se puede afirmar que la actuación probatoria está regida por principios constitucionales como son: el principio de inocencia, el in dubio pro reo, el principio de respeto a la dignidad de la persona, derecho de defensa; y por principios procesales que rigen directamente la actividad probatoria, por ejemplo: el principio de legalidad, principio de libertad probatoria.

1640 Cfr. PICO I JUNOY, J., El derecho a la prueba en el proceso civil, Barcelona, 1996, págs. 13-14. Con el mismo entendimiento, la jurisprudencia del Tribunal Constitucional español al definir que "el derecho a la prueba es el poder jurídico que se reconoce a quien interviene como litigante en un proceso de provocar la actividad procesal necesaria para lograr la convicción del órgano judicial sobre la existencia o inexistencia de los hechos relevantes para la decisión del conflicto que es objeto del proceso" (SSTC, 246/2000, de 16.10.2000 y 88/2004, de 10.5.2004).

1641 Siguiendo esta línea de raciocinio, dispone de forma clara la STC 123/1997, de 1.7.1997, que "sólo debe entenderse como prueba la practicada en el juicio oral bajo la inmediación del órgano judicial decisor y con observancia de los principios de contradicción y publicidad".

1642 Cfr. MARTÍN GARCÍA, P., "Conceptos básicos sobre la eficacia de la prueba", VV.AA., La actuación de la policía judicial en el proceso penal, Madrid, 2006, pág. 31.

1643 Véase la STS 428/2005, de 6.4.2005. De otra parte, nos parece algo prácticamente libre de dudas que las reglas de producción de las pruebas bien se consideran un conjunto de límites que deberán ser obedecidos, a la vez que cumplen una importante y destacada función de garantía. Efectivamente, parece evidente que 
pruebas y controvertir las que se aleguen en su contra desde de un proceso constituye un derecho constitucional fundamental, y dado que la declaración de no admisión de una prueba puede conllevar la violación del derecho de defensa y del debido proceso, con innegable perjuicio para el inculpado, el investigador debe proceder con extrema cautela y, en caso de duda, optar por la no admisión de la prueba. Pero hay que tomar cuidado pues el derecho fundamental a la prueba, como reiteradamente nos recuerda el Tribunal Constitucional español, no tiene un carácter ilimitado o absoluto ${ }^{1644}$.

Estas limitaciones que excluyen este carácter absoluto vendrán de encuentro a la necesidad de evitarse la banalización del principio de la libertad probatoria. Es necesario que la actividad probatoria, como el resto toda la actividad procesal, cumpla con el interés social de realizar la justicia y más, que se preserven las exigencias del bien común de respeto a la moralidad y a la dignidad de la persona humana.

Sobre la cuestión anteriormente planteada, señala MORA MORA que hablar de límites al trabajo de la obtención de elementos probatorios nos pone ahora en un difícil predicado frente a una de las supuestas reglas de oro de los sistemas probatorios actuales en el sentido de que "todo se puede probar y por cualquier medio". Se trata, según esta última fórmula, de la búsqueda de la "verdad real o material" que, sin embargo, por la propia estructura de nuestro sistema de derechos, tenemos que aceptar que debe competir con otros principios de igual o incluso mayor rango 1645 .

Así, el derecho a la prueba es fundamental en la medida en que es inherente a la persona y tiene además diversos mecanismos de refuerzo propios de los derechos fundamentales ${ }^{1646}$. De todo modo, el contenido esencial del derecho a la prueba es la posibilidad que tiene la persona de utilizar todos los medios posibles en aras de convencer al Juez sobre la verdad del interés material perseguido. Se caracteriza, además, por ser un instrumento de la persona por lo que de manera alguna puede expandirse hasta el límite de arrasar con los demás derechos fundamentales. Estamos, pues, anteun derecho subjetivo exigible al Juez cuyo objeto es una acción u omisión en la actividad probatoria. Incluso, en su conexión con el derecho al acceso a la justicia, puede tratarse de una prestación económica para hacer seriamente efectivo este derecho, operando en todo tipo de proceso judicial o extrajudicial ${ }^{1647}$.

Incluso se puede afirmar que siendo un derecho fundamental, el derecho a la prueba presenta claramente un doble carácter:en su dimensión subjetiva, las partes -o un tercero legitimado en un procedimiento- tienen el derecho de producir la prueba necesaria con la finalidad de acreditar los hechos que configuran su pretensión o su defensa; de otro lado,

dentro del panorama del derecho probatorio, las garantías establecen un ámbito intangible para las personas frente al poder estatal y, como consecuencia, se formaliza y limita el acceso de la información al proceso penal. Con más detalles sobre el tema, Cfr. RUIZ JARAMILLO, L. B., "El derecho a la prueba como un derecho fundamental", Revista de Estudios de Derecho, vol. 64, núm. 143, Antioquia, 2007, págs. 182-206 y MORA MORA,L. P., "La prueba como derecho fundamental", Revista Iberoamericana de Derecho Procesal Constitucional, núm. 4, 2005, págs. 169-187.

${ }^{1644}$ Cfr. las SSTC 2/1982, de 29.1.1982 y 113/2009, de 11.5.2009.

1645 Véase al respeto, MORA MORA, L. P., "La prueba como derecho fundamental", cit., pág. 174.

1646Además, "el carácter fundamental del derecho a la prueba comporta que todos sus límites deban encontrar una justificación en un bien, interés o derecho constitucionalmente reconocido, en orden a impedir la frustración de la máxima actividad probatoria". Véase al respecto, PICO I JUNOY, J., "El derecho a la prueba en el proceso penal. Luces y sombras", VV.AA., Estudios sobre prueba penal. Actos de investigación y medios de prueba en el proceso penal: competencia, objeto y límites, Vol. 1, Madrid, 2010, pág. 32.

1647 Vid. RUIZ JARAMILLO, L. B., "El derecho a la prueba como un derecho fundamental", cit., pág. 182. 
desde su dimensión objetiva, comporta el deber del Juez de la causa de solicitar, actuar y dar el mérito jurídico que corresponda a los medios de prueba en la sentencia.

En línea con este raciocinio, el derecho constitucional a la prueba sería una fase esencial del debido proceso y del cabal ejercicio de la defensa en juicio o, si se prefiere, uno de los elementos constitutivos que concurren a definir el proceso justo ${ }^{1648}$.

La consecuencia es que el carácter fundamental del derecho a la prueba está en que es un derecho típicamente individual, inherente a la persona, de aplicación directa, justiciable mediante la acción de tutela. Se encuentra, además, entre los derechos que deberían ser regulados siempre mediante una ley ${ }^{1649}$.

De todo lo expuesto, se puede afirmar que el derecho a la prueba es fundamental en la medida que es propio y natural del ser humano. La condición humana está íntimamente ligada al uso que de la prueba se haga y de la justicia de la decisión sobre la existencia de los hechos por parte del Juez. En este contexto, lo que si importa es el alcance de la eficiencia probatoria con respeto a las garantías constitucionales inherentes a la persona investigada o imputada.

VI.1.3. El valor probatorio a ser dado a las pruebas obtenidas por el agente encubierto.

La cuestión que se busca analizar ahora se refiere al hecho de posicionarse ante la cuestión de si son integralmente válidas las informaciones, datos y pruebas obtenidas a partirde la utilización de agentes encubiertos infiltrados enuna determinada organización criminal 1650 .

No es tarea fácil contestar de modo directo y sin vacilaciones a esta indagación ${ }^{1651}$.

Como regla general, el recurso al agente encubierto en el marco de la persecución de determinadas especies graves de criminalidad ha sido adoptado por un sinnúmero de países, los cuales vienen estableciendo las condiciones jurídicas en que dichas actuaciones son susceptibles de realización sin incurrir en conductas delictivas y siendo susceptibles de aprovechamiento en el marco de la teoría general de la prueba ${ }^{1652}$.

1648 Vid. MORELLO, A. M., La prueba, tendencias modernas, Buenos Aires, 1991, págs. 13 y 177.

${ }^{1649}$ RUIZ JARAMILLO, L. B., "El derecho a la prueba como un derecho fundamental", cit., págs. 187-188.

1650 Sobre esta discusión, aduce GARCÍA MUÑOZ que "determinar el valor probatorio de las actuaciones y diligencias policiales podría constituir a priori una contradicción en los términos, pero tiene una utilidad descriptiva nada desdeñable y apunta hacia una cuestión no exenta de dificultad que exige indagar en la doctrina y jurisprudencia para legar a una aproximación al estado actual de la cuestión". Vid. GARCÍA MUÑOZ, P. L., "La actividad policial con incidencia probatoria", VV.AA., Estudios sobre prueba penal. Actos de investigación y medios de prueba en el proceso penal: competencia, objeto y límites, Vol. 1, Madrid, 2010, pág. 171.

${ }^{1651}$ Ciñéndonos al ordenamiento procesal penal brasileño, STANZIOLA VIEIRA plantea la cuestión de que la prueba obtenida por el agente encubierto enfrentaría problemas en razón de una nítida "atipicidad probatoria", hecho este que no ocurre en la legislación portuguesa. En este sentido, Cfr. STANZIOLA VIEIRA, R., "Agente infiltrado - estudo comparativo dos sistemas processuais penais português e brasileiro (ou a imprescindibilidade da tipicidade processual como requisito de admissibilidade dos meios de pesquisa de prova no processo penal)", Revista Brasileira de Ciências Criminais, núm. 87, 2010, págs. 205 y ss. Sobre el tema de la tipicidad procesal MADEIRA DEZEN señala que la misma "tiene fundamento no sólo en la regla del debido proceso legal, como también en el imperativo de la legalidad y que, aún, actúa sobre las normas que proveen garantías a los jurisdiccionados". Vid. MADEIRA DEZEN, G., Da prova penal. Tipo processual, provas típicas e atípicas, Campinas, 2008, pág. 55.

1652 En este sentido, vid. ARMENTA DEU, T., "Exclusionary rule: convergencias y divergencias entre Europa y América", cit., pág. 85. 
Como hemos venido haciendo indicación, ya se percibe la importancia de disponer en los ordenamientos jurídicos de una regulación detallada y completa del tema del agente encubierto, exigencia esta que evitaría violaciones al principio de legalidad ${ }^{1653}$ a la vez que por tratarse de una técnica restrictiva de derechos fundamentales deberán sus requisitos y límites quedar claramente expuestos en una ley penal.

Sin embargo, seguramentese producirán violaciones, por mínimas que sean, a derechos fundamentales delante de la actuación concreta de un agente encubierto que ingresa en una organización criminal mediante el uso del engaño y de la disimulación. No habrá otro modo para que el agente estatal penetre en el centro de la organización criminal mediante la sumisión muchas veces a peligrosas "pruebas de confianza" exigidas como prerrequisito de admisión al grupo, sin la comisión casi obligatoria de infracciones de escasa gravedad como violaciones de domicilio y falsedades documentales, amén de intromisiones más complejas al derecho de intimidad y privacidad de otros miembros del grupo.

Lo importante en todo caso es dejar claro que el respeto al sistema de derechos fundamentales y libertades públicas se refleja igualmente en la actividad del Estado frente a la criminalidad organizada ${ }^{1654}$. Queda muy claro, pues, que la limitación de un derecho fundamental así como la introducción de su resultado en un proceso exigen el respeto de requisitos constitucionales y de legalidad ordinaria ${ }^{1655}$.

De este modo, aunque la lucha contra la delincuencia organizada suponga el reforzamiento de las leyes procesales penales, así como el establecimiento de disposiciones especiales ${ }^{1656}$, siempre debe respetarse de forma proporcional a los derechos y garantías del investigado ${ }^{1657}$. De otro modo, la consecuencia podrá consistir en el logro de pruebas marcadas por vicios insanables que van a conducir a su absoluta ineficacia probatoria en el proceso.

Así, como planteamiento inicial dependerá la valoración probatoria del análisis de todo un contexto que ha de permear la actuación concreta del infiltrado. De este modo,

\footnotetext{
1653Dentro de este contexto "conforme al principio de legalidad de la actividad procesal y de la prueba en especial, todo elemento de convicción que se incorpore al proceso debe respetar las normas constitucionales que preserven derechos esenciales de las personas". Cfr. JAUCHEN, E. M., Tratado de la prueba en materia penal, Buenos Aires, 2002, pág. 613.

1654 GUZMÁN FLUJA., "El agente encubierto y las garantías del proceso penal", cit., pág. 5.

${ }^{1655}$ Cfr. MARTÍNEZ GARCÍA, E., Actos de investigación e ilicitud de la prueba, cit., pág. 47. Incluso, algún sector doctrinario señala que "la actividad de los agentes infiltrados en el marco de las investigaciones de delincuencia organizada y la eficacia posterior en el proceso de los elementos de prueba obtenidos, quedará condicionada por el respecto a los principios del proceso penal, esencialmente el derecho de defensa y la presunción de inocencia". Véase, RIFÁ SOLER, J. M; RICHARD GONZÁLEZ, M; RIAÑO BRUN, I., Derecho procesal penal, Pamplona, 2006, pág. 285.

1656 Cfr. TIEDEMANN, K., "El futuro del proceso penal europeo. Aspectos de interés, en especial sobre la lucha antiterrorista", http://www.espaciojudicialeuropeo.es.

${ }^{1657} \mathrm{~A}$ este respecto establece la Exposición de Motivos de la Ley 5/1999, de 13 de enero de modificación de la Ley de Enjuiciamiento Criminal en materia de perfeccionamiento de la acción investigadora relacionada con el tráfico ilícito de drogas y otras actividades ilícitas graves: los límites de las técnicas propuestas de investigación se encuentran en el sistema de derechos y garantías que la Constitución reconoce a todo imputado, ya que por más abyectas que sean las formas de delincuencia que se trata de combatir, ello no justifica la utilización de medios investigadores que puedan violentar garantías constitucionales. Por tanto, la búsqueda de medios jurídicos eficaces para luchar contra la criminalidad organizada no debe comportar un detrimento de la plena vigencia de los principios, derechos y garantías constitucionales, y la preservación de los aludidos principios, derechos y garantías exige, siempre que exista conflicto, que el mismo se resuelva en favor de estos últimos, porque ellos constituyen el verdaderofundamento de nuestro sistema democrático.
} 
resolver la disyuntiva entre la intervención del agente encubierto frente al sistema de garantías tiene una gran repercusión procesal, pues sólo si la actuación del agente ha sido respetuosa con los derechos fundamentales se podrá otorgar validez procesal de las pruebas obtenidas ${ }^{1658}$.

Efectivamente, parece evidente que por tratarse de empleo de una técnica de uso excepcional y con características invasivas a garantías fundamentales de aquellas personas sometidas a un proceso penal, deberá el contexto probatorio que se pretende utilizar en juicio quedar congruente con las reglas procesales y constitucionales inherentes a un Estado de Derecho.

Incluso afirma PICÓI JUNOY que uno de los problemas más complejos de resolver respeto del derecho a la valoración de la prueba practicada es el de su alcance, esto es, determinar qué dosis de valoración de los resultados probatorios es exigible en la sentencia ${ }^{1659}$.

Desde el planteamiento que aquí se sostiene es notoria la imperiosa y obligatoria necesidad de que el juzgador promueva una completa motivación en la sentencia de los presupuestos que han contribuido a su convicción ${ }^{1660}$ para que la prueba se presente como un instrumento que corrobora informaciones relevantes a la búsqueda de la verdad de los hechos.

Incluso, más que la motivación, en general el principio de publicidad dentro del panorama garantista del proceso penal, el cual debe ser considerado, juntamente con la oralidad y la legalidad, como rasgos estructurales y constitutivos del método acusatorio, obliga a una transparencia de los actos del Estado, quedando el proceso abiertamente expuesto al conocimiento popular y sujetando la justicia a un control.

Del mismo modo, para dar validez a las pruebas obtenidas por el agente encubierto, debe llevarse a cabo un control judicial efectivo de sus actuaciones, mediante un mecanismo que le obliga a informar al órgano jurisdiccional, a la mayor brevedad posible, sobre la investigación que se vaya practicando ${ }^{1661}$.

Obviamente, el recurso a la técnica del agente encubierto presentará particularidades y formas especiales de comprensión de determinados aspectos, a la vez que la publicidad de los actos practicados por el infiltrado deberán quedar restrictos a las autoridades responsables por el control de legalidad de la operación ${ }^{1662}$. Con esta actitud

${ }^{1658}$ Cfr. ESPINOSA DE LOS MONTEROS, R. Z., "Las reglas de exclusión probatoria al hilo del desarrollo de la infiltración policial", Temas Socio-Jurídicos, vol. 27, núm. 57, Bucaramanga, 2009, pág. 74.

1659 Vid. PICO I JUNOY, J., "El derecho a la prueba en el proceso penal. Luces y sombras", cit., pág. 39.

1660 Del mismo modo, es lógica la conclusión presentada por RIFÁ SOLER, de que "la libre apreciación de la prueba conlleva la libertad del juzgador de instancia para valorarla. Ahora bien, esta libertad no implica arbitrariedad sino que exige que el juez explique el iter mental que ha seguido". Cfr. RIFÁ SOLER, J. M., "Actos de investigación, actos de instrucción y actos de prueba", cit., pág. 149.

1661 MOLINA MANSILLA, Mạ. C., Mecanismos de investigación policial: entrega vigilada y agente encubierto, cit., pág. 36.

1662 Respeto a este control de la operación, importante destacar que "el agente encubierto deberá poner en conocimiento bajo su responsabilidad todas las cuestiones que se vayan planteando y máxime cuando se pisotean otros derechos fundamentales como puede ser por ejemplo la intervención de una comunicación telefónica, que afecta al secreto de las comunicaciones, o cualquier tipo de situación o circunstancia que se presente como ajena al delito, o cualquier otro tipo de diligencia que surge paralelamente con el hecho delictivo que se está investigando". Cfr. en este sentido, SUITA PÉREZ, N., "La diligencia de investigación por medio del agente encubierto", cit., pág. 253. 
se intenta evitar el peligro de la exposición directa de la integridad corporal del agente bien como de su propia vida o de sus familiares.

Este planteamiento se completa como tendremos oportunidad de analizar en líneas siguientes, con la constatación de que el valor probatorio de tales diligencias deberá originarse del examende los criterios de proporcionalidad aplicados al caso en concreto.

Cambiando la vertiente del análisis, hemos visto anteriormente que la figura del agente encubierto se justifica por la necesidad de llevar a cabo investigaciones en el seno de tramas organizadas internacionales con las dificultades que ello implica. Se trata de una verdad enfrentada en los días actuales por los órganos de persecución penal delante del crecimiento y desarrollo estructural y logístico de verdaderas "empresas" creadas para la práctica de delitos de alta gravedad y marcados por un destacable desvalor social.

Entonces se observa la importancia de intentar conseguir penetrar en el seno de una específica organización criminal por un agente estatal, con la finalidad de visualizar y descubrir los secretos y la forma de estructuración del grupo de delincuentes ${ }^{1663}$, posibilitando a través de los órganos de persecución la desarticulación del mismo con la consecuente detención de sus miembros.

Se trata, en definitiva, de una figura polémica pero actualmente necesaria en razón del grado alcanzadopor las actuaciones del crimen organizado transnacional1664. Así, en multitud de ocasiones no existirá otro modo para poder desentrañar los entresijos de las bandas organizadas con las características, y por lo tanto la enorme peligrosidad y lesividad ${ }^{1665}$.

Por eso, se hace necesario centrar la cuestión partiendo de la consideración de que el hecho del cierre de los "secretos" estructurales y logísticos de algunos grupos de delincuentes organizados, muy especialmente aquellos con características de transnacionalidad como el narcotráfico y el terrorismo, conlleva a una actuación policial basada en la utilización de técnicas sofisticadas de investigación como son los agentes infiltrados, de modo a descubrirse informaciones y datos útiles a la desarticulación del grupo criminal con la consecuente detención de aquellas personas responsables por la práctica de delitos graves ${ }^{1666 .}$

\footnotetext{
1663 Por este motivo, señala MOLINA PÉREZ que en lo se refiere a la labor del agente encubierto "el único objetivo, o finalidad, es el de desvelar y poner de manifiesto el proceder delictivo de los infractores". Cfr. MOLINA PÉREZ, T., "Técnicas especiales de investigación del delito: el agente provocador, el agente infiltrado y figuras afines (y II)", cit., pág. 161.

1664 En este contexto, "esta criminalidad se presenta como fruto de una evolución con respecto a la delincuencia ordinaria que se ha modificado no sólo en cuanto a la titularidad de la acción penal: de un solo individuo ha pasado al consorcio de personas organizadas para delinquir; sino en la cualificación y cuantificación profesional de estos grupos que se asocian para delinquir y que cada vez suponen un mayor perjuicio para la sociedad por ser entramados mucho más hermenéuticos, inflexibles, agresivos, violentos y sofisticados". Cfr. ESPINOSA DE LOS MONTEROS, R. Z., "Las reglas de exclusión probatoria al hilo del desarrollo de la infiltración policial", cit., pág. 72.

1665 Vid. POZO PÉREZ, M., "El agente encubierto como medio de investigación de la delincuencia organizada en la Ley de Enjuiciamiento Criminal española", cit., pág. 267. También no se pone en duda que la intervención del agente encubierto requiere que se trate de un delito grave, atendiendo no sólo a la previsión legal de una pena privativa de libertad grave, sino además a la trascendencia social del delito que se trata de investigar. Vid. la STS 4533/2007, de 27.6.2007.

$1666 \mathrm{Al}$ respeto, es importante señalar que "si la criminalidad organizada, especializada, utiliza de unos medios de actuación que se encuentran totalmente cerrados al exterior, la intervención de la policía exige, a menudo, trasladarse a la investigación de ese ambiente". Véase, MOLINA PÉREZ, T., "Técnicas especiales de
} 
Es necesario, sin embargo, aclarar que deberán ser utilizados preliminarmente todos los métodos tradicionales de búsqueda de la verdad en la investigación, dejando la utilización de este medio extraordinario como ultima ratio, en razón de su fuerte carga de restricción de las garantías fundamentales ${ }^{1667}$.

Funcionaría entonces la regla de agotamiento previo de otras técnicas de investigación consideradas como menos agresivas a las garantías fundamentales del ciudadano sometido a la persecución penal, dejando el recurso al agente infiltrado para situaciones de destacada gravedad delante de la insuficiencia de los medios ordinarios de búsqueda de informaciones, datos y pruebas relativos a una determinada organización criminal.

Así, puesto que estas técnicas encubiertas de investigación son especiales, sólo pueden ser desarrolladas en determinadas circunstancias y sólo frente a esta especial forma de criminalidad que se configura como una criminalidad cualificada 1668 .

Más que esto, se puede afirmar que la actuación de un agente infiltrado produce un efecto inmediato de investigación y aseguramiento de fuentes de prueba, típico de la fase de instrucción y, conducente a la preparación del juicio oral mediante la averiguación del delito e identificación del delincuente ${ }^{1669}$; tiende por lo tanto, a la formación del juicio de acusación ${ }^{1670}$, la formación de la pretensión penal.

Y tiene que ser de este modo en razón de que la fase de investigación de un proceso penal tiene por objeto lograr esclarecer las circunstancias de comisión de un hecho delictivo y averiguar la persona de su autor o autores. En realidad, toda la fase de investigación criminal está dirigida a la obtención de informaciones sobre estos extremos, las cuales una vez analizadas y depuradas pueden convertirse en fuentes de prueba que serán las únicas que podrán aportarse en el juicio oral y que tras pasar por los filtros de los derechos de defensa y contradicción, oralidad y publicidad, pueden llegar a convertirse en pruebas de cargo que justifiquen el dictado de una sentencia de condena ${ }^{1671 .}$

Se destaca, pues, la necesidad de que la investigación criminal ejercida a través de agentes infiltrados en bandas criminales venga permeada por la obediencia irrestricta a

investigación del delito: el agente provocador, el agente infiltrado y figuras afines", Anuario Jurídico y Económico Escurialense, XLI, 2008, pág. 185.

1667 De este modo, "otro aspecto de suma importancia consiste enreconocer que como regla general el recurso al agente infiltrado tiene que estar de acuerdo con el principio de la indisponibilidad y de la imposibilidad objetiva de buscarse las pruebas y la verdad por otro medio menos gravoso". Cfr. GUEDES VALENTE, M. M., "A investigação do crime organizado. Buscas domiciliárias nocturnas, o agente infiltrado e intervenção nas comunicações", cit., pág. 174. Siguiendo este mismo pensamiento, destaca SUITA PÉREZ que "como toda medida susceptible de restringir un derecho fundamental, deberá tener un carácter excepcional y sólo se adoptará cuando no exista otro medio de investigación del delito menos gravoso para los imputados, lo que normalmente se traduce en que el mismo sea la ultima ratio". Vid. SUITA PÉREZ, N., "La diligencia de investigación por medio del agente encubierto", cit., págs. 247-248.

1668Véase al respeto, ESPINOSA DE LOS MONTEROS, R. Z., "Las reglas de exclusión probatoria al hilo del desarrollo de la infiltración policial", cit., pág. 72.

${ }^{1669}$ GIMENO SENDRA, V., et alli., Derecho procesal penal, cit., pág. 368.

1670 Cfr. MORENO CATENA, V., et alli., El proceso penal, cit., págs. 2118-2119.

1671 En este sentido, vid. GUZMÁN FLUJA, V.C ., "El agente encubierto y las garantías del proceso penal", cit., págs. 205-206. Todavía, es absolutamente perceptible que el resultado de las investigaciones llevadas a cabo por el agente encubierto infiltrado, a falta de intervención de la autoridad judicial en la confección de una prueba preconstituida, solamente podrá ser llevada a juicio, con plena aptitud para enervar la presunción de inocencia, a través de la declaración testifical del citado agente encubierto en juicio oral que el Tribunal sentenciador valorará en consciencia. Vid. DELGADO MARTíN, J., Criminalidad organizada, cit., pág. 101 y SEOANE SPIEGELBERG, J. L., "Aspectos procesales del delito de trafico de drogas", cit., pág. 345. 
los principios y postulados aplicables a esta especie de medida restrictiva de derechos fundamentales. Se trata de encuadrar esta técnica de investigación dentro del contexto de un proceso penal garantista donde se destaca el equilibrio armónico entre la eficiencia estatal y la protección de derechos fundamentales.

De otro modo, si actúa motu proprio, sin cumplir las previsiones legales, es evidente que los resultados que pudiera obtener se encontrarían invalidados porque estaríamos ante una prueba obtenida con vulneración de derechos fundamentales. Resulta claro que integraría un supuesto de prueba prohibida ${ }^{1672}$.

Además, las reglas del procedimiento probatorio y los principios que les son pertinentes merecen especial atención cuando el tema incluye medidas de investigación que restringen derechos fundamentales ${ }^{1673}$. Es lo que se pasa en concreto delante de la hipótesis de una operación encubierta realizada a través de la infiltración policial en casos de delincuencia organizada, a la vez que estas operaciones están limitadas de todo modo por los principios penales sustantivos y procesales propios de un Estado Constitucional de Derecho y bajo la premisa de que el Estado nunca podrá convertirse en partícipe de esos delitos, sin criterio alguno de proporcionalidad y necesidad extrema.

Partiendo de la consideración de que el agente encubierto actúa a priori resguardado por una causa de justificación, concretamente, según nuestro modo de pensar, por el estricto cumplimiento de un deber legal, es claro concluirse que la prueba ha sido obtenida mediante una acción justificada, por lo que en este supuesto la prueba obtenida puede ser eficaz ${ }^{1674}$. No debe desconocerse, en todo caso, que la eficacia quedaría condicionada a la valoración de la prueba desde la óptica del modo como ha sido obtenida, bien como llevándose en consideración si la forma de su incorporación al proceso ha cumplido con la normativa procesal aplicable.

Pero no es solo esto, pues para dar validez a las pruebas obtenidas por el infiltrado debe llevarse a cabo un control judicial efectivo de sus actuaciones mediante un mecanismo que le obliga a informar al órgano jurisdiccional, a la mayor brevedad posible, sobre la investigación que se vaya practicando ${ }^{1675}$.

1672 POZO PÉREZ, M., "El agente encubierto como medio de investigación de la delincuencia organizada en la Ley de Enjuiciamiento Criminal, cit., pág. 299. Esto significa que los agentes policiales y los órganos judiciales deben respetar las reglas establecidas en la LECrim para la adquisición y la práctica de la prueba respectivamente, so pena de que la prueba sea inutilizada por este motivo, por ser declarada nula. Véase al respeto, ESPINOSA DE LOS MONTEROS, R. Z., "Las reglas de exclusión probatoria al hilo del desarrollo de la infiltración policial", cit., pág. 74.

1673 Destacando este pensamiento, vid. CORRÊA DE CARVALHO, J. T., Tráfico de drogas: Prueba penal y medidas restrictivas de derechos fundamentales, cit., pág. 349.

1674En este sentido, la posición defendida por LÓPEZ BARJA DE QUIROGA, J., "El agente encubierto", cit., pág. 1957.

1675 Vid. MOLINA MANSILLA, Mạ. C., Mecanismos de investigación policial: entrega vigilada y agente encubierto, cit., pág. 36. Destacase que este control de la operación de infiltración se trata de una indispensable inspección respeto a la legalidad de los actos practicados por el infiltrado y que por supuesto vendrá a demostrar la fiabilidad de las pruebas obtenidas y la respectiva valoración de las mismas en el proceso. Y más, pues según MONTÓN GARCÍA "las actuaciones que el agente encubierto pueda desarrollar en el ejercicio de su cargo deben ser prudentes y proporcionadas a la finalidad que pretende lograrse, lo que significa que están sujetas a dos limitaciones importantes: una, la provocación para delinquir, pues ésta produciría impunidad y la consiguiente pérdida de eficacia de los resultados obtenidos; y otra, que su acción afecte a derechos fundamentales, en cuyo caso deberá informar al Juez que le autorizó para que éste le permita la práctica de aquélla expresamente". Cfr. MONTÓN GARCÍA, Ma․ L., "Agente provocador y agente encubierto: ordenemos conceptos", cit., pág. 2. 


\section{VI.1.4. Relevancia del testimonio del agente encubierto.}

El punto de partida para la comprensión del valor de las declaraciones del infiltrado en la instrucción criminal se refiere al hecho de que mientras aquellos funcionarios que actúan como agentes encubiertos no sean convocados a identificarse y prestar juramento en el sumario judicial sus informaciones no ingresarán a los fines probatorios con el valor de "prueba testimonial"1676.

Si lo anterior es correcto, entonces de modo alguno se puede infravalorar la importancia del testimonio del agente que ha tenido la oportunidad,desde de las entrañas del grupo criminal, observar y conocer profundamente todas las características y formas de actuar de la organización. A este respeto, el infiltrado es igualmente, en calidad de testigo, otro factor importante a la hora de constituir la prueba. La credibilidad de sus manifestaciones, con menos complicaciones que el arrepentido, corresponde también a la íntima convicción de los Jueces ${ }^{1677}$.

De lo dicho resulta que esta fuente de producción de prueba no tendrá el debido y esperado valor probatorio sies llevado a juicio de forma independiente y sin cualquier otro medio probatorio que venga a corroborar la esencia de las informaciones prestadas. En consecuencia, el testimonio del agente encubierto no será por sí mismo prueba suficiente para fundamentar una sentencia condenatoria, si no es corroborado por otros medios de prueba válidos ${ }^{1678}$.

Así entendido, la cuestión altamente controvertida y objeto de alta complejidad se refiere a la eventual valoración de las afirmaciones efectuadas por el agente encubierto en juicio, en condición de testigo de todo lo que ha presenciado en el ambiente donde se quedó infiltrado.

Como puede observarse de lo anteriormente expuesto, debido a las dificultades probatorias en materia de investigaciones sobre la actuación del crimen organizado sería de extrema importancia para el órgano juzgador oír los relatos, o sea, los conocimientos detallados obtenidos por el infiltrado durante el período en que ha permanecido dentro de la estructura de la organización criminal. Se estaría, pues, exponiendo directamente al órgano jurisdiccional informaciones y datos sobre los hechos investigados los cuales,por cierto, se someterán a la formación de la libre convicción del juzgador. De este modo, se aproximaa la verdad $y$, en consecuencia, se permite que la defensa conozca las imputaciones hechas en contra las personas sometidas al proceso penal ${ }^{1679}$.

1676 CORVALÁN, V. R., "Agente encubierto y testigo de identidad reservada", Suplemento de Jurisprudencia Penal de La Ley, Buenos Aires, 1997, pág. 922.

${ }_{1677 C f r}$. la STS 7021/1995, de 14.2.1995. El problema que suscitan los agentes encubiertos en lo concerniente a sus declaraciones y a la ponderación de las mismas, se refiere, por lo general, a casos en los que se pretende hacer valer mediante testigos de referencia, las informaciones proporcionadas por el agente infiltrado sin que éste haya comparecido en el juicio oral (vid. SSTC. 146/2003 de 14.6.2003, 41/2003, de 27.2.2003 y 119/2002, de 25.11.2002), no siendo factible tal posibilidad. (STS 1316/2011, de 1.3.2011).

1678 Vid. MARTín ANCÍN, F.; ÁLVAREZ RODRÍGUEZ, J.R., Metodología del atestado policial. Aspectos procesales y jurisprudenciales. Práctica jurídica, Madrid, 1999, pág. 39.

1679 Defendiendo la necesidad de que la defensa durante la instrucción criminal sepa de la intervención de un agente encubierto, señala CORRÊA DE CARVALHO que "una cosa es garantizar la protección al policía que actuó como encubierto, otra es impedir que la defensa tenga conocimiento de que hubo un agente infiltrado en la organización. Para que la defensa sea efectiva no hay duda de que los abogados deben conocer las pruebas". Cfr. CORREAA DE CARVAlHo, J. T., Tráfico de drogas: Prueba penal y medidas restrictivas de derechos fundamentales, cit., pág. 355. Nos parece muy acertada la posición anteriormente defendida, a la vez que representa obediencia al principio de la simétrica paridad de armas en el proceso penal, donde el proceso debe 
Sobre este asunto es importante esclarecer que la efectiva protección de los testigos, tanto si son agentes encubiertos como si no lo son, se configura como una pieza clave para la lucha contra el crimen organizado ${ }^{1680}$.

Esto significa de forma sencilla que el problema procesal que suscitan los agentes encubiertos en lo concerniente a sus declaraciones y a la ponderación de las mismas se refiere, por lo general, a casos en los que se pretende hacer valer mediante testigos de referencia las informaciones proporcionadas por el agente infiltrado, sin que éste haya comparecido en el juicio oral. Pero, en la medida que el agente encubierto sea conocido por su real identidad por el Tribunal, comparezca ante éste y sus manifestaciones tengan corroboraciones objetivas que permiten juzgar sobre su veracidad, no existen razones para excluir completamente la prueba basada en sus dichos ${ }^{1681}$.

Sin embargo, habrá que partir de la idea de que el agente encubierto quedará en la misma posición de un testigo común, y desde que se presente personalmente delante del Juez y de las partes envueltas en el proceso penal1682, y pueda declarar todo lo que tiene conocimiento, sin vacilaciones o intereses espurios, podrá prestar importante contribución a la busca de la verdad procesal, facilitándose la convicción del juzgador y la consecuente condena de las personas que de hecho han practicado conductas graves dentro del entorno de una organización criminal.

Otra situación de especial interés consiste en exponer lo que puede hacer para proteger la identidad del infiltrado en la instrucción criminal ${ }^{1683}$.

Respeto a esta intrigante cuestión, CORRÊA DE CARVALHO señala que no hay duda de que si la defensa reclama la presencia del infiltrado en juicio tendrá que comparecer y testificar; sin embargo, lo que se pone en duda es si sería válida una condena en un proceso en el que hubo una infiltración y se aprovecharon los resultados de la misma para justificar la resolución condenatoria sin la prueba testifical del agente encubierto ${ }^{1684}$.

Más allá de las situaciones en las que así se haya querido, imagínese la posibilidad de la muerte del infiltrado con posterioridad ala finalización de la operación encubierta. En este caso, ¿las informaciones y pruebas aportadas por él en los informes periódicos a sus superiores y a la autoridad judicial y aportados al proceso no tendrían validez? La respuesta sólo podría ser negativa, y la razón reside en el hecho de que la presencia del testigo estaría perjudicada en el acto del juicio, sin embargo, quedarían al conocimiento de

ser comprendido y practicado como una garantía, luego, cuando se inicia un proceso no se ejercita un ilícito, al contrario se practicaunderecho constitucionalmente asegurado. Con más detalles, vid. FAZZALARI, E., Instituições de direito processual, Campinas, 2006. 102.

${ }^{1680}$ Adoptando este pensamiento, vid. DELGADO MARTíN, J., Criminalidad organizada, cit., nota 224, pág.

1681 Cfr. la STS 3957/1999, de 05.6.1999.

1682 Evitase con esto que el agente encubierto figure como un testigo oculto, o sea aquel que se presta sin ser visto por el acusado. Y en esta hipótesis, se considera que esta declaración testifical controvertida ha de analizarse donde la perspectiva del derecho a un juicio público con todas las garantías, desde una triple vertiente de exigencia: publicidad, contradicción e igualdad de armas. Vid. MAGRO SERVET, V., "Régimen legal de los testigos protegidos en el proceso penal", La Ley Penal, núm. 75, octubre/2010, http://revistalaleypenal.laley.es.

1683 Nótese que la prensa española ha noticiado en tiempos recientes, que el Estado no cuida bien a los testigos protegidos, en especial de topos infiltrados en organizaciones terroristas. Vid. con más detalles, BAQUERO M. MARTÍNEZ, A., "La amenaza islamista en España. La figura del infiltrado es ya clave en la lucha antiterrorista", El periódico de Aragón, 02/03/2008, http://www.elperiodicodearagon.com.

1684 Vid. CORRÊA DE CARVALHO, J. T., Tráfico de drogas: Prueba penal y medidas restrictivas de derechos fundamentales, cit., pág. 355. 
la defensa de los imputados las pruebas originadas de la operación policial, posibilitándose todavía la puesta en práctica de la contradicción.

Y más que todo esto, el Juez tendría la libertad apta a la formación de su libre convicción ${ }^{1685}$ para conferir el valor que reputase más fiable a la prueba, desde que la condena se fundamentase en un contexto formado por otras pruebas obtenidas de forma lícita y que la sentencia presente una motivación jurídica ${ }^{1686} \mathrm{como}$ requisito imprescindible a la prestación jurisdiccional.

No cabe negar, sin embargo, que la regla tiene que ser que el agente encubierto declara de forma regular en la instrucción como testigo, lo que pondría en evidencia la necesidad de protección a su identidad real en razón de los riesgos y peligros que esta actividad infiltrada le ha generado.

Como bien explica RAMOS MÉNDEZ, las necesidades de autoprotección del sistema ante nuevas formas de delincuencia y, sobre todo, ante la proyección de éstas sobre las instituciones procesales, han obligado a revisar el mantenimiento de las medidas de protección de testigos acordadas en la instrucción ${ }^{1687}$.

El secreto en la protección de testigos tiene como fin ocultar la identidad de una persona que declara con tal calidad hasta que legalmente se estime que ya no es necesaria la confidencialidad. Son dos los objetivos de la reserva: salvaguardar la seguridad del declarante y/o garantizar el éxito de la averiguación.

Algún autor, como CUBILLO LÓPEZ, sostiene incluso que el mantenimiento de la identidad supuesta del agente encubierto cuando vaya a declarar en el proceso no se configura como algo automático sino que exige una "resolución judicial motivada". De un lado, no revelar la identidad real del agente parece una exigencia propia de la figura, algo casi necesario para si correcto funcionamiento. Pero, de otro lado, y en tanto que ello puede limitar las posibilidades defensivas o de contradicción frente al testimonio, ha de justificarse que estas posibilidades no se restringen de forma grave o que pesa más la necesidad de proteger los bienes jurídicos del agente en el caso concreto. Además, la acusación habrá de argumentar a favor del mantenimiento de la identidad supuesta del agente, como medio para proteger los bienes y derechos de éste así como las necesidades operativas de la policía -al igual que el acusado tendrá que motivar, en su caso, en qué medida concreta desconocer la identidad real do agente le causa indefensión-; y esto aunque se considere que existe una predisposición legal favorable a que se mantenga la identidad ficticia del agente durante su actuación en el proceso ${ }^{1688}$.

\footnotetext{
${ }^{1685}$ Recuérdese que el sistema procesal penal español por fuerza del artículo 741 de la LECrim consagra el sistema de la libre valoración de la prueba.

1686 La exigencia de motivación en la sentencia viene de encuentro a la necesidad de explicitarse las razones que llevaron el Juez a valorar concretamente las pruebas aportadas al proceso. Evitase con esto decisiones que pueden plantear dudas sobre la imparcialidad del órgano juzgador. Respeto a esta exigencia, decía RAMOS MÉNDEZ que "se ha fomentado como una espécie de temor ancestral a descubrir las cartas, a saber qué piensa el tribunal, como si lo que hubiese de primar fuese el celo en guardar los secretos del reino". Cfr. RAMOS MÉNDEZ, F., Enjuiciamiento civil, Barcelona, 2008, pág. 632. Más que esto, "toda condena deve venir precedida de una mínima actividad probatoria de cargo, practicada con todas las garantías, lo que obliga a motivar la sentencia con la valoración de la prueba realizada por el tribunal". Véase con detalles, la STC 31/1981, de 28.7.1981.

1687 Vid. RAMOS MÉNDEZ, F., Enjuiciamiento criminal, cit., pág. 323.

1688Vid. CUBILLO LÓPEZ, I. J., La protección de testigos en el proceso penal, Pamplona, 2009, págs. 80-81. Por esta razón, manifiesta DELGADO MARTíN en el sentido de que "difícilmente se aceptará esa función si el ordenamiento no garantiza adecuadamente la integridad física tanto del agente como de su familia, lo que pasa
} 
Desde esta perspectiva, cabe comprender que considerándose la actividad de infiltración del agente la propia cautela recomienda que el mismo pueda trabajar bajo la alteración de su propia identidad. Evidentemente que en esta especie de operación siempre habrá riesgos personales para el infiltrado, pero cuanto más pudieren ser evitados estos riesgos mejor será para la preservación de la integridad física del agente.

Una de las formas de preservación es la concesión, a través de resolución judicial relativa de la autorización de la propia infiltración, de que le sea expedida una tarjeta de identidad falsa con destino y uso exclusivo a la actividad de infiltración a que se destina, prohibida su empleo para cualquier otra actuación que no sea correlativa con aquella objeto de la investigación. En consecuencia, la verdadera identidad del agente encubierto deberá ser conocida tan solamente por el Juez, por el Fiscal y por el superior jerárquico del mismo ${ }^{1689}$.

Una salida interesante para intentar resolver esta problemática de la omisión de los verdaderos datos personales del agente encubierto que figura como testigo en un determinado juicio sería que en circunstancias que exigieren la preservación de la seguridad de estos testigos podría la autoridad judicial permitir que estos coloquen la huella digital en la declaración en lugar de su firma, debiendo en estos casos ser obligatoria la participación del Ministerio Fiscal y de la defensa como garantizadores de que dicha huella corresponde a la persona que ha declarado. En esta hipótesis, se omitiría la referencia al nombre y otros datos generales de estas personas (v.g., la fecha y lugar de nacimiento) en el texto del acta, la que se hará formar parte del expediente correspondiente con la constancia sobre el levantamiento de la identificación y su destino.

Para que se mantenga la identidad ficticia del agente policial durante su declaración en el juicio, al igual que en todo caso de testimonio anónimo, resulta clave que ello no suponga una eliminación de la contradicción procesal, lo que conllevará que se permita el interrogatorio efectivo y necesario del agente ante el tribunal sentenciador ${ }^{1690}$.

Así, su condición de testigo protegido y la posibilidad de utilización de identidad supuesta y ocultación de sus verdaderos datos personales, aunque presente algunas dificultades, no generarían ninguna nulidad, irregularidad o violación al derecho de

ineludiblemente por el mantenimiento en secreto de su identidad real, tanto durante toda la tramitación del proceso penal como una vez finalizado éste". Vid. DELGADO MARTíN, J., "El proceso penal ante la criminalidad organizada. El agente encubierto", cit., pág. 23.

1689 Cfr. MENDRONI, M. B., Crime organizado. Aspectos gerais e mecanismos legais, cit., pág. 60. Sobre esta discusión, importante destacar la Recomendación n. 35 del Grupo de Trabajo Oficioso de Expertos sobre Técnicas Especiales de Investigación (Prácticas óptimas y recomendaciones sobre los obstáculos jurídicos a las entregas vigiladas y las operaciones encubiertas) de Naciones Unidas: "Se debe garantizar la máxima protección posible del agente infiltrado, durante y después de la operación. Esto incluye la protección física durante y después de la operación y la protección de su identidad (protección antes, durante y después del juicio)". Vid. el informe del Grupo de Trabajo Oficioso de Expertos sobre Técnicas Especiales de Investigación (Prácticas óptimas y recomendaciones sobre los obstáculos jurídicos a las entregas vigiladas y las operaciones encubiertas) de Naciones Unidas, elaborado por la Oficina contra la droga y el delito, septiembre de 2005. En este documento los expertos señalaron que los Estados deben advertir que el riesgo de vida que corren los agentes es mayor cuando se combate la delincuencia organizada transfronteriza grave. El riesgo es igualmente alto para los agentes encubiertos que trabajan en países que carecen de los recursos suficientes para otorgar protección que en jurisdicciones pequeñas donde hay riesgo significativo de contacto posterior.

1690 Vid. CUBILLO LÓPEZ, I. J., La protección de testigos en el proceso penal, cit., pág. 82. 
defensa, en razón de la necesidad de preservación de la integridad física del infiltrado y por estar siendo obedecido el principio de proporcionalidad ${ }^{1691}$.

Como explica RIFÁ SOLER, lo que no puede admitirse es la incomparecencia en juicio del agente infiltrado a los efectos de garantizar su seguridad y su sustitución por un testigo de referencia para preservar el anonimato de aquél ${ }^{1692}$. Nos parece correcta esta posición pues quedarían violados un sinnúmero de principios procesales y constitucionales, en especial el derecho de la defensa en conocer integralmente la esencia de la prueba producida por el órgano acusador. Por este motivo, como se vendrá en líneas siguientes, quedaría como situación excepcional la utilización de la videoconferencia para casos que se relacionen con situaciones donde el testigo se encuentre en incontestable situación de riesgo y peligro de vida. 0 incluso en la hipótesis de inviabilidad del transporte del acusado en razón de inminente peligro de rescate del mismo por otros miembros de la organización criminal.

En virtud de lo expuesto, el testimonio del agente infiltrado en condiciones de anonimato sin comparecencia al juicio conlleva problemas porque colisiona con principios estructurales del proceso penal, especialmente delante de los principios de inmediacióny contradicción. De hecho, no habiendo un contacto directo e inmediato de los sujetos procesales con el testigo anónimo, ni la posibilidad de interrogarlo en condiciones efectivas, acreciendo a esto la ya mencionada dificultad de fiscalización de la forma como el agente ha adquirido los conocimientos que va a transmitirse, es de constatar que este testimonio es prestado en condiciones extremamente adversas y limitadoras del derecho de defensa ${ }^{1693}$.

Así las cosas, y teniendo en cuenta las consideraciones anteriormente planteadas, el agente encubierto podrá ser utilizado como testigo, declarando sobre sus funciones específicas, los hechos que presenció y las circunstancias como se desenvolvieron.

El testimonio del infiltrado debe ser por lo tanto valorado conforme todas las circunstancias que han permeado su actuación y además en confrontación con las demás pruebas corroboradas, porque al igual que cualquier otro testigo puede deformar la realidad y tener interés en no decir la verdad ${ }^{1694 .}$

\footnotetext{
1691 Siguiendo esta misma línea de pensamiento, vid. CORRÊA DE CARVALHO, J. T., Tráfico de drogas: Prueba penal y medidas restrictivas de derechos fundamentales, cit., págs. 355-356.

1692RIFÁ SOLER, J. M., "El agente encubierto o infiltrado en la nueva regulación de la LECrim", cit., pág. 176. DELGADO MARTÍN señala también otros extremos que sirven para hacer efectiva la contradicción en estos casos, como son que "el órgano judicial debe informar al imputado sobre la naturaleza del agente encubierto, aunque siga ocultando su identidad real" y que el tribunal ha de tener acceso a los datos reales del agente encubierto, de cara a tenerlos en cuenta al valorar su declaración. Vid. DELGADO MARTíN, J., "El proceso penal ante la criminalidad organizada. El agente encubierto", cit., págs. 24-25. Con profundidad sobre esta discusión, Cfr. ALFONSO RODRÍGUEZ, O., La ineficacia probatoria del testimonio secreto, Bogotá, 1996. Con una opinión distinta, señala RIVERA MORALES que "no es ilícito quese reserve su identidad, ni que no comparezca ante la audiencia oral. Se entiende así que el Estado debe protegerlo al igual que cualquier otro testigo". Cfr. RIVERA MORALES, R., Actos de investigación y pruebas en el proceso penal, cit., págs. 234-235.

1693 Vid. PEREIRA, S., "A recolha de prova por agente infiltrado", cit., págs. 155-156. Además, no se puede olvidarse de que será necesario que el testimonio anónimo del infiltrado en el juicio, venga corroborado por otros medios de prueba con el objetivo de fundamentar la sentencia condenatorio de los acusados de pertenecieren a la organización criminal.

${ }^{1694}$ De hecho, sus palabras tendrán gran importancia como prueba en se tratando de infiltraciones de largo tiempo, o sea, con una duración razonable para la obtención de la confianza de los miembros del grupo y para la recogida de informaciones y datos imprescindibles a la eficiencia de la investigación.
} 
Cuando se trata del testimonio de un agente encubierto, la limitación que ordinariamente supone para la contradicción ignorar la identidad real del que declara es menor que en otros casos de testimonios anónimos, pues toda la posible relación previa entre el testigo y el acusado se ha desarrollado sobre la base de la identidad ficticia del agente, de manera que éste será el contexto desde que se pretenderá cuestionar el testimonio o poner de manifiesto hechos o circunstancias que resten credibilidad a su autor ${ }^{1695}$.

Como fácilmente puede deducirse el testimonio del agente infiltrado en condiciones de no revelación de su identidad, en razón de sus características que especialmente vienen a restringir derechos fundamentales como hemos visto, deberá presentar un valor probatorio correspondiente a esta condición ${ }^{1696}$.

El agente encubierto mantendría su anonimato y no constaría su identidad personal aunque declararía en el juicio oral pudiendo interesar la utilización de medios que eviten su contacto físico con los acusados. Puede entonces declarar desde la ocultación, a diferencia de otros testigos que interesan la declaración por videoconferencia por temor u otras circunstancias ${ }^{1697}$. Esta sería la única posibilidad de no comparecencia del agente, el cual prestaría su declaración físicamente lejos de la sala de vistas, aunque pueda ser visualizado a través de imágenes en vídeo y con sonido.

Surge entonces la oportunidad de utilizar la más alta tecnología a través del empleo de la videoconferencia1698, la cual deberá ser considerada como un excelente medio de auxilio probatorio para el proceso penal a fin de que las distancias no impidan cumplir con el principio de inmediación entre el Juez instructor y los actos procesales, dando las debidas garantías al imputado en un proceso que se relacione con delitos graves practicados por la delincuencia organizada.

En todo caso será precisa la exteriorización, a través de auto judicial motivado, de las razones que avalan o justifican el empleo de la videoconferencia, a fin de posibilitar a las partes la impugnación de este modo de llevar a cabo la práctica de un determinado acto procesal, en el supuesto de que consideren que tal comportamiento implica la misma de algún derecho fundamental ${ }^{1699}$. 183.

1695 Cfr. RIFÁ SOLER, J. M., "El agente encubierto o infiltrado en la nueva regulación de la LECrim", cit., pág.

1696 PEREIRA, S., "A recolha de prova por agente infiltrado", cit., pág. 157.

1697 Vid. MAGRO SERVET, V., Manual práctico de actuación policial-judicial en medidas de limitación de derechos fundamentales, cit., pág. 193. Sobre el uso de la videoconferencia en el proceso penal, es muy interesante la observación de CATOIRA al señalar que "al no poder afirmarse la integridad del respeto a las garantías procesales habituales, la decisión acerca de la celebración de un Juicio con la presencia mediante videoconferencia de los acusados requiere prestar inexcusable atención a criterios de proporcionalidad que relacionen el sacrificio de tales derechos con la relevancia de las causas que aconsejan semejante medida". Cfr. CATOIRA, A.A., " La tecnologización de la prueba en el proceso penal. La videoconferencia: objeciones y ventajas", Anuario da Facultade de Dereito da Universidade da Coruña, núm. 13, 2009, pág. 28.

1698 Por esta razón, ciñéndonos al ordenamiento procesal penal español, "la videoconferencia se convierte en un instrumento técnico idóneo para posibilitar la aplicación de las medidas de protección de testigos y peritos en causas criminales contemplas en la LO 19/1994, de 23 de diciembre, en aquellos supuestos en los que concurra un peligro grave a la persona, libertad o bienes de quien pretenda ampararse en la medida de protección, o de su cónyuge o persona a quien se halle ligado por análoga relación de afectividad o sus ascendientes, descendientes o hermanos". Cfr. URBANO CASTRILLO, E; TORRES MORATO, M. Á., La prueba ilícita penal. Estudio jurisprudencial, cit., págs. 357-358.

1699 En este sentido, Cfr. URBANO CASTRILLO, E; TORRES MORATO, M. Á., La prueba ilícita penal. Estudio jurisprudencial, cit., pág. 357. 
Tomando como presupuesto una vez más que por medio del proceso no se puede obtener la verdad a toda costa, premisa que constituye una reivindicación fundamental de la protección del individuo frente al poder punitivo estatal el Estado tendrá, en consecuencia, que respetar y ceñirse a lo legalmente establecido, respetando con ello la dignidad de la persona, la estricta vigilancia en los requisitos de restricción de los derechos fundamentales y los principios reguladores de la prueba, que intentan lograr un juicio justo y con todas las garantías ${ }^{1700}$.

En síntesis, lo que se debe dejar claro es que no es admisible la incomparecencia injustificable en juicio del agente infiltrado y su sustitución por testigos de referencia argumentando pretendidas razones de seguridad, de modo que sólo la imposibilidad real de oír a los testigos directos o presenciales del hecho permite atribuir eficacia probatoria a los testigos de referencia ${ }^{1701}$.

Por otro lado, está claro que el testimonio del agente encubierto no puede ser secreto ${ }^{1702}$, debiéndose evitar la violación innecesaria de algunos postulados básicos del Estado de Derecho como son la contradicción y la lealtad procesal. Afirmado ello, debe de ser esclarecido lo que se debe entender por "secreto". Como es sabido, secreto no es equivalente a anónimo, por supuesto. La revelación de los datos para que tenga eficacia procesal debe ser controvertible en el juicio mediante la comparecencia a la vista del funcionario que personalmente llevó a cabo la actuación investigadora1703.

En este sentido, respecto a la declaración del infiltrado como testigo y el principio de contradicción, BECERRA señala que el agente encubierto y su eventual manifestación procesal en la forma de un testigo de identidad reservada no debería echar en saco roto las facultades de control de la producción de la prueba durante el juicio oral que tiene el acusado ${ }^{1704}$.

En lo que hace al agente encubierto y su presentación en juicio, se admite en países como Alemania la "prueba subrogada", es decir, que sea el jefe del agente encubierto quien se presente en el interrogatorio. Así mismo, se ha considerado la posibilidad de que el agente se presente enmascarado, o detrás de un panel1705. No estamos de acuerdo con

1700DAGDUG KALIFE, A., La prueba testimonial ante la delincuencia organizada, cit., pág. 339.

1701Vid. ZARAGOZA AGUADO, J. A., "Tratamiento penal y procesal de las organizaciones criminales en el Derecho español. Especial referencia al tráfico ilegal de drogas", cit., pág. 112. Además, las SSTC, 217/89, de 21.12.1989; 303/93, de 25.10.1993; 35/95, de 6.2.1995 y 7/99, de 8.2.1999.

1702 Por esta razón, se suele afirmar que "el testimonio secreto es el reflejo de la incapacidad del Estado para investigar, acusar, juzgar y sentenciar a las personas infractoras de la ley penal por los cauces normales". Cfr. ALFONSO RODRÍGUEZ, O., La ineficacia probatoria del testimonio secreto, cit., pág. 15.

1703 Corroborando esta afirmación, incluso se puede afirmar que la validez constitucional de las declaraciones de testigos con reserva de identidad depende objetivamente del respeto incondicional las garantías que rodean la realización y valoración de la prueba, así como de la posibilidad cierta de que esta pueda ser ampliamente controvertida por la defensa técnica. Por lo tanto, si durante la declaración del agente encubierto como testigo no está presente el miembro del Ministerio Fiscal; si no se levanta el acta separada con la identidad del declarante; si el Juez no puede conocer esa identidad para valorar adecuadamente la declaración; si, por ello, la defensa no puede contrainterrogar al testigo, la prueba será nula por violación del núcleo esencial del derecho fundamental al debido proceso.

1704 Vid. BECERRA, N. E., "La justicia penal nuevamente entre garantía y eficiencia: el arrepentido y el agente encubierto. Algunas preocupaciones previas", La Ley, año LXIII, núm. 25, 1999, pág. 3.

1705 Esta hipótesis concreta iba en contra la esencia de un proceso penal garantista, pues hay que matizar que "la lucha por el proceso justo, especialmente intensa en la esfera del enjuiciamiento penal, ha sido a lo largo de la historia, en primer lugar, la lucha por que las actuaciones del proceso no sean secretas para las partes". Cfr. GONZÁLEZ GARCÍA, J. M., "Entre el derecho de defensa y el derecho a la información: viejas y 
estas soluciones apuntadas pues las reputamos contrarias a todos los principios constitucionales inherentes al derecho probatorio como son la publicidad, la contradicción, la igualdad de armas y en especial el derecho a una defensa amplia.

$\mathrm{Al}$ respecto, los Tribunales internacionales han expresado en diversas sentencias su parecer. Ello surge de varios precedentes dictados por el Tribunal Europeo de Derechos Humanos, comenzando por el caso Kostovsky v. The Netherlands (20.11.1989), el que se exigió la presencia del testigo por cuanto la defensa tenía el derecho de interrogar al testigo y observar sus distintas reacciones. Este posicionamiento fue seguido en los casos Lüdi v. Switzerland (15.6.1992) y Van Mechelen v. The Netherlands (23.4.1997) cuyas sentencias condenatorias fueron revocadas por cuanto la declaración de los agentes encubiertos, al iniciar la investigación, fue la única prueba para fundar la condena, no contando la defensa con su derecho al cross examination ${ }^{1706}$.

Nos parece más acertado que la problemática respeto del testigo del infiltrado y la consecuente preservación de su identidad podrá ser resueltaa través de dos formas: en la primera, el agente encubierto comparece delante del Juez como un testigo normal, y sin cualquier forma de protección de su aspecto físico, presta sus declaraciones frente a frente con los imputados. Cabría en esta hipótesis esperar del Estado una actuación irreparable de protección a este funcionario que se quedó expuesto a conocimiento público, incidiendo sobre el mismo su incorporación en un programa de protección de testigos, el cual tenga por objetivo asegurar la integridad física y la vida del infiltrado y de sus familiares ${ }^{1707}$. La segunda posibilidad sería la utilización como ya hemos afirmado delavideoconferencia ${ }^{1708}$, y en este caso, el infiltrado no tendría contacto directo con el imputado y otras personas, aunque su identidad, al menos física, resulte desvelada y requiera del mismo modo su inclusión en un programa de protección de testigos.

Desde el planteamiento que aquí se sostiene,queda muy claro que la infiltración no es prueba, ni el agente encubierto es una prueba, pero la técnica de infiltración puede permitir la obtención de informaciones por el agente las cuales podrán servir como fuentes de prueba ${ }^{1709}$. Dicho en otras palabras, la infiltración no tiene una función

nuevas cuestiones sobre la publicidad de las actuaciones del proceso penal", Revista del Poder Judicial, núm. 80, 2005, pág. 67.

1706 Vid. MONTOYA, M. D., "El agente encubierto en la lucha contra el crimen organizado en la Argentina", cit., pág. 323.

1707 Siguiendo esta misma orientación, señala "si corre riesgo su integridad física, deberá el Estado preveer un programa eficiente de protección de testigos, llegando incluso a cambiar su identidad, con posterioridad al juicio, si fuere necesario". Cfr. PRUNOTTO LABORDEA, A., "Pruebas ilícitas", VV.AA, La fe del hombre en sí mismo o la lucha por la libertad a través del proceso. El Mundo procesal rinde homenaje al Maestro Adolfo Alvarado Velloso, Lima. 2008, pág. 62.

1708 En esta hipótesis, "la autorización de la declaración del acusado a través de videoconferencia resulta excepcional, por lo que el órgano judicial tiene que motivar la medida como proporcionada y adecuada al caso. En este sentido, el Tribunal Europeo de Derechos Humanos al resolver el caso Marcello Viola vs. Italia, justifica la comparecencia virtual y la consiguiente declaración del imputado en razones de orden publico, prevención del delito, protección de los derechos de los testigos y las victimas, asi como el cumplimiento de la garantía procesal del plazo razonable de la duración de los procesos". Cfr. ., CATOIRA, A.A., "La tecnologización de la prueba en el proceso penal. La videoconferencia: objeciones y ventajas", cit., págs. 35-36.

${ }^{1709}$ En opinión de CORRÊA DE CARVALHO "es indiscutible que la labor del agente policial infiltrado le permitirá acceder a otras informaciones que pueden permitir o exigir la utilización de otros medios de prueba, sean éstos complementarios e indiciarios o autónomos y conclusivos. Una de estas hipótesis es la indicación por el agente encubierto de otras personas que puedan testificar acerca de los hechos investigados. Así, debido a la labor del infiltrado, la prueba testifical será optimizada". Vid. CORRÊA DE CARVALHO, J. T., Tráfico de drogas: Prueba penal y medidas restrictivas de derechos fundamentales, cit., pág. 351. Fundamental además es promover la distinción entre los medios de prueba y los actos de investigación: los primeros se practicarán en 
netamente investigadora, ni exclusivamente probatoria, sino que constituye un medio de investigación con formación y adquisición de fuentes de prueba, objeto de aportación y valoración en el acto del plenario ${ }^{1710}$.

En este contexto, la prueba solamente podrá ser considerada ilícita o no valida en los casos en que el agente infiltrado induce el sujeto provocado a practicar la infracción penal, o sea, cuando seduce con engaño para la práctica del delito1711. La violación de derechos fundamentales en este caso no constituye restricción legitima, pero sí implica en total vaciamiento de su contenido esencial, mostrándose absolutamente desproporcionado e igualmente intolerable cualquier aceptación ${ }^{1712}$.

No se podría cerrar este apartado sin citar la posición adoptada por Naciones Unidas al recomendar que se deba garantizar la máxima protección posible del agente infiltrado, durante y después de la operación. Esto incluye la protección física durante y después de la operación y la protección de su identidad (protección antes, durante y después del juicio) ${ }^{1713}$.

Incluso en algunas situaciones, en especial tras una operación encubierta prolongada, tal vez sea necesario que un agente deje de trabajar como policía o desempeñe tareas diferentes por su propia protección. En este caso, los Estados quizá deseen permitir el retiro anticipado de esas personas o disponer su traslado o ascenso.

el juicio oral para acreditar los hechos y, en su caso, enervar la presunción de inocencia y fundar la imposición de la pena. Ya los actos de investigación son la fuente de la prueba, pero no constituyen en sí mismos pruebas. Su finalidad específica no es la fijación definitiva de los hechos, para éstos trasciendan a la resolución judicial, sino la de preparar el juicio oral, proporcionando a tal efecto los elementos necesarios para la acusación y defensa y para la dirección del debate contradictorio atribuido al juzgador competente para conocer del juicio oral y dictar sentencia. Véase, en este sentido, la jurisprudencia del Tribunal Constitucional español: SSTC 141/2001, de 29.5.2001; 57/2002, de 11.3.2002 y 2/2002, de 14.1.2002. 93.

1710 Cfr. LÓPEZ-FRAGOSO ÁLVAREZ, T., Las intervenciones telefónicas en el proceso penal, Madrid, 2001, pág.

1711 Esta idea no va en contra la utilización del engaño como técnica de obtención de la confianza para ingreso en la organización criminal. Mejor explicando, "el modo de actuar con engaño y disimulación es el punto clave en la operación de infiltración, pues no habrá otro modo del agente adentrar en el clan criminal. Y lo más importante es destacar una vez más que no debe confundirse la provocación del delito por parte del agente encubierto, con una actuación de aparente conformidad, que no incita a delinquir, pero que puede engañar al delincuente, engaño que debe ser considerado lícito, y por ello, incapaz de romper la eficacia probatoria del testimonio del agente". Vid. REDONDO HERMIDA, A., "El agente encubierto en la jurisprudencia española y en la doctrina del Tribunal Europeo de Derechos Humanos", cit., pág. 98. Del mismo modo, aceptando el uso legítimo del engaño en la infiltración, señala MAIA DA COSTA que "la conducta del agente infiltrado será constitucionalmente admisible, malogrado constituir un medio engañoso de prueba, pero solo frente a ciertos presupuestos: aquellos que derivan del principio constitucional de proporcionalidad". Vid. MAIA DA COSTA, E., "Agente provocador. Validade das provas", Revista do Ministério Público, núm. 93, Lisboa, 2003, pág. 173.

1712 Vid. JESUS, D. E; BECHARA, F. R., "Agente infiltrado: reflexos penais e processuais", http://www.jus2.uol.com.br.

1713 Vid. la Recomendación n. 35 del Grupo de Trabajo Oficioso de Expertos sobre Técnicas Especiales de Investigación (Prácticas óptimas y recomendaciones sobre los obstáculos jurídicos a las entregas vigiladas y las operaciones encubiertas), de la Oficina contra la droga y el delito, Septiembre de 2005. Corroborando la citada posición asumida por Naciones Unidas, cítese también la Recomendación 36 que establece que entre las medidas que se pueden emplear para proteger la identidad del agente durante el proceso judicial, con arreglo al ordenamiento jurídico de que se trate, figuren: a) la utilización de declaraciones escritas, en contraposición con las declaraciones orales; b) la vista a puerta cerrada/secreta; c) la legislación que proteja a los agentes de la difusión de informaciones sobre su identidad y prevea penas graves para quienes la transgredan; d) la utilización de pantallas artefactos, pelucas, gafas de sol, etc, para ocultar la identidad del agente; e) las declaraciones anónimas y f) las restricciones en la admisión de preguntas que puedan revelar la identidad del agente, incluida información sobre su trabajo, domicilio particular, situación de familia del agente, etc. 
Este proceder protegerá al agente de que se conozca su participación en operaciones encubiertas y, en consecuencia, funcionará indirectamente como forma de protección.

Por fin, llegamos a la conclusión de que los resultados de la investigación van a conducir al aseguramiento de fuentes de prueba valorables en el juicio oral siempre en función de su licitud ${ }^{1714}$. Conforme la obediencia a los parámetros constitucionales y procesales referentes al derecho probatorio y desde que la prueba aportada por el agente encubierto junto al juicio se encuentre corroborada por otras fuentes de demostración de la verdad de los hechos imputados, habrá que valorarse las informaciones y datos prestados por el infiltrado con vistas a esperarse una condena criminal de aquellas personas consideradas miembros de la organización criminal y que efectivamente tengan practicado delitos graves.

\section{VI.2. Un eterno dilema: las prohibiciones de la prueba en el proceso penal.}

\section{VI.2.1. Breves consideraciones sobre las prohibiciones probatorias.}

El problema de la incorporación de la información en el proceso penal plantea, a la luz de los principios que la rigen, el establecer los límites precisos entre aquella prueba que puede ingresar válidamente en el proceso y aquélla que no puede ser admitida. En otros términos, se afirma que hay ciertos hechos o el medio de obtenerlos que se sustraen del conocimiento de los tribunales puesto que su incorporación se realizó violando una ley o una garantía constitucional ${ }^{1715}$.

De lo dicho resulta que en un Estado de Derecho en el cual el fin del proceso penal consiste de forma irrenunciable ala protección de las garantías y libertades fundamentales de las personas en los procedimientos de búsqueda de la verdad, la obtención y el aseguramiento de la prueba se constituyen en un problema esencial toda vez que exige determinar qué pruebas son admisibles y cuáles son inadmisibles en el marco de un sistema de valores, principios y reglas en aras de que las decisiones restrictivas y de injerencia en la esfera de libertad de las personas sea legítima.

Así es que si se define la regla de exclusión probatoria como el mecanismo constitucional mediante el cual se excluye o no se admite en un proceso la prueba obtenida con violación de los derechos fundamentales, entonces ésta persigue garantizar la efectividad de los derechos fundamentales ${ }^{1716}$. Incluso se podría afirmar que en la regla

1714GÓMEZ DE LIAÑO FONSECA-HERRERO, M., Criminalidad organizada y medios extraordinarios de investigación, cit., pág. 231.

1715 Vid. ALVAREZ, A. E., "La prueba prohibida en el proceso penal", Revista de Ciencias Penales, número 4, Montevideo, 1999, pág. 7. Este mismo autor, trabaja con la clasificación de las prohibiciones probatorias en prohibición de adquisición de la prueba y prohibición de valoración de la prueba. La primera de ellas, implica limitaciones a la búsqueda de información y está dirigida a ordenar la actividad de investigación de los órganos del Estado. Ya la prohibición de valoración conlleva a la consecuencia de que la prueba obtenida por medios ilícitos no puede ser valorada para fundar una decisión en perjuicio del imputado. Cfr. "La prueba prohibida en el proceso penal", cit., págs. 10-11. Del mismo modo, observa JAUCHEN que "las garantías constitucionales imponen los límites al principio de la libertad probatoria". Vid. JAUCHEN, E. M., Tratado de la prueba en materia penal, cit., pág. 613.

1716 Asumiendo esta posición, véase BOLAÑOS ARIAS, C. A., "El debilitamiento de la regla de exclusión probatoria en el ordenamiento jurídico penal colombiano", Revista Electrónica de la Facultad de Derecho y Ciencias Políticas, núm. 1, 2009, pág. 7, http://www.revinut.udea.edu.co. 
de exclusión, antes que proteger derechos fundamentales, se erige una barrera para valorar la totalidad del material probatorio por parte del Juez ${ }^{1717}$.

Desde el planteamiento que aquí se sostiene surge la cuestión de las prohibiciones probatorias, donde el interés en una persecución penal eficiente se enfrenta hoy frecuentemente con los derechos y garantías del ciudadano individual ${ }^{1718}$. En este caso nos parece que sobre todo en la adquisición de la prueba debe hallarse un delicado equilibrio entre la necesidad del Estado a través de los órganos de persecución penal de descubrir la verdad y las garantías constitucionales que vengan a preservar derechos esenciales de las personas.

Uno de los primeros en tratar este tema desde el punto de vista de la prueba ha sido BELING quien, en 1903 publicó una obra precursora sobre la materia en la que acuñó por primera vez el término de "prohibiciones probatorias", expresión con la cual pretendía manifestar que existen limitaciones a la averiguación de la verdad dentro de la investigación en el proceso penal debido a intereses contrapuestos de índole colectiva e individual1719.

Respeto a estas limitaciones, se puede afirmar que en el proceso penal la búsqueda de la verdad está limitada además por el respeto a unas garantías que tienen incluso el carácter de derechos humanos reconocidos como tales en todos los textos constitucionales

${ }^{1717} \mathrm{Cfr}$. MONSALVE CORREA, S., "La prueba ilícita en el proceso penal colombiano a partir de la Constitución de 1991", Revista de la Facultad de Derecho y Ciencias Políticas, vol. 40, núm. 113, Medellín, 2010, pág. 372.

1718 En este sentido, Cfr. STRUENSEE, E., "La prueba prohibida", trad. Patricia Ziffer, Revista Peruana de Ciencias Penales, núm. 4, 1994, pág. 665. Respeto a las consideraciones históricas y generales en la doctrina de las prohibiciones probatorias, véase PÉREZ LUGO, M., "Algunos planteamientos sobre las prohibiciones de prueba en Alemania", Capítulo Criminológico, vol. 25, núm. 1, 1997, págs. 29-33.

1719 AMBOS, K., "Las prohibiciones de utilización de pruebas en el proceso penal alemán - fundamentación teórica y sistematización", Revista de Política Criminal, vol. 4, núm. 7, 2009, pág. 2, http://www.politicacriminal.cl/Vol_04/n_07/Vol4N7A1.pdf. Por eso BELING ha sido el primer autor europeo continental que ha tratado directamente el tema de las pruebas prohibidas y propuso una clasificación ordenada de las mismas de acuerdo con la legislación vigente entonces en Alemania, básicamente la StPO(Ley de Enjuiciamiento Criminal de 1877), con seis posibilidades, muchas de las cuales tienen vigencia en la actualidad. Sin embargo, hoy está necesidad de sistematización es todavía más acuciante, porque el mundo moderno está evolucionando desde hace unas décadas por culpa de la criminalidad actual, muy grave, muy tecnificada y de efectos devastadores, hacia planteamientos inimaginables, que exigen que ese campo de tensiones entre Democracia, Libertad y Seguridad, es decir, entre efectividad de la persecución penal por el Estado y respeto a los derechos constitucionales del acusado, que es el proceso penal, quedara mejor definido y dogmáticamente construido de forma tal que permitiera dar la solución práctica adecuada en cada momento. Era necesario entonces establecer un marco jurídico adecuado para esta problemática, a la que en general se ha llamado en la Europa continental "prueba prohibida", o "prueba ilícita", como referencia plástica directa a los límites de la investigación en el proceso penal. Y más, según este mismo autor "el fundamento de la existencia de la prueba prohibida resulta así, en una democracia que goza de un proceso penal propio de un Estado de Derecho, muy claro, puesto que es el propio Estado democrático el que, al consagrar un catálogo de derechos fundamentales en su Constitución, a los que otorga valor de inviolables y carácter preferente sobre todos los demás (art. 10.1 CE), está exigiendo que cualquier acto que vulnere alguno o algunos de esos derechos fundamentales carezca de eficacia probatoria en el proceso. Por eso valorar judicialmente en el proceso una prueba prohibida, significa llanamente que se están ignorando las garantías constitucionales sobre las que se sustenta el propio proceso, particularmente el proceso penal, es decir, que se está atacando directamente el derecho al proceso con todas las garantías del art. $24.2 \mathrm{CE}$, o principio del proceso debido o justo". Véase con más detalles, GÓMEZ COLOMER, J. L., "La prohibición de investigar la verdad a cualquier precio en el sistema adversarial (el caso español)", Conferencia pronunciada en el Congreso Internacional de Derecho Procesal Penal sobre "Evaluación y restos del sistema penal acusatorio: un debate sobre sus debilidades y perspectivas", organizado por la Universidad Sergio Arboleda los días 5 y 6 de octubre en Bogotá, 8 y 9 de octubre en Santa Marta, págs 4-5. http://www.usergioarboleda.edu.co/santamarta/institucional/escuelas/derecho/eventos/1e_congreso_penal /ponencias/prueba_prohibida_juangomez.pdf. 
y leyes procesales de todos los países de nuestra área cultural. Por todo ello, la afirmación de que el objeto del proceso penal es la búsqueda de la verdad material debe ser relativizada y, desde luego, se puede decir, sin temor a equivocarse, que en el Estado de Derecho en ningún caso se debe buscar la verdad a toda costa o a cualquier precio ${ }^{1720}$. Así, no todo es lícito en el descubrimiento de la verdad ${ }^{1721}$, del mismo modo que la búsqueda de la verdad no puede realizarse a costa de vulnerar derechos fundamentales ${ }^{1722}$. Y tiene que ser de este modo en razón de la existencia de límites impuestos a la preservación del Estado de Derecho, evitándose la violación innecesaria de derechos y garantías de aquellas personas sometidas a la persecución penal.

Esto sentado, lo que interesa es esclarecer que el descubrimiento de la verdad, vinculada a la realización de la justicia a través de la vía de la búsqueda, identificación y punición de los agentes del crimen, no podrá reclamar la utilización de las pruebas de algún modo relativo a él área problemática de las prohibiciones de la prueba ${ }^{1723}$.

Desde esta perspectiva, la obtención de la verdad que se requiere en un proceso no es un valor absoluto, sino que debe tener como base el respeto de la dignidad humana, de ahí la imposición de reglas que garanticen el respeto de las más elementales garantías y derechos del ser humano cuando se trate de buscar la tan apreciada verdad. Dicho en otras palabras, sobre todo en la adquisición de la prueba debe hallarse un delicado equilibrio entre la necesidad del Estado de descubrir la verdad y las garantías constitucionales que preserven derechos esenciales de las personas.

Frente a esta constatación se observa que en numerosos supuestos delictivos adquirirá una importancia indiscutible la investigación preprocesal que lleve a cabo la Policía Judicial o el Ministerio Fiscal en su caso, ya que estas actividades, constatadas en diligencias de prevención o preliminares, van a constituir el sustrato básico de la prueba de los hechos que se imputen al sometido al proceso penal. Y como ya hemos visto anteriormente, los actos de investigación no han de tener valor probatorio sino para determinar la procedencia o no de un juicio y, en aquellos casos en que existan injerencias en derechos fundamentales y libertades públicas debe existir un control judicial en su práctica, principalmente cuando el rendimiento probatorio puede resultar decisivo al valorar la actividad probatoria ${ }^{1724}$.

Téngase presente, además, que esta fase de investigación de los hechos delictivos ya ocurridos, o en aras de sucederse, acaba por encontrarse con el gran problema que afecta

1720 Cfr. MUÑOZ CONDE, F., "La búsqueda de la verdad en el proceso penal", Revista de Derecho y Proceso penal, núm. 1, 1999, pág. 95.

1721 ATS 3773 de 18 de junio de 1992.

1722STS 4784/1995, de 29.9.1995. Del mismo modo es cierto que "la obtención de la verdad no parece ser un valor con entidad suficiente para fundamentar o apoyar las excepciones a las reglas de exclusión ya que, aun cuando una prueba es excluida del proceso penal, este fin se satisface con el seguimiento riguroso del rito establecido para juzgar, y por lo tanto cuando se excluye una prueba ilícita lo que se hace es reafirmar la necesidad de llegar a una verdad o por lo menos de cierta verdad respetuosa del procedimiento prestablecido y de los derechos fundamentales". Véase MONSALVE CORREA, S., "La prueba ilícita en el proceso penal colombiano a partir de la Constitución de 1991", cit., pág. 372.

1723 Vid. COSTA ANDRADE, M., Sobre as proibições de prova em processo penal, Coimbra, 2006, pág. 81. En esta clásica obra, el citado autor fuertemente influenciado por la doctrina alemana, ha elaborado un estudio muy profundizado sobre la comprensión del concepto y del régimen general de las prohibiciones de la prueba.

1724 Véase al respecto, GARCÍA MUÑOZ, P. L., "La actividad policial con incidencia probatoria", cit., pág. 230. 
la comunidad internacional en este inicio de siglo: la expansión sin límites de la delincuencia organizada transnacional ${ }^{1725}$.

Delante de esta realidad, se agrava la tensión entre la seguridad colectiva y los derechos fundamentales del ciudadano ${ }^{1726}$, y como consecuencia se nota el incremento de forma avasalladora de una sociedad globalizada y marcada por situaciones de riesgos, donde el crimen organizado empieza a actuar en moldes verdaderamente empresariales y con notoria sofisticación 1727 y fuerte aparato logístico y estructural.

Todavía se hace imprescindible la adaptación de las técnicas de investigación a la clandestinidad y sinuosidad de estas formas más graves de delincuencia como el narcotráfico, el terrorismo y la delincuencia financiera ${ }^{1728}$.

La explicación a esta afirmación se debe al hecho de que la perpetración de los delitos, y cuanto más graves en un sentido más acusado, suele realizarse en condiciones que faciliten la impunidad de sus autores. Partiendo de esta realidad, no es menos cierto que la recopilación de material de investigación directo es tarea altamente laboriosa cuando no imposible de conseguir con éxito. Así, en muchas ocasiones lo que la Policía, el Ministerio Fiscal y, en su caso, el Juez de Instrucción obtienen se limita a la recogida de varios indicios de criminalidad salpicados de alguna que otra declaración testifical directamente probatoria, siendo las de esta clase muy difíciles de conseguir por el desasosiego, y hasta el miedo, que los testigos presenciales suelen experimentar frente a las posibles represalias de los criminales ${ }^{1729}$.

Esto nos pone en presencia de una interesante cuestión, o sea, las notorias dificultades enfrentadas por los órganos de persecución penal frente a la actuación de organizaciones criminales dotadas de una estructura altamente marcada por una logística

1725 Por esta razón señala ARMENTA DEU que "el aumento de la delincuencia organizada sofisticada y su creciente globalización convierte su persecución y castigo con las normas actuales es ciertamente difícil cuando no imposible, conduciendo a absoluciones indeseables". Cfr. ARMENTA DEU, La prueba ilícita (Un estudio comparado), Madrid, 2009, pág. 59.

1726 Corroborando esta afirmación, se puede destacar que "la confrontación dialéctica entre interés público y privado, cuyo tamiz o árbitro en cada caso, es el concreto proceso de que se trate, busca hallar nuevos y permanentes equilibrios que no quiebren, por ninguno de sus flancos o polos del tema: el garantismo y la evitación de la impunidad". Vid. URBANO CASTRILLO, E; TORRES MORATO, M. Á., La prueba ilícita penal. Estudio jurisprudencial, cit., pág. 67.

1727 De este modo, "esta sofisticación y profesionalización supone la proclamación como expertos en técnicas delictuales (como la supresión de la prueba), en técnicas jurídicas o económicas -que le permiten eludir la acción de la justicia-, médicas, informáticas. En definitiva, se convierten en verdaderos especialistas que se permiten delinquir con mayor facilidad y seguridad. Además, otro de los factores que influye en el crecimiento de las redes criminales es el uso de las nuevas tecnologías que ha supuesto para los entramados organizativos, presuntamente criminales, la gran expansión de sus acciones delictivas pues se les brinda más fácilmente la oportunidad de crear lazos de confraternización con otras organizaciones, que antes actuaban de forma aislada, que les permiten acaparar más actividades ilícitas, expandirse territorialmente y hacerse más fuertes ante las instituciones nacionales e internacionales. Estos avances tecnológicos servirán de igual forma para que los miembros de las organizaciones criminales eludan la acción de la justicia mediante lacreación de identidades virtuales que hacen imposible aprehender a los verdaderos culpables de los delitos". Cfr. ESPINOSA DE LOS MONTEROS, R. Z., "Las reglas de exclusión probatoria al hilo del desarrollo de la infiltración policial", cit., págs. 72-73.

${ }^{1728}$ En este contexto, el art. 20 de la Convención de Naciones Unidas contra la Delincuencia Transnacional Organizada (Convención de Palermo) de 2000 contiene una referencia a estas técnicas especiales de investigación, considerando como tales la entrega vigilada, la vigilancia electrónica o de otra índole y las operaciones encubiertas, así como su utilidad e idoneidad en la lucha contra la criminalidad organizada.

1729 Vid. VELAYOS MARTíNEZ, M. I., El testigo de referencia en el proceso penal, Valencia, 1998, pág. 21. 
empresarial1730. Sin embargo, algunas de las técnicas modernas y eficaces de investigación como el agente encubierto están limitadas por los principios penales sustantivos y procesales propios de un Estado de Derecho ${ }^{1731}$, bajo la premisa de que el Estado nunca podrá convertirse en partícipe incondicional de delitos.

Interesante también destacar que, por un lado, es indiscutible que la protección de los bienes jurídicos de los individuos y de la sociedad sólo puede ser garantizada frente a las formas modernas de criminalidad organizada con la ayuda de métodos encubiertos de investigación, y por otro que una prohibición indiscriminada de estas técnicas no puede ser considerada desde el punto de vista político criminal pero también son evidentes los inmensos peligros que para la libertad representa esta forma de lucha contra la criminalidad, y consecuentemente la necesidad de fijar legalmente sus presupuestos y de establecer los medios institucionales para evitar mal uso. Se trata, en definitiva, de analizar y valorar si el indudable interés en la mayor eficacia de la acción policial se concilia con el respecto de los principios del Estado de Derecho ${ }^{1732}$.

Nos parece que una armonía procesal penal, equilibrándose los vectores eficacia y garantías, daría una respuesta concreta y justa a toda la problemática anteriormente referida, donde la libertad probatoria sería la regla pero tendría que ser limitada por el impedimento del aporte de algunas pruebas obtenidas de forma contraria a los principios del Estado de Derecho.

En el moderno proceso penal, entendiendo por tal el característico del Estado de Derecho, es decir, el que consagra la presunción de inocencia del imputado y la garantía de sus derechos fundamentales frente al poder punitivo del Estado ${ }^{1733}$, el tema más característico y, al mismo tiempo, más complejo y difícil de precisar, por lo menos en relación con algunos casos controvertidos, es sin duda el de las llamadas prohibiciones probatorias ${ }^{1734}$.

1730 Desde ahí surge la idea recientemente consolidada por la jurisprudencia española en el sentido de que la desvirtuación de la presunción de inocencia exige prueba válida y lícita de suficiente contenido incriminador para ser prueba de cargo. Pero no tiene que ser necesariamente prueba directa, puesto que el derecho a la presunción de inocencia no se opone a que la convicción judicial en un proceso penal pueda tomarse sobre la base de una prueba de carácter indiciario; es decir, que como prueba objetiva de cargo se admite la llamada prueba de indicios, por la cual a partir de determinados hechos o datos base cabe racionalmente deducir la realidad del hecho consecuencia. Cfr. las STS 1468/2011 de 11.3.2011 y SAN 3887/2011.

1731 Esta idea adquiere especial relevancia según SUITA PÉREZ a partir de la constatación de que "la intervención de agentes infiltrados como un medio de investigación deberá estar muy acotada y rodeada de todas las garantías, habida cuenta que como entiende la doctrina más autorizada desde el inicio de la autorización se ponen en jaque derechos fundamentales de los ciudadanos y referentes al principio de legalidad". Cfr. SUITA PÉREZ, N., "La diligencia de investigación mediante la entrega vigilada", cit., pág. 257.

1732 PAZ RÚBIO, J. Ma et alli., La prueba en el proceso penal. Su práctica ante los tribunales, cit., pág. 385.

1733 Corroborando esta afirmación, quedaría muy claro que el marco constitucional de la actividad procesal probatoria está integrado, de una parte, por las exigencias de carácter general derivadas de los principios procesales constitucionalizados y, de otra, por exigencias de carácter más concreto, referidas, no tanto a la actividad probatoria en general, sino a determinadas diligencias de prueba, en la medida en que dichas diligencias pueden entrar en colisión con ciertos derechos fundamentales del inculpado. Vid. con detalles, VEGAS TORRES, J., Presunción de inocencia y prueba en el proceso penal, Madrid, 1993.

1734 Vid. MUÑOZ CONDE, F., "De la prohibición de autoincriminación al Derecho procesal penal del enemigo", VV.AA., Terrorismo y Estado de Derecho, J. R. Serrano Piedecasas y E. Demetrio Crespo coords., Madrid, 2010, pág. 107. 
Si todo lo anterior es correcto, entonces la prueba debe cumplir con ciertos requisitos para ser admitida en juicio. A saber, debe ser pertinente, idónea y, además, poseer relevancia en relación objetiva y subjetiva al hecho investigado y a sus autores ${ }^{1735}$.

En este punto nos cumple señalar que es incontestable que la libertad probatoria implica libertad de medios y de objeto de prueba, salvo, claro está, las expresamente prohibidas por la ley procesal penal, y también las que vienen a violar el orden jurídico establecido, el cual contiene las garantías procesales que han sido recepcionadas tanto en la Constitución como en los Tratados Internacionales.

Dicho en otras palabras, existe una regla general en el sentido de que en el proceso penal se permite probar de todo -principio de la libertad probatoria- y a priori por cualquier medio, salvo, por excepción, algunas hipótesis taxativas de prohibiciones determinadas por la ley1736.

VI.2.2. Las dificultades probatorias en materia de criminalidad organizada. La prueba penal obtenida en operaciones encubiertas.

No se discute en estos días sobre las dificultades de obtención de pruebas en casos relacionados con el fenómeno de la delincuencia organizada ${ }^{1737}$. Esto nos lleva a comprender que las manifestaciones de este fenómeno son mucho más complejas, en cuanto a su investigación y prueba, que cualquier otra modalidad delictiva, sobre todo cuando la actividad que se detecta en las actuaciones policiales y judiciales es embrionaria, sin haberse concretado, afortunadamente, en resultados catastróficos.

Las explicaciones a esta grave constatación son varias, y de este modo surge la necesidad de analizarse algunos puntos esenciales.

\footnotetext{
1735 Por esta razón, advierte ROXIN que "el esclarecimiento de hechos punibles no sujeto a límite alguno entrañaría el peligro de destruir muchos valores colectivos e individuales". Vid. ROXIN, C., Derecho procesal penal, cit., pág. 191. Siguiendo el mismo raciocinio, afirmar ARMENTA DEU que "no debe prevalecer el interés de protección y de castigo de las conductas infractoras si para ello se lesionan injustificadamente o desproporcionadamente los derechos (fundamentales o no sólo estos), comprendiendo aquí tanto los de contenido material (derecho a la inviolabilidad del domicilio y de las comunicaciones; a la integridad corporal, a la libertad) como los que determinan el carácter justo y equitativo del proceso (derecho de contradicción, derecho de defensa, derecho de asistencia letrada, derecho a utilizar los medios de prueba pertinentes)". Vid. ARMENTA DEU, La prueba ilícita (Un estudio comparado), cit., pág. 22.

1736 Como ha señalado GÁLVEZ MUÑOZ, "el sacrificio que impone la regla de exclusión no es, desde luego, en modo alguno despreciable, pero se entiende que el objetivo merece la pena: la tutela efectiva de los derechos fundamentales. La regla de exclusión supone, ciertamente, sacrificar la obtención de la verdad en el proceso, principio que tanta importancia tiene para el buen fin de la tarea de impartir justicia, pero es que la verdad no puede conseguirse a cualquier precio: al precio de sacrificar valores que se juzgan más importantes". Cfr. GÁLVEZ MUNÕZ, L., La ineficacia de la prueba obtenida con violación de derechos fundamentales, cit., pág. 61.
}

1737 Según nos cuenta HEFENDEHL, "los miembros de la organización criminal no sólo actúan en secreto sino que tratan de desaparecer las huellas del delito, lo que dificulta enormemente la investigación penal y la obtención de pruebas de cargo. Para destruir cualquier posible evidencia de sus ilícitos y evitar ser descubiertos emplean cualquier método por lesivo que sea, como amenazas, extorsiones, chantajes, secuestros, lesiones e incluso la muerte contra quienes puedan develar sus actividades". Vid. HEFENDEHL, R., "¿La criminalidad organizada como fundamento de un derecho penal del enemigo o de autor?", Derecho Penal y Criminología, Vol. 25, núm. 75, Bogotá, 2004, pág. 59. También destacando estas dificultades probatorias, opina BALTAZAR JR en el sentido de que "en el ámbito del crimen organizado ha acentuadas dificultades probatorias. La prueba en delitos de criminalidad organizada es fragmentaria, dispersa, semejante a un verdadero mosaico, montado a partir de varias fuentes diversas, para permitir llegarse a una conclusión, sea por la pluralidad de agentes, por la utilización de una estructura empresarial como órgano protector, por la jerarquía y compartimentación, sea por la adopción sistemática de otras rutinas de secreto y destrucción de las pruebas". Vid. BALTAZAR JR, J. P., Crime organizado e proibição de insuficiência, cit., págs. 169-170. 
En primer lugar, con relación a grupos organizados para la práctica de delitos, el entramado está preparado para proteger a los dirigentes de la organización, que son los que deciden, y a los cuales resulta altamente complicado acceder. Estos "cerebros de la organización" distribuyen los "roles" en función de las aptitudes de cada uno de los individuos, que se encuentran sometidos a una férrea jerarquía, disciplina y control interno ${ }^{1738}$.

Esto significa, sencillamente, que los grandes "capos" o jefes del grupo criminal son personas alejadas del entorno donde se practican concretamente los delitos, o sea, siempre buscan estar muy distantes de la parte operacional de la criminalidad, buscando con esta actitud no sersorprendidos por las autoridades de persecución.

Una investigación que se repute seria y marcada por la eficiencia en la persecución de delitos graves es aquélla que tiene por finalidad atacar todos los sectores que componen una específica organización criminal, fulminando desde los miembros "pequeños" del grupo hasta aquellos que se encuentran en el ápice de la estructura piramidal (jefes).

En segundo, estas organizaciones criminales poseen una multitud de medios a su disposición para tratar de hacer desaparecer las huellas de los delitos que se hayan podido cometer y, de esta manera, al destruir las posibles evidencias del ilícito generarán una dificultad extraordinaria tanto para llevar a cabo la investigación del delito como para que después, si fuese necesario por la apertura del juicio oral, pueda realizarse la prueba ${ }^{1739}$. A este modo particular de actuar se puede denominar de "cultura de la supresión de la prueba"1740.

La puesta en práctica de esta cultura de supresión de la prueba intenta de todas las formas, limpiar cualquier huella o rastro dejado después de la práctica del delito, destruyendo los primeros pasos de la investigación y perjudicando la obtención de la verdad de los hechos.

De este modo, como los delitos son cometidos de forma profesional y buscando el lucro, los delincuentes se preocupan anticipadamente en evitar su descubrimiento y en destruir o dificultar el acceso a las huellas o a las evidencias, amén de crear datos falsos, inventar coartadas, producir autores e inducir a falsas confesiones ${ }^{1741}$.

También en lo relativo a las dificultades de obtención de pruebas relativas al crimen organizado, NÚÑEZ PAZ y GUILLÉN LÓPEZ señalan que dentro de la realidad actual, en donde los criminales organizados ignoran la amenaza de la pena, cada vez mayor e insuficiente, uno de los mayores problemas que se presenta para los órganos de persecución penal es la comprobación de la autoría y participación de estos en la comisión de actividades vinculadas con el narcotráfico u otro delito de delincuencia organizada, fundamentalmente, por la distancia y espacio temporal entre órganos de ejecución directa

1738 Vid. GÓMEZ DE LIAÑO FONSECA-HERRERO, M., Criminalidad organizada y medios extraordinarios de investigación, cit., pág. 48.

1739 POZO PÉREZ. M. del, "El agente encubierto como medio de investigación de la delincuencia organizada en la Ley de Enjuiciamiento Criminal española", cit., pág. 274.

1740 Con más detalles, véase FAZZONE, E., "La valorización de la prueba en los procesos de criminalidad organizada", cit., pág. 419.

1741 Cfr. GIACOMOLLI, N. J., "A garantia do devido processo penal e a criminalidade organizada," Revista de Estudos Criminais, núm. 14, 2004, pág. 115. 
y el centro de decisiones ${ }^{1742}$. Y lo más grave es que con frecuencia los órganos de persecución penal se tropiezan con problemas para obtener pruebas que les permitan llegar hasta ese centro de poder, hasta el "hombre de atrás"1743.

De todo modo, resulta indudable que lo esencial para la supervivencia de la organización criminal es que ella impida el descubrimiento de los delitos que sus miembros practican y de la identidad misma de esos miembros, principalmente de los líderes del clan. Por esto, ella actúa en orden a evitar el hallazgo de fuentes de prueba de sus crímenes: haz con que desaparezcan los instrumentos utilizados para la práctica delictuosa y con que prevalezca la ley del silencio entre sus componentes; intimida testigos; busca por medio de tecnologías avanzadas los locales donde se encuentran sus miembros para evitar interceptaciones ambientales; usa teléfonos y móviles de modo a dificultar la interceptación, prefiriendo hablar por medio de dialectos o lenguas menos conocidas; etc. Así, los Estados se han visto en situación de crear mecanismos especiales para descubrir las fuentes de pruebas, de conservarlas y de permitir la producción diferenciada de la prueba para proteger víctimas, testigos, colaboradores, etcétera ${ }^{1744}$.

Otro factor de extrema importancia en lo relativo a las dificultades probatorias en materia de combate al crimen organizado se refiere al hecho absolutamente incontestable de que el poder de inversión financiera del Estado en términos de perfeccionamiento y estructuración de los órganos de persecución penal es muy inferior a las ganancias percibidas por algunos de los más destacados grupos de delincuentes organizados y aplicadas directamente en la mejora del poder logístico y profesional de estas verdaderas empresas creadas para la practica de delitos graves. Todo esto conduce también a la imperiosa necesidad de mejora de la capacitación a los miembros de los cuerpos policiales, con la finalidad de proporcionar un trabajo de excelencia en materia de seguridad de la colectividad ${ }^{1745}$.

En todo caso, no se puede dejar de mencionar que las reglas de valoración de la prueba para delitos practicados por la delincuencia organizada han de ser distintas de las que hay que aplicar en el enjuiciamiento penal del resto de las conductas delictivas recogidas en las normas penales. Mientras que un delito, por ejemplo un homicidio, es un delito instantáneo en que el Fiscal puede probar los elementos objetivos y subjetivos del tipo penal, donde el Derecho Penal ha establecido reglas muy estrictas para su valoración, en un delito cometido por un grupo organizado estamos en presencia de una actividad criminal que se extiende en el tiempo, que es a la vez un delito continuo -respecto de los

1742 Vid. NÚÑEZ PAZ, M. A.; GUILLÉN LÓPEZ, G., "Entrega vigilada agente encubierto y agente provocador. Análisis de los medios de investigación en materia de drogas", cit., pág. 95.

1743 Así lo piensa CHOCLÁN MONTALVO, J. A., La organización criminal. Tratamiento penal y procesal, cit., pág. 57.

1744 SCARANCE FERNANDES, A., "O equilíbrio entre a eficiência e o garantismo e o crime organizado", cit., pág. 245.

1745 Sobre esta constatación, destaca GÓMEZ COLOMER la necesidad de "reforzar la legalidad de la investigación del crimen de manera que todos los que intervengan en ella estén lo suficientemente formados y capacitados como para evitar para siempre esos fallos técnicos causantes de nulidades procesales y motivadores subsiguientes de absoluciones indeseadas. La idónea formación policial en estos temas jurídicos aparece en este sentido como la primera meta a alcanzar para retornar al garantismo. Con ello se contribuiría a demás y notablemente a preparar a ese instrumento necesario que es el proceso, para que sirviera mejor y con mayor efectividad en la lucha contra los más execrables delitos y sus despiadados autores". Cfr. GÓMEZ COLOMER, J. L., "Prueba prohibida e interpretación de la jurisprudencia del Tribunal Constitucional y del Tribunal Supremo españoles", Anuario de Derecho penal 2008: Temas penales en la jurisprudencia del Tribunal Constitucional, Lima, 2009, pág. 187. 
delitos-predicado- y un delito continuado - respecto al delito de delincuencia organizada. En consecuencia, el material probatorio ha de ser analizado y valorado en su conjunto ${ }^{1746 .}$

En estrecha relación con lo anterior, no se puede olvidar una vez más que el agente encubierto ha sido reglamentado en general como un funcionario público que fingiendo no serlo se infiltra por disposición judicial en una organización delictiva con el propósito de proporcionar desde el centro de la organización, informaciones que permitan el enjuiciamiento de sus integrantes y como consecuencia natural, el desbaratamiento de esa asociación ilícita. Y en este momento de la investigación deberán ser obtenidas informaciones y datos que puedan constituir en futuras pruebas que van a servir como fundamento para una condena penal de los participantes del grupo delictivo.

Cierto es que la cuestión de la validez de las pruebas obtenidas a través de una infiltración policial podrá ser analizada bajo dos orientaciones.

En principio, las pruebas obtenidas por el agente infiltrado o encubierto son válidas o lícitas desde que este no actúe de tal forma que se torne en un verdadero provocador, siendo crucial la obediencia al debido proceso legal y al principio de la dignidad de la persona humana, haciéndose necesario el control jurisdiccional de la respectiva técnica de investigación ${ }^{1747}$. A favor de esta solución se argumenta que la clave estaría en la aplicación concreta de la proporcionalidad en sus vertientes de necesidad, idoneidad y ponderación delante del caso concreto.

Esta observación es muy relevante pues el infiltrado que venga a incitar a terceras personas a la práctica de delitos deberá responder como agente provocador y tendrá su responsabilidad penal, civil y disciplinaria, analizada de forma correspondiente al grado de su contribución para el delito. Por lo tanto, en lo que concierne a la validez de la prueba obtenida en una operación encubierta es importante destacar que en España el Tribunal Supremo ha tenido la oportunidad de declarar que la actuación policial infiltrada no busca en sí misma ser fuente de prueba de los hechos -aunque nada impide que lo sea- sino proporcionar datos y elementos de convicción para desarticular la organización criminal, siendo tales datos y elementos los que, a la postre, conforman la convicción judicial. En este caso concreto, se trataba del hallazgo mediante registros de vehículos, registros domiciliarios y cacheos y ocupaciones personales de toda una serie de palpables pruebas de la implicación de los acusados (la existencia del propio laboratorio, la incautación de una ingente cantidad de droga, dinero, coches, útiles de transformación, encuentros y contactos para el desarrollo de la actividad criminal, conversaciones telefónicas, etc.). Esos elementos de convicción se obtuvieron a través de las informaciones que iba proporcionando el agente infiltrado ${ }^{1748}$.

De modo contrario, en una segunda posición se podría sostener que la información que obtengan los agentes infiltrados respecto del grupo organizado de delincuentes difícilmente podrá ser utilizada como fuente fundamentadora de una sentencia condenatoria a los integrantes de una organización criminal pues aquélla será obligatoriamente obtenida por ellos en base a un engaño, ya que de otra manera los

\footnotetext{
1746 Vid. BUSCAGLIA, E et alli, "Delincuencia organizada y derechos humanos: ¿Cómo controlar el uso de las técnicas modernas de investigación? El caso de las intervenciones de comunicaciones privadas", cit., pág. 41.

1747 En este sentido vid. KNIJNIK, D., A prova nos Juízos Cível, Penal e Tributário, Rio de Janeiro, 2007, págs. 117 y ss.

1748 Vid. con detalles, la STS 7.815/2007, de 15.11.2007.
} 
delincuentes jamás iban a revelar datos e informaciones a los infiltrados. Se ignora, por lo tanto la posibilidad de aprovechamiento de los fundamentos del principio de proporcionalidad.

Nos parece que esta segunda posición está dotada de un excesivo rigorismo, a la vez que desde que son respetados ciertos límites de actuación de estos agentes el trabajo de infiltración puede ser considerado conducente a la salvaguarda de cadenas delictivas de difícil aprehensión ${ }^{1749}$. Así, deberá ser aceptada la idea de poder utilizar algunos medios extraordinarios de prueba, entre ellos los agentes encubiertos, con carácter excepcional, cuando los mismos resulten indispensables para superar dificultades insalvables por los medios ordinarios en la investigación de graves delitos y siempre que sus actuaciones y el valor de sus informaciones se enmarquen en una rígida legalidad, respetuosa de los derechos fundamentales de los ciudadanos ${ }^{1750}$.

El infiltrarse en una organización delictiva significa penetrar en ésta, volverse un integrante más de ella. Para los efectos procesales, se trata de obtener información desde dentro, percibir un mayor número de hechos o sucesos, acceder a partícipes de mayor jerarquía dentro del grupo, etc. Todas estas características lo hace un testigo de gran importancia, pues con la información obtenida y vertida en juicio puede obtener resultados condenatorios para un mayor número de partícipes criminales y, a su vez, luchar de modo más eficaz contra la organización criminal respectiva ${ }^{1751 .}$

Volviendo al tema de la posibilidad de que el agente infiltrado figure como testigo en el proceso penal1752, y sin perjuicio del análisis que ya hemos hecho anteriormente, se puede considerar que en este aspecto habrá que considerar que aunque la gran mayoría de las legislaciones no se manifieste sobre esta posibilidad, la permisibilidad para que el agente encubierto pueda comparecer como testigo en juicio con relación a las acciones y situaciones que ha presenciado es una realidad incontestable ${ }^{1753}$.

${ }^{1749}$ En este sentido, ARMENTA DEU sostiene la posibilidad de actuación del agente encubierto, incluso con la limitación de derechos fundamentales, desde que obedecidos los siguientes presupuestos: " 1) previsión normativa (principio de legalidad formal y material); 2) adoptarse en el marco de un proceso, es decir, jurisdiccionalidad; 3) necesidad cualificada de motivación; 4) estar sujeta al principio de proporcionalidad "strictosensu"; y 5) ejecución y control judicial de la medida. Y en el plano más concreto, las diversas regulaciones limitan más o menos cada uno o determinados aspectos de un presupuesto en concreto, en atención a circunstancias sociales, políticas o de simple directrices de política criminal en atención a circunstancias sociales, políticas o de simple directrices de política criminal". Con más detalles, Cfr. ARMENTA DEU, T., "Exclusionary rule: convergencias y divergencias entre Europa y América", cit., págs. 90-92.

1750 CAFFERATA NORES, J. I., "La desnaturalización bélica del proceso penal y los medios extraordinarios de investigación", Cuaderno núm. 2, Departamento de Derecho Procesal Penal y práctica profesional de la Facultad de Derecho y Ciencias Sociales de la Universidad Nacional de Córdoba, 1997, pág. 11.

1751 DAGDUG KALIFE, A., La prueba testimonial ante la delincuencia organizada, cit., págs. 319-320.

1752 Para un proficuo estudio en carácter general, respecto al tema de la prueba a través de testigos, vid. RIVES SEVA, A. P., La prueba de testigos en la jurisprudencia penal, Madrid, 2003.

1753 De se destacar que en España, el Tribunal Supremo antes mismo de reglamentación de la figura del agente encubierto en la LECrim, a través del artículo 282 bis, mismo con fundamentos poco cercanos a la realidad actual de este medio de investigación criminal, había se pronunciado en el sentido de la validez de esta técnica de investigación, dándole el tratamiento de la prueba testifical. Así, la STS 818/1995, de 14.2.1995, ha dictado que "el infiltrado es, en calidad de testigo, otro factor importante a la hora de constituir la prueba. $\mathrm{Si}$ el arrepentido está en conexión con la figura del coimputado, el infiltrado, que a diferencia del anterior no es parte en el proceso, es un testigo evidentemente relevante que ha de ser relacionado con la figura del agente provocador. La credibilidad de sus manifestaciones, con menos complicaciones que el arrepentido, corresponde también a la íntima convicción de los jueces. El infiltrado no está dentro del proceso porque es un testigo cualificado que a su vez puede ser, o no, provocador de la infracción, que a su vez puede ser, o no, miembro de las fuerzas de seguridad. La actuación del infiltrado en la mecánica delictiva se basa en el ya casi 
Una regla al menos es incontestable: cuando los componentes de la Policía y en general, de los Cuerpos de Seguridad, comparecen ante el Tribunal sentenciador y declaran sobre lo que oyeron, vieron o percibieron, su testimonio alcanza la condición de prueba testifical ${ }^{1754}$.

En este mismo sentido, los artículos 297 y 717 de la LECrim otorgan a las declaraciones, respecto a hechos de conocimiento propio de autoridades y funcionarios policiales, el valor de declaraciones testificales, apreciables según el criterio racional. De todo modo, desde una perspectiva jurisprudencial, vale decir que el testimonio de los agentes de policía que ratificaron en el plenario su declaración incriminatorias de haber visto los actos ilícitos realizados por la parte acusada es apto para enervar la presunción de inocencia ${ }^{1755}$.

Efectivamente, a los efectos que ahora nos interesa tratar, es importante poner de manifiesto que el agente encubierto a nivel procesal disfruta de idénticas cautelas que los testigos y peritos protegidos ${ }^{1756}$.

Y más que esto. Nada impide la valoración completa de sus declaraciones; muy al contrario, todo conlleva a esta providencia, a la vez que su testimonio será de gran importancia para conocer a fondo todas las actividades y la estructura logística de la organización criminal, una vez que él mismo habrá convivido dentro de la organización. Estará, pues, en condiciones de exponer al juzgador todo lo que ha presenciado en el interior del clan criminal y, además, podrá detallar el modus operandi utilizado para la práctica de las conductas graves.

En realidad, el agente encubierto podrá y deberá indicar otros elementos de prueba a la justicia penalde forma que con ellos se fortalezca su testimonio en juicio.Como consecuencia, pruebas documentales, películas, fotografías, grabaciones y otras formas de prueba admitidas jurídicamente han de servir para dar soporte a las declaraciones que vengan a ser prestadas por el infiltrado respecto a la organización criminal. Estos datos

agotado espíritu de colaboración ciudadana por el que se constituyen métodos de averiguación del delito y de su autor; distintos de los habituales históricamente". Además, esta misma sentencia acaba por dispensar a la figura del infiltrado un tratamiento procesal, como prueba testifical, similar a del confidente, al afirmar que "el infiltrado, que actúa también durante el delito aun cuando no forma parte de él, se confunde con el delator cuando éste no es más que el denunciador o acusador, que por supuesto no tiene que ser anónimo. El infiltrado es más bien un confidente introducido en el ambiente delictivo que se está investigando. Es como el colaborador judicial que ahora se trata de imponer legamente aun cuando no exista una concreta regulación legal de tal figura, lo que no deja de ser lógico en tanto que el infiltrado no es ni siquiera presunto delincuente, sólo un medio de prueba, posible provocador, que como tal ha se ser considerado".

1754 En este sentido, la opinión de RIVES SEVA, A. P., La prueba de testigos en la jurisprudencia penal, cit., pág. 38. Del mismo modo ha sido reconocido por la jurisprudencia en España, vid. SSTS 5435/1992, de 3.6.1992; 1902/1996, de 6.3.1996; 6713/1997, de 15.9.1997, etc.

1755 Vid. STS 1227/2006, 15.12.2006.

1756 Vid. en España, el artículo 282 bis 2 de la LECrim. Sin embargo, los funcionarios de la Policía Judicial que han participado de una investigación criminal como agentes encubiertos pueden mantener en el eventual proceso judicial posterior, su identidad supuesta. En este sentido, vid. RODRÍGUEZ FERNÁNDEZ, R., "El agente encubierto y la entrega vigilada", cit., pág. 101. De observarse también que en Portugal, de acuerdo con el artículo 4o, 3 y 4 de Ley 101/2001, el infiltrado podrá figurar como testigo respecto a los hechos apurados durante la operación encubierta de que tenga participado. En este sentido, es prevista la posibilidad de que el agente encubierto que ha actuado bajo una identidad ficticia o supuesta, pueda mediante la autorización de la autoridad judicial competente, prestar su testigo en el respectivo proceso. En este sentido PINTO DE ALBUQUERQUE entiende que "el agente infiltrado, relativamente aquello que ha presenciado durante la acción encubierta, puede testificar sin cualquier restricción, desde que su acción tenga sido realizada en obediencia al dispuesto en la Ley no. 101/2001". Vid. PINTO DE ALBUQUERQUE, P., Comentário do Código de Processo Penal, Lisboa, 2007, pág. 902. 
son absolutamente valiosos y servirán para demostrar el grado de profesionalidad y sofisticación empleados por los destacados grupos de delincuentes organizados de actuación transnacional.

Por fin, cuestión especialmente sensible se refiere al siguiente interrogante: ¿podría el agente encubierto realizar una operación de compra o adquisición de droga para conseguir la prueba de la dedicación al narcotráfico?

En opinión de MAGRO SERVET, se elimina de las posibilidades operativas de actuación del agente encubierto las que consistan en una excitación, incitación, invitación, provocación o proposición para delinquir, o que sea el agente quien venda la mercancía. Se admiten, sin embargo, los de compra o adquisición y así, la STS de 8.2.1991, declara no haber existido delito provocado en una operación en la que funcionarios de policía, fingiéndose supuestos compradores se ponen en contacto con los delincuentes aparentando su interés en adquirir 500 gramos de heroína y cuando los delincuentes muestran las bolsas conteniendo la sustancia y los supuestos compradores comprueban las características de la heroína, proceden a su detención. Así, se considera que los agentes encubiertos no cometieron delito provocado; es decir, no se originó la comisión del delito, sino la salida a la luz del ya consumado ${ }^{1757}$.

A favor de esta solución es preciso en todo caso hacer la siguiente aclaración: la actuación del infiltrado en el entramado criminal, adquiriendo la droga como forma de descubrir las personas responsables por esta actividad delictiva de venda, desde que proporcional a los fines de la investigación, especialmente delante de la obediencia a los criterios de necesidad e idoneidad de la conducta, servirán como matiz de la ponderación de los bienes jurídicos en conflicto e indicarán si la operación encubierta ha sido exenta de responsabilidad penal o de otra orden al funcionario estatal, amén de poderse considerar la prueba obtenida apta a los fines de valoración probatoria.

VI.2.3. Los descubrimientos fortuitos o los hallazgos casuales del agente infiltrado.

En este momento de la investigación conviene hacer mención de manera individualizada la cuestión de los hallazgos casuales. El tema que se plantea se refiere a la posibilidad de que aparezcan en el marco de la investigación otros delitos diferentes de aquéllos sobre los cuales se concedió la autorización para la infiltración policial.

Es posible que el agente infiltrado, en el desarrollo de su investigación, tenga conocimiento de nuevos hechos delictivos o imputados distintos de los previstos en la autorización de la infiltración. Surge a este respeto la obligación del agente de poner en conocimiento de la autoridad penal competente los datos obtenidos. Sin embargo, a la hora de proceder a investigar estos hallazgos, y de verificar la validez probatoria de las informaciones obtenidas, se deben observar algunas variables relevantes, como la conexión entre los delitos, la actuación de delincuencia organizada y la inclusión de los mismos en el listado de delitos autorizados ${ }^{1758}$.

1757 MAGRO SERVET, V., Manual práctico de actuación policial-judicial en medidas de limitación de derechos fundamentales, cit., pág. 188.

1758 Vid., con más detalles, CORRÊA DE CARVALHO, J. T., Tráfico de drogas: Prueba penal y medidas restrictivas de derechos fundamentales, cit., pág. 366. 
Se trata de modo general del tema de los "hallazgos fortuitos" o de los "descubrimientos ocasionales". Así es que en el desarrollo de la investigación el agente puede adquirir de manera fortuita conocimiento sobre la comisión de nuevos hechos delictivos y nuevos imputados, no comprendidos en el ámbito de la autorización, o lo que es lo mismo, no buscados por ser desconocidos ${ }^{1759}$.

Surgiría la duda respeto de cómo valorar la posibilidad de una extensión automática de la resolución judicial frente al aparecimiento de nuevas informaciones y datos relativos a otros temas o personas diversas de aquellas expuestas anteriormente al Juez, y que fueron objeto de autorización para la investigación concreta de una organización criminal 1760 .

Nos parece, sin que quepa ninguna duda, que en este caso se deberá solicitar una extensión de la autorización ${ }^{1761 .}$

Por lo que respecta a los innegables descubrimientos casuales generados en estas investigaciones, conviene diferenciar entre el hallazgo fortuito de circunstancias objetivas excluidas o incluidas en la ley. Más en concreto, para solventar los problemas de los hallazgos casuales acaecidos en el marco de una entrada y registro o una intervención telefónica la jurisprudencia ha utilizado el criterio de la conexión entre el ilícito descubierto ocasionalmente y el delito objeto del proceso donde se obtiene dicho descubrimiento, sin posibilidad de trasladar las respuestas proporcionadas por el Derecho alemán. En el caso del agente encubierto, la situación es frontalmente opuesta ${ }^{1762}$.

Según DELGADO MARTÍN, cuando el agente encubierto, durante el desarrollo de la investigación para la que se encuentra autorizado, descubre la existencia de hechos delictivos nuevos que no están amparados por la resolución judicial habilitante, nos hallamos ante los denominados hallazgos o descubrimientos ocasionales o casuales. La autorización judicial tiene su ámbito propio, sin que el agente encubierto pueda extender su actuación a cualquier delito del que tenga conocimiento durante su infiltración en un grupo de delincuencia organizada ${ }^{1763 .}$

En síntesis y como resumen de todo lo expuesto sobre esta problemática, concluimos afirmando que la admisión del uso de los elementos probatorios logrados por el agente en otro proceso favorece, dadas las interrelaciones entre organizaciones, que una

1759Vid. GÓMEZ DE LIAÑO FONSECA-HERRERO, M., "El agente encubierto como medio de investigación del terrorismo en el contexto internacional", cit., pág. 430.

1760 Es también significativo, a nuestro juicio, el argumento de que la extensión automática de la resolución judicial violaría de modo muy especial el principio de especialidad que debe permear la actuación del agente encubierto. Dicho en otras palabras, lo que se quiere decir es que la información recolectada solamente podrá ser usada para probar la acusación que fue materia de la investigación. Excepcionalmente podrá ser utilizada para el esclarecimiento de otros delitos, desde que exista una valoración del Juez con fundamento en la proporcionalidad. Con esta consideración, se quiere evitar que el agente infiltrado venga a laborar de forma semejante a la figura de los undercovers del Derecho norteamericano.

1761 También adoptando este pensamiento, véase SUITA PÉREZ, N., "La diligencia de investigación por medio del agente encubierto", cit., pág. 255. Y la razón es que cuando el infiltrado ha sido autorizado a ingresar en la organización criminal se utilizando de una identidad supuesta, ya debería constar de la resolución el objetivo específico para la operación, evitándose con esto el uso abusivo y sin límites de la autorización judicial.

1762 GÓMEZ DE LIAÑO FONSECA-HERRERO, M., "Infiltración policial y proceso penal", cit., págs. 219-220.

1763 DELGAdo MARTíN, J., Criminalidad Organizada, cit., pág. 69. Sobre el tema, la STS 1424/1993, de 18.6.1993, estima que la autorización de una intervención telefónica no puede transformarse en una especie de persecución del comportamiento genérico de una o varias personas a través de las conversaciones telefónicas, lo cual es totalmente inaceptable. 
sola infiltración genere un sin fín de elementos probatorios, y al tiempo supone una merma de las garantías exigibles en la limitación de derechos. De un lado, porque el Juez de Instrucción tuvo la oportunidad de autorizar una infiltración y, si no lo hizo, pudo ser debido a la ausencia de la debida proporcionalidad. De otro, porque tendría lugar un quebranto del derecho de defensa al no poder rebatir las partes el control de la legitimidad de la medida del agente encubierto en atención a su causa concreta ${ }^{1764}$.

Nos parece que la teoría de la ponderación de intereses viene dar respuesta a los problemas relativos a los casos de los conocimientos casuales o fortuitos. Este asunto debe, a nuestro modo de pensar, ser analizado en una perspectiva de estudio conjunto del fin de la protección de la garantía de no admisibilidad de la prueba, de la ausencia de dolo en la violación y de la ponderación de los intereses en colisión ${ }^{1765}$.

Se quiere decir con esto que por regla general estos descubrimientos casuales, obtenidas de forma imprevista y sin una autorización específica de la autoridad competente para que sean investigadas, deberán ser objeto de nueva resolución autorizante, como forma de evitarse eventuales vicios en la producción de la prueba en juicio.

Sin embargo, como toda regla presenta excepciones, sostenemos que en situaciones sui generis, esto es, dotadas del carácter de excepcionalidad y siempre fundamentadas en el principio de proporcionalidad, sería posible la existencia de hallazgos o descubrimientos ocasionales o casuales en situaciones que no necesitaran de una autorización judicial ${ }^{1766}$, hipótesis en la cual el descubrimiento podrá ser válido y no se generarán los problemas típicos del descubrimiento casual en sentido estricto. Imagínese, por ejemplo, el caso concreto donde una camera de vigilancia de seguridad de un edificio comercial venga a captar casualmente un delito practicado en la calle. En este caso, se puede utilizarse la prueba en el proceso penal contra el autor del crimen, sin necesidad de que tenga sido autorizada la grabación.

\section{VI.2.4. El agente encubierto y la prueba ilícita.}

VI.2.4.1. Puntos de partida para la comprensión de la teoría de la prueba ilícita.

De nuevo destacamos que la búsqueda de la verdad en una sociedad democrática nunca puede justificar o legitimar cualquier método para desvelarla, o sea, no se puede obtener la verdad real a cualquier precio, pues no todo es lícito en el descubrimiento de la

1764 Cfr. GÓMEZ DE LIAÑO FONSECA-HERRERO, M., "El agente encubierto como medio de investigación del terrorismo en el contexto internacional", cit., págs. 432-433.

1765 Esto significa, sencillamente, que "en el supuesto de una colisión de principios y, más concretamente, de derechos fundamentales, prevalecerá uno u otro en función de las circunstancias. Lo cual se deriva del hecho de que no existen derechos absolutos, que siempre prevalezcan sobre otros, sino que en cada caso de colisión habrá que llevarse a cabo una ponderación de los derechos en juego para determinar cuál de ellos, teniendo en cuenta las circunstancias del caso, prevalecerá en ese caso concreto". Vid. RUIZ RUIZ, R., "La ponderación en la resolución de colisiones de derechos fundamentales. Especial referencia a la jurisprudencia constitucional española", Revista Telemática de Filosofía del Derecho, núm. 10, 2006/2007, págs. 62-63.

1766 Sobre esta cuestión, DÍAZ CABIABLE y MARTÍN MORALES afirman que "también se debe observar que la utilización de un hallazgo casual como fuente de prueba no supone una ruptura de un derecho fundamental cuando existe una orden autorizante homogénea con el objeto descubierto. Sólo cuando se trate de hechos que no guarden conexión con la investigación autorizada podría surgir algún problema". Véase, DÍAZ CABIABLE, J. A; MARTÍN MORALES, R., La garantía constitucional de la inadmisión de la prueba ilícitamente obtenida, Madrid, 2001, pág. 177. 
verdad1767. La prueba penal deberá entonces ser obtenida e incorporada al proceso siempre con respeto a los principios del Estado de Derecho ${ }^{1768 .}$

Es preferible que en caso de duda en cuanto a eventuales violaciones innecesarias y sin proporción a los derechos fundamentales de las personas sometidas a la persecutio criminis, que se haga la opción por la aplicación del principio de exclusión de la prueba.

Surge como consecuencia de lo anteriormente planteado la cuestión de la ineficacia de la prueba obtenida con violación de derechos fundamentales ${ }^{1769}$. En este aspecto concreto, constatada la no admisibilidad de las pruebas obtenidas con violación de derechos fundamentales, su recepción procesal implica una ignorancia de las garantías propias al proceso, implicando también una inaceptable confirmación institucional de la desigualdad entre las partes en el juicio, desigualdad que se ha procurado antijurídicamente en su provecho quien ha recabado instrumentos probatorios en desprecio a los derechos fundamentales de otro ${ }^{1770}$.

Este nos parece ser el entendimiento que deberá prevalecer delante de la búsqueda por la afirmación de un Derecho Procesal penal garantista especialmente direccionado a la prevalencia de los derechos fundamentales de los ciudadanos.

En efecto, la problemática de la incorporación de la información en el proceso penal plantea, a la luz de los principios que la rigen, el tener que establecer los límites precisos entre aquella prueba que puede ingresar válidamente y aquélla que no puede ser admitida en razón de vicios insanables. En otros términos, hay ciertos hechos o el medio de obtenerlos que se sustraen del conocimiento de los tribunales, puesto que su incorporación se realizó violando una ley o una garantía constitucional1771.

Parece evidente que superadas antiguas concepciones, llevadas a la práctica durante siglos y que propiciaban la búsqueda de la verdad a todo costo, la investigación de la verdad en el actual proceso penal no es un valor absoluto sino que se halla limitada por los valores éticos y jurídicos del Estado de Derecho ${ }^{1772}$.

Justificando este contexto, surge el tema de la prueba ilícitamente obtenida y sus importantes consecuencias en el proceso penal ${ }^{1773}$.

1767 Vid. ATS 3773/1992 de 18.6.1992 y STS 4784/1995, de 29.9.1995.

1768 Siguiendo esta orientación, señala CAFFERATA NORES que "la legalidad del elemento de prueba será presupuesto indispensable para su utilización en abono de un convencimiento judicial válido. Su posible ilegalidad podrá obedecer a dos motivos: su irregular obtención o su irregular incorporación al proceso". Vid. CAFFERATA NORES, J. I., La prueba en el proceso penal, cit., pág. 18.

${ }^{1769}$ Para un completo estudio jurisprudencial respecto a este tema, Cfr. GÁLVEZ MUÑOZ, L., La ineficacia de la prueba obtenida con violación de derechos fundamentales. Normas y jurisprudencia (TEDH, TC, TS, TSJ y AP) en los ámbitos penal, civil, contencioso administrativo y social, Navarra, 2003. También, URBANO CASTRILLO, E; TORRES MORATO, M. Á., La prueba ilícita penal. Estudio jurisprudencial, Navarra, 2003.

1770 Cfr. la STC 114/1984, de 29.11.1984.

1771 De este modo, la absoluta invalidad de la prueba ilícita infirma claramente la eficacia demostrativa de los hechos cuya realidad material ella pretende evidenciar. Se trata de la consecuencia que deriva necesariamente de la garantía constitucional que tutela la situación jurídica de los imputados en el juicio penal y que va a excluir la posibilidad de la utilización procesal de la prueba cuya ilicitud venga a ser reconocida por la autoridad judicial. Y es así en razón de que la prueba ilícita es prueba sin idoneidad, por lo tanto sin el valor que debería prestar a la formación de la convicción del juzgador. Más que esto, no se puede decir que esta prueba presente las cualidades para su incorporación al proceso frente a la ausencia de eficacia jurídica.

1772 Cfr. URBANO CASTRILLO, E; TORRES MORATO, M. Á., La prueba ilícita penal. Estudio jurisprudencial, cit., pág. 33.

1773 De este modo, nos resta demostrar que "el ámbito natural de la regla de exclusión es, desde luego, el proceso penal. Aquí se pone de relieve como en ningún otro lugar, la necesidad de tutelar los derechos 
La cuestión es, como es lógico, susceptible de distintos enfoques y perspectivas, pero, según GÁLVEZ MUÑOZ, la forma más adecuada de abordarla consiste en tomar como punto de partida el conflicto de intereses que plantea la obtención de pruebas con vulneración de derechos fundamentales y la posibilidad de utilizarlas o no en el proceso, para pasar después a examinar la ponderación de intereses en que se apoyan los formuladores de la regla de exclusión ${ }^{1774}$.

Esta regla se revela como un método representativo de una correcta búsqueda de la más adecuada forma de incorporación de un elemento de prueba al proceso, con vistas a la obtención de la verdad real1775. Desde ahí que el interés en una persecución penal eficiente se enfrenta hoy frecuentemente con los derechos del ciudadano individual. Nos referimos a la tensión existente entre la perspectiva instrumental punitiva y la perspectiva instrumental garantista.

Con relación a este conflicto incide directamente el tema de las prohibiciones probatorias ${ }^{1776}$.

En estrecha relación con lo anterior, parece evidente que delante de la criminalidad pos moderna, especialmente aquélla que actúa en clave empresarial, con uso de la sofisticación y utilizando la violencia para la obtención de sus objetivos, el Estado necesita de un refinamiento del instrumental persecutorio el cual no interfiera en la protección de las garantías tradicionales y de la eficiencia delante de las nuevas demandas, so pena de no hacerse frente al imperativo de protección de la dignidad del hombre en el siglo XXI. Esta perspectiva también impone una nueva discusión sobre los criterios políticos criminales de incentivo a la formación de la verdad con el respecto a las garantías mínimas de eticidad del proceso.

Respeto a la prueba considerada ilícita, la variabilidad del concepto y la configuración de esta especie de prueba efectivamente tienen mucho que ver con la tensión entre la tutela de bienes esenciales para la sociedad a través del proceso penal y las garantías exigidas, bien para limitar los derechos fundamentales, bien para adoptar medidas necesarias para alcanzar aquellos fines ${ }^{1777}$.Así, delante de este cuadro de tensiones sensibles inherentes al proceso penal surge el problema de la no admisibilidad de las pruebas ilícitas como expresión de una colisión entre la protección de los derechos fundamentales contra la arbitrariedad de la persecución penal, pero también del peligro de una ineficiencia que la hipertrofia de las garantías puede proporcionar ${ }^{1778}$. Una vez más, llamamos la atención sobre los perjuicios que podrán surgir ante una eventual y abusiva

fundamentales de los ciudadanos por encima de la obtención de la verdad procesal". Vid. GÁLVEZ MUNÕZ, L., La ineficacia de la prueba obtenida con violación de derechos fundamentales, cit., pág. 65.

${ }^{1774}$ En esta sentido, GÁLVEZ MUNÕZ, L., La ineficacia de la prueba obtenida con violación de derechos fundamentales, cit., pág. 53.

1775 Así el Juez deberá tener en cuenta las reglas de la experiencia y de la sana crítica, dado que será preciso examinar la presencia o no de un nexo causal entre una prueba y otra, al igual que entrar a ponderar entre diversos factores, tales como los derechos fundamentales del procesado, aquellos de las víctimas y terceros, al igual que el cumplimiento estatal de investigar y sancionar efectivamente el delito.

1776 Vid. STRUENSEE, E., "La prueba prohibida", Revista Peruana de Ciencias Penales, núm. 4, 1994, pág. 665.

1777Véase al respeto, ARMENTA DEU, La prueba ilícita (Un estudio comparado), cit., pág. 58. Siguiendo esta perspectiva, es notoria la idea de que no se consigue proteger un derecho fundamental suprimiendo otro derecho fundamental pues el problema de las pruebas ilícitas no puede ser analizado en el plan meramente procesal, muy al contrario, pero como garantía de respeto a derechos fundamentales cuya protección originase de la normativa constitucional.

1778 PIEROBOM DE ÁVILA, T. A., Provas ilícitas e proporcionalidade, cit., págs. 69-70. 
instrumentalización de las garantías, situación donde estas últimas vendrán a servir como barrera infranqueable ala eficiencia procesal.

Sin embargo, lo más importante en este momento es dejar claro que el problema de las pruebas ilícitas ha sido tratado en el Derecho comparado de diversas maneras; eso sí, siempre conservando un núcleo común entre los diversos sistemas ${ }^{1779}$.

En España, por ejemplo, el Tribunal Constitucional ha creado la tesis de la conexión de antijuridicidad con el fin de justificar las excepciones a la regla de exclusión de las pruebas ilícitas. Así, una prueba se deberá excluir del proceso sólo cuando exista una relación de causalidad y una conexión de antijuridicidad entre la lesión y las pruebas. Para determinar cuándo no hay conexión de antijuridicidad deberán concurrir dos factores: primero, que la prueba derivada hubiera podido obtenerse normalmente por medios independientes a la lesión -perspectiva interna-; segundo, que no sea muy necesaria una contundente protección del derecho fundamental afectado por la ilicitud -perspectiva externa-. Para este último factor es necesario, ineludiblemente, recurrir a un juicio de ponderación entre ciertos intereses públicos y los derechos fundamentales de las personas ${ }^{1780}$.

\section{VI.2.4.2. En busca de un concepto para la prueba ilícita}

Es algo común afirmarse que se entiende por prueba ilícita aquella que es contraria a la dignidad humana, que vulnera derechos fundamentales o que interfiere con determinados preceptos constitucionales ${ }^{1781}$. Así, el ilícito está referido a lo que es obtenido de forma ilegal, como acontece en el caso de la prueba que ofende el Derecho material y, del mismo modo, lo que viene a ser captado de modo ilegítimo como en la hipótesis de la introducción en el proceso de una prueba que ha sido indebidamente agregada a los autos.

\footnotetext{
${ }^{1779}$ Así en Inglaterra se aplica un modelo de exclusionary rule que incluye, además de la prueba ilícitamente obtenida, la prueba del hearseay (prueba de referencia) y la prueba del mal carácter. Vid. con más detalles, VOGLER, R., "Últimas tendencias probatoriasen Inglaterra: en especial las reglas de exclusión", Prueba y proceso penal: análisis especial de la prueba prohibida en el sistema penal español y en el derecho comparado, Gómez, J. L. Coord., Valencia, 2008, págs. 403 y ss. Monograficamente para un estudio más completo de los varios sistemas sobre la prueba ilícita, vid. ARMENTA DEU, T., La prueba ilícita (Un estudio comparado), Madrid, 2009.

${ }^{1780}$ Cfr. GASCÓN, M.,"¿Freedom of proof?: El incuestionable debilitamiento de la regla de exclusión de la prueba ilícita", Jueces para la democracia: Información y debate, 2005, pág. 52. Sobre la tesis de la conexión de antijuridicidad, Cfr. la SSTS 5067/2009, de 6.7.2009; 1025/2007, de 19.1.2007; 7467/2006, de 17.11.2006 y 1379/2003, de 28.2.2003.

${ }^{1781}$ No se puede olvidar que el derecho cuya violación originará la ilicitud de la prueba habrá que ser un derechofundamental. También que la prueba ilícita es decurrente de la violación de la norma constitucional atributiva de derechos materiales. Corroborando estas afirmaciones, sostienen DÍAZ CABIALE y MARTÍN MORALES que "hay prueba ilícita cuando existe lesión de un derecho fundamenta, pero no siempre que un derecho fundamental resulta menoscabado en una actuación probatoria cabe hablar de la ilicitud del artículo 11.1. Para que se pueda hablar de ilicitud probatoria, además del binomio actividad probatoria/menoscabo de derecho fundamental, tiene que darse un nexo de causalidad entre ambos. La obtención de la fuente de prueba tiene que ser el resultado de lesionar el derecho fundamental, como el menoscabo del derecho a la integridad física para obtener la confesión de una persona, por caso. La característica que define la prueba ilícitamente obtenida es que la lesión del derecho fundamental se provoca para poder obtener una fuente de prueba que de otra manera sería muy dudoso que se lograra". Vid. DÍAZ CABIALE, J. A; MARTÍN MORALES, R., La garantía constitucional de la prueba ilícitamente obtenida, Madrid, 2001, págs. 96-97.
} 
En palabras de RUIZ VADILLO, la expresión "pruebas ilícitas o irregulares" comprende toda prueba ilegal o prohibida, y ésta existe cuando se falta en su origen y/o desarrollo a un derecho fundamental ${ }^{1782}$.

Siguiendo este contexto, la prueba ilícita sería aquella producida infringiéndose las normas o principios puestos en la Constitución y por otras leyes, frecuentemente para la protección de las libertades públicas y de los derechos de la personalidad, en especial de la intimidad 1783 .

En realidad, como señala ARMENTA DEU, la prueba ilícita patentiza la tensión entre la tutela de bienes esenciales de la sociedad a través del proceso penal, como medio ineludible de realización del Derecho Penal, así como la propia libertad y derechos de los ciudadanos a quienes se imputa una lesión de tales bienes esenciales ${ }^{1784}$. Sin embargo, nos parece acertado afirmar que las pruebas ilícitas son las pruebas no aptas a la formación del convencimiento judicial por estar impregnadas por vicios que vienen a comprometer la norma material, así como a los principios constitucionales. En consecuencia, lo ilícito es una manifestación de la antijuridicidad, que en un planteamiento del Estado de Derecho en el que la Constitución, integrada por valores, principios y demás normas jurídicas representa la ley máxima, significa una manifestación espuria de lo jurídico ${ }^{1785}$.

Importante destacar que se percibe, en general, un sinnúmero de ordenamientos jurídicos, muy especialmente aquellos de países democráticamente avanzados, los cuales prevén la no admisibilidad las pruebas ilícitamente obtenidas ${ }^{1786}$. La justificativa sería, lógicamente, que el respeto a los derechos y garantías fundamentales de sus ciudadanos que un Estado social y democrático de Derecho se auto impone, tiene en el proceso, y en el proceso penal en particular, una concreción que supone la imposibilidad de otorgar eficacia a las pruebas logradas con infracción de tales derechos y garantías, de manera que la verdad, cuyo hallazgo constituye un desiderátum de aquél, no puede ser alcanzada a cualquier precio, porque la investigación de la verdad en el actual proceso penal no es un valor absoluto, sino que se halla limitada por los valores éticos y jurídicos propios del

${ }^{1782}$ Cfr. RUIZ VADILLO, E., "La actividad probatoria en el proceso penal español y las consecuencias de violarse en ella algún principio constitucional de producirse determinadas irregularidades procesales", VV.AA., La prueba en el proceso penal, Cuadernos de Derecho Judicial, Madrid, 1992, pág. 81.

1783 Véase con más detalles GRINOVER, A. P.; SCARANCE FERNANDES, A.; GOMES FILHO, A.M., As nulidades no processo penal, 2. a edición, São Paulo, 1982, pág.109.

1784 Vid. ARMENTA DEU, T., La prueba ilícita (Un estudio comparado), Madrid, 2009, pág. 21.

1785 Vid. URBANO CASTRILLO, E; TORRES MORATO, M. A., La prueba ilícita penal. Estudio jurisprudencial, cit., pág. 63.

${ }^{1786}$ Cítese como ejemplo España donde el artículo 11.1 LOPJ establece que "no surtirán efecto las pruebas obtenidas, directa o indirectamente, violentando los derechos o libertades fundamentales". Y en lo que interesa en nuestro trabajo, el fundamento sería siempre lo mismo, o sea, de el sólo hecho de introducir un agente encubierto en una investigación puede vulnerar seriamente caros derechos fundamentales no sólo del investigado sino incluso de terceros, y por lo mismo tanto la información que recoja como los elementos materiales probatorios y evidencias físicas, pueden estar basados en el desconocimiento de las garantías de protección de dichos derechos. En el mismo sentido ya había sido reconocida la misma idea en la STC 114/1984, de 29.11.1984: "El problema de la admisibilidad de la prueba ilícitamente obtenida se perfila siempre en una encrucijada de intereses, debiéndose así optar por la necesaria procuración de la verdad en el proceso o por la garantía, por el ordenamiento en su conjunto, de las situaciones jurídicas subjetivas de los ciudadanos. Estas últimas acaso puedan ceder ante la primera exigencia cuando su base sea estrictamente infra constitucional pero no cuando se trate de derechos fundamentales que traen su causa, directa e inmediata, de la norma primera del ordenamiento. En tal supuesto puede afirmarse la exigencia prioritaria de atender a su plena efectividad, relegando a un segundo término los intereses públicos ligados a la fase probatoria del proceso". Para un estudio proficuo del artículo 11.1 de la LOPJ, cfr. URBANO CASTRILLO, E; TORRES MORATO, M. Á., La prueba ilícita penal. Estudio jurisprudencial, cit., págs. 42-56. 
Estado de Derecho, entre los que se encuentra el pleno respecto a la ley y a los derechos inviolables de la persona (art. 10.1 CE) ${ }^{1787}$.

Llegado a este punto, y hechas las consideraciones preliminares sobre la ilicitud probatoria, se hace necesario ahora lanzar algunas otras consideraciones fundamentales respeto a la teoría de la prueba ilícita ${ }^{1788 .}$

Ahora no sería adecuado y pertinente analizar la cuestión de la distinción entre los conceptos de "prueba ilícita" y "prueba irregular", a la vez que solo la primera nos interesa para un pleno y eficaz entendimiento de la repercusión de la valorización de la prueba obtenida a través de actuaciones encubiertas ${ }^{1789}$.

Según las enseñanzas de ARMENTA DEU1790, la existencia de un régimen legal da pie a un concepto normativo, si bien esto sucede en pocos países: Holanda en el art. 359A WvSv; Italia a través de la "inutilizabilidad" (art. 191 CPP) o Chile en el art. 276 del CPP. Resulta más frecuente la inexistencia de dicho régimen legal, operando en su lugar una concepción jurisprudencial o doctrinal con mayor o menor apoyadura en diferentes preceptos.

Más excepcional todavía es la inclusión de la prohibición de prueba ilícita en la propia Constitución, como sucede en Brasil1791 y en Portugal ${ }^{1792}$, que comprende la regla de exclusión en la "violación del debido proceso"1793, configuración esta en consonancia

1787 Cfr. RAMOS RUBIO, C., "La prueba ilícita y su reflejo en la jurisprudencia", VV.AA., La prueba en el proceso penal, Madrid, 2000, págs.15-16.

1788Sobre conceptos generales de ilicitud probatoria y, en general, sobre el tratamiento de la prueba ilícita, vid. DÍAZ CABIALE, J.A; MARTÍN MORALES, R., La garantía constitucional de la inadmisión de La prueba Ilícitamente obtenida, Madrid, 2001; ECHARRI CASI, F. J., "Prueba ilícita: conexión de antijuridicidad y hallazgos casuales", Revista del Poder Judicial, núm. 69, 2003; GONZÁLEZ MONTES, J. L., "La prueba obtenida ilícitamente com violación de los derechos fundamentales", Revista del Poder Judicial, núm. 1, 1990; MARTíNEZ GARCÍA, E., Eficacia de la prueba ilícita en el proceso penal, (a la luz la STC 81/98 de 2 de abril), Valencia, 2003; MIRANDA ESTRAMPES, M., El concepto de prueba ilícita y su tratamiento en el proceso penal, 2a edición, Barcelona, 2004; PÉREZ MARÍN, Mạ. A., "En torno a la prueba ilícita", Revista de Derecho Procesal, núms. 2-4, 2001.

1789 Justificase este nuestro pensamiento, a la vez que la diferencia entre la prueba ilícita y la prueba irregular habrá de advertirse en un segundo grado, en relación con las pruebas relacionadas con ellas, ya que para las derivadas de las pruebas ilícitas se imponen asimismo la ineficacia como lógica consecuente de una suerte de contaminación (fruit of the poisonous tree doctrine), mientras que para las derivadas de las simplemente irregulares no se produce tal radical consecuencia, y nada obsta a que la convicción se obtenga por otros acreditamientos en la materia. Vid. con más detalles, las sentencia del Tribunal Supremo (SSTS 9428/1994, de 17.12.1994 y de 9871996, de 5.2.1996). Muy interesante también es la opinión de PLANCHAT TERUEL al señalar que "la complejidad de abordar la ilicitud probatoria se encuentra, de buen principio, no solamente con un problema de ámbito o alcance, sino hasta con otro de denominación. En efecto, numerosas son las citas a prueba prohibida, irregular o ilícita que en la mayoría de los supuestos abarcan situaciones paralelas, caracterizadas todas por la vulneración de derechos fundamentales en el íter de su obtención, pero tampoco es pacífico entre los estudiosos que siempre que se utiliza alguno de los términos indicados la relevancia de la norma quebrantada sea idéntica; así, existen posiciones que entienden que será prueba prohibida aquella que infringe derechos fundamentales mientras que será irregular la que afecta a norma legal ordinaria". Vid. PLANCHAT TERUEL, J. M., "Prueba ilícita. Fundamento y tratamiento", VV.AA., Estudio sobre prueba penal. Actos de investigación y medios de prueba en el proceso penal: competencia, objeto y límites, Vol. 1, Madrid, 2010, pág. 88.

1790 Cfr. con detalles, ARMENTA DEU, T., "La verdad en el filo de la navaja (nuevas tendencias en materia de prueba ilícita)", cit., págs. 354-356.

1791 Vid. art. 5ํ, LVI, de la Constitución Federal.

1792 Vid. art. 32 de la Constitución Portuguesa.

${ }^{1793}$ En Colombia, el art. 29 de la Constitución declara nula de pleno derecho la prueba obtenida con violación del debido proceso. 
con el art. 69.7 del Estatuto de Roma (1998); y que quizás por eso coincide con la perspectiva del Tribunal Europeo de Derechos Humanos sobre el "proceso justo".

Otros países, como México, en su regulación federal, a falta de normativa expresa acuden al principio de legalidad a tenor del catálogo de derechos fundamentales o garantías individuales (art. 14 y 16 de la Constitución de los Estados Unidos de México), en tanto las normas en el ámbito de los Estados Federados reformadas en las últimas décadas van incorporando el concepto de prueba ilícita, aunque sin mayor desarrollo legal.

Algo semejante ocurre en Argentina, donde no existe previsión legal expresa en el Código Nacional, ni en el de la mayoría de los que se aplican en muchas Provincias, si bien las más recientes reformas sí contemplan disposiciones legales expresas al respeto ${ }^{1794}$. Y en idénticas circunstancias Alemania distingue entre "pruebas prohibidas legalmente" y "reglas de exclusión", sin que se precise conexión alguna con la vulneración de derechos fundamentales (el art. 136a III StPO anuda la prueba ilícita a la infracción de normas reguladoras de la prueba); tal y como hace Uruguay, Bélgica o Francia.

Por fin, en España se utilizan términos como "prueba ilícita", "prueba prohibida", "prueba irregular" o "prueba ilegal", refiriéndolo a circunstancias diversas. Se detecta así un concepto amplio de prueba ilícita, cuya nota común es configurarla más allá de la obtenida o practicada con vulneración de derechos fundamentales, y otro calificado de estricto, que se circunscribe a la infracción de derechos fundamentales ${ }^{1795}$.

Otra consideración de interés es la relacionada con el hecho de que la concepción teórica de la prueba ilícitamente obtenida ${ }^{1796}$ tiene un referente muy caracterizado en la doctrina y la práctica norteamericana de las reglas de exclusión de la prueba irregular, plásticamente denotada como teoría de "los frutos del árbol envenenado", o sea, la prohibición de utilizar la evidencia obtenida por un medio regular pero que aparece como fruto de un acto anterior irregular ${ }^{1797}$.

1794Art. 211 CPP de Buenos Aires; Art. 207 CPP de Mendoza; y art. 194, CPP de Córdoba.

1795Entre los que defienden un "concepto amplio", cítese CONSO para quien toda norma relativa a fuentes o medios de prueba penales se dirigen a garantizar el derecho de defensa del imputado, de modo que toda infracción debe estimarse como prueba ilícita, en la medida que infringe el "derecho a un proceso con todas las garantías". Vid. CONSO, G., "Natura giuridica delle norme sulla prova nel processo penale", Rivista italiana di diritto e procedura penale, 1970, págs.. 1 y ss.; y en igual sentido: LÓPEZ BARJA DE QUIROGA, J., Las escuchas telefónicas y la prueba ilegalmente obtenida, Madrid, 1989, aunque este autor defienda el término "prueba prohibida" como más general y adecuado para todos los supuestos. Con una orientación semejante DEVIS ECHANDIA amplia la ilicitud probatoria a la violación de cualquier tipo o categoría de norma jurídica, incluso de principios generales del derecho. Vid. DEVIS ECHANDIA, H., Teoría general de la prueba judicial, tomo I, 5a edición, Buenos Aires, 1988, pág. 539. Desde una "perspectiva más estricta", está muy extendida la posición que limita el concepto de "prueba ilícita" a la obtenida con violación de derechos fundamentales, reservando otros conceptos, como el de "prueba prohibida" a las violaciones de toda norma o derecho fundamental. Vid. GONZÁLEZ MONTES, J. L., "La prueba obtenida ilícitamente con violación de derechos fundamentales (el derecho constitucional a la prueba y sus límites", Revista de Derecho Procesal, núm. 1, 1990, págs. 31 y ss. Una visión general reciente en ARMENTA DEU, T., "La prueba ilícita y reforma del proceso penal", Revista del Poder Judicial, número especial (Propuestas para una nueva Ley de Enjuiciamiento Criminal), núm. 19, 2006, págs. 177-211.

1796 Un tratamiento del asunto en modo general se puede verse en MIRANDA ESTRAMPES, M., El concepto de prueba ilícita y su tratamiento en el proceso penal, 2ª edición, Barcelona, 2004 y ARMENTA DEU, T., La prueba ilícita (Un estudio comparado), Madrid, 2009.

1797 Con más detalles sobre esta concepción dogmática, vid. CAFFERATA NORES, J. I., "Los frutos del árbol envenenado", Revista Doctrina Penal, año 9, Buenos Aires, 1986, págs. 491 y ss. En realidad, es consagrada la idea de que "la doctrina de los frutos del árbol envenenado comporta un problema capital y que, en el fondo, es el que late toda la construcción teórica de la prueba ilícita: su alcance. La problemática viene conociéndose como "efecto reflejo" y se plantea en los siguientes términos: si la indudable carencia de eficacia de la prueba 
De todo modo, imprescindible es destacar la regla general, pero no absoluta, de que en el curso del procedimiento de investigación y en el marco de producciones de pruebas admisibles está permitido producir injerencias en derechos fundamentales ${ }^{1798}$.

Consecuencia lógica apunta en el sentido de que para llevar a cabo el proceso penal son indispensables las injerencias en la esfera individual; y por cierto, tanto para asegurar el proceso de conocimiento como para asegurar la ejecución penal ${ }^{1799}$. Todavía deberán ser impuestos límites a esta producción de pruebas.

Por lo demás, el gran número de derechos y garantías constitucionales no pueden ser considerados como absolutos y libres de injerencias, delante del constante choque a que son sometidos. El principio de convivencia de las libertades obliga a una relativizaciónde estos derechos, evitándose que sean ejercidos de modo perjudicial al orden público y a las libertades ajenas.

La doctrina moderna ha dejado claro que la decisión judicial de no expulsar del proceso las pruebas que son ilícitas supone, en primer lugar, el desconocimiento del derecho fundamental material violado a través de la injerencia ilegítima; en segundo lugar, el desconocimiento del derecho al proceso celebrado con todas las garantías constitucionalmente protegidas; $y$, finalmente, el desconocimiento de las garantías constitucionales que integran el derecho al proceso penal del ciudadano-procesado, sin las cuales no existe proceso, ni tutela judicial efectiva ${ }^{1800}$.

Corroborando lo anteriormente afirmado, cítese en lo que nos interesa el ejemplo de que la actividad de transporte de droga no es considerada como más que una mera colaboración simulada del agente encubierto, que no invalida las pruebas obtenidas ni constituye delito provocado 1801 .

ilícita (exclusión) se extiende a todas las restantes lícitas que traigan causa de aquella o, si por el contrario, puede reconocerse validez a éstas en determinadas condiciones". Cfr. PLANCHAT TERUEL, J. Ma.., "Prueba ilícita. Fundamento y tratamiento", cit., pág. 97. Además, para un amplio y detallado estudio del tema, en especial por su interés en una perspectiva comparatista del sistema americano con el español actual, véase DÍAZ CABIALE, J. A; MARTÍN MORALES, R., La garantía constitucional de la prueba ilícitamente obtenida, Madrid, 2001.

1798 Sosteniendo esta regla de carácter general, Vid. ROXIN, C., Derecho procesal penal, cit., pág. 203. Todavía esclarece el profesor alemán que "la valoración es absolutamente imposible cuando ella lesiona el núcleo esencial intangible de la personalidad y, con ello, la dignidad humana". Vid. ROXIN, C., Derecho procesal penal, cit., pág. 191. Todavía, en lo relativo al tema del agente encubierto y la prueba ilícita, importante es citar la preocupación demostrada por MAIER y GUARIGLIA al señalaren "la necesidad de reafirmar la inadmisibilidad de la valoración judicial de aquella prueba mediata o inmediatamente adquirida mediante una acción estatal irregular, con total prescindencia de consideraciones complementarias, como la gravedad del hecho atribuido al investigado, o el error del agente de la persecución penal sobre la ilicitud de su actuación. Ello aún más frente a las tendencias deformantes del procedimiento penal que hoy se perciben claramente, y que amplían las facultades de injerencia estatal a niveles que, poco tiempo atrás, no hubieran sido imaginables, tales como la introducción del agente encubierto en varias legislaciones, o el desarrollo de nuevos métodos de vigilancia electrónica". Cfr. MAIER, J. B; GUARIGLIA, F., "Las prohibiciones de valoración probatoria en el procedimiento penal", Revista de Ciencias Penales, núm. 4, Montevideo, 1998, pág. 190.

${ }^{1799}$ ROXIN, C., Derecho procesal penal, cit., pág. 249.

1800 Vid. MARTÍNEZ GARCÍA, E., Actos de investigación e ilicitud de la prueba. El derecho al proceso y sus garantías como límite a la actuación de los poderes públicos en la investigación del delito, cit., págs. 29-30, nota 20. Siguiendo el mismo raciocinio, vid. BANDRÉS SÁNCHEZ-CRUZAT, J. M., Derecho fundamental al proceso debido y el Tribunal Constitucional, cit., pág. 102.

1801 REDONDO HERMIDA, A., "El agente encubierto en la jurisprudencia española y en la doctrina del Tribunal Europeo de Derechos Humanos", cit., pág. 99. En este sentido, es pertinente señalar que la actuación policial no supone una auténtica provocación, pues la decisión del sujeto activo siempre es libre y anterior a la intervención puntual del agente encubierto, aunque éste, siempre por iniciativa del autor de la infracción criminal, llegue a ejecutar labores de adquisición o transporte de los efectos del delito (art. 282 bis de la 
Otra situación que nos ha despertado la curiosidad es la referente a la eventual valoración de una prueba obtenida por el infiltrado a través de la práctica de un delito. Respecto a esta cuestión, BARJA DE QUIROGA se pronuncia en el sentido de que la prueba obtenida por el agente encubierto mediante la comisión de un delito, pero del que está exento de responsabilidad criminal por concurrir causa de justificación, es hábil y eficaz cuando dicha exención ha sido declarada por un Juez ${ }^{1802}$.

Estamos absolutamente de acuerdo con esta conclusión, pues deberá partirse del presupuesto de que se la medida limitativa de injerencia a derechos fundamentales ha sido analizada por la autoridad competente, bajo los principios de legalidad y proporcionalidad, la prueba eventualmente obtenida en esta operación presentará valor apto a ingresar como medio legal de formación de la convicción del juzgador.

Con esta idea se pretende dejar claro que la autoridad que concede la resolución motivada para inicio de una operación de infiltración policial, al tener analizada la hipótesis concreta a la luz de los parámetros de constitucionalidad, en especial la proporcionalidad de la medida, legitima este medio extraordinario de investigación, hecho este que provocará la consecuente validez de la prueba obtenida.

Desde el planteamiento que aquí se sostiene es imperioso tratar ahora de la importancia del principio de proporcionalidad frente al tema de la prueba ilícita ${ }^{1803}$.

En una primera aproximación a este asunto, se puede considerar que no es la violación a cualquier norma constitucional o legal que importará la ilicitud de la prueba, pero tan solo en aquellas hipótesis en que hubiere ausencia de respecto a las normas o principios de derecho material relacionados con la protección de las libertades públicas.En este sentido, la violación en la obtención de la prueba deberá caracterizar la lesión al derecho material y configurar la infracción del Derecho penal, civil o administrativo.

Con efecto, en un sinnúmero de situaciones la violación a la norma de naturaleza procesal no llevará siempre a la ilicitud de la prueba, pero solamente a su nulidad.

Por lo demás, es necesario considerar que la teoría de la proporcionalidad o de la preponderancia de bienes consiste exactamente en una construcción doctrinal y jurisprudencial que se introduce en los sistemas de no admisibilidad de la prueba obtenida ilícitamente, permitiendo que se proceda a una elección entre los valores constitucionalmente relevantes puestos en conflicto1804.

Así, se plantea la duda sobre cómo resolver el problema de enfrentarse con una prueba obtenida ilícitamente y como ubicarla en el proceso penal garantista.

La lógica jurídica apunta en el sentido de habrá que conciliarse el interés público en descubrir la verdad en el proceso y la necesidad impostergable de tutelarse de manera efectiva los derechos y garantías fundamentales de los ciudadanos; es decir, en otorgar la

LECrim), u otras tareas de auxilio o colaboración similares, simulando así una disposición a delinquir que permite una más efectiva intervención policial.

1802 Vid. LÓPEZ BARJA DE QUIROGA, J., "El agente encubierto", cit., pág. 3.

1803 Con riqueza de detalles sobre este tema cfr. ZUMSTEIN RIBEIRO, L. E., "Liberdades públicas e a inadmissibilidade das provas ilícitas frente ao princípio da proporcionalidade", Revista Jurídica da Universidade de Franca, núm. 12, 2004, págs. 129-132. 58.

1804 AVOLIO, L. F. T., Provas ilícitas: interceptações telefônicas e gravações clandestinas, São Paulo, 1995, pág. 
máxima protección jurídica a los mismos a fin de lograr su plena realización ${ }^{1805}$. Volvemos otra vez más a defender la idea de una armonización procesal penal.

En virtud de lo expuesto, existe una predisposición doctrinal y jurisprudencial a nivel internacional en orden a aceptar en estos casos un principio de rango constitucional, el cual se origina de una interpretación sistemática de las normas constitucionales que han de permitir el sacrificio de un derecho o garantía constitucional en pro de otro también del mismo nivel jerárquico: el postulado de la proporcionalidad ${ }^{1806}$.

Se observa que en este caso deberá observarse el principio de proporcionalidad bajo dos aspectos fundamentales: primero, como protector de la libertad, pues viene a impedir que el Estado se distancie o incluso impida el ejercicio de los derechos fundamentales; segundo, como límite a la libertad de actuación del legislador en elegir valores que habrán de imponer graves perjuicios a los ciudadanos, haciendo con que exista la observancia necesaria a la adecuación, a la exigibilidad de que los medios utilizados sean proporcionales a los fines buscados.

Adoptado el principio de proporcionalidad, que pone en la balanza valores constitucionales en conflicto, se hace perfectamente posible la utilización de una prueba ilícita o de su derivación en casos excepcionales y graves, como en el caso de la actuación delos grupos organizado, cuando no sea posible la acreditación de los hechos por otros medios, teniendo en cuenta la relatividad de los derechos y garantías constitucionales y el hecho de que estos no pudieren salvaguardar prácticas ilícitas.

Esta sería, según nuestro modo de pensar, la única forma de compatibilizar la eficacia de la prueba eventualmente obtenida de forma ilícita y las actuaciones de los agentes encubiertos que laboran en la búsqueda de combatir la expansión de la delincuencia organizada.

En razón de todo lo que ha sido expuesto hasta ahora, se puede concluir respeto a la actuación concreta del agente encubierto que su admisibilidad y eficacia queda supeditada al estricto sometimiento de los agentes a lo dispuesto en dichas normas, que en términos generales y como medida limitativa de derecho fundamental comprende los siguientes requisitos:
a) carácter excepcional;
b)resolución habilitante;
c)juicio de proporcionalidad;
d)especialidad;
e) motivación;
f)ultima ratio;
g)indicios racionales de criminalidad; $y$
h)control judicial.

\footnotetext{
1805 Analizando con profundidad estos presupuestos, Vid. GÁLVEZ MUNÕZ, L., La ineficacia de la prueba obtenida con violación de derechos fundamentales, cit., págs. 54-55.

1806 Véase sobre la relación de este principio y la prueba ilícita, MARIANO DA SILVA, C. M., "Provas ilícitas e o princípio da proporcionalidade", Carta Forense, noviembre 2010, págs. A18-A19, http://www.cartaforense.com.br; ZUMSTEIN RIBEIRO, L. E., "Liberdades públicas e a inadmissibilidade das provas ilícitas frente ao princípio da proporcionalidade", Revista Jurídica da Universidade de Franca, ano 7, núm. 12, 2004, págs. 129-132.
} 
El cumplimiento de tales condiciones no resulta, sin embargo, suficiente a efectos probatorios -para enervar la presunción de inocencia-; se exige, además, que el agente infiltrado testifique en la fase plenaria del juicio, cumplimentando los requisitos de oralidad, contradicción y publicidad ${ }^{1807}$.

\section{VI.2.5. La prueba ilícita pro societate y el criterio de la proporcionalidad.}

Hasta aquí se ha comprobado que surge como consecuencia al cuadro detensiones sensibles, ínsito al proceso penal, el problema de la no admisibilidad de las pruebas ilícitas como expresión de una colisión entre la protección de los derechos fundamentales contra la arbitrariedad de la persecutio criminis, pero también del peligro de la ineficiencia que la hipertrofia de las garantías puede proporcionar ${ }^{1808}$.

En el proceso penal la aplicación de la prohibición de pruebas ilícitas, sies considerada como una garantía absoluta, puede generar, en ocasiones, situaciones de innegable desproporción con la protección conferida al derecho entonces violado -en la producción de la prueba-, y ello en detrimento de la protección del derecho de la víctima del delito ${ }^{1809}$.

Si lo anterior es correcto, entonces la situación tiende a volverse muy compleja cuando se trata de investigaciones referentes a organizaciones criminales que a través de la práctica de delitos de grave repercusión social provocan innumerables perjuicios y daños a la sociedad, hecho este que viene a provocar un alto grado de sentimientos de impunidad en la ciudadanía.

Por esta razón puede surgir el peligro de una abusiva instrumentalización de las garantías, de suerte que este matiz hipergarantista aniquilaría el objetivo de encontrarse un proceso justo ${ }^{1810}$.

El problema central radicaría, según nuestra opinión,en la cuestión de la posibilidad excepcional del reconocimiento de la prueba ilícita pro societate, o sea, aquélla en favor de la preservación de la seguridad colectiva de la sociedad.

De otra parte, es imprescindible reconocer preliminarmente que parte de la doctrina, especialmente en ordenamientos iberoamericanos, acostumbraa aceptarla teoría

\footnotetext{
1807 Vid. ARMENTA DEU, T., "Exclusionary rule: convergencias y divergencias entre Europa y América", cit., pág. 85.

1808 Según nuestro modo de pensar, en realidad, no siendo los derechos fundamentales absolutos, mismo el derecho a la prueba podrá en ciertas situaciones ser limitado cuando hubiere una colisión con otros principios constitucionales.

1809 PACELLI DE OLIVEIRA, E., Curso de Processo Penal, cit., pág. 324.

1810Perfectas en este sentido, las advertencias hechas por la consagrada doctrina española: "Naturalmente que se trata, una vez más, de encontrar el más justo equilibrio para que el derecho no se convierta en abuso o fraude de ley, sobretodo porque se ha dicho muchas veces que el abuso no es uso sino corruptela (abusus non est usus, sed corruptela). Por eso es también cierto que el derecho, todo derecho, puede tener sus excepciones para supuestos igualmente excepcionales. En consecuencia, los principios constitucionales han de ser respectados obligatoriamente, pero en casos especiales, muy especiales, el mantenerlos hasta sus últimas consecuencias puede llegar a situaciones imposibles y, a la vez, a la impunidad penal más absoluta en detrimento de supremos intereses, si aquéllos se interpretan arbitraria e ilógicamente". Cfr. GONZÁLEZCÚELLAR, A; HERNÁNDEZ GUIJARRO, J. J.; PAZ RUBIO, J. M.; RODRIGUEZ RAMOS, L.; TOMÉ PAULE, J., Ley de enjuiciamiento criminal y ley del jurado, Madrid, 2001, pág. 179. También muy importante señalar que en Brasil el Supremo Tribunal Federal reconoce la posibilidad de aplicación de una ponderación de intereses pro societate cuando ocurrir un abuso de las garantías constitucionales (RE 212.081, de 05 de diciembre de 1997 y HC 69.204, de 26 de mayo de 1992).
} 
de la prueba ilícita pro reo ${ }^{1811}$, justificándose este entendimiento en razón de que se trata de la aplicación doctrinal y jurisprudencial en cuanto a la admisibilidad de las pruebas ilícitas con la finalidad de promover el convencimiento judicial cuando estas tengan por finalidad la defensa del imputado.

Apoyada en valores supremos de la libertad humana y del ideal de justicia, y en homenaje al derecho de defensa, la prueba ilícita pro reo ha sido acepta incluso por encima de la violación de derechos fundamentales de terceras personas e incluso de la propia sociedad.

En palabras de PELLEGRINI GRINOVER, no deja de ser en último análisis manifestación del principio de proporcionalidad la posición prácticamente unánime que reconoce la posibilidad de utilización, en el proceso penal, de la prueba favorable al acusado, aunque obtenida con violación de sus derechos fundamentales. Se trata de la aplicación de la proporcionalidad en la óptica del derecho de defensa, también constitucionalmente asegurado, y de forma prevalente en el proceso penal. No obstante, la justificativa de la aceptación de la prueba ilícita pro reo reside también en ponderaciones de carácter político, por cuanto su denegación podría estimular al investigador sin lealtad, que tendría interés en obtenerla intencionalmente en contra las prescripciones legales, estableciendo así las premisas para su exclusión y, quizás, para la condena ${ }^{1812}$.

Esto sentado, lo que interesa ahora es esclarecer el contenido de la prueba ilícita pro societate y el actual estado de esta cuestión en el proceso penal contemporáneo.

En esta hipótesis se entiende que cuando se tiene por meta proteger a la sociedad como un todo, no se tiene en mente la protección de un ente abstracto; mas al contrario, a cada uno de los miembros de la colectividad individualmente considerados ${ }^{1813}$.

El fundamento de aceptación de esta modalidad de prueba sería la defensa del interés público y de la sociedad, pues visaría proteger no a un derecho individual pero si a un interés mayor compuesto por todos los miembros de la colectividad ante de las consecuencias que podrán surgir de la impunidad de ciertas conductas graves practicadas por grupos de delincuentes organizados.

Por lo tanto, cuando se admite como forma de convencimiento una prueba inicialmente contaminada por el vicio de la ilicitud, se busca proteger a todos y a cada uno de los ciudadanos en particular que puedan venir a sufrir las consecuencias de la actividad delictiva. Este planteamiento se encuadra perfectamente en la caótica situación generada por la expansión del crimen organizado.

Desde ahí surge la necesidad de compatibilizar la protección genérica de los derechos fundamentales, a través de la regla de la exclusión, con el deber del Estado de perseguir la criminalidad ${ }^{1814}$. Así las cosas, habrá que partir de la consideración de que no

1811 Cfr. TOURINHo FILHO, F. C., Processo Penal, 25a edición, São Paulo, 2003, págs. 234; PACELLI DE OLIVEIRA, E., Curso de Processo Penal, Belo Horizonte, 2006, págs. 30-31; MIRABETE, J. F., Processo Penal, 13a edición, São Paulo, 2002, págs. 261-262.

1812 Cfr. PELLEGRINI GRINOVER, A., Novas tendências do Direito Processual: de acordo com a Constituição de 1988, 2a edición, São Paulo, 1990, págs. 88-89.

1813Siguiendo esta misma orientación, Cfr. ANDRADE MENDONÇA, R. P., Provas ilícitas: Limites à licitud probatória, 2ª edición, Rio de Janeiro, 2004, pág. 92 y ss.

1814 Vid. DE LA OLIVA SANTOS, A., "Sobre la ineficacia de las pruebas ilícitamente obtenidas", La ley, núms. 8-9, 2003, pág. 6. 
se puede aceptar la existencia de principios absolutos, que siempre se presentan superiores a otros.

Cabe considerar, además, que no se puede afirmar que el derecho de defensa sea siempre superior al deber de protección penal de la colectividad, pues una afirmación como esta vendría a aniquilar la lógica del sistema de coordinación de los principios procesales. Sin embargo, la cuestión que se acaba de analizar, según nuestro entendimiento ${ }^{1815}$, apunta en el sentido de que deberá ser admitida la utilización de la proporcionalidad como criterio de ponderación ${ }^{1816}$ de los intereses en concurrencia en la admisión de la prueba ilícita. En esencia, consideramos que deberán ser sopesados los valores puestos en juego, teniendo en cuenta que la sociedad es tan merecedora de protección cuanto el individuo.

Pues bien, a partir de estas premisas, ARANHA denomina la teoría de la proporcionalidad en lo relativo a la problemática de las pruebas ilícitas como la "teoría del interés prevalente", afirmando que en ciertas situaciones la sociedad, representada por el Estado,tiene que conciliar dos intereses fundamentales relevantes, antagónicos y que a ella cumple preservar: la defensa de un principio constitucional y la necesidad de perseguir y punir a los delincuentes. La solución debe enfatizar el interés que prevalece y que, como tal, debe ser preservado ${ }^{1817}$.

Dicho de otra forma, se percibe que la rigidez de la gran mayoría de los ordenamientos jurídicos que disponen sobre la no admisibilidad de las pruebas ilícitas en el proceso viene siendo atenuado por la doctrina y por la jurisprudencia1818 con fundamento en la teoría de la proporcionalidad, originaria del Derecho alemán.

Según esta concepción dogmática, la prohibición de las pruebas obtenidas a través de medios ilícitos es un principio relativo que permite, de manera excepcional y en casos especialmente graves, la utilización de la prueba ilícita siempre que, estando en juego dos derechos fundamentales, se pretenda proteger el derecho más importante o que presente una valoración mayor atribuida por el ordenamiento positivo en detrimento de otro derecho que se pretende mitigar.

En esta línea de raciocinio, se observa que ninguna libertad pública es absoluta, y de este modo, existirá la posibilidad de la violación en algunos casos, como por ejemplo en la hipótesis en que se percibe que el derecho tutelado es más destacado que otro derecho fundamental que se estaría violando.

Queda muy claro, pues, que debe hacer uso del principio de equilibrio de los valores en contrastante, por lo cual estando en colisión derechos constitucionalmente protegidos, se busca la prevalencia de aquél que presente mayor interés o mayor relevancia para el

${ }^{1815} \mathrm{Cfr}$. en el mismo sentido CAPEZ, que sostiene que "la cuestión, aunque controvertida, habrá que resolvese, una vez más, con la aplicación del principio de proporcionalidad, siempre en carácter excepcional y en casos extremamente graves para admitirse la prueba ilícita, sea pro reo o pro societate". Vid. CAPEZ, F., Curso de processo penal, 9ª edición, São Paulo, 2003, pág. 261.

1816 Sobre este tema de la ponderación en la óptica del Tribunal Constitucional español, importante destacar que "hay, pues, que ponderar, en cada caso, los intereses en tensión para dar acogida preferente en su decisión a uno u otro de ellos (interés público en la obtención de la verdad procesal e interés, también, en el reconocimiento de plena eficacia a los derechos fundamentales)". Así, véase la sentencia STC 114/1984, de 29.11.1984.

1817 ARANHA, A. J. C., Da prova no processo penal, 5ae edición, São Paulo, 1999, pág. 64.

1818 Cítese como ejemplos en Brasil, la jurisprudencia del STJ (HC 3972/RJ y HC 4138/RJ) y del STF (HC 70.814/SP). 
ordenamiento jurídico en orden a armonizar la aparente oposición entre ellos, de acuerdo con la propia esencia del postulado de la proporcionalidad.

Incluso, no se podrá olvidar que cuando la impunidad generada por la prohibición de admitirse pruebas ilícitas en los procesos por casos relativos a la actuación de los grupos organizados los daños a los ciudadanos no son menos graves, ya que resulta comprometido el deber estatal de promoción de la justicia y la erradicación de la marginalidad, así como puede haber un comprometimiento moral de la estructura administrativa del Estado en razón de la fuerza corruptiva de las conductas perpetradas por los delincuentes.

En resumen, en lo relativo a la cuestión del aprovechamiento de la prueba ilícita a favor de la acusación, se puede afirmar que el criterio de proporcionalidad ${ }^{1819}$ podrá válidamente ser utilizado en las hipótesis en que no se pone en riesgo la aplicabilidad potencial y finalista de la norma de no admisibilidad. Así es que cuando no se concreta el incremento o estimulo a la práctica de ilegalidad por los agentes productores de la prueba será posible, a priori, y en casos excepcionales, la aplicación de la regla de proporcionalidad como forma de aprovecharse la prueba obtenida ilícitamente. En síntesis, dependerá también del caso en concreto donde el juzgador tendrá la tarea de valorar los elementos probatorios y aclarar si deberán servir a los fines de búsqueda de la verdad procesal.

Y más, analizándose la proporcionalidad pro societate se percibe que no se trata todavía de invocar el principio a favor o contra el acusado, sino de verificar en cada situación concreta si la restricción impuesta a alguno de los derechos del imputado es necesaria, adecuada y justificable en razón del valor que se protege ${ }^{1820}$.

Al fin, un ejemplo hipotético podría explicitar todo lo que hemos intentado demostrar. Imagínese la situación en que un policía encubierto en una investigación contra un grupo terrorista descubre, a través de una interceptación telefónica no autorizada en razón de la ausencia de tiempo hábil para se buscar la autorización judicial, que la banda criminal va a colocar en práctica un gran atentado a través de un coche bomba que quedará aparcado muy próximo a la Puerta del Sol en la ciudad de Madrid, en un día de verano y en horario de gran circulación de personas. El infiltrado, ante las informaciones obtenidas, se adelanta e informa los hechos al cuerpo policial de apoyo, el cual, de manera inmediata, detiene a dos miembros de la banda terrorista antes de que hayan podido abandonar el coche. Ante este caso concreto, cabe preguntarse si esta prueba obtenida ilícitamente - la grabación telefónica de la trama delictiva- podrá ser utilizada en el juicio contra los acusados. A nuestro juicio, la respuesta más acertada tendría sentido afirmativo, puesto que ha sido a través del descubrimiento del atentado que se evitó la muerte de un sinnúmero de personas inocentes, quedando de forma directa puesta en peligro la seguridad ciudadana. Y más que esto, ya que ha sido fundamental el

1819 Todavía, como bien observa PACELLI DE OLIVEIRA, "el examen del cabimiento del juicio de proporcionalidad debe pasar también no solo por la identificación de un tensión o conflicto entre principios constitucionales relativos a la efectiva protección de derechos fundamentales (del imputado y de la víctima), pero también por la elaboración de criterios objetivos, tanto cuanto posibles, en que la escoja por uno de los principios pueda no implicar el sacrificio integral del otro". Vid. PACELLI DE OLIVEIRA, E., Curso de Processo Penal, cit., pág. 326. Destacando también el valor del principio de proporcionalidad como vector central y imprescindible a la aceptación excepcional de la prueba ilícita pro societate, Cfr. ANDRADE MENDONÇA, R. P., Provas ilícitas: Limites à licitud probatória, cit., pág. 93.

1820 Esta la opinión defendida por SCARANCE FERNANDES, A., Processo Penal Constitucional, cit., pág. 210. 
análisis de la proporcionalidad en todos sus aspectos esenciales para llegarse a esta conclusión.

\section{VI.3. El principio de proporcionalidad como limitante fundamental en el uso de agentes infiltrados.}

VI.3.1. La valoración de la prueba obtenida en infiltraciones policiales a la luz del principio de proporcionalidad.

Antes de adentrarnos de lleno en el tema de la proporcionalidad, hay que matizar y dejar claro que los derechos fundamentales constituyen la piedra angular y la sustancia vivificante de un Estado social y Democrático de Derecho. Y no solo esto: los derechos fundamentales constituyen los pilares básicos de nuestra organización jurídico-política, por lo que su vulneración debe provocar un rechazo más que absoluto, lo que implica, entre otras cosas y por lo que ahora interesa, la imposibilidad de otorgar eficacia jurídica a las pruebas obtenidas por medio de la infracción de tales derechos ${ }^{1821}$.

También es importante destacar una vez más que los derechos fundamentales no son absolutos, pero no lo es menos que tampoco puede atribuirse dicho carácter a los límites a que ha de someterse el ejercicio de los mismos. Todas las normas relativas a tales derechos se integran en un único ordenamiento inspirado por los mismos principios ${ }^{1822}$.

Del mismo modo se puede afirmar que la tarea constitucional conferida al legislador para la concreción de los derechos fundamentales no es rellenada tan solo con la generación de instituciones y reglamentos de derecho material, sino también con la colocación a la disposición del instrumental procesal necesario.

Siendo así las cosas, nos cumple considerar que ningún derecho fundamental es ilimitado ${ }^{1823} \mathrm{y}$, en consecuencia, no toda pretensión jurídica tiene asegurado el éxito simplemente por estar fundamentada en el ejercicio de un derecho fundamental reconocido por la Constitución. También, que los límites a los derechos fundamentales, esto es, la posibilidad de que una pretensión basada en el ejercicio de un derecho se vea jurídicamente - frustrada pueden provenir tanto de otros derechos fundamentales como de los llamados "bienes constitucionalmente protegidos", los cuales pueden estar implícitamente reconocidos en el texto constitucional o bien derivar de éste de forma mediata o indirecta (no es claro si con ello sólo se quiere decir que son consecuencias lógicas de otros elementos de la Constitución o bien su sentido es más extenso).

1821 Cfr. GÁLVEZ MUNÕZ, L., La ineficacia de la prueba obtenida con violación de derechos fundamentales, cit., págs. 59-60.

1822 Véase al respeto, la STC 254/1998, de 21.12.1988. Es hecho ya consolidado que "no existen derechos ilimitados. Todo derecho tiene sus límites que en relación con los derechos fundamentales, establece la Constitución por sí misma en algunas ocasiones, mientras en otras el límite deriva de una manera mediata o indirecta de tal norma, en cuanto ha de justificarse por la necesidad de proteger o preservar no sólo otros derechos constitucionales, sino también otros bienes constitucionalmente protegidos" (STC 2/1982, de 29.1.1982). En este sentido, afirma CARBONELL que "no existen derechos absolutos, sino que cada derecho se enfrenta a la posibilidad de ser limitado. La cuestión que interesa entonces es de qué manera y con qué requisitos se pueden limitar los derechos". Vid. CARBONELL, M., "Nuevas formas de proteger los derechos fundamentales", VV.AA, El principio de proporcionalidad y protección de los derechos fundamentales, M. Carbonell coord., México, 2008, pág. 8.

1823Desde este contexto, "el Estado estará legitimado para intervenir en la libertad o tratar de forma desigual cuando estuviera presente la concreción de un límite constitucional al derecho fundamental atingido y la concretización del mismo restar justificado con base en el criterio de la proporcionalidad". Vid. DIMOULIS, D; MARTINS, L., Teoria geral dos direitos fundamentais, 3 a edición, 2011, pág. 127. 
Para la determinación en cada caso de la solución a adoptar cuando se produce una controversia entre pretensiones incompatibles basadas en derechos fundamentales, o bien entre un derecho fundamental y un bien constitucionalmente protegido, se utiliza un mecanismo que se suele llamar "ponderación" entre los distintos elementos en juego ${ }^{1824}$.

Traspasadas estas observaciones se impone ahora plantear algunas cuestiones imprescindibles a una correcta compresión de este postulado de rango constitucional, explícita o implícitamente formulado: el principio de proporcionalidad en materia penal.

Durante el desarrollo de nuestro trabajo ya hemos tenido la oportunidad, en un sinnúmero de veces, de nos referir al principio de proporcionalidad. Y la razón es sencilla, al tratarse de un postulado de índole constitucional que presenta esencial importancia en el estudio del tema del agente encubierto y su actuación dentro del marco de un proceso penal garantista.

No sería exagerado afirmar que la mejor solución para encuadrar la figura del agente encubierto en el marco de un proceso penal garantista estaría representado por el principio de proporcionalidad y sus derivaciones, o sea, la necesidad, la adecuación y la proporcionalidad en sentido estricto.

No se pretende en este apartado, ni mucho menos, agotar la de por sí inagotable bibliografía que sobre este tema existe ${ }^{1825}$; no obstante, sí parece preciso hacer mención a algunas notas esenciales respeto a esto principio y su estrecha relación con el tema de las operaciones encubiertas.

A modo de conceptuación, sería correcto afirmar que se trata de una técnica de interpretación de los derechos fundamentales cuyo objetivo es tutelarlos de mejor manera, expandiendo tanto como sea posible su ámbito de protección, pero haciendo que todos los derechos sean compatibles entre ellos en la medida en que sea posible. De hecho, el principio de proporcionalidad constituye hoy en día quizá el más conocido y el más recurrente "límite de los límites" a los derechos fundamentales y en esa medida supone una barrera frente a intromisiones indebidas en el ámbito de los propios derechos ${ }^{1826}$.

Así es que el principio de proporcionalidad constituye la regla fundamental a tener en cuenta para analizar la constitucionalidad de las restricciones y limitaciones de los derechos fundamentales y libertades públicas ${ }^{1827}$. Muy especialmente, volvemos a afirmar, en lo relativo al tema del agente encubierto.

1824 Para un cuidadoso análisis de este asunto, vid. MARTíNEZ ZORRILLA, D., Conflictos constitucionales, ponderación e indeterminación normativa, cit., pág. 30. Para la concreción de esta técnica en lo relativo al aspecto probatorio, importante analizar particularmenteen la hipótesis la repercusión social del delito, la gravedad del vicio probatorio, el valor demostrativo de laprueba en cuestión, el grado de la sospecha y los intereses constitucionales en juego dentro de los cuales se destaca el interés en que la violación de los bienes jurídicos tutelados por el Derecho penal no quede en la impunidad sacrificándose la verdad real.

1825 Sobre el tema de la proporcionalidad, de modo a profundizarse, vid. AGUADO CORREA, T., El principio de proporcionalidad en Derecho Penal, Madrid, 1999; BERNAL PULIDO, C., El principio de proporcionalidad y los derechos fundamentales, Madrid, 2003; GONZÁLEZ-CUELLAR SERRANO, N., Proporcionalidad y derechos fundamentales en el proceso penal, Madrid, 1990; LOPERA MESA, G. P., Principio de proporcionalidad y ley penal, Madrid, 2006.

1826 CARBONELL, M., "Nuevas formas de proteger los derechos fundamentales", cit., pág. 8.

1827 Así, por ejemplo, en España, el principio de proporcionalidad ha sido recibido por el Tribunal Constitucional por influencia de la jurisprudencia del Tribunal Europeo de Derechos Humanos y de la doctrina y jurisprudencia alemanas, y tiene su origen en el Derecho Administrativo de policía, extendiéndose posteriormente al conjunto del Derecho Administrativo, en cuyo ámbito se entendía como prohibición del exceso, directamente relacionada con la prohibición de la arbitrariedad de la administración. Posteriormente, 
Se justifica este entendimiento según la constatación de que la regla de la proporcionalidad tiene como función imperiosa la necesidad de asegurar la supremacía del contenido de las normas relativas a los derechos y garantías fundamentales en contraposición a la actuación del Estado. Se busca de esta forma propiciar al ciudadano y a la propia colectividad más seguridad y menos injusticias, a la vez que este postulado presenta como objetivo encontrar en los casos concretos de colisión de derechos fundamentales la debida y acertada razonabilidad, equilibrándose los intereses en juego a través de la regla de la ponderación ${ }^{1828}$.

De otra parte, se hace obligatorio en este punto señalar que la proporcionalidad es parte inseparable de la justicia, pues sin aquélla no existe ésta ${ }^{1829}$. En palabras de ARMENTA DEU, el principio de proporcionalidad, cuyos orígenes se sitúan en el Derecho Administrativo de policía en Alemania, es en definitiva una técnica tendente a que la consecución de los intereses públicos no se haga a costa de los derechos e intereses de los particulares, debiendo alcanzarse un equilibrio —una proporción-1830.

La proporcionalidad tiene su campo de aplicación principal en el marco de los derechos fundamentales, actuando como criterio valorativo constitucional determinante máximo de las restricciones imponibles a la esfera básica de los ciudadanos por el Estado en la realización de sus fines ${ }^{1831}$.

Con todo, defiende AGUADO CORREA que la importancia del principio de proporcionalidad en el ámbito procesal penal se debe a la confrontación individuo-Estado que tiene lugar en el seno del proceso penal y la consiguiente lesión de derechos fundamentales, tales como la libertad personal, secreto de las comunicaciones, honor, inviolabilidad del domicilio ${ }^{1832}$. Tales restricciones no se justifican si no es en orden a la consecución de los fines que persigue el ejercicio del ius puniendi del Estado.

ha pasado a considerarse como un principio general de todos los sectores del Derecho Público, cobrando especial importancia como criterio legitimador de las limitaciones y restricciones de los derechos fundamentales, tanto en el nivel de la regulación legal de las mismas (el legislador no puede imponer limitaciones desproporcionadas a los derechos fundamentales), como en el de su aplicación judicial (los órganos jurisdiccionales no pueden autorizar medidas restrictivas de los derechos fundamentales si en el caso concreto resultan desproporcionadas). En definitiva, el principio de proporcionalidad se configura como un límite a las medidas restrictivas de los derechos fundamentales, prohibiendo aquellas en las que resulte desproporcionado, en el caso concreto, el sacrificio del derecho afectado, en relación con la finalidad que con las mismas se pretende alcanzar. Vid. con detalles sobre este pensamiento, GONZÁLEZ-CÚELLAR SERRANO, N., Proporcionalidad y derechos fundamentales, cit., págs. 21 y ss.

1828 Con una opinión distinta, afirma VILLAVERDE MENÉNDEZ que "la ponderación conduce inevitablemente a la jerarquización entre los derechos fundamentales, por cuanto la resolución de sus conflictos no se solventará examinando sus recíprocos límites, sino postergando la aplicación de uno en beneficio de la aplicación del otro según la jerarquía de los valores o intereses que encarnen. Ya no se aplican ambos derechos fundamentales al caso, sino que se acuerda suspender la vigencia de uno de los derechos en ese caso concreto (que puede recuperar, sin embargo, en otro posterior similar) para aplicar en plenitud el elegido en la ponderación". Véase VILLAVERDE MENÉNDEZ, I., "La resolución de conflictos entre derechos fundamentales. El principio de proporcionalidad", VV.AA., El principio de proporcionalidad y protección de los derechos fundamentales, México, 2008, pág. 165.

1829 Vid. RUIZ VADILLO, E., "Principios generales. Legalidad, proporcionalidad, etc.", VV.AA., La prueba en el proceso penal, Madrid, 1993, pág. 55.

1830 En este sentido, Cfr. ARMENTA DEU, T., Lecciones de Derecho Procesal Penal, 3a edición, MadridBarcelona, 2007.

1831 PEDRAZ PENALVA, E; ORTEGA BENITO, V., "El principio de proporcionalidad y su configuración en la jurisprudencia del Tribunal Constitucional y literatura especializada alemanas", VV.AA., Constitución, jurisdicción y proceso, Madrid, 1990, pág. 287.

1832 Vid. AGUADO CORREA, T., El principio de proporcionalidad en Derecho Penal, cit., págs. 93-94. 
Así, pues, la proporcionalidad de una medida limitativa de los derechos fundamentales y, en lo que nos interesa en este trabajo, la actuación de agentes infiltrados en bandas criminales practicantes de delitos graves, no sólo exige que resulte idónea, necesaria y proporcionado el sacrificio que comporta el derecho fundamental ${ }^{1833}$. Estos requisitos carecen de sentido si no se ponen en relación con la consecución de un fin legítimo: por ello, la medida será proporcionada si es idónea e imprescindible para alcanzarlo, y si el sacrificio del derecho resulta equilibrado en relación con la satisfacción del interés público perseguido que se obtiene.

Pero además, dicha medida de infiltración policial para fines de investigación criminal sólo será legítima si está prevista en la ley y se acuerda por un órgano jurisdiccional después de ponderar los intereses en conflicto — derecho fundamental limitado y consecución del interés público perseguido-, ponderación que deberá plasmarse en la motivación de la resolución judicial por la que se acuerde la medida1834.

Durante la investigación delictiva pueden adoptarse determinadas medidas restrictivas de derechos fundamentales. La legalidad y admisibilidad de las mismas, según ESPINOSA DE LOS MONTEROS, quedará subordinada al estricto respecto del principio de proporcionalidad en el momento de su adopción y desarrollo, condicionando la legitimidad de la actuación a que ésta sea necesaria o imprescindible para la consecución de un fin propio en una "sociedad democrática"1835. Caso contrario, la prueba obtenida en estas operaciones encubiertas no tendrían posibilidad de presentar validez y eficacia, a la vez que obtenidas de forma ilícita y con vulneración irrazonable de las garantías fundamentales.

Se trata, según GUZMÁN FLUJA, de someter la infiltración policial a un, cuando menos, triple filtro que garantice su completa necesidad y que vele por su mayor ajuste posible a los postulados del proceso penal garantista. En este sentido, debe recordarse que la proporcionalidad se mide en atención a exigencias especialmente fuertes derivadas de establecer conceptos muy estrictos de "criminalidad organizada" y de "delitos muy graves". Por ello, sólo si se trata de organizaciones criminales que tienen una capacidad de actuación que resulte particularmente lesiva o perniciosa para el conjunto de la sociedad, y sólo si se trata de conductas delictivas que supongan ataques fuertemente reprobables,

1833 Así ha sido definido por el TC "que la exigencia constitucional de proporcionalidad de las medidas limitativas de derechos fundamentales requiere, además de la previsibilidad legal, que sea una medida idónea, necesaria y proporcionada en relación con un fin constitucionalmente legítimo". Vid. la STC 169/2001, DE 16.7.2001.

1834 En este mismo sentido, vid. GÓMEZ AMIGO, L., Las intervenciones corporales como diligencias de investigación penal, Navarra, 2003, pág. 55. Adoptando la misma línea de entendimiento respecto a la concurrencia del principio de proporcionalidad como un presupuesto de legitimidad específico para la adopción de una medida restrictiva de derechos fundamentales, ha decido el Tribunal Constitucional español en la STC 207/1996, de 16.12.1996, que "la constitucionalidad de cualquier medida restrictiva de derechos fundamentales (...) viene determinada por la estricta observancia del principio de proporcionalidad. En este sentido, hemos destacado (SSTC 66/1995, de 8.5.1995 y 55/1996, de 28.3.1996) que, para comprobar si una medida restrictiva de un derecho fundamental supera el juicio de proporcionalidad, es necesario constatar si cumple los tres siguientes requisitos o condiciones: si tal medida es susceptible de conseguir el objetivo propuesto (juicio de idoneidad); si, además, es necesaria en el sentido de que no exista otra medida más moderada para la consecución de tal propósito con igual eficacia (juicio de necesidad); y, finalmente, si la misma es ponderada o equilibrada, por derivarse de ella más beneficios o ventajas para el interés general que perjuicios sobre otros bienes o valores en conflicto (juicio de proporcionalidad en sentido estricto)".

1835 Vid. ESPINOSA DE LOS MONTEROS, R. Z., El policía infiltrado. Los presupuestos jurídicos en el proceso penal español, cit., pág. 367; FASSBENDER, B., "El principio de proporcionalidad en la Jurisprudencia del Tribunal Europeo de Derechos Humanos", Cuadernos de Derecho Público, núm. 5, 1998, pág. 52. 
no sólo a la paz social, sino a valores tan esenciales como la vida, la dignidad humana, la libertad, sólo en estos casos es cuando la respuesta proporcionada puede incluir el recurso a medios también más gravemente lesivos o de mayor injerencia en la esfera de los derechos fundamentales ${ }^{1836}$.

De hecho, nos parece muy acertado este anterior pensamiento citado, teniendo en cuenta que no se puede aceptar la utilización de medios extraordinarios de investigación policial, entre ellas las infiltraciones policiales, muy restrictivas de derechos fundamentales, sin un control relativo a la necesidad e idoneidad de la autorización de la medida1837. Y es así por qué al utilizarse el agente encubierto para investigaciones que no sean de delitos graves, sin participación de organizaciones criminales y lo más grave, sin control judicial, estaríamos incentivando conductas antigarantistas al mismo tiempo en que quedaría banalizado el uso de estas técnicas de investigación ${ }^{1838}$.

Por esto, resulta imprescindible someter los pedidos de autorización para operaciones encubiertas a un filtro rígido y marcado por el carácter de excepcionalidad, de modo que este control sirva - a través del principio de proporcionalidad-como un arma de seguridad a la sociedad, al individuo y al Estado, evitándose de este modo una flexibilización abusiva de los derechos y garantías fundamentales de aquellas personas sometidas a la persecución penal. Con esta imprescindible actitud, es posible encontrar una zona de equilibrio que pueda a través de criterios de razonabilidad, proceder a la búsqueda de una solución al caso concreto, donde se presente el binomio eficacia garantista ${ }^{1839}$.

Estrechamente relacionado con la tan mencionada zona de equilibrio la intervención del agente encubierto hay que circunscribirla en el campo de tensión existente entre el deber de los poderes públicos de realizar una eficaz represión de la conducta delictiva y la protección de que tales derechos deben dispensar el Estado ${ }^{1840}$, justificándose así la

1836 GUZMÁN FLUJA, V., "El agente encubierto y las garantías del proceso penal", cit., págs. 224-225.

1837 En este sentido, "el fundamento justificante de la intervención policial se asienta, esencialmente, en el principio de proporcionalidad, pues sólo una finalidad de la suficiente relevancia podrá compensar debidamente la gravedad de la restricción del derecho fundamental". Cfr. la STS 1574/2004, de 8.3.2004.

1838 De la nota de proporcionalidad se deriva como consecuencia que este medio excepcional de investigación a través de agentes encubiertos requiere, también, una gravedad acorde y proporcionada a los delitos a investigar. Ciertamente que el interés del Estado y de la sociedad en la persecución y descubrimiento de los hechos delictivos es directamente proporcional a la gravedad de estos, por ello, solo en relación a la investigación de delitos graves, que son los que mayor interés despiertan su persecución y castigo, será adecuado el sacrificio de la vulneración de derechos fundamentales para facilitar su descubrimiento, pues en otro caso, el juicio de ponderación de los intereses en conflicto desaparecería si por delitos menores, incluso faltas se generalizase este medio excepcional de investigación, que desembocaría en el generalizado quebranto de derechos fundamentales de la persona sin justificación posible.

1839 Todavía hay que aclarase que por presentaren estos medios extraordinarios de investigación fuerte carga de abusividad a los derechos fundamentales, en la alternativa entre la eficacia del poder estatal y las garantías del ciudadano, incluso el en nivel superior de mayor agresividad en la respuesta, la primera debe ceder ante la segunda. Dicho de otro modo, la autoridad que tenga que analizar un pedido de expedición de resolución motivada para una operación encubierta, en caso de duda respecto a la necesidad, idoneidad y adecuación de la medida a los postulados del proceso penal garantista, deberá decidir por la denegación del pedido. Con esta opinión, Vid. también, GUZMÁN FLUJA, V., "El agente encubierto y las garantías del proceso penal", cit., pág. 225.

1840 MORENO CATENA, V., "Garantías de los derechos fundamentales en la investigación penal", Revista del Poder Judicial, núm. Especial II, 1997, pág. 133. Incluso muy importante citar la opinión de GÁLVEZ MUÑOZ al señalar que "el conflicto de intereses entre la obtención de la verdad en el proceso, por un lado, y la necesidad de tutelar los derechos fundamentales, por otro, no puede resolverse en abstracto y de una vez para siempre. Estamos, desde luego, de acuerdo en que los derechos fundamentales deben, en principio, abstracción hecha 
existencia del principio de proporcionalidad, que exige la ponderación de los intereses en conflicto ${ }^{1841 .}$

En la hipótesis de una infiltración policial estarían en juego o en colisión dos postulados de rango constitucional: de un lado, la eficacia buscada por el Estado a través del ius puniendi como forma de garantizar el derecho a seguridad colectiva; de otro, la garantía representada por el respecto a los derechos humanos fundamentales de aquel ciudadano que venga a situarse como investigado o imputado en un proceso penal (tensión eficacia versus garantías).

Sin embargo, hay que aclarar que la proporcionalidad es el método utilizado para la resolución de las colisiones de los principios. No es, según opinión de ALEXY, un principio en este sentido, pues la proporcionalidad en sí misma no entra en colisión con otros principios ${ }^{1842}$. Antes, es el procedimiento - conforme la clasificación del sistema de ALEXY 1843- para la solución de las colisiones de los principios.

Finalmente, es usual encontrar descrito que el principio de proporcionalidad como método de resolución de colisiones posee subprincipios o máximas parciales: adecuación, necesidad y proporcionalidad en sentido estricto.

Así, la exigencia de proporcionalidad comprendería tres exigencias o mecanismos para determinar si una norma o decisión que incide sobre los derechos fundamentales es proporcional $\mathrm{y}$, por ende, constitucionalmente legítima: adecuación, necesidad y ponderación.

de cualquier otra circunstancia, prevalecer sobre la verdad procesal". Cfr. GÁLVEZ MUNÕZ, L., La ineficacia de la prueba obtenida con violación de derechos fundamentales, cit., pág. 123.

1841 Vid. GONZÁLEZ-CÚELLAR SERRANO, N., Proporcionalidad y derechos fundamentales, cit., págs. 17-21; GONZÁLEZ BEILFUSS, El principio de proporcionalidad en la Jurisprudencia del Tribunal Constitucional, Navarra, 2003, pág. 97. Así es que planteado el problema de la colisión o encuentro entre derechos y libertades fundamentales en confronto con la eficacia estatal, como en la hipótesis de autorización para inicio de una infiltración a través de agentes encubiertos, "la solución consistirá en otorgar la preferencia de su respeto a uno de ellos, justamente aquél que lo merezca, tanto por su propia naturaleza, como por las circunstancias concurrentes en su ejercicio. No se trata, sin embargo, de establecer jerarquías de derechos ni prevalencias $a$ priori, sino de conjugar, desde la situación jurídica creada, ambos derechos o libertades, ponderando, pesando cada uno de ellos, en su eficacia recíproca, para terminar decidiendo y dar preeminencia al que se ajuste más al sentido y finalidad que la Constitución señala, explícita o implícitamente". Cfr. la STC 320/1994, de 28.11.1994.

${ }^{1842}$ Cfr. ALEXY, R., Teoría de los derechos fundamentales, cit., pág. 122, nota 84. Dentre los varios criterios adoptados por la doctrina sobre el tema de los derechos fundamentales, hemos citado el desarrollado por Robert Alexy en razón de que Tribunal Constitucional español aplica los criterios de resolución de colisiones de derechos sistematizados y expuestos por el citado autor y que trata de resolver dichas colisiones conforme a un procedimiento racional y justificado. Corroborando esta afirmación, véase RUIZ RUIZ, R., "La ponderación en la resolución de colisiones de derechos fundamentales. Especial referencia a la jurisprudencia constitucional española", cit., pág. 74. También JUAN MORESO al señalar que "en la teoría jurídica contemporánea la concepción más articulada de la ponderación, es decir, de la técnica consistente en resolver los conflictos entre principios que establecen derechos, es la de Robert Alexy". Cfr. JUAN MORESO, J., "Alexy y la aritmética de la ponderación", VV.AA., El principio de proporcionalidad y protección de los derechos fundamentales, México, 2008, pág. 63. Sin embargo, es muy importante señalar que se ha criticado que la máxima de la ponderación de ALEXY es una fórmula hueca, que no añade nada al acto mismo de pesar o de comprobar el juego relativo de dos magnitudes escalares, mostrándose incapaz de explicar por qué efectivamente un principio pesa más que otro; Cfr. con fuerte carga crítica, DE LORA, P., "Tras el rastro de la ponderación", Revista Española de Derecho Constitucional, núm. 60, 2000, págs. 363 y s. Otra crítica similar en GARCÍA AMADO. J. A., "¿Ductibilidad del derecho o exaltación del juez? Defensa de la ley frente a (otros) valores y principios", Escritos sobre filosofía del derecho, Santa Fe de Bogotá, 1997, pág. 208

1843 Para una profunda comprensión de las ideas defendidas por Robert Alexy sobre la teoria de la ponderación, Vid. ALEXY, R., "Las fórmula del peso", VV.AA., El principio de proporcionalidad y protección de los derechos fundamentales, México, 2008, págs. 11-38 y "Epílogo a la teoría de los derechos fundamentales", trad. C. Bernal Pulido, Revista Española de Derecho Constitucional, núm.66, 2002, págs. 13-64 


\section{a) Adecuación.}

La adecuación puede ser entendida como la idoneidad del medio utilizado para la persecución del fin deseado ${ }^{1844}$. Y esta idoneidad se traduce en la adaptación del medio al fin, es decir, que la norma debe ser apta para alcanzar efectivamente el objetivo pretendido. 0 dicho en otros términos, lo primero que se exige de una medida es que tenga un fin y lo segundo, que sea adecuada para el logro de ese fin.

El primer canon para precisar la proporcionalidad de una medida es que ésta sea susceptible de alcanzar el objetivo perseguido con ella: limitar el derecho fundamental como única forma para alcanzar un determinado propósito, el cual debe ser, además, constitucionalmente lícito. Esa medida restrictiva sólo es válida si es también funcionalmenteidónea; esto es, aquella medida restrictiva en efecto sirve para limitar el derecho por la razón que justifica la existencia del límite1845.

En opinión de BERNAL PULIDO, este subprincipio supone que toda intervención en los derechos fundamentales debe ser adecuada para contribuir a la obtención de un fin constitucionalmente legítimo ${ }^{1846}$.

Este principio, también denominado por BARNES como "juicio de aptitud"1847, representa la idea de que lo primero que se exige de una medida restrictiva de derechos es que tenga un fin determinado y que sea lícito, permeado por la legalidad; y el segundo, que esta sea adecuada para alcanzar el objetivo propuesto.

Correcto entonces es afirmar que, en general, la adecuación como principio fundamental de la proporcionalidad tiene por objeto verificar que la intervención en derechos fundamentales representa un medio idóneo o adecuado para contribuir al logro del fin que se pretende alcanzar con la misma ${ }^{1848}$.

Pensamos que el juicio de adecuación tiene una profunda relación con la cualidad de la medida aplicada. En este sentido, una medida deberá ser considerada adecuada si

\footnotetext{
${ }^{1844}$ En consecuencia, es previsible que "este principioexige realizar un juicio de ponderación entre la afectación que supone para el derecho fundamental implicado y la gravedad del ilícito que se trata de acreditar". Vid. la STS 1425/2004, de 13.4.2004. Sin embargo, de acuerdo con las palabras de PRIETO SANCHÍS, "la actuación que afecte a un principio o derecho constitucional ha de mostrarse consistente con el bien o con la finalidad en cuya virtud se establece. Si esa actuación noes adecuada para la realización de lo prescrito en una norma constitucional, ello significa que para esta última resulta indiferente que se adopte o no la medida en cuestión; y entonces, dado que sí afecta, en cambio, a la realización de otra norma constitucional, cabe excluir la legitimidad de la intervención". Vid. PRIETO SANCHÍS, L., Justicia Constitucional y Derechos Fundamentales, Madrid, 2003, pág. 200.

1845 VILLAVERDE MENÉNDEZ, I., VV.AA., "La resolución de conflictos entre derechos fundamentales. El principio de proporcionalidad", cit., pág. 169.

1846 Vid. BERNAL PULIDO, C., El principio de proporcionalidad y los derechos fundamentales, cit.,pág. 687. Incluso determinado sector de la doctrina llega a afirmar que "la idoneidad o adecuaciónde la medida hace referencia a la exigencia de que la medida adoptada contribuya (sea apta o útil) a la obtención del fin constitucionalmente legítimo, porque se parte de la idea de que una lesión o sacrificio de un derecho o bien constitucional sólo se justifica si, entre otros requisitos, se hace para la obtención de un fin valioso. Si la medida no es idónea o adecuada para la obtención de ese fin, se trata de una lesión inútil e injustificada". Cfr. MARTÍNEZ ZORRILLA, D., Conflictos constitucionales, ponderación e indeterminación normativa, cit., pág. 241.

1847 BARNES, J., "Introducción al principio de proporcionalidad en el derecho comparado y comunitario", Revista de Administración Pública, núm. 135, 1994, pág. 521.

1848 Vid. LOPERA MESA, G. P., Principio de proporcionalidad y ley penal, cit., pág. 387. En este contexto, "el examen de idoneidad supone por lo menos un fin. Cuando se determina más de un fin, la idoneidad del medio debe ser comprobada en relación con todos los fines. La reducción o ampliación de los fines determinados requiere ser justificada". Cfr. CLÉRICO, L., "El examen de proporcionalidad: entre el exceso por acción y la insuficiencia por omisión o defescto", VV.AA., El principio de proporcionalidad y protección de los derechos fundamentales, México, 2008, pág. 119, nota 18.
} 
consigue alcanzar la finalidad buscada, causando el menor perjuicio posible a un determinado bien sujeto a un conflicto.

En consonancia con lo anteriormente expuesto, la idoneidad constituye un criterio de carácter empírico, inserto en la prohibición constitucional de exceso, que hace referencia, tanto desde una perspectiva objetiva como subjetiva, a la causalidad de las medidas en relación con sus fines y exige que las injerencias faciliten la obtención del éxito perseguido en virtud de su adecuación cualitativa, cuantitativa y de su ámbito subjetivo de aplicación ${ }^{1849}$.

Una medida es adecuada cuando ostente calidad esencial que la habilite a alcanzar el fin pretendido - adecuación cualitativa一, cuando su duración o intensidad ha sido conducente con su finalidad - adecuación cuantitativa - y cuando dirigida a un individuo sobre el cual han incidido las circunstancias exigibles para ser actuada —adecuación subjetiva- La restricción al individuo en razón de la necesidad de represión a la criminalidad organizada será adecuada si ha sido apta y relevante para demostrar la práctica del delito investigado o imputado a alguien, si la duración no ha sido excesiva y si ha sido referido a un individuo sobre el cual incidan las circunstancias que conduzcan a la obtención o producción de la prueba ${ }^{1850}$.

Así es que en la infiltración policial sólo podemos hablar de adecuación cualitativa cuando se puedan conseguir datos relevantes sobre el entramado organizativo con efectos probatorios en un proceso penal ${ }^{1851}$.

En otros términos, lo que se quiere dejar claro es la importancia de que los órganos de persecución penal, preliminarmente a la infiltración del agente encubierto en la organización criminal, consigan obtener datos e informaciones que vengan a demostrar que este grupo deberá ser objeto de investigación, incluso porque el infiltrado tendrá que poseer al menos conocimientos esenciales sobre el funcionamiento del mismo.

En otra vertiente, conforme señala ESPINOSA DE LOS MONTEROS, la intervención del agente encubierto en la investigación penal supone la presencia engañosa del Estado en la vida de los investigados. Esta presencia es intensa y continua en relación con otros medios de investigación. Así, la permisibilidad del Estado para la autorización de la infiltración debe tener como requisito básico que la organización criminal en la que se pretende infiltrar a un agente revista caracteres de gravedad, que ponga en peligro la seguridad del Estado y el correcto funcionamiento de las instituciones. Sólo así, podremos hablar de adecuación cuantitativa ${ }^{1852}$.

1849 GONZÁLEZ-CUELLAR SERRANO, N., Proporcionalidad y derechos fundamentales en el proceso penal, cit., pág. 154. Esta también la opinión de ARMENTA DEU al señalar que "la idoneidad como adecuación objetiva y subjetiva de la causalidad de la medida limitativa en relación con sus fines, de modo que las injerencias sean adecuadas cualitativa, cuantitativamente y en su ámbito subjetivo de aplicación". Vid. ARMENTA DEU, T., Lecciones de Derecho Procesal Penal, cit., pág. 59.

1850 SCARANCE FERNANDES, A., "O equilíbrio entre a eficiência e o garantismo e o crime organizado", cit., pág. 238.

1851 Vid. GASCÓN INCHAUSTI, F., Infiltración policial y “agente encubierto”, cit., pág. 126.

1852 Cfr. ESPINOSA DE LOS MONTEROS, R. Z., El policía infiltrado. Los presupuestos jurídicos en el proceso penal español, cit., pág. 381. Al respecto, es de concluir que no siempre, por el simple hecho de que la investigación se refiera a un grupo organizado de delincuentes, deba ser utilizada la técnica del agente encubierto. Imagínese, pues, utilizarse de este medio extraordinario de investigación, con toda su carga negativa de flexibilización de derechos fundamentales, en la hipótesis de se investigar una banda de jóvenes que practica hurtos en supermercados visando la venda posterior de la res furtiva para la compra de drogas. 
Se exige, pues, el requisito de la gravedad de las actuaciones del grupo criminal1853, considerando la repercusión de sus actividades como factor de reproche social provocador de perjuicios y daños irreparables al buen desarrollo de la sociedad. Sólo de este modo se podrá justificar el empleo de técnicas policiales como el engaño y la disimulación como forma de ingreso del infiltrado en una determinada organización criminal.

Se puede concluir que el medio de investigación a través de la utilización de la figura del agente encubierto es idóneo cuando con su ayuda puede ser fomentado el fin deseado de desarticulación de una determinada organización criminal.

La medida de investigación a través del agente encubierto se reputará carente de idoneidad cuando su relación con el fin objetivadoen la operación sea de causalidad negativa, porque dificulte o aleje su consecución, o cuando su implementación resulte indiferente de cara a la realización del fin perseguido.

Para finalizar es muy importante destacar que solamente los medios de investigación criminal considerados como adecuados pueden ser proporcionados, esto es, encuentran una primera justificativa constitucional habilitándose para participar del test siguiente de la necesidad ${ }^{1854}$.

b) Necesidad.

La medida restrictiva no sólo debe ser idónea material y funcionalmente para limitar el derecho en razón de su fundamento; además, de entre las posibles maneras de imponer la medida restrictiva sólo cabe elegir la forma o el medio que resulte menos gravosa para alcanzar aquella finalidad ${ }^{1855}$.

Esta forma menos grave para que se pueda obtener el fin buscado con la medida corresponde al requisito de la necesidad. Dicho en otros términos, se reputará necesaria la medida restrictiva de las garantías esenciales del ciudadano cuandono exista un medio alternativo que, siendo igualmente idóneo, al mismo tiempo resulte más benigno desde la perspectiva de los derechos fundamentales objeto de intervención. Así, mientras el juicio de idoneidad se orienta a establecer la eficacia de la medida enjuiciada, el de necesidad se configura como un examen de su eficiencia, es decir, de su capacidad, en comparación con

Seria entonces inadecuada la utilización de la infiltración policial en razón de flagrante violación al principio de proporcionalidad y al requisito de la ultima ratio a ser obligatoriamente aplicado en estos casos.

${ }^{1853}$ En todo caso, no se puede olvidar que la resolución judicial que autorice la inferencia debe motivar su adopción comprobando que los hechos para cuya investigación se solicita revisten caracteres de hecho delictivo y que la solicitud y la adopción guardan la debida proporcionalidad entre el contenido del derecho fundamental afectado y la gravedad del hecho delictivo investigado. Del mismo modo, es cierto afirmar que de la nota de proporcionalidad se deriva como consecuencia que este medio excepcional de investigación requiere, también una gravedad acorde y proporcionada a los delitos a investigar. Ciertamente que el interés del Estado y de la Sociedad en la persecución y descubrimiento de los hechos delictivos es directamente proporcional a la gravedad de estos, por ellos, sólo en relación a la investigación de delitos graves, que son los que mayor interés despiertan su persecución y castigo, será adecuado el sacrificio de la vulneración de derechos fundamentales para facilitar su descubrimiento, pues en todo caso, el juicio de ponderación de los intereses en conflicto desaparecería si por delitos menores, incluso faltas se generalizase este medio excepcional de investigación, que desembocaría en el generalizado quebranto de derechos fundamentes de la personal sin justificación posible.

1854 En este sentido, Cfr. DIMOULIS, D; MARTINS, L., Teoria geral dos direitos fundamentais, cit., pág. 194.

1855 Vid. VILLAVERDE MENÉNDEZ, I., VV.AA., "La resolución de conflictos entre derechos fundamentales. El principio de proporcionalidad", cit., pág. 169. Del mismo modo, la opión de al señalar que "no deben existir otros medios menos gravosos para obtener la misma finalidad". Cfr., PÉREZ-CRUZ MARTíN, A. J., "Videovigilancia y derecho a la intimidad: ¿Un nuevo ejemplo de conflicto entre el derecho a la seguridad pública y el derecho fundamental a la intimidad?, Anuario da Facultade de Dereito da Universidade da Coruña, no. 1997, pág.. 408. 
otros medios, de alcanzar la finalidad propuesta con el menor sacrificio posible de otros principios en juego ${ }^{1856}$.

El subprincipio de la necesidad, también denominado de "intervención mínima", "intervención menos gravosa" o "subsidiariedad", corresponde al hecho de que no basta la adecuación del medio al fin. En palabras de GUERREIRO, este requisito también es conocido como "juicio de indispensabilidad"1857.

Lo que se percibe respeto a este criterio de la proporcionalidad es que el recurso a la lesión del derecho fundamental resulte necesario por ser inevitable, esto es, por no estar a disposición del poder público otro instrumento menos lesivo o menos ofensivo para alcanzar la finalidad perseguida ${ }^{1858}$.

Se exige, por lo tanto, la adopción de la alternativa menos gravosa o restrictiva de los derechos. Dicho de otro modo, para se saberse una medida es necesaria se debe indagar se existe otra medida igualmente eficaz.

Delante de lo anteriormente expuesto, estaría justificado que las infiltraciones por agentes encubiertos solamente deberán ser llevadas a cabo, de modo estrictamente excepcional, como ultima ratio ${ }^{1859}$, cuando se trate de investigaciones complejas, marcadas por la participación de grupos organizados de delincuentes de carácter muchas veces transnacional y dedicados a la comisión de delitos de relevante gravedad y repercusión social.

Además de ser idóneo, el medio utilizado debe ocasionar la menor restricción posible. Es preciso, para no ser desproporcionado, que el medio sea necesario al objetivo buscado, verificándose esta necesidad por el análisis de las alternativas puestas para el alcance del fin. Así, para resolver sobre la imprescindibilidad de la medida excepcional destinada a depurar casos de delincuencia organizada, normalmente muy gravosapara el individuo, debe el Juez concluir si existe o no otra medida apta para de alcanzar el mismo fin ${ }^{1860}$.

Quedaría por lo tanto definido que en caso de alguna duda en cuanto a la pertinencia objetiva y subjetiva de la medida violadora de derechos fundamentales, se inclinaría la balanza a favor de la libertad, de la preservación de los derechos fundamentales de la persona que estaría a punto de sufrir violaciones en sus garantías constitucionales.

1856 Cfr. LOPERA MESA, G. P., "Principio de proporcionalidad y control constitucional de las leyes penales", VV.AA., El principio de proporcionalidad y protección de los derechos fundamentales, M. Carbonell coord., México, 2008, pág. 181.

1857 Cfr. MEDINA GUERREIRO, M., La vinculación negativa del legislador a los derechos fundamentales, Madrid, 1996, pág. 129. Este mismo principio es denominado por PEDRAZ PENALVA y ORTEGA BENITO como "principio de exigibilidad" y es entendido por los citados autores como "aquel presupuesto que exige que el medio elegido para la consecución del fin propuesto no pueda ser sustituido por otro que resulte igualmente eficaz para ese fin pero que no limite ningún derecho fundamental o que lo lesione en menor medida". Cfr. Cfr. PEDRAZ PENALVA, E; ORTEGA BENITO, V., "El principio de proporcionalidad y su configuración en la jurisprudencia del Tribunal Constitucional y literatura especializada alemanas", cit., pág. 296.

1858 Vid. GASCÓN INCHAUSTI, F., Infiltración policial y “agente encubierto”, cit., pág. 128.

1859 Esto significa que si la consecución de una finalidad constitucionalmente legítima puede lograrse a través de una pluralidad de medidas, es imperativo escoger aquella que menos perjuicios cause al derecho fundamental o bien jurídico constitucional que limita. Sin embargo, lo que se quiere dejar claro es que otras medidas de investigación menos intrusivas a derechos fundamentales deberán ser previamente agotadas antes de ponerse en práctica una operación encubierta mediante el uso de agentes infiltrados.

1860 Vid. SCARANCE FERNANDES, A., "O equilíbrio entre a eficiência e o garantismo e o crime organizado", cit., págs. 238-239. 
El fundamento justificante de la intervención policial a través de la actuación de un agente encubierto se asienta entonces, esencialmente, en el principio de proporcionalidad, pues sólo una finalidad de suficiente relevancia podrá compensar debidamente la gravedad de la restricción del derecho fundamental ${ }^{1861 .}$

De otra parte, importante destacar que la necesidad significa la utilización, entre las varias medidas aptas, de la más favorable, más suave o menos restrictiva. Así es que implica en la necesidad de hacerse una comparación de las alternativas aptas y optimizar la menor lesión posible.

En este sentido, la necesidad se refiere a la índole o magnitud de la limitación que por ese medio debe soportar un derecho o libertad, de manera que entre una variedad de medios posibles el elegido debe ser aquel que representa una limitación menor.

Se busca a través de este postulado examinar si la medida adoptada podría ser cualificada como la menos restrictiva de las normas iusfundamentales de entre las otras posibles, y al mismo tiempo eficaces.

En realidad, de modo específico con relación a la actuación del agente encubierto, deberá hacerse hincapié en el hecho de que en el contexto de la infiltración policial debemos tener en cuenta que no todos los entramados criminales son susceptibles de investigación por el infiltrado, si no sólo cuando las demás diligencias de investigación resulten insuficientes, inadecuados e ineficaces frente a este tipo de criminalidad ${ }^{1862}$.

Se trataría de analizar si las autoridades de persecución penal han agotado todas las técnicas y métodos de investigación para lograrse obtener el objetivo de desmantelamiento del grupo criminal, utilizándose a priori, antes de poner en práctica una infiltración policial, otros medios de investigación amparada por la legalidad, como por ejemplo las observaciones, detenciones, apertura y examen de correspondencia privada, intervención y observaciones telefónicas, uso de informantes, entrada y registro en lugar cerrado, videovigilancia, etc.

Delante de los argumentos anteriormente detallados, se observa que la técnica del agente encubierto infiltrado en la delincuencia organizada será considerada necesaria cuando no pudo ser establecido otro medio, igualmente adecuado para el logro del fin de desarticulación de una determinada organización criminal, pero que suponga una menor restricción para los derechos fundamentales de los investigados.

Como colofón al tema, habrá que concluir que si no hay adecuación y necesidad de la medida concreta no habrá por que establecer un juicio de ponderación o de proporcionalidad sobre la materia, pues este ha quedado perjudicado.

c) La proporcionalidad en sentido estricto.

Hemos visto que el medio es idóneo cuando con su ayuda puede ser fomentado el fin deseado; es necesario, cuando no pudo ser establecido otro medio, igualmente adecuado

1861 Vid. la STS 1570/2004, de 08.03.2004.

1862 Vid. ESPINOSA DE LOS MONTEROS, R. Z., El policía infiltrado. Los presupuestos jurídicos en el proceso penal español, cit., págs. 382-383. Del mismo modo, siguiendo esta línea de pensamiento, "la infiltración policial no debe configurarse como una regla general de actuación en las investigaciones de la delincuencia organizada sino que deberá atenderse a los intereses en juego en cada caso concreto para determinar si es necesaria o no la actuación de un agente encubierto". Véase, GUZMÁN FLUJA, V., "El agente encubierto y las garantías del proceso penal", cit., pág. 205; ZARAGOZA AGUADO, J. A., "Nuevos instrumentos procesales en la lucha contra la criminalidad organizada", La protección de testigos y peritos en causas criminales, 2001, págs. $10-12$. 
para el logro del fin, pero que suponga una menor restricción para el derecho fundamental afectado.

Una vez que se ha considerado que la decisión cumple con las exigencias de idoneidad y necesidad, el siguiente paso consiste en analizar la proporcionalidad en sentido estricto ${ }^{1863}$, esto es, si el grado de satisfacción del derecho o bien constitucional que prevalece compensa la lesión o menoscabo del otro bien o derecho ${ }^{1864}$.

Efectivamente, la medida, además de ser idónea material y funcionalmente para limitar el derecho y hacerlo para proteger los otros derechos, bienes o intereses que imponen el límite, y necesaria e imprescindible, en el sentido de que entre las posibles sea la menos gravosa pero suficiente para ser idónea, debe ser equitativa en el reparto de los sacrificios. El derecho fundamental debe ser limitado en lo estrictamente necesario para asegurar la protección de aquellos otros derechos, bienes o intereses que lo limitan. Por tanto, el daño a estos últimos debe ser real o un riesgo cierto, y mayor que el que sufrirían si el derecho fundamental no se limita 1865 .

De este modo la limitación al derecho fundamental debe ser proporcional en sentido estricto, debe guardar una relación razonable con el peso e importancia de los argumentos que hablan a favor de una mayor y mejor protección del derecho afectado.

Se trata del postulado de la ponderación ${ }^{1866}$ de intereses propiamente dicho. Este procedimiento de ponderación es denominado por HESSE como principio de concordancia práctica el cual, junto con la de unidad de la Constitución, debe orientar el hecho de hacer compatible los intereses en colisión mediante una interpretación orientada al problema concreto ${ }^{1867 .}$

1863 Este criterio se caracteriza en resumen por el examen de la ponderación que deberá ocurrir entre las ventajas y las desventajas jurídicas a los bienes encontrados a tras de la intervención y del propósito buscado por el Estado. Se utiliza entonces de la metáfora de la balanza, en la cual se realiza una ponderación de los valores o bienes jurídicos, valorando el respectivo peso y debiendo prevalecer aquella queen la situación concreta presenta mayor urgencia o importancia. En este sentido, véase DIMOULIS, D; MARTINS, L., Teoria Geral dos Direitos Fundamentales, cit., pág. 210.

1864 Vid. MARTÍNEZ ZORRILLA, D., Conflictos constitucionales,ponderación e indeterminación normativa, cit., pág. 244.

1865 Cfr. VILLAVERDE MENÉNDEZ, I., VV.AA., "La resolución de conflictos entre derechos fundamentales. El principio de proporcionalidad", cit., pág. 170.

$1866 \mathrm{Al}$ respeto, señala GUASTINI de forma acentuadamente crítica que "ponderar no significa atemperar, conciliar o algo por el estilo; es decir, no significa hallar un punto de equilibrio, una solución intermedia, que tenga en cuenta ambos principios en conflicto y que de algún modo aplique o sacrifique parcialmente a ambos. La ponderación consiste sobre todo en sacrificar o descartar un principio aplicando el otro". Cfr. GUASTINI, R., "Principios de Derecho y discrecionalidad judicial", trad. de P. Andrés Ibáñez, Jueces para la democracia, núm. 34, 1999, pág. 44. La afirmación anterior podría conllevar a una idea "cerrada" de que la ponderación no sería compatible con la tesis del equilibrio entre normas o bienes, sin embargo, se puede encontrar en las palabras de PRIETO SANCHÍS las explicaciones necesarias al correcto entendimiento de la cuestión: "ciertamente, en el mundo del derecho el resultado de la ponderación no ha de ser necesariamente el equilibrio entre tales intereses, razones o normas; en ocasiones tal equilibrio, que implica un sacrificio parcial y compartido, se muestra imposible y entonces la ponderación desemboca en el triunfo de alguno de ellos en el caso concreto. En cambio, donde sí ha de existir equilibrio es en el plano abstracto o de la validez: en principio, han de ser todos del mismo valor, pues de otro modo no habría nada que ponderar; sencillamente, en caso de conflictose impondría el de más valor. Ponderar es, pues, buscar la mejor decisión (la mejor sentencia, por ejemplo)cuando en la argumentación concurren razones justificatorias conflictivas y del mismo valor". Cfr. PRIETO SANCHÍS, L.,"El juicio de ponderación constitucional", VV.AA., El principio de proporcionalidad y protección de los derechos fundamentales, México, 2008, pág. 91.

1867 Vid. HESSE, K., Elementos de direito constitucional da República Federal da Alemanha, trad. Luís Afonso Heck, Porto Alegre, 1998, pág. 66. 
Significa que aunque el medio elegido sea el que represente una limitación menor esta limitación debe ser proporcionada, es decir, no podrá ser de tal magnitud que implique vaciar de su contenido mínimo esencial el derecho o libertad en cuestión.

La ponderación es considerada entonces como un procedimiento práctico común en el razonamiento jurídico y sus resultados se consideran aceptables en general, no sólo en la práctica jurídica, sino también en la vida cotidiana ${ }^{1868 .}$

En otros términos, mediante su aplicación, se procede a la realización de una ponderación de intereses en el caso concreto de manera que si la injerencia en los derechos del ciudadano conlleva un sacrificio razonable o proporcionado de los mismos en relación con el interés que se persigue con la medida podrá procederse a su adopción ${ }^{1869}$; o dicho de otro modo y recogiendo la doctrina constitucional alemana, el principio de proporcionalidad en sentido estricto implica que la gravedad de la lesión y la trascendencia de sus razones justificativas han de estar en adecuada proporción ${ }^{1870}$.

Para comprender bien el significado de la ponderación como eje central de la proporcionalidad en sentido estricto, es fundamental citar a ALEXY, quien defiende que los principios son mandatos de optimización. Los principios no serían normas que establezcan exactamente lo que debe hacerse, sino normas que exigen que algo sea realizado en la mayor medida posible, dentro de las posibilidades jurídicas y reales existentes. El ámbito de lo jurídicamente posible está determinado por principios y reglas que juegan en sentido contrario. Por su parte, los enunciados fácticos acerca del caso determinan el ámbito de lo fácticamente posible1871. Desde esta perspectiva, la ponderación representaría el mecanismo para intentar resolver esta incompatibilidad entre normas prima facie.

Adoptado el criterio de la ponderación en la hipótesis concreta, podría ajustarse la medida limitativa de derechos fundamentales a los marcos de un proceso penal garantista, a la vez que se habría encontrado la efectividad del binomio eficacia-garantías.

Así se supone que en realidad la ponderación de los intereses en juego, es decir, las ventajas derivadas a favor de la protección del fin público, deben compensar los perjuicios causados en el derecho que se limita ${ }^{1872}$. Y más que esto, pues al efectuar la ponderación debe tenerse también presente la relevancia que en la misma tiene el criterio de la proporcionalidad como principio inherente del Estado de Derecho cuya condición de canon de constitucionalidad tiene especial aplicación cuando se trata de proteger derechos

1868BERNAL PULIDO, C., "La racionalidad de la ponderación", VV.AA., El principio de proporcionalidad y protección de los derechos fundamentales, México, 2008, pág. 45.

${ }^{1869}$ GONZÁLEZ-CUELLAR SERRANO, N., Proporcionalidad y derechos fundamentales en el proceso penal, cit.,págs. 225 y ss. Importante también sobre el tema, la STS 1813/2000, de 27.11.2000.

1870 En este sentido, este requisito consiste en establecer si la medida guarda una relación razonable con elfin que se procura alcanzar. También significa que la aplicación de un determinado instrumento o medio para alcanzar un determinado objeto o finalidad no debe ser irrazonable en sus relaciones recíprocas.

1871 Cfr. ALEXY, R., Teoría de los derechos fundamentales, cit., pág. 86. Sin embargo, como bien esclarece BERNAL PULIDO "la ponderación no ofrece ni garantiza una articulación sistemática de todos los principios jurídicos que, en consideración de su jerarquía, resuelva de antemano todas las posibles colisiones entre ellos y todas las posibles incompatibilidades entre las normas prima facie que fundamentan". Vid. BERNAL PULIDO, C., "La racionalidad de la ponderación", cit., pág.. 48.

1872 Vid. RODRÍGUEZ DE SANTIAGO, J. Māe, La ponderación de bienes e intereses en el Derecho Administrativo, Madrid, 2000, pág. 105. 
fundamentales frente a limitaciones o constricciones procedan estas de normas o resoluciones singulares ${ }^{1873}$.

Y se justifica esta necesidad de ponderar los intereses en conflicto en razón de la limitación de algún derecho fundamental, de manera que se sopesen los intereses individuales - los del titular del derecho fundamental-generalmente con el interés estatal que se pretende salvaguardar con la limitación ${ }^{1874}$.

Analizando este parámetro desde la óptica de una infiltración mediante la utilización de agentes encubiertos, habrá que concluir que la autoridad competente para decidir respeto a expedición de la resolución judicial motivada, debe analizar con carácter previo si la medida relativa a las tareas de investigación del infiltrado responde efectivamente a un equilibrio entre el interés general que se alcanza con la puesta en práctica de la operación policial y el perjuicio que origina sobre otros bienes en conflicto (las garantías y derechos de los investigados).

Habiendo una ponderación compleja en la protección penal, delante de la necesidad de proteger al máximo la libertad del investigado/imputado contra una irracionalidad punitiva y, también, promover al máximo el deber del Estado y el derecho de todos los ciudadanos y de la víctima de protección penal, la proporcionalidad posee una doble dimensión: significa prohibición de exceso y de insuficiencia. La prohibición de exceso se expresa cuando existe restricción de derechos fundamentales y ha sido por mucho tiempo, confundida como un sinónimo de la propia proporcionalidad y sus tres subprincipios (adecuación, necesidad y proporcionalidad en sentido estricto). Junto a ello, existe un nuevo ropaje de la proporcionalidad que viene ganando espacio junto a la doctrina constitucional contemporánea: la prohibición de insuficiencia ${ }^{1875}$.

La prohibición de insuficiencia no tiene un tratamiento dogmático tan sólido como la prohibición de exceso. Sin embargo, es posible identificar algunas características de esta perspectiva de la proporcionalidad. La principal es que se trata de una prohibición de la omisión mínimanente eficaz por parte del Estado de los derechos fundamentales.

Es una verdad incontestable que el principio de la proporcionalidad es normalmente invocado para justificar la adopción de medidas excepcionales de restricción a derechos individuales en relación al crimen organizado. Todavía, su aplicación debe observar los presupuestos y requisitos exigidos por la doctrina, con la finalidad de evitarse los excesos y no privar el individuo de derechos fundamentales para su exigencia digna. En pocas palabras, deberá ocurrir un "balance entre costes y beneficios"1876.

Según la opinión de SCARANCE FERNANDES, un presupuesto especial para la actuación del principio es de naturaleza formal, o sea, la legalidad. Así, el uso de medios especiales de obtención de pruebas o de medios de prueba extraordinarios o atípicos para

1873 Véase la STC 85/1992, de 8.6.1992.

1874 Con esta orientación, Cfr. ARMENTA DEU, T., Lecciones de Derecho Procesal Penal, cit., pág. 59. En nuestra opinión, deberá hacerse concreto el juicio en un balanceo entre las ventajas y las desventajas de la medida.

1875 Cfr. PIEROBOM DE ÁVILA, T. A., Provas ilícitas e proporcionalidade, cit., pág. 57. Así nos parece que existe una violación al cumplimiento de una obligación de protección o de prestación positiva iusfundamental cuando las reglamentaciones atacadas y las medidas estatales sean inidóneas o defectuosas para alcanzar el fin de protección obligatorio o cuando quedan muy por detrás de lo obligado.

1876 Esta expresión "balance entre costos y beneficios" parece indicar que será razonable toda medida que suponga un coste justificado en relación con los beneficios. 
la represión a la criminalidad organizada solo será posible con la invocación de la proporcionalidad, en la hipótesis de estar permitido por la legislación. Por tanto, la ley debe: reglar y explicitar claramente la medida excepcional de obtención o producción de prueba, con los requisitos necesarios para su aplicabilidad; indicar el procedimiento a ser observado; especificar los órganos, entidades o personas legitimadas a requerirla y efectivar la concretamente; indicar la autoridad competente para autorizarla y la motivación necesaria de la decisión a ser proferida ${ }^{1877}$.

Al final del análisis de este último subprincipio es imprescindible destacar que el examen de la proporcionalidad en sentido estricto se desarrolla según la doctrina de MARTÍNEZ ZORRILLA en tres fases consecutivas: la determinación del grado de la lesión o menoscabo que la decisión provoca en uno de los elementos en conflicto; la determinación del grado o la importancia de la satisfacción del otro elemento del conflicto, y la comparación de las magnitudes anteriores en orden a comprobar si la importancia de la satisfacción del elemento prevalente justifica la lesión o afectación del otro elemento ${ }^{1878}$.

Con el planteamiento expuesto hemos tenido la oportunidad de analizar los tres subprincipios de la proporcionalidad, correlacionando estos al tema del agente encubierto.

Aun respecto al tema de la proporcionalidad, es imprescindible no dejar de citar en el ámbito del Tribunal Europeo de Derecho Humanos la sentencia Teixeira de Castro versus Portugal, de 9.6.1998, en la cual se dejó claro que la intervención de agentes encubiertos debe estar circunscrita y rodeada de garantías, incluso en el tráfico de estupefacientes. En efecto, si la expansión de la delincuencia organizada lleva a no dudar de la adopción de medidas apropiadas, no queda más que, en una sociedad democrática, el derecho a que una buena administración de justicia ocupe un lugar tan preminente que no podamos sacrificarla por conveniencia. Como se puede apreciar, se percibe en esta sentencia un llamamiento general en el sentido de que mismo en caso de investigaciones contra el crimen organizado, deberá hacerse presente de forma irrenunciable, el principio de proporcionalidad.

En realidad, la proporcionalidad hace referencia a la propia motivación del auto que permite la medida, es decir, a la valoración de los indicios y sospechas fundadas y contrastables de los que se pueda inferir que se está cometiendo o se va a cometer un delito, la idoneidad de la medida, su necesidad y la ponderación de la misma como consecuencia necesaria del desarrollo de la investigación ${ }^{1879}$.

Se exige, pues, que el órgano jurisdiccional realice un juicio de proporcionalidad entre la finalidad perseguida y las circunstancias concurrentes que aconsejan tal restricción, dado que una medida de este tipo que fuera desproporcionada e irrazonable contrariaría los derechos fundamentales implicados en los actos de investigación ${ }^{1880}$.

1877 SCARANCE FERNANDES, A., "O equilíbrio entre a eficiência e o garantismo e o crime organizado", cit., pág. 238.

1878 Cfr. MARTÍNEZ ZORRILLA, D., Conflictos constitucionales, ponderación e indeterminación normativa, cit., pág. 245.

1879 En este sentido, vid. la opinión de MAPELLI CAFFARENA, B; GONZÁLEZ CANO, Mạ. I y AGUADO CORREA, T., Estudios sobre Delincuencia Organizada. Medios, instrumentos y estrategias de la investigación policial, cit., pág. 55. También, la SSTEDH de 15.6.1992, caso Ludi y de 9.6.1998, caso Teixeira de Castro.

1880 MARTÍNEZ GARCÍA, E., Eficacia de la prueba ilícita en el proceso penal (a la luz la STC 81/98 de 2 de abril), Valencia, 2003, pág. 162. 
Partiendo del presupuesto de que este medio extraordinario de investigación supone un plus de lesividad en las garantías procesales, señala ESPINOSA DE LOS MONTEROS que la infiltración no puede ser un medio de investigación generalizado para asegurar la eficacia del proceso penal frente a las organizaciones criminales sino que, por el contrario, habrá que optar a los intereses en juego en cada caso. Así, la gravedad de la conducta delictiva de la organización, la implantación de la organización en nuestro Estado, la perjudicial actuación para la sociedad, la influencia negativa que a modo de corrupción puede incidir en los poderes públicos, son elementos a tener en cuenta a la hora de ponderar la necesaria intervención de un agente encubierto ${ }^{1881}$.

Amén de la gravedad de las conductas perpetradas por la organización criminal a la hora de comprobarse la proporcionalidad de la medida de autorización de la infiltración policial, deberá el Juez o la autoridad que posee la misma atribución, prestar especial atención a otros elementos inherentes al encuentro de la razonabilidad: la duración de la infiltración; la amplitud de las facultades que se concedan al agente encubierto en el desempeño de sus labores como infiltrado; y el destino que ha de recibir la información obtenida a través de la infiltración ${ }^{1882}$.

En un primer término, como ya hemos tenido oportunidad de analizar, la cuestión de la duración del plazo de infiltración, así como las eventuales prórrogas, son temas que no han sido tratados con el rigor necesario en las legislaciones u ordenamientos jurídicos penales de nuestro entorno. A pesar de la relevancia del tema, en especial por su relación íntima con la búsqueda de la proporcionalidad de la medida limitativa de derechos y garantías fundamentales, se percibe muchas veces que el legislador ordinario ha dejado este factor temporal libre de reglas, hecho este que podrá relacionar las operaciones encubiertas como abusivas medidas de investigación criminal ${ }^{1883}$.

En lo relativo a la amplitud de las facultades concedidas al infiltrado durante la labor de infiltración, existen lógicamente límites que deberán ser observados como forma a no proporcionar al mismo "una carta en blanco" que venga a justificar posteriores actuaciones ilícitas o inmorales que puedan macular su actuación.

Incluso, serán estos límites que van a delinear la eventual responsabilidad penal, civil o administrativa del agente encubierto, derivando de sus actuaciones la toma de providencias por parte del mismo Estado que le otorgo la identidad supuesta y la autorización para infiltrarse en la banda criminal o incluso de personas individuales que vengan a sentirse perjudicadas y con sus derechos violados en razón de la labor del infiltrado ${ }^{1884}$.

1881 Vid. ESPINOSA DE LOS MONTEROS, R. Z., El policía infiltrado. Los presupuestos jurídicos en el proceso penal español, cit., pág. 386.

1882 Así lo piensa GASCÓN INCHAUSTI, F., Infiltración policial y “agente encubierto”, cit., pág. 133.

1883 En este punto nos cabe una vez más recordar que "una vez integrado en la asociación delictiva, la labor del agente encubierto se centra en practicar las diligencias necesarias para facilitar el descubrimiento del delito, la identificación de los delincuentes y localizar y asegurar las fuentes de prueba". Cfr. GUTIÉRREZ ZARZA, Mà . Á., Investigación y enjuiciamiento de los delitos económicos, cit., pág. 250.

${ }^{1884}$ Con relación al aspecto probatorio en la tarea investigatoria del infiltrado, señala ALONSO PÉREZ que "la exención de responsabilidad criminal justifica la acción delictiva del agente encubierto, concediendo eficacia probatoria a los resultados conseguidos con ella. Todavía, de se decidir enjuiciar al agente, bien porque su actividad haya infringido algún derecho fundamental o porque no sea aplicable el beneficio, la obtención es ilegal, por lo que deviene ineficaz su utilización". Cfr. ALONSO PÉREZ, F., Medios de investigación en el proceso penal, cit, pág. 575. 
Por fin, en cuanto al destino de las informaciones, datos o pruebas obtenidas por el agente durante la operación de investigación, es normal que se espere su entrega a las autoridades de persecución penal encargadasde la fiscalización del trabajo del infiltrado mientras estuviera en las entrañas de la organización criminal.

El gran problema surge a partir del instante en que el infiltrado tiene la obligación de repasar estos datos e informaciones de manera segura y libre de riesgos a su integridad física y a su propia vida ${ }^{1885}$. En este contexto, y desde el punto de vista de la dinámica criminal y siguiendo la disposición del artículo 282 bis 1 LECrim, la información que vaya obteniendo el agente encubierto deberá ser puesta a la mayor brevedad posible en conocimiento de quien autorizó la investigación. Asimismo, dicha información deberá aportarse al proceso en su integridad y se valorará en conciencia por el órgano judicial competente.

Como cierre a este asunto, se impone llegar a la conclusión de que la regla de la proporcionalidad es el parámetro decisivo para juzgar sobre la legitimidad constitucional de medidas restrictivas de los derechos fundamentales, y, en concreto de las actuaciones de los agentes encubiertos, de modo que estas últimas podrán ser lícitamente ordenadas como diligencias de investigación penal en la medida en que resulten proporcionadas.

Por ello, hacer referencia a los presupuestos de legitimidad de las medidas de infiltración de agentes estatales en grupos de delincuentes organizados es lo mismo que preguntarse sobre su proporcionalidad.

Aplicada esta regla de proporcionalidad a los casos de actuación de los agentes encubiertos, se podrá muy probablemente, verificarse en la situación concreta, si la ponderación justificaría la utilización de esta técnica especial de investigación criminal 1886 .

En resumen, el desarrollo del principio de proporcionalidad supone la verificación de tres aspectos fundamentales frente a las actuaciones que comprometan garantías superiores: debe verificarse la idoneidad del procedimiento para alcanzar el fin buscado; debe establecerse que no existan otros mecanismos menos lesivos para las garantías ciudadanas que permitan alcanza el mismo fin; y debe constatarse que exista proporcionalidad entre elfin perseguido y el nivel deafectación de derechos que elacto de investigación implica.

VI.3.2. La posible afección de derechos fundamentales en la actuación de un agente encubierto.

En este último apartado tendremos la oportunidad de analizar uno de los temas más sensibles referentes al estudio de la figura denominada agente encubierto: la eventual

\footnotetext{
1885 En este sentido, "los agentes encubiertos tendrán que poner en conocimiento del Juez, en su integridad toda la información que vayan recabando de sus investigaciones, al objeto de que éste acuerde las resoluciones procedentes, según lo que sea útil para la instrucción, por lo que le está vedado al infiltrado seleccionar a su libre arbitrio qué información le facilitará al Juez Instructor". Véase al respeto, PAZ RUBIO, J. Ma et alli., La prueba en el proceso penal. Su práctica ante los Tribunales, cit, pág. 401.

1886 Por este motivo, "la ponderación culmina cuando se ha agotado el sopesamiento de los argumentos que hablan a favor y en contra del peso de los principios, de la intensidad de la restricción a la luz de las circunstancias del caso concreto". Vid. CLÉRICO, L., "El examen de proporcionalidad: entre el exceso por acción y la insuficiencia por omisión o defescto", cit., pág. 152.
} 
violación de los derechos fundamentales a consecuencia de la actuación de un agente infiltrado en una organización criminal.

Para comprender mejor el significado de estos derechos clasificados como "fundamentales" habrá que analizar en que consisten los mismos, que indican exactamente, cómo y hasta donde deban ser jurídicamente tutelados, partiéndose de la tesis de la "relatividad de los derechos fundamentales", la cual ha sido denominada de "máxima de la cesión reciproca"1887.

De inicio, nos proponemos esclarecer qué significado tienen los derechos fundamentales ${ }^{1888}$ de una persona.

Sin pretensión de profundizar sobre la teoría de los derechos fundamentales, se hace imprescindible citar el clásico concepto de FERRAJOLI en el sentido de que los derechos fundamentales son aquellos derechos subjetivos que corresponden universalmente a todos los seres humanos en cuanto dotados del status de personas o ciudadanos, con capacidad de obrar; entendiendo por derecho subjetivo cualquier expectativa positiva de prestación - o negativa - de no sufrir lesiones - adscrita a un sujeto por una norma jurídica; y por status la condición de un sujeto, prevista así mismo por una norma jurídica positiva como presupuesto de su idoneidad para ser titular de situaciones y/o autor de los actos que son ejercicios de éstas ${ }^{1889}$.

Así, por derechos fundamentales o humanos puede entenderse el conjunto de facultades e instituciones que, concretan las exigencias de la libertad, la igualdad y la seguridad en cuanto expresión de la dignidad de los seres humanos, en un contexto histórico determinado, las cuales deben ser aseguradas, promovidas y garantizadas por los ordenamientos jurídicos a nivel nacional, supranacional e internacional, formando un verdadero subsistema dentro de estos ${ }^{1890}$.

Los conceptos ofrecidos anteriormente conducen a una idea de que los derechos y garantías fundamentales normalmente consagrados a nivel constitucional no son ilimitados ${ }^{1891}$, una vez que encuentran sus límites en los demás derechos que igualmente presentan rango constitucional.

Así, cuando de la existencia de un conflicto entre dos o más derechos fundamentales ${ }^{1892} \mathrm{el}$ intérprete deberá utilizar el principio de la concordancia práctica o de

${ }^{1887}$ Cfr. TAVARES, A. R., Curso de Direito Constitucional, São Paulo, 2006, págs. 452-453.

1888Para un análisis más profundizado respecto al tema de los derechos fundamentales, vid. BARTOLOMÉ CENZANO, J. C., Derechos fundamentales y libertades públicas, Valencia, 2003; DÍEZ-PICAZO, L. M., Sistema de derechos fundamentales, Madrid, 2003.

1889 FERRAJOLI, L., "Derechos fundamentales", Derechos y garantías. La ley del más débil, 2ª edición, Madrid, 2001, pág. 37.

${ }^{1890}$ Cfr. NOGUEIRA ALCALÁ, H., "Aspectos de una Teoría de los Derechos Fundamentales: La delimitación, Regulación, Garantías y Limitaciones de los Derechos Fundamentales", Revista Ius et Praxis, vol. 11, núm. 2, 2005, pág. 15.

1891 El Tribunal Constitucional ha señalado reiteradamente que el art. 24.2 CE no atribuye un ilimitado derecho de las partes a que se admitan y se practiquen todos los medios de prueba propuestos, sino solo aquellas que, propuestas en tiempo y forma, sean licitas y pertinentes (STC 70/2002 de 3.4.2002). Del mismo modo, el derecho a la prueba no es absoluto, ni se configura como un derecho ilimitado o incondicionado a que se admitan todas las pruebas propuestas por las partes o a que se practiquen todas las admitidas con independencia de su necesidad y posibilidad (SSTC 36/1983, de 11.5.1983; 89/1986, de 1.7.1986; 22/1990, de 15.2.1990; 59/1991, de 14.3.1991).

1892 Sobre la cuestión, señala VILLAVERDE MENÉNDEZ que "en rigor habría que decir que los conflictos, si existen, lo son entre el derecho fundamental y sus límites; y en la medida en que entre sus límites están los 
la armonización, de modo que coordine y equilibre los bienes en colisión, evitando el sacrificio total de unos en relación a otros, realizando una reducción proporcional del ámbito de alcance de cada uno de estos principios, siempre en búsqueda del verdadero significado de la norma y de la armonía del texto constitucional con su finalidad propia. Deberá ser buscado, entonces, un régimen de intangibilidad de los derechos fundamentales, cumpliendo al Estado no solamente respetando estos derechos sino también garantizando su efectividad ${ }^{1893}$.

De otra parte, a día de hoy es indiscutible que las diligencias de investigación y de prevención criminal pueden generar tres consecuencias distintas respeto de los derechos fundamentales del investigado. Pueden no afectar, ni limitar, ni vulnerar sus derechos; pueden limitar legítimamente sus derechos fundamentales; o pueden vulnerar ilegítimamente sus derechos fundamentales, generando pruebas ilícitas ${ }^{1894}$. Nos interesa en este momento, analizar con detalles la segunda posibilidad, o sea, la de una restricción ponderada y proporcional de derechos fundamentales de las personas sometidas al proceso penal 1895 .

En este contexto, la limitación de los derechos constitucionales se lleva a cabo por la necesidad de coordinar su protección con otros bienes y derechos constitucionalmente reconocidos ${ }^{1896}$.

Dicho en otros términos, los derechos fundamentales solo pueden ser restringidos cuando esta medida sea necesaria e indispensable, especialmente en la búsqueda de resguardar y proteger otros derechos e intereses protegidos por la tutela constitucional.

De esta forma, en lo que nos interesa tratar respeto de los aspectos probatorios relativos a la actuación del infiltrado, se extrae la constatación de que no se puede vulnerar derechos y garantías fundamentales sin la adecuada y debida justificación constitucional, jurisdiccional y legal, so pena de inutilidad de las pruebas obtenidas a través de esta técnica de investigación ${ }^{1897}$.

derechos fundamentales o constitucionales de terceros, sí se puede decir que existen conflictos entre derechos fundamentales. Lo que ocurre es que esta forma de expresarse es engañosa ya que hace pensar en una colisión entre derechoscuando la colisión es entre el derecho fundamental y sus límites". Cfr. VILLAVERDE MENÉNDEZ, I., "La resolución de conflictos entre derechos fundamentales. El principio de proporcionalidad", VV.AA., El principio de proporcionalidad y protección de los derechos fundamentales, México, 2008, pág. 161.

1893 GOMES CANOTILHO, J. J.; MOREIRA, V., Constituição da República Portuguesa anotada, vol. I, Coimbra, 2007, pag. 208.

1894 Vid. CORRÊA DE CARVALHO, J. T., Tráfico de drogas. Prueba penal y medidas restrictivas de derechos fundamentales, cit., pág. 88.

1895 La razón que fundamenta esta conclusión sería que "el orden o el sistema de valores constitucional no se encuentra jerarquizado axiológicamente. La relación lógica o sistemática entre los bienes jurídicos protegidos en los derechos constitucionales fundamentales no puede reducirse, por consiguiente, a esquemas de supraordenación o jerarquía". Cfr. SOLOZÁBAL ECHAVARRÍA, J. J. "Algunas cuestiones básicas de la teoría de los derechos fundamentales", Revista de Estudios Políticos. Nueva Época, núm. 71, Enero-Marzo, Madrid, 1991, pág. 98.

1896 Véase al respeto, TORRES DEL MORAL, A., Principios de derecho constitucional español, Madrid, 2004, pág. 318.

1897 En este sentido, señala RAMÍREZ JARAMILLO que respeto a los límites de la actuación del agente encubierto, deberá ser un regla que "siempre que necesite afectar un derecho fundamental de un tercero o del investigado, deberá obtener la respectiva autorización de la autoridad judicial competente, y en todo caso, con los debidos controles y revisión de la medida ante el juez de control de garantías". Vid. RAMÍREZ JARAMILLO, A. D., El agente encubierto frente a los derechos fundamentales a la intimidad y a la no autoincriminación, cit., pág. 49. Incluso se observa que en España, el art. 11.1 de la LOPJ define que no surtirán efecto las pruebas obtenidas, directa o indirectamente, violentando los derechos o libertades fundamentales. 
En realidad, los derechos fundamentales y sus limitaciones conviven en un régimen de concurrencia normativa de exclusión mutua ${ }^{1898 .}$

Y más, no es ocioso recordar en este momento que la eficacia en la respuesta penal contra determinadas actividades criminales, por muy graves que éstas sean, no justifica el sacrificio ilimitado de los derechos fundamentales y de las garantías constitucionales que el Estado de Derecho reconoce a todos los ciudadanos, porque la protección, tutela y respeto de tales derechos y garantías constituye el principal fundamento de los modernos sistemas democráticos. De ahí que el uso de técnicas excepcionales de investigación, como en la hipótesis de los agentes encubiertos, que en definitiva pueden producir una intromisión más o menos importante en los derechos individuales de cada persona, deba sujetarse a criterios restrictivos en su aplicación y a un acentuado control judicial que asegure una solución equilibrada y ponderada para los intereses en conflicto ${ }^{1899}$.

No cabe negar, sin embargo, que tratándose del derecho probatorio, el Estado de Derecho pierde cada vez más en importancia frente a la lucha contra la criminalidad, especialmente aquella marcada por el carácter de transnacionalidad. Los motivos, como ya hemos afirmado anteriormente, serían las dificultades probatorias en materia de combate a la delincuencia organizada y también la prevalencia muchas veces del eficientismo penal sobre las garantías fundamentales de aquellas personas sometidas a la persecución penal.

En consecuencia, el análisis del agente infiltrado debe situarse dentro del ámbito de los métodos secretos de investigación del delito, es decir, aquéllos en los que el Estado accede a la esfera privada del ciudadano sin su conocimiento, y menos aún con su consentimiento. Aquí radica el efecto perverso del agente encubierto, de donde nacen la mayor parte de los problemas procesales y los mayores riesgos para el adecuado respeto de los derechos fundamentales del ciudadano ${ }^{1900}$.

Nuestra tarea consistirá en minimizar esta problemática, y al mismo tiempo demostrar la viabilidad del medio extraordinario de investigación criminal representado por agente encubierto,pero una vez que sean obedecidas las reglas de proporcionalidad y del debido proceso legal.

Es algo común la afirmación de que el agente encubierto se infiltra de una manera abstrusa en el contexto social, valiéndose de la falacia. En esa mentira viviente que es él mismo, crea relaciones humanas, amistades, penetra en intimidades, recibe confidencias, presencia escenas a las que en absoluto hubiera tenido acceso de conocerse su verdadera condición ${ }^{1901 .}$

1898 BALAGUER CALLEJÓN, F., Manual de derecho constitucional, Madrid, 2005, pág. 60.

1899 Vid. ZARAGOZA AGUADO, J. A., "Tratamiento penal y procesal de las organizaciones criminales en el Derecho español. Especial referencia al tráfico ilegal de drogas", cit., págs. 114-115. Siguiendo por esta línea de pensamiento, afirma CORREAA DE CARVALHO que "se puede afirmar que la restricción de derechos fundamentales exige un motivo (justificación teleológica), una habilitación legal, una autorización judicial fundamentada en indicios delictivos y basada en la proporcionalidad (adecuación, necesidad y proporcionalidad en sentido estricto) de la medida". Cfr. CORRÊA DE CARVALHO, J. T., Tráfico de drogas. Prueba penal y medidas restrictivas de derechos fundamentales, cit., pág. 325.

1900 Vid. DELGADO MARTíN, J., Criminalidad Organizada, cit., pág. 83.

1901SEQUEROS SAZATORNIL, F., El tráfico de drogas ante el ordenamiento jurídico, Madrid, 2000, págs. 788789. Esta sería una de las criticas más duras en contra el agente encubierto, partiéndose de la constatación de que este efectivamente mantiene a través de la ocultación de su verdadera identidad, una proximidad muy destacable a los secretos de los otros miembros de la organización criminal, aprovechándose de la confianza y amistad adquiridos para invadir la intimidad y la privacidad de estas personas investigadas. 
No vamos defender aquí, sin más y directamente, que lo anteriormente afirmado no corresponda efectivamente a la verdad; nuestro objetivo se dirige a demostrar que existen justificativas lógicas y legales que vienen a posibilitar el empleo excepcional de esta técnica de investigación encubierta en hipótesis donde la gravedad de las conductas ${ }^{1902}$ atentan la seguridad colectiva, exponiendo a peligro la paz y la seguridad ciudadana.

De todo modo, es importante aclarar que el sistema de garantías supone la consagración de los derechos humanos que se apoyan en la existencia de diferentes pactos y tratados a nivel internacional, y las propias Constituciones a nivel interno de cada Estado ${ }^{1903}$.

Considerando los derechos y garantías fundamentales como todos aquellos derechos subjetivos que corresponden universalmente a todos los seres humanos en cuanto dotados del status de personas, de ciudadanos o personas con capacidad de obrar1904, nos parece pertinente apuntar que delimitar el contenido de un derecho fundamental constituye una actividad hermenéutica tendente a precisar cuáles son las facultades o posibilidades de actuación que cada derecho fundamental ofrece a su titular o, dicho en otros términos, cuál es su ámbito jurídicamente protegido ${ }^{1905}$.

Así, en este momento, el propósito es mirar los límites y controles con que debe contar la actuación encubierta para que no se genere un desconocimiento de los derechos a la intimidad, a la no autoincriminación, a la autodeterminación informativa y a otros derechos, debido a la posibilidad de que el agente encubierto pueda invadir a la esfera de privacidad mínima con que todo individuo debe contar, al tener acceso a datos de la vida íntima del investigado. Además, por el éxito de la investigación, puede verse tentado a inducir al investigado para que declare hechos incriminatorios que permitan obtener pruebas de cargo contra él mismo, omitiendo las debidas cautelas para obtener tal información y elementos derivados de la misma en el marco de un proceso justo, es decir, del debido proceso tanto en la investigación como en el juicio penal.

Todavía nadie pone en discusión que en ningún caso estará justificada la limitación de derechos fundamentales, como la libertad o la intimidad, en aras de la seguridad, si no existe efectivamente un riesgo y, además, si la medida restrictiva de ese derecho carece de eficacia en relación con su control ${ }^{1906}$.

En este contexto es imprescindible señalar que ciertos derechos fundamentales, como el derecho a la integridad física, el derecho a la intimidad en sus diversas manifestaciones -como la inviolabilidad del domicilio o el secreto de las comunicaciones - o el derecho a la autodeterminación informativa han constituido tradicionalmente límites a la actividad de los poderes públicos responsables del descubrimiento del delito y de sus pruebas; pero se ven asediados con una fuerza cada vez

1902 Para establecer la gravedad que justificaría el recurso a la técnica de infiltración policial no solo se debe atender a la previsión legal de una pena privativa de libertad grave, sino además debe valorarse la trascendencia social del delito que se trata de investigar. Cfr. la STS 4533/2007, de 27.6.2007.

1903 En este sentido, Cfr. ESPINOSA DE LOS MONTEROS, R. Z., El policía infiltrado. Los presupuestos jurídicos en el proceso penal español, cit., pág. 163.

1904 Cfr. FERRAJOLI, L., Los fundamentos de los derechos fundamentales, Madrid, 2001, págs. 19 y ss.

1905 En este sentido, vid. DOMINGO, T., ¿Conflictos entre derechos fundamentales?, Madrid, 2001, pág. 95.

1906En este sentido, la opinión de CORCOY BIDASOLO, M., "La perspectiva jurídico-penal", VV.AA., La seguridad pública ante el Derecho penal, Buenos Aires, 2010, pág. 3. 
mayor siempre que se introducen en el ordenamiento nuevas técnicas de investigación penal, que parecen justificarse en todo caso con el argumento de su mayor eficacia1907.

Y más que eso, pues como estos derechos no tienen el carácter absoluto, podrán ser restringidos a través de la técnica de ponderación como solución de conflictos de intereses, para determinar el contenido y resolver las situaciones de colisión de cualesquiera principios jurídicos ${ }^{1908}$. Esto significa que los derechos afectadospor la actuación del agente encubierto pueden ser limitados, respetando en todo caso lo previsto por la ley ${ }^{1909}$.

Se percibe entonces que en principio dos serían estos derechos violados: el derecho a la autodeterminación informativa, que consiste en el derecho de saber quién, cómo y cuando se tiene información de sí mismo, o sea, de elegir libremente el destinatario de una charla en la esfera privada, y el derecho a la intimidad en sentido amplio y en sentido estricto, así comprendidas la esfera privada e íntima.

Sin embargo, algunos autores como NÚÑEZ PAZ y GUILLÉN LÓPEZ incluyen también el especial derecho de todo ciudadano a no declarar contra sí mismo y a no confesarse culpable si se considera pasivo en la actividad jurisdiccional penal ${ }^{1910}$.

Por lo tanto, a lo sumo, quedarían especialmente en tres los derechos más afectados por la actuación del infiltrado: intimidad, autodeterminación informativa y no autoincriminación.

\section{a) El derecho a la intimidad.}

Si quisiéramos hablar un poco sobre el surgimiento de la intimidad ${ }^{1911}$ como categoría jurídica, tendríamos que decir que la misma es una invención de la modernidad e históricamente vinculada con el nacimiento de la burguesía que, en su defensa por la autonomía y la individualidad, empieza a construir un determinado ámbito salvaguardado de la injerencia de los demás, resaltándose al inicio la relación entre intimidad y propiedad, pues ésta era condición para acceder a aquélla, pero luego, a finales del siglo XIX, con la generalización de la clase burguesa, la intimidad se extiende a todas las

1907 Vid. GASCÓN INCHAUSTI, F., "Prólogo" a la obra Tráfico de drogas. Prueba penal y medidas restrictivas de derechos fundamentales, Curitiba, 2009, pág. 10.

1908 Los principios han dado lugar en los últimos tiempos a una abundante y compleja literatura teórica, en algunos casos con posiciones diversas. En lo que aquí respecta sólo nos interesa rescatar la idea de que los principios son normas aptas para la ponderación. Para un mayor análisis nos remitimos a: ALEXY, R., "Sistema jurídico, principios jurídicos y razón práctica", trad. de Manuel Atienza,Doxanúm. 5, 1988, págs. 139-151; PRIETO SANCHÍS, L., Ley, principios, derechos, Madrid, 2002, págs. 47-69; GARCÍA FIGUEROA, A., Principios y positivismo jurídico. El no positivismo principialista en las teorías de Ronald Dworkin y Robert Alexy, Madrid, 1998.

${ }^{1909}$ ESPINOSA DE LOS MONTEROS, R. Z., El policía infiltrado. Los presupuestos jurídicos en el proceso penal español, cit., págs.165-166.

1910 Cfr. NÚÑEZ PAZ, M. A;GUILLÉN LÓPEZ, G., "Entrega vigilada, agente encubierto y agente provocador: Análisis de los medios de investigación en materia de tráfico de drogas", cit., págs 134 y ss.

1911 Para se obtener un estudio muy completo y profundo respecto al tema, vid. CABEZUELO ARENAS, A. L., Derecho a la intimidad, Valencia, 1998; FARIÑAS MATONI, L. M., El derecho a la intimidad, Madrid, 1983; SAN MIGUEL, RODRÍGUEZ-ARANGO, L. G ., "Reflexiones sobre la intimidad como límite de la libertad de expresión", VV.AA., Estudios sobre el derecho a la intimidad, Madrid, 1992; HERRERO-TEJEDOR, F., La intimidad como derecho fundamental, 1aㅡ edición, Madrid, 1998; IGLESIAS CUBRIA, M., El derecho a la intimidad, Oviedo, 1970; REBOLLO DELGADO, L., El derecho fundamental a la intimidad, 2ª edición, Madrid, 2005. 
personas, al pasar de tener como fundamento el ser un bien de una clase social a surgir de la inviolabilidad de la persona humana1912.

Pero fue sólo a partir de 1890, cuando WARREN y BRANDEIS publican el trabajo "The right to privacy", que la intimidad se empieza a formular en términos técnicojurídico, aunque su aparición expresa en textos normativos sólo comenzó a mediados del siglo $\mathrm{XX}^{1913}$.

En el Derecho comparado suelen utilizarse varios términos para referirse a la idea de intimidad, pudiéndose citar en Italia donde se habla de riservatezza, en Francia donde de utiliza la expresión vie privée o en Alemania cuando se habla de privatsphäre. También en los países anglosajones emplean el término privacy, y en los países de lengua portuguesa la expresión intimidade. Más allá de ello, hay un cierto consenso por parte de la doctrina jurídica en afirmar que el concepto de derecho a la intimidad es de difícil elaboración ${ }^{1914}$, básicamente porque el derecho a la intimidad está sujeto a ciertas circunstancias que nos impiden establecer un concepto estático ${ }^{1915}$.

Aunque sea previsible que se encuentre en la doctrina un mosaico infinito de definiciones para referirse a la noción de intimidad, nos parece adecuado a los fines de nuestro trabajo utilizar el concepto formulado por O'CALLAGHAN, quien señala que se trata del poder concedido a la persona sobre el conjunto de actividades que forman un círculo íntimo, personal y familiar, poder que le permite excluir a los extraños de entrometerse en él y de darle una publicidad que no desee el interesado ${ }^{1916}$. También LÓPEZ JACOISTE ha defendido que el derecho a la intimidad tiene un ámbito propio de protección que no es otro que la vida privada de la persona, el cual engloba la vida familiar, y que está protegido contra injerencias externas ${ }^{1917}$. 0 en lenguaje más sencillo, la intimidad sería el derecho a no ser conocidos, en ciertos aspectos, por los demás. Es un derecho al secreto, a que los demás no sepan lo que somos o lo que hacemos ${ }^{1918 .}$

Sin embargo, amén del sinnúmero de conceptos que se pueden buscar en la doctrina y en la jurisprudencia, ha sido el libro de HIXSON, denominado "Privacyin a public society", publicado en el año 1987, el que, desde su propio título, demostró la paradójica ambivalencia en la que hoy se debate el derecho a la intimidad: la avasalladora invasión de

1912 Vid. SUÁREZ, E. M., "Estado de la cuestión sobre el derecho a la intimidad", Dikaion - Revista de la Facultad de Derecho de La Sabana, Vol., 3, 1994, págs. 67-68.

1913 MARTÍNEZ MARTÍNEZ, R., Tecnologías de la información, policía y Constitución, Valencia, 2001, pág. 58. En el artículo de Warren y Brandeis encontramos una definición ya clásica y consagrada que hizo fortuna: la intimidad es the right to be alone, ou sea, el derecho a estar solo, el derecho a la soledad.

1914 Vid. entre otros, RODRÍGUEZ RUIZ, B., El secreto de las comunicaciones: tecnología e intimidad, Madrid, 1998, pág. 4; SAN MIGUEL, RODRÍGUEZ-ARANGO, L. G ., "Reflexiones sobre la intimidad como límite de la libertad de expresión", VV.AA., Estudios sobre el derecho a la intimidad, Madrid, 1992, págs. 21-22; LÓPEZ DÍAS, E., El derecho al honor y el derecho a la intimidad, Madrid, 1996, pág. 187; FARIÑAS MATONI, L. M., El derecho a la intimidad, Madrid, 1983, pág. 309.

1915 El propio TC reconoció que "los criterios y estimaciones arraigados en la cultura de la sociedad", son condicionantes a la hora de determinar lo que se debe entender como atentatorio a la intimidad, y por lo tanto, lo qué es digno de protección jurídica por el derecho a la intimidad. Cfr. la STC 37/1988, de 15.2.1988, F. J. 7. 38.

1916 Vid. O’CALLAGHAN, X., Libertad de expresión y sus límites: honor, intimidad e imagen, Madrid, 1991, pág.

1917 LÓPEZ JACOISTE, J. J., “Intimidad, honor e imagen ante la responsabilidad civil”, VV.AA., Libro homenaje a Juan Berchmans Vallet de Goytisolo, Junta de Decanos de los Colegios Notariales de España, vol. IV, Madrid, 1988, pág. 537.

1918 SAN MIGUEL, RODRÍGUEZ-ARANGO, L. G, "Reflexiones sobre la intimidad como límite de la libertad de expresión", VV.AA., Estudios sobre el derecho a la intimidad, cit., pág. 18. 
lo público de todas las esferas de la vida humana y, como contrapunto, la exigencia apremiante de preservar determinados espacios para la supervivencia de los privados ${ }^{1919}$.

En lo que nos interesa en este estudio, con relación a la violación al derecho de intimidad ${ }^{1920}$ del eventual sospechoso o investigado, suele afirmarse que la finalidad inmediata de la actuación del agente infiltrado, como técnica de investigación, es esencialmente la de conseguir generar en los miembros de la organización criminal una confianza por la que le sea permitido la presencia, o incluso participación, en sus actividades. De esta forma, la sola existencia de un agente encubierto afecta al derecho a la intimidad de los investigados porque, ocultando su condición de policía, observa y oye lo que ocurre en conversaciones y conductas que tienen lugar en su presencia, o en domicilios de personas físicas y jurídicas a los que tiene acceso ${ }^{1921 .}$

Ya se percibe una constatación lógica e indiscutible: la actuación del infiltrado provoca violaciones al derecho a la intimidad de aquellas personas investigadas. Así, es razonable afirmar que se ve afectada la intimidad, cuando el acceso a la esfera privada del investigado y las informaciones obtenidas por el infiltrado no se facilitaría espontáneamente si se supiera que se trata de un agente policial ${ }^{1922}$.

En opinión de GASCÓN INCHAUSTI, la infiltración es lesiva por sí misma, con independencia de las posibles actuaciones que lleve a cabo el agente encubierto; de lo contrario, no haría falta una autorización judicial inicial para la infiltración en cuanto tal, y serían suficientes las autorizaciones singulares para actuaciones concretas -v.g., intervenir comunicaciones o registrar domicilios-1923.

Partiendo de esta idea nos parece claro que mientras sea algo indiscutible que la actuación del infiltrado tiene como consecuencia inmediata la afectación del derecho a la intimidad de aquellas personas investigadas, el hecho de que una autoridad estatal permita a través de una resolución motivada el inicio de la operación encubierta, a partir de un análisis del caso concreto a la luz de los principios de proporcionalidad y debido proceso legal, viabiliza por completa la labor del infiltrado, quedando restringido

1919 Cfr. PÉREZ LUÑO, A. E., "El derecho a la intimidad", VV.AA., Constitución y derechos fundamentales, J. Betegón; F. J. Laporta; J. Ramón de Páramo y Prieto Sanchís, L coords., Madrid, 2004, pág. 639.

1920 Según opinión de SUITA PÉREZ, incluso "la ocultación de la verdadera identidad del agente afecta por sí sola el derecho a la intimidad, y provoca en consecuencia una restricción al derecho de la intimidad de todos los componentes de la banda organizada". SUITA PÉREZ, "La diligencia de investigación por medio del agente encubierto", cit., pág. 251.

1921Por su parte, estima LÓPEZ ORTEGA que "es forzoso reconocer que la intervención de un agente encubierto puede afectar a la esfera individual, pues a diferencia de otras técnicas de investigación permite abarcar numerosos aspectos de la vida privada de la persona"; añadiendo posteriormente que, "cuando se trata de infiltración en redes organizadas, se requiere una intervención muy activa del agente, que debe recurrir a engaños muy elaborados para sorprender la confianza de las personas que pueden proporcionarle información de los hechos cometidos o en preparación". Vid. LÓPEZ ORTEGA, J. J., "Prueba y proceso equitativo. Aspectos actuales de la jurisprudencia europea", Cuadernos de Derecho Judicial, Volumen dedicado a "La Jurisprudencia del Tribunal Europeo de Derechos Humanos", Madrid, 1993, págs. 282 y 283. Ya en opinión de DELGADO MARTÍN, es precisamente el derecho a la intimidad el que se ve restringido por la actuación del agente encubierto; utiliza, sin embargo, un concepto de derecho a la intimidad muy amplio, "configurado como el poder de control sobre las informaciones que son relevantes para cada sujeto", muy semejante, como puede apreciarse, a lo que la doctrina alemana ha conceptuado como derecho de autodeterminación informativa. Vid. DELGADO MARTÍN, J., "El proceso penal ante la criminalidad organizada. El agente encubierto", Actualidad Penal, núm.1, 2000, págs. 8-9.

1922 Vid. CORRÊA DE CARVALHO, J. T., Tráfico de drogas. Prueba penal y medidas restrictivas de derechos fundamentales, cit., pág. 323.

1923 GASCÓN INCHAUSTI, F., Infiltración policial y “agente encubierto”, cit., pág. 105. 
legalmente el derecho fundamental del investigado. Ahora bien, esta restricción citada no se puede concretizar de forma ilimitada, sin criterios y sin trazos de razonabilidad.

Por su parte CORRÊA DE CARVALHO, siguiendo una línea de pensamiento con la cual estamos de acuerdo, señala con claridad que en la situación del agente encubierto el interés colectivo a una tutela efectiva que restablezca la orden legal y el poder/deber estatal de aplicar el derecho penal — persecución penal- permiten al legislador ordinario definir los criterios de restricción de la intimidad de una persona investigada o procesada, conforme a la ponderación de los bienes dispuestos. Así, los derechos fundamentales a la intimidad y al libre desarrollo de la personalidad son restringidos legítimamente por la infiltración autorizada y no hay ilegalidad en las acciones investigadoras fundadas en el engaño inherente al disfraz adoptado ${ }^{1924}$.

Bastaría en este caso añadir que llegada a la conclusión de que en la hipótesis concreta el pedido de autorización para una operación de infiltración consigue cumplir con los requisitos de idoneidad de la medida, o sea, que el agente encubierto mientras sea una diligencia restrictiva de derechos fundamentales resulta necesario para que las autoridades de persecución penal puedan alcanzar el fin de desmantelar la organización criminal; de necesidad, en el sentido de que el Estado haya agotado todas las posibilidades de investigación de los hechos, resultando infructíferos los intentos a través de medios e investigación tradicionales; y por fin, de proporcionalidad en sentido estricto, de modo a que delante del juicio de proporcionalidad instaurado frente al conflicto entre derechos fundamentales de rango constitucional, exista una correlación adecuada entre la intensidad del ataque al derecho y el resultado que se va a conseguir o obtener con la infiltración del agente, quedaría legitimada y oportuna la utilización de la técnica investigativa del agente encubierto, flexibilizándose el derecho a la intimidad.

Todavía, para una mejor comprensión del tema, es imprescindible referirse una vez más al hecho de que es algo incontestable que el derecho a la intimidad, como cualquier otro derecho fundamental, no es absoluto, y por lo tanto la inviolabilidad de la vida privada no es algo incondicional, pues ante ciertos supuestos, el ámbito personal y familiar constituido por las circunstancias íntimas debe ceder por exigencias del bien común ${ }^{1925}$.

Piénsese concretamente en una balanza donde están en posiciones opuestas el respecto a la intimidad de uno o de varios investigados, y de otro la preservación de la seguridad colectiva, donde millones de personas se encuentran en riesgo en razón de la actuación de una determinada banda de terroristas organizados.

1924 Vid. CORRÊA DE CARVALHO, J. T., Tráfico de drogas: Prueba penal y medidas restrictivas de derechos fundamentales, cit., pág. 357. Incluso, el propio Tribunal Constitucional español ha establecido que el derecho a la intimidad no es un derecho absoluto, como no lo es ninguno de los derechos fundamentales, pudiendo ceder ante intereses constitucionalmente relevantes siempre que el recorte que aquellos hayan de experimentar se revele como necesario para lograr el fin legítimo previsto, proporcionando para alcanzarlo y, en todo caso, sea respetuoso con el contenido esencial del derecho. Vid. SSTC, 70/2002, de 3.4.2002; 156/2001, de 2.7.2001 y 57/1994, de 28.2.1994.

1925 En este sentido, Cfr. MADRID-MALO GARIZÁBAL, M., Derechos fundamentales, Bogotá, 1997, pág. 203. También es la opinión del Tribunal Supremo en España, en la STS 5527/2003, de 17.9.2003, donde se ha afirmado que " ... este derecho que en definitiva es el derecho de toda persona a su intimidad, no tiene un carácter absoluto sino relativo si tenemos en cuenta que en toda sociedad democrática existen determinados valores que pueden justificar su limitación entre los que se encuentran la prevención del delito que incluya su investigación y castigo, orientado por fines de prevención general y especial y que también constituye un interés constitucionalmente legítimo". 
Pues, en efecto, quedaría claro que las necesidades públicas que permiten la injerencia en la vida privada son el interés público de la justicia, la seguridad nacional, el orden público, la prevención de infracciones penales y la protección de la salud y los intereses científicos, históricos y artísticos ${ }^{1926}$.

Sin embargo, para su limitación, por pequeña que sea, es necesario respectar la llamada regla de la proporcionalidad de los sacrificios. De esta forma, la suspensión del derecho ya sea ésta general o individual, no lleva implícita ni la desaparición del derecho ni la ausencia de límites a la actuación del Estado. Es clara una mayor discrecionalidad del poder del Estado, pero ello no implica arbitrariedad ${ }^{1927 .}$

Y que no se olvide de algo muy importante: esta tarea del Estado frente a la limitación excepcional de derechos fundamentales - como la intimidad-, como puede suponerse, no es nada sencilla. Además, se cree que para la persecución de delitos graves, en ocasiones, el Estado puede limitar fuertemente el derecho a la intimidad, para evitar la impunidad del delincuente, justificándose en intereses jurídicos de superior jerarquía, procedimientos que ponen a la luz pública hechos íntimos; considerándose, además, que el derecho a la intimidad no puede oponerse a la acción de las autoridades judiciales para aplicar sanciones, resolver conflictos o definir situaciones jurídicas ${ }^{1928 .}$

En apretada síntesis se podría concluir, citándo a ESPINOSA DE LOS MONTEROS, que el derecho a la intimidad puede verse limitado por los poderes públicos en la prevención e investigación del delito. Y más, el Estado impone necesaria para la efectiva seguridad de los ciudadanos ante los ataques de la criminalidad organizada y siempre que se respeten los límites para la adopción de una infiltración policial ${ }^{1929}$.

Otro punto de interés en lo relativo al estudio de la obtención de pruebas por el infiltrado y su valoración en el proceso penal dice respeto a si quedaría admisible este medio de investigación criminal a luz del derecho a la integridad moral de la persona investigada.

1926 Vid. FARIÑAS MATONI, L. M., El derecho a la intimidad, cit., pág. 309. También siguiendo esta línea, el Convenio Europeo de Derechos Humanos ha afirmado que "no podrá haber injerencia de la autoridad pública en el ejercicio de este derecho, sino en tanto en cuanto esta injerencia esté prevista por la ley y constituya una medida que, en una sociedad democrática, sea necesaria para la seguridad nacional, la seguridad pública, el bienestar económico del país, la defensa del orden y la prevención del delito, la protección de la salud o de la moral, o la protección de los derechos y las libertades de los demás". Con más detalles, Cfr. CARRILO SALCEDO, J. A., El convenio europeo de derechos humanos, Madrid, 2003, págs. 27 y ss.

1927 En este sentido, la opinión de REBOLLO DELGADO, L., El derecho fundamental a la intimidad, cit., pág. 445. Como consecuencia de este raciocinio, se puede afirmar que mismo estando restringido el derecho a la intimidad de una persona investigada a través de una infiltración policial, los excesos y las arbitrariedades eventualmente cometidas por el agente encubierto tendrán como respuesta la toma de providencia del propio Estado y del ciudadano que se torna victima (responsabilidad penal, civil y incluso administrativa), encerrándose la operación encubierta por ausencia de legalidad en la actuación del infiltrado. Y la explicación es sencilla, a la vez que debe el agente encubierto actuar estrictamente de acuerdo con lo permitido en la resolución judicial y guiado por criterios de razonabilidad.

1928 Vid. MADRID-MALO GARIZÁBAL, M., Derechos fundamentales, cit., pág. 204. Incluso, habrá que referirse una vez más a la memorable sentencia del Tribunal Europeo de Derechos Humanos, de 15.6.92, caso "Lüdi versus Confederación Helvética", en donde se ha establecido que la actuación del agente encubierto puede invadir la intimidad del investigado, pero dicha lesión del derecho fundamental a la intimidad debe ceder ante las exigencias de seguridad pública. El citado Tribunal sostiene que la posibilidad del descubrimiento de la intimidad por parte del agente es un riesgo que debe asumir quien se dedica a la ilícita actividad del tráfico de drogas.

${ }^{1929}$ ESPINOSA DE LOS MONTEROS, R. Z., El policía infiltrado. Los presupuestos jurídicos en el proceso penal español, cit., pág. 175. 
Respecto a esta cuestión, RUI PEREIRA aduce que en realidad la utilización de agentes infiltrados no es necesariamente ofensiva de este valor constitucional. Para verificar si la prueba por el obtenida está marcada por el vicio de la inconstitucionalidad habrá que verificar cuales son las finalidades buscadas por los agentes de la justicia. Si estuviéramos frente actividades preordenadas básicamente a la represión, tal no se compadece bien con las disposiciones constitucionales, por lo que la prueba será nula. Todavía, si la finalidad de la operación presenta carácter preventivo, el mismo autor entiende que la Constitución no prohíbe el recurso al agente infiltrado. Concluye, afirmando que la ponderación de las normas constitucionales relevantes en esta materia no debe excluir el recurso al agente encubierto, desde que ello sea siempre concebido como modo necesario, adecuado y proporcionado de impedir la práctica de futuros crimines y asegurar la incolumidad de bienes jurídicos ${ }^{1930}$.

En este contexto, la figura del agente encubierto será admisiblesi en las circunstancias en causa se respetan los principios de legalidad, de necesidad, de proporcionalidad y si no hubo violación del núcleo esencial del derecho. Solo si observando estas condiciones se infiere que la infiltración habrá de constituir una intromisión no abusiva de los derechos fundamentales, representará una actividad lícita de búsqueda de pruebas, y las pruebas desde ahí originadas serán consideradas validas ${ }^{1931}$.

En resumen, como ya mencionado antes, la infiltración mediante la ocultación de la condición de policía, esencia de la figura del agente encubierto, determina por sí sola una restricción del derecho a la intimidad de los miembros de la organización investigada ${ }^{1932}$.Y la única consecuencia que se puede arrojarse de esta constatación es que esa invasión de la esfera privada es aún más intensa en los casos de grupos de compleja estructura en los que tanto por la más larga duración de la infiltración como por la necesidad de una mayor integración en la organización el agente tiene más amplio acceso a los datos propios de la vida privada de los investigados, muchos de ellos ajenos a la propia misión ${ }^{1933}$.

Aunque estando de acuerdo con la situación anteriormente presentada, ponemos de manifiesto una vez más que por no ser la intimidad un derecho constitucional de índole absoluta e intocable habrá que interpretarse su eventual flexibilización en hipótesis excepcionales de actuación de un agente encubierto, como algo necesario y significativo a los fines de preservación de otros intereses también constitucionalmente amparados, tales como la seguridad nacional y de la propia sociedad delante del terror impuesto por las actuaciones de la delincuencia organizada. Y así mismo, dependerá la afectación de este

\footnotetext{
1930 Vid. en este sentido, PEREIRA, R., "Do agente encoberto na ordem jurídica portuguesa", VV.AA., I Congresso de Processo Penal, Lisboa, 2004, pág. 236. 97.

1931 ALVES MEREIS, M.A., "Homens de confiança", VV.AA., II Congreso de Proceso Penal, Lisboa, 2006, pág.

1932En cambio, la STEDH de 15.6.1992 (caso Lüdi; Base de Datos El Derecho 92/13838), apartándose del criterio de la Comisión (parágrafos 29 y 36) estima, en su parágrafo 40, que "el recurso a un agente encubierto no afecta por si, ni en combinación con las escuchas telefónicas, a la esfera privada del demandante en el sentido del art. 8 "pues desde el momento en que el Sr. Lüdi aceptó la transacción sobre la droga "debía pues darse cuenta de que cometía un acto criminal por aplicación del art. 19 de la Ley sobre estupefacientes y que corría el riesgo en consecuencia de encontrar un funcionario de policía infiltrado encargado de desenmascararlo". Entendemos, en cambio, que la intromisión en la esfera privada del investigado existe, aunque pueda quedar justificado por la finalidad de la investigación, siendo insatisfactorio el criterio manejado por el TEDH.

1933Vid. LÓPEZ ORTEGA, J. J., "Prueba y proceso equitativo. Aspectos actuales de la jurisprudencia europea", cit., pág. 283.
} 
derecho por las actuaciones del infiltrado, del grado de profundidad y complejidad de la operación encubierta, teniendo en cuenta que habrá casos en que hasta mismo no se podrá en puridad hablarse en violación de la intimidad de las personas investigadas, en razón de las insignificantes conductas practicadas por el agente estatal ${ }^{1934}$. Cítese como buen ejemplo la hipótesis de las infiltraciones de corto plazo, donde el infiltrado no llega a profundizar con lazos de amistad con otros miembros de la banda criminal, o hasta incluso en la hipótesis de alguna organización que utilice códigos y dialectos que vengan a dificultar la comprensión y la obtención de informaciones ${ }^{1935}$.

\section{b) El derecho a autodeterminación informativa.}

En 1983 el Tribunal Constitucional Federal Alemán dictó una sentencia que representó el primer paso en la elaboración y construcción del derecho a la autodeterminación informativa, acuñándose por primera vez este término. Así, aparece por primera vez, con independencia de haber sido utilizado por los estudiosos, en la sentencia del Tribunal Constitucional Alemán de 15.12.1983, relativa a la Ley del Censo de la República Federal Alemana ${ }^{1936 .}$

Este derecho se construye tomando como fundamento el concepto de intimidad o vida privada, puesto que trata de ofrecer tutela a la persona respecto a sus datos de carácter personal ante una posible utilización abusiva de los mismos mediante la informática u otro tratamiento automatizado ${ }^{1937}$.

La autodeterminación informativa ${ }^{1938}$ tiene cierta relación con el derecho al libre desarrollo de la personalidad. La parte central de dicho derecho equidista en la elección libre del destinatario de la comunicación y se concluye una vez éste haya recibido; en otros términos, no existe un derecho a que el receptor de la comunicación no divulgue a su vez lo recibido ${ }^{1939}$.

1934 Confirmando esta idea, señala ESPINOSA DE LOS MONTEROS que "la intervención del agente encubierto, no siempre comprometerá el derecho a la intimidad en el mismo grado sino que dependerá de las relaciones que el infiltrado entable con los miembros de la organización". Vid. ESPINOSA DE LOS MONTEROS, R. Z., El policía infiltrado. Los presupuestos jurídicos en el proceso penal español, cit., pág. 177.

1935 En este caso, podríase todavía hablarse de violación a otros derechos del investigado, a ejemplo de la inviolabilidad del domicilio.

1936 Importante señalar que la Sentencia del Tribunal Constitucional Alemán de 15.12.1983, que declaró inconstitucionales algunos artículos de la Ley del Censo de la República Federal Alemana, ha marcado un hito en la defensa de los derechos de la persona a preservar su vida privada. El recurso contra dicha Ley fue interpuesto por simpatizantes del movimiento de "los verdes", quienes obtuvieron una resolución cautelar del Tribunal Constitucional el 13 de abril de 1983, por la que se suspendió la entrada en vigor de la Ley del Censo y posteriormente la decisión definitiva sobre el fondo del recurso. En esta sentencia el Tribunal Constitucional germano señala que la proliferación de centros de datos ha permitido, gracias a los avances tecnológicos producir una imagen total y pormenorizada de la persona respectiva, un perfil de la personalidad, incluso en el ámbito de su intimidad, convirtiéndose así el ciudadano en "hombre de cristal".

1937HERRÁN ORTIZ, A. I., La violación de la intimidad en la protección de datos personales, Madrid, 1998, págs. 74-75. Monográficamente sobre el tema, véase DE LA CUEVA, P. L. M., "El derecho a la autodeterminación informativa",Temas Clave de la Constitución Española, Madrid, 1990.

1938 Con más detalles sobre este asunto, Cfr. MARTÍNEZ MARTÍNEZ, R., Una aproximación crítica a la autodeterminación informativa, Madrid, 2004; MURILLO DE LA CUEVA, P. L; PIÑAR MAÑAS, J. L., El derecho a la autodeterminación informativa, Madrid, 2009.

1939 GASCÓN INCHAUSTI, F., Infiltración policial y "agente encubierto", cit., pág. 95. En similar orientación encontramos la STS 702/1997, de 20.5.1997, la cual dispone que "las conversaciones que un ciudadano no perteneciente al poder pueda tener con otro, pueden grabarse por aquél sin precisar de autorización judicial, así como que, no hay vulneración del derecho a la intimidad cuando el propio recurrente es el que ha exteriorizado sus pensamientos sin coacción de ninguna especie. Tal exteriorización indica que el titular del derecho no desea que su intimidad permanezca fuera del alcance del conocimiento de los demás. Proyectar 
El postulado ahora analizado implica el derecho de los ciudadanos a saber quién, cómo y cuándo se tiene información sobre uno mismo; o dicho de otro modo, consiste en el derecho a elegir libremente al destinatario de la conversación y al testigo de la esfera privada. En esencia, se trata del derecho a que las relaciones de las personas con el Estado acontezca libres de engaños ${ }^{1940}$. En términos más concretos, éste es el derecho que tienen las personas a decidir por sí mismas cuándo y dentro de qué límites procede revelar secretos referentes a su propia vida.

La peculiaridad que nos interesa dice respeto a la constatación fáctica de que en caso de una infiltración de un agente encubierto junto a un grupo de delincuentes organizados, obviamente estarán todos los investigados ayunos de protección en cuanto a sus informaciones personales, quedando sus datos, opiniones, preferencias, hábitos, etc., expuestos a una persona no confiable, esto en razón de que durante la permanecía del infiltrado junto a sus "nuevos compañeros", estará el mismo a todo tiempo, gracias a la amistad conquistada y al engaño perpetrado, teniendo acceso al rol de actividades habituales, rutinas y confidencias de aquéllos.

De toda suerte, es verdad que solo el hecho de la infiltración afecta a la intimidad lato y llegado el caso strictu sensu, ya que aun cuando el agente encubierto únicamente busca información referente a ilícitos accede, sin pretenderlo, a datos de carácter reservado sobre la esfera privada, e incluso íntima, del investigado y de las personas de su entorno ajenas a las indagaciones, toda vez que observa y escucha aquello que, bien acontece en su presencia, o bien le cuentan. El poder público penetra en la vida del ciudadano sin su consentimiento, en tanto que la aquiescencia del investigado con que cuenta el agente no sirve para justificar la restricción del derecho, en la medida en que el consentimiento está viciado por venir fundado en el engaño ${ }^{1941}$.

Además, la actuación del agente encubierto hará necesaria en muchas ocasiones la utilización de medios materiales para garantizar su solvencia — dinero principalmente-, y en otras, el empleo de adminículos o instrumentos que sirvan para facilitar la investigación, como micrófonos, cámaras, aparatos fotográficos, reactivos, precipitantes y contrastes de uso, etc. Así, la sentencia del Tribunal Supremo de 21.6.1993 declaraba la habilidad de estos últimos como medios predispuestos para permitir el descubrimiento del autor del delito, aunque en dicho supuesto se trataba del uso de una sustancia reveladora fluorescente que sirvió luego para demostrar que el procesado había sido el autor de la sustracción de los billetes marcados de esa forma. También se podrían obtener filmaciones y grabaciones siempre que no se vulnere el derecho a la intimidad o la dignidad de la persona afectada por la grabación para obtener pruebas del delito por el

que el derecho a la intimidad alcanza inclusive al interés de que ciertos actos, que el sujeto a comunicado a otros, sean mantenidos en secreto por quien ha sido destinatario de tal comunicación, importa una exagerada extensión del efecto horizontal que se pudiera otorgar al derecho fundamental a la intimidad".

1940 En este sentido, vid. GASCÓN INCHAUSTI, F., Infiltración policial y “agente encubierto", cit., págs. 94-95.

1941GÓMEZ DE LIAÑO FONSECA-HERRERO, M., "Infiltración policial y proceso penal", cit., págs. 207-208. En opinión de DELGADO MARTÍN, desde el punto de vista estrictamente procesal, la actividad del agente encubierto afecta gravemente a distintos derechos fundamentales de las personas investigadas. No solamente significa una injerencia continuada en su vida privada, atentando contra el derecho a la intimidad, sino que también determina restricciones de su derecho de defensa, tanto durantela instrucción como durante el juicio oral. Vid. DELGADO MARTÍN, J., Criminalidad Organizada, cit., pág. 83. 
agente encubierto. Ello siempre que las grabaciones se realicen en espacios abiertos, libres y públicos, pero en el domicilio del sospechoso ${ }^{1942}$.

Cierto es que los derechos fundamentales son un logro de la historia y como tal deben de ser irrenunciables e inamovibles, pero nadie debe "rasgarse las vestiduras", cuando ante el fin supremo de la convivencia en libertad, en ciertos casos existan de manera clara y determinantes límites a los derechos individuales de algunos elementos de la sociedad, que no cumplen las normas dadas ${ }^{1943}$.

En esta línea de comprensión del tema, la libertad o el derecho a la libre decisión del afectado, in casu, del investigado, quedaría flexibilizado de modo excepcional, sidelante de un análisis de la proporcionalidad de esta limitación de derechos fundamentalesse llegarse a la conclusión de que el acceso de las autoridades de persecución penal, a través de los informes del agente encubierto, sería útil a los fines de salvaguardar los intereses de la seguridad colectiva en razón de la actuación de un determinado agrupamiento de delincuentes organizados para la practica de delitos graves y con repercusión social altamente negativa.

También es interesante señalar que cuando las actuaciones de investigación puedan afectar a los derechos fundamentales, el agente encubierto deberá solicitar del órgano judicial competente las autorizaciones que para estos supuestos establezca la Constitución y la ley, así como cumplir las demás previsiones legales aplicables ${ }^{1944}$. En efecto, quedaría minorada la eventual violación de un derecho fundamental del ciudadano investigado, teniendo como presupuesto la orden motivada en forma de resolución dictada por un órgano judicial con base en los preceptos de la proporcionalidad y legalidad de esta medida de investigación. Se trata de una providencia obligatoria a los efectos de no provocar una vulneración o violación injusta e ilegal sobre las garantías constitucionales inherentes a la cualidad de ciudadano presentada por el sospechoso investigado.

Por fin, dentro del tema analizado, hay que dejar claro que cualquier disertación jurídica sobre la figura del agente encubierto no puede obviar la regulación alemana de su homónimo, el VerdeckterErmittler, previsto en los §§ 100a-100e de la Ordenanza Procesal Penal, StPO. De forma mayoritaria, la doctrina procesal penal y constitucional alemana ha concluido que la sola presencia del agente encubierto en el entorno delictivo afecta el"derecho a la autodeterminación informativa"1945.

1942 Vid. MAGRO SERVET, V., Manual práctico de actuación policial-judicial en medidas de limitación de derechos fundamentales, cit., págs. 188-199.

1943 Vid. PEÑA ECHEVERRÍA, M. J., "La delincuencia organizada y su problemática desde la óptica de la investigación policial", cit., pág. 159.

1944 RIFÁ SOLER, J. M; RICHARD GONZÁLEZ, M; RIAÑO BRUN, I., Derecho procesal penal, Pamplona, 2006, pág. 286. Así, cuando la práctica de una diligencia por parte del agente encubierto pudiera afectar a algún derecho fundamental, será preciso recabar la correspondiente autorización judicial cuando haber previsión en la ley. En este punto, destacase que pocos ordenamientos jurídicos penales, a ejemplo de España, imponen al agente encubierto, la necesidad de obtención de una autorización de la autoridad competente, en la hipótesis de posible violación de derechos fundamentales del investigado o imputado (art. 282 bis 3 de la LECrim).

1945GÓMEZ DE LIAÑO FONSECA-HERRERO, M., "Infiltración policial y proceso penal", cit., págs. 205-206. 


\section{c) Derecho a la no autoincriminación.}

Este derecho se encuentra representado por la expresión latina nemo tenetur se ipsum accusare, que significa que la persona no es obligada a producir prueba contra sí mismo, o sea, que no puede ser impuesto a ella el deber de auto incriminarse ${ }^{1946}$.

Además, el derecho a la no autoincriminación parte del principio de que la carga de la prueba corresponde al que acusa, pues en virtud de la presunción de inocencia al acusado no se le puede obligar a contribuir con su propia condena; o en otras palabras, tiene la libertad de decidir si desea introducir información o elementos de prueba al proceso que lo puedaincriminar ${ }^{1947}$.

Partiendo del supuesto de que el principio del nemo tenetur posee orígenes en Inglaterra del siglo XIX, o en palabras de COSTA ANDRADE, más precisamente, a partir del año de 16791948 , habrá de esclarecerse que la garantía a no autoincriminarse tiene su base fundamental en el principio del derecho al silencio ${ }^{1949}$, el cual representa así el núcleo casi absoluto del citado principio.

De otra parte, es pacífica la idea que el derecho a no autoincriminarse tiene como primer fundamento el reconocimiento del instinto natural del hombre atinente a la propia conservación pues, salvo excepciones patológicas, la tendencia de todo comportamiento humano va inconscientemente acompañada de un resguardo de la propia existencia, siendo entonces contrario a la naturaleza forzar al ser humano para que reconozca algo que le traerá aparejadas consecuencias perjudiciales ${ }^{1950 .}$

Según expone MONTERO AROCA, el derecho al silencio es una manifestación de la presunción de inocencia y en las normas reguladoras del proceso penal no sólo no se puede imponer al acusado o investigado deber ni carga alguna relativa a la declaración, sino que incluso no puede permitirse que el Juez extraiga consecuencias negativas para aquél del ejercicio de su derecho al silencio ${ }^{1951 .}$

Importante también señalar, citando a ROXIN, que el derecho a no autoincriminarse tiene como garantía el deber de información previa a cualquier declaración del

\footnotetext{
1946 Con más profundidad respeto a este principio, Cfr. SILVA DIAS, A; COSTA RAMOS,V., $O$ direito a não auto-inculpação (Nemo tenetur se ipsum accusare) no processo penal e contra-ordenacional português, Coimbra, 2009; SCHIRMER ALBUQUERQUE, M., A garantia de não auto-incriminação. Extensão e limites, Belo Horizonte, 2008.

1947BEDOYA SIERRA, L. F., La limitación de derechos fundamentales en el sistema acusatorio colombiano, Medellín, 2008, pág. 152.

1948 Vid. COSTA ANDRADE, M., Sobre as proibições de prova no processo penal, Coimbra, 1992, pág. 9. Profundizando sobre el probable origen de la consagración legal del derecho contra la autoincriminación, señala JAUCHEN que: "Aparece en los primeros escritos canónicos, siendo posteriormente incorporada en el decreto de Graciano bajo estas palabras: Yo no le digo que se incrimine a sí mismo públicamente, ni se acuse usted mismo en frente de otros. Así lo sostiene San Crisóstomo (400 a. C.) comentando la Epístola de San Pablo a los Hebreos cuando dijo: No te digo que descubras eso, tu pecado, ante el público como una condecoración, ni que te acuses delante de otros". Cfr., JAUCHEN, E. M., Derechos del imputado, Bogotá, 2005, pág. 182.

1949 Conviene señalar a respecto que "el derecho al silencio ha venido a ser adoptado por la mayoría de las legislaciones procesales penales de los Estados de Derecho modernos, así como ha tenido una acogida y merecido consagración escrita en documentos internacionales de protección de los derechos del hombre, como es el caso del artículo 6o de la Convención Europea de Derechos del Hombre y del artículo 14 del Pacto Internacional sobre los derechos civiles y políticos de la ONU". Con más detalles, vid. FIGUEIREDO DIAS, J; COSTA ANDRADE, M; COSTA PINTO, F. L., Supervisão, direito ao silêncio e legalidade da prova, Coimbra, 2009, págs. 37 y ss.

1950 Véase, JAUCHEN, E. M., Derechos del imputado, cit., págs. 181-182.

1951Vid. MONTERO AROCA, J., Proceso penal y libertad. Ensayo polémico sobre el nuevo proceso penal, Navarra, 2008, págs. 420-421.
} 
investigado, la prohibición del uso de métodos ilegítimos para obtener información contra su voluntad, como malos tratos, agotamiento, ataques corporales, suministro de drogas, tortura, engaño, hipnosis, promesa de sentencias ilegales, detector de mentiras, alteración de la memoria o de la capacidad de compresión, y la prohibición de valorar la declaración realizada sin cumplir cualquiera de los anteriores requisitos ${ }^{1952}$.

La relación entre esta especie de derecho y la actuación del agente infiltrado puede ser explicada por las conductas engañosas eventualmente utilizadas por el Estado para obtener una declaración sobre la culpabilidad del miembro de la organización criminal.

El problema surge entonces delante de la constatación de que debe tenerse en cuenta que, en el marco de un proceso de corte acusatorio y garantista, la colaboración del investigado o acusado en el esclarecimiento de la verdad de los hechos por los cuales se le formule una imputación, sólo debe obtenerse gracias a la plena voluntad consciente y libre del mismo, previamente informado y asesorado por su defensor, que ponderando los costos y beneficios de hablar o de no hacerlo, tome una decisión al respecto; sólo así el investigado es tratado como persona y considerado como una de las partes en el proceso, el cual por lo mismo tiene derecho de ejercer su derecho de defensa como bien le plazca ${ }^{1953}$.

En este sentido, es algo normal que el infiltrado se utilice de una identidad supuesta para conseguir la amistad y confianza de los miembros del grupo criminal, con el objetivo de conocer los secretos y detalles de la estructura del clan objeto de investigación. Y más, pues iba a trabajar con la estrategia del engaño y de la disimulación para demostrar a los delincuentes su lealtad y ganas de pertenecer a la organización.

Así, frente a la utilización de la figura del agente encubierto como medio de investigación, se plantea la posibilidad de que el derecho fundamental a la no autoincriminación quede prácticamente anulado, debido a que es muy probable que el agente encubierto induzca al investigado para que le declare hechos o cosas autoincriminantes, que le faciliten luego obtener pruebas de cargo contra el mismo, sin el cumplimiento de las debidas cautelas para obtener tal información y elementos en el marco de un proceso justo.

Deberá ser tratada la cuestión, partiéndose de dos situaciones distintas: cuando el agente encubierto formula directamente preguntas al investigado tendientes a obtener datos autoincriminantes, y cuando el agente encubierto simplemente escucha lo que el investigado le cuenta sin que antes le haya formulado una pregunta autoincriminante.

En la primera situación, como acertadamente señala RAMÍREZ JARAMILLO, si el agente encubierto, buscando la confesión del investigado, a través de preguntas le sacara respuestas autoincriminantes, el derecho a la no autoincriminación sería vulnerado en su más alto grado, pues no sólo habría omitido informarle todas las advertencias antes de recibirle tales manifestaciones, sino que como funcionario de la policía judicial encargado en la investigación, habría asumido un papel activo con la finalidad de obtener información autoincriminatoria del investigado; es decir, al preguntarle ejerce cierta

\footnotetext{
${ }^{1952}$ ROXIN, C., La evolución de la política criminal, el derecho penal y el proceso penal, trad. Carmen Gómez Rivero y Ma . del Carmen Cantizano, Valencia, 2000, págs. 127 y 132.

1953 Véase, RAMÍREZ JARAMILLO, A. D., El agente encubierto frente a los derechos fundamentales a la intimidad y a la no autoincriminación, cit., pág. 109.
} 
forma de presión sobre la voluntad del investigado, lo que se torna incompatible con el derecho a no declarar1954.

Estaríamos delante de una hipótesis clara e incontestable de provocación del delito por parte del agente encubierto, a la vez que el investigado ha sido forzado (en razón del engaño empleado) a declarar contra su propia defensa.

De otra parte, si el infiltrado tan solo escucha las confesiones del investigado sobre eventuales delitos practicados, nos parece que estaríamos delante de simples declaraciones espontáneas prestadas por él mismo. No se trataría entonces de una violación al principio de la no autoincriminación ${ }^{1955}$.

Analizadas estas cuestiones y tomándose en cuenta los eventuales derechos que quedarían violados en la hipótesis de una infiltración a través de un agente encubierto (intimidad, el derecho a autodeterminación informativa y la no autoincriminación) surge una vez más la duda respeto a si podría o no, el Estado, promover restricciones de esta especie a los derechos fundamentales de la persona investigada.

Contestando esta interrogante, hemos de concluir afirmando que el Estado podrá restringir un derecho fundamental, mediante por ejemplo, una intromisión en la intimidad de la persona, sólo en aquellos supuestos en los que exista un grado suficiente de imputación de un delito, es decir, cuando existan razones objetivas que permitan la probabilidad de que ese sujeto esté cometiendo o haya cometido un delito. Únicamente la concurrencia de esos indicios legitima al Estado para rebasar el ámbito intangible de la libertad personal en el desarrollo de la investigación . En otro caso, se estaría otorgando a los órganos estatales una patente de corso para inmiscuirse en la vida privada de los ciudadanos, lo que resulta aún más grave en supuestos de actuación clandestina de agentes que ocultan su identidad ${ }^{1956}$.

Y más, en materia probatoria cabe que la admisión de un medio de prueba que se obtuvo con la lesión de un derecho fundamental vulnere el derecho a la presunción de inocencia de la parte contraria, en cuanto que este derecho ampara la calidad de la actividad probatoria producida ${ }^{1957}$.

Amén de estas consideraciones, nos toca indagar si hubo en el caso concreto de obtención de datos o pruebas por el infiltrado, un menoscabo a los derechos y garantías de la persona investigada, ya que hemos visto que para evitarse la violación inmoderada a la presunción de inocencia, deberá la resolución judicial autorizante de la labor del agente encubierto, quedar sometida a existencia de indicios suficientes de que exista una actuación de personas entorno a un grupo de delincuentes organizados, con la meta de practicaren delitos de gravedad y que puedan poner en riesgo la seguridad individual y colectiva.

Nos parece que como respuesta honesta a esta cuestión, sería muy interesante establecer de modo claro cuales serían en realidad las exigencias generales para la

1954 RAMÍREZ JARAMILLO, A. D., El agente encubierto frente a los derechos fundamentales a la intimidad y a la no autoincriminación, cit., pág. 112.

1955 El fundamiento para esta conclusión podría ser buscada en la doctrina de ROXIN que señala que "cuando alguien, fuera de un interrogatorio, se acusa frente a la policía de un delito, puede emplearse esta declaración en su contra aunque no haya sido instruido de sus derechos". Cfr., ROXIN, C., "La protección de la persona en el Derecho procesal penal alemán", cit., pág. 144.

1956 DELGADO MARTÍN, J., Criminalidad Organizada, cit., pág. 89.

1957 Vid. DÍAZ CABIALE, J. A., La admisión y práctica de la prueba en el proceso penal, Madrid, 1992, pág. 14. 
restricción de los derechos fundamentales de la persona sometida a un proceso penal, en la hipótesis de una infiltración de un agente encubierto en una organización criminal.

Se puede citar a tres de estos principales requisitos que deberán ser exigidos junto a los órganos de persecución estatal. En primer término, la exigencia de obediencia al principio de legalidad, o sea, habrá que estar a la regulación constitucional en concreto de cada derecho fundamental. En segundo lugar , cumple observar a necesidad impostergable de una autorización judicial ${ }^{1958}$ en el sentido de permitirse la restricción o flexibilización de un derecho fundamental; en definitiva, el control jurisdiccional, en cuanto a la limitación de cada derecho fundamental, depende en última instancia de las características propias de éste, pudiendo darse el caso de que tenga lugar con anterioridad a la propia restricción ${ }^{1959}$. En último lugar, el requisito de la proporcionalidad, el cual corresponde a la prohibición de exceso, sobre todo en las restricciones de los derechos fundamentales, a través de los principios de idoneidad, adecuación y la proporcionalidad en sentido estricto (o valoración de intereses).

Por fin, surge una cuestión planteada por BARJA DE QUIROGA, al afirmar que el problema surge cuando sin transgresión de derechos fundamentales se ha obtenido la prueba realizando una acción delictiva y se ha declarado que el agente encubierto está exento de responsabilidad criminal en relación con ella. Si se mantiene que la naturaleza jurídica de la exención ha de constituir una causa de justificación y, además, judicialmente ha sido declarada su concurrencia, esto quiere decir que la prueba se ha obtenido mediante una acción justificada, por lo que en este supuesto la prueba obtenida puede ser eficaz ${ }^{1960}$. Nos parece perfecta la observación anterior, pues a partir del momento en que una autoridad competente analice y decida expedir una resolución motivada y basada en los principios del debido proceso legal y de la proporcionalidad, este mandado judicial presenta fuerza jurídica como acto valido y perfecto, no importando que venga a provocar alguna violación a un derecho o garantía fundamental de la persona investigada.

Al fin de nuestro trabajo, esperamos que las reflexiones planteadas puedan contribuir de forma concreta para un provechoso encaje del uso de la técnica del agente encubierto frente al proceso penal, especialmente en razón del paradigma garantista que permea toda la concepción constitucional de la persecución penal frente a las más graves formas de criminalidad.

\footnotetext{
1958 En este sentido, deberá recordarse que para comprobar si la meida restrictiva de un derecho fundamental supera el juicio de proporcionalidad, es necesario constatar si cumple los tres siguientes requisitos o condiciones: "si tal medida es suceptible de conseguir el objetivo propuesto (juicio de idoneidad); si además, es necesaria en el sentido de que no exista otra medida más moderada para la consecución de tal próposito con igual eficacia (juicio de necesidad); y finalmente, si la misma es ponderada o equilibrada, por derivarse de ella más benefícios o ventajas para el interés general que perjuicios sobre otros bienes o valores en conflicto (juicio de proporcionalidad, en sentido estricto). Vid. SSTC 66/1995, de 8.5.1995; 55/1996, de 28.3.1996 y 207/1996, de 16.12.1996.

1959 DÍAZ CABIALE, J. A., La admisión y práctica de la prueba en el proceso penal, cit., pág. 135. 1960 Vid. LÓPEZ BARJA DE QUIROGA, J., Tratado de Derecho Procesal Penal, cit., pág. 537.
} 


\section{CONCLUSIONES}

Como resultado de nuestras investigaciones hemos alcanzado diversas conclusiones, que debidamente estratadas presentamos a continuación:

Primera.- El crecimiento y desarrollo de nuevas formas graves de criminalidad han puesto el Proceso penal en situación de alarma, a la vez que la persecución penal realizada en los moldes tradicionales, con métodos de investigación ya ampliamente conocidos, viene demostrándose insuficiente en el combate a la delincuencia moderna. Se impone entonces el establecimiento de reglas procesales compatibles con la modernización del crimen organizado, pero siempre respetando en lo posible los derechos y garantías fundamentales de los investigados o imputados.

Segunda.- La tensión de fuerzas resultante del conflicto entre la obligación estatal de sancionar los actos delictivos y la también necesaria preservación de las garantías fundamentales del ciudadano deberá ser resuelta a través del establecimiento de una armonía procesal penal, alcanzándose un equilibrio entre los vectores garantía y eficacia a través de la vigencia del principio de proporcionalidad.

Tercera.- El proceso penal contemporáneo deberá presentar en un Estado constitucional de Derecho la efectividad sancionadora estatal y el respeto a las garantías y derechos fundamentales de la persona sometida a la persecución criminal.

Cuarta.- En el contexto de un proceso penal equilibrado no se admite que la búsqueda de la eficiencia penal sea realizada a cualquier costo, por mucho que se trate de delitos practicados en el ámbito de la criminalidad organizada. Siendo así, se imponen límites que deberán ser obedecidos en el respeto a las reglas constitucionales inherentes a la defensa de los derechos fundamentales.

Quinta.- El peligro del crecimiento de una abusiva instrumentalización de las garantías puede convertir el proceso penal en un instrumento simbólico de freno a la delincuencia, hecho este que vendrá a contribuir a su descrédito frente a la sociedad, siendo incluso un nítido factor negativo de estímulo al trabajo de las autoridades de persecución penal.

Sexta.- El garantismo como modelo constitucional de inspiración iuspositivista consiste en un movimiento jurídico penal que busca la legitimación de la intervención punitiva del Estado a través de la observancia por éste de derechos y garantías individuales y colectivos, por lo que no es incompatible con la persecución a los delitos graves practicados especialmente por organizaciones criminales de actuación transnacional. Sin embargo, el peligro ideológico de su equivocada interpretación en un 
sentido único de defensa de derechos fundamentales de índole individual frente a eventuales abusos estatales — garantismo monocular e hiperbólico- podrá desvirtuar la función constitucional del proceso penal de equilibrar los vectores eficiencia y garantía.

Séptima.- Los derechos y garantías constitucionales no son siempre absolutos, debiendo centrarse la cuestión en los límites que deberán ser obedecidos en caso de violación de los mismos en situaciones especialmente excepcionales. En este contexto, se justifica la restricción de algunos derechos y garantías fundamentales del ciudadano, en cuando de la necesaria preservación de la seguridad colectiva en hipótesis de actuación delictiva de organizaciones criminales en supuestos como el narcotráfico, el terrorismo y otros delitos graves. La clave en este caso consiste en llevar a cabo una adecuada ponderación de los bienes en conflicto.

Octava.- Los actos típicos de situaciones de "emergencia penal", donde leyes demasiado rigurosas y sin criterios de eficacia comprobada, añadidos a medidas fundamentadas en la teoría del Derecho Procesal penal del enemigo, en las que se restringen garantías básicas sin criterios jurídicos debidamente fundamentados, no pueden ser considerados como propuestas legítimas y eficientes para el combate de la delincuencia organizada transnacional.

Novena.- Se impone en los días de hoy una lectura constitucional del proceso penal, pues este último deberá cimentar sus pilares en la normativa constitucional, de modo que se convierta en un punto central de equilibrio entre los valores "poder estatal" y "libertad". En este contexto, el proceso penal cumple dos funciones de fundamental importancia: por un lado, hacer viable la aplicación de la sanción en caso de práctica de una conducta delictiva, y de otro servir como instrumento efectivo de defensa de las garantías individuales y colectivas.

Décima.- Nuevas formas de investigación criminal necesitan ser incorporadas en los ordenamientos jurídicos de las distintas regiones del mundo con la finalidad de establecer una igualdad en términos de enfrentamiento a la actuación de organizaciones criminales de gran porte. Así, se hace necesario profundizar en la puesta en práctica de las bases de la inteligencia criminal, buscándose con esta actitud conocer a fondo los secretos y estructuración de estos grupos delictivos.

Décimo primera.- La figura del agente encubierto se presenta como una técnica eficaz y poderosa de penetración en el submundo de la delincuencia organizada, buscándose conocer y recoger informaciones, datos y pruebas que vengan a contribuir para el enjuiciamiento criminal de las personas responsables por la práctica de delitos graves. En consecuencia de lo afirmado, se convierte en una conditio sine qua non el uso por el infiltrado de las técnicas de disimulación y engaño a través del uso de identidad supuesta. 
Décimo segunda.- Los miembros de los cuerpos policiales son las personas adecuadas para la participación, elaboración y puesta en práctica del plan de infiltración a través de agentes encubiertos, a la vez que son los que poseen habilidades técnicas y un entrenamiento específico para enfrentarse a situaciones de absoluta hostilidad y peligro.

Décimo tercera.- Como medio extraordinario de investigación criminal, el agente encubierto deberá pautar sus conductas en el respeto de los principios de legalidad, especialidad, subsidiariedad, control judicial y proporcionalidad. Obedeciendo a estos postulados de rango constitucional, la actuación encubierta será conforme con las bases de un proceso penal garantista, tornándose lícitas las conductas del infiltrado realizadas desde que presenten relación de respeto al objeto de la investigación y al tenor de la resolución autorizante.

Décimo cuarta.- La responsabilidad penal, civil y disciplinaria del infiltrado dependerá de la expresa previsión legal, quedando el agente exento de responsabilidad cuando sus actuaciones presenten directa relación con la investigación y las mismas no lesionen, sin criterios jurídicos, derechos y garantías fundamentales de la persona sometida a la persecución penal.

Décimo quinta.- Las operaciones encubiertas a través del empleo de agentes infiltrados presentan en la práctica grandes niveles de eficacia en la lucha contra la expansión de las formas más graves de criminalidad. Así, en casos de nacotráfico, lavado de activos o terrorismo se emplean agentes encubiertos solamente en casos comprobados de actuación de organizaciones criminales, siempre que esté constatada la gravedad de los hechos. Aunque el plan y estructuración de la operación de infiltración presenta un costo financiero elevado, los resultados obtenidos en muchos supuestos justifican la inversión que deberán los Estados prestar a esta técnica de investigación.

Décimo sexta.- El agente encubierto se aprovecha de una oportunidad favorable para involucrarse en el ámbito íntimo del sospechoso para de esa manera poder investigar y prevenir un delito que no podría haber sido interceptado de otra forma. En este contexto, el empleo de agentes encubiertos quedaría condicionado a la obediencia al principio de ultima ratio: su empleo es el último recurso cuando hayan sido agotadas todas las formas tradicionales de investigación, las cuales menos invasivas a derechos fundamentales. Del mismo modo, en el análisis de la viabilidad jurídica de la infiltración se impone por encima de todo el respeto al principio de proporcionalid como criterio de valoración de obediencia a los requisitos de necesidad, idoneidad y ponderación, de forma que quede legitimada la actuación estatal contra las afecciones a la intimidad, la autodeterminación informativa y no autoincriminación inherentes a los ciudadanos investigados.

Décimo séptima.- La prueba aportada al proceso y obtenida a partir de una operación a través de agentes infiltrados en una determinada organización criminal merece ser admitida como una prueba más dentro del conjunto de actos probatorios, a si 
tomamos en cuenta el hecho de que la limitación a los derechos fundamentales del sospechoso se encuentran justificados a la luz del principio de proporcionalidad y sus vectores de idoneidad, necesidad y ponderación. Deberá incluso ser admitido el testimonio del infiltrado, momento en que el Juez tendrá que valorar el contenido de sus declaraciones tomando en consideración su condición de agente policial que ha recibido autorización judicial para infiltrarse en una organización delictiva.

Décimo octava.- Respeto a la prueba obtenida por el agente encubierto, tiene particular importancia el análisis del nivel de la restricción llevada a cabo en los derechos fundamentales del investigado, surgiendo en este punto tres cuestionamientos centrales: si el medio de investigación elegido es apto a la obtención del fin perseguido en la operación encubierta; si han sido previamente intentados los demás medios de investigación menos invasivos a las garantías constitucionales; y si las ventajas derivadas del fin publico de preservación de la seguridad colectiva compensan los eventuales perjuicios provocados a los derechos que tienen que ser limitados. En cada caso, si pueden ser contestadas positivamente las tres anteriores preguntas se tendrán por cumplidos los presupuestos para que sea viable jurídicamente una autorización para que pueda actuar el agente infiltrado.

Décimo novena.- En clave operativa, el futuro del tema del agente encubierto dependerá de una inversión financiera significativa de los Estados en los cuerpos policiales, amén de una reglamentación detallada y específica de todos los principales requisitos exigibles para el plan de infiltración: competencia autorizante, duración de la medida, la posibilidad de prórrogas, la forma de control de la operación, las causas de exención de responsabilidad del infiltrado, etcétera. 


\section{BIBLIOGRAFÍA}

ABADE, D. N., Garantias do processo penal acusatório, Rio de Janeiro, 2005.

ABADINSKY, H., Organized Crime, Chicago, 1997.

ADRIASOLA, G., El nuevo derecho sobre tóxicos y el lavado de dinero, Montevideo, 1994.

AGUADO CORREA, T., El principio de proporcionalidad en Derecho Penal, Madrid, 1999.

AGUADO CORREA, T., GONZÁLEZ CANO, Ma․ I.; MAPELLI CAFFARENA, B; Estudios sobre Delincuencia Organizada. Medios, instrumentos y estrategias de la investigación policial, Sevilla, 2001.

AGUDO ZAMORA, M. J., "La interpretación de los derechos y libertades constitucionales a través de los tratados internacionales: la técnica del artículo 10.2", Estudios Penales y Jurídicos, Córdoba, 1996.

AGUILAR LÓPEZ, M. A., "Presunción de inocencia", http://www.reformapenal.inacipe.gob.mx.

AGUILLERA PORTALES, R. E; LÓPEZ SÁNCHEZ, R., "Los derechos fundamentales en la filosofía jurídica garantista de Luigi Ferrajoli", Revista Letras Jurídicas, núm. 4, 2007, http://letrasjuridicas.cuci.udg.mx/.

AINAGA VARGAS, Ma. C., "Nota sobre el Estado Constitucional Democrático de Derecho", Revista Letras Jurídicas, vol. 7, 2003, http://www.letrasjuridicas.com.

ALBERTO JULIANO, M; RUBÉN AUED, N., La probation y otros institutos del derecho penal, Buenos Aires, 2001.

ALBRECHT, H. J, Criminalidad transnacional, comercio de narcóticos y lavado de dinero, Bogotá, 2001.

ALBRECHT, P. A., Kriminologie, Munich, 1999.

ALDECOA LUZÁRRAGA, F., La Europa que viene: el Tratado de Lisboa, Madrid, 2008.

ALEO, S., Sistema penale e criminalità organizzata. Le figure delittuose associative, Milán, 1999.

ALEXY, R., Teoría de los derechos fundamentales, Madrid, 2001.

- "Sistema jurídico, principios jurídicos y razón práctica", trad. de Manuel Atienza, Revista Doxa, núm. 5, 1988.

- "Las fórmula del peso", VV.AA., El principio de proporcionalidad y protección de los derechos fundamentales, México, 2008.

- "Epílogo a la teoría de los derechos fundamentales", trad. C. Bernal Pulido, Revista Española de Derecho Constitucional, núm. 66, 2002.

- "Colisão de direitos fundamentais e realização de direitos fundamentais no Estado Constitucional Democrático", Revista de Direito Administrativo, núm. 217, 1999.

ALFONSO RODRÍGUEZ, O., La ineficacia probatoria del testimonio secreto, Bogotá, 1996.

ALMEIDA FERRO, A. L., Crime organizado e organizações criminosas mundiais, Curitiba, 2009.

ALMEIDA DE MORAES, A. R., Direito Penal do Inimigo. A terceira velocidade do Direito Penal, Curitiba, 2008.

ALONSO GARCÍA, R., Tratado de Lisboa y versiones consolidadas de los Tratados de la Unión Europea y de funcionamiento de la Unión Europea, Madrid, 2008. 
ALONSO GARCÍA, R; SARMIENTO, D., La carta de los Derechos Fundamentales de la Unión Europea, explicaciones, concordancias, jurisprudencia, Madrid, 2006.

ALONSO PÉREZ, F., Medios de investigación en el proceso penal. Legislación, comentarios, jurisprudencia y formularios, 2a edición, Madrid, 2003.

ALSCHULER, A. W., "Plea bargaining and his history", Columbia Law Review, 1979.

ALVARADO VELLOSO, A., El debido proceso de la garantía procesal, Buenos Aires, 2003.

- Garantismo procesal contra actuación judicial de oficio, Valencia, 2005.

- "El garantismo procesal", VV.AA., Activismo y garantismo procesal, Córdoba, 2009.

ÁLVAREZ, A. E., "La prueba prohibida en el proceso penal", Revista de Ciencias Penales, número 4, Montivideo, 1999.

ÁLVAREZ RODRÍGUEZ, J. R; MARTÍN ACÍN, F., Metodología del atestado policial. Aspectos procesales y jurisprudenciales. Práctica jurídica, Madrid, 1999.

ÁLVAREZ SACRISTÁN, I., La justicia y su eficacia. De la Constitución al proceso, Madrid, 1999.

ÁLVAREZ-VALDÉS, I. G., “Equipos conjuntos de investigación”, La Ley Penal, núm. 2, año 1, Madrid, 2004.

ALVES BENTO, R., "Agente infiltrado. Busca pela legitimação constitucional", Limites Constitucionais da Investigação, L. F. Gomes; P. Taques y R. Sanches Cunha coords., São Paulo, RT, 2009.

ALVES MEREIS, M. A., O regime das provas obtidas pelo agente provocador em Processo Penal, Coimbra, 1999.

AMBOS, K., Processo Penal Europeu, Preservação das garantias e direitos individuais (Princípios processuais e análise da Convenção Européia de Direitos Humanos), Rio de Janeiro, 2008.

- Terrorismo, tortura y Derecho penal. Respuestas en situaciones de emergencia, Barcelona, 2009.

- Derecho penal el enemigo, trad. C. Gómez-Jara Díez y M. Lamadrid, Bogotá, 2007.

- "Breves comentarios sobre la reforma judicial en América Latina", Política Criminal, núm. 2, 2006.

- "Las prohibiciones de utilización de pruebas en el proceso penal alemán fundamentación teórica y sistematización", Revista Política Criminal, vol. 4, núm. 7, 2009, pág. 2, http://www.politicacriminal.cl/Vol_04/n_07/Vol4N7A1.pdf.

AMODIO, E., Processo penale. Diritto europeo e Common Law. Dal rito inquisitório al giusto processo, Milano, 2003.

- "I pentiti nella commow law", Rivista Italiana di Diritto e Procedura Penale, núm. 4, 1986.

ANARTE BORRALLO, E., "Conjeturas sobre la criminalidad organizada", VV.AA., Delincuencia organizada, Aspectos penales, procesales y criminológicos, J. C. Ferré Olivé y E. A. Borrallo Coords., Huelva, 1999.

ANDRADE FERNANDES, F., O processo penal como instrumento de política criminal, Coimbra, 2001.

ANDRADE MENDONÇA, R. P., Provas ilícitas: Limites à licitud probatória, 2ª edición, Rio de Janeiro, 2004.

ANDRÉS IBÁÑEZ, P., Prueba y convicción judicial en el proceso penal, Buenos Aires, 2009.

- "Sobre los derechos fundamentales del imputado en la investigación criminal", Revista de Derecho Penal, núm. 14, Montevideo, 2004. 
- "Ni fiscal instructor ni Habermas procesalista", Revista Jueces para la Democracia, núms. 16-17, 1992.

- "Luigi FERRAJOLI: los derechos rigurosamente en serio", Nexos, México, 2008.

- "Garantismo: una teoría crítica de la jurisdicción", Garantismo: estudios sobre el pensamiento jurídico de Luigi FERRAJOLI, Carbonell, M., Salazar, P, coords., Madrid, 2005.

- "Garantismo y Proceso Penal", Garantismo y Derecho Penal, J. O. Sotomayor Acosta coord., Bogotá, 2006.

- "El caso Naseiro en el país de las garantías", http://www.juecesdemocracia.es.

- "El fiscal en la actual regresión inquisitiva del proceso penal", Teoría \& Derecho - Revista de Pensamiento Jurídico, núm. 1, 2007.

ANDRIOLI, V., La convenzione europea dei diritti dell'uomo e il processo giusto, 1964.

APONTE CARDONA, A., Guerra y Derecho Penal del enemigo, Bogotá, 2006.

ARAGONESES ALONSO, P., Proceso y Derecho Procesal, 2ª edición, Madrid, 1997.

- Instituciones de Derecho Procesal Penal, 5a edición, col. S. Aragoneses Martínez, Madrid, 1984.

ARAGONESES ALONSO, P; VIADA LÓPEZ-PUIGCEVER, C., Curso de Derecho Procesal Penal, 2. edición, Madrid, 1968-1970.

ARAGONESES MARTÍNEZ, S; DE LA OLIVA SANTOS, A; HINOJOSA SEGOVIA, R; MUERZA ESPARZA, J; TOMÉ GARCÍA, J. A., Derecho Procesal Penal, Octava edición, Madrid, 2007.

ARANGÜENA FANEGO, C., "Garantías procesales de los sospechosos e imputados", VV.AA., El proceso penal en la Unión Europea: garantías esenciales, Valladolid, 2008.

- "Avances en la cooperación judicial penal en la Unión Europea", VV.AA., Logros, iniciativas y retos institucionales y económicos : la Unión Europea del siglo XXI, I. Vega Mocoroa coord., 2005.

ARÁNGUEZ SÁNCHEZ, C., El delito de blanqueo de capitales, Madrid/Barcelona, 2000.

ARANHA, A. J. C., Da prova no processo penal, 5a edición, São Paulo, 1999.

ARAÚJO CINTRA, A. C., GRINOVER, A. P y DINAMARCO, C. R., Teoria Geral do Processo, 5a edición, São Paulo, 1985.

ARAÚJO DA SILVA, E., Crime organizado. Procedimento probatório, São Paulo, 2003.

ARCINIEGAS MARTÍNEZ, G. A., Policía judicial y sistema acusatorio, Bogotá, 2007.

ARLACCHI, P., "Tendencias de la criminalidad organizada y de los mercados ilegales en el mundo actual", Revista del Poder Judicial, núm. 16, 1985.

ARMENTA DEU, T., Lecciones de Derecho Procesal Penal, 3a edición, Madrid-Barcelona, 2007.

- La prueba ilícita (Un estudio comparado), Madrid, 2009.

- "Principios y sistemas del proceso penal español", El nuevo derecho penal español: estudios penales en memoria del profesor José Manuel Valle Muñiz, G. Quintero Olivares y F. Morales Prats coords., Pamplona, 2001.

-"La verdad en el filo de la navaja (nuevas tendencias en materia de prueba ilícita)", Revista Ius Et Praxis, año 13, núm. 2, 2007.

-"La prueba ilícita y reforma del proceso penal", Revista del Poder Judicial, número especial (Propuestas para una nueva Ley de Enjuiciamiento Criminal", núm.19, 2006.

- "Exclusionary rule: convergencias y divergencias entre Europa y América", Revista de Estudios de la Justicia, núm. 11, 2009. 
AROCENA, G. A., "El agente encubierto. Consideraciones político-criminales", VV.AA., Temas de derecho procesal penal (Contemporáneos), J. I. Cafferata Nores y G. A. Arocena coords., Córdoba, 2001.

ASENCIO MELADO, J. M., La reforma del Proceso Penal, 1ae edición, Madrid, 2011.

- Prueba prohibida y prueba preconstituida, Madrid, 1989.

AUGUSTO MEREIS, M., $O$ regime das provas obtidas pelo agente provocador em processo penal, Coimbra, 1999.

- "Homens de confiança", Será o caminho?, II congresso de Processo Penal, Coimbra, 2006.

AVILÉS GÓMEZ, M., Criminalidad organizada: los movimientos terroristas, San Vicente (Alicante), 2004.

AVOLIO, L. F. T., Provas ilícitas: interceptações telefônicas e gravações clandestinas, São Paulo, 1995.

AYALA CORAO, C. M., "La ejecución de sentencias de la corte interamericana de derechos humanos", Estudios Consticuionales, año 5, núm. 1, Talca, 2007.

BACIGALUPO, E., El debido proceso penal, Buenos Aires, 2005.

BACIGALUPO SAGGESE, M., La aplicación de la doctrina de los "los límites inmanentes" a los Derechos Fundamentales sometidos a reserva de limitación legal. A propósito de la sentencia del Tribunal Administrativo Federal alemán de 18 de octubre de 1990, Revista Española de Derecho Constitucional, núm. 38, Mayo-Agosto, 1993.

BADARÓ, G. H; LOPES JR, A., Direito ao Processo Penal no Prazo Razoável, Rio de Janeiro, 2006.

BALACLOCHE PALAO, J; ZARZALEJOS NIETO, J., Aspectos fundamentales de Derecho Procesal Penal, Madrid, 2010.

BALAGUER CALLEJÓN, F., "Fuentes de Derecho, espacios constitucionales y ordenamientos jurídicos", Revista Española de Derecho Constitucional, núm. 69, 2003.

BALTAZAR JR, J. P., Crime organizado e proibição de insuficiência, Porto Alegre, 2010.

- "Limites constitucionais à investigação. 0 conflito entre o direito fundamental a segurança e o direito de liberdade no âmbito da investigação criminal", Limites constitucionais da investigação, R. Sánchez Cunha., P. Taques y L. F. Gomes coords., São Paulo, 2009.

BAQUERO M. MARTÍNEZ, A., "La amenaza islamista en España. La figura del infiltrado es ya clave en la lucha antiterrorista", El periódico de Aragón, 02.03.2008, http://www.elperiodicodearagon.com.

BANDRÉS SÁNCHEZ-CRUZAT, J. M., Derecho fundamental al proceso debido y el Tribunal Constitucional, Navarra, 1992.

BAPTISTA MACHADO, J., Introdução ao Direito e ao discurso legitimador, Coimbra, 1998.

BAQUER, L. M; PARDO, I. O., Derechos Fundamentales y Constitución, Madrid, 1988.

BARBOSA, R., Atos Inconstitucionais, São Paulo, 2003.

BARBOSA MOREIRA, J. C., "A Constituição e as provas ilicitamente obtidas", Revista Forense, vol. 337, 1997.

BARCELONA LLOP, J., "El secreto policial. Acceso a archivos y registros de la policía. Los ficheros automatizados de las fuerzas y cuerpos de seguridad", Cuadernos del Consejo General del Poder Judicial, volumen dedicado a Acceso judicial a la obtención de datos, núm. 25, Madrid, 1997.

BARONA VILAR, S., Seguridad, celeridad y justicia penal, Valencia, 2004. 
- "Conformidad del acusado, paradigma de eficiencia de la Justicia Penal", VV.AA., Terrorismo y Proceso Penal Acusatorio, J. L. Gómez Colomer y J. L. Gonzáles Cussac coords., Valencia, 2006.

BARONA VILAR, S; MONTERO AROCA, J., GÓMEZ COLOMER, J. L., MONTÓN REDONDO, A., Derecho Jurisdiccional III, Proceso Penal, 12ª edición, Valencia, 2004.

BARATTA, A., Criminología crítica y crítica del Derecho Penal, México, 2000.

- "La política criminal y el Derecho Penal de la Constitución: Nuevas reflexiones sobre el modelo integrado de las Ciencias Penales", Revista de la Faculdad de Derecho de la Universidad de Granada, núm. 2, 1999.

- "Diritto alla sicurezza o sicurezza dei diritto", La bilancia e la misura. Democracia e diritto, núm. 5, 2001.

BARATTA, A; SILBERNAGL, M., "La legislación de emergencia y la cultura jurídica garantista en el proceso penal", Cuadernos de política criminal, núm. 28, 1986.

BARROS, M. A., A busca da verdade no processo penal, 2ª edición, São Paulo, 2010.

BARROS, M. A; LAVOURA ROMÃO, C. E., "Internet e videoconferência no processo penal", Revista Centro de Estudos Judiciários, núm. 32, Brasília, 2002.

BASTARRECHE BEngOA, T., Constitución y Ministerio Público: Holanda, Italia y España, Cizur Menor, 2010.

BAUMAN, Z., "El eterno retorno de la violencia", Modernidad y violencia colectiva, Josetxo Beriain Razquin coord., Madrid, 2004.

BECCARIA, C., De los delitos y de las penas, trad. J. Antonio de las Casas, Madrid, 1996.

BECCHI, A., Criminalità organizata. Paradigmi e scenari delle organizzazioni mafiose in Italia, Roma, 2000.

BECERRA, N. E., "La justicia penal nuevamente entre garantía y eficiencia: el arrepentido y el agente encubierto. Algunas preocupaciones previas", La Ley, año LXIII, núm. 25, 1999.

BECHARA, F. R., "Criminalidade Organizada e procedimento diferenciado: entre eficiência e garantismo", VV.AA., Direito Penal Especial, Processo Penal e Direitos Fundamentais, Visão Luso-Brasileira, J. Faria Costa y M. A. Marques da Silva coords., São Paulo, 2006.

BECHARA, F. R; JESUS, D. E., "Agente infiltrado: reflexos penais e processuais", http://www.jus2.uol.com.br.

- "Crime organizado e o sigilo na investigação", Revista Sintesis de Direito Penal e Direito Processual Penal, núm. 32, Porto Alegre, 2005.

BECK, F. R., Perspectivas de controle ao crime organizado e crítica à flexibilização das garantias, São Paulo, 2004.

BECK, U., La sociedad de riesgo. Hacia una nueva modernidad, Barcelona, 1998.

-Sobre el terrorismo y la guerra, Barcelona, 2003.

- "El mundo después del 11-S", Diario El país, 19.10.2001.

BEDAQUE, J. R. S; CRUZ E TUCCI, J. R; CALABRICH, B., Investigação criminal pelo Ministério Público. Fundamentos e limites constitucionais, São Paulo, 2007.

BEDÊ JÚNIOR, A; SENNA, G., Princípios do Processo Penal. Entre o garantismo e a efetividade da sanção, São Paulo, 2009.

BEERNAERT, M. A., "Repentis ou collaborateurs de justice: quelle légitimité dans le système pénal?", Droit et société, núm. 55, 2003.

BENEYTO PÉREZ, J. M., "Identidad y conflictos culturales. La nueva perspectiva dela seguridad", VV.AA., La seguridad de la Unión Europea: Nuevos factores de crisis, 
Cuadernos de Estrategia (Instituto Español de Estudios Estratégicos), núm. 134, , Madrid, 2007.

BENÍTEZ ORTÚZAR, I. F., El colaborador con la justicia. Aspectos sustantivos procesales y penitenciarios derivados de la conducta del "arrepentido", Madrid, 2004.

BENITO LÓPEZ, A. Ma; SÁEZ VALCÁRCEL, R., "La investigación penal", VV.AA., Hacia un nuevo proceso penal, Madrid, 2006.

BENTHAN, J., Tratado de las Pruebas Judiciales, vol. I, trad. Osorio Florit, Buenos Aires, 1959.

BERGALLI, R., "Emergencia: una cultura específica", presentación de la monografía "Emergencia y crisis del Estado social. Análisis de la excepcionalidad penal y motivos de su perpetuación", Barcelona, 1988.

BERNAL CUÉLLAR, J., MONTEALEGRE LYNETT, E., El proceso penal, 4ํa edición, Bogotá, 2002.

BERNAL PULIDO, C., El principio de proporcionalidad y los derechos fundamentales, Madrid, 2003.

- "La racionalidad de la ponderación", VV.AA., El principio de proporcionalidad y protección de los derechos fundamentales, México, 2008.

BERNARD CORBOZ, L., L`agent infiltré, Revue Penale Suisse, núm. 111, 1993.

BERTOLINO, P. J., Proceso penal y servicio de la justicia, La Plata, 1992.

BIANCHINI, A; GOMES, L.F; GARCÍA-PABLOS DE MOLINA, A., Direito Penal. Introdução e princípios, vol. 1, São Paulo, 2007.

BINDART CAMPOS, G., Manual de la Constitución Reformada, Tomo II, Buenos Aires, 2000.

BINDER, A. M., Política criminal, de la formulación a la praxis, Buenos Aires, 1997.

- Introducción al derecho procesal penal, 2ª edición, Buenos Aires, 1999.

- "Tensiones político-criminales en el proceso penal", Revista Jueces para la democracia, núm. 60, 2007.

BLANCO CORDERO, I., El delito de blanqueo de capitales, Navarra, 2002.

- "Criminalidad organizada y mercados ilegales", Eguzkilore, San Sebastián, 1997.

BLANCO CORDERO, I., SÁNCHEZ GARCIA DE PAZ, I., "Principales instrumentos internacionales (de Naciones Unidas e la Unión Europea) relativos al crimen organizado: la definición de la participación en una organización criminal y los problemas de aplicación de la ley penal en el espacio", Revista Penal, núm. 6, 2000.

BLANCO ESCANDÓN, C., "El nuevo proceso penal en América Latina", http://www.bibliojuridica.org.

BLANCO NAVARRO, J. M., "Estrategia Española contra el Crimen Organizado 2011-2014", http://www.ateneadigital.es/RevistaAtenea/REVISTA/articulos/GestionNoticias_609 6_ESP.asp.

BLANCO PEÑALVER, A., "El estado actual de las garantías procesales penales en el ámbito de la Unión Europea", VV.AA., Derecho y Justicia Penal en el siglo XXI, Liber Amicorum en homenaje al profesor Antonio González-Cuéllar García, Madrid, 2006.

BOBBIO, N., A era dos direitos, Rio de Janeiro, 1992.

BOLAÑOS ARIAS, C. A., "El debilitamiento de la regla de exclusión probatoria en el ordenamiento jurídico penal colombiano", Revista Electrónica de la Facultad de Derecho y Ciencias Políticas, núm. 1, 2009.

BOLLE, P. H., "La lutte contre la criminalité économique en Suisse", Schweizerische Zeitschrift für Strafrecht, Tomo 98, 1981. 
BONAVIDES, P., Curso de Direito Constitucional, São Paulo, 1993.

BOSSARD, A., "Las funciones policiales", Policía y Sociedad Democrática, Madrid, 1983.

BOUCHARD, M., "Guantánamo: morte do processo penal e início do apocalipse", Revista do Ministério Público, ano 25, núm. 97, Lisboa, jan/mar 2004.

BOURDIEU, P., ¿Qué significa hablar?, Economía de los intercambios lingüísticos, Madrid, 1985.

BRADY, H., "Europol y el Modelo europeo de inteligencia criminal: una respuesta no estatal a la delincuencia organizada", Real Instituto Elcano, núm. 126, 2007, http://www.realinstitutoelcano.org.

BRAGE CAMAZANO, J., Los límites a los derechos fundamentales, Madrid, 2004.

BRANDARIZ GARCÍA, J. A., "Itinerarios de evolución del sistema penal como mecanismo de control social en las sociedades contemporáneas", VV.AA., Nuevos retos del Derecho penal de la globalización, P. Faraldo Cabana coord., Valencia, 2004.

BRAUM, S., "La investigación encubierta como característica del proceso penal autoritario", VV.AA., La Insostenible situación del Derecho Penal, Instituto de Ciencias Criminales de Frankfurt, Granada, 2000.

BRAZ, J., Investigação Criminal. A organização, o método e a prova. Os desafios da nova criminalidade, Coimbra, 2009.

BUJOSA VADELL, L. M., La cooperación procesal de los Estados con la Corte Penal Internacional, Barcelona, 2008.

- "Prólogo" a la obra, "La prueba testimonial ante la delincuencia organizada", México, 2006.

BUJOSA VADELL, L; HUERTAS MARTÍN, I; POZO PÉREZ, M; VICENTE JIMÉNEZ, C., Derecho procesal penal, Salamanca, 2007.

BULL, H. P., Die Staatsaufgabennach dem Grundgesetz. 2, Kronberg, 1977.

BUSCAGLIA, E; GOECKENJAN, I; GONZÁLEZ RUIZ, S; MENDIETA JIMÉNEZ, E; MERLE, A., "Delincuencia organizada y derechos humanos: ¿Cómo controlar el uso de las técnicas modernas de investigación? El caso de las intervenciones de comunicaciones privadas", VV.AA., Reflexiones en torno a la Delincuencia Organizada, E. Buscaglia y S. González Ruiz coords., México, 2005.

BYNUM, T. S., "Controversies in the study of the organized crime", Organized Crime in America: Concepts and Controversies, 1987.

CABEZAS, J., Infiltrados de ETA a Al Qaeda, Barcelona, 2004.

CABEZUDO RODRÍGUEZ, N., "Sobre la conveniencia de atribuir la instrucción penal al Ministerio Fiscal", Revista Jurídica de Castilla y León, núm. 14, 2008.

CACIAGLI, M., Clientelismo, Corrupción y Criminalidad Organizada. Evidencias empíricas y propuestas teóricas a partir de los casos italianos, Madrid, 2006.

CAFFARENA, B. M., "Problemas de la ejecución penal frente a la criminalidad organizada", VV.AA., La criminalidad organizada ante la Justicia, Faustino Gutiérrez-Alviz Conradi coord., Sevilla, 1996.

CAFFERATA NORES, J. I., "Crisis de eficacia de la investigación penal, causas, peligros, soluciones (Derecho de a víctima a una investigación eficiente), Ejercicio concreto del poder penal Límites, abusos, desafíos, J. I. Cafferata Nores coord., Córdoba, 2006.

- Cuestiones actuales sobre el proceso penal, 2ª edición, Buenos Aires, 1998.

- Derechos individuales y proceso penal, Córdoba, 1984. 
- Proceso penal y derechos humanos. La influencia de la normativa supranacional sobre derechos humanos de nivel constitucional en el proceso penal argentino, Buenos Aires, 2000.

- La prueba en el proceso penal, Buenos Aires, 2003.

- "La eficacia de la investigación penal en el Estado de Derecho", Revista Brasileira de Ciências Criminais, núm. 35, 2001.

- "Medios extraordinarios de investigación y desnaturalización bélica del proceso penal", Cuestiones actuales del proceso penal, Buenos Aires, 1998.

- "La desnaturalización bélica del proceso penal y los medios extraordinarios de investigación", Cuaderno núm. 2, Departamento de Derecho Procesal Penal y práctica profesional de la Facultad de Derecho y Ciencias Sociales de la Universidad Nacional de Córdoba, 1997.

- "Los frutos del árbol enevenenado", Revista Doctrina Penal, año 9, Buenos Aires, 1986.

CÁLIX VALLECILLO, C. D., "Actuaciones del agente encubierto en el ámbito del blanqueo de capitales. Conductas típicas y su posible justificación", Revista Letras Jurídicas , núm. 1, 2005, http://letrasjuridicas.cuci.udg.mx/.

CALABRICH, B; CRUZ E TUCCI, J. R; BEDAQUE, J. R. S., Investigação criminal pelo Ministério Público. Fundamentos e limites constitucionais, São Paulo, 2007.

CALLEGARI, A. L., "Controle social e criminalidade organizada", VV.AA., Crime Organizado. Tipicidade, Política Criminal, Investigação e Processo, Porto Alegre, 2008.

CALVO SÁNCHEZ, M. C., "Prólogo" a la obra "Hacia un verdadero espacio judicial europeo", L. M, Bujosa Vadell coord., Granada, 2008..

- "La fase de investigación en el nuevo proceso penal abreviado regulado por la Ley Orgánica 7/1988 de 28 de diciembre”, La Ley, tomo 2, 1990.

CAncio Melí́, M., "Derecho penal del enemigo y delitos de terrorismo: algunas consideraciones sobre la regulación de las infracciones en materia de terrorismo en el código penal español después de la LO 7/2000", Revista Peruana de Ciencias Penales, núm. 13, Lima, 2003.

CANCIO MELÍA, M; JAKOBS, G., Derecho Penal del Enemigo, 1ae edición, Madrid, 2003.

CAPARRÓS, E. A. F., El delito de blanqueo de capitales, Madrid, 1998.

- "Criminalidad organizada", VV.AA., El nuevo Código penal: primeros problemas de aplicación, Mạ . Luz Gutiérrez Frances y V. Sánchez López coords., Salamanca, 1997.

CAPARRÓS, E. A; MERCHÁN MATEOS, J. F; RODRÍGUEZ GARCÍA, N; ZARAGOZA AGUADO, J. A., Delincuencia económica y blanqueo de capitales, Salamanca, 2005 (inédito).

CAPEZ, F., Curso de processo penal, 9a edición, São Paulo, 2003.

CARBONELL, M., Neoconstitucionalismo(s), Madrid, 2005.

"Nuevas formas de proteger los derechos fundamentales", VV.AA, El principio de porporcionalidad y protección de los derechos fundamentales, M. Carbonell coord., México, 2008.

CARBONELL MATEU, J. C., "Terrorismo: algunas reflexiones sobre el concepto y el tratamiento penal", VV.AA., Terrorismo y proceso penal acusatorio, J. L. Gómez Colomer; J. L. González Cussac coords., Valencia, 2006.

CARBONELL SÁNCHEZ, M., "La garantía de los derechos sociales en la teoría de Luigi FERRAJOLI", Garantismo: estudios sobre el pensamiento jurídico de Luigi Ferrajoli, Carbonell, M; Salazar, P, coords., Madrid, 2005. 
CARLOS FONSECA, J., "Direitos, liberdades e garantias individuais e os desafios impostos pelo combate à criminalidade organizada. Um périplo pelas reformas penais em curso em Cabo Verde, com curtas paragens em Almagro e Budapeste", Liber Discipulorum para Jorge de Figueiredo Dias, M. Costa Andrade; J. Faria Costa; A. Miranda Rodrigues y M. João Antunes coords., Coimbra, 2003.

CARDOSO PEREIRA, F., "A moderna investigação criminal: infiltrações policiais, entregas controladas e vigiadas, equipes conjuntas de investigação e provas periciais de inteligência", Limites Constitucionais da Investigação, L. F. Gomes; P. Taques y R. Sanches Cunha coords., São Paulo, RT, 2009.

."As equipes conjuntas de investigação criminal", Revista jurídica do Ministério Público do Estado do Mato Grosso, ano 3, num. 5, julho/dezembro 2008.

- "Meios extraordinários de investigação criminal: infiltrações policiais e entregas vigiadas (controladas)", Revista da Associação Brasileira de Professores de Ciências Penais, núm. 6, São Paulo, 2007.

- "A investigação criminal realizada por agentes infiltrados", Revista Jurídica do Ministério Público de Mato Grosso, ano 2, núm. 2, 2007.

CARMONA SALGADO, C., "La circulación y entrega vigilada de drogas y el agente encubierto en el marco de la criminalidad organizada sobre narcotráfico", VV.AA., Estudios jurídico-penales y Político-criminales sobre tráfico de drogas y figuras afines, $L$. Morillas Cueva coord., Madrid, 2003.

CARNELUTTI, F., Das provas no Processo Penal, 1a edición, Campinas, 2005.

- Derecho Procesal Civil y Penal, trad. E. Figueroa Alfonso, México, 1997.

- Cómo se hace un proceso, Bogotá, 1994.

CARNEVALI RODRÍGUEZ, R., "La criminalidad organizada. Una aproximación al derecho penal italiano, en particular la responsabilidad de las personas jurídicas y la confiscación", Revista Ius et Praxis, año 16, núm. 2º 2010.

CARO CORIA, D. C., "Las garantías constitucionales del proceso penal", Anuario de Derecho Constitucional Latinoamericano, Tomo II, 2006.

CARRIÓ, A. D., Garantías constitucionales en el proceso penal, 5a edición, Buenos Aires, 2007.

- "Agente encubiertos y testigos de identidad reservada: armas de doble filo, ¿confiadas a quién?", Cuadernos de Doctrina y Jurisprudencia Penal, vol. 3, núm. 6, Buenos Aires, 1997.

CARRIZO GONZÁLEZ, A., "La colaboración entre Estados en el ámbito penal: técnicas de cooperación jurídica internacional", VV.AA., Hacia un Derecho penal $\sin$ fronteras, $M \stackrel{a}{a} . R$. Diego Días-Santos y V. Sánchez López coords., Madrid, 2000.

CAROCCA PÉREZ, A., Garantía constitucional de la defensa procesal, Barcelona, 1997.

CASSANI, B., "Agentes encubiertos e informantes como medios de prueba contra el crimen organizado", VV.AA., El crimen organizado. Desafíos y perspectivas en el marco de la globalización, Buenos Aires, 2005.

CASSANI, U., "Le blanchissage d'argent", Fiches Jurídiques Suisses, Genève, 1994.

CASSEL, D., "El derecho Internacional de los Derechos Humanos y la detención preventiva", Revista Instituto Interamericano de Derechos Humanos, núm. 21, enerojunio 1995.

CASTILLEJO MANZANARES, R; MORENO CATENA, V., La persecución de los delitos en el Convenio de Schengen, Valencia, 1999. 
CASTILLO BARRENTES, E., "Criminalidad organizada", Cuadernos de política criminal, núm. $50,1993$.

CASTRESANA FERNÁNDEZ, C., "Corrupción, globalización y delincuencia organizada", VV.AA., La corrupción en un mundo globalizado: Análisis interdisciplinar, N. Rodríguez García y E. A. Fabián Caparrós coords., Salamanca, 2004.

CASTRO MORAL, L; JAIME-JIMÉNEZ, Ó., "La criminalidad organizada en la Unión Europea. Estado de la cuestión y respuestas institucionales", Revista Cidob d'Afers Internacionals, núm. 91, 2010.

CATOIRA, A. A., " La tecnologización de la prueba en el proceso penal. La videoconferencia: objeciones y ventajas", Anuario da Facultade de Dereito da Universidade da Coruña, núm. 13, 2009.

CERDÁN, M., RUBIO, A., Lobo, un topo en las entrañas de ETA, 9a edición, Barcelona, 2004.

CERRO ESTEBAN, J. A., "El sistema de garantías constitucionales en los procesos judiciales sobre criminalidad organizada", http://www.cej.justicia.es/.

CERVINI, R; GOMES, L. F., Crime organizado. Enfoques criminológico, jurídico (Lei 9.034/95) e político-criminal, São Paulo, 1995.

CHAUÍ, M., Convite à filosofia, São Paulo, 2003.

CHELAZZI, G., La dissociazione dal terrorismo, Milan, 1981.

CHIAVARIO, M., Processo e garanzie della persona, Milano, 1982.

- "Giustizia penale, Carta dei diritti e Corte europea dei diritti umani", Rivista italiana di diritto e procedura penale, 2002.

- "Direitos humanos, processo penal e criminalidade organizada", Revista Brasileira de Ciências Criminais, núm. 5, São Paulo, 1994.

- "La justicia penal italiana, a la búsqueda continua de un proceso justo", VV.AA., Terrorismo y Proceso Penal Acusatorio, Valencia, 2006.

- "Garanzie individuali ed efficienza del processo", Il giusto processo, Milano, 1998.

CHOCLÁN MONTALVO, J. A., La organización criminal: tratamiento penal y procesal, Madrid, 2000.

- "La criminalidad organizada. Concepto. La asociación ilícita. Problemas de autoria y participación", La criminalidad organizada. Aspectos sustantivos, procesales y orgánicos, Cuadernos de Derecho Judicial, 2001.

- "Videoconferencia y proceso penal", Actualidad Jurídica Aranzadi, en 18.3.2002.

CIRINO DOS SANTOS, J., "Crime Organizado", Revista Brasileira de Ciências Criminais, núm. 42, 2003.

CLARIÁ OLMEDO, J. A., Derecho Procesal Penal, Tomo 1, Buenos Aires, 1998.

CLÉRICO, L., "El examen de proporcionalidad: entre el exceso por acción y la insuficiencia por omisión o defescto", VV.AA., El principio de proporcionalidad y protección de los derechos fundamentales, México, 2008.

CLIMENT DURÁN, C., La prueba penal, doctrina y jurisprudencia, Valencia, 1999.

CLIMENT DURÁN, C; GARCÍA GONZÁLEZ, J; PASTOR ALCOY, F; PÉREZ MARTÍNEZ, A., Las drogas en el nuevo Código penal. Doctrina, jurisprudencia y formularios, Valencia, 1998.

COMAS ARNAU, D., "Delincuencia e inseguridad ciudadana", VV.AA., España, sociedad y política, S. G. San Julián coord., Madrid, 1990.

COMES RAGA, I; JORDÁN DÍAZ-RONCERO, Ma․ J., "El arrepentimiento postdelictual en España: un ensayo acerca de su viabilidad como instrumento combativo del crimen organizado", La Ley Penal, núm. 77, 2010, http://revista-laleypenal.laley.es. 
CONDE-PUMPIDO TOURÓN, C., "El Ministerio Fiscal frente a la nueva criminalidad", Cuaderno del Instituto Vasco de Criminología, San Sebastián, núm. 20 , 2006.

CONSO, G., "Natura giuridica delle norme sulla prova nel processo penale", Rivista italiana di diritto e procedura penale, 1970.

CONTRERAS AlFARO, L. H., Corrupción y Principio de Oportunidad Penal. Alternativas en materia de prevención y castigo a la respuesta penal tradicional, Salamanca, 2005.

COQUILLAT VICENTE, Á; MORENO CATENA, V.; DE DIEGO DÍEZ, L. A; JUANES PECES, Á; SUÁREZ-BÁRCENA, E. L., El proceso penal. Doctrina, jurisprudencia y formularios, Valencia, 2000.

CORCOY BIDASOLO, M., "La perspectiva jurídico-penal", VV.AA., La seguridad pública ante el Derecho penal, Buenos Aires, 2010.

CORDÓN MORENO, F., Las garantías constitucionales del proceso penal, 2ª̣ edición, Navarra, 2002.

CORRÊA DE CARVAlHo, J. T., Tráfico de drogas. Prueba penal y medidas restrictivas de derechos fundamentales, Curitiba, 2009.

CORTÉZ DOMÍNGUEZ, V; GIMENO SENDRA, V; MORENO CATENA, V. M., Derecho Procesal Penal, segunda edición, Madrid, 1997.

CORVALÁN, V. R., "Agente encubierto y testigo de identidad reservada", Suplemento de Jurisprudencia Penal de La Ley, Buenos Aires, 1997.

COSTA ANDRADE, M., Sobre as proibições de prova em proceso penal, Coimbra, 2006.

CRUZ E TUCCI, J. R; BEDAQUE, J. R. S; CALABRICH, B., Investigação criminal pelo Ministério Público. Fundamentos e limites constitucionais, São Paulo, 2007.

CUBILLO LÓPEZ, I. J., La protección de testigos en el proceso penal, Pamplona, 2009.

CUNHA, E. M; FRISONI, V. B., Igualdade: extensão constitucional, Cadernos de direito constitucional e ciência política, vol. 4, núm. 16, São Paulo, 1996.

CUOCOLO, F., Principi di Diritto Costituzionale, 2ª edición, Milano, 1999.

CURBET, J., La glocalización de la (in) seguridad, Madrid, 2006.

D'AMICO, S., Il colaboratore della giustizia, Roma, 1995.

DAGDUD KALIFE, A., La prueba testimonial ante la delincuencia organizada, México, 2006.

DÂMASO SIMÕES, E., "Cooperacción judicial en materia penal dentro de la Unión Europea. Perfeccionamiento de los mecanismos de acción y coordinación", Revista del Ministerio Fiscal, núm. 9, Madrid, 2001.

DAMIÁN MORENO, J., “¿Un Derecho Procesal de Enemigos?”, Derecho Penal del Enemigo. El discurso penal de la exclusión, vol. 1, Buenos Aires, 2006.

DAUDET, M. G; FRONDIZI, R. J., Garantías y eficiencia en la prueba penal, La Plata, 2000.

DAUNIS RODRÍGUEZ, A., "Seguridad, Derechos humanos y garantías penales: ¿Objetivos comunes o aspiraciones contrapuestas?", VV.AA., Derecho penal de la democracia vs. Seguridad pública, I. Berdugo Gómez de la Torre y N. Sanz Mula coords., Granada, 2005.

DAVIN, J., A criminalidad organizada transnacional. A cooperação judiciária e policial na UE, Coimbra, 2004.

DE DIEGO DÍEZ, L. A; COQUILLAT VICENTE, Á; MORENO CATENA, V; JUANES PECES, Á; SUÁREZ-BÁRCENA, E. L., El proceso penal. Doctrina, jurisprudencia y formularios, Valencia, 2000.

DE LA CUEVA, P. L. M.,"El derecho a la autodeterminación informativa", Temas Claves de la Constitución Española, Madrid, 1990. 
DE LA MATA AMAYA, J., "La utilización de la videoconferencia en las actuaciones judiciales", Actualidad Penal, núm. 47-48, 2002.

DE LA OLIVA SANTOS, A., "Sobre la ineficacia de las pruebas ilícitamente obtenidas", $L a$ Ley, núms. 8-9, 2003.

DE LA OLIVA SANTOS, A; ARAGONESES MARTÍNEZ, S; HINOJOSA SEGOVIA, R; MUERZA ESPARZA, J; TOMÉ GARCÍA, J. A., Derecho Procesal Penal, Octava edición, Madrid, 2007.

DE LORA, P., "Tras el rastro de la ponderación", Revista Española de Derecho Constitucional, núm. 60, 2000.

DE MAGLIE, C., L'agent provocatore. Un'indagine dommatica e politico-criminale, Milano, 1991.

DE VERO, G., Tutela penale dell'ordine pubblico, Milano, 1988.

DEA., D. E., Undercover, New York, 2000.

DEL MORAL GARCÍA, A., "Ministerio Fiscal y reforma de la justicia", Jueces para la democracia, núm. 43, 2002.

DEL VALLE, C. P., "Sobre los orígenes del Derecho penal del enemigo. Algunas reflexiones en torno a Hobbes y Rousseau", Cuadernos de política criminal, núm. 75, Madrid, 2001.

DEL ROSAL, M. C., Tratado de Derecho Procesal Penal Español, Madrid, 2008.

DELGADO AGUADO, J et alli, VV.AA., Estudios sobre la violencia, J. Delgado Aguado coord., Madrid, 2006.

DELGADO GARCÍA, Ma․ D., "El agente encubierto: técnicas de investigación. Problemática y legislación comparada", VV.AA., La criminalidad organizada ante la justicia, F. Gutiérrez-Alviz y Conradi coord., Sevilla, 1996.

- "Configuración jurisprudencial del delito de blanqueo de dinero procedente del tráfico de drogas. ¿Inversión de la carga de la prueba?", http://www.cej.justicia.es/pdf/publicaciones/fiscales/FISCAL07.pdf.

- "La prueba indiciaria en el Delitos de Lavado de Activos. Perspectiva del Fiscal", htpp://www.juschubut.gov.ar/03_direcciones/9.../Prueba-Perspectiva-Fiscal.pdf.

DELGADO MARTÍN, J., La criminalidad organizada (comentarios a la LO 5/99, de 13 de enero, de modificación de la Ley de Enjuiciamiento Criminal en materia de perfeccionamiento de la acción investigadora relacionada con el tráfico ilícito de drogas y otras actividades ilícitas graves),Barcelona, 2001.

- "El proceso penal ante la criminalidad organizada. El agente encubierto", Actualidad Penal, núm. 1, 2000.

DELL'ANDRO, R., "Agente provocatore", Enciclopédia del Diritto, Milano, 1958.

DEMETRIO CRESPO, E., "Del Derecho penal liberal al Derecho penal del enemigo", Revista de Derecho Penal Y Criminología, núm. 14, Madrid, 2004.

DENCKER, F., "Gefährlichkeitsvermutung statt Tatschuld -Tendenzen der neueren Strafrechtsentwicklung-", StV 6/1988.

DEUTSCHMANN, D; RICARDO, R., Guantánamo: A Critical History of the Us Base in Cuba, Melbourne, 2008.

DEVIS ECHANDÍA, H., Teoría general de la Prueba Judicial, Tomo I, 6aa edición, Buenos Aires, 1988.

- Módulo de Derecho Civil y Procesal Civil de la Academia de la Magistratura, Lima, 1998.

DEZEM, G. M; PONTES, E. F., "Crime organizado e devido processo legal", Estudos de processo penal: o mundo à revelia, F. Hassan Choukr coord., Campinas, 2000. 
DIAS FERREIRA, V. P., "Problémes poses par la mise em oevre dês opérations undercover dans les domaine de la lutte contre lê trafic de stupéfiants", Revue de droit et de pénal criminologie, núm. 76, 1996.

DÍAZ CABIALE, J. A., La admisión y práctica de la prueba en el proceso penal, Madrid, 1992.

DÍAZ CABIALE, J. A; MARTÍN MORALES, R., La garantía constitucional de la prueba ilícitamente obtenida, Madrid, 2001.

DÍAZ-MAROTO Y VILLAREJO, J., "Algunos aspectos jurídicos -penales y procesales de la figura del arrepentido", La Ley, núm. 05, 1996.

DÍAZ MARTÍNEZ, M; GIMENO SENDRA, V; TORRES DEL MORAL, A; MORENILLA ALLARD, P., Los Derechos Fundamentales y su protección jurisdiccional, Madrid, 2007.

DÍEZ-PICAZO PONCE DE LEÓN, L. M., "Siete tesis sobre la idea de Fiscal investigador", Teoría \& Derecho - Revista de Pensamiento Jurídico, núm. 1, 2007.

DIEZ RIPOLLÉS, J. L., "El Derecho penal simbólico y los efectos de la pena", Crítica y justificación del Derecho penal en el cambio de siglo, Cuenca, 2003.

- "El nuevo modelo penal de la seguridad ciudadana", Revista Electrónica de Ciencia Penal y Criminología, núm. 06, 06-03, 2004, http://www.criminet.ugr.es/recpc/.

DIMOULIS, D; MARTINS, L., Teoria geral dos direitos fundamentais, 3a edición, São Paulo, 2011.

DIMOULIS, D. D., OTO, E., Teoria do Direito Neoconstitucional, São Paulo, 2008.

DINAMARCO, C. R.; GRINOVER, A. P; ARAÚJO CINTRA, A. C., Teoria Geral do Processo, 5a edición, São Paulo, 1985.

DOMINGO, T., ¿Conflictos entre derechos fundamentales?, Madrid, 2001.

DOMINIONI, O., "L'esperienza della legislazione sui pentiti opinioni a confronto", Legislazione sui pentiti. Legislazione Penale, 1983.

DONINI, M., "El derecho penal frente al enemigo", VV.AA., Derecho penal del enemigo, $M$. Cancio Meliá y C. Gómez-Jara Díez coords., Madrid, 2006.

- "La valutazione delle dichiarazioni dei pentiti", Rivista di Diritto Processuale, Padova, vol. 41, núm. 4, 1986.

ECHARRI CASI, F. J; GONZÁLEZ GARCÍA, S., Aspectos procesales de la delincuencia económica, M. J. Vallejo y F. Bernate Ochoa coords., Bogotá, 2005.

ECHEBÚRUA, E; GUERRICA ECHEVARRÍA, C., Abuso sexual en la infancia, Barcelona, 2005.

ECHARRI CASI, F. J., "Prueba ilícita: conexión de antijuricidad y hallazgos casuales", Revista del Poder Judicial, núm. 69, 2003.

- "Las partes en el proceso penal. Alcance de la responsabilidad subsidiaria", http://www.cej.justicia.es/pdf/publicaciones/secretarios_judiciales/SECJUD19.pdf.

EDWARDS, C. E., El arrepentido, el agente encubierto y la entrega vigilada, Buenos Aires, 1996.

EICHENWALD, K., El confidente: una historia real, 1aㅡ edición, Barcelona, 2009.

ESPARZA LEIBAR, I., El principio del proceso debido, Barcelona, 1995.

ESPINA RAMOS, J. A., "La instrucción por el Ministerio Fiscal: La reforma eternamente pendiente", AA.VV., La reforma de la Justicia penal. Aspectos materiales y procesales, Valladolid, 2008.

ESPINOSA DE LOS MONTEROS, R. Z., El policía infiltrado. Los presupuestos jurídicos en el proceso penal español, Valencia, 2010.

- "El agente encubierto en el ordenamiento jurídico español", La prueba en el espacio europeo de libertad, seguridad y justicia penal, Navarra, 2006. 
- "Implicaciones del Tratado de Lisboa en la lucha contra la delincuencia organizada", Revista General de Derecho Penal, núm. 14, 2010, http://www.iustel.com.

- "Las reglas de exclusión probatoria al hilo del desarrollo de la infiltración policial", Temas Socio-Jurídicos, vol. 27, núm. 57, Bucaramanga, 2009.

ESTEBAN NAVARRO, M. A., VV.AA., "Contrainteligencia y operaciones encubiertas", Inteligencia, Valencia, 2012.

FAINBERG, M. H., La inseguridad ciudadana, Buenos Aires, 2003.

FAIRÉN GUILLÉN, V., " Imagen preliminar y fragmentaria de la Reforma Procesal Penal a fines de 1991", Revista de Derecho Procesal, núm. 1, 1992.

FALCONE, R. A., Las garantías del imputado frente a la persecución penal estatal, Buenos Aires, 2007.

FARALDO CABANA, P., "Un derecho penal de enemigos para los integrantes de organizaciones criminales: la ley orgánica $7 / 2003$, de 30 de junio, de medidas de reforma para el cumplimiento íntegro y efectivo de las penas", Política criminal y sistema penal, I. Rivera Beiras coord., Barcelona, 2005.

FARIÑAS MATONI, L. M., El derecho a la intimidad, Madrid, 1983.

FAZZALARI, E., Istituzioni di diritto processuale, Padova, 1992.

- Instituições de Direito Processual, 1a edición, Campinas, 2006.

FAZZONE, E., "La valorización de la prueba en los procesos de criminalidad organizada", Revista del Poder Judicial, núm. 48, 1997.

FEDERICO DELGADO, J., La denuncia anónima, Buenos Aires, 1999.

FEIJóo SÁNCHEZ, B., "El derecho penal del enemigo y el Estado democrático de Derecho", Revista Peruana de Ciencias Penales, núm. 18, Lima, 2006.

FEITOZA PACHECO, D., O princípio da proporcionalidade no Direito processual penal brasileiro, Rio de Janeiro, 2007.

- Direito Processual Penal. Teoria, crítica e praxis, 3a edición, Niterói, 2005.

FELDENS, L., Direitos fundamentais e direito penal: garantismo, deveres de proteção, princípio da proporcionalidade, jurisprudência constitucional penal, jurisprudência dos tribunais de direitos humanos, Porto Alegre, 2008.

FENECH NAVARRO, M., El proceso penal, Madrid, 1982.

FERNANDES, F., O Processo penal como instrumento de política criminal, Coimbra, 2001.

FERNÁNDEZ TOMÁS, A., La Carta de los Derechos Fundamentales de la Unión Europea, Valencia, 2002.

FERNÁNDEZ APARICIO, J. M., "El delito provocado y el agente encubierto", Actualidad Penal, núm. 44, Madrid, 2002.

FERNÁNDEZ LÓPEZ, M., Prueba y presunción de inocencia, Madrid, 2005.

FERNÁNDEZ RODRÍGUEZ, M. D., Los límites del ius puniendi, Anuario de Derecho Penal y Ciencias Penales, Madrid, Vol. 47, 1994.

FERNÁNDEZ ROZAS, J. C., "El espacio de libertad, seguridad y justicia consolidado por la Constitución Europea", La Ley, núm. 6097, 2004, http://www.laley.es.

FERRACUTI, F., "Legislación sobre el arrepentimiento en los delitos terroristas. Un primer análisis de los problemas planteados y de los resultados obtenidos en Italia", Revista de la Facultad de Derecho de la Universidad Complutense de Madrid, monográfico 11, Homenaje al prof. L. Jiménez de Asúa, 1986.

FERRAJOLI, L., "Garantías y Derecho Penal", Democracia y garantismo, Madrid, 2008.

- Derechos y garantías. La ley del más débil, segunda edición, Madrid, 2001. 
- Los fundamentos de los derechos fundamentales, 2 a edición, Madrid, 2005.

- Derecho y razón. Teoría del garantismo penal, trad. Andrés Ibáñez, Ruiz Miguel, Bayón Mohino, Terradillos Basoco y Cantarero Bandrés (del original de 1989), Madrid, 1995.

- "El paradigma del Derecho Penal Mínimo", Garantismo y Derecho Penal, J. O. Sotomayor Acosta coord., Bogotá, 2006.

- "Garantías", Democracia y garantismo, Madrid, 2008.

- "Garantías y Derecho Penal", Garantismo y Derecho Penal, J. O. Sotomayor Acosta coord., Bogotá, 2006.

- "Por una esfera pública del mundo", Democracia y garantismo, Madrid, 2008.

-"El Derecho Penal del Enemigo y la disolución del Derecho Penal", Democracia y garantismo, Madrid, 2008.

FERRÉ OLIVÉ, J. C., "Blanqueo de capitales y criminalidad organizada", Delincuencia organizada. Aspectos penales, procesales y criminológicos, E. Anarte Borralo y J. C. Ferré Olive coords., Huelva, 1999.

FERREIRO BAAMONDE, X. X; PÉREZ-CRUZ MARTÍN, A. J; PIÑOL RODRÍGUEZ, J. R; SEOANE SPIEGELBERG, J. L., Derecho Procesal Penal, 1ae edición, Navarra, 2009.

FERRUA, P., Il giusto processo, Bologna, 2005.

FIANDACA, G., "Lotta Allá criminalità organizzata di stampo mafioso nella legislazione penale italiana", Le estrategie di contrasto Allá criminalità organizzata nella prospettiva di diritto comparato, Gabriele Fornasari coord., Padua, 2002.

FIGUEIREDO DIAS, J., "O direito penal entre a sociedade industrial e a sociedade do risco", Revista Brasileira de Ciências Criminais, núm. 33, São Paulo, 2001.

- Algumas reflexões sobre o Direito penal e a Sociedade de Risco, Lisboa, 2000.

FISCHER, D., "O que é garantismo penal (integral)?", Garantismo Penal Integral, Salvador, 2010.

- "Garantismo penal integral (e não o garantismo hiperbólico monocular) e o princípio da proporcionalidade: breves anotações de compreensão e aproximação de seus ideais", http://www.revistadoutrina.trf4.jus.br.

FLORES PÉREZ, C. A., Análisis, técnicas y herramientas en el combate a la delincuencia organizada con fundamento en la Convención de Palermo, México, 2007.

FLORES PRADA, I., El Ministerio Fiscal en España, Valencia, 1999.

FLORIAN, E., De las pruebas penales, trad. J. Guerrero, 3ª edición, vol. I, Bogotá, 1982.

FOFFANI, L., "Criminalidad organizada y criminalidad económica", Revista Penal, núm. 7, 2001.

FRANCO, A. S., Leis penais especiais e sua interpretação jurisprudencial, 7ạ edición, São Paulo, 2001.

FRISONI, V. B; CUNHA, E. M., Igualdade: extensão constitucional, Cadernos de direito constitucional e ciência política, vol. 4, núm. 16, São Paulo, 1996.

FRONDIZI, R. J., DAUDET, M. G., Garantías y eficiencia en la prueba penal, La Plata, 2000.

FUENTES SORIANO, O., "La instrucción por el fiscal en un nuevo proceso penal", VV.AA., Nuevos retos de la justicia penal, J. Ma . Asencio Melado y O. Fuentes Soriano coords., Madrid, 2008.

FUMARULO, S., "Delincuencia organizada y seguridad: represión y prevención", Análisis, técnicas y herramientas en el combate a la delincuencia organizada y corrupción, México DF, 2007. 
FURTADO, F., "O agente infiltrado", Direito e Cidadania, ano V, números 16-17, Praia, 20022003.

GABRIEL ORSI, O., Sistema penal y crimen organizado. Estrategias de aprehensión y criminalización del conflicto, Buenos Aires, 2007.

GALINDO, J. J., "La eficiencia del sistema penal (poder y control)", http://www.insyde.org.mx.

GÁLVEZ MUNÕZ, L., La ineficacia de la prueba obtenida con violación de derechos fundamentales. Normas y jurisprudencia (TEDH, TC, TS, TSJ y AP) en los ámbitos penal, civil, contencioso administrativo y social, Navarra, 2003.

GARBERÍ LlOBREGAT, J., Constitución y Derecho Procesal. Los fundamentos constitucionales del Derecho Procesal, Navarra, 2009.

- "¿Fiscal instructor?: Pocas ventajas y un gran inconveniente", Revista Jurídica de Castilla y León, núm. 14, 2008.

GARCÍA, E. V., Los equipos conjuntos de investigación penal, Madrid, 2006.

GARCIA, J. E., La droga, problema de vigencia universal: perspectiva policial, Madrid, 1993.

GARCÍA AMADO. J. A., "¿Ductibilidad del derecho o exaltación del juez? Defensa de la ley frente a (otros) valores y principios", Escritos sobre filosofía del derecho, Santa Fé de Bogotá, 1997.

GARCÍA FIGUEROA, A., Principios y positivismo jurídico. El no positivismo principialista en las teorías de Ronald Dworkin y Robert Alexy, Madrid, 1998.

GARCÍA MORILLO, J., La protección judicial de los derechos fundamentales, Valencia, 1994.

GARCÍA MUÑOZ, P. L., "La actividad policial con incidencia probatoria", VV.AA., Estudios sobre prueba penal. Actos de investigación y medios de prueba en el proceso penal: competencia, objeto y límites, vol. 1, Madrid, 2010.

GARCÍA-PABLOS DE MOLINA, A., Introducción al Derecho Penal, Madrid, 2005.

GARCÍA-PABlOS DE MOLINA, A; GOMES, L.F; BIANCHINI, A., Direito Penal. Introdução e princípios, vol. 1, São Paulo, 2007.

GARCÍA RAMÍREZ, S., "Algunas cuestiones del proceso penal", Memorias del Congreso Internacional de Culturas y Sistemas Jurídicos Comparados, http://www.bibliojuridica.org.

GARCÍA RIVAS, N., "Criminalidad organizada y tráfico de drogas", Revista Penal, núm. 2, 1998.

- "La tutela de las garantías penales tras el Tratado de Lisboa", Revista General de Derecho Penal, núm. 14, 2010, http::/www.iustel.com.

GARCÍA SAN JOSÉ, D. I., "Alcance de las obligaciones internacionales asumidas por los estados europeos en materia de derechos y libertades de los nacionales y extranjeros a la luz del artículo 1 del Convenio Europeo para la Protección de los Derechos y Libertades Fundamentales", Migrantes y derecho: problemas actuales de la coordinación comunitaria de las prestaciones sociales en España, A. María Chocrón Giráldez coord., Murcia, 2006.

GARCÍA SÁNCHEZ, B., "Técnicas de investigación de la delincuencia organizada: perspectiva penal", Revista Letras Jurídicas, vol. 20, 2009, http:://www.letrasjuridicas.com.

GARCÍA VALDÉS, C., "La legislación antiterrorista. Derecho vigente y proyectos continuistas", Temas de Derecho Penal (penología, parte especial, proyectos de reforma), Madrid, 1992. 
GARCÍA VARELA, R., "La motivación de la sentencia", La Ley, núm. 6, 2000.

GARCÍA VITORIA, I., "La Declaración Universal de los Derechos Humanos y el sistema europeo de protección de los Derechos Fundamentales", Los derechos humanos sesenta años después: (1948-2008), Valladolid, 2009.

GARGARELLA, R., "Justicia penal y desigualdad social", Claves de razón práctica, núm. 188, 2008.

- "Mano dura sobre el castigo. Igualdad y comunidad", Nueva Doctrina Penal, Buenos Aires, 2007.

GARRIDO GENOVÉS, V., Principios de criminología, Valencia, 1999.

GARZÓN VÁLDES, E; HUSTER, S; MOLINA, F., Terrorismo y Derechos Fundamentales, Madrid, 2010.

GASCÓN ABELLÁN, M., "La teoría general del garantismo. A propósito de la obra de L. Ferrajoli. Derecho y Razón", VV.AA., Garantismo y Derecho Penal, J. O. Sotomayor Acosta coord., Bogotá, 2006.

- "¿Freedom of proof?: El incuestionable debilitamiento de la regla de exclusión de la prueba ilícita", Jueces para la democracia: Información y debate, 2005.

- "La teoría general del garantismo: rasgos principales", Garantismo: estudios sobre el pensamiento jurídico de Luigi FERRAJOLI, Carbonell, M; Salazar, P, coords., Madrid, 2005.

GASCÓN INCHAUSTI, F., Infiltración policial y "agente encubierto", Granada, 2001.

- "Los procesos penales en Europa: líneas de evolución y tendencias", Revista de Derecho Procesal, 2009.

GASPAR, A. H., "Os novos desafios do processo penal no século XXI e os direitos fundamentais (um difícil equilíbrio)", Revista Portuguesa de Ciência Criminal, año 15, núm. 2, Coimbra, 2005.

- "As exigências da investigação no processo penal durante a fase de instrução", VV.AA., Que futuro para o Direito processual penal?, Simpósio em homenagem a Jorge de Figueiredo Dias, por ocasião dos 20 anos do Código de Processo Penal português, Coimbra, 2009.

GAYRAUD, J. F., El G-9 de las mafias en el mundo. Geopolítica del crimen organizado, Barcelona, 2005.

GIACOMOLLI, N. J., "A garantia do devido processo penal e a criminalidade organizada", Revista de Estudos Criminais, núm. 14, 2004.

GIANFORMAGGIO, L., "Diritto e ragione tra essere e dover essere", Le ragioni del garantismo. Discutendo com Luigi FERRAJOLI, Torino, 1993.

GIMENO SENDRA, V., Fundamentos del Derecho Procesal, Madrid, 1981.

- Derecho Procesal Penal, 2ª edición, Madrid, 2007.

- El Ministerio Fiscal - Director de la Instrucción, 1aㅡ edición, Madrid, 2006.

- "Cuestiones prejudiciales devolutivas y non bis in idem en el proceso penal", La Ley, núm. 5817, 2003.

- "Los derechos de acción penal, al juez legal y de defensa y sus derechos instrumentales", VV.AA., Comentarios a la legislación penal, Tomo 1, M. Bajo Fernández coord., Madrid, 1982.

- "La reforma de la Ley de Enjuiciamiento Criminal y la posición del Ministerio Fiscal en la investigación penal", AA.VV., La posición del fiscal en la investigación penal: la reforma de la Ley de Enjuiciamiento Criminal, Real Instituto Elcano, 2005. 
GIMENO SENDRA, V; TORRES DEL MORAL, A; MORENILLA ALLARD, P; DÍAZ MARTÍNEZ, M., Los Derechos Fundamentales y su protección jurisdiccional, Madrid, 2007.

GIMENO SENDRA, V; CORTÉZ DOMÍNGUEZ, V; MORENO CATENA, V. M., Derecho Procesal Penal, 2 ${ }^{\text {a }}$ edición, Madrid, 1997.

GISBERT POMATA, M., "La circulación o entrega vigilada y el agente encubierto", Revista de las Facultades de Derecho y Ciencias Económicas y Empresariales, núm. 55, 2002.

GLASER, J., Zur Lehre von Dolus des Ansfifters, II, Der Gerichtssal, 1858.

GOECKENJAN, I; BUSCAGLIA, E; GONZÁLEZ RUIZ, S; MENDIETA JIMÉNEZ, E; MERLE, A., "Delincuencia organizada y derechos humanos: ¿Cómo controlar el uso de las técnicas modernas de investigación? El caso de las intervenciones de comunicaciones privadas", VV.AA., Reflexiones en torno a la Delincuencia Organizada, E. Buscaglia y $S$. González Ruiz coords., México, 2005.

GOLDSCHMIDT, J., Problemas jurídicos y políticos del Proceso Penal, Barcelona, 1935.

GOMES, A. F., "Caracteres do crime organizado", VV.AA., Crime organizado e suas conexões com o Poder Público. Comentários a Lei 9.034/95: considerações críticas, Rio de Janeiro, 2000.

GOMES, L. F., "Videoconferência: Lei n. 11.900, de 08.01.2009", http://www.lfg.com.br.

GOMES, L. F., CERVINI, R; Crime organizado. Enfoques criminológico, jurídico (Lei 9.034/95) e político-criminal, São Paulo, 1995.

GOMES, L.F; GARCÍA-PABLOS DE MOLINA, A., BIANCHINI, A., Direito Penal. Introdução e princípios, vol. 1, São Paulo, 2007.

GOMES, L. F; MAZZUOLI, V. O., Comentários a Convenção Americana de Direitos Humanos. Pacto de San José da Costa Rica, São Paulo, 2010.

GOMES, M. G. M., "Devido processo legal e direito ao procedimento adequado", Revista Brasileira de Ciências Criminais, núm, 55, São Paulo, 2005.

GOMES, R. C., O crime organizado na visão da Convenção de Palermo, Belo Horizonte, 2008.

- A videoconferência ou interrogatório on-line, seus contornos legais e a renovação do processo penal célere e eficaz", Revista Instituto Iob, Porto Alegre, 2007.

GOMES CANOTILHO, J. J., Terrorismo e Direitos fundamentais, Coimbra, 2009.

- O problema da responsabilidade do Estado por actos lícitos, Coimbra, 1983.

GOMES FILHO, A. M., Direito à prova no Processo Penal, São Paulo, 1997.

- A motivação das decisões penais, São Paulo, 2001.

- Presunção de inocência no processo penal, São Paulo, 1991.

- "Também em matéria processual provoca inquietação a Lei anti-crime organizado", Boletim do Instituto Brasileiro de Ciências Criminais, núm. 13, São Paulo, 1994.

GOMES FILHO, A. M; SCARANCE FERNANDES, A; GRINOVER, A. P., As nulidades no processo penal, $2^{\text {a }}$ edición, São Paulo, 1982.

GÓMEZ, L., España Connection. La implacable expansión del crimen organizado en España, Barcelona, 2005.

GÓMEZ COLOMER, J. L., Constitución y Proceso Penal, Madrid, 1996.

- "Estado de Derecho y Policía Judicial Democrática: Notas sobre el alcance y límites de la investigación policial en el proceso penal, con consideración especial de los actos de mayor relevancia", VV.AA., El proceso penal en el Estado de Derecho (Diez estudios doctrinales), Lima, 1999. 
- "Estado democrático y modelo policial: una propuesta de diseño de cara a lograr una investigación eficaz del crimen", La policía en los Estados de Derecho Latinoamericanos, Un proyecto internacional de investigación, Bogotá, 2003.

- "La investigación criminal: problemas actuales y perspectivas de unificación internacional", Revista del Poder Judicial, núm. 64, 2001.

- "Prueba prohibida e interpretación de la jurisprudencia del Tribunal Constitucional y del Tribunal Supremo españoles", Anuario de Derecho penal 2008: Temas penales en la jurisprudencia del Tribunal Constitucional, Lima, 2009.

- "La prohibición de investigar la verdad a cualquier precio en el sistema adversarial (el caso español)", Conferencia pronunciada en el Congreso Internacional de Derecho Procesal Penal sobre "Evaluación y restos del sistema penal acusatorio: un debate sobre sus debilidades y perspectivas", organizado por la Universidad Sergio Arboleda los días 5 y 6 de octubre en Bogotá, 8 y 9 de octubre en Santa Marta, http://www.usergioarboleda.edu.co/santamarta/institucional/escuelas/derecho/eve ntos/1er_congreso_penal/ponencias/prueba_prohibida_juangomez.pdf.

GÓMEZ COLOMER, J. L.; MONTERO AROCA, J; MONTÓN REDONDO, A., BARONA VILAR, S., Derecho Jurisdiccional III, Proceso Penal, 12ª edición, Valencia, 2004.

GÓMEZ DE LIAÑO FONSECA-HERRERO, M., Criminalidad organizada y medios extraordinarios de investigación, Madrid, 2004.

- "Infiltración policial y proceso penal", VV.AA., Investigación y prueba en el proceso penal, N. Gonzáles-Cuéllar Serrano y Á. Sanz Hermida coords., Madrid, 2006.

- El agente encubierto como medida de investigación del terrorismo en el contexto internacional", VV.AA., Terrorismo y Estado de Derecho, J. R. Serrano-Piedecasas y E. Demetrio Crespo coods., Madrid, 2010.

- "Límites y garantías procesales en la investigación mediante agente encubiertos", La Ley, año XXV, núm. 6142, 7 de diciembre de 2004, http://www.diariolaley.laley.es.

GÓMEZ DE LIAÑO GONZÁLEZ, F., El proceso penal. Tratamiento Jurisprudencial, 7a edición, Oviedo, 2004.

- "La investigación criminal: problemas actuales y perspectivas de unificación internacional", Revista del Poder Judicial, núm. 64, 2001.

GÓMEZ ORBANEJA, E., HERCE QUEMADA, V., Derecho Procesal Penal, 10ª edición, Madrid, 1984.

GÓMEZ SILVA, P; LÓPEZ CALVO, P., Investigación criminal y criminalística, Bogotá, 2000.

GONÇALVES, F., JOÃO ALVES, M., GUEDES VALENTE, M. M., Lei e Crime. O agente infiltrado Versus o agente provocador. Os princípios do processo penal, Coimbra, 2001.

GONÇALVES, F; JOÃO ALVES, M., A prova do crime. Meios legais para a sua obtenção, Coimbra, 2009.

GONZÁLEZ, H. R., Estado de no derecho, emergencia y derechos constitucionales, Buenos Aires, 2007.

GONZÁLEZ, R. L., "Cuestiones referidas a la utilización de agentes encubiertos en la represión del narcotráfico", Doctrina Judicial, núm. 33, 1996.

GONZÁLES BEILFUSS, M., El principio de proporcionalidad en la jurisprudencia del Tribunal Constituciona, Navarra, 2003.

GONZÁLEZ CANO, Ma. I; MAPELLI CAFFARENA, B; AGUADO CORREA, T., Estudios sobre Delincuencia Organizada. Medios, instrumentos y estrategias de la investigación policial, Sevilla, 2001. 
GONZÁLES-CASTELL, A. C., "El agente infiltrado en España y Portugal. Estudio comparado a la luz de las garantías y de los principios constitucionales", VV.AA., Criminalidade organizada e criminalidade de massa. Interferências e ingerências mútuas, M. M. Guedes Valente coord., Coimbra, 2009.

GONZÁLEZ-CÚELLAR, A; HERNÁNDEZ GUIJARRO, J. J; PAZ RUBIO, J. Mํạ RODRIGUES RAMOS, L; TOMÉ PAULE, J., Ley de enjuiciamiento criminal y ley del jurado, Madrid, 2001.

GONZÁLEZ-CUELLAR SERRANO, N., Proporcionalidad y derechos fundamentales en el proceso penal, Madrid, 1990.

- "Investigación y prueba: los nuevos retos ante la reforma del proceso penal", VV.AA., Investigación y prueba en el Proceso Penal, Madrid, 2006.

GONZÁLEZ CUSSAC, J. L., "El renacimiento del pensamiento totalitario en el seno del Estado de Derecho: la doctrina del derecho penal del enemigo", Revista Penal, núm. 19, Barcelona, 2007.

GONZÁLEZ GARCÍA, J. M., "Entre el derecho de defensa y el derecho a la información: viejas y nuevas cuestiones sobre la publicidad de las actuaciones del proceso penal", Revista del Poder Judicial, núm. 80, 2005.

GONZÁLEZ GARCÍA, S; ECHARRI CASI, F. J., Aspectos procesales de la delincuencia económica, M. J. Vallejo y F. Bernate Ochoa coords., Bogotá, 2005.

GONZÁLEZ MONGUÍ, P. E., La policía judicial en el sistema penal acusatorio, Bogotá, 2007.

GONZÁLEZ MONTES, J. L., "La prueba obtenida ilícitamente con violación de derechos fundamentales (el derecho constitucional a la prueba y sus límites", Revista de Derecho Procesal, núm. 1, 1990.

GONZÁLEZ MOTA, V. J., "La especialización de la Fiscalía en la investigación de la criminalidad organizada", Corrupción y delincuencia económica, N. Rodríguez García y E. Fabián Caparrós coords, Bogotá, 2008.

GONZÁLEZ RIVAS, J. J., "La importancia de la Carta de Derechos Fundamentales de la Unión Europea en los ámbitos civil y penal: Reflexiones sobre la Conferencia de Presidentes de Tribunales Supremos y Fiscales Generales de la Unión Europea, celebrada en Madrid en 2010", Noticias de la Unión Europea, núm. 315, 2011.

GONZÁLEZ RUIZ, S; BUSCAGLIA, E; GOECKENJAN, I; MENDIETA JIMÉNEZ, E; MERLE, A., "Delincuencia organizada y derechos humanos: ¿Cómo controlar el uso de las técnicas modernas de investigación? El caso de las intervenciones de comunicaciones privadas", VV.AA., Reflexiones en torno a la Delincuencia Organizada, E. Buscaglia y S. González Ruiz coords., México, 2005.

GONZÁLES VIADA, N., Derecho penal y globalización. Cooperación penal internacional, Madrid, 2009.

GORDILLO ÁLVAREZ-VALDÉS, I., "Equipos conjuntos de investigación”, La ley penal Revista de derecho penal, procesal y penitenciario, vol. 1, núm. 2, 2004.

GÓRRIZ ROYO, E. Mạ., "La presunción de inocencia como criterio de aplicación del Derecho penal", VV.AA., Constitución, Derechos Fundamentales y Sistema Penal. Semblanzas y estudios con motivo del setenta aniversario del profesor Tomás Salvador Vives Antón, M. L.Cuerda Arnau coord., Valencia, 2009.

GRACIA MARTÍN, L., El horizonte del finalismo y el derecho penal del enemigo, Valencia, 2005. 
- Prolegómenos para la lucha por la modernización y expansión del Derecho penal y para la crítica del discurso de resistencia, Valencia, 2003.

- "Consideraciones críticas sobre el actualmente denominado Derecho penal del enemigo", Revista Electrónica de Ciencia Penal y Criminología, núm. 7, 2005, http://www.criminet.ugr.es/recpc.

- "¿Qué es modernización del Derecho penal?", La Ciencia del Derecho penal ante el nuevo siglo, Madrid, 2002.

GRANADOS PÉREZ, C., "Instrumentos procesales en la lucha contra el crimen organizado. Agente encubierto. Entrega vigilada. El arrepentido. Protección de testigos. Posición de la jurisprudencia", VV.AA., La criminalidad organizada. Aspectos sustantivos, procesales y orgánicos, C. Granado Pérez coord., Madrid, 2001.

GRANDinetTI C. DE CARVAlHO, L. G., Processo Penal e Constituição, 4aㅡ edición, Rio de Janeiro, 2006.

- "Garantias Constitucionais-Processuais Penais (A efetividade e a ponderação de garantias no processo penal)", Revista Escola da Magistratura do Estado do Rio de Janeiro, vol. 6, núm. 23, Rio de Janeiro, 2003.

GRAZIOSI, B; OLIVEIRO FERRARÍS, A., ¿Qué es la pedofilia?, 1a edición, Barcelona, 2004.

GRECO, L., "Garantias fundamentais do processo: o processo justo", http://www.mundojuridico.adv.br.

- "O conceito de prova", Revista da faculdade de Direito de Campos, año IV, núm. 4, 2003.

GRECO, L. F, "Sobre o chamado Direito penal do inimigo", Revista da Faculdade de Direito de Campos, núm. 7, 2005.

GRECO, R., Direito Penal do Equilíbrio. Uma visão minimalista do Direito Penal, Niterói, 2005.

- Atividade Policial. Aspectos Penais, Processuais Penais, Administrativos e Constitucionais, Niteroi, 2009.

GRECO FILHO, V., Manual de Processo Penal, São Paulo, 1997.

GREVI, V., Processo penale e criminalità organizzata, Bari, 1993.

Nuovo códice di procedura penale e procesi di criminalità organizzata: un primo bilancio, Processo penale e criminalitá organizzata, Roma/Bari, 1993.

- "Garanzie individuali ed esigenze di difesa sociale nel processo penale(a cura di Lucio Lanfranchi)", Garanzie Costituzionali e Diritti Fondamentali, Roma, 1997.

- GRINOVER, A. P., O processo em evolução, Rio de Janeiro, 1996.

- Novas tendências do Direito Processual: de acordo com a Constituição de 1988, 2ª edición, São Paulo, 1990.

- "As garantias constitucionais do processo", Novas tendências do direito processual de acordo com a Constituição de 1988, São Paulo, 1990.

- "Lineamentos gerais do novo processo penal na América Latina", Revista de Processo, São Paulo, vol. 15, núm. 58, 1990.

GRINOVER, A. P; ARAÚJO CINTRA, A. C; DINAMARCO, C. R., Teoria Geral do Processo, 5a edición, São Paulo, 1985.

GRINOVER, A. P; SCARANCE FERNANDES, A; GOMES FILHO, A.M., As nulidades no processo penal, $2^{\text {a }}$ edición, São Paulo, 1982.

GUARIGLIA, F., "El agente encubierto. ¿Un nuevo protagonista en el procedimiento penal?", Revista Jueces para la Democracia, núm. 23, 1994. 
- "El agente encubierto se vuelve provocador. Un nuevo desacierto de la casación", Suplemento de Jurisprudencia Penal, Buenos Aires, 1998.

GUARIGLIA, F; MAIER, J. B., "Las prohibiciones de valoración probatoria en el procedimiento penal", Revista de Ciencias Penales, núm. 4, Montevideo, 1998.

GUASTINI, R., "Principios de Derecho y discrecionalidad judicial", trad. de P. Andrés Ibáñez, Jueces para la democracia, núm. 34, 1999.

GUEDES VALENTE, M. M., Regime Jurídico da Investigação Criminal. Comentado e anotado, 3aㅡ edición, Coimbra, 2003.

- Teoria Geral do Direito Policial, Tomo I, Coimbra, 2005.

- "A Investigação do crime organizado. Buscas domiciliárias, o agente infiltrado e intervenção nas comunicações", VV.AA., Criminalidade organizada e criminalidade de massa. Interferências e ingerências mútuas, Coimbra, 2009.

GUEDES VALENTE, M. M., GONÇALVES, F., JOÃO ALVES, M., Lei e Crime. $O$ agente infiltrado Versus o agente provocador. Os princípios do processo penal, Coimbra, 2001.

GUERRA FILHO, W. S., Processo constitucional e direitos fundamentais, São Paulo, 1999.

GUERRERO, B; SALCEDO-ALBARÁN, E y LEÓN-BELTRÁN, I., "La reconfiguración cooptada del Estado: Más allá de la concepción tradicional de captura económica del Estado", http://www.transparenciacolombia.org.co/Portals/0/Captura\%20del\%20Estad.pdf.

GUERRERO PERALTA, O. J., Fundamentos teóricos constitucionales del nuevo proceso penal, Bogotá, 2007.

GUILLÉN LÓPEZ, G; NÚÑEZ PAZ, M. A., "Entrega vigilada agente encubierto y agente provocador. Análisis de los medios de investigación en materia de drogas", Anuario de Derecho Penal y Ciencias Penales, Tomo LXI, Madrid, 2008.

- "El arrepentido en el ámbito del crimen organizado y en el tráfico de drogas: el artículo 376 del Código Penal español", Revista de Derecho de Extremadura, núm. 5, 2009.

GUSY, C., "Rechtsgüterschutz als Staatsaufgabe", Die öffentliche Verwaltung, 1996.

GUTIÉRREZ DE CABIEDES Y FERNANDEZ DE HEREDIA, E., PRIETO-CASTRO y FERRÁNDIZ, L., Derecho procesal penal, $2^{\text {a }}$ edición, Madrid, 1978.

GUTIÉRREZ ZARZA, Ma․ Á., Investigación y enjuiciamiento de los delitos económicos, $1^{\text {a }}$ edición, Madrid, 2000.

GÚZMAN, R; MATUS ACUÑA, J. P., Lecciones de Derecho penal Chileno. Parte especial, 2a edición, Talca, 2002.

GUZMÁN FLUJA, V. C., Anticipación y preconstitución de la prueba en el Proceso Penal, Valencia, 2006.

- "El agente encubierto y las garantías del proceso penal", VV.AA., La prueba en el Espacio Europeo de libertad, seguridad y justicia penal, Navarra, 2006.

GWINNER, E; RADBRUCH, G., Historia de la criminalidad (Ensayo de una criminología histórica), Barcelona, 1955.

HÄBERLE, P., "El Tratado de Reforma de Lisboa de 2007", Revista de Derecho Constitucional Europeo, núm. 9, 2008.

HASSAN CHOUKR, F., Garantias constitucionais na investigação criminal, Rio de Janeiro, 2006.

- Processo Penal de Emergência, Rio de Janeiro, 2002.

- "A ordem constitucional e o processo penal", Revista Brasileira de Ciências Criminais, núm. 8, São Paulo, 1994.

- HASSEMER, W., Critica al Derecho Penal de hoy, Buenos Aires, 1995. 
- "Processo penal e direitos fundamentais", Jornadas de Direito Processual Penal e Direitos Fundamentais, M. F. Palma coord., Coimbra, 2004.

- Fundamentos de Derecho Penal, trad. F. Muñoz Conde y L. Arroyo Zapatero, Barcelona, 1984.

- "Límites del Estado de Derecho para el combate contra la criminalidad organizada", Revista de la Asociación de Ciencias Penales de Costa Rica, núm. 14, http://www.cienciaspenales.org.

- "Sobre el Ejercicio Abusivo de los Derechos" VV.AA., El Penalista Liberal, J. L. Guzmán Dalbora coord., Buenos Aires, 2004.

HEFENDEHL, R., "¿La criminalidad organizada como fundamento de un derecho penal del enemigo o de autor?", Derecho Penal y Criminología, vol. 25, núm. 75, Bogotá, 2004.

HELIE, M. F., Traté de l'instruction criminelle ou théorie du Code di instruction criminelle, Paris, 1866.

HENKEL, H., Strafverfahrensrecht, Stuttgart/Köln, 1953.

HENRIQUES GASPAR, A., "As exigências da investigação no processo penal durante a fase de instrução", VV.AA., Que futuro para o Direito processual penal?, Simpósio em homenagem a Jorge de Figueiredo Dias, por ocasião dos 20 anos do Código de Processo Penal português, Coimbra, 2009.

HERCE QUEMADA, V; GOMEZ ORBANEJA, E., Derecho Procesal Penal, 10ª edición, Madrid, 1984.

HERMIDA, Á. R., "El agente infiltrado y su regulación por el Derecho español", Periódico "El mundo", 31.1.2008.

HERNÁNDEZ GUIJARRO, J. J; GONZÁLEZ-CÚELLAR, A; PAZ RUBIO, J. Mạa; RODRIGUES RAMOS, L; TOMÉ PAULE, J., Ley de enjuiciamiento criminal y ley del jurado, Madrid, 2001.

HERNANDO MARTÍN, F., "La guardia civil en la lucha contra el crimen organizado: técnicas de información, metodología operativa y directrices policiales en las investigaciones", http://www.cej.justicia.es.

HERRERO HERRERO, C., Criminología, Parte general y especial, Madrid, 1997.

HERRERO TENEDOR, F., La intimidad como derecho fundamental, Madrid, 1998.

HIDALGO, M. J., "Conformación de la línea persecutoria en el proceso penal, Coherencia y continuidad", Exigencias actuales de la persecución penal, Propuestas, discusiones, práctica judicial, Córdoba, 2004.

HINOJOSA SEGOVIA, R; ARAGONESES MARTÍNEZ, S; DE LA OLIVA SANTOS, A; MUERZA ESPARZA, J; TOMÉ GARCÍA, J. A., Derecho Procesal Penal, Octava edición, Madrid, 2007.

HOYOS SANCHO, M., "Armonización de los procesos penales, reconocimiento mutuo y garantías esenciales", VV.AA., El proceso penal en la Unión Europea: garantías esenciales, Valladolid, 2008.

HORACIO OBLIGADO, D., "Sobre la génesis de los principios y garantías del proceso penal", Garantías, medidas cautelares e impugnaciones en el proceso penal, Rosario, 2005.

HUERTAS MARTÍN, Ma. I., El sujeto pasivo del proceso penal como objeto de la prueba, primera edición, 1998.

HUERTAS MARTÍN, I; BUJOSA VADELL, L;POZO PÉREZ, M; VICENTE JIMÉNEZ, C., Derecho procesal penal, Salamanca, 2007. 
HURTADO POZO, J., "Globalización y delincuencia organizada", Orientaciones de la Política Criminal legislativa, M. Moreno Hernández coord., México, 2005.

HUSTER, S; GARZÓN VÁLDES, E y MOLINA, F., Terrorismo y Derechos Fundamentales, Madrid, 2010.

KAISER, G., Organizaed crime, Kongressakten XIV, Internationaler Strafrechtkongress Asociación Internacional de Derecho Penal, 1989.

KELLENS, G., "L'évolución de la theorie du crime organisé", Criminología y Derecho penal al servicio de la persona, Libro homenaje al profesor Antonio Beristain, San Sebastián, 1989.

KNIJNIK, D., A prova nos Juízos Cível, Penal e Tributário, Rio de Janeiro, 2007.

IBAÑEZ Y GARCÍA VELASCO, M., Curso de Derecho Procesal Penal, Madrid, 1969.

IGLESIAS RÍO, M. A., "Criminalidad organizada y delincuencia económica: aproximación a su incidencia global", VV.AA., El nuevo derecho penal español: estudios penales en memoria del profesor José Manuel Valle Muñiz, Pamplona, 2001.

ISENSEE, J., Das Grundrecht auf Sicherheit. Zu den Schutzpflichten des Freiheitlichen Verfassungsstaates, Berlin, 1983.

JAÉN VALLEJO, M., Los principios de la prueba en el proceso penal, Bogotá, 2006.

JAIME-JIMÉNEZ, Ó; CASTRO MORAL, L., " La criminalidad organizada en la Unión Europea. Estado de la cuestión y respuestas institucionales", Revista Cidob d'Afers Internacionals, núm. 91, 2010.

JAKOBS, G., "Criminalización en el estadio previo a la lesión de un bien jurídico", VV.AA., Bases para una teoría funcional del Derecho penal, Lima, 2000.

JAKOBS, G., CANCIO MELÍA, M., Derecho Penal del Enemigo, 1ae edición, Madrid, 2003.

JAKOBS, G., CANCIO MELIÁ, M., Direito Penal do Inimigo, Noções e críticas, trad. A. Luís Callegari y N. José Giacomolli, Porto Alegre, 2005.

JAUCHEN, E. M., Tratado de la prueba en materia penal, Buenos Aires, 2002.

JESCHECK, H. H., "Entre dogmatisme et pragmatismo: l'evolution des expérienses contemporaines de codification et des pratiques legislatives", Nouvelles Études Pénales, núm 17, Toulouse, 1998.

JESUS, D. E., "¿Particular pode atuar como agente infiltrado?", http://www.damasio.com.br.

JESUS, D. E; BECHARA, F. R., "Agente infiltrado: reflexos penais e processuais", http://www.jus2.uol.com.br.

JIMÉNEZ CAMPO, J., Derechos fundamentales, Concepto y garantías, Madrid, 1999.

JIMÉNEZ DIAZ, Ma. J., Seguridad ciudadana y Derecho penal, Madrid, 2006.

JIMÉNEZ FERNÁNDEZ, R., "Los equipos conjuntos de investigación", http://www.cienciaspenales.net.

JIMÉNEZ VILLAREJO, C., "Transnacionalización de la delincuencia y persecución penal", Crisis del sistema político, criminalización de la vida pública e independencia judicial, $P$. Andrés Ibáñez coord., Consejo General del Poder Judicial, Madrid, 1998.

JOÃO ALVES, M., GUEDES VALENTE, M. M., GONÇALVES, F., Lei e Crime. $O$ agente infiltrado Versus o agente provocador. Os princípios do processo penal, Coimbra, 2001.

JOÃO ALVES, M; GONÇALVES, F; A prova do crime. Meios legais para a sua obtenção, Coimbra, 2009. 
JORDÁN DÍAZ-RONCERO, Ma․ J; COMES RAGA, I., "El arrepentimiento postdelictual en España: un ensayo acerca de su viabilidad como instrumento combativo del crimen organizado", La Ley Penal, núm. 77, 2010, http://www.revista-laleypenal.laley.es.

JUAN MORESO, J., "Alexy y la aritmética de la ponderación", VV.AA., El principio de proporcionalidad y protección de los derechos fundamentales, México, 2008.

JUANES PECES, Á; SUÁREZ-BÁRCENA, E. L; DE DIEGO DÍEZ, L. A; COQUILLAT VICENTE, Á; MORENO CATENA, V., El proceso penal. Doctrina, jurisprudencia y formularios, Valencia, 2000.

LAJE ANAYA, J., Narcotráfico y derecho penal argentino, Córdoba, 1998.

LAMARCA PÉREZ, C., "Sobre el concepto de terrorismo (a propósito del caso Amedo)", Anuario de Derecho Penal y Ciencias Penales, 1993.

LANZAROTE MARTINEZ, P., Vulneración del Plazo Razonable en el Proceso Penal, Madrid, 2005.

LARRAURI PIJOAN, E., "Criminología crítica: Abolicionismo y Garantismo", VV.AA., Garantismo y Derecho Penal, J. O. Sotomayor Acosta coord., Bogotá, 2006.

LASCANO, C. J., "La insostenible modernización del derecho penal basada en un derecho penal para enemigos: como manifestación de un nuevo derecho penal autoritario", Pensamiento Penal del Sur, Buenos Aires, 2004.

LAURIA TUCCI, R., Direitos e Garantias individuais no Processo Penal Brasileiro, 2ª edición, São Paulo, 2004.

LAVOURA ROMÃO, C. E; BARROS, M. A., "Internet e videoconferência no processo penal", Revista do Centro de Estudos Judiciários, núm. 32, Brasília, 2002.

LEÃO, N. C., "Direitos fundamentais, garantias constitucionais e processo penal", Revista do Conselho Nacional de Política Criminal e Penitenciária, Brasília, Julho 98/dezembro 99.

LEMES JÚNIOR, A. P., "A investigação criminal diante das organizações criminosas e o posicionamento do Ministério Público", Caderno Jurídico: Novas formas de criminalidade, ano 1, vol. 1, núm. 3, São Paulo, 2001.

LEÓN-BELTRÁN, I; SALCEDO-ALBARÁN, E y GUERRERO, B., "La reconfiguración cooptada del Estado: Más allá de la concepción tradicional de captura económica del Estado", http://www.transparenciacolombia.org.co/Portals/0/Captura\%20del\%20Estad.pdf.

LEONE, G., Tratado de Derecho Procesal Penal, trad. S. Santís Melendo, vol. II, Buenos Aires, 1963.

- Elementi di Diritto e Procedura Penale, Napoli, 1981.

LESSA, I., "Na senda vestibular do crime", http://www.bbc.co.uk/portuguese/noticias/2009/09/090914_ivanlessa_tp.shtml.

LESCH, H. H., "Hörfalle und Kein Ende - Zur Verwertbarkeit von Selbstbelastenden Angaben des Beschuldigten in der Untersuchungshaft", GA, núm. 141, 2000.

LIEBMAN, E. T., "Diritto costizionale e processo civile", Rivista de diritto processuale, Padova, 1952.

LIÑÁN NOGUERAS, D. J; MANGAS MARTÍN, A., Instituciones y Derecho de la Unión Europea, 6a edición, Madrid, 2010.

LLERA SÚAREZ-BÁRCENA, E, El modelo constitucional de investigación penal, Valencia, 2001.

LLERA SUÁREZ-BÁRCENA, E; DE DIEGO DÍEZ, L. A; COQUILLAT VICENTE, Á; MORENO CATENA, V; JUANES PECES, Á., El proceso penal. Doctrina, jurisprudencia y formularios, Valencia, 2000. 
LLOBET ANGLÍ, M., Derecho penal del terrorismo. Límites de su punición en un Estado democrático, Madrid, 2010.

LOBO DA COSTA, H. R., "Os rumos da política criminal cinco anos depois do 11 de setembro. Política criminal e dogmática penal: entre a judicialização e a administrativização", VV.AA., Repressão penal e crime organizado, São Paulo, 2009.

LOPERA MESA, G. P., "Principio de proporcionalidad y control constitucional de las leyes penales", VV.AA., El principio de proporcionalidad y protección de los derechos fundamentales", M. Carbonell coord., México, 2008.

LOPES JR, A., Direito processual e sua conformidade constitucional, Vol. I, Rio de Janeiro, 2007.

- Sistemas de investigações preliminares no Processo Penal, 4ae edición, Rio de Janeiro, 2006.

- Introdução crítica ao Processo Penal, 4⿳亠丷a edição, Rio de Janeiro, 2006.

- "A instrumentalidade garantista do processo penal", http://www.juspodivm.com.br.

LOPES JR, A., BADARÓ, G. H., Direito ao Processo Penal no Prazo Razoável, Rio de Janeiro, 2006.

LÓPEZ BARJA DE QUIROGA, J., Tratado de Derecho Procesal Penal, 2ª edición, Navarra, 2007.

- Las escuchas telefónicas y la prueba ilegalmente obtenida, Madrid, 1989.

- "Posición de la Unión Europea sobre el crimen organizado", Número monográfico sobre "La criminalidad organizada. Aspectos sustantivos, procesales y orgánicos", Cuadernos de Derecho Judicial, núm. II, 2001.

- "El agente encubierto", La Ley, Diario 4778, Madrid, 1999.

LÓPEZ CALVO, P., GÓMEZ SILVA, P., Investigación criminal y criminalística, Bogotá, 2000.

LÓPEZ DÍAS, E., El derecho al honor y el derecho a la intimidad, Madrid, 1996.

LÓPEZ-FRAGOSO ÁLVAREZ, T., Las intervenciones telefónicas en el proceso penal, Madrid, 2001.

LÓPEZ JACOISTE, J. J., Intimidad, honor e imagen ante la responsabilidad civil, VV.AA., Libro homenaje a Juan Berchmans Vallet de Goytisolo, Junta de Decanos de los Colegios Notariales de España, vol. IV, Madrid, 1988.

LÓPEZ ORTEGA, J. J., "Prueba y proceso equitativo. Aspectos actuales en la jurisprudencia del Tribunal Europeo de Derechos Humanos", Derechos y Libertades, Revista del Instituto Bartolome de las Casas, año 1, núm. 2, 1993-1994.

LÓPEZ RODRÍGUEZ, J. A., "Resumen de La Policía Judicial y la obsoleta Ley de Enjuiciamiento Criminal", La Ley, núm. 7637, 2011.

LÓPEZ SÁNCHEZ, R; AGUILLERA PORTALES, R. E., "Los derechos fundamentales en la filosofía jurídica garantista de Luigi FERRAJOLI", Revista Letras Jurídicas, núm. 4, 2007, http://www.letrasjuridicas.cuci.udg.mx/.

LÓPEZ SUÁREZ, N., "Inseguridad ciudadana: construcción o percepción subjetiva", Revista Iter Criminis, México, 1999.

LÓPEZ YAGÜES, V., "Circulación o entrega vigilada de drogas u otros efectos", VV.AA., Investigación y prueba en el proceso penal, Madrid, 2006.

LORCA NAVARRETE, A. Mㅁ., Estudios sobre garantismo procesal. El derecho procesal conceptuado a través de la metodología del garantismo procesal: el denominado "Derecho de la garantía de la función jurisdiccional, San Sebastián, 2009. 
- "Garantismo procesal y participación ciudadana en la administración de justicia mediante la institución del jurado. El modelo español", Revista del Instituto de la Judicatura Federal, núm. 25, México, 2008.

LORENTZ BLANK, G., "Instrumentalidade garantista do processo penal", Revista do Ministério Público do Estado de Minas Gerais, Belo Horizonte, 2005.

LOUREIRO, J., Agente infiltrado? Agente provocador! Reflexões sobre o 1o acórdão do T. E. D. Homem - 9 junho 1998. Condenação do Estado Português, Coimbra, 2007.

LUCAS MARTÍN, I., "La prueba en el proceso penal en el contexto de la Unión Europea", VV.AA., El proceso penal en la Unión Europea: garantías esenciales, M. Hoyos Sancho coord., Valladolid, 2008.

LUCAS SOSA, G., " Abuso de Derechos Procesales", VV.AA., Abuso dos Direitos Processuais, J. C. Barbosa Moreira coord., Rio de Janeiro, 2000.

LUCIANO GARCIA, J. A., "La crisis o el cuestionamiento al sistema penal. La diacronia genealogica entre el garantismo y la eficiencia", Revista de Ciencias Penales, núm. 2, Montevideo, 1996.

LUHMANN, W., Soziologie des Risikos, Berlin, 1991.

MACHADO, M. R. A., Sociedade do risco e Direito Penal. Uma avaliação de novas tendências político-criminais, São Paulo, 2005.

MADEIRA DEZEN, G., Da prova penal. Tipo processual, provas típicas e atípicas, Campinas, 2008.

MADRID, D., Insider, Un policía infiltrado en las grades ultra, Madrid, 2005.

MAGARIÑOS, M., "Garantías constitucionales del derecho procesal penal", Doctrina Penal, año 11, números 41-44, Buenos Aires, 1988.

MAGAZ ÁLVAREZ, R., "Respuestas político-criminales a la delincuencia internacional: narcotráfico y terrorismo", VV.AA., Elementos básicos de investigación criminal, J. Collado Medina coord., Madrid, 2007.

MAGRO SERVET, V., Manual práctico de actuación policial-judicial en medidas de limitación de derechos fundamentales, Madrid, 2006.

- "Régimen legal de los testigos protegidos en el proceso penal", La Ley Penal, núm. 75, octubre/2010, http://www.revista-laleypenal.laley.es.

- "La viabilidad legal del uso de la videoconferencia para la celebración de los juicios penales", Actualidad Jurídica Aranzadi, núm. 519, 2002.

MAIA DA COSTA, E., "Agente provocador. Validade das provas", Revista do Ministério Público, núm. 93, Lisboa, 2003.

MAIER, J. B., Derecho Procesal Penal, tomo I, Buenos Aires, 2002.

- Derecho Procesal Penal. Fundamentos, Buenos Aires, 1999.

- "¿Es posible todavía la realización del proceso penal en el marco de un Estado de Derecho?," VV.AA., Estudos em homenagem a professora Ada Pellegrini Grinover, F. L. Yarshell y M. Z. de Morais coords., São Paulo, 2005.

MAIER, J. B; GUARIGLIA, F., "Las prohibiciones de valoración probatoria en el procedimiento penal", Revista de Ciencias Penales, núm. 4, Montevideo, 1998.

MAIEROVITCH, W., "A matriz terrorista do crime organizado e o fenômeno da eversão", Justiça Penal 3, O crime organizado (Itália e Brasil), J. C. Penteado coord., São Paulo, 1995.

MALAN, D. R., "Processo Penal do inimigo", Revista Brasileira de Ciências Criminais, Vol. 14, núm. 59, São Paulo, 2006. 
MALATESTA, N. F. D., A lógica das provas em matéria criminal, trad. Paolo Capitanio, São Paulo, 1996.

MALTZ, M., "Defining Organizad Crime", Handbook of Organized Crime in the United States, Westport, 1994.

MANCILLA OVANDO, J. A., Las garantías individuales y su aplicación en el proceso penal, Estudio constitucional del proceso penal, México, 1988.

MANGAS MARTÍN, A., Carta de los derechos fundamentales de la Unión Europea: comentario artículo por artículo, VV.AA., A. Mangas Martín y L. N. González Alonso coords., Madrid, 2008.

MANGAS MARTÍN, A; LIÑÁN NOGUERAS, D. J., Instituciones y Derecho de la Unión Europea, 6a edición, Madrid, 2010.

MANNA, A., "Erosión de las Garantías individuales en nombre de la eficacia de la acción de lucha contra el terrorismo: La privacy", VV.AA., Derecho Penal del Enemigo, El discurso penal de la exclusión, vol. 2, Buenos Aires, 2006.

MANZINI, V., Tratado de Derecho Procesal Penal, trad. S. Sentís Melendo y M. Ayerra Redin, Buenos Aires, 1951.

MAPELLI CAFFARENA, B., "Problemas de la ejecución penal frente a la criminalidad organizada", La Criminalidad Organizada ante la Justicia, F. Gutiérrez-Alviz Conrado coord., Sevilla, 1996.

MAPELLI CAFFARENA, B; GONZÁLEZ CANO, Ma. I; AGUADO CORREA, T., Estudios sobre Delincuencia Organizada. Medios, instrumentos y estrategias de la investigación policial, Sevilla, 2001.

MARQUES, J., "Métodos de investigação da criminalidade económico-financeira", Revista do Ministério Público, núm. 110, año 28, Lisboa, 2007.

MARQUES DA SILVA, G., Curso de processo penal, vol. 1, Lisboa, 2000.

- Curso de processo penal II, Lisboa, 1999.

MARCHAL ESCALONA, A. N., "Drogas. Actuación policial. Problemas en la investigación", Drogodependencia y Derecho, Cuadernos de Derecho Judicial, vol. VIII, 2003.

MARCOS DE CANO, A. M., "La seguridad jurídica. Su configuración actual", Estudios en homenaje al profesor Gregorio Peces-Barba, vol. 2., 2008.

MARIANO DA SILVA, C. M., "Provas ilícitas e o princípio da proporcionalidade", Carta Forense, noviembre 2010, págs. A18-A19, http://www.cartaforense.com.br.

MARTÍ MÁRMOL, J. L., "El fundamentalismo de Luigi FERRAJOLI: un análisis crítico de su teoría de los derechos fundamentales", Garantismo: estudios sobre el pensamiento jurídico de Luigi FERRAJOLI, M. Carbonell y P. Salazar coords., Madrid, 2005.

MARTÍ MINGARRO, L., "Prólogo" a la obra "La prueba ilícita penal, estudio jurisprudencial", Navarra, 2003.

MARTÍN, F. H., "La guardia civil en la lucha contra el crimen organizado: técnicas de información, metodología operativa y directrices policiales en las investigaciones", http://www.cej.justicia.es.

MARTÍN ACÍN, F; ÁLVAREZ RODRÍGUEZ, J. R., Metodología del atestado policial. Aspectos procesales y jurisprudenciales. Práctica jurídica, Madrid, 1999.

MARTÍN DIZ, F., "Los equipos conjuntos de investigación como técnica de cooperación procesal en la Unión Europea”, Revista del Poder Judicial, núm. 78, Madrid, 2005. 
- "Garantías procesales básicas en la Carta de Derechos Fundamentales de la Unión Europea", VV.AA., La Carta de Derechos Fundamentales de la Unión Europea : una perspectiva pluridisciplinar, A. A. Herrero de la Fuente coord., 2003.

MARTÍN GARCÍA, P., "Conceptos básicos sobre la eficacia de la prueba", VV.AA., La actuación de la policía judicial en el proceso penal, Madrid, 2006.

MARTÍN MORALES, R; DÍAZ CABIALE, J. A., La garantía constitucional de la prueba ilícitamente obtenida, Madrid, 2001.

MARTÍN PALLÍN, J. A., "Impacto social, criminológico, político y normativo del tráfico de drogas". VV.AA., Delitos contra la salud pública y contrabando, Cuadernos de Derecho Judicial, Madrid, 2000.

MARTÍN Y PÉREZ DE NANCLARES, J; URREA CORRES, M., Tratado de Lisboa, Madrid, 2008.

MARTINS, L; DIMOULIS, D., Teoria geral dos direitos fundamentais, 3a edición, 2011.

MARTÍNEZ-BUJÁN PÉREZ, C., Algunas reflexiones sobre la moderna teoría del Big Crunch en la selección de bienes jurídico penales (especial referencia al ámbito económico)", La Ciencia del Derecho Penal ante el nuevo siglo, Madrid, 2002.

MARTÍNEZ GARCÍA, E., Eficacia de la prueba ilícita en el proceso penal (a la luz la STC 81/98 de 2 de abril), Valencia, 2003.

- Actos de investigación e ilicitud de la prueba. El derecho al proceso y sus garantías como límite a la actuación de los poderes públicos en la investigación del delito, Valencia, 2009.

MARTÍNEZ PABÓN, S. J., La labor del agente encubierto en el sistema penal acusatorio, Bogotá, 2009.

MARTÍNEZ PÉREZ, R., Policía Judicial y Constitución, Navarra, 2001.

MARTÍNEZ ZORRILLA, D., Conflictos constitucionales, ponderación e indeterminación normativa, Madrid, 2007.

MASSON, C. R., "O Direito penal do inimigo", VV.AA., Processo Penal e garantias constitucionais, M. A. Marques da Silva coord., São Paulo, 2006.

MATA-MOUROS, F., "O agente infiltrado", Revista do Ministério Público, ano 22, núm. 85, Lisboa, 2001.

MATÍA SACRISTÁN, A., "El Tratado de Lisboa en el proceso de construcción europea", Boletín de Información del Ministerio de Justicia, año 62, núm. 2058, 2008.

MATUS ACUÑA, J. P; GÚZMAN, R., Lecciones de Derecho penal Chileno. Parte especial, 2a edición, Talca, 2002.

MAURÍCIO, A; PINHEIRO, R., A Constituição e o processo penal, Coimbra, 2007.

MARX, G., Undercover: Police surveillance in America, Berkeley, 1988.

MAZZUOLI, V. O; GOMES, L. F., Comentários a Convenção Americana de Direitos Humanos. Pacto de San José da Costa Rica, São Paulo, 2010.

MEDINA, J. L., "El derecho a la seguridad colectiva: un derecho fundamental en permanente expansión y progresión", La Ley, núm. 5, 2005.

MEDINA ARIZA, J. J., "Una introducción al estudio criminológico del crimen organizado", VV.AA., Delincuencia Organizada. Aspectos penales, procesales y criminológicos, J. C. Ferré Olivé y E. Anarte Borrallo coords., Huelva, 1999.

MEDINA GUERREIRO, M., La vinculación negativa del legislador a los derechos fundamentales, Madrid, 1996. 
MENA ÁLVAREZ, J. M., "Tratamiento penal del partícipe arrepentido", Cuadernos del Consejo General del Poder Judicial, volumen dedicado a Delitos contra la salud pública, núm. XXI, Madrid, 1992.

MENDES, G. F., "Os direitos fundamentais e seus múltiplos significados na ordem constitucional", Anuário Iberoamericano de Justicia Constitucional, núm. 8, 2004.

MENDIETA JIMÉNEZ, E; GONZÁLEZ RUIZ, S; BUSCAGLIA, E; GOECKENJAN, I; MERLE, A., "Delincuencia organizada y derechos humanos: ¿Cómo controlar el uso de las técnicas modernas de investigación? El caso de las intervenciones de comunicaciones privadas", VV.AA., Reflexiones en torno a la Delincuencia Organizada, E. Buscaglia y S. González Ruiz coords., México, 2005.

MENDONÇA, A. B., "A reforma do Código de Processo Penal sob a ótica do garantismo integral", Garantismo penal integral, Salvador, 2010.

MENDOZA BREMAUNTZ, E., Delincuencia global, Córdoba, 2005.

MENDOZA BUERGO, B., El Derecho Penal en la sociedad de riesgos, Madrid, 2001.

MENDOZA MUÑOZ, J; PAZ RUBIO, J. M; MORICHE, R. R; OLLÉ SESÉ, M., La prueba en el proceso penal. Su práctica ante los Tribunales, Madrid, 1999.

MENDRONI, M. B., Crime Organizado. Aspectos gerais e mecanismos legais, São Paulo, 2007.

MERCHÁN MATEOS, J. F; CAPARRÓS, E. A; RODRÍGUEZ GARCÍA, N; ZARAGOZA AGUADO, J.

A., Delincuencia económica y blanqueo de capitales, Salamanca, 2005 (inédito).

MERLE, A; MENDIETA JIMÉNEZ, E; GONZÁLEZ RUIZ, S; BUSCAGLIA, E; GOECKENJAN, I., "Delincuencia organizada y derechos humanos: ¿Cómo controlar el uso de las técnicas modernas de investigación? El caso de las intervenciones de comunicaciones privadas", VV.AA., Reflexiones en torno a la Delincuencia Organizada, E. Buscaglia y $S$. González Ruiz coords., México, 2005.

MICHAUD, Y., La violencia, Madrid, 1998.

MILITELLO, V., "Iniciativas supranacionales en la lucha contra la criminalidad organizada y el blanqueo en el ámbito de las nuevas tecnologías", Derecho Penal, sociedad y nuevas tecnologías, L. Zúñiga Rodríguez, C. Méndez Rodríguez y Mạ. R. Diego Díaz-Santos coords., Madrid, 2001.

MINGARDI, G., "O trabalho da Inteligência no controle do Crime Organizado", Revista Estudos Avançados da Universidade de São Paulo, núm. 61, São Paulo, 2007, http://www.scielo.br/pdf/ea/v21n61/a04v2161.pdf.

MIR PUIG, S., Introducción a las bases del Derecho Penal, Barcelona, 1976.

MIRABETE, J. F., Processo Penal, 13ª edición, São Paulo, 2002.

MIRANDA COUTINHO, J. N., "Efetividade do processo penal e golpe de cena: um problema às reformas processuais", VV.AA., Escritos de Direito e Processo Penal em homenagem ao professor Paulo Cláudio Tovo, A. Wunderlich coord., Rio de Janeiro, 2001.

MIRANDA RODRIGUES, A., "A defesa do argüido: uma garantia constitucional em perigo no admirável mundo novo", Revista Portuguesa de Ciencia Criminal, núm. 12, Lisboa, 2002.

MIRANDA ESTRAMPES, M., La mínima actividad probatoria en el proceso penal, Barcelona, 1997.

- El concepto de prueba ilícita y su tratamiento en el proceso penal, 2ª edición, Barcelona, 2004. 
MIRÓ LLENARES, F., "Democracias en crisis y Derecho penal del enemigo: política criminal frente al terrorismo en los Estados democráticos antes y después del 11 de septiembre de 2001", Cuadernos de política criminal, núm. 87, 2005.

MITTERMAIER, C. J. A., Tratado da prova em matéria criminal, Campinas, 2004.

MOCCIA, S., "Emergência e defesa dos direitos fundamentais", Revista Brasileira de Ciências Criminais, núm. 25, São Paulo, 1999.

- "Seguridad y Sistema Penal", VV.AA., Derecho Penal del Enemigo, El discurso penal de la exclusión, vol. 2, Buenos Aires, 2006.

MOLINA, F; HUSTER, S; GARZÓN VÁLDES, E., Terrorismo y Derechos Fundamentales, Madrid, 2010.

MOLINA MONSILLA, Mํ. C., Mecanismos de investigación policial: entrega vigilada y agente encubierto, Barcelona, 2009.

- El delito de narcotráfico, Barcelona, 2008.

- "La circulación y entrega vigilada de objetos de delito", La Ley penal, núm. 61, 2009.

MOLINA PÉREZ, T., "Técnicas especiales de investigación del delito: el agente provocador, el agente infiltrado y figuras afines (y II)", Anuario Jurídico y Económico Escurialense, XLII, 2009.

- "Técnicas especiales de investigación del delito: el agente provocador, el agente infiltrado y figuras afines", Anuario Jurídico y Económico Escurialense, XLI, 2008.

MONSALVE CORREA, S., "La prueba ilícita en el proceso penal colombiano a partir de la Constitución de 1991", Revista de la Facultad de Derecho y Ciencias Políticas, vol. 40, núm. 113, Medellín, 2010.

MONTALVO SANTAMARÍA, A., "La prevención del blanqueo de capitales de origen ilícito", Información Comercial Española, núm. 741, Madrid, 1995.

MONTAÑES PARDO, M. Á, La presunción de inocencia. Análisis doctrinal y jurisprudencial, Pamplona, 1999.

MONTEALEGRE LYNETT, E; BERNAL CUÉLLAR, J., El proceso penal, 4ํa edición, Bogotá, 2002.

MONTERO AROCA, J., Proceso y Garantía Civil y Penal. El proceso como garantía de libertad $y$ de responsabilidad, Valencia, 2006.

- Proceso penal y libertad. Ensayo polémico sobre el nuevo proceso penal, Navarra, 2008.

- "La denuncia anónima y su eficacia como acto de iniciación del procedimiento preliminar penal", VV.AA., Primeras Jornadas sobre Problemas Actuales de la Justicia Penal, Granada, 1994.

MONTERO AROCA, J., GÓMEZ COLOMER, J. L., MONTÓN REDONDO, A., BARONA VILAR, S., Derecho Jurisdiccional III, Proceso Penal, 12ª edición, Valencia, 2004.

MONTERO GÓMEZ, A., "Doctrina de infiltración para inteligencia contraterrorista", Revista Athena Paper, vol. 2, núm. 3, 2007, http://www.athenainteligence.org.

MONTESINOS GARCÍA, A., La videoconferencia como instrumento probatorio en el proceso penal, Madrid, 2009.

MONTESQUIEU, C., De L'Esprit des Lois, Paris, 1965.

MONTÓN GARCÍA, M. L., "Agente provocador y agente encubierto: ordenemos conceptos". La Ley, año XX, núm. 4826, 1999.

MONTÓN REDONDO, A.; MONTERO AROCA, J; GÓMEZ COLOMER, J. L.; BARONA VILAR, S., Derecho Jurisdiccional III, Proceso Penal, 12ª edición, Valencia, 2004. 
MONTOYA, M. D., Mafia y Crimen Organizado, Aspectos legales. Autoria mediata. Responsabilidad penal de los aparatos organizados de poder, Buenos Aires, 2004.

- Informantes y técnicas de investigación encubiertas. Análisis Constitucional y Procesal Penal, $2^{\text {a }}$ edición, Buenos Aires, 2001.

- "El agente encubierto en la lucha contra el crimen organizado en la Argentina", Revista de Derecho Penal, Procesal Penal y Criminología, vol. 1, núm. 2, Mendoza, 2001.

MORA MORA, L. P., "La prueba como derecho fundamental", Revista Iberoamericana de Derecho Procesal Constitucional, núm. 4, 2005.

MORA MOLINA, J. J., El garantismo jurídico de Luigi Ferrajoli, Huelva, 2004.

MORAS MOM, J. R., La investigación en el proceso penal. Técnica del descubrimiento, Buenos Aires, 1998.

MORAES PITOMBO, A. S. A., Organização Criminosa. Nova perspectiva do tipo legal, São Paulo, 2009.

MOREIRA, E. R., Neoconstitucionalismo. A Invasão da Constituição, São Paulo, 2008.

MORELLO, A. M., El proceso justo, La Plata, 1994.

- Constitución y proceso. La nueva edad de las garantías jurisdiccionales, La Plata-Buenos Aires, 1998.

- La prueba, tendencias modernas, Buenos Aires, 1991.

MORENILLA ALLARD, P; DÍAZ MARTÍNEZ, M; GIMENO SENDRA, V; TORRES DEL MORAL, A., Los Derechos Fundamentales y su protección jurisdiccional, Madrid, 2007.

MORENO, J. D., ¿Un derecho procesal de enemigos? VV.AA., Derecho penal del enemigo, El discurso penal de la exclusión, M.Cancio Meliá y C. Gómez-Jara Díez coords., Buenos Aires, 2006.

MORENO CATENA, V., - El secreto en la prueba de testigos del proceso penal, Madrid, 1980.

- "La Justicia Penal y su reforma", Revista Justicia, núm. 2, 1988.

- "Dependencia orgánica y funcional de la Policía Judicial", Revista del Poder Judicial, núm. Especial VIII (Seguridad ciudadana), 1989.

- "Los elementos probatorios obtenidos con la afectación de derechos fundamentales durante la investigación penal", VV.AA., Prueba y Proceso Penal. Análisis especial de la prueba prohibida en el sistema español y en el derecho comparado, J. L. Gómez Colomer coord., Valencia, 2008.

- "El enjuiciamiento de delitos de terrorismo y el derecho de defensa", VV.AA., Terrorismo y proceso penal acusatorio, Valencia, 2006.

- $\quad$ "El papel del Juez y del Fiscal durante la investigación del delito", VV.AA., Hacia un nuevo proceso penal, Manuales de formación continuada, Madrid, 2006.

- "La protección de los testigos y peritos en el proceso penal español", Delincuencia organizada. Aspectos penales, procesales y criminológicos, J. C. Ferré Olivé y E. Anarte Borrallo coords., Huelva, 1999.

- "Los agentes encubiertos en España", Revista do Ilustre Colegio de Abogados de Madrid, núm. 10, 1999.

- "Garantías de los derechos fundamentales en la investigación penal", Revista del Poder Judicial, número especial II, 1997.

MORENO CATENA, V. M; CORTÉZ DOMÍNGUEZ, V; GIMENo SENDRA, V., Derecho Procesal Penal, 2 ${ }^{\text {a }}$ edición, Madrid, 1997.

MORENO CATENA, V; CORTÉZ DOMÍNGUEZ; GIMENO SENDRA, V., Lecciones de Derecho Procesal Penal, Madrid, 2003. 
MORENO CATENA, V; CASTILLEJO MANZANARES, R., La persecución de los delitos en el Convenio de Schengen, Valencia, 1999.

MORENO CATENA, V.; COQUILLAT VICENTE, Á; DE DIEGO DÍEZ, L. A; JUANES PECES, Á; SUÁREZ-BÁRCENA, E. L., El proceso penal. Doctrina, jurisprudencia y formularios, Valencia, 2000.

MORELLO, A., Constitución y proceso. La nueva edad de las garantías jurisdiccionales, La Plata-Buenos Aires, 1998.

MORICHE, R. R; MENDOZA MUÑOZ, J; PAZ RUBIO, J. M; OLLÉ SESÉ, M., La prueba en el proceso penal. Su práctica ante los Tribunales, Madrid, 1999.

MORILlAS CUEVA, L., Derecho penal. Parte general, fundamentos conceptuales y metodológicos del Derecho penal, Madrid, 2004.

- "El delito de tráfico de drogas en sentido estricto", VV.AA., Estudios jurídico-penales y político-criminales sobre tráfico de drogas y figuras afines, Lorenzo Morillas Cueva coord., Madrid, 2003.

MOSCATO DE SANTAMARIA, C. B., El agente encubierto en el Estado de Derecho, Buenos Aires, 2000.

MOURAZ LOPES, J., "O crime econômico fiscal e o processo penal", II Congresso de Processo Penal, Coimbra, 2006.

MUERZA ESPARZA, J., "Instrumentos procesales en la lucha contra la criminalidad organizada", VV.AA., Derecho Procesal Penal Económico, Madrid, 2003.

MUERZA ESPARZA, J; HINOJOSA SEGOVIA, R; ARAGONESES MARTÍNEZ, S; DE LA OLIVA SANTOS, A; TOMÉ GARCÍA, J. A., Derecho Procesal Penal, Octava edición, Madrid, 2007.

MUÑOZ CONDE, F., La búsqueda de la verdad en el proceso penal, $2^{\text {a }}$ edición, Buenos Aires, 2003.

- De nuevo sobre el Derecho penal del enemigo, Buenos Aires, 2005.

- "¿Dominio de la voluntad en virtud de aparatos de poder organizados en organizaciones no desvinculadas del Derecho?, Problemas fundamentais de Direito Penal, libro homenaje a Claus Roxin, M. C. Valdágua coord., Lisboa, 2002.

- "Los orígenes ideológicos del Derecho penal del enemigo", Revista Penal, núm. 26, 2010.

- "La búsqueda de la verdad en el proceso penal", Revista de Derecho y proceso penal, núm. 1, 1999.

- "Los arrepentidos en el caso de la criminalidad o delincuencia organizada", La criminalidad organizada ante la justicia, F. Gutiérrez-alviz y Conradi coord., Sevilla, 1996.

- "De la prohibición de autoincriminación al Derecho procesal penal del enemigo", VV.AA., Terrorismo y Estado de Derecho, J. R. Serrano Piedecasas y E. Demetrio Crespo coords., Madrid, 2010.

MUNÕZ NEIRA, O., Sistema penal acusatorio de Estados Unidos, Bogotá, 2006.

MUÑOZ SÁNCHEZ, J., La moderna problemática jurídico penal del Agente Provocador, Valencia, 1995.

MURCHISON, K. M., "The Entrapment Defense in Federal Courts: Modern Developments", Mississippi Law Journal, núm. 47, 1976.

MURILLO DE LA CUEVA, P. L., "Perspectivas del derecho a la autodeterminación informativa", Revista de Internet, Derecho y Política, núm. 5, 2007.

MURILLO DE LA CUEVA, P. L; PIÑAR MAÑAS, J. L., El derecho a la autodeterminación informativa, Madrid, 2009. 
MUSACCHIO, V., "Derecho penal económico, criminalidad organizada y Unión Europea", Revista Brasileira de Ciências Criminales, núm. 60, 2006.

MUSCO, E., "Los colaboradores de la justicia entre el pentitismo y la calumnia: problemas y perspectivas", Revista Penal, núm. 2, 1998.

NARANJO DE LA CRUZ, R., "Los limites de los derechos fundamentales en las relaciones entre particulares: la buena fe", Boletín Oficial del Estado - Centro de Estudios Políticos y Constitucionales, Madrid, 2000.

NAVAJAS RAMOS, L., "Policía Judicial, composición, funciones y principios de actuación. Unidades Orgánicas de la Policía Judicial: su dependencia funcional y orgánica", Eguzkilore, núm. 13, San Sebastián, 1999.

- "La prueba videográfica en el proceso penal: su valor y límites para su obtención", Eguzkilore, núm. 12, San Sebastián, 1998.

NEÑEZ, E. V., CUESTA, E. P., "Aspectos procesales de la videoconferencia", La Ley Penal, vol. 5, núm. 46, 2008.

NERIA, C., "El arrepentido y el Agente encubierto: reflexiones acerca de un proyecto de ley contra las actividades terroristas", La Ley, Tomo 1997-B.

NICOLÁS MARCHAL ESCALONA, A., Manual de lucha contra la droga, Cizur Menor (Navarra), 2011.

NIEVA FENOLL, J., La valoración de la prueba, Madrid, 2010.

- "La protección de derechos fundamentales en las diligencias policiales de investigación del proceso penal", La Ley Penal, núm. 50, 2008.

NOGUEIRA ALCALÁ, H., Teoría y dogmática de los derechos fundamentales, México, 2003.

- Consideraciones sobre el derecho fundamental a la presunción de inocência, Revista Ius et Praxis, vol.11, núm.1, Talca, 2005, http://www.scielo.cl.

- "Aspectos de una Teoría de los Derechos Fundamentales: La Delimitación, Regulación, Garantías y Limitaciones de los Derechos Fundamentales", Revista Ius et Praxis, vol. 11, núm. 2, Talca, 2005.

NÚÑEZ PAZ, M. A., "Consideración critica en torno al Código penal español", Anuario de Deecho Penal y Ciencias Penales, vol. LII, 1999.

NÚÑEZ PAZ, M. A; GUILLÉN LÓPEZ, G., "Entrega vigilada agente encubierto y agente provocador. Análisis de los medios de investigación en materia de drogas", Anuario de Derecho Penal y Ciencias Penales, Tomo LXI, Madrid, 2008.

"El arrepentido en el ámbito del crimen organizado y en el tráfico de drogas: el artículo 376 del Código Penal español", Revista de Derecho de Extremadura, núm. 5, 2009.

OBLIGADO, D. H., "Sobre la génesis de los principios y garantías del proceso penal", Garantías, medidas cautelares e impugnaciones en el proceso penal, C. A. Chiara Díaz coord., Rosário, 2005.

OCHOA, C. A., "El agente encubierto", Semanario jurídico Fallos y doctrina, núm. 1057, 1995.

OCHOA MONZÓ, V., "Sujetos de la investigación en el proceso penal español", Investigación y Prueba en el Proceso Penal, Á. Sanz Hermida coord., Madrid, 2006.

OLÁSOLO ALONSO, H; PÉREZ CEPEDA, A. N., Terrorismo internacional y conflicto armado, Valencia, 2008.

OLIVEIRO FERRARÍS, A; GRAZIOSI, B., ¿Qué es la pedofilia?, 1a edición, Barcelona, 2004.

OLLÉ SESÉ, M; MORICHE, R. R; MENDOZA MUÑOZ, J; PAZ RUBIO, J. M., La prueba en el proceso penal. Su práctica ante los Tribunales, Madrid, 1999. 
OLMEDO CARDENETE, M. "La provocación al delito y el Agente Provocador en el tráfico de drogas", VV.AA., Estudios jurídico-penales y político criminales sobre el tráfico de drogas y figuras afines, Madrid, 2003.

ONETO, I., $O$ agente infiltrado: contributo para a compreensão do regime jurídico das acções encobertas, Coimbra, 2005.

ORÉ GUARDIA, A., Manual de derecho procesal penal, 2ª edición, Lima, 1999.

- "Panorama del Proceso Penal Peruano y reformas urgentes", http://www.incipp.org.pe.

ORLANDI, R., "La lucha procesal penal contra la criminalidad organizada en Italia", VV.AA., Terrorismo y proceso penal acusatorio, Valencia, 2006.

ORTELLS RAMOS, M., "Exclusividad jurisdiccional para la restricción de derechos fundamentales y ámbitos vedados a la injerencia jurisdiccional", Cuadernos de Derecho Judicial, núm. 12, Madrid, 1996.

ORTIZ PRADILLO, J. C., "El uso de la videoconferencia en el proceso penal español", Revista Brasileira de Ciências Criminais, vol. 15, núm. 67, São Paulo, 2007.

ORTIZ ÚRCULO, J. C., "Garantías del imputado en el proceso penal", Estudios Jurídicos. Ministerio Fiscal, Madrid, 2002.

OTO, E; DIMOULIS, D. D., Teoria do Direito Neoconstitucional, São Paulo, 2008.

OTTO Y PARDO, I., Derechos fundamentales y Constitución, Madrid, 1988.

OVEJERO PUENTE, A. M., Constitución y Derecho a la presunción de inocencia, Valencia, 2007.

PACELLI DE OLIVEIRA, E., Curso de Processo Penal, Belo Horizonte, 2006.

- Processo e hermenêutica na tutela penal dos direitos fundamentais, Belo Horizonte, 2004.

PACHECO, R., Crime Organizado. Medidas de controle e infiltração policial, Curitiba, 2007.

PACKER, H. L., "Two models of the criminal process", Pennsylvania Law review, 1964.

PALACIOS LUQUE, D., "Introducción a la prueba en el proceso penal", Planes provinciales y territoriales de formación, Consejo General del Poder Judicial, vol. II, año 1992.

PALAZZO, F., "Estado constitucional de derecho y derecho penal (consideraciones comparadas a propósito de la reforma constitucional argentina de 1994)", Revista Penal, núm. 2, 1998.

PALMA, Ma . F., "O problema penal do processo penal", Jornadas de Direito Processual Penal e direitos fundamentais, Maria Fernanda Palma coord., Coimbra, 2004.

PALMA HERRERA, J. M., Los delitos de blanqueo de capitales, Madrid, 2000.

PARDO, I. O; BAQUER, L. M. R., Derechos Fundamentales y Constitución, Madrid, 1988.

PARDO MATEOS, R. J., "Fenomenología del delito: delincuencia tradicional y nuevas formas de delincuencia", VV.AA., Teoría y práctica de la investigación criminal, J. Collado Medina coord., Madrid, 2009.

PAREDES, E. A., Los discursos de emergencia y los procesos de criminalización, Revista de Derecho penal, procesal penal y criminología, Mendoza, 2002.

PAREJO NAVAJAS, T., "La Carta de los derechos fundamentales de la Unión Europea", Derechos y Libertades - Revista del Instituto Bartolomé de las Casas, año 14, núm. 22, 2010.

PASTOR, D. R., Tensiones: ¿derechos fundamentales o persecución penal sin límites?, Buenos Aires, 2004.

- El plazo razonable en el Proceso del Estado de Derecho: una investigación acerca del problema de la excesiva duración del proceso penal y sus posibles soluciones, Buenos Aires, 2002. 
PASTOR ALCOY, F., Prueba de indicios, credibilidad del acusado y presunción del inocente, Valencia, 2003.

PASTOR LÓPEZ, M., El proceso de persecución. Análisis del concepto, naturaleza y específicas funciones de la instrucción criminal, Valencia, 1979.

PAVARINI, M., "Lo sguardo artificiale sul crimine organizzato", AA. VV., Lotta alla criminalità organizzata: gli strumenti normativi (a cura di Giostra e Insolera), Milano, 1993.

PAZ RUBIO, J. Mạ; MENDOZA MUÑOZ, J; MORICHE, R. R; OLLÉ SESÉ, M., La prueba en el proceso penal. Su práctica ante los Tribunales, Madrid, 1999.

PAZ RUBIO, J. Må; HERNÁNDEZ GUIJARRO, J. J; GONZÁLEZ-CÚELLAR, A; RODRIGUES RAMOS, L; TOMÉ PAULE, J., Ley de enjuiciamiento criminal y ley del jurado, Madrid, 2001.

PECES-BARBA, G., et alli, Lecciones de derechos fundamentales, Madrid, 2004.

PEDRAZ PENALVA, E., Constitución, jurisdicción y proceso, Madrid, 1990.

- "Actividad policial preprocesal", Revista de Derecho Procesal, año 2009.

- "El principio de proporcionalidad y principio de oportunidad", Constitución, jurisdicción y proceso, Madrid, 1990.

- "Notas sobre Policía y Justicia Penal", Revista Jurídica de Castilla y León, núm. 14, 2008.

PENÍN ALEGRE, C., "Nuevos instrumentos de cooperación jurídica internacional con Iberoamérica", VV.AA., Investigación y prueba en el proceso penal, N. González-Cuellar Serrano y A. S. Hermida coods., Madrid, 2006.

PEÑA ECHEVERRÍA, M. J., "La delincuencia organizada y su problemática desde la óptica de la investigación policial", Revista Criminalia, Año LXVI, núm. 1, México, 2000.

PEÑA FREIRE, A. M., La garantía en el Estado Constitucional de Derecho, Madrid, 1997.

PEREIRA, S., "A recolha da prova por agente infiltrado", VV.AA., Prova Criminal e Direito de Defesa. Estudos Sobre Teoria da Prova e Garantias de Defesa em Processo Penal, F. L da Costa Pinto y T. Pizarro Beleza coords., Coimbra, 2010.

PÉREZ ARROYO M. R. "La provocación de la prueba, el agente provocador y el agente encubierto: la validez de la prueba y del delito en la lucha contra la criminalidad organizada desde el sistema de pruebas prohibidas en el Derecho penal y procesal penal", La Ley, números 4987, 4988 e 4989, 8-10 de febrero de 2000.

- "La prueba provocada como supuesto de prueba prohibida en el proceso penal", Revista Jurídica de Castilla la Mancha, núm. 27, 1999.

PÉREZ CEBADERA, Mạ . Á., "Las medidas antiterroristas en Estados Unidos de Norteamérica al final de la presidencia Bush", VV.AA., Terrorismo y Estado de Derecho, J. R. Serrano Piedecasas y E. Demetrio Crespo coords., Madrid, 2010.

PÉREZ CEPEDA, A. I., La seguridad como fundamento de la deriva del Derecho Penal postmoderno, Madrid, 2007.

PÉREZ-CRUZ MARTÍN, A. J., "Videovigilancia y derecho a la intimidad: ¿Un nuevo ejemplo de conflicto entre el derecho a la seguridad pública y el derecho fundamental a la intimidad?", Anuario da Facultade de Dereito da Universidade da Coruña, no 1, 1997.

PÉREZ-CRUZ MARTÍN, A. J; FERREIRO BAAMONDE, X. X; PIÑOL RODRÍGUEZ, J. R; SEOANE SPIEGELBERG, J. L., Derecho Procesal Penal, 1aㅡ edición, Navarra, 2009.

PÉREZ DAZA, A., "Sistema procesal acusatorio y delincuencia organizada", VV.AA., Análisis, técnicas y herramientas en el combate a la delincuencia organizada con fundamento en 
la Convención de Palermo, M. Herrán Salvatti., J. L. Santiago Vasconcelos., S. González Ruiz y E. Mendieta Jiménez coords., 1a edición, México, 2007.

PÉREZ GIL, J., "Entre los hechos y la prueba: reflexiones acerca de la adquisición probatoria en el proceso penal", Revista Jurídica de Castilla y León, núm. 14, 2008.

- "Investigación penal y nuevas tecnologías: Algunos de los retos pendientes", Revista Jurídica de Castilla y León, núm. 7, 2005.

PÉREZ LUGO, M., "Algunos planteamientos sobre las prohibiciones de prueba en Alemania", Capítulo Criminológico, vol. 25, núm. 1, 1997.

PÉREZ LUÑO, A. E., Derechos Humanos, Estado de Derecho y Constitución, 3aㅗ edición, Madrid, 1990.

- Los derechos fundamentales, Madrid, 1984.

- "Seguridad jurídica", El derecho y la justicia, vol. 2, 1996.

- "La seguridad jurídica: una garantía del Derecho y la Justicia", Boletín de la Facultad de Derecho de la Universidad Nacional de Educación a Distancia, núm.15, 2000.

PÉREZ MARÍN, Ma . A., "En torno a la prueba ilícita", Revista de Derecho Procesal, núms. 2-4, 2001.

PÉREZ MORENO, E. P., Precisiones acerca de las garantías del imputado (A propósito de los Derechos ciudadanos)", Ejercicio concreto del poder pena. Limites, abusos, desafios, J.

I. Cafferata Nores coord., Córdoba, 2006.

PÉREZ DE NANCLARES, J. M., Tratado de Lisboa, Madrid, 2008.

PÉREZ-PEDRERO, E. B., "La presunción de inocencia", Parlamento y Constitución - Anuario, núm. 5, 2001.

PÉREZ ROYO, J., "La democracia frente al terrorismo global", VV.AA., Terrorismo, democracia y seguridad en perpectiva constitucional", M. Carrasco Durán coord., Madrid- Barcelona-Buenos Aires, 2010.

PICÓ JUNOY, J. M., Las garantías constitucionales del proceso, Barcelona, 1997.

- El derecho a la prueba en el proceso civil, Barcelona, 1996.

- "El derecho procesal entre el garantismo y la eficacia: Un debate mal planteado", VV.AA., Proceso civil e ideología. Un prefacio, una sentencia, dos cartas y quince ensayos, Valencia, 2006.

- "El derecho a la prueba en el proceso penal. Luces y sombras", VV.AA., Estudios sobre prueba penal. Actos de investigación y medios de prueba en el proceso penal: competencia, objeto y límites, vol. 1, Madrid, 2010.

PIEROBOM DE ÁVILA, T. A., Provas ilícitas e proporcionalidade, Rio de Janeiro, 2007.

PINHEIRO, R., MAURÍCIO, A., A Constituição e o processo penal, Coimbra, 2007.

PIÑOL RODRÍGUEZ, J. R; PÉREZ-CRUZ MARTÍN, A. J; FERREIRO BAAMONDE, X. X; Derecho Procesal Penal, 1aㅡ edición, Navarra, 2009.

PINTO DE ALBUQUERQUE, P., Comentário do Código de Processo Penal, Lisboa, 2007.

PISANI, M., - Attualità di Cesare Beccaria, Milano, 1998.

- "Diritto premiale e sistema penale: rapporti e intersezioni", VV.AA., Diritto premiale $e$ sistema penale, Milano, 1983.

PISAPIA, G. D, "Relazione introductiva" al Convengo in Ricardo di Pietro Nuvolone: La legislazione premiale, Milano, 1987.

PLANCHAT TERUEL, J. M., "Prueba ilícita. Fundamento y tratamiento", VV.AA., Estudio sobre prueba penal. Actos de investigación y medios de prueba en el proceso penal: competencia, objeto y límites, Vol. 1, Madrid, 2010. 
PLANET ROBLES, S., "Políticas de seguridad y prevención en el Estado español en materia de delincuencia organizada", VV.AA., La seguridad en la sociedad del riesgo. Un debate abierto, Barcelona, 2003.

PODVAL, R., "Das restrições aos direitos e garantias individuais para combate ao terrorismo", Revista Brasileira de Ciências Criminais, núm. 23, 1994.

POLAINO-ORTS, M., Derecho penal del enemigo. Desmitificación de un concepto, Córdoba, 2006.

POLASTRI LIMA, M., Processo penal Europeu. Preservação e direitos individuais (Princípios processuais e análise da Convenção Européia de Direitos Humanos), Rio de Janeiro, 2008.

PONTES, E. F; DEZEM, G. M., "Crime organizado e devido processo legal", Estudos de processo penal: o mundo à revelia, F. Hassan Choukr coord., Campinas, 2000.

PORTILLA, E., "El agente encubierto en la ley de drogas: la lucha contra la droga en la sociedad de riesgo", Política Criminal, año 2, núm. 2, 2006.

PORTILlA CONTRERAS, G., El Derecho penal entre el cosmopolitismo universalista y el relativismo posmodernista, Valencia, 2008.

-"El Derecho penal y procesal penal del enemigo. Las viejas y nuevas políticas de seguridad frente a los peligros internos-externos", VV.AA., Dogmática y Ley Penal, libro homenaje a Enrique Bacigalupo, Tomo I, J. L. Barja de Quiroga; J. M. Zugaldía Espinar coords., Madrid/Barcelona, 2004.

- "Fundamentos teóricos del Derecho penal y procesal penal del enemigo", Jueces para la democracia, núm. 49, 2004.

POZO PÉREZ, M., "El agente encubierto como medio de investigación de la delincuencia organizada en la Ley de Enjuiciamiento Criminal española", Revista Criterio Jurídico, vol. 6, Santiago de Cali, 2006.

POZO PÉREZ, M; HUERTAS MARTÍN, I; BUJOSA VADELL, L; VICENTE JIMÉNEZ, C., Derecho procesal penal, Salamanca, 2007.

POZO RUÍZ, F., "La Carta de los Derechos Fundamentales de la Unión Europea: Un paso más en la protección de los derechos humanos", Ciudadanía: dinámicas de pertenencia y exclusión, Logroño, 2003.

PRADEL, J., Procédure pénale, 10 ${ }^{\mathrm{a}}$ edición, Paris, 2000.

PRADO, G., "Proceso penal e Estado de Direito no Brasil: considerações sobre a fidelidade do juiz à lei penal", Revista de Estudos Criminais, Sapucaia do Sul, 2004.

PRADO, L. R., Curso de Direito Penal, vol. 1, 8ª edición, São Paulo, 2008.

PRADO SALDARRIAGA, V. R., "La entrega vigilada: orígenes y desarrollos", http://www.unifr.ch.

PRIETO-CASTRO y FERRÁNDIZ, L., GUTIERREZ DE CABIEDES Y FERNANDEZ DE HEREDIA, E., Derecho procesal penal, $2^{\text {a }}$ edición, Madrid, 1978.

PRIETO SANCHÍS, L., Justicia Constitucional y Derechos Fundamentales, Madrid, 2003.

- Ley, principios, derechos, Madrid, 2002.

- "Observaciones sobre las antinomias y el criterio de ponderación", Cuadernos de Derecho Público, núm. 11, 2000.

- "El juicio de ponderación constitucional", VV.AA., El principio de proporcionalidad y protección de los derechos fundamentales, México, 2008. 
PRUNOTTO LABORDEA, A., Pruebas ilícitas, VV.AA, La fe del hombre en sí mismo o la lucha por la libertad a través del proceso. El Mundo procesal rinde homenaje al Maestro Adolfo Alvarado Velloso, Lima. 2008.

QUEIROZ, P. S., Direito Penal, Parte Geral, São Paulo, 2005.

QUERALT JIMÉMEZ, J. J., Introducción a la policía judicial, Barcelona, 1999.

- "Recientes novedades legislativas en materia de lucha contra la criminalidad organizada: Ley Orgánica 5/1999 de 14 de enero", La Ley, 1999-6.

QUÉRÉ, S; RAUFER, X., Le crime Organize, 2ª edición, Paris, 2001.

QUINTANAR DIEZ, M., "El agente encubierto", Revista Letras Jurídicas, núm. 1, http://letrasjuridicas.cuci.udg.mx/.

RADBRUCH, G; GWINNER, E., Historia de la criminalidad (Ensayo de una criminología histórica), Barcelona, 1955.

RAMÍREZ BARBOSA, P. A., Crime Organizado. Tipicidade, Política criminal, Investigação e Processo, Porto Alegre, 2008.

RAMÍREZ JARAMILLO, A. D., El agente encubierto frente a los derechos fundamentales a la intimidad y a la no autoincriminación, Medellín, 2010.

RAMOS MÉNDEZ, F., Enjuiciamiento Criminal, Octava lectura constitucional, Barcelona, 2006.

- Enjuiciamiento civil, Barcelona, 2008.

- El proceso penal, Barcelona, 1993.

- Derecho procesal civil, T. 1, 3ª edición, Barcelona, 1986.

- Derecho y Proceso, Barcelona, 1978.

- "La influencia de la Constitución en el Derecho Procesal Civil", Revista de Derecho Procesal, número 1, 1983.

RAMOS RUBIO, C., "La prueba ilícita y su reflejo en la jurisprudencia", VV.AA., La prueba en el proceso penal, Madrid, 2000.

RANGEL, P., Direito Processual Penal, 5a edición, Rio de Janeiro, 2001.

- Investigação direta pelo Ministério Público, Rio de Janeiro, 2009.

- "O clone da inquisição terrorista", http://www.jusvi.com/artigos/1319.

RAUFER, X; QUÉRÉ, S., Le crime Organize, 2ª edición, Paris, 2001.

REDONDO HERMIDA, A., "El agente encubierto en la jurisprudencia española y en la doctrina del Tribunal Europeo de Derechos Humanos", La Ley Penal, núm. 45, Madrid, 2008.

RESTA, E., "I'l diritto penale premiale: nuove estrategie di controlllo sociale", Dei delitti e delle pene, núm. 1, 1983.

REY HUIDOBRO, L. F., El delito de tráfico de drogas. Aspectos penales y procesales, Valencia, 1999.

- "La entrega vigilada de drogas. El artículo 263 bis de la Ley de Enjuiciamiento Criminal", Revista del Ministerio Fiscal, núm. 2, 1999.

RIAÑO BRUN, I., La instrucción criminal en el proceso penal, Navarra, 2008.

RIAÑO BRUN, I; RICHARD GONZÁLEZ, M; RIFÁ SOLER, J. M., Derecho procesal penal, Pamplona, 2006.

RIBEIRO PLETSCH, N., Formação da prova no jogo processual penal, São Paulo, 2007.

RICARDO, R; DEUTSCHMANN, D., Guantánamo: A Critical History of the Us Base in Cuba, Melbourne, 2008. 
RICHARD GONZÁLEZ, M., "La competencia del Ministerio Fiscal para la investigación de actos delictivos. Diligencias preliminares y competencias de instrucción en el procedimiento de menores", VV.AA., Estudios sobre prueba penal. Actos de investigación y medios de prueba en el proceso penal: competencia, objeto y límites, vol. I, Madrid, 2010.

RICHARD GONZÁLEZ, M; RIFÁ SOLER, J. M; RIAÑO BRUN, I., Derecho procesal penal, Pamplona, 2006.

RIFÁ SOLER, J. M., "El agente encubierto o infiltrado en la nueva regulación de la LECrim", Poder Judicial, núm. 55, 1999.

- "Actos de investigación, actos de instrucción y actos de prueba", VV.AA., Estudios sobre prueba penal. Actos de investigación y medios de prueba en el proceso penal: competencia, objeto y límites, Madrid, 2010.

RIFÁ SOLER, J. M; RICHARD GONZÁLEZ, M; RIAÑO BRUN, I., Derecho procesal penal, Pamplona, 2006.

RIGHI, E., "Los límites de la persecución penal y la tutela de derechos fundamentales", Cuadernos de Doctrina y Jurisprudencia Penal, Buenos Aires, 1996.

RIQUERT, M. A., Crisis Penal, Política Criminal, globalización y Derecho Penal, Buenos Aires, 2007.

RIPOL CARULLA, S., El Sistema Europeo de Protección de los Derechos Humanos y el Derecho Español, Barcelona. 2007.

RIVERA MORALES, R., Actos de investigación y pruebas en el proceso penal, Barquisimeto, 2008.

RIVES SEVA, A. P., La prueba en el proceso penal. Doctrina de la Sala Segunda del Tribunal Supremo, 3aㅡ edición, Navarra, 1999.

- La prueba de testigos en la jurisprudencia penal, Madrid, 2003.

RODOVALHO PODVAL, M. F; PODVAL, R., "Das restrições aos direitos e garantias individuais para combate ao terrorismo", Revista Brasileira de Ciências Criminais, São Paulo, núm. 23, 1994.

RODRÍGUEZ, A., " Sobre la naturaleza jurídica de la Carta de Derechos Fundamentales de la Unión Europea", Revista de Derecho Político, núm. 51, 2001.

RODRÍGUEZ, A. D., "Seguridad, Derechos Humanos y Garantías Penales: ¿Objetivos comunes o aspiraciones contrapuestas?", VV.AA., Derecho penal de la democracia vs seguridad pública, I. B. Gómez de la Torre y N. Sanz Mulas, coords., Granada, 2005.

RODRÍGUEZ DEVESA, J. M., Derecho Penal Español. Parte general, Madrid, 1949.

RODRÍGUEZ FERNÁNDEZ, R., "Comentarios a la LO 5/1999, de 13 de enero: la entrega vigilada y el agente encubierto", Actualidad Jurídica Aranzadi, núm. 380, 1999.

- "El agente encubierto y la entrega vigilada", Criminalidad organizada: reunión de la sección nacional española preparatoria del XVI Congreso de la Asociación Internacional de Derecho Penal, en Budapest, Toledo, 1999.

RODRÍGUEZ GARCÍA, N., La justicia penal negociada, Experiencias de Derecho Comparado, Salamanca, 1997.

- "Cooperação judicial penal e Ministério Público Europeu", Revista dos Tribunais, núm. 834, 2005.

- "El derecho premial como remedio para lograr que la justicia penal española sea eficaz. Reflexiones a partir de la nueva regulación de la conformidad del acusado en el 
procedimiento abreviado", VV.AA., La influencia de la ciencia penal alemana en Iberoamérica, Estudios en homenaje a Claus ROXIN, México, 2003.

- "Medios de prueba restrictivos de derechos fundamentales. Las intervenciones telefónicas", Conflicto social y sistema penal (Diez estudios sobre la actual reforma), M. R. D. Díaz Santos, E. A. F. Caparrós, L. Zuñiga Rodríguez coords., Madrid, 1996.

- "Análisis de la nueva regulación del principio del consenso en el procedimiento abreviado español", VV.AA., Líber Discipulorum para Jorge de Figueiredo Dias, Coimbra, 2003.

- "Asistencia judicial penal para luchar contra la corrupción, el blanqueo de capitales y la delincuencia organizada. Algunos apuntes sobre el convenio de Unión Europea de 2000", Corrupción y delincuencia económica, N. Rodríguez García y E. A. Fabián Caparrós coords., Bogotá, 2008.

- "Globalización de la delincuencia versus globalización de la justicia penal: una lucha desigual", Revista Xurídica Galega, núm. 37, 2002.

RODRÍGUEZ GARCÍA, N; MERCHÁN MATEOS, J. F; CAPARRÓS, E. A; ZARAGOZA AGUADO, J. A., Delincuencia económica y blanqueo de capitales, Salamanca, 2005 (inédito).

RODRÍGUEZ-MAGARIÑOS, F. G., "La presunta prueba pericial de inteligencia: análisis de la STS de 22 de mayo de 2009", La Ley Penal, núm. 64, 2009.

RODRÍGUEZ MOURULlO, G., Derecho Penal. Parte general, Madrid, 1978.

RODRÍGUEZ RAMOS, L; PAZ RUBIO, J. Mạ; HERNÁNDEZ GUIJARRO, J. J; GONZÁLEZCÚELLAR, A; TOMÉ PAULE, J., Ley de enjuiciamiento criminal y ley del jurado, Madrid, 2001.

RODRÍGUEZ RUIZ, B., El secreto de las comunicaciones: tecnología e intimidad, Madrid, 1998.

ROMERO ARIAS, E., La presunción de inocencia. Estudio de algunas consecuencias de la constitucionalización de este derecho, Pamplona, 1985.

ROMERO COLOMA, A. M., "Alcance de los principios del proceso penal español a la luz del ordenamiento constitucional", Actualidad Penal, Madrid, 1995.

RONCONI, D. R., "O princípio constitucional da igualdade e a desigualdade (i) legal deste princípio na legislação brasileira”, Novos Estudos Jurídicos, núm. 12, Itajaí, 2001.

ROSAL BLASCO, B. D., "Criminalidad organizada y nuevas tecnologías, algunas consideraciones fenomenológicas y político-criminales", Número monográfico sobre "La criminalidad organizada. Aspectos sustantivos, procesales y orgánicos", Cuadernos de Derecho Judicial, núm. II, 2001.

ROXIN, C., Derecho procesal penal, Buenos Aires, 2000.

- "La protección de la persona en el Derecho procesal penal alemán", trad. de M. García Cantizano, VV.AA, La evolución de la Política criminal, el Derecho penal y el Proceso penal, Valencia, 2000.

- "Problemas de autoría y participación en la criminalidad organizada", VV.AA., Delincuencia organizada. Aspectos penales, procesales y criminológicos, J. C. Ferre Olive y E. A. Borallo coords., Huelva, 1999.

RUBÉN AUED, N., ALBERTO JULIANO, M., La probation y otros institutos del derecho penal, Buenos Aires, 2001.

RUBERT PASCUAL, D. S., Inteligencia criminal. El surgimiento de un actor global, 1a edición, Madrid, 2008.

RUBIO, A.; CERDÁN, M., Lobo, un topo en las entrañas de ETA, 9ª edición, Barcelona, 2004. 
RUBIO LARA, P.A., Derecho penal y seguridad ciudadana, 1aㅡ edición, Madrid, 2009.

RUBIO LLORENTE, F., "El principio de legalidad", Revista española de derecho constitucional, año 13, núm. 39, 1993.

RUDI, D. M., Protección de testigos y proceso penal, Buenos Aires, 2002.

RUIZ ANTÓN, L. F., El agente provocador en el Derecho penal, Madrid, 1982.

- "La provocación policial como forma de reprimir el tráfico ilícito de droga", VV.AA., La problemática de la droga en España, Madrid, 1986.

RUIZ JARAMILLO, L. B., "El derecho a la prueba como un derecho fundamental", Revista de Estudios de Derecho, vol. 64, núm. 143, Antioquia, 2007.

RUIZ VADILLO, E., Estudios de Derecho procesal penal, Granada, 1995.

- "La actividad probatoria en el proceso penal español y las consecuencias de violarse en ella algún principio constitucional de producirse determinadas irregularidades procesales", VV.AA., La prueba en el proceso penal, Cuadernos de Derecho Judicial, Madrid, 1992.

RUIZ RUIZ, R., " La ponderación en la resolución de colisiones de derechos fundamentales. Especial referencia a la jurisprudencia constitucional española", Revista Telemática de Filosofía del Derecho, núm. 10, 2006/2007.

RUKHSANA KHAN, M., Diário de Guantánamo, 1aa edición, São Paulo, 2008.

SÁEZ VALCÁRCEL, R; BENITO LÓPEZ, A. Mà-, "La investigación penal", VV.AA., Hacia un nuevo proceso penal, Madrid, 2006.

SALAS CALERO, L., "La Ley Patriótica USA", VV.AA., Terrorismo y proceso penal acusatorio, J. L. Gómez Colomer y J. L. González Cussac coords., Valencia, 2006.

SALCEDO-ALBARÁN, E; LEÓN-BELTRÁN, I y GUERRERO, B., "La reconfiguración cooptada del Estado: Más allá de la concepción tradicional de captura económica del Estado", http://www.transparenciacolombia.org.co/Portals/0/Captura\%20del\%20Estad.pdf.

SAN MIGUEL, RODRÍGUEZ-ARANGO, L. G ., "Reflexiones sobre la intimidad como límite de la libertad de expresión", VV.AA., Estudios sobre el derecho a la intimidad, Madrid, 1992.

SÁNCHEZ GARCÍA DE PAZ, I., La criminalidad organizada. Aspectos penales, procesales, administrativos y policiales, Madrid, 2005.

- "Función político-criminal del delito de asociación para delinquir: desde el Derecho penal político hasta la lucha contra el crimen organizado", VV.AA., Libro homenaje al Dr. Marino Barbero Santos, in memorian, volumen II, Cuenca, 2001.

- "El coimputado que colabora con la justicia penal (con atención a las reformas introducidas en la regulación española por las Leyes Orgánicas 7 y 15/2003)", http://www.criminet.ugr.es/recpc.

SÁNCHEZ GARCIA DE PAZ, I; BLANCO CORDERO, I., "Principales instrumentos internacionales (de Naciones Unidas e la Unión Europea) relativos al crimen organizado: la definición de la participación en una organización criminal y los problemas de aplicación de la ley penal en el espacio", Revista de la Universidad de Castilla La Mancha, núm. 6, 2000.

SANCHIS CRESPO, C., "La justicia en la Constitución Europea: Aproximación al derecho a la presunción de inocencia a través de la doctrina del Tribunal Europeo de Derechos Humanos", VV.AA., Garantías fundamentales del proceso penal en el espacio judicial europeo, A. de la Oliva Santos, T. Armenta Deu y Mä. Pia Calderón Cuadrado coords., Madrid, 2007. 
SANMARTÍN, J., La violencia y sus claves, Barcelona, 2000.

SANTANA, S. P., "A tensão dialética entre os ideais de garantia, eficiência e funcionalidade", VV.AA., Novos desafios do Direito Penal no terceiro milênio, Estudos em homenagem ao prof. Fernando Santana, Gamil Föppel coord., Rio de Janeiro, 2008.

SANZ HERMIDA, Á. M.a , "La lucha contra la delincuencia organizada: la Decisión Marco 2008/841/JAI, de 24 de octubre", Revista General de Derecho Procesal, núm. 17, 2009, http://www.iustel.com.

SANZ MULA, N., "Pornografía en la web. El reto del Derecho penal ante el más vergonzoso uso de las nuevas tecnologías", Ciencia Policial, núm. 86, Madrid, 2008.

SANZO BRODT, L. A., Do estrito cumprimento de dever legal, Porto Alegre, 2005.

SARLET, I. W., A eficácia dos direitos fundamentais, 8ª edición, Porto Alegre, 2007.

- "Constituição e proporcionalidade: o direito penal e os direitos fundamentais entre a proibição de excesso e de insuficiência", Revista Brasileira de Ciências Criminais, núm. 47, São Paulo, 2004.

SARMIENTO, D; ALONSO GARCÍA, R., La carta de los Derechos Fundamentales de la Unión Europea explicaciones, concordancias, jurisprudencia, Madrid, 2006.

SAVIANO, R., Gomorra, 3ae edición, Rio de Janeiro, 2009.

SCARANCE FERNANDES, A., Processo Penal Constitucional, 4aㅡ edición, São Paulo, 2005.

- "O equilíbrio entre a eficiência e o garantismo e o crime organizado", Revista Brasileira de Ciências Criminais, núm. 70, São Paulo, 2008.

- "O equilíbrio na repressão do crime organizado", VV.AA., Crime Organizado. Aspectos processuais, São Paulo, 2009.

- "O equilíbrio na investigação criminal", VV.AA., Estudos em homenagem à Professora Ada Pellegrini Grinover, F. L. Yarshell y M. Zanoide de Moraes coords., São Paulo, 2005.

SCARANCE FERNANDES, A; GRINOVER, A. P; GOMES FILHO, A.M., As nulidades no processo penal, 2a edición, São Paulo, 1982.

SCHWIND, H. D., Kriminologie. Eine praxisorientierte Einführung mit Beispielen 17. Auflage, Heidelberg, 2007.

SCHÖNKE, A., "Límites de la prueba en el derecho procesal", Revista de Derecho Procesal, núm. 3, 1955.

SCHMIDT, E., Los fundamentos teoricos y constitucionales del Derecho Procesal Penal, trad. J. Manuel Nuñez, Córdoba, 2006.

SCHNEIDER, J. J., "Recientes investigaciones criminológicas sobre la criminalidad organizada", Revista de Derecho Penal y Criminología, núm. 3, 1993.

SCHÜNEMANN, B., Die deutsche Strafrechtswissenschaft nach der Jahrtausendwende, GA 2001.

- "Derecho penal del enemigo: crítica a las insoportables tendencias erosivas en la realidad de la administración de justicia penal y de su insoportable desatención teórica", VV.AA., Derecho Penal del Enemigo, M. Cancio Meliá y C. Gómez-Jara Díez coords., Madrid, 2006.

SENNA, G; BEDÊ JÚNIOR, A., Princípios do Processo Penal. Entre o garantismo e a efetividade da sanção, São Paulo, 2009.

SENTÍS MELENDO, S., El proceso civil, Buenos Aires, 1959.

- La prueba, Buenos Aires, 1979.

SEOANE SPIEGELBERG, J. L., Derecho Procesal Penal, 1aㅡ edición, Navarra, 2009. 
-"Aspectos procesales del delito de trafico de drogas", Actualidad Penal, núm. 20, 1996.

SEOANE SPIEGELBERG, J. L ; PIÑOL RODRÍGUEZ, J. R; PÉREZ-CRUZ MARTÍN, A. J; FERREIRO BAAMONDE, X. X., Derecho Procesal Penal, 1a edición, Navarra, 2009.

SEQUEROS SAZARTORNIL, F., El tráfico de drogas ante el ordenamiento jurídico. Evolución normativa, doctrinal y jurisprudencial, Madrid, 2000.

SERRA DOMÍNGUEZ, M., Jurisdicción, Acción y Proceso, Barcelona, 2008.

- "El Ministerio fiscal", Revista de Derecho Procesal Iberoamericano, núms. 3 y 4, Madrid, 1979.

SERRANO, M., "Crimen transnacional organizado y seguridad internacional. Cambio y continuidad", VV.AA., Crimen transnacional organizado y seguridad internacional. Cambio y continuidad, M. Serrano y M. Berdal coords., México, 2005.

SFERLAZZA, O., Proceso acusatorio oral y delincuencia organizada, México, 2006.

SHELLEY, L., "The penetration of state and private sector strutures by criminal networks: It's impact on governance in Russia and others states of the former Soviet Union", Seminar on the impact of organizad crime and corruption on governance in the SADC region, Pretoria, 18-19 de abril, 2002.

SICA, L., Direito penal de emergência e alternativas à prisão, São Paulo, 2002.

SILBERNAGL, M; BARATTA, A., "La legislación de emergencia y la cultura jurídica garantista en el proceso penal", Cuadernos de política criminal, núm. 28, 1986.

SILVA, E. A., Crime Organizado, São Paulo, 2003.

SILVA FERNANDES, P., Globalização, "Sociedade de risco" e o futuro do Direito Penal. Panorâmica de alguns problemas comuns, Coimbra, 2001.

SILVA JARDIM, A., "Bases Constitucionais para um Processo Penal Democrático", Direito Processual Penal, 7a edición, Rio de Janeiro, 1999.

SILVA JUNIOR, W. N., Curso de Direito Processual Penal: Teoria (Constitucional) do Processo Penal, 1aㅡ edición, Rio de Janeiro, 2008.

SILVA SÁNCHEZ, J. Ma., Aproximación al Derecho penal contemporáneo, Barcelona, 1992.

- La expansión del Derecho Penal. Aspectos de la política criminal en las sociedades postindustriales, $2^{\text {a }}$ edición, Madrid, 2001.

SILVEIRA FILHO, S. L., "Neoliberalismo, mídia e movimento de lei e ordem: rumo ao Estado de polícia", Discursos Sediciosos. Crime, direito e sociedade, núms. 15-16, Rio de Janeiro, 2007.

SIMANCAS, M., "El espacio de libertad, seguridad y justicia", Ciencias Policiales, núm. 67, Madrid, 2003.

SIRACUSANO, D., "Introduzione ao giusto processo", Il giusto proceso, Milano, 1998.

SMITH, C. S., The Eight O'Clock Ferry to the Windward Side: Fighting the Lawless World of Guantanamo Bay, New York, 2007.

SOLOMINE, M. A., "Praxis instructoria en un Estado de Derecho. Entre las garantías y la eficiencia", Cuadernos de doctrina y jurisprudencia penal, vol. 5, núm. 9B, Buenos Aires, 1999.

SOLOZÁBAL ECHAVARRÍA, J. J., La igualdad en la aplicación de la ley, libro Homenaje al Profesor Dr. Gonzalo Rodríguez Mourullo, Navarra, 2005.

- "Algunas cuestiones básicas de la teoría de los derechos fundamentales", Revista de Estudios Políticos - Nueva Época, núm. 71, Enero-Marzo, Madrid, 1991.

SORIANO SORIANO, J. R., "El terrorismo y el Tribunal Supremo", VV.AA., Terrorismo y proceso penal acusatorio, Valencia, 2006. 
SOTO NIETO, F., El delito de tráfico ilegal de drogas: su relación con el delito de contrabando, 1ํㅡㄹ edición, Madrid, 1989.

- "Ética profesional y su proyección en la prueba penal", La Ley, 1994-2.

SOTOMAYOR ACOSTA, J. O., "Los estragos de la lucha contra la criminalidad organizada en el sistema penal: el caso colombiano", Revista de Derecho Penal, núm. 17, Montevideo, 2008.

SOUTO DE MOURA, J., "A protecção dos direitos fundamentais no processo penal", I Congresso de Processo Penal, Coimbra, 2005.

STANZIOLA VIEIRA, R., "Agente infiltrado - estudo comparativo dos sistemas processuais penais português e brasileiro (ou a impressindibilidad da tipicidade processual como requisito de admissibilidade dos meios de pesquisa de prova no processo penal)", Revista Brasileira de Ciências Criminais, núm. 87, 2010.

STORTONI, L., Criminalità organizzata e legislazione di emergenza, Dei delitti e delle pene, 3 , 1992.

- "Criminalità organizzata ed emergenza: il problema delle garanzie", Criminalità organizzata e riposte ordinamentali. Tra efficienza e garanzia, S. Moccia coord., Nápoles, 1999.

STRECK, L., "A dupla face do principio da proporcionalidade: da proibição de excesso (übermassverbot) à proibição deficiente (untermassverbot) ou de como não há blindagem contra normas penais inconstitucionais", Revista da Associação dos Juízes do Rio Grande do Sul, núm. 97, Porto Alegre, 2005.

STRUENSEE, E., "La prueba prohibida", trad. Patricia Ziffer, Revista Peruana de Ciencias Penales, núm. 4, 1994.

SUÁREZ SÁNCHEZ, A., El debido proceso penal, Bogotá, 2001.

SUBIJANA ZUNZUNEGUI, I. J., "Policía Judicial y el Derecho a la intimidad em el seno de la investigación criminal", Cuaderno del Instituto Vasco de Criminología, San Sebastián, núm. 10 Extraordinario, 1997.

SUITA PÉREZ, N., "La diligencia de investigación mediante la entrega vigilada", La actuación de la policía judicial en el proceso penal, Madrid/Barcelona, 2006.

TARUFFO, M., La prueba de los hechos, Madrid, 2002.

TAVARES, J., Teoría do injusto penal, $3^{3}$ edición, Belo Horizonte, 2003.

TIEDEMANN, K., Introducción al derecho penal y al derecho penal procesal, Barcelona, 1989.

- "El futuro del proceso penal europeo. Aspectos de interés, en especial, sobre la lucha antiterrorista", http://www.espaciojudicialeuropeo.es.

TOLEDANO TOLEDANO, J. R., "La actuación policial y la eximente del cumplimiento de un deber", Ciencias Policiales, núm. 92, Madrid, 2009.

TOLEDO MACHADO, M., Proibições de excesso e proteção insuficiente no direito penal, São Paulo, 2008.

TOMÉ GARCÍA, J. A; MUERZA ESPARZA, J; HINOJOSA SEGOVIA, R; ARAGONESES MARTÍNEZ, S; DE LA OLIVA SANTOS, A., Derecho Procesal Penal, Octava edición, Madrid, 2007.

TOMÉ PAULE, J; RODRIGUES RAMOS, L; PAZ RUBIO, J. Mạ; HERNÁNDEZ GUIJARRO, J. J; GONZÁLEZ-CÚELLAR, A., Ley de enjuiciamiento criminal y ley del jurado, Madrid, 2001.

TONINI, P., Diritto processuale penale. Manuale breve, Milán, 2009. 
TORRÂO, F. P., A relevância político-criminal da suspensão provisória do processo, Coimbra, 2000.

TORRES, C., "El agente encubierto", Cuadernos del Departamento de Derecho Penal y criminología, núm. 2, Córdoba, 1998.

TORRES DEL MORAL, A; GIMENO SENDRA, V; MORENILLA ALLARD, P; DÍAZ MARTÍNEZ, M., Los Derechos Fundamentales y su protección jurisdiccional, Madrid, 2007.

TORRES MORATO, M. Á; URBANO CASTRILlO, E., La prueba ilícita penal. Estudio jurisprudencial, Navarra, 2003.

TOURINHO FILHO, F. C., Processo Penal, 25a edición, São Paulo, 2003.

TZU, S., A arte da guerra, São Paulo, 2007.

ÚBEDA-PORTUGUÉS, J. E., "Análisis de los efectos negativos de la delincuencia organizada en la sociedad internacional", Anales de la Universidad Metropolitana, vol. 9, núm. 2, 2009.

UBERTIS, G., "La ricerca della verità giudiziale", La conoscenza del fatto nel processo penale, Milano, 1992.

- "La prueba penal. Perfiles jurídicos y epistemológicos", https://www.ucursos.cl/derecho/2008/1/D124T0763/31/material_docente/bajar?id_material=160 283.

UGARTE, J. M., Legislación de inteligencia, legitimidad y eficacia, Guatemala, 2000.

URBANO CASTRILLO, E., "La investigación tecnológica del delito", Los nuevos medios de investigación en el proceso penal. Especial referencia a la tecnovigilancia, Cuadernos de Derecho Judicial, Madrid, 2007.

URBANO CASTRILLO, E; TORRES MORATO, M. Á., La prueba ilícita penal. Estudio jurisprudencial, Navarra, 2003.

ÚBEDA PORTUGUÉS, J. E., "Análisis de los efectos negativos de la delincuencia organizada en la sociedad internacional", Anales de la Universidad Metropolitana, vol. 9, núm. 2 (Nueva Serie), 2009.

URREA CORRES, M; MARTÍN Y PÉREZ DE NANCLARES, J., Tratado de Lisboa, Madrid, 2008.

VALLEJO, M. J., Derechos fundamentales del proceso penal, 2ª edición, Bogotá, 2006.

VALLINES GARCÍA, E., Los equipos conjuntos de investigación penal. En el marco de la cooperación policial y judicial entre los Estados de la Unión Europea, Madrid, 2006.

VARELA, C. A., Fundamentos constitucionales del derecho procesal, Buenos Aires, 1999.

VARGAS VIANCO, J. E., "Eficiencia en la Justicia", Sistemas Judiciales, Buenos Aires, 2003.

VARI, M., "Acesso alla giustizia e tutela dei diritti e delle libertà fondamentali", Diritti di libertà e diritti sociali tra giudice costituzionale e giudice comune, Nápoles, 1997.

VÁZQUEZ SOTELO, J. L., Presunción de inocencia del imputado e íntima convicción del Tribunal, Barcelona, 1984.

- "La presunción de inocencia", Los principios del proceso penal y la presunción constitucional de inocencia, núm. V, Cuadernos de Derecho Judicial, Madrid, 1992.

VEGAS TORRES, J., Presunción de inocencia y prueba en el proceso penal, Madrid, 1993.

VEIGA, C., Considerações sobre a relevância dos antecedentes criminais do argüido no proceso penal, Coimbra, 2000.

VELAYOS MARTÍNEZ, M. I., El testigo de referencia en el proceso penal, Valencia, 1998.

VELASCO NUÑEZ, E., "El confidente", La Ley, núm. 3, 1993.

- "Entregas vigiladas, infiltración y agente encubierto en internet", Justicia - Revista de Derecho Procesal, núms., 1-2, 2010. 
VÉLEZ MARICONDE, A., Derecho procesal penal, Tomo II, Buenos Aires, 1969.

VÉLEZ RODRÍGUEZ, L. A., "La lucha contra el crimen organizado como dilema para el Estado de Derecho. Aproximación a una alternativa", Revista Juridica, vol. 5, núm. 2, Caldas, 2008.

VERCHER NOGUERA, A., "Reflexiones sobre ministerio fiscal y la lucha contra la corrupción en medio ambiente", VV.AA., Corrupción y delincuencia económica, $N$. Rodríguez García y E. Fabián Caparrós coords, Bogotá, 2008.

VERVAELE, J. A. E, La legislación antiterrorista en Estados Unidos, ¿Inter arma silent leges?, Buenos Aires, 2007.

VIADA LÓPEZ-PUIGCEVER, C; ARAGONESES ALONSO, P., Curso de Derecho Procesal Penal, 2 a edición, Madrid, 1968-1970.

VICENTE JIMÉNEZ, C., POZO PÉREZ, M; HUERTAS MARTÍN, I; BUJOSA VADELL, L., Derecho procesal penal, Salamanca, 2007.

VIGNA, P. L., "La cooperación judicial frente al crimen organizado", El crimen organizado. Desafíos y perspectivas en el marco de la globalización, Buenos Aires, 2005.

VILLAR, M. A., "La libertad y el proceso penal. La garantía del máximo riesgo procesal aceptable", Doctrina Penal, núms. 59/60, Buenos Aires, 1992.

VILLAVERDE MENÉNDEZ, I., "La resolución de conflictos entre derechos fundamentales. El principio de proporcionalidad", VV.AA., El principio de proporcionalidad y protección de los derechos fundamentales, México, 2008.

VÍQUEZ, K., "Derecho penal del enemigo ¿Una quimera dogmática o un modelo orientado al futuro?", Política Criminal, núm. 3, 2007.

VIVES ANTÓN, T.S., "El proceso de la presunción de inocencia", VV.AA., Jornadas de Direito Processual Penal e Direitos Fundamentais, Coimbra, 2004.

VOGLER, R., "Últimas tendencias probatorias en Inglaterra: en especial las reglas de exclusión", Prueba y proceso penal: análisis especial de la prueba prohibida en el sistema penal español y en el derecho comparado, Gómez, J. L. coord., Valencia, 2008.

VON BELING, E. L., Derecho Procesal Penal, Trad. Miguel Fenech, Barcelona, 1943.

VV.AA., "Crisis de la Justicia y reformas procesales”, I Congreso de Derecho Procesal de Castilla y León, M. C. Calvo Sánchez y E. Pedraz Penalva coords., Madrid, 1988.

- Teorías actuales en el Derecho Penal, 75o aniversario del Código Penal, Buenos Aires, 1998.

- Informe de la Secretaria Ejecutiva sobre las Técnicas Especiales de Investigación, originario de la Reunión del Grupo de Expertos para el control del Lavado de Activos, Marzo 16-18, Washington DC, 2005, http://www.cicad.oas.org.

- Garantismo. Estudios sobre el pensamiento jurídico de Luigi Ferrajoli, M. Carbonell y P. Salazar coords., Madrid, 2005.

- La tensión entre libertad y seguridad. Una aproximación socio jurídica, María J. Bernuz Beneitez y A. I. Pérez Cepeda coords., La Rioja, 2005.

- Processo Penal e garantias constitucionais, M. A. Marques da Silva coord., São Paulo, 2006.

- Garantismo y Derecho Penal, J. O. Sotomayor Acosta coord., Bogotá, 2006.

- El desafío de la criminalidad organizada, Nieves Sanz Mula coord., Granada, 2006.

- Análisis, técnicas y herramientas en el combate a la delincuencia organizada con fundamento en la Convención de Palermo, M. Herrán; J. L. Santiago; S. González y E. mendieta coords., México, 2007.

- Derecho Penal de Excepción, Terrorismo y Inmigración, P. Faraldo Cabana coord., Valencia, 2007. 
- Carta de los derechos fundamentales de la Unión Europea: comentario artículo por artículo, A. Mangas Martín y L. N. González Alonso coords., Madrid, 2008.

- El proceso penal en la Unión Europea: garantías esenciales, M. Hoyos Sancho coord., Valladolid, 2008.

- El tratado de Lisboa: análisis y perspectivas, Carlos R. Fernández Liesa; C. M. Díaz Barrado; M. A. Alcoceba Gallego y A. Manero Salvador coords., Madrid, 2008.

- Estudios sobre el Tratado de Lisboa, F. J. Matia Portilla coord., Madrid, 2009.

- Garantismo penal integral. Questões penais e processuais, criminalidad moderna e a aplicação do modelo garantista no Brasil, B. Calabrish; D. Fischer y E. Pelella coords., Salvador, 2010.

- Terrorismo y Estado de Derecho, J. R. Serrano-Piedecasas; E. Demetrío Crespo coords., Madrid, 2010.

WEIGEND, T., "Los sistemas penales frente al reto del crimen organizado", International Review of Penal Law, vol. 68, 1997.

WILLIAMS, P., "Cooperación entre organizaciones criminales", Crimen transnacional organizado y seguridad internacional: cambio y continuidad, M. R. Berdal y M. Serrano coords., México, 2006.

ZAFFARONI, R. E., - El enemigo en el derecho penal, Buenos Aires, 2006.

- "En torno al concepto del crimen organizado", VV.AA., Nada personal. Ensayos sobre crimen organizado y sistema de justicia, Buenos Aires, 2001.

- "La creciente legislación penal y los discursos de emergencia", VV.AA., Teorías Actuales en el Derecho Penal, Buenos Aires, 1998.

- "Globalización y crimen organizado", 2007, www.cienciaspenales.ne.

- "Globalización y sistema penal en America Latina: de la seguridad nacional a la urbana", Revista Brasileira de Ciências Criminais, vol. 5, núm. 20, São Paulo, 1997.

- "Criminalidad y corrupción", Revue Internationale de Droit Penal, núm. 1-2, 1997.

- "Crime organizado: uma categorização frustrada", Discursos sediciosos, crime, direito e sociedade, Rio de Janeiro, 1996.

- "El crimen organizado: una categorización frustrada", Cuadernos del Departamento de Derecho Penal y Criminología de la UNC, núm. 1, 1995.

- "Buscando o inimigo: de satã ao Direito penal cool", Criminologia e subjetividade, Rio de Janeiro, 2006.

- "¿Es posible un Derecho penal del enemigo no autoritario?, VV.AA., Libro en homenaje al Profesor Dr. Gonzalo Rodríguez Mourullo, Navarra, 2005.

- "Impunidad del agente encubierto y del delator: Una tendencia legislativa Latinoamericana", Révue Internationale de Droit Pénal, año 67, Toulouse, 1996.

ZAMBRANO PASQUEL, A., "Derecho Penal del Enemigo y Amparo de Libertad", http://www.revistajuridicaonline.co.

ZARAGOZA AGUADO, J. A., "Tratamiento penal y procesal de las organizaciones criminales en el Derecho español. Especial referencia al tráfico ilegal de drogas", VV.AA., "Delitos contra la salud pública y contrabando", Cuadernos de Derecho Judicial, núm. 5, 2000.

- Cuestiones penales y procesales relacionadas con la delincuencia organizada", Jornadas sobre delitos contra la salud pública en materia de drogas, Estudios jurídicos Ministerio Fiscal, núm. VI, 1999. 
- "Nuevos instrumentos procesales en la lucha contra la criminalidad organizada, La protección de testigos y peritos en causas criminales", Jornadas Internacionales de Derecho Procesal: Ponencias y comunicaciones, Málaga, 2001.

- "Las pruebas en los casos de Criminalidad Organizada: com énfasis en las pruebas indiciarias", Revista do Ministério Público, año 4, núm. 16, Santo Domingo, 2010.

ZARAGOZA AGUADO, J. A; RODRÍGUEZ GARCÍA, N.; MERCHÁN MATEOS, J. F.; CAPARRÓS, E. A., Delincuencia económica y blanqueo de capitales, Salamanca, 2005 (inédito).

ZARZALEJOS NIETO, J; BANACLOCHE PALAO, J., Aspectos fundamentales de Derecho Procesal Penal, Madrid, 2010.

ZIEGLER, J. Os senhores do crime: novas máfias contra a democracia, trad. Manuela Torres, Lisboa, 1999.

ZUMSTEIN RIBEIRO, L. E., "Liberdades públicas e a inadmissibilidade das provas ilícitas frente ao princípio da proporcionalidade", Revista Jurídica da Universidade de Franca, núm. 12, 2004.

ZÚÑIGA RODRÍGUEZ, L., Criminalidad organizada y sistema de derecho penal. Contribución a la determinación del injusto penal de organización criminal, Granada, 2009.

- Criminalidad organizada, Derecho penal y sociedad. Apuntes para el análisis", VV.AA., El desafío de la criminalidad organizada, Nieves Sanz Mulas coord., Granada, 2006.

- "Redes internacionales y criminalidad., a propósito del modelo de participación en organización criminal", VV.AA., Derecho penal ante la globalización, Madrid, 2002.

- "Criminalidad organizada, Unión Europea y sanciones a empresas", Criminalidad organizada, Almagro, 1999.

YACOBUCCI, G. J., "Política criminal y delincuencia organizada", VV.AA., Crimen Organizado. Desafíos y perspectivas en el marco de la globalización, Buenos Aires, 2005.

- "Los tipos penales relacionados con el crimen organizado", VV.AA., El crimen organizado. Desafíos y perspectivas en el marco de la globalización, Buenos Aires, 2005. 